TULIO FRANCO TEIXEIRA

Evolução dos caracteres sexuais secundários em Characidae (Teleostei: Characiformes) 
MUSEU DE ZOOLOGIA

UNIVERSIDADE DE SÃO PAULO

PROGRAMA DE PÓS-GRADUAÇÃO EM SISTEMÁTICA, TAXONOMIA E BIODIVERSIDADE

\section{Evolução dos caracteres sexuais secundários em Characidae (Teleostei: Characiformes)}

\section{Versão Original}

TULIO FRANCO TEIXEIRA

Orientador:

Prof. Dr. Naércio Aquino Menezes

Tese de Doutorado - Programa de Pós Graduação em

Sistematica, taxonomia animal e Biodiversidade do Museu de Zoologia da Universidade de São Paulo

São Paulo

2016 


\section{Advertência}

Não autorizo a reprodução e divulgação total ou parcial deste trabalho, por qualquer meio convencional ou eletrônico.

\section{Notice}

I do not authorize the reproduction and dissemination of this work in part or entirely by any means eletronic or conventional. 


\section{Teixeira, Tulio Franco}

Evolução dos caracteres sexuais secundários em Characidae (Teleostei: Characiformes)/ Tulio Franco Teixeira; orientador Naércio Aquino Menezes. - São Paulo, SP: 2016. $459 \mathrm{p}$.

Tese (doutorado) - Programa de Pós-Graduação em Sistemática, Taxonomia e Biodiversidade, Museu de Zoologia da USP, 2016.

1. Characidae - Dimorfismo sexual - Evolução. 2. Characidade Dimorfismo sexual. I. Menezes, Naércio, orient. II. Título.

Banca Examinadora

Prof. Dr. Instituição:

Julgamento: Assinatura:

Prof. Dr. Instituição:

Julgamento: Assinatura:

Prof. Dr. Instituição:

Julgamento: Assinatura:

Prof. Dr. Instituição:

Julgamento: Assinatura:

Prof. Dr. Instituição:

Julgamento: Assinatura: 
Dedico este volume a todos aqueles que de coração sabem o quanto são importantes em minha vida, principalmente aos meus, mais do que amados, pai, mãe, irmão e irmã. Agradecido por tudo, amo vocês. 


\section{Agradecimentos}

“...bom, agora falta só agradece...." - bom, descobri que este "só" foi subestimar este processo. Eu, particularmente acredito que uma das maiores qualidades que um ser humano pode ter é a gratidão, esse sentimento é enaltecedor, é dar amor ao receber. Meu caros amigos, tenho para mim que todos os momentos, todos os atos, todas as coisas que ouvimos, falamos, sentimentos, enfim, todas as experiências que temos move um pouco a direção de nossa vida. Todos, definitivamente todos vocês contribuíram no processo de desenvolvimento pessoal e consequentemente profissional do TULIO que está aqui, pensando, neste momento. Peço a cada um que feche os olhos e lembrem de algum momento comigo, Lembrou?...saiba que este momento, mexeu comigo, me fez crescer como ser humano. Portanto, não acho que seria justo citar alguém em específico neste tópico. Mas ao Francisco Donizete Teixeira, Emília Maria Franco Teixeira, Tales Franco Teixeira e Rafaela Franco Teixeira simplesmente eu devo a minha vida, meus princípios, meu caráter. Estas pessoas são a minha raiz, a minha inspiração, estão no meu ninho me mantendo quentinho sempre que chove, me mantendo protegido contra tudo. Você são os amores da minha vida, amo vocês de uma forma indescritível.

Com tudo, este projeto não seria viável sem o aporio financiamento da FAPESP: processo (2012/01263-2). 


\section{Resumo}

Dentre todas as famílias de Characiformes, Characidae, com 1209 espécies válidas é, sem dúvida, a mais problemática, com suas relações intra e inerfamiliares em Characiformes ainda pouco definidas. Isto se deve à imensa diversidade e variação morfológica presente em seus representantes. Embora alguns trabalhos, tanto morfológicos quanto moleculares, incluindo um grande número de táxons terminais tenham sido realizados, as relações intra e interfamiliares continuam controversas. Estes trabalhos, no entanto corroboram o monofiletismo de um grupo caracterizado pela ausência do osso supra-orbital, um caráter aparentemente redutivo: clado 204 de Mirande, 2010, Clado 37 de Oliveira et al.,2011, Clado A de Malabarba \& Weitzman, 2003 - semelhante ao "ortí clade" proposto em Ortí \& Meyer, 1997.

Diversos autores resumiram as principais dificuldades enfrentadas por ictiólogos no estudo de relações intra e interfamiliares em Characidae: 1) grande diversidade aliada à relativa pouca divergência morfológica, 2) redução em tamanho, com consequente perda/truncamento de muitas estruturas por pedomorfose, 3) falta de boas séries de exemplares bem preservados e sexualmente desenvolvidos em coleções, e 4) necessidade de mais informação quanto ao colorido em vida e dimorfismo sexual. O dimorfismo sexual tem sido estudado extensivamente em Characidae, se mostrando informativo na resolução de grupos em níveis menos inclusivos, como Glandulocaudinae sensu Weitzman \& Menezes (1998) e Xenurobryconini. Embora tenha havido um notável avanço no conhecimento dos caracteres sexuais secundários em Characidae, nota-se que grande parte dos estudos se restringem aos táxons com caracteres sexuais secundários mais evidentes, mais especializados e em grupos muito pouco inclusivos. Nesta contribuição realizamos uma análise anatômica comparada incluindo um grande número de espécies, representando todos os grupos menos inclusivos citados em literatura na tentativa de encontrar padrões que reflitam a evolução dos grupos menos inclusivos. Como resultado, desvendamos uma diversidade incrível nestes caracteres, que se mostraram potencialmente informativos na resolução de relações de grupos menos inclusivos em Characidae. 


\section{Abstract}

Among all Characiforms families, Characidae, with 1209 valid species is, undoubtedly, the most problematic, with its relationships within Characiformes still poorly defined. This is due to the great diversity and morphological variation among its members. Although some recent studies, both morphological and molecular including a great number of terminal taxa were performed, its intra and inter-family relations are still very controversial. These studies however, corroborate the monophyly of a group characterized by the absence of supra-orbital bone, a seemingly reductive character: Clade 204 of Mirande, 2010, Clade 37 of Oliveira et al., 2011, Clade A of Malabarba \& Weitzman, 2003 - similar to the "Ortí clade" proposed in Ortí \& Meyer, 1997.

As summarized by many authors in literature the main difficulties faced by ichthyologists in the study of intra and inter-familial relationships in Characidae: 1) diversity combined with relatively little morphological divergence, 2 ) reduction in size with consequent loss/truncation of many structure by paedomorphosis, 3) lack of good series of well-preserved sexually developed specimens into collections, and 4) the need form more information about the of color in life and sexual dimorphism. The sexual dimorphism has been studied extensively in Characidae, being very informative on the resolution of less inclusive groups, as Glandulocaudinae sensu Weitzman \& Menezes (1998) and Xenurobryconini. Although there has been a remarkable advance in the knowledge os secondary sexual character in Characidae, it is clear that most of the studies are restricted to taxa with secondary sexual characters more evident, more specialized and on very less inclusive groups. In this contribution we performed an anatomical comparative analysis including a large number of species, representing all less inclusive groups cited in literature in attempt to find which patterns reflect the evolution of the less inclusive groups within the family. As a result, we unveil an incredible diversity in these characters, which might be potentially informative in resolving relations less inclusive groups in Characidae. 


\section{Lista de Figuras}

\section{(Todas as figuras estão no apêndice, exceto as figuras 1 e 2)}

Figura1. Esquema de um raio ramificado em vista lateral esquerda. As linhas pontilhadas horizontais representam as bifurcações mencionadas na descrição para cada ramo pós bifurcação. A linha pontilhada vertical, representa a linha mediana do raio e deve ser extrapolada para cada ramo. A letra "A" representa os ramos anteriores de cada bifuração e "P" os ramos posteriores..

Figura 2. Esquema de um raio ramificado em vita lateral esquerda. Linha pontilhadas na horizontal repreantam o local e o número de cada bifurcação. Os número (1 a 16) apontam para cada série de segmentos com processo ósseos, cuja estenção máxima estáuma linha paralela à margem dos raios em diferentes locais. .404

Figura 3. Nadadeira peitoral de macho de Characidium xanthopterum em vista dorsal (a) e detalhe em vista dorsal (b), evidenciando a distribuição dos processos ósseos.

Figura 4. Nadadeira pélvica de macho de Characidium xanthopterum em vista dorsal (canto superior esquerdo), raio ramificado em vista dorsal (central), detalhe dos processos ósseos em vista dorsal (canto inferior esquerdo) e detalhe dos processos ósseos em vista lateromedial (canto inferior direito).

Figura 5. Nadadeira pélvica de macho de Characidium xavante em vista dorsal (a) vista dorsal do raio ramificado (b), vista lateromedial (c), detalhe em vista dorsal (d) e detalhe em vista lateromedial.

Figura 6. Nadadeira anal de machos de Carnegiella strigata em vista lateral esquerda, evidenciando o formato do perfil da margem distal da nadadeira e distribuição dos processos ósseos.

Figura 7. Distribuição, posição e formato dos processos ósseos no hemitriquium esquerdo do raio ramificado da nadadeira anal de machos de Carnegiella strigata. (a) vista lateral, (b) vista anteroposterior, (c) detalhe em vista lateral e (d) detalhe em vista anteroposterior.

Figura 8. Nadadeira anal de machos de Thoracocharax stellatus em vista lateral esquerda, evidenciando o formato do perfil da margem distal da nadadeira e distribuição dos processos ósseos. 
Figura 9. Distribuição, posição e formato dos processos ósseos no hemitriquium esquerdo do raio ramificado da nadadeira anal de machos de Thoracocharax stellatus. (a) vista lateral, (b) vista anteroposterior, (c) detalhe em vista lateral e (d) detalhe em vista anteroposterior.

Figura 10. Porção anterior da nadadeira anal de machos de Myloplus rubripinnis. (a) distribuição e orientação das duas formas de processos ósseos e (b) detalhe da primeira forma (lappet) nos raios anteriores.

Figura 11. Nadadeira anal de machos (a) e de fêmeas (b) de Aphyocharax anisitsi em vista lateral esquerda, evidenciando o formato do perfil distal das nadadeiras nos dois sexos e distribuição dos processos ósseos na nadadeira anal de macho.

Figura 12. Distribuição, posição e formato dos processos ósseos no hemitriquium esquerdo do raio ramificado da nadadeira anal de machos de Aphyocharax anisitsi. (a) vista lateral do primeiro raio ramificado, (b) vista lateral do décimo sexto raio ramificado, (c) detalhe em vista lateral do primeiro raio ramificado, (d) detalhe em vista anteroposterior do primeiro raio ramificado e (e) detalhe em vista anteroposterior do décimo sexto raio ramificado.

Figura 13. Distribuição, posição e formato dos processos ósseos no hemitriquium ventral da nadadeira pélvica esquerda de machos de Aphyocharax anisitsi. (a) vista ventral, (b) vista lateromedial, (c) detalhe em vista ventral e (d) detalhe em vista lateromedial.

Figura 14. Brânquia com glândula branquial em vista lateral direita (a), detalhe da região anterior do ceratobranquial direito, evidenciando a glândula branquial (b) em Aphyocharax anisitsi.

Figura 15. Nadadeira anal de machos de Prionobrama paraguayensis em vista lateral esquerda, evidenciando o formato do perfil distal da nadadeiras e distribuição dos processos ósseos.

Figura 16. Distribuição, posição e formato dos processos ósseos no hemitriquium esquerdo do raio ramificado da nadadeira anal de machos de Prionobrama paraguayensis. (a) vista anteroposterior, (b) vista lateral, (c) detalhe em vista lateral e (d) detalhe em vista anteroposterior.

Figura 17. Distribuição, posição e formato dos processos ósseos no hemitriquium ventral da nadadeira pélvica esquerda de machos de Prionobrama paraguayensis. (a) vista ventral, (b) detalhe em vista lateral, (c) detalhe em vista lateromedial. 
Figura 18. Brânquia com glândula branquial em vista lateral direita (a), detalhe da região anterior do ceratobranquial direito, evidenciando a glândula branquial (b) em Prionobrama paraguayensis.

Figura 19. Nadadeira anal de machos de Microschemobrycon casiquiare evidenciando o formato do perfil distal da nadadeira e distribuição dos processos ósseos.

Figura 20. Distribuição, posição e formato dos processos ósseos no hemitriquium esquerdo do raio ramificado da nadadeira anal de machos de Microschemobrycon casiquiare. (a) vista lateral, (b) vista anteroposterior, (c) detalhe em vista lateral e (d) detalhe em vista anteroposterior.

Figura 21. Distribuição, posição e formato dos processos ósseos no hemitriquium ventral do raio ramificado da nadadeira pélvica direita de machos de Microschemobrycon casiquiare. (a) vista ventral, (b) vista lateromedial, (c) detalhe em vista ventral e (d) detalhe em vista lateromedial.

Figura 22. Nadadeira anal de machos de Parecbasis cyclolepis (a), detalhe da porção anterior da nadadeira anal (b), evidenciando o formato da nadadeira e a distribuição dos processos ósseos.

Figura 23. Distribuição, posição e formato dos processos ósseos no hemitriquium direito do raio ramificado da nadadeira anal de machos de Parecbasis cyclolepis. (a) vista lateral, (b) vista anteroposterior, (c) detalhe em vista lateral e (d) detalhe em vista anteroposterior.

Figura 24. Nadadeira anal de machos de Astyanax abramis em vista lateral esquerda, evidenciando o formato do perfil da margem distal da nadadeira a distribuição dos processos ósseos.

Figura 25. Nadadeira pélvica de machos (a) e de fêmeas (b) de Astyanax abramis em vista lateral esquerda, evidenciando o formato e comprimento da nadadeira nos dois sexos.

Figura 26. Nadadeira dorsal de machos (a) e de fêmeas (b) de Astyanax abramis em vista lateral esquerda, evidenciando o formato e comprimento da nadadeira nos dois sexos.

Figura 27. Distribuição, posição de inserção e formato dos processos ósseos no hemitriquium esquerdo do raio ramificado da nadadeira anal de machos de Astyanax abramis. (a) vista latera, (b) detalhe em vista lateral e (c) detalhe em vista anteroposterior.

Figura 28. Distribuição, posição de inserção e formato dos processos ósseos no hemitriquium ventral do raio ramificado da nadadeira pélvica direita de machos de Astyanax abramis. (a) 
vista ventral, (b) vista lateromedial, (c) detalhe em vista ventral e (d) detalhe em vista lateromedial.

Figura 29. Nadadeira anal de machos de Astyanax lineatus em vista lateral esquerda, evidenciando o formato do perfil da margem distal da nadadeira e distribuição dos processos ósseos.

Figura 30. Distribuição, posição de inserção e formato dos processos ósseos no hemitriquium esquerdo do raio ramificado da nadadeira anal de machos de Astyanax lineatus. (a) vista lateral, (b) vista anteroposterior, (c) detalhe em vista lateral e (d) detalhe em vista anteroposterior.

Figura 31. Distribuição, posição de inserção e formato dos processos ósseos no hemitriquium ventral do raio ramificado da nadadeira pélvica direita de machos de Astyanax lineatus. (a) vista ventral, (b) vista lateromedial, (c) detalhe em vista ventral e (d) detalhe em vista lateromedial.

Figura 32. Cabeça de machos (a) e de fêmeas (b) de Astyanax lineatus em vista lateral esquerda, evidenciando a distribuição dos tubérculos reprodutivos na cabeça do macho.

Figura 33. Nadadeira anal de machos (a) e de fêmeas (b) de Astyanax cf. jordani em vista lateral esquerda, evidenciando o formato da margem distal da nadadeira nos dois sexos e distribuição dos processos ósseos na nadadeira anal do macho.

Figura 34. Nadadeira pélvica de machos (a) e de fêmeas (b) de Astyanax cf. jordani em vista ventral, evidenciando o formato da nadadeira nos dois sexos.

Figura 35. Distribuição, posição de inserção e formato dos processos ósseos no hemitriquium esquerdo do raio ramificado da nadadeira anal de machos de Astyanax cf. jordani. (a) vista lateral, (b) vista anteroposterior, (c) detalhe em vista lateral e (d) detalhe em vista anteroposterior.

Figura 36. Distribuição, posição de inserção e formato dos processos ósseos no hemitriquium ventral do raio ramificado da nadadeira pélvica direita de machos de Astyanax cf. jordani. (a) vista ventral, (b) vista lateromedial, (c) detalhe em vista ventral e (d) detalhe em vista lateromedial.

Figura 37. Nadadeira anal de machos (a) e de fêmeas (b) de Hyphessobrycon anisitsi em vista lateral esquerda, evidenciando o formato da margem distal da nadadeira nos dois sexos e distribuição dos processos ósseos na nadadeira anal de macho. 
Figura 38. Distribuição, posição de inserção e formato dos processos ósseos no hemitriquium esquerdo do raio ramificado da nadadeira anal de machos de Hyphessobrycon anisitsi. (a) vista lateral, (b) detalhe em vista lateral e (c) detalhe em vista anteroposterior.

Figura 39. Distribuição, posição de inserção e formato dos processos ósseos no hemitriquium ventral do raio ramificado da nadadeira pélvica direita de machos de Hyphessobrycon anisitsi. (a) vista ventral, (b) detalhe em vista ventral e (c) detalhe em vista lateromedial.

Figura 40. Porção anterior da nadadeira anal de machos de Markiana nigripinnis em vista lateral esquerda, evidenciando o formato da margem distal a distribuição dos processos ósseos na nadadeira.

Figura 41. Distribuição, posição de inserção e formato dos processos ósseos no hemitriquium esquerdo do raio ramificado da nadadeira anal de machos de Markiana nigripinnis. (a) vista lateral, (b) detalhe em vista lateral e (c) detalhe em vista anteroposterior.

Figura 42. Nadadeira anal de fêmeas (a) e de machos (b) de Psellogrammus kennedyi em vista lateral esquerda, evidenciando o formato da margem distal da nadadeira nos dois sexos e a distribuição dos processos ósseos na nadadeira anal de macho.

Figura 43. Distribuição, posição de inserção e formato dos processos ósseos no hemitriquium esquerdo do raio ramificado da nadadeira anal de machos de Psellogrammus kennedyi. (a) vista lateral, (b) detalhe em vista lateral e (c) detalhe em vista anteroposterior.

Figura 44. Distribuição, posição de inserção e formato dos processos ósseos no hemitriquium ventral do raio ramificado da nadadeira pélvica direita de machos de Psellogrammus kennedyi. (a) vista ventral, (b) detalhe em vista ventral e (c) detalhe em vista lateromedial.

Figura 45. Nadadeira anal de machos (a) e de fêmeas (b) de Astyanax brachypterigium em vista lateral esquerda, evidenciando o formato do perfil distal das nadadeiras nos dois sexos e distribuição dos processos ósseos na nadadeira anal de macho.

Figura 46. Nadadeira pélvica de machos (a) e de fêmeas (b) de Astyanax brachypterigium em vista lateral ventral, evidenciando o formato e comprimento da nadadeira nos dois sexos.

Figura 47. Distribuição, posição e formato dos processos ósseos no hemitriquium esquerdo do raio ramificado da nadadeira anal de machos de Astyanax brachypterigium. (a) vista lateral, (b) vista anteroposterior, (c) detalhe em vista lateral, (d) detalhe em vista anteroposterior.

Figura 48. Distribuição, posição e formato dos processos ósseos no hemitriquium ventral da nadadeira pélvica direita de machos de Astyanax brachypterigium. (a) vista ventral, (b) vista lateromedial, (c) detalhe em vista ventral e (d) detalhe em vista lateromedial. 
Figura 49. Nadadeira anal de machos (a) e de fêmeas (b) de Astyanax courensis em vista lateral esquerda, evidenciando o formato do perfil distal das nadadeiras nos dois sexos e distribuição dos processos ósseos na nadadeira anal e de tubérculos reprodutivos nas escamas de macho.

Figura 50. Nadadeira pélvica de machos (a) e de fêmeas (b) de Astyanax courensis em vista lateral ventral, evidenciando o formato e comprimento da nadadeira nos dois sexos.

Figura 51. Distribuição, posição e formato dos processos ósseos no hemitriquium esquerdo do raio ramificado da nadadeira anal de machos de Astyanax courensis. (a) vista lateral, (b) detalhe em vista lateral e (c) detalhe em vista anteroposterior.

Figura 52. Distribuição, posição e formato dos processos ósseos no hemitriquium ventral da nadadeira pélvica direita de machos de Astyanax courensis. (a) vista ventral, (b) vista lateromedial, (c) detalhe em vista ventral e (d) detalhe em vista lateromedial.

Figura 53. Distribuição, posição e formato dos processos ósseos no hemitriquium ventral da nadadeira peitoral direita de machos de Astyanax courensis. (a) vista dorsal, (b) vista lateromedial, (c) detalhe em vista dorsal e (d) detalhe em vista lateromedial.

Figura 54. Cabeça de machos (a) e de fêmeas (b) de Astyanax courensis em vista lateral esquerda, evidenciando a distribuição dos tubérculos reprodutivos na cabeça do macho.

Figura 55. Nadadeira anal de machos (a) e de fêmeas (b) de Astyanax goyanensis em vista lateral esquerda, evidenciando o formato do perfil distal das nadadeiras nos dois sexos e distribuição dos processos ósseos na nadadeira anal e de tubérculos reprodutivos nas escamas de macho.

Figura 56. Nadadeira pélvica de machos (a) e de fêmeas (b) de Astyanax goyanensis em vista lateral ventral, evidenciando o formato e comprimento da nadadeira nos dois sexos.

Figura 57. Distribuição, posição e formato dos processos ósseos no hemitriquium esquerdo do raio ramificado da nadadeira anal de machos de Astyanax goyanensis. (a) vista lateral, (b) detalhe em vista lateral e (c) detalhe em vista anteroposterior.

Figura 58. Distribuição, posição e formato dos processos ósseos no hemitriquium ventral da nadadeira pélvica direita de machos de Astyanax goyanensis. (a) vista ventral, (b) vista lateromedial, (c) detalhe em vista ventral e (d) detalhe em vista lateromedial.

Figura 59. Distribuição, posição e formato dos processos ósseos no hemitriquium ventral da nadadeira peitoral direita de machos de Astyanax goyanensis. (a) vista dorsal, (b) vista lateromedial, (c) detalhe em vista dorsal e (d) detalhe em vista lateromedial. 
Figura 60. Cabeça de machos (a) e de fêmeas (b) de Astyanax goyanensis em vista lateral esquerda, evidenciando a distribuição dos tubérculos reprodutivos na cabeça do macho.

Figura 61. Nadadeira anal de machos (a) e de fêmeas (b) de Astyanax rivularis em vista lateral esquerda, evidenciando o formato do perfil distal das nadadeiras nos dois sexos e distribuição dos processos ósseos na nadadeira anal e de tubérculos reprodutivos nas escamas de macho.

Figura 62. Nadadeira pélvica de machos (a) e de fêmeas (b) de Astyanax rivularis em vista lateral ventral, evidenciando o formato e comprimento da nadadeira nos dois sexos.

Figura 63. Distribuição, posição e formato dos processos ósseos no hemitriquium esquerdo do raio ramificado da nadadeira anal de machos de Astyanax rivularis. (a) vista lateral, (b) detalhe em vista lateral e (c) detalhe em vista anteroposterior.

Figura 64. Distribuição, posição e formato dos processos ósseos no hemitriquium ventral da nadadeira pélvica direita de machos de Astyanax rivularis. (a) vista ventral, (b) detalhe em vista ventral e (c) detalhe em vista lateromedial.

Figura 65. Distribuição, posição e formato dos processos ósseos no hemitriquium ventral da nadadeira peitoral direita de machos de Astyanax rivularis. (a) vista dorsal, (b) vista lateromedial, (c) detalhe em vista dorsal e (d) detalhe em vista lateromedial.

Figura 66. Cabeça de machos (a) e de fêmeas (b) de Astyanax rivularis em vista lateral esquerda, evidenciando a distribuição dos tubérculos reprodutivos na cabeça do macho.

Figura 67. Nadadeira anal de machos (a) e de fêmeas (b) de Hasemania kalunga em vista lateral esquerda, evidenciando o formato do perfil distal das nadadeiras nos dois sexos e distribuição dos processos ósseos na nadadeira anal de macho.

Figura 68. Nadadeira pélvica de machos (a) e de fêmeas (b) de Hasemania kalunga em vista lateral ventral, evidenciando o formato e comprimento da nadadeira nos dois sexos.

Figura 69. Distribuição, posição e formato dos processos ósseos no hemitriquium esquerdo do raio ramificado da nadadeira anal de machos de Hasemania kalunga. (a) vista lateral, (b) detalhe em vista lateral e (c) detalhe em vista anteroposterior.

Figura 70. Nadadeira anal de machos (a) e de fêmeas (b) de Hyphessobrycon vinaceus em vista lateral esquerda, evidenciando o formato do perfil distal das nadadeiras nos dois sexos e distribuição dos processos ósseos na nadadeira anal e tubérculos reprodutivos nas escamas de macho.

Figura 71. Nadadeira pélvica de machos (a) e de fêmeas (b) de Hyphessobrycon vinaceus em vista lateral ventral, evidenciando o formato e comprimento da nadadeira nos dois sexos. 
Figura 72. Distribuição, posição e formato dos processos ósseos no hemitriquium esquerdo do raio ramificado da nadadeira anal de machos de Hyphessobrycon vinaceus. (a) vista lateral, (b) vista anteroposterior, (c) detalhe em vista lateral, (d) detalhe em vista anteroposterior.

Figura 73. Distribuição, posição e formato dos processos ósseos no hemitriquium ventral da nadadeira pélvica direita de machos de Hyphessobrycon vinaceus. (a) vista ventral, (b) detalhe em vista ventral e (c) detalhe em vista lateromedial.

Figura 74. Distribuição, posição e formato dos processos ósseos no hemitriquium ventral da nadadeira peitoral direita de machos de Hyphessobrycon vinaceus. (a) vista dorsal, (b) detalhe em vista dorsal e (c) detalhe em vista lateromedial.

Figura 75. Distribuição, posição e formato dos processos ósseos no hemitriquium esquerdo do raio ramificado da nadadeira caudal de machos de Hyphessobrycon vinaceus. (a) vista lateral, (b) vista mediolateral, (c) detalhe em vista lateral, (d) detalhe em vista mediolateral.

Figura 76. Nadadeira anal de machos de Oligosarcus jenynsii em vista lateral esquerda, evidenciando o formato do perfil da margem distal da nadadeira e distribuição dos processos ósseos.

Figura 77. Distribuição, posição e formato dos processos ósseos no hemitriquium esquerdo do raio ramificado da nadadeira anal de machos de Oligosarcus jenynsii. (a) vista lateral, (b) vista anteroposterior, (c) detalhe em vista lateral, (d) detalhe em vista anteroposterior.

Figura 78. Distribuição, posição e formato dos processos ósseos no hemitriquium ventral da nadadeira pélvica direita de machos de Oligosarcus jenynsii. (a) vista ventral, (b) vista lateromedial, (c) detalhe em vista ventral e (d) detalhe em vista lateromedial.

Figura 79. Distribuição, posição de inserção e formato dos processos ósseos no hemitriquium esquerdo do raio ramificado da nadadeira anal de machos de Brycon falcatus. (a) vista lateral, (b) vista anteroposterior, (c) detalhe em vista lateral e (d) detalhe em vista anteroposterior.

Figura 80. Nadadeira anal de machos (a) e de fêmeas (b) de Bryconops affinis em vista lateral esquerda, evidenciando o formato do perfil distal das nadadeiras nos dois sexos e distribuição dos processos ósseos na nadadeira anal de macho.

Figura 81. Nadadeira pélvica de machos (a) e de fêmeas (b) de Bryconops affinis em vista ventral, evidenciando o formato da nadadeira nos dois sexos.

Figura 82. Distribuição, posição de inserção e formato dos processos ósseos no hemitriquium esquerdo do raio ramificado da nadadeira anal de machos de Bryconops affinis. (a) vista 
latera, (b) vista anteroposterior, (c) detalhe em vista lateral e (d) detalhe em vista anteroposterior.

Figura 83. Distribuição, posição de inserção e formato dos processos ósseos no hemitriquium ventral do raio ramificado da nadadeira pélvica direita de machos de Bryconops affinis. (a) vista ventral, (b) vista lateromedial, (c) detalhe em vista lateral e (d) detalhe em vista lateromedial.

Figura 84. Nadadeira anal de machos de Acestrocephalus sardina em vista lateral esquerda, evidenciando o formato do perfil da margem distal da nadadeira e distribuição dos processos ósseos.

Figura 85. Distribuição, posição e formato dos processos ósseos no hemitriquium esquerdo do raio ramificado da nadadeira anal de machos de Acestrocephalus sardina. (a) vista lateral, (b) detalhe em vista lateral e (c) detalhe em vista anteroposterior.

Figura 86. Distribuição, posição e formato dos processos ósseos no hemitriquium ventral da nadadeira pélvica esquerda de machos de Acestrocephalus sardina. (a) vista ventral, (b) vista lateromedial, (c) detalhe em vista ventral e (d) detalhe em vista lateromedial.

Figura 87. Nadadeira anal de machos de Bryconexodon juruenae em vista lateral esquerda, evidenciando o formato do perfil da margem distal da nadadeira e distribuição dos processos ósseos.

Figura 88. Distribuição, posição e formato dos processos ósseos no hemitriquium esquerdo do raio ramificado da nadadeira anal de machos de Bryconexodon juruenae. (a) vista lateral, (b) detalhe em vista anteroposterior.

Figura 89. Nadadeira anal de machos de Charax stenopterus em vista lateral esquerda, evidenciando o formato do perfil da margem distal da nadadeira e distribuição dos processos ósseos.

Figura 90. Distribuição, posição e formato dos processos ósseos no hemitriquium esquerdo do raio ramificado da nadadeira anal de machos de Charax stenopterus. (a) vista lateral, (b) vista anteroposterior, (c) detalhe em vista lateral, (d) detalhe em vista anteroposterior.

Figura 91. Distribuição, posição e formato dos processos ósseos no hemitriquium ventral da nadadeira pélvica esquerda de machos de Charax stenopterus. (a) vista ventral, (b) detalhe em vista ventral e (c) detalhe em vista mediolateral. 
Figura 92. Nadadeira anal de machos de Roeboides descalvadensis em vista lateral esquerda, evidenciando o formato do perfil da margem distal da nadadeira e distribuição dos processos ósseos.

Figura 93. Distribuição, posição e formato dos processos ósseos no hemitriquium esquerdo do raio ramificado da nadadeira anal de machos de Roeboides descalvadensis. (a) vista lateral, (b) vista anteroposterior, (c) detalhe em vista lateral, (d) detalhe em vista anteroposterior.

Figura 94. Distribuição, posição e formato dos processos ósseos no hemitriquium ventral da nadadeira pélvica direita de machos de Roeboides descalvadensis. (a) vista ventral, (b) vista lateromedial, (c) detalhe em vista ventral e (d) detalhe em vista lateromedial.

Figura 95. Distribuição, posição e formato dos processos ósseos no hemitriquium esquerdo do raio ramificado da nadadeira anal de machos de Roeboides microlepis. (a) vista lateral, (b) vista anteroposterior, (c) detalhe em vista lateral, (d) detalhe em vista anteroposterior.

Figura 96. Distribuição, posição e formato dos processos ósseos no hemitriquium ventral da nadadeira pélvica direita de machos de Roeboides microlepis. (a) vista ventral, (b) detalhe em vista ventral e (c) detalhe em vista lateromedial.

Figura 97. Distribuição, posição e formato dos processos ósseos no hemitriquium esquerdo do raio ramificado da nadadeira anal de machos de Acinocheirodon melanogramma. (a) vista lateral, (b) vista anteroposterior, (c) detalhe em vista lateral, (d) detalhe em vista anteroposterior.

Figura 98. Distribuição, posição e formato dos processos ósseos no hemitriquium ventral da nadadeira pélvica esquerda de machos de Acinocheirodon melanogramma. (a) vista ventral, (b) vista lateromedial, (c) detalhe em vista ventral e (d) detalhe em vista lateromedial.

Figura 99. Distribuição, posição e formato dos processos ósseos no hemitriquium direito da nadadeira caudal de machos de Acinocheirodon melanogramma. (a) detalhe em vista lateral, (b) detalhe em vista lateromedial.

Figura 100. Brânquia com glândula branquial em vista lateral direita (a), detalhe da região anterior do ceratobranquial direito, evidenciando a glândula branquial em Acinocheirodon melanogramma.

Figura 101. Nadadeira anal de machos (a) e de fêmeas (b) de Cheirodon interruptus em vista lateral esquerda, evidenciando o formato do perfil distal das nadadeiras nos dois sexos e distribuição dos processos ósseos na nadadeira anal de macho. 
Figura 102. Distribuição, posição e formato dos processos ósseos no hemitriquium esquerdo do raio ramificado da nadadeira anal de machos de Cheirodon interruptus. (a) vista lateral, (b) vista anteroposterior, (c) detalhe em vista lateral, (d) detalhe em vista anteroposterior.

Figura 103. Distribuição, posição e formato dos processos ósseos no hemitriquium ventral da nadadeira pélvica direita de machos de Cheirodon interruptus. (a) vista ventral, (b) vista lateromedial, (c) detalhe em vista ventral e (d) detalhe em vista lateromedial.

Figura 104. Pedúnculo caudal de machos (a) e de fêmeas (b) de Cheirodon interruptus, evidenciando a exposição e formato da extremidade distal dos raios procurrentes ventrais de macho.

Figura 105. Brânquia com glândula branquial em vista lateral direita (a), detalhe da região anterior do ceratobranquial direito, evidenciando a glândula branquial (b) em Cheirodon interruptus.

Figura 106. Nadadeira anal de machos (a) e de fêmeas (b) de Compsura heterura em vista lateral esquerda, evidenciando o formato do perfil distal das nadadeiras nos dois sexos e distribuição dos processos ósseos na nadadeira anal de macho.

Figura 107. Nadadeira pélvica de machos (a) e de fêmeas (b) de Compsura heterura em vista lateral ventral, evidenciando o formato e comprimento da nadadeira nos dois sexos.

Figura 108. Distribuição, posição e formato dos processos ósseos no hemitriquium esquerdo do raio ramificado da nadadeira anal de machos de Compsura heterura. (a) vista lateral, (b) vista anteroposterior, (c) detalhe em vista lateral, (d) detalhe em vista anteroposterior.

Figura 109. Distribuição, posição e formato dos processos ósseos no hemitriquium ventral da nadadeira pélvica direita de machos de Compsura heterura. (a) vista ventral, (b) vista lateromedial, (c) detalhe em vista ventral e (d) detalhe em vista lateromedial.

Figura 110. Detalhe do final do pedúnculo caudal e origem dos raios do lobo ventral da nadadeira caudal de machos (a) e de fêmeas (b) de Compsura heterura, evidenciando as escamas modificadas nos dois sexos.

Figura 111. Nadadeira anal de machos de Heterocheirodon yatai em vista lateral esquerda, evidenciando o formato do perfil da margem distal da nadadeira e distribuição dos processos ósseos.

Figura 112. Distribuição, posição e formato dos processos ósseos no hemitriquium direito do raio ramificado da nadadeira anal de machos de Heterocheirodon yatai. (a) vista lateral, (b) detalhe em vista lateral e (c) detalhe em vista anteroposterior. 
Figura 113. Distribuição, posição e formato dos processos ósseos no hemitriquium ventral da nadadeira pélvica direita de machos de Heterocheirodon yatai. (a) vista ventral, (b) vista lateromedial, (c) detalhe em vista ventral e (d) detalhe em vista lateromedial.

Figura 114. Brânquia com glândula branquial em vista lateral direita (a), detalhe da região anterior do ceratobranquial direito, evidenciando a glândula branquial (b) em de Heterocheirodon yatai.

Figura 115. Nadadeira anal de machos (a) e de fêmeas (b) de Odontostilbe pequira em vista lateral esquerda, evidenciando o formato do perfil distal das nadadeiras nos dois sexos e distribuição dos processos ósseos na nadadeira anal de macho.

Figura 116. Nadadeira pélvica de machos (a) e de fêmeas (b) de Odontostilbe pequira em vista lateral esquerda, evidenciando o formato e comprimento da nadadeira nos dois sexos.

Figura 117. Nadadeira dorsal de machos (a) e de fêmeas (b) de Odontostilbe pequira em vista lateral esquerda, evidenciando o formato e comprimento da nadadeira nos dois sexos.

Figura 118. Distribuição, posição e formato dos processos ósseos no hemitriquium esquerdo do raio ramificado da nadadeira anal de machos de Odontostilbe pequira. (a) vista lateral, (b) vista anteroposterior, (c) detalhe em vista lateral, (d) detalhe em vista anteroposterior.

Figura 119. Distribuição, posição e formato dos processos ósseos no hemitriquium ventral da nadadeira pélvica direita de machos de Odontostilbe pequira. (a) vista ventral, (b) vista lateromedial, (c) detalhe em vista ventral e (d) detalhe em vista lateromedial.

Figura 120. Brânquia com glândula branquial em vista lateral direita (a), detalhe da região anterior do ceratobranquial direito, evidenciando a glândula branquial (b) em de Odontostilbe pequira.

Figura 121. Nadadeira anal de machos (a) e de fêmeas (b) de Serrapinnus calliurus em vista lateral esquerda, evidenciando o formato do perfil distal das nadadeiras nos dois sexos e distribuição dos processos ósseos na nadadeira anal de macho.

Figura 122. Nadadeira pélvica de machos (a) e de fêmeas (b) de Serrapinnus calliurus em vista lateral ventral, evidenciando o formato e comprimento da nadadeira nos dois sexos.

Figura 123. Distribuição, posição e formato dos processos ósseos no hemitriquium esquerdo do raio ramificado da nadadeira anal de machos de Serrapinnus calliurus. (a) vista lateral, (b) detalhe em vista lateral e (c) detalhe em vista anteroposterior. 
Figura 124. Distribuição, posição e formato dos processos ósseos no hemitriquium ventral da nadadeira pélvica direita de machos de Serrapinnus calliurus. (a) vista ventral, (b) vista lateromedial, (c) detalhe em vista ventral e (d) detalhe em vista lateromedial.

Figura 125. Brânquia com glândula branquial em vista lateral direita (a), detalhe da região anterior do ceratobranquial direito, evidenciando a glândula branquial (b) em Serrapinnus calliurus.

Figura 126. Nadadeira anal de machos de Heterocharax virgulatus (a) e detalhe da porção anterior (b) em vista lateral esquerda, evidenciando o formato do perfil da margem distal da nadadeira e distribuição dos processos ósseos.

Figura 127. Distribuição, posição e formato dos processos ósseos no hemitriquium esquerdo do raio ramificado da nadadeira anal de machos de Heterocharax virgulatus. (a) vista lateral, (b) vista anteroposterior, (c) detalhe em vista lateral, (d) detalhe em vista anteroposterior.

Figura 128. Distribuição, posição e formato dos processos ósseos no hemitriquium ventral da nadadeira pélvica direita de machos de Heterocharax virgulatus. (a) vista ventral, (b) vista lateromedial, (c) detalhe em vista ventral e (d) detalhe em vista lateromedial.

Figura 129. Nadadeira anal de machos de Hoplocharax goethei em vista lateral esquerda, evidenciando o formato do perfil da margem distal da nadadeira e distribuição dos processos ósseos.

Figura 130. Distribuição, posição e formato dos processos ósseos no hemitriquium esquerdo do raio ramificado da nadadeira anal de machos de Hoplocharax goethei. (a) vista lateral, (b) vista anteroposterior, (c) detalhe em vista lateral, (d) detalhe em vista anteroposterior.

Figura 131. Distribuição, posição e formato dos processos ósseos no hemitriquium ventral da nadadeira pélvica direita de machos de Hoplocharax goethei. (a) vista ventral, (b) vista lateromedial, (c) detalhe em vista ventral e (d) detalhe em vista lateromedial.

Figura 132. Distribuição, posição e formato dos processos ósseos no hemitriquium ventral da nadadeira peitoral direita de machos de Haplocharax goethei. (a) vista ventral, (b) vista lateromedial, (c) detalhe em vista ventral e (d) detalhe em vista lateromedial.

Figura 133. Nadadeira anal de machos (a) e de fêmeas (b) de Hyphessobrycon bifasciatus em vista lateral esquerda, evidenciando o formato do perfil distal das nadadeiras nos dois sexos e distribuição dos processos ósseos na nadadeira anal de macho. 
Figura 134. Nadadeira pélvica de machos (a) e de fêmeas (b) de Hyphessobrycon bifasciatus em vista lateral esquerda, evidenciando o formato e comprimento da nadadeira nos dois sexos.

Figura 135. Nadadeira pélvica de machos (a) e de fêmeas (b) de Hyphessobrycon bifasciatus em vista lateral ventral, evidenciando o formato e comprimento da nadadeira nos dois sexos.

Figura 136. Distribuição, posição e formato dos processos ósseos no hemitriquium esquerdo do raio ramificado da nadadeira anal de machos de Hyphessobrycon bifasciatus. (a) vista lateral, (b) vista anteroposterior, (c) detalhe em vista lateral, (d) detalhe em vista anteroposterior.

Figura 137. Distribuição, posição e formato dos processos ósseos no hemitriquium ventral da nadadeira pélvica direita de machos de Hyphessobrycon bifasciatus. (a) vista ventral, (b) detalhe em vista ventral e (c) detalhe em vista lateromedial.

Figura 138. Nadadeira anal (a) e caudal (b) de machos de Hyphessobrycon luetkenii em vista lateral esquerda, evidenciando o formato e distribuição dos processos ósseos nas nadadeiras e presença de tubérculos reprodutivos nas escamas.

Figura 139. Nadadeira dorsal de machos de Hyphessobrycon luetkenii em vista lateral esquerda. (a) formato da nadadeira e (b) detalhe dos raios com processos ósseos.

Figura 140. Detalhe dos raios da nadadeira caudal de machos de Hyphessobrycon luetkenii em vista lateral esquerda (a) e detalhe dos processos ósseos em vista mediolateral (b).

Figura 141. Distribuição, posição e formato dos processos ósseos no hemitriquium esquerdo do raio ramificado da nadadeira anal de machos de Hyphessobrycon luetkenii. (a) vista lateral e (b) vista anteroposterior.

Figura 142. Distribuição, posição e formato dos processos ósseos no hemitriquium ventral da nadadeira pélvica direita de machos de Hyphessobrycon luetkenii. (a) vista ventral, (b) vista lateromedial, (c) detalhe em vista ventral e (d) detalhe em vista lateromedial.

Figura 143. Porção anterior da nadadeira anal de machos de Piabucus melanostomus. (a) distribuição e orientação das duas formas de processos ósseos e (b) detalhe da primeira forma (lappet) nos raios anteriores.

Figura 144. Porção posterior da nadadeira anal de machos (a) e de fêmeas (b) de Piabucus dentatus, evidenciando o formato do perfil da margem distal da nadadeira anal nos dois sexos e distribuição dos processos ósseos na nadadeira de macho. 
Figura 145. Distribuição, posição de inserção e formato do processos ósseos no hemitriquium esquerdo do raio ramificado anterior da nadadeira anal de machos de Piabucus dentatus. (a) vista anteroposterior, (b) vista lateral, (c) detalhe em vista lateral da segunda forma de processos ósseos e (d) detalhe em vista anteroposterior da segunda forma de processos ósseos, (e) detalhe em vista lateral da primeira forma (lappet) de processos ósseos e (f) detalhe em vista anteroposterior da primeira forma (lappet) de processos ósseos.

Figura 146. Distribuição, posição de inserção e formato dos processos ósseos no hemitriquium direito do raio ramificado posterior da nadadeira anal em Piabucus dentatus. (a) vista lateral da primeira forma (lappet), (b) vista anteroposterior da primeira forma (lappet), (c) detalhe em vista lateral da primeira forma (lappet) e (d) detalhe em vista anteroposterior da primeira forma (lappet).

Figura 147. Nadadeira anal de macho de Hollandichthys multifasciatus em vista lateral esquerda, evidenciando o formato do perfil da margem distal da nadadeira e distribuição dos processos ósseos.

Figura 148. Nadadeira pélvica de machos (a) e de fêmeas (b) de Hollandichthys multifasciatus em vista lateral esquerda, evidenciando o formato e comprimento da nadadeira nos dois sexos.

Figura 149. Distribuição, posição e formato dos processos ósseos no hemitriquium esquerdo do raio ramificado da nadadeira anal de machos de Hollandichthys multifasciatus. (a) vista lateral, (b) vista anteroposterior, (c) detalhe em vista lateral, (d) detalhe em vista anteroposterior.

Figura 150. Distribuição, posição e formato dos processos ósseos no hemitriquium ventral da nadadeira pélvica direita de machos de Hollandichthys multifasciatus. (a) vista ventral, (b) vista lateromedial, (c) detalhe em vista ventral e (d) detalhe em vista lateromedial.

Figura 151. Nadadeira anal e pélvica de machos (a) e de fêmeas (b) de Nematocharax venustus em vista lateral esquerda, evidenciando o formato do perfil distal das nadadeiras nos dois sexos e distribuição dos processos ósseos na nadadeira anal de macho.

Figura 152. Nadadeira dorsal de machos (a) e de fêmeas (b) de Nematocharax venustus em vista lateral ventral, evidenciando o formato e comprimento da nadadeira nos dois sexos.

Figura 153. Distribuição, posição e formato dos processos ósseos no hemitriquium esquerdo do raio ramificado da nadadeira anal de machos de Nematocharax venustus. (a) vista lateral, (b) vista anteroposterior, (c) detalhe em vista lateral, (d) detalhe em vista anteroposterior. 
Figura 154. Distribuição, posição e formato dos processos ósseos no hemitriquium ventral da nadadeira pélvica direita de machos de Nematocharax venustus. (a) vista ventral, (b) vista lateromedial, (c) detalhe em vista ventral e (d) detalhe em vista lateromedial.

Figura 155. Distribuição, posição e formato dos processos ósseos no hemitriquium esquerdo do raio ramificado da nadadeira anal de machos de Salminus brasiliensis. (a) vista lateral, (b) vista anteroposterior, (c) detalhe em vista lateral, (d) detalhe em vista anteroposterior.

Figura 156. Distribuição, posição e formato dos processos ósseos no hemitriquium ventral da nadadeira pélvica direita de machos de Salminus brasiliensis. (a) vista ventral, (b) vista lateromedial, (c) detalhe em vista ventral e (d) detalhe em vista lateromedial.

Figura 157. Distribuição, posição e formato dos processos ósseos no hemitriquium esquerdo do raio ramificado da nadadeira anal de machos de Salminus hilarii. (a) vista lateral, (b) vista anteroposterior, (c) detalhe em vista lateral, (d) detalhe em vista anteroposterior.

Figura 158. Distribuição, posição e formato dos processos ósseos no hemitriquium ventral da nadadeira pélvica esquerda de machos de Salminus hilarii. (a) vista ventral, (b) vista lateromedial, (c) detalhe em vista ventral e (d) detalhe em vista lateromedial.

Figura 159. Nadadeira anal de machos (a) e de fêmeas (b) de Deuterodon iguape em vista lateral esquerda, evidenciando o formato do perfil distal das nadadeiras nos dois sexos e distribuição dos processos ósseos na nadadeira anal de macho.

Figura 160. Nadadeira pélvica de machos (a) e de fêmeas (b) de Deuterodon iguape em vista lateral ventral, evidenciando o formato e comprimento da nadadeira nos dois sexos.

Figura 161. Distribuição, posição e formato dos processos ósseos no hemitriquium esquerdo do raio ramificado da nadadeira anal de machos de Deuterodon iguape. (a) vista lateral, (b) vista anteroposterior, (c) detalhe em vista anteroposterior, (d) detalhe em vista lateral.

Figura 162. Distribuição, posição e formato dos processos ósseos no hemitriquium ventral da nadadeira pélvica direita de machos de Deuterodon iguape. (a) vista ventral, (b) vista lateromedial, (c) detalhe em vista ventral e (d) detalhe em vista lateromedial.

Figura 163. Nadadeira anal de machos (a) e de fêmeas (b) de Hemigrammus bleheri em vista lateral esquerda, evidenciando o formato do perfil distal das nadadeiras nos dois sexos e distribuição dos processos ósseos na nadadeira anal de macho. 
Figura 164. Distribuição, posição e formato dos processos ósseos no hemitriquium esquerdo do raio ramificado da nadadeira anal de machos de Hemigrammus bleheri. (a) vista lateral, (b) detalhe em vista lateral e (c) detalhe em vista anteroposterior.

Figura 165. Nadadeira anal de machos (a) e de fêmeas (b) de Hemigrammus rhodostomus em vista lateral esquerda, evidenciando o formato do perfil distal das nadadeiras nos dois sexos e distribuição dos processos ósseos na nadadeira anal de macho.

Figura 166. Distribuição, posição e formato dos processos ósseos no hemitriquium esquerdo do raio ramificado da nadadeira anal de machos de Hemigrammus rhodostomus. (a) vista lateral, (b) vista anteroposterior, (c) detalhe em vista lateral, (d) detalhe em vista anteroposterior.

Figura 167. Nadadeira anal de machos de Hemigrammus ulreyi em vista lateral esquerda, evidenciando o formato do perfil da margem distal da nadadeira e distribuição dos processos ósseos.

Figura 168. Nadadeira pélvica de machos (a) e de fêmeas (b) de Hemigrammus ulreyi em vista lateral esquerda, evidenciando o formato e comprimento da nadadeira nos dois sexos.

Figura 169. Distribuição, posição e formato dos processos ósseos no hemitriquium esquerdo do raio ramificado da nadadeira anal de machos de Hemigrammus ulreyi. (a) vista lateral, (b) vista anteroposterior, (c) detalhe em vista lateral, (d) detalhe em vista anteroposterior.

Figura 170. Distribuição, posição e formato dos processos ósseos no hemitriquium ventral da nadadeira pélvica esquerda de machos de Hemigrammus ulreyi. (a) vista ventral, (b) detalhe em vista ventral e (c) detalhe em vista lateromedial.

Figura 171. Nadadeira pélvica de machos (a) e de fêmeas (b) de Hemigrammus unilineatus em vista lateral esquerda, evidenciando o formato e comprimento da nadadeira nos dois sexos.

Figura 172. Distribuição, posição e formato dos processos ósseos no hemitriquium esquerdo do raio ramificado da nadadeira anal de machos de Hemigrammus unilineatus. (a) vista lateral, (b) vista anteroposterior, (c) detalhe em vista lateral, (d) detalhe em vista anteroposterior.

Figura 173. Distribuição, posição e formato dos processos ósseos no hemitriquium ventral da nadadeira pélvica direita de machos de Hemigrammus unilineatus. (a) vista ventral, (b) vista lateromedial, (c) detalhe em vista ventral e (d) detalhe em vista lateromedial. 
Figura 174. Nadadeira pélvica de machos de Hemigrammus herbertaxelrodi em vista ventral (a) e em vista lateral esquerda (b), evidenciando o formato e comprimento da nadadeira.

Figura 175. Distribuição, posição e formato dos processos ósseos no hemitriquium esquerdo do raio ramificado da nadadeira anal de machos de Hemigrammus herbertaxelrodi. (a) vista lateral, (b) vista anteroposterior, (c) detalhe em vista lateral, (d) detalhe em vista anteroposterior.

Figura 176. Distribuição, posição e formato dos processos ósseos no hemitriquium ventral da nadadeira pélvica direita de machos de Hemigrammus herbertaxelrodi. (a) vista ventral, (b) vista lateromedial, (c) detalhe em vista ventral e (d) detalhe em vista lateromedial.

Figura 177. Nadadeira anal de machos (a) de Jupiaba yarina e detalhe da porção anterior (b) em vista lateral esquerda, evidenciando o formato do perfil da margem distal da nadadeira e distribuição dos processos ósseos.

Figura 178. Nadadeira pélvica de machos (a) e de fêmeas (b) de Jupiaba yarina em vista lateral esquerda, evidenciando o formato e comprimento da nadadeira nos dois sexos.

Figura 179. Distribuição, posição e formato dos processos ósseos no hemitriquium esquerdo do raio ramificado da nadadeira anal de machos de Jupiaba yarina. (a) vista lateral, (b) vista anteroposterior, (c) detalhe em vista lateral, (d) detalhe em vista anteroposterior.

Figura 180. Distribuição, posição e formato dos processos ósseos no hemitriquium ventral da nadadeira pélvica direita de machos de Jupiaba yarina. (a) vista ventral, (b) detalhe em vista ventral e (c) detalhe em vista lateromedial.

Figura 181. Nadadeira anal de machos de Moenkhausia sanctaefilomenae em vista lateral esquerda, evidenciando o formato do perfil da margem distal da nadadeira e distribuição dos processos ósseos.

Figura 182. Distribuição, posição e formato dos processos ósseos no hemitriquium esquerdo do raio ramificado da nadadeira anal de machos de Moenkhausia sanctaefilomenae. (a) vista lateral, (b) vista anteroposterior, (c) detalhe em vista lateral, (d) detalhe em vista anteroposterior.

Figura 183. Distribuição, posição e formato dos processos ósseos no hemitriquium ventral da nadadeira pélvica direita de machos de Moenkhausia sanctaefilomenae. (a) vista ventral, (b) vista lateromedial, (c) detalhe em vista ventral e (d) detalhe em vista lateromedial. 
Figura 184. Nadadeira anal de machos de Poptella paraguayensis em vista lateral esquerda, evidenciando o formato do perfil da margem distal da nadadeira e distribuição dos processos ósseos.

Figura 185. Distribuição, posição e formato dos processos ósseos no hemitriquium esquerdo do raio ramificado da nadadeira anal de machos de Poptella paraguayensis. (a) vista lateral, (b) vista anteroposterior, (c) detalhe em vista lateral, (d) detalhe em vista anteroposterior.

Figura 186. Distribuição, posição e formato dos processos ósseos no hemitriquium ventral da nadadeira pélvica direita de machos de Poptella paraguayensis. (a) vista ventral, (b) vista lateromedial, (c) detalhe em vista ventral e (d) detalhe em vista lateromedial.

Figura 187. Nadadeira anal de machos de Stethaprion crenatum em vista lateral esquerda, evidenciando o formato do perfil da margem distal da nadadeira e distribuição dos processos ósseos.

Figura 188. Distribuição, posição e formato dos processos ósseos no hemitriquium direito do raio ramificado da nadadeira anal de machos de Stethaprion crenatum. (a) vista lateral, (b) vista anteroposterior, (c) detalhe em vista lateral, (d) detalhe em vista anteroposterior.

Figura 189. Distribuição, posição e formato dos processos ósseos no hemitriquium ventral da nadadeira pélvica direita de machos de Stethaprion crenatum. (a) vista ventral, (b) vista lateromedial, (c) detalhe em vista ventral e (d) detalhe em vista lateromedial.

Figura 190. Nadadeira anal de machos de Tetragonopterus argenteus em vista lateral esquerda, evidenciando o formato do perfil da margem distal da nadadeira e distribuição dos processos ósseos.

Figura 191. Distribuição, posição e formato dos processos ósseos no hemitriquium esquerdo do raio ramificado da nadadeira anal de machos de Tetragonopterus argenteus. (a) vista lateral, (b) vista anteroposterior, (c) detalhe em vista lateral, (d) detalhe em vista anteroposterior.

Figura 192. Distribuição, posição e formato dos processos ósseos no hemitriquium ventral da nadadeira pélvica direita de machos de Tetragonopterus argenteus. (a) vista ventral, (b) vista lateromedial, (c) detalhe em vista ventral e (d) detalhe em vista lateromedial.

Figura 193. Brânquia com glândula branquial em vista lateral direita (a), detalhe da região anterior do ceratobranquial direito, evidenciando a glândula branquial (b) em Tetragonopterus argenteus. 
Figura 194. Nadadeira anal de machos (a) e de fêmeas (b) de Bryconamericus cf. peruanus em vista lateral esquerda, evidenciando o formato do perfil distal das nadadeiras nos dois sexos e distribuição dos processos ósseos na nadadeira anal de macho.

Figura 195. Distribuição, posição e formato dos processos ósseos no hemitriquium esquerdo da nadadeira anal de machos de Bryconamericus cf. peruanus. (a) vista lateral, (b) vista anteroposterior, (c) detalhe em vista lateral e (d) detalhe em vista anteroposterior.

Figura 196. Distribuição, posição e formato dos processos ósseos no hemitriquium ventral da nadadeira pélvica de machos de Bryconamericus cf. peruanus. (a) vista ventral, (b) venta lateromedial, (c) detalhe em vista ventral, (c) detalhe em vista lateromedial.

Figura 197. Brânquia com glândula branquial em vista lateral direita (a), detalhe da região anterior do ceratobranquial direito, evidenciando a glândula branquial (b) em Bryconamericus cf. peruanus.

Figura 198. Nadadeira anal de machos (a) e de fêmeas (b) de Diapoma speculiferum em vista lateral esquerda, evidenciando o formato do perfil distal das nadadeiras nos dois sexos e distribuição dos processos ósseos na nadadeira anal de macho.

Figura 199. Distribuição, posição e formato dos processos ósseos no hemitriquium esquerdo do raio ramificado da nadadeira anal de machos de Diapoma speculiferum. (a) vista lateral, (b) vista anteroposterior, (c) detalhe em vista lateral, (d) detalhe em vista anteroposterior.

Figura 200. Distribuição, posição e formato dos processos ósseos no hemitriquium ventral da nadadeira pélvica direita de machos de Diapoma speculiferum. (a) vista ventral, (b) vista lateromedial, (c) detalhe em vista ventral e (d) detalhe em vista lateromedial.

Figura 201. Pedúnculo caudal de machos (a) e de fêmeas (b) de Diapoma speculiferum, evidenciando a exposição e formato da extremidade distal dos raios procurrentes ventrais de macho.

Figura 202. Nadadeira pélvica de machos (a) e de fêmeas (b) de Diapoma speculiferum em vista ventral, evidenciando o formato da nadadeira nos dois sexos.

Figura 203. Nadadeira anal de machos de Eretmobrycon bayano em vista lateral esquerda, evidenciando o formato do perfil da margem distal da nadadeira e distribuição dos processos ósseos.

Figura 204. Nadadeira caudal de machos (a) e de fêmeas (b) de Eretmobrycon bayano em vista lateral esquerda, evidenciando o formato das nadadeiras. 
Figura 205. Pedúnculo caudal de machos (a) e de fêmeas (b) de Eretmobrycon bayano, evidenciando a disposição das escamas posteriores das séries de escamas ventrais à série de escamas mediana.

Figura 206. Nadadeira pélvica de machos (a) e de fêmeas (b) de Eretmobrycon bayano em vista lateral ventral, evidenciando o formato e comprimento da nadadeira nos dois sexos.

Figura 207. Distribuição, posição e formato dos processos ósseos no hemitriquium direito do raio ramificado da nadadeira anal de machos de Eretmobrycon bayano. (a) vista lateral, (b) vista anteroposterior, (c) detalhe em vista lateral e (c) detalhe em vista anteroposterior.

Figura 208. Distribuição, posição e formato dos processos ósseos no hemitriquium ventral da nadadeira pélvica direita de machos de Eretmobrycon bayano. (a) vista ventral, (b) vista lateromedial, (c) detalhe em vista ventral e (d) detalhe em vista lateromedial.

Figura 209. Nadadeira anal de machos (a) e de fêmeas (b) de Gephyrocharax atracaudata em vista lateral esquerda, evidenciando o formato do perfil distal das nadadeiras nos dois sexos e distribuição dos processos ósseos na nadadeira anal de macho.

Figura 210. Nadadeira pélvica de machos (a) e de fêmeas (b) de Gephyrocharax atracaudata em vista lateral ventral, evidenciando o formato e comprimento da nadadeira nos dois sexos.

Figura 211. Nadadeira dorsal de machos (a) e de fêmeas (b) de Gephyrocharax atracaudata em vista lateral esquerda, evidenciando o formato e comprimento da nadadeira nos dois sexos.

Figura 212. Nadadeira caudal de machos de Gephyrocharax atracaudata (a) e detalhe do lobo ventral (b) em vista lateral esquerda, evidenciando o formato do perfil da margem distal da nadadeira e distribuição dos processos ósseos.

Figura 213. Pedúnculo caudal de machos (a) e de fêmeas (b) de Gephyrocharax atracaudata, evidenciando o número e disposição das escamas do lobo ventral da nadadeira caudal e o órgão caudal.

Figura 214. Distribuição, posição e formato dos processos ósseos no hemitriquium esquerdo do raio ramificado da nadadeira anal de machos de Gephyrocharax atracaudata. (a) vista lateral, (b) vista anteroposterior, (c) detalhe em vista lateral, (d) detalhe em vista anteroposterior.

Figura 215. Distribuição, posição e formato dos processos ósseos no hemitriquium ventral da nadadeira pélvica esquerda de machos de Gephyrocharax atracaudata. (a) vista ventral, (b) vista lateromedial, (c) detalhe em vista ventral e (d) detalhe em vista lateromedial. 
Figura 216. Distribuição, posição e formato dos processos ósseos no hemitriquium esquerdo da nadadeira caudal de machos de Gephyrocharax atracaudata. (a) vista lateral esquerda e (b) detalhe em vista lateral esquerda.

Figura 217. Nadadeira anal de machos de Hysteronotus megalostomus: (a) porção anterior evidenciando a distribuição dos processos ósseos e (b) detalhe dos processos ósseos em vista lateral e anteroposterior.

Figura 218. Nadadeira pélvica direita de machos de Hysteronotus megalostomus em vista ventral, evidenciando a distribuição dos processo ósseos na nadadeira.

Figura 219. Nadadeira caudal de machos de Hysteronotus megalostomus em vista lateral esquerda, evidenciando a distribuição dos processos ósseos e posição da escama modificada (a) e detalhe da escama modificada (b).

Figura 220. Brânquia com glândula branquial em vista lateral direita, evidenciando a glândula branquial ocupando todos os filamentos branquiais do ceratobranquial em Hysteronotus megalostomus.

Figura 221. Nadadeira anal de machos (a) e de fêmeas (b) de Knodus heteresthes em vista lateral esquerda, evidenciando o formato do perfil distal das nadadeiras nos dois sexos e distribuição dos processos ósseos na nadadeira anal de macho.

Figura 222. Nadadeira pélvica de machos (a) e de fêmeas (b) de Knodus heteresthes em vista ventral, evidenciando o formato e comprimento da nadadeira nos dois sexos.

Figura 223. Distribuição, posição e formato dos processos ósseos no hemitriquium esquerdo do raio ramificado da nadadeira anal de machos de Knodus heteresthes. (a) vista lateral, (b) vista anteroposterior, (c) detalhe em vista lateral, (d) detalhe em vista anteroposterior.

Figura 224. Distribuição, posição e formato dos processos ósseos no hemitriquium ventral da nadadeira pélvica direita de machos de Knodus heteresthes. (a) vista ventral, (b) vista lateromedial, (c) detalhe em vista ventral e (d) detalhe em vista lateromedial.

Figura 225. Brânquia com glândula branquial em vista lateral direita (a) e detalhe da região anterior evidenciando a glândula branquial (b) em Knodus heteresthes.

Figura 226. Nadadeira anal de machos (a) e de fềmeas (b) de Pseudocorynopoma doriae em vista lateral esquerda, evidenciando o formato do perfil distal das nadadeiras nos dois sexos e distribuição dos processos ósseos na nadadeira anal de macho. 
Figura 227. Porção anterior da nadadeira anal de machos de Pseudocorynopoma doriae (a) e detalhe das membranas interradiais de raios do lobo anterior da nadadeira, evidenciando as projeções digitiformes (b).

Figura 228. Nadadeira dorsal de machos (a) e de fêmeas (b) de Pseudocorynopoma doriae em vista lateral esquerda, evidenciando o formato e comprimento da nadadeira nos dois sexos.

Figura 229. Nadadeira peitoral de machos (a) e de fêmeas (b) de Pseudocorynopoma doriae em vista lateral ventral, evidenciando o formato e comprimento da nadadeira nos dois sexos.

Figura 230. Distribuição, posição e formato dos processos ósseos no hemitriquium esquerdo do raio ramificado da nadadeira anal de machos de Pseudocorynopoma doriae. (a) vista lateral, (b) vista anteroposterior, (c) detalhe em vista lateral e (c) detalhe em vista anteroposterior.

Figura 231. Distribuição, posição e formato dos processos ósseos no hemitriquium ventral da nadadeira pélvica direita de machos de Pseudocorynopoma doriae. (a) vista ventral, (b) vista lateromedial, (c) detalhe em vista ventral e (d) detalhe em vista lateromedial.

Figura 232. Porção ventral do pedúnculo caudal de machos (a) e de fêmeas (b) de Pseudocorynopoma doriae, evidenciando o formato e disposição das escamas posteriores das séries de escamas ventrais à série de escamas da linha lateral.

Figura 233. Nadadeira anal de machos (a) e de fêmeas (b) de Scopaeocharax rhinodus em vista lateral esquerda, evidenciando o formato do perfil distal das nadadeiras nos dois sexos e distribuição dos processos ósseos na nadadeira anal de macho.

Figura 234. Nadadeira pélvica de machos (a) e de fêmeas (b) de Scopaeocharax rhinodus em vista ventral, evidenciando o formato e comprimento da nadadeira nos dois sexos.

Figura 235. Nadadeira pélvica de machos (a) e de fêmeas (b) de Scopaeocharax rhinodus em vista lateral esquerda, evidenciando o formato e comprimento da nadadeira nos dois sexos.

Figura 236. Nadadeira dorsal de fêmeas (a) e de machos (b) de Scopaeocharax rhinodus em vista lateral esquerda, evidenciando o formato e comprimento da nadadeira nos dois sexos.

Figura 237. Pedúnculo caudal e nadadeira caudal de machos (a) e fêmeas (b) de Scopaeocharax rhinodus em vista lateral esquerda, evidenciando a escama modificada e o formato dos lobos nos dos sexos.

Figura 238. Pedúnculo caudal e nadadeira caudal de machos (a) e de fêmeas (b) de Scopaeocharax rhinodus, evidenciando o número e disposição das escamas. 
Figura 239. Distribuição, posição e formato dos processos ósseos no hemitriquium esquerdo do raio ramificado da nadadeira anal de machos de Scopaeocharax rhinodus. (a) vista lateral, (b) vista anteroposterior, (c) detalhe em vista lateral, (d) detalhe em vista anteroposterior.

Figura 240. Distribuição, posição e formato dos processos ósseos no hemitriquium ventral da nadadeira pélvica direita de machos de Scopaeocharax rhinodus. (a) vista ventral, (b) vista lateromedial, (c) detalhe em vista ventral e (d) detalhe em vista lateromedial.

Figura 241. Distribuição, posição e formato dos processos ósseos no hemitriquium esquerdo da nadadeira caudal de machos de Scopaeocharax rhinodus. (a) vista lateral esquerda do lobo dorsal e (b) vista lateral esquerda do lobo ventral.

Figura 242. Esquema de um raio ramificado em vista lateral, evidenciando a distribuição das séries de processos ósseos e as bifurcações. 


\section{Sumário}

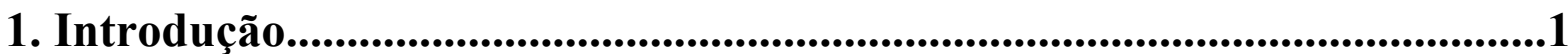

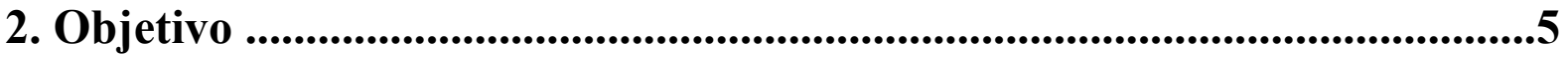

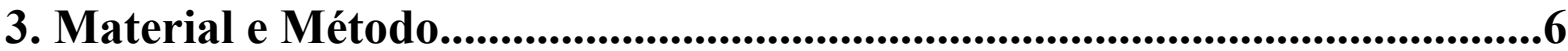

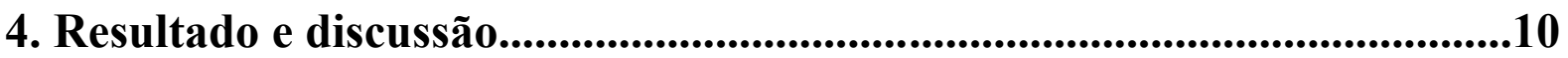

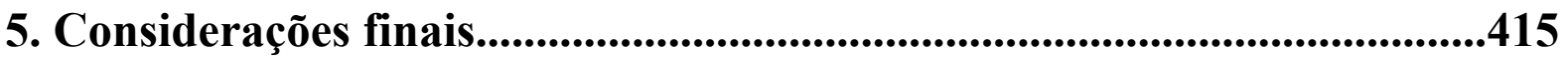

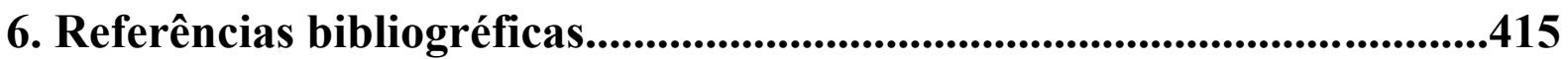




\section{Introdução}

A ordem Characiformes compreende atualmente atualmente 2089 espécies válidas (Eschmeyer \& Fong, 2016). O número de famílias reconhecidas na ordem tem variado historicamente em decorrência das diferentes delimitações da família Characidae (Moreira, 2007), principalmente em relação à conceituação de Serrasalmidae, Acestrorhynchidae, Cynodontidae e Alestidae, que podem ser reconhecidas como famílias distintas ou subgrupos de Characidae (Machado-Allison, 1982; 1983, 1985, 1986; Uj, 1990; Lucena \& Menezes, 1998; Jégu, 2003; Malabarba e Weitzman, 2003; Menezes, 2003; Toledo-Pizza, 2000, 2003 e 2007; Calcagnotto et al.,2005; Zanata, 2005; Orti et al.,1996; Javonillo et al.,2010; Mirande, 2010; Oliveira et al.,2011).

Dentre todas as famílias, Characidae, com 1209 espécies válidas (Eschmeyer \& Fong, 2016) é, sem dúvida, a mais problemática, com suas relações intra e interfamiliares dentro de Characiformes ainda pouco definidas. Isto se deve à imensa diversidade e variação morfológica presente em seus representantes. Os membros de Characidae (Sensu Mirande, 2010) variam de algus milímetros de coprimento padrão, como é o caso das espécies de Cyanogaster Mattox et al., (2013) e Xenurobryconini (Weitzman \& Fink, 1985; Moreira, 2005), a mais de um metro de comprimento padrão, como é o caso de algumas espécies de Salminus (Lima \& Britski, 2007). Existe também uma vairação enorme de hábitos alimentares, desde espécies carnívoras como as de Acestrorhynchus Eigenmann \& Kennedyi 1903 (Silva \& Goitein, 2007) a espécies lepidophagas (que se alimentam de escamas) como as de Roeboides Günther 1864 (Novakowski \& Hahn, 2004). Os membros de Characidae apresentam também uma diversidade ainda maior do modo reprodutivo, com espécies migradoras com fecundidade alta e período reprodutivo curto (e.g. Samlminus) a espécies 
inserminadoras, que depositam pacotes de espermatozoide na luz do ovário das fêmeas (e.g. membros de Glandulocaudinae sensu Weitzman \& Menezes, 1998) (Vazzoler \& Menezes, 1992; Burns et al., 1995; Vazzoler, 1996; Weitzman et al., 2005; Azevedo, 2010). Tão impressionante quanto à diversidade no modo reprodutivo e provavelmente relacionada a esta, é a incrível variação de características dimórficas, caracteres sexuais secundários presentes.

Embora alguns trabalhos, tanto morfológicos (Mirande, 2009, 2010) quanto moleculares (Javonillo et al., 2010; Oliveira et al, 2011), incluindo um grande número de taxons terminais tenham sido realizadas, as relações intra e interfamiliares continuam muito controversas. Estes trabalhos, no entanto corroboram o monofiletismo de um grupo caracterizado pela ausência do osso supra-orbital, um caráter aparentemente redutivo: (clado 204 de Mirande, 2010; Clado 37 de Oliveira et al.,2011; Clado A de Malabarba \& Weitzman, 2003 - semelhante ao "ortí clade" proposto em Ortí \& Meyer, 1997)

Weitzman \& Fink (1983), Weitzman \& Palmer (1997b) e Weitzman \& Malabarba (1998) resumiram as principais dificuldades enfrentadas por ictiólogos no estudo de relações intra e interfamiliares em Characidae: 1) grande diversidade aliada à relativa pouca divergência morfológica, 2) redução em tamanho, com consequente perda/truncamento de muitas estruturas por pedomorfose, 3) falta de boas séries de exemplares bem preservados e sexualmente desenvolvidos em coleções, e 4) necessidade de mais informação quanto ao colorido em vida e dimorfismo sexual.

De fato, os grupos monofiléticos bem corroborados em Characidae apresentam caracteres relacionados ao dimorfismo sexual como sinapomorfia [e.g. Xenurobryconini (weitzman \& Fink, 1985), Glandulocaudainae (Menezes \& Weitzman, 2009), Compsurini (Malabarba, 1998; Jerep, 2011). Observamos também que embora tentivamente, sem análise filogenética, pequenos grupos supostamente monofiléticos, atualmente incluídos em 
Tetragonopterinae (sensu Mirande, 2010), como o grupo Rosy-Tetras (Weitzman \& Palmer, $1997^{\mathrm{a}}$ ), grupo Hyphessobrycon loweae (Ingeninto et al., 2013), grupo Hemigrammus ocellifer (lima \& Sousa, 2009) e o grupo Hemigrammus bleheri, H. rhodostomus e Petitella gerogiae (Lima \& Sousa, 2009) foram propostos baseado no compartilhamente de caracteres sexuais secundários.

De modo geral, caracteres sexuais secundários são aqueles que diferenciam machos e fêmeas da mesma espécie e que não estão diretamente relacionados ao processo reprodutivo e que são selecionados através de seleção sexual (Darwin, 1981). Os caracteres sexuais secundários encontrados em Characidae estão basicamente relacionados ao tamanho, comprimento e formato das nadadeiras, presença e distribuição de ganchos nos raios de nadadeiras e estruturas associadas, glândula branquial, modificações de escamas e raios de nadadeiras, modificação de procurrentes ventrais e padrão de colorido. Em Characidae a condição dimórfica relacionada ao formato do corpo pode estar associada tanto a diferenças no comprimento padrão, onde as fêmeas são geralmente maiores que os machos: Salminus (Moraes \& Schubart, 1955; Cordiviola, 1966; Godoy, 1975; Lima, 2006) e Astyanax (Von Ihering \& Azevedo, 1936; Andrade et al.,1984) ou na altura e comprimento do pedúnculo caudal: Hyphessobrycon negodagua (Lima \& Gerhard, 2001) e quase todos os membros de Glanulocaudinae (Menezes \& Weitzman, 2009).

Dimorfismo quanto ao comprimento e formato das nadadeiras tem sido bastante discutidos, principalmente em gêneros incertae sedis: Hyphessobrycon (Weitzman \& Palmer, 1997a,b; Costa \& Géry, 1994; Moreira, et al.,2002b,c; Teixeira et al, 2013); em gêneros da tribo Compsurini (Malabarba, 1998); em gêneros atualmente alocados em Stevardiinae sensu Mirande (2010): Bryconadenos (Weitzman et al.,2005); Attonitus (Vari \& Ortega, 2000) e 
$\overline{\text { Bryttanichthys (Weitzman et al.,2005); e todos os gêneros de Glandulocaudinae (Menezes \& }}$ Weitzman, 2009).

A presença de ganchos (= órgão de contato de Wiley \& Collette, 1970 e Collette, 1977) nas nadadeiras é um dos caracteres sexuais secundários mais evidentes dentro da família. Ganchos são processos desenvolvidos na superfície de segmentos individuais dos raios, podendo diferir em forma, posição e possivelmente função entre as espécies que os apresentam (Malabarba \& Weitzman, 2003). Segundo Roberts (1973) a primeira referência a órgão de contato (=ganchos) foi feita por Jenyns (1842) quando mencionou a presença de "asperities" nas nadadeiras de Cheirodon (= Astyanax scabripinnis). Naquela ocasião, que aparentemente constitui a primeira menção de caracteres sexuais secundários em Characidae, Jenyns (1842) concluiu que essas estruturas representavam um caráter dimórfico presente nos machos, no entanto, Jenyns não fez menção alguma quanto ao formato ou distribuição destas estruturas. Foi Eigenmann (1908 - 1929) o primeiro a se atentar a estas estruturas, atribuindo forma e distribuição nas nadadeiras, usando inclusive como caracteres diagnósticos de chaves de identificação. O primeiro nome usado por Eigenmann para se referir a estas estruturas foi "Hooklets" (tradução apra espínula), na descrição de Gymnocorymbus thayeri. Eigenmann 1908, logo se referio às estururas de Moekhausia ceros como "hooks". Desde então, presença de ganchos foi mencionda em vários trabalhos, principalmente os que contém descrição de novos táxons.

Outra estrutura bastante interessante, é a glândula branquial. Estas glândulas são modificações nos filamentos branquiais anteriores do primeiro arco branquial de machos maduros, e possivelmente estão relacionadas à liberação de feromônio (Burns \& Weitzman, 1996; Bushman et al.,2002). A distribuição, morfologia e prostas de homologia das glândulas 
brânquiais foram extensamente estudadas em Characidae (Bushmane et al., 2002; Oliveria et al., 2012; Terán et al., 2014).

Como podemos observar a diversidade de caracteres sexuais secundários em Characidae é espetacular e foi extremamente explorada em grupos menos inclusivos e segundo a proposta de Mirande (2010), derivados em Characidae. É interessante notar, que esta variação se mostrou extremamente informativa filogeneticamente, sustentando grupos bem corroborados, principalmente aqueles incluídos tradicionalmente em Glandulocaudinae (sensu Weitzman \& Menezes, 1998). Embora tenha havido um notável avanço no conhecimento dos caracteres sexuais secundários em Characidae, nota-se que grande parte dos estudos se trestrinjem aos taxons com caracteres sexuais secundários mais evidentes, mais especializados e em grupos muito pouco inclusivos, muitas vezes compostos por menos de cinco espécies. Ao longo de alguns anos, tenho observado padrões interessantes em caracteres dimórficos pouco explorados, mais sutís e em taxons incertae sedis em Characidae (sensu Lima et al., 2003). Tenho encontrado também, possíveis direções de especialização dos caracteres mais conhecidos em grupos bem estudados, como Glandulocaudinae (sensu Weitzman \& Menezesm, 1998). Com esses possíveis padrões em mente, junto à comprovada informatividade dos caracteres sexuais secundários na resolução de grupos em níveis menos inclusivos, acreditamos que uma análise anatômica comparada detalhada de alguns destes caracteres de uma forma mais abrangente em Characidae, pudesse possibilitar o levantamente de informações e interprestações que viessem a lançar luz sobre as relações de grupos algun grupos menos conhecidos em Characidae.

\section{Objetivo}


Descrever e realizar uma análise anatômica comparada dos caracteres sexuais secundários de uma forma ampla em Characidae, afim de evidenciar padrões que possam no futuro, em conjunto com outros caracteres, lançar luz sobre as relações de grupos menos inclusivos.

\section{Material e Métodos}

\section{Seleção de táxons terminais}

A escolha do grupo interno se baseou principalmente nas espécies analisadas na proposta filogenética de Characidae baseada em dados morfológicos apresentada por Mirande (2010). Dentre estas, prioridade foi dada a espécies representantes de todos os grupos menos inclusivos previamente apontados na literatura e pelos especialistas do respectivo grupo como detentores de caracteres sexuais secundários. Nos grupos com propostas filogenéticas disponíveis, sempre que possível, foram analisados táxons em diferentes níveis de inclusão na filogenia. Sendo assim, com algumas exceções, a maioria dos táxons analisados neste trabalho foram incluídos na proposta de Mirande (2010). O grupo externo é composto por representantes das famílias Crenuchidae, Gasteropelecidae e Serrasalmidae que apresentam caracteres sexuais secundários semelhantes aos presentes em membros de Characidae. formado pelos representantes de todos os gêneros de Characiformes, exceto Characidae (sensu Mirande, 2010), que apresentem esses caracteres. Todo o material examinado pertencem à coleção ictiológica do Museu de Zoologia da Universidade de São Paulo.

\section{Caracteres sexuais secundários analisados}


Os caracteres estudados nesta contribuição são: tamanho, medido através do maior coprimento padrão; formato de nadadeiras; processos ósseos, glândula abranquial e órgão caudal.

\section{Anatomia comparada}

Para descrição e análise anatômica comparada desses caracteres neste projeto, a utilização de exemplares adultos maduros com os caracteres em seu estado ótimo de desenvolvimento era imprescindível. Como observado aqui, existe uma certa variação intrasexual no desenvolvimento de algunas dos caracteres, principalmente nos processos ósseos. Alguns machos possuem hipertrofia dos processos óssseos, apresentando uma condição que naturalmente não representa a expressão destes na espécie. A análise de um macho hipertrofiado com certeza afetaria os resultados da análise. Para determinar o estado de desenvolvimento ótimo destes caracteres e selecionar os melhores exemplares para as análises, uma análise anatômica comparada exaustiva do máximo possível de machos de cada espécies, incluindo sempre que possível lotes coletado em períodos e locais diferentes foi realizada, no intuito de entender a variação existente e definir o estado que melhor representa cada espécie. A sexagem dos exemplares foi realizada através de análise macroscópicas do estádio de desenvolvimento das gônadas seguindo Vazzoler (1996). Após enonctrar o exemplar que melhor representa o dimorfismo sexual da espécie, este era inserido em uma solução de alizarina Red S com alcool 70\% para corar os raios, procesoss ósseos, escamas e as glândulas branquiais. O raio da nadadeira como maiores processo ósseos foram desarticulados dos interradiais, logo os hemitriquiums foram separados e acomodados em KY para fotografia. Para a análise e descrição da glândula branquial, os ósseos hiomandibular, 
opérculo, inter e subopéruclo, infraorgitais, maxiar, dentário e premaxilar foram desarticulados do lado direto da cabeça. A descrição e medidas dos processos ósseos e glândula branquial foram realizadas através de imagens realizadas em uma lupa de automontagem (Leica MZ16 com câmera acoplada). Todos os caracteres foram ilustrados. No caso de táxons que apresentaram condições semelhantes dos caracteres sexuais secundários, foram apresentadas descrições generalizadas dos mesmos.

\section{Descrição dos processo ósseos.}

Como mencionado acima o raio da nadadeira com maiores processos ósseos foi utilizado para a descrição dos mesmos. Como veremos a seguir, os processos ósseos, em algumas espécies se distribuem em quase todos os segmentos da nadadeira. A descrição deta distribuiçãoo acabou se tornando bastante complicada uma vez que o raio ramificado apresenta várias bifurcações e cada ramo destas bifurcações bifurcam mais uma ou duas vezes. Para facilitar o entendimento destas descrições, sugerimos a observaçãoo do esquema apresentado (FIG. 1), 


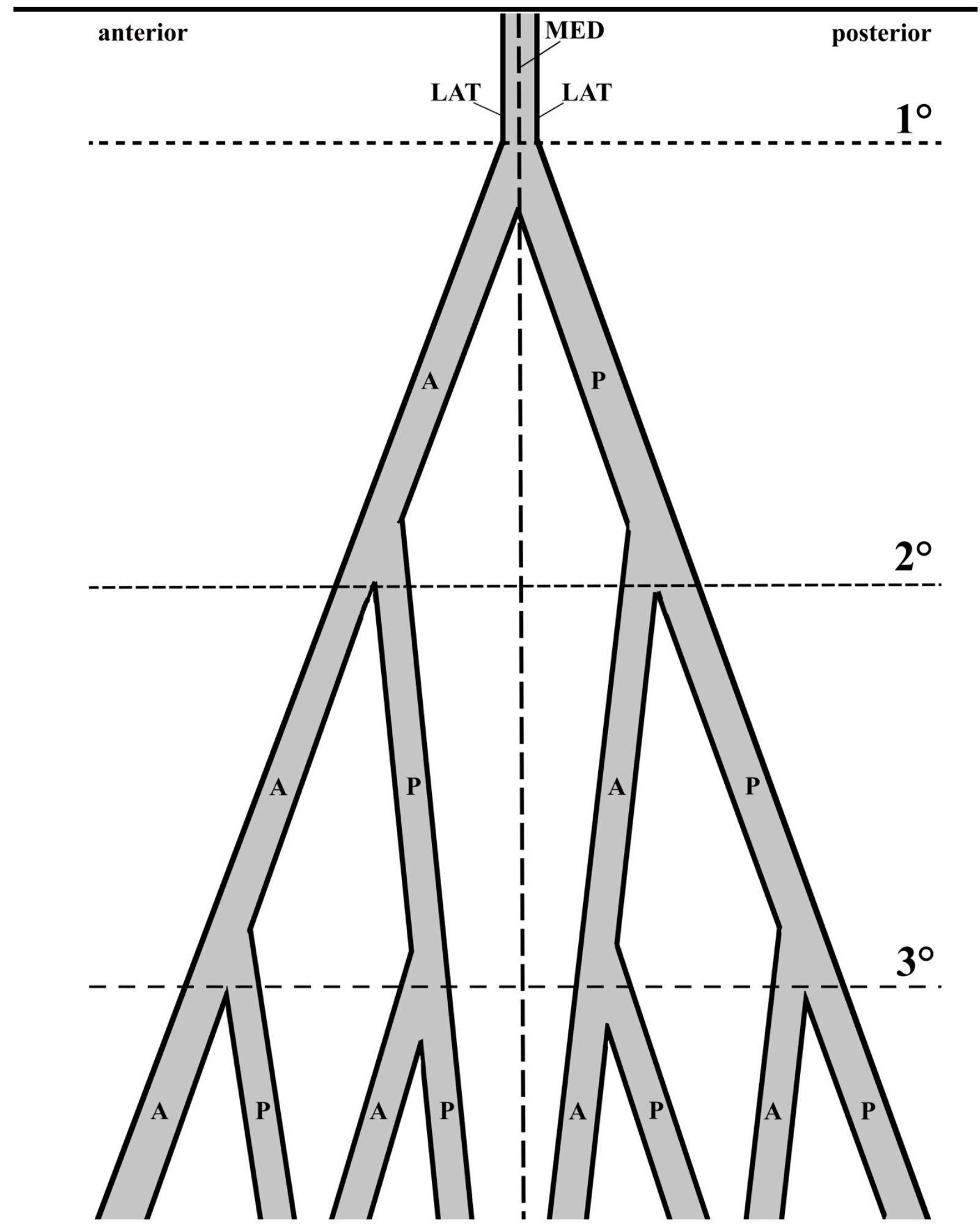

Figura 1. Esquema de um raio ramificado em vista lateral esquerda. As linhas pontilhadas horizontais representam as bifurcações mencionadas na descrição para cada ramo pós bifurcação. A linha pontilhada vertical, representa a linha mediana do raio e deve ser 
extrapolada para cada ramo. A letra "A" representa os ramos anteriores de cada bifuração e "P" os ramos posteriores.

\section{Resultado e discussão}

\subsection{Descrição dos caracteres sexuais secundários e anatomia comparada}

Nesta seção são descritos os caracteres sexuais secundários relacionados ao comprimento padrão, formato de nadadeiras, processos ósseos, glândula branquial, tubérculos reprodutivos e órgão caudal dos táxons terminais incluídos.

\section{Família Crenuchidae}

\section{CHARACIDIINAE}

Characidium xanthopterum Silveira, Langeani, Graça, Pavanelli \& Buckup 2008

Figs. 3 e 4

Localidade tipo: município de Caldas Novas, riacho fora do Parque Estadual de Caldas Novas, Goiás, Brasil.

Material examinado: MZUSP 113907, 4, Brazil, Goiás, São João da Aliança, Ribeirão das Brancas, Afl. Rio Tocantinzinho, ponte no Km, 71 da GO 118, entre São Gabriele São Joãoda Aliança, bacia do rio Tocantins, $14.8964444^{\circ} \mathrm{S}, 47,5828889^{\circ} \mathrm{W}$, Oyakawa et al., 27/11/2012. MZUSP 113897, 1, Brazil, Goiás, Sã João da Aliança, ribeirão das Brancas, afl. Rio Tocantinzinho, km 65 da GO 118, Birindelli et al., 27/11/2012. MZUSP 115607, 2, Brazil, 
Mato Grosso do Sul, Alcinópolis, córrego afl. Do rio Taquari, próx, Gaz. Taquarizinho, prop.

Sr. Manuel Carrizo, Oyakawa et al., 26/08/2013.

\section{Caracteres sexuais secundários}

Os caracteres sexuais secundários em C. xanthopterum relacionam-se ao comprimento padrão e presença de processos ósseos em nadadeiras.

Comprimento padrão: fêmeas alcançam maiores valores de comprimento padrão em relação aos machos. MZSUP 113907, 2 machos (36.3-37.9 mm CP) e 2 fêmeas (41.9-45.2 mm CP); MZUSP 113897, 1 macho (37.4 mm CP); MZUSP 115607, 2 macho (30.3-38.5 mm CP);

Processos ósseos: presentes nas nadadeiras pélvica e peitoral de machos.

Nadadeira pélvica com processos ósseos presentes e restritos a segmentos do hemitricuium dorsal. Nadadeira pélvica com processos ósseos nas extremidades proximal e distal de cada segmento de hemitriquium do primeiro ao quinto raio ramificado, disrtribuindo-se em $63 \%$ dos raios ramificados (até 8 raios ramificados). Raios ramificados com processos óesseos presentes tanto em segmentos proximais quanto em segmentos distais à primeira bifurcação. Proximalmente à primeira bifurcação, os processos ósseos estão presentes em até três segmentos. Distalmente à primeira bifurcação, os processos ósseos estão presentes em todos os segmentos dos ramos medial e lateral. Processos ósseos com secção transversal de sua inserção ovalada proximodistalmente. O maior comprimento de sua inserção ocupa $15 \%$ do comprimento proximodistal do segmento no qual está inserido. Em todos os segmentos, os processos ósseos desenvolvem-se tanto em sua extremidade distal quanto em sua extremidade proximal na face dorsal do segmento no qual desenvolvem-se. O processo da extremidade distal de um segmento junto ao processo da extremidade proximal do segmento imediatamente distal aparenta formar uma estrutura combinada, coberta por tecido. Os processos ósseos são retos e, em secção transversal, variam de ovalados proximodistalmente a 
$\overline{\text { cilíndricos ao longo de seu comprimento total. } \mathrm{O} \text { diâmetro de sua extremidade distal equivale }}$ a $20 \%$ do seu maior comprimento no local de sua inserção no segmento no qual está inserido. Em seu estado máximo de desenvolvimento, o seu comprimento total não alcança o comprimento proximodistal do segmento no qual está inserido. O comprimento do maior processo ósseo equivale a $41 \%$ do comprimento proximodistal do segmento no qual está inserido. $\mathrm{Na}$ nadadeira pélvica os processos ósseos apresentam tamanhos semelhantes ao longo da nadadeira; terceiro raio ramificado com o maior número de segmentos com processos ósseos. No raio os processos ósseos apresentam tamanhos semelhantes.

Nadadeira peitoral com processos ósseos restritos a segmentos do hemitricuium dorsal. Nadadeira peitoral com processos ósseos nas extremidades proximal e distal de cada segmento de hemitriquium do último raio simples ao quinto raio ramificado, disrtribuindo-se em $56 \%$ dos raios ramificados (até 9 raios ramificados). Último raio simples com processos ósseos do segundo ao décimo-primeiro segmento, que é o décimo segmento proximal do raio. Raios ramificados com processos presentes tanto em segmentos proximais quanto em segmentos distais à primeira bifurcação. Proximalmente à primeira bifurcação, os processos ósseos estão presentes em até cinco segmentos. Distalmente à primeira bifurcação, os processos ósseos estão presentes em todos os segmentos dos ramos medial e lateral. Processos ósseos com inserção ovalada proximodistalmente. Em todos os segmentos, os processos ósseos desenvolvem-se tanto em sua extremidade distal quanto em sua extremidade proximal na face dorsal do segmento no qual desenvolvem-se. O processo da extremidade distal de um segmento junto ao processo da extremidade proximal do segmento imediatamente distal aparenta formar uma estrutura combinada, coberta por tecido. Os processos ósseos são retos. Em secção transversal, os processos ósseos variam de ovalados proximodistalmente a cilíndricos ao longo de seu comprimento total. Em seu estado máximo de desenvolvimento, o 
seu comprimento total não alcança o comprimento proximodistal do segmento no qual está inserido. Na nadadeira peitoral os processos ósseos aumentam e diminuem de tamanho em direção lateromedial; primeiro raio ramificado com maior número de segmentos com processos ósseos e maiores processos ósseos. Quarto raio ramificado com o maior número de segmentos com processos ósseos. No raio os processos ósseos aumentam e diminuem de tamanho em direção proximodistal.

\section{Characidium xavante Graça, Pavanelli \& Buckup 2008}

Fig. 5

Localidade tipo : Córrego Xavante, Primavera do Leste, Mato Grosso, Brasil

Parátipos: MZUSP 87744, 20, Brasil, Mato Grosso, Primavera do Leste, córrego Xavante, bacia do rio Xingú, $13^{\circ} 55^{\prime} 43.0^{\prime}$ S, 5315’45.0”W, LIRP, 20/01/2002. MZUSP 87745, 20, Brasil, Mato Grosso, Paranatinga, primeiro riacho após a ponte do rio Culuene, bacia do rio Xingu, $13^{\circ} 55^{\prime} 43.0^{\prime}$ S, $53^{\circ} 15^{\prime} 45.0^{\prime \prime} \mathrm{W}$, LIRP, 10/01/2002. Não tipos: MZUSP 91912, 9, Brasil, Mato Grosso, Paranatinga, rio Culuene, na futura área da $\mathrm{PCH}$ Paranatinga, bacia do rio Xingu, $13^{\circ} 49^{\prime} 0.0^{\prime}$ 'S, 5315’0.0”W, J. L. Birindelli et al., 21/08/2006. MZUSP 94212, 7, Brasil, Matogrosso, rio Culuene, corredeira, 1349’0.0”S, 5349’0.0”W, F. C. T. Lima et al., 05/2007. MZUSP 97849, 4, Brasil, Mato Grosso, Primavera do Leste, ponte sobre o rio Xavante, 14³8’23.0’S, 5355’37.0’W, N. Menezes et al., 18/01/2002.

\section{Caracteres sexuais secundários}

Os caracteres sexuais secundários em C. xavante relacionam-se ao comprimento padrão e presença de processos ósseos em nadadeiras. 
Comprimento padrão: fêmeas alcançam maiores valores de comprimento padrão que machos. MZUSP 87744, 5 machos (17.5-21.9 mm CP) e 6 fêmeas (17.1-21.1); MZUSP 97849, 2 machos (22.6-22.23 mm CP) e 2 fêmeas (25.8-26.1 mm CP); MZUSP 91912, 2 machos (22.3-23.6 mm CP) e 4 fêmeas (21.1-23.1 mm CP)

Processos ósseos: presentes na nadadeira pélvica de machos.

Nadadeira pélvica com processos ósseos presentes e restritos a segmentos do hemitricuium dorsal. Nadadeira pélvica com um processo ósseo por segmento de hemitriquium do primeiro ao sétimo raios ramificados, disrtribuindo-se em $87 \%$ dos raios ramificados (8 raios ramificados). Raios ramificados com processos ósseos presentes tanto em segmentos proximais quanto em segmentos distais à primeira bifurcação. Proximalmente à primeira bifurcação, os processos ósseos estão presentes em até três segmentos. Distalmente à primeira bifurcação, os processos ósseos estão presentes em até seis segmentos do ramo medial e em até quatro segmentos proximais à segunda bifurcação deste ramo; existem nos dois ramos até dois segmentos sem processos ósseos intercalados com segmentos com processos ósseos. Processos ósseos com inserção arredondada. O maior diâmetro de sua inserção no segmento ocupa $25 \%$ do comprimento proximodistal do segmento no qual está inserido. Os processos ósseos estão inseridos na face dorsal dos segmentos no qual estão inseridos. Ao longo de seu comprimento total, os processos ósseos apresentam uma curvatura de $40^{\circ}$ em relação ao eixo proximodistal do segmento no qual estão inseridos e desenvolvem-se em direção distal em relação ao segmento no qual estão inseridos. Em secção transversal, os processos ósseos são cilíndricos ao longo de seu comprimento total, afilando-se muito pouco e terminando em uma extremidade arredondada. O diâmetro de sua extremidade distal equivale a $90 \%$ de seu diâmetro no local de sua inserção no segmento no qual está inserido. Em seu estado máximo de desenvolvimento, o seu comprimento total não alcança o comprimento proximodistal do 
$\overline{\text { segmento no qual está inserido. O comprimento do maior processo ósseo equivale } 42 \% \text { do }}$ comprimento proximodistal do segmento no qual está inserido. Na nadadeira, os processos ósseos aumentam e diminuem de tamanho em direção lateromedial; segmentos do terceiro raio ramificado com mais processos ósseos que os segmentos dos demais raios; os processos ósseos são maiores que nos outros raios . Em cada raio, os processos ósseos decrescem aumentam e diminum de tamanho em direção proximodistal.

\section{CRENUCHINAE}

\section{Crenhuchus spillurus}

\section{Localidade tipo:}

Material examinado: MZUSP 62773, 91, Guiana, Demerara, rio Essequibo, pequeno igarapé de água preta no lado oposto ao acampamento, C. Watson, et al., 23/11/1997.

Comprimento padrão: machos alcançam maiores valores que fêmeas. MZUSP 62773, 9 machos (26.4-47.7 mm CP) e 15 fêmeas (24.8-37.2 mm CP)

\section{Caracteres sexuais secundários}

Os caracteres sexuais secundários de C. spillurus estão relacionados ao comprimento padrão, formato de nadadeiras padrão de colorido.

Formato de nadadeiras: machos diferem de fêmeas pelo formato da margem distal da nadadeira anal e formato da nadadeira dorsal.

Perfil da margem distal da nadadeira anal de machos lanceolada. Nadadeira anal de aumentando gradualmente de tamanho do primeiro raio simples ao quinto rio ramificado (raio 
mais longo) e diminuição acentuada deste ao nono raio ramificado. Extremidade distal do quinto raio ramificado ultrapassando muito o limite posterior do pedúnculo caudal. Perfil da margem distal da nadadeira anal de fêmeas convexa/truncada. Nadadeira aumentando de tamanho do primeiro raio simples ao primeiro raio ramificado (raio mais longo) e diminuição gradual muito pouco deste ao sétimo e redução mais acentuada do sétimo ao nono raio ramificado. Extremidade distal do quinto raio ramificado no máximo alcança o limite posterior do pedúnculo caudal.

Perfil distal da nadadeira dorsal de machos com dois lobos, um anterior e um posterior. Lobo anterior falcado, formado pelo aumento gradual de tamanho do primeiro raio simples ao oitavo raio ramificado (raio mais longo da nadadeira); sétimo e oitavo raio se projetando como filamentos em relação ao raio imediatamente posterior, devido à diminuição acentuada de tamanho do oitavo ao nono raio ramificado. Lobo posterior convexo, formado pelo aumento gradual de tamanho do nno ao décimo primeiro raio ramificado (raio mais longo do lobo posterior) e diminuição gradual deste ao décimo quarto raio ramificado.

Perfil distal da nadadeira dorsal de fêmeas com dois lobos, um anterior e um posterior. Lobo anterior convexo, formado pelo aumento gradual do primeiro raio simples ao segundo raio ramificado (raio mais longo da nadadeira) e diminuição gradual deste ao sétimo raio ramificado. Lobo posterior convexo formado pelo aumento gradual do oitavo ao décimo primeiro raio ramificado (raio mais longo do lobo posterior) e diminuição deste ao décimo quarto raio ramificado.

\section{Família Gasteropelecidae}

\section{Carnegiella strigata (Gunther 1864)}


Fig. 6 e 7

Localidade tipo: sem localidade.

Material examinado: MZUSP 87339, 1, Brasil, Amazonas, Rio Preto da Eva, Igarapé afluente do rio Preto da Eva, depois do balneário do Encanto da Mata, bacia do rio Amazonas, 2³7'10.2”S, 5944’30.5”W, MZUSP/USP, 03/07/2003; MZUSP 87340, 1, Brasil, Amazonas, Rio Preto da Eva, rio Preto da Eva, cerca de $15 \mathrm{~km}$ ao norte da cidade, pela estrada que passa pelo Igarapé Manu, bacia do rio Amazonas, $2^{\circ} 35^{\prime} 57.7^{\prime} \mathrm{S}, 59^{\circ} 45^{\prime} 10.1^{\prime \prime} \mathrm{W}$, O. Oyakawa et al., 03/07/2003; MZUSP 87341, 1, Brasil, Amazonas, Rio Preto da Eva, Braço do rio Preto da Eva, no recanto da Mata, bacia do rio Amazonas, 2³8’25.8”S, 5944’5.7’W, MZUSP/USP, 03/07/2003; MZUSP 87342, 4, Brasil, Amazonas, Rio Preto da Eva, Igarapé Água Verde, na estrada na margem esquerda do rio Preto da Eva, , abaixo da cidade, bacia do rio Amazonas, 244’22.7’S, 5941'15.5’W, MZUSP/USP, 05/07/2003; MZUSP 87343, 2, Brasil, Amazonas, Rio Preto da Eva, rio Preto da Eva, acima da cidade, bacia do rio Amazonas, 241’S, 59 ${ }^{\circ}$ 42’W, MZUSP/USP, 08/07/2003; MZUSP 87344, 1, Brasil Amazonas, Rio Preto Eva, rio Preto da Eva, abaixo do Encanto da Mata, bacia do rio Amazonas, 2³8’58”S, 5943’50.1’W, MZUSP/USP. MZUSP 21027, 2, Brasil, Amazonas, Igarapé junto de Porto Antunes, Rio Jutaí, bacia do rio Solimões, Exp. Permanente da Amazônia, 22/10/1968; MZUSP 21028, 32, Brasil, Amazonas, igarapé do rio Içapó, na foz do rio Jutaí, bacia do rio Solimões, Exp. Permanente da Amazônia, 23/10/1968; MZUSP 21036, 5, Brasil, Amazonas, Fonte Boa, Igarapé n7úmero 1, bacia do rio Solimões, Exp. Permanente da Amazônia, 25/10/1968; MZUSP 21037, 6 (3 corados, 29.13, 32.41 e 32.50 mm CP), Brasil, Amazonas, Fonte Boa, igarapé número 3, bacia do rio Solimões, Exp. Permanente da Amazônia, 25/10/1968; MZUSP 85275, 4, Brasil, Amazonas, Fonte Boa, Alti-Paraná, acima 
do lago Buiu-Açú, NW de Fonte Boa, bacia do rio Solimões, 02³1'00”'S, 6606’00”W, Exp. Permanente da Amazônia, 12/10/1968. MZUSP 21582, 5, Brasil, Amazonas, rio Cuieiras e afluentes, bacia do rio negro, Exp. Alpha Helix, 11/1978; MZUSP 59194, 8, Brasil, Amazonas, Igarapé em Soão João, perto de Tapurucuara (= Santa Isabel do Rio Negro), Exp. Permanente da Amazônia, 23/10/1972; MZUSP 62070, 3, Brasil, Amazonas, rio Negro, Tapera, poça de praia, bacia do reio Negro, Exp. Permanente da Amazônia, 07/11/1972; MZUSP 66736, 7, Brasil, Amazonas, São João, próximo de Tapurucuara (= Santa Isabel do rio Negro), beira de lago de ilha, bacia do rio Negro, Exp. Permanente da Amazônia, 21/10/1972; MZUSP 66737, 15 (2 corados, 26.37-27.27mm CP), Brasil, Amazonas, São joão, próximo de Tapurucuara (= Santa Isabel do rio Negro), beria do lago de ilha, bacia do rio Negro, Exp. Permanente da Amazônia, 21/10/1972; MZUSP 66741, 19, Brasil, Amazonas, Tapurucuara (=Santa Isabel do rio Negro), Igarapé em são joão, bacia do rio Negro, Exp. Permanente da Amazônia, 27/10/1972; MZUSP 74069, 3, Brasil, Amazonas, São João, próximo a Tapurucuara (= Santa Isabel do Rio Negro), Igarapé de terra firme, bacia do rio Negro, 23/10/1972; MZUSP 74249, 36, Brasil, Amazonas, Manaus, Igarapé Jaradá, afluente da margem direita do rio Cuieiras, ca. De $40 \mathrm{~km}$ da boca, bacia do rio Negro, Exp. Alpha Helix, 31/01/1977; MZUSP 85282, 2, Brasil, Amazonas, Santa Isabel do Rio Negro, São João, bacia do rio Negro, 00²4’00”S, 6502’00”W, Exp. Permanente da Amazônia, 27/10/1972; MZUSP 85284, 15 (1 corado, 29.7 mm CP), Brasil, Amazonas, São João, próx. de Tapurucuara (= Santa Isabel do rio Negro), bacia do rio Negro, $0^{\circ} 24^{\prime} 0.0^{\prime}$ 'S, $65^{\circ} 2^{\prime} 0.0^{\prime \prime} \mathrm{W}$, Exp. Permanente da Amazônia, 27/10/1972; MZUSP 92503, 2, Brasil, Amazonas, Igarapé Castanha, afluente do rio Tiquié, próximo a foz, bacia do rio Negro, $00^{\circ} 12^{\prime} 00^{\prime} \mathrm{S}$, 69³5’00”W, F. C. T. Lima et al., 08/2006; MZUSP 113078, 7, Brasil, Roraima, Caracaraí, poça temporária que se conecta no igarapé pupunha, atrás da vilade Caicubi, bacia do rio 
Negro, 1¹'28.0”S, 625’20.0”W, O. Oyakawa et al., 11/09/2011. MZUSP 7913, 5, Brasil, Pará, Terra Santa, Igarapé do rio Jamari, acima de Terra Santa, bacia do rio Amazonas, 0207’00”S, 56²9’00’W, Exp. Permanente da Amazônia, 14/12/1967; MZUSP 20869, 1, Brasil, Pará, Cachoeira do Arari, Ilha do Marajó, rio Arari, bacia do rio Amazonas, N. Menezes, 07/1966. MZUSP 21407, 15, Brasil, Pará, Igarapé Centrinho, Barreirinha, bacia do rio Tapajós, 24/11/1970; MZUSP 85271, 4, Brasil, Pará, Barreirinha, Igarapé Centrinho, bacia do rio Tapajós, Exp. Permanente da Amazônia, 24/11/1970; MZUSP 92737, 3, Brasil, Pará, Pimental, rio Tapajós, margem direita em Pimental, bacia do rio Tapajós, L. Sousa, J. Birindelli, 11/11/2006. MZUSP 85272, 2, Brasil, Pará, Igarapé Urubu, perto do Posto de Trocará, rio Tocantins, bacia do rio Tocantins, Exp. Permanente da Amazônia, 24/09/1970; MZUSP 85273, 1, Brasil, Pará, Baião, Igarapé do Limão, rio Tocnantins, 0250’00”S, 4940’00’W, Exp. Permanente da Amazônia, 09/091970; MZUSP 105744, 1, Brasil, Pará, Igarapé Miri, igarapé, Mcajateua, rio Moju, bacia do rio Tocantins, $01^{\circ} 57^{\prime} 51^{\prime \prime S}, 48^{\circ} 54^{\prime} 18^{\prime \prime} \mathrm{W}$, M. Marinho, D. Bastos, 09/04/2010. MZUSP 26105, 6, Peru, Loreto, Jenaro Herrera, Requena, bacia do rio Ucayali, H. Ortega, 30/06/1979; MZUSP 26331, 10 (2 corados, 29.0030.29 mm CP), Peru, Loreto, Moronacocha, Maynas, Iquitos, H. Ortega, 26/8/1978; MZUSP 85598, 2 (1 corado, 30.4 mm CP), Peru, Loreto, Requena, Quebrada no Km 3 da estrada de Jenaro Herrera/Colonia Anagamos, acima do "aguajal", bacia do rio Ucayali, 455,889'S, 73³8, 756’W, H. Ortega, W. Crampton, R. Reis, F. Lima, 14/01/2004; MZUSP 85615, 9 (1 corado, 32.65 mm CP), Perú, Loreto, Requena, Quebrada Salomé Caño, ca. 9 km E. de Jenaro Herrera na estrada para Colônia Angamo, bacia do rio Ucayali, $04^{\circ} 54,355^{\prime}$ S, $73^{\circ} 35,606^{\prime} \mathrm{W}$, H. Ortega, W. Crampton, R. Reis \& F. C. Lima, 13/01/2004. MZUSP 85633, 1, Peru, Loreto, Requena, Pequena Quebrada afluente da Quebrada Chica, ca. 2 km SSE de Jenaro Herrera, na trilha para a comunidade de Pumacahua, bacia do rio Ucayali, H. Ortega, W. Crampton, R. 
Reis \& F. C. Lima, 13/01/2004. MZUSP 106702, 2, Peru, Madre de Dios, Mazuko, rio Planchon, cruzando el puentede la carretera interoceânica, 36.3 km N de Puerto Maldonado, bacia do rio Amazonas, 12¹6’38’S, 6909’09’W, J. Birindelli, N. Lujan, D. Taphorn, D. Brooks, 28/07/2010. MZUSP 38703, Equador, Napo, Tributário do rio Jatuncocha, cerca de $1 \mathrm{~km}$ acima da Laguna Jatuncocha, bacia do rio Napo, $1^{\circ} 0 .{ }^{\prime} \mathrm{S}, 75^{\circ} 31.6^{\prime} \mathrm{W}$, D. Stewart, M. Ibarra.

\section{Caracteres sexuais secundários}

Os caracteres sexuais secundários em C. strigata relacionam-se ao comprimento padrão e presença de processos ósseos em nadadeiras.

Comprimento padrão: fêmeas alcançam maiores valores de comprimento padrão em relação aos machos. MZUSP 7913, 2 machos (28.5-30.9 mm CP) e 3 fêmeas (28.9-34.5 mm CP); MZUSP 21027, 1 macho (30.0 mm CP) e 1 fêmea (32.5 mm CP); MZUSP 21028, 14 machos (25.1-29.6 mm CP) e 9 fêmeas (24.1-33.5 mm CP); MZUSP 21036, 2 machos (31.4-35.4 mm CP) e 3 fêmeas (31.1-34.7 mm CP); MZUSP 21037, 3 machos (28.7-31.8 mm CP) e 3 fêmeas (34.3-36.9 mm CP); MZUSP 21407, 5 machos (24.8-26.9 mm CP) e 6 fêmeas (26.3-32.5 mm CP); MZUSP 21582, 1 machos $(33.3 \mathrm{~mm} \mathrm{CP})$ e 5 fêmeas $(33.7-38.3 \mathrm{~mm} \mathrm{CP})$; MZUSP 26105, 6 jovens (18.4-21.2 mm CP); MZUSP 26331, 3 machos (28.0-30.6 mm CP) e 7 jovens (16.7-23.3 mm CP); MZUSP 38703, 1 macho (21.7 mm CP) e 4 fêmeas (20.3-29.0 mm CP); MZUSP 59194, 2 machos (27.2-28.3 mm CP), 1 fêmea (29.6 mm CP) e 5 jovens (21.1-23.3 mm CP); MZUSP 62070, 3 fêmeas (23.6-31.0 mm CP); MZUSP 63573, 4 machos (23.8-29.5 mm CP) e 4 fêmeas (24.2-31.7 mm CP); MZUSP 66736, 3 machos (23.4-28.0 mm CP) e 4 fêmeas (23.7-31.5 mm CP); MZUSP 66737, 5 machos (26.1-28.2 mm CP) e 6 fêmeas (25.033.8mm CP); MZUSP 66741, 2 machos (27.0-28.2 mm CP), 5 fêmeas (24.0-32.2 mm CP) e 12 jovens (22.7-24.6 mm CP); MZUSP 74069, 1 fêmeas (21.0 mm CP) e 2 jovens (21.1-22.0 


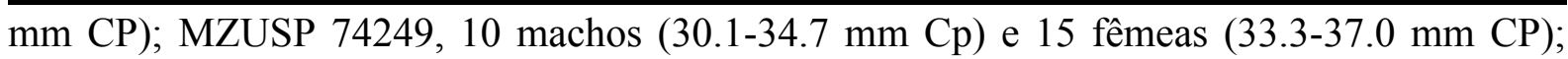
MZUSP 85271, 2 machos (26.0-26.3 mm CP) e 2 fêmeas (27.0-28.5 mm CP); MZUSP 85272, 2 jovens (20.3-20.7 mm CP); MZUSP 85273, 1 fêmea (26.2 mm CP); MZUSP 85275, 2 machos (22.2-22.5 mm CP) e 2 fềmeas (24.8-26.5 mm CP); MZUSP 85282, 1 fêmeas (23.7 mm CP) e 1 jovens (23.0 mm CP); MZUSP 85284, 2 machos (23.6-30.1 mm CP) e 9 fêmeas (24.1-33.2 mm CP); MZUSP 85598, 2 machos (28.5-30.5 mm CP); MZUSP 85615, 4 machos (23.7-32.7 mm CP) e 5 fêmeas (29.8-35.1 mm CP); MZUSP 85633, 1 jovens (21.2 mm CP); MZUSP 87339, 1 macho (30.7 mm CP); MZUSP 87340, 1 machos (31.7 mm CP); MZUSP 87341, 1 macho (32.1 mm CP); MZUSP 87342, 1 macho (25.9 mm CP) e 3 fêmeas (27.0-35.8 mm CP); MZUSP 87343, 1 joven (21.3 mm CP); MZUSP 87344, 1 fêmea (36.4 mm CP); MZUSP 92503, 1 fêmea (29.8 mm CP); MZUSP 105744, 1 macho (27.5 mm CP); MZUSP 106702, 2 fêmeas (24.4-25.6 mm CP); MZUSP 113078, 4 machos (28.5-28.5 mm CP) e 2 fêmeas (27.8-31.8 mm CP).

Processos ósseos: presentes na nadadeira anal de machos.

Nadadeira anal com até dois (geralmente um) processos ósseos por segmento de hemitriquium, do primeiro ao décimo quinto raios ramificados, disrtribuindo-se em até $65 \%$ (até 23 raios) dos raios ramificados Nestes, os processos ósseos estão presentes tanto em segmentos proximais quanto em segmentos distais à primeira bifurcação. Proximalmente à primeira bifurcação, os processos ósseos estão presentes em até seis segmentos. Distalmente à primeira bifurcação, os processos ósseos estão presentes e restritos a até cinco segmentos do ramo posterior, imediatamente distais à bifurcação. Processos ósseos assimétricos bilateralmente. Em todos os segmentos, os processos ósseos estão inseridos na face lateroposterior/posterior em relação à nadadeira. Processos ósseos com inserção ovalada proximodistalmente. O maior comprimento de sua inserção ocupa $45 \%$ do comprimento 
$\overline{\text { proximodistal do segmento no qual está inserido. Ao longo de seu comprimento total, os }}$ processos ósseos apresentam uma curvatura de $35^{\circ}$ e desenvolvem-se em direção proximal em relação ao eixo proximodistal do segmento no qual estão inseridos. Em secção transversal, os processos ósseos variam de ovalados proximodistalmente a cilíndricos ao longo de seu comprimento total, afilando-se gradualmente terminando em uma extremidade arredondada (nunca pontiaguda). $\mathrm{O}$ diâmetro de sua extremidade distal equivale a $30 \%$ do maior comprimento de sua inserção no segmento no qual está inserido. Em seu estado de desenvolvimento máximo, seu comprimento total não alcança o comprimento proximodistal do segmento onde está inserido. O comprimento do maior processo ósseo equivale a $40 \%$ do comprimento proximodistal do segmento no qual está inserido. Na nadadeira anal, os processos ósseos aumentam e diminuem de tamanho em direção anteroposterior; sétimo e oitavo raios ramificados com o maior número de segmentos com processos ósseos e processos ósseos maiores. No raio, os processos ósseos diminuem de tamanho em direção proximodistal.

\section{Thoracocharax stellatus (Kner 1858)}

Figs. 8 e 9

Localidade tipo: rio Cuiabá, Brazil.

Material examinado: MZUSP 4415, 1, Brasil, Mato Grosso, município de Santo Antônio de Leverger, rio Cuiabá, bacia do rio Paraguai, C. Olson, 11/1966; MZUSP 21510, 1, Brasil, Mato Grosso, Município de Cuiabá, rio Coxipó da Ponte (afl. Do rio Cuiabá), vila de Coxipó da Ponte, bacia do rio Paraguai, K. Silimon 28/10/1975; MZUSP 21658, 3, Brasil, Mato Grosso, município de Santo Antônio de Leverger, rio Cuiabá, bacia do rio Paraguai, CAPIPAM, 03/05/1977; MZUSP 38155, 5, Brasil, Mato Grosso, munícipio de Santo Antônio 
de Leverger, rio Cuiabá, bacia do rio Paraguai, CEPIPAM, 03/05/1977; MZUSP 44299, 4, Brasil, Mato Grosso, Barra do Bugres, rio Jauquara em Jauquara (afl. Do rio dos Passaros), bacia do rio Paraguai, Exp. MZUSP/USNM/MCP, 10/08/1991;.MZUSP 78822, 19 (3 corados), Brasil, Mato Grosso, Cáceres, rio Cachoeirinha, na estrada cáceres/Porto estrela, bacia do rio Paraguai, H.tskii et al., 17/02/2002; MZUSP 90656, 5 (1 corado, 44.7 mm CP), Brasil, Mato Grosso, Cáceres, rio Sepotuba (trecho médio), bacia do rio Paraguai, 15²4'37'S, 57²2’20”W, H. Britski et al., 04/03/2002; MZUSP 90667, 1, Brasil, Mato Grosso, Cáceres, rio Sepotuba (trecho médio), bacia do rio Paraguai, $15^{\circ} 16^{\prime} 35^{\prime \prime}$, 57² $2^{\prime} 50^{\prime} \mathrm{W}, \mathrm{H}$. Britski et al., 03/2002. MZUSP 38064, 2, Brasil, Mato Grosso do Sul, Coxim, rio Taquaei, bacia do rio Paraguai, Alfredo Carvalho, 23/10/1980; MZUSP 52505, 2, Brasil, Mato Grosso do Sul, rio Piquiri, Pantanal de Paiaguás, baida sede da Faz. Santo Antônio, bacia do rio Paraguai, T. Lipparelli, 18/03/1993.

\section{Caracteres sexuais secundários}

Os caracteres sexuais secundários em T. stellatus relacionam-se ao comprimento padrão e presença de processos ósseos em nadadeiras.

Comprimento padrão: fêmeas com maiores valores de comprimento padrão em relação aos machos. MZUSP 4415, 1 fêmea (42.2 mm CP); MZUSP 21510, 1 fêmea (46.3 mm CP); MZUSP 21658, 1 macho (40.6 mm CP) e 2 fêmeas (38.5-44.9 mm CP); MZUSP 38064, 1 macho (39.4 mm CP) e 1 fêmea (50.2 mm CP); MZUSP 38155, 4 machos (39.4-42.9 mm CP) e 1 fêmea (47.2 mm CP); MZUSP 44299, 3 machos (38.1-39.1 mm CP) e 1 fêmea (39.4 mm CP); MZUSP 52505, 2 machos (37.66-38.69 mm CP); MZUSP 78822, 9 machos (39.7-45.5 mm CP) e 5 fêmeas (43.3-49.8 mm CP); MZUSP 90656, 5 machos (43.7-46.5 mm CP); MZUSP 90667, 1 macho (44.4 mm CP);

Processos ósseos: presentes na nadadeira anal de machos. 
Nadadeira anal com um processo ósseo por segmento de hemitriquium do sexto ao vigésimo oitavo raio ramificado, distribuindo-se em até $53 \%$ dos raios ramificados (38 raios ramificados). Raios ramificados com processos ósseos presentes tanto em segmentos proximais quanto em segmentos distais à primeira bifurcação. Proximalmente à primeira bifurcação, os processos estão presentes em até um segmento. Distalmente à primeira bifurcação os processos ósseos estão presentes e restritos a até três segmentos do ramo posterior, imediatamente distais à bifurcação. No hemitriquium direito de um dos raios ramificados de um exemplar, dentre todos os que foram analisados, os processos ósseos estão presentes em até três segmentos do ramo posterior e em até dois segmentos do ramo anterior, imediatamente distais à primeira bifurcação. Processos ósseos simétricos bilateralmente. Em todos os segmentos, os processos ósseos estão inseridos na face lateroposterior em relação à nadadeira. Processos ósseos com secção transversal ovalada proximodistalmente no local de sua inserção. O maior comprimento no local de sua inserção ocupa $50 \%$ do comprimento proximodistal do segmento no qual está inserido. Os processos ósseos desenvolvem-se perpendicularmente à sua inserção. Ao longo de seu comprimento total, os processos ósseos apresentam uma curvatura de $55^{\circ}$, desenvolvem-se em direção proximal em relação ao eixo proximodistal do segmento no qual estão inseridos. Em secção transversal, os processos ósseos variam de ovalados proximodistalmente a cilíndricos ao longo de seu comprimento total, afilando-se gradualmente e terminando em uma extremidade arredondada. O diâmetro de sua extremidade distal equivale a $23 \%$ do maior comprimento no local de sua inserção no segmento no qual está inserido. Em seu estado máximo de desensolvimento, o seu comprimento total não alcança o comprimento proximodistal do segmento no qual está inserido. O comprimento do maior processo ósseo equivale a $44 \%$ do comprimento proximodistal do segmento no qual está inserido. Na nadadeira anal os processos ósseos 
aumentam e diminuem de tamanho em direção anteroposterior; décimo segundo e décimo terceiro raio ramificado com o maior número de segmentos com processos ósseos; processos ósseos com tamanhos semelhantes do nono ao vigésimo terceiro raio ramificado. No raio os processos ósseos diminuem de tamanho em direção proximodistal.

\section{Família Serrasalmidae}

\section{Myloplus rubripinnis (Muller \& Troschel 1844)}

Fig. 10

Localidade tipo: Essequibo.

Material examinado: MZUSP 13916, Brasil, Rondônia, rio Machado, praia do Cururu, 20/10/1978.

\section{Caracteres sexuais secundários}

Os caracteres sexuais secundários em M. rubripinnis relacionam-se ao formato de nadadeiras e presença de "crochets".

Formato da nadadeira: Machos diferem de fêmeas pelo formato da margem distal das nadadeira anal e da nadadeira dorsal.

Perfil da margem distal da nadadeira anal de machos com dois lobos conspícuos. Lobo anterior, com margem côncava, devido ao aumento graudal de tamanho do último raio simples ao primeiro raio ramificado (raio mais longo do lobo) e diminuição acentuada de tamanho deste ao quinto raio ramificado. Segundo lobo com margem convexa, devido ao aumento gradual de tamanho do sexto ao décimo sexto raio ramificado (raio mais longo do 
segundo lobo) e diminuição gradual de tamanho a partir deste até o vigésimo sexto raio ramificado. Fêmeas com com margem do lobo anterior côncava.

Extremidade distal do primeiro (raio mais longo) ao último raio ramificado com extensões filamentosas. Filamentos diminuem gradualmente de tamanho em direção anteroposterior. Raios da nadadeira dorsal de fêmeas sem extensões filamentosas em sua extremidade distal.

Crochets: presente em machos.

Os crochets são projeções pontiagudas da extremidade distal dos raios em direção lateroventral em relação ao eixo proximodistal do raio. Presentes na extremidade distal de cada hemitriquium, do ramo posterior da primeira bifurcação do quinto raio ramificado ao último raio ramificado da nadadeira anal.

\section{Família Characidae}

\section{APHYOCHARACINAE}

\section{Aphyocharax anisitsi Eigenmann \& Kennedy 1903}

Figs. 11 a 14

Localidade tipo: Asuncion, Paraguay.

Material examinado: MZUSP 53926, 35, Brasil, Paraguay, Alto Paraguay, Puerto Lídia, bacia do rio Paraguay, margem do rio em frente a Estancia Puerto Lídia, M. Medina et al., 07/09/1997. MZUSP 79182, 18, Brasil, Mato Grosso, Barão de Melgaço, CEPIPAM, 1997.

\section{Caracteres sexuais secundários}




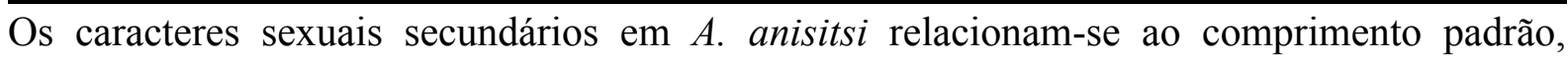
formato de nadadeiras, presença de processos ósseos, formato longitudinal do corpo e glândula branquial.

Comprimento padrão: fêmeas alcançam maiores valores de comprimento padrão em relação aos machos. MZUSP 53926, 10 machos (26-30.1 mm CP) e 11 fêmeas (27.1-30.8 mm CP), MZUSP 79182, 8 machos (29.3-32.6 mm CP) e 10 fêmeas (27.9-33.1 mm CP).

Formato de nadadeiras: machos diferem de fêmeas pelo formato do perfil da margem distal da nadadeira anal.

Perfil da margem distal do lobo anterior da nadadeira anal de machos convexo. Lobo anterior formado pelo aumento gradual do último raio simples ao segundo raio ramificado (raio mais longo) e diminuição gradual de tamanho deste ao quinto raio ramificado; perfil reto do sexto ao último raio ramificado, devido à diminuição gradual de tamnho em direção posterior. Perfil da margem distal da nadadeira anal de fêmeas com lobo anterior convexo conspícuo. Lobo anterior formado pelo aumento gradual de tamanho do último raio simples ao segundo raio ramificado (raio mais longo) e diminuição acentuada deste ao quinto raio ramificado; perfil reto do sexto ao último raio ramificado, devido à diminuição graudal de tamanho em direção anteroposterior.

Processos ósseos: presentes nas nadadeiras anal e pélvica de machos.

Nadadeira anal com até dois (geralmente um; dois no primeiro raio ramificado) processos ósseos por segmento de hemitriquium, do último raio simples ao décimo sétimo raio ramificado, disrtribuindo-se em $90 \%$ dos raios ramificados (até 20 raios ramificados). Último raio simples com processos ósseos do terceiro ao sexto segmento, décimo segmento proximal à extremidade distal do raio. Raios ramificados com processos ósseos tanto em segmentos proximais quanto em segmentos distais à primeira bifurcação. Proximalmente à primeira 
$\overline{\text { bifurcação, os processos ósseos estão presentes em até quatro segmentos. Distalmente à }}$ primeira bifurcação, os processos ósseos estão presentes e restritos a até quatro segmentos do ramo posterior. Processos ósseos simétricos bilateralmente. Processos ósseos com inserção arredondada do último raio simples ao quinto raio ramificado e ovalada proximodistalmente do sexto ao último raio com processos ósseos. O diâmetro da inserção dos processos ósseos arredondados equivalem $21 \%$ do comprimento proximodistal do segmento no qual està inserido. O maior comprimento da inserção dos processos ósseos com inserção ovalada proximodistalmente ocupa $55 \%$ do comprimento proximodistal do segmento no qual está inserido. Em todos os segmentos, os processos ósseos estão inseridos na face lateroposterior em relação à nadadeira, desenvolvem-se perpendicularmente à sua inserção no segmento no qual estão inseridos. Ao longo de seu comprimento total, os processos ósseos do último raio simples ao quinto raio ramificado apresentam uma curvatura de $40^{\circ}$ em relação ao eixo proximodistal do segmento no qual está inserido e desenvolvem-se em direção proximal em relação ao eixo proximodistal do segmento no qual estão inseridos. Em um quarto (1/4) proximal de seu comprimento total, os processos ósseos do sexto ao último raio ramificado apresentam uma curvatura de $50^{\circ}$ em relação ao eixo proxiodistal do segmento no qual estão inseridos e desenvolvem-se em direção proximal em relação ao eixo proximodistal do segmento no qual estão inseridos. Em secção transversal, os processos ósseos do primeiro ao quinto raio ramificado são cilíndricos ao longo do seu comprimento total, afilando-se gradualmente e terminando em uma extremidade arredondada. O diâmetro de sua extremidade distal equivale a $36 \%$ de seu diâmetro no local de sua inserção. Em secção transversal, os processos ósseos do sexto ao último raio ramificado variam de ovalados proximodistalmente a cilíndricos ao longo de seu comprimento total. O diâmetro de sua extremidade distal equivale a $18 \%$ do maior comprimento no local de sua inserção no segmento. Em seu estado máximo 
$\overline{\text { de desenvolvimento, o seu comprimento total não alcança o comprimento proximodistal do }}$ segmento no qual está inserido. O comprimento do maior processo ósseo do primeiro ao quinto raio ramificado equivale a $23 \%$ do comprimento proximodistal do segmento no qual está inserido. Comprimento do maior processo ósseo do sexto ao último raio ramificado, $84 \%$ do comprimento proximodistal do segmento no qual está inserido. Na nadadeira anal os processos óessos aumentam de tamanho em direção anteroposterior; primeiro raio ramificado com maior número de segmentos com processos ósseos; décimo sexto raio ramificado com processos ósseos maiores. Do primeiro ao quinto raios ramificados, os processos ósseos apresentam tamanhos semelhantes em direção proximodistal. Do sexto ao último raio ramificado, os processos ósseos aumentam e diminuem de tamanho em diração proximodistal; o maior processo ósseo está no primeiro segmento distal à primeira bifurcação, na metade distal da série de processos ósseos.

Nadadeira pélvica com processos ósseos presentes e restritos a segmentos do hemitricuium ventral. Nadadeira pélvica com até dois processos ósseos por segmento de hemitriquium ventral do raio simples ao quinto raio ramificado, $83 \%$ (6 raios ramificados). Raio simples com processos ósseos nos cinco segmentos proximais, o mais proximal, mais longo. Raios ramificados com processos ósseos tanto em segmentos proximais quanto distais à primeira bifurcação. Processos ósseos presentes também em segmentos distais à segunda bifurcação do ramo medial da primeira bifurcação. Proximalmente à primeira bifurcação, os processos estão presentes em todos os segmentos; segmentos mais proximal (mais longo) com até 16 processos ósseos ao longo de seu comprimento. Distalmente à primeira bifurcação e proximalmente às segunda ramificações, os processos ósseos estão presente e restritos a todos os segmentos do ramo medial da primeira bifurcação. Distalmente à segunda bifurcação do ramo medial da primeira bifurcação, os processos ósseos estão restritos a até dois segmentos 
$\overline{\text { do ramo medial, imediatamente distais à bifurcação. Processos ósseos com secção transversal }}$ arredondada no local onde se inserem. O diâmetro no local de sua inserção ocupa $30 \%$ do comprimento proximodistal do segmento no qual está inserido. Em todos os segmentos, com exceção do mais proximal (mais longo), os processos estão inseridos na região ventromedial. No segmento mais proximal (mais longo) a inserção dos processos muda da face ventromedial para a face ventrolateral do segmento em direção distoproximal. Os processos ósseos desenvolvem-se perpendicularmente à sua inserção no segmento no qual estão inseridos. Em um quarto (1/4) proximal de seu comprimento total, os processos ósseos apresentam uma curvatura de $65^{\circ}$ em relação ao segmento no qual está inseridos e desenvolvem-se em direção proximal (ligeiramente medial) em relação ao eixo proximodistal do segmento no qual estão inseridos. Em secção transversal, os processos ósseos são cilíndricos ao longo de seu comprimento, afilando-se muito pouco gradualmente e terminando em uma extremidade arredondada. O diâmetro em sua extremidade distal equivale a $21 \%$ do diâmetro no local de sua inserção no segmento. Em seu estado máximo de desenvolvimento, o seu comprimento total não alcança o comprimento proximodistal do segmento no qual está inserido. O comprimento do maior processo ósseo equivale a $68 \%$ do comprimento proximodistal do segmento no qual está inserido. Na nadadeira pélvica os processos aumentam e diminuem de tamanho em direção lateromedial; segundo e terceiro raio ramificado com maior número de processos ósseos e maiores processos ósseos. No raio os processos ósseos aumentam e diminuem de tamanho em direção proximodistal; o maior processo ósseo é o imediatamente proximal à primeira bifurcação, metade da série de processos ósseos.

Eixo longitudinal do corpo: machos diferem de fêmeas por apresentar uma leve curvatura em direção ventral na metade posterior do comprimento padrão. 
Glândula branquial: presente em machos maduros

Glândula branquial formada pela fusão do segundo ao quinto filamentos branquiais anteriores do ceratobranquial do primeiro arco branquial de machos maduros. Glândula branquial disrtribuindo-se em espaço correspondente a 19\% dos filamentos branquiais. Glândula branquial disrtribuindo-se em espaço correspondente a $17 \%$ do comprimento do ceratobranquial. Celulas colunares não visíveis lateralmente. Abertura da glândula branquial não visível lateralmente.

\section{Prionobrama paraguayensis (Eigenmann 1914)}

Figs. 15 a 18

Localidade tipo: cáceres, rio Paraguay, Brasil.

Material examinado: MZUSP 44407, 14, Brasil, Mato Grosso, Cáceres, rio Paraguay em Cáceres e arredores, bacia do rio Paraguay, $16^{\circ} 4^{\prime} 0.0^{\prime \prime} \mathrm{S}, \quad 57^{\circ} 41^{\prime} 0.0^{\prime} \mathrm{W}$, Exp. MZUSP/USNM/MCP/UFMT. MZUSP 54063, 17, Paraguai, Alto Paraguay, margem esquerda do rio Paraguay, em praia arenosa acima da Estância Cerrito, bacia do rio Paraguay, $21^{\circ} 26^{\prime} 0.0^{\prime} \mathrm{N}, 57^{\circ} 55^{\prime} 0.0^{\prime} \mathrm{E}$, Sarmiento et al., 10/09/1997.

\section{Caracteres sexuais secundários}

Os caracteres sexuais secundários em $P$. paraguayensis relacionam-se ao comprimento padrão, presença de processos ósseos em nadadeiras e glândula branquial.

Comprimento padrão: fêmeas alcançam maiores valores de comprimento padrão em relação aos machos. MZUSP 44407, 4 machos (29.4-32.5 mm CP) e 8 fêmeas (32.0-32.7 mm CP); MZUSP 54063, 6 machos (24.2-32 mm CP) e 11 fêmeas (25.4-36.3 mm CP), MZUSP 79182, 6 machos (29.3-32.6 mm CP).

Processos ósseos: presentes nas nadadeiras anal e pélvica dos machos adultos . 
$\overline{\text { Nadadeira anal com até três (geralmente um) processos ósseos por segmento do primeiro ao }}$ décimo sétimo raio ramificado, disrtribuindo-se em 57\% dos raios ramificados (até 30 raios ramificados). Processos ósseos presentes tanto em segmentos proximais quanto em segmentos distais à primeira bifurcação. Proximalmente à primeira bifurcação os processos ósseos estão presentes em até quatro segmentos. Distalmente à primeira bifurcação os processos ósseos estão restritos à até cinco segmentos do ramo posterior. Processos ósseos simétricos bilateralmente. Processos ósseos com inserção arredondada. O diâmetro de sua inserção ocupa $18 \%$ do comprimento proximodistal do segmento no qual está inserido. Em todos os segmentos, os processos ósseos estão inseridos na face lateroposterior em relação à nadadeira. Desenvolvem-se perpendicularmente à sua inserção no segmento no qual estão inseridos. Ao longo de seu comprimento total, os processos ósseos apresentam uma curvatura de $20^{\circ} \mathrm{e}$ desenvolvem-se em direção proximal em relação ao eixo proximodistal do segmento no qual estão inseridos. Em secção transversal, os processos ósseos são cilíndricos ao longo de todo o seu comprimento, afilando-se gradualmente e terminando em uma extremidade arredondada. O diâmetro de sua extremidade distal equivale a 42 \% do diâmetro no local de sua inserção no segmento no qual está inserido. Em seu estado máximo de desenvolvimento, seu comprimento total não alcança o comprimento proximodistal do segmento no qual está inserido. O comprimento do maior processo ósseo equivale a $38 \%$ do comprimento proximodistal do segmento no qual está inserido. $\mathrm{Na}$ nadadeira anal os processos ósseos apresentam tamanhos semelhantes; segundo raio ramificado com maior número de segmentos com processos ósseos. Nos raios, os processos decrescem de tamanho em direção proximodistal; o maior processo ósseo localiza-se no segundo segmento distal à primeira bifurcação, na metade distal da série de processos ósseos. 
$\overline{\text { Nadadeira pélvica com processos ósseos restritos a segmentos do hemitricuium ventral e }}$ com até três (geralmente dois) processos ósseos por segmento do primeiro ao sexto raios ramificados, disrtribuindo-se em $85 \%$ dos raios ramificados (7 raios ramificados). Processos ósseos presentes tanto em segmentos proximais quanto em segmentos distais à primeira bifurcação. Processos ósseos presentes também em segmentos distais à segunda bifurcação dos ramos medial e lateral da primeira bifurcação. Processos ósseos presentes também em segmentos distais à terceira bifurcação do ramo medial da segunda bifurcação do ramo medial da primeira bifurcação. Proximalmente à primeira bifurcação, os processos ósseos estão presentes em até dois segmentos (inclusive no mais proximal, mais longo); segmento mais proximal com um processo na porção distal. Distalmente à primeira bifurcação e proximalmente à segunda bifurcação, os processos ósseos estão presentes em todos os segmentos do ramo medial e em até dois segmentos do ramo lateral, imediatamente proximais à bifurcação deste ramo. Distalmente à segunda bifurcação do ramo medial da primeira bifurcação, os processos ósseos estão presentes em até três segmentos do ramo medial e em até um segmento do ramo lateral, imediatamente distal à bifurcação. Distalmente à segunda bifurcação do ramo lateral da primeira bifurcação, os processos ósseos estão restritos a até três segmentos do ramo medial, imediatamente distais à ramificaçào. Processos ósseos com secção transversal arredondada no local de inserção. O diâmetro no local de sua inserção ocupa $22 \%$ do comprimento proximodistal do segmento no qual está inserido. Em todos os segmentos os processos ósseos estão inseridos na face ventromedial, com exceção dos dois segmentos do ramo medial da primeira bifurcação imediatamente proximais à segunda bifurcação deste ramo, no qual os processos ósseos estão inseridos tanto na face ventromedial quanto na face ventrolateral. Os processos ósseos desenvolvem-se perpendicularmente à sua inserção no segmento. Ao longo de seu comprimento, os processos ósseos apresentam uma 
curvatura de $15^{\circ}$ em relação ao eixo proximodistal do segmento no qual estão inseridos e desenvolvem-se em direção proximal em relação ao eixo proximodistal do segmento no qual estão inseridos. Em secção transversal, os processos ósseos são cilíndricos ao longo de todo seu comprimento, afilando-se gradualmente e terminando em uma extremidade arredondada. O diâmetro em sua extremidade distal equivale a $42 \%$ do diâmetro no local de sua inserção no segmento. Em seu estado máximo de desenvolvimento, seu comprimento total não alcança o comprimento proximodistal do segmento no qual está inserido. O comprimento do maior processo ósseo equivale a $31 \%$ do comprimento proximodistal do segmento no qual está inserido. Na nadadeira pélvica os processos ósseos apresentam tamanhos semelhantes em direção lateromedial; segundo raio ramificado com maior número de segmentos com processos ósseos. Nos raios, os processos ósseos aumentam e diminuem de tamanho em direção proximodistal; o maior processo ósseo localiza-se no segmento imediatamente proximal à segunda bifurcação, na metade distal da série de processos ósseos.

Glândula branquial: presente em machos.

Glândula branquial formada pela fusão do terceiro ao sexto filamentos branquiais anteriores do ceratobranquial do primeiro arco branquial. Glândula branquial disrtribuindo-se em 19\% do espaço correspondente aos filamentos branquiais do ceratobranquial do primeiro arco branquial. Glândula branquial disrtribuindo-se em 14\% do comprimento do ceratobranquial. Células colunares não visíveis lateralmente. Abertura da glândula não visível lateralmente.

\section{APHYODITEINAE}

\section{Microschemobrycon casiquiare Bohlke 1953}

Figs. 19 a 21 
Localidade tipo: corredeiras de São Gabriel, São Gabriel do rio Negro, Amazonas, Brasil. Material examinado: MZUSP 109936, 63, Brasil, Amazonas, rio Negro Praia de Urumari, bacia do rio Negro, 0`58’0.0”S, 6257’0.0’W, M. Goulding, 06/10/1979.

\section{Caracteres sexuais secundários:}

Os caracteres sexuais secundários em $M$. casiquiare relacionam-se ao comprimento padrão e presença de processos ósseos em nadadeiras.

Comprimento padrão: fêmeas apresentam maiores valores de comprimento padrão em relação aos machos. MZUSP 109936, 26 machos (25.6-27.1 mm CP) e 29 fêmeas (27.6-28 $\mathrm{mm} \mathrm{CP})$.

Processos ósseos: presentes nas nadadeiras anal e pélvica de machos.

Nadadeira anal com até três (geralmente dois) processos ósseos por segmento de hemitriquium do último raio simples ao quinto raio ramificado, distribuídos em $31 \%$ dos raios ramificados (até 16 raios rmificados). Último raio simples com processos ósseos do segundo ao sétimo segmentos, quinto segmento proximal à extremidade distal do raio. Raios ramificados com processos ósseos presentes tanto em segmentos proximais quanto em segmentos distais à primeira bifurcação. Proximalmente à primeira bifurcação, os processos ósseos estão presentes em todos os segmentos, inclusive o segmento mais proximal, mais longo. Distalmente à primeira bifurcação, os processos ósseos estão presentes e restritos a até cinco segmentos do ramo posterior, imediatamente distais à bifurcação. Processos ósseos assimétricos bilateralmente. Processos ósseos com inserção arredondada. O diâmetro no local de sua inserção ocupa $24 \%$ do comprimento proximodistal do segmento no qual está inserido. Em todos os segmentos, os processos ósseos estão inseridos na face lateroposterior em relação à nadadeira. Os processos ósseos desenvolvem-se perpendicularmente à inserção no segmento 
no qual estão inseridos. Ao longo de seu comprimento, total os processos ósseos apresenteam uma curvatura de $45^{\circ}$ em relação ao eixo proximodistal do segmento no qual estão inseridos e desenvolvem-se em direção proximal (ligeiramente medial) em relação ao segmento no qual estão inseridos. Em secção transversal, os processos ósseos são cilíndricos ao longo de todo o seu comprimento, afilando-se gradualmente e terminando uma extremidade pontiaguda. $\mathrm{O}$ diâmetro de sua extremidade distal equivale a $22 \%$ do diâmetro de sua inserção no segmento no qual está inserido. Em seu estado máximo de desenvolvimento, seu comprimento total não alcança o comprimento proximodistal do segmento no qual está inserido. O comprimento do maior processo ósse equivale e $33 \%$ do comprimento proximodistal do segmento no qual está inserido. Na nadadeira anal os processos ósseos aumentam e diminuem gradualmente de tamanho em direção anteroposterior; segundo e terceiro raios ramificados com maior número de segmentos com processos ósseos e processos ósseos maiores. Nos raios, os processos ósseos aumentam e diminuem de tamanho em direção proximodistal; o maior processo ósseo localiza-se no segmento imediatamente distal à primeira bifurcação, na metade proximal da série de processos ósseos.

Nadadeira pélvica com processos ósseos restritos a segmentos do hemitricuium ventral. Nadadeira pélvica com até três (normalmente dois) processos ósseos por segmento do hemitriquium ventral, do raio simples ao sexto raio ramificado, distribuindo-se em $85 \%$ dos raios ramificados (7 raios rmificados). Raio simples com processos ósseos nos dois segmentos mais proximais. Raios ramificados com processos ósseos tanto em segmentos proximais quanto em segmentos distais à primeira bifurcação. Processos ósseos presentes também em segmentos distais à segunda bifurcação do ramo medial da primeira bifurcação. Proximalmente à primeira bifurcação, os processos ósseos estão presentes em todos os segmentos, inclusive o mais proximal, mais longo; segmento mais proximal com até doze 
$\overline{\text { processos ósseos. Distalmente à primeira bifurcação os processos ósseos estão presentes em }}$ todos os segmentos do ramo medial e em até dois segmentos do ramo lateral, imediatamente proximais à segunda bifurcação. Distalmente à segunda bifurcação do ramo medial da primeira bifurcação, os processos ósseos estão restritos a um segmento do ramo medial, imediatamente distal à bifurcação. Processo ósseo com secção transversal arredondada no local da inserção. O diâmetro no local de sua inserção ocupa $21 \%$ do comprimento proximodistal do segmento no qual está inserido. Em todos os segmentos, os processos ósseos estão inseridos na face ventromedial. No segmento mais proximal (mais longo) de cada raio a inserção dos processos ósseos migra ligeiramente da face ventrolateral à face ventral do segmento em direção distoproximal. Os processos ósseos desenvolvem-se perpendicularmente à inserção nos segmentos no qual estão inseridos. Ao longo de seu comprimento total, os processos ósseos apresentam uma curvatura de $25^{\circ}$ em relação ao ssegmento no qual estão inseridos e desenvolvem-se em direção proximomedial em relação ao eixo proximodistal do segmento no qual estão inseridos. Em secção transversal, os processos ósseos têm forma cilíndrica ao longo de todo o seu comprimento, total, afilando-se gradualmente e terminando em uma extremidade ponstiaguda. O diâmetro de sua extremidade distal equivale a $40 \%$ do diâmetro no local de sua inserção no segmento no qual está inserido. Em seu estado de desenvolvimento máximo, o seu comprimento total não alcança o comprimento proximodistal do segmento no qual está inserido. Comprimento do maior processo ósseo, $39 \%$ do comprimento proximodistal do segmento no qual está inserido. $\mathrm{Na}$ nadadeira pélvica os processos ósseos decrescem aumentam e diminuem gradualmente de tamanho em direção lateromedial; segundo e terceiro raios ramificados com maior número de segmentos com processos ósseos e maiores processos ósseos. Nos raios, os processos ósseos aumentam e diminuem de tamanho em direção proximodistal; no segmento imediatamente 
proximal à primeira bifurcação ocorre o maior processo ósseo, na metade proximal da série de processos ósseos.

\section{Parecbasis cyclolepis Eigenmann 1914}

Figs. 22 e 23

Localidade tipo: São Antônio do Rio Madeira, Brazil.

Material examinado: MZUSP 25956, 3, Perú, Ucayali, Cel. Portilho, Ri Ucayali, Masisea, Prov. Coronel Portillo, Depto. Ucayali, H. Ortega, 06/10/1975.

\section{Caracteres sexuais secundários:}

Os caracteres sexuas secundários de $P$. cyclolepis relacionam-se à presença processos ósseos. Processos ósseos: presentes na nadadeiras anal de machos.

Nadadeira anal com um processo ósseo por segmento de hemitriquium, do último raio simples ao sexto raio ramificado, distribuindo-se em $27 \%$ dos raios ramificados (até 22 raios ramificados). Último raio simples com processos ósseos presentes do sexto ao décimo segmentos, o quinto segmento proximal à extremidade distal do raio. Raios ramificados com processos ósseos restritos a segmentos distais à primeira bifurcação. Processos ósseos presentes também em segmentos distais à segunda bifurcação do ramo posterior da primeira bifurcação. Distalmente à primeira bifurcação e proximalmente às segundas ramificações, os processos ósseos estão restritos a até cinco segmentos do ramo posterior, imediatamente proximais à segunda bifurcação deste ramo. Distalmente à segunda bifurcação do ramo posterior, os processos ósseos estão restritos a até dois segmentos do ramo posterior, imediatamente distais à bifurcação. Processos ósseos simétricos bilateralmente. Processos ósseos com inserção ovalada proximodistalmente. O maior comprimento de sua inserção 
ocupa $34 \%$ do compimento proximodistal do segmento no qual está inserido. Em todos os segmentos, os processos ósseos estão inseridos na face lateroposterior em relação à nadadeira e desenvolvem-se perpendicularmente à sua inserção no segmento. Ao longo de seu comprimento, os processos ósseos apresentam uma curvatura de $35^{\circ}$ em relação ao eixo proximodistal do segmento no qual estão inseridos e desenvolvem-se em direção proximal em relação ao segmento no qual estão inseridos. Em secção transversal, os processos ósseos variam de ovalados proximodistalmente a cilíndricos ao longo de seu comprimento, afilandose gradualmente e terminando em uma extremidade arredondada. O diâmetro de sua extremidade distal ocupa $16 \%$ do seu maior comprimento no local de sua inserção no segmento. Em seu estado máximo de desenvolvimento, o seu comprimento total não alcança o comprimento proximodistal do segmento no qual está inserido. O comprimento do maior processo ósseo quivale a $38 \%$ do comprimento proximodistal do segmento no qual está inserido. Na nadadeira anal os processos ósseos aumentam e diminuem de tamanho em direção anteroposterior; segundo e terceiro raios ramificados com maior número de segmentos com processos ósseos e com processos ósseos maiores. No raio os processos ósseos decrescem em tamanho em direção proximodistal; o maior processo ósseo ocorre no quarto segmento proximal à segunda bifurcação, na metade proximal da série de processos ósseos.

\section{Tyttobrycon marajoara Marinho, Bastos \& Menezes 2013}

Localidade tipo: Igarapé Olho D’água, Marajó Island, Vila União, 05051”S, 48³4’01”W, Pará State, Brazil. 
Material examinado: parátipo. MZUSP 106110, 75, Brasil, Pará, Salvaterra, Balneáreo

Olho no Olho em Igarapé, Ilha do Marajó, bacia costeria, 050’51”S, 48³4’1”W, M. M. F. Marinho et al., 10/04/2010.

\section{Caracteres sexuais secundários}

Os caracteres sexuais secundários em T. marajoara relacionam-se ao comprimento padrão, formato de nadadeiras e presença de processos ósseos em nadadeiras.

Comprimento padrão: Fêmeas alcançam maiores valores de comprimento padrão em relação aos machos; MZUDP 106110, 35 machos (15.9-19.3 mm CP) e 33 fêmeas (17.4-20 $\mathrm{mm} \mathrm{CP})$.

Formato de nadadeiras: machos diferem das fêmeas pelo formato da margem distal da nadadeira anal e formato da nadadeira pélvica.

Perfil da margem distal da nadadeira anal de machos com lobo anterior convexo. Lobo anterior formado pelo aumento gradual de tamanho do último raio simples ao segundo raio ramificado (raio mais longo) e diminuição gradual deste ao quinto raio ramificado; perfil reto do sexto ao último raio ramificado, devido à diminuição gradual de tamanho dos raios em direção anteroposterior. Perfil da margem distal da nadadeira anal de fêmeas com lobo anterior convexo conspícuo. Lobo formado pelo aumento gradual em tamanho do último raio simples ao segundo raio ramificado (raio mais longo) e diminuição acentuada deste ao quinto raio ramificado; perfil reto deste ao último raio ramificado, devido à diminuição gradual de tamanho dos raios em direção anteroposterior.

Extremidade distal do primeiro raio ramificado (raio mais longo) da nadadeira pélvica de machos alcança o quarto ou quinto raio ramificado da nadadeira anal. Extremidade distal do primeiro raio ramificado (raio mais longo) da nadadeira pélvica de fêmeas alcança no máximo a origem da nadadeira anal. 
Processos ósseos: presentes nas nadadeiras anal, pélvica e dorsal de machos.

Nadadeira anal de machos com um processo ósseo por segmento de hemitriquium do último raio simples ao quinto raio ramificado, distribuindo-se em 36\% dos raios ramificados (até 14 raios ramificados). Último raio simples com processos ósseos do segundo segmento ao segundo segmento proximal à extremidade distal do raio, incluindo, portanto, quase todos os segmentos do raio. Raios ramificados com processos ósseos presentes tanto em segmentos proximais quanto em segmentos distais à primeira bifurcação. Proximalmente à primeira bifurcação, os processos ósseos estão presentes em até três segmentos. Distalmente à primeira bifurcação, os processos ósseos estão restritos a até sete segmentos do ramo posterior, imediatamente distais à primeira ramificaçào. Processos ósseos simétricos bilateralmente. Inserção do processo ósseo no segmento ovalada proximodistalmente. Em todos os segmentos os processos ósseos estão inseridos na face lateroposterior em relação à nadadeira. Os processos ósseos desenvolvem-se perpendicularmente à sua inserção no segmento no qual estão inseridos. Ao longo de todo o comprimento, os processos ósseos apresentam uma curvatura de $30^{\circ}$ em relação ao eixo proximodistal do segmento no qual está inserido e desenvolvem-se em direção proximal em relação ao eixo proximodistal do segmento no qual estão inseridos. Em secção transversal, os processos ósseos variam de ovalados proximodistalmente a cilíndricos ao longo de todo o comprimento, afilando-se gradualmente e terminando em uma extremidade pontiaguda. Em seu estado máximo de desenvolvimento, o comprimento do processo não alcança o comprimento proximodistal do segmento no qual está inserido. $\mathrm{Na}$ nadadeira anal os processos ósseos aumentam e diminuem em tamanho em direção anteroposterior; primeiro e segundo raios ramificados com maior número de segmentos com processos ósseos e com processos ósseos maiores. No raio os processos ósseos diminuem de tamanho em direção proximodistal. 
$\overline{\text { Nadadeira pélvica com processos ósseos restritos a segmentos do hemitricuium ventral. }}$ Nadadeira pélvica com até dois (geralmente um) processos ósseos por segmento do hemitriquium ventral, do raio simples ao sexto raio ramificado, disrtribuindo-se em $85 \%$ dos raios ramificados (7 raios ramificados). Raio simples com processos ósseos em até oito segmentos na metade distal do hemitriquium. Raios ramificados com processos ósseos presentes tanto em segmentos proximais quanto em segmentos distais à primeira bifurcação. Processos ósseos presentes também em segmentos distais à segunda bifurcação dos ramos medial e lateral da primeira bifurcação. Proximalmente à primeira bifurcação os processos estão presentes em até quatro segmentos. Distalmente à primeira bifurcação e proximalmente às segundas ramificações, os processos ósseos estão restritos a todos os segmentos do ramo medial. Distalmente à segunda bifurcação do ramo medial da primeira bifurcação os processos ósseos estão presentes em todos os segmentos do ramo medial e em até três segmentos do ramo lateral, imediatamente distais à bifurcação. Distalmente à segunda bifurcação do ramo lateral da primeira bifurcação, os processos ósseos estão restritos a quase todos os segmentos do ramo medial, imediatamente distais à bifurcação. Processos ósseos com inserção ovalada proximodistalmente no local da inserção. Em todos os segmentos dos ramos mediais, os processos óseos estão inseridos na face ventromedial, com exceção dos segmentos do ramo lateral da segunda bifurcação do ramo medial da primeira bifurcação, nos quais os processos ósseos estão inseridos na face ventrolateral em relação à nadadeira. Os processos ósseos desenvolvem-se perpendicularmente à sua inserção no segmento no qual estão inseridos. No quarto (1/4) proximal de seu comprimento total, os processos ósseos apresentam sofrem uma curvatura de $55^{\circ}$ em relação ao segmento no qual estão inseridos e desenvolvem-se em direção proximal (ligeiramente medial) em relação ao eixo proximodistal do segmento no qual estão inseridos. Em secção transversal, os processos variam de ovalados 
$\overline{\text { proximodistalmente a cilíndricos ao longo de todo o comprimento, afilando-se gradualmente } \mathrm{e}}$ terminando em uma extremidade pontiaguda. Em seu estado máximo de desenvolvimento, seu comprimento total não alcança o comprimento proximodistal do segmento no qual está inserido. Na nadadeira pélvica os processos aumentam e diminuem de tamanho em direção lateromedial; segundo e terceiro raios ramificado com maior número de segmentos com processos ósseos e processos ósseos maiores. No raio os processos ósseos decrescem em aumentam e diminuem de tamanho em direção proximodistal.

Nadadeira dorsal com até três processos ósseos por segmento nos dois raios simples. Primeiro raio simples com processos ósseos do segundo ao segmento mais distal do raio. Segundo raio simples com processos ósseos do sexto segmento proximal ao segmento mais distal do raio. Processos ósseos simétricos bilateralmente. Processos ósseos com inserção arredondada no local da inserção. Em todos os segmentos, os processos ósseos estão inseridos tanto na face láteroanterior quanto na face lateroposterior em relação à nadadeira. Os processos ósseos desenvolvem-se perpendicularmente à sua inserção no segmento no qual estão inseridos. Ao longo de todo o seu comprimento, os processos ósseos apresentam uma curvatura de $30^{\circ}$ em relação ao eixo proximodistal do segmento no qual esta inserido e desenvolvem-se em direção proximal em relação ao eixo proximodistal do segmento no qual estão inseridos. Em secção transversal, os processos ósseos são cilíndricos ao longo de todo o comprimento, afilando-se gradualmente e terminanando em uma extremidade arredondada. Em seu estado máximo de desenvolvimento, o comprimento total não alcança o comprimento proximodistal do segmento no qual está inserido. Na nadadeira os processos ósseos aumentam de tamanho em direção anteroposterior; segundo raio com maior número de processos ósseos e processos ósseos maiores. No raio os processos apresentam tamanho semelhantes. 
Astyanax CLADE

Astyanax abramis (Jenyns 1842)

Figs. 24 a 28

Localidade tipo: rio Paraná, Rosário, Argentina.

Material examinado: MZUSP 28541, 20, Brasil, Mato Grosso do Sul, cidade de Coxim, rio Taquaril, bacia do rio Paraguay, A. Carvalho, 10/1984.

\section{Caracteres sexuais secundários}

Os caracteres sexuais secundários em A. abramis relacionam-se com comprimento padrão, formato de nadadeiras e presença de processos ósseos.

Comprimento padrão: Fêmeas alcançam maiores valores em relação aos machos. MZUSP 28541, 11 machos (63.8-77.5 mm CP) e 9 fêmeas (64.3-82.5 mm CP).

Formato de nadadeiras: Machos diferem de fêmeas pelo formato das nadadeiras pélvica e dorsal.

Extremidade distal do raio simples (raio mais longo) da nadadeira pélvica de machos adultos alcança o segundo raio ramificado da nadadeira anal. Nadadeira pélvica de machos sobrepõese ao orifício urogenital em vista ventral. Extremidade distal do raio simples (raio mais longo) da nadadeira de fêmeas adultas não alcança a origem da nadadeira anal. Nadadeira pélvica de fêmeas não sobrepõe-se ao orifício urogenital em vista ventral.

Nadadeira dorsal de machos com um decréscimo notável do último raio simples (mais longo da nadadeira); a partir do terceiro raio ramificado, os raios decrescem em tamanho gradualmente, cracterizando um formato falcado ao perfil distal da nadadeira. Nadadeira 
dorsal de fêmeas com o raio simples do mesmo comprimento que os dois raios ramificados anteriores, a partir dos quais o comprimento dos raios diminuem de tamanho gradualmente.

Processos ósseos: presentes nas nadadeiras anal e pélvica.

Nadadeira anal com um processo ósseo por segmento de hemitriquium, do último raio simples ao trigésimo raio ramificado, distribuindo-se em 94\% dos raios ramificados (até 32 raios ramificados). Raio simples com processos ósseos do nono ao vigésimo segmento, que é o segmento mais distal do raio . Raios ramificados com processos ósseos tanto em segmentos proximais quanto em segmentos distais à primeira bifurcação, presentes também em segmentos distais à segunda bifurcação dos ramos posterior e anterior da primeira bifurcação. Proximalmente à primeira bifurcação, os processos ósseos estão presentes em até dois segmentos. Distalmente à primeira bifurcação e proximalmente às segundas ramificações, os processos ósseos estão presentes em todos os segmentos do ramo posterior e em até três segmentos do ramo anterior, imediatamente proximais à segunda bifurcação deste ramo. Distalmente à segunda bifurcação do ramo posterior da primeira bifurcação, os processos ósseos estão presentes em todos os segmentos do ramo posterior e em até dois segmentos do ramo anterior mais distais do ramo. Distalmente à segunda bifurcação do ramo anterior da primeira bifurcação, os processos ósseos estão presentes em todos os segmentos do ramo posterior e em até três segmentos do ramo anterior, a partir do segundo segmento distal à bifurcação. Processos ósseos assimétricos bilateralmente. Processo ósseo com secção transversal ovalada proximodistalmente. O maior comprimento na inserção do processo ósseo ocupa $46 \%$ do comprimento proximodistal do segmento no qual está inserido. Em todos os segmentos, os processos ósseos estão inseridos na face lateroposterior em relação à nadadeira, com exceção do segmento do ramo anterior da segunda bifurcação do ramo posterior da primeira bifurcação, no qual os processos ósseos estão inseridos na face láteroanterior em 
$\overline{\text { relação à nadadeira. Os processos ósseos desenvolvem-se perpendicularmente à sua inserção }}$ no segmento no qual estão inseridos. Ao longo de seu comprimento total, os processos ósseos apresentam uma curvatura de $45^{\circ}$ em relação ao eixo proximodistal do segmento no qual está inserido e desenvolvem-se em direção proximal (ligeiramente medial) em relação ao segmento no qual estão inseridos. Em secção transversal, os processos ósseos variam de ovalados proximodistalmente a cilíndricos ao longo de todo o seu comprimento, afilando-se gradualmente e terminando em uma extremidade pontiaguda/arredondada. O diâmetro de sua extremidade distal equivale a $14 \%$ do maior comprimento no local de sua inserção no segmento. Em seu estado máximo de desenvolvimento, seu comprimento não alcança o comprimento proximodistal do segmento no qual está inserido. Comprimento do maior processo ósseo, $47 \%$ do comprimento proximodistal do segmento no qual está inserido. $\mathrm{Na}$ nadadeira anal os processos ósseos aumentam e diminuem gradualmente de tamanho; segundo e terceiro raios ramificados com maior número de segmentos com processos ósseos e processos ósseos maiores. Nos raios, os processos ósseos aumentam e diminuem de tamanho em direção proximodistal; o maior processo ósseo está no segundo segmento distal à primeira bifurcação, na metade proximal da série de processos ósseos.

Nadadeira pélvica com processos ósseos restritos a segmentos do hemitricuium ventral. Nadadeira pélvica com até dois (geralmente um) processos ósseos por segmento de hemitriquium ventral do pirmeiro ao sétimo raio ramificado, disrtribuindo-se em $100 \%$ dos raios ramificados (7 raios ramificados). Raios ramificados com processos ósseos tanto em segmentos proximais quanto em segmentos distais à primeira bifurcação. Processos ósseos presentes em segmentos distais à segunda bifurcação dos ramos medial e lateral da primeira bifurcação e também em segmentos distais à terceira bifurcação dos ramos medial e lateral da segunda bifurcação do ramo lateral da primeira bifurcação. Proximalmente à primeira 
bifurcação, dois processos estão presentes na porção distal do segmento mais proximal, mais longo. Distalmente à primeira bifurcação e proximalmene às segundas ramificações, os processos ósseos estão presentes em todos os segmentos dos ramos medial e lateral. Distalmente à segunda bifurcação do ramo medial, os processos ósseos estão presentes em todos os segmentos dos ramos medial e lateral. Distalmente à segunda bifurcação do ramo lateral da primeira bifurcação, os processos ósseos estão presentes em todos os segmentos dos ramos medial e lateral Distalmente à terceira bifurcação do ramo lateral da segunda bifurcação do ramo lateral da primeira bifurcação, os processos ósseos estão presentes em todos os segmentos do ramo medial e nos quatro segmentos mais distais do ramo lateral. Distalmente à terceira bifurcação do ramo medial da segunda bifurcação do ramo lateral da primeira bifurcação, os processos ósseos estão presentes em todos os segmentos do ramo medial e até quatro segmentos do ramo lateral, imediatamente distais à bifurcação. Processos ósseos com inserção ovalada proximodistalmente. O maior comprimento no local da inserção dos processos ósseos ocupa $28 \%$ do comprimento proximodistal do segmento no qual estão inseridos. Proximalmente à primeira bifurcação, no segmento mais proximal, o mais longo, os processos ósseos estão inseridos na face ventrolateral. Nos segmentos do ramo lateral da primeira bifurcação, os processos ósseos estão inseridos na face ventrolateral. Nos dois segmentos do ramo lateral da segunda bifurcação do ramo lateral da primeira bifurcação, os processos ósseos estão inseridos na face ventrolateral; do terceiro segmento ao segmento imediatamente proximal à terceira bifurcação, os processos ósseos estão inseridos na face ventromedial. Nos segmentos do ramo medial da segunda bifurcação do ramo lateral da primeira bifurcação, os processos ósseos estão inseridos na face ventromedial dos três segmentos imediatamente distais à bifurcação; nos demais segmentos deste ramo os processos ósseos estão inseridos tanto na face ventromedial quanto na face ventrolateral. Nos segmentos 
$\overline{\text { dos ramo lateral da terceira bifurcação do ramo lateral da segunda bifurcação do ramo lateral }}$ da primeira bifurcação, os processos ósseos estão inseridos na face face ventromedial. Nos segmentos do ramo medial da terceira bifurcação dos ramos medial e lateral da segunda bifurcação do ramo lateral da primeira bifurcação, os processos ósseos estão inseridos na face ventromedial. Nos segmentos do ramo lateral da terceira bifurcação do ramo medial da segunda bifurcação do ramo lateral da primeira bifurcação, os processos ósseos estão inseridos na face ventrolateral dos dois segmentos imediatamente distais à bifurcação e na face ventromedial dos dois segmentos a partir do segundo segmento distais à bifurcação. Nos segmentos do ramo medial da primeira bifurcação, os processos ósseos estão inseridos na face ventromedial, exceto os dois segmentos imediatamente proximais à segunda bifurcação deste ramo, na qual os processos ósseos estão inseridos tanto na face ventromedial quanto na face ventrolateral. Nos segmentos do ramo medial da segunda bifurcação do ramo medial da primeira bifurcação, os processos ósseos estão inseridos na face ventromedial. Nos segmentos do ramo lateral da segunda bifurcação do ramo medial da primeira bifurcação, os processos ósseos estão inseridos na face ventrolateral. Os processos ósseos desenvolvem-se perpendicularmente à sua inserção nos segmentos. No quarto (1/4) proximal de seu comprimento, os processos ósseos apresentam uma curvatura de $80^{\circ}$ em relação ao eixo proximodistal do segmento no qual estão inseridos e desenvolvem-se em direção proximomedial em relação ao eixo proximodistal do segmento no qual estão inserido. Em secção transversal, os processos ósseos variam de ovalados proximodistalmente a cilíndricos ao longo de todo o seu comprimento, afilando-se-se gradualmente e terminando em uma extremidade arredondada. O diâmetro em sua extremidade distal ocupa $15 \%$ do maior comprimento no local de sua inserção no segmento no qual está inserido. Em seu estado máximo de desenvolvimento, seu comprimento não alcança o comprimento proximodistal do 
$\overline{\text { segmento no qual está inserido. O comprimento do maior processo ósseo equivale a } 74 \% \text { do }}$ comprimento proximodistal do segmento no qual está inserido. $\mathrm{Na}$ nadadeira pélvica os processos ósseos aumentam e diminuem gradualmente de tamanho em direção lateromedial; segundo e terceiro raios ramificado com o maior número de segmentos com processos ósseos e processos ósseos maiores. Nos raios, os processos ósseos aumentam e diminuem de tamanho em direção proximodistal; o maior processo ósseo localiza-se no segmento imediatamente distal à segunda bifurcação do ramo medial da primeira bifurcação.

\section{Astyanax asuncionensis Géry 1972}

Localdade tipo: rio Paraguay e alto rio Tocantins.

Material examinado: MZUSP 59630, 19, Brasil, Mato Grosso do Sul, Aquidauana, Rio Taboco (pântano), 204’12”S, 55³8’37’W, A. Machado, B. Chernoff, 30/08/1998.

\section{Caracteres sexuais secundários}

Os caracteres sexuais secundários em $A$. asuncionensis relacionam-se ao comprimento padrão e presença de processos ósseos em nadadeiras.

Comprimento padrão: fêmeas alcançam maiores valores de comprimento padrão em relação aos machos. MZUSP 59630, 9 machos (36.6-42.7 mm CP) e 11 fêmeas (37.4-50.6 mm CP)

Processos ósseos: presentes nas nadadeira anal e pélvica.

Nadadeira anal com até dois processos ósseos por segmento de hemitriquium, do último raio simples até o décimo primeiro raio ramificado, distribuindo-se em 38\% dos raios ramificados (até 29 raios ramificados). Raio simples com processos ósseos do sexto ao décimo terceiro segmento, que é o segmento mais distal do raio. Raios ramificados com processos ósseos tanto em segmentos proximais quanto em segmentos distais à primeira bifurcação. Processos 
ósseos presentes também em segmentos distais à segunda bifurcação do ramo anterior da primeira bifurcação. Proximalmente à primeira bifurcação, os processos ósseos estão presentes em até três segmentos. Distalmente à primeira bifurcação e proximalmente às segundas ramificações, os processos ósseos estão presentes em todos os segmentos do ramo posterior e em até três segmentos do ramo anterior, imediatamente proximais à segunda bifurcação. Distalmente à segunda bifurcação do ramo anterior da primeira bifurcação, os processos ósseos estão presentes em até dois segmentos do ramo posterior, imediatamente distais à bifurcação. Processos ósseos assimétricos bilateralmente. Processos ósseos com inserção ovalada proximodistalmente. Em todos os segmentos, os processos estão inseridos na face lateroposterior em relação à nadadeira anal. Os processos ósseos desenvolvem-se perpendicularmente à sua inserção no segmento no qual estão inseridos. Ao longo do comprimento, os processos ósseos apresentam uma curvatura de $45^{\circ}$ em relação ao eixo proximodistal do segmento no qual está inserido e desenvolvem-se em direção proximal (ligeiramente medial) em relação ao eixo proximodistal do segmento no qual estão inseridos. Em secção transversal, os processos ósseos variam de ovalados proximodistalmente a cilíndricos ao longo de seu comprimento, afilando-se gradualmente e terminando em uma extremidade distal arreondada. Em seu estado máximo de desenvolvimento, o comprimento total não alcança o comprimento proximodistal do segmento no qual está inserido. $\mathrm{Na}$ nadadeira anal os processos diminuem em tamanho em direção anteroposterior; primeiro e segundo segmentos com maior número de segmentos com processos ósseos e processos ósseos maiores. No raio os processos ósseos diminuem de tamanho em direção proximodistal. Nadadeira pélvica com processos ósseos restritros a segmentos do hemitriquium ventral. Nadadeira pélvica com até dois processos ósseos por segmento, do primeiro ao sexto raio ramificado, disrtribuindo-se em $85 \%$ dos raios ramificados (7 raios ramificados). Raios 
$\overline{\text { ramificados com processos tanto em segmentos proximais quanto distais à primeira }}$ bifurcação. Processos ósseos presentes também em segmentos distais à segunda bifurcação do ramo lateral da primeira bifurcação. Proximalmente à primeira bifurcação, os processos estão presentes em um segmento. Distalmente à primeira bifurcação e proximalmente à segunda bifurcação, os processos ósseos estão presentes em todos os segmentos do ramo medial e em até três segmentos do ramo anterior, imediatamente proximais à segunda bifurcação. Distalmente à segunda bifurcação do ramo lateral da primeira bifurcação, os processos ósseos estão restritos a até três segmentos do ramo medial, imediatamente distais à bifurcação. Distalmente à segunda bifurcação do ramo medial da primeira bifurcação, os processos ósseos estão presentes em todos os segmentos do ramo medial e em até dois segmentos do ramo lateral, imediatamente distais à bifurcação. Processos ósseos com inserção ovalada proximodistalmente. Em todos os segmentos, os processos ósseos estão inseridos na face ventromedial, com exceção de quatro segmentos do ramo medial da primeira bifurcação imediatamente proximais à segunda bifurcação, no qual os processos ósseos estão inseridos tanto na face ventromedial quanto na face ventrolateral e nos segmentos do ramo lateral da segunda bifurcação do ramo medial da primeira bifurcação, os quais os processos ósseos estão inseridos na face ventrolateral. Os processos ósseos desenvolvem-se perpendicularmente à sua inserção no segmento no qual estão inseridos. No quarto (1/4) proximal de seu comprimento, os processos ósseos apresentam uma curvatura de $45^{\circ}$ em relação ao eixo proximodistal do segmento no qual estão inseridos e desenvolvem-se em direção proximomedial em relação ao eixo proximodistal do segmento no qual estão inseridos, afilando-se gradualmente e terminando em uma extremidade arredondada. Em seu estado máximo de desenvolvimento, o seu comprimento total não alcança o comprimento proximodistal do segmento no qual está inserido. Na nadadeira pélvica os processos 
$\overline{\text { diminuem em tamanho e em número em direção lateromedial; primeiro e segundo raios }}$ ramificados com maior número de segmentos com processos ósseos e processos ósseos maiores. No raio os processos ósseos diminuem de tamanho em direção proximodistal.

\section{Astyanax lineatus (Perugia 1891)}

Figs. 29 a 32

Localidade tipo: rio Paraguay, Villa Maria, Mato Grosso, Brasil.

Material examinado: MZUSP 99272, 71, Brasil, Mato Grosso, Nortelândia, ribeirão Santana, abaixo da PCH Arrozensal, fazenda Arrosensal, 14¹9'8.0”S, 56 44'50.0”W, F. A. Machado et al., 10/2005. MZUSP 59712, 12, Brasil, Mato Grosso, Costa Rica, riacho Água Clara, a 3 km da Fazenda Rio Bonito, bacia do rio Taquari, $18^{\circ} 15^{\prime} 6.0^{\prime} \mathrm{S}, 53^{\circ} 27^{\prime} 50.0^{\prime \prime} \mathrm{W}$, O. Oyakawa et al., 31/08/1998.

\section{Caracteres sexuais secundários}

Os caracteres sexuais secundários em A. lineatus relacionam-se ao comprimento padrão, presença de processos ósseos em nadadeiras e presença de tubérculos reprodutivos.

Comprimento padrão: fêmeas alcançam maiores valores de comprimento padrão em relação aos machos. MZUSP 99272, 20 machos (37.3-64.4 mm CP) e 25 fêmeas (46.9-66.9 mm CP).

Processos ósseos: presentes nas nadadeiras anal e pélvica de machos maduros.

Nadadeira anal com um processo ósseo por segmento do hemitriquium, do último raio simples ao vigésimo quarto raio ramificado, distribuindo-se em $85 \%$ dos raios ramificados (até 28 raios ramificados). Raio simples com processos ósseos do oitavo ao vigésimo terceiro segmentos, o mais distal do raio. Raios ramificados com processos ósseos tanto em segmentos proximais quanto em segmentos distais à primeira bifurcação. Processos ósseos presentes 
também em segmentos distais à segunda bifurcação dos ramos anterior e posterior da primeira bifurcação. Proximalmente à primeira bifurcação os processos estão presentes em até dois segmentos. Distalmente à primeira bifurcação os processos ósseos estão restritos a todos os segmentos do ramo posterior; existe um ou dois segmentos sem processos ósseos intercalados com os segmentos com processos ósseos. Distalmente à segunda bifurcação do ramo anterior da primeira bifurcação, os processos ósseos estão restritos a todos os segmentos do ramo posterior. Distalmente à segunda bifurcação do ramo posterior da primeira bifurcação, os processos ósseos estão presentes em todos os segmentos do ramo posterior e em até dois segmentos do ramo anterior, segmentos mais distais do ramo; existe um ou dois segmentos sem processos ósseos intercalados com segmentos com processos ósseos no ramo posterior. Processos ósseos simétricos bilateralmente. Processos ósseos com inserção ovalada proximodistalmente no local da inserção. O maior comprimento de sua inserção ocupa 39\% do comprimento proximodistal do segmento no qual está inserido. Em todos os segmentos, os processos ósseos estão inseridos na face lateroposterior, com exceção dos segmentos do ramo anterior da segunda bifurcação do ramo posterior da primeira bifurcação, no qual o processo ósseo está inserido na face lateroanterior. Os processos ósseos desenvolvem-se perpendicularmente à sua inserção no segmento no qual estão inseridos. No quarto $(1 / 4)$ proximal de seu comprimento t, os processos ósseos apresentam uma curvatura de $45^{\circ} \mathrm{em}$ relação ao eixo proximodistal do segmento no qual está inserido e desenvolvem-se em direção proximal (ligeiramente medial) em relação ao eixo proximodistal do segmento no qual estão inseridos. Em secção transversal, os processos ósseos variam de ovalados proximodistalmente a cilíndricos ao longo de todo o seu comprimento, afilando-se gradualmente e terminando em uma extremidade arredondada. O diâmetro de sua extremidade distal equivale a $29 \%$ do maior comprimento de sua inserção no segmento no qual está inserido. Em seu estado máximo de 
$\overline{\text { desenvolvimento, seu comprimento total não alcança o comprimento proximodistal do }}$ segmento no qual está inserido. O comprimento do maior processo ósseo equivale a $45 \%$ do comprimento proximodistal do segmento no qual está inserido. Na nadadeira anal os processos ósseos aumentam e diminuem de tamanho gradualmente em direção anterposterior; segundo e terceiro raios ramificados com maior número de segmentos com processos ósseos e processos ósseos maiores. Nos raios, os processos ósseos aumentam e diminuem de tamanho em direção proximodistal; o maior processo ósseo localiza-se no segundo segmento proximal à segunda bifurcação, na metade distal da série de processos ósseos.

Nadadeira pélvica com processos ósseos restritos a segmentos do hemitricuium ventral. Nadadeira pélvica com um processo ósseo por segmento do hemitriquium ventral do primeiro ao sexto raios ramificados, disrtribuindo-se em $85 \%$ dos raios ramificados (7 raios ramificados). Raios ramificados com processos restritos a segmentos distais à primeira bifurcação. Processos ósseos presentes também em segmentos distais à segunda bifurcação dos ramos medial e lateral da primeira bifurcação, presentes também em segmentos distais à terceira bifurcação dos ramos medial e lateral da segunda bifurcação dos ramos medial e lateral da primeira bifurcação. Distalmente à primeira bifurcação e proximalmente às segundas ramificações, os processos ósseos estão restritos a todos os segmentos do ramo medial. Distalmente à segunda bifurcação do ramo medial da primeira bifurcação, os processos ósseos estão presentes em todos os segmentos do ramo medial e em até seis segmentos do ramo lateral, imediatamente proximais à terceira bifurcação deste ramo; existe um ou dois segmentos sem processos ósseos intercalados com segmentos com processos ósseos no ramo medial. Distalmente à terceira bifurcação do ramo medial da segunda bifurcação do ramo medial da primeira bifurcação, os processos estão restritos a todos os segmentos do ramo medial. Distalmente à terceira bifurcação do ramo lateral da segunda 
bifurcação do ramo medial da primeira bifurcação, os processos estão presentes em até três segmentos do ramo medial e em até dois segmentos do ramo lateral, segmentos mais distais destes ramos. Distalmente à segunda bifurcação do ramo lateral da primeira bifurcação, os processos ósseos estão restritos a até nove segmentos do ramo medial, imediatamente distais à bifurcação; existe um ou dois segmentos sem processos ósseos inetercalados com segmentos com processos ósseos neste ramo. Distalmente à teceira bifurcação dos ramos medial e lateral da segunda bifurcação do ramo lateral da primeira bifurcação, os processos ósseos estão presentes em até três segmentos dos ramos medial e lateral, segmentos mais distais. Processos ósseos ovalados proximodistalmente no local de sua inserção, proximodistalmente. O maior comprimento do processo ósseo ocupa $42 \%$ do comprimento proximodistal do segmento no qual está inserido. Em todos os segmentos, os processos ósseos estão inseridos na face ventromedial, com exceção do primeiro segmento proximal à terceira bifurcação do ramo lateral da segunda bifurcação do ramo medial da primeira bifurcação, na qual os processos ósseos estão inseridos tanto na face ventromedial quanto na face ventrolateral. Nos demais segmentos os processos ósseos estão inseridos na face ventrolateral. Os processos ósseos desenvolvem-se perpendicularmente à sua inserção nos segmentos no qual estão inseridos. No um quarto (1/4) proximal de seu comprimento, os processos ósseos apresentam uma curvatura de $60^{\circ}$ em relação ao eixo proximodistal do segmento no qual estão inseridos e desenvolvemse em direção proximomedial em relação ao eixo proximodistal do segmento no qual estão inseridos. Em secção transversal, os processos ósseos variam de ovalados proximodistalmente a cilíndricos ao longo de seu comprimento total, afilanado-se gradualmente e terminando em uma extremidade pontiaguda. $\mathrm{O}$ diâmetro em sua extremidade distal equivale a $15 \%$ de seu maior comprimento no local de sua inserção no segmento no qual stá inserido. Em seu estado máximo de desenvolvimento, seu comprimento não alcança o comprimento proximodistal do 
$\overline{\text { segmento no qual está inserido. O comprimento do maior processo ósseo equivale a } 85 \% \text { do }}$ comprimento proximodistal do segmento no qual está inserido. $\mathrm{Na}$ nadadeira pélvica os processos ósseos aumentam e diminuem gradualmente de tamanho em direção lateromedial; quinto raio ramificado com o maior número de segmentos com processos ósseos e processos ósseos maiores. Nos raios, os processos ósseos aumentam e diminuem de tamanho em direção proximodistal; o maior processo ósseo localiza-se no primeiro segmento distal à segunda bifurcação do ramo posterior da primeira bifurcação, na metade proximal da série de processos ósseos.

Tubérculos reprodutivos: presente em machos.

Tubérculos reprodutivos presentes na cabeça de machos, sobre o osso maxilar, primeiro e segundo infraorbitais, região interorbital e região gular.

\section{Astyanax cf. jordani (Hubbs \& Innes 1936)}

Figs. 33 a 36

Localidade tipo: rio subterrâneo, região montanhosa com floresta, na região sudeste de San Luis Potosí, Mexico.

Material examinado: MZUSP 100742, 19 (1, d\&c), México, San Luis Potosí, rio Ojo Frío, bridge on $\mathrm{N}$ edge of Rascon, $22^{\circ} 0{ }^{\prime} 0.0^{\prime} \mathrm{N}, 99^{\circ} 18^{\prime} 0.0 \mathrm{~W}, \mathrm{~N}$. Humphries et al..

\section{Caracteres sexuais secundários}

Os caracteres sexuais secundários em A. mexicanus relacionam-se ao comprimento padrão, formato de nadadeiras e presença de processos ósseos.

Comprimento padrão: fêmeas alcançam maiores valores e comprimento padrão em relação aos machos. MZUSP 100742, 3 machos (46.9-54.1 mm CP) e 9 fêmeas (55.3-70.2 mm CP). 
Formato de nadadeiras: machos diferem de fêmeas pelo formato do perfil da margem distal da nadadeira anal e formato da nadadeira pélvica

Perfil da margem distal da nadadeira anal de machos quase reta, o lobo anterior pouco desenvolvido, formado pelo aumento discreto de tamanho do último raio simples e do segundo raio ramificado (raio mais longo), com diminuição pouco acentuada deste até o quinto raio ramificado; sua margem distal ligeiramente convexa, perfil reto do sexto ao último raio ramificado. Nadadeira anal de fêmeas com margem distal do lobo anterior conspicuamente côncava. Lobo anterior formado pelo aumento gradual do último raio simples e segundo raio ramificado (raio mais longo) e diminuição acentuada de tamanho deste ponto até o quinto raio ramificado; perfil reto do sétimo ao último raio ramificado. Extremidade distal do primeiro raio ramificado (raio mais longo) da nadadeira pélvica de machos alcançando a origem da nadadeira anal. Nadadeira pélvica sobrepondo-se ao orifício urogenital em vista ventral. Extremidade distal do primeiro raio ramificado (raio mais longo) da nadadeira pélvica de fêmeas não alcança a origem da nadadeira anal. Nadadeira pélvica não sobrepõe-se ao orifício urogenital em vista ventral.

Processos ósseos: presentes nas nadadeiras anal e pélvica de machos maduros.

Nadadeira anal com um processo ósseo por segmento do hemitriquium, do último raio simples ao nono raio ramificado, distribuindo-se em $45 \%$ dos raios ramificados (até 20 raios ramificados). Raio simples com processos ósseos do décimo ao décimo nono segmento, que é o segundo segmento proximal à extremidade distal do raio; um segmento sem processo ósseo intercalado com segmentos de processos ósseos ao longo do raio. Raios ramificados com processos ósseos em segmentos tanto proximais quanto distais à primeira bifurcação. Processos ósseos presentes também em segmentos distais à segunda bifurcação do ramo anterior da primeira bifurcação. Proximalmente à primeira bifurcação, os processos estão 
$\overline{\text { presentes em até dois segmentos. Distalmente à primeira bifurcação os processos ósseos estão }}$ presentes em até nove segmentos do ramo posterior e em até três segmentos do ramo anterior, imediatamente proximais à segunda bifurcação deste ramo; alguns segmentos sem processos ósseos intercalados com os segmentos com processos ósseos no ramo posterior. Distalmente à segunda bifurcação do ramo anterior da primeira bifurcação, os processos ósseos estão restritos a até três segmentos do ramo posterior, imediatamente distais à bifurcação; um ou dois segmentos sem processos ósseos intercalados com segmentos com processos ósseos no ramo posterior. Processos ósseos assimétricos bilateralmente. Processo ósseo com inserção ovalada proximodistalmente no local da inserção. O maior comprimento do processo ósseo no local de sua inserção ocupa $40 \%$ do comprimento proximodistal do segmento no qual está inserido. Em todos os segmentos, os processos ósseos estão inseridos na face lateroposterior em relação à nadadeira e desenvolvem-se perpendicularmente à sua inserção no segmento no qual estão inseridos. Ao longo de seu comprimento, os processos ósseos apresentam uma curvatura de $50^{\circ}$ em relação ao eixo proximodital do segmento no qual estão inseridos e desenvolvem-se em direção proximal (ligeiramente medial) em relação ao eixo proximodistal do segmento no qual estão inseridos. Em secção transversal, os processos ósseos variam de ovalados proximodistalmente a cilíndricos ao longo de seu comprimento, afilando-se gradualmente e terminando em uma extremidade arredondada. Diâmetro de sua extremidade distal, $15 \%$ do seu maior comprimento no local de sua inserção no segmento no qual está inserido. Em seu estado de desenvolvimento máximo, seu comprimento não alcança o comprimento proximodistal do segmento no qual está inserido. O comprimento do maior processo ósseo equivale a $50 \%$ do comprimento proximodistal do segmento no qual está inserido. Na nadadeira anal os processos ósseos aumentam e diminuem gradualmente de tamanho em direção anterposterior; segundo e terceiro raios ramificados com maior número 
$\overline{\text { de segmentos com processos ósseos e processos ósseos maiores. Nos raios, os processos }}$ ósseos aumentam e diminuem de tamanho em direção proximodistal; o maior processo ósseo localiza-se no quinto segmento distal à primeira bifurcação, na metade proximal da série de processos ósseos.

Nadadeira pélvica com processos ósseos restritos a segmentos do hemitricuium ventral. Nadadeira pélvica com um processo ósseo por segmento de hemitriquium ventral do primeiro ao sexto raio ramificados, distribuindo-se em $85 \%$ dos raios ramificados ( 7 raios ramificados). Raios ramificados com processos ósseos tanto em segmentos proximais quanto distais á primeira bifurcação. Processos ósseos presentes também em segmentos distais à segunda bifurcação dos ramos medial e lateral da primeira bifurcação. Proximalmente à primeira bifurcação, os processos ósseos estão presentes em até três segmentos. Distalmente à primeira bifurcação e proximalmente às segundas bifurcaçãoes, os processos ósseos estão presentes em todos os segmentos dos ramos medial e em até três segmentos do ramo lateral, imediatamente proximais à segunda bifurcação deste ramo. Distalmente à segunda bifurcação do ramo medial da primeira bifurcação, os processos ósseos estão presentes em todos os segmentos do ramo medial e em até três segmentos do ramo lateral, imediatamente distais à segunda bifurcação; existe um segmento sem processos ósseos intercalado com os segmentos com processos ósseos neste ramo. Distalmente à segunda bifurcação do ramo lateral da primeira bifurcação, os processos ósseos estão presentes em todos os segmentos do ramo medial e em um segmento do ramo lateral, a partir do sétimo segmento distal à terceira bifurcação. Processos ósseos com inserção ovalada proximodistalmente no local de suas inserções. O maior comprimento no local da inserção ocupa $47 \%$ do comprimento proximodistal do segmento no qual está inserido. Em todos os segmentos, os processos ósseos estão inseridos na face ventromedial em relação à nadadeira, com exceção do segmento do 
$\overline{\text { ramo medial da primeira bifurcação imediatamente proximal à segunda bifurcação deste }}$ ramo, na qual os processos ósseos estão inseridos tanto na face ventrolateral (menor) quanto na face ventromedial (espelhados) e dos segmentos do ramo lateral da segunda bifurcação do ramo medial da primeira bifurcação, nas quais os processos ósseos estão inseridos na face ventrolateral. Os processos ósseos desenvolvem-se perpendicularmente à sua inserção nos segmentos no qual estão inseridos. Em seu terço (1/3) proximal, os processos ósseos apresentam uma curvatura de $60^{\circ}$ em relação ao eixo proximodistal do segmento no qual estão inseridos e desenvolvem-se em direção proximal (ligeiramente medial) em relação ao eixo proximodistal do segmento no qual estão inseridos. Em secção transversal, os processos ósseos variam de ovalados proximodistalmente a cilíndricos ao longo de seu comprimento, afilando-se gradualmente e terminando em uma extremidade levemente arredondada. $\mathrm{O}$ diâmetro de sua extremidade distal equivale a $14 \%$ do maior comprimento no local de sua inserção nos segmentos no qual está inserido. Em seu estado máximo de desenvolvimento, seu comprimento não alcança o comprimento proximodistal do segmento no qual está inserido. Comprimento do maior processo ósseo, $84 \%$ do comprimento proximodistal do segmento no qual está inserido. Na nadadeira pélvica os processos ósseos decrescem gradualmente de tamanho em direção lateromedial; segundo raio ramificado com o maior número de segmentos com processos ósseos e processos ósseos maiores. Nos raios, os processos ósseos aumentam e diminuem de tamanho em direção proximodistal; o maior processo ósseo localiza-se no segundo segmento proximal à segunda bifurcação do ramo medial da primeira rmaificaçào, na metade proximal da série de processos ósseos.

Tubérculos reprodutivos: presentes em machos maduros.

Tubérculos reprodutivos presentes, sobre o osso maxilar, primeiro e segundo infraorbitais, região interorbital e região gular na cabeça de machos. 


\section{Hyphessobrycon anisitsi (Eigenmann 1907)}

Fig. 37 a 39

Material examinado: MZUSP 100477, 43, Brasil, São Paulo, Sorocaba, Açudes na Fazenda Boa Vista, bacia do rio Tietê, 2322’18”S, 47³3’58”W, H. Britski \& E. Baena, 18/09/2008.

\section{Caracteres sexuais secundários:}

Os caracteres sexuais secundários em $H$. anisitsi relacionam-se ao comprimento padrão, formato de nadadeiras e presença de processos ósseos.

Comprimento padrão: fêmeas alcançam maiores valores de comprimento padrão em relação aos machos. MZUSP, 4 machos (37.6-44.1 mm CP) e 32 fêmeas (51.5- 56.6 mm CP).

Formato de nadadeiras: Machos diferem de fêmeas pelo formato do perfil da margem distal da nadadeira anal e formato da nadadeira pélvica.

Perfil da margem distal da nadadeira anal de machos praticamente reta, com um lobo anterior pouco pronunciado e margem distal convexa. Lobo anterior formado pelo aumento do último raio simples e segundo raio ramificado (raio mais longo) e diminuição gradual de tamanho deste ao quinto raio ramificado; perfil reto do sexto ao último raio ramificado. Perfil da margem distal do lobo anterior da nadadeira anal conspicuamente côncavo. Lobo anterior formado pelo último raio simples, segundo raio ramificado (raio mais longo) com diminuição acentuada deste ao quinto raio ramificado; perfil reto do sexto ao último raios ramificados que diminuem gradativamente de tamanho em sentido anteroposterior.

Extremidade distal do primeiro raio ramificado (raio mais longo) da nadadeira pélvica de machos alcançando o segundo raio ramificado da nadadeira anal. Nadadeira pélvica de machos sobrepondo-se ao orifício urogenital em vista ventral. Extremidade distal do primeiro 
$\overline{\text { raio ramificado (raio mais longo) da nadadeira pélvica de fêmeas alcançando a origem da }}$ nadadeira anal, sem ultrapassar o último raio simples da nadadeira anal. Nadadeira pélvica de fêmeas não sobrepondo-se ao orifício urogenital em vista ventral.

Processos ósseos: presentes nas nadadeiras anal e pélvica de machos.

Nadadeira anal com um processo ósseo por segmento do hemitriquium, do último raio simples ao décimo raio ramificado, $41 \%$ dos raios ramificados (até 24 raios ramificados). Raio simples com processos ósseos em até cinco segmentos na parte mais distal do raio. Raios ramificados com processos ósseos presentes tanto em segmentos proximais quanto distais à primeira bifurcação. Proximalmente à primeira bifurcação, os processos ósseos estão presentes em até cinco segmentos. Distalmente à primeira bifurcação, os processos ósseos estão restritos a até nove segmentos do ramo posterior da primeira bifurcação, imediatamente distais à bifurcação. Processos ósseos assimétricos bilateralmente. Processos ósseos inserção ovalada proximodistalmente. O maior comprimento do processo ósseo no local da inserção, ocupa $30 \%$ do comprimento proximodistal do segmento no qual está inserido. Em todos os segmentos, os processos ósseos estão inseridos na face lateroposterior em relação à nadadeira e desenvolvem-se perpendicularmente à sua inserção no segmento no qual estão inseridos. Ao longo de seu comprimento, os processos ósseos apresentam uma curvatura de $30^{\circ}$ em relação aoeixo proximodistal do segmento no qual estão inseridos e desenvolvem-se em direção proximal em relação ao eixo proximodistal do segmento no qual estão inseridos. Em secção transversal, os processos ósseos variam de ovalados proximodistalmente a cilíndricos ao longo de seu comprimento, afilando-se gradualmente e terminando em uma extremidade arredondada. $\mathrm{O}$ diâmetro de sua extremidade distal equivale a $15 \%$ do seu maior comprimento no segmento no qual está inserido. Em seu estado máximo de desenvolvimento, seu comprimento não alcança o comprimento proximodistal do segmento no qual está inserido. 
$\overline{\text { Comprimento do maior processo ósseo, } 49 \% \text { do comprimento proximodistal do segmento no }}$ qual está inserido. $\mathrm{Na}$ nadadeira anal os processos ósseos aumentam e diminuem gradualmente de tamanho em direção anteroposterior; segundo e terceiro raios ramificados com maior número de segmentos com processos ósseos e processos ósseos maiores. Nos raios, os processos ósseos aumentam e diminuem de tamanho em direção proximodistal; o maior processo ósseo localiza-se no segundo segmento distal à segunda bifurcação do ramo posterior da primeira ramificaçào, na metade distal da série de processos ósseos.

Nadadeira pélvica com processos ósseos estão restritos a segmentos do hemitricuium ventral, com um processo ósseo por segmento de hemitriquium ventral do segundo ao quinto raio ramificado, disrtribuindo-se em $71 \%$ dos raios ramificados ( 7 raios ramificados). Processos ósseos presentes tanto em segmentos proximais quanto em segmentos distais à primeira bifurcação. Proximalmente à primeira bifurcação, os processos ósseos estão presentes em até dois segmentos. Distalmente à primeira bifurcação e proximalmente à segundas bifurcaçãoes, os processos ósseos estão restritos a todos os segmentos do ramo medial. Distalmente à segunda bifurcação do ramo medial da primeira bifurcação os processos ósseos estão presentes em até dois segmentos, imediatamente distais à segunda bifurcação; existe um segmento sem processos ósseos intercalado com os segmentos com processos ósseos neste ramo. Processos ósseos com inserção ovalada proximodistalmente. O maior comprimento de sua inserção ocupa $28 \%$ do comprimento proximodistal do segmento no qual está inserido. Em todos os segmentos, os processos ósseos estão inseridos na face ventromedial em relação à nadadeira. Os processos ósseos desenvolvem-se perpendicularmente à sua inserção nos segmentos no qual estão inseridos. Ao longo de seu comprimento, os processos ósseos apresentam uma curvatura de $30^{\circ}$ em relação ao eixo proximodistal do segmento no qual está inserido e desenvolvem-se em direção proximal em 
$\overline{\text { relação ao eixo proximodistal do segmento no qual estão inseridos. Em secção transversal, os }}$ processos ósseos variam de ovalados proximodistalmente a cilíndricos ao longo de seu comprimento, afilando-se gradualmente e terminando em uma extremidade levemente arredondada. O diâmetro de sua extremidade distal equivale a $16 \%$ do maior comprimento no local de sua inserção nos segmentos no qual está inserido. Em seu estado máximo de desenvolvimento, seu comprimento não alcança o comprimento proximodistal do segmento no qual está inserido. O comprimento do maior processo ósseo equivale a $84 \%$ do comprimento proximodistal do segmento no qual está inserido. $\mathrm{Na}$ nadadeira pélvica os processos ósseos aumentam e diminuem gradualmente de tamanho em direção lateromedial; segundo raio ramificado com o maior número de segmentos com processos ósseos e processos ósseos maiores. Nos raios, os processos ósseos aumentam e diminuem de tamanho em direção proximodistal; o maior processo ósseo localiza-se no terceiro segmento distal à primeira bifurcação do ramo medial da primeira rmaificaçào, na metade proximal da série de processos ósseos.

\section{Markiana nigripinnis (Perugia 1891)}

Fig. 40 e 41

Localidade tipo: Rio de la Plata, South America.

Material examinado: MZUSP 18850, 48, Brasil, Mato Grosso, Poconé, rio Cuiabá, bacia do rio Paraguay, 16³0’0.0”S, 56²4’0.0”W, CEPIPAM, 09/1977.

\section{Caracteres sexuais secundários}

Os caracteres sexuais secundários em $M$. nigripinnis relacionam-se ao comprimento padrão e presença de processos ósseos. 
Comprimento padrão: fêmeas alcançam maiores valores de comprimento padrão em relação aos machos. MZUSP 18850, 15 machos (76.7-85.4 mm CP) e 19 fêmeas (78-98.7 mm CP)

Processos ósseos: presentes na nadadeira anal de machos.

Nadadeira anal com um processo ósseo por segmento do último raio simples até o trigésimo sétimo raio ramificado, disrtribuindo-se em 93\% dos raios ramificados (até 40 raios rmaificados). Último raio simples com processos ósseos do quinto ao sexto segmento proximal à extremidade distal do raio. Processos ósseos presentes também em segmentos distais à segunda bifurcação do ramo posterior da primeira bifurcação. Proximalmente à primeira bifurcação os processos ósseos estão presentes em até quatro segmentos. Distalmente à primeira bifurcação os processos ósseos estão restritos a todos os segmentos do ramo posterior; um ou dois segmentos sem processos ósseos intercalados com os segmentos com processos ósseos neste ramo. Distalmente à segunda bifurcação do ramo posterior da primeira bifurcação, os processos ósseos estão restritos a até três segmentos do ramo posterior, imediatamente distais à bifurcação. Processos ósseos assimétricos bilateralmente. Processos ósseos com inserção ovalada proximodistalmente. O maior comprimento no local de sua inserção ocupa $56 \%$ do comprimento proximodistal do segmento no qual está inserido. Em todos os segmentos, os processos ósseos estão inseridos na face lateroposterior em relação à nadadeira e desenvolvem-se perpendicularmente à suas inserções no segmento no qual estão inseridos. Ao longo de seu comprimento, os processos ósseos apresentam uma curvatura de $30^{\circ}$ e desenvolvem-se em direção proximal em relação ao eixo proximodistal do segmento no qual estão inseridos. Em secção transversal, os processos ósseos variam de ovalados proximodistalmente a cilíndricos ao longo de seu comprimento total, afilando-se gradualmente e terminando em uma extremidade arredondada. Diâmetro de sua extremidade distal, $29 \%$ do maior comprimento no local de sua inserção no segmento no qual está 
inserido. Em seu estado máximo de desenvolvimento, seu comprimento total não alcança o comprimento proximodistal do segmento no qual está inserido. O maior comprimento do maior processo ósseo equivale a $56 \%$ do comprimento proximodistal do segmento no qual está inserido. Na nadadeira anal os processos ósseos aumentam e diminuem gradualmente de tamanho em direção anterposterior; segundo e terceiro raios ramificados com maior número de segmentos com processos ósseos e processos ósseos maiores. Nos raios, os processos ósseos aumentam e diminuem de tamanho em direção proximodistal; o maior processo ósseo localiza-se no segundo segmento distal proximal à segunda bifurcação do ramo posterior da primeira rmaificaçào, na metade distal da série de processos ósseos.

\section{Psellogrammus kennedyi (Eigenmann 1903)}

Figs. 42 a 44

Localidade tipo: Campo Grande, Paraguay.

Material examiando: MZUSP 59549, 65, Brasil, Mato Grosso do Sul, Aquidauana, rio Taboco na Fazenda Taboco - Braço Morto, bacia do rio Paraguay, 204’38”S, 55³8’81”W, A. Machado \& B. Chernoff, 30/08/1998. MZUSP 54128, 35, Brasil, Paraguay, Alto Paraguay, Puerto Voluntad, na Estância Voluntad, bacia do Paraguay, D, Mandelburguer et al., 06/06/1997.

\section{Caracteres sexuais secundários}

Os caracteres sexuais secundários em $P$. kennedyi relacionam-se ao comprimento padrão, formato de nadadeiras e presença de processos ósseos. 
Comprimento padrão: fêmeas alcançam maiores valores de comprimento padrão em relação aos machos. MZUSP 59549, 21 machos (29.8-40.1 mm CP) e 33 fêmeas (31.50-43.5 mm $\mathrm{CP})$.

Formato de nadadeiras: machos diferem de fêmeas pelo formato do perfil da margem distal da nadadeira anal.

Perfil da margem distal da nadadeira anal de machos reto, ligeiramente convexa, com a diminuição gradual do primeiro e segundo raios ramificados (raios mais longos) ao último raio ramificado. Perfil da margem distal do lobo anterior da nadadeira anal de fêmeas côncavo. Lobo anterior formado pela diminuição acentuada de tamanho do primeiro e segundo raios ramificados (raios mais longos) ao quinto raio ramificado; perfil reto do sétimo ao último raio ramificado.

Processos ósseos: presentes nas nadadeiras anal e pélvica de machos.

Nadadeira anal com um processo ósseo por segmento do hemitriquium do último raio simples ao décimo segundo raio ramificado, distribuindo-se em $28 \%$ dos raios ramificados (até 43 raios ramificados). Raio simples com processos ósseos do oitavo ao décimo terceiro segmento, que é o segundo segmento proximal à extremidade distal do raio. Raios ramificados com processos ósseos tanto em segmentos proximais quanto em segmentos distais à primeira bifurcação. Processos ósseos presentes também em segmentos distais à segunda bifurcação do ramo posterior da primeira bifurcação. Proximalmene à primeira bifurcação, os processos ósseos estão presentes em até dois segmentos. Distalmente à primeira bifurcação, os processos ósseos estão restritos a todos os segmentos do ramo posterior. Distalmente à segunda bifurcação do ramo posterior da primeira bifurcação, os processos ósseos estão restritos a até dois segmentos do ramo posterior, imediatamente distais à bifurcação. Processos ósseos simétricos bilateralmente. Processos ósseos com inserção 
ovalada proximodistalmente. O maior comprimento de inserção ocupa $36 \%$ do comprimento proximodistal do segmento no qual está inserido. Em todos os segmentos os processos ósseos estão inseridos na face lateroposterior em relação à nadadeira. Os processos ósseos desenvolvem-se perpendicularmente ao eixo proximodistal do segmento no qual estão inseridos. Ao longo de seu comprimento, os processos ósseos apresentam uma curvatura de $25^{\circ}$ em relação ao eixo proximodistal do segmento no qual estão inseridos e desenvolvem-se em direção proximal em relação ao segmento no qual estão inseridos. Em secção transversal, os processos ósseos variam de ovalados proximodistalmente a cilíndricos, afilando-se gradualmente e terminando em uma extremidade distal arredondada. O diâmetro de sua extremidade distal equivale a $18 \%$ do maior comprimento de sua inserção no segmento no qual está inserido. Em seu estado máximo de desenvolvimento, seu comprimento total não alcança comprimento proximodistal do segmento no qual está inserido. Comprimento do maior processo ósseo, $32 \%$ do comprimento proximodistal do segmento no qual está inserido. $\mathrm{Na}$ nadadeira anal os processos decrescem aumentam e diminuem gradualmente de tamanho em direção anteroposterior; segundo e terceiro raios ramificados com maior número de segmentos com processos ósseos e processos ósseos maiores. No raio os processos ósseos decrescem aumentam e diminuem de tamanho em direção proximodistal.

Nadadeira pélvica com processos ósseos presentes e restritos a segmentos do hemitricuium ventral. Nadadeira pélvica com até dois (geralmente dois) processos ósseos por segmento do hemitriquium ventral do primeiro ao sexto raio ramificado, disrtribuindo-se em $85 \%$ do total de raios ramificados (7 raios ramificados). Raios ramificados com processos ósseos restritos aos segmentos distais à primeira bifurcação. Processos ósseos presentes também em segmentos distais à segunda bifurcação do ramo medial da primeira bifurcação. Distalmente à primeira bifurcação, os processos ósseos estão restritos a todos os segmentos do ramo medial. 
Distalmente à segunda bifurcação do ramo medial da primeira bifurcação, os processos ósseos estão restritos em até seis segmentos do ramo medial, imediatamente distais à bifurcação. Processos ósseos com secção transversal ovalada proximodistalmente. O maior comprimento de sua inserção ocupa 7\% no comprimento proximodistal do segmento no qual está inserido. Em todos os segmentos, os processos ósseos estão inseridos na face ventromedial em relação à nadadeira e desenvolvem-se perpendicularmente à sua inserção no segmento no qual estão inseridos. Marioria dos processos ósseos retos, outros, ao longo de seu comprimento, apresentam uma curvatura de $30^{\circ} \mathrm{em}$ relação ao eixo proximodistal do segmento no qual estão inseridos e desenvolvem-se em direção proximal em relação ao segmento no qual estão inseridos. Em secção transversal, os processos ósseos variam de ovalados proximodistalmente a cilíndricos, afilando-se gradualmente e terminanando em uma extremidade distal arredondada. Diâmetro de sua extremidade distal, $28 \%$ do maior comprimento no local de sua inserção no segmento no qual está inserido. Em seu estado máximo de desenvolvimento, seu comprimento não alcança o comprimento proximodistal do segmento no qual está inserido. O comprimento do maior processo ósseo equivale a $17 \%$ do comprimento proximodistal do segmento no qual está inserido. Na nadadeira pélvica os processos apresentam tamanho semelhante; primeiro e segundo raios ramificados com maior número de segmentos com processos ósseos. No raio os processos ósseos aumentam e diminuem de tamanho em direção proximodistal.

Astyanax scabripinnis GROUP (sensu Teixeira et al. in prep.)

\section{Astyanax brachypterigium Bertaco \& Malabarba 2001}

Figs. 45 a 48 
Localidade tipo: Bom Jesus, arroio Agua Branca, $28^{\circ} 36^{\prime} \mathrm{S}, 50^{\circ} 24^{\prime} \mathrm{W}$, Rio Grande do Sul, Brazil, elevation 1050 meters.

Material examinado: MZUSP 41698, 110, Brasil, Rio Grande do Sul, Bom Jesus, arroio Agua Branca, entrada Bom Jesus/São Joaquim, bacia do rio Uruguay, $28^{\circ} 35^{\prime} \mathrm{S}, 50^{\circ} 23^{\prime} \mathrm{W}$, Carlos Oliveira, 15/01/1989.

\section{Caracteres sexuais secundários:}

Os caracteres sexuais secundários em A. brachypterygium relacionam-se ao comprimento padrão, formato de nadadeiras e presença de processos ósseos.

Comprimento padrão: fêmeas alcançam maiores valores de comprimento padrão em relação aos machos. MZUSP 41698, 16 machos (35.8-47.5 mm CP) e 27 fêmeas (43.6-76.3 mm CP).

Formato e comprimento de nadadeiras: machos diferem de fêmeas pelo formato do perfil da margem distal da nadadeira anal e formato da nadadeira pélvica.

Perfil da margem distal da nadadeira anal de machos apenas ligeiramente convexo, praticamente reto. Lobo anterior formado pelo aumento do último raio simples e segundo raio ramificado (raio mais longo) e diminuição gradual dos raios a partir destes até último raio ramificado. Perfil da margem distal do lobo anterior da nadadeira anal de fêmeas conspicuamente convexo. Lobo anterior formado pelo aumento em tamanho do último raio simples e segundo raio ramificado (raio mais longo) com diminuição gradual a partir destes até o quinto raio ramificado; perfil distal reto do sexto ao último raio ramificado. Extremidade distal do primeiro raio ramificado (raio mais longo) da nadadeira pélvica de machos ultrapassando o orifício urogenital. Nadadeira pélvica sobrepõe-se ao orifício urogenital em vista ventral. Extremidade distal do primeiro raio ramificado (raio mais longo) da nadadeira pélvica das fêmeas não ultrapassando o orifício urogenital. Nadadeira pélvica não cobre o orifício urogenital em vista ventral. 
Processos ósseos: presentes nas nadadeiras anal e pélvica de machos.

Nadadeira anal de machos com um processo ósseo por segmento doe hemitriquium do último raio simples ao sétimo raio ramificado, distribuindo-se em $47 \%$ dos raios ramificados (até 15 raios ramificados). Último raio simples com processos ósseos presentes em até sete segmentos da metade distal do raio, nunca até a extremidade do raio. Raios ramificados com processos ósseos tanto em segmentos proximais quanto distais à primeira bifurcação. Proximalmente à primeira bifurcação os processos ósseos estão presentes em até dois segmentos. Distalmente à primeira bifurcação, os processos ósseos estão presentes e restritos a até onze segmentos do ramo posterior; existe até um segmento sem processos ósseos intercalado com segmentos com processo ósseo. Processos ósseos simétricos bilateralmente. Inserção dos processos ósseos arredondada. O diâmetro de sua inserção ocupa $37 \%$ do comprimento proximodistal do segmento no qual está inserido. Em todos os segmentos, os processos ósseos estão inseridos na face láteroposterior em relação à nadadeira. Os processos ósseos desenvolvem-se perpendicularmente à sua inserção no segmento no qual estão inseridos. Os processos ósseos são geralmente retos, podendo apresentar no quarto (1/4) proximal de seus comprimentos total, uma curvatura de 20 a $25^{\circ}$ em relação ao segmentos no qual estão inseridos e se desenvolver reto em direção proximal em relação ao eixo próximodistal do segmento no qual estão inseridos. Em secção transversal, os processos ósseos são cilíndricos ao longo de todo o seu comprimento total, afilando-se gradualmente e terminando em uma extremidade arredondada. $\mathrm{O}$ diâmetro da sua extremidade distal equivale $25 \%$ do diâmetro de sua inserção no segmento no qual está inserido. Em seu estado máximo de desenvolvimento, o seu comprimento total não alcança o comprimento proximodistal do segmento no qual está inserido. O comprimento do maior processo ósseo equivale $93 \%$ do comprimento proximodistal do segmento no qual está inserido. Na nadadeira anal os 
$\overline{\text { processos aumentam e diminuem em tamanho em direção anteroposterior; primeiro e segundo }}$ raios ramificados com maior número de segmentos com processos ósseos e processos ósseos maiores. No raio os processos ósseos aumentam e diminuem de tamanho em direção proximodistal; o maior processo ósseos localiza-se no quarto segmento distal à primeira bifurcaçãoo, na metade proximal da série de processos ósseos.

Nadadeira pélvica com processos ósseos restritos a segmentos do hemitricuium ventral. Nadadeira pélvica com um processo ósseo por segmentos de hemitriquium ventral, do primeiro ao quinto raios ramificados, disrtribuindo-se em $71 \%$ dos raios ramificados (7 raios ramificados). Raios ramificados com processos ósseos restritos a segmentos distais à primeira bifurcação. Processos ósseos presentes também em segmentos distais à segunda bifurcação do ramo medial da primeira bifurcação. Distalmente à primeira bifurcação e proximalmente à segunda bifurcação do ramo medial da primeira bifurcação, os processos ósseos estão restritos a até oito segmentos do ramo medial, imediatamente proximais à segunda bifurcação. Distalmente à segunda bifurcação do ramo medial da primeira bifurcação os processos ósseos estão presentes e restritos a até oito segmentos do ramo medial, imediatamente distais à segunda bifurcação; um segmento sem processos ósseos intercalado com segmentos com processos ósseos. Processos ósseos com inserção arredondada. O diâmetro de sua inserção,= ocupa $30 \%$ do comprimento próximodistal do segmento no qual está inserido. Em todos os segmentos os processos ósseos estão inseridos na face ventromedial em relação à nadadeira. Os processos ósseos desenvolvem-se perpendicularmente à sua inserção no segmento no qual estão inseridos. Ao longo de seu comprimento, os processos ósseos apresentam uma curvatura de $30^{\circ}$ em relcão ao eixo proximodistal do segmento no qual estão inseridos e desenvolvemse em direção proximal (ligeiramente medial) em relação ao eixo proximodistal do segmento no qual estão inseridos. Em secção transversal os processos ósseos são cilíndricos ao longo de 
seu comprimento, afilando-se muito pouco gradualmente e terminando em uma extremidade arredondada. O diâmetro de sua extremidade distal equivale a $21 \%$ do diâmetro de sua inserção no segmento no qual estão inseridos. Em seu estado máximo de desenvolvimento, o comprimento total não alcança o comprimento proximodistal do segmento nos quais estão inseridos. O comprimento do maior processo ósseo equivale a $71 \%$ do comprimeto proximodistal do segmento no qual està inserido. Na nadadeira pélvica os processos diminuem em tamanho; primeiro e segundo raios com maior número de segmentos com processos ósseos e processos ósseos maiores. No raio os processos ósseos diminuem de tamanho em direção próximodistal; o maior processo ósseo localiza-se no quarto segmento proximal à segunda bifurcação, na metade proximal da série de processos ósseos.

\section{Astyanax cremnobates Bertaco \& Malabarba 2001}

Localidade tipo: Rio Grande do Sul, São Francisco de Paula, tributary of rio Santa Cruz, $29^{\circ} 23^{\prime} \mathrm{S}, 50^{\circ} 32^{\prime} \mathrm{W}$, Brazil, elevation 850 meters.

Material examinado: Parátipo. MZUSP 62712, 7, Brasil, Rio Grande do Sul, São Francisco de Paula, córrego afluente do ri Santa Cruz, bacia do rio Jacui, R. E. Reis et al., 11/11/2001.

\section{Caracteres sexuais secundários:}

Os caracteres sexuais secundários em A. cremnobates relacionam-se ao comprimento padrão, formato de nadadeiras, presença de processos ósseos e presença de glândula branquial.

Comprimento padrão: fêmeas alcançam maiores valores de comprimento padrão em relação aos machos. MZUSP 62712, 9 machos (37.9-49.1 mm CP) e 5 fêmeas (42.7-66.2 mm CP).

Formato de nadadeiras: machos diferem de fêmeas pelo formato do perfil da margem distal da nadadeira anal e formato da nadadeira pélvica. 
Perfil da margem distal do lobo anterior da nadadeira anal de machos discretamente convexo. Lobo anterior formado pelo aumento de tamanho do último raio simples e segundo raio ramificados (raio mais longo) e diminuição gradual de tamanho a partir destes até o quinto raio ramificado; perfil reto do sexto ao último raio ramificado. Perfil da margem distal da nadadeira anal de fêmeas com lobo anterior da nadadeira anal conspicuamente convexo. Extremidade distal do primeiro raio ramificado (raio mais longo) da nadadeira pélvica em machos alcançando a origem da nadadeira anal, mas não ultrapassando o último raio simples. Nadadeira pélvica sobrepõe-se ao orifício urogenital em vista ventral. Extremidade distal do primeiro raio ramificado (raio mais longo) da nadadeira pélvica de fêmeas não alcançando a origem da nadadeira anal. Nadadeira pélvica não sobrepondo-se ao orifício urogenital em vista ventral.

Processos ósseos: presentes nas nadadeiras anal e pélvica de machos.

Nadadeira anal de machos com um processo ósseo por segmento de hemitriquium do último raio simples ao sétimo raio ramificado, disrtribuindo-se em $41 \%$ dos raios ramificados (até 17 raios ramificados). Último raio simples com processos ósseos presentes nos segmentos da metade distal do raio, até o sexto segmento proximal à extremidade distal. Raios ramificados com processos ósseos tanto em segmentos proximais quanto em segmentos distais à primeira bifurcação. Processos ósseos presentes também em segmentos distais à segunda bifurcação dos ramos anterior e posterior da primeira bifurcação. Proximalmente à primeira bifurcação os processos ósseos estão presentes em até três segmentos. Distalmente à primeira bifurcação e proximalmente às segundas ramificações, os processos ósseos estão presentes em até oito segmentos do ramo posterior e em até um segmento no ramo anterior, imediatamente proximal à segunda bifurcação desse ramo; existem até dois segmentos sem processos ósseos intercalado com segmentos com processos ósseos. Distalmente à segunda bifurcação do ramo 
$\overline{\text { posterior da primeira bifurcação, os processos ósseos estão presentes e restritos a até três }}$ segmentos do ramo posterior, imediatamente distal à bifurcação; existe até um segmento sem processos ósseos intercalados com os segmentos com processos ósseos. Distalmente à segunda bifurcação do ramo anterior da pimeira bifurcação, os processos ósseos estão presentes e restritos a até dois segmentos do ramo posterior, imediatamente distais à bifurcação. Processos ósseos simétricos bilateralmente. Processos ósseos com inserção arredondada. Em todos os segmentos, os processos ósseos estão inseridos na face lateroposterior em relação à nadadeira. Os processos ósseos desenvolvem-se perpendicularmente à sua inserção no segmento no qual estão inseridos. Processos ósseos geralmente retos, alguns apresentam em sua extremidade distal uma pequena curvatura de $20^{\circ}$ em relação ao eixo proximodistal do segmento no qual estão inseridos e desenvolvem-se em direção proximal (ligeiramente medial) em relação ao segmento no qual estão inseridos. Em secção transversal, os processos ósseos são cilíndricos ao longo de seu comprimento, afilando-se gradualmente e terminando em uma extremidade arredondada. Em seu estado máximo de desenvolvimento, o seu comprimento total não alcança o comprimento proximodistal do segmento no qual está inserido. Na nadadeira anal os processos aumentam e diminuem gradualmente de tamanho em direção anteroposterior; terceiro e quarto raio ramificado com maior número de segmentos e processos ósseos maiores. No raio os processos ósseos aumentam e diminuem de tamanho em direção proximodistal.

Nadadeira pélvica com processos ósseos presentes e restritos a segmentos da hemitiquia ventral. Nadadeira pélvica com um processo ósseo por segmentos de hemitriquium ventral do primeiro ao quinto raio ramificado, disrtribuindo-se em $71 \%$ dos raios ramificados (7 raios ramificados). Raios ramificados com processos ósseos restritos a segmentos distais à primeira bifurcação. Processos ósseos presentes também em segmentos distais à segunda bifurcação do 
$\overline{\text { ramo medial da primeira bifurcação. Distalmente à primeira bifurcação e proximalmente às }}$ segundas ramificações, os processos ósseos estão restritos a até cinco segmentos do ramo medial, imediatamente proximais à segunda bifurcação; existe um segmentos sem processos ósseos intercalados com segmentos com processos ósseos. Distalmente à segunda bifurcação do ramo medial da primeira bifurcação, os processos ósseos estão presentes e restritos a até três segmentos do ramo medial; existem até dois segmentos sem processos ósseos intercalados com segmentos com processos ósseos. Processos ósseos com inserção arredondada. Em todos os segmentos, os processos estão inseridos na face ventromedial em relação à nadadeira. Os processos ósseos desenvolvem-se perpendicularmente à sua inserção no segmento no qual estão inseridos. Ao longo de seu comprimento total, os processos ósseos sofrem uma curvatura de $30^{\circ}$ em relação ao eixo proximodistal do segmento no qual estão inseridos e desenvolvem-se em direção proximal (ligeiramente medial) em relação ao eixo proximodistal do segmento no qual estão inseridos. Os processos ósseos são cilíndricos ao longo de seu comprimento total, afilando-se muito pouco gradualmente e terminando em uma extremidade arredondada. Em seu estado máximo de desenvolvimento, o seu comprimento total não alcança o comprimento proximodistal do segmento no qual está inserido. $\mathrm{Na}$ nadadeira os processos ósseos aumentam e diminuem em direção lateromedial; segundo e terceiro raio ramificado com o maior número de segmentos com processos ósseos e processos ósseos maiores. No raio os processos aumentam e diminuem em tamanho em direção proximodistal.

Glândula branquial: presente em machos maduros.

Glândula formada pela fusão incompleta do primeiro ao décimo filamento branquial do primeiro arco branquial. A fusão ocorre na porção proximal de dois em dois filamentos: primeiro e segundo, terceiro e quarto, quinto e sexto, sétimo e oitavo, nono e décimo. 
Glândula branquial distribuindo-se em 31\% dos filamentos branquiais. Células colunares não visíveis lateralmente. Abertura da glândula visível lateralmente, nos 60 a 75\% distais do filamento branquial.

\section{Astyanax courensis Bertaco, Carvalho \& Jerep 2010}

Figs. 49 a 54

Localidade tipo: Rio dos Couros at Parque Portal da Chapada, tributary of rio Tocantinzinho, upper rio Tocantins basin, Alto Paraíso, Goiás, Brazil, $14^{\circ} 09^{\prime} 58^{\prime}$ 'S $44^{\circ} 35^{\prime} 43^{\prime \prime} \mathrm{W}$, elevation 1135 meters.

Material examinado: MZUSP 113864, 45, Brasil, Goiás, Alto Paraíso de goiás, rio dos Couros na cachoeira São Bento, bacia do rio Tocantins, $14,162556^{\circ} \mathrm{S}, 47.594111^{\circ} \mathrm{W}$, Dagosta \& Marinho, 28/11/2012.

\section{Caracteres sexuais secundários}

Os caracteres sexuais secundários em $A$. courensis relacionam-se ao comprimento padrão, formato de nadadeiras, presença de processos ósseos, presença de glândula branquial e tubérculos reprodutivos.

Comprimento padrão: fêmeas alcançam maiores valores de comprimento padrão em relação aos machos. MZUSP 113864, 22 machos (31.6-52 mm CP) e 23 fêmeas (33.7-54 mm CP).

Formato e comprimento de nadadeiras: machos diferem de fêmeas pelo formato do perfil da margem distal da nadadeira anal e formato da nadadeira pélvica.

Perfil da margem distal da nadadeira anal de machos com lobo anterior convexo discreto. Lobo anterior formado pelo aumento gradual de tamanho do último raio simples ao segundo raio ramificado (raio mais longo) e diminuição gradual de tamanho deste ao quinto raio 
$\overline{\text { ramificado; perfil reto do sexto ao último raio ramificado devido à diminuição gradual de }}$ tamanho em direção anteroposterior. Perfil da margem distal da nadadeira anal de fêmeas com lobo anterior da nadadeira anal convexo conspícuo. Lobo anterior formado pelo aumento gradual de tamanho do último raio simples ao segundo raio ramificado (raio mais longo) e diminuição acentuada deste ao quinto raio ramificado; perfil reto do sexto ao último raio ramificado devido à diminuição gradual de tamanho em direção anteroposterior.

Extremidade distal do primeiro raio ramificado (raio mais longo) de machos ultrapassa o orifício urogenital. Nadadeira pélvica de machos sobrepõe o orifício urogenital em vista ventral. Extremidade dsital do primeiro raio ramificado (raio mais longo) da nadadeira anal de fêmeas não ultrapassa o orifício urogeital. Nadadeira pélvica de fêmeas não sobrepõe o orifício urogenital em vista ventral.

Processos ósseos: presentes nas nadadeiras anal, pélvica e peitoral de machos.

Nadadeira anal de machos com um processo ósseo por segmento de hemitriquium do último raio simples ao sexto raio ramificado, disrtribuindo-se em $35 \%$ dos raios ramificados (até 17 raios ramificados). Último raio simples com processos ósseos do sétimo ao décimo terceiro segmento, que é o segundo segmento proximal à extremidade distal do raio. Raios ramificados com processos ósseos tanto em segmentos proximais quanto em segmentos distais à primeira bifurcação. Processos ósseos presentes também em segmentos distais à segunda bifurcação do ramo anterior da primeira bifurcação. Proximalmente à primeira bifurcação os processos ósseos estão presentes em até quatro segmentos. Distalmente à primeira bifurcação e proximalmente à segunda bifurcação, os processos ósseos estão presentes e restritos a até oito segmentos do ramo posterior; existem um ou dois segmentos sem processos osseos intercalados com segmentos com processos ósseos. Distalente à segunda bifurcação do ramo anterior da primeira bifurcação, os processos ósseos estão 
presentes em um segmento. Processos ósseos simétricos bilateralmente. Processos ósseos com inserção arredondada. O diâmetro de sua inserção ocupa $27 \%$ do comprimento proximodistal do segmento no qual está inserido. Em todos os segmentos, os processos ósseos estão inseridos na face lateroposterior em relação à nadadeira. Os processo ósseos desenvolvem-se perpendicularmente à sua inserção no segmento no qual está inserido. Processos ósseos geralmente retos, podendo, ao longo de seu comprimeto total, apresentar uma curvatura de $15^{\circ}$ em relação ao segmento no qual estão inseridos e desenvolvem-se em direção proximal em relação ao segmento no qual estão inseridos. Em secção transversal os processos ósseos são cilíndricos em toda sua extensão, afilando-se gradualmente e terminando em uma extremidade arredondada. O diâmetro de sua extremidade distal equivale a $30 \%$ do diâmetro de sua inserção no segmento no qual está inserido. Em seu estado máximo de desenvolvimento, o seu comprimento total não alcança o comprimento proximodistal do segmento no qual está inserido. Na nadadeira anal os processos aumentam e diminuem em tamanho em direção anteroposterior; segundo raio ramificado com o maior número de segmentos com processos ósseos. No raio os processos ósseos aumentam e diminuem de tamanho em direção proximodistal; o maior processo ósseos está no segundo segmento distal à primeira bifurcação, na metade proximal da série de processos ósseos.

Nadadeira pélvica com processos ósseos presentes e restritos a segmentos do hemitricuium ventral. Nadadeira pélvica com um processo ósseo por segmentos de hemitriquium ventral do primeiro ao quarto raio ramificado, distribuindo-se em $57 \%$ dos raios ramificado (7 raios ramificados). Raios ramificados com processos ósseos restritos a segmentos distais à primeira bifurcação. Processos ósseos presentes também em segmentos distais à segunda bifurcação do ramo medial da primeira bifurcação. Distalmente à primeira bifurcação os processos ósseos estão presentes e restritos a até cinco segmentos do ramo medial, imediatamente proximais à 
segunda bifurcação; existe um segmento sem processos ósseos intercalado com segmentos com processos ósseos. Distalmente à segunda bifurcação do ramo medial da primeira bifurcação os processos ósseos estão presentes e restritos a até três segmentos do ramo medial, imediatamente distais à bifurcação; existe um segmento sem processos ósseos intercalados com processos ósseos com processos ósseos. Processos ósseos com inserção arredondada. O diâmetro de sua inserção ocupa $15 \%$ do comprimento proximodistal do segmento no qual está inserido. Em todos os segmentos, os processos óseos estão inseridos na face ventromedial em relação à nadadeira. Os processo ósseos desenvolvem-se perpendicularmente à sua inserção no segmento no qual estão inseridos. Os processos ósseos são praticamente retos, podendo, ao longo de seu comprimento total, apresentar uma curvatura de $35^{\circ}$ em relação ao eixo proximodistal do segmenteo no qual estão inseridso e desenvolver-se em direção medioproximal em relação ao segmento no qual estão inseridos. Em secção transversal, os processos ósseos são cilindricos ao longo de seu comprimento, afilando-se muito pouco e terminando em uma extremidade arredondada. O diâmetro de sua extremidade distal equivale a $63 \%$ do diâmetro de sua inserção no segmento no qual está inserido. Em seu estado máximo de desenvolvimento, o seu comprimento total não alcança o comprimento proximodistal do segmento no qual está inserido. Na nadadeira, os processos ósseos aumentem e diminuem gradualmente de tamanho em direção lateromedial; primeiro e segundo raio ramificado com o maior número de segmentos com processos ósseos e processos ósseos maiores. No raio os processos óesseos diminuem de tamanho em direção proximodistal; o maior processo ósseos está no terceiro segmento proximal à segunda bifurcação, na metade proximal da série de processos ósseos.

Nadadeira peitoral com processos ósseos restritos a segmentos do hemitricuium dorsal. Nadadeira peitoral com um processo ósseo por segmento de hemitriquium dorsal do primeiro 
ao quinto raio ramificado, disrtribuindo-se em $38 \%$ dos raios ramificados (até 13 raios ramificados). Raios ramificados com processos óesseos presentes tanto em segmentos proximais quanto em segmentos distais à primeira bifurcação. Processos ósseos presentes também em segmentos distais à segunda bifurcação do ramo lateral da primeira bifurcação. Proximalmente à primeira bifurcação, os processos estão presentes em todos os segmentos, inclusive no segmento mais proximal (mais longo). O segmento mais proximal apresenta até oito processos em sua porção distal. Distalmente à primeira bifurcação, os processos ósseos estão presentes em até dez segmentos do ramo medial, imediatamente distais à bifurcação e em até seis segmentos do ramo lateral a partir do quinto segmento distal à bifurcação; existe um ou dois segmentos sem processos ósseos insetercalados com segmentos com processos ósseos tanto no ramo medial quanto no ramo lateral. Processos ósseos com inserção arredondada. O diâmetro de sua inserção ocupa 19\% do comprimento proximodistal do segmento no qual está inserido. Em todos os segmentos, os processos óseos estão inseridos na face dorsal ou dorsomedial em relação à nadadeira. Os processos ósseos desenvolvem-se perpendicularmente à sua inserção no segmento no qual estão inseridos. Processos ósseos retos. Em secção transversal, os processos ósseos são cilíndricos em toda sua extensão, afilando-se gradualmente e terminando em uma extremidade arredondada. O diâmetro de sua extremidade distal equivalendo a $67 \%$ do diâmetro de sua inserção no segmento no qual está inserido. Em seu estado máximo de desenvolvimento, o seu comprimento total não alcança o comprimento proximodistal do segmento no qual está inserido. O comprimento do maior processo ósseo equivale a $42 \%$ do comprimento proximodistal do segmento no qual está inserido. Na nadadeira os processos aumentam e diminuem de tamanho em direção lateromedial; segundo e terceiro raio ramificado com maior número de segmentos com processos ósseos e maiores processos ósseos. No raio os processos ósseos aumentam e 
$\overline{\text { diminuem de tamanho em direção proximodistal; maior processo ósseos presente no tereiro }}$ segmento proximal à primeira bifurcação, na metade proximal da série de processos ósseos. Tubérculos reprodutivos: presentes em machos maduros.

Machos maduros com tubérculos reprodutivos distribuídos na cabeça (regiões aterorbital e supraorbital, série infraorbital, opérculo e pré-opérculo) e na margem posterior da face exterior das escamas da segunda ou terceira série de escamas imediatamente dorsal à série longidtudinal de escamas até a primeira série de escamas dorsal à origem da nadadeira pélvica.

Glândula branquial: presente em machos maduros.

Glândula branquial formada pela fusão do primeiro ao décimo quarto filamento branquial do ceratobraquial do primeiro arco branquial. Glândula branquial disrtribuindo-se em $45 \%$ dos filamentos branquiais do ceratobranquial. Células colunares não visíveis lateralmente. Abertura da glândula visível lateralmente, nos $75 \%$ distais do filamento branquial.

\section{Astyanax goyanensis (Miranda Ribeiro 1944)}

Figs. 55 a 60

Localidade tipo: Rio do Couro, Veadeiros, Estado de Goiás, Brazil.

Material examinado: MZUSP 113968, 62, Brasil, Goiás, Alto Paraiso de Goiás, córrego afluente do rio dos Couros na estrada entre Alto Paraiso e São Jorge, bacia do rio Tocantins, $14.1620556^{\circ} \mathrm{S}, 47.6111111^{\circ} \mathrm{W}$, Dagosta \& Marinho, 28/11/2012.

\section{Caracteres sexuais secundários}

Os caracteres sexuais secundários em $A$. goyanensis relacionam-se ao comprimento padrão, formato de nadadeiras, presença de processos ósseos, tubérculos reprodutivos e glândula branquial. 
Comprimento padrão: fêmeas alcançam maiores valores de comprimento padrão em relação aos machos. MZUSP 113968, 15 machos (38-50.6 mm CP) e 14 fêmeas (43.6-57 mm CP)

Formato e comprimento de nadadeiras: machos diferem de fêmeas pelo formato do perfil da margem distal da nadadeira anal e formato da nadadeira pélvica.

Perfil da margem distal da nadadeira anal de machos com lobo anterior convexo discreto. Lobo anterior formado pelo aumento gradual de tamanho do último raio simples ao segundo raio ramificado (raio mais longo) e diminuição gradual de tamanho deste ao quinto raio ramificado; perfil reto do sexto ao último raio ramificado devido à diminuição gradual de tamanho em direção anteroposterior. Perfil da margem distal da nadadeira anal de fêmeas com lobo anterior da nadadeira anal convexo conspícuo. Lobo anterior formado pelo aumento gradual de tamanho do último raio simples ao segundo raio ramificado (raio mais longo) e diminuição acentuada deste ao quinto raio ramificado; perfil reto do sexto ao último raio ramificado devido à diminuição gradual de tamanho em direção anteroposterior.

Extremidade distal do primeiro raio ramificado (raio mais longo) da nadadeira pélvica de machos ultrapassa o orifício urogenital. Nadadeira pélvica sobrepõe o orifício urogenital em vista ventral. Extremidade distal do primeiro raio ramificado (raio mais longo) da nadadeira pélvica de fêmeas não ultrapassa o orifício urogenital. Nadadeira pélvica de fêmeas não sobrepõe o orifício urogenital em vista ventral.

Processos ósseos: presentes nas nadadeiras anal, pélvica e peitoral de machos.

Nadadeira anal com um processo ósseo por segmento de hemitriquium do último raio simples ao décimo quinto raio ramificado, disrtribuindo-se em $94 \%$ dos raios ramificados (até 16 raios ramificados). Último raio simples com processos ósseos presentes do quarto ou quinto segmento mais proximal até o sexto segmento proximal à extremidade distal do raio, disrtribuindo-se em mais que a metade do raio. Raios ramificados com processos ósseos tanto 
em segmentos proximais quanto distais à primeira bifurcação. Proximalmente à primeira bifurcação os processos ósseos estão presentes em até cinco segmentos (geralmente cinco). Distalmente à primeira bifurcação, os processos ósseos estão presentes em até oito segmentos do ramo posterior e em quatro segmentos do ramo anterior, imediatamente proximais à segunda bifurcação; existem até dois segmentos sem processos ósseos instercalados com segmento com processos ósseos em ambos os ramos. Processos ósseos simétricos bilateralmente. Processos ósseos com inserção arredondada. O diâmetro se sua inserção ocupa $17 \%$ do comprimento proximodistal do segmento no qual está inserido. Em todos os segmentos, os processos ósseos estão inseridos na face lateroposterior em relação à nadadeira. Os processos ósseos desenvolvem-se perpendicularmente à sua inserção no segmento no qual estão inseridos. O processos ósseos são geralmente retos, podendo ao longo de seu comprimento total, sofrer uma curvatura de $10^{\circ}$ em relação ao segmento no qual estão inseridos e desenvolver-se em direção proximal (ligeiramente medial) em relação ao eixo proximodistal do segmento no qual estão inseridos. Em secção transversal, os processos ósseos são cilíndricos ao longo de seu comprimento total, afilando-se gradualmente e terminando em uma extremidade arredondada. O diâmtero de sua extremidade distal equivale a 50\% do diâmetro de sua inserção no segmento no qual está inserido. Em seu estado máximo de desenvolvimento, o seu comprimento total não alcança o comprimento proximodistal do segmento no qual está inserido. O comprimento do maior processo ósseo, $55 \%$ do comprimento proximodistal do segmento no qual está inserido. $\mathrm{Na}$ nadadeira anal os processos aumentam e diminuem em tamanho em direção anteroposterior; segundo e terceiro raio ramificado com maior número de segmentos com processos ósseos e processos ósseos maiores. No raio os processos ósseos aumentam e diminuem de tamanho em direção 
proximodistal; o maior processo ósseos está no quarto segmento distal à primeira bifurcação, na metade proximal da série de processos ósseos.

Nadadeira pélvica com processos ósseos presentes e restritos a segmentos do hemitricuium ventral. Nadadeira pélvica com um processo ósseo por segmentos de hemitriquium ventral do primeiro ao quarto raio ramificado, distribuindo-se em $57 \%$ dos raios ramificados ( 7 raios ramificados). Raios ramificados com processos ósseos restritos aos segmentos distais à primeira bifurcação. Processos ósseos presentes também em segmentos distais à segunda bifurcação do ramo medial da primeira bifurcação. Distalmente à primeira bifurcação os processos ósseos estão presentes e restritos a até sete segmentos (quase todos) do ramo medial, imediatamente proximais à segunda bifurcação; existe um segmento sem processos ósseos intercaldo com segmento com processos ósseos. Distalmente à segunda bifurcação do ramo medial da primeira bifurcação os processos ósseos estão presentes e restritos a até quatro segmentos do ramo medial, imediatamente distais à bifurcação; existe um segmento sem processos ósseos intercaldo com segmentos com processos ósseos. Processos ósseos com inserção arredondada. O diâmetro de sua inserção oucpa 17\% do comprimento proximodistal do segmento no qual está inserido. Em todos os segmentos, os processos óseos estão inseridos na face ventromedial em relação à nadadeira. Os processos ósseos desenvolvem-se perpendicularmente à sua inserção no segmento no qual estão inseridos. Ao longo de seu comprimento total, os processos ósseos apresentam uma curvatura de $15^{\circ}$ em relação ao eixo proximodistal do segmento no qual estão inseridos e desenvolvem-se em direção proximal (ligeiramente medial) em relação ao segmento no qual estão inseridos. Em secção transversal, os processos ósseos são cilíndricos ao longo de seu comprimento total, afilando-se muito pouco gradualmente e terminando em uma extremidade arredondada. O diâmtero de sua extremidade distal equivale a $55 \%$ do diâmetro de sua inserção no segmento no qual está 
inserido. Em seu estado máximo de desenvolvimento, o seu comprimento total não alcança o comprimento proximodistal do segmento no qual está inserido. O comprimento do maior processo ósseos equivale a $39 \%$ do comprimento proximodistal do segmento no qual está inserido. Na nadadeira, os processos ósseos aumentam e diminuem gradualmente de tamanho em direção lateromedial; primeiro e segundo raio ramificado com o maior número de segmentos com processos ósseos e processos ósseos maiores. No raio os processos aumentam e diminuem de tamanho em direção proximodistal; o maior processo ósseos está no segmento imediatamente proximal à segunda bifurcação, na metade, metade distal da série de processos ósseos.

Nadadeira peitoral com processos ósseos presentes e restritos a segmentos do hemitricuium dorsal. Nadadeira peitoral com um processo ósseo por segmentos de hemitriquium dorsal do raio simples ao sétimo raio ramificado, 54\% dos raios ramificados (até 13 raios ramificados). Raio simples com processos ósseos presentes do segundo segmento mais proximal até o sexto segmento proximal à extremidade distal do raio. Raios ramificados com processos presentes tanto em segmentos proximais quanto distais à primeira bifurcação. Processos ósseos presentes também em segmentos distais à segunda bifurcação dos ramos medial e lateral da primeira bifurcação. Proximalmente à primeira bifurcação, os processos estão presentes em todos os segmentos, inclusive no segmento mais proximal (mais longo). O segmento mais proximal apresenta até oito processos em sua porção distal. Distalmente à primeira bifurcação, os processos ósseos estão presentes em todos os segmentos do ramo medial e em um segmento do ramo lateral, imediatamente proximal à segunda rmaificação; existem até dois segmentos sem processos ósseos intercalados com segmentos com processos ósseos. Distalmente à segunda bifurcação do ramo medial da primeira bifurcação, os processos ósseos estão presentes em até cinco segmentos do ramo lateral, imediatamente distais à bifurcação e 
em até quatro segmentos do ramo medial; existem até dois segmentos sem processos ósseos intercalados com segmentos com processos ósseos em ambos os ramos. Distalmente à segunda bifurcação do ramo medial da primeira bifurcação, os processos ósseos estão presentes e restritos a até três segmentos do ramo medial, imediatamente distais à bifurcação; existe um segmento sem processo ósseo intercalado com segmentos com processos ósseos. Processos ósseos com inserção arredondada. O diâmetro de sua inserção ocupa 19\% do comprimento proximodistal do segmento no qual está inserido. Em todos os segmentos, os processos óseos estão inseridos na face dorsal ou dorsomedial, com exceção dos segmentos do ramo lateral da primeira bifurcação e da segunda bifurcação deste ramo, no qual os processos ósseos estão inseridos na face dorsal ou dorsolateral em relação à nadadeira. Os processos ósseos desenvolvem-se perpendicularmente à sua inserção no segmento no qual está inserido. Os processos ósseos são geralmente retos, podendo apresentar uma curvatura de $20^{\circ}$ e se desenvolver em direção proximal em relação ao segmento no qual está inserido. Em secção transversal, os processos ósseos são cilíndricos ao longo de seu comprimento padrão, afilando-se muito pouco gradualmente e terminando em uma extremidade arredondada. $\mathrm{O}$ diâmtero de sua extremidade distal equivale a50\% do diâmetro de sua inserção no segmento no qual está inserido. Em seu estado máximo de desenvolvimento, o seu comprimento total não alcança o comprimento proximodistal do segmento no qual está inserido. O comprimento do maior processo ósseo equivale a $54 \%$ do comprimento proximodistal do segmento no qual está inserido. $\mathrm{Na}$ nadadeira os processos aumentam e diminuem de tamanho em direção lateromedial; primeiro e segundo raio ramificado com maior número de processos ósseos e processos ósseos maiores. No raio os processos ósseos aumentam e diminuem de tamanho gradualmente em direção proximodistal; o maior processo ósseo está no segundo segmento distal à primeira bifurcação, na metade proximal da série de processos ósseos. 
Tubérculos reprodutivos: presentes tanto em machos quanto em fêmeas maduros. Sendo assim, o dimorfismo sexual está relacionado à distribuição e não à presença.

Machos maduros com tubérculos reprodutivos distribuídos na cabeça (regiões aterorbital e supraorbital, série infraorbital, maxilar, opérculo e pré-opérculo) e na margem posterior da face externa de todas as escamas do corpo, exceto as escamas da primeira série de escamas dorsal à origem da nadadeira pélvica e escamas das séries ventrais a esta. Fêmas maduras com tubérculos reprodutivos distribuídos no opérculo e na margem posterior da face exterior das escamas da segunda série de escamas imediatamente dorsal à serie longidtudinal até a primeira série de escamas ventral a esta.

Glândula branquial: presente em machos maduros.

Glândula branquial formada pela fusão do primeiro ao décimo oitavo filamento branquial do ceratobranquial do primeiro arco branquial. Glândula branquial disrtribuindo-se em 58\% dos filamentos branquiais do ceratobranquial. Células colunares não visíveis lateralmente. Abertura da glândula não visível lateralmente.

\section{Astyanax rivularis (Lutken 1875)}

Figs. 61 a 66

Localidade tipo: Rio das velhas, Minas Gerais State, Brazil.

Material examinado: MZUSP 035393, 14, Brasil, Minas Gerais, Fortaleza de Minas, Riacho Afluente, do rio São João, próximo a estrada de ferro Minas-Perobas, bacia do rio Grande, $20^{\circ} 54^{\prime} \mathrm{S}, 46^{\circ} 40^{\prime} \mathrm{W}$, Carlos Oliveira.

\section{Caracteres sexuais secundários:}


Os caracteres sexuais secundários de $A$. rivularis relacionam-se ao comprimento padrão, formato de nadadeiras, presença de processos ósseos e tubérculos reprodutivos.

Comprimento padrão: fêmeas alcançam maiores valores de comprimento padrão em relação aos machos. MZUSP 035393, 3 machos (52.2-56.6 mm CP) e 6 fêmeas (52.8-75.4 mm CP).

Formato de nadadeiras: machos diferem de fêmeas pelo formato da nadadeira pélvica.

Extremidade distal do primeiro raio ramificado (raio mais longo) da nadadeira pélvica de machos ultrapassa o orifício urogenital. A nadadeira pélvica sobrepõe o orifício urogenital em vista ventral. Extremidade distal do primeiro raio ramificado (raio mais longo) da nadadeira pélvica de fêmeas não ultrapassa o orifício utogenital. Nadadeira pélvica não sobrepõe o orifício urogenital em vista ventral.

Processos ósseos: presente nas nadadeiras anal, pélvica e peitoral de machos.

Nadadeira anal de machos com um processo ósseo por segmento de hemitriquium do último raio simples ao décimo quarto raio ramificado, distribuindo-se em $88 \%$ dos raios ramificados (até 16 raios ramificados). Último raio simples com processos ósseos presentes nos segmentos da metade distal do raio, até o terceiro segmento proximal à extremidade distal. Raios ramificados com processos ósseos tanto em segmentos proximais quanto em segmentos distais à primeira bifurcação. Processos ósseos presentes também em segmentos distais à segunda bifurcação dos ramos anterior e posterior da primeira bifurcação. Proximalmente à primeira bifurcação os processos ósseos estão presentes em até quatro segmentos. Distalmente à primeira bifurcação e proximalmente às segundas ramificações, os processos ósseos estão presentes e restritos a até nove segmentos do ramo posterior, geralmente todos os segmentos; existe até dois segmentos sem processos ósseos intercalados com segmentos com processos ósseos. Distalmente à segunda bifurcação do ramo posterior da primeira bifurcação, os processos ósseos estão presentes e restritos a até cinco segmentos do ramo posterior, 
imediatamente distais à bifurcação. Distalmente à segunda bifurcação do ramo anterior da pimeira bifurcação, os processos estão presentes e restritos a até quatro, imediatamente distais à bifurcação. Processos ósseos simétricos bilateralmente. Processos ósseos com inserção arredondada. O diâmetro de sua inserção ocupa $13 \%$ do comprimento proximodistal do segmento no qual está inserido. Em todos os segmentos, os processos ósseos estão inseridos na face lateroposterior em relação à nadadeira. Os processos ósseos desenvolvem-se perpendicularmente à sua inserção no segmento no qual estão inseridos. Os processos ósseos são geralmente retos, pondedo apresentar ao longo de seu comprimento total uma curvatura de $25^{\circ}$ em relação ao eixo proximodistal do segmento no qual estão inseridos e desenvolverse em direção proximal em relação ao eixo proximodistal do segmento no qual estão inseridos. Os processos ósseos são cilíndricos ao longo de seu comprimento total, afilando-se gradualmente e terminando em uma extremidade arredondada. O diâmetro de sua extremidade distal equivale a $60 \%$ do diâmetro de sua inserção no segmento no qual está inserido. Em seu estado máximo de desenvolvimento, o seu comprimento total não alcança o comprimento proximodistal do segmento no qual está inserido. O comprimento do maior processo ósseo equivale a57\% do comprimento proximodistal do segmento no qual está inserido. $\mathrm{Na}$ nadadeira anal os processos aumentam e diminuem em tamanho em direção anteroposterior; segundo e terceiro raio ramificado com maior número de segmentos com processos ósseos e processos ósseos maiores. No raio os processos ósseos aumentam e diminuem de tamanho em direção proximodistal; o maior processo ósseos presente no segundo segmento proximal à segunda bifurcação do ramo posterior da primeira bifurcação, na metade, metade distal da série de processos ósseos.

Nadadeira pélvica com processos ósseos presentes e restritos a segmentos do hemitricuium ventral. Nadadeira pélvica com com até dois (geralmente um) processos ósseos por segmentos 
$\overline{\text { de hemitriquium ventral do último raio simples ao quinto raio ramificado, disrtribuindo-se em }}$ $71 \%$ dos raios ramificados (7 raios ramificados). Raio simples com processos ósseos em até nove segmentos da metade distal do raio. Raios ramificados com processos ósseos tanto em segmentos distais quanto roximais à primeira bifurcação. Processos ósseos presentes também em segmentos distais à segunda bifurcação dos ramos lateral e medial da primeira bifurcação. Proximalmente à primeira bifurcação, os processos ósseos estão presentes em até dois segmentos, incluindo o segmento mais proximal (mais longo). Distalmente à primeira bifurcação e proximalmente às segundas ramificações, os processos ósseos estão presentes em todos os segmentos do ramo medial e em até dois segmentos do ramo lateral, imediatamente proximais à segunda bifurcação; com segmentos sem processos ósseos intercalados com segmentos com processos ósseos. Distalmente à segunda bifurcação do ramo medial da primeira bifurcação, os processos ósseos estão presentes em até nove segmentos do ramo medial e em até três segmentos do ramo lateral, imediatamente distais à bifurcação. Distalmente à segunda bifurcação do ramo lateral da primeira bifurcação, os processos ósseos estão presentes e restritos a até quatro segmentos do ramo medial, imediatamente distais à bifurcação; existem até dois segmentos sem processos ósseos intercalados com segmentos com processos ósseos. Processos ósseos com inserção arredondada. O diâmetro de sua inserção ocupa $27 \%$ do comprimento proximodistal do segmento no qual está inserido. Em todos os segmentos os processos ósseos estão inseridos na face ventromedial, com exceção dos segmentos do ramo lateral da segunda bifurcação do ramo medial da primeira bifurcação, no qual os processos ósseos estão ineridos na dace ventrolateral. Os processos ósseos desenvolvem-se perpendicularmente à sua inserção no segmento no qual estão inseridos. Ao longo de seu comprimento total, os processos ósseos apresentam uma curvatura de $25^{\circ}$ e desenvolvem-se em direção proximal (ligeiramente medial) em relação ao segmento no qual 
estão inseridos. Em secção transversal, os processos osseos são cilíndricos ao longo de seu comprimento total, afilando-se muito pouco gradualmente e terminando em uma extremidade arredondada. O diâmetro de sua extremidade distal equivale a $26 \%$ do diâmetro de sua inserção no segmento no qual está inserido. Em seu estado máximo de desenvolvimento, o seu comprimento total não alcança o comprimento proximodistal do segmento no qual está inserido. O comprimento do maior processo ósseo equivale a $79 \%$ do comprimento proximodistal do segmento no qual está inserido. Na nadadeira os processos ósseos aumentem e diminuem de tamnho em direção lateromedial; primeiro e segundo raio ramificado com o maior número de segmentos com processos ósseos e processos ósseos maiores. No raio os processos aumentam e diminuem de tamanho em direção proximodistal; o maior processo ósseos está no terceiro segmento proximal à segunda bifurcação do ramo medial da primeira bifurcação, na metade proximal da série de processos ósseos.

Nadadeira peitoral com processos ósseos presentes e restritos a segmentos do hemitricuium dorsal. Nadadeira peitoral com até dois (geralmente um) processos ósseos por segmentos de hemitriquium dorsal do primeiro ao oitavo raio ramificado, $62 \%$ dos raios ramificados (até 13 raios ramificados). Raios ramificados com processos presentes tanto em segmentos proximais quanto distais à primeira bifurcação. Processos ósseos presentes também em segmentos distais à segunda bifurcação dos ramos medial e lateral da primeira bifurcação. Proximalmente à primeira bifurcação, os processos estão presentes em todos os segmentos, inclusive no segmento mais proximal (mais longo). O segmento mais proximal apresenta até nove processos, geralmente na metade distal do segmento. Distalmente à primeira bifurcação e proximalmente à segundas ramificações, os processos ósseos estão presentes em todos os segmentos do ramo medial e em até sete segmentos do ramo lateral, imediatamente proximais à segunda bifurcação. Distalmente à segunda bifurcação do ramo medial da primeira 


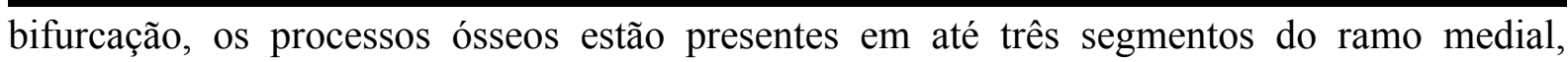
imediatamente distais à bifurcação e em até um segmentos do ramo lateral, imeditamente distal à bifurcação. Distalmente à segunda bifurcação do ramo lateral da primeira bifurcação, os processos ósseos estão presentes em até cinco segmentos do ramo medial e em até três segmentos do ramo lateral, imeditamente distais à bifurcação. Processos ósseos com inserção arredondada. O diâmetro de sua inserção ocupa $28 \%$ do comprimento proximodistal do segmento no qual está inserido. Em todos os segmentos os processos ósseos estão inseridos na face dorsal/dorsomedial, com exceção dos segmentos do ramo lateral da segunda bifurcação dos ramos medial e lateral da primeira bifurcação no qual os processos ósseos estão inseridos na face dorsolateral. Os processos ósseos desenvolvem-se perpendicularmente à sua inserção no segmento no qual estão inseridos. Processos ósseos retos. Em secção transversal, os processos ósseos são cilíndricos ao longo de seu comprimento total, afilando-se muito pouco gradualmente e terminando em uma extremidade arredondada. O diâmetro de sua extremidade distal equivale a 50\% do diâmetro de sua inserção no segmento no qual está inserido. Em seu estado máximo de desenvolvimento, o seu comprimento total não alcança o comprimento proximodistal do segmento no qual está inserido. O comprimento do maior processo ósseo equivale a $65 \%$ do comprimento proximodistal do segmento no qual está inserido. $\mathrm{Na}$ nadadeira os processos ósseos aumentam e diminuem de tamanho em direção lateromedial; primeiro e segundo raio ramificado com maior número de segmentos com processos ósseos e processos ósseos maiores. No raio os processos ósseos aumentam e diminuem de tamanho em direção proximodistal; o maior processo ósseo está no primeiro segmento proximal à segunda bifurcação; o maior processo ósseos está no segundo segmento proximal à segunda bifurcação, na metade proximal da série de processos ósseos. 
Tubérculos reprodutivos: presentes tanto em machos quanto em fêmeas maduros. Sendo assim, o dimorfismo sexual está relacionado à distribuição e desenvolvimento, e não à presença.

Machos maduros com tubérculos reprodutivos grandes distribuídos na cabeça (frontal, parietal, regiões aterorbital e supraorbital, série infraorbital, maxilar, opérculo, preopérculo, interopérculo e região gular) e na margem posterior da face externa de todas as escamas do corpo, exceto as escamas da região ventral à cintura peitoral e anterior à cintura pélvica. Fêmas maduras com tubérculos reprodutivos menores distribuídos na cabeça (frontal, parietal, regiões supraorbital e série infraorbital, maxilar, opérculo e suborpérculo) e na margem posterior da face exterior das escamas da segunda série de escamas dorsais à serie longidtudinal até a segunda série de escamas dorsal à origem da nadadeir apélvica.

\section{Hasemania kalunga Bertaco \& Carvalho 2010}

Fig. 67 a 69

Localidade tipo: Goiás, Cavalcante, córrego in the road GO 241 between Cavalcante and Minaçú, tributary of rio das Almas, rio Paranã drainage, upper rio Tocantins basin, 13³6’56.7’S, 47³1’06.6”W, Brazil, elevation 1163 meters.

Material examinado: MZUSP 113969, 188, Brasil, Goiás, Cavalcante, rio João Rodrigues afluente do rio Claro, sob ponte da estrada da comunidade Kalunga, bacia do rio Tocantins, 13. 6156667S, -47. 5185833W, Oyakawa et al., 30/11/2012.

\section{Caracteres sexuais secundários}

Os caracteres sexuais secundários em H. kalunga relacionam-se ao comprimento padrão, formato de nadadeiras, presença de processos ósseos e tubérculos reprodutivos. 
Comprimento padrão: fêmeas alcançam maiores valores de comprimento padrão em relação aos machos. MZUSP 113969, 14 machos (28.9-42.1 mm CP) e 15 fêmeas (30.6-47.5 mm $\mathrm{CP})$.

Formato de nadadeiras: machos diferem de fêmeas pelo formato do perfil da margem distal da adadeira anal e formato da nadadeiral pélvica.

Perfil da margem distal da nadadeira anal de machos com lobo anterior convexo discreto. Lobo anterior formado pelo aumento gradual de tamanho do último raio simples ao segundo raio ramificado (raio mais longo) e diminuição gradual de tamanho deste ao quinto raio ramificado; perfil reto do sexto ao último raio ramificado devido à diminuição gradual de tamanho em direção anteroposterior. Perfil da margem distal da nadadeira anal de fêmeas com lobo anterior da nadadeira anal convexo conspícuo. Lobo anterior formado pelo aumento gradual de tamanho do último raio simples ao segundo raio ramificado (raio mais longo) e diminuição acentuada deste ao quinto raio ramificado; perfil reto do sexto ao último raio ramificado devido à diminuição gradual de tamanho em direção anteroposterior.

Extremidade distal do primeiro raio ramificado (raio mais longo) da nadadeira pélvica de machos ultrapassa o orifício urogenital. Nadadeira pélvica sobrepõe o orifício urogenital em vista ventral. Extremidade distal do primeiro raio ramificado (raio mais longo) da nadadeira pélvica de fêmeas não ultrapassa o orifício urogenital. Nadadeira pélvica de fêmeas não sobrepõe o orifício urogenital em vista ventral.

Processos ósseos: presentes na nadadeira anal de machos.

Nadadeira anal de machos com um processo ósseo por segmento de hemitriquium do último raio simples ao sexto raio ramificado, disrtribuindo-se em $43 \%$ dos raios ramificados (até 14 raios ramificados). Último raio simples com processos ósseos presentes em até quatro segmentos da metade distal do raio, nunca até a extremidade do raio. Raios ramificados com 
$\overline{\text { processos ósseos presentes tanto em segmentos proximais quanto em segmentos distais à }}$ primeira bifurcação. Proximalmente à primeira bifurcação os processos ósseos estão presentes em até três segmento. Distalmente à primeira bifurcação, os processos ósseos estão presentes e restritos a até cinco segmentos do ramo posterior, imediatamente distais à bifurcação; existe um segmento sem processos ósseos intercalados com segmentos com processo ósseo. Processos ósseos simétricos bilateralmente. Processos ósseos com inserção arredondada. O diâmetro de sua inserção ocupa $40 \%$ do comprimento proximodistal do segmento no qual está inserido. Em todos os segmentos, os processos ósseos estão inseridos na face lateroposterior em relação à nadadeira. Os processos ósseos desenvolvem-se perpendicularmente à sua inserção no segmento no qual estão inseridos. Ao longo de seu comprimento total, os processos ósseos apresentam uma curvatura de $15^{\circ}$ em relação ao eixo proxmodistal do segmento no qual estão inseridos e desenvolvem-se em direção proximal em relação ao eixo proximodistal do segmento no qual estão inseridos. Em secção transversal, os processos ósseos são cilíndricos ao longo de seu comprimento total, afilando-se gradualmente e terminando em uma extremidade ponstiaguda. O diâmetro de sua extremidade distal quivale a $36 \%$ do diâmetro de sua inserção no segmento no qual está inserido. Em seu estado máximo de desenvolvimento, o seu comprimento total não alcança o comprimento proximodistal do segmento no qual está inserido. O comprimento do maior processo ósseo equivale a $94 \%$ do comprimento proximodistal do segmento no qual está inserido; segundo raio ramificado com maior número de segmentos com processos ósseos e processos ósseos maiores. No raio, os processos ósseos aumentam e diminuem de tamanho em direção proximodistal, o maior processo ósseo está no quarto segmento distal à primeira bifurcação, na metade/metade distal da série de processos ósseos.

Tubérculos reprodutivos: presente em machos maduros. 
$\overline{\text { Machos maduros com tubérculos reprodutivos na cabeça (opérculo) e na borda posterior da }}$ face exterior das escamas da série de escamas da linha mediana do corpo.

\section{Hyphessobrycon vinaceus Bertaco, Malabarba \& Dergam 2007}

Fig. 70 a 75

Localidade tipo: Minas Gerais, São João do Paraíso, rio São João, Tributary of rio Pardo, $15^{\circ} 09^{\prime} 50^{\prime} \mathrm{S}, 42^{\circ} 09^{\prime} 45^{\prime} \mathrm{W}$, Brazil.

Material examinado: MZUSP 112422, 87, Brazil, Minas Gerais, Rio Pardo de Minas, rio Sussuarana, afluente do rio Preto, afluente do rio Pardo, $-15.3947306 \mathrm{~S},-42.6088333 \mathrm{~W}$, Birindelli et al., 08/08/2012.

\section{Caracteres sexuais secundários}

Os caracteres sexuais secundários de $H$. vinaceus relacionam-se ao comprimento padrão, formato de nadadeiras, presença de processos ósseos e tubérculos reprodutivos.

Comprimento padrão: fêmeas alcançam maiores valores de comprimento padrão em relação aos machos. MZUSP 112422, 12 machos (28.6-39.9 mm CP) e 27 fêmeas (30.7-45.7 mm $\mathrm{CP})$.

Formato de nadadeiras: mahos diferem de fêmeas pelo formato do perfil da margem distal da adadeira anal e formato da nadadeiral pélvica de fêmeas.

Perfil da margem distal da nadadeira anal de machos com lobo anterior convexo discreto. Lobo anterior formado pelo aumento gradual de tamanho do último raio simples ao segundo raio ramificado (raio mais longo) e diminuição gradual de tamanho deste ao quinto raio ramificado; perfil reto do sexto ao último raio ramificado devido à diminuição gradual de tamanho em direção anteroposterior. Perfil da margem distal da nadadeira anal de fêmeas com 
$\overline{\text { lobo anterior da nadadeira anal convexo conspícuo. Lobo anterior formado pelo aumento }}$ gradual de tamanho do último raio simples ao segundo raio ramificado (raio mais longo) e diminuição acentuada deste ao quinto raio ramificado; perfil reto do sexto ao último raio ramificado devido à diminuição gradual de tamanho em direção anteroposterior.

Extremidade distal do primeiro raio ramificado (raio mais longo) da nadadeira pélvica de alcança o primeiro raio ramificado da nadadeira anal. Nadadeira pélvica sobrepõe o orifício urogenital em vista ventral. Extremidade distal do primeiro raio ramificado (raio mais longo) da nadadeira pélvica de fêmeas não ultrapassa o orifício urogenital, Nadadeira pélvica de fêmeas não sobrepõe o orifício urogenital em vista ventral.

Processos ósseos: presentes nas nadadeiras anal, pélvica, peitoral e caudal de machos.

Nadadeira anal de machos com até dois processos ósseos por segmento de hemitriquium do último raio simples ao décimo sétimo raio ramificado, distribuindo-se em $84 \%$ dos raios ramificados (até 19 raios ramificados). Último raio simples com processos ósseos presentes do quarto ou quinto segmento mais proximal até o quarto segmento proximal à extremidade distal do raio, disrtribuindo-se em mais que a metade do raio. Raios ramificados com processos ósseos tanto em segmentos proximais quanto em segmentos distais à primeira bifurcação. Processos ósseos presentes também em segmentos distais à segunda bifurcação do ramo anterior da primeira bifurcação. Proximalmente à primeira bifurcação os processos ósseos estão presentes em até quatro segmentos. Distalmente à primeira bifurcação, os processos ósseos estão presentes em até nove segmentos do ramo posterior e em até dois segmentos do ramo anterior, imediatamente proximais à segunda bifurcação desse ramo. Distalmente à segunda bifurcação do ramo anterior da primeira bifurcação, os processos ósseos estão presentes em até dois segmentos do ramo posterior, imediatamente distais à bifurcação. Processos ósseos simétricos bilateralmente. Processos ósseos com inserção 
arredondada. O diâmetro de sua inserção ocupa $23 \%$ do comprimento proximodistal do segmento no qual está inserido. Em todos os segmentos, os processos ósseos estão inseridos na face lateroposterior em relação à nadadeira. Os processos ósseos desenvolvem-se perpendicularmente à sua inserção no segmento no qual estão inseridos. Os processos ósseos são geralmente retos, podendo apresentar uma leve curvatura de $10^{\circ}$ em relação ao segmento no qual estão inseridos e desenvolver-se em direção proximal em relação ao segmento no qual estão inseridos. Em secção transversal, os processo com forma cilíndrica em toda sua extensão, afilando-se gradualmente e terminando em uma extremidade posntiaguda/arredondada. O diâmetro de sua extremidade distal equivale a 34\% do diâmetro de sua inserção no segmento no qual está inserido. Em seu estado máximo de desenvolvimento, o seu comprimento total não alcança o comprimento proximodistal do segmento no qual está inserido. O comprimento do maior processo ósseo equivale a $48 \%$ do comprimento proximodistal do segmento no qual está inserido. Na nadadeira anal os processos amentam e diminuem gradualmente de tamanho em direção anteroposterior; segundo e terceiro raio ramificado com maior número de segmentos com processos ósseos e processos ósseos maiores. No raio os processos ósseos aumentam e diminuem de tamanho em direção proximodistal; o maior processo ósseos esta no segmento imediatamente distal à priprimeira bifurcação, na metade proximal da série de processos ósseos.

Nadadeira pélvica com processos ósseos presentes e restritos a segmentos do hemitricuium ventral. Nadadeira pélvica com um processo ósseo por segmentos de hemitriquium ventral do segundo ao quinto raio ramificado, $57 \%$ dos raios ramificados (7 raios ramificados). Raios ramificados com processos ósseos presentes e restritos aos segmentos distais à primeira bifurcação. Processos ósseos presentes também em segmentos distais à segunda bifurcação do ramo medial da primeira bifurcação. Distalmente à primeira bifurcação os processos ósseos 
$\overline{\text { estão presentes e restritos a até três segmentos do ramo medial, imediatamente proximais à }}$ segunda bifurcação. Distalmente à segunda bifurcação do ramo medial da primeira bifurcação os processos ósseos estão presentes e restritos a até dois segmentos do ramo medial, imediatamente distais à bifurcação. Processos ósseos com inserção arredondada. O diâmetro de sua inserção ocupa $10 \%$ do comprimento proximodistal do segmento no qual está inserido. Em todos os segmentos os processos ósseos estão inseridos na face ventromedial em relação à nadadeira. Os processos ósseos desenvolvem-se perpendicularmente à sua inserção no segmento no qual estão inseridos. Os processos ósseos são geralmente retos, podendo apresentar, ao longo de seu comprimento total, uma leve curvatura de $10^{\circ}$ em relação ao comprimento proximodistal do segmento no qual estão inseridos e desenvolver-se em direção proximal em relação ao eixo proximodistal do segmento no qual estão inseridos. Em secção transversal, os processos ósseos são cilíndricos ao longo de seu comprimento total, afilandose muito pouco gradualmente e terminanado em uma extremidade arredondada. $\mathrm{O}$ diâmetro de sua extremidade distal equivale $43 \%$ do diâmetro de sua inserção no segmento no qual está inserido. Em seu estado máximo de desenvolvimento, o seu comprimento total não alcança o comprimento proximodistal do segmento no qual está inserido. $\mathrm{O}$ comprimento do maior processo ósseo equivale $30 \%$ do comprimento proximodistal do segmento no qual está inserido. Na nadadeira, os processos ósseos aumentam e diminuem de tamanho em direção lateromedial; segundo e terceiro raio ramificado com maior número de segmentos com processos ósseos e processos ósseos maiores. No raio, os processos ósseos apresentam tamanhos semelhantes em direçãoo proximodistal.

Nadadeira peitoral com processos ósseos presentes e restritos a segmentos do hemitricuium dorsal. Nadadeira peitoral com um processo ósseo por segmentos de hemitriquium dorsal do primeiro ao terceiro raio ramificado, disrtribuindo-se em $25 \%$ dos raios ramificados (até 12 
$\overline{\text { raios ramificados). Processos ósseos presentes tanto em segmentos proximais quanto distais à }}$ primeira bifurcação. Proximalmente à primeira bifurcação, os processos ósseos estão presentes em até cinco segmentos. Distalmente à primeira bifurcação, os processos ósseos estão presentes em até quatro segmentos do ramo lateral e em até um segmento do ramo medial, imediatamente distal à ramificaçào. Processos ósseos com inserção arredondada. O diâmetro de sua inserção ocupa $14 \%$ do comprimento proximodistal do segmento no qual está inserido. Em todos os segmentos, os processos ósseos estão inseridos na face dorsal/dorsomedial, com exceção dos segmentos do ramo lateral, no qual os processos óseos estão inseridos na face dorsal/dorsolateral em relação à nadadeira. Os processos ósseos desenvolvem-se perpendicularmente à sua inserção nos segmentos no qual estão inseridos. Os processos ósseos são retos. Em secção transversal, os processos ósseos são cilíndricos ao longo de seu comprimento total, afilando-se muito pouco gradualmente e terminanando em uma extremidade arredondada. $\mathrm{O}$ diâmetro de sua extremidade distal equivale a $63 \%$ do diâmetro de sua inserção no segmento no qual está inserido. Em seu estado máximo de desenvolvimento, o seu comprimento total não alcança o comprimento proximodistal do segmento no qual está insrido. O comprimento do maior processo ósseo equivale a $35 \%$ do comprimento proximodistal do segmento que está inserido. Na nadadeira, os processos ósseos apresentam tamanhos semelhantes; primeiro e segundo segmento com maior número de segmentos com processos ósseos. No raio os processos ósseos apresentam tamanhos semelhantes.

Nadadeira caudal com até dois (geralmente um) processo ósseo por segmentos de hemitriquium do quinto ao décimo quarto raio ramificado, disrtribuindo-se em 59\% dos raios ramificados (17 raios ramificados, i,9/8,i). Em todos os raios ramificados, os processos estão restritos a segmentos distais à primeira bifurcação. Processos ósseos presentes também em 
segmentos distais à segunda bifurcação do ramo medial da primeira bifurcação. Distalmente à primeira bifurcação e proximalmente à segunda bifurcação, os processos ósseos estão presentes e restritos a até oito segmentos do ramo medial, imediatamente proximais à segunda bifurcação. Nono raio ramificado com processos ósseos em até sete segmentos dos ramos medial e lateral da primeira bifurcação. Distalmente à segunda bifurcação do ramo medial da primeira bifurcação (nos raios do lobo ventral), os processos ósseos estão presentes e restritos a até cinco segmentos do ramo medial, imediatamente distais à segunda bifurcação. Distalmente à segunda bifurcação do ramo lateral da primeira bifurcação (nos raios do lobo ventral), os processos ósseos estão presentes e restritos a até cinco segmentos do ramo lateral, imediatamente distais à segunda bifurcação. Processos ósseos simétricos bilateralmente. Processos ósseos com inserção arredondada. O diâmetro de sua inserção ocupa $12 \%$ do comprimento proximodistal do segmento no qual está inserido. Nos segmentos do ramo medial, os processos ósseos estão inseridos na face lateromedial, nos segmentos do ramo lateral, os processos osseos estão insridos na face laterolateral em relação à nadadeira. Os processos ósseos desenvolvem-se perpendicularmente à sua inserção no segmento no qual estão inseridos. Os processos ósseos são geralmente retos, podendo apresentar, ao longo de seu comprimento total, uma curvatura de $20^{\circ}$ em relação ao eixo proximodistal do segmento no qual estão inseridos e desenvolver-se em direção proximal em relação ao eixo proximodistal do segmento no qual estão inseridos. Em secção transversal, os processos ósseos são cilíndricos ao longo de seu comprimento total, afilando-se gradualmente e terminando em uma extremidade arredondada. O diâmetro de sua extremidade distal equivale a 56\% do diâmetro de sua inserção no segmento no qual está inserido. Em seu estado máximo de desenvolvimento, o seu comprimento total não alcança o comprimento proximodistal do segmento no qual está inserido. O comprimento do maior processo ósseo eaquivale a $38 \%$ do 
comprimento proximodistal do segmento que em está inserido. $\mathrm{Na}$ nadadeira, os processos ósseos apresentam tamanhos semelhantes; nono raio com maior número de segmentos com processos ósseos. No raio os processos ósseos apresentam tamanhos semelhantes.

Tubérculos reprodutivos: presentes em machos.

Tubérculos reprodutivos presentes na cabeça (em todos os ossos) e na margem distal da face externa de todas as escamas do corpo de machos maduros, exceto nas escamas da região ventral do corpo.

\section{Bramocharax CLADE}

\section{Oligosarcus jenynsii (Gunther 1864)}

Figs. 76 a 78

Localidade tipo: Lago de água doce de Maldonado, Uruguay.

Material examinado: MZUSP 37262, 2, Brasil, Rio Grande do Sul, riacho do Salso (Afl. Do rio Ibicuí), estrada Livramento/Rosário do Sul, bacia do rio Jacuí, R. E. Reis et al., 23/07/1986. MZUSP 42370, 6, Argentina, Laguna dos Lobos, Provincia de Buenos Aires, Miquelarena \& Casciotta, 10/01/1991.

\section{Caracteres sexuais secundários:}

Os caracteres sexuais secundários em O. Jenynsii relacionam-se ao comprimento padrão, formato de nadadeiras e presença de processos ósseos.

Comprimento padrão: fêmeas alcançam maiores valores de comprimento padrão em relação aos machos. MZUSP 37262, 2 machos (113.4-130.3 mm CP); MZUSP 42370, 2 machos (98.5-109.5 mm CP) e 2 fêmeas (102.7-124.6 mm CP). 
Processos ósseos: presentes nas nadadeiras anal e pélvica de machos.

Nadadeira anal com um processo ósseo por segmento de hemitriquium do último raio simples até o décimo primeiro raio ramificado, disrtribuindo-se em $41 \%$ dos raios ramificados (até 27 raios ramificados). Raio simples com processos ósseos do sexto ao décimo sexto segmento, oitavo segmento proximal à extremidade distal do raio. Raios ramificados com processos ósseos presentes tanto em segmentos proximais quanto em segmentos distais à primeira bifurcação. Processos ósseos presentes também em segmentos distais à segunda bifurcação dos ramos anterior e posterior da primeira bifurcação. Processos ósseos presentes também em segmentos distais à terceira bifurcação do ramo anterior da segunda bifurcação do ramo anterior da primeira bifurcação. Proximalmente à primeira bifurcação, os processos ósseos estão presentes em até dois segmentos. Distalmente à primeira bifurcação e proximalmente às segundas ramificações, os processos ósseos estão presentes em todos os segmentos do ramo posterior e em até quatro segmentos do ramo anterior, imediatamente proximais à segunda bifurcação. Distalmente à segunda bifurcação do ramo anterior da primeira bifurcação, os processos ósseos estão presentes em todos os segmentos do ramo posterior e em até três segmentos do ramo anterior, imediatamente proximais à terceira bifurcação deste ramo. Distalmente à terceira bifurcação do ramo anterior da segunda bifurcação do ramo anterior da primeira bifurcação, os processos ósseos estão presentes e restritos a um segmento do ramo posterior. Distalmente à segunda bifurcação do ramo posterior da primeira bifurcação, os processos ósseos estão presentes em todos os segmentos do ramo posterior e em até três segmentos do ramo anterior, a paritr do segundo segmento distal à bifurcação. Processos ósseos simétricos bilateralmente. Processo ósseos com inserção ovalada proximodistalmente. O maior comprimento de sua inserção ocupa $63 \%$ do comprimento proximodistal do segmento no qual está inserido. Em todos os segmentos, os 
$\overline{\text { processos ósseos estão inseridos na face lateroposterior em relação à nadadeira, exceto os }}$ segmentos do ramo anterior da primeira bifurcação e do ramo anterior da segunda bifurcação do ramo posterior da primeira bifurcação, no qual os processos ósseos estão inseridos na face lateroanterior em relação à nadadeira. Os processos ósseos desenvolvem-se perpendicularmente à sua inserção no segmento. Ao longo de seu comprimento total, os processos ósseos apresentam uma curvatura de $28^{\circ}$ em relação ao eixo proximodistal do segmenteo no qual estão inseridos e desenvolvem-se em direção proximal em relação ao eixo proximodistal do segmento no qual estão inseridos. Em secção transversal, os processos ósseos variam de ovalados proximodistalmente a cilíndricos ao longo de seu comprimento total, afilando-se gradualmente e terminando em uma extremidade pontiaguda. O diâmetro de sua extremidade distal equivale a $15 \%$ do maior comprimento da inserção inserção no segmento no qual está inserido. Em seu estado máximo de desenvolvimento, seu comprimento total não alcança o comprimento proximodistal do segmento no qual está inserido. O comprimento do maior processo ósseo equivale $67 \%$ do comprimento proximodistal do segmento no qual está inserido. $\mathrm{Na}$ nadadeira anal os processos ósseos aumentam e diminuem gradualmente de tamanho em direção anteroposterior; segundo raio com o maior número de segmentos com processos ósseos e processos ósseos maiores. Nos raios, os processos ósseos aumentam e diminuem de tamanho em direção proximodistal; maior processo ósseos no segmento imediatamente proximal à segunda bifurcação do ramo posterior da primeira bifurcação, metade da série de processos ósseos.

Nadadeira pélvica com processos ósseos restritos a segmentos do hemitricuium ventral. Nadadeira pélvica com até dois (geralmente um) processo ósseo por segmento de hemitriquium ventral do pirmeiro ao sétimo raio ramificado, disrtribuindo-se em $100 \%$ dos raios ramificados (7 raios ramificados). Raios ramificados com processos ósseos presentes 
tanto em segmentos proximais quanto em segmentos distais à primeira bifurcação. Processos ósseos presentes também em segmentos distais à segunda bifurcação dos ramos medial e lateral da primeira bifurcação. Processos ósseos presentes também em segmentos distais à terceira bifurcação dos ramos medial e lateral da segunda bifurcação dos ramos medial e lateral da primeira bifurcação. Proximalmente à primeira bifurcação, vinte quatro processos ósseos estão presentes, ao longo de todo o comprimento proximodistal do segmento mais proximal, mais longo. Distalmente à primeira bifurcação e proximalmente às segundas ramificações, os processos ósseos estão presentes em todos os segmentos do ramo medial e lateral. Distalmente à segunda bifurcação do ramo medial da primeira bifurcação, os processos ósseos estão presentes em todos os segmentos do ramo medial e em até seis segmentos do ramo lateral, imediatamente proximais à terceira bifurcação deste ramo. Distalmente à terceira bifurcação do ramo medial da segunda bifurcação do ramo medial da primeira bifurcação, os processos ósseos estão presentes em todos os segmentos do ramo medial e em quatro segmentos do ramo lateral, imediatamente distais à bifurcação. Distalmente à terceira bifurcação do ramo lateral da segunda bifurcação do ramo medial da primeira bifurcação, os processos ósseos estão presentes em todos os segmentos do ramo lateral e em dois segmentos do ramo medial, imediatamente distais à bifurcação. Distalmente à segunda bifurcação do ramo lateral da primeira bifurcação, os processos ósseos estão presentes em até cinco segmentos do ramo lateral, imediatamente distais à bifurcação e em até oito segmentos do ramo medial, imediatamente proximais à terceira bifurcação. Distalmente à terceira bifurcação do ramo lateral da segunda bifurcação do ramo lateral da primeira bifurcação, os processos ósseos estão presentes em todos os segmentos do ramo medial, imediatamente distais à bifurcação e em cinco segmentos do ramo lateral, imediatamente distais à bifurcação. Distalmente à terceira bifurcação do ramo medial da segunda bifurcação 
do ramo lateral da primeira bifurcação, os processos ósseos estão presentes em todos os segmentos do ramo medial e em até cinco segmentos do ramo lateral, imediatamente distais à bifurcação. Processos ósseos com inserção ovalada proximodistalmente. O maior comprimento de sua inserção equivale a 55\% do comprimento proximodistal do segmento no qual está inserido. Proximalmente à primeira bifurcação, no segmento mais proximal, mais longo, os processos ósseos estão inseridos na face ventrolateral, com dois processos ósseos na porção mais distal do segmento, inseridos na face ventromedial (espelhados). Nos segmentos do ramo lateral da primeira bifurcação, os processos ósseos estão inseridos na face ventrolateral. Nos segmentos do ramo lateral da segunda bifurcação do ramo lateral da primeira bifurcação, os processos ósseos estão inseridos na face ventrolateral. Nos segmentos do ramo medial da segunda bifurcação do ramo lateral da primeira bifurcação, os processos ósseos estão inseridos na face ventromedial. Nos segmentos dos ramos mediais da terceira bifurcação dos ramos medial e lateral da segunda bifurcação do ramo lateral da primeira bifurcação, os processos ósseos estão inseridos na face ventromedial. Nos segmentos dos ramos laterais da terceira bifurcação dos ramos medial e lateral da segunda bifurcação do ramo lateral da primeira bifurcação, os processos ósseos estão inseridos na face ventrolateral. Nos segmentos do ramo medial da primeira bifurcação, os processos ósseos estão inseridos na face ventromedial. Nos segmentos do ramo medial da segunda bifurcação do ramo medial da primeira bifurcação, os processos ósseos estão inseridos na face ventromedial. Nos segmentos dos ramos mediais da terceira bifurcação dos ramos medial e lateral da segunda bifurcação do ramo medial da primeira bifurcação, os processos ósseos estão inseridos na face ventromedial. Nos segmentos do ramo lateral da segunda bifurcação do ramo medial da primeira bifurcação, os processos ósseos estão inseridos na face ventrolateral. Nos segmentos dos ramos laterais da terceira bifurcação dos ramos lateral e medial da segunda bifurcação do ramo medial da 
primeira bifurcação, os processos ósseos estão inseridos na face ventrolateral em relação à nadadeira. Os processos ósseos desenvolvem-se perpendicularmente à sua inserção nos segmentos no qual estão inseridos. Ao longo de seu comprimento total, os processos ósseos apresentam uma curvatura de $50^{\circ}$ em relação ao eixo proximodistal do segmento no qual estão inseridos e desenvolvem-se em direção proximal em relação ao segmento no qual estão inseridos. Em secção transversal, os processos ósseos variam de ovalados proximodistalmente a cilíndricos ao longo de seu comprimeto total, afilando-se gradualmente e terminando em uma extremidade pontiaguda/arredondada. O diâmetro de sua extremidaded distal equivale a $22 \%$ do maior comprimento de sua inserção no segmento no qual está inserido. Em seu estado máximo de desenvolvimento, o seu comprimento total ultrapassa o comprimento proximodistal do segmento no qual está inserido. O comprimento do maior processo ósseo equivale a $134 \%$ do comprimento proximodistal do segmento no qual está inserido. $\mathrm{Na}$ nadadeira pélvica os processos ósseos aumentam e diminuem gradualmente de tamanho em direção lateromedial; segundo e terceiro raio ramificado com o maior número de segmentos com processos ósseos e processos ósseos maiores. Nos raios, os processos ósseos aumentam e diminuem de tamanho em direção proximodistal; o maior processo ósseos está presente no quarto segmento distal à primeira bifurcaçãoo, na metade proximal da série de processos ósseos.

\section{BRYCONINAE}

\section{Brycon falcatus Mulher \& Troschel 1844}

Fig. 79

Localidade tipo: rio Jocintins e rio Capin (= Capim), estado do Pará, Brasil. 
Material examinado: MZUSP 16448, 1 de 24, Brasil, rio São Domingos, afluente do rio das Mortes, povoado de São Domingos, bacia do rio Tocanitns, Exp. Butantã/Dept de Zoologia. MZUSP 18077 (1, d\&c), Brasil, Pará, Baião, igarapé do Limão, bacia do rio Tocantins, 250’0.0’S, 4940’0.0”W, Exp. Permanente na Amazônia, 09/09/1970.

\section{Caracteres sexuais secundários}

Os caracteres sexuais secundários em B. falcatus relacionam-se ao comprimento padrão, formato de nadadeiras e na presença de processos ósseos.

Comprimento padrão: fêmeas alcançam maiores valores de comprimento padrão em relação aos machos (Flávio C. T. Lima, com. pess.).

Formato de nadadeiras: machos diferem de fêmeas pelo formato do perfil da margem distal da nadadeira anal.

Perfil da margem distal da nadadeira anal de machos com lobo anterior discretamente convexo, quase reto. Lobo anterior formado pelo aumento de tamanho do último raio simples ao primeiro raio ramificado (raio mais longo) e diminuição discreta deste ao quinto ou sexto raio ramificado; perfil reto do sexto ao último raio ramificado da nadadeira anal devido à diminuição gradual de tamanho em direção anteroposterior. Perfil da margem distal da ndadeira anal de fêmeas com um lobo anterior convexo. Lobo anterior formado pela diminuição acentuada do último raio simples ao quinto raio ramificado; perfil reto do sexto ao último raio ramificado.

Processos ósseos: presentes na andadeiras anal dos machos adultos.

Nadadeira anal com um processo ósseo por segmento de hemitriquium do primeiro ao sétimo raio ramificado, disrtribuindo-se em até $32 \%$ do total de raios ramificados (até 26 raios ramificados). Raios ramificados com processos ósseos presentes tanto em segmentos proximais quanto em segmentos distais à primeira bifurcação. Proximalmente à primeira 
bifurcação, os processos ósseos estão presentes em até dois segmentos. Distalmente à primeira bifurcação, os processos ósseos estão presentes e restritos a até nove segmentos do ramo posterior. Processos ósseos simétricos bilateralmente. Processos ósseos com inserção ovalada proximodistalmente. O maior comprimento de sua inserção ocupa $41 \%$ do comprimento proximodistal do segmento no qual está inserido. Em todos os segmentos os processos ósseos estão inseridos na face lateroposterior do segmento no qual estão inseridos em relação à nadadeira. Os processos ósseos desenvolvem-se perpendicularmente à sua inserção no segmento no qual estão inserido. Ao longo de seu comprimento total, o maior processo ósseo apresenta uma curvatura de $50^{\circ}$ em relação ao eixo proximodistal do segmento no qual está inserido e desenvolve-se em direção proximal em relação ao segmento no qual está inserido. Em secção transversal, os processos ósseos variam de ovalados proximodistalmente a cilíndricos ao longo de seu comprimento total, afilando-se gradualmente e termnando em uma extremidade arredondada. Diâmetro de sua extremidade distal, $18 \%$ do maior comprimento de sua inserção no segmento no qual está inserido. Em seu estado máximo de desenvolvimento, seu comprimento total (da inserção à extremidade independentemente da curvatura) não alcança o comprimento proximodistal do hemitriquium onde se insere. O comprimento do maior processo ósseo equivale a $41 \%$ do comprimento do segmento no qual está inserido. Na nadadeira anal os processos aumentam e diminuem gradualmente de tamanho em direção anteroposterior; segundo e terceiro raio ramificado com maior número de segmentos com processos ósseos e processos ósseos maiores. No raio os processos ósseos aumentam e diminuem de tamanho em direção proximodistal; maior processo ósseos presente

\section{Bryconops CLADE}




\section{Bryconops affinis (Gunther 1864)}

Figs. 80 a 83

\section{Localidade tipo: Guyana.}

Material examinado: MZUSP 109088, 37, Guiana, Potaro-Siparuni, rio Kuribrong, no acampamento “upstream Kuribrong”, bacia do rio Essequibo, $5^{\circ} 20^{\prime} 30.0^{\prime} \mathrm{N}, 59^{\circ} 20^{\prime} 30.0^{\prime} \mathrm{W}, \mathrm{F}$. C. T. Lima et al., 03/2011. MZUSP 108910, 3 M e 1 F de 26, Guiana, Potaro-Siparuni, rio Kuribrong, no acampamento "Topo da montanha", bacia do rio Essequibo, 5²0’35"N, 59³3’04’W, F. C. T. Lima et al., 04/2010.

\section{Caracteres sexuais secundários}

Os caracteres sexuais secundários em B. affinis relacionam-se ao comprimento padrão, formato de nadadeiras e à presença de processos ósseos.

Comprimento padrão: fêmeas alcançam maiores valores de comprimento padrão em relação aos machos (Andrade et al., 2001).

Formato de nadadeiras: machos diferem de fêmeas pelo formato do perfil da margem distal da nadadeira anal e formato da nadadeira pélvica.

Perfil da margem distal da nadadeira anal de machos reto do último raio simples ao último raio ramificado, sem lobo anterior visível. Perfil da margem distal da ndadeira anal de fêmeas com um lobo anterior ligeiramente côncavo visível. Lobo anterior formado pelo aumento do último raio simples ao segundo raio ramificado (raio mais longo) e diminuição deste ao quinto raio ramificado; reto do sexto ao último raio ramificado devido à diminuição gradual de tamanho em direção anteroposterior. 
$\overline{\text { Extremidade distal do primeiro raio ramificado (raio mais longo) da nadadeira pélvica de }}$ machos ultrapassa o orifício urogenital mans não alcança a origem da nadadeira anal. Nadadeira pélvica sobrepõe o orifício urogenital em vista ventral. Extremidade distal o primeiro raio ramificado (raio mais longo) da nadadeira pélvica de fêmeas não ultrapassa o orifício utogenital. Nadadeira pélvica de fêmeas na sobrepõe ao orifício urogenital em vista ventral.

Processos ósseos: presentes nas nadadeira anal e pélvica de machos.

Nadadeira anal com um processo ósseo por segmento de hemitriquium do último raio simples ao vigésimo segundo raio ramificado, disrtribuindo-se em $84 \%$ dos raios ramificados (até 26 raios ramificados). Raio simples com processos ósseos do quarto ao sétimo segmento, sexto segmento proximal à extremidade distal do raio. Raios ramificados com processos ósseos presentes tanto em segmentos proximais quanto em segmentos distais à primeira bifurcação. Processos ósseos presentes também em segmentos distais à segunda bifurcação do ramo posterior da primeira bifurcação. Proximalmente à primeira bifurcação, os processos ósseos estão presentes em até quatro segmentos. Distalmente à primeira bifurcação os prcessos ósseos estão presentes e restritos a todos os segmentos do ramo posterior. Distalmente à segunda bifurcação, os processos ósseos estão presentes e restritos a até dois segmentos do ramo posterior, imediatamente distais à bifurcação. Processos ósseos simétricos bilateralmente. Processos ósseos com inserção ovalada proximodistalmente. O maior comprimento de sua inserção ocupa $52 \%$ do comprimento proximodistal do segmento no qual está inserido. Em todos os segmentos os processos ósseos estão inseridos na face lateroposterior em relação à nadadeira. Os processos ósseos desenvolvem-se perpendicularmente à sua inserção no segmento. Ao longo de seu comprimento total, os processos ósseos apresentam uma curvatura de $53^{\circ}$ em relação ao eixo proximodistal do 
$\overline{\text { segmento no qual estão inseridos e desenvolvem-se em direção proximal (ligeiramente }}$ medial) em relação ao segmento no qual estão inseridos. Em secção transversal, os processos ósseos variam de ovalados proximodistalmente a cilíndricos ao longo de seu comprimento total, afilando-se gradualmente e terminanando em uma extremidade arredondada. O diâmetro de sua extremidade distal equivale a $12 \%$ do maior comprimento de sua inserção no segmento no qual está inserido. Em seu estado máximo de desenvolvimento, o seu comprimento total não alcança o comprimento proximodistal do segmento no qual está inserido. O comprimento do maior processo ósseo equivale a $44 \%$ do comprimento proximodistal do segmento no qual está inserido. Na nadadeira anal os processos ósseos aumentam e diminuem gradualmente de tamanho; terceiro raio ramificado com o maior número de semgmentos com processos ósseos; décimo primeiro e décimo segundo raio ramificado com processos ósseos maiores. Nos raios, os processos ósseos aumentam e diminuem de tamanho em direção proximodistal; o maior processo ósseos está presente no segmento imediatamente proximal à primeira bifurcação, metade/metade proximal da série de processos ósseos.

Nadadeira pélvica com processos ósseos presentes e restritos a segmentos do hemitricuium ventral. Nadadeira pélvica com um processo ósseo por segmento do raio simples ao sexto raio ramificado, disrtribuindo-se em $85 \%$ dos raios ramificados (7 raios ramificados). Raio simples com processos ósseos do terceiro ao quinto segmento, décimo segmento proximal à extremidade distal do raio. Raios ramificados com processos ósseos presentes tanto em segmentos proximais quanto em segmentos distais à primeira bifurcação. Processos ósseos presentes também em segmentos distais à segunda bifurcação do ramo medial da primeira bifurcação. Processos ósseos presentes também em segmentos distais à terceira bifurcação do ramo medial da segunda bifurcação do ramo medial da primeira bifurcação. A primeira bifurcação ocorre no segmento mais proximal. Proximalmente à primeira bifurcação até 
$\overline{\text { quatro processos ósseos estão presentes, na porção distal do segmento mais proximal em }}$ todos os raios. Distalmente a primeira bifurcação, os processos ósseos estão presentes e restritos a todos os segmentos do ramo medial. Distalmente à segunda bifurcação do ramo medial da primeira bifurcação, os processos ósseos estão presentes e restritos a todos os segmentos do ramo medial. Distalmente à terceira bifurcação do ramo medial da segunda bifurcação do ramo medial da primeira bifurcação, os processos ósseos estão presentes e restritos a até dois segmentos, imediatamente distais à bifurcação. Processos ósseos com inserção ovalada proximodistalmente. O maior comprimento de sua inserção ocupa $46 \%$ do comprimento proximodistal do segmento no qual está inserido. Em todos os segmentos, os processos ósseos estão inseridos na face ventromedial em relação à nadadeira. Os processos ósseos desenvolvem-se perpendicularmente à sua inserção no segmento no qual estão inseridos. Ao longo de seu comprimento total, os processos ósseos apresentam uma curvatura de $40^{\circ}$ em elação ao eixo proximodistal do segmento no qual estão inseridos e desenvolvemse em direção proximal em relação ao segmento no qual estão inseridos. Em secção transversal, os processos ósseos variam de ovalados proximodistalmente a cilíndricos ao longo de seu comprimento total, afilando-se gradualmente e terminando em uma extremidade pontiaguda. O siâmetro de sua extremidade distal equivale a $9 \%$ do maior comprimento de sua inserção no segmento no qual está inserido. Em seu estado máximo de desenvolvimento, o seu comprimento total não alcança o comprimento proximodistal do segmento no qual está inserido. O comprimento do maior processo ósseo equivale a $44 \%$ do comprimento proximodistal do segmento no qual está inserido. Na nadadeira pélvica o processos ósseos aumentam e diminuem gradualmente de tamanho em direção lateromedial; segundo e terceiro raio ramificado com o maior número de segmentos com processos ósseos e maiores processos ósseos. Nos raios os processos ósseos aumentam e diminuem de tamanho em direção 
proximodistal; o maior processo ósseo no segmento imediatamente distal à segunda rmaificação, metade/metade distal da série de processos ósseos.

\section{CHARACINAE}

\section{Acestrocephalus sardina (Folwer 1913)}

Fig. 84 a 86

Localidade tipo: rio Madeira, aproximadamente 200 milhas a leste de $62^{\circ} 20^{\prime} \mathrm{W}$, Amazonas, Brasil.

Material examinado: MZUSP 91581, 1, Brasil, Amazonas, rio Uaupés, 255’00”S, 69³8’00”W, J. Chernela. MZUSP 99777, 2, Brasil, Mato Grosso, Aripuanã, rio Aripuanã, Balneário Primavera a sjuante do Salto de Dardanelos, bacia do rio Madeira, $10^{\circ} 09^{\prime} 54$ ”S, 59²6’55”W, F. A. Machad et al., 12/12/2004. MZUSP 100545, 4, Brasil, Mato Grosso, Aripuaão, rio Aripuanã, balneário Primavera (abaixo do salto de Dardanelos/Andorinhas) bacia do rio Madeira, $10^{\circ} 10^{\prime} 06^{\prime} \mathrm{S}, 5^{\circ}$ 26’50”W, F. A. Machado et al., 03/04/2004. MZUSP 101081, 2, Brasil, Mato Grosso, Aripuanã, Rio Aripuanã, Balneãrio Primavera, 10¹0’54’S, 59²6’55’W, F. A. Machado et al., 11/10/2004.

\section{Caracteres sexuais secundários}

Os caracteres sexuais secundários em $A$. sardina relacionam-se ao comprimento padrão e à presença de processos ósseos.

Comprimento padrão: fêmeas alcançam maiores valores de comprimento padrão em relação aos machos. MZUSP 91581, 1 fêmea, (94.3 mm CP); MZUSP 99777, 1 macho (87.6 mm CP) e 1 fêmea (106.0 mm CP); MZUSP 100545, 4 machos (80.6-91.3 mm CP); MZUSP 101081, 2 fêmeas $(85.7-103.1 \mathrm{~mm} \mathrm{CP})$. 
Processos ósseos: presentes nas nadadeiras anal e pélvica de machos.

Nadadeira anal com até três (geralmente dois) processos ósseos por segmento de hemitriquium do último raio simples ao décimo terceiro raio ramificado, disrtribuindo-se em $39 \%$ dos raios ramificados (até 33 raios ramificados). Raio simples com processos ósseos do nono ao décimo terceiro segmento, que é o décimo segundo segmento proximal à extremidade distaldo raio. Raios ramificados com processos ósseos tanto em segmentos proximais quanto em segmentos distais à primeira bifurcação do terceiro ao último raio ramificado; primeiro raio ramificado com processos ósseos presentes e restritos a segmentos distais à primeira bifurcação. Processos ósseos presentes também em segmentos distais à segunda bifurcação do ramo posterior da primeira bifurcação. Proximalmente à primeira bifurcação, os processos ósseos estão presentes em até dois segmentos. Distalmente à primeira bifurcação, os processos ósseos estão presentes e restritos a todo os segmentos do ramo posterior. Distalmente à segunda bifurcação do ramo posterior da primeira ramificção, os processos ósseos estão presentes e restritos a até quatro segmentos, imediatamente distais à bifurcação. Processos ósseos assimétricos bilateralmente. Em todos os segmentos, os processos ósseos estão inseridos na face lateroposterior em relação à nadadeira. Inserção dos processo ósseos migra ligeiramente da face mais posterior à mais lateral em direção distoproximal em relação ao raio. Processos ósseos com inserção arredondada. O diâmetro de sua inserção ocupa 9\% do comprimento proximodistal do segmento no qual está inserido. Os processos ósseos desenvolvem-se perpendicularmente à inserção no segmento no qual estão inseridos. Ao longo de seu comprimento total, os processos ósseos apesentam uma curvatura de $55^{\circ} \mathrm{e}$ desenvolvem-se em direção proximal ou proximolateral em relação ao segmento no qual estão inseridos. Em secção transversal, os processos ósseos são cilíndricos ao longo de seu comprimento total, afilando-se gradualmente e terminando em uma extremidade arredondada. 
O diâmetro de sua extremidade distal ocupa $29 \%$ do diâmetro de sua inserção no segmento no qual está inserido. Em seus estado máximo de desenvolvimento, seu comprimento total não alcança o comprimento proximodistal do segmento no qual está inserido. O comprimento proximodistal do maior processo ósseo da nadadeira equivale a $26 \%$ do comprimento proximodistal do segmento no qual está inserido. $\mathrm{Na}$ nadadeira anal os processos ósseos aprsentam tamanho semelhante; terceiro raio com o maior número de segmentos com processos ósseos. No raio os processos ósseos aumentam e diminuem de tamanho em direção proximodistal; o maior processo ósseos presente no segundo segmento proximal à segunda bifurcação, na metade da série de processos ósseos.

Nadadeira pélvica com processos ósseos presentes e restritos a segmentos do hemitricuium ventral. Nadadeira pélvica com dois processos ósseos por segmento de hemitriquium ventral do primeiro ao sexto raio ramificado, distribuindo-se em $85 \%$ dos raios ramificados (7 raios ramificados). Raios ramificados com processos ósseos presentes e restritos a segmentos distais à primeira bifurcação. Processs ósseos presentes também em segmentos distais à segunda bifurcação do ramo medial da primeira bifurcação. Distalmente à primeira bifurcação, os processos ósseos estão presentes em todos os segmentos do ramo medial. Distalmente à segunda bifurcação do ramo medial da primeira bifurcação, os processos ósseos estão presentes e restritos a todos os segmentos do ramo medial. Processos ósseos com inserção ovalada proximodistalmente. O maior comprimento de sua inserção ocupa $17 \%$ do comprimento proximodistal do segmento no qual está inserido. Em todos os segmentos, os processos ósseos estão inseridos na face vantromedial em relação à nadadeira. Os processos ósseos desenvolvem-se perpendicularmente à sua inserção no segmento. Ao longo de seu comprimento total, os processos ósseos aprsentam uma curvatura de $55^{\circ}$ em relação ao eixo proximodistal do segmento no qual está inserido e desenvolvem-se em direção proximal em 
$\overline{\text { relação ao segmento no qual estão inseridos. Em secção transversal, os processos ósseos }}$ variam de ovalados proximodistalmente a cilíndricos ao longo de seus comprimento total, afilando-se gradualmente e terminando em uma extremidade arredondada. O diâmetro de sua extremidade distal equivale a $29 \%$ do maior comprimento de sua inserção no segmento no qual está inserido. Em seu estado máximo de desenvolvimento, o seu comprimento total não alcança o comprimento proximodistal do segmento no qual está inserido. O comprimento do maior processo ósseo equivale a $25 \%$ do comprimento proximodistal do segmento no qual está inserido. Não foi possível avaliar a variação do tamanho dos processos ósseos ao longo da nadadeira; terceiro raio ramificado com o maior número de segmentos com processos ósseos. Nos raios os processos aumentam e diminuem de tamanho em direçãoo proximodistal; o maior processo ósseos está presente no segundo segmento distal à primeira bifurcação, metade proximal do segmento.

\section{Bryconexodon juruenae Géry 1980}

Fig. 87 e 88

Localidade tipo: alto rio Juruena, tributário do rio Tapajós, Mato Grosso, Brasil.

Material examinado: MZUSP 96607, 5, Brasil, Mato Grosso, Peixoto de Azevedo, rio Peixoto de Azevedo, afluente do rio Teles Pires, bacia do rio Tapajós, 10¹3'14”S, 5458'02”W, J. L. Birindelli et al., 16/10/2007. MZUSP 96748, 4, Brasil, Mato Grosso, Peixoto de Azevedo, tributário da margem direita do rio Peixoto de Azevedo, afluente do rio Teles Pires, bacia do rio Tapajós, J. L. Birindelli et al., 17/10/2007.

\section{Caracteres sexuais secundários:}


Os caracteres sexuais secundários em $B$. juruenae relacionam-se ao comprimento padrão e à presença de processos ósseos.

Comprimento padrão: fêmeas alcançam maiores valores de comprimento padrão em relação aos machos. MZUSP 96748, 3 machos (65.8-78 mm CP) e 1 fêmea (69 mm CP); MZUSP 96607, 3 machos (54.7-71.1 mm CP) e 1 fêmea (91.4 mm CP).

Processos ósseos: presentes na nadadeira anal de machos adultos.

Nadadeira anal com até dois (geralmente um) processo ósseo por segmento de hemitriquium do primeiro ao quarto raio ramificado, disrtribuindo-se em 18\% dos raios ramificados (até 22 raios ramificado). Raios ramificados com processos ósseos presentes e restritos a segmentos distais à primeira bifurcação. Distalmente à primeira bifurcação, os processos ósseos estão presentes e restritos a até quatro segmentos do ramo posterior, a partir do segundo segmento distal à bifurcação. Processos ósseos assimétricos bilateralmente. Processos ósseos com inserção ovalada proximodistalmente. O maior comprimento de sua inserção ocupa $24 \%$ do comprimento proximodistal do segmento no qual está inserido. Em todos os segmentos, os processos ósseos estão inseridos na face lateroposterior em relação à nadadeira. Os processos ósseos desenvolvem-se perpendicularmente à sua inserção no segmento. Ao longo de seu comprimento total, os processos ósseos apresentam uma curvatura de $45^{\circ}$ em relação ao eixo proximodistal do segmento no qual está inserido e desenvolvem-se em direção proximal em relação ao eixo proximodistal do segmento no qual estão inseridos. Em secção transversal, os processos ósseos variam de ovalados proximodistalmente a cilíndricos ao longo de seu comprimento total, afilando-se gradualmente e terminando em uma extremidade pontiaguda. O diâmetro de sua extremidade distal equivale $11 \%$ do maior comprimento de sua inserção no segmento no qual está inserido. Em seu estado máximo de desenvolvimento, o seu comprimento total não alcança o comprimento proximodistal do segmento no qual está 
inserido. O comprimento do maior processo ósseo equivale a $23 \%$ do comprimento proximodistal do segmento no qual está inserido. Na nadadeira anal os processos ósseos aumentam gradualmente em direção anteroposterior; segundo raio ramificado com o maior número de segmentos com processos ósseos e processos ósseos maiores. Nos raios, os processos ósseos aumentam e diminuem de tamanho em direção proximodistal; o maior processo ósseo está presente no terceiro segmento distal à bifurcação, na metade distal da série de processos ósseos.

\section{Charax stenopterus (Cope 1894)}

Fig. 89 a 91

Localidade tipo: Alto rio Jacuhy (= Jacuí), Rio Grande do Sul, Brazil.

Material examinado: MZUSP 19945, 1, Brasil, Rio Grande do Sul, Viamão, Arroio Fiuza, Expedição MZUSP/USNM, 9/12/1979. MZUSP 37852, 2, Brasil, Mato Grosso do Sul, Corumba, Fazenda Nhumirim, Nhecolâncida, Baía de sede, bacia do rio Paraguay, $19^{\circ} 15^{\prime} 0.0^{\prime}$ S, 57²’0.0”W, G. M. Mourão \& E. K. Bastos.

\section{Caracteres sexuais secundários}

Os caracteres sexuais secundários em C. stenopterus relacionam-se ao comprimento padrão e presença de processos ósseos.

Comprimento padrão: fêmeas alcançam maiores valores de comprimento padrão em relação aos machos. MZUSP 19945, 1 macho (61.4 mm CP); MZUSP 91581, 1 fêmea (94.3mm CP). Processos ósseos: presentes na nadadeira anal e pélvica de machos adultos.

Nadadeira anal com até dois (geralmente um) processos ósseos por segmento de hemitriquium do último raio simples ao décimo terceiro raio ramificado, disrtribuindo-se em 
$\overline{27 \% \text { dos raios ramificados (até } 48 \text { raios ramificados). Último raio simples com processos }}$ ósseos do terceiro ao décimo terceiro segmento, sétimo segmento proximal à extremidade distal. Raios ramificados com processos ósseos tanto em segmentos proximais quanto em segmentos distais à primeira bifurcação. Processos ósseos presentes também em segmentos distais à segunda bifurcação do ramo posterior da primeira bifurcação. Proximalmente à primeira bifurcação, os processos ósseos estão presentes em até quatro segmentos. Distalmente à primeira bifurcação, os processos ósseos estão presentes e restritos a todos os segmentos do ramo posterior. Distalmente à segunda bifurcação do ramo posterior da primeira bifurcação, os processos ósseos estão presentes e restritos a um segmento do ramo posterior, imediatamente distal à bifurcação. Processos ósseos simétricos bilateralmente. Processos ósseos com inserção arredondada. O diâmetro de sua inserção ocupa $23 \%$ do comprimento proimodistal do segmento no qual está inserido. Em todos os segmentos os processos ósseos estão inseridos na face lateroposterior. Os processos ósseos desenvolvem-se perpendicularmente à suas inserções no segmento no qual estão inseridos. Em sua metade (1/2) os processos apresentam uma curvatura de $50^{\circ}$ e desenvolvem-se em direção medial (ligeiramente em direção proximal) em relação ao eixo proximodistal do segmento no qual estão inseridos. Os processos ósseos são cilíndricos ao longo de seu comprimento total, afilando-se muito pouco e terminando em uma extremidade arredondada. O diâmetro de sua extremidade dsital equivale a $40 \%$ do maior comprimento de sua inserção no segmento no qual está inserido. Em seus estado máximo de desenvolvimento, seu comprimento total não alcança o comprimento proximodistal do segmento no qual está inserido. O comprimento do maior processo ósseo da nadadeira equivale a $22 \%$ do comprimento proximodistal do segmento no qual está inserido. Na nadadeira anal os processos ósseos apresentam tamanhos semelhantes em todos os raios; primeiro ao quinto raio ramificado com maior número de 
$\overline{\text { segmentos com processos ósseos. No raio os processos ósseos aumentam e diminuem de }}$ tamanho em direção proximodistal; os maiores processos ósseos estão presentes no segmento imediatamente distal à bifurcação, na metade ou metade distal da série de processos ósseos.

Nadadeira pélvica com processos ósseos presentes e restritos a segmentos do hemitricuium ventral. Nadadeira pélvica com até dois (geralmente um) processos ósseos por segmento do raio simples até o quinto raio ramificado, disrtribuindo-se em $71 \%$ dos raios ramificados ( 7 raios ramificados). Raio simples com processos ósseos do décimo segundo ao décimo quarto segmento, sétimo segmento proximal à extremidade distal do raio. Raios ramificados com processos ósseos tanto em segmentos proximais quanto em segmentos distais à primeira bifurcação. Processos ósseos presentes também em segmentos distais à segunda bifurcação do ramo medial da primeira bifurcação. Processos ósseos presentes também em segmentos distais à terceira bifurcação do ramo medial da segunda bifurcação do ramo medial da primeira bifurcação. Proximalmente à primeira bifurcação, os processos ósseos estão presentes em até dois segmentos (inclusive o raio mais proximal, mais longo). Raio mais proximal, mais longo, com um processo ósseo em sua extremidade distal. Distalmente à primeira bifurcação, os processos ósseos estão presentes e restritos a todos os segmentos do ramo medial. Distalmente à segunda bifurcação do ramo medial da primeira bifurcação, os processos ósseos estão presentes e restritos a todos os segmentos do ramo medial. Distalmente à terceira bifurcação do ramo medial da segunda bifurcação do ramo medial da primeira bifurcação, os processos ósseos estão presentes e restritos a até um segmento do ramo medial, imediatamente distal à ramificaçào. Processos ósseos com inserção arredondada. O maior comprimento de sua inserção, $12 \%$ do comprimento proximodistal do segmento no qual está inserido. Em todos os segmentos, os processos ósseos estão inseridos na face ventromedial. Os processos ósseos desenvolvem-se perpendicularmente à sua inserção nos segmentos no 
qual estão inseridos. Em sua metade (1/2) os processos sofrem uma curvatura de $55^{\circ}$ em relação ao segmento no qual estão inseridos e desenvolvem-se em direção medial (ligeiramente em direção proximal) em relação ao eixo proximodistal do segmento no qual estão inseridos. O processos ósseos sãp cilíndricos ao longo de seu comprimento total, afilando-se muito pouco e terminanado em uma extremidade arredondada. O diâmetro de sua extremidade distal equivale a $55 \%$ do maior comprimento de sua inserção no segmento no qual está inserido. Em seus estado máximo de desenvolvimento, o seu comprimento total não alcança o comprimento proximodistal do segmento em está inserido. O comprimento do maior processo ósseo da nadadeira equivale a $40 \%$ do comprimento proximodistal do segmento no qual está inserido. Na nadadeira pélvica os processos ósseos apresentam tamanhos semelhantes em todos os raios; primeiro raio ramificado com maior número de segmentos com processos ósseos. No raio os processos ósseos aumentam e diminuem de tamanho em direção proximodistal; o maior processo ósseos está presente no segmento imediatamente procimal à segunda bifurcação, na metade/metade proximal do raio.

\section{Roeboides descalvadensis Fowler 1932}

Fig. 92 a 94

Localidade tipo: Descalvados, Mato Grosso, Brasil.

Material examinado: MZUSP 6286, 4M e 1F de 24, Brasil, Amazonas, Lago Castro, boca do rio Purus, bacia do rio Purus, $03^{\circ} 42^{\prime} 00^{\prime \prime} \mathrm{S}, 61^{\circ} 28^{\prime} 00^{\prime \prime} \mathrm{W}$, Expedição Permanente à Amazônia, 11/1967.

\section{Caracteres sexuais secundários}


Os caracteres sexuais secundários em $R$. descalvadensis relacionam-se ao comprimento padrão e à presença de processos ósseos.

Comprimento padrão: fêmeas alcançam maiores valores de comprimento padrão em relação aos machos. MZUSP 6286, 10 machos (36.4-40.9 mm CP) e 12 fêmeas (33.1-41.5 mm CP)

Processos ósseos: presentes nas nadadeiras anal e pélvica de machos maduros.

Nadadeira anal com até dois (normalmente um) processos ósseos por segmento de hemitrichium do último raio simples ao décimo segundo raio ramificado, disrtribuindo-se em $23 \%$ dos raios ramificados (até 52 raios ramificados). Último raio simples com processos ósseos do segmento mais proximal, mais longo, ao sexto segmento, oitvo segmento proximal à extremidade distal do raio. Raios ramificados com processos tanto em segmentos proximais quanto em segmentos distais à primeira bifurcação. Proximalmente à primeira bifurcação, os processos ósseos estão presentes em até seis segmentos, todos. Distalmente à primeira bifurcação, os processos ósseos estão presentes e restritos a até três segmentos do ramo posterior, imediatamente distais à bifurcação. Processos ósseos assimétricos bilateralmente. Processos ósseos com inserção ovalada proximodistalmente. O maior comprimento de sua inserção ocupa $10 \%$ do comprimento proximodistal do segmento no qual está inserido. Em todos os segmentos, os processos ósseos estão inseridos na face posterior/lateroposterior. Os processos ósseos desenvolvem-se perpendicularmente à sua inserção no segmento. Ao longo de seu comprimento, os processos ósseos são retos, com uma leva curvatura em alguns processos, em direção proximal em relação ao segmento no qual estão inseridos. Em secção transversal, os processos ósseos variam de ovalados proximodistalmente a cilíndricos em direção proximodistal, afilando-se gradualmente e terminando em uma extremidade pontiaguda. O diâmetro de sua extremidade distal equivale a $14 \%$ do maior comprimento de sua inserção no segmento no qual está inserido. Em seu estado máximo de desenvolvimento, 
o seu comprimento total não alcança o comprimento proximodistal do segmento no qual está inserido. O comprimento do maior processo ósseo equivale a $23 \%$ do comprimento proximodistal do segmento no qual está inserido. Na nadadeira anal os processos ósseos mantêm tamanho semelhante; primeiro e segundo raio ramificado com maior número de segmentos com processos ósseos. Nos raios, os processos ósseos aumentam e diminuem de tamanho em direção proximodistal; o maior processo ósseos está no segundo segmento proximal à primeira bifurcação, na metade/metade proximal da série de processos ósseos.

Nadadeira pélvica com processos óseos presentes e restritos a segmentos do hemitricuium ventral. Nadadeira pélvica com até dois (normalmente dois) processos ósseos por segmento do primeiro ao sexto raio ramificado, distribuindo-se em $85 \%$ dos raios ramificados (7 raios ramificados). Raios ramificados com processos ósseos tanto em segmentos proximais quanto distais à primeira bifurcação. Processos ósseos presentes também em segmentos distais à segunda bifurcação do ramo medial da primeira bifurcação. Proximalmente à primeira bifurcação, os processos ósseos estão presentes em até dois segmentos. Distalmente à primeira bifurcação os processos ósseos estão presentes e restritos a todos os segmentos do ramo medial. Distalmente à segunda bifurcação do ramo medial da primeira bifurcação, os processos ósseos estão presentes e restritos a até um segmento do ramo medial, imediatamente distal à bifurcação. Processos ósseos com inserção ovalada proximodistalmente ou arredondada (em alguns processos). O maior comprimento de sua inserção ocupa $10 \%$ do comprimento proximodistal do segmento no qual está inserido. Em todos os segmentos, os processos ósseos estão inseridos na face ventromedial do segmento no qual está inserido. Os processos ósseos desenvolvem-se perpendicularmente à sua inserção nos segmentos no qual estão inseridos. Ao longo de seu comprimento total, os processos ósseos são retos. Em secção transversal, os processos ósseos variam de ovalados 
$\overline{\text { proximodistalmente a cilíndricos em direção proximodistal, afilando-se gradualmente e }}$ terminando em uma extremidade pontiaguda/arredondada. Diâmetro de sua extremidade distal, $22 \%$ do maior comprimento de sua inserção no segmento no qual está inserido. Em seu estado máximo de desenvolvimento, o seu comprimento total não alcança o comprimento proximodistal do segmento no qual está inserido. O comprimento do maior processo ósseo equivale a $15 \%$ do comprimento proximodistal do segmento no qual está inserido. $\mathrm{Na}$ nadadeira pélvica os processos ósseos apresentam tamanhos semelhantes até o último raio, onde diminui discretamente de tamanho; seguno e terceiro raio ramificado com o maior número de segmentos com processos ósseos. Nos raios, os processos ósseos aumentam e diminuem de tamanho em direção proximodistal; o maior processo ósseo está presente no terceiro segmento proximal à segunda rmaificaçao, metade/metade proximal do raio.

\section{Roeboides microlepis (Reinhardt 1851)}

Figs. 95 e 96

Localidade tipo: rio Paraguay, Brasil.

Material examinado: MZUSP 1658, 1M (132.2 mm CP), Brasil, Amazonas, rio Juruá, Garbe, 190.

\section{Caracteres secuais secundários}

Os caracteres sexuais secundários em $R$. microlepis relacionam-se à presença de processos ósseos.

Comprimento padrão: Baixo número de lotes com exemplares maduros sexualmente impossibiliataram a sexagem e consequentemente a avaliação deste caráter.

Processos ósseos: presentes nas nadadeiras anal e pélvica de machos. 
Nadadeira anal com até dois (geralmente um) processos ósseos por segmento de hemitriquium do quarto ao trigésimo sétimo raio ramificado, disrtribuindo-se em $64 \%$ do total de raios ramificados (até 51 raios ramificados). Raio ramificado com processos ósseos tanto em segmentos proximais quanto em segmentos distais à primeira bifurcação. Processo ósseos presentes também em segmentos distais à segunda bifurcação do ramo posterior da primeira bifurcação. Proximalmente à primeira bifurcação, os processos ósseos estão presentes em até três sementos. Distalmente à primeira bifurcação, os processos ósseos estão presentes e restritos a todos os segmentos do ramo posterior. Distalmente à segunda bifurcação do ramo posterior da primeira bifurcação, os processos ósseos estão presentes e restritos a até dois segementos do ramo posterior, imediatamente distais à bifurcação. Processos ósseos assimétricos bilateralmente. Processo ósseo com inserção ovalada proximodistalmente. $\mathrm{O}$ maior comprimento de sua inserção ocupa $33 \%$ do comprimento proximodistal do segmento no qual está inserido. Em todos os segmentos, os processos ósseos estão inseridos na face lateroposterior em relação à nadadeira. Os processos ósseos desenvolvem-se perpendicularmente à sua inserção no segmento no segmento no qual estão inseridos. Ao longo de seu comprimento total, os processos ósseos apresentam uma curvatura de $39^{\circ} \mathrm{em}$ relação ao eixo proximodistal do segmento no qual estão inseridos e desenvolvem-se em direção proximal (ligeiramente lateral) em relação ao eixo proximodistal do segmento no qual estão inseridos. Em secção transversal, os processos ósseos variam de ovalados proximodistalmente a cilíndricos ao longo de seu comprimento total, afilando-se gradualmente e terminando em uma extremidade arredondada. O diâmetro de sua extremidade distal equivale a $23 \%$ do maior comprimento de sua inserção no segmento no qual está inserido. Em seu estado máximo de desenvolvimento, o seu comprimento total não alcança o comprimento proximodistal do segmento no qual está inserido. O comprimento do maior 
processo ósseo equivale a $30 \%$ do comprimento proximodistal do segmento no qual está inserido. Na nadadeira anal os processos ósseos aumentam e diminuem gradualmente de tamanho em direção anteroposterior; décimo terceiro, décimo quarto e décimo quinto raio ramificado com maior número de segmentos com processos ósseos e maiores processos ósseos. Nos raios, os processos ósseos aumentam e diminuem de tamanho em direção proximodistal; o maior processo ósseos está no segmento imediatamente distal à primeira bifurcação, na metade proximal do segmento.

Nadadeira pélvica com processos ósseos presentes e restritos a segmentos do hemitricuium ventral. Nadadeira pélvica com até dois (geralmente um) processos ósseos por segmento de hemitriquium ventral do primeiro ao quinto raio ramificado, disrtribuindo-se em $71 \%$ dos raios ramificados (7 raios ramificados). Processos ósseos presentes tanto em segmentos proximais quanto em segmentos distais à primeira bifurcação. Processos ósseos presentes também em segmentos distais à segunda bifurcação do ramo medial. Proximalmente à primeira bifurcação existem até quatro processos ósseos na porção mais distal do segmento mais proximal, mais longo. Distalmente à primeira bifurcação, os processos ósseos estão presentes e restritos a todos os segmentos do ramo medial. Distalmente à segunda bifurcação do ramo medial da primeira bifurcação, os processos ósseos estão presentes e restritos a todos os segmentos do ramo medial. Processos ósseos com inserção ovalada proximodistalmente. O maior comprimento de sua inserção ocupa $37 \%$ do comprimento proximodistal do segmento no qual está inserido. Em todos os segmentos, os processos ósseos estão inseridos na face ventromedial do segmento no qual está inserido. Os processos ósseos desenvolvem-se perpendicularmente à sua inserção nos segmentos no qual estão inseridos. No quarto (1/4) proximal de seu comprimento total, os processos ósseos apresentam uma curvatura de $45^{\circ} \mathrm{e}$ desenvolvem-se em direção proximal em relação ao eixo proximodistal do segmento no qual 
estão inseridos. Em secção transversal, os processos ósseos variam de ovalados proximodistalmente a cilíndricos ao longo de seu comprimento total, afilando-se gradualmente e terminando em uma extremidade pontiaguda/arredondada. O diâmetro de sua extremidade distal equivale a $20 \%$ do maior comprimento de sua inserção no segmento no qual está inserido. Em seu estado máximo de desenvolvimento, o seu comprimento total não alcança o comprimento proximodistal do segmento no qual está inserido. O comprimento do maior processo ósseo, equivale a $47 \%$ do comprimento proximodistal do segmento no qual está inserido. Na nadadeira pélvica os processos ósseos aumentam e diminuem gradualmente de tamanho em direção lateromedial; quarto raio ramificado com o maior número de segmentos com processos ósseos e processos ósseos maiores. Nos raios, os processos ósseos aumentam e diminuem de tamanho em direção proximodistal; o maior processo ósseos está no segmento imediatamente proximal à primeira bifurcação, na metade proximal da série de processos ósseos.

\section{CHEIRODONTINAE}

\section{Acinocheirodon melanogramma Malabarba \& Weitzman 1999}

Figs. 97 a 100

Localidade tipo: Brasil, Minas Gerais, Município de Bocaiuva, córrego Cachoeira, tributário do rio Jequitaí, kilometro 413 da BR bacia do rio São Francisco, 135, 17²2 'S, $44^{\circ} 02^{\text {’W }}$. Material examinado: MZUSP 52434, 8, Brasil, Minas Gerais, Itira, rio Jequitinhonha, abaixo da foz do rio Araçuaí, bacia do rio Jequitinhonha, $16^{\circ} 47^{\prime} 00^{\prime} \mathrm{S}, 42^{\circ} 03^{\prime} 00^{\prime \prime} \mathrm{W}, \mathrm{J}$. C. Garavello et al., 10/01/1989. 


\section{Caracteres sexuais secundários}

Os caracteres sexuais secundários em A. melanogramma relacionam-se ao comprimento padrão, formato de nadadeiras, presença de processos ósseos, procurrentes ventrais e glândula brânquial.

Comprimento padrão: machos alcançam maiores valores de comprimento padrão em relação às fêmeas. MZUSP 52434, 2 machos (28.3-30.5 mm CP) e 1 fêmea (29.3 mm CP).

Formato de nadadeiras: machos diferem de fêmeas pelo formato do perfil da margem distal da nadadeira anal, formato das nadadeiras pélvica e caudal e formato dos três raios procurrentes ventrais posteriores.

Perfil da margem distal da nadadeira de machos com dois lobos. Lobo anterior formado pelo aumento de tamanho do último raio simples ao segundo raio ramificado (raio mais longo) e diminuição gradual deste ao oitavo ou nono raio ramificado. Lobo posterior formado pelo aumento gradual de tamanho do nono raio ramificado ao décimo sétimo raio ramificado (raio mais longo do lobo posterior) e diminuição gradual deste ao último riao ramificado; riao mais longo do lobo posterior alcança o nono raio procurrente ventral contado em direção posteroanterior. Perfil da margem distal da nadadeira anal de fêmeas com lobo anterior côncavo. Lobo anteiror formado pelo aumento gradual de tamanho do último raio simples ao segundo raio ramificado (raios mais longos) e diminuição acentuada deste ao oitavo ou nono raio ramificado; perfil reto do nono ao último raio ramificado devido à diminuição gradual dos raios ramificados em direção anteroposterior, raios ramificados posteriores são os menores raios da nadadeira.

Extremidade distal do primeiro raio ramificado (raio mais longo) da nadadeira pélvica de machos ultrapassa a origem da nadadeira anal, nunca ultrapassando o último raio simples. Nadadeira pélvica de machos sobrepõe o orifício urogenital em vista ventral. Extremidade 
distal do primeiro raio ramificado (raio mais longo) da nadadeira pélvica de fêmeas ultrapassa a origem do orifício urogenital, mas não alcança a origem da nadadeira anal. Nadadeira pélvica das fêmeas não sobrepõe o orifício urogenital em vista ventral.

Segmentos do décimo segundo e décimo terceiro raio ramificado (no lobo ventral) da nadadeira caudal de machos (raios com processos ósseos) quadrados, tão longos quanto largos, devido a uma expansão dorsoventral. Décimo segundo e décimo terceiro raio ramificado com um espaçamento, com um tercido espesso localizado lateralmente à membranda interradial. Segmentos dos raios da nadadeira caudal de fêmeas mais copridos que largos, semelhantes aos segmentos dos demais raios da nadadeira. Espaçamento entre os raios da nadadeira caudal, constante.

Processos ósseos: presentes nas nadadeiras anal, pélvica e caudal de machos.

Nadadeira anal com até dois processos ósseos por segmento de hemitriquium do último raio simples ao nono raio ramificado, disrtribuindo-se em $47 \%$ dos raios ramificados (até 19 raios ramificados). Último raio simples com processos ósseos do quinto ao décimo quarto segmento, quinto segmento proximal à extremidade distal do raio. Processos ósseos presentes tanto em segmentos proximais quanto em segmentos distais à primeira bifurcação. Processos ósseos presentes também em segmentos distais à segunda bifurcação do ramo posterior da primeira bifurcação. Proximalmente à primeira bifurcação, os processos ósseos estão presentes em até quatro segmentos. Distalmente à primeira bifurcação e proximalmente às segunda ramificações, os processos ósseos estão presentes e restritos a todos os segmentos do ramo posterior. Distalmente à segunda bifurcação do ramo posterior da primeira bifurcação, os processos ósseos estão presentes e restritos a até um segmento do ramo posterior, imediatamente distal à bifurcação. Processos ósseos simétricos bilateralmente. Processos ósseos com inserção ovalada proximodistalmente. O maior comprimento de sua inserção 
ocupa $28 \%$ do comprimento proximodistal do segmento no qual está inserido. Em todos os segmentos, os processos ósseos estão inseridos na face lateroposterior em relação à nadadeira. Os processos ósseos desenvolvem-se perpendicularmente à sua inserção no segmento. Em direção distoproximal os processos ósseos se direcionam de mais posteriormente a mais lateralmente. No um quarto (1/4) proximal de seu comprimento total, os processos ósseos sofrem uma curvatura de $45^{\circ}$ em relação ao eixo proximodistal do segmento no qual estão inseridos e desenvolvem-se em direção proximal em relação ao segmento no qual estão inseridos. Em secção transversal, os processos ósseos variam de ovalados proximodistalmente a cilíndricos, afilando-se gradualmente e terminando em uma extremidade distal arredonda/pontiaguda. O diâmtero de sua extremidade distal equivale a $25 \%$ do maior comprimento de sua inserção no segmento no qual está inserido. Em seu estado máximo de desenvolvimento, o seu comprimento total não alcança o comprimento proximodistal do segmento no qual está inserido. O comprimento do maior processo ósseo equivale a $61 \%$ do comprimento proximodistal do segmento no qual está inserido. Na nadadeira anal os processos aumentam e diminuem gradualmente de tamanho em direção anteroposterior; terceiro e quarto raio ramificado com maior número de segmentos com processos ósseos e processos ósseos maiores. No raio os processos ósseos aumentam e diminuem de tamanho em direção proximodistal.

Nadadeira pélvica com processos ósseos presentes e restritos a segmentos do hemitricuium ventral. Nadadeira pélvica com até três (geralmente dois) processos ósseos por segmento no hemitriquium ventral do raio simples ao sétimo raio ramificado, disrtribuindo-se em $100 \%$ dos raios ramificados (7 raios ramificados). Raio simples com processos ósseos do segmento mais proximal (mais longo) ao nono segmento, nono segmento proximal à extremidade distal do raio. Raios ramificados com processos ósseos presentes tanto em segmentos proximais 
$\overline{\text { quanto em segmentos distais à primeira bifurcação. Proximalmente à primeira bifurcação, os }}$ processos ósseos estão presentes em todos os segmentos, inclusive o mais proximal (mais longo) em todos os raios. Inserção dos processos ósseos proximais à primeira bifurcação migrande da face ventromedial à face ventral em direção distoproximal. Processos ósseos presentes também em segmentos distais à segunda bifurcação dos ramos medial e lateral da primeira bifurcação. Distalmente à primeira bifurcação, os processos ósseos estão presentes em todos os segmentos dos ramos medial e lateral. Distalmente à segunda bifurcação do ramo medial, os processos ósseos estão presentes em todos os segmentos dos ramos medial e lateral. Distalmente à segunda bifurcação do ramo lateral da primeira bifurcação, os processos ósseos estão presentes em todos os segmentos dos ramos medial e em até sete segmentos do ramo lateral, a partir do segundo segmento distal à bifurcação. Processos ósseos com inserção arredondada. O diâmetro de sua inserção ocupa $23 \%$ do comprimento proximodistal do semgento no qual está inserido. Nos segmentos proximais à primeira bifurcação, os processos ósseos estão inseridos tanto na face ventromedial quanto na face ventrolateral. Em todos os segmentos do ramo medial da primeira bifurcação e segunda bifurcação deste ramo, os processos ósseos estão inseridos na face ventromedial, com exceção de um segmento imediatamente proximal à segunda bifurcação, no qual os processos ósseos estão inseridos tanto na face ventromeidal quanto na face ventrolateral. Nos segmentos do ramo lateral da segunda bifurcação do ramo medial da primeira bifurcação, os processos ósseos estão inseridos na face ventrolateral. Em todos os segmentos do ramo lateral da primeira bifurcação, os processos ósseos estão inseridos na face ventrolateral, com exceção de dois segmentos imediatamente proximais à primeira bifurcação, no qual os processos ósseos estão inseridos tanto na face ventromedial quanto na face ventrolateral. Nos segmentos dos ramos medial e lateral da segunda bifurcação do ramo lateral da primeira bifurcação, os processos 
ósseos estão inseridos na face ventromedial. Em três segmentos (mais distais) do ramo medial da segunda bifurcação do ramo lateral da primeira bifurcação, os processos ósseos estão inseridos tanto na face ventromedial quanto na face ventrolateral. Inserção dos processos ósseos do segmento mais proximal do raio (o mais longo) migrando da face ventromedial pra face ventral em sentindo distoproximal. Os processos ósseos desenvolvemse perpendicularmente à sua inserção no segmento no qual estão inseridos. No um quarto (1/4) proximal de seu comprimento total, os processos ósseos apresenteam uma curvatura de $55^{\circ}$ em relação ao eixo proximodistal do segmenteo no qual sestão inseridos e desenvolvemse em direção proximal em relação ao segmento no qual estão inseridos. Em secção transversal, os processos ósseos são cilíndricos ao longo de seu comprimento total, afilandose gradualmente e terminando em uma extremidade pontiaguda. O diâmetro de sua extremidade distal equivale a $16 \%$ do diâmetro de sua inserção no segmento no qual está inserido. Em seu estado máximo de desenvolvimento, o seu comprimento total não alcança o comprimento proximodistal do segmento no qual está inserido. O comprimento do maior processo ósseo equivale a76\% do coprimento proximodistal do segmento no qual está inserido. Na nadadeira pélvica os processos ósseos apresentam tamanhos semelhantes do primeiro ao sexto raio ramificado, diminuindo no último raio; segundo e terceiro raio ramificado com o maior número de segmentos com processos ósseos. Nos raios os processos ósseos aumentam e diminuem de tamanho em direção proximodistal; o maior processo ósseos está no primeiro segmento distal à segunda bifurcação, na metade posterior da série de processos ósseos.

Nadadeira caudal com até três (geralmente um) processos ósseos por segmento no décimo primeiro e décimo segundo raio ramificado, disrtribuindo-se em $12 \%$ dos raios ramificados (17 raios ramificados). Processos ósseos presentes tanto em segmentos proximais quanto 
distais à primeira bifurcação. Processos ósseos presentes também em segmentos distais à segunda bifurcação do ramo dorsal da primeira bifurcação. Proximalmente à primeira bifurcação, os processos ósseos estão presentes em até dois segmentos. Distalmente à primeira bifurcação e proximalmente às segundas ramificações, os processos ósseos estão presentes e restritos a todos os segmentos do ramo medial, imediatamente distais à bifurcação. Distalmente à segunda bifurcação do ramo medial da primeira bifurcação, os processos ósseos estão presentes e restritos a até dois segmento do ramo medial, imediatamente distais à ramifiação. Processos ósseos simétricos bilateralmente. Processos ósseos com inserção ovalada proximodistalmente. O maior comprimento de sua inserção ocupa $54 \%$ do comprimento proximodistal do segmento no qual está inserido. Em todos os segmentos, os processos ósseos estão inseridos na face mediolateral em relação à nadadeira, com exceção do quinto segmento distal à primeira bifurcação que apresenta um segmento inserido também na face laterolateral. Embora sempre na face mediolateral do segmento, a inserção dos processos migra da face mais lateral à mais medial em direção proximodistal em relação ao raio. Os processos ósseos desenvolvem-se medioproximalmente à sua inserção no segmento no qual estão inseridos. Em seu um quinto (1/5) proximal, os processos ósseos sofrem uma curvatura de $35^{\circ}$ em relação ao eixo proximodistal do segmento no qual estão inseridos e desenvolvemse em direção proximal em relação ao segmento no qual está inserido. Em secção transversal, os processos ósseos são cilíndricos ao longo de seu comprimento total, afilando-se muito pouco em direção proximodistal e terminando em uma extremidade arredondada. O diâmetro de sua extremidade distal equivale a $13 \%$ do diâmetro de sua inserção no segmento no qual está inserido. Em seu estado máximo de desenvolvimento, seu comprimento total ultrapassa o comprimento proximodistal do segmento no qual está inserido. O comprimento do maior processo ósseo equivale a $124 \%$ do comprimento proximodistal do segmento no qual está 
$\overline{\text { inserido. Na nadadeira anal os processos apresentam tamanhos semelhantes; décimo segundo }}$ raio ramificado com maior número de segmentos com processos ósseos. No raio os processos ósseos aumentam e diminuem de tamanho em direção proximodistal; o maior processo ósseos está no terceiro segmento dista; à primeira rmaificação, na metade proximal da série de processos ósseos.

Glândula branquial: presente em machos maduros.

Glândula brancuiqal formada pela fusão do primeiro ao décimo terceiro filamento branquial anterior do ceratobraquial do primeiro arco branquial de machos maduros. Glândula branquial disrtribuindo-se em $52 \%$ dos filamentos branquiais do ceratobranquial do primeiro arco branquial. Glândula branquial distribuindo-se em $48 \%$ do comprimento do ceratobraanquial. Células colunares visíveis ao longo da porção lateral dos filamentos mofidicados. Abertura da glândula branquial em $90 \%$ do filamento braqnuial.

\section{Cheirodon interruptus (Jenyns 1842)}

Figs. 101 a 105

Localidade tipo: Laguna del Diario, $34^{\circ} 54^{\prime} \mathrm{S}, 55^{\circ} 00^{\prime} \mathrm{W}$, in Maldonado, Uruguay.

Material examinado: MZUSP 18894, 79, Brasil, Rio Grande do Sul, Porto Alegre, arroio no município de Belém-novo perto de Porto Alegre, bacia do rio Jacuí, $30^{\circ} 12^{`} 0.0$ ”S, 51²'0.0’W, Exp. MZUSP/USNM, 21/09/1977. MZUSP 19037, 39, Brasil, Rio Grande do

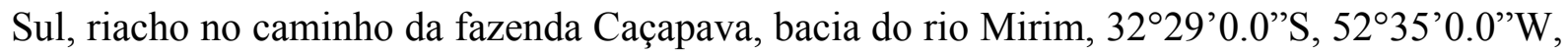
Exp. MZUSP/USNM, 13/12/1979.

\section{Caracteres sexuais secundários}




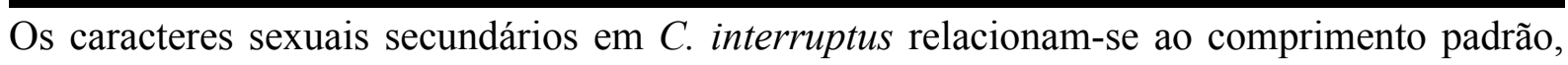
formato de nadadeiras, presença de processos ósseos, raios procurrentes ventrais e glândula branquial.

Comprimento padrão: fêmeas alcançam maiores valores de comprimento padrão em relção aos machos. MZUSP 18894, 43 machos (25.7-34.4 mm CP) e 36 fêmeas (26.8-39.9 mm CP).

Formato de nadadeiras: machos diferem de fêmeas pelo formato do perfil da margem distal da nadadeira anal.

Perfil da margem distal da nadadeira anal de machos reta, divido à diminuição gradual de tamanho do segundo raio ramificado (raio mais longo) ao último raio ramificado. Perfil da margem distal da nadadeira anal de fêmeas com um lobo anterior convexo conspícuo. Lobo anterior formado pelo aumento gradual de tamanho do último raio simples ao segundo raio ramificado (raio mais longo) e diminuição deste ao quinto raio ramificado; perfil reto do sexto ao último raio ramificado devido à diminuição gradual de tamanho em direção anteroposterior.

Processos ósseos: presentes nas nadadeiras anal e pélvica de machos e fêmeas. Sendo assim, a presença de processos ósseos nas nadadeiras não é dimórfica, mas sim sua distribuição e desenvolvimento.

Nadadeira anal com até dois (geralmente um) segmentos de hemitriquium do último raio simples ao décimo primeiro raio ramificado, distribuindo-se em $58 \%$ dos raios ramificados (até 19 raios ramificados). Raio simples com processos ósseos do terceiro ao nono segmento, oitavo segmento proximal à extremidade distal do raio. Raios ramificados com processos ósseos presentes tanto em segmentos proximais quanto em segmentos distais à primeira bifurcação. Proximalmente à primeira bifurcação os processos ósseos estão presentes em até cinco segmentos, incluindo o segmento mais proximal, mais longo. Distalmente à primeira 
$\overline{\text { bifurcação, os processos ósseos estão presentes e restritos a até sete segmentos do ramo }}$ posterior, imediatamente distais à bifurcação. Processos ósseos simétricos bilateralmente. Processos ósseos com inserção ovalada proximodistalmente. O maior comprimento de sua inserção ocupa 38\% do comprimento proximodistal do segmento no qual está inserido. Em todos os segmentos, os processos ósseos estão inseridos na face lateroposterior em relação à nadadeira. Os processos ósseos desenvolvem-se perpendicularmente à sua inserção no segmento no qual estão inseridos. No um quarto (1/4) proximal de seu comprimento total, os processos ósseos apresentam uma curvatura de aproximadamente $50^{\circ}$ em relação ao eixo proximodistal do segmento no qual estão inseridos e desenvolvem-se em direção proximal em relação ao eixo proximodistal do segmento no qual estão inseridos. Em secção transversal, os processos ósseos variam de ovalados proximodistalmente a cilíndrico ao longo de seu comprimento total, afilando-se gradualmente e terminando em uma extremidade pontiaguda/arredondado. $\mathrm{O}$ diâmetro de sua extremidade distal equivale a $12 \%$ do maior comprimento de sua inserção no segmento no qual está inserido. Em seu estado máximo de desenvolvimento, o seu comprimento total não alcança o comprimento proximodistal do segmento no qual está inserido. O comprimento do maior processo ósseo equivale a $68 \%$ do comprimento proximodistal do segmento no qual está inserido. $\mathrm{Na}$ nadadeira anal os processos ósseos aumentam e diminuem gradualmente de tamanho em direção anteroposterior; primeiro e segundo raio ramificado com o maior número de segmentos com processos ósseos; sexto e sétimo raio ramificado com os maiores processos ósseos. Nos raios os processos ósseos aumentam e diminuem de tamanho em direção proximodistal; o maior processo ósseos está no terceiro segmento distal à primeira bifurcação, na metade/metade dsital da série de processos ósseos. 
$\overline{\text { Nadadeira pélvica com processos ósseos presentes e restritos a segmentos do hemitricuium }}$ ventral. Nadadeira pélvica com até dois (geralmente dois) processos ósseos por segmento de hemitriquium ventral do raio simples ao sexto raio ramificado, disrtribuindo-se em $100 \%$ dos raios ramificados (seis raios ramificados). Raio simples com processos ósseos presentes do segmento mais proximal (mais longo) ao oitavo segmento, décimo primeiro segmento proximal à extremidade distal do raio. Raios ramificados com processos ósseos presentes tanto em segmentos proximais quanto em segmentos distais à primeira bifurcação. Processos ósseos presentes também em segmentos distais à segunda bifurcação dos ramos medial e lateral da primeira bifurcação. Proximalmente à primeira bifurcação, os processos estão presentes em todos os segmentos, inclusive o mais proximal (mais longo). Segmento mais proximal com até nove processos ósseos ao longo de todo seu comprimento proximodistal. Distalmente à primeira bifurcação, os processos ósseos estão presentes em todos os segmentos dos ramos medial e lateral. Distalmente à segunda bifurcação dos ramos medial e lateral da primeira bifurcação do primeiro raio ramificado, os processos ósseos estão presentes em todos os segmentos dos ramos medial e lateral. Processos ósseos com inserção arredondada. O diâmetro de sua inserção ocupa $37 \%$ do comprimento proximodistal do segmento no qual está inserido. Em todos os segmentos proximais à primeira bifurcação, os processos ósseos estão inseridos tanto na face ventrolateral quanto na face ventromedial. Inserção dos processos ósseos dos segmentos proximais à primeira bifurcação inseridos na face ventromedial migrando da face ventromedial para a face ventrolateral em direção proximodistal. Nos segmentos do ramo medial da primeira bifurcação com processos ósseos inseridos na face ventromedial, com exceção de até quatro segmentos imediatamente proximais à segunda bifurcação deste ramo, no qual os processos ósseos estão inseridos tanto na face ventromedial quanto na face ventrolateral. Nos segmentos do ramo lateral da primeira 
$\overline{\text { bifurcação com processos ósseos inseridos na face ventrolateral, com exceção de cinco }}$ segmentos imediatamente proximais à segunda bifurcação deste ramo, no qual os processos ósseos estão inseridos tanto na face ventrolateral quanto na face ventromedial. Nos segmentos do ramo medial da segunda bifurcação dos ramos medial e lateral da primeira bifurcação com processos ósseos inseridos na face ventromedial. Nos segmentos do ramo lateral da segunda bifurcação dos ramos medial e lateral da primeira bifurcação com processos ósseos inseridos na face ventrolateral, com exceção dos dois segmentos mais distais do ramo lateral, no qual os processos ósseos estão inseridos tanto na face ventro lateral quanto na face ventromedial. Os processos ósseos desenvolvem-se perpendicularmente à sua inserção no segmento no qual estão inseridos. No um quarto (1/5) proximal de seu comprimento total, os processos ósseos apresentam uma curvatura de $45^{\circ}$ em relaçãoao eixo proximodistal do segmentoe no qual estão inseridos e desenvolvem-se em direção proximal em relação ao segmento no qual estão inseridos. Em secção transversal, o processos ósseos são cilíndricos ao longo de seu comprimento total, afilando-se gradualmente e terminando em uma extremidade pontiaguda. O diâmetro de sua extremidade distal equivale a $21 \%$ do maior comprimento de sua inserção no segmento no qual está inserido. Em seu estado máximo de desenvolvimento, o seu comprimento total não alcança o comprimento proximodistal do segmento no qual está inserido. O comprimento do maior processo ósseo equivale a $67 \%$ do comprimento proximodistal do segmento no qual stá inserido. Na nadadeira pélvica os processos ósseos aumentam e diminuem gradualmente de tamanho em direção lateromedial; terceiro raio ramificado com maior número de segmentos com processos ósseos e processos ósseos maiores. Nos raios os processos ósseos aumentam e diminuem de tamanho em direção proximodistal; o maior processo ósseo está no segmento imediatamente proximal ao à primeira bifurcação, na metade/metade proximal da série de processos ósseos. 
Glândula branquial: presente em machos maduros.

Glândula branquial formada pela fusão do primeiro ao sexto filamente branquial do ceratobranquial do primeiro arco branquial. Glândula branquial disrtribuindo-se em $26 \%$ dos filamentos branquiais do ceratobranquial do primeiro arco branquial. Glândula branquial disrtribuindo-se em 19\% do comprimento do ceratobranquial. Células colunares não visíveis lateralmente. Abertura da glândula branquial visível lateralmente, nos $75 \%$ distal do filamento branquial.

\section{Compsura heterura Eigenmann 1915}

Figs. 106 a 110

Localidade tipo: Brasil, Rio Itapicurú no qualimadas.

Material examinado: MZUSP 54621, 91, Brasil, Bahia/Minas Gerais, Urandi, Rio Verde Pequeno, na estrada de Urandi para Espinosa, R. E. Reis et al., 19/07/1993.

\section{Caracteres sexuais secundários}

Os caracteres sexuais secundários em $C$. heterura relacionam-se ao comprimento padrão, formato de nadadeiras, presença de processos ósseos, glândula branquial e órgão caudal.

Comprimento padrão: Fêmeas alcançam maiores valores de comprimento padrão em relação aos machos. MZUSP 54627, 31 machos (23.9-26.7 mm CP) e 60 Fêmeas (20.9-28.7 $\mathrm{mm} \mathrm{CP})$.

Formato de nadadeiras: Machos diferem de fêmeas pelo formato do perfil da margem distal da nadadeira anal e formato da nadadeira pélvica.

Perfil da Margem distal da nadadeira anal de machos quase reta, com lobo anterior discreto, ligeiramente convexo. Lobo anterior formado pelo aumento gradual do último raio simples ao 
segundo raio ramificado (raio mais longo) e diminuição gradual deste ao quinto raio ramificado; perfil reto do sexto ao último raio ramificado do sexto ao último raio ramificado devido à diminuição gradual de tamanho em direção anteroposterior. Perfil da margem distal das nadadeira anal de fêmeas com lobo anterior côncavo conspícuo. Lobo anterior formado pelo aumento gradual de tamanho do último raio simples ao segundo raio ramificado (raio mais longo) e diminuição acentuada de tamanho deste ao quinto raio ramificado; perfil reto do sexto ao último raio ramificado devido à diminuição gradual de tamanho em direção anteroposterior.

Extremidade distal do primeiro raio ramificado (raio mais longo) da nadadeira pélvica de machos ultrapassa a origem da nadadeira anal, nunca ultrapassando o último raio simples. Nadadeira pélvica sobrepõe o orifício urogenital em vista ventral. Extremidade distal do primeiro raio ramificado (raio mais longo) da nadadeira pélvica de fêmeas não alcança a origem da nadadeira anal. Nadadeira pélvica não sobrepõe orifício urogenital em vista ventral. Processos ósseos: presentes nas nadadeiras anal e pélvica de machos.

Nadadeira anal com até dois processos ósseos por segmento de hemitriquium do último raio simples ao décimo quinto raio ramificado, disrtribuindo-se em $83 \%$ dos raios ramificados (até 18 raios ramificados). Último raio simples com processos ósseos do segundo segmento mais proximal até o quinto segmento proximal à extremidade distal do raio. Processos ósseos presentes tanto em segmentos proximais quanto em segmentos distais à primeira bifurcação. Processos ósseos presentes também em segmentos distais à segunda bifurcação do ramo posterior da primeira bifurcação. Proximalmente à primeira bifurcação, os processos ósseos estão presentes em até quatro segmento. Distalmente à primeira bifurcação e proximalmente às segunda ramificações, os processos ósseos estão presentes e restritos a todos os segmentos do ramo posterior. Distalmente à segunda bifurcação do ramo posterior da primeira 
$\overline{\text { bifurcação, os processos ósseos estão presentes e restritos a até um segmento do ramo }}$ posterior, imediatamente distal à bifurcação. Processos ósseos simétricos bilateralmente. Processos ósseos com inserção ovalada proximodistalmente. O maior comprimento de sua inserção oucpa $43 \%$ do comprimento proximodistal do segmento no qual está inserido. Em todos os segmentos, os processos ósseos estão inseridos na face lateroposterior em relação à nadadeira. Os processos ósseos desenvolvem-se perpendicularmente à sua inerção no segmento no qual estão inseridos. No quarto (1/4) proximal de seu comprimento total, os processos ósseos apresentam uma curvatura de $70^{\circ}$ em relação ao eixo proximodistal do segmento no qual estão inseridos e desenvolvem-se em direção proximomedial em relação ao eixo proximodistal do segmento no qual estão inseridos. Em secção transversal, os processos ósseos variam de ovalados proximodistalmente a cilíndricos ao longo de seu comprimento total, afilando-se gradualmente e terminando em uma extremidade distal arredondada/pontiaguda. O diâmetro de sua extremidade distal equivale a $17 \%$ do maior comprimento de sua inserção no segmento no qual está inserido. Em seu estado máximo de desenvolvimento, o seu comprimento total não alcança o comprimento proximodistal do segmento no qual está inserido. O comprimento do maior processo ósseo equivale $92 \%$ do comprimento proximodistal do segmento no qual está inserido. $\mathrm{Na}$ nadadeira anal os processos aumentam e diminuem gradualmente de tamanho em direção anteroposterior; primeiro e segundo raio ramificado com o maior número de segmentos com processos ósseos; décimo primeiro, décimo segundo ou décimo terceiro raio ramificado com os maiores processos ósseos. No raio os processos ósseos aumentam e diminuem de tamanho em direção proximodistal; o maior processo ósseos está no segundo segmento distal à primeira bifurcação, na metade/metade dsital da série de processos ósseos. 
$\overline{\text { Nadadeira pélvica com processos ósseos presentes e restritos a segmentos da hemiriquia }}$ ventral. Nadadeira pélvica com até três processos ósseos por segmento no hemitriquium ventral do raio simples ao sexto raio ramificado, oupando $100 \%$ dos raios ramificados (6 raios ramificados). Raio simples com processos ósseos do segundo segmento mais proximal até o sétimo segmento, sétimo segmento proximal à extremidade distal do raio. Raios ramificados com processos ósseos presentes tanto em segmentos proximais quanto em segmentos distais à primeira bifurcação. Proximalmente à primeira bifurcação, os processos estão presentes em todos os segmentos, inclusive o mais proximal (mais longo) em todos os raios. Segmento mais proximal com até seis processos ósseos em sua porção distal. Processos ósseos presentes também em segmentos distais à segunda bifurcação dos ramos medial e lateral da primeira bifurcação. Distalmente à primeira bifurcação e proximalmente às segundas ramificações, os processos ósseos estão presentes em todos os segmentos do ramo medial e em até cinco segmentos do ramo lateral, imediatamente proximais à segunda bifurcação. Distalmente à segunda bifurcação do ramo medial da primeira bifurcação, os processos ósseos estão presentes em todos os segmentos dos ramos medial e lateral. Distalmente à segunda bifurcação do ramo lateral da primeira ramidiação, os processos ósseos estão presentes em todos os segmentos do ramo medial e em até cinco segmentos do ramo lateral, a partir do segundo segmento distal à bifurcação. Processos ósseos com inserção arredondada. O diâmetro de sua inserção quivale $10 \%$ do comprimento proximodistal do segmento no qual está inserido. Em todos os segmentos, os processos estão inseridos na face medioventral, com exceção dos segmentos do ramo lateral da segunda bifurcação do ramo medial da primeira bifurcação, no qual os processos ósseos estão inseridos na face ventrolateral e de até três segmentos do ramo medial da primeira bifurcação imediatamente proximais à segunda bifurcação deste ramo e de até cinco segmentos dos ramo medial e lateral da segunda 
$\overline{\text { bifurcação do ramo medial da primeira bifurcação no qual os processos óssoes estão presentes }}$ tanto na face ventromeidal quanto na face ventrolateral. Os processos ósseos desenvolvem-se perpendicularmente ao segmento no qual estão inseridos. Os rocessos ósseos são geralmente retos, podendo sofrer, ao longo de seu comprimento total, uma curvatura de $35^{\circ}$ e se desenvolver em direção proximal (ligeiramente medial) em relação ao eixo proximodistal do segmento no qual estão inseridos. Em secção transversal, os processos ósseos são cilíndricos ao longo de seu comprimento total, afilando-se gradualmente e terminando em uma extremidade redonda/pontiaguda. Diâmetro de sua extremidade distal, 36\% do diâmetro de sua inserção no segmento no qual está inserido. Em seu estado máximo de desenvolvimento, o seu comprimento total não alcança o comprimento proximodistal do segmento no qual está inserido. Comprimento do maior processo ósseo, $26 \%$ do comprimento proximodistal do segmento no qual está inserido. Na nadadeira pélvica, os processos ósseos apresentem tamnhos semelhantes em todos os raios; terceiro e quarto raio ramificado com maior número de segmentos com processos ósseos. Nos raios, os processos ósseos aumentam e diminuem de tamanho em direção proximodistal; o maior processo ósseos está presente no primeiro segmento proximal à segunda rmaificação, na metade, metade distal da série de processos ósseos.

Glândula branquial: presente em machos maduros.

Glandula branquial formada pela fusão do primeiro ao décimo terceiro filamento branquial anterior do ceratobranquial do primeiro arco branquial de machos maduros. Glândula branquial disrtribuindo-se em $76 \%$ do total de filamentos branquiais do certaobranquial do primeiro arco branquial. Glândula branquial disrtribuindo-se em $74 \%$ do comprimento do ceratobranquial. Células colunares visíveis ao longo da porção lateral dos filamentos mofidicados e na porção proximal entre os filamentos modificados. 
Órgão Caudal: Presente em ambos os sexos, porém mais desenvolvido em machos (Jerep, 2011).

O órgão caudal restrito ao lobo ventral da nadadeira caudal. É formado pela modificação composta das escams posteriores da série de escamas da linha mediana e das três séries de escamas ventrais a esta, mais uma série de escamas pequenas mais ventral, que se inicia no final do pedúnculo caudal. A abertura é composta por duas escamas modificadas e é direcionada posteriormente (ligeiramente ventral) abrangendo o raio simples ventral da nadadeira caudal e do décimo terceiro ao décimo sétimo raio ramificado (no lobo ventral). $\mathrm{O}$ complexo do órgão caudal se estende horizontalmente da porção posterior do pedúnculo caudal até a porção mediana do nono e décimo raio ramificado e verticalmente da face dorsal do oitavo raio ramificado até a extremidade do do último raio procurrente ventral (contado posteroanteriormente). Todas as escamas das séries de escamas envolvidas no complexo do órgão caudal se modificam anteroposterioremente a partir do final do pedúnculo caudal, de uma escama cicloide normal, igual à aquelas escamas de outros locais do corpo, à escama mais posterior de cada série, que é sempre a mais modificada. A abertura do órgão caudal é formada por duas escamas. Dorsalmente, a abertura do órgão caudal é limitada pela escama mais posterior (mais modificada) da terceira série de escamas abaixo da série de escamas da linha mediana. Ventralmente a abertura do órgão caudal é limitada pela escama mais posterior (mais modificada) da quarta série de escamas abaixo da série de escamas da linha madiana, aquela mais ventral, que se inicia no final do pedúnculo caudal. Dorsalmente à escama que dorsal que compõe a abertura do órgão caudal estão duas escamas também modificadas, uma se trata da escama mais posterior da série de escamas da linha mediana e a outra, posicionada imediatamente posterioremente a esta se trata da escama mais posterior da primeira série de escamas abaixo da série de escamas da linha mediana. As escamas modificadas posicionadas 
$\overline{\text { dorsalmente à abertura do órgão caudal se mantem reta em direção posterior com limite dorsal }}$ na face dorsal do oitavo raio ramificado. A observação dos circulii e radii destas escamas indica o desenvolvimento posterior da metade dorsal das escamas enquanto que a metade ventral da escama aumenta muito pouco tanto posteriormente quanto ventralmente, os radii estão direcionados posteroventralmente em direção à abertura do órgão caudal. A observaçõ dos circulii e radii da escama que limita ventralmente a abertura do órgão caudal indica o desenvolvimento posterior da metade ventral da escama enquanto que a metade dorsal aumenta muito pouco tanto posteriormente quanto dorsalmente, os radii estão direcionados posterodorsalmente em direção à abertura do órgão caudal.

\section{Heterocheirodon yatai (Casciotta, Miquelarena \& Protogino 1992)}

Figs. 111 a 114

Localidade tipo: Arroyo El Palmar, Paraje La Glorieta, Parque Nacional El Palmar, Entre Rios, Argentina.

Material examinado: MZUSP 59971, 137, Brasil, Rio Grande do Sul, Alegrete, Arroio Garupá, entre os municípios de Alegretee Quaraí, C. A. S. Lucena \& P. Avila, 11/12/1988.

\section{Caracteres sexuais secundários}

Os caracteres sexuais secundários em $H$. yatai relacionam-se ao comprimento padrão, presença de processos ósseos e glândula branquial.

Comprimento padrão: fêmeas alcançam maiores valores de comprimento padrão em relação aos machos. MZUSP 59971, 14 machos (25-30.0 mm CP) e 20 fêmeas (22.5-31.3 mm CP). Processos ósseos: presentes nas nadadeiras anal e pélvica de machos. 
Nadadeira anal com até três (geralmente dois) processos ósseos por segmento de hemitriquium do último raio simples ao nono raio ramificado, disrtribuindo-se em $43 \%$ dos raios ramificados (até 21 raios ramificados). Último raio simples com processos ósseos do segundo ao quarto segmento, sétimo segmentos proximal à extremidade distal do raio. Processos ósseos presentes tanto em segmentos proximais quanto em segmentos distais à primeira bifurcação. Processos ósseos presentes também em segmentos distais à segunda bifurcação do ramo anterior da primeira bifurcação. Proximalmente à primeira bifurcação, os processos ósseos estão presentes em até três segmentos. Linha anteroposterior na porção mais proximal de cada raio com processos ósseos, paralela à base da nadadeira anal. Distalmente à primeira bifurcação e proximalmente às segunda bifurcação, os processos ósseos estão presentes em até cinco segmentos do ramo posterior e em até dois segmentos do ramo anterior, imediatamente proximais à segunda bifurcação. Distalmente à segunda bifurcação do ramo anteiror da primeira bifurcação, os processos ósseos estão presentes e restritos a até dois segmentos do ramo posterior, imediatamente distais à ramifiação. Processos ósseos assimétricos bilateralmente. Processos ósseos com inserção ovalada proximodistalmente. Maior comprimento de sua inserção, $30 \%$ do comprimento proximodistal do segmento no qual está inserido. Em todos os segmentos, os processos ósseos estão inseridos na face posterior, exceto três segmentos mais distais do ramo posterior da primeira bifurcação, no qual os processos ósseos estão inseridos tanto na face posterior quanto na face anterior. Os processos ósseos desenvolvem-se perpendicularmente e ligeiramente lateralmente ao eixo proximodistal do segmento no qual estão inseridos. Ao longo de seu comprimento total, os processos ósseos sofrem uma curvatura de $30^{\circ}$ e desenvolvem-se em direção proximal (ligeiramente lateral) em relação ao segmento no qual estão inseridos. Em secção transversal, os processos ósseos variam de ovalados proximodistalmente a cilíndricos ao longo de seu 
comprimento total, afilando-se gradualmente e terminando em uma extremidade posntiaguda/arredondada. Também em direção proximodistal, os processos ósseos se afilam gradualmente e terminando em uma extremidade pontiaguda. Diâmetro de sua extremidade distal, $17 \%$ do maior comprimento de sua inserção no segmento no qual está inserido. Em seu estado máximo de desenvolvimento, o seu comprimento total não alcança o comprimento proximodistal do segmento no qual está inserido. Comprimento do maior processo ósseo, $25 \%$ do comprimento proximodistal do segmento no qual está inserido. Na nadadeira anal os processos aumentam e diminuem gradualmente de tamanho em direção anteroposterior; segundo e terceiro raio ramificados com maior número de segmentos com processos ósseos e maiores processos ósseos. No raio os processos ósseos aumentam e diminuem de tamanho em direção proximodistal; o maior processo ósseos está no segundo segmento distal à primeira bifurcaçãoo, na metade proximal da série de processos ósseos.

Nadadeira pélvica com processos ósseos presentes e restritos a segmentos do hemitricuium ventral. Nadadeira pélvica com até dois (geralmente dois) processos ósseos por segmento do primeiro ao sétimo raio ramificado, disrtribuindo-se em $100 \%$ dos raios ramificados (7 raios ramificados). Segmento mais proximal com até dez processos ósseos em seus dois terços (2/3) distais. Raios ramificados com processos ósseos presentes tanto em segmentos proximais em segmentos quanto distais à primeira bifurcação. Proximalmente à primeira bifurcação, os processos estão presentes em todos os segmentos, inclusive o mais proximal (mais longo). Processos ósseos presentes também em segmentos distais à segunda bifurcação dos ramos medial e lateral da primeira bifurcação. Distalmente à primeira bifurcação e proximalmente às segundas ramificações, os processos ósseos estão presentes em todos os segmentos do ramo medial e em até quatro segmentos do ramo lateral, imediatamente proximais à segunda bifurcação deste ramo. Distalmente à segunda bifurcação do ramo medial da primeira 
$\overline{\text { bifurcação, os processos ósseos estão presentes em todos os segmentos do ramo medial e em }}$ até um segmento do ramo lateral, imediatamente distal à bifurcação. Distalmente à segunda bifurcação do ramo lateral da primeira bifurcação, os processos ósseos estão presentes e restritos a até três segmentos do ramo medial, imediatamente distais à bifurcação. Processos ósseos com inserção ovalada proximodistalmente. Maior comprimento de sua inserção, $29 \%$ do comprimento proximodistal do segmento no qual está inserido. Em todos os segmentos, os processos ósseos estão inseridos na face ventromedial, com exceção do semegmento imediatamente proximal à segunda bifurcação do ramo medial da primeira bifurcação, no qual os processos ósseos estão inseridos tanto na face ventromedial quanto na face ventrolateral e dos segmentos do ramo lateral da segunda bifurcação do ramo medial da primeira bifurcação, no qual os processos estão inseridos a face ventrolateral. Processos ósseos inseridos nos segmentos do ramo medial da primeira bifurcação e no ramo posterior da segunda bifurcação deste ramo migrando da face ventromedial à face ventrolateral em direção distoproximal. Os processos ósseos desenvolvem-se perpendicularmente à sua inserção no segmento no qual estão inseridos. Ao longo de seu comprimento proximodistal, os processos ósseos sofrem uma curvatura de $50^{\circ}$ e desenvolvem-se em direção proximal em relação ao eixo proximodistal do segmento no qual estão inseridos. Em secção transversal, os processos ósseos variam de ovalados proximodistalmente a cilíndricos ao longo do seu comprimento total, afilando-se gradualmente ate terminar em uma extremidade pontiaguda. Diâmetro de sua extremidade distal, $25 \%$ do maior comprimento de sua inserção no segmento no qual está inserido. Em seu estado máximo de desenvolvimento, o seu comprimento total não alcança o comprimento proximodistal do segmento no qual está inserido. Comprimento do maior processo ósseo, $45 \%$ do comprimento proximodistal do segmento no qual está inserido. Na nadadeira pélvica o processos ósseos aumentam e diminuem de tamanho em direção lateromedial; segundo e 
terceiro raio ramificado com o maior número de segmentos com processos ósseos e maiores processos ósseos. Nos raios os processos ósseos aumentam e diminuem de tamanho em direção proximodistal; o maior processo ósseos está no segundo segmento distal à primeira bifurcação, na metade distal da série de processos ósseos.

Glândula branquial: presente em machos

Glândula branquial formada pela fusão do primeiro ao oitavo filamento branquial do ceratobranquial do primeira arco branquial. Glândula branquial distribuindo-se em $35 \%$ dos filamentos branquiais do ceratobranquial. Glândula branquial disrtribuindo-se em $27 \%$ do comprimento do ceratobanquial. Células colunares visíveis ao longo da porção lateral dos fialamentes modificados. Abertura da glândula branquial visível lateralmente, nos $70 \%$ distais do filamento branquial.

Odontostilbe pequira (Steindachner, 1882):

Figs. 115 a 120

Localidade tipo: Brasil, Mato Grosso, Cuiabá.

Material examinado: MZUSP 089963, 283, Brasil, Mato Grosso, Cáceres, rio Sepotuba (trecho médio), O. Froelich et al.

\section{Caracteres sexuais secundários:}

Os caracteres sexuai ssecundários em $O$. Pequira relacionam-se ao comprimento padrão, formato da nadadeira de nadadeiras, presença de processos ósseos e glândula branquial.

Comprimento padrão: Machos alcançam maiores valores de comprimento padrão quando comparado com as fêmeas. MZUSP 089963, 32 machos (27.8-30.8 mm CP) e 31 fêmeas $(27,1-29,6 \mathrm{~mm} \mathrm{CP})$. 
Formato de nadadeiras: machos diferem de fêmeas pelo formato do perfil da margem distal da nadadeira anal e formato das nadadeira pélvica e dorsa.

Perfil da margem distal da nadadeira anal de machos com lobo anterior ligeiramente convexo. Lobo anterior formado pelo aumento gradual de tamanho do último raio simples ao segundo raio ramificado (raio mais longo) e diminuição gradual deste ao quinto raio ramificado; perfil reto deste ponto ao último raio ramificado, devido à diminuição gradual de tamanho em direção anteroposterior. Perfil da margem distal de fêmeas com lobo anterior côncavo conspícuo Lobo anterior formado pelo aumento graudal do último raio simples ao segundo raio ramificado (raio mais longo) e diminuição acentuada deste ao quinto raio ramificado; perfil reto deste ponto ao último raio ramificado, devido à diminuição gradual de tamanho em direção anteroposterior.

Extremidade distal do raio simples (raio mais longo) da nadadeira pélvica de machos alcança o quinto raio ramificado da nadadeira anal. Raio simples da nadadeira pélvica de machos filamentoso. Extremidade distal do primeiro raio ramificado (raio mais longo) da nadadeira pélvica de fêmeas não alcança a origem da nadadeira anal. Raio simples da nadadeira pélvica de fêmeas não filamentoso.

Extremidade do raio simples (raio mais longo) da nadadeira dorsal de machos alcança a origem da nadadeira adiposa quando adpresso. Raio simples da nadadeira dorsal de machos filamentoso. Extremidade distal do primeiro raio ramificado (raio mais longo) da nadadeira dorsal de fêmeas não alcança a origem da nadadeira adiposa quando adpressa. Raio simples da nadadeira dorsal de fêmeas não filamentoso.

Processos ósseos: presente nas nadadeiras anal e pélvica de machos.

Nadadeira anal com ate dois (geralmente um) processos ósseos por segmento de hemitriquium do último raio simples ao sétimo raio ramificado, disrtribuindo-se em $33 \%$ dos 
$\overline{\text { raios rmaificados (até } 21 \text { raios ramificados). Raio simples com processos ósseos do segundo }}$ ao nono segmento, quinto segmento proximal à extremidade distal do raio. Raios ramificados com processos ósseos tanto em segmentos proximais quanto em segmentos distais à primeira bifurcação Processos ósseos presentes também em segmentos distais à segunda bifurcação do ramo posterior da primeira bifurcação. Proximalmente à primeira bifurcação os processos ósseos estão presentes em até três segmentos. Linha anteroposterior na porção mais proximal de cada raio com processos ósseos, paralela à base da nadadeira anal. Distalmente à primeira bifurcaçãoo, os processos ósseos estão presentes e restritos a todos os segmentos do ramo posterior. Distalmente à segunda bifurcação do ramo posterior da primeira bifurcação, os processos ósseos estão presentes e restritos a até dois segmentos do ramo posterior, imediatamente distais à bifurcação. Processos ósseos simétricos bilateralmente. Processos ósseos com inserção ovalada proximodistalmente. Maior comprimento de sua inserção, $23 \%$ do comprimento proximodistal do segmento no qual está isnerido. Em todos os segmentos, os processos ósseos estão inseridos na face lateroposterior em relação à nadadeira. Os processos ósseos desenvolvem-se perpendicularmente à sua inserção no segmento no qual estão inseridos. Ao longo de seu comprimento total, os processos ósseos sofrem uma curvatura de $40^{\circ}$ e desenvolvem-se em direção proximal em relação ao segmento no qual estão inseridos. Em secção transversal, os processos ósseos variam de ovalados proximodistalmente a cilíndricos ao longo de seu comprimento total, afilando-se gradualmente e terminando em uma extremidade ponstiaguda/arredondada. Diâmetro de sua extremidade distal, $17 \%$ do maior comprimento de sua inserção no segmento no qual está inserido. Em seu estado máximo de desenvolvimento, o seu comprimento total não alcança o comprimento proximodistal do segmento no qual está inserido. Comprimento do maior processo ósseo, $37 \%$ do comprimento proximodistal do segmento no qual está inserido. Na nadadeira anal os 
$\overline{\text { processos ósseos aumentam e diminuem de tamanho em direção anteroposterior; segundo e }}$ terceiro raio ramificado com maior número de segmentos com processos ósseos e maiores processos ósseos. No raio, os processos ósseos aumentam e diminuem gradualmente de tamanho em direção proximodistal; o maior processo ósseos está no terceiro segmento distal à primeira bifurcação, na metade/metade distal do série de processos ósseos.

Nadadeira pélvica com processos ósseos presentes e restritos a segmentos do hemitricuium ventral. Nadadeira pélvica com até dois (geralmente um) processos ósseos por segmento de hemitriquium ventral do primeiro ao sétimo raio ramificado, disrtribuindo-se em $100 \%$ dos raios ramificados (7 raios ramificados). Raios ramificados com processos ósseos presentes tanto em segmentos proximais quanto em segmentos distais à primeira bifurcação. Proximalmente à primeira bifurcação, os processos estão presentes em todos os segmentos, inclusive o mais proximal, mais longo. Processos ósseos presentes também em segmentos distais à segunda bifurcação dos ramos medial e lateral da primeira bifurcação. Processos ósseos presentes também em segmentos distais à terceira bifurcação dos ramos medial e lateral do ramo lateral da primeira bifurcação e do ramo lateral da segunda bifurcação do ramo medial da primeira bifurcação. Distalmente à primeira bifurcação, os processos estão presentes em todos os segmentos do ramo medial e em até três segmentos do ramo lateral, imediatamente proximais à segunda bifurcação deste ramo. Distalmente à segunda bifurcação do ramo medial da primeira bifurcação, os processos ósseos estão presentes em todos os segmentos dos ramos medial e lateral. Distalmente à segunda bifurcação do ramo lateral da primeira bifurcação, os processos ósseos estão presentes em todos os segmentos do ramo medial e em até dois segmentos do ramo lateral, imediatamente proximais à terceira bifurcação deste ramo. Distalmente à terceira bifurcação do ramo lateral da segunda bifurcação do ramo medial da primeira bifurcação, os processos ósseos estão preentes em em 
$\overline{\text { todos os segmentos dos ramos lateral e medial. Distalmente à terceira bifurcação do ramo }}$ medial da segunda bifurcação do ramo lateral da primeira bifurcação, os processos ósseos estão presentes em todos os segmentos. Distalmente à terceira bifurcação do ramo lateral da segunda bifurcação do ramo lateral primeira bifurcação, os processos ósseos estão presentes e restritos a todos os segmentos do ramo medial. Processos ósseos com inserção arredondada. Diametro de sua inserção, $23 \%$ do comprimento proximodistal do segmento no qual está inserido. Em todos os segmentos, os processos ósseos estão inseridos na face medioventral em relação à nadadeira, com exceção dos segmentos do ramo lateral da segunda bifurcação do ramo medial da primeira bifurcação e do ramo lateral da terceira bifurcação do ramo lateral da segunda bifurcação do ramo medial da primeira bifurcação, no qual os processos ósseos estão inseridos na face ventrolateral e do segmento imediatamente proximal à terceira bifurcação do ramo lateral da segunda bifurcação do ramo medial da primeira bifurcação no qual os processos ósseos estão inserids tanto na face ventromedial quanto na face ventrolateral. Processos ósseos dos segmentos proximais à primeira rmaificação com inserção embora ainda na face ventromedial, migrando muito pouco da porção mais medial pra face mais ventral. Os processos ósseos desenvolvem-se perpendicularmente à sua inserção no segmento no qual estão inseridos. No seu um quarto (1/4) proximal de seu comprimento total, os processos ósseos sofrem uma curvatura de $65^{\circ}$ em direção proximal em relação ao segmento no qual estão inseridos. Em secção transversal, os processos ósseos são cilíndricos ao longo de seu comprimento total, afilando-se gradualmente e terminando em uma extremidade pontiaguda/arredondada. Diâmetro de sua extremidade distal, $22 \%$ do diâmetro de sua inserção no segmento no qual está inserido. Em seu estado máximo de desenvolvimento, seu comprimento total não alcança o comprimento proximodistal do segmento no qual está inserido. Comprimento do maior processo ósseo, $73 \%$ do comprimento proximodistal do 
$\overline{\text { segmento no qual está inserido. Na nadadeira pélvica, os processos ósseos aumentam e }}$ diminuem gradualmente de tamanho em direção lateromedial; terceiro e quarto raios ramificados com maior número de segmentos com processos ósseos e maiores processos ósseos. Nos raios os processos ósseos aumentam e diminuem de tamanho em direção proximodistal; o maior processo ósseo está no segmento imediatamente proximal à segunda rmaificação do ramo medial, na metade, metade distal da série de processos ósseos.

Glândula branquial: presente em machos maduros.

Glândula branquial formada pela fusão do primeiro ao oitavo filamento branquial anterior do ceratobranquial do primeiro arco branquial. Glândula branquial disrtribuindo-se em $38 \%$ do total de filamentos branquiais do primeiro arco branquial. Glândula branquial disrtribuindo-se em 35\% do comprimento do ceratobranquial. Células colunares visíveis na porção lateral dos filamentos braquiais modificados. Abertura da glândula branquial visível lateralmente, nos $77 \%$ do distais dos filamentos branquiais.

\section{Serrapinnus calliurus (Boulenger 1900)}

Figs. 121 a 125

Localidade tipo: Coradanzinho, Brasil; San Lonrenzo, província de Jujuy, Argentina. Material examinado: MZUSP 59831, 748, Brasil, Mato Grosso do Sul, Bonito, Córrego alagado na entrada da propriedade do "Projeto vivo" (próximo à barra do rio Formoso), bacia do rio rio Paraguay, $21^{\circ} 5^{`} 28^{\prime} \mathrm{S}, 56^{\circ} 14^{` 2} 28^{\prime} \mathrm{W}, \mathrm{O}$. Oyakawa et al., 05/09/1998.

\section{Caracterese sexuais secundários}




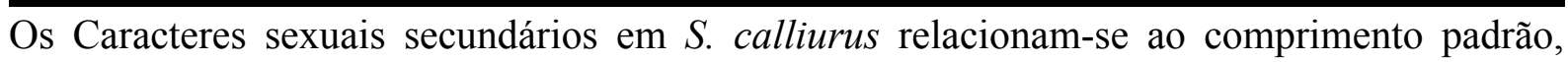
formato de nadadeiras, formato da base da nadadeira anal, formato dos raios procurrentes ventrais, presença de processos ósseos, eixo longitudinal do corpo e glândula branquial.

Comprimento padrão: fêmeas alcançam maiores valores de comprimento padrão em relação aos machos. MZUSP 59831, 18 machos (23.5-28.8 mm CP) e 23 fêmeas (22.3-30.2 mm CP)

Formato de nadadeiras: Machos diferem das fêmeas pelo formato do perfil da base da nadadeira anal, pelo perfil da margem distal da nadadeira anal, pelo formato dos segmentos de hemitriquium dos raios ramificados do lobo anterior da nadadeira anal e pelo formato da nadadeira pélvica.

Perfil da base da nadadeira anal de machos com sua porção anterior convexa (região que abrange os sete raios ramificados anteriores, raios que compoem o lobo anterior da nadadeira) e direcionada dorsoposteriormente, a partir deste ponto (a partir do oitavo raio ramificado) é reta, ligeiramente convexa, e com inclinação dorsoposterior menos acentuada. Base da nadadeira anal de fêmeas ligeiramente côncava ao longo de toda sua extensão, com inclinação dorsoposterior leve.

Perfil da margem distal da nadadeira anal de machos com um lobo anterior convexo. Lobo anterior convexo formado pelo aumento gradual de tamanho do último raio simples ao segundo raio ramificado (raio mais longo) e diminuição gradual deste ao sexto ou sétimo raio ramificado; perfil reto deste ponto ao último raio ramificado devido à diminuição gradual de tamanho em direção anteroposterior. Perfil da margem distal da nadadeira anal de fêmeas côncava, devido à diminuição acentuada em tamanho do segundo raio ramificado (raio mais longo) até o sexto ou sétimo raio ramificado; perfil reto deste até o último raio ramificado devido à diminuição gradual destes raios em direção anteroposterior. 
$\overline{\text { Segmentos de hemitriquium dos raios que compõem o lobo anterior da nadadeira anal de }}$ machos (do último raio simples ao sexto ou sétimo raio ramificado) distintamente expandidos anteroposteirormente, atribuindo aos segmentos (exceto o segmento mais proximal) um formato aquadradado com cantos bem definidos; pelo menos duas vezes mais largos que os raios ramificados que não compõem o lobo anterior da mesma nadadeira e que todos os raios da nadadeira anal das fêmeas. Terceiro e quarto raios ramificados mais robustos e expandidos anteroposteriormente que os demais. Segmentos de hemitriquium dos raios da nadadeira anal de fêmeas sem expansão anteroposterior, raios mais longos (proximodistalmente) que largos (anteroposteriormente)

Extremidade distal do raio simples (raio mais longo) da nadadeira pélvica de machos ultrapassa o orifício urogenital. Nadadeira pélvica sobrepõe o orfício urogenital em vista ventral. Extremidade distal do raio simples (raio mais longo) da nadadeira pélvica de fêmeas não ultrapassa o orifício urogenital. Nadadeira pélvica não sobrepõe o orifício urogenital em vista ventral.

Raios procurrentes ventrais: machos diferem de fêmeas pelo formato dos procurrentes ventrais.

Raios procurrentes ventrais de machos hipertrofiados, expandidos lateralmente e embora não fundidos, dispostos muito próximos anteroposteriormente. Extremidade distal dos procurrentes expostos, fora da pele e músculos. Raios procurrentes de fêmeas cilíndricos, visivelmente "afastados" um do outro e inclusos, não expostos.

Processos ósseos: presentes nas nadadeiras anal e pélvica de machos.

Nadadeira anal com até nove processos ósseos por segmento de hemitriquium do último raio simples ao oitvo raio ramificado, distribuindo-se em $36 \%$ dos ramificados (até 22 raios ramificados). Último raio simples com processos ósseos do segmento mais proximal ao nono 
segmento, oitavo segmento proximal à extremidade distal do raio. Processos ósseos presentes tanto em segmentos proximais quanto em segmentos distais à primeira bifurcação. Processos ósseos presentes também em segmentos distais à segunda bifurcação dos ramos anterior e posterior da primeira bifurcação. Proximalmente à primeira bifurcação, os processos ósseos estão presentes em até três segmentos, inclusive o mais proximal. Distalmente à primeira bifurcação e proximalmente às segunda ramificações, os processos ósseos estão presentes em todos os segmentos do ramo posterior e em até três segmentos do ramo anterior da primeira bifurcação, imediatamente proximais à segunda bifurcação deste ramo. Distalmente à segunda bifurcação do ramo posterior da primeira bifurcação, os processos ósseos estão presentes em até dois segmentos do ramo posterior e em até dois segmentos do ramo anterior, imediatamente distais à bifurcação. Distalmente à segunda bifurcação do ramo anterior da primeira bifurcação, os processos ósseos estão presentes e restritos a até dois segmentos do ramo posterior, imediatamente distais à bifurcação. Processos ósseos assimétricos bilateralmente. Processos ósseos com inserção arredondada. Diâmetro de sua inserção, 33\% do comprimento proximodistal do segmento no qual está inserido. Em todos os segmentos, os processos ósseos estão inseridos tanto na face posterior quanto na face lateroposterior formando as vezes duas séries não muito bem definidas de processos ósseos, com exceção de três segmentos do ramo posterior imediatamente proximais à segunda bifurcação, no qual os processos ósseos estão inseridos tanto na face lateroposterior quanto na face anterior/lateroanterior em relação à nadadeira e dos segmentos do ramo anterior da segunda bifurcação do ramo posterior da primeira bifurcação, no qual os processos ósseos estão inseridos na face anterio/lateroanterior. Os processos ósseos desenvolvem-se perpendicularmente à sua inserção no segmento no qual estão inseridos. Ao longo de seu comprimento total, os processos ósseos sofrem uma curvatura de $45^{\circ}$ e desenvolvem-se em 
$\overline{\text { direção proximal em relação ao eixo proximodistal do segmento no qual está inserido. Em }}$ secção transversal, os processos ósseos são cilíndricos, se afilando gradualmente e terminando em uma extremidade distal arredondada. Diâmetro de sua extremidade distal, 17\% do diâmetro de sua inserção no segmento no qual está inserido. Em seu estado máximo de desenvolvimento, o seu comprimento total não alcança o comprimento proximodistal do segmento no qual está inserido. Comprimento do maior processo ósseo $40 \%$ do comprimento proximodistal do segmento no qual está inserido. Na nadadeira anal os processos aumentam e diminuem em tamanho gradualmente de tamanho em direção anteroposterior; segundo e terceiro raio ramificado com maior número de segmentos e maiores processos ósseos. No raio os processos ósseos aumentam e diminuem gradualmente de tamanho em direção proximodistal; o maior processo ósseo está no segundo segmento proximal à segunda bifurcação, na metade distal da série de processos ósseos.

Nadadeira pélvica com processos ósseos presentes e restritos a segmentos do hemitricuium ventral. Nadadeira pélvica com até três processos ósseos por segmento no hemitriquium ventral do primeiro ao sétimo raio ramificado, disrtribuindo-se em $100 \%$ dos raios ramificados (7 raios ramificados). Raios ramificados com processos ósseos presentes tanto em segmentos proximais quanto em segmentos distais à primeira bifurcação. Proximalmente à primeira bifurcação, os processos estão presentes em todos os segmentos, inclusive o mais proximal, mais longo. Processos ósseos presentes também em segmentos distais à segunda bifurcação dos ramos medial e lateral da primeira bifurcação. Distalmente à primeira bifurcação do primeiro raio ramificado, os processos ósseos estão presentes em todos os segmentos dos ramos medial e lateral. Distalmente à segunda bifurcação do ramo medial da primeira bifurcação, os processos ósseos estão presentes em todos os segmentos dos ramos medial e lateral. Distalmente à segunda bifurcação do ramo lateral da primeira bifurcação, os 
$\overline{\text { processos ósseos estão presentes em todos os segmentos do ramo medial e em até três }}$ segmentos do ramo lateral, a partir do segundo segmento distal à bifurcação. Processos ósseos com inserção arredondada. Diametro de sua inserção, $23 \%$ do comprimento proximodistal do segmento no qual etá inserido. No segmento proximal à primeira bifurcação, os processos ósseos estão inseridos tanto na face ventromedial quando na face ventrolateral (segmentos da metade distal do segmento). Nos segmentos do ramo medial da primeira bifurcação, os processos ósseos estão inseridos na face ventromedial, com exceção de três segmentos imediatamente proximais à segunda bifurcação, no qual os processos ósseos estão inseridos tanto na face ventromedial quanto na face ventrolateral. No segmentos do ramo lateral da primeira bifurcação, os processos ósseos estão inseridos na face ventrolateral, com exceção de três segmentos imediatamente proximais à segunda bifurcação, no qual os processos ósseos estão inseridos tanto na face ventrolateral quanto na face ventromedial. Nos segmentos do ramo medial da segunda bifurcação do ramo medial da primeira bifurcação os processos ósseos estão inseridos na face ventromedial, com exceção de até três segmentos mais distais deste ramo, no qual os processos ósseos estão inseridos tanto na face ventromedial quanto na face ventrolateral. Nos segmentos do ramo lateral da segunda bifurcação do ramo medial da primeira bifurcação, os processos ósseos estão inseridos na face ventrolateral, com exceção de três segmentos mais distais deste ramo, no qual os processos osseos estão inseridos tanto na face ventromedial quanto na face ventrolateral. Nos segmentos do ramo medial da segnda bifurcação do ramo lateral da primeira bifurcação do ramo lateral da primeira bifurcação, os processos ósseos estão inseridos na face ventromedial, com exceção de dois segmentos a partir da segunda bifurcação, no qual os processos ósseos estão inseridos tanto na face ventromedial quanto na face ventrolateral. Nos segmentos do ramo lateral da segunda bifurcação do ramo lateral da primeira bifurcação, os processos ósseos estão inseridos na face 
ventromedial. Processos ósseos do segmento mais proximal do raio (o mais longo) com sua inserção migrando da face ventromedial pra face ventral/ventrolateral em sentindo distoproximal. Os processos ósseos desenvolvem-se perpendicularmente à sua inserção no segmento no qual está inserido. No um quarto (1/4) proximal de seu comprimento total, os processos ósseos sofrem uma curvatura de $50^{\circ}$ e desenvolvem-se em direção proximal (ligeiramente medial) em relação ao segmento no qual estão inseridos. Em secção transversal, os processos ósseos são cilíndricos ao longo de seu comprimento toral, afilando-se gradualmente e terminando em uma extremidade pontiaguda/redonda. Diâmetro de sua extremidade distal, $20 \%$ do diâmetro de sua inserção no segmento no qual está inserido. Em seu estado máximo de desenvolvimento, seu comprimento total não alcança o comprimento proximodistal do segmento no qual está inserido. Comprimento do maior processo ósseo, $50 \%$ do comprimento proximodistal do segmento no qual está inserido. Na nadadeira pélvica o processos ósseos apresentam tamanhos semelhantes do primeiro ao sexto raio ramificado, diminuindo no último raio; terceiro e quarto raios ramificados com maio rnúmero de segmentos com processos ósseos. Nos raios os processos ósseos aumentam e diminuem de tamanho em direção proximodistal; o maior processo ósseo está no segmento imediatamente distal à primeira bifurcação, na metade distal da série de processos ósseos.

Glândula branquial: presente em machos maduros.

Glândula branquial formada pela fusão do primeiro ao nono filamento branquial anterior do primeiro arco branquial de machos maduros. Glândula branquial disrtribuindo-se em $45 \%$ dos filamentos branquiais do ceratobranquial. Glândula branquial disrtribuindo-se em $48 \%$ do comprimento do ceratobranquial. Células colunares visíveis na porção lateral dos filamentos braquiais modificados. Abertura da glândula branquial visível lateralmente, nos $76 \%$ distais do comprimento proximodistal dos filamentos branquiais. 


\section{Spintherobolus papilliferus Eigenmann 1911}

Localidade tipo: Alto da Serra, bacia do rio Tietê, São Paulo, Brasil.

Material examinado: MZUSP 39080, 7, Brasil, São Paulo, Salesópolis, ribeirão Curiagno, afluente do rio Claro, estação biológica de Boracéia, bacia do rio Tietê, O. Froehlich, 11/09/1988; MZUSP 51021, 1, Brasil, São Paulo, rio Ipiranga, bacia do rio Tietê, $23^{\circ} 33^{\prime} 00^{\prime}$ 'S, 46³8’00”W, H. Luederwaldt, 01/1929; MZUSP 72837, 4, Brasil, São Paulo, Paranapiacaba, último ribeirão cruzando a estrada antes da cidade, bacia do rio Tietê, R. M. C. Castro, 20/03/1980.

\section{Caracteres sexuais secundários}

Os caracteres sexuais secundários em $S$. papiliferus relacionam-se ao comprimento padrão, formato de nadadeiras, presença de processos ósseos e formato de procurrentes ventrais.

Comprimento padrão: machos alcançam maiores valores de comprimento padrão em relação às fêmeas. MZUSP 39080, 3 machos (39.3-61.0 mm CP) e 2 fêmeas (35.5-38.3 mm CP); MZUSP 51021, 1 fêmea (60.5 mm CP); MZUSP 72837, 1 macho (57.7 mm CP) e 2 fêmeas (50.1-50.5 mm CP).

Formato de nadadeiras: Machos diferem de fêmeas pelo formato dos segmentos de hemitriquium da nadadeira anal e pelo formato da nadadeira pélvica.

Segmentos de hemitriquium da nadadeira anal de machos mais robustos, extremamente retangulares, devido a uma forte expansão anteroposterior. Segmentos de hemitriquium de fêmeas menos retangulares que os de machos, embora mais largos do que compridos (proximodistalmente). 
$\overline{\text { Extremidade distal do segundo raio ramificado (raio mais longo) da nadadeira pélvica de }}$ machos ultrapassam a origem da nadadeira anal, mas não o primeiro raio ramificado. Nadadeira pélvica de machos sobrepõe o orifício urogeital em vista ventral. Extremidade distal do segundo raio ramificado (raio mais longo) da nadadeira pélvica de fêmeas não alcança o orifício urogenital. Nadadeira pélvica não sobrepõe o orifício urogenital em vista ventral.

Raios procurrentes ventrais: machos diferem de fêmeas pelo formato dos raio sprocurrentes ventrais.

Raios procurrentes ventrais de machos com sua extremidade distal exposta, mesmo que um pouco; procurrentes estendidos anteroposteriormente, com sua porção proximal fundida em uma base que se estende ligeiramente lateralmente, aumentando de tamanho em direção anteroposterior e com a extremidade arredondada. Raios procurrentes de fêmeas cilíndricos e espaçados, inclusos no corpo.

Processos ósseos: presentes na nadadeira pélvica de machos maduros.

Nadadeira pélvica com processos ósseos presentes e restritos a segmentos do hemitricuium ventral. Nadadeira pélvica com até quatro processos ósseos por segmento no hemitriquium ventral do raio simples ao quinto raio ramificado, disrtribuindo-se em $67 \%$ dos raios ramificados (6 raios ramificados). Raio simples com processos ósseos do terceiro ao quinto segmento proximal à extremidade distal do raio. Raios ramificados com processos ósseos presentes tanto em segmentos proximais quanto em segmentos distais à primeira bifurcação. Proximalmente à primeira bifurcação, os processos estão presentes em todos os segmentos, inclusive o mais proximal, mais longo. Processos ósseos presentes também em segmentos distais à segunda bifurcação do ramo medial da primeira bifurcação. Distalmente à primeira bifurcação, os processos estão presentes e restritos a todos os segmentos do ramo medial. 
$\overline{\text { Distalmente à segunda bifurcação do ramo medial da primeira bifurcação, os processos ósseos }}$ estão presentes e restritos a até seis segmentos do ramo medial, imediatamente distais à bifurcação. Processos ósseos com inserção ovalada proximodistalmente. Em todos os segmentos, os processos ósseos estão inseridos na face medial/medioventral em relação à nadadeira. Inserção dos processos ósseos do segmento mais proximal do raio (o mais longo) migrando da face ventromedial pra face ventral/vetrolateral em sentindo distoproximal. Os processos ósseos desenvolvem-se "desorganizadamente" com tamanhos, direção e grau curvatura distintos em relação à sua inserção no segento no qual estão inseridos. Processos ósseos com forma irregular, geralmente cilíndricos e afilando-se gradualmente e terminando em uma extremidade arredondada. Em seu estado máximo de desenvolvimento, o seu comprimento total não alcança o comprimento proximodistal do segmento no qual está inserido. Na nadadeira pélvica o processos ósseos apresentam tamanhos semelhantes do primeiro ao quarto raio ramificado, diminuindo no último raio; segundo e terceiro raio ramificado com o maior número de segmentos com processos ósseos. Nos raios os processos ósseos aumentam e diminuem de tamanho em direção proximodistal; o maior processo ósseos está na porção distal do raio mais longo; na metade proximal da série de processos ósseos.

\section{HETEROCHARACINAE}

\section{Heterocharax virgulatus Toledo-Piza 2000}

Figs. 126 a 128

Localidade tipo: rio Negro, na confluência com o rio Urubaxi, $0^{\circ} 35 \mathrm{~S}, 64^{\circ} 45^{\prime} \mathrm{W}$, Amazonas, Brasil. 
Material examinado: MZUSP 95278, 16, Brasil, Amazonas, Manaus, Igarapé da margem esquerda do rio Cuieirasm cerca de $20 \mathrm{~km}$ da boca, bacia do rio Negro, $03^{\circ} 00^{\prime} 00^{\prime} \mathrm{S}$, 60¹1’00’W, Alpha Helix Exp. 27/01/1977.

\section{Caracteres sexuais secundários}

Os caracteres sexuais secundários em $H$. virgulatus relacionam-se ao comprimento padrão e presença de processos ósseos.

Comprimento padrão: fêmeas alcançam maiores valores de comprimento padrão em relação aos machos. MZUSP 95278, 8 machos (32.7-37.8 mm CP), e 8 fêmeas (35.9-43.0 mm CP).

Processos ósseos: presentes nas nadadeiras anal, pélvica e peitoral de machos.

Nadadera anal com até dois (geralmente um) processos ósseos por segmento de hemitriquium do último raio simples ao trigésimo terceiro raio ramificado, disrtribuindo-se em $100 \%$ dos raios ramificados (até 33 raios ramificado). Último raio simples com processos ósseos do segmento mais proximal ao décimo segmento, quarto segmento proximal à extremidade distal do raio. Raios ramificados com processos ósseos tanto em segmentos proximais quanto em segmentos distais à primeira bifurcação. Processos ósseos presentes também em segmentos distais à segunda bifurcação dos ramos anterior e posterior da primeira bifurcação. Processos ósseos presentes também em segmentos distais à terceira bifurcação do ramo anterior da segunda bifurcação do ramo anterior da primeira bifurcação. Proximalmente à primeira bifurcação, os processos ósseos estão presentes em todos os segmentos. Distalmente à primeira bifurcação, os processos ósseos estão presentes em todos os segmentos do ramo posterior e em até dois segmentos do ramo anterior, imediatamente proximais à segunda bifurcação. Distalmente à segunda bifurcação do ramo anterior da primeira bifurcação, os processos ósseos estão presentes e restritos a até seis segmentos do ramo posterior, imediatamente distais à bifurcação e em um segmento do ramo anterior. 
Distalmente à segunda bifurcação do ramo posterior da primeira bifurcação, os processos ósseos estão presentes em até quatro segmentos dos ramos anterior e posterior, imediatamente distais à bifurcação. Distalmente à terceira bifurcação do ramo anterior da segunda bifurcação do ramo anterior da primeira bifurcação, os processos ósseos estão presentes e restritos a até três segmentos do ramo posterior, a partir da segunda bifurcação distal à bifurcação. Processos ósseos assimétricos bilateralmente. Processos ósseos com inserção arredondada. $\mathrm{O}$ diâmetro de sua inserção ocupa $15 \%$ do comprimento proximodistal do segmento no qual está inserido. Em todos os segmentos os processos ósseos estão inseridos na face lateroposterior, com exceção dos segmentos do ramo anterior da segunda bifurcação do ramo posterior da primeira bifurcação, no qual os processos ósseos estão inseridos na face lateroanterior ou lateral. Os processos ósseos desenvolvem-se perpendicularmente à sua inserção no segmento no qual estão inseridos. Processos ósseos geralmente retos. Em secção transversal, os processos ósseos são cilíndricos ao longo de seu comprimento total, afilando-se muito pouco e terminando em uma extremidade arredondada. Diâmetro de sua extremidade distal, $20 \%$ do diâmetro de sua inserção no segmento no qual está inserido. Em seus estado máximo de desenvolvimento, o seu comprimento total não alcança o comprimento proximodistal do segmento no qual está inserido. O comprimento do maior processo ósseo equivale $15 \%$ do comprimento proximodistal do segmento no qual está inserido. Na nadadeira anal os processos ósseos aumentam e diminuem gradualmente de tamanho em direção anteroposterior; segundo e terceiro raio ramificado com maior número de segmentos com procesoss ósseos; quarto, quinto e sexto raio ramificado com maiores processos ósseos. No raio os processos ósseos aumentam e diminuem de tamanho em direção proximodistal; o maior processo ósseo está na metade proximal do raio. 
Nadadeira pélvica com processos ósseos presentes tanto em segmentos do hemitricuium ventral e quanto em segmentos do hemitricuium dorsal. Nadadeira pélvica com um processo ósseo por segmento de hemitriquium ventral do primeiro ao quarto raio ramificado, disrtribuindo-se em 57\% dos raios ramificados (7 raios ramificados). Raios ramificados com processos ósseos presentes e restritos a segmentos distais à primeira bifurcação. Processos ósseos presentes também em segmentos distais à segunda bifurcação dos ramos medial e lateral da primeira bifurcação. Distalmente à primeira bifurcação, os processos ósseos estão presentes em até dois segmentos do ramo medial, imediatamente proximais à segunda bifurcação deste ramo e em um segmento do ramo lateral, imediatamente proximal à segunda bifurcação deste ramo. Distalmente à segunda bifurcação do ramo medial da primeira bifurcação, os processos ósseos estão presentes e restritos a até três segmentos, imediatamente distais à bifurcação. Distalmente à segunda bifurcação do ramo lateral da primeira bifurcação, os processos ósseos estão presentes e restritos a um segmento do ramo lateral, imediatamente distal à bifurcação. Processos ósseos com inserção arredondada. O diâmtero de sua inserção ocupa $10 \%$ do comprimento proximodistal do segmento no qual está inserido. Em todos os segmentos, os processos ósseos estão inseridos na face ventromedial, com exceção dos segmentos dos ramos laterais da primeira bifurcação e da segunda bifurcação deste ramo, no qual os processos ósseos estão inseridos na face ventrolateral. Os processos ósseos desenvolvem-se perpendicularmente à sua inserção no segmento no qual estão inseridos. Processos ósseos retos. Em secção transversal, os processos ósseos são cilíndricos ao longo de seu comprimento total, afilando-se muito pouco e terminando em uma extremidade arredondada. O diâmetro de sua extremidade distal equivale a $28 \%$ do diâmetro de sua inserção no segmento no qual está inserido. Em seu estado máximo de desenvolvimento, o seu comprimento total não alcança o comprimento proximodistal do segmento no qual está 
inserido. O comprimento do maior processo ósseo equivale a $13 \%$ do comprimento proximodistal do segmento no qual está inserido. Na nadadeira pélvica o processos ósseos apresentam tamanhos semelhantes em todos os raios; primeiro e segundo raio ramificado com o maior número de segmentos com processos ósseos. Nos raios os processos ósseos apresentam tamanhos semelhantes.

Nadadeira peitoral com processos ósseos tanto em segmentos da hemiriquia ventral quanto sem segmentos do hemitricuium dorsal. Nadadeira peitoral com um processo ósseo por segmento de hemitruium dorsal do terceiro ao oitavo raio ramificado, disrtribuindo-se em $46 \%$ dos raios ramificados (11 raios ramificados). Raios ramificados com processos ósseos presentes e restritos a segmentos distais à primeira bifurcação. Distalmente à primeira bifurcação, os processos ósseos estão presentes e restritos a até dois segmentos do ramo medial, imediatamente proximais à segunda bifurcação deste ramo. Processos ósseos assimétricos bilateralmente. Processos ósseos com inserção arredondada. Em todos os segmentos com processos ósseos, os processos ósseos estão inseridos na face dorsomedial do segmento em em relação à nadadeira. Os processos ósseos se desenvolven perpendicularmente à sua inserção no segmento no qual estão inseridos. Processos ósseos retos. Em secção transversal, os processos ósseos são cilíndricos ao longo de seu comprimento total, afilando-se muito pouco e terminando em uma extremidade arredondada. Em seu estado máximo de desenvolvimento, o seu comprimento total não alcança o comprimento proximodistal do segmento no qual está inserido. Na nadadeira pélvica o processos ósseos apresentam tamanhos semelhantes em todos os raios; quarto raio ramificado com o maior número de segmentos com processos ósseos. Nos raios os processos ósseos apresentam tamanhos semelhantes em direção proximodistal. 


\section{Hoplocharax goethei Géry 1966}

Figs. 129 a 132

Localidade tipo: "igarapé da Mãe Joana", perto de Manaus, baixo rio Negro, Brasil. Material examinado: MZUSP 95273, 49, Brasil, Amazonas, Manaus, igarapé da margem esquerda do rio Cuieiras, c. $20 \mathrm{~km}$ da boca, bacia do rio Negro, $03^{\circ} 00^{\prime} 00^{\prime \prime} \mathrm{S}, 60^{\circ} 11^{\prime} 00^{\prime \prime} \mathrm{W}$, alpha Heliz Exp., 27/01/1977.

\section{Caracteres sexuais secundários}

Os caracteres sexuais secundários em $H$. goethei relacionam-se ao comprimento padrão e presença de processos ósseos.

Comprimento padrão: fêmeas alcançam maiores valores de comprimento padrão em relação aos machos. MZUSP 95273, 31 machos (26.6-30.4 mm CP) e 15 fêmeas (25.4-31.7 mm CP).

Processos ósseos: presente nas nadadeiras anal, pélvica e peitoral de machos e fêmeas. Em relação aos processos ósseos, machos diferem de fêmeas apenas na distribuição e desenvolvimento destes nas nadadeiras anal, pélvica e peitoral.

Nadadera anal de machos maduros com até três processos ósseos por segmento de hemitriquium do último raio simples ao vigésimo sétimo raio ramificado, disrtribuindo-se em $100 \%$ dos raios ramificados (até 27 raios ramificados). Último raio simples com processos ósseos em todos os segmentos do raio, inclusive o mais proximal, mais longo. Segmento mais próximal, mais longo com processos ósseos distribuídos ao longo de todo seu comprimento total. Raios ramificados com processos ósseos tanto em segmentos proximais quanto em segmentos distais à primeira bifurcação. Processos ósseos presentes também em segmentos distais à segunda bifurcação dos ramos anterior e posterior da primeira bifurcação. Proximalmente à primeira bifurcação, os processos ósseos estão presentes em todos os 
segmentos. Distalmente à primeira bifurcação, os processos ósseos estão presentes em todos os segmentos do ramo posterior em até quatro segmentos do ramo anterior, imediatamente proximais à segunda bifurcação deste ramo. Distalmente à segunda bifurcação do ramo anterior da primeira bifurcação, os processos ósseos estão presentes em até três segmentos dos ramos anterior e posterior, imediatamente distais às ramificações. Distalmente à segunda bifurcação do ramo posterior da primeira bifurcação, os processos ósseos estão presentes em até três segmentos dos ramos anterior e posterior, imediatamente distais à bifurcação. Processos ósseos assimétricos bilateralmente. Processos ósseos com inserção arredondada. O diâmetro de sua inserção ocupa $9 \%$ do comprimento proximodistal do segmento no qual está inserido. Em todos os segmentos os processos ósseos estão inseridos na face lateral ou lateroposterior, com exceção dos segmentos dos ramos anteriores tanto da primeira quanto das segundas ramificações, no qual os processos ósseos estão inseridos na face lateroanterior ou lateral. Os processos ósseos desenvolvem-se perpendicularmente à sua inserção ou ligeriamene laterodistalmente no segmento no qual estão inseridos. Processos ósseos retos. Em secção transversal, os processos ósseos são cilíndricos ao longo de seu comprimento total, afilando-se muito pouco e terminando em uma extremidade arredondada. O diâmetro de sua extremidade distal equivale a $28 \%$ do diâmetro de sua inserção no segmento no qual está inserido. Em seus estado máximo de desenvolvimento, o seu comprimento total não alcança o comprimento proximodistal do segmento no qual está inserido. O comprimento do maior processo ósseo da nadadeira equivale $20 \%$ do comprimento proximodistal do segmento no qual está inserido. Na nadadeira anal os processos ósseos apresentam tamanhos semelhantes do último raio simples ao segundo raio ramificado, diminuição acentuada de tamanho do segundo para o terceiro raio ramificado, tamanho semelhante do terceiro ao último raio ramificado; primeiro e segundo raio ramificado com maior número de segmentos com 
$\overline{\text { procesoss ósseos e maiores processos ósseos. No raio os processos ósseos aumentam e }}$ diminuem de tamanho em direção proximodistal.

Nadadeira pélvica com processos ósseos tanto na hemitriquia dorsal quanto na hemitriquia ventral. Nadadeira pélvica com até dois (geralmente um) processos ósseos por segmento de hemitriquium ventral do raio simples ao sétimo raio ramificado, disrtribuindo-se em $100 \%$ dos raios ramificados (7 raios ramificados). Raio simples com processos ósseos do terceiro ao segmento da extremidade distal do raio. Raios ramificados com processos ósseos presentes tanto em segmentos proximais quanto em segmentos distais à primeira bifurcação. Proximalmente à primeira bifurcação, os processos estão presentes em um segmento. Distalmente à primeira bifurcação, os processos ósseos estão presentes em até quatro segmentos dos ramos medial e lateral, imediatamente distaisis à bifurcação. Processos ósseos assimétricos bilateralmente. Processos ósseos com inserção arredondada. O diâmtero de sua inserção ocupa $7 \%$ do comprimento proximodistal do segmento no qual está inserido. Em todos os segmentos com processos ósseos, os processos estão inseridos na face ventral ou ventromedial, com exceção dos segmentos do ramo lateral da primeira bifurcação no qual os processos ósseos estão inseridos na face ventrolateral ou ventral. Os processos ósseos se desenvolven perpendicularmente à sua inserção no segmento no qual estão inseridos. Processos ósseos retos. Em secção transversal, os processos ósseos são cilíndricos ao longo de seu comprimento total, afilando-se muito pouco e terminando em uma extremidade arredondada. O diâmetro de sua extremidade distal equivale a 36\% do diâmetro de sua inserção no segmento no qual está inserido. Em seu estado máximo de desenvolvimento, o seu comprimento total não alcança o comprimento proximodistal do segmento no qual está inserido. O comprimento do processo ósseos equivale a 10\% do comprimento proximodistal do segmento no qual está inserido. Na nadadeira pélvica o processos ósseos apresentam 
$\overline{\text { tamanhos semelhantes em todos os raios; primeiro e segundo raio ramificado com o maior }}$ número de segmentos com processos ósseos. Nos raios os processos ósseos apresentam tamanhos semelhantes.

Nadadeira peitoral com processos ósseos tanto na hemitriquia dorsal quanto na hemitriquia ventral. Nadadeira peitoral com até três (geralmente dois) processos ósseos por segmento de hemitriquium dorsal do primeiro ao oitavo raio ramificado, distribuindo-se em $100 \%$ dos raios ramificados (8 raios ramificados). Raios ramificados com processos ósseos presentes tanto em segmentos proximais quanto distais à primeira bifurcação do primeiro ao sexto raio ramificado; restante dos raios com processos ósseos restritos a segmentos distais à primeira bifurcação. Proximalmente à primeira bifurcação, os processos ósseos estão presentes em todos os segmentos do hemitriquium dorsal, inclusive o mair proximal. Distalmente à primeira bifurcação, os processos ósseos estão presentes em até cinco segmentos dos ramos medial e lateral, imediatamente distais à bifurcação. Processos ósseos assimétricos bilateralmente. Processos ósseos com inserção arredondada. O diâmetro de sua inserção, 6\% do comprimento proximodistal do segmento no qual está inserido. Em todos os segmentos com processos ósseos, os processos estão inseridos irregularmente na face dorsal, podendo estar mais medial nos segmentos do ramo medial ou mais lateral nos segmentos do ramo lateral. Os processos ósseos se desenvolven perpendicularmente à sua inserção no segmento no qual estão inseridos. Processos ósseos retos. Os processos ósseos são cilíndricos ao longo de seu comprimento total, afilando-se muito pouco e terminando em uma extremidade arredondada. O diâmetro de sua extremidade distal equivale a $35 \%$ do diâmetro de sua inserção no segmento no qual está inserido. Em seu estado máximo de desenvolvimento, seu comprimento total não alcança o comprimento proximodistal do segmento onde se insere. $\mathrm{O}$ omprimento do processo ósseos equivale a $9 \%$ do comprimento proximodistal do segmento 
no qual se insere. Na nadadeira peitoral o processos ósseos apresentam tamanhos semelhantes em todos os raios; primeiro e segundo raio ramificado com o maior número de segmentos com processos ósseos. Nos raios os processos ósseos aumentam e diminuem de tamanho em direção proximodistal.

Hyphessobrycon luetkenii CLADE

\section{Hyphessobrycon bifasciatus Ellis 1911}

Figs. 133 a 137

Localidade tipo: rio Parahyba em Campos, Brasil.

Material examinado: MZUSP 103202, 35, Brasil, São Paulo, São Paulo, Lago marginal do rio Tietê, na confluência com o córrego Jacu, Jd Pantanal, próx. Rod. Ayrton Sena, Av. Jacu Pessego2329’01’S, 46²7’15’W, Oyakawa, 18/06/2009.

\section{Caracteres sexuais secundários}

Os caracteres sexuais secundários em $H$. bifasciatus apresentam caracteres relacionam-se ao formato de nadadeiras e presença de processos ósseos.

Comprimento padrão: fêmeas alcançam maiores valores de comprimento padrão em relação aos machos. MZUSP 103202, 22 machos (29.9-40.2 mm CP) e 13 fêmeas (33.4-42.3 mm $\mathrm{CP})$.

Formato de nadadeiras: machos diferem de fêmeas pelo formato do perfil da margem disstal da nadadeira anal e formato da nadadeira pélvica.

Perfil da margem distal da nadadeira anal de machos ligeiramente convexa ao longo de seu comprimento total, pelo aumento gradual de tamanho do último raio simples ao segundo raio ramificado (raio mais longo) e diminuição gradual de tamanho deste ao último raio 
ramificado. Perfil da margem distal da nadadeira anal de fêmeas com lobo anterior côncavo. Lobo anterior formado pelo aumento gradual de tamanho do último raio simples ao segundo raio ramificado e diminuição acentuada deste ao sexto raio ramificado; perfil rato deste ponto ao último raio ramificado, devido à diminuição gradual de tamanho em direção anteroposterior.

Extremidade dsital do primeiro raio ramificado (raio mais longo) da nadadeira pélvica de machos alcança o quinto raio ramificado da nadadeira anal. A nadadeira pélvica cobre o orifício urogenital em vista ventral. Extremidade distal do primeiro raio ramificado (raio mais longo) da nadadeira pélvica de fêmeas alcançam no máximo o segundo raio ramificado da nadadeira anal. A nadadeira não cobre o orifício urogenital em vista ventral.

Processos ósseos: presentes nas nadadeiras anal e pélvica.

Nadadeira anal com até dois processos ósseos por segmento hemitriquium do último raio simples ao décimo nono raio ramificado, disrtribuindo-se em $32 \%$ dos raios ramificados (até 28 raios ramificados). Raio simples com processos ósseos do quinto ao décimo segundo segmento, décimo segmento proximal à extremidade distal do raio. Raios ramificados com processos ósseos tanto em segmentos proximais quanto em segmentos distais à primeira bifurcação. Processos ósseos presentes também em segmentos distais à segunda bifurcação do ramo posterior da primeira bifurcação. Proximalmente à primeira bifurcação os processos ósseos estão presentes em até quatro segmentos (geralmente três). Distalmente à primeira bifurcação e proximalmente às segundas ramificações, os processos ósseos estão presentes em todos os segmentos do ramo posterior e em até dois segmentos do ramo anterior, a partir do segundo segmento distal à bifurcação. Distalmente à segunda bifurcação do ramo posterior da primeira rmaificação, os processos ósseos estão presentes e restritos a até três segmentos do ramo posterior, imediatamente distias à bifurcação. Processos ósseos assimétricos 
$\overline{\text { bilateralmente. Processos ósseos com inserção arredondada. O diâmetro de sua inserção }}$ ocupa $25 \%$ do comprimento proximodistal do segmento no qual está inserido. Em todos os segmentos os processos ósseos estão inseridos na face lateroposterior. Os processos ósseos desenvolvem-se perpedicularmente à sua inserção no segmento no qual estãp inseridos. Os processos ósseos são geralmente retos, podendo sofrer uma pequena curvatura de $10^{\circ}$ e se desenvolver em direção proximal em relação ao segmento no qual estão inseridos. Em secção transversal, os processos ósseos são cilíndricos em toda sua extensão, afilando-se gradualmente e terminando em uma extremidade arredondada. O diâmetro de sua extremidade distal equivale a $67 \%$ do diâmetro de sua inserção no segmento no qual está inserido. Em seu estado máximo de desenvolvimento, o seu comprimento total não alcança o comprimento proximodistal do segmento no qual está inserido. O comprimento do maior processo ósseo equivale a $36 \%$ do comprimento proximodistal do segmento no qual está inserido. $\mathrm{Na}$ nadadeira anal os processos aumentam e diminuem de tamanho em direção anteroposterior; segundo e terceiro raio ramificado com maior número de segmentos com processos ósseos e maiores processos óssseos. No raio os processos ósseos aumentam e diminuem de tamanho em direção proximodistal; o maior processo ósseos está o segundo segmento distal à primeira bifurcação, na metade proximal da série de processos ósseos.

Nadadeira pélvica com processos ósseos presentes e restritos a segmentos do hemitricuium ventral. Nadaeira pélvica com um processo ósseo por segmento de hemitriquium ventral do primeiro ao quarto raio ramificado, disrtribuindo-se em $56 \%$ dos raios ramificados (até 7 raios ramificados). Processos ósseos presentes e restritos a segmentos distais à primeira bifurcação. Processos óseos presentes também em segmentos distais à segunda bifurcação dos ramos medial e lateral da primeira bifurcação. Distalmente à primeira bifurcação e proximalmente à segunda bifurcação, os processos ósseos estão presentes e restritos a até três segmentos do 
ramo medial, imediatamente proximais à segunda bifurcação deste ramo. Distalmente à segunda bifurcação do ramo medial da primeira bifurcação, os processos estão presentes e restritos a quase todos os segmentos do ramo medial, imediatamente distais à bifurcação. Distalmente à segunda bifurcação do ramo lateral da primeira bifurcação, os processos estão presentes e restritos a até cinco segmentos do ramo medial, na extremidade distal do ramo. Processos ósseos com inserção ovalada proximodistalmente. O aiâmetro de sua inserção ocupa $12 \%$ do comprimento proximodistal do segmento no qual está inserido. Em todos os segmentos, os processos ósseos estão inseridos na face medioventralmente. Os processos ósseos desenvolvem-se perpendicularmente à usa inserção no segmento no qual estão inseridos. Ao longo de seu comprimento total, os processos ósseos sofre uma curvatura de $25^{\circ}$ e desenvolvem-se em direção medioproximal em relação ao segmento no qual estão inseridos. Em secção transversal, os processos ósseos variam de ovalados proximodistalmente a cilíndricos ao longo de seu comprimento total, afilando-se muito pouco gradualmente e terminando em uma extremidade normalmente pontiaguda/arredondada. $\mathrm{O}$ diâmetro de sua extremidade distal equivale a $33 \%$ do maior comprimento de seua inserção no segmento no qual está inserido. Em seu estado máximo de desenvolvimento, o seu comprimento total não alcança o comprimento proximodistal do segmento no qual se insere. O comprimento do maior processo ósseo equivale a $18 \%$ do comprimento proximodistal do segmento no qual está inserido. $\mathrm{Na}$ nadadeira pélvica, os processos ósseos apresentam tamanho semelhante; segundo e terceiro raio com maior número de segmentos com processos ósseos. No raio, os processos ósseos apresentam tamanhos semelhantes.

\section{Hyphessobrycon luetkenii (Boulenger 1887)}

Figs. 138 a 142 
Localidade tipo: San Lorenzo, Rio Grande Sul, Brasil.

Material examinado: MZUSP 18882, 272, Brasil, Rio Grande do Sul, Belém Novo, arroio Chapéu Virado, bacia do Jacuí, 30¹2’0.0”S, 51²’0.0”W, Exp. MZUSP/USNM, 21/09/1977.

\section{Caracteres sexuais secundários}

Os caracteres sexuais secundários em H. Luetkenii relacionam-se ao comprimento padrão, formato de nadadeiras, presença de processos ósseos e tubérculos reprodutivos.

Comprimento padrão: fêmeas alcançam maiores valores de comprimento padrão em relação aos machos. MZUSP 18882, 108 machos (31.6-52 mm CP) e 90 fêmeas (33.7-54 mm CP).

Formato de nadadeiras: machos diferem de fêmeas pela forma do perfil da margem distal da nadadeira anal

Perfil da margem distal da nadadeira anal de machos com lobo anterior ligeiramente convexo, quase reto. Lobo anterior formado pelo aumento gradual de tamanho do último raio simples ao segundo raio ramificado (raio mais longo) e diminuição graudal deste ao quinto raio ramificado; perfil reto deste ponto ao último raio ramificado, devido à diminuição gradual de tamanho em direção anteroposterior. Perfil da margem distal da nadadeira anal de fêmeas com lobo anterior côncavo conspícuo. Lobo anterior formado pelo aumento graudal de tamanho do último raio simples ao segundo raio ramificado (raio mais longo) e diminuição graudal deste ao quinto raio ramificado; perfil reto deste ao último raio ramificado, devido à diminuição gradual de tamanho em direção anteroposterior.

Extremidade distal do primeiro raio ramificado (raio mais longo) da nadadeira pélvica de machos ultrapassa o orifício urogenital, mas não alcança a origem da nadadeira anal. Extremidade distal do primeiro raio ramificado (raio mais longo) da nadadeira pélvica de 
fêmeas não ultrapassa o orifício urogenital. Não sobrepõe o orifício urogenital em vista ventral.

Processos ósseos: presentes nas nadadeiras anal, pélvica, peitoral, dorsal e caudal de machos. Femeas maduras com processos ósseos na nadadeira anal. Sendo assim, a presença de processos ósseos na nadadeira anal não é o caráter dimórfico, mas seu desenvolvimento e distribuição.

Nadadeira anal de machos com até dois (geralmente um) processos ósseos por segmento de hemitriquium do último raio simples ao vigésimo primeiro raio ramificado, disrtribuindo-se em $96 \%$ dos raios ramificados (até 22 raios ramificados). Raio simples com processos ósseos do segundo ao décimo segundo segmento, terceiro segmento proximal à extremidade distal do raio. Raios ramificados com processos ósseos presentes tanto em segmentos proximais quanto em segmentos distais à primeira bifurcação. Processos ósseos presentes também em segmentos distais à segunda bifurcação dos ramos anterior e posterior da primeira bifurcação. Proximalmente à primeira bifurcação os processos ósseos estão presentes em até quatro segmentos. Distalmente à primeira bifurcação e proximalmente às segundas ramificações, os processos ósseos estão presentes em todos os segmentos do ramo posterior e em até três segmentos do ramo anterior, imediatamente proximais à segunda bifurcação. Distalmente à segunda bifurcação do ramo posterior da primeira bifurcação, os processos ósseos estão presentes em até quatro segmentos do ramo posterior e em até dois segmento do ramo anterior, imediatamente distais à bifurcação. Distalmente à segunda bifurcação do ramo anterior da primeira bifurcação, os processos ósseos estão presentes em até três segmentos do ramo posterior e em até um segmento do ramo anterior, imediatamente distais à bifurcação. Processos ósseos simétricos bilateralmente. Processos ósseos com inserção arredondada. O diâmetro de sua inserção ocupa $18 \%$ do comprimento proximodistal do segmento no qual está 
inserido. Em todos os segmentos, os processos ósseos estão inseridos na face lateroposterior em relação à nadadeira, com exceção dos segmentos do ramo anterior da segunda bifurcação dos ramos anterior e posterior da primeira bifurcação, no qual os processos ósseos estão inseridos na falce lateroanterior. Os processos ósseos desenvolvem-se perpendicularmente à sua inserção no segmento no qual estão inseridos. Processos ósseos geralmente retos, podendo sofrer uma curvatura de $25^{\circ}$ ao longo de seu comprimento total, e se desenvolver em direção proximomedial em relação ao segmento no qual está inserido. Em secção transversal, os processos são cilíndricos ao longo de seu coprimento total, afilando-se gradualmente e terminando em uma extremidade arredondada. O diâmetro de sua extremidade distal equivale $67 \%$ do diâmetro de sua inserção no segmento no qual está inserido. Em seu estado máximo de desenvolvimento, o seu comprimento total não alcança o comprimento proximodistal do segmento no qual está inserido. O comprimento do maior processo ósseo equivale a $36 \%$ do comprimento proximodistal do segmento no qual está inserido. Na nadadeira anal os processos aumentam e diminuem de tamanho; segundo e terceiro raio ramificado com o maior númeo de segmentos com processos ósseos e maiores processos ósseos. No raio os processos ósseos aumentam e diminuem de tamanho em direção proximodistal; o maior processo ósseos está no terceiro segmento imediatamente distal à primeira bifurcação, na metade/metade proximal da série de processos ósseos.

Nadadeira pélvica com processos ósseos em segmentos tanto do hemitricuium ventral quanto do hemitricuium dorsal. Nadadeira pélvica com até dois (geralmente um) processos ósseos por segmento de hemitriquium ventral do raio simples ao sexto raio ramificado, disrtribuindo-se em 86\% dos raios ramificados (7 raios ramificaods). Raio simples com um processo em um segmento da metade distal do hemitriquium. Raios ramificados com processos ósseos presentes e restritos a segmentos distais à primeira bifurcação. Processos 
$\overline{\text { ósseos presentes também em segmentos distais à segunda bifurcação dos ramos medial e }}$ lateral da primeira bifurcação. Distalmente à primeira bifurcação e proximalmente à segundas ramificações, os processos ósseos estão presentes e restritos a até dois segmentos do ramo medial, imediatamente proximais à segunda bifurcação deste ramo. Distalmente à segunda bifurcação do ramo medial da primeira bifurcação, os processos ósseos estão presentes e restritos a todos os segmentos do ramo medial. Distalmente à segunda bifurcação do ramo lateral da primeira bifurcação, os processos ósseos estão presentes e restritos a todos os segmentos do ramo medial. Processos ósseos assimétricos bilateralmente. Processos ósseos com inserção arredondada. O diâmetro de sua inserção ocupa $9 \%$ do comprimento proximodistal do segmento no qual está inserido. Em todos os segmentos os processos óseos estão inseridos na face ventromedial em relação à nadadeira. Os processos ósseos desenvolvem-se perpendicularmente à sua inerção no segmento no qual estão inseridos. Os processos ósseos são geralmente retos, podendo sofrer uma curvatura de $40^{\circ}$ ao longo de seu comprimento total e se desenvolver em direção medial/proximomedial em relação ao segmento no qual estão inseridos. Em secção transversal, os processos ósseos são cilíndricos ao longo de seu comprimento total, afilando-se muito pouco e terminando em uma extremidade arredondada. O diâmetro de sua extremidade distal, 50\% do diâmetro de sua inserção no segmento no qual está inserido. Em seu estado máximo de desenvolvimento, o seu comprimento total não alcança o comprimento proximodistal do segmento no qual está inserido. O comprimento do maior processo ósseo equivale a $22 \%$ do comprimento proximodistal do segmento no qual está inserido. Na nadadeira pélvica os processos diminuem de tamanho em direção lateromedial; terceiro raio ramificado com maior número de segmentos com processos ósseos; primeiro raio ramificado com maiores processos ósseos. No raio os processos ósseos aumentam e diminuem de tamanho em direção proximodistal; o 
maior processo ósseos está no quinto segmento distal à primeira bifurcação, na metade proximal do segmento no quals está inserido.

Nadadeira peitoral com processos ósseos presentes e restritos a segmentos do hemitricuium dorsal. Nadadeira peitoral com até dois (geralmente um) processos ósseos por segmentos de hemitriquium dorsal do primeiro ao oitavo raio ramificado, disrtribuindo-se em $72 \%$ dos raios rmaificados (até 11 raios ramificados). Raios ramificados com processos ósseos presentes e restritos a segmentos distais à primeira bifurcação. Processos ósseos presentes também em segmentos distais à segunda bifurcação do ramo lateral da primeira bifurcação. Distalmente à primeira bifurcação e proximalmente à segunda bifurcação, os processos ósseos estão presentes e restritos a todos os segmentos do ramo lateral. Distalmente à segunda bifurcação do ramo lateral da primeira bifurcação, os processos ósseos estão presentes e restritos a até cinco segmentos do ramo lateral, imediatamente distais à bifurcação. Processos ósseos com inserção arredondada. Em todos os segmentos os processos óseos estão inseridos na face dorsolateral em relação à nadadeira. Os processos ósseos desenvolvem-se perpendicularmente à usa inserção no segmento no qual está inserido. Processos ósseos retos. Em secção transversal, os processos ósseos são cilíndricos ao longo de seu comprimento total, afilando-se muito pouco e terminando em uma extremidade arredondada. Em seu estado máximo de desenvolvimento, o comprimento total não alcança o comprimento proximodistal do segmento no qual está inserido. Na nadadeira peitoral os processos diminuem em tamanho lateromedial; segundo e terceiro raio ramificado com maior número de segmentos com processos ósseos e maiores processos ósseos. No raio os processos ósseos diminuem de tamanho em direção proximodistal.

Nadadeira dorsal com um processo ósseo por segmento do primeiro ao sexto raio ramificado, disrtribuindo-se em 67\% (nove raios ramificados). Raios ramificados com 
$\overline{\text { processos ósseos presentes e restritos a segmentos distais à primeira bifurcação. Processos }}$ ósseos presentes também em segmentos distais à segunda bifurcação dos ramos anterior e posterior da primeira bifurcação. Distalmente à primeira bifurcação os processos estão presentes e restritos a até cinco segmentos do ramo posterior, imediatamente proximais à segunda bifurcação deste ramo. Distalmente à segunda bifurcação do ramo anterior da primeira bifurcação, os processos ósseos estão presentes e restritos a até quatro segmentos do ramo anterior, imediatamente distais à bifurcação. Distalmente à segunda bifurcação do ramo posterior da primeira bifurcação, os processos ósseos estão presentes em até três segmentos do ramo anterior e em até dois segmenteos do ramo posterior, imediatamente distais à bifurcação. Processos ósseos simétricos bilateralmente. Processo ósseos com inserção arredondada. O diâmetro de sua inserção ocupa $8 \%$ do comprimento proximodistal do segmento no qual está inserido. Em todos os segementos, os processos ósseos estão inseridos na face lateroposterior em relação à nadadeira, com exceção dos segmentos do ramo anterior da segunda bifurcação dos ramos anterior e posterior da primeira ramificaçào, no qual os processos ósseos estão inseridos na face lateroanterior. Os processos ósseos desenvolvem-se perpendicularmente em relação à sua inserção no segmento no qual estão inseridos. Ao longo de seu comprimento total, os processos ósseos sofrem uma curvatura de $40^{\circ}$ e desenvolvem-se em direção medial em relação ao segmento no qual estão inseridos. Em secção transversal os processos ósseos são cilíndricos ao longo de seu comprimento total, afilando-se gradualmente e terminando em uma extremidade arredondada. O diâmetro de sua extremidade distal equivale a $56 \%$ do diâmetro de sua inserção no segmento no qual está inserido. Em seu estado máximo de desenvolvimento, o seu comprimento total não alcança o comprimento proximodistal do segmento no qual está inserido. Na nadadeira dorsal os processos diminuem em tamanho em direção anteroposterior; segundo raio ramificado com maior número de 
$\overline{\text { segmentos com processos ósseos e maiores processos ósseos. No raio os processos ósseos }}$ diminuem de tamanho em direção proximodistal.

Nadadeira caudal com um processo ósseo por segmentos de hemitriquium do primeiro ao décimo sétimo raio ramificado, disrtribuindo-se em $100 \%$ dos total de raios ramificados (17 raios ramificados). Raios ramificados com processos ósseos presentes e restritos a segmentos distais à primeira bifurcação. Processos ósseos presentes também em segmentos distais à segunda bifurcação dos ramos ventral e dorsal da primeira bifurcação dos raios dos lobos dorsal e ventral. Processos ósseos presentes também em segmentos distais à terceira bifurcação do ramo medial da segunda bifurcação do ramo medial da primeira bifurcação dos raios do lobo dorsal. Distalmente à primeira bifurcação e proximalmente à segunda bifurcação, os processos ósseos estão presentes em até seis segmentos do ramo medial e em até quatro segmentos do ramo lateral, imediatamente proximais à segunda bifurcação e em até quatro segmentos do ramo lateral do raio mais medial do lobo dorsal, imediatamente dstais à bifurcação. Distalmente à segunda bifurcação do ramo medial da primeira bifurcação dos raios do lobo ventral e proximalmente à terceira bifurcação, os processos ósseos estão presentes e restritos a todos os segmentos do ramo medial. Distalmente à segunda bifurcação do ramo lateral da primeira bifurcação dos raios do lobo ventral e proximalmente à terceira bifurcação, os processos ósseos estão presentes e restritos a até três segmentos do ramo lateral, imediatamente distais à segunda bifurcação. Distalmente à segunda bifurcação do ramo lateral da primeira bifurcação dos raios do lobo dorsal e proximalmente à terceira bifurcação, os processos ósseos estão presentes e restritos a todos os segmentos do ramo lateral. Distalmente à terceira bifurcação do ramo medial da segunda bifurcação do ramo medial da primeira bifurcação dos raios do lobo dorsal, os processos ósseos estão presentes e restritos a até três segmentos do ramo medial, imediatamente distais à terceira bifurcação. 
Distalmente à terceira bifurcação do ramo lateral da segunda bifurcação do ramo lateral da primeira bifurcação dos raios do lobo dorsal, os processos ósseos estão presentes e restritos a até três segmentos do ramo lateral, imediatamente distais à terceira bifurcação. Processos ósseos simétricos blateralmente. Processo ósseos com inserção arredondada. O diâmetro de sua inserção equivale a $11 \%$ do comprimento proximodistal do segmento no qual stá inserido. Em todos os segementos os processos ósseos estão inseridos na face laterolateral em relação à nadadeira, com exceção dos segmentos dos ramos mediais das ramificações, no qual os processos ósseos estão inseridos na face lateromedial. Os processos ósseos desenvolvem-se perpendicularmente e ligeiramente lateral à sua inserção no segmento no qual estão inseridos. Os processos são geralmente retos, podendo sofrer ao longo de seu comprimento total, uma curvatura de $20^{\circ}$ e se desenvolver em direção medioproximal em relação ao segmento no qual está inserido. Em secção transversal, os processos ósseos são cilíndricos ao longo de seu comprimento total, afilando-se gradualmente e terminando em uma extremidade arredondada. O diâmetro de sua extremidade distal equivale a 55\% do diâmetro de sua inserção no segmento no qual está inserido. Em seu estado máximo de desenvolvimento, o seu comprimento total não alcança o comprimento proximodistal do segmento no qual está inseridso. O comprimento do maior processo ósseo equivale a $40 \%$ do comprimento total do segmento no qual está inserido. Na nadadeira anal os processos apresentam tamanhos semelhantes; raios laterais com maior número de segmentos com processos ósseos. No raio os processos ósseos diminuem de tamanho em direção proximodistal.

Tubéculos reprodutivos: presente em machos.

Machos com tubérculos reprodutivos na cabeça e na margem posterior da face externa de todas as escamas do corpo, exceto as escamas da parte ventral do corpo.

\section{IGUANODECTINAE}




\section{Piabucus dentatus (Koelreuter 1763)}

Figs. 143 a 146

\section{Localidade tipo: Brazil.}

Material examinado: MZUSP 62445, 2, Venezuela, Sucre, sistema del Turupano, en el Pueblo de Ajies, J. N. Baskin \& O. Castillo, 08/12/1980.

\section{Caracteres sexuais secundários}

Os caracteres sexuais secundários em $P$. dentatus relacionam-se ao comprimento padrão e ao formato de nadadeiras e presença de processos ósseos.

Comprimento padrão: machos alcançam maiores valores de comprimento padrão que fêmeas. MZUSP 62445, 1 macho (135,5 mm CP) e 1 fêmea $(94,5$ mm CP).

Formato de nadadeiras: Machos diferem de fêmeas pelo formato do perfil da margem distal da nadadeira anal e pelo formato dos segmentos de hemitriquium dos raios da nadadeira anal. Perfil da margem distal da nadadeira anal de machos com um lobo posterior. Lobo posterior formado pelo aumento gradual de tamanho do primeirio ao quadragésimo raio ramificado mais longo, diminuição gradual de tamnho deste ao último raio ramificado. Raio mais longo ultrapassando a origem da nadadeira caudal. Perfil da margem distal da nadadeira de fêmeas reto, com a diminuição gradual do primeiro ao último raio ramificado; último raio ramificado da nadadeira mais curtos, não alcançando a origem da nadadeira caudal.

Segmentos de hemitriquium da nadadeira anal de machos mais robustos, de arredondados a rectangulares, devido a uma expansão anteroposterior. Segmentos de hemitriquium de fêmeas menos robustos que os de machos, mais compridos (proximodistalmente) que largos (anteroposteriormente). 
Processos ósseos: presentes na nadadeira anal de machos.

Nadadeira anal com duas formas de processos ósseos. A primeira forma, (Lappet de Bohlke, 1954) está presente em até dois (geralmente um) por segmento de heimitriquium do último raio simples até o sétimo raio ramificado e do trigésimo quarto ao quadragésimo segundo raio ramificado, distribuindo-se em $33 \%$ dos raios ramificados (42 raios ramificados). Proximalmente à primeira bifurcação do raios simples ao sétimo raio ramificado, os lappets estão presentes e restritos ao segmento mais proximal dos raios, mais longo. Em todos os segmentos, os lappets estão inseridos na face lateral/lateroposterior em relação à nadadeira. Do trigésimo quarto ao trigésimo nono raio ramificado, os lappets estão presentes e restritos a segmentos proximais à primeira bifurcação. Do quadragésimo ao quadragésimo segundo raio ramificado, os lappets estão presentes tanto em segmentos proximais quanto em segmentos distais à primeira bifurcação. Proximalmente à primeira bifurcação os lappets estão presentes em até quatorze segmentos, todos os segmentos proximais. Distalmente à primeira bifurcação, os Lappets estão presentes em até sete segmentos do ramo posterior e em um segmento do ramo anterior, a partir do terceiro segmento imediatamente distal à bifurcação. Lappets simétricos bilateralmente. Lappets com inserção ovalada proximodistalmente. O maior comprimento de sua inserção ocupa 100\%, do comprimento proximodistal do segmento no qual está inserido. Em todos os segmentos do trigésimo quarto ao quadragésimo segundo raio ramificado, os lappets estão inseridos na face lateroposterior em relação à nadadeira. Os lappets desenvolvem-se perpendicularmente à sua inserção no segmento no qual estão inseridos. Ao longo de seu comprimento total, o maior lappet sofre uma curvatura de $55^{\circ}$ e se desenvolve em direção proximal em relação ao segmento no qual está inserido. Em secção transversal, os lappet variam de ovalado proximodistalmente a ovalado horizontalmente ao longo de seu comprimento total, se alargando horizontalmente e afilando-se e terminando em 
uma extremidade ovalada horizontalmente. O maior comprimento de sua extremidade distal equivale a $29 \%$ do comprimento de sua inserção no segmento no qual está inserido. Em seu estado máximo de desenvolvimento, o seu comprimento total não alcança o comprimento proximodistal do segmento no qual se insere. O comprimento do maior Lappet equivale a $77 \%$ do comprimento proximodistal do segmento no qual está inserido. Do último raio simples ao sétimo raio ramificado, os lappets aumentam e diminuem de tamanho gradualmente em direção anteroposterior; quarto e quinto raio ramificado com maiores Lapptes. Do trigésimo quarto ao quadragésimo segundo raio ramificado, o lappets aumentam e diminuem gradualmente de tamanho em direção anteroposterior; quadragésimo raio ramificado com o maior número de Lappets e maiores Lappets. Nos raios, os lappets diminuem de tamanho e mudam de forma em direção proximodistal.

A segunda forma está presente em até três (geralmente dois) processos ósseos por segmento do último raio simples ao décimo segundo raio ramificao, disrtribuindo-se em $29 \%$ dos raios ramificados (até 42 rais ramificados). No último raio simples, os processos ósseos estão presentes do segundo segmento ao quinto segmento proximal à extremidade distal do raio. Raios ramificados, com processos ósseos presentes tanto em segmentos proximais quanto em segmentos distais à primeira bifurcação. Processos ósseos presentes também em segmentos distais à segunda bifurcação dos ramos posterior e anterior da primeira bifurcação. Proximalmente à primeira bifurcação, os processos ósseos estão presentes em até oito segmentos. Distalmente à primeira bifurcação e proximalmente à segunda bifurcação, os processos ósseos estão presentes em todos os segmentos do ramo posterior e em até quatro segmentos do ramo anterior, imediatamente próximas à segunda bifurcação deste ramo. Distalmente à segunda bifurcação do ramo posterior da primeira bifurcação, os processos ósseos estão presentes em até seis segmentos do ramo posterior e em até cinco segmentos do 
$\overline{\text { ramo anterior, imediatamente distias à bifurcação. Distalmente à segunda bifurcação do ramo }}$ anterior da primeira bifurcação, os processos ósseos estão presentes e restritos a até quatro segmentos do ramo posterior, imediatamente distais à bifurcação. Processos ósseos simétricos bilateralmente. Processos ósseos com inserção ovalada proximodistalmente. O maior comprimento de sua inserção ocupa $33 \% \%$ do comprimento proximodistal do segmento no qual está inserido. Em todos os segmentos, os processos ósseos estão inseridos na face posterior (ligeiramente lateral), com exceção de até cinco segmentos do ramo posterior da primeira bifurcação, imediatamente proximais à segunda bifurcação deste ramo, no qual os processos ósseos estão inseridos tanto na face posterior quanto na face anterior e dos segmentos do ramo anterior da segunda bifurcação do ramo posterior da primeira bifurcação, no qual os processos ósseos estão inseridos na face anterior (ligeiramente lateral). Os processos ósseos desenvolvem-se perpendicularmente à sua inserção no segmento no qual estão inseridos. Ao longo de seu comprimento total, os processos ósseos sofrem uma curvatura de $45^{\circ}$ e desenvolvem-se em direção proximal em relação ao segmento no qual estão inseridos. Em secção transversal, os processos ósseos são ovalados proximodistalmente ao longo de seu comprimento total, afilando-se gradualmente e terminando em uma extremidade pontiaguda. O diâmetro de sua extremidade distal equivale a $10 \%$ do maior comprimento de sua inserção no segmento no qual está inserido. Em seu estado máximo de desenvolvimento, o seu comprimento total não alcança o comprimento proximodistal do segmento no qual está inserido. O comprimento do maior processo ósseo equivale a $21 \%$ do comprimento proximodistal do segmento no qual está inserido. Na nadadeira os processos ósseos apresentam tamanhos semelhantes; sétimo raio ramificado com o maior número de segmentos com processos ósseos. No raio, os processos ósseos apresentam tamanhos semelhantes. 


\section{Peseudochalceus CLADE}

\section{Hollandichthys multifasciatus (Eigenmann \& Norris 1900)}

Figs. 147 a 150

Localidade tipo: Cubatão, São Paulo, Brasil.

MZUSP 113633, 25, Brasil, São Paulo, São Bernardo do Campo, rio Cubatão, bacia costeira, 23.911263으, $46.488632^{\circ} \mathrm{W}$, B. Abreu-Santos \& P. D. T. Côrrea, 13/07/2012.

Comprimento padrão: machos alcançam maiores valores de comprimento padrão em relação às fêmeas. MZUSP 113633, 14 machos (59.9-96.0 mm CP) e 11 fêmeas (60.2-78.1 $\mathrm{mm} \mathrm{CP})$.

\section{Caracteres sexuais secundários}

Os caracteres sexuais secundários de $H$. multifasciatus relacionam-se ao comprimento padrão, formato de nadadeiras e presença de processos ósseos.

Formato de nadadeiras: Machos diferem de fêmeas pelo formato do perfil da margem distal da nadadeira anal e formato da nadadeira pélvica.

Perfil da margem distal da nadadeira anal de machoscom um lobo posterior. Lobo posterior formado pelo aumento de tamanho do vigésimo sexto ao vigésimo nono raio ramificado; vigésimo oitavo raio ramificado mais longo, formando um pequeno filamento que ultrapassa a inserção dos raios principais da nadadeira caudal. Perfil da margem distal da nadadeira anal de fêmeas reta, com uma redução gradual de tamanho do primeiro ao último raio ramificado; raios posteriores não ultrapassam a inserção dos raios principais da nadadeira caudal. 
$\overline{\text { Extremidade distal do primeiro raio ramificado (raio mais longo) da nadadeira pélvica de }}$ machos alcança o terceiro raio ramificado da nadadeira anal. Primeiro raio ramificado filamentoso. Extremidade distal do segundo raio ramificado (raio mais longo) da nadadeira pélvica de fêmeas não alcança a origem da nadadeira anal. Margem distal da nadadeira pélvica de fêmeas relativamente truncada/arredondada. Em ambos os sexos todos os raios da nadadeira são ramificados, não apresentam raio simples.

Processos ósseos: presentes nas nadadeiras anal e pélvica de machos.

Nadadeira anal com um processo ósseo por segmento de hemitriquium do quarto ao vigésimo nono raio ramificado, disrtribuindo-se em $84 \%$ dos raios ramificados (até 31 raios ramificados). Raios ramificados com processos ósseos tanto em segmentos proximais quanto em segmentos distais à primeira bifurcação. Proximalmente à primeira bifurcação, os processos ósseos estão presentes em até dois segmentos. Distalmente à primeira bifurcação e proximalmente à segunda bifurcação, os processos ósseos estão presentes e restritos a até oito segmentos do ramo posterior, imediatamente distais à bifurcação. Processos ósseos simétricos bilateralmente. Processos ósseos com inserção ovalada proximodistalmente. O maior comprimento de sua inserção ocupa $34 \%$ do comprimento proximodistal do segmento no qual está inserido. Em todos os segmentos, os processos ósseos estão inseridos na face lateroposterior em relação à nadadeira. Os processo ósseos desenvolvem-se perpendicularmente ao segmento no qual estão inseridos. Ao longo de seu comprimento total, os processos ósseos sofrem uma curvatura de $45^{\circ}$ e desenvolvem-se em direção proximal em relação ao segmento no qual estão inseridos. Em secção transversal, os processos ósseos variam de ovalados proximodistalmente a cilíndricos, afilando-se gradualmente e terminando em uma extremidade arredondada. O diâmetro de sua extremidade distal equivale a $23 \%$ do maior comprimento de sua inserção no segmento no qual está inserido. Em seu estado 
máximo de desenvolvimento, o seu comprimento total não alcança o comprimento proximodistal do segmento no qual está inserido. O comprimento do maior processo ósseo equivale a $49 \%$ do comprimento proximodistal do segmento no qual está inserido. $\mathrm{Na}$ nadadeira anal os processos óessos aumentam e diminuem de tamanho em direção anteroposterior; décimo raio ramificado com maior número de segmentos com processos ósseos e maiores processos ósseos. Nos raios, os processos ósseos aumentam e diminuem gradualmente de tamanho em direção proximodistal.

Nadadeira pélvica com processos ósseos presentes e restritos a segmentos do hemitricuium ventral. Nadadeira pélvica com um processo ósseo por segmento de hemitriquium ventral do terceiro ao quinto raio ramificado, disrtribuindo-se em $43 \%$ dos raios ramificados (7 raios ramificados). Raios ramificados com processos ósseos tanto em segmentos proximais quanto em segmentos distais à primeira bifurcação. Proximalmente à primeira bifurcação os processos ósseos estão presentes em todos os todos os segmentos, inclusive o mais proximal. Segmento mais proximal com até quatro processos ósseos em sua porção distal. Distalmente à primeira bifurcação e proximalmente às segundas ramificações, os processos ósseos estão presentes e restritos a até cinco segmentos do ramo medial, imediatemente distais à bifurcação. Processos ósseos com inserção ovalada proximodistalmente. O maior comprimento de sua inserção ocupa $70 \%$ do comprimento proximodistal do segmento no qual está inserido. Em todos os segmentos, os processos ósseos estão inseridos na face lateromedial em relação à nadadeira. Os processos ósseos desenvolvem-se perpendicularmente à sua inserção no segmento. Ao longo de seu comprimento total, os processos ósseos sofrem uma curvatura de $40^{\circ}$ e desenvolvem-se em direção proximal em relação ao segmento no qual estão inseridos. Em secção transversal, os processos ósseos variam de ovalado proximodistalmente a cilíndrico ao longo de seu comprimento total, 
afilando-se muito e terminando em uma extremidade pontiaguda. $\mathrm{O}$ diâmetro de sua extremidade distal equivale a $6 \%$ do maior comprimento de sua inserção no segmento no qual está inserido. Em seu estado máximo de desenvolvimento, o seu comprimento total não alcança o comprimento proximodistal do segmento no qual está inserido. O comprimento do maior processo ósseo equivale a $81 \%$ do comprimento proximodistal do segmento no qual está inserido. Na nadadeira pélvica os processos ósseos diminuem em tamanho do terceiro ao quinto raio ramificado; terceiro raio ramificado com maior número de segmentos com processos ósseos e maiores processos ósseos. No raio os processos ósseos aumentam e diminuem de tamanho em direção proximodistal; o maior processo ósseos está no segmento imediatamente proximal à bifurcação, metade da série de processos ósseos

\section{RHOADSIINAE}

\section{Nematocharax venustus Weitzman, Menezes \& Britski 1986}

Figs. 151 a 154

Localidade tipo: rio Jequitinhonha, em Itaobim, Minas Gerais, município Medina, Brasil, $16^{\circ} 40^{\prime} \mathrm{S}, 41^{\circ} 23^{\prime} \mathrm{W}$.

Material examinados: MZUSP 111253, 57, Brasil, Bahia, São José da Vitória, rio afluente do rio Una, bacia do leste, $15.0978^{\circ} \mathrm{S}, 39.3528^{\circ} \mathrm{W}$, J.L. Birindelli et al., 14/08/2012.

\section{Caracteres sexuais secundários}

Os caracteres sexuais secundários em $N$. venustus relacionam-se ao comprimento padrão, formato de nadadeiras e presença de processos ósseos. 
Comprimento padrão: machos alcançam maiores valores de comprimento padrão em relação às fêmeas. MZUSP 111253, 18 machos (35.1-50.9 mm CP) e 13 fêmeas (29.9-38.7 $\mathrm{mm} \mathrm{CP})$.

Formato de nadadeiras: Machos diferem de fềmeas pelo formato do perfil da margem distal das nadadeira anal e formato das nadadeiras pélvica e dorsal.

Perfil da margem distal da nadadeira anal de machos com lobo anterior convexo conspícuo. Lobo anterior formado pelo aumento acentuado de tamanho do último raio simples ao sexto raio ramificado (raio mais longo) e diminuição acentuada deste ao décimo raio ramificado; perfil reto deste ponto ao último raio ramificado, devido à diminuição de tamanho em direção anteroposterior. Sexto raio ramificado filamentoso, alcançando a inserção dos raios principais da nadadeira caudal. Perfil da margem distal da nadadeira anal de fêmeas com lobo anterior convexo. Lobo formado pelo aumento de tamanho do último raio simples ao quinto raio ramificado (mais longo da nadadeira) e diminuição deste ao sexto raio ramificado; perfil reto deste ponto ao último raio ramificado, devido à diminuição de tamanho em direção anteroposterior. Quinto raio ramificado, não filamentoso.

Extremidade distal do primeiro raio ramificado (raio mais longo) da nadadeira pélvica de machos alcança a inserção dos raios principais da nadadeira caudal. Nadadeira pélvica de machos sobrepõe o orifício urogenital em vista ventral. Nadadeira pélvica de machos com extensão filamentosa do ramo medial do primeiro raio ramificado. Primeiro raio ramificado mais longo. Extremidade distal do primeiro raio ramificado da nadadeira pélvica alcança o segundo raio ramificado da nadadeira anal. Nadadeira pélvica das fêmeas não combrem o orifício urogenital em vista ventral. Nadadeira pélvica de fêmeas sem extençao filamentosa.

Nadadeira dorsal de machos com aumento acentuado de tamanho do último raio simples ao primeiro raio ramificado e diminuição pequena de tamanho do primeiro ao quarto raio 
ramificado; diminuição acentuada do quarto ao quinto raio ramificado; a partir deste ponto os raios diminuem gradualmente de tamanho em direção posterior. Primeiro, segundo, terceiro e quarto raio ramificado filamentoso, alcançando a extremidade distal do lobo dorsal da nadadeira caudal. Nadadeira dorsal de fêmeas com aumento discreto de tamanho do último raio simples ao primeiro raio ramificado e diminuição gradual deste ao último raio ramificado. Raios da nadadeira dorsal das fêmeas sem extensão filamentosa, não alcançam a origem da nadadeira caudal.

Processos ósseos: presentes nas nadadeiras anal e pélvica de machos.

Nadadeira anal com até três (geralmente um) processos ósseos por segmento de hemitriquium do último raio simples ao décimo terceiro raio ramificado, disrtribuindo-se em $54 \%$ dos raios ramificados (até 24 raios ramificados). Último raio simples com processos em todos os segmentos do raio. Raios ramificados com processos ósseos presentes tanto em segmentos proximais quanto em segmentos distais à primeira bifurcação. Processos ósseos presentes também em segmentos distais à segunda bifurcação do ramo posterior da primeira bifurcação. Proximalmente à primeira bifurcação, os processos ósseos estão presentes em até dez segmentos, todos os segmentos proximais à primeira bifurcação. Distalmente à primeira bifurcação e proximalmente às segunda ramificações, os processos ósseos estão presentes e restritos a todos os segmentos do ramo posterior. Distalmente à segunda bifurcação do ramo posterior da primeira bifurcação, os processos ósseos estão presentes e restritos a até treze segmentos do ramo posterior, imediatamente distais à bifurcação. Processos ósseos simétricos bilateralmente. Processos ósseos com inserção arredondada. O maior comprimento de sua inserção ocupa $35 \%$ do comprimento proximodistal do segmento no qual está inserido. Em todos os segmentos, os processos ósseos estão inseridos na face lateroposterior em relação à nadadeira. Os processos ósseos desenvolvem-se perpendicularmente à sua inserção no 
$\overline{\text { segmento no qual estão inseridos. Ao longo de seu comprimento total, os processos ósseos }}$ sofrem uma curvatura de $45^{\circ}$ e desenvolvem-se em direção medial ou mediodistal em relação ao segmento no qual estão inseridos. Em secção transversal, os processos ósseos são cilindricos, afilando-se gradualmente e terminando em uma extremidade distal arredondada. O diâmetro de su extremidade distal ocupa $21 \%$ do diâmetro de sua inserção no segmento no qual está inserido. Em seu estado máximo de desenvolvimento, seu comprimento total não alcança o comprimento proximodistal do segmento no qual está inserido. O comprimento do maior processo ósseo equivale a $20 \%$ do comprimento proximodistal do segmento no qual está inserido. $\mathrm{Na}$ nadadeira anal os processos aumentam e diminuem gradualmente de tamanho em direção anteroposterior; quarto raio ramificado com maior número de segmentos com processos ósseos e maiores processos ósseos. No raio os processos ósseos aumentam e diminuem discretamente de tamanho em direção proximodistal; o maior processo ósseo está no segundo segmento proximal à primeira bifurcação, meade proximal da série de processos ósseos.

Nadadeira pélvica com processos ósseos restritos a segmentos do hemitricuium ventral. Nadadeira anal com até dois (geralmente dois) processos ósseos por segmento no hemitriquium ventral do segundo ao quarto raio ramificado, disrtribuindo-se em $57 \%$ dos raios ramificados (7 raios ramificados). Raios ramificados com processos restritos a segmentos distais à primeira bifurcação. Processos ósseos presentes também em segmentos distais à segunda bifurcação do ramo medial da primeira bifurcação. Distalmente à primeira bifurcação e proximalmente à segunda bifurcação, os processos ósseos estão presentes e restritos a todos os segmentos do ramo medial. Distalmennte à segunda bifurcação do ramo medial da primeira bifurcação os processos ósseos estão presentes e restritos a até três segmentos do ramo medial, imediatamente distais à segunda bifurcação. Processos ósseos 
com inserção arredondada. O diâmetro de sua inserção ocupa $5 \%$ do comprimento proximodistal do segmento no qual está inserido. Em todos os segmentos, os processos ósseos estão inseridos na face ventromedial em relação à nadadeira. Os processos ósseos desenvolvem-se perpendicularmente à sua inerção no segmento no qual estão inseridos. Processos ósseos retos. Em secção transversal, os processos ósseos são cilíndricos, afilando-se gradualmente e terminando em uma extremidade arredondada. O diâmetro de sua extremidade distal equivale a $34 \%$ do diâmetro de sua inserção no segmento no qual está inserido. Em seu estado máximo de desenvolvimento, seu comprimento total não alcança o comprimento proximodistal do segmento no qual está inserido. O comprimento do maior processo ósseo equivale a $10 \%$ do comprimento proximodistal do segmento no qual está inserido. $\mathrm{Na}$ nadadeira pélvica os processos ósseos apresentam tamanhos semelhantes; terceiro raio ramificado com o maior número de segmentos com processos ósseos. Nos raios os processos ósseos não apresentam diferença visível de tamanho.

\section{SALMININAE}

\section{Salminus brasiliensis Cuvier 1916}

Figs. 155 e 156

\section{Localidade tipo: Brazil.}

Material examinado: MZUSP 118664, 1, Brasil, Mato Grosso, em frente a Jupiá, bacia do rio Paraná, 27'10.0”S, 5145’0.0”W, P. Vanzolini \& S. Saiar, 04/12/1960. MZUSP 88600, 1, Brasil, Mato Grosso, Cáceres, rio Sepotuba (trecho médio), bacia do rio Paraguay, 15²'58.0”S, 5740’52.0”W, O. Froehlich et al.. MZUSP 21616, 1, Brasil, Paraná, Guaíra, 
rio Paraná acima de Sete Quedas, bacia do rio Paraná, 2440.0”S, 5416’0.0”W, CETESB. MZUSP 20661, 1, Brasil, Paraná, bacia do rio Paraná, 245’0.0”S, 54¹6’0.0”W, CETESB, 1977.

\section{Caracteres sexuais secundários}

Os caraceres sexuais secundários em $S$. brasiliensis relacionam-se ao comprimento padrão, formato de nadadeiras e presença de processos ósseos.

Comprimento padrão: fêmeas alcançam maiores valores de comprimento padrão em relação aos machos (e.g., Moraes \& Schubart, 1955: 58-59; Cordiviola, 1966; Godoy, 1975: 321; Sverlij \& Espinach Ros, 1986, Lima, 2006).

Formato de nadadeiras: machos diferem de fêmeas pelo formato do perfil da margem distal da nadadeira anal.

Perfil da margem distal da nadadeira anal de machos com lobo anterior discretamente convexo, quase reto. Lobo anterior formado pelo aumento de tamanho do último raio simples ao primeiro raio ramificado (raio mais longo) e diminuição discreta deste ao quinto ou sexto raio ramificado; perfil reto do sexto ao último raio ramificado da nadadeira anal devido à diminuição gradual de tamanho em direção anteroposterior. Perfil da margem distal da ndadeira anal de fêmeas com um lobo anterior convexo. Lobo anterior formado pela diminuição acentuada do último raio simples ao quinto raio ramificado; perfil reto do sexto ao último raio ramificado.

Processos ósseos: presentes nas nadadeiras anal e pélvica de machos.

Nadadeira anal com um processo ósseo por segmento de hemitriquium do primeiro ao décimo sétimo raio ramificado, disrtribuindo-se em $70 \%$ dos raios ramificados (até 24 raios ramificados). Raios ramificados com processos ósseos presentes tanto em segmentos proximais quanto em segmentos distais à primeira bifurcação. Processos ósseos presentes 
também em segmentos distais à segunda bifurcação do ramo posterior da primeira bifurcação. Processos ósseos presentes também em segmentos distais à terceira bifurcação do ramo posterior da segunda bifurcação do ramo posterior da primeira bifurcação. Proximalmente à primeira bifurcação, os processos ósseos estão presentes em até um segmento, imediatamente proximal à bifurcação. Distalmente à primeira bifurcação, os processos ósseos estão presentes e restritos a todos os segmentos do ramo posterior. Distalmente à segunda bifurcação do ramo posterior da primeira bifurcação, os processos ósses estão presentes e restritos a todos os segmentos do ramo posterior. Distalmente à terceira bifurcação do ramo posterior da segunda bifurcação do ramo posterior da primeira bifurcação, os processos ósseos estão presentes e restritos a até doze segmentos, imediatamente distais à bifurcação. Processos ósseos simétricos bilateralmente. Processo ósseo com inserção ovalada proximodistalmente. O maior comprimento de sua inserção ocupa $53 \%$ do comprimento proximodistal do segmento no qual está inserido. Em todos os segmentos, os processos ósseos estão inseridos na face lateroposterior em relação à nadadeira. A inserção dos processos ósseos nos raios migra da face lateroposterior à face lateral em direção proximodistal. Os processos ósseos desenvolvem-se perpendicularmente à sua inserção no segmento. Ao longo de seu comprimento total, os processos ósseos sofrem uma curvatura de $35^{\circ}$ e desenvolvem-se em direção proximal em relação ao eixo proximodistal do segmento no qual estão inseridos. Em secção transversal, os processos ósseos variam de ovalados proximodistalmente a cilíndricos ao longo de seu comprimento total, afilando-se gradualmente e terminando em uma extremidade pontiaguda/arredondada. O diâmetro de sua extremidade distal equivale a $15 \%$ do maior comprimento de sua inserção no segmento no qual está inserido. $\mathrm{Na}$ metade proximal da série de processos ósseos, os processos sofrem uma pequena bifurcação em sua extremidade distal, voltando a ficar unicuspidado em sua porção mais proximal. Em seu 
estado máximo de desenvolvimento, o seu comprimento total não alcança o comprimento proximodistal do segmento no qual está inserido. O comprimento do maior processo ósseo equivale a $60 \%$ do comprimento proximodistal do segmento no qual está inserido. $\mathrm{Na}$ nadadeira anal os processos ósseos aumentam e diminuem gradualmente de tamanho em direção anteroposterior; número de segmentos com processos ósseos semelhante entre os raios ramificados; terceiro raio ramficiado com maiores processos ósseos. Nos raios, os processos ósseos aumentam e diminuem de tamanho em direção proximodistal; maior processo ósseo presente no segundo segmento imediatamente próximal à terceira bifurcação do ramo posterior da segunda bifurcação do ramo posterior da primeira bifurcação, na metade distal da série de segmentos com processos ósseos.

Nadadeira pélvica com um processos ósseos restritos a segmentos do hemitricuium ventral. Nadadeira pélvica com um processo ósseo por segmento do primeiro ao sexto raio ramificado, disrtribuindo-se em $85 \%$ dos raios ramificados (7 raios ramificados). A primeira bifurcação ocorre na porção distal do segmento mais proximal dos raios (o mais longo). Imediatamente distalmente à primeira bifurcação os segmentos sofrem a segunda bifurcação, sendo assim não existem segmentos entre a primeira e segunda bifurcação nos ramos medial e lateral. Processos ósseos presentes em segmentos proximais à primeira bifurcação. Processos ósseos presentes também em segmentos distais à segunda bifurcação do ramo medial da primeira bifurcação. Processos ósseos presentes também em segmentos distais à terceira bifurcação do ramo medial da segunda bifurcação do ramo medial da primeira bifurcação. Proximalmente à primeira bifurcação, até sete processos ósseos estão presentes, na porção distal do segmento mais proximal, mais longo. Distalmente à segunda bifurcação do ramo medial da primeira bifurcação, os processos ósseos estão presentes e restritos a todos os segmentos do ramo medial. Distalmente à terceira bifurcação do ramo medial da segunda bifurcação do ramo 
$\overline{\text { medial da primeira bifurcação, os processos ósseos estão presentes e restritos a até quinze }}$ segmentos do ramo medial, imediatamente distais à bifurcação. Processo ósseo com inserção ovalada proximodistalmente. O maior comprimento de sua inserção ocupa $57 \%$ do comprimento proximodistal do segmento no qual está inserido. Em todos os segmentos, os processos ósseos estão inseridos na face ventromedial em relação à nadadeira. Os processos ósseos desenvolvem-se perpendicularmente à sua inserção nos segmentos. Ao longo de seu comprimento total, os processos ósseos sofrem uma curvatura de $40^{\circ}$ e desenvolvem-se em direção proximal em relação ao eixo proximodistal do segmento no qual estão inseridos. Em secção transversal, os processos ósseos variam de ovalados proximodistalmente a cilíndricos ao longo de seu comprimento total, afilando-se gradualmente e terminando em uma extremidade arredondada. O diâmetro de sua extremidade distal equivale a $25 \%$ do maior comprimento de sua inserção no segmento no qual está inserido. Do primeiro ao quinto raio ramificado os processos ósseos ficam bifurcados e/ou trifurcados em direção distoproximal, próximo ao segmento mais proximal, mais longo. Em seu estado máximo de desenvolvimento, o seu comprimento total não ultrapassa o comprimento proximodistal do segmento no qual está inserido. O comprimento do maior processo ósseo equivale a $89 \%$ do comprimento proximodistal do segmento no qual está inserido. $\mathrm{Na}$ nadadeira pélvica os processos ósseos aumentam e diminuem gradualmente de tamanho em direção lateromedial; terceiro raio ramificado com o maior número de segmentos com processos ósseos; quinto raio ramificado com maiores processos ósseos. Nos raios, os processos ósseos aumentam e diminuem de tamanho em direção proximodistal; maior processo ósseo presente nos segundo segmento imediatamente proximal à terceira bifurcação. Nos raios os processos ósseos variam de uma extremidade cônica a bicuspidada ou tricuspidada em direção proximodistal. 
Salminus hilarii Valenciennes 1850

Figs. 157 e 158

Localidade tipo: São Francisco, Brazil.

Material examinado: MZUSP 20475, 3, Brasil, São Paulo, Miguelópolis, represa de Volta Grande, CETESB, 31/10/1975.

\section{Caracteres sexuais secundários}

Os caracteres sexuais secundários de $S$. hilarii relacionam-se ao comprimento padrão, formato de nadadeiras e presença de processos ósseos.

Comprimento padrão: fêmeas alcançam maiores valores de comprimento padrão em relação aos machos. MZUSP 20475, 2 machos $(217.7-225.9 \mathrm{~mm} \mathrm{CP})$ e 1 fêmea $(231.0 \mathrm{~mm}$ CP). Segundo Godoy (1975), a maior fêmea de Salminus hilarii registrada por ele alcançou $42 \mathrm{~cm}$ de comprimento total e aproximadamente $1 \mathrm{~kg}$ de peso, o maior macho, alcançou $32 \mathrm{~cm}$ e 310 gramas.

Formato de nadadeiras: machos diferem de fêmeas pelo formato do perfil da margem distal da nadadeira anal.

Perfil da margem distal da nadadeira anal de machos com lobo anterior convexo discreto, quase reto. Lobo anterior formado pelo aumento de tamanho do último raio simples ao primeiro raio ramificado (raio mais longo) e diminuição discreta deste ao quinto ou sexto raio ramificado; perfil reto do sexto ao último raio ramificado da nadadeira anal devido à diminuição gradual de tamanho em direção anteroposterior. Perfil da margem distal da ndadeira anal de fêmeas com um lobo anterior convexo. Lobo anterior formado pela diminuição acentuada do primeiro raio ramificado (raio mais longo) ao quinto raio 
$\overline{\text { ramificado; perfil reto do sexto ao último raio ramificado devido à diminuição graudal de }}$ tamanho em direção anteroposterior.

Processos ósseos: presentes nas nadadeiras anal e pélvica de machos.

Nadadeira anal com um processo ósseo por segmento de hemitriquium do último raio simples ao décimo oitavo raio ramificado, distribuindo-se em $75 \%$ dos raios ramificados (até 24 raios ramificados). Raio simples com processos ósseos do sétimo ao vigésimo terceiro segmento, oitavo segmento proximal à extremidade distal do raio. Processos ósseos presentes tanto em segmentos proximais quanto em segmentos distais à primeira bifurcação Processos ósseos presentes também em segmentos distais à segunda bifurcação do ramo posterior da primeira bifurcação. Proximalmente à primeira bifurcação, os processos ósseos estão presentes em até um segmento, imediatamente proximal à bifurcação. Distalmente à primeira bifurcação, os processos ósseos estão presentes e restritos a todos os segmentos do ramo posterior. Distalmente à segunda bifurcação do ramo posterior da primeira bifurcação, os processos ósses estão presentes e restritos a até seis segmentos do ramo posterior, imediatamente distais à bifurcação. Processos ósseos simétricos bilateralmente. Processos ósseos com inserção ovalada proximodistalmente. O maior comprimento de sua inserção ocupa $61 \%$ do comprimento proximodistal do segmento no qual está inserido. Em todos os segmentos, os processos ósseos estão inseridos na face lateroposterior em relação à nadadeira. A inserção dos processos ósseos nos raios migra da face lateroposterior à face lateral em direção proximodistal. Os processos ósseos desenvolvem-se perpendicularmente à sua inserção no segmento. Ao longo de seu comprimento total, os processos ósseos sofrem uma curvatura de $40^{\circ}$ e desenvolvem-se em direção proximal em relação ao segmento no qual estão inseridos. Em secção transversal, os processos ósseos variam de ovalados proximodistalmente a cilíndricos ao longo de seu comprimento total, afilando-se 
gradualmente e terminando em uma extremidade pontiaguda/arredondada. O diâmetro de sua extremidade distal equivale a $14 \%$ do maior comprimento de sua inserção no segmento no qual está inerido. Em seu estado máximo de desenvolvimento, seu comprimento total não alcança o comprimento proximodistal do segmento no qual está inserido. O comprimento do maior processo ósseo equivale $71 \%$ do comprimento proximodistal do segmento no qual está inserido. Na nadadeira anal os processos ósseos aumentam gradualmente e diminuem gradualmente de tamanho em direção anteroposterior; número de segmentos com processos ósseos é semelhante entre os raios ramificados; terceiro raio ramificado com maiores processos ósseos. Nos raios, os processos ósseos aumentam e diminuem de tamanho em direção proximodistal; maior processo ósseo presente no segmento imediatamente distal à segunda bifurcação do ramo posterior da primeira ramirifação, na metade distal da série de processos ósseos.

Nadadeira pélvica com processos ósseos restritos a segmentos do hemitricuium ventral. Nadadeira pélvica com um processo ósseos por segmento do primeiro ao sexto raio ramificado, distribuindo-se em $85 \%$ dos raios ramificados (7 raios ramificados). A primeira bifurcação ocorre na porção distal do segmento mais proximal dos raios (o mais longo). Imediatamente depois da primeira bifurcação os segmentos sofrem a segunda bifurcação, sendo assim não existem segmentos entre a primeira e segunda bifurcação nos ramos medial e lateral. Processos ósseos presentes em segmentos proximais à primeira bifurcação. Processos ósseos presentes também em segmentos distais à segunda bifurcação do ramo medial da primeira bifurcação. Processos ósseos presentes também em segmentos distais à terceira bifurcação do ramo medial da segunda bifurcação do ramo medial da primeira bifurcação. Proximalmente à primeira bifurcação, um processo ósseo está presente, na porção distal do segmento mais proximal, mais longo. Distalmente à segunda bifurcação do ramo medial da 
$\overline{\text { primeira bifurcação, os processos ósseos estão presentes e restritos a todos os segmentos do }}$ ramo medial. Distalmente à terceira bifurcação do ramo medial da segunda bifurcação do ramo medial da primeira bifurcação, os processos ósseos estão presentes em até três segmentos do ramo medial, imediatamente distais à bifurcação. Processos ósseos com inserção ovalada proximodistalmente. O maior comprimento de sua inserção ocupa $58 \%$ do comprimento proximodistal do segmento no qual está inserido. Em todos os segmentos, os processos ósseos estão inseridos na face ventromedial em relação à nadadeira. Os processos ósseos desenvolvem-se perpendicularmente à sua inserção nos segmentos no qual estão inseridos. Ao longo de seu comprimento total, os processos ósseos sofrem uma curvatura de $50^{\circ}$ e desenvolvem-se em direção proximal em relação ao eixo proximodistal do segmento no qual estão inseridos. Em secção transversal, os processos ósseos variam de ovalados proximodistalmente a cilíndricos ao longo se seu comprimento total, afilando-se gradualmente e terminando em uma extremidade pontiaguda/arredondada. O diâmetro de sua extremidade distal equivale a $8 \%$ do maior comprimento de sua inserção no segmento no qual está inserido. No quinto raio ramificado os processos ósseos ficam bifurcados em direção distoproximal, próximo ao segmento mais proximal, mais longo. Em seu estado máximo de desenvolvimento, o seu comprimento total não alcança o comprimento proximodistal do segmento no qual está inserido. O comprimento do maior processo ósseo equivale a $73 \%$ do comprimento proximodistal do segmento no qual está inserido. $\mathrm{Na}$ nadadeira pélvica os processos ósseos aumentam e diminuem gradualmente de tamanho em direção lateromedial; quinto raio ramificado com o maior número de segmentos com processos ósseos e maiores processos ósseos. Nos raios, os processos ósseos aumentam e diminuem de tamanho em direção proximodistal; maior processo ósseo presente nos segundo segmento imediatamente 
$\overline{\text { proximal à terceira bifurcação. Nos raios os processos ósseos variam de uma extremidade }}$ cônica a bicuspidada em direção proximodistal.

\section{TETRAGONOPTERINAE}

\section{Brachychalcinus copei (Steindachner 1882)}

Localidade tipo: Tabatinga, rio Amazonas, Brasil.

Material examinado: MZUSP 95808, 15, Brasil, Mato Grosso, Itaúba, córrego a beira de estrada de terra, afluente do rio Teles Pires, bacia do rio Tapajós, $11^{\circ} 07^{\prime} 12^{\prime} \mathrm{S}, 55^{\circ} 26^{\prime} 08^{\prime \prime} \mathrm{W}$, J.L.O.Birindelli \& P. Hollanda Carvalho, 30/09/2007.

\section{Caracteres sexuais secundários}

Os caracteres sexuais secundários em $B$. copei relacionam-se ao comprimento padrão e à presença de processos ósseos.

Comprimento padrão: fêmeas alcançam maiores valores de comprimento padrão em relação aos machos. MZUSP 95808, 6 machos (41.7-57.1 mm CP) e 9 fêmeas (46.6-57.4 mm CP).

Processos ósseos: presentes nas nadadeiras anal e pélvica de machos.

Nadadeira anal com até três (geralmente dois) processos ósseos por segmento de hemitriquium do último raio simples ao vigésimo nono raio ramificado, disrtribuindo-se em 97\% dos raios ramificados (até 30 raios ramificados). Último raio simples com processos ósseos do quarto ao décimo quinto segmento, segundo segmento proximal à extremidade distal do raio. Raios ramificados com processos ósseos presentes tanto em segmentos proximais quanto em segmentos distais à primeira bifurcação. Processos ósseos presentes também em segmentos distais à segunda bifurcação dos ramos anterior e posterior da primeira 
bifurcação. Proximalmente à primeira bifurcação, os processos ósseos estão presentes em até um segmento (apenas no primeiro raio ramificado); restante dos raios com processos ósseos restritos a segmentos distais à primeira bifurcação. Distalmente à primeira bifurcação e proximalmente às segunda ramificações, os processos ósseos estão presentes em todos os segmentos do ramo posterior e em até seis segmentos do ramo anterior, imediatamente proximais à segunda bifurcação. Distalmente à segunda bifurcação do ramo posterior da primeira bifurcação, os processos ósseos estão presentes em todos os segmentos dos ramos posterior e anterior. Distalmente à segunda bifurcação do ramo anterior da primeira bifurcação, os processos ósseos estão presentes em todos os segmentos dos ramos posterior e anterior. Processos ósseos simétricos bilateralmente. Processos ósseos com inserção arredondada. Em todos os segmentos, os processos ósseos estão inseridos na face lateroposterior, com exceção de seis segmentos do ramo posterior da primeira bifurcação, imediatamente proximais à segunda bifurcação e de dois segmentos do ramo anterior da primeira rmaificação, imediatamente proximais à segunda bifurcação, no qual os processos ósseos estão inseridos tanto na face lateroposterior quanto na face lateroanterior, dos segmentos do ramo anterior da segunda bifurcação do ramo posterior da primeira bifurcação, dos segmentos do ramo anterior da primeira bifurcação e dos segmentos do ramo anterior da segunda bifurcação deste ramo, no qual os processos ósseos estão inseridos na face lateroanterior. Os processos ósseo desenvolvem-se perpendicularmente à sua inserção no segmento no qual estão inseridos. Ao longo de seu comprimento total, os processos ósseos sofrem uma curvatura de $50^{\circ}$ e desenvolvem-se em direção proximal em relação ao segmento no qual estão inseridos. Em secção transversal, os processos ósseos são cilíndricos ao longo de secu comprimento toal, afilando-se gradualmente e terminando em uma extremidade distal pontiaguda/arredondada. Em seu estado máximo de desenvolvimento, o seu comprimento 
total não alcança o comprimento proximodistal do segmento no qual está inserido. $\mathrm{Na}$ nadadeira anal os processos aumentam e diminuem gradualmente de tamanho em direção anteroposterior; segundo e terceiro raio ramificado com maior número de segmentos com processos ósseos e maiores processos ósseos. No raio os processos ósseos aumentam e diminuem de tamanho em direção proximodistal.

Nadadeira pélvica com processos ósseos presentes e restritos a segmentos do hemitricuium ventral. Nadadeira pélvica com até dois (geralmente dois) processos ósseos por segmento no hemitriquium ventral do primeiro ao quinto raio ramificado, disrtribuindo-se em $71 \%$ dos raios ramificados (6 raios ramificados). Raios ramificados com processos ósseos tanto em segmentos proximais quanto em segmentos distais à primeira bifurcação. Processos ósseos presentes também em segmentos distais à segunda bifurcação do ramo medial da primeira bifurcação. Distalmente à primeira bifurcação e proximalmente à segunda bifurcação, os processos ósseos estão presentes e restritos a todos os segmentos do ramo medial. Distalmennte à segunda bifurcação do ramo medial da primeira bifurcação os processos ósseos estão presentes e restritos a todos segmentos do ramo medial. Em todos os segmentos, os processos ósseos estão inseridos na face ventromedial. Processos ósseos com inserção arredondada. Os processos ósseos desenvolvem-se perpendicularmente à sua inserção no segmento no qual estão inseridos. Ao longo de seu comprimento total, os processos ósseos sofrem uma curvatura de $50^{\circ}$ em direção proximal, ligeiramente medial em relação ao eixo proximodistal do segmento no qual estão inseridos. Em secção transversal, os processos ósseos são cilíndricos, afilando-se gradualmente e terminando em uma extremidade arredondada/pontiaguda. Em seu estado máximo de desenvolvimento, o seu comprimento total não alcança o comprimento proximodistal do segmento no qual está inserido. $\mathrm{Na}$ nadadeira pélvica os processos ósseos aumentam discretamente de tamanho do raio simples 
ao primeiro e segundo raio ramificado e diminuem visivelmente até quinto raio ramificado; primeiro e segundo raio ramificado com o maior número de segmentos com processos ósseos e maiores processos ósseos. Nos raios os processos ósseos não apresentam diferença visível de tamanho.

\section{Deuterodon iguape Eigenmann 1907}

Figs. 159 a 163

\section{Localidade tipo: Brasil, Iguapé.}

Material examinado: MZUSP 88262, 37, Brasil, São Paulo, Iporanga, rio Pilões, bacia do Ribeira, M. R. Santos \& M. Morato, 19/01/1995.

\section{Caracteres sexuais secundários}

Os caracteres sexuais secundários em D. iguape relacionam-se ao comprimento padrão, formato de nadadeiras e presença de processos ósseos.

Comprimento Padrão: fêmeas alcançam maiores valores de comprimento padrão em relação aos machos. MZUSP 88262, 2 machos (78.6-82.2 mm CP) e 35 fêmeas (71.9-101.9 mm CP). Formato de nadadeiras: machos diferem de fêmeas pelo perfil da margem distal da nadadeira anal e formato da nadadeira pélvica.

Perfil da margem distal da nadadeira anal de machos relativamente reta, com um lobo anterior discreto. Lobo anterior formado pelo aumento gradual de tamanho do último simples ao segundo raio ramificado (raio mais longo) e diminuição gradual deste ao sexto raio ramificado; perfil reto deste ponto ao último raio ramificado devido à diminuição gradual de tamanho em direção anteroposterior. Perfil da margem distal da nadadeira anal de fêmeas com lobo anterior côncavo conspícuo. Lobo anterior formado pela diminuição acentuada de 
tamanaho do segundo raio ramificado (raio mais longo) ao sexto raio ramificado; perfil reto deste ponto ao último raio ramificado, devido à diminuição gradual de tamanho em direção anteroposterior.

Extremidade distal do primeiro raio ramificado (raio mais longo) da nadadeira pélvica de machos alcança a origem da nadadeira anal, mas não ultrapassa o último raio ramificado da nadadeira anal. A nadadeira pélvica sobrepõe o orifício urogenital em vista ventral. Extremidade do primeiro raio ramificado (raio mais longo) da nadadeira pélvica de fêmeas não ultrapassa a origem da nadadeira anal. Nadadeira pélvicae não sobrepõem o orifício urogenital em vista ventral.

Processos ósseos: presentes nas nadadeiras anal e pélvica de machos maduros.

Nadadeira anal com um processo ósseo por segmento de hemitriquium do último raio simples ao décimo raio ramificado, disrtribuindo-se em até $48 \%$ dos raios ramificados (até 21 raios ramificados). Último raio simples com processos ósseos do oitavo ao trigésimo terceiro segmento, segmento mais distal do raio. Processos ósseos presentes tanto em segmentos proximais quanto em segmentos distais à primeira bifurcação. Processos ósseos presentes também em segmentos distais à segunda bifurcação dos ramos anterior e posterior da primeira bifurcação. Proximalmente à primeira bifurcação, os processos ósseos estão presentes em até quatro segmentos. Distalmente à primeira bifurcação e proximalmente às segunda ramificações, os processos ósseos estão presentes e restritos a todos os segmentos do ramo posterior. Distalmente à segunda bifurcação do ramo posterior da primeira bifurcação, os processos ósseos estão presentes e restritos a até dois segmentos do ramo posterior, imediatamente distais à bifurcação. Distalmente à segunda bifurcação do ramo anterior da primeira bifurcação, os processos ósseos estão presentes e restritos a até quatro segmentos do ramo posterior, imediatamente distais à bifurcação. Processos ósseos simétricos 
bilateralmente. Processos ósseos com inserção ovalada proximodistalmente. O maior comprimento de sua inserção ocupa $54 \%$ do comprimento proximodistal do segmento no qual está inserido. Em todos os segmentos os processos ósseos estão inseridos na face lateroposterior em relação à nadadeira. Os processos ósseos desenvolvem-se perpendicularmente à sua inserção no segmento. Ao longo de seu comprimento total, os processos ósseos sofrem uma curvatura de $40^{\circ}$ e desenvolvem-se em direção proximal, ligeiramente medial em relação ao segmento no qual estão inseridos. Em secção transversal, os processos ósseos variam de ovalados proximodistalmente a cilíndricos ao longo de seu comprimento total, afilando-se gradualmente e terminando em uma extremidade distal arredondada. O diâmtero de sua extremidade distal equivale a $11 \%$ do maior comprimento de sua inserção no segmento no qual está inserido. Em seu estado máximo de desenvolvimento, seu comprimento total não alcança o comprimento proximodistal do segmento no qual está inserido. O comprimento do maior processo ósseo equivale a $53 \%$ do comprimento proximodistal do segmento no qual está inserido. Na nadadeira anal os processos aumentam e diminuem gradualmente de tamanho em direção anteroposterior; terceiro e quarto raio ramificado com maior número de segmentos com processos ósseos e maiores processos ósseos. No raio os processos ósseos aumentam e diminuem de tamanho em direção proximodistal; o maior processo ósseos está no terceiro segmento distal à segunda bifurcação da segunda bifurcação do ramo posteriorda primeira bifurcação, metade, metade proximal.

Nadadeira pélvica com processos ósseos presentes e restritos a segmentos do hemitriquium ventral. Nadadeira pélvica com um processo ósseo por segmento (com exceção do segmento mais proximal, mais longo) no hemitriquium ventral do primeiro ao sétimo raio ramificado (sete raios ramificados), odisrtribuindo-se em 100\% dos raios ramificados da nadadeira. Raios ramificados com processos ósseos presentes tanto em segmentos proximais quanto em 
segmentos distais à primeira bifurcação. Processos ósseos presentes também em segmentos distais à segunda bifurcação dos ramos medial e lateral da primeira bifurcação. Processos ósseos presentes também sem segmentos distais à terceira bifurcação do ramo medial da segunda bifurcação do ramo medial da primeira bifurcação. Proximalmente à primeira bifurcação, os processos estão presentes em todos os segmentos, inclusive o mais proximal (mais longo). Segmento mais proximal, mais longo com até cinco processos ósseos no segundo, terceiro e quarto raio ramificado. Distalmente à primeira bifurcação e proximalmente às segundas ramificações, os processos ósseos estão presentes e restritos a todos os segmentos do ramo medial. Distalmente à segunda bifurcação do ramo medial da primeira bifurcação, os processos ósseos estão presentes em todos os segmentos do ramo medial e em até quatro segmentos do ramo lateral, imediatamente distais à bifurcação. Distalmente à segunda bifurcação do ramo lateral da primeira bifurcação, os processos ósseos estão presentes em todos os segmentos do ramo medial. Distalmente à terceira rmaficação do ramo medial da segunda bifurcação do ramo medial da primeira bifurcação, os processos ósseos estão presentes e restritos a dois segmentos do ramo medial, imediatamente distais à bifurcação. Inserção dos processos ovalada proximodistalmente. O maior comprimento de sua inserção equivale a $73 \%$ do comprimento proximodistal do segmento no qual está inserido. Em todos os segmentos, os processos ósseos estão inseridos na face ventromedial em relação à nadadeira, com exceção dos segmentos do ramo lateral da segunda bifurcação do ramo medial da primeira bifurcação, no qual os processos ósseos estão inseridos face ventrolateral. Os processos ósseos desenvolvem-se perpendicularmente à sua inserção no segmento no qual está inserido. Ao longo de seu comprimento total, os processos ósseos sofrem uma curvatura gradual de $48^{\circ}$ e desenvolvem-se em direção proximal em relação ao segmento no qual está inserido. Em secção transversal, os processos ósseos variam de ovalados proximodistalmente 
a cilíndricos, afilando-se gradualmente e terminando em uma extremidade pontiaguda. $\mathrm{O}$ diâmtero de sua extremidade distal equivale a $9 \%$ do maior comprimento de sua inserção no segmento no qual está inserido. Em seu estado máximo de desenvolvimento, seu comprimento total não alcança o comprimento proximodistal do segmento onde está inserido. O comprimento do maior processo ósseo equivale a $92 \%$ do comprimeto proximodistal do segmento no qual está inserido. Na nadadeira pélvica o processos ósseos aumentam e diminuem gradualmente de tamanho em diração latermedial; segundo e terceiro raio ramificado com o maior número de segmentos com processos ósseos e maiores processos ósseos. Nos raios os processos ósseos aumentam e diminuem de tamanho em direção proximodistal.

\section{Gymnocorymbus ternetzi (Boulenger 1895)}

Localidade tipo: Descalvados, Mato Grosso, rio Paraguay, $16^{\circ} 46^{\prime} \mathrm{S}$, 57 $44^{\prime} \mathrm{W}$, Brasil. Material examinado: MZUSP 28065, 5, Brasil, Mato Grosso, Lagoa próxima ao rio Jaurú, Porto Esperidião, bacia do rio Paraguay, MZ. Polomoroeste, 15/11/1983. MZUSP 96717, 12, Brasil, Mato Grosso, Barão de Melgaço, rio Mutum, entre vila de Mimoso, e Joselândia (Pantanal Paiaguás), bacia do rio Paraguay, 16¹9’30’S, 5549’59’W, F. A. Machado et al., $30 / 09 / 2001$

\section{Caracteres sexuais secundários}

Os caracteres sexuais secundários de G. ternetzi relacionam-se ao comprimento padrão e presença de processos ósseos. 
Comprimento padrão: fêmeas alcançam maiores valores de comprimento padrão em relação aos machos. MZUSP 28065, 2 machos (36.4-38.9 mm CP) e 3 fêmeas (38.9-42.4 mm CP); MZUSP 96717, 9 machos (35.4-38.9 mm CP) e 3 fềmeas (33.4-42.5 mm CP).

Processos ósseos: presentes nas nadadeira anal e pélvica de machos maduros.

Nadadeira anal com até dois (geralmente um) processos ósseos por segmento de hemitriquium do último raio simples ao sétimo raio ramificado, disrtribuindo-se em $19 \%$ dos raios ramificados (até 36 raios ramificados). Último raio simples com processos ósseos do nono segmento mais proximal até o décimo segundo segmento, sexto segmento proximal à extremidade distal do raio. Raios ramificados com processos ósseos presentes e restritos a segmentos distais à primeira bifurcação. Processos ósseos presentes também em segmentos distais à segunda bifurcação do ramo posterior da primeira bifurcação. Distalmente à primeira bifurcação e proximalmente às segunda ramificações, os processos ósseos estão presentes e restritos a todos os segmentos do ramo posterior. Distalmente à segunda bifurcação do ramo posterior da primeira bifurcação, os processos ósseos estão presentes e restritos a até três segmentos do ramo posterior, imediatamente distais à bifurcação. Processos ósseos assimétricos bilateralmente. Inserção dos processos ósseos ovalada proximodistalmente. Em todos os segmentos, os processos ósseos estão inseridos na face lateroposterior em relação à nadadeira. Os processos ósseo desenvolvem-se perpendicularmente ao eixo proximodistal do segmento. Processos ósseos geralmente retos ao longo de seu comprimento total. Em secção transversal, os processos ósseos variam de ovalado proximodistalmente a cilíndricos ao longo de seu comprimento total, afilando-se gradualmente e terminando em uma extremidade arredondada.posntiaguda. Em seu estado máximo de desenvolvimento, seu comprimento total não alcança o comprimento proximodistal do segmento no qual está inserido. Na nadadeira anal os processos aumentam e diminuem gradualmente de tamanho em direção 
anteroposterior; primeiro e segundo raio ramificado com maior número de segmentos com processos ósseos e maiores processos ósseos. No raio os processos ósseos aumentam e diminuem discretamente de tamanho em direção proximodistal.

Nadadeira pélvica com processos ósseos presentes e restritos a segmentos do hemitriquium ventral. Nadadeira pélvica com até dois (geralmente um) processos ósseos por segmento no hemitriquium ventral do primeiro raio ao quarto raio ramificado, disrtribuindo-se em $57 \%$ dos raios da nadadeira (7 raios ramificados). Raios ramificados com processos ósseos presentes e restritos a segmentos distais à primeira bifurcação. Processos ósseos presentes também em segmentos distais à segunda bifurcação do ramo medial da primeira bifurcação. Distalmente à primeira bifurcação e proximalmente às segundas ramificações, os processos ósseos estão presentes e restritos a até quatro segmentos do ramo medial, imeditamente proximais à segunda bifurcação deste ramo. Distalmente à segunda bifurcação do ramo medial da primeira bifurcação, os processos ósseos estão presentes e restritos a até três segmentos do ramo medial, imediatamente distais à bifurcação. Processos ósseos assimétricos bilateralmente. Em todos os segmentos, os processos ósseos estão inseridos na face medial/lateromedial. Processos ósseos com inserção arredondada. Os processos ósseos se desenvolven perpendicularmente à sua inserção no segmento no qual está inserido. Processos geralmente retos. Em secção transversal, os processos ósseos são cilíndricos, diâmetro se mantem ao longo de seu comprimento proximodistal, extremidade distal arredondada. Em seu estado máximo de desenvolvimento, seu comprimento total não alcança o comprimento proximodistal do segmento no qual se insere. Na nadadeira pélvica o processos ósseos diminuem discretamente de tamanho em direção lateromedial; primeiro e segundo raio ramificado com o maior número de segmentos com processos ósseos e maiores processos 
ósseos. Nos raios os processos ósseos aumentam e diminuem de tamanho em direção proximodistal.

\section{Hemigrammus bleheri Géry \& Mahnert, 1986}

Fig. 163 e 164

Localidade tipo: Middle rio Negro, Amazonas, Brasil.

Material examinado: MZUSP 29435, 6675, Brasil, Amazonas, ro Negro, confluência com o rio Urubaxi, bacia do rio Negro, 00³1'00”S, 6450’00”W, M. Goulding, 08/02/1980.

\section{Caracteres sexuais secundários}

Os carateres sexuais secundários em $H$. bleheri relacionam-se ao comprimento padrão, formato de nadadeiras e presença de processos ósseos.

Comprimento padrão: fêmeas alcançam maiores valores de comprimento padrão em relação aos machos. MZUSP 33 machos (24.9-29.8 mm CP) e 16 fêmeas 25.3-30.2 mm CP).

Formato de nadadeira: Machos diferem de fêmeas pelo formato do perfil da margem distal da nadadeira anal.

Perfil da margem distal da nadadeira anal de machos com lobo anterior ligeiramente convexo. Lobo anterior formado pelo aumento discreto de tamanho do último raio simples so segundo raio ramificado (raio mais longo) e diminuição gradual deste ao quinto raio ramificado; perfil reto deste ponto ao último raio ramificado, devido à redução gradual de tamanho em direção anteroposterior. Perfil da margem distal da nadadeira anal de fêmeas com lobo anterior côncavo. Lobo anterior formado pelo aumento gradual do último raio simples ao segundo raio ramificado (raio mais longo) e diminuição gradual deste ao quinto raio ramificado; perfil reto 
$\overline{\text { deste ponto até o último raio ramificado, devido à redução gradual de tamanho em direção }}$ anteroposterior.

Processos ósseos: presentes na nadadeira anal de machos.

Nadadeira anal com um processo ósseo por segmento de hemitriquium do primeiro ao quinto raio ramificado, distribuindo-se em até $36 \%$ dos raios ramificados (até 14 raios ramificados). Raios ramifcados com processos ósseos presentes tanto em segmentos proximais quanto distais à primeira bifurcação. Proximalmente à primeira bifurcação, os processos ósseos estão presentes em até um segmento. Distalmente à primeira bifurcação, os processos ósseos estão presentes e restritos a um segmento do ramo posterior, com um segmento sem processo ósseo intercalado. Processos ósseos com simétricos bilateralmente. Processos ósseos com inserção ovalada proximodistalmente. O maior comprimento de sua inserção, $60 \%$ do comprimento proximodistal do segmento no qual está inserido. Em todos os segmentos, os processos ósseos estão inseridos na face lateroposterior em relação à nadadeira. Os processos ósseos desenvolvem-se perpendicularmente à sua inserção no segmento. Em seu um quarto (1/4) proximal de seu comprimento total, os processos ósseos sofrem uma curvatura de $47^{\circ}$ e desenvolvem-se em direção proximal em relação ao segmento no qual estão inseridos. Em secção transversal, os processos ósseos variam de ovalados proximodistalmente a cilíndricos em direção proximodistal ao longo de seu comprimento total, afilando-se gradualmente e terminando em uma extremidade distal arredondada. $\mathrm{O}$ diâmetro de sua extremidade distal equivale a 15\% do maior comprimento de sua inserção no segmento no qual está inserido. Em seu estado máximo de desenvolvimento, seu comprimento total não ultrapassa o comprimento proximodistal do segmento no qual se insere. O comprimento do maior processo ósseo equivale a $84 \%$ do comprimento proximodistal do segmento no qual está inserido. Na nadadeira anal os processos aumentam e 
$\overline{\text { diminuem gradualmente de tamanho em direção anteroposterior; terceiro raio com maior o }}$ número de segmentos com processos ósseos e maiores processos ósseos. No raio os processos ósseos diminuem acentuadamente de tamanho em direção proximodistal; o maior processo ósseos está presente no primeiro segmento distal à primeira bifurcação, metade proximal da série de processos ósseos.

\section{Hemigrammus rhodostomus Ahl, 1924}

Figs. 165 e 166

Localidade tipo: Pará, Brasil.

Material examinado: MZUSP 17997, 152, Brasil, Pará, Badajós, ;agp Bernardinho, perto de Badajós, rio Capim, EPA, 20/08/1970.

\section{Caracteres sexuais secundários}

Os caracteres sexais secundários de H. rhodostomus relacionam-se ao comprimento padrão, formato de nadadeiras e presença de processos ósseos.

Comprimento padrão: fêmeas alcançam maiores valores de comprimento padrão em relação aos machos. MZUSP 17997, 7 machos (26.1-27.1 mm CP) e 150 fêmeas (16.1-31.2 mm CP). Formato de nadadeiras: machos diferem de fêmeas pelo perfil da margem distal da nadadeira anal.

Perfil da margem distal da nadadeira anal de machos praticamente reto reto, com lobo anterior ligeiramente convexo muito discreto. Lobo anterior formado pelo aumento discreto do último raio simples ao segundo raio ramificado (ramio mais longo) e diminuição gradual deste ao ao quinto raio ramificado; perfil reto deste ponto ao último raio ramificado, devido à redução gradual de tamanho em direção anteroposterior. Perfil da margem distal da nadadeira anal de 
fêmeas com lobo anterior côncavo conspícuo. Lobo lobo anterior formado pelo aumento graudal do último raio simples ao segundo raio ramificado (raio mai longo) e diminuição acentuada deste ao quinto raio ramificado; perfil reto do sexto ao último raio ramificado, devido à redução gradual de tamanho em direção anteroposterior.

Processos ósseos: presentes na nadadeira anal de machos.

Nadadeira anal com um processo ósseo por segmento de hemitriquium do primeiro ao oitavo raio ramificado, distribuindo-se em até $61 \%$ dos raios ramificados (até 13 raios ramificados). Raios ramifcados com processos ósseos presentes tanto em segmentos proximais quanto distais à primeira bifurcação. Proximalmente à primeira bifurcação, os processos ósseos estão presentes em até um segmento (primeiro raio ramificado), demais raios ramificados com processos ósseos restritos a segmentos distais à primeira bifurcação. Distalmente à primeira bifurcação, os processos ósseos estão presentes e restritos a até três segmentos do ramo posterior, sempre com um segmento sem processos ósseos intercalado com segmentos com processos ósseos. Processos ósseos simétricos bilateralmente. Processos ósseos com inserção ovalada proximodistalmente. O maior comprimento de sua inserção ocupa $55 \%$ do comprimento proximodistal do segmento no qual está inserido. Em todos os segmentos os processos ósseos estão inseridos na face lateroposterior em relação à nadadeira. Os processos ósseos desenvolvem-se perpendicularmente ao eixo proximodistal do segmento. Ao longo de seu comprimento total, os processos ósseos sofrem uma curvatura de $45^{\circ}$ e desenvolvem-se em direção proximal (ligeiramente medial) em relação ao segmento no qual está inserido. Em secção transeversal, os processos ósseos variam de ovalados proximodistalmente a cilíndricos ao longo de seu comprimento total, afilando-se gradualmente e terminando em uma extremidade distal arredondada. O diâmetro de sua extremidade distal equivale a $22 \%$ do maior comprimento de sua inserção no segmento no qual está inserido. Em seu estado 
$\overline{\text { máximo de desenvolvimento, seu comprimento total alcança mas não ultrapassa o }}$ comprimento proximodistal do segmento no qual se insere. O comprimento do maior processo ósseo equivale a $63 \%$ do comprimento proximal do segmento no qual está inserido. Na nadadeira anal os processos aumentam e diminuem gradualmente de tamanho em direção anteroposterior; terceiro raio ramificado com maior número de segmentos com processos ósseos e maiores processos ósseos. No raio os processos ósseos diminuem acentuadamente de tamanho em direção proximodistal; o maior processo ósseos está inserido no primeiro segmento distal à bifurcação, na metade proximal da série de segmentos.

\section{Hemigrammus ulreyi (Boulenger 1895)}

Figs. 167 a 170

Localidade tipo: Descalvados, Mato Grosso, Brasil.

Material examinado: MZUSP 75113, 10, Brasil, Mato Grosso, Itiquira, Lagoas entre os rio Piquiri e Itiquira, fazenda Santo Antônio do Paraíso, bacia do rio Paraguay, J. C. Oliveira \& J. H. B. Medeiros, 10/1984. MZUSP 59538, 206, Brasil, Mato Grosso do Sul, Rio Verde de M. G. Anhuma, abaixo da esrada, menor conexão, com o canal, principal, 199'67’S, 55¹7’86”W, A. Machado \& B. Chernoff, 28/08/1998.

\section{Caracteres sexuais secundários}

Os caracteres sexuais secundários de H. ulreyi relacionam-se com o comprimento padrão, formato de nadadeiras e presença de processos ósseos.

Comprimento padrão: fêmeas alcançam maiores valores de comprimento padrão em relação aos machos. MZUSP 59538, 8 machos (28.8-29.7 mm CP) e 24 fêmeas (25.6-31.2 mm CP); 
MZUSP 75113, 5 (2 corados) machos (22.9-29.63 mm CP) e 5 (2 corados) fêmeas (30.2-33.9 $\mathrm{mm} \mathrm{CP).}$

Formato de nadadeiras: machos diferem de fêmeas pelo comprimento da nadadeira pélvica. Extremidade distal do primeiro raio ramificado (raio mais longo) da nadadeira pélvica de machos maduros alcança o segundo ou terceiro raio ramificado da nadadeira anal.

Extremidade distal do primeiro raio ramificado (raio mais longo) da nadadeira pélvica de fêmeas maduras alcançam a origem da nadadeira anal de machos, mas não ultrapassa o último raio simples.

Processos ósseos: presentes nas nadadeiras anal e pélvica de machos maduros.

Nadadeira anal com um processo ósseo por segmento de hemitriquium do último raio simples ao terceiro raio ramificado, disrtribuindo-se em até $13 \%$ dos raios ramificados (até 24 raios ramificados). Último raio simples com processos ósseos do sexto ao vigésimo segmento, segmento mais proximal até o segmento mais distal do raio. Processos ósseos presentes tanto em segmentos proximais quanto distais à primeira bifurcação. Processos ósseos presentes também distalmente à segunda bifurcação dos ramos anterior e posterior da primeira bifurcação. Proximalmente à primeira bifurcação, os processos ósseos estão presentes em até três segmentos. Distalmente à primeira bifurcação e proximalmente às segunda ramificações, os processos ósseos estão presentes em todos os segmentos do ramo posterior e em até dois segmentos do ramo anterior, imediatamente proximal à bifurcação. Distalmente à segunda bifurcação do ramo posterior da primeira bifurcação, os processos ósseos estão presentes em todos os segmentos dos ramos anterior e posterior. Distalmente à segunda bifurcação do ramo anterior da primeira raificação, os processos ósseos estão presentes em todos os segmentos do ramo posterior e em até dois segmentos do ramo anterior, mais distais do ramo. Processos ósseos com simétricos beilateralmente. Processos ósseos com inserção ovalada 
proximodistalmente. O maior comprimento de sua inserção ocupa $55 \%$ do comprimento proximodistal do segmento no qual está inserido. Em todos os segmentos, os processos ósseos estão inseridos na face posterior/lateroposterior, com exceção dos segmentos do ramo anterior da segunda bifurcação do ramo posterior da primeira bifurcação, no qual os processos ósseos estão inseridos na face anterior em relação à nadadeira e do segmento imediatamente proximal à segunda bifurcação do ramo posterior da primeira bifurcação, no qual os processos ósseos estão inseridos tanto na face posterior quanto na face anterior. Os processos ósseos desenvolvem-se perpendicularmente à sua inserção no segmento. Ao longo de seu comprimento total, os processos ósseos sofrem uma curvatura de $45^{\circ}$ e desenvolvem-se em direção proximl (ligeiramente lateral) em relação ao eixo proximodistal do segmento no qual estão inseridos. Em secção transversal, os processos ósseos variam de ovalados proximodistalmente a cilíndricos em direção proximodistal, afilando-se gradualmente e terminando em uma extremidade pontiaguda. O diâmetro de sua extremidade distal equivale a 14\% do maior comprimento da inserção no segmento no qual está inserido. Em seu estado máximo de desenvolvimento, seu comprimento total não alcança o comprimento proximodistal do segmento no qual está isnerido. O comprimento do maior processo ósseo equivale a $76 \%$ do comprimento proximodistal do segmento no qual está inserido. $\mathrm{Na}$ nadadeira anal os processos aumentam e diminuem gradualmente de tamanho em direção anteroposterior; segundo raio ramificado com maior número de segmentos com processos ósseos e maiores processos ósseos. No raio os processos ósseos diminuem visivelmente de tamanho em direção proximodistal; o maior processo ósseos está presente no terceiro segmento proximal à primeira bifurcação, na extremidade proximal da série de processos ósseos. 
Nadadeira pélvica com processos ósseos presentes e restritos aos segmentos do hemitriquium ventral. Nadadeira pélvica com um processo ósseo por segmento no hemitriquium ventral do raio simples ao sétimo raio ramificado, disrtribuindo-se em $100 \%$ dos raios ramificados (sete raios ramificados). Raios simples com processos ósseos do segndo segmento ao décimo quarto segmentos, segmento mais distal do raio. Raios ramificados com processos ósseos presentes tanto em segmentos proximais quanto em segmentos distais à primeira bifurcação nos dois primeiros raios ramificados. Do terceiro ao sétimo raio ramificado os processos ósseos estão restritos ao segmentos distais à segunda bifurcação dos ramos medial e lateral da primeira bifurcação. Processos ósseos presentes também em segmentos distais à segunda bifurcação dos ramos medial e lateral da primeira bifurcação. Proximalmente à primeira bifurcação, os processos estão presentes em até três segmentos. Distalmente à primeira bifurcação e proximalmente às segundas ramificações, os processos ósseos estão presentes e restritos a todos os segmentos do ramo medial. Distalmente à segunda bifurcação do ramo medial da primeira bifurcação, os processos ósseos estão presentes em todos os segmentos do ramo medial e em até três segmentos do ramo lateral, mais distais do ramo. Distalmente à segunda bifurcação do ramo lateral da primeira bifurcação, os processos ósseos estão presentes em até três segmentos do ramos medial e lateral, mais distais do ramo. Processo ósseo com inserção ovalada proximodistalmente. O maior comprimento da inserção do processo ósseo ocupa 57\% do comprimento proximodistal do segmento no qual está inserido. Em todos os segmentos, os processos estão inseridos na face medial, com exceção dos segmentos dos ramo lateral da segunda bifurcação dos ramos medial e lateral da primeira bifurcação, no qual os processos estão inseridos tanto na face medial quanto lateral. Os processos ósseos desenvolvem-se perpendicularmente à sua inserção no segmento no qual está inserido. Ao longo de seu comprimento total, os processos 
ósseos sofrem uma curvatura de $60^{\circ}$ e desenvolvem-se em direção proximal em relação ao segmento no qual estão inseridos. Em secção transversal, os processos ósseos variam de ovalados proximodistalmente a cilíndricos ao longo de seu comprimento total, afilando-se gradualmente e terminando em uma extremidade pontiaguda. O diâmetro de sua extremidade distal equivale a $14 \%$ do maior comprimento de sua inserção no segmento no qual está inserido. Em seu estado máximo de desenvolvimento, seu comprimento total não alcança o comprimento proximodistal do segmento no qual está inserido. O comprimento do maior processo ósseos equivale a $62 \%$ do comprimento proximodistal do segmento no qual está inserido. Na nadadeira pélvica o processos ósseos aumentam discretamente de tamanho do primeiro ao segundo raio ramificado e diminuem visivelmente deste ao terceiro raio ramificado; deste raio até o sétimo raio ramificado os processos apresentam tamanhos semelhantes; primeiro e segundo raio ramificado com o maior número de segmentos com processos ósseos e maiores processos ósseos. Nos raios os processos ósseos aumentam e diminuem de tamanho em direção proximodistal; o maior processo ósseo está presente no terceiro segmento distal à primeira bifurcação.

\section{Hemigrammus unilineatus (Gill, 1858)}

Figs. 171 a 173

Localidade tipo: Ilha Trindade, Índias ocidentais.

Material examinado: MZUSP 105777, 69, Brasil, Barcarena, igarapé de reserva ecológica, na estrada próximo à Caripi, bacia do rio Tocantins, $1^{\circ} 29^{\prime} 58.0^{\prime} ’ \mathrm{~S}, 48^{\circ} 42^{\prime} 8.0^{\prime}$ W, M. Marinho \& D. Bastos, 09/04/2010.

\section{Caracters sexuais secundários}


$\overline{\text { Os caracteres sexuais secundários de } H \text {. unilineatus relacionam-se ao comprimento padrão, }}$ formato de nadadeiras e presença de processos ósseos.

Comprimento padrão: fêmeas alcançam maiores valores de comprimento padrão em relação aos machos. MZUSP 106777, 27 machos (28.3-29.6 mm CP) 42 (34.9-39.2 mm CP).

Formato de adadeiras: machos difrem de fêmeas pelo formato da nadadeira pélvica.

Extremidade do primeiro raio ramificado (raio mais longo) da nadadeira pélvica de machos alcança o primeiro raio ramificado da nadadeira anal. Extremidade distal do primeiro raio ramificado (raio mais longo) da nadadeira pélvica de fêmeas alcança no máximo a origem da nadadeira anal.

Processos ósseos: presentes nas nadadeiras anal e pélvica de machos mauduros.

Nadadeira anal com até quatro (geralmente três) processos ósseos por segmento de hemitriquium do último raio simples ao oitavo raio ramificado, disrtribuindo-se em $31 \%$ do total de raios ramificados (até 26 raios ramificados). Último raio simples com processos ósseos do sexto segmento até o decimo nono segmento, segmento mais distal do raio. Primeiro raio ramificado com processos ósseos presentes tanto em segmentos proximais quanto distais à primeira bifurcação; demais raios ramiicados com processos ósseos restritos a segmentos distais à primeira bifurcação. Processos ósseos presentes também em segmentos distais à segunda bifurcação dos ramos anterior e posterior da primeira bifurcação. Proximalmente à primeira bifurcação, os processos ósseos estão presentes em até quatro segmentos. Distalmente à primeira bifurcação e proximalmente às segunda ramificações, os processos ósseos estão presentes em todos os segmentos do ramo posterior e em até três segmentos do ramo anterior, imediatamente proximais à segunda bifurcação deste ramo. Distalmente à segunda bifurcação do ramo posterior da primeira bifurcação, os processos ósseos estão presentes em todos os segmentos dos ramos anterior e posterior. Distalmente à 
segunda bifurcação do ramo anterior da primeira raificação, os processos ósseos estão presentes em todos os segmentos do ramo posterior e em até três segmentos do ramo anterior, mais distais deste ramo. Processos ósseos assimétricos bilateralmente. Processos ósseos com inserção arredondada. O diâmetro de sua inserção ocupa 7\% do comprimento proximodistal do segmento no qual está inserido. Em todos os segmentos, os processos ósseos estão inseridos na face posterior, com exceção de dois segmentos do ramo posterior da primeira bifurcação imediatamente proximais à segunda bifurcação deste ramo, no qual os processos ósseos estão inseridos tanto na face posterior quanto na face anterior e daqueles do ramo anterior da segunda bifurcação do ramo posterior da primeira bifurcação, no qual os processos ósseos estão inseridos na face anterior. Processos ósseos geralmente retos, desenvolvem-se tanto em direção proximal quanto distal em relação ao eixo proximodistal do segmento. Em secção transversal, os processos ósseos são cilíndricos ao longo e seu comprimento total, o diâmetro se mantem ao longo de seu comprimento proximodistal, extremidade distal arredondada. O diametro de sua extremidade distal equivale a $42 \%$ do diâmetro de sua inserção no segmento no qual está inserido. Em seu estado máximo de desenvolvimento, seu comprimento total não alcança o comprimento proximodistal do segmento no qual está inserido. O comprimento do maior processo ósseo equivale a $32 \%$ no comprimento proximodistal do segmento no qual stá nserido. Na nadadeira anal os processos aumentam e diminuem gradualmente de tamanho em direção anteroposterior; primeiro segmento com maior número de segmentos com processos ósseos e maiores processos ósseos. No raio os processos ósseos aumentam e diminuem discretamente de tamanho em direção proximodistal; o maior processo ósseos esta no terceiro segmento proximal à segunda bifurcação do ramo posterior da primeira bifurcação, na metade/metade proximal. 
Nadadeira pélvica com processos ósseos presentes e restritos aos segmentos do hemitricuium ventral. Nadadeira pélvica com até três (geralmente dois) processos ósseos por segmento no hemitriquium ventral do raio simples ao sétimo raio ramificado, odisrtribuindose em $100 \%$ dos raios ramificados (sete raios ramificados). Raios simples com processos ósseos do sexto ao décimo nono segmento, segmento mais distal do raio. Raios ramificados com processos ósseos presentes tanto em segmentos proximais quanto distais à primeira bifurcação nos dois primeiros raios ramificados. Do terceiro ao sétimo raio ramificado os processos ósseos estão restritos ao segmentos distais à primeira bifurcação. Proximalmente à primeira bifurcação, os processos estão presentes em até dois segmentos. Processos ósseos presentes também em segmentos distais à segunda bifurcação dos ramos medial e lateral da primeira bifurcação. Distalmente à primeira bifurcação e proximalmente às segundas ramificações, os processos ósseos estão presentes em todos os segmentos do ramo medial e em até três segmentos do ramo lateral, imediatamente proximais à segunda bifurcação deste ramo. Distalmente à segunda bifurcação do ramo medial da primeira bifurcação, os processos ósseos estão presentes em todos os segmentos dos ramos medial e lateral. Distalmente à segunda bifurcação do ramo lateral da primeira bifurcação, os processos ósseos estão presentes em todos os segmentos do ramo medial e em até seis segmentos (mais distais) do ramo lateral, a partir do segundo segmento distal à bifurcação. Processos ósseos com inserção arredondada. Diâmentro de sua inerção, $7 \%$ do comprimento proximodistal do segmento no qual está inserido. Em todos os segmentos os processos estão inseridos na face medial em relação à nadadeira, com exceção de dois segmentos do ramo medial da primeira bifurcação (imediatamente proximais à segunda bifurcação deste ramo), no qual os processos estão inseridos tanto na face medial quanto lateral e dos segmentos do ramo lateral da segunda bifurcação do ramo medial da primeira bifurcação, no qual os processos ósseos estão 
inseridos na face lateral, três segmentos mais distais com processos ósseos tanto na face medial uquanto na face lateral. Processos geralmente retos e desenvolvem-se tanto proximalmente quanto distalmente em relação ao eixo proximodistal do segmento. Em secção transversal, os processos ósseos são cilíndricos, o diâmetro se mantem ao longo de seu comprimento total e termina em um extremidade distal arredondada. O diâmetro de sua extremidade distal equivale a $50 \%$ do diâmetro de sua inserção. Em seu estado máximo de desenvolvimento, seu comprimento totalnão alcança o comprimento proximodistal do segmento no qual está inserido. O comprimento do maio processo ósseo equivale a $13 \%$ do comprimento proximodistal do segmento no qual está inserido. Na nadadeira pélvica os processos ósseos aumentam e diminuem discretamente de tamanho em direção lateromedial; segundo e terceiro raio ramificado com o maior número de segmentos com processos ósseos e maiores processos ósseos. Nos raios os processos ósseos aumentam e diminuem de tamanho em direção proximodistal; o maior processo ósseos está no segmento imediatamente proximal à segunda bifurcação do ramo medial da primeira bifurcação, na metade da série de processos ósseos.

\section{Hyphessobrycon herbertaxelrodi Géry 1961}

Figs. 174 a 176

Localidade tipo: Coxim no rio Taquary (= Taquari), bacia do rio Paraguay, Mato Grosso, Brasil.

Material examinado: MZUSP 103764, 20, Brasil, Mato Grosso do Sul, Coxim, Córrego Aldeia, bacia do Alto Taquari, 18²8’50'S, 5440’37’W, Fujihara César, 09/12/2007. MZUSP 103837, 50, Brasil, Mato Grosso do Sul, Coxim, córrego Toni, estrada de terra 
Coxim Pedro Gomes, bacia do Alto Taquari, 18²9’2.0”S, 54³8’54.0”W, Fujihara, $22 / 06 / 2007$.

\section{Caracteres sexuais secundários}

Os caracteres sexuais secundários em $H$. herbertaxelrodi relacionam-se ao comprimento padrão, formato de nadadeiras e presença de processos ósseos.

Comprimento padrão: fêmeas alcançam maiores valores de comprimento padrão em relação aos machos. MZUSP 103764, 7 machos (21.7-23.2 mm CP) e 13 fêmeas (19.5-26.2 mm CP); MZUSP 103837, 11 machos (18.2-22.1 mm CP) e 39 (18.3-26.9 mm CP).

Formato de nadadeiras: machos diferem de fêmeas pelo formato da nadadeira pélvica.

Extremidade distal do primeiro raio ramificado (mais longo) da nadadeira pélvica de machos alcança o segundo raio ramificado da nadadeira anal. Nadadeira pélvica sobrepõe o orifício urogenital em vista ventral. Extremidade distal do primeiro raio ramificado (mais longo) da nadadeira pélvica de fêmeas alcança a origam da nadadeira anal, mas não ultrapassa o primeiro raio ramificado. Nadadeira pélvica não sobrepõe o orifício urogenital em vista ventral.

Processos ósseos: presentes nas nadadeiras anal e pélvica de machos.

Nadadeira anal com até dois (geralmente um) processos ósseos por segmento de hemitriquium do último raio simples ao nono raio ramificado, disrtribuindo-se em até $43 \%$ dos raios ramificados (até 21 raios ramificados). Último raio simples com processos ósseos do sexto segmento mais proximal até o décimo segundo segmento, quarto segmento proximal à extremidade distal do raio. Raios ramificados com processos ósseos presentes tanto em segmentos proximais quanto em segmentos distais à primeira bifurcação. Processos ósseos presentes também em segmentos distais à segunda bifurcação do ramo anterior da primeira bifurcação. Proximalmente à primeira bifurcação, os processos ósseos estão presentes em até 
$\overline{\text { dois segmentos (no primeiro raio ramificado); demais raios ramificados com processos }}$ restritos a segmentos distais à primeira bifurcação. Distalmente à primeira bifurcação e proximalmente às segunda ramificações, os processos ósseos estão presentes em todos os segmentos do ramo posterior e em até um segmento do ramo anterior, imediatamente proximal à segunda bifurcação deste ramo. Distalmente à segunda bifurcação do ramo anterior da primeira bifurcação, os processos ósseos estão presentes e restritos a até três segmentos do ramo anterior, a partir do segundo segmento distal à bifurcação. Processos ósseos simétricos bilateralmente. Em todos os segmentos, os processos ósseos estão inseridos na face posterior, com exceção dos segmentos do ramo anterior da segunda bifurcação do ramo anterior da primeira bifurcação. Processos ósseos com inserção ovalada proximodistalmente. O maior comprimento de sua inserção ocupa $32 \%$ do comprimento proximodistal do segmento no qual está inserido. Os processos ósseos desenvolvem-se perpendicularmente à sua inserção no segmento. Ao longo de seu comprimento total, os processos ósseos sofrem uma curvatura de $35^{\circ}$ e desenvolvem-se em direção proximal em relação ao segmento no qual estão inseridos. Em secção transversal, os processos ósseos variam de ovalados proximodistalmente a cilíndricos em direção proximodistal, afilando-se gradualmente e terminando em uma extremidade distal arredondada. O diâmetro de sua extremidade distal equivale a $14 \%$ do maior compriemro de sua inerção no segmento no qual está inserido. Em seu estado máximo de desenvolvimento, seu comprimento total não alcança o comprimento proximodistal do segmento no qual se insere. O comprimento do maior processo ósseo equivale a $24 \%$ do comprimento proximodistal do segmento no qual está inserido. Na nadadeira anal os processos aumentam e diminuem gradualmente de tamanho em direção anteroposterior; segundo e terceiro processos ósseos com maior número de segmentos com processos ósseos e maiores processos. No raio os processos ósseos aumentam e 
$\overline{\text { diminuem de tamanho em direção proximodistal; o maior processo ósseos está no terceiro }}$ segmento distal à primeira bifurcação, na metade proximal à série de processos ósseos.

Nadadeira pélvica com processos ósseos presentes e restritos a segmentos da hemiqtriquia ventral. Nadadeira pélvica com até dois processos ósseos por segmento no hemitriquium ventral do raio simples ao terceiro raio ramificado, distribuindo-se em $43 \%$ dos raios ramificados (sete raios rmaificados). Raio simples com processos ósseos em todos os segmentos do raio. Raios ramificados com processos ósseos tanto em segmentos proximais quanto distais à primeira bifurcação. Processos ósseos presentes também em segmentos distais à segunda bifurcação do ramo lateral da primeira bifurcação. Proximalmente à primeira rmamificação, os processos ósseos estão presentes em até quatro segmentos, inclusive o mais proximal, mais longo. Segmentos mais proximal, com até dois segmentos em sa porção distal, em todos os raios com processos ósseos. Distalmente à primeira bifurcação e proximalmente às segundas ramificações, os processos ósseos estão presentes em todos os segmentos do ramo medial e em a até cinco segmentos do ramo lateral, imediatamente proximais à segunda bifurcação deste ramo. Em todos os segmentos, os processos ósseos estão inseridos na face ventromedial em relação à nadadeira. Processos ósseos com inserção ovalada proximodistalmente. O maior comprimento de sua inserção ocupa $30 \%$ do comprimento proximodistal do segmento no qual está inserido. Os processos ósseos desenvolvem-se perpendicularmente à sua inserção no segmento. Ao longo de seu comprimento total, os processos ósseos sofrem uma curvatura de $40^{\circ}$ em direção proximal em relação ao segmento no qual está inserido. Em secção transversal, os processos ósseos variam de ovalados proximodistalmente a cilíndricos ao longo de seu comprimento total, afilando-se gradualmente e terminando em uma extremidade pontiaguda. O diâmtero de sua extremidade distal equivale a $13 \%$ do maior comprimento de sua inserção no segmento no qual está 
inserido. Em seu estado máximo de desenvolvimento, seu comprimento total não alcança o comprimento proximodistal do segmento no qual está inserido. O comprimento do maior processo ósseo equivale a $33 \%$ do comprimento proximodistal do segmento no qual está inserido. Na nadadeira pélvica os processos ósseos aumentam e diminuem discretamente em direção lateromedial; segundo raio ramificado com maior número de segmentos com processos ósseos e maiores processos ósseos. Nos raios os processos ósseos aumentam e diminuem de tamanho em direção proximodistal; o maior processo ósseos está no segundo segmento distal à primeira bifurcação, na metade/metade proximal da série de processos ósseos.

\section{Jupiaba abramoides (Eigenmann 1909)}

Localidade tipo: rio Potaro, Tumatumari, Guyana.

Material examinado: MZUSP 109157, 33, Guyana, Potaro-Siparuni, Rio Kuribrong, arredores do acampamento da base da montanha, $05^{\circ} 24^{\prime} 49^{\prime \prime} \mathrm{N}, 59^{\circ} 31^{\prime} 48^{\prime \prime} \mathrm{W}$, F.C.T. Lima et al., 25-29/03/2011.

\section{Caracteres sexuais secundários}

Os caracteres sexuais secundários em J. abramoides estão elacionados ao comprimento padrão e presença de processos ósseos.

Comprimento padrão: fêmeas alcançam maiores valores de comprimento padrão em relação aos machos. MZUSP 109157, 14 machos (88.2-101.1 mm CP) e 19 Fêmeas (87.8-115.5 mm $\mathrm{CP})$.

Processos ósseos: presentes nas nadadeiras anal e pélvica de machos maduros. 
Nadadeira anal com até dois processos ósseos por segmento de hemitriquium do último raio simples ao nono raio ramificado, disrtribuindo-se em 35\% dos raios ramificados (até 26 raios ramificados). Último raio simples com processos ósseos do oitavo segmento mais proximal até o segmento mais distal do raio. Raios ramificados com processos ósseos presentes e restritos a segmentos distais à primeira bifurcação. Processos ósseos presentes também em segmentos distais à segunda bifurcação dos ramos anterior e posterior da primeira bifurcação. Distalmente à primeira bifurcação e proximalmente às segunda ramificações, os processos ósseos estão presentes e restritos a todos os segmentos do ramo posterior. Distalmente à segunda bifurcação do ramo posterior da primeira bifurcação, os processos ósseos estão presentes em até dez segmentos do ramo posterior em até cinco segmentos do ramo anterior, a partir do segundo segmento distal à primeira bifurcação. Distalmente à segunda bifurcação do ramo anterior da primeira bifurcação, os processos ósseos estão presentes e restritos a até cinco segmentos do ramo posterior, a partir do terceiro ou quarto segmento distal à bifurcação. Processos ósseos simétricos bilateralmente. Processos ósseos com inserção ovalada proximodistalmente. Em todos os segmentos, os processos ósseos estão inseridos na face lateroposterior em relação à nadadeira, com exceção dos segmentos do ramo anterior da segunda bifurcação do ramo posterior da primeira bifurcação, no qual os processos ósseos desenvolvem-se na face lateroanterior em relação à nadadeira. Os processos ósseos desenvolvem-se perpendicularmente à sua inserção no segmento no qual está inserido. Ao longo de seu comprimento total, os processos ósseos sofrem uma curvatura de $45^{\circ} \mathrm{e}$ desenvolvem-se em direção proximal em relação segmento no qual estão inseridos. Em secção ransversal os processos ósseos variam de ovalados proximodistalmente a cilíndricos ao longo de seu comprimento total, afilando-se gradualmente e terminando em uma extremidade distal posntiaguda/arredondada. Em seu estado máximo de desenvolvimento, seu 
comprimento total não alcança o comprimento proximodistal do segmento no qual está inserido. Na nadadeira anal os processos aumentam e diminuem gradualmente de tamanho em direção anteroposterior; segundo e terceiro raio ramificado com maior número de segmentos com processos ósseos e maiores processos ósseos. No raio os processos ósseos aumentam e diminuem de tamanho em direção proximodistal.

Nadadeira pélvica com processos ósseos presentes e restritos a segmentos do hemitriquium ventral. Nadadera pélvica com até dois processos ósseos por segmento (com exceção do segmento mais proximal, mais longo) no hemitriquium ventral do primeiro ao sexto raio ramificado (sete raios ramificados), disrtribuindo-se em $85 \%$ dos raios da nadadeira. Raios ramificados com processos ósseos restritos a segmentos distais à primeira bifurcação. Processos ósseos presentes também em segmentos distais à segunda bifurcação do ramo medial da primeira bifurcação. Distalmente à primeira bifurcação e proximalmente às segundas ramificações, os processos ósseos estão presentes e restritos a até cinco segmentos do ramo medial, imediatamente proximais à segunda bifurcação. Distalmente à segunda bifurcação do ramo medial da primeira bifurcação, os processos ósseos estão presentes e restritos a até oito segmentos do ramo medial, imediatamente distal à bifurcação. Inserção dos processos ovalada proximodistalmente. Em todos os segmentos, os processos ósseos estão inseridos na face ventromedial em relação à nadadeira. Os processos ósseos desenvolvem-se perpendicularmente à sua inserção no segmento no qual está inserido. Ao longo de seu comprimento total, os processo ósseos sofrem uma curvatura gradual em direção proximal em relação ao segmento no qual está inserido. Em secção transversal, os processos ósseos variam de ovalados proximodistalmente a cilíndricos ao longo de seu comprimento total, afilando-se gradualmente e terminando em uma extremidade pontiaguda/arredondada. Em seu estado máximo de desenvolvimento, seu comprimento total não alcança o comprimento 
proximodistal do segmento no qual está inserido. Na nadadeira pélvica os processos ósseos aumentam discretamente de tamanho do primeiro ao segundo raio ramificado e diminuem visivelmente até sétimo raio ramificado; segundo raio ramificado com o maior número de segmentos com processos ósseos e maiores processos ósseos. Nos raios os processos ósseos aumentam e diminuem de tamanho em direção proximodistal.

\section{Jupiaba yarina Zanata 1997}

Figs. 177 a 180

Localidade tipo: Riacho Monjolinho, rio Arinos, Mato Grosso, Brasil.

Material examinado: Parátipo. MZUSP 45363, 20, Brasil, Mato Grosso, Nobres, riacho Formoso, na fazenad Sonho Dourado (sede da fazenda), estrada Nobres-rio Novo, município de Nobres, $14^{\circ} 25^{\prime}$ S, $55^{\circ} 50^{\prime} \mathrm{W}$, N.A. Menezes et al., 25/10/1992.

\section{Caracteres sexuais secundários}

Os caracteres sexuais secundários em $J$. yarina relacionam-se ao comprimento padrão, formato de nadadeiras e presença de processos ósseos.

Comprimento padrão: fêmeas alcançam maiores valores de comprimento padrão em relação aos machos. MZSUP 45363, 11 machos (54.7-63.8 mm CP) e 3 fêmeas (51.7-64.8 mm CP).

Formato de nadadeiras: Machos diferem de fêmeas pelo formato da nadadeira pélvica Extremidade distal do raio simples (raio mais longo) da nadadeira pélvica de machos alcança o segundo ou terceiro raio ramificado da nadadeira anal. Raio simples da nadadeira pélvica de machos mais alongada que os demais raios, formando um pequeno filamento. Extremidade distal do primeiro raio ramificado (raio mais longo) da nadadeira pélvica de fêmeas não alcança a origem da nadadeira anal. 
Processos ósseos: presentes nas nadadeiras anal, pélvica, dorsal e caudal de machos maduros. Nadadeira anal com até dois (geralmente um) processos ósseos por segmento de hemitriquium do penúltimo raio simples ao vigésimo sexto raio ramificado, disrtribuindo-se em até $96 \%$ dos raios ramificados (até 27 raios ramificados). Penúltimo raio simples com processos ósseos nos três segmentos mais distais. Último raio simples com processos ósseos do terceiro ao vigésimo segmento, segmento mais distal do raio. Raios ramificados com processos ósseos presentes tanto em segmentos proximais quanto distais à primeira bifurcação. Processos ósseos presentes também em segmentos distais à segunda bifurcação dos ramos anterior e posterior da primeira bifurcação. Processos ósseos presentes também em segmentos distais à terceira bifurcação do ramo anterior da segunda bifurcação do ramo anterior da primeira bifurcação. Proximalmente à primeira bifurcação, os processos ósseos estão presentes em até três (geralmente um) segmentos. Distalmente à primeira bifurcação e proximalmente às segundas ramificações, os processos ósseos estão presentes em todos os segmentos do ramo posterior e em até quatro segmentos do ramo anterior, imediatamente proximais à segunda bifurcação deste ramo. Distalmente à segunda bifurcação do ramo posterior da primeira bifurcação, os processos ósseos estão presentes em todos os segmentos dos ramos posterior e anterior. Distalmente à segunda bifurcação do ramo anterior da primeira bifurcação, os processos ósseos estão presentes em todos os segmentos dos ramos anterior e posterior. Distalmente à terceira bifurcação do ramo anterior da segunda bifurcação do ramo anterior da primeira bifurcação, os processos ósses estão presentes em todos os segmentos dos ramos anterior e posterior. Processos ósseos assimétricos bilateralmente. Inserção dos processos ósseos ovalada proximodistalmente. O maior comprimento de sua inserção ocupa $28 \%$ do comprimento proximodistal do segmento no qual está inserido. Em todos os segmentos do ramo posterior da primeira bifurcação os processos ósseos estão inseridos na 
$\overline{\text { face lateroposterior, com exceção de três segmentos proximais à segunda bifurcação deste }}$ ramo, no qual os processos ósseos estão inseridos tanto na face lateroposterior quanto na face lateroanterior. Em todos os segmentos do ramo anterior da primeira bifurcação os processos estão inseridos na face lateroanterior, com exceção do segmento imediatamente proximal à segunda bifurcação deste ramo, no qual os processos estão inseridos tanto na face lateroposterior quanto na face lateroanterior. Em todos os segmentos do ramo posterior da segunda bifurcação dos ramos anterior e posterior da primeira bifurcação os processos estão inseridos na face lateroposterior, com exceção de três a quatro segmentos mais distais, no qual os processos se inserem tanto na face lateroposterior quanto lateroanterior. Em todos os segmentos do ramo anterior da segunda bifurcação dos ramos anterior e posterior da primeira bifurcação os processos ósseos estão inseridos na face lateroanterior, com exceção de três a quatro segmentos mais distais, no qual os segmentos estão inseridos tanto na face lateroposterior quanto na face lateroanterior. Em todos os segmentos do ramo anterior da terceira bifurcação do ramo anterior da segunda bifurcação do ramo anterior da primeira bifurcação, os processos ósseos estão inseridos na face lateroanterior, com exceção dos dois segmentos mais distais no qual os processos ósseos estão inseridos tanto na face lateroanterior quanto na face lateroposterior. Em todos os segmentos do ramo posterior da terceira bifurcação do ramo anterior da segunda bifurcação do ramo anterior da primeira bifurcação, os processos ósseos estão inseridos tanto na face lateroanterior quanto na face lateroposterior. Os processos ósseos desenvolvem-se perpendicularmente à sua inserção no segmento. Ao longo de seu comprimento total, os processos ósseos sofrem uma curvatura de $35^{\circ}$ e desenvolvem-se em direção proximal (ligeiramente medial) em relação ao segmento no qual estão insridos. Em secção transversal, os processos ósseos variam de ovalado proximodsitalmente a cilíndrico ao longo de seu comprimento total, afilando-se gradualmente 
e terminando em uma extremidade distal pontiaguda/arredondada. O diâmetro de sua extremidade dsital equivale a $19 \%$ do maior comprimento de sua inserção no segmento no qual está inserido. Em seu estado máximo de desenvolvimento, seu comprimento total não alcança o comprimento proximodistal do segmento no qual se insere. O comprimento do maior processo ósseo equivale a $43 \%$ do comprimento proximodistal do segmento no qual está inserido. Na nadadeira anal os processos aumentam e diminuem gradualmente de tamanho em direção anteroposterior; segundo, terceiro raios ramificados com maior número de segmentos com processos ósseos e maiores processos ósseos. No raio os processos ósseos aumentam e diminuem de tamanho em direção proximodistal; o maior processo ósseo está no quint segmento próximal à segunda bifurcação do ramo posterior, na metade proximal da série de processos ósseos.

Nadadeira pélvica com processos ósseos presentes e restritos a segmentos do hemitriquium ventral. Nadadeira pélvica com até dois (geralmente um) processos ósseos por segmento no hemitriquium ventral do raio simples ao sétimo raio ramificado, disrtribuindo-se em $100 \%$ dos raios ramificados (sete raios ramificados). Raio simples com processos ósseos do quinto ao vigésimo terceiro segmento, quinto segmento proximal à extremidade distal do raio. Raios ramificados com processos ósseos tanto em segmentos proximais quanto em segmentos distais à primeira bifurcação. Processos ósseos presentes também em segmentos distais à segunda bifurcação dos ramos medial e lateral da primeira bifurcação. Processos ósseos presentes também em segmentos distais à terceira bifurcação dos ramos medial e lateral da segunda bifurcação do ramo medial da primeira bifurcação. Proximalmente à primeira bifurcação, os processos ósseos estão presentes em até um segmento; no terceiro raio ramificado, a prmeira bifurcação ocorre no raio mais proximal, processo presente na extremidade distal deste segmento. Distalmente à primeira bifurcação e proximalmente à 
segunda bifurcação, os processos ósseos estão presentes em todos os segmentos do ramo medial e em até dois segmentos do ramo lateral, imediatamente proximais à segunda bifurcação deste ramo. Distalmennte à segunda bifurcação do ramo medial da primeira bifurcação os processos ósseos estão presentes em todos os segmentos dos ramos medial e lateral. Distalmente à segunda bifurcação do ramo lateral da primeira bifurcação, os processos estão presentes em todos os segmentos dos ramos lateral e medial. Distalmete à terceira bifurcação dos ramos medial e lateral da segunda bifurcação do ramo medial da primeira bifurcação, os processos ósseos estão presentes em todos os segmentos. Distalmente à terceira bifurcação dos ramos medial e lateral da segunda bifurcação do ramo lateral da primeira bifurcação, os processos ósseos estão presentes em todos os segmentos. Inserção dos processos ósseos arredondada. O diâmetro de sua inserção ocupa 14\% do comprimento total do segmento no qual está inserido. Em todos os segmentos dos ramos medial e lateral da primeira bifurcação, os processos ósseos estão inseridos na face ventromedial. Em todos os segmentos do ramo medial da segunda bifurcação do ramo medial da primeira bifurcação, os processos ósseos estão inseridos na face ventromedial, com exceção de quatro segmentos imediatamente proximais à terceira bifurcação deste ramo, no qual os processos estão inseridos tanto na face ventromedial quanto na face ventrolateral. Em todos os segmentos do ramo lateral da segunda bifurcação do ramo medial da primeira bifurcação, os processos ósseos estão inseridos na face ventrolateral, com exceção de três segmentos imediatamente proximais à terceira bifurcação deste ramo, no qual os processos estão inseridos tanto na face ventromedial quanto na face ventrolateral. Em todos os segmentos dos ramo medial da segunda bifurcação do ramo lateral da primeira bifurcação, os processos ósseos estão inseridos na face ventromedial, com exceção de três segmentos imediatamente proximais à terceira bifurcação deste ramo, no qual os processos estão inseridos tanto na face 
ventromedial quanto na face ventrolateral. Em todos os segmentos dos ramo lateral da segunda bifurcação do ramo lateral da primeira bifurcação, os processos ósseos estão inseridos na face ventrolateral, com exceção de três segmentos imediatamente proximais à terceira bifurcação deste ramo, no qual os processos estão inseridos tanto na face ventromedial quanto na face ventrolateral. Em todos os segementos dos ramos mediais da terceira bifurcação dos ramos lateral e medial da segunda bifurcação dos ramos medial e lateral da primeira bifurcação, os processos estão inseridos na face ventromedial, com exceção de até três segmentos mais distais destes ramos, no qual os processos ósseos estão presentes tanto na face ventromedial quanto na face ventrolateral. Em todos os segmentos dos ramos laterais da terceira bifurcação dos ramos medial e lateral da segunda bifurcação dos ramos medial e lateral da primeira bifurcação, os processos estão inseridos na face ventrolateral, com exceção de até três segmentos mais distais destes ramos, no qual os processos ósseos estão ineridos tanto na face ventromedial quanto na face ventrolateral. Os processos ósseos desenvolvem-se perpendicularmente à sua inerção no segmento. No um quarto $(1 / 4)$ proximal de seu comprimento total, os processos ósseos sofrem uma curvatura de $85^{\circ}$ e se desenovlem em direção proximomedial em relação ao segmento no qual está inserido. Demais processos ósseos geralmente retos, com uma ligeira curvatura em direção proximomedial. Em secção transversal, os processos ósseos são cilíndricos ao longo de seu comprimento, afilando-se gradualmente e terminando em uma extremidade arredondada/pontiaguda. O diâmetro de sua extremidade dsital equivale a $40 \%$ do diâmetro de sua inserção no segmento no qual está inserido. Em seu estado máximo de desenvolvimento, seu comprimento total não alcança o comprimento proximodistal do segmento no qual está inserido. O comprimento do maior processo ósseo equivale a $37 \%$ do comprimento proximodistal do segmento no qual se insere. Na nadadeira pélvica os processos ósseos 
$\overline{\text { aumentam e diminuem de tamanho em direção lateromedial em relação à nadadeira; segundo }}$ e terceiro raio ramificado com o maior número de segmentos com processos ósseos e maiores processos ósseos. Nos raios os processos ósseos aumentam e diminuem de tamanhdo em direção proximodistal; o maior processo ósseos está no segundo segmento distal à bifurcação, metade proximal do raio.

Nadadeira dorsal com um processo ósseo por segmento do último raio simples ao nono raio ramificado, disrtribuindo-se em 100\% do total de raios ramificados (nove raios ramificados). Último raio simples com processos ósseos do vigésimo quinto ao trigésimo segmento, segmento mais distal do raio. Raio ramificado com processos ósseos presentes e restritos a segmentos distais à primeira bifurcação. Processos ósseos presentes também em segmentos distais à segunda rmaificação dos ramos anterior e posterior da primeira bifurcação. Processos ósseos presentes também em segmentos distais à terceira bifurcação do ramo anterior da segunda bifurcação do ramo anterior da primeira bifurcação. Distalmente à primeira bifurcação, os processos ósseos estão presentes e restritos a treze segmentos do ramo posterior (sem segunda bifurcação) a partir do terceiro segmento distal à bifurcação. Distalmente à segunda bifurcação do ramo anterior da primeira bifurcação, os processos ósseos estão presentes em até quatro segmentos do ramo anterior (imediatamente proximal à terceira rmaificaçõ deste ramo) e em sete segmentos do ramo posterior, a partir do quinto segmento distal à bifurcação. Distalmente à terceira bifurcação do ramo anterior da segunda bifurcação do ramo anterior da primeira bifurcação, os processos ósseos estão presentes em todos os segmentos dos ramos anterior e posterior. Processos ósseos com assimétricos bilateralmente. Processos ósseos com inserção arredondada. O diâmetro de sua inserção ocupa $6 \%$ do comprimento proximodistal do segmento no qual está inserido. Nos segementos do ramo anterior da segunda bifurcação do ramo anterior da primeira bifurcação, os processos ósseos 
estão inseridos tanto na face lateroanterior quanto na face lateroposterior. Nos segmentos do ramo posterior da segunda bifurcação do ramo anterior os processos estão inseridos na face lateroposterior, com exceção de quatro segmento mais diatais, no qual os processos estão inseridos tanto na face lateroanterior quanto na face lateroposterior. Nos segmentos do ramo anterior da segunda bifurcação do ramo posterior da primeira bifurcação, os processos estão inseridos na face lateroanterior, com exceção dos sete segmentos mais distais, no qual os processos estão inseridos tanto na face lateroanterior quanto na face lateroposterior. Nos segmentos do ramo posterior da primeira bifurcação do, os processos ósseos estão inseridos na face lateroposterior. Os processo ósseos desenvolvem-se perpendicularmente à sua inserção no segmento. Processos ósseos são geralmente reto. Em secção transversal, os processos ósseos são cilíndricos ao longo de seu comprimento total, afilando-se gradualmente e terminando em uma extremidade arredondada. O diâmetro de sua extremidade distal equivale a $35 \%$ do diâmetro de sua inserção no segmento no qual está inserido. Em seu estado máximo de desenvolvimento, seu comprimento total não alcança o comprimento proximodistal do segmento no qual se insere. O comprimento do maior processo ósseo equivale a $17 \%$ do comprimento proximodistal do segmentos no qual está inserido. Na nadadeira os processos ósseos apresentam tamanho semelhantes em todos os raios; segundo e terceiro raio com maior número de segmentos com processos ósseos. No raio os processos ósseos apresentam tamanhos semelhantes.

\section{Moenkhausia sanctaefilomenae (Steindachnaer 1907)}

Figs. 181 a 183

Localidade tipo: Lagoa em Santa Filomena em rio Parnahyna, Brasil. 
Material examinado: MZUSP 59805, 11, Brasil, Mato Grosso do Sul, Costa Rica, riacho Água Clara, a $3 \mathrm{~km}$ da Fazenda rio Bonito, bacia do rio Paraguay, O. Oyakawa et al., 31/08/1998. MZUSP 88123, 8, Brasil, Mato Grosso, eneral Carneiro, estrada para cachoeira

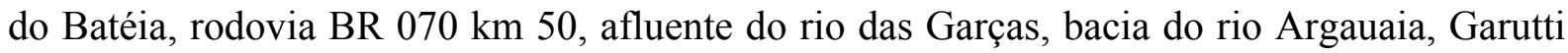
et al., 06/082005.

\section{Caracteres sexuais secundários}

Os caracteres sexuais secundários de M. Sanctafilomenae relacionam-se ao compimento padrão, formato de nadadeiras e presença de processos ósseos.

Comprimento padraão: fêmeas alcançam maiores valores de comprimento padrão em relação aos machos. MZUSP 59805, 9 machos (38.0-56.5 mm CP) e 1 fêmea (57.8 mm CP); MZUSP 88123, 3 machos (55.6-55.9 mm CP) e 5 fêmeas (42.9-59.8 mm CP).

Formato de nadadeiras: Machos diferem de fêmeas pelo comprimento da nadadeira pélvica. Extremidade distal do primeiro raio ramificado (raio mais longo) da nadadeira pélvica de machos alcança o último raio simples da nadadeira anal. Extremidade distal do primeiro raio ramificado (raio mais longo) da nadadeira pélvica de fêmeas não alcança a origem da nadadeira anal.

Processos ósseos: presentes nas nadadeiras anal e pélvica de machos maduros.

Nadadeira anal com até dois (geralmente um) processos ósseos por segmento de hemitriquium do último raio simples ao quinto raio ramificado, disrtribuindo-se em até $21 \%$ dos raios ramificados (até 24 raios ramificados). Último raio simples com processos ósseos do oitavo segmento mais proximal ao vigésimo segmento, terceiro segmento proximal à extremidade distal do raio. Raios ramificados com processos ósseos presentes tanto em segmentos proximais quanto distais à primeira bifurcação. Processos ósseos presentes também distalmente à segunda bifurcação do ramo posterior da primeira bifurcação. 
Proximalmente à primeira bifurcação, os processos ósseos estão presentes em até dois segmentos. Proximalmente à primeira bifurcação, os processos ósseos estão inseridos na face lateroposterior. Distalmente à primeira bifurcação e proximalmente às segunda ramificações, os processos ósseos estão presentes e restritos a todos os segmentos do ramo posterior. Distalmente à segunda bifurcação do ramo posterior da primeira bifurcação, os processos ósseos estão presentes e restritos a até quatro segmentos do ramo posterior. Processos ósseos com assimétricos bilateralmente. Processos ósseos com inserção arredondada. O diâmetro de sua inserção ocupa $11 \%$ do comprimento proximodistal do segmento no qual está inserido. Em todos os segentos, os processos estão inseridos na face lateroposterior. Os processos ósseos se desenvolven perpendicularmente à sua inserção no segmento. Ao longo de seu comprimento total, os processos ósseos sofrem uma curvatura de $30^{\circ}$ e desenvolvem-se em direção proximal em relação ao raio no qual está inserido. Em secção transversal os processos ósseos são cilíndrica ao longo de todo seu comprimento proximodistal, afilando-se gradualmente e terminando em uma extremidade distal arredondada $\mathrm{O}$ diâmetro de sua extremidade distal equivale a $29 \%$ do maior comprimento da inserção no segmeno no qual está inserido. Em seu estado máximo de desenvolvimento, seu comprimento total não alcança o comprimento proximodistal do segmento no qual está inserido. O comprimento do maior processo ósseo equivale a $33 \%$ o comprimento proximodistal do segmento no qual está inserido. Na nadadeira anal os processos aumentam e diminuem gradualmente de tamanho em direção anteroposterior; segundo e terceiro raio ramificado com maior número de segmentos com processos ósseos e maiores processos ósseos. No raio os processos ósseos aumentam e diminuem de tamanho em direção proximodistal; o maior processo ósseos está presente no quarto segmento distal à primeira bifurcação, metade proximal da série de processos ósseos. 
$\overline{\text { Nadadeira pélvica com processos ósseos restritos a segmentos do hemitriquium ventral. }}$ Nadadeira pélvica com até dois (geralmente um) processos ósseos por segmento do primeiro ao segundo raio ramificado, disrtribuindo-se em $29 \%$ dos raios ramificados da nadadeira (7 raios ramificados). Processos ósseos presentes tanto em segmentos proximais quanto distais à primeira bifurcação. Processos ósseos presentes também em segmentos distais à segunda bifurcação do ramo medial da primeira bifurcação. Proximalmente à primeira bifurcação, um processo ósseo está presente, no mais proximal, mais longo. Distalmente à primeira bifurcação, os processos ósseos estão presentes e restritos a até seis segmentos do ramo medial, a partir do segundo segmento distal à bifurcação. Distalmente à segunda bifurcação, os processos ósseos estão presentes e restritos a até cinco segmentos do ramo medial, imediatamente distais à bifurcação. Processos ósseos com inserção arredondada. O maior comprimento da inserção do processo ósseo ocupa $15 \%$ do comprimento proximodistal do segmento no qual está inserido. Em todos os segmentos, os processos ósseos estão inseridos na face ventromedial do segmento no qual está inserido. Os processos ósseos desenvolvem-se perpendicularmente à sua inserção nos segmentos em qu estão inseridos. Ao longo de seu comprimento, os processos ósseos sofrem uma curvatura de $40^{\circ}$ e desenvolvemse em direção proximmedial em relação ao eixo proximodistal do segmento no qual estão inseridos. Em secção transversal, a circunferência dos processos ósseos é cilíndrica ao longo de seu comprimento total, afilando-se gradualmente e terminando em uma extremidade arredondada. O diâmetro de sua extremidade distal equivale a 50\% do maior comprimento de sua inserção no segmento no qual está inserido. Em seu estado máximo de desenvolvimento, seu comprimento total não alcança o comprimento proximodistal do segmento no qual está inserido. O comprimento do maior processo ósseo equivale a $25 \%$ do comprimento proximodistal do segmento no qual está inserido. Na nadadeira pélvica os processos ósseos 
$\overline{\text { diminuem gradualmente de tamanho do primeiro ao segundo raio ramificado; primeiro raio }}$ ramificado com o maior número de segmentos com processos ósseos e maiores processos ósseos. Nos raios, os processos ósseos aumentam e diminuem de tamanho em direção proximodistal; o maior processo ósseos está no terceiro segmento distal à segunda bifurcação, na metade distal da série de processos ósseos.

\section{Moenkhausia xinguensis (Steindachnaer 1882)}

Localidade tipo: rio Xingú, Brasil.

Material examinado: MZUSP 111853, 35, Brasil, Pará, Altamira, praia do rio Xingu, próximo a Cachoeira do Espelho, bacia do rio Xingu, 3³6’31.0”S, 52 21'3.0”W, O. Oyakawa et al., 17/11/2011.

\section{Caracteres sexuais secundários}

Os caracteres sexuais secundários de $M$. Xinguensis relacionam-se ao comprimento padrão e presença de processos ósseos.

Comprimento padrão: fêmeas alcançam maiores valores de comprimento padrão em relação aos machos. MZUSP 111853, 13 machos (40.1-52.9 mm P) e 22 fêmeas (38.8-53.7 mm P).

Processos ósseos: presentes nas nadadeira anal e pélvica de machos maduros.

Nadadeira anal com até dois (geralmente um) processos ósseos por segmento de hemitriquium do último raio simples ao sétimo raio ramificado, disrtribuindo-se em até $29 \%$ dos raios ramificados (até 24 raios ramificados). Último raio simples com processos ósseos nos três segmentos mais distais do raio. Raios ramificados com processos ósseos restrito a segmentos distais à primeira bifurcação. Processos ósseos presentes também distalmente à segunda bifurcação dos ramos anterior e posterior da primeira bifurcação. Distalmente à 
$\overline{\text { primeira bifurcação e proximalmente às segunda ramificações, os processos ósseos estão }}$ presentes em até cinco segmentos do ramo posterior (imediatamente proximais à segunda bifurcação deste ramo) e em até um segmento do ramo anterior (imediatamente proximal à segunda bifurcação deste ramo). Distalmente à segunda bifurcação do ramo posterior da primeira bifurcação, os processos ósseos estão presentes em todos os segmentos do ramo posterior e em até um segmento do ramo anterior, imediatamente distal à bifurcação. Distalmente à segunda bifurcação do ramo anterior da primeira bifurcação, os processos ósseos estão presentes e restritos a até dois segmentos do ramo posterior imediatamente distais à bifurcação. Processos ósseos assimétricos bilateralmente. Processos ósseos com inserção ovalada proximodistalmente. Em todos os segmentos, os processos estão inseridos na face lateroposterior em relação à nadadeira com exceção do segmento do ramo anterior da segunda rbifurcação do ramo posterior da primeira bifurcação, no qual os processos ósseos estão inseridos na face lateroposterior. Os processos ósseos desenvolvem-se perpendicularmente à sua inserção no segmento no qual está inserido. Ao longo de seu comprimento total, os processos ósseos sofrem uma curvatura de $45^{\circ}$ e desenvolvem-se em direção proximal (ligeiramente lateral) em relação ao segmento no qual está inserido. Em secção transversal, os processos ósseos variam de ovalados proximodistalmente a cilíndricos ao longo de seu comprimento total, afilando-se gradualmente e terminando em uma extremidade distal arredondada. Em seu estado máximo de desenvolvimento, seu comprimento total não alcança o comprimento proximodistal do segmento no qual está inserido. Na nadadeira anal os processos aumentam e diminuem gradualmente de tamanho em direção anteroposterior; segundo e terceiro raio ramificado com maior número de segmentos com processos ósseos e maiores processos ósseos. No raio os processos ósseos aumentam e diminuem de tamanho em direção proximodistal. 
$\overline{\text { Nadadeira pélvica comprocessos ósseos presentes e restritos a segmentos do hemitriquium }}$ ventral. Nadadeira pélvica com até dois (geralmente um) processos ósseos por segmento no hemitriquium ventral do primeiro ao sexto raio ramificado, disrtribuindo-se em $85 \%$ dos raios da nadadeira (sete raios ramificados). Raios ramificados com processos ósseos presentes e restritos a segmentos distais à primeira bifurcação. Processos ósseos presentes também em segmentos distais à segunda bifurcação dos ramos medial e lateral da primeira bifurcação. Processos ósseos presentes também em segmentos distais à terceira bifurcação do ramo lateral da segunda bifurcação do ramo medial da primeira bifurcação, à terceira bifurcação dos ramos lateral e medial da segunda bifurcação do ramo lateral da primeira bifurcação. Distalmente à primeira bifurcação, os processos ósseos estão presentes e restritos a até seis segmentos do ramo medial, imeditamente proximais à segunda bifurcação deste ramo.. Distalmennte à segunda bifurcação do ramo medial da primeira bifurcação os processos ósseos estão presentes em até quatro segmentos do ramo medial (imediatamente distais à bifurcação) e em até três segmentos do ramo lateral, imeditamente proximal à terceira bifurcação deste ramo. Distalmente à terceira bifurcação do ramo lateral da segunda bifurcação do ramo medial da primeira bifurcação, os processos ósseos estão presentes em até um segmento do ramo medial, imeditamente distal à bifurcação. Distalmente à segunda bifurcação do ramo lateral da primeira bifurcação, os processos ósseos estão presentes e restritos a até dois segmentos do ramo medial (imediatamente proximal à terceira bifurcação deste ramo). Distalmente à terceira bifurcação do ramo medial da segunda bifurcação do ramo lateral da primeira bifurcação, os processos ósseos estão presentes e restritos a até dois segmentos, imeditamente distais à bifurcação. Distalmente à terceira bifurcação do ramo lateral da segunda bifurcação do ramo lateral da primeira bifurcação, os processos ósseos estão presentes e restritos a até quatro segmentos mais distais do ramo lateral. Sinerção dos processos ósseos arredondada. 
Em todos os segmentos, os processos ósseos estão inseridos na face ventromedial. Os processos ósseos desenvolvem-se perpendicularmente à sua inserção nos segmentos no qual estão inseridos. Ao longo de seu comprimento proximodistal, os processos ósseos sofrem uma curvatura paulatina de aproximadamente $50^{\circ}$ e desenvolvem-se em direção proximomedial em relação ao eixo proximodistal do segmento no qual está inserido. Em secção transversal, os processos ósseos são cilíndricos, afilando-se gradualmente e terminando em uma extremidade arredondada/pontiaguda. Diâmetro da extremidade distal semelhante ao diamtro de sua inserção no segmento no qual està inserido. Em seu estado máximo de desenvolvimento, seu comprimento total não alcança o comprimento proximodistal do segmento no qual está inserido. Na nadadeira pélvica os processos ósseos apresentam tamanho semelhante; segundo e terceiro raio ramificado com o maior número de segmentos com processos ósseos. Nos raios os processos ósseos apresentam tamanhos semelhantes.

\section{Paracheirodon axelrodi (Schultz 1956)}

Localidade tipo: igarapé perto de Tomar, rio Negro, perto de Porto Velho, Brasil.

Material examinado: MZUSP 66717, 35, Brasil, Amazonas, são João, próximo de Tapurucuara, beira de lago de ilha, bacia do rio Negro, EPA, 21/10/1972. MZUSP 63553, 19, Brasil, Amazonas, Santa Isabel do rio Negro, são João, próximo a Tapurucuara (=Santa Isabel), $00^{\circ} 24^{\prime} 00^{\prime} \mathrm{S}, 65^{\circ} 02^{\prime} 00^{\prime \prime} \mathrm{W}, \mathrm{EPA}, 24 / 10 / 1972$.

\section{Caracteres sexuais secundários}

Os caracteres sexuais secundários em $P$. axelrodi esão relacionados ao comprimento padrão, formato de nadadeiras e presença de processos ósseos. 
Comprimento padrão: fêmeas alcançam maiores valores de comprimento padrão em relação aos machos. MZUSP 66717, 2 machos (19.3-22.9 mm CP) e 33 fêmeas (19-25 mm CP); MZUSP 63553, 6 machos (18.8-23 mm CP) e 9 fêmeas (19.9-25 mm CP).

Formato de nadadeiras: machos diferem de fêmeas pelo formato do perfil da margem distal da nadadeira anal e pelo formato da nadadeira pélvica.

Perfil da margem distal da nadadeira anal de machos com lobo anterior ligeiramente convexo. Lobo anterior formado pelo aumento de tamanho do último raio simples ao segundo raio ramificado (maior raio) e redução gradual deste ao quinto raio ramificado; perfil reto deste ponto até o último raio ramificado, devido à redução gradual de tamanho em direção anteroposterior. Perfil da margem distal da nadadeira anal de fêmeas com lobo anterior côncavo conspícuo. Lobo anterior formado pela diminuição acentuada do último raio simples e primeiro raio ramificado (maior raio) até o quinto raio ramificado; perfil reto deste ponto ao último raio ramificado, devido à redução gradual de tamanho em direção anteroposterior.

Extremidade distal do primeiro raio ramificado (mais longo) de machos alcança o segundo raio ramificado da nadadeira anal. Extremidade distal do primeiro raio ramificado (mais longo) de fêmeas alcança a origem da nadadeira anal.

Processos ósseos: presentes na nadadeira pélvica de machos.

Nadadeira pélvica com processos ósseos presentes e restritos a segmentos do hemitriquium ventral. Nadadeira pélvica com até dois (geralmente dois) processos ósseos por segmento no hemitriquium ventral do raio simples ao sexto raio ramificado, distribuindo-se em $85 \%$ dos raios ramificados (sete raios ramificados). Raio simples com processos ósseos do sétimo ao décimo segmento, segundo segmento proximal à extremidade distal do raio. Raios ramificados com processos ósseos presentes tant em segmentos proximais quanto distais à primeira bifurcação. Proximalmente à primeira bifurcação os processos ósseos estão presentes 
em todos os segmentos, inclusive o mais proximal (mais longo). Processos ósseos presentes também em segmentos distais à segunda bifurcação dos ramos medial e lateral da primeira bifurcação. Distalmente à primeira bifurcação e proximalmente à segunda bifurcação, os processos ósseos estão presentes em todos os segmentos do ramo medial e em até quatro segmentos do ramo lateral, imediatamente proximal à segunda bifurcação deste ramo. Distalmennte à segunda bifurcação do ramo medial da primeira bifurcação os processos ósseos estão presentes em todos os segmentos dos ramos medial e lateral. Distalmente à segunda bifurcação do ramo lateral os processos ósseos estão presentes em todos os segmentos do ramo medial e em até três segmentos do ramo lateral, mais distais deste ramo. Inserção dos processos arredondada. Em todos os segmentos, os processos ósseos estão inseridos na face ventromedial, com exceção de quatro segmentos (imediatamente eproximais à segunda bifurcação) do ramo medial da primeira bifurcação, no qual os processos ósseos estão inseridos tanto na face ventromedial quanto na face ventrolateral e do ramo lateral da segunda bifurcação do ramo medial da primeira bifurcação, no qual os processos ósseos estão inseridos na face ventrolateral. Os processos ósseos desenvolvem-se perpendicularmente à sua inserção no segmento. Processos ósseos retos. Em secção transversal, os processos ósseos são cilíndricos ao longo de seu comprimento total, afilando-se e terminando em uma extremidade arredondada. Em seu estado máximo de desenvolvimento, seu comprimento total não alcança o comprimento proximodistal do segmento no qual está inserido. Na nadadeira pélvica os processos ósseos aumentam e diminuem discretamente de tamanho em direção lateromedial; primeiro e segundo raio ramificado com o maior número de segmentos com processos ósseos e maiores processos ósseos. Nos raios os processos ósseos aumentam e diminuem discretamente de tamanho em direção proximodistal. 


\section{Poptella paraguayensis (Eigenamann 1907)}

Figs. 184 a 186

Localidade tipo: Descalvados, Mato Grosso, Brasil.

Material examinado: MZUSP 19844, 49, Brasil, Mato Grosso, Barão de Melgaço, Boca do Croará, cerca de $25 \mathrm{~km}$ de Barão de Melgaço, bacia do rio Paraguay, 16¹1'0.0”S, 5557’0.0”W, CEPIPAM \& H. A. Britski, 03/05/1977. MZUSP 59525, 231, Brasil, Mato Grosso do Sul, Rio Verde de M. G., Lagoa Corixão, aprox.. 6,5 km a oeste do rio Anhuma, na rodovia, bacia do rio Negro, 198'18.0”S, 55²0'53.0”W, A. Machado \& B. Chernoff, 28/08/1998.

\section{Caracteres sexuais secundários}

Os caracteres sexuais secundários de $P$. paraguayesis relacionam-se ao comprimento padrão e presençaa de processos ósseos.

Comprimento padrão: fêmeas alcançam maiores valores de comprimento padrão em relação aos machos. MZUSP 59525, 54 machos (42.5-51.2 mm CP) e 69 fêmeas (39.4-52.1 mm CP). Processos ósseos: presentes nas nadadeiras anal e pélvica de machos maduros.

Nadadeira anal com até dois (geralmente um) processos ósseos por segmento de hemitriquium do último raio simples ao décimo raio ramificado, disrtribuindo-se em $30 \%$ dos raios ramificados (até 33 raios ramificados). Último raio simples com processos ósseos do quinto ao décimo quarto segmento, segundo segmento proximal à extremidade distal do raio. Raios ramificados com processos ósseos presentes tanto em segmentos proximais quanto distais à primeira bifurcação. Processos ósseos presentes também em segmentos distais à segunda bifurcação dos ramos anterior e posterior da primeira bifurcação. Proximalmente à primeira bifurcação, os processos ósseos estão presentes em até três (geralmente um) 
$\overline{\text { segmentos. Distalmente à primeira bifurcação e proximalmente às segunda ramificações, os }}$ processos ósseos estão presentes em todos os segmentos do ramo posterior e em até quatro segmentos do ramo anterior, imediatamente proximais à segunda bifurcação. Distalmente à segunda bifurcação do ramo posterior da primeira bifurcação, os processos ósseos estão presentes em todos os segmentos dos ramos posterior e anterior. Distalmente à segunda bifurcação do ramo anterior da primeira bifurcação, os processos ósseos estão presentes em até cinco segmentos do ramo posterior e em um segmento do ramo anterior, em ambos os ramos a partir do segmento distal à bifurcação. Processos ósseos assimétricos bilateralmente. Inserção dos processos ósseos arredondada. O diâmetro de sua inserção ocupa $25 \%$ do comprimento proximodistal do segmento no qual está inserido. Em todos os segmentos, os processos ósseos estão inseridos na região lateroposterior, com exceção de um segmento proximal à segunda bifurcação do ramo anterior da primeira bifurcação e de dois segmentos proximais à segunda bifurcação do ramo posterior da primeira bifurcação, no qual os processos ósseos estão inseridos tanto em na face lateroposterior quanto na face lateroanterior (processos da face lateroanterior distintamente menores que) e dos segmentos do ramo anterior da segunda bifurcação dos ramos posterior e anterior da primeira bifurcação, no qual os processos ósseos estão inseridos na face lateroanterior. Os processos ósseos desenvolvemse perpendicularmente ao à sua inserção no segmento no qual está inserido. Processos ósseos geralmente retos, alguns apresentam uma ligeira curvatura de $5^{\circ}$, e se desenvolve em direção proximal e em relação ao segmento no qual está inserido. Em secção transversal, os processos ósseo são cilíndricos ao longo de seu comprimento total, afilando-se gradualmente e terminando em uma extremidade distal pontiaguda/arredondada. O diâmetro de sua extremidade distal equivale a $25 \%$ do maior comprimento de sua inserção no segmento no qual está inserido. Em seu estado máximo de desenvolvimento, seu comprimento total não 
$\overline{\text { alcança o comprimento proximodistal do segmento no qual está inserido. O comprimento do }}$ maior processo ósseo equivale a $43 \%$ do comprimento proximodistal do segmento no qual está inserido. $\mathrm{Na}$ nadadeira anal os processos aumentam e diminuem gradualmente de tamanho em direção anteroposterior; segundo e terceiro raios ramificados com maior número de segmentos com processos ósseos e maiores processos ósseos. No raio os processos ósseos aumentam e diminuem de tamanho em direção proximodistal. $\mathrm{O}$ angulo dos processos se mantêm constante ao longo do raio; o maior processo ósseo está no terceiro segmento distal à primeira bifurcação, na metade proximal da série de processos ósseos.

Nadadeira pélvica com processos ósseos restritos a segmentos do hemitriquium ventral. Nadadeira pélvica com até dois (geralmente dois) processos ósseos por segmento no hemitriquium ventral do raio simples ao quarto raio ramificado, disrtribuindo-se em $57 \%$ dos raios ramificados (sete raios ramificados). Raio simples com processos ósseos do sétimo ao décimo segmento, quinto segmento proximal à extremidade distal do raio. Raios ramificados com processos ósseos restritos a segmentos distais à primeira bifurcação. Processos ósseos presentes também em segmentos distais à segunda bifurcação do ramo medial da primeira bifurcação. Distalmente à primeira bifurcação e proximalmente à segunda bifurcação, os processos ósseos estão presentes e restritos a todos os segmentos do ramo medial. Distalmennte à segunda bifurcação do ramo medial da primeira bifurcação os processos ósseos estão presentes e restritos a até quatro segmentos do ramo medial, imediatamente distais à bifurcação. Processos ósseos com inserção arredondada. O maior comprimento da inserção do processo ósseo ocupa $10 \%$ o comprimento proximodistal do segmento no qual está inserido. Em todos os segmentos, os processos ósseos estão iseridos na face ventromedial. Os processos ósseos se desenvolven perpendicularmente à sua inserção no segmento. Ao longo de seu comprimento total, os processos ósseos sofrem uma curvatura de 
$20^{\circ}$ em direção proximal (ligeiramente medial) em relação ao eixo proximodistal do segmento no qual está inserido. Em secção transversal, os processos ósseos são cilíndricos ao longo de seu comprimento total, afilando-se gradualmente e terminando em uma extremidade arredondada/pontiaguda. O diâmetro de sua extremidade distal equivale a 19\% do diâmetro de sua inserção no segmento no qual está inserido. Em seu estado máximo de desenvolvimento, seu comprimento total não alcança o comprimento proximodistal do segmento no qual está inserido. O comprimento do maior processo ósseo equivale a $10 \%$ do comprimento proximodistal do segmento no qual está inserido. Na nadadeira pélvica os processos ósseos aumentam discretamente de tamanho do raio simples ao primeiro e segundo raio ramificado e diminuem visivelmente até quarto raio ramificado; primeiro e segundo raio ramificado com o maior número de segmentos com processos ósseos e maiores processos ósseos. Nos raios os processos ósseos não apresentam diferença visível de tamanho.

\section{Pristella maxillaris (Ulrey 1894)}

Localidade tipo: Los Castillas, rio Orinoco, Venezuela.

Material examinado: MZUSP 96474, 66, Venezuela, Bolivar, Caicara del Orinoco, Laguna de Castilleros (Marginal ao rio Orinoco) estação de Aquicultura, da Universidade de Oriente, bacia do rio Orinoco, 7³0’51.0”'S, 669'20.0”'W.

\section{Caracteres sexuais secundários}

Os caracteres sexuais secundários em $P$. maxillaris relacionam-se ao comprimento padrão, formato da nadadeiras e presença de processos ósseos.

Comprimento padrão: fêmeas alcançam maiores valores de comprimento padrão em relação aos machos. MZUSP 96474, 16 machos (22.8-23.6 mm CP) e 32 fêmeas (23.9-27.8 mm CP). 
Formato de nadadeiras: machos diferem de fêmeas pelo comprimento da nadadeira pélvica. Extremidade distal do primeiro raio ramificado (raio mais longo) da nadadeira pélvica de machos alcança o terceiro raio ramificado da nadadeira anal. Nadadeira pélvica de machos sobrepõe o orifício urogenital em vista ventral. Extremidade distal do primeiro raio ramificado (raio mais longo) da nadadeira pélvica de fêmeas alcança a origem da nadadeira anal, mas não ultrapassa o último raio simples. Nadadeira pélvica das fêmeas não sobrepõe o orifício urogenital em vista ventral.

Processos ósseos: presentes nas nadadeiras anal e pélvica de machos maduros.

Nadadeira anal com um processo ósseo por segmento de hemitriquium do último raio simples ao décimo primeiro raio ramificado, distribuindo-se em $50 \%$ dos raios ramificados (até 22 raios ramificados). Último raio simples com processos ósseos do quinto segmento mais proximal até o terceiro segmento proximal à extremidade distal do raio. Processos ósseos presentes tanto em segmentos proximais quanto distais à primeira bifurcação. Processos ósseos presentes também distalmente à segunda bifurcação do ramo posterior da primeira bifurcação. Proximalmente à primeira bifurcação, os processos ósseos estão presentes em até seis segmentos. Distalmente à primeira bifurcação e proximalmente às segunda ramificações, os processos ósseos estão presentes e restritos a todos os segmentos do ramo posterior. Distalmente à segunda bifurcação do ramo posterior da primeira bifurcação, os processos ósseos estão presentes e restritos a até dois segmentos do ramo posterior, imediatamente distal à bifurcação. Processos ósseos simétricos bilateralmente. Processos ósseos com inserção ovalada proximodistalmente. Em todos os segmentos, os processos ósseos estão inseridos na face lateroposterior em relação à nadadeira. Os processos ósseos se desenvolve perpendicularmente à sua inserção no segmento no qual estão inseridos. Ao longo de seu comprimento total sofre uma curvatura de $45^{\circ}$ e desenvolvem-se em direção proximal 
$\overline{\text { (ligeiramente medial) em relação ao eixo proximodistal do segmento no qual estão inseridos. }}$ Em secção transversal, os processos ósseos variam de ovalados proximodistalmente a cilíndricos ao longo de seu comprimento total, afilando-se gradualmente e terminando em uma extremidade distal pontiaguda. Em seu estado máximo de desenvolvimento, seu comprimento total não alcança o comprimento proximodistal do segmento no qual está inserido. Na nadadeira anal os processos aumentam e diminuem gradualmente de tamanho em direção anteroposterior; terceiro raio ramificado com maior número de segmentos com processos ósseos e maiores processos ósseos. No raio os processos ósseos diminuem de tamanho em direção proximodistal.

Nadadeira pélvica com processos ósseos presentes e restritos a segmentos do hemiqitruium ventral. Nadadeira pélvica com um processo ósseo por segmento (com exceção do segmento mais proximal, mais longo) no hemitriquium ventral do raio simples ao sétimo raio ramificado, distribuindo-se em 100\% dos raios ramificados (sete raios ramificados). Raio simples com processos ósseos do segmento mais proximal (mais longo) ao quinto segemento proximal à extremidade distal do raio. Raios ramificados com processos ósseos presentes tanto em segmentos proximais quanto em segmentos distais à primeira bifurcação no primeiro rao ramificado; processos restritos a semgmentos distais à primeira bifurcação nos demais raios. Proximalmente à primeira bifurcação, os processos estão presentes em todos os segmentos, inclusive o mais proximal (mais longo). Processos ósseos presentes também em segmentos distais à segunda bifurcação dos ramos medial e lateral da primeira bifurcação. Distalmente à primeira bifurcação e proximalmente às segundas ramificações, os processos ósseos estão presentes e restritos a todos os segmentos do ramo medial. Distalmente à segunda bifurcação do ramo medial da primeira bifurcação, os processos ósseos estão presentes em todos os segmentos do ramo medial e em até três segmentos do ramo lateral, 
imediatamente distais à bifurcação. Distalmente à segunda bifurcação do ramo lateral da primeira bifurcação, os processos ósseos estão presentes e restritos a todos os segmentos do ramos medial. Inserção dos processos ovalada proximodistalmente. Em todos os segmentos com processos ósseos, os processos ósseos estão inseridos na face ventromedial, com exceção do segmento do ramo lateral da segunda bifurcação do ramo medial da primeira bifurcação, no qual os processos ósseos estão inseridos na face ventrolateral em relação à nadadeira. Os processos ósseos desenvolvem-se perpendicularmente à sua inserção no segmento no qual estão inseridos. Ao longo de seu comprimento proximoditsal, o processo ósseo (tanto da face ventrolateral quanto da face ventromedial) sofre uma curvatura gradual de $45^{\circ}$ em direção proximal em relação ao eixo proximodistal do segmento. Em secção transversal, os processos ósseos variam de ovalados proximodistalmente a cilíndricos ao longo de seu comprimento total, afilando-se gradualmente e terminando em uma extremidade pontiaguda. Em seu estado máximo de desenvolvimento, seu comprimento total não alcança o comprimento proximodistal do segmento onde se insere. $\mathrm{Na}$ nadadeira pélvica o processos ósseos aumentam discretamente de tamanho do raio simples ao segundo raio ramificado e diminuem drasticamente até o sétimo raio ramificado; primeiro e segundo raio ramificado com o maior número de segmentos com processos ósseos e maiores processos ósseos. Nos raios os processos ósseos aumentam e diminuem de tamanho em direção proximodistal.

\section{Stethaprion crenatum Eigenman 1916}

Figs. 187 a 189

Localidade tipo: San Joaquín, Bolivia. 
Material examinado: MZUSP 57730, 24, Brasil, Pará, rio Amazonas, bacia do rio Amazonas, $01^{\circ} 54^{\prime}$ S, $55^{\circ} 31^{\prime}$ W, F. Langeani et al., 23/10/1994.

\section{Caracteres sexuais secundários}

Os caracteres sexuais secundários em $S$. crenatum relacionam-se ao comprimento padrão e à presença de processos ósseos.

Comprimento padrão: Fêmeas alcançam maiores valores de comprimento padrão em relação aos machos. MZUSP 57730, 2 machos (56.3-60.3 mm CP) e 22 fêmeas (63.5-85.7 $\mathrm{mm} \mathrm{CP)}$

Processos ósseos: presentes nas nadadeiras anal e pélvica de machos maduros.

Nadadeira anal com até três (geralmente dois) processos ósseos por segmento de hemitriquium do último raio simples ao décimo raio ramificado, disrtribuindo-se em $26 \%$ dos raios ramificados (até 39 raios ramificados). Último raio simples com processos ósseos do oitavo ao décimo quarto segmento, segundo segmento proximal à extremidade distal do raio. Processos ósseos presentes tanto em segmentos proximais quanto em segmento distais à primeira bifurcação. Processos ósseos presentes também em segmentos distais à segunda bifurcação dos ramos anterior e posterior da primeira bifurcação. Proximalmente à primeira bifurcação, os processos ósseos estão presentes em até um segmento. Distalmente à primeira bifurcação e proximalmente às segunda ramificações, os processos ósseos estão presentes em todos os segmentos do ramo posterior e em até três segmentos do ramo anterior, imediatamente proximais à segunda bifurcação. Distalmente à segunda bifurcação do ramo posterior da primeira bifurcação, os processos ósseos estão presentes em todos os segmentos dos ramos posterior e anterior. Distalmente à segunda bifurcação do ramo anterior da primeira bifurcação, os processos ósseos estão presentes e restritos a até seis segmentos do ramo posterior, imediatamente distais à bifurcação. Processos ósseos assimétricos bilateralmente. 
Inserção dos processos ósseos arredondada. O diâmetro de sua inserção ocupa $12 \%$ do comprimento proximodistal do segmento no qual está inserido. Em todos os segmentos os processos ósseos estão inseridos na face lateroposterior, com exceção dos segmentos dos ramo anterior da segunda bifurcação do ramo posterior da primeira bifurcação, no qual os processos estão inseridos na face lateroanterior e dos dois processos do ramo posterior da primeira bifurcação, imediatamente proximais à segunda bifurcação, no qual os processos estão inseridos tanto na face lateroposterior quanto na face lateroanterior. Os processos ósseos desenvolvem-se perpendicularmente ao eixo proximodistal do segmento no qual estão inseridos. Processos ósseos geralmente retos, apodendo sofrer uma leve curvatura de $30^{\circ}$ e se desenvolver em direção proximal (ligeiramente medial) em relação ao segmento no qual estão inseridos. Em secção transversal, os processos ósseos são cilíndricos, afilando-se gradualmente e terminando em uma extremidade distal pontiaguda/arredondada. Diâmetro de sua extremidade distal, $22 \%$ do diâmetro de sua inserção no segmento no qual está inserido. Em seu estado máximo de desenvolvimento, seu comprimento total não alcança o comprimento proximodistal do segmento no qual está inserido. O comprimento do mior processo ósseo equivale a $40 \%$ do comprimento proximodistal do segmento no qual está inserido. Na nadadeira anal os processos aumentam e diminuem gradualmente de tamanho em direção anteroposterior; terceiro raio ramificado com maior número de segmentos com processos ósseos e maiores processos ósseos. No raio os processos ósseos aumentam e diminuem de tamanho em direção proximodistal; o maior processo ósseo está presente no quarto segmento do ramo posterior distal à primeira bifurcação, na metade proximal da série de processos ósseos.

Nadadeira pélvica com processos ósseos retritos a segmentos do hemitriquium ventral. Nadadeira pélvica com até dois (geralmente um) processos ósseos por segmento no 
hemitriquium ventral do raio simples ao quarto raio ramificado, odisrtribuindo-se em $57 \%$ dos raios ramificado (seis raios ramificados). Raio simples com processos ósseos do quinto ao nono segmento, segundo segmento proximal à extremidade distal do raio. Raios ramificados com processos ósseos restritos a segmentos distais à primeira bifurcação. Processos ósseos presentes também em segmentos distais à segunda bifurcação do ramo medial da primeira bifurcação. Distalmente à primeira bifurcação e proximalmente à segunda bifurcação, os processos ósseos estão presentes em até seis segmentos do ramo medial (a partir do terceiro segmento distal à bifurcação) e em um segmento do ramo lateral, segundo segmento proximal à extremidade distal desse ramo. Distalmente à segunda bifurcação do ramo medial da primeira bifurcação, os processos ósseos estão presentes e restritos a todos os segmentos do ramo medial. Processos ósseos com inserção arredondada. O diâmetro da inserção do processo ósseo ocupa $4 \%$ do comprimento proximodistal do segmento no qual está inserido. Em todos os segmentos os processos estão inseridos na face ventromedial. Os processos ósseos desenvolvem-se perpendicularmente à sua inserção no segmento. Ao longo de seu comprimento total, os processos ósseos sofrem uma curvatura de aproximadamente $60^{\circ} \mathrm{e}$ desenvolvem-se em direção proximomedial em relação ao segmento no qual estão inseridos. Em secção transeversal, os processos ósseos são cilíndricos ao longo de seu comprimento total, afilando-se gradualmente e terminando em uma extremidade arredondada/pontiaguda. $\mathrm{O}$ diâmetro de sua extremidade distal equivale a 50\% do maior comprimento de sua inserção no segmento no qual está inserido. Em seu estado máximo de desenvolvimento, seu comprimento total não alcança o comprimento proximodistal do segmento no qual está inserido. $\mathrm{O}$ comprimento do maior processo ósseo equivale a $16 \%$ do comprimento proximodistal do segmento no qual está inserido. Na nadadeira pélvica o processos ósseos aumentam discretamente de tamanho do raio simples ao primeiro raio ramificado e diminuem 
visivelmente até quinto raio ramificado; primeiro e segundo raio ramificado com o maior número de segmentos com processos ósseos e maiores processos ósseos. Nos raios os processos ósseos aumentam e diminuem de tamanho em direção proximodistal; o maior processo ósseos está no segundo segmento proximal à segunda bifurcação, na metade/metade distal da série de processos ósseos.

\section{Tetragonopterus argenteus Cuvier 1816}

Figs. 190 a 193

Localidade tipo: desconhecida.

Material examinado: MZUSP 5449, 5, Brasil, Pará, Oriximiná, rio Trombetas, bacia do rio Trombetas, 0146’00”S, 5552’00”W, Expedição Permanente à Amazônia, 1967. MZUSP 18586, 5, Brasil, Mato Grosso, Cuiabá, Coxipó da ponte, rio Coxipó da Ponte, bacia do rio Paraguay, 15³8’00’S, 5603’00”W, K. De Silimon, 28/10/1975. MZUSP 17509, 10, Brasil, Amazonas, Sãno Antonio do Içá, boca do rio Içá, bacia do rio Içá, 0308’00”S, 6757’00”W, Expedição Permanente à Amazônia, 17/10/1968.

\section{Caracteres sexuais secundários}

Os caracteres sexuais secundários em $T$. argenteus relacionam-se ao comprimento padrão e presença de processos ósseos.

Comprimento padrão: Fêmeas alcançam maiores valores de comprimento padrão em relação aos machos. MZUSP 17509, 5 machos (63.9-69.4 mm CP) e 5 fêmeas (61.6-75.8 mm CP), MZUSP 18586, 1 macho (83.1 mm CP) e 4 fêmeas (73.9-93.8 mm CP).

Processos ósseos: presentes nas nadadeiras anal e pélvica de machos maduros. 
Nadadeira anal com até dois (geralmente um) processos ósseos por segmento de hemitriquium do último raio simples ao nono raio ramificado, disrtribuindo-se em $28 \%$ dos raios ramificados (até 32 raios ramificados). Raio simples com processos ósseos do quarto ao oitavo segmento, déximo segundo segmento proximal à extremidade distal do raio. Processos ósseos presentes tanto em segmentos proximais quanto distais à primeira bifurcação. Processos ósseos presentes também em segmentos distais à segunda bifurcação do ramo posterior da primeira bifurcação. Proximalmente à primeira bifurcação, os processos ósseos estão presentes de três a quatro segmentos. Distalmente à primeira bifurcação e proximalmente às segunda ramificações, os processos ósseos estão presentes e restritos a todos os segmentos do ramo posterior. Distalmente à segunda bifurcação do ramo posterior da primeira bifurcação, os processos ósseos estão presentes e restritos a até três segmentos do ramo posterior, imediatamente distais à bifurcação. Processos ósseos simétricos bilateralmente. Processos ósseos com inserção ovalada proximodistalmente. O maior comprimento de sua inserção ocupa $43 \%$ do comprimento proximodistal do segmento no qual está inserido. Em todos os segmentos, os processos ósseos estão inseridos na face lateroposterior em relação à nadadeira. Os processos ósseos desenvolvem-se perpendicularmente ao eixo proximodistal do segmento no qual estão inseridos. Ao longo de seu comprimento, os processos ósseos sofrem uma curvatura de $45^{\circ}$ e desenvolvem-se em direção proximal em relação ao segmento no qual estão inseridos. Em secção transversal, os processos ósseos variam de ovalados proximodistalmente a cilíndricos, afilando-se gradualmente e terminando em uma extremidade distal pontiaguda/arredondada. O diâmetro de sua extremidade distal ocupa $13 \%$ do maior comprimento de sua inserção no segmento no qual está inserido. Em seu estado máximo de desenvolvimento, seu comprimento total não alcança o comprimento proximodistal do segmento no qual está inserido. O comprimento do 
maior processo ósseo equivale a $57 \%$ do comprimento proximodistal do segmento no qual está inserido. $\mathrm{Na}$ nadadeira anal os processos aumentam e diminuem gradualmente de tamanho em direção anteroposterior; segundo e terceiro raio ramificado com maior número de segmentos com processos ósseos e maiores processos ósseos. No raio os processos ósseos aumentam e diminuem de tamanho em direção proximodistal; o maior processo ósseos está no terceiro segmento distal à primeira bifurcação, na metade proximal da série de processos ósseos.

Nadadeira pélvica com processos ósseos presentes e restritos a segmentos do hemitriquium ventral. Nadadeira pélvica com um processo ósseo por segmento no hemitriquium ventral do primeiro ao sexto raio ramificado, odisrtribuindo-se em $100 \%$ dos raios da nadadeira (sete raios ramificados). Raios ramificados com processos ósseos restritos a segmentos distais à primeira bifurcação. Processos ósseos presentes também em segmentos distais à segunda bifurcação do ramo medial da primeira bifurcação. Processos ósseos presentes também em segmentos distais à terceira bifurcação do ramo medial da segunda bifurcação do ramo medial da primeira bifurcação. Distalmente à primeira bifurcação e proximalmente às segundas ramificações, os processos ósseos estão presentes e restritos a até quatro segmentos do ramo medial, imediatamente proximais à segunda bifurcação deste ramo. Distalmente à segunda bifurcação e proximalmente à terceira bifurcação do ramo medial da primeira bifurcação, os processos ósseos estão presentes e restritos a todos os segmentos do ramo medial. Distalmente à terceira bifurcação do ramo medial da segunda bifurcação da primeira bifurcação, os processos ósseos estão presentes e restritos a até três segmentos do ramo medial, imediatamente distais à bifurcação. Processos ósseos com inserção ovalada proximodistalmente. O maior comprimento de sua inserção ocupa $27 \%$ do comprimento proximodistal do segmento no qual está inserido. Em todos os segmentos, os processos ósseos 
estão inseridos na face ventromedial em relação à nadadeira. Os processos ósseos desenvolvem-se perpendicularmente à sua inserção no segmento no qual está inserido. Ao longo de seu comprimento proximoditsal, os processos ósseos sofrem uma curvatura de aproximadamente $50^{\circ}$ e desenvolvem-se em direção proximal em relação ao segmento no qual estão inseridos. Em secção transversal os processos óssos variam de ovalados proximodistalmente a cilíndricos, afilando-se gradualmente e terminando em uma extremidade arredondada/pontiaguda. O Diâmetro de sua extremidade distal equivale a $22 \%$ do maior comprimento de sua inserção no segmento no qual está inserido. Em seu estado máximo de desenvolvimento, seu comprimento total (da inserção à extremidade independentemente da curvatura) não alcança o comprimento proximodistal do segmento onde se insere. O comprimento do maior processo ósseo equivale a $34 \%$ do comprimento proximodistal do segmento no qual está inserido. Na nadadeira pélvica o processos ósseos aumentam e diminuem discretamente de tamanho em direção lateromedial; segundo e terceiro raio ramificado com o maior número de segmentos com processos ósseos e maiores processos ósseos. Nos raios os processos ósseos aumentam e diminuem de tamanho em direção proximodistal, o maior processo ósseos no segundo segmento distal à segunda bifurcação, na metade proximal da série de processos ósseos.

Glândula branquial: formada pela fusão do primeiro ao décimo sexto filamento branquial anterior do primeiro arco branquial de machos maduros. Glândula branquial disrtribuindo-se em Orifício localizado no quarto distal dos filamentos.

STEVARDIINAE

Bryconamericus exodon Eigenmann 1907 
Localidade tipo: Puerto Max, Paraguay.

Material examinado: MZUSP 59730, 446, Brasil, Mato Grosso do Sul, Corquinho, riacho cerca de $30 \mathrm{~km}$ antes da cidade de Rio Negro, bacia do rio Paraguay, 1941'5"S, 5458’17’W, O. Oyakawa et al., 18/08/1998.

\section{Caracteres sexuais secundários}

Os caracteres sexuais secundários em B. exodon relacionam-se ao comprimento padrão, presença de processos ósseos e glândula branquial.

Comprimento padrão: fêmeas alcançam maiores valores de comprimento padrão em relação aos machos. MZUSP 59730, 21 machos (24.8-35.4 mm CP) e 34 fêmeas (23.2-43.9 mm CP).

Processos ósseos: presentes nas nadadeiras anal e pélvica de machos

Nadadeira anal com um processo ósseo por segmento de hemitriquium, do último raio simples ao sexto raio ramificado, distribuindo-se em até $32 \%$ dos raios ramificados (até 19 raios ramificados). Último raio simples com processos ósseos do quarto ao oitavo segmentos, sétimo segmento proximal à extremidade distal do raio. Processos ósseos presentes tanto em segmentos proximais quanto em segmentos distais à primeira bifurcação. Proximalmente à primeira bifurcação, os processos ósseos estão presentes em até quatro segmentos. Distalmente à primeira bifurcação e proximalmente às segunda ramificações, os processos ósseos estão restritos a todos os segmentos do ramo posterior. Processos ósseos simétricos bilateralmente. Processos ósseos com inserção ovalada proximodistalmente. Em todos os segmentos, os processos ósseos estão inseridos na face lateroposterior em relação à nadadeira. Os processos ósseos se desenvolvem-se perpendicularmente à sua inserção no segmento no qual estão inseridos. Ao longo de seu comprimento, os processos ósseos apresentam uma curvatura de $50^{\circ}$ e desenvolvem-se em direção proximal em relação ao eixo proximodistal do 
segmento no qual estão inseridos. Em secção transversal, os processos ósseos variam de ovalados proximodistalmente a cilíndricos ao longo de seu comprimento, afilando-se gradualmente e terminando em uma extremidade distal pontiaguda. Em seu estado máximo de desenvolvimento, o seu comprimento não alcança o comprimento proximodistal do segmento no qual está inserido. $\mathrm{Na}$ nadadeira anal os processos ósseos aumentam e diminuem gradualmente de tamanho em direção anteroposterior; segundo e terceiro raios ramificados com maior número de segmentos com processos ósseos e processos ósseos mais desenvolvidos. No raio os processos ósseos decrescem de tamanho em direção proximodistal. Nadadeira pélvica com processos ósseos restritos a segmentos do hemitriquium ventral. Nadadeira pélvica com um processo ósseo por segmento (com exceção do segmento mais proximal, mais longo) no hemitriquium ventral do primeiro ao sexto raios ramificados, distribuindo-se em $86 \%$ dos raios ramificados (7 raios ramificados). Raios ramificados com processos ósseos presentes tanto em segmentos proximais quanto em segmentos distais à primeira bifurcação. Processos ósseos presentes também em segmentos distais à segunda bifurcação dos ramos medial e lateral da primeira bifurcação. Proximalmente à primeira bifurcação, os processos estão presentes em todos os segmentos; segmento mais proximal, mais longo e 3 a 4 segmentos em sua metade distal. Distalmente à primeira bifurcação e proximalmente às segundas ramificações, os processos ósseos estão presentes em todos os segmentos do ramo medial e em até dois segmentos do ramo lateral, imediatamente proximais à segunda bifurcação deste ramo. Distalmente à segunda bifurcação do ramo medial da primeira bifurcação, os processos ósseos estão presentes em todos os segmentos dos ramos medial e lateral. Distalmente à segunda bifurcação do ramo lateral da primeira bifurcação os processos ósseos estão presentes e restritos a até três segmentos do ramo medial, imediatamente proximais à bifurcação. Processos ósseos com inserção ovalada 
$\overline{\text { proximodistalmente. Em todos os segmentos, os processos ósseos estão inseridos na face }}$ ventromedial, com exceção de um segmento do ramo medial da primeira bifurcação imediatamente proximal à segunda bifurcação deste ramo, no qual os segmentos estão inseridos tanto na face ventromedial quanto na face ventrolateral, e em todos os segmentos do ramo lateral da segunda bifurcação do ramo medial da primeira bifurcação no qual os processos ósseos estão inseridos na face ventrolateral. Os processos ósseos desenvolvem-se perpendicularmente à inserção no segmento no qual estão inseridos. Em direção distoproximal os processos ósseos se direcionam de mais medialmente a mais ventralmente. Em seu quarto (1/4) proximal, os processos ósseos apresentam uma curvatura de aproximadamente $45^{\circ}$ e desenvolvem-se em direção proximal a proximomedial em relação ao em relação ao eixo proximodistal do segmento no qual estão inseridos. Em secção transversal, os processos ósseos variam de ovalados proximodistalmente a cilíndricos ao longo de seu comprimento, afilando-se gradualmente e terminando em uma extremidade levemente arredondada. Em seu estado máximo de desenvolvimento, seu comprimento não alcança o comprimento proximodistal do segmento no qual está inserido. Na nadadeira pélvica os processos ósseos decrescem de tamanho em direção lateromedial; terceiro raio ramificado com maior número de segmentos com processos ósseos e processos ósseos mais desenvolvidos. Nos raios os processos ósseos decrescem de tamanho em direção proximodistal.

Glândula branquial: presente em machos.

Glandula brânquial formada pela fusão do primeiro ao nono filamentos branquiais do ceratobranquial do primeiro arco branquial. Glândula branquial distribuindo-se em $40 \%$ dos filamentos branquiais no ceratobranquial. Células branquiais pouco visíveis lateralmente. Abertura da glândula branquial na extremidade do filamento branquial. 


\section{Bryconamericus inheringi (Boulenger 1887)}

Localidade tipo: São Lorenço, Rio Grande do Sul, Brasil.

Material examinado: MZUSP 18983, 17, Brasil, Rio Grande do Sul, Lajeado, rio Forqueta, em Marques de Souza, bacia do rio Jacuí, 29²0’00”S, 5205’00”W, Expedição MZUSP/USNM, 07/12/1979.

\section{Caracteres sexuais secundários}

Os caracteres sexuais secundários em $B$. inheringi relacionam-se ao comprimento padrão, presença de processos ósseos e glândula branquial.

Comprimento padrão: machos alcançaram maiores valores de comprimento padrão em relação às fêmeas. MZUSP 18983, 5 machos $(41.5-52.1 \mathrm{~mm} \mathrm{CP})$ e 6 fêmeas $(29.7-51.5 \mathrm{~mm}$ $\mathrm{CP})$.

Processos ósseos: presentes nas nadadeiras anal e pélvica de machos

Nadadeira anal com um processo ósseo por segmento de hemitriquium do último raio simples ao sexto raio ramificado, distribuindo-se em até 33\% dos raios ramificados (até 18 raios ramificados). Último raio simples com processos ósseos do quinto ao décimo segmentos, o décimo segmento proximal à extremidade distal do raio. Raios ramificados com processos ósseos presentes tanto em segmentos proximais quanto distais à primeira bifurcação. Processos ósseos presentes também em segmentos distais à segunda bifurcação do ramo posterior da primeira bifurcação. Proximalmente à primeira bifurcação, os processos ósseos estão presentes em até quatro segmentos. Distalmente à primeira bifurcação e proximalmente à segunda bifurcação, os processos ósseos estão restritos a todos os segmentos do ramo posterior. Distalmente à segunda bifurcação do ramo posterior da primeira 


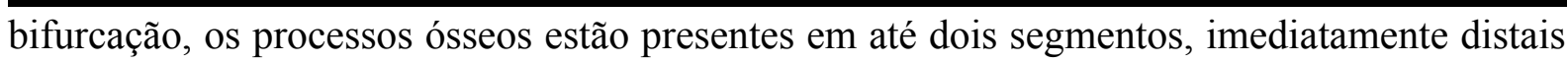
à bifurcação. Processos ósseos simétricos bilateralmente. Processos ósseos com inserção ovalada proximodistalmente. Em todos os segmentos os processos ósseos estão inseridos na face lateroposterior em relação à nadadeira. Os processos ósseos se desenvolvem-se perpendicularmente à inserção no segmento no qual estão inseridos. Ao longo de seu comprimento, os processos ósseos apresentam uma curvatura de $50^{\circ}$ e desenvolvem-se em direção proximal em relação ao eixo proximodistal do segmento no qual estão inseridos. Em secção transversal, os processos ósseos variam de ovalados proximodistalmente a cilíndricos ao longo do comprimento, afilando-se gradualmente e terminando em uma extremidade distal levemente arredondada. Em seu estado máximo de desenvolvimento, o seu comprimento total não alcança o comprimento proximodistal do segmento no qual está inserido. Na nadadeira anal os processos ósseos aumentam e diminuem gradualmente de tamanho em direção anteroposterior; segundo e terceiro raios ramificados com maior número de segmentos com processos ósseos e processos ósseos maiores. No raio os processos ósseos aumentam e diminuem de tamanho em direção proximodistal.

Nadadeira pélvica com processos ósseos restritos a segmentos do hemitriquium ventral. Nadadeira pélvica com um processo ósseo por segmento (com exceção do segmento mais proximal, mais longo) do hemitriquium ventral do primeiro ao sétimo raios ramificados, distribuindo-se em $100 \%$ dos raios ramificados (7 raios ramificados). Raios ramificados com processos ósseos presentes tanto em segmentos proximais quanto distais à primeira bifurcação. Processos ósseos presentes também em segmentos distais à segunda bifurcação dos ramos medial e lateral da primeira bifurcação. Proximalmente à primeira bifurcação, os processos estão presentes em todos os segmentos; segmento mais proximal, mais longo, com até cinco segmentos em sua metade distal. Distalmente à primeira bifurcação e proximalmente 
às segundas ramificações, os processos ósseos estão restritos a todos os segmentos do ramo medial e em até dois segmentos do ramo lateral, imediatamente proximais à segunda bifurcação deste ramo. Distalmente à segunda bifurcação do ramo medial da primeira bifurcação, os processos ósseos estão presentes em todos os segmentos dos ramos medial e lateral. Distalmente à segunda bifurcação do ramo lateral da primeira bifurcação os processos ósseos estão presentes em todos os segmentos dos ramos medial e em todos os segmentos laterais, a partir do segundo segmento distal à bifurcação. Processos ósseos assimétricos bilateralmente. Em todos os segmentos, os processos ósseos estão inseridos na face ventromedial, com exceção dos segmentos do ramo lateral da segunda bifurcação do ramo medial da primeira bifurcação nos quais os processos ósseos estão inseridos na face ventrolateral. Em direção distoproximal os processos ósseos se direcionam de mais medialmente a mais ventralmente. Os processos ósseos desenvolvem-se perpendicularmente à sua inserção no segmento no qual estão inseridos. Em seu quarto proximal (1/4), os processos ósseos apresentam uma curvatura de $45^{\circ}$ e desenvolvem-se em direção proximal (ligeiramente medial) em relação ao segmento no qual estão inseridos. Em secção transversal, os processos ósseos variam de ovalados proximodistalmente a cilíndricos ao longo do comprimento, afilando-se gradualmente e terminando em uma extremidade pontiaguda. Em seu estado máximo de desenvolvimento, seu comprimento total não alcança o comprimento proximodistal do segmento no qual está inserido. Na nadadeira pélvica os processos ósseos decrescem de tamanho em direção lateromedial; quarto e quinto raios ramificados com maior número de segmentos com processos ósseos e processos ósseos mais desenvolvidos. Nos raios os processos ósseos decrscem de tamanho em direção proximodistal.

Glândula branquial: presente em machos 
Glandula branquial formada pela fusão do primeiro ao sexto e fusão incompleta do nono e décimo filamentos branquiais do ceratobranquial do primeiro arco branquial. Glândula branquial representa $29 \%$ dos filamentos do ceratobranquial. Células colunares pouco visíveis lateralmente. Abertura da glândula branquial na extremidade distal do filamento branquial.

\section{Bryconamericus cf. peruanus (Müller \& Troschel 1845)}

Figs. 194 a 197

Localidade tipo: perto de Lima, Peru.

Material examinado: MZUSP 18311, 4, Ecuador, Arroyo Bambine, afluente do rio Crystal, em Montalvo, Los Rios, T. Roberts et al., 06/11/1971.

\section{Caracteres sexuais secundários:}

Os caracteres sexuais secundários em B. cf. peruanus relacionam-se ao comprimento padrão, formato de nadadeiras, presença de processos ósseos e glândula branquial.

Comprimento padrão: machos alcançam maiores valores de comprimento padrão em relação às fêmeas. MZUSP 18311, 2 machos (59.1-64.4 mm CP) e 2 fêmeas (52.0-63.2 mm $\mathrm{CP})$.

Formato de nadadeiras: machos diferem de fêmeas pelo formato do perfil da margem distal da nadadeira anal e formato da nadadeira caudal.

Perfil da margem distal do lobo anterior da nadadeira anal discretamente convexo. Lobo anterior formado pelo aumento de tamanho do último raio simples e segundo raio ramificado (raio mais longo) e diminuição discreta de tamanho deste ao oitavo raio ramificado; perfil reto do nono ao último raio ramificado.. Perfil da margem distal do lobo anterior da nadadeira anal de fêmeas conspicuamente convexo. Lobo anterior formado pelo aumento gradual de tamanho 
$\overline{\text { do ultimo raio simples e segundo raio ramificado (raio mais longo) e diminuição acentuada }}$ deste ao quinto raio ramificado; perfil reto do sexto ao último raio ramificado.

Nadadeira caudal de machos com lobo inferior ligeiramente mais longo e expandido dorsoventralmente que o lobosuperior. Nadadeira caudal de fêmeas com os lobos superior e inferior do mesmo tamanho.

Processos ósseos: presentes nas nadadeiras anal e pélvica de machos maduros.

Nadadeira anal com duas formas de processos ósseos. A primeira constituída por um processo ósseo por segmento do hemitriquium do primeiro ao nono raio ramificados, disrtribuindo-se em 31\% dos raios ramificados (até 29 raios ramificados). Raios ramificados com processos ósseos presentes e restritos a segmentos distais à primeira bifurcação. Processos ósseos presentes também em segmentos distais à segunda bifurcação do ramo posterior da primeira bifurcação. Proximalmente à primeira bifurcação, os processos ósseos estão presentes em um segmento. Distalmente à primeira bifurcação e proximalmente à segunda, os processos ósseos estão presentes e restritos a até cinco segmentos, imediatamente proximais à segunda bifurcação deste ramo. Distalmente à segunda bifurcação do ramo posterior da primeira bifurcação, os processos ósseos estão presentes e restritos a até seis segmentos do ramo posterior, imediatamente distais à bifurcação. Processos ósseos simétricos bilateralmente. Processos ósseos com inserção ovalada proximodistalmente. O maior comprimento de sua inserção ocupa $38 \%$ do comprimento proximodistal do segmento no qual está inserido. Em todos os segmentos, os processos ósseos estão inseridos na face lateroposterior em relação à nadadeira. Os processos ósseos desenvolvem-se perpendicularmente à inserção no segmento no qual estão inseridos. Em um quarto (1/4) proximal de seu comprimento, os processos ósseos apresentam uma curvatura de $55^{\circ}$ e desenvolvem-se em direção proximal (ligeiramente medial) em relação ao segmento no qual 
estão inseridos. Em secção transversal, os processos ósseos variam de ovalados proximodistalmente a cilíndricos ao longo do comprimento afilando-se gradualmente e terminando em uma extremidade distal arredondada. $\mathrm{O}$ diâmetro de sua extremidade distal equivale a $17 \%$ do maior comprimento de sua inserção no segmento. Em seu estado máximo de desenvolvimento, seu comprimento não alcança comprimento proximodistal do segmento no qual se insere. Comprimento do maior processo ósseo, $46 \%$ do comprimento proximodistal do segmento no qual está inserido. Na nadadeira anal os processos aumentam e diminuem gradualmente de tamanho em direção anteroposterior; quinto e sexto raios ramificados, com maior número de segmentos com processos ósseos e processos ósseos maiores. No raio os processos ósseos aumentam e diminuem de tamanho em direção proximodistal.

A segunda forma é constituída por um processo ósseo por segmento do hemitriquium do último raio simples ao vigésimo oitavo raio ramificado, disrtribuindo-se em 97\% dos raios ramificados (até 29 raios ramificados). Último raio simples com processos ósseos do sexto ao nono segmentos, o oitavo segmento proximal à extremidade distal do raio. Raios ramificados com processos ósseos presentes tanto em segmentos proximais quanto distais à primeira bifurcação. Proximalmente à primeira bifurcação, os processos ósseos estão presentes em todos os segmentos. Distalmente à primeira bifurcação e proximalmente à segunda ramificações, os processos ósseos estão restritos a até quatro segmentos, imediatamente distais à bifurcação. Processos ósseos simétricos bilateralmente. Processos ósseos com inserção arredondada. O diâmetro de sua inserção ocupa 30\% do comprimento proximodistal do segmento no qual está inserido. Em todos os segmentos, os processos ósseos estão inseridos na face lateral/lateroposterior em relação à nadadeira. Os processo ósseos desenvolvem-se de forma reta formando um angulo de $60^{\circ}$ e desenvolvem-se em direção distal/distomedial em relação ao eixo proximodistal do segmento no qual estão inseridos. Em 
secção transversal, os processos ósseos variam de cilíndricos a alongados horizontalmente ao longo de seu comprimento total, afilando-se gradualmente e terminando em uma extremidade distal ligeiramnte arredondada. O maior comprimento de sua extremidade distal equivale a 13\% do diâmetro de sua inserção no segmento.. Em seu estado máximo de desenvolvimento, o comprimento não alcança o comprimento proximodistal do segmento no qual está inserido. Comprimento do maior processo ósseo, $32 \%$ do comprimento proximodistal do segmento no qual está inserido. Na nadadeira anal os processos aumentam e diminuem gradualmente de tamanho em direção anteroposterior; primeiro e segundo raios ramificados com maio rnúmero de segmentos com processos ósseos; sexto raio ramificado com processos ósseos maiores. No raio os processos ósseos aumentam de tamanho proximodistalmente.

Nadadeira pélvica com processos ósseos restritos a segmentos do hemitriquium ventral. Nadadeira pélvica com um processo ósseo por segmento (com exceção do segmento mais proximal, mais longo) no hemitriquium ventral do primeiro ao sétimo raios ramificados, distribuídos em 100\% dos raios ramificados (7 raios ramificados). Raios ramificados com processos ósseos tanto em segmentos proximais quanto distais à primeira bifurcação. Processos ósseos presentes também em segmentos distais à segunda bifurcação dos ramos lateral e medial da primeira bifurcação. Processos ósseos presentes também em segmentos distais à terceira bifurcação do ramo lateral da segunda bifurcação do ramo lateral da primeira bifurcação. Proximalmente à primeira bifurcação, os processos estão presentes em todos os segmentos, inclusive o mais proximal, mais longo; segmento mais proximal, mais longo com seis processos ósseos. Distalmente à primeira bifurcação e proximalmente às segundas ramificações, os processos ósseos estão presentes em todos os segmentos do ramo medial e em um segmento do ramo lateral, imediatamente proximal à segunda bifurcação deste ramo. Distalmente à segunda bifurcação do ramo medial da primeira bifurcação, os processos ósseos 
estão presentes em todos os segmentos dos ramos medial e lateral. Distalmente à segunda bifurcação do ramo lateral da primeira bifurcação, os processos ósseos estão presentes em todos os segmentos do ramos medial e em até cinco segmentos do ramo lateral, imediatamente proximais à terceira bifurcação deste ramo. Distalmente à terceira bifurcação do ramo lateral da segunda bifurcação do ramo lateral da primeira bifurcação, os processos estão restritos a todos os segmentos do ramo medial. Processos ósseos com inserção arredondada. Diâmetro de sua inserção, $30 \%$ do comprimento proximodistal do segmento no qual está inserido. Em todos os segmentos, os processos ósseos estão inseridos na face ventromedial em relção à nadadeira, com exceção de até quatro segmentos do ramo medial da primeira bifurcação, imediatamente proximais à segunda bifurcação deste ramo, no qual os processos estão inseridos tanto na face ventromedial quanto na face ventrolateral (espelhados). Em todos os segmentos do ramo medial da segunda bifurcação do ramo medial da primeira bifurcação, os processos estão inseridos na face ventromedial, com exceção do terceiro segmento proximal à extremidade distal do ramo, no qual os processos estão inseridos tanto na face ventromedial quanto na face ventrolateral. Em todos os segmentos do ramo lateral da segunda bifurcação do ramo medial da primeira bifurcação, os processos ósseos estão inseridos na face ventrolateral, com exceção de três segmentos mais distais do ramo, no qual os segmentos estão inseridos tanto na face ventrolateral quanto na face ventromedial. Em todos os segmentos do ramo medial da segunda bifurcação do ramo lateral da primeira bifurcação, os processos ósseos estão inseridos na face ventromedial, com exceção dos seis segmentos mais distais do ramo, no qual os processos ósseos estão inseridos tanto na face ventromedial quanto na face ventrolateral (espelhados). Em todos os segmentos do ramo lateral da segunda bifurcação do ramo lateral da primeira bifurcação, os processos ósseos estão inseridos na face ventromedial. Em todos os segmentos do ramo medial da terceira 
bifurcação do ramo lateral da segunda bifurcação do ramo lateral da primeira bifurcação, os processos ósseos estão inseridos na face ventromedial. Processos ósseos desenvolvem-se perpendicularmente à inserção no segmento. Em seu um quarto (1/4) proximal, os processo ósseos apresentam uma curvatura de $70^{\circ}$ e desenvolvem-se de forma reta em direção proximal (ligeiramente medial) em ralação ao segmento no qual estão inseridos. Em secção transversal, os processos ósseos são cilíndricos ao longo de seu comprimento, afilando-se gradualmente e terminando em uma extremidade ligeiramente pontiaguda. O diâmetro de sua inserção equivale a $29 \%$ do diâmetro no segmento no qual está inserido. Em seu estado máximo de desenvolvimento, o seu comprimento não alcança o comprimento proximodistal do segmento onde está inserido. Comprimento do maior processo ósseo $95 \%$ do comprimento proximodistal do segmento no qual está inserido. Na nadadeira pélvica os processos ósseos aumentam e diminuem gradualmente de tamanho em direção lateromedial em relação à nadadeira; quarto, quinto e sexto raios ramificados com o maior número de segmentos com processos ósseos e processos ósseos maiores. Nos raios os processos ósseos aumentam e diminuem de tamanho em direção proximodistal.

Glândula branquial: presente em machos maduros.

Glândula branquial formada pela fusão do primeiro ao terceiro filamentos branquiais, do quarto e do quinto, e fusão incompleta do sexto ao oitavo filamentos branquiais. Glândula branquial distribuindo-se em $20 \%$ dos filamentos branquiais do ceratobranquial e $16 \%$ do comprimento do ceratobranquial. Células colunares não visíveis lateralmente. Abertura da glândula branquial visível lateralmente, nos $76 \%$ distais do filamento branquial.

\section{Cyanocharax alburnus (Hensel 1870)}


Localidade tipo: Porto Alegre, Brasil.

Materail examinado: MZUSP 43574, 20, Brasil, Rio Grande do Sul, rio dos Sinos, acima da cidade, bacia do rio Jacuí, 2945’00”S, 51¹0’00”W, Expediçãp MZUSP/MCP, 17/01/1991.

\section{Caracteres sexuais secundários}

Os caracteres sexuais secundários em C. alburnus relacionam-se ao comprimento padrão, formato de nadadeiras, presença de processos ósseos e glândula branquial.

Comprimento padrão: fêmeas alcançam maiores valores de comprimento padrão em relação aos machos. MZUSP 43574, 14 machos (44.8-56.8 mm CP) e 6 fêmeas (54.1-67.9 mm CP).

Formato de nadadeiras: machos diferem de fêmeas pelo formato do perfil da margem distal da nadadeira anal.

Perfil da margem distal do lobo anterior da nadadeira anal de machos discretamente convexo. Lobo anterior formado pelo aumento em tamanho do último raio simples e segundo raio ramificado (raio mais longo) com diminuição discreta de tamanho deste ao quinto raio ramificado; perfil reto do sexto ao último raio ramificado. Fêmeas com margem distal do lobo anterior distintamente convexo pela diminuição acentuada do segundo raio ramificado (raio mais longo) ao quinto raio ramificado; perfil reto do sexto ao último raio ramificado. Processos ósseos: presentes nas nadadeira anal e pélvica de machos.

Nadadeira anal com até dois (geralmente um) processos ósseos por segmento do hemitriquium do último raio simples ao décimo sétimo raio ramificado, distribuindo-se em até $74 \%$ dos raios ramificados (até 23 raios ramificados). Último raio simples com processos ósseos do segundo ao décimo segundo segmentos na parte mais proximal do raio, que é sétimo proximal à extremidade distal do raio. Raios ramificados com processos ósseos presentes tanto em segmentos proximais quanto em segmentos distais à primeira bifurcação. Processos ósseos presentes também em segmentos distais à segunda bifurcação dos ramos 
anterior e posterior da primeira bifurcação e também em segmentos distais à terceira bifurcação do ramo anterior da segunda bifurcação do ramo anterior da primeira bifurcação. Proximalmente à primeira bifurcação, os processos ósseos estão presentes em até quatro segmentos. Distalmente à primeira bifurcação e proximalmente às segunda ramificações, os processos ósseos estão restritos a todos os segmentos do ramo posterior. Distalmente à segunda bifurcação do ramo posterior da primeira bifurcação, os processos ósseos estão presentes em todos os segmentos dos ramos anterior e posterior. Distalmene à segunda bifurcação do ramo anterior da primeira bifurcação, os processos ósseos estão presentes em todos os segmentos do ramo posterior e em até três segmentos do ramo anterior, imediatamente proximais à terceira bifurcação deste ramo. Distalmente à terceira bifurcação do ramo anterior da segunda bifurcação do ramo anterior da primeira bifurcação, os processos ósseos estão restritos a até dois segmentos do ramo posterior, imediatamente distais à bifurcação. Processos ósseos com assimetria bilateral. Processos ósseos com secção transversal ovalada proximodistalmente no local da inserção. Em todos os segmentos, os processos ósseos estão inseridos na face láteroposterior, com exceção de um processo do ramo posterior da primeira bifurcação, imediatamente proximal à segunda bifurcação deste ramo, no qual os processos estão inseridos tanto na face láteroposterior quanto na láteroanterior e em todos os segmentos do ramo anterior da segunda bifurcação do ramo posterior da primeira bifurcação, na qual os processos estão inseridos na face láteroanterior. Os processos ósseos desenvolvem-se perpendicularmente à sua inserção no segmento no qual estão inseridos. Ao longo do comprimento total, os processos ósseos apresentam uma curvatura de $50^{\circ}$ e desenvolvem-se em direção proximal (ligeiramente medial) em relação ao segmento no qual estão inseridos. Em secção transversal, os processos ósseos variam de ovalados proximodistalmente a cilíndricos ao longo do comprimento, afilando-se-se 
$\overline{\text { gradualmente e terminando em uma extremidade distal levemente pontiguda. Em seu estado }}$ máximo de desenvolvimento, o comprimento não alcança o comprimento proximodistal do segmento no qual está inserido. Na nadadeira anal os processos ósseos aumentam e diminuem gradualmente de tamanho em direção anteroposterior; segundo, terceiro e quarto raios ramificados com maior número de segmentos com processos ósseos e processos ósseos maiores. No raio os processos ósseos decrescem aumentam e diminuem de tamanho em direção proximodistal.

Nadadeira pélvica com processos ósseos restritos a segmentos do hemitriquium ventral. Nadadeira pélvica com até dois (geralmente um) processos ósseos por segmento (com exceção do segmento mais proximal, mais longo) no hemitriquium ventral do primeiro ao sexto raios ramificados, distribuindo-se em $100 \%$ dos raios ramificados (6 raios ramificados). Raios ramificados com processos ósseos tanto em segmentos proximais quanto em segmentos distais à primeira bifurcação. Processos ósseos presentes também em segmentos distais à segunda bifurcação dos ramos lateral e medial da primeira bifurcação e também em segmentos distais à terceira bifurcação dos ramos mediais e distais da segunda bifurcação dos ramos medial e lateral da primeira bifurcação. Proximalmente à primeira bifurcação, os processos ósseos estão presentes em todos os segmentos, inclusive o mais proximal; segmento mais proximal com nove processos ósseos posicionados distoproximalmente. Distalmente à primeira bifurcação e proximalmente às segundas ramificações, os processos ósseos estão presentes em todos os segmentos do ramo medial e em até dois segmentos do ramo lateral, imediatamente proximais à segunda bifurcação deste ramo. Distalmente à segunda bifurcação do ramo medial da primeira bifurcação, os processos ósseos estão presentes em todos os segmentos dos ramos medial e lateral. Distalmente à terceira bifurcação dos ramos medial e lateral da segunda bifurcação do ramo medial da primeira bifurcação, os processos ósseos 
$\overline{\text { estão presentes em todos os segmentos dos dois ramos. Distalmente à segunda bifurcação do }}$ ramo lateral da primeira bifurcação, os processos ósseos estão presentes em todos os segmentos do ramos medial e em até três segmentos do ramo lateral, imediatamente proximais à terceira bifurcação deste ramo. Distalmente à terceira bifurcação do ramo medial da segunda bifurcação do ramo lateral da primeira bifurcação, os processos ósseos estão presentes em todos os segmentos dos ramos medial e lateral. Distalmente à terceira bifurcação do ramo lateral da segunda bifurcação do ramo lateral da primeira ramificação, os processos ósseos estão presentes em todos os segmentos do ramo medial e em até três segmentos do ramo lateral, a paritr do segundo segmento distal à bifurcação. Processos ósseos com secção transversal ovalada proximodistalmente. Em todos os segmentos proximais à primeira bifurcação, os processos ósseos estão inseridos na face ventromedial. Em todos os segmentos, os processos ósseos estão inseridos na face ventromedial, com exceção de quatro segmentos imediatamente proximais à segunda bifurcação do ramo medial, nos quais os processos ósseos estão inseridos tanto na face ventromedial quanto na ventrolateral. Em todos os segmentos do ramo medial da segunda bifurcação do ramo lateral da primeira bifurcação, os processos estão inseridos na face ventromedial. Em todos os segmentos do ramo lateral da segunda bifurcação do ramo medial da primeira bifurcação, os processos estão inseridos na face ventrolateral, com exceção de um segmento imediatamente proximal à terceira bifurcação deste ramo, no qual os processos ósseos estão inseridos tanto na face ventromedial quanto na ventrolateral. Em todos os segmentos do ramo medial da terceira bifurcação dos ramos medial e lateral da segunda bifurcação dos ramos medial e lateral da primeira bifurcação, os processos ósseos estão inseridos na face medial. Em todos os segmentos do ramo lateral da terceira bifurcação dos ramos medial e lateral da segunda bifurcação dos ramos medial e lateral da primeira bifurcação, os processos ósseos estão inseridos na face lateral, com exceção do ramo lateral 
$\overline{\text { da terceira bifurcação do ramo lateral da segunda bifurcação do ramo lateral da primeira }}$ bifurcação, no qual os processos ósseos estão inseridos na face medial. No segmento mais proximal, mais longo, a inserção dos processos ósseos aparece mais ventralmente em direção distoproximal. Os processos ósseos desenvolvem-se perpencidularmente à sua inserção no segmento.. No quarto (1/4) proximal de seu comprimento, os processos ósseos apresentam uma curvatura de $55^{\circ}$ e desenvolvem-se em direção proximal (ligeiramente medial) em relação ao segmento no qual estão inseridos. Em secção transversal os processos ósseos variam de ovalados proximodistalmente a cilíndricos ao longo do comprimento, afilando-se gradualmente e terminando t em uma extremidade levemente arredondada. Em seu estado máximo de desenvolvimento, o comprimento não alcança o comprimento proximodistal do segmento no qual está inserido. Na nadadeira pélvica o processos ósseos aumentam e diminuem gradualmente de tamanho em direção láteromedial; terceiro raio ramificado com maior número de segmentos com processos ósseos e processos ósseos maiores. Nos raios os processos ósseos aumentam e diminuem de tamanho em direção proximodistal.

Glândula branquial: presente em machos maduros.

Glândula branquial formada pela fusão do primeiro ao décimo filamentos branquiais no ceratobranquial do primeiro arco branquial. Glândula branquial disrtribuindo-se em $30 \%$ do total de filamentos do ceratobranquial do primeiro arco branquial. Células colunares pouco visíveis lateralmente. Abertura da glândula branquial localizando-se nos $85 \%$ distais do filamento branquial.

\section{Diapoma speculiferum Cope 1894}

Figs. 198 a 202 
Localidade tipo: Alto rio Jacuí, Rio Grande do Sul, Brasil.

Material examinado: MZUSP 19921, 1, Brasil. Rio Grande do Sul, Lajeado, rio Forqueta, em Marques de Souza, bacia do rio Jacuí, 29²0’00”S, 5205’00”W, Expedição MZUSP/USNM, 07/12/1979. MZUSP 28247, 7, Brasil, Rio Grando do Sul, Lajeado, arroio

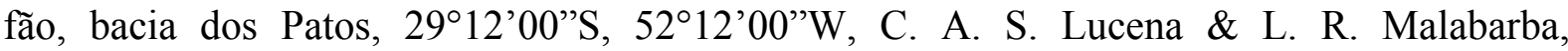
16/11/1983. MZUSP 61454, 2, Brasil, Rio Grande do Sul, S. Ant. Da Patrulha, arroio da patrulha, e Caraa, Menezes et al., 17/01/1991.

\section{Caracteres sexuais secundários}

Os caracteres sexuais secundários em $D$. speculiferum relacionam-se ao comprimento padrão, formato de nadadeiras, presença de processos ósseos e órgão caudal.

Comprimento padrão: machos alcançam maiores valores de comprimento padrão em relação às fêmeas. MZUSP 19921, 1 macho (38.9 mm CP); MZUSP 28247, 7 fêmeas (30.838.2 mm CP); MZUSP 61454, 1 macho (40.2 mm CP) e 1 fêmea (38.4 mm CP).

Formato de nadadeiras: Machos diferem de fêmeas pelo formato do perfil da margem distal da nadadeira anal, pelo formato da nadadeira pélvica e procurrentes ventrais.

Nadadeira anal de machos com um lobo anterior e outro posterior. Lobo anterior com margem distal convexa, em consequência do aumento em tamanho do último raio simples e primeiro raio ramificado (raio mais longo) e diminuição gradual deste ao sexto raio ramificado; perfil reto do sexto ao vigésimo terceiro raio ramificado. Lobo posterior formado pelo aumento do vigésimo terceiro ao vigésimo sétimo raio ramificado (raio mais longo) e diminuição deste ao último raio ramificado; extremidade distal do vigésimo sétimo raio ramificado ultrapassando a origem do raio procurrentes ventral mais anterior. Perfil da margem distal da nadadeira anal de fêmeas côncavo, devido à diminuição acentuada em tamanho que ocorre desde o primeiro 
$\overline{\text { raio ramificado (raio mais longo) ao quinto raio ramificado; perfil reto do sexto ao último raio }}$ ramificado.; último raio ramificado não alcançando o raio procurrente ventral mais anterior. Extremidade distal do primeiro raio ramificado (raio mais longo) da nadadeira pélvica de machos alcançando e ultrapassando a origem da nadadeira anal, mas nunca ultrapassando o último raio simples. Nadadeira pélvica de machos sobrepondo-se ao orifício urogenital em vista ventral. Extremidade distal do primeiro raio ramificado (raio mais longo) da nadadeira pélvica de fêmeas não alcançando a origem da nadadeira anal. Nadadeira pélvica de fêmeas não sobrepondo-se ao orifício urogenital em vista ventral.

Processos ósseos: presentes nas nadadeiras anal e pélvica de machos.

Nadadeira anal com até dois (geralmente um) processos ósseos por segmento do hemitriquium, do último raio simples ao décimo segundo raio ramificado, distribuindo-se em até $41 \%$ dos raios ramificados (até 29 raios ramificados). Último raio simples com processos ósseos do quarto ao décimo segmento, que é o terceiro segmento proximal à extremidade distal do raio. Processos ósseos presentes tanto em segmentos proximais quanto em segmentos distais à primeira bifurcação. Processos ósseos presentes também em segmentos distais à segunda bifurcação do ramo anterior da primeira bifurcação. Proximalmente à primeira bifurcação, os processos ósseos estão presentes em até três segmentos. Distalmente à primeira bifurcação e proximalmente à segunda bifurcação, os processos ósseos estão presentes em todos os segmentos do ramo posterior e em até dois segmentos do ramo anterior, imediatamente proximais à segunda bifurcação. Distalmente à segunda bifurcação do ramo anterior da primeira bifurcação, os processos ósseos estão presentes em até três segmentos do ramo posterior imediatamente distais à bifurcação e em até três segmentos do ramo anterior, a partir do terceiro segmento distal à segunda bifurcação. Distalmente à segunda bifurcação do ramo posterior da primeira bifurcação, os processos ósseos estão restritos a até dois 
segmentos do ramo anterior, imediatamente distais à bifurcação. Processos ósseos assimétricos bilateralmente, Processos ósseos com inserção arredondada. O diâmetro de sua inserção ocupando $31 \%$ do comprimento proximodistal do segmento no qual está inserido. Em todos os segmentos, os processos ósseos estão inseridos na face lateroposterior, com exceção de até quatro segmentos no ramo posterior da primeira bifurcação imediatamente proximais à segunda bifurcação, no qual os processos ósseos estão inseridos tanto na face Láteroposterior quanto na láteroanterior e dos segmentos do ramo anterior da segunda rmaificação do ramo posterior da primeira bifurcação, nos quais os processos ósseos estão isneridos na face láteroanterior. Os processos ósseo desenvolvem-se perpendicularmente á inserção no segmento no qual estão inseridos. No quarto (1/4) proximal do comprimento, os processos ósseos apresentam uma curvatura de $55^{\circ}$ e desenvolvem-se em direção proximal (ligeiramente medial) em relação ao segmento no qual estão inseridos. Em secção transversal, os processos ósseos são cilíndricos ao longo do comprimento, afilando-se gradualmente e terminando em uma extremidade distal arredondada. O diâmetro de sua extremidade distal equivale a $36 \%$ do diâmetro de inserção no segmento no qual está inserido. Em seu estado máximo de desenvolvimento, o comprimento não alcança o comprimento proximodistal do segmento no qual está inserido. O comprimento do maior processo ósseo, $52 \%$ do comprimento proximodistal do segmento no qual está inserido. Na nadadeira anal os processos aumentam e diminuem gradualmente de tamanho em direção anteroposterior; primeiro e segundo raios ramificados com maior número de segmentos com processos ósseos; quarto, quinto e sexto raios ramificados com processos ósseos mais desenvolvidos. No raio os processos ósseos aumentam e diminuem de tamanho em direção proximodistal.

Nadadeira pélvica com processos ósseos restritos a segmentos do hemitriquium ventral. Nadadeira pélvica com até dois (geralmente um) processos ósseos por segmento (com 
$\overline{\text { exceção do segmento mais proximal, mais longo) no hemitriquium ventral do primeiro ao }}$ sétimo raios ramificados, o que representa presença em 100\% dos raios da nadadeira (7 raios ramificados). Raios ramificados com processos ósseos tanto em segmentos proximais quanto distais à primeira bifurcação. Raios ramificados com processos ósseos presentes também em segmentos distais à segunda bifurcação dos ramos lateral e medial da primeira bifurcação. Proximalmente à primeira bifurcação, os processos ósseos estão presentes em todos os segmentos (inclusive o segmento mais proximal, mais longo) do terceiro ao sétimo raios ramificados; segmento mais proximal com até cinco processos ósseos em direção proximodistal. Distalmente à primeira bifurcação e proximalmente às segundas ramificações, os processos ósseos estão presentes em todos os segmentos do ramo medial e em até três segmentos do ramo lateral, imediatamente proximais à segunda bifurcação deste ramo. Distalmente à segunda bifurcação do ramo medial da primeira bifurcação, os processos ósseos estão presentes em até dois segmentos dos ramos medial e lateral, imediatamente distais à bifurcação. Distalmente à segunda bifurcação do ramo lateral da primeira bifurcação, os processos ósseos estão presentes em até um segmento do ramo medial, imediatamente dorasal à bifurcação e em até um segmento do ramo lateral, a partir do terceiro segmento distal à bifurcação. Processos ósseos assimétricos bilateralmente, com inserção arredondada. O diâmetro de sua inserção ocupa $22 \%$ do comprimento proximodistal do segmento no qual está inserido. Em todos os segmentos, os processos ósseos estão inseridos na face ventromedial, com exceção de dois segmentos do ramo medial da primeira bifurcação imediatamente proximais à segunda bifurcação deste ramo, no qual os processos estão inseridos tanto na face ventromedial quanto na face ventrolateral e de todos os segmentos do ramo lateral da segunda bifurcação do ramo medial da primeira bifurcação, nos quais os processos ósseos estão inseridos na face ventrolateral. No segmento mais proximal, mais longo, a inserção dos 
$\overline{\text { processos ósseos muda ligeiramente da face ventrolateral a mais ventral em direção }}$ distoproximal. Os processos ósseos desenvolvem-se perpendicularmente à inserção nos segmentos no qual estão inseridos. Em seu quinto (1/5) proximal, os processos ósseos apresentam uma curvatura de aproximadamente $75^{\circ}$ e desenvolvem-se linha reta em direção proximomedial em relação ao eixo proximodistal do segmento no qual estão inseridos. Em secção transversal, os processos ósseos são cilíndricos ao longo do comprimento, afilando-se gradualmente e terminando em uma extremidade ligeiramente pontiaguda. O diâmetro de sua extremidade distal equivale a $37 \%$ do diâmetro de inserção no segmento. Em seu estado máximo de desenvolvimento, o comprimento total não alcança o comprimento proximodistal do segmento no qual está inserido. Comprimento proximodistal dos processos ósseos $89 \%$ do comprimento proximodistal do segmento no qual está inserido. Na nadadeira pélvica o processos ósseos aumentam gradualmente de tamanho em direção láteromedial; quinto e sexto raios ramificados com maior número de segmentos com processos ósseos e processos ósseos maiores. Nos raios os processos ósseos aumentam e diminuem de tamanho em direção proximodistal; o maior processo ósseo localiza-se no segundo segmento do ramo medial distal à primeira rmaificação.

Órgão caudal: presente e modificado em machos maduros.

O órgão caudal está restrito ao lobo ventral da nadadeira caudal. É formado pela modificação das escamas posteriores da série de escamas da linha lateral e das três séries de escamas ventrais a esta, e uma série de cinco escamas (mencionada abaixo) e tecido intumescido. A abertura do órgão caudal está direcionada pósteroventralmente abrangendo os três raios procurrentes ventrais mais distais, o raio simples principal ventral da nadadeira caudal e o décimo sétimo raio ramificado. Horizontalmente, o complexo do órgão caudal estende-se da porção posterior do pedúnculo caudal até a porção mediana do décimo e décimo primeiro raio 
$\overline{\text { ramificado e verticalmente da face dorsal do décimo raio ramificado até a extremidade do }}$ quinto raio procurrente ventral (contado posteroanteriormente). Todas as escamas das séries de escamas envolvidas no complexo do órgão caudal modificam-se anteroposterioremente a partir do final do pedúnculo caudal, de uma escama ciclóide normal, igual àquelas de outros locais do corpo, à escama mais posterior de cada série, que é sempre a mais modificada. Três são as escamas modificadas da série de escamas da linha lateral envolvidas no complexo do órgão caudal. Esta série de escamas modificadas mantém-se em linha reta em direção posterior com limite dorsal na face dorsal do décimo raio ramificado, e compõem o limite dorsal do órgão caudal. A observação dos circulii destas escamas indica o desenvolvimento posterior da metade dorsal das escamas enquanto que a metade ventral da escama aumenta muito pouco tanto posteriormente quanto ventralmente; a altura das três escamas é semelhante à das escamas não modificadas, resultando em uma escama mais longa do que alta. A série de três escamas da linha lateral envolvidas no complexo do órgão caudal sobrepõem-se completamente a metade proximal do décimo ao décimo terceiro raio ramificado. Três são as escamas da primeira série de escamas abaixo da linha lateral envolvidas no complexo do órgão caudal. A observação dos circulii indica que as duas escamas posteriores desta série (as modificadas) aumentam de altura, através do desenvolvimento em direção posterodorsal e ventral; desenvolvimento posterodorsal mais acentuado. Diferentemente das escamas modificadas da linha lateral, estas escamas modificadas curvam-se ventralmente e a última escama modificada compõe toda a porção lateral da abertura do órgão caudal. Duas são as escamas da segunda série de escamas abaixo da linha lateral envolvidas no complexo do órgão caudal. Apenas a escama mais distal é modificada. A observação dos circulii indica que a escama modificada (a mais posterior) desta série tem altura maior devido ao desenvolvimento posterodorsal e posteroventral; a margem posterior desta escama é 
ligeiramente côncava, com a porção dorsal e ventral convexas. A escama modificada desta série compõe o limite anteroventral da abertura do órgão caudal. Duas são as escamas da terceira série de escamas abaixo da linha lateral envolvidas no complexo do órgão caudal. Todas estas escamas são semelhantes às outras escamas do corpo. A escama mais distal desta série compõe, junto com a escama modificada da segunda série, o limite anteroventral da abertura do órgão caudal. Existe ainda, um complexo de cinco escamas individuais que decrescem de tamanho em direção posterior, sendo a segunda escama a maior. Estão organizadas de maior a menor e com certa sobreposição, sendo a primeira a mais lateral. São mais compridas que altas e estão direcionadas posterodorsalmente. A primeira escama está localizada imediatamente posterior à escama posterior da série de escamas da linha lateral, o restatante das escamas na linha da primeira série de escamas abaixo da linha lateral. Estas escamas estão fortemente aderidas à metade proximal do décimo primeiro ao décimo sexto raios ramificados. De acordo com o padrão de sobreposição laterais entre as escamas das séries dorsal e ventral, provavelmente estas escamas sejam oriundas da primeira série de escamas abaixo da linha lateral. No entanto, serão tratadas como um complexo de escamas individuais até que um trabalho de desenvolvimento ontogenético deste complexo seja realizado. Individualmente, lateralmente à porção exposta dos três procurrentes ventrais posteriores, e ao raio simples principal ventral e décimo sétimo raio ramificado (raios da abertura do órgão caudal) existe uma pequena faixa de tecido cujo limite proximal em cada raio é mais denso e estão localizados exatamente na porção medial à margem distal da ultima escama da primeira série de escamas abaixo da linha lateral, que compõem o limite lateral da abertura da órgão caudal.

\section{Eretmobrycon bayano Fink 1976}


Fig. 203 a 208

Localidade tipo: Poço em pequeno riacho a cerca de 19 kilometros ao longo da estrada de El Llano ao Carti, bacia do rio Bayano, Panama.

Material examinado: Parátipo: MZUSP 14049, 3, Panamá, Poço em pequeno riacho a erca de 19 kilometros ao longo da estrada de El Llano ao Carti, bacia do rio Bayano, Phail \& Gresslar, 10/03/1973.

Não tipo: MZUSP 18522, 3, Panamá, primeiro riacho, na estrada do el Llanoao Carti, aproximadamente $11 \mathrm{Km}$, da estrada principal, entre Chapo e a represa de Bayano, bacia do rio Bayano, D. L. Kramer, 15/01/1975.

\section{Caracteres sexuais secundários}

Os caracteres sexuais secundários em E. bayano relacionam-se ao comprimento padrão, formato de nadadeiras e presença de processos ósseos.

Comprimento padrão: machos alcançam maiores valores de comprimento padrão em relação às fêmeas. MZUSP 14049, 3 machos (42.5-45.6 mm CP); MZUSP 18522, 2 machos (47.0-50.8 mm CP) e 1 fêmea (36.6 mm CP).

Formato de nadadeiras: machos diferem de fêmeas pelo formato da nadadeira pélvica e caudal.

Extremidade distal do primeiro raio ramificado (raio mais longo) da nadadeira pélvica de machos ultrapassando o orifício urogenital, mas não alcançando a origem da nadadeira anal. Nadadeira pélvica de machos sobrepõe-se ao orifício urogenital em vista ventral. Extremidade distal do primeiro raio ramificado (raio mais longo) da nadadeira pélvica de fêmeas não ultrapassando o orifício urogenital. Nadadeira pélvica não sobrepõe-se ao orifício urogenital em vista ventral. 
$\overline{\text { Nadadeira caudal de machos com lobo inferior mais longo e expandido dorsoventralmente }}$ que o lobo superior. Lobo inferior hipertrofiado do décimo raio ramificado ao antipenúltimo raio procurrente inferior. Raios do lobo inferior da nadadeira caudal de machos aumentando de tamanho e largura dorsoventral dos segmentos (em relação ao comprimento proximodistal do segmento), do décimo raio ramificado ao raio simples ventral. Décimo sexto e décimo sétimo raios ramificados mais longos e maisdesenvolvido. Desenvolvimento do lobo inferior resultante do aumento no número de bifurcações nos raios ramificados, largura dorsoventral (mais largos que longos proximodistalmente) dos segmentos do hemitriquium e espessamento das membranas interradiais.

Nadadeira caudal de fêmeas como lobos superior e inferior com mesmo tamanho e formato.

Processos ósseos: presentes nas nadadeiras anal e pélvica de machos.

Nadadeira anal com um processo ósseo por segmento de hemitriquium, do último raio simples ao vigésimo nono raio ramificado, disrtribuindo-se em até $97 \%$ dos raios ramificados (até 30 raios ramificados). Último raio simples com processos ósseos do sétimo segmento mais proximal até o décimo segundo segmento, sétimo segmento proximal à extremidade distal do raio. Processos ósseos presentes tanto em segmentos proximais quanto em segmentos distais à primeira bifurcação. Processos ósseos presentes também em segmentos distais à segunda bifurcação do ramo anterior da primeira bifurcação. Proximalmente à primeira bifurcação, os processos ósseos estão presentes em até dez segmentos. Distalmente à primeira bifurcação e proximalmente à segunda bifurcação, os processos ósseos estão presentes em todos os segmentos do ramo posterior e em até quatro segmentos do ramo anterior, imediatamente proximais à segunda bifurcação deste ramo. Distalmente à segunda bifurcação do ramo anterior da primeira bifurcação, os processos ósseos estão presentes em até cinco segmentos do ramo posterior imediatamente distais à bifurcação e em até quatro 
$\overline{\text { segmentos do ramo anterior, imediatamente distais à bifurcação. Processos ósseos simétricos }}$ bilateralmente. Processos ósseos com secção transversal ovalada proximodistalmente no local da inserção. O maior comprimento de sua inserção ocupa $37 \%$ do comprimento proximodistal do segmento no qual está inserido. Em todos os segmentos, os processos ósseos estão inseridos na face lateroposterior, com exceção de dois segmentos imediatamente distais à segunda bifurcação do ramo anterior da primeira bifurcação, nos quais os processos ósseos estão inseridos tanto na face lateroanterior quanto na face lateroposterior e de todos os segmentos do ramo anterior da segunda bifurcação do ramo anterior da primeira bifurcação no qual os processos ósseos estão inseridos na face lateroanterior. Os processos ósseos desenvolvem-se perpendicularmente à sua inserção no segmento no qual estão inseridos. No quarto (1/4) proximal de seu comprimento total, os processos ósseos apresentam uma curvatura de $60^{\circ}$ e desenvolvem-se em direção proximal (ligeiramente medial) em relação ao segmento no qual estão inseridos. Em secção transversal, os processos ósseos variam de ovalados proximodistalmente a cilíndricos ao longo de seu comprimento, afilando-se gradualmente e terminando em uma extremidade distal pontiaguda. O diâmetro de sua extremidade distal equivale a $10 \%$ do maior comprimento na inserção no segmento no qual está inserido. Em seu estado máximo de desenvolvimento, o comprimento não alcança o comprimento proximodistal do segmento no qual está inserido. Comprimento do maior processo ósseo, $95 \%$ do comprimento proximodistal do segmento no qual está inserido. $\mathrm{Na}$ nadadeira anal os processos aumentam e diminuem gradualmente de tamanho em direção anteroposterior; segundo e terceiro raios ramificados com maior número de segmentos com processos ósseos e processos ósseos maiores. No raio os processos ósseos aumentam e diminuem de tamanho em direção proximodistal; o maior processo ósseo localiza-se no terceiro segmento proximal à terceira bifurcação da série de processos ósseos. 
Nadadeira pélvica com processos ósseos restritos a segmentos do hemiriquium ventral. Nadadeira pélvica com um processo ósseo por segmento (com exceção do segmento mais proximal, mais longo) no hemitriquium ventral do primeiro ao oitavo raios ramificados, disrtribuindo-se em $100 \%$ dos raios ramificados (oito raios ramificados). Raios ramificados com processos ósseos tanto em segmentos proximais quanto em distais à primeira bifurcação. Processos ósseos presentes também em segmentos distais à segunda bifurcação dos ramos lateral e medial da primeira bifurcação. Proximalmente à primeira bifurcação, os processos ósseos estão presentes em todos os segmentos, inclusive no mais proximal, mais longo. Distalmente à primeira bifurcação e proximalmente às segundas bifurcações, os processos ósseos estão presentes em todos os segmentos do ramo medial e em até quatro segmentos do ramo lateral, imediatamente proximais à segunda bifurcação deste ramo. Distalmente à segunda bifurcação do ramo medial da primeira bifurcação, os processos ósseos estão presentes em todos os segmentos dos ramos medial e lateral. Distalmente à segunda bifurcação do ramo lateral da primeira bifurcação, os processos ósseos estão presentes em todos os segmentos do ramos medial e em até dez segmentos do ramo lateral, a partir do terceiro segmento distal à bifurcação deste ramo. Processos ósseos com inserção arredondada. O diâmetro de sua inserção ocupa $23 \%$ do comprimento proximodistal do segmento no qual está inserido. Em todos os segmentos proximais à primeira bifurcação e em todos os segmentos dos ramos medial e lateral da primeira bifurcação, os processos ósseos estão inseridos na face ventromedial, com exceção de cinco segmentos do ramo medial da primeira bifurcação, imediatamente proximais à segunda bifurcação deste ramo, no qual os processos estão inseridos tanto na face ventromedial quanto na face ventrolateral. Em todos os segmentos do ramo medial da segunda bifurcação do ramo medial da primeira bifurcação, os processos estão inseridos na face ventromedial, com exceção de dois segmentos mais distais 
do ramo, no qual os processos estão inseridos tanto na face ventromedial quanto na ventrolateral. Em todos os segmentos do ramo lateral da segunda bifurcação do ramo medial da primeira bifurcação, os processos ósseos estão inseridos na face ventrolateral, com exceção dos dois segmentos mais distais do ramo, nos quais os processos estão inseridos tanto na face ventrolateral quanto na ventromedial. Em todos os segmentos do ramo medial da segunda bifurcação do ramo lateral da primeira bifurcação, os processos ósseos estão inseridos na face ventromedial, com exceção dos seis segmentos mais distais do ramo, nos quais os processos ósseos estão inseridos tanto na face ventromedial quanto na ventrolateral. Em todos os segmentos do ramo lateral da segunda bifurcação do ramo lateral da primeira bifurcação, os processos ósseos estão inseridos na face ventromedial. No segmento mais proximal, mais longo, a inserção dos processos ósseos muda ligeiramente da face ventrolateral à mais ventral em direção distoproximal. Os processos ósseos desenvolvem-se perpendicularmente à sua inserção no segmento no qual estão inseridos. No um quarto (1/4) proximal do comprimento, os processos ósseos apresentam uma curvatura de $45^{\circ}$ e desenvolvem-se em linha reta em direção proximal ou proximolateral em relação ao eixo proximodistal do segmento no qual estão ineridos. Em secção transversal, os processos ósseos são cilíndricos ao longo do comprimento afilando-se gradualmente e terminando em uma extremidade levemente arredondada. O diâmetro de sua extremidade distal, 24\% do diâmetro da inserção no segmento no qual está inserido. Em seu estado máximo de desenvolvimento, o comprimento total não alcança o comprimento proximodistal do segmento no qual está inserido. Comprimento do maior processo ósseo $71 \%$ do comprimento proximodistal do segmento no qual está inserido. $\mathrm{Na}$ nadadeira pélvica os processos ósseos aumentam e diminuem gradualmente de tamanho em direção lateromedial; terceiro e quarto raios ramificados com maior número de segmentos com processos ósseos e processos ósseos maiores. Nos raios os 
$\overline{\text { processos ósseos decrescem de tamanho em direção proximodistal; o maior processo ósseo }}$ localiza-se no terceiro segmento proximal à segunda bifurcação, na metade da série de processos ósseos.

\section{Gephyrocharax atracaudata (Meek \& Hildebrand 1912)}

Figs. 209 a 216

Localidade tipo: rio Frijoles, zona do Canal, Panamá.

Material examinado: MZUSP 19389, 5, Panamá, zona do Canal, rio Cardenas, behind ft. Clayton, Luftin \& Tyson, 19/04/1962. MZUSP 19702, 16, Córrego que desagua no lago Miraflores, zona do Canal, Britski, 11/1965.

\section{Caracteres sexuais secundários}

Os caracteres sexuais secundários em G. atracaudata relacionam-se ao comprimento padrão, formato de nadadeiras e presença de processos ósseos e órgão caudal.

Comprimento padão: machos alcançam maiores valores de comprimento padrão em relação às fêmeas. MZUSP 19389, 2 machos (37.1-40.5 mm CP) e 2 fêmeas (29.2-37.5 mm CP); MZUSP 19702, 3 machos (36.9-42.3 mm CP) e 5 fềmeas (40.0-41.1 mm CP).

Formato de nadadeiras: machos diferem de fêmeas pelos formatos do perfil da margem distal da nadadeiras anal, pélvica, dorsal e caudal.

Perfil da margem distal da nadadeira anal de machos reto, devido à diminuição gradual de tamanho do primeiro (raio mais longo) ao último raios ramificados. Do primeiro ao oitavo raio ramificado (raios com processos ósseos) os raios são mais depressos que os raios posteriores (raios sem processos ósseos) dando a impressão que o nono raio ramificado é maior. Perfil da margem distal do lobo anterior da nadadeira anal ligeiramente convexo, 
$\overline{\text { devido a diminuição gradual de tamanho do primeiro raio ramificado (raio mais longo) ao }}$ quinto raios ramificados; perfil reto do sexto ao último raio raimificado, devido à diminuição gradual de tamanho.

Perfil da margem distal da nadadeira pélvica de machos com dois lobos, formando um "S" em direção anteromedial, em vista ventral. Lobo lateral nitidamente côncavo, devido à diminuição de tamanho dos raios simples e primeiro ramificado e presença de um lobo medial conspicuamente convexo, formado pelo aumento gradual de tamanho do segundo ao quarto raios ramificados (este último o raio mais longo do lobo e da nadadeira) e diminuição gradual de tamanho deste ao útimo raio ramificado da nadadeira pélvica. Raios ramificados do lobo medial da nadadeira pélvica mais longos que o raio simples; raios do lobo medial sobrepõe-se ao orifício urogenital em vista ventral e alcança a origem da nadadeira anal. Perfil da margem distal da nadadeira pélvica de fêmeas com dois lobos discretos, formando um "S" pouco evidente em direção lateromedial, em vista ventral. Lobo lateral côncavo discreto, devido à diminuição de tamanho do raio simples (raio mais longo) ao primeiro raio ramificado e um lobo medial convexo conspícuo, devido ao aumento gradual de tamanho do segundo ao terceiro raio ramificado (raio mais longo do lobo), e diminuição gradual de tamanho deste ao último raio ramificado. Raios do lobo medial não sobrepõe-se ao orifício urogenital em vista ventral e não alcança a origem da nadadeira anal.

Perfil da margem distal da nadadeira dorsal de machos lanceolada, o sexto raio ramificado, quando a nadadeira está adepressa, estendendo-se mais posteriormente. Perfil da margem distal da nadadeira dorsal de fêmeas convexo. Quarto raio ramificado estendendo-se mais posterioremente em relação aos outros raios da nadadeira quando esta está adepressa.

Nadadeira caudal de machos com lobo superior mais desenvolvido; raios mais inferiores do lobo superior direcionados ventralmente; extremidade distal do nono, décimo e décimo 
$\overline{\text { primeiro raios ramificados na linha horizontal da primeira e/ou segunda série de escamas }}$ abaixo da linha lateral. Nadadeira caudal de fêmeas com lobos igualmente desenvolvidos, extremidade distal do nono, décimo e décimo primeiro raios ramificados na liha horizontal da linha lateral.

Último e penúltimo raios procurrentes inferiores da nadadeira caudal de machos modificados; penúltimo raio procurrente com projeções ósseas laminares nos segmentos, em direção ventral e dorsal; último raio procurrente com uma região côncava na face ventral da porção mediana, em posição exatamente dorsal à projeção óssea dorsal do penúltimo procurrente inferior. Procurrentes ventrais de fêmeas cilíndricos.

Processos ósseos: presentes nas nadadeiras anal, pélvica e caudal de machos.

Nadadeira anal com até dois (geralmente um) processos ósseos por segmento de hemitriquium, do último raio simples ao sétimo raio ramificados, distribuindo-se em até $27 \%$ dos raios ramificados (até 26 raios ramificados). Último raio simples com processos ósseos do quinto ao décimo quinto segmentos, segundo segmento proximal à extremidade distal do raio. Processos ósseos presentes e restritos a segmentos distais à primeira bifurcação. Processos ósseos presentes também em segmentos distais à segunda bifurcação dos ramos anterior e posterior da primeira bifurcação. Distalmente à primeira bifurcação e proximalmente à segunda bifurcação, os processos ósseos estão inseridos em até seis segmentos do ramo posterior, a partir do primeiro ou segundo segmento distal à primeira bifurcação e em até dois segmentos do ramo anterior, imediatamente proximais à segunda bifurcação deste ramo. Distalmente à segunda bifurcação do ramo anterior da primeira bifurcação, os processos ósseos estão presentes em até cinco segmentos do ramo posterior, imediatamente distais à bifurcação e em até dois segmentos do ramo anterior, a partir do terceiro segmento distal à bifurcação. Distalmente à segunda bifurcação do ramo posterior da primeira bifurcação, os 
$\overline{\text { processos ósseos estão presentes em até quatro segmentos do ramo posterior, imediatamente }}$ distais à bifurcação e em até três segmentos do ramo anterior, imediatamente distais à bifurcação. Processos ósseos simétricos bilateralmente, Processos ósseos inserção ovalada proximodistalmente. O maior comprimento de sua inserção ocupa $27 \%$ do comprimento proximodistal do segmento no qual está inserido. Em todos os segmentos os processos ósseos estão inseridos na face lateroposterior, com exceção dos segmentos do ramo posterior da primeira bifurcação, imediatamente proximais à segunda bifurcação deste ramo, nos quais os processos ósseos estão inseridos tanto na face lateroposterior quanto na lateroanterior e em todos os segmentos do ramo anterior da segunda bifurcação do ramo posterior da primeira bifurcação, nos quais os processos ósseos estão inseridos na face lateroanterior. Os processos ósseos desenvolvem-se perpendicularmente à inserção no segmento no qual estão inseridos. No quinto (1/5) proximal de seu comprimento total, os processos ósseos apresetam uma curvatura de $85^{\circ}$ e desenvolvem-se em direção proximomedial em relação ao segmento no qual estão inseridos. Em sua porção distal os processos ósseos podem ainda apresentar uma curvatura gradual em direção lateral em relação à nadadeira. Em secção transversal, os processos ósseos variam de ovalados proximodistalmente a cilíndricos ao longo do comprimento, afilando-se gradualmente e terminando em uma extremidade distal levemente arredondada. O diâmetro de sua extremidade distal equivale a $18 \%$ do maior comprimento do segmento no qual está inserido. Em seu estado máximo de desenvolvimento, o comprimento ultrapassa o comprimento proximodistal do segmento no qual está inserido. Comprimento do maior processo ósseo, $131 \%$ do comprimento proximodistal do segmento no qual está inserido. Na nadadeira anal os processos aumentam e diminuem gradualmente de tamanho em direção anteroposterior; quinto e sexto raios ramificados com maior número de segmentos com processos ósseos e processos ósseos maiores. No raio os processos ósseos aumentam e 
$\overline{\text { diminuem tamanho em direção proximodistal; o maior processo ósseo localiza-se no }}$ segmento mais proximal com processo ósseo.

Nadadeira pélvica com processos ósseos restritos a segmentos do hemitriquium ventral. Nadadeira pélvica com até dois (geralmente um) processos ósseos por segmento, do raio simples ao sexto raios ramificados, disrtribuindo-se em $85 \%$ dos raios ramificados ( 7 raios ramificados). Raio simples com processos ósseos do terceiro segmento mais proximal ao décimo terceiro segmento, segundo segmento proximal à extremidade distal do raio. Raios ramificados com processos ósseos presentes tanto em segmentos proximais quanto distais à primeira bifurcação. Proximalmente à primeira bifurcação, os processos estão presentes em todos os segmentos, inclusive o mais proximal, mais longo. Segmento mais proximal com seis processos ósseos em direção distoproximal. Processos ósseos presentes também em segmentos distais à segunda bifurcação dos ramos medial e lateral da primeira bifurcação. Processos ósseos presentes também em segmentos distais à segunda bifurcação dos ramos medial e lateral da primeira bifurcação. Processos ósseos presentes também em segmentos distais à terceira bifurcação dos ramos medial e lateral da segunda bifurcação dos ramos medial e lateral da primeira bifurcação. Distalmente à primeira bifurcação e proximalmente às segundas bifurcações, os processos ósseos estão presentes em todos os segmentos do ramo medial e em até dois segmentos do ramo lateral, imediatamente proximais à segunda bifurcação deste ramo. Distalmente à segunda bifurcação do ramo medial da primeira bifurcação, os processos ósseos estão presentes em todos os segmentos dos ramos medial e lateral. Distalmente à segunda bifurcação do ramo lateral da primeira bifurcação, os processos ósseos estão presentes em todos os segmentos do ramo medial e em até três segmentos do ramo lateral, imediatamente proximais à terceira bifurcação deste ramo. Distalmente a terceira bifurcação dos ramos medial e lateral da segunda bifurcação dos ramos medial e lateral da 
$\overline{\text { primeira bifurcação, os processos ósseos estão presentes em todos os segmentos dos ramos }}$ medial e lateral. Processos ósseos com secção transversal arredondada lo local da inserção. Em todos os segmentos proximais à primeira bifurcação e dos ramos medial e lateral da primeira bifurcação, os processos ósseos estão inseridos na face ventromedial, com exceção de dois segmentos do ramo medial da primeira bifurcação, imediatamente proximal à segunda bifurcação deste ramo nos quais os processos estão presentes tanto na face ventromedial quanto na ventrolateral. Em todos os segmentos do ramo medial da segunda bifurcação do ramo medial da primeira bifurcação, os processos estão inseridos na face ventromedial, com exceção dos quatro segmentos proximais à terceira bifurcação deste ramo, no qual os processos ósseos estão presentes tanto na face ventromedial quanto na ventrolateral. Em todos os segmentos do ramo lateral da segunda bifurcação do ramo medial da primeira bifurcação, os processos ósseos estão inseridos na face ventrolateral, com exceção dos quatro segmentos proximais à terceira bifurcação deste ramo, nos quais os processos ósseos estão inseridos tanto na face ventrolateral quanto na ventromedial. Nos segmentos do ramo medial da segunda bifurcação do ramo lateral da primeira bifurcação os processos ósseos estão inseridos na face ventromedial, com exceção dos quatro segmentos proximais à terceira bifurcação deste ramo, nos quais os processos ósseos estão inseridos tanto na face ventromedial quanto na face ventrolateral. Nos segmentos do ramo lateral da segunda bifurcação do ramo lateral da primeira bifurcação, os processos ósseos estão inseridos na face ventromedial. Nos segmentos do ramo medial da terceira bifurcação dos ramos medial e lateral da segunda bifurcação dos ramos medial e lateral da primeira bifurcação e nos segmentos do ramo lateral da terceira bifurcação do ramo lateral da segunda bifurcação do ramo lateral da primeira bifurcação, os processos ósseos estão inseridos na face ventromedial. Nos segmentos do ramo lateral da terceira bifurcação dos ramos lateral e medial da segunda bifurcação do ramo medial da 
$\overline{\text { primeira bifurcação e nos segmentos do ramo lateral da terceira bifurcação do ramo medial da }}$ segunda bifurcação do ramo lateral da primeira bifurcação, os processos ósseos estão inseridos na face ventrolateral. No segmento mais proximal, mais longo, a inserção dos processos ósseos muda ligeiramente da face ventrolateral à mais ventral em direção distoproximal. Os processos ósseos desenvolvem-se perpendicularmente à sua inserção no segmento. No quinto (1/5) proximal de seu comprimento, os processos ósseos apresentam uma curvatura de $85^{\circ}$ e desenvolvem-se em direção proximomedial em relação ao eixo proximodistal do segmento no qual estão inseridos. Em secção transversal, os processos ósseos são cilíndricos ao longo do comprimento, afilando-se gradualmente e terminando em uma extremidade levemente arredondada. O diâmetro na extremidade distal equivale a $25 \%$ do diâmetro de sua inserção no segmento. Em seu estado máximo de desenvolvimento, o comprimento não alcança o comprimento proximodistal do segmento no qual está inserido. $\mathrm{O}$ comprimento do maior processo ósseo equivale a $95 \%$ do proximodistal do segmento no qual está inserido. Na nadadeira pélvica os processos ósseos decrescem de tamanho em direção lateromedial em relação à nadadeira; segundo e terceiro raios ramificados com maior número de segmentos com processos ósseos e processos ósseos maiores. Nos raios, os processos ósseos aumentam e diminuem de tamanho em direção proximodistal; o maior processo ósseo localiza-se no quinto segmento proximal à terceira bifurcação, na metade distal da série de processos ósseos.

Nadadeira caudal com até dois (geralmente dois) processos ósseos por segmento do décimo quarto ao décimo sexto raios ramificados (lobo inferior), distribuindo-se em $12 \%$ dos raios ramificados (17 raios ramificados). Processos ósseos restritos a segmentos distais à primeira bifurcação. Processos ósseos presentes também em segmentos distais à segunda bifurcação do ramo dorsal da primeira bifurcação. Distalmente à primeira bifurcação, os processos ósseos 
$\overline{\text { estão restritos a todos os segmentos do ramo medial. Distalmente à segunda bifurcação do }}$ ramo medial da primeira bifurcação, os processos ósseos estão restritos a até cinco segmentos do ramo medial, imediatamente distais à bifurcação. Processos ósseos simétricos bilateralmente com secção ovalada proximodistalmente. O maior comprimento de sua inserção ocupa $9 \%$ do comprimento proximodistal do segmento no qual está inserido. Em todos os segmentos, os processos ósseos estão inseridos na face lateromedial. Os processos ósseos desenvolvem-se perpendicularmente à sua inserção no segmento no qual estão inseridos. No um quarto (1/4) proximal de seu comprimento total, os processos ósseos sofrem uma curvatura de $60^{\circ}$ e desenvolvem-se em direção proximal em relação ao segmento no qual estão inseridos. Em secção transversal, os processos ósseos variam de ovalados proximodistalmente a cilíndricos ao longo de seu comprimento total, afilando-se gradualmente e terminando em uma extremidade arredondada/pontiaguda. O diâmetro de sua extremidade distal equivale a $21 \%$ do maior comprimento de sua inserção no segmento no qual está inserido. Em seu estado máximo de desenvolvimento, o seu comprimento total não alcança o comprimento proximodistal do segmento no qual está inserido. O comprimento do maior processo ósseo equivale a $17 \%$ do comprimento proximodistal do segmento no qual está inserido. No lobo ventral os processos ósseos apresentam tamanho semelhante em direção lateromedial; décimo quinto raio com o maior número de segmento com processos ósseos. No raio os processos ósseos aumentam e diminuem gradualmente de tamanho em direção proximodistal; o maior processo ósseos está no segundo segmento proximal à segunda bifurcação, na metade proximal da série de processos ósseos.

Órgão caudal: presente em machos.

O órgão caudal é restrito ao lobo ventral da nadadeira caudal. O órgão caudal apresenta uma escama extremamente modificada, que compõe sozinha a abertura do órgão e uma escama 
com uma ligeira modificação dorsalmente à esta. Pela observação do padrão de sobreposiçãoo entre escamas das sérires de escamas adjacentes das series de escamas da linha lateral e abaixo desta e dos circulii e radii acredito que a escama mais modificada, qu ecompõe a abertura do órgão, se trata da escama mais posterior da primeira série de escamas abaixo da linha lateral e asegunda escama, que compõe a abertura do órgão caudal, se trata da escama mais posterior da segunda série de escamas abaixo da linha lateral. Verticalmente, a escama mais modificada sobrepõe a origem do décimo segundo raio ramificado ao penúltimo raio procurrente ventral da nadadeira caudal, inclusive o raio simples principal ventral. Horizontalmente, a escama sobrepõe lateralmente um quinto (1/5) dos raios principais do lobo ventral. A escama modificada apresenta uma forma lanceolada, com o seu um terço $(1 / 3)$ dorsal sem radii e representando a porção mais posterior do órgão caudal; os dois terços (2/3) ventrais da escama modificada, com radii bem marcado direcionados posteoventralmente, em direção à abertura do órgão caudal. A condição mencionada acima indica que a metade dorsal desta escama se desenvolve posteriormente enquando que a metade ventral não se desenvolve, o desenvolvimento da metade dorsal resulta no direcionamento posteroventral dos radii. Este tipo de desenvolvimento ocorre também na única oura escama modificada do órgão caudal, a escama mais posterior da primeira série de escama abaixo da linha lateral. A abertura do órgão caudal se estande do décimo segundo raio ao penúltimo raio procurrente ventral. $\mathrm{O}$ limite dorsal da abertura do órgão caudal é formado por um forte tecido ligadando a margem dorsal da escamam modificada à face dorsal e lateral da metade proximal do décimo segundo raio ramificado e na face lateral da metade do décimo terceiro raio ramificado. O limite ventral da abertura do órgão caudal é formado por um forte tecido ligando a margem ventroposterior da escama modificada à face lateral da metade distal do penúltimo raio 
procurrente ventral da nadadeira caudal. O limite lateral é formado por uma escama modificada. Apenas uma escama compõe a abertura do órgão caudal.

\section{Hemibrycon surinamensis Géry 1962}

Localidade tipo: Brownscreek, kilometro 114 da linha férrea de Paramaribo-Dam, bacia do rio Paramacca, Suriname.

Material examinado: MZUSP 30529, 27, Brasil, Pará, Caldeirão, rio Itacaiunas, bacia do rio Tocantins, M. Goulding, 15/10/1983. MZUSP. MZUSP 30530, 5, Brasil, Pará, rio Itacaiunas, estrda de ferro, $10 \mathrm{~km}$ leste do N-4, bacia do rio Tocantins, $05^{\circ} 52^{\prime} 00^{\prime \prime} \mathrm{S}, 50^{\circ} 32^{\prime} 00^{\prime \prime} \mathrm{W}$, M. Goulding, 13/10/1983.

\section{Caracteres sexuais secundários}

Os caracteres sexuais secundários em $H$. surinamensis relacionam-se ao comprimento padrão, formato de nadadeiras, presença de processos ósseos e glândula branquial.

Comprimento padrão: fêmeas alcançam maiores valores de comprimento padrão em relação aos machos. MZUSP 30529, 15 (32.9-66.9 mm CP) e 8 fêmeas (40.7-88.4 mm CP); MZUSP 30530, 2 machos (60.1-69.3 mm CP) e 1 fêmea (60.7 mm CP).

Formato de nadadeiras: machos diferem de fêmeas pelo formato da nadadeira pélvica.

Extremidade distal do raio simples (raio mais longo) da nadadeira pélvica de machos maduros alcança o último raio simples da nadadeira anal. Nadadeira pélvica sobrepõe o orifico urogenital em vista vetral. Extremidade distal do raio simples (raio mais longo) da nadadeira pélvica de fêmeas adultas ultrapassa o orifício urogenital, mas não alcança a origem da nadadeira anal. Nadadeira pélvica não sobrepõe o orifício urogenital.

Processos ósseos: presentes nas nadadeiras anal e pélvica de machos maduros. 
$\overline{\text { Nadadeira anal com um processo ósseo por segmento de hemitriquium do último raio }}$ simples ao décimo sétimo raio ramificado, disrtribuindo-se em até $63 \%$ dos raios ramificados (até 27 raios ramificados). Último raio simples com processos ósseos do quarto ao vigésimo segundo segmento, terceiro segmento proximal à extremidade distal do raio. Raios ramificados com processos ósseos presentes tanto em segmentos proximais quanto distais à primeira bifurcação. Processos ósseos presentes também em segmentos distais à segunda bifurcação dos ramos anterior e posterior da primeira bifurcação. Proximalmente à primeira bifurcação, os processos ósseos estão presentes em até quatro segmentos. Distalmente à primeira bifurcação e proximalmente às segunda ramificações, os processos ósseos estão presentes e restritos a todos os segmentos do ramo posterior. Distalmente à segunda bifurcação do ramo posterior da primeira bifurcação, os processos ósseos estão presentes e restritos a até nove segmentos do ramo posterior, imediatamente distais à bifurcação. Distalmene à segunda bifurcação do ramo anterior da primeira bifurcação, o processo ósseos està presente em todos os segmentos do ramo posterior, imediatamente posterior à bifurcação. Processos ósseos simétricos bilateralmente. Processos ósseos com inserção ovalada proximodistalmente. Em todos os segmentos, os processos ósseos estão inseridos na face lateroposterior em relação à nadadeira. Os processos ósseos desenvolvem-se perpendicularmente ao eixo proximodistal do segmento. Ao longo de seu comprimento total, os processos ósseos sofrem uma curvatura de $45^{\circ}$ e desenvolvem-se em direção proximal e ligeiramente medial em relação ao eixo proximodistal do segmento no qual está inserido. Em secção transversal, os processos ósseos variam de ovalados proximodistalmente a cilíndricos ao longo de seu comprimento, afilando-se gradualmente e terminando em uma extremidade arredondada. Em seu estado máximo de desenvolvimento, seu comprimento total não alcança o comprimento proximodistal do segmento no qual está inserido. Na nadadeira anal os 
processos aumentam e diminuem gradualmente de tamanho em direção anteroposterior; terceiro raio ramificado com maior número de segmentos; sétimo raio ramificado com maiores processos ósseos No raio os processos ósseos aumentam e diminuem de tamanho em direção proximodistal; o maior processo ósseos está no segundo segmento distal à primeira bifurcação, na metade proximal do raio.

Nadadeira pélvica com processos ósseos restritos a segmentos do hemitriquium ventral. Nadadeira pélvica com um processo ósseo por segmento de hemitriquium ventral do primeiro ao sétimo raio ramificado, disrtribuindo-se em $100 \%$ dos raios ramificados (sete raios ramificados). Raios ramificados com processos ósseos tanto em segmentos proximais quanto distais à primeira bifurcação. Processos ósseos presentes também em segmentos distais à segunda bifurcação dos ramos lateral e medial da primeira bifurcação. Proximalmente à primeira rmaificação, os processos ósseos estão presentes em todos os segmentos, inclusive o mais proximal, mais longo; segmento mais longo com até sete segmentos em sua porção distal. Distalmente à primeira bifurcação e proximalmente às segundas ramificações, os processos ósseos estão presentes em todos os segmentos do ramo medial e em até dois segmentos do ramo lateral, imediatamente proximais à segunda bifurcação deste ramo. Distalmente à segunda bifurcação do ramo lateral da primeira bifurcação, os processos ósseos estão presentes e restritos a todos os segmentos do ramo medial. Distalmente à segunda bifurcação do ramo medial da primeira bifurcação, os processos ósseos estão presentes em todos os segmentos dos ramos lateral e medial. Processos ósseos com inserção ovalada proximodistalmente. Em todos os segmentos, os processos ósseos estão inseridos na face ventromedial, com exceção de dois segmentos do ramo medial da primeira bifurcação (imediatamente proximais à segunda bifurcação deste ramo), no qual os processes ósseos estão inseridos tanto na face lateral quanto medial e de todos os segmentos do ramo lateral da 
$\overline{\text { segunda bifurcação do ramo medial da primeira bifurcação, no qual os processos ósseos estão }}$ inseridos na face ventrolateral. Os processos ósseos desenvolvem-se perpendicularmente em relação ao eixo proximodistal do segmento. Em seu um quarto (1/4) proximal, os processos ósseos sofrem uma curvatura de aproximadamente $45^{\circ}$ e desenvolvem-se em direção proximal em relação ao eixo proximodistal do segmento. Em secção transversal, os processos ósseos variam de ovalados proximodistalmente a cilíndricos ao longo de seu comprimento total, afilando-se gradualmente e terminando em uma extremidade pontiaguda/arredondada. Em seu estado máximo de desenvolvimento, o seu comprimento total não alcança o comprimento proximodistal do segmento no qual está inserido. Na nadadeira pélvica o processos ósseos aumentam e diminuem gradualmente de tamanho em direção lateromedial em relação à nadadeira; terceiro raio ramificado com o maior número de segmentos com processos ósseos e maiores processos ósseos. Nos raios os processos ósseos aumentam e diminuem de tamanho em direção proximodistal; o maior processo ósseo está no segundo segmento distal à primeira bifurcação, na metade proximal da série de processos ósseos.

Glândula branquial: presente em machos

Glândula branquial do segundo ao décimo segundo filamento branquial, logo décimo terceiro fundico com o décimo quarto, décimo quinto com décimo sexto e décimo sétimo com décimo oitavo. Glândula branquial disrtribuindo-se em $50 \%$ dos filamentos branquiais do ceratobranquial. Glândula branquial disrtribuindo-se em $47 \%$ do comprimento do ceratobranquial. Células colunares não visíveis lateralmente. Abertura da glândula branquial visível lateralmente, em 90\% do comprimento do filamento branquial.

\section{Hysteronotus megalostomus Eigenmann 1911}

Fig. 217 a 220 
Localidade tipo: Rio das Velhas.

Material examinado: Brasil, Minas Gerais: MZUSP 51775, 3, Brasil, Minas Gerais, Fortuna de Minas, Rio Paraopeba, fazenda Cahaparral (ponta da Taquara), bacia do rio São Francisco, C. B. M. Alves, 7/10/1994; MZUSP 54501, 3, Brasil, Minas Gerais, Presidente Juscelino, Córrego Jataí na estrada Curvelo/Diamantina, rio das Velhas, bacia do rio São Francisco, R. E. Reis et al., 11/07/1993; MZUSP 54597, 56, Brasil, Minas gerais, Montes Claros, rio Verde Grande, na estrada de Montes Claros para Janaúba, bacia do rio São Francisco, R. E. Reis et al., 20/07/1993; MZUSP 54598, 10, Brasil, Minas Gerais, Presidente Juscelino, córrego jataí na estrada Curvelo/Diamantina, rio das Velhas, bacia do rio São Francisco, R. E. Reis et al., 11/07/1993; MZUSP 73705, 3, Brasil, Minas Grais, Cardeal Mota, rio Cipó, jusante do Parque Nacional da Serra do Cipó, fazenda do Mosteiro, rio das Velhas, bacia do rio Sõa Francisco, C. B. M. Alves, 2/07/2000.

\section{Caracteres sexuais secundários}

Os caracteres sexuais secundários em $H$. megalostomus relacionam-se ao comprimento padrão, formato de nadadeiras, presença de processos ósseos e glândula branquial.

Comprimento padrão: machos alcançam maiores valores de comprimento padrão em relação às fêmeas. MZUSP 51775, 1macho (28.8 mm CP) e 2 fêmeas (31.6-32.3mm CP); MZUSP 54597, 27 machos (27.8-33.8 mm CP) e 26 fêmeas (25.5-33 mm CP); MZUSP 54598, 4 fêmeas (28-30.5 mm CP); MZUSP 73705, 3 machos (33.2-35.1 mm CP).

Formato de nadadeiras: machos diferem e fêmeas pelo formato da nadadeira pélvica.

Extremidade distal do terceiro raio ramificado (raio mais longo) da nadadeira pélvica de machos alcança a origem da nadadeira pélvica, sem ultrpassá-la. Nadadeira pélvica sobrepõe o orifício urogenital em vista ventral. Quatro raios ramificados mediais, a partir do segundo 
$\overline{\text { raio ramificado da nadadeira pélvica de machos posicionado dorsalmente ao primeiro raio }}$ ramificado e raio simples. Extremidade distal do primeiro raio ramificado (raio mais longo) da nadadeira pélvica de fêmeas ultrapassa o orifício urogenital mas não alcança a origem da nadadeira anal. Nadadeira pélvica de fêmeas não sobrepõe o orifício urogenital em vista ventral. Raios da nadadeira pélvica de fêmeas posicionados lateromedialemnte uns aos outros.

Processos ósseos: presentes nas andadeira anal, pélvica e caudal de machos maduros.

Nadadeira anal com um processo ósseo por segmento de hemitriquium do penúltimo raio simples ao décimo terceiro raio ramificado, disrtribuindo-se em $37 \%$ dos raios ramificados (35 raios ramificados). Último raio simples com processos ósseos do sétimo ao décimo quarto segmento, segmento mais distal do raio. Processos ósseos presentes tanto em segmentos proximais quanto em segmentos distais à primeira bifurcação. Proximalmente à primeira bifurcação, os processos ósseos estãp presentes em até cinco segmentos. Distalmente à primeira bifurcação, os processos ósseos estão presentes e restritos a até quatro segmentos do ramo posterior. Processos ósseos simétricos bilateralmente. Processos ósseos com inserção ovalada proximodistalmente. O maior comprimento de sua inserção ocupa $39 \%$ do comprimento proximodistal do segmento no qual está inserido. Em todos os segmentos os processos ósseos estão isneridos na face lateroposterior. Os processos ósseos desenvolvem-se perpendicularmente à sua inserção no segmento no qual estão inseridos. No um quarto (1/4) próximal de seu comprimento total, os processos ósseos sofrem uma curvatura de $70^{\circ} \mathrm{e}$ desenvolvem-se em direção proximomedial em relação ao eixo proximodistal do segmento no qual estão inseridos. Em secção transversal os processos ósseos variam de ovalados proximodistalmente à cilíndricos ao longo de seu comprimento total, se afila gradualmente e terminando em uma extremidade pontiaguda/arredondada. O diâmetro de sua extremidade distal equivale a $15 \%$ do maior comprimento de sua inserção no segmento no qual está 
inserido. Em seu estado máximo de desenvolvimento, o seu comprimento total alcança ou ultrapassa o comprimento proximodistal do segmento no qual está inserido. O comprimento do maior processo ósseos equivale a $84 \%$ do comprimento porximodistal do segmento no qual está inserido. Na nadadeira, os processos ósseos aumentam e diminuem de tamanho em direção anteroposterior; sétimo raio ramificado com maior número de segmentos com processos ósseos e maiores processos ósseos. No raio, os processos ósseos diminuem de tamanho em direção proximodistal; o maior processo ósseos está até no quinto segmento proximal à primeira bifurcação, na extremidade proximal doa série de processos ósseos.

Nadadeira pélvica com processo ósseos presentes e restritos a segmentos do hemitriquium ventral. Nadadeira pélvica com um processo ósseo por segmento de hemitriquium do raio simples ao sexto raio ramificado, o que representa $100 \%$ dos raios ramiciados (6 raios ramificados). Raio simples com processos ósseos so segmento mais proximal ao segundo segmento proximal à extremidade distal do raio. Processos ósseos presentes tanto em segmentos proximais quanto em segmentos distais à primeira bifurcação. Processos ósseos presentes também em segmentos distais à segunda bifurcação dos ramos medial e lateral da primeira bifurcação. Proximalmente à primeira rmaificaçào, os processos ósseos estão presentes em até quatro segmentos, inclusive o mais proximal, mais longo. Distalmente a primeira bifurcação, os processos ósseos estão presentes em todos os segmentos do ramo medial e em até seis segmentos do ramo lateral, imediatamente próximas à segunda rmaificação deste ramo. Distalmente à segunda bifurcação do ramo medial, os processos ósseos estão presentes e restritos à até dois segmentos do rmao medial. Distalmente à segunda rmaificação do ramo lateral da primeira bifurcação, os processos ósseos estão presentes e restritos a até dois segmentos do ramo medial. Processos ósseos com inserção ovalada proximodistalmente. O maior comprimento de sua inserção ocupa 51\% do comprimento 
proximodistal do segmento no qual está inserido. Em todos os segmentos, os processos ósseos estão inseridos na face ventromedial em relação à nadadeira. Processos ósseos do ramo medial da segunda bifurcação do ramo medial da primeira bifurcação e dos segmentos proximais à primeira bifurcação com inserção migrando ligeiramente de ventromedial a mais ventral. Os processos ósseos desenvolvem-se perpendicularmente à sua inserção no segmento em qu está inserido. No terço (1/4) proximal de seu comprimento total, os processos ósseos sofre uma curvatura de $75^{\circ}$ e desenvolvem-se em direção proximomedial em relação ao segmento no qual estão inseridos, em secção transversal, os processos ósseos variam de ovalados proximodistalmente a cilíndricos, afilando-se gradualmente e terminando em uma extremidade pontiaguda/arredondada. $\mathrm{O}$ diâmetro de sua extremidade distal equivale a $14 \%$ do maior comprimento de sua inserção no segmento no qual esá inserido. Em seu estado máximo de desenvolvimento, o seu comprimento total ultrapassa o comprimento proximodistal do segmento em ue está inserido hemitriquium onde se insere. O comprimento do maior processo ósseo equivale $105 \%$ do comprimento proximodistal do segmento no qual está inserido. $\mathrm{Na}$ nadadeira, os processos ósseos aumentam e diminuem de tamanho em direção lateromedial; segundo e terceiro raio amificado com maior número de segmentos com processos ósseos e maiores processos ósseos. No raio, os processos aumentam e diminuem de tamanho em direção proximodistal; o maior processo ósseos está no terceiro segmento do ramo medial, distal à primeira bifurcação, na metade proximal da série de processos ósseos.

Nadadeira caudal com um processo ósseo por segmento de hemitriquium do décimo ao décimo quinto raio ramificado (raios do lobo ventral), disrtribuindo-se em aproximadamente $30 \%$ dos raios ramificados (17 raios ramificados ná fórmula i,9/8,1). Raios ramificados com processos osseos presentes tanto em segmentos proximais quanto em segmentos distais à primeira bifurcação. Processos ósseos presentes também em segmentos distais à segunda 
$\overline{\text { rmaificaçào do ramo medial da primeira bifurcação do ramo medial da primeira rmaifiação. }}$ Proximalmente à primeira rmaificação, os processos ósseos estão presentes em até seis segmentos. Distalmente à primeira bifurcação, os processos ósseos estão presentes e restritos a todos os segmentos do ramo medial. Distalmente à segunda rmaificaçào do ramo medial da primeira rmaificaçàom os processos ósseos estão presentes e restritos a até dois segmentos do ramo medial. Processos ósseos simétricos bilateralmente. Processos ósseos com inserção ovalada proximodistalmente. O maior comprimento de sua inserção ocupa $32 \%$ do comprimento proximodistal do segmento no qual está inserido. Em todos os segmentos, os processos ósseos desenvolvem-se perpendicularmente à sua inserção no segmento no qual está inserido. No quarto (1/4) proximal de seu comprimento total, os processos ósseos sofrem uma curvatura de $45^{\circ}$ e desenvolvem-se em direção proximal em relação ao eixo proximodistal do segmento no qual estão inseridos. Em secção transversal, os processos ósseos variam de ovalados proximodistalmene a cilíndricos ao longo de seu comprimento total, afilando-se gradualmente e terminando em uma extremidade pontiaguda/arredonada. $\mathrm{O}$ diâmetro de sua extremidade distal equivale a 33\% do coprimento proximodistal do segmento no qual está inserido. Em seu estado máximo de desenvolvimento, o seu comprimento total não alcança o comprimento proximodistal do segmento no qual está inserido. O comprimento do maior processo ósseo equivale a $71 \%$ do cmprimento proximodistal do segmento no qual está inserido. Na nadadeira os processos ósseos apresentam tamanhos semelhantes; décimo quinto raio ramificado com o maior número de segmentos com processos ósseos. No raio, os processos ósseos aumetam e diminuem de tamanho em direção proximodistal; o maior processo ósseo é o segndo segmento da série de processos ósseos em direçãoo proximodistal, na metade proximal da série de processos ósseos.

Glândual branquial: presente em machos maduros. 
Glândula branquial formada pela fusão do primeiro ao vigésimo filamento branquial do ceratobranquial do primeiro arco branquial. Glândual branquial disrtribuindo-se em 95\% dos filamentos branquiais do ceratobranquial (21 filamentos). Glândual branquial disrtribuindo-se em 98\% do cmprimento do ceratobranquial. Células colunares visíveis ao longo de toda a lateral dos filamentos modificados e na porção proximal, entre os filamentos. Abertura da glândula branquial não visível lateralmente.

Órgão caudal: presente na nadadeira caudal de machos adultos.

O órgão caudal é restrito ao lobo ventral da nadadeira caudal. É formado por uma escama modificada localizada posteriormente às três séries de escamas abaixo da linha lateral, e tecido glandular. Verticalmente, a escama modificada sobrepõe a origem de todos os raios do lobo ventral da nadadeira cadual, inclusive o raio simples principal ventral. Horizontalmente se extende aos três quartos (3/4) proximais dos raios do lobo ventral. A área exposta da escama possui duas áreas principais: a metade ventral é laminar com a margem posterior em forma de uma espécie de lobo quase triandular, com sua extremidade posterior direcionada posteroventralmente; a metade dorsal apresenta uma forma tridimensional e se assemelha a uma "chave de boca" sendo a parte dorsal desta mais robusta e laminar, com a extremidade distal muito arredondada, a parte ventral é mais estreita com sua extremidade distal pontiaguda. A parte dorsal da escama modificada, tridimensional, compõem os limites anterior e ventral da abertura da glândula. Os limites dorsal e posterior são compostos por um tecido glandular, completando assim uma abertura conspícua. O tecido glândular não se restrinje às áreas descritas acima, cobrindo também a porção proximal de todos os raios do lobo ventral da nadadeira caudal, da margem posterior de toda a porção exposta da escama modificada à metade proximal das membranas interradiais entre o décimo e décimo primeiro 
raio principal da nadadeira caudal até a membrana interradial entre o décimo sétimo raio ramificado e o raio principal ventral da nadadeira caudal.

\section{Knodus heteresthes (Eigenmann 1908)}

Fig. 221 a 225

Localidade tipo: rio Tapajós, Brasil.

Material examinado: MZUSP 099983, 75, Brasil, Pará, Jacareacanga, rio Teles Pires, a jusante das Sete Quedas, baica do rio Tapajós, 09³0’38’S, 5646’42’W, L. M. Sousa \& A. Netto-Ferreira.

\section{Caracteres sexuais secundários}

Os caracteres sexuais secundários de K. Heteresthes relacionam-se ao comprimento padrão, formato de nadadeiras, presença de processos ósseos e glândula branquial.

Comprimento padrão: fêmeas alcançam maiores valores de comprimento padrão em relação aos machos. MZUSP 099983, 12 machos (37.8-48.5 mm CP) e 63 fêmeas (37.3-53.5 mm CP) Formato de nadadeiras: machos diferem de fêmeas pelo formato do perfil da margem distal da nadadeira anal e pelo formato da nadadeira pélvica.

Perfil da margem distal da nadadeira anal de machos com lobo anterior discreto convexo. Lobo anterior formado pelo aumento discreto de tamanho do último raio simples ao segundo raio ramificado (raio mais longo) e diminuição discreta de tamanho deste ao quinto raio ramificado; perfil reto do sexto ao último raio ramificado, divdo à diminuição gradual de tamanho emd direção anteroposterior. Perfil da margem distal da nadadeira anal de fêmeas com com lobo anterior côncavo. Lobo anterior formado pelo aumento gradual de tamanho do último raio simples ao segundo riao ramificado (raio mais longo) e diminuição acentuada 
$\overline{\text { deste ao quinto raio ramificado; perfil reto do sexto ao último raio ramificado, devido à }}$ diminuição gradual de tamanho em direção anteroposterior. Do sexto ao último raio ramificado com tamanhos semelhantes.

Extremidade distal do primeiro raior ramificado (raio mais longo) da nadadeira pélvica de machos alcança a origem da nadadeira anal, sem ultrapassar o últio raio simples. Nadadeira pélvica sobrepõe ao orifício urogenital em vista ventral. Extremidade distal do prieior raio ramificado (raio mais longo) da nadadeira pélvica de fêmeas ultrapassa o orifício urogenital, mas não alcaná a origem da nadadeira anal. Nadadeira pélvica não sobrepõe o orifício urogenital em vista ventral.

Processos ósseos: presentes nas nadadeiras anal e pélvica de machos maduros.

Nadadeira anal com um processo ósseo por segmento de hemitriquium do último raio simples ao décimo primeiro raio ramificado, distribuindo-se em $68 \%$ dos raios ramificados (até 16 raios ramificados). Último raio simples com processos ósseos do segundo ao décimo segmento do raio, décimo quinto segmento proximal à extremidade distal do raio. Raios ramificados com processos ósseos presentes tanto em segmentos proximais quanto em segmentos distais à primeira bifurcação. Processos ósseos presentes também em segmentos distais à segunda bifurcação dos ramos anterior e posterior da primeira bifurcação. Proximalmente à primeira bifurcação, os processos ósseos estão presentes em até quatro segmentos. Distalmente à primeira bifurcação e proximalmente às segunda ramificações, os processos ósseos estão presentes em todos os segmentos do ramo posterior e em até um segmento do ramo anterior, imediatamente proximal à segunda bifurcação deste raio. Distalmente à segunda bifurcação do ramo posterior da primeira bifurcação, os processos ósseos estão presentes em até cinco segmentos do ramo posterior, imediatamente distais à bifurcação e em até dois segmentos do ramo anterior, a partir do segundo segmento distal à 
bifurcação. Distalmene à segunda bifurcação do ramo anterior da primeira bifurcação, o processo ósseos está presente em até cinco segmentos do ramo posterior, imediatamente distais à bifurcação e em até um segmento do ramo anterior, a partir do quinto segmento distal à bifurcação. Processos ósseos simétricos bilateralmente. Processos ósseos com inserção ovalada proximodistalmente. O maior comprimento de sua inserção ocupa $33 \%$ do comprimento proximodistal do segmento no qual está inserido. Em todos os segmentos, os processos ósseos estão inseridos na face lateroposterior, com exceção dos dois segmentos do ramo anterior da segunda bifurcação do ramo posterior da primeira bifurcação, no qual os processos ósseos estão inseridos na face lateroanterior. Os processo ósseos desenvolvem-se perpendicularmente à inserção do segmento. Em se um quarto (1/4) proximal, os processos ósseos sofrem uma curvatura de $35^{\circ}$ e desenvolvem-se em direção proximal/proximomedial em relação ao eixo proximodistal do segmento no qual está inserido. Em secção transversal, os processos ósseos variam de ovalado proximodistalmente a cilíndrico ao longo de seu comprimento total, afilando-se gradualmente e terminando em uma extremidade distal pontiagudo/arredondada. O diâmtero de sua extremidade distal equivale a $23 \%$ do maior comprimento de sua inserção no segmento no qual está nserido. Em seu estado máximo de desenvolvimento, seu comprimento total (da inserção à extremidade distal) não alcança o comprimento proximodistal do segmento no qual se insere. O comprimento do maior processo ósseo equivale a $40 \%$ do comprimento do segmento no qual está inserido. $\mathrm{Na}$ nadadeira anal os processos aumentam e diminuem gradualmente de tamanho em direção anteroposterior; terceiro raio ramificado com maior número de segmentos com processos ósseos e maiores processos. No raio os processos ósseos aumentam e diminuem de tamanho em direção proximodistal; o maior processo ósseo está no terceiro segmento proximal à segnda bifurcação, na metade/metade proximal da série de processos ósseos. 
Nadadeira pélvica com processos ósseos presentes e restritos a segmentos do hemitriquium ventral. Nadadeira pélvica com um processo ósseo por segmento (com exceção do segmento mais proximal, mais longo) no hemitriquium ventral do primeiro ao sexto raio ramificado, disrtribuindo-se em $100 \%$ dos raios ramificados (seis raios ramificados). Raios ramificados com processos ósseos em segmentos tanto proximais quanto em segmentos distais à primeira bifurcação. Processos ósseos presentes também em segmentos distais à segunda bifurcação dos ramos lateral e medial da primeira bifurcação. Processos ósseos presentes também em segmentos distais à terceira bifurcação dos ramos medial e distal da segunda bifurcação dos ramos medial e lateral da primeira bifurcação. Distalmente à primeira bifurcação e proximalmente às segundas ramificações, os processos ósseos estão presentes em todos os segmentos do ramo medial e em até dois segmentos do ramo lateral, imediatamente proximais à segunda bifurcação deste ramo. Distalmente à segunda bifurcação do ramo medial da primeira bifurcação, os processos ósseos estão presentes em todos os segmentos dos ramos medial e lateral. Distalmente à terceira bifurcação do ramo medial da segunda bifurcação do ramo medial da primeira bifurcação, os processos óesseos estão presentes em todos os segmentos dos ramos medial e lateral. Distalmetnte à terceira bifurcação do ramo lateral da segunda bifurcação do ramo medial da primeira bifurcação, os processos ósseos estão presentes e restritos a todos os segmentos do ramo medial. Distalmente à segunda bifurcação do ramo lateral da primeira bifurcação, os processos ósseos estão presentes em todos os segmentos do ramos medial e em até quatro segmentos do ramo lateral, imediatamente proximais à terceira bifurcação deste ramo. Distalmente à terceira bifurcação do ramo medial da segunda bifurcação do ramo lateral da primeira bifurcação, os processos ósseos estão presentes em todos os segmentos dos ramos medial e lateral. Distalmente à terceira bifurcação do ramo lateral da segunda bifurcação do ramo lateral da primeira ramirifacação, os processos 
ósseos estão presentes e restritos a todos os segmentos do ramo medial. Inserção dos processos ovalada proximodistalmente. O maior comprimento de sua inserção no segmento ocupa $17 \%$ do comprimento proximodistal do segmento no qual está inserido. Em todos os segmentos, os processos ósseos estão inseridos na face ventromedial, com exceção de um segmento do ramo medial da primeira bifurcação, imediatamente proximal à segunda bifurcação deste ramo, no qual os processos ósseos estão inseridos tanto na face medial quanto na face ventrolateral, de quatro segmentos do ramo lateral da segunda bifurcação do ramo medial da primeira bifurcação, imediatamente distais à bifurcação e dos segmentos do ramo lateral da terceira bifurcação dos ramos medial e lateral da segunda bifurcação do ramo medial da primeira bifurcação, no qual os processos ósseos estão inseridos na face venrolateral. Os processos ósseos se desenvolven perpencidularmente à sua inserção no segmento no qual estão inseridos. Em seu um quarto (1/4) proximal, os processos ósseos sofrem uma curvatura de $40^{\circ}$ e desenvolvem-se em direção proximal em relação ao eixo proximodistal do segmento. Em secção transversal, os processos ósseos variam de ovalado proximodistalmente a cilíndrico ao longo de seu comprimento proximodistal, afilando-se gradualmente e terminando em uma extremidade pontiaguda/arredondada. O diâmetro de sua extremidade distal equivale a $22 \%$ do maior comprimento de sua inserção no segmento no qual está inserido. Em seu estado máximo de desenvolvimento, seu comprimento total não alcança o comprimento proximodistal do segmento no qual está inserido. O comprimento proximodistal dos processos ósseos qeuivalem a 57\% do comprimento proximodistal dos segmentos no qual se inserem. Na nadadeira os processos ósseos aumentam e diminuem gradualmente de tamanho em direção latermedial; terceiro raio ramificado com o maior número de segmentos com processos ósseos e maiores processos ósseos. Nos raios os processos ósseos aumentam e diminuem de tamanho em direção proximodistal; o maior 
processo ósseos está no segmento imediatamente proximal à segunda rmaificação do ramo medial; na metade distal da série de processos ósseos.

Glândula branquial: presente em machos maduros.

Glândula branquial formada pela fusão do terceiro ao sétimo filamento branquial anterior do ceratobranquial do primeiro arco branquial. Glandula branquial distribuindo-se em $21 \%$ dos filamentos branquiais do ceratobranquial. Glândula branquial disrtribuindo-se em $18 \%$ do comprimento do ceratobranquial. Células colunares não visíveis lateralmente. Abertura da glândula não visível lateralmente.

\section{Knodus moenkhausii (Eigenmann \& Kenndy 1903)}

Lolicade tipo: Arroyo Trementina, Paraguay.

Material examinado: MZUSP 111946, 30, Brasil, Minas Gerais, Patrocínio, ribeirão Salitre, tributário do rio Araguari, bacia do rio Paranaíba, L. F. Salvador et al., 00/08/2012.

\section{Caracteres sexuais secundários}

Os caracteres sexuais secundários em K. Moenkhausii relacionam-se ao comprimento padrão, formato de nadadeiras, presença de processos ósseos e glândula branquial.

Comprimento padrão: fêmeas alcançam maiores valores de comprimento padrão em relação aos machos. MZUSP 111946, 18 machos (28.7-35.4 mm CP) e 11 fêmeas (28.7-36.2 mm $\mathrm{CP})$.

Formato de nadadeiras: machos diferem de fêmeas pelo formato do perfil da margem distal da nadadeira anal e formato da nadadeira pélvica.

Perfil da margem distal da nadadeira anal de machos com lobo anterior ligeiramente convexo, quase reto. Lobo anterior formado pelo aumento gradual do último raio simples ao segundo 
$\overline{\text { raio ramificado (raio mais longo) e diminuição graudal deste ao quinto raio ramificado; perfil }}$ reto do sexto ao último raio ramificado devido à diminuição gradual de tamanho de direçãoo anteroposterior. Perfil da margem distal da nadadeira anal de fêmeas com um lobo anterior ligeiramente côncavo. Lobo anterior formado pelo aumento graudal de tamanho do último raio simples ao segundo raio ramficiado (raio mais longo) e diminuição deste ao quinto raio ramificado; perfil do sexto ao último raio ramificado, devido à diminuição graudal de tamanho em direçãoo anteroposterior. O dimorfismo aparenta ser insexistente no temanho, parece ser dimorfico porque a concentração de tecido nos processos óseos arma os raios.

Extreidade distal do primeiro raio ramificado (raio maais longo) da nadadeira pélvica de machos ultrapassa o orifício urogenital, quase alcançando a origem da nadadeira anal. Nadadeira pélvica sobrepõe o orifício urogenital em vista ventral. Extremidade distal da do primeiro raio ramificado (raio msia longo) da nadadeira pélvica de fêmeas ultrapassa o orifício urogenital por pouco. Nadadeira pélvica de fêmeas não sobrepõe o orifício urogenital em vista ventral.

Processos ósseos: presentes nas nadadeiras anal e pélvica de machos maduros.

Nadadeira anal com até dois (geralmente um) processos ósseos por segmento de hemitriquium do último raio simples ao nono raio ramificado, disrtribuindo-se em $45 \%$ do total de raios ramificados (até 20 raios ramificados). Último raio simples com processos ósseos do segundo ao décimo segmento do raio, sexto segmento proximal à extremidade distal do raio. Processos ósseos presentes tanto em segmentos proximais quanto em segmentos distais à primeira bifurcação. Processos ósseos presentes também em segmentos distais à segunda bifurcação dos ramos anterior e posterior da primeira bifurcação. Proximalmente à primeira bifurcação, os processos ósseos estão presentes em até três segmentos. Distalmente à primeira bifurcação e proximalmente às segunda ramificações, os 
$\overline{\text { processos ósseos estão presentes em todos os segmentos do ramo posterior e em até três }}$ segmento do ramo anterior, imediatamente proximais à segunda bifurcação deste ramo. Distalmente à segunda bifurcação do ramo posterior da primeira bifurcação, os processos ósseos estão presentes em até cinco segmentos dos ramos anterior e posterior, imediatamente distais à bifurcação. Distalmene à segunda bifurcação do ramo anterior da primeira bifurcação, os processos ósseos estào presentes em até quatro segmentos do ramo posterior e em até três segmentos do ramo anterior, a partir do segundo segmento imediatamente distal à bifurcação. Em todos os segmentos, os processos ósseos estão inseridos na face lateroposterior, com exceção dos segmentos do ramo anterior da segunda bifurcação do ramo posterior da primeira bifurcação no qual os processos estão inseridos na face lateroanterior. Processos ósseos simétricos bilateralmente. Processos ósseos com inserção ovalada proximodistalmente. Os processos ósseos desenvolvem-se perpendicularmente à sua inserção no segmento no qual estão inseridos. Em se quarto (1/4) proximal, os processos ósseos sofrem uma curvatura de $40^{\circ}$ e desenvolvem-se em direção proximal/proximomedial em relação ao eixo proximodistal do segmento no qual estão inseridos. Em secção transversal, os processos ósseos variam de ovalados proximodistalmente a cilíndricos ao longo de seu comprimento, afilando-se gradualmente e terminando em uma extremidade distal pontiaguda/arredondada. Em seu estado máximo de desenvolvimento, o seu comprimento total não alcança o comprimento proximodistal do segmento no qual está inserido. Na nadadeira anal os processos aumentam e diminuem gradualmente de tamanho em direção anteroposterior; terceiro raio ramificado com maior número de segmentos com processos ósseos e maiores processos. No raio os processos ósseos aumentam e diminuem de tamanho em direção proximodistal. 
$\overline{\text { Nadadeira pélvica com processos ósseos presentes e restritos a segmentos do hemitriquium }}$ ventral. Nadadeira pélvica com até dois (geralmente um) processos ósseos por segmento de hemitriquium ventral do primeiro ao sétimo raio ramificado (sete raios ramificados), disrtribuindo-se em $100 \%$ dos raios ramificados. Raios ramificados com processos ósseos tanto em segmentos proximais quanto em segmentos distais à primeira bifurcação. Processos ósseos presentes também em segmentos distais à segunda bifurcação dos ramos lateral e medial da primeira bifurcação. Proximalmente à primeira bifurcação, os processos ósseos estão presentes em todos os segmentos, inclusive o proimal. Distalmente à primeira bifurcação e proximalmente às segundas ramificações, os processos ósseos estão presentes em todos os segmentos do ramo medial e em até cinco segmentos do ramo lateral, imediatamente proximais à bifurcação. Distalmente à segunda bifurcação do ramo medial da primeira bifurcação, os processos ósseos estão presentes em todos os segmentos dos ramos medial e lateral. Distalmente à segunda bifurcação do ramo lateral da primeira bifurcação, os processos ósseos estão presentes em todos os segmentos do ramos medial e em todos os segmentos do ramo lateral, a partir do segundo segmento distal a bifurcação. Processos ósseos com inerção ovalada proximodistalmente. Em todos os segmentos os processos ósseos estão inseridos na face ventromedial, com exceção de um segmento do ramo medial da primeira bifurcação (imediatamente proximal à segunda bifurcação deste ramo), no qual os processos ósseos estão inseridos tanto na face medial quanto na face ventrolateral (espelhados) e de todos os segmentos do ramo lateral da segunda bifurcação do ramo medial da primeira bifurcação, no qual os processos ósseos estão inseridos na face ventrolateral. Os processos ósseos se desenvolven perpendicularmente à sua inserção no segmento no qual estão inseridos. Em seu quarto (1/4) proximal, os processos ósseos sofrem uma curvatura de aproximadamente $40^{\circ} \mathrm{e}$ desenvolvem-se em direção proximomedial em relação ao eixo proximodistal do segmento no 
qual estão inseridos. Em secção transeversal, os processos ósseos variam de ovalados proximodistalmente a cilíndricos ao longo de seu comprimento total, afilando-se gradualmente e terminando em uma extremidade pontiaguda/arredondada. Em seu estado máximo de desenvolvimento, o seu comprimento total não alcança o comprimento proximodistal do segmento no qual está inserido. Na nadadeira pélvica os processos ósseos aumentam e diminuem gradualmente de tamanho em direção lateromedial; terceiro e quarto raio ramificado com o maior número de segmentos com processos ósseos e maiores processos ósseos. Nos raios os processos ósseos aumentam e diminuem de tamanho em direção proximodistal.

Glândula branquial: presente em machos maduros.

Glândula branquial formada pela fusão do primeiro ao oitavo filamento branquial do ceratobranquial do primeiro arco branquial. Oitavo e nono filamentos branquiais com fusão incompleta. Décimo terceiro e décimo quarto filamentos com inicio de fusão. Fusão imcompleta do décimo sétimo ao vigésimo filamento. Glândula branquial disrtribuindo-se em $23 \%$ dos filamentos branquiais do ceratobranquial do primeiro arco branquial. Células colunares não visíveis lateralmente. Abertuta da glândula branquial não visível lateralmente.

\section{Pseudocorynopoma doriae Perugia 1891}

Fig. 226 a 232

Localidade tipo: Rio de la Plata, Argentina.

Material examinado: MZUSP 4479, 2, Brasil, Rio Grande do Sul, rio dos sinos, Porto do Vicente, São Leopoldo, H. Meirelles, 13/03/1965. MZUSP 53232, 7, Brasil, Rio Grande do Sul, São Pedro, rio Ibicuí-Mirim, na estrada Santa Maria-São Pedro, 29³7’00”S, 


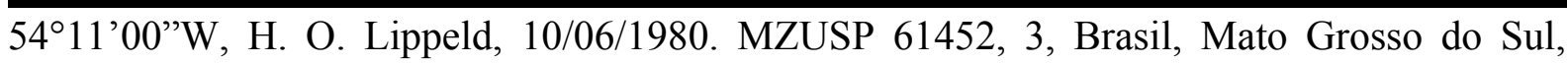
Santo Antônio da Patrulha, arroio dos Carvalhos, entre Santo Antoônio da Patrulha e Caraa, Menezes et al., 17/01/1991.

\section{Caracteres sexuais secundários}

Os caracteres sexuais secundários de $P$. doriae relacionam-se ao comprimento padrão, formato de nadadeiras, presença de processos ósseos e órgão caudal.

Comprimento padrão: machos alcançam maiores valores de comprimento padrão em relação às fêmeas. MZUSP 4479, 1 macho (49.6 mm CP) e 1 fêmea (48.8 mm CP); MZUSP 53232, 7 machos (40.6-50.5 mm CP); MZUSP 61452, 2 machos (39.7-43.1 mm CP).

Formato de nadadeiras: machos diferem de fêmeas pelo formato do perfil da margem distal das nadadeiras anal e dorsal.

Perfil da margem distal da nadadeira anal de machos com três lobos, dois anteriores e um posterior. Primeiro lobo do último raio simples ao quinto raio ramificado. Primeiro lobo ligeiramente convexo pelo aumento gradual de tamanho do último raio simples ao segundo e terceiro raio ramificado (raios mais longos da nadadeira) e diminuição gradual do tereiro ao quarto raio ramificado, diminuição em tamanho do quarto ao quinto raio acentuada. Membranas interradiais dos raios que compõem o primeiro lobo aumentam em direção proximodistal, aumentando consequentemente a distância entre os raios; maior distância pelo menos três vezes a distância interradial dos raios da porção mediana da nadadeira (do décimo quarto ao último raio ramificado). Membranas interradiais do último raio simples ao quarto raio ramificado com séries proximodistais (paralelas aos raios) de pequenas projeções individuais laterais de tecido em forma de bastão. Segundo lobo do sexto ao décimo segundo raio ramificado. Segundo lobo convexo pelo aumento gradual de tamanho do sexto ao nono raio ramificado (raio mais longo do segundo lobo) e diminuição gradual do nono ao décimo 
$\overline{\text { srgundo raio ramificado. Segmentos de hemitriquia dos raios ramificados que compõem o }}$ segundo lobo, diferentemente dos outros raios da nadadeira, distintamente mais largos (anteroposteriormente) que longos (proximodistalmente). Raios que compõem o segundo lobo apresentam mais ramificações que os demais raios da nadadeira. Membranas interradiais dos raios que compõem o segundo lobo, diferentemente das membranas interradias do primeiro lobo, são muito fortes e reduzidas, quase inexistentes até a metade dos raios, o que consequentemente mantem os raios que compõem o segundo lobo firmemente atrelados. $\mathrm{O}$ formato dos segmentos dos raios junto à condição das membranas interradiais dos raios do segundo lobo, proporciona ao lobo uma firmeza e robustez visivelmente maior a estes raios em relação aos outros raios da nadadeira. Perfil reto do décimo terceiro ao vigésimo oitavo raio ramificado, onde começa o terceiro lobo. Terceiro lobo do vigésimo oitavo ao trigésimo sexto raio ramificado. Terceiro lobo convexo pelo aumento gradual de tamanho do vigésimo oitavo raio ramificado ao trigésimo quarto e trigésimo quinto raio ramificado (raios mais longos do lobo) e diminuição gradual do trigésimo quinto ao trigésimo sexto raio ramificado. Maior raio do terceiro lobo alcança a porção posterior do pedúnculo caudal. Perfil da margem distal da nadadeira anal de fêmeas com um lobo anterior. Lobo ligeiramente convexo pelo aumento gradual do último raio simples ao terceiro raio ramificado (raio mais longo) e diminuição gradual do quarto ao décimo raio ramificado; perfil reto do décimo primeiro ao último raio ramificado, devido à diminuição gradual em direção anteroposterior. Último riao ramificado da nadadeira anal de fêmeas não alcança a porção posterior do pedúnculo caudal.

Nadadeira dorsal de machos com aumento acentuado de tamanho do último raio simples ao terceiro raio ramificado (raio mais longo) e diminuição acentuada do terceiro ao quarto raio ramificado, a partir deste ponto os raios aumentam gradualmente de tamanho em direção posterior. Primeiro, segundo e terceiro raio ramificado são filamentosos, ultrapassando a 
$\overline{\text { porção posterior do pedúnculo caudal e alcançando a metade do raio simples dorsal principal }}$ da nadadeira caudal. Último raio ramificado da nadadeira dorsal ultrapassando a nadadeira adiposa. Nadadeira dorsal de fêmeas com aumento discreto de tamanho do último raio simples ao primeiro raio ramificado (raio mais longo) e diminuição gradual deste ao último raio ramificado. Raios da nadadeira dorsal das fêmeas sem extensão filamentosa e não alcançando a origem da nadadeira adiposa.

Extremidade distal do raio simples e primeiro raio ramificado (raios mais longos) da nadadeira peitoral de machos alcançam o orifício urogenital. Extremidade distal do raio simples e primeiro raio ramificado (raios mais longos) da nadadeira peitoral de fêmeas não alcanca o orifício urogenital.

Processos ósseos: presentes nas nadadeiras anal e pélvica de machos maduros.

Nadadeira anal com um processo ósseo por segmento de hemitriquium do sexto ao décimo segundo raio ramificado, disrtribuindo-se em até $16 \%$ do total de raios ramificados (até 37 raios ramificados). Raios ramificados com processos ósseos presentes e restritos a segmentos distais à primeira bifurcação. Processos ósseos presentes também em segmentos distais à segunda bifurcação dos ramos anterior e posterior da primeira bifurcação. Processos ósseos presentes também em segmentos distais à terceira bifurcação dos ramos anterior e posterior da segunda bifurcação do ramo anterior da primeira bifurcação. Processos ósseos presentes também em segmentos distais à terceira bifurcação do ramo anterior da segunda bifurcação do ramo posterior da primeira bifurcação. Distalmente à primeira bifurcação e proximalmente às segundas ramificações, os processos ósseos estão presentes e restritos a todos os segmentos do ramo posterior. Distalmente à segunda bifurcação do ramo posterior da primeira bifurcação, os processos ósseos estão presentes em todos os segmentos dos ramos anterior e posterior. Distalmente à terceira bifurcação do ramo anterior da segunda bifurcação do ramo 
posterior da primeira bifurcação, os processos ósseos estão presentes e restritos a todos os segmentos do ramo anterior. Distalmente à segunda bifurcação do ramo anterior da primeira bifurcação e proximalmente às segundas ramificações, os processos ósseos estão presentes em rodos os segmentos do ramo posterior e em até dois segmentos do ramo anterior, imediatamente proximais à terceira bifurcação. Distalmente à terceira bifurcação do ramo posterior da segunda bifurcação do ramo anterior da primeira bifurcação, os processos ósseos estão presentes em todos os segmentos dos ramos anterior e posterior. Distalmente à terceira bifurcação do ramo anterior da segunda bifurcação do ramo anterior da primeira bifurcação, os processos ósseos estão presentes em todos os segmentos do ramo posterior e em dois segmentos do ramo anterior, imediatamente distais à bifurcação. Inserção dos processos ósseos do ramo posterior da primeira rmaificaçào migrande da face lateroposterior à face lateral em direção distoproximal. Processos ósseos assimétricos bilateralmente. Processos ósseos com inserção ovalada proximodistalmente. O maior comprimento de sua inserção, $36 \%$ do comprimento proximodistal do segmento no qual está inserido. Em todos os segmentos os processos ósseos estão inseridos na face lateroposterior em relação à nadadeira, com exceção de um segmento do ramo posterior da primeira bifurcação (imediatamente proximal à segunda bifurcação deste ramo), no qual os processos ósseos estão inseridos tanto na face lateroposterior quanto na face lateroanterior e em todos os segmentos dos ramos anteriores tanto das segundas ramificações quanto das terceiras ramificações, no qual os processos ósseos estão inseridos na face lateroanterior. Os processos ósseos desenvolvem-se perpendicularmente à sua inserção no segmento. Ao longo de seu comprimento, os processos ósseos sofrem uma curvatura de $55^{\circ}$ e desenvolvem-se em direção proximomedial em relação ao segmento no qual estão inseridos. Em secção transversal, os processos ósseos variam de ovalados proximodistalmente a cilíndricos ao longo de seu comprimento total, afilando-se 
gradualmente e terminando em uma extremidade distal pontiaguda. O diâmetro de sua extremidade distal equivale a $28 \%$ do maior comprimento da inserção no segmento que está inserido. Em seu estado máximo de desenvolvimento, seu comprimento total não alcança o comprimento proximodistal do segmento no qual está inserido. O Comprimento do maior processo ósseo da nadadeira equivale a $60 \%$ do comprimento proximodistal do segmento no qual está inserido. Na nadadeira anal os processos aumentam e diminuem gradualmente de tamanho em direção anteroposterior; nono e décimo raio ramificado com maior número de segmentos com processo ósseos e maiores processos ósseos. No raio os processos ósseos aumentam e diminuem de tamanho em direção proximodistal, processos ósseos dos ramos anteriores pouco menores que aqueles dos ramos posteriores; o maior processo ósseos está no segundo segmento distal à segunda bifurcação do ramo poaterior da primeira bifurcação, na metade/metade distal da série de processos ósseos.

Nadadeira pélvica com processos ósseos presentes em segmentos tanto do hemitriquium dorsal quanto do hemitrichium ventral. Nadadeira pélvica com até oito processos ósseos (geralmente dois) por segmento de hemitriquium ventral do primeiro ao quarto raio ramificado, distribuindo-se em $80 \%$ do total de raios ramificados (cinco raios ramificados). Raios ramificados com processos ósseos tanto em segmentos proximais quanto em segmentos distais à primeira bifurcação. Processos ósseos presentes também em segmentos distais à segunda bifurcação dos ramos lateral e medial da primeira bifurcação. Proximalmente à primeira bifurcação, os processos ósseos estão presentes em todos os segmentos; segmento mais proximal com proessos ósseos em seus três quartos (3/4) distais. Distalmente à primeira bifurcação e proximalmente às segundas ramificações, os processos ósseos estão presentes em todos os segmentos do ramo medial e em até cinco segmentos do ramo lateral, imediatamente peoximais à segunda ramificaçào. Distalmente à segunda bifurcação do ramo lateral da 
$\overline{\text { primeira bifurcação, os processos ósseos estão presentes em até cinco segmentos do ramo }}$ medial e em até quatro segmentos do ramo lateral. Distalmente à segunda rmaificação do ramo medial da primeira bifurcação, os processos ósseos estão presentes e trestritos a três segments do ramo medial, imediatamente distais à bifurcação. Processos ósseos assimétricos bilateralmente. Inserção dos processos ósseos arredondada. O maior comprimento de sua inserção ocupa $11 \%$ do comprimento proximodistal do segmento no qual está inserido. Em todos os segmentos, os processos ósseos estão inseridos na face ventromedial, com exceção de sete segmentos do ramo medial da primeira bifurcação (imediatamente proximais à segunda bifurcação deste ramo) e de até quatro segmentos do ramo lateral da primeira bifurcação (imediatamente proximais à bifurcação) no qual os processos ósseos estão inseridos tanto na face ventromedial quanto na face ventrolateral (espelhados), e de todos os segmentos do ramo lateral da segunda bifurcação do ramo lateral da primeira bifurcação, no qual os processos ósseos estão inseridos na face ventrolateral. Processos ósseos desenvolvemse perpendicularmente à sua inserção no segmento no qual está inserido. Processos ósseos geralmente retos e desenvolvem-se em direção ventral ou ventrolateral em relação ao eixo proximodistal do segmento no qual está inserido. Em secção transversal, os processos ósseos variam de ovalados proximodistalmente a cilíndricos ao longo de seu comprimento total, se afilan do gradualmente e terminando em uma extremidade arredonadada. O diâmetro de sua extremiae deistal equivale a $56 \%$ do diâmetro de sua inserção no segmento no qual está inserido. Em seu estado máximo de desenvolvimento, seu comprimento total não alcança o comprimento proximodistal do segmento no qual se insere. $\mathrm{O}$ comprimento do maior processo ósseo equivale a $16 \%$ do comprimento proximodistal do segmento no qual está inserido. Na nadadeira pélvica os processos ósseos apresentam tamanho semelhante em todos os rais ramificados com processos ósseos; segundo raio ramificado com o maior número de 
segmentos com processos ósseos. Nos raios os processos ósseos apresentam tamanhos semelhantes em direção proximodistal.

Órgão caudal: presente e mais desenvolvido, elaborado em machos adultos.

O órgão caudal é restrito ao lobo ventral da nadadeira caudal. É formado por uma escama modificada localizada posteriormente às três séries de escamas abaixo da linha lateral e tecido intumescido. Verticalmente, a escama modificada sobrepõe a origem de todos os raios do lobo ventral da nadadeira caudal, inclusive o raio simples principal ventral. Horizontalmente, a escama alcança um quinto (1/5) dos raios principais do lobo ventral. A área exposta da escama possui duas áreas principais: a metade ventral um lobo laminar arredondado, com sua extremidade posterior direcionada posteriormente; verticalmente cobre a origem do décimo quinto raio ramificado ao raio simples principal ventral. A metade dorsal apresenta uma forma tridimensional e se assemelha a uma "chave de boca" sendo a parte dorsal desta mais robusta e laminar, com a extremidade distal meio triabular direcionada posterodorsalmente, a parte ventral é mais estreita com sua extremidade distal pontiaguda, em forma de anzol com sua extremidade distal direcionada laterodorsalmente. Toda a região exposta da escama modificada é completamente coberta por tecido, exceto a porção ventral da metade dorsal da escama (em forma de "chave de boca"). O tecido se estende até a porção mediana do décimo primeiro e décimo segundo raios ramificados. Além do tecido mencionado a cima, a escama está fixada no corpo anterioremente por um ligamento da fasce subdérmica ligada a toda a extremidade anterior da escama modificada e medialmente por tecido. A abertura do órgão caudal está localizada na metade dorsal da escama modificada, na porção tridimensional com forma de "chave de boca". Os limites anterior e lateroanterior, ventral e lateroventral, e dorsal e laterodorsal da abertura do órgão caudal são limitados pela combinação de escama e tecido. Limite posterior formado excluivamente por tecido. 


\section{Scopaeocharax rhinodus (Böhlke 1958)}

Fig. 233 a 241

Localidade tipo: Cava de Pavos, Quebrada de Puente Perez, cerca de 1/4 mila a cima do rio Huallaga, cercanias de Tingo Maria, província de Huanuco, Peru.

Material examinado: MZUSP 110537, 24, Perú, Huánuco, Tingo Maria, quebrada Oro, afluente do rio Huallaga - lado direito, a montante da confluência com o rio Monzón, 09¹9’22”S, 7601’45”W, T. F. Teixeira \& L. Chocano, 31/08/2011.

\section{Caracteres sexuais secundários}

Os caracteres sexuais secundários em S. rhinodus relacionam-se com comprimento padrão, formato de nadadeiras, presença de processos ósseos, glândula branquial e glândula caudal.

Comprimento padrão: machos alcançam maiores valores de comprimento padrão em relação às fêmeas. MZUSP 110537, 5 (3 corados) machos $(21.1-29.0$ mm CP) e 9 (1 corada) fêmeas (18.8-28.5 mm CP).

Formato de nadadeiras: Machos diferem de fêmeas pelo formato do perfil da margem distal da nadadeira anal e formato das nadadeiras pélvica, dorsal e caudal.

Perfil da margem distal da nadadeira de machos com um lobo anterior e um lobo posterior. Lobo anterior ligeiramente côncavo, quase reto devido à diminuição discreta de tamanho do último raio simples (raio mais longo) ao quarto raio ramificado; a partir deste ponto os raios aumentam de tamanho gradualmente em direção posterior, formando o lobo posterior. Lobo postrerior formado pelo aumento gradual do quinto a décimo quinto raio ramificado; extremidade distal do último raio ramificado alcançando o segundo raio procurrente ventral anterior. Perfil da margem distal da nadadeira anal de fêmeas côncava conspícua, devido à 
$\overline{\text { diminuição acentuada em tamanho do último raio simples (raios mais longos) ao quarto raio }}$ ramificado; perfil reto deste até o último raio ramificado devido à diminuição gradual de tamanho em direção anteroposterior; último raio ramificado não alcança os raios procurrentes ventrais.

Extremidade distal do terceiro raio ramificado (raio mais longo) da nadadeira pélvica de machos ultrapassa a origem da nadadeira anal, nunca ultrapassando o último raio simples; sempre ultrapassa o orifício urogenital. Os três raios ramificados mediais da nadadeira pélvica de machos estão posicionados dorsolateralmente aos raios laterais (caráter 63 de Weitzman \& Fink, 1985). Extremidade distal do tereiro raio ramificado (raio mais longo) da nadadeira pélvica de fêmeas não alcança o orifício urogenital. Raios ramificados da nadadeira pélvica de fêmeas posicionadas medialmente um ao outro. Em nenhum dos sexos a nadadeira cobre o orifício urogenital em vista ventral.

Perfil da margem distal da nadadeira dorsal de machos lanceolada, com o teceiro (raio mais longo) e quarto raio ramificado, quando a nadadeira está depressa, se estendendo mais posteriormente. Perfil da margem distal da nadadeira dorsal de fêmeas ligeiramente convexa, com todos os raios se estendendo até o mesmo ponto posteriormente, quando esta está depressa. Primeiro raio ramificado é o mais longo.

Nadadeira caudal de machos modificada, com lobo dorsal mais expandido (aquadradado) que o lobo ventral; lobo dorsal sobrepondo o lobo ventral lateralmente. Raios principais da nadadeira caudal de machos robustos, devido à expansão dorsoventral dos segmentos dos raios. Nono e décimo raio ramificado da nadadeira caudal modificados. Nono (décimo raio principal de Weitzman \& Fink, 1985: fig. 13) raio ramificado com a extremidade proximal (na articulação com o hypural 3) mais expandida, arredondada, que os demais raios, e com a metade distal curvada ventroposteriormente, com uma projeção óssea membranosa 
laterodorsal com a margem dorsal rugosa (caráter 61 de Weitzman \& Fink, 1985). Décimo (décimo primeiro raio principal de Weitzman \& Fink, 1985: fig. 13) raio ramificado com a extremidade proximal (na articulação com o hypural 2) muito expandida em forma de foiçe, e com a metade distal curvada ventroposteriormente, com uma projeção ósseoa membranosa laterodorsal rugosa. Nadadeira caudal de fêmeas com os lobos ventral e dorsal simétricos.

Três raios procurrentes ventrais posteriores de machos com expansão laminar ventral.

Nadadeira caudal de fêmeas sem modificações, com os lobos ventral e dorsal com as mesmas dimensões.

Processos ósseos: presentes nas nadadeiras anal, pélvica e caudal de machos maduros.

Nadadeira anal com um processo ósseo por segmento de hemitriquium do segundo ao décimo segundo raio ramificado, disrtribuindo-se em $73 \%$ dos raios ramificados (até 15 raios ramificados). Raios ramificados com processos ósseos presentes tanto em segmentos proximais quanto em segmentos distais à primeira bifurcação. Proximalmente à primeira bifurcação, os processos ósseos estão presentes em até três segmentos. Distalmente à primeira bifurcação, os processos ósseos estão presentes e restritos a até oito segmentos do ramo posterior. Processos ósseos com simetria bilateral exata. Processos ósseos com inserção arredondada. O diâmetro de sua inserção ocupa $23 \%$ do comprimento proximodistal do segmento que está inserido. Em todos os segmentos, os processos ósseos estão inseridos na face posterior em relação à nadadeira. Os processos ósseos desenvolvem-se perpendicularmente à sua inserção no segmento. No um nono (1/9) proximal de seu comprimento total, os processos ósseos sofrem uma curvatura de $80^{\circ}$ e desenvolvem-se em direção proximal em relação ao segmento no qual està inserido. Em secção transversal, os processos ósseos são cilíndricos ao longo de seu comprimento total, afilando-se gradualmente e terminando em uma extremidade distal pontiaguda. O diâmetro de sua extremidade distal 
equivale a $17 \%$ do diâmetro de sua inserção no segmento no qual está inserido. Em seu estado máximo de desenvolvimento, o seu comprimento total ultrapassa o comprimento proximodistal do segmento no qual se insere. O comprimento do maior processo ósseo equivale a $131 \%$ do comprimento proximodistal do segmento no qual está inserido. $\mathrm{Na}$ nadadeira anal os processos aumentam e diminuem gradualmente de tamanho em direção anteroposterior; décimo e décimo primeiro raio ramificado com maior número de segmentos com processo ósseos e maiores processos ósseos. No raio os processos ósseos aumentam e diminuem de tamanho em direção proximodistal; o maior processo ósseos está no primeiro segmento distal à primeira bifurcação, na metade/metade proximal da série de processos ósseos.

Nadadeira pélvica com processos presentes e restritos aos segmentos do hemitriquium ventral. Nadadeira pélvica com até dois processos ósseos por segmento (com exceção do segmento mais proximal, mais longo) do hemitriquium ventral do primeiro ao sétimo raio ramificado (sete raios ramificados), disrtribuindo-se em 100\% dos raios ramificados. Raios ramificados com processos ósseos presentes tanto em segmentos proximais quanto em segmentos distais à primeira bifurcação. Proximalmente à primeira bifurcação, os processos estão presentes em todos os segmentos, inclusive o mais proximal; segmento mais proximal (mais longo) com até 8 processos em sua metade distal. Distalmente à primeira bifurcação, os processos ósseos estão presentes em todos os segmentos do ramo medial e em até oito segmentos do ramo lateral, a partir do terceiro segmento distal à bifurcação. Processos ósseos com inserção arredondada. O diâmetro de sua inserção ocupa $33 \%$ do comprimento proximodistal do segmento no qual está inserido. Em todos os segmentos, os processos ósseos estão inseridos na face ventromedial, com exceção de cinco segmentos do ramo medial da primeira bifurcação imediatamente proximais à segunda bifurcação deste ramo, no qual os 
$\overline{\text { processos ósseos inseridos tanto na face ventromedial quanto na face ventrolateral }}$ (espelhados). Os processos ósseos desenvolvem-se perpendicularmente à sua inserção no segmento. Em seu quinto (1/5) proximal, os processos ósseos sofrem uma curvatura de aproximadamente $60^{\circ}$ e desenvolvem-se em direção proximal, ligeiramente medial, em relação ao exo proximodistal do segmento no qual estão inseridos. Em secção transversal, os processos ósseos são cilíndricos ao longo de seu comprimento total, afilando-se gradualmente e terminando em uma extremidade pontiaguda. O diâmetro de sua extremidade distal equivale a $23 \%$ do diâmetro de sua inserção no segmento no qual está inserido. Em seu estado máximo de desenvolvimento, o seu comprimento total não alcança o comprimento proximodistal do segmento no qual está inserido. O comprimento do maior processo ósseo equivale a $84 \%$ do comprimento proximodistal do segmento no qual está inserido. Na nadadeira pélvica os processos ósseos diminuem de tamanho em direção lateromedial; terceiro raio ramificado com o maior número de segmentos com processos ósseos; primeiro raio ramificado com maiores processos ósseos. Nos raios os processos ósseos aumentam e diminuem de tamanho em direção proximodistal; o maior processo ósseos está no sexto segmento dsital à primeira bifurcação, na metademetade proximal da série de processos ósseos.

Nadadeira caudal com um processo ósseo por segmento do primeiro ao sétimo raio ramificado (lobo dorsal) e do décimo quinto ao décimo sétimo raios ramificado (lobo ventral), disrtribuindo-se em $52 \%$ dos raios ramificados (17 raios ramificados). Processos ósseos presentes tanto em segmentos proximais quanto distais à primeira bifurcação dos raios ramificados do lobo dorsal e em segmentos distais à primeira bifurcação dos raios ramificados do lobo ventral. Processos ósseos presentes também em segmentos distais à segunda bifurcação do ramo lateral da primeira bifurcação do décimo sétimo raio ramificado. Proximalmente à primeira bifurcação dos raios ramificados do lobo dorsal, os processos 
ósseos estão presentes em até três segmentos. Distalmente à primeira bifurcação dos raios ramificados do lobo dorsal, os processos ósseos estão presentes e restritos a até sete segmentos do ramo medial. Distalmente à primeira bifurcação dos raios ramificados do lobo ventral, os processos ósseos estão presentes e restritos a até seis segmentos do ramo medial. Distalmente à segunda bifurcação do ramo medial da primeira bifurcação do décimo sétimo raio ramificado do lobo ventral, os processos ósseos estão presentes e restritos a até quatro segmento do ramo medial, imediatamente distais à ramificaçào. Processos ósseos com simetria bilateral exata. Processos ósseos com inserção arredondada. O diâmetro de sua inserção oucpa $20 \%$ do comprimento proximodistal do segmento no qual está inserido. Em todos os segmentos, os processos ósseos estão inseridos na face lateromedial. Nos segmentos dos raios do lobo dorsal, os processos ósseos desenvolvem-se perpendicularmente (ligeiramente inclinados distalemante) à sua inserção no segmento no qual estão inseridos. Ao longo de seu comprimento total, os processos ósseos sofrem uma curvatura gradual de $55^{\circ}$ e se desenvolve em direção distal em relação ao segmento no qual sestão inseridos. Nos segmentos dos raios ramificados do lobo ventral, os processos ósseos desenvolvem-se perpendicularmente à sua inserção no segmento no qual estão inseridos. Ao longo de seu comprimento total, os processos ósseos sofrem uma curvatura graudla de $30^{\circ}$ e desenvolvemse em direção proximal em relação ao segmento no qual estão inseridos. Em secção transeversal, os processos ósseos tanto do raios do lobo dorsal quanto dos raios do lobo ventral são cilíndricos, afilando-se gradualmente e terminando em uma extremidade pontiaguda. O diâmetro de sua extremidade distal equivale a 31\% (processos ósseos do lobo dorsal) e $28 \%$ (processos ósseos do lobo ventral) do diâmetro de sua inserção no segmento no qual está inserido. No estado máximo de desenvolvimento dos processos ósseos dos raios do lobo dorsal, o seu comprimento total não alcança o comprimento proximodistal do segmento 
$\overline{\text { no qual está inserido. O comrpimento do maior processo ósseo equivale a } 94 \% \text { em relação ao }}$ comprimento proximodistal do segmento no qual estão inseridos. No estado máximo de desenvolvimento dos processos dos raios do lobo ventral, o seu comprimento total não alcança o comprimento proximodistal do segmento no qual está inserido. O comrpimento do maior processo ósseo equivale a $32 \%$ em relação ao comprimento proximodistal do segmento no qual estão inseridos. No lobo dorsal da nadadeira caudal os processos ósseos aumentam de tamanho em direção lateromedial; sexto raio com o maior número de segmentos com processos ósseos; sétimo raio com maiores processos ósseos. No lobo ventral os processos ósseos diminuem de tamanho em direção lateromedial; décimo sexto raio raificado com o maior número de segmentos com processos ósseos; décimo sétimo raio ramificado com os maiores processos ósseos. Nos raios tanto do lobo ventral, quanto do lobo dorsal, os processos ósseos aumentam e diminuem de tamanho em direção proximodistal.

Glândula branquial: presente em machos maduros.

Glândula branquial formada pela fusão do segundo ao sétimo filamento branquial anterior do ceratobranquial do primeiro arco branquial. Glandula branquial disrtribuindo-se em $33 \%$ dos filamentos branquiais do ceratobranquial do primeiro arco branquial. Glândula branquial disrtribuindo-se em $34 \%$ do comprimento do ceratobranquial. Células colunares pouco visíveis lateralmente. Abertura da glândula branquial não visível lateralmente.

Órgão caudal (Weitzman \& Fink, 1985; p. 77-83): presente em machos adultos.

Órgão caudal localizado posterioremente à série de escamas da linha mediana (continuação da série da linha lateral), a primeira série de escamas acima e a primeira série de escamas abaixo da série de escamas da linha mediana. O órgão caudal apresenta uma escama extremamente modificada (escama principal), que compõe sozinha a abertura do órgão e duas escamas adjacentes com uma ligeira modificação, as duas sobrepõem a escama principal dorsalmente e 
$\overline{\text { ventralmente. } \mathrm{O} \text { padrão de sobreposição entre escamas das sérires de escamas adjacentes }}$ indica que a escama mais modificada, que compõe a abertura do órgão, se trata da escama mais posterior da primeira série de escamas acima da linha lateral. A escama sobrepondo lateralmente a porção dorsoanterior da escama modificada aparenta se tratar da escama mais posterior da segunda série de escamas acima da linha lateral, a escama com tamanho semelhante sobrepondo lateralmente a porção ventroanterior da escama modificada aparenta se tratar da escama mais posterior da primeira série de escamas abaixo da linha lateral. Verticalmente, a escama modificada sobrepõe a porção proximal do quarto ao décimo sétimo raio ramificado. Horizontalmente, a escama modificada alcança do quarto proximal dos raios mais dorsais e ventrais e completamente os raios medianos (nono e décimo raio ramificao). A área exposta da escama apresenta um formato geral arredondado/lanceolado com um lobo dorsal arredondado sobrepondo a porcão proximal do quarto ao oitavo raio ramificado e um lobo ventral maior com margem distal também arredondada sobrepondo completamente o nono e décimo raio ramificado e a metade proximal do nono ao décimo sétimo raio ramificado. Os limites dorsal, posterior e posteroventral são compostos por um tecido denso. Porção ventral da escama modificada sem tecido conectivo, caracterizando a abertura da glândula caudal. A abertura do órgão caudal é posteroventral (mais ventral) e se estande do décimo sexto ao décimo sétimo raio ramificado. O limite dorsal da abertura do órgão caudal é formado por um forte tecido conectivo ligadando as margens posterior e dorsal da escama modificada à face lateral do quarto ao décimo raio ramificado. O limite ventral da abertura do órgão caudal é formado por um forte tecido ligando a margem ventral da escama modificada à face lateral da porção proximal do décimo sétio raio ramificado. O limite lateral é formado por uma escama modificada. 


\section{Caracteres sexuais secundários em characiformes}

Nesta contribuição definimos dois tipos gerais de caracteres sexuais secundários: os caracteres morfométricos e os caracteres estruturais. Os caracteres morfométricos são aqueles que aparentemente se desenvolvem de forma contínua em relação ao crescimento, de forma alométrica e não estão relacionados com a maturação gonadal ou seja, aparentemente independem de aporte hormonal (e.g. comprimento padrão, altura do corpo, altura do pedúnculo caudal e comprimento do pedúnculo caudal, comprimento de nadadeiras, formato de nadadeiras, modificação de escamas). Os caracteres estruturais por outro lado, são aqueles cujo surgimento e desenvolvimento estão aparentemente em interseção e em desenvolvimento linear com o início da maturação gonadal, completamente dependentes de aporte hormonal (e.g. processo ósseo, tecido glandular, glândula branquial, tubérculo reprodutivo).

A seguir, os caracteres sexuais secundários analisados, suas variações e sua distribuição nas famílias de Characiformes e nos grupos menos inclusivos de Characidae são apresentados e discutidos.

\section{Caracteres morfométricos}

\section{Tamanho.}

Dimorfismo sexual relacionado a tamanho talvez seja uma das categorias mais comuns de dimorfismo sexual em peixes, os machos sendo maiores que as fêmeas ou fêmeas maiores que machos. A revisão da literatura revelou que a documentação deste tipo de dimorfismo em Characiformes aparece, mais comumente, em contribuições sobre biologia reprodutiva. 
$\overline{\text { Apesar do grande número de contribuições abordando aspectos taxonômicos e filogenéticos }}$ de grupos de Characiformes, a diferença de tamanho entre sexos não foi explicitamente mencionada como dimorfismo sexual e nunca testada em análises filogenéticas. Em algumas contribuições, no entanto, as amplitudes de variação do comprimento padrão foram apresentadas separadamente por sexo (e.g. Menezes et al., 2003; Menezes \& Weitzman, 2009; Menezes et al., 2009a; Menezes et al., 2009b; Menezes \& Weitzman, 2011; Menezes et al., 2013). Na verdade, o que pode ser observado nestes trabalhos é que se as espécies não apresentarem caracteres sexuais secundários óbvios, nenhuma atenção ao sexo é dada.

Este caráter foi definido aqui com base no maior comprimento padrão alcançado por cada sexo, e duas condições foram consideradas: 1 - fêmeas podem ser maiores que machos e 2 - machos maiores que fêmeas.

Dentre os táxons analisados, a condição 1 está presente em todos os representantes analisados de Crenuchidae, Gasteropelecidae e em todos os taxons de Characidae, com exceção dos seguintes: Iguanodectinae (Piabucus melanostomus), Rhoadsiinae (Nematocharax venustus), Cheirodontinae [i.e. Acinocheirodon melanogramma e Spintherobolus papiliferus] e Stevardiinae [i.e. Bryconamericus cf. iheringii, Bryconamericus cf. peruanus, Eretmobrycon bayano, Gephyrocharax atracaudata, Hysteronotus megalostomus, Knodus heteresthes, K. moenkhausii, Pseudocorynopoma doriae e Scopaeocharax rhinodus).

Como observado, tudo indica que fêmeas maiores que machos representaria um estado plesiomórfico em Characidae e caracterizaria uma condição derivada em Iguanodectinae e em dois dos clados mais derivados em Characidae, Cheirodontinae e Stevardiinae.

\section{Formato das nadadeiras.}




\section{Nadadeira anal}

Os caracteres sexuais secundários encontrados estão relacionados basicamente ao formato da base da nadadeira anal e formato da margem distal da nadadeira anal.

Quanto à base da nadadeira anal, observamos que na maioria dos taxons examinados a base da nadadeira anal tanto de machos como de fêmeas são retas e direcionadas posterodorsalmente. Em outras no entanto, a base da nadadeira anal de machos é ligeiramente convexa em relação à da fêmea de forma sutil (Fig. 80 e 37). Em algumas espécies, a base da nadadeira anal é muito convexa em sua metade anterior e reta em sua metade posterior (direcionada posterodorsalmente, quase paralelamente ao eixo horizontal do corpo), formando em casos extremos uma mudança acentuada na direção de desenvolvimento dos raios ali inseridos, fazendo com que os raios inseridos na região de transição se sobreponham. Dentre os taxons analisados, esta condição foi encontrada apenas em Serrapinnus calliurus (Fig. 121a) (Malabarba \& Jerep 2014: fig. 1) e representaria uma sinapomorfia do gênero. Esta condição aprentemente se deve a especializações da musculatura do complexo da nadadeira anal associada aos raios do lobo anterior nas espécies deste gênero. Esta modificação compõe um complexo de modificações da nadadeira anal nas espécies deste gênero, junto a uma série de especializações derivadas no formato dos raios da região anterior da nadadeira, curvatura ventral do pedúnculo caudal e modificação dos raios procurrentes ventrais. Estas especializações foram extensamente estudas neste gênero e grupos relacionados (e.g. Malabarba, 1998; Buhrnheim, 2006; Jerep, 2011). Interessante notar que, em casos extremos, a região anterior da nadadeira é deslocada verticalmente (quase perpendicular ao eixo horizontal do corpo), fazendo com que a convexidade da região anterior fique oposta (quase 
espelhada) à convexidade formada pelos raios procurrentes ventrais, que também estão dispostos na vertical (em relação ao eixo horixontal do corpo) devido à forte curvatura ventral do pedúnculo caudal (Malabarba 1998: fig. 4; Malabarba \& Jerep, 2014: fig. 1).

Dentre os taxons analisados, dimorfismo sexual na margem distal da nadadeira anal foi encontrado no táxon analisado de Serrasalmidae e nos seguintes taxons em Characidae: Salmininae, Bryconinae, Iguanodectinae (Fig. 144), Clado Bryconops, (Fig. 80), Rhoadsiinae (Fig. 151), Tetragonopterinae [Deuterodon iguape (Fig. 159), Hemigrammus bleheri (Fig. 163), H. rhodostomus (Fig. 165) e Paracheirodon axelrodi], Clado Hyphessobrycon luetkenii [H. bifasciatus (Fig. 133) e H. luetkenii (Fig. 138)], Clado Astyanax [A. cf. jordani (Fig. 33), H. anisitsi (Fig. 37) e Psellogrammus kennedyi (Fig. 42)], Grupo A. scabripinnis [sensu Teixeira et al., em prep. (Figs. 45, 49, 55, 62, 67), Aphycharacinae [Aphyohcarax anisitsi (Fig. 11)], Aphyoditeinae [Tyttobrycon marajoara], Cheirodontinae [Acinocheirodon melanogramma, Cheirodon interruptus (Fig. 101), Compsura heterura (Fig. 106), Odontostilbe pequira (Fig. 115) e Serrapinnus calliurus (Fig. 121)] e Stevardiinae [Bryconamericus cf. peruanus (Fig. 194), Cyanocharax alburnus, Diapoma speculiferum (Fig. 198), Gephyrocharax atracaudata (Fig. 209), Knodus heteresthes (Fig. 221), Pseudocorynopoma doriae (Fig. 226) e Scopaeocharax rhinodus (Fig. 223)].

Entretanto, nos seguintes táxons foram encontradas algumas variações: 1 - nadadeira com um lobo anterior discreto, ligeiramente convexo, quase reto (até o $5^{\circ}$ ou $8^{\circ}$ raios ramificados), com segundo ou terceiro raios maiores - presente em Salmininae, Bryconinae, Clado Bryconops, Tetragonopterinae [Deuterodon iguape (Fig. 159a), Hemigrammus bleheri (Fig. 163a), H. rhodostomus (Fig. 165a) e Paracheirodon axelrodi] Clado Hyphessobrycon luetkenii [H. luetkenii (Fig. 138)], Clado Astyanax [A. cf. jordani (Fig. 33a), Hyphessobrycon anisitsi (Fig. 36a) e Psellogrammus kennedyi (Fig. 42b)], Grupo Astyanax scabripinnis 
$\overline{\text { (exceto A. rivularis), Cheirodontinae [Cheirodon interruptus (Fig. 101a) e Compsura }}$ heterura (Fig. a)] e Stevardiinae [Bryconamericus cf. peruanus (Fig. XX) e Knodus heteresthes (Fig. XX)106], 2 - nadadeira reta ou convexa ao longo de todo o perfil distal, sem lobos - presente no Clado Hyphessobrycon luetkenii [H. bifasciatus (Fig. 133a)] e Stevardiinae [Gephyrocharax atracaudata (Fig. 209a)], 3 - lobo anterior anterior conspícuo (até o $5^{\circ}$ ou $7^{\circ}$ ), com segundo ou terceiro raios maiores e decréscimo acentuado do maior raio ao $5^{\circ}$ ou $7^{\circ}$ raio - presente em Aphyocharacinae [Aphyocharax anisitsi (Fig. 11a)] e Cheirodontinae [Odontostilbe pequira (Fig. 115) e Serrapinnus calliurus (Fig. 121a)], 4 lobo anterior conspícuo (até o $10^{\circ}$ ), com o sexto raio maior e filamentoso - está presente em Rhoadsiinae [Nematocharax venustus (Fig. 151a)] e provavelmente representa uma autopomorfia do gênero, 5 - perfil reto anteriormente e aumentando gradualmente em direção posterior até formar um lobo posterior - presente apenas em Iguanodectinae e no Clado Pseudochalceus , $6-3$ lobos conspícuos - presente e provavelmente representando uma autopomorfia de Pseudocorynopoma doriae e 7 - dois lobos anteriores - presente apenas em Serrasalimidae e provavelmente representando uma sinapomorfia dos táxons Mylesinus Valenciennes 1850, Myleus Müller \& Troshel 1844, Ossubtus Jégu 1992, Tometes Valenciennes 1850 e Utiaritichthys Miranda Ribeiro 1937, um grupo monofilético recobrado por Dahdul (2007) e todos eles menos Utiaritichthys por Jégu (2004).

A condição 1 como aqui definida refere-se às nadadeiras onde o lobo anterior é realmente discreto e os raios posteriores ao lobo são, na maioria das espécies, distintamente maiores que os raios equivalentes na nadadeira anal das fêmeas. Nesta condição, a diminuição em tamanho do maior raio do lobo anterior (raio mais longo da nadadeira) ao primeiro raio após o lobo é muito pequena. Acreditamos que esta condição seja na verdade o resultado do aumento dos raios posteriores ao lobo anterior da nadadeira. 
A condição 1 é o tipo mais comum de dimorfismo referente à nadadeira anal em Characidae, presente inclusive nos táxons de clados considerados basais em Characidae (com exceção de Iguanodectinae), que possuem o osso supraorbital (Mirande, 2010: c. 70). Portanto esta condição representaria o estado plesiomórfico em Characidae.

Além das espécies mencionadas, a condição 2 está presente também em Hyphessobrycon kayabi Teixeira, Lima \& Zuanon 2013, H. heliacus Moreira, Landim \& Costa 2002, H. loweae Costa \& Géry 1994 e H. peugeoti Ingenito, Lima \& Buckup 2013. Esta característica foi, entre outras, utilizada por Ingenito et al. (2013) como uma suposta sinapomorfia desse grupo, nomeado por eles como "grupo H. loweae”. O grupo H. loweae também inclui Hyphessobrycon elachys Weitzman 1985 e H. moniliger Moreira, Lima \& Costa 2002. A condição do perfil da nadadeira anal de H. loweae e H. elachys é única em Characidae (ver Weitzman, 1985: fig. 1 e Moreira et al., 2002: fig. 1) e, aparentemente, representaria uma condição derivada em relação às demais espécies do grupo $H$. loweae. Sendo assim, estas duas espécies podem representar um subgrupo monofilético dentro do grupo $H$. loweae. Isto é fortalecido pela compartilhamento de outros caracteres aparentemente derivados em Tetragonopterinae, como a presença de um processo na região proximal dos raios da nadadeira anal, presentes apenas nas espécies do grupo $H$. loweae (ver Teixeira et al., 2013 e Ingenito et al., 2013 para discussão).

O estado 3, como definido aqui, é caracterizado basicamente pela presença de um lobo conspícuo; no entanto, diferentemente da maioria das espécies caracterizdas pela condição 1 , a nadadeira da fêmea é relativamente mais parecida às dos machos. Como pode ser observado nas figuras, a condição presente nos machos dos taxons listados como possuindo a condição 3 é bastante semelhante às nadadeiras das respectivas fêmeas. Nestes taxons o que origina o dimorfismo sexual é a presença de processos ósseos que, de alguma forma, "arma" a 
nadadeira. Embora não citados aqui e provavelmente os melhores exemplos deste tipo de dimorfismo, são os representantes do grupo Rosy-Tetras de Weitzman \& Palmer, 1997 (ver Weitzman \& Palmer, 1997: fig. 3). Nestas espécies o formato da nadadeira dos machos também se assemelha de certa forma ao das fêmeas, havendo apenas,uma concavidade maior na nadadeira dos machos causada pelo redução acentuada dos maiores raios da nadadeira (primeiro, segundo e terceiro) raios do lobo anterior. A única espécie do grupo Rosy-Tetras incluída por (Mirande, 2010), Hyphessobrycon socolofi Weitzman 1977, compõe um dos clados mais derivados de Tetragonopterinae. Sendo assim, a condição presente nas espécies do grupo Rosy-Tetras é a mais derivada em Tetragonopterinae e uma sinapomorfia deste grupo, como sugerido por Weitzman \& Palmer (1997a).

A ausência de dimorfismo com relação ao formato distal da nadadeira anal está presente em todos os taxons analisados de Crenuchidae, Gasteropelecidae e nos seguintes taxons de Characidae: Heterocharacinae, Characinae, Clado Bramocharax, Tetragonopterinae (Brachychalcinus copei, Gymnocorymbus ternetzi, Hemigrammus ulreyi, H. unilineatus, Hyphessobrycon herbertaxelrodi, Monnekhausia sanctafilomenae, M. xinguensis, Poptella paraguayensis, Sthetaprion crenatum e Tetragonopterus argenteus), Clado Astyanax (Astyanax abramis, A. assucnionensis, A. lineatus e Markiana nigripinnis), Grupo A. scabripinnis (A. rivularis), Aphyocharacinae (Prionobrama paraguayensis), Aphyoditeinae (Microschemobrycon casiauiare), Cheirodontinae (Spintherobolus papiliferus), Stevardiinae (Hemibrycon surinamensis, Hyseronotus megalostomus, Bryconamericus cf. exodon, B. cf. iheringi e Eretmobrycon bayano).

Os taxons sem dimorfismo evidente no perfil da margem distal nadadeira anal apresentam três condições diferentes: 1 - um lobo discreto (perfil quase reto) na região anterior da nadadeira anal, com o primeiro, segundo ou terceiro raios ramificados maiores, 
$\overline{\text { seguido de um perfil reto; } 2 \text { - lobo anterior conspícuo formado pelo último raio simples e }}$ primeiros oito raios ramificados (geralmente 6); 3 - nadadeira reta ou convexa ao longo de todo o seu perfil distal.

A primeira condição caracteriza o Clado Bramocharax [Oligosarcus jenynsii (fig. 76)], Clado Astyanax [A. abramis (Fig. 24) e A. lineatus (Fig. 29)]. O segundo estado está presente em Heterocharacinae (Figs. 126 e 129 ), Characinae [Bryconexodon Juruenae (Fig. 87) e Acestrocephalus sardinae (Fig. 84)], Tetragonoterinae [Hemigrammus ulreyi (Fig. 167), H. unilineatus, Jupiaba abrammoides, Jupiana yarina (Fig. 117), Pristella maxillaris, Poptella paraguayensis (Fig. 184) e Tetragonopterus argenteus (Fig. 190)], Aphyoditeinae [Microschemobrycon casiquiare (Fig. 19) e Parecbasis cyclolepis (Fig. 22)], Cheirodontinae [Heterocheirodon yatai (Fig. 111)]. O terceiro estado está presente em Characinae [Charax stenopterus (Fig. 89), Roeboides descalvadensis (Fig. 92) e R. microlepis] e Tetragonopterinae [Brachychalcinus copei, Gymnocorymbus ternetzi, Moenkhausia sanctafilomenae (Fig. 181), Stethaprion crenatum (Fig. 187), ].

As diferentes formas do perfil da margem distal da nadadeira anal presente nos taxons sem dimorfismo são indênticas a algumas condições presentes em táxons com dimorfismo. A condição 1 tanto nas espécies com dimorfismo quanto nas espécies sem dimorfismo reforça a idéia de que esta seja a condição plesiomíorfica em Characidae, da qual derivaram as outras condições ao longo da evolução. O estado 3 (nos taxons sem dimorfismo) e o estado 2 (nos taxons com dimorfismo) por exemplo, são indênticos. Se desconsiderássemos a presença de dimorfismo, este formato de nadadeira estaria presente no Clado Hyphessobrycon luetkeni $[H$. bifasciatus (dimorfismo presente) e H. luetkenii (dimorfismo ausente)], Characinae [Charax stenopterus, Roeboides descalvadensis e R. microlepis (todos sem dimorfismo)], Tetragonopterinae [Brachychalcinus copei, Gymnocorymbus ternetzi, Markiana nigripinnis, 
$\overline{\text { Moenkhausia sanctafilomenae, Stethaprion crenatum e Grupo H. loweae (todos sem }}$ dimorfismo)] e Stevardiinae (Gephyrocharax atracaudata). Em Characinae este estado é uma provável sinapomorfia do Clado 214 de Mirande (2010) e do clado 40 de Mattox \& ToledoPiza (2012). Em Stevardiinae até agora, só encontramos este caráter em Gephyrocharax atracaudata e espécies de Chrysobrycon Weitzman \& Menezes 1998, ambas com dimorfismo (Vanegas-Rios et al., 2011: fig. 1,2 e Vanegas-Rios et al., 2014: fig. 1), sugerindo este caráter como uma sinapomorfia destas duas espécies. Thomaz et al., (2015) incluiu estas duas espécies em sua tribo Stevardiini, mas tendo Chrysobrycon como gênero irmão de Pseudocorynompoma e Gephyrocharax como gênero irmão de Corynopoma. Além de Stevardiinae e Characinae (grupos monofiléticos bem corroborados), esta condição está restrita a Brachychalcinus copei, Gymnocorymbus ternetzi, Hyphessobrycon luetkenii, $H$. bifasciatus, Grupo H. loweae, Markiana nigripinnis, Moenkhausia sanctafilomenae e Stetharpion crenatum. Estas espécies compartilham também o corpo alto. Dentre estas espécies estão aquelas que tradicionalmente compõem a subfamília Stethaprioninae (sensu Reis, 1989). Mirande (2009) redefiniu esta subfamília com o acréscimo de Gymnocorymbus e Stichonodon. Stichonodon também apresenta o estado 3 e o corpo alto. Em Mirande (2010) as espécies de Stethaprioninae (sensu Reis, 1989) mais Gymnocorymbus e Stichonodon foram incluídas em Tetragonopterinae, junto com possíveis espécies de Moenkhaussia. A relação de espécies de Moenkhausia de corpo alto com Stethaprioninae foi hipotetizada por Géry (1997) e Reis (1989). Em Mirande (2010), Hyphessobrycon bifasciatus e H. luetkeni foram consideradas como um clado separado de Tetragonopterinae e do Clado Astyanax. No entanto, foram incluídas no Clado Astyanax por Mirande (2009) junto com Markiana nigripinnis. Como observado acima esta condição também está presente e é potencialmente uma sinapomorfia das espécies do grupo Hyphessobrycon loweae, espécies que também 
apresentam corpo alto, mas tamanho menores. A única espécies do grupo $H$. loweae incluída por Mirande (2010) é parte de um clado derivado em Characidae. Portanto, as relações intergenéricas em Characidae, principalmente nos taxons considerados incertae sedis por Lima et al. (2003) ainda estão longe de uma resolução. Tendo em vista a presença restrita e derivada do formato da margem distal da nadadeira anal e a grande altura do corpo nas espécies mencionadas acima, acreditamos que elas possivelmente compõem um clado monofilético, com agrupamentos monofiléticos menos inclusivos, sendo o grupo $H$. loweae provavelmente um dos clados mais derivados. Este grupo equivale ao Clado C de Javonillo et al. (2010).

\section{Nadadeira pélvica.}

Os caracteres sexuais secundários referentes à nadadeira pélvica estão relacionados basicamente ao comprimento e formato. O comprimento foi analisado de acordo com o comprimento do maior raio da nadadeira.

Dentre os taxons analisados, o dimorfismo quanto ao tamanho da nadadeira pélvica foi encontrado no Clado Bryconops, Clado Pseudochalceus, Rhoadsiinae, Tetragonopterinae [Deuterodon iguape (Fig. 160), Hemigrammus ulreyi (Fig. 168), H. unilineatus, Hyphessobrycon herbertaxelrodi (Fig. 174), Jupiaba yarina (Fig. 178), M. sanctafilomenae, Paracheirodon axelrodi e Pristella maxillaris], Clado Hyphessobrycon luetkeni [Hyphessobrycon bifasciatus (Fig. 134 e 135)], Clado Astyanax [A. abramis (Fig. 25), A. cf. jordani (Fig. 34), Hyphessobrycon anisitsi, Grupo A. scabripinnis (Figs. 45, 50, 56, 62, 68 e 71), Aphyoditeinae (Tyttobrycon marajoara), Cheirodontinae [Acinocheirodon melanogramma, Cheirodon interruptus, Odontostilbe pequira (Fig. 116), Serrapinnus calliurus (Fig. 122) e Spintherobolus papiliferus] e Stevardiinae [Diapoma speculiferum (Fig. 
202), Hysteronotus megalostomus, Hemibrycon surinamensis, Knodus heteresthes (Fig. 223), K. monekhausii e Scopaeocharax rhinodus (Fig. 234)].

Com relação ao comprimento, quatro condições gerais foram encontradas: 1 - pélvica ultrapassando o orifício urogenital mas não alcançando a extremidade anterior da base da nadadeira anal, 2 - pélvica ultrapassando a extremidade anterior da base da nadadeira anal e 3 - ultrapassando o pedúnculo caudal.

A condição 1 está presente no Clado Bryconops (Fig. 80), no Grupo A. scabripinnis (Figs. 45, 50, 56, 62, 68 e 71) e Cheirodontinae [Serrapinnus calliurus (Fig. 122)]. A condição 2, presente em todas as outras espécies (exceto Nematocharax venustus). Nematocharax venustus foi o único táxon a apresentar a condição 3.

Dentre os taxons analisados, as espécies apresentaram variações quanto a sua posição em relação ao orifício urogenital. Duas condições foram definidas: 1- nadadeira pélvica posicionada ventralmente ao orifício urogenital, cobrindo-o ventralmente e 2 - pélvica posicionada lateralmente ao orifício urogenital, sem cobri-lo ventralmente.

Dentre os taxons analisados o estado 1 está presente no Clado Bryconops (Fig. 80), Tetragonopterinae [Deuterodon iguape (Fig. 160), Hyphessobrycon herbertaxelrodi (Fig. 174), Pristella maxillaris], Clado Hyphessobrycon luetkenii [H. bifasciatus (Fig. 135)], Clado Astyanax [A. abramis, A. cf. jordani (Fig. 34), Hyphessobrycon anisitsi], Grupo A. scabripinnis (Figs. 45, 50, 56, 62, 68 e 71),, Aphyoditeinae (Tyttobrycon marajoara), Cheirodontinae [Acinocheirodon melanogramma, Compsura heterura (Fig. 107), Serrapinnus calliurus (Fig. 122), Spintherobolus papiliferus] e Sevardiinae [Hemibrycon surinamensis, Hysteronotus megalostomus, Knodus heteresthes (Fig. 22), K. moenkhausii, Scopaeocharax rhinodus (Fig. 234)].

O estado 2 está presente nos demais taxons. 


\section{Nadadeira caudal.}

Dentre os taxons analisados, o dimorfismo no formato da nadadeira caudal foi encontrado apenas em Cheirodontinae [Acinocheirodon melanogramma (Fig. XX)] e Stevardiinae [Bryconameirus cf. peruanus (Fig. XX), Eretmobrycon bayano (Fig. XX), Gephyrocharax atracudata (Fig. XX) e Scopaeocharax rhinodus (Fig. XX)]. De cordo com as propostas vijentes de relações em Characidae (Javonillo et al., 2005; Mirande, 2010; Oliveira et al., 2011) o dimorfismo no formato da nadadeira anal surgiu duas vezes independentemente na evolução da família e a ausência de dimorfismo é provavelmente a condição plesiomórfica.

O dimorfismo no formato da nadadeira caudal é, naturalmente, o resultado de uma séries de mofidicaçãoes relacionadas aos raios da nadadeira caudal. Estas modificações nestes grupos foram extensamente estudadas (Weitzman \& fink, 1985; Malbarba, 1998; Weitzman \& Menezes, 1998; Buhrnheim, 2006; Jerep, 2011).

Em Cheirodontinae o dimorfismo sexual está no formato do lobo inferior da nadadeira caudal foi proposta como uma sinapomorfia do clado 103 em Compsuirini (sensu Jerep, 2011). O dimorfismo sexual nestas espécies se deve a modificações no formato e disposição dos raios principais $12,13,14$ e 15 , o que atribui ao lobo inferior da nadadeira caudal um formato mais "robusto", uma área maior do que o lobo dorsal. Jerep (2011) analisou estas modificações e codificou caracteres que se mostraram informativos filogeneticamente na resolução das relações intergenercias nesta tribo.

Além dos taxons analisados de Stevardiinae (sensu Mirande, 2010), o dimorfismo sexual na nadadeira anal está aparentemente presente apenas nos taxons de Glandulocaudinae 
$\overline{\text { (sensu Menezes \& Weitzman, 1998). O dimorfismo sexual nestes taxons também está se deve }}$ a modificações nos raios principais do lobo inferior da nadadeira caudal. Estas modificações foram destrinchadas e utilizadas como caracteres que se mostraram informativos nas relações intragenéricas de Glandulocaudinae (sensu Weitzman \& Menezes, 1998) e de grupos menos inclusivos como Xenurobriconini (Weitzman \& Fink, 1985) e glandulocaudinae (sensu Menezes \& Weitzman (2009). No entanto duas condições gerais foram obasevadas. Na primeira condição o dimorfismo se deve ao alargamento dos segmentos de hemitriquium dos raios principais do lobo inferior da nadadeira caudal. Além de Bryconamericus cf. peruanus e Eretmobrycon bayano esta condição foi encontrada apenas em Glandulocauda melanopleura (Ellis, 1912) Menezes \& Weitzman (2009; figs. 11, 12 e 13), G. caerulea Menezes \& Weitzman 2009 (figs. 20, 21 e 22) e Lophiobrycon weitzmani Castro, Ribeiro, Benine \& Melo 2003 (Menezes \& weitzman, 2009: figs. 3 e 4).

Bryconamericus cf. peruanus e Eretmobrycon bayano foram recentemente agrupados na tripo Eretmobryconini por Thomaz et al. (2015) junto a uma série de outras espécies de Bryconamericus. Eretmobryconini por sua vez saiu como o grupo irmão dos demais Stevardiinae (sensu Mirande, 2010; Thomaz et al., 2015). Dentres estas espécies esta condição está presente também em B. dahli Roman-Valencia 200 (Román-Valencia et al., 2015:fig. 1) e B. ecuadorensis Roman, Valencia, Ruiz, Taphorn, Jiménez-Prado \& GarcíaAlzate 2015 (fig. 3). Isto sugere esta condição, como uma possível sinapomorfia suportando Eretmobriconini (sensu Thomaz et al., 2015) com a inclusão de B. ecuadorensis. Ainda nesta proposta, B. peruanus e B. dahli estão em um dos clados mais basais e Eretmobrycon bayano em um dos clados mais derivados. Em B. perunaus esta condição é menos acentuada que a apresentada por E. bayano. Isto indica fortemente a condição de E. bayano como derivada em Eretmobryconini. 
Em Glandulocaudinae (sensu Menezes \& Weitzman, 2009) por outro lado esta condição é aparentemente plesiomórfica uma vez que Lophiobrycon e Glandulocauda são os gêneros mais basais no clado. Isto faz muito sentido, já que esses dois gêneros também apresentam os estados plesiomórficos de outros caracteres sexuais secundários neste grupo como a complexidade no órgão caudal (ver Menezes \& Weitzman, 2009 para discussã) e provavelmente o maior número de processos ósseos na primeira série de segmentos com processos ósseos (ver seção XX nesta contribuição).

A presença única em Characidae da mesma condição em Eretmobrycon bayano (e demais espécies) e Lophiobrycon e Glandulocauda, espécies de clados basais em Glandulocaudinae (sensu Menezes \& Weitzman, 2009) sugere uma relação entre Eretmobryconini e Glandulocaudinae (sensu Menezes \& Weitzman, 2009). Como mencionado acima, na proposta de Thomaz et al. (2015) Eretmobryconni sai como grupo irmão dos demais Stevardiinae (sensu Mirande, 2010). Glandulocaudinae sensu (Menezes \& Weitzman, 2009) por sua vez, foi proposto junto com Landônia, grupo irmão dos demais Glandulocaudinae (sensu Weitzman \& Menezes, 1998) (Menezes \& Weitzman, 1998; Ferreita et al., 2011).

Frente ao discutido acima, acreditamos que Eretemobryconini (sensu Thomax etla., 2015) e Glandulocaudinae (sensu Menezes \& Weitzman, 2009) possam ser provavelmente relacionados e posicionados na base de um grupo formado por eles e Glandulocaudinae (sensu Weitzman \& Menezes, 1998) e este grupo numa posição mais derivada dentro de Setavardiinae (sensu Mirande, 2010). Com esta conformação o dimorfísmo sexual na nadadeira caudal em Stevrdiinae (sensu Mirande, 2010) teria surjido uma vez só, com a condição apresentada por Eretmobryconini mais Glandulocaudinae (sensu Menezes \& Weitzman, 2009) como uma transição entre a condição presente nos demais Characidae e a 
condição mais complexa nos demais gêneros de Glandulocaudinae (sensu Weitzman \& Menezes, 1998). Isto é corrodorado pela presença e formato do órgão caudal. Discussão realizada a seguir.

\section{Órgão caudal}

O órgão caudal é basicamente uma modificação das escamas posteriores das séries de escamas do corpo, em que as margens posteriores e ventrais das escamas são livres, formando uma "câmara" entre as escamas e os raio da nadadeira caudal.

Dentre os taxons analisados, a presença de órgão caudal foi encontrada apenas em Cheirodontinae [Compsura heterura (Fig. XX)] e Stevardiinae [Gephyrocharax atracudata (Fig. XX) e Scopaeocharax rhinodus (Fig. XX)]. De cordo com as propostas vijentes de relações em Characidae (Javonillo et al., 2005; Mirande, 2010; Oliveira et al., 2011) a presença de órgão caudal surgiu duas vezes independentemente na evolução da família e a ausência desse órgão é provavelmente a condição plesiomórfica. De fato, todos os taxons analisados de Characidae apresentaram o desenvolvimento das escamas do lobo superior e inferior da nadadeira caudal semelhantes.

Estas modificações foram extensamente estudadas em nestes taxons (Weitzman \& fink, 1985; Malbarba, 1998; Weitzman \& Menezes, 1998; Buhrnheim, 2006; Jerep, 2011).

Em Cheirodontinae a presença de órgão caudal está restrita a Compsuirini (sensu Jerep, 2011). Jerep (2011) analisou estas modificações e codificou caracteres que se mostraram informativos filogeneticamente na resolução das relações intergenéricas nesta tribo. 
Além dos taxons analisados de Stevardiinae (sensu Mirande, 2010), o órgão caudal está presente apenas nos taxons de Glandulocaudinae (sensu Menezes \& Weitzman, 1998). Dentro desta subfamília o órgão caudal apresenta uma série de modificações, que praticamente definem as suas relações intergenéricas (Weitzman \& Fink, 1985 Weitzman \& Menezes, 1998; Menezes \& Weitzman, 2009). No entanto, de forma geral podemos encontrar algumas condições. Na primeira condição, as escamas que compõem o órgão caudal fazem parte das séries de escamas acima da linha lateral e existe participação de raios modificados no órgão caudal (participam da abertura do órgão). Esta condição é exclusiva de espécies mais derivadas de Mimagoniates (ver Weitzman et al., 2005; Menezes \& Weitzman, 2009) e derivada da condição de Lophyobrycon e Glandulocauda (Menezes \& Weitzman, 2009: fig. 22 e 23). No entanto, Glalndulocauda também apresenta uma escama maior que as escamas do corpo pronunciando-se no lobo ventral da nadadeira e adpressa aos raios, sem formar câmara (ver Menezes \& Weitzman, 2009: fig 22).

$\mathrm{Na}$ segunda condição a abertura do órgão caudal é composto apenas por escamas modificadas. Todos os taxons de Glandulocaudinae (sensu Menezes \& Weitzman, 2009) apresentam esta condição (exceto as espécies mais derivadas Mimagoniates). Todavia existe uma variação no órgão caudal destas espécies, no número e configuração das escamas. Em alguns taxons o órgão caudal é formado por apenas uma escama (apenas uma escma participa da abertura posterior) [e.g. Corynopoma (Weitzman \& Fink, 1985: fig. 16), Gephyrocharax (Fig. XX), Hysteronotus (Fig. XX), Iotabrycon (Weitzman \& Fink, 1985: figs. 10 e 23), Pseudocorynopoma (Fig. XX), Scopaeocharax (Fig. XX), Tyttocharax (Weitzman \& Fink, 1985: fig. 24) e Xenurobrycon (Weitzman \& Fink, 1985: fig. 11)]. e em outros o órgão é formado por duas ou mais (mais de duas escamas participam da abertura posterior) [e.g. 
$\overline{\text { Chrysobrycon (Menezes \& Weitzman, 2009: fig. 10), Diapoma (Fig. XX), Phenacobrycon }}$ (Weitzman \& Fink, 1985: fig. 20 e Planaltina (Menezes \& Weitzman, 2009: fig. 15).

Ferreira et al., (2011) apresentou uma clado monofilético composto por todos os taxons de Glandulocaudinae (sensu Weitzman \& Menezes, 1998), com Glandulocaudinae (sensu Menezes \& Weitzman (2009) como grupo irmão de Stevardiinae (sensu Weitzman et al., 2005). Na mesma contribuição, Ferreira et al. (2011) recobrou Lepidocharax como grupo irmão de todos os outros Stevardiinae (sensu Weitzman et al., 2005). A disposição das escamas no lobo inferior da nadadeira caudal de Lepidocharax é mais parecida à do restantes de Stevardiinae (sensu Mirande, 2010) do que à dos taxons aos quais está relacionada, principalmente pelo fato das escamas do lobo ventral estarem adpressas aos raios da nadadeira, sem formar a câmara (Ferreira, et al., 2011:fig. 10). Sendo assim, a proposta de relações apresentada por Ferreira et al. (2011) indica um sentido de modificação claro em Stevardiinae (sensu Weitzman et al., 2005) no número e disposição das escamas do lobo inferior da nadadeira caudal. Neste grupo as escamas se modificam de uma condição onde mais de duas escamas avançam sobre a o lobo inferior da nadadeira, sem formar câmara em clados basais a uma escama altamente modificada formando um órgão caudal complexo em clados derivados. Esta último condição seria uma sinapomorfia para o clado 12 de Ferreira et al. (2011).

Uma condição muito semelhante está presente em Eretmobrycon bayano (fig. XX). Nesta espécies as escamas avançam significativamente sobre os raios do lobo inferior da nadadeira caudal e as mais posteriores são bem maiores do que as escamas do corpo e não formam câmara. Embora semelhantes à das fêmeas, esta condição em E. bayano é claramente dimórfica. A condição pesente nos machos de E. bayano é muito semelhante à condição presente nas fêmeas de Gephyrocharax (Fig. XX) e Diapoma (Fig. XX). Isto reforça a 
$\overline{\text { proposta de que Eretmobryconini possa ser relacionado e posicionado na base de um grupo }}$ formado por eles e Glandulocaudinae (sensu Weitzman \& Menezes, 1998).

\section{Caracteres estruturais}

\section{Processos ósseos nas nadadeiras}

Como mencionado no material e métodos, a caracterização dos táxons baseou-se na presença de processos ósseos nas nadadeiras. Desta forma, a ausência de processos ósseos foi conferida apenas em algumas espécies, que não foram incluídas no trabalho.

A presença de processos ósseos nas nadadeiras de membros de Characiformes vem sendo documentada desde Eigenmann, no início do século XX. Embora os processos ósseos tenham sido documentados em um grande número de espécies em Characiformes, esta informação está esparsa na literatura. Mais recentemente, Wiley \& Collette (1970) e Collette (1977) fizeram uma revisão com os vários autores e suas contribuições nos quais os processos ósseos foram documentados ou descritos até o final da década de 70. Malabarba \& Weitzman (2003) apresentaram um sumário, incluindo os membros de Characiformes nos quais os processos ósseos estão presentes ou ausentes e também os gêneros nos quais a presença ou ausência era desconhecida, sem especificar, contudo, em quais nadadeiras estão presentes. A presença de processos ósseos em nadadeiras é relativamente simples de notar, uma vez que são em geral facilmente observáveis quando presentes, às vezes tão fortes que podem ser sentidos quando o dedo é passado da base à extremidade distal dos raios (Jenyns, 1942). A determinação da ausência de processos ósseos nas nadadeiras por outro lado, é algo bastante 
raro em trabalhos de taxonomia. Nestes apenas mencina-se que os processos ósseos não foram observados nas nadadeiras, afirmativa que não implica ausência de processos ósseos.

Existe, portanto, bastante insegurança quanto a afirmação de ausência de processos ósseos, pelo fato de não ser muito bem entendida a real relação do desenvolvimento dos processos ósseos nas nadadeiras em função do desenvolvimento gonadal.

Mais recentemenete, Mirande (2009: c. 306 e 2010: c. 307) codificou a presença ou ausência de processos ósseos nas nadadeiras de uma forma mais abrangente em Characiformes. Dentre os táxons do grupo externo de Mirande (2010), a presença de processos ósseos em nadadeiras (c. 307: 1) foi codificada para Carnegiella strigata e Thoracocharax stellatus (táxons que compõem o clado 170 em Gasteropelecidae sensu Mirande, 2010). A ausência de pocessos ósseos nas nadadeiras (c. 307: 0) foi codificada em representantes de Cypriniformes, Distichodontidae (Distichodus maculatus), Parodontidae, Hemiodontidae, Anotosmidae, Prochilodontidae, Curimatidae, Erythrinidae e Crenuchidae (Characidium rachovii e Characidium borellii).

Dentre os táxons do grupo interno de Mirande (2010) a presença de processos ósseos em nadadeiras (c. 307: 1) foi codificada em relação a grande parte dos táxons. A ausência de processos ósseos (c. 307: 0) foi codificada e listada como autopomorfia de Astyanax paris Azpelicueta, Almirón, \& Casciotta 2002, Bryconamericus mennii Miquelarena, Protogino, Filiberto \& López 2002, Exodon paradoxus Müller \& troschel 1844, Hasemania nana (Lütken 1875), Hyphessobrycon elachys, Inpaichthys kerri Géry \& Junk 1977, Pseudochalceus kyburzi Schultz 1966 e Rhoadsia altipinna Fowler 1911 e sinapomorfia do clado 207 [Paragoniates alburnus Steindachner 1876, Xenagoniates bondi Myers 1942 e Phenagoniates macrolepis (Meek \& Hildebrand 1913)], clado 283 [Jupiaba scologaster (Weitzman \& Vari 1986), Jupiaba mucronata (Eigenmann 1909), Deuterodon langei 
$\overline{\text { Travassos } 1957 \text { e Deuterodon iguape], clado } 297 \text { [Moenkhausia cf. intermedia Eigenmann }}$ 1908 e Moenkhausia dichroura (Kner 1858)], clado 301 [Thayeria olbliqua (Kner 1858) e Thayeria boehlkei Weitzman 1957], Gymnocharacinae [Nematobrycon palmeri Eigenmann 911, Gymnocharacinus bergii Steindachner 1903, Grundulus cochae Román-Valência, Paepke \& Pantoja 2003 e Coptobrycon bilineatus (Ellis 1911)]. Os processos ósseos foram codificados como ausentes (Mirande, 2010: c. 307: 1>0) também nos táxons que compõem Agoniatinae (i.e. Agoniates Müller \& Troshcel 1845), o clado 174 (i.e. Raphiodon vulpinus Spix \& Agassiz 1829, Cynodon Spix \& Agassiz 1829 e Hydrolicus e Acestrorhynchus pantaneiro Menezes 1992) e nos táxons que compõem o clado 302 em Bryconinae (i.e. Triportheus nematurus (Kner 1858) e T. pantanensis Malabarba 2004), embora não tenha sido considerado como caráter derivado destes clados. Esta codificação foi conferida e confirmada.

Como veremos nas seções seguintes, vários dos gêneros citados acima possuem espécies com processos ósseos em alguma nadadeira, com exceção de Coptobrycon Géry 1966, Cynodon, Exodon Müller \& Troschel 1844, Grundulus Valenciennes 1846, Gymnocharacinus Steindachner 1903, Hydrolycus, Inpaichthys Géry \& Junk 1977, Nematobrycon Eigenmann 1911, Myxiops Zanata \& Akama 2004, Paragoniates Steindachner 1876, Raphiodon Agassiz 1829, Rhoadsia Fowler 1911, Thayeria Eigenmann 1908, Triportheus Cope 1872 e Xenagoniates Myers 1942

Dentre os táxons analisados por Mirande (2010), este caráter foi codificado como desconhecido (c. 307: ?) em Acestrocephalus sardina, Agoniates anchovia Eigenmann 1914, Aphyodite granmica Eigenmann 1912, Brycon meeki Eigenmann \& Hildebrand 1918, Brycon orbignyanus (Valensciennes 1850), Brycon pesu Müller \& Troschel 1845, Bryconamericus scleroparius (Regan 1908), Bryconops melanurus (Bloch 1794), Chalceus macrolepidotus Cuvier 1818, Cynopotamus argenteus (Valenciennes 1837), Deuterodon iguape, 
$\overline{\text { Heterocharax macroplepis Eigenmann 1912, Hoplocharax goethei, Hyphessobrycon }}$ pulchripinnis Ahl 1937, Iguanodectes geisleri Géry 1970, Jupiaba mucronata, Lonchogenys ilisha Myers 1927, Phenagoniates macrolepis, Roeboexodon geryi (Puyo 1948), Stichonodon insignis (Steindachner 1876), Microschemobrycon casiquiare e Parecbasis cyclolepis. A presença ou ausência de processos ósseos em alguns destes táxons foi conferida e será apresentada nas subseções seguintes.

Além de Mirande (2009, 2010), vários autores incluíram caracteres codificando a presença ou ausência de processos ósseos em análises de cunho filogenético, em análises de grupos menos inclusivos em Characidae (Weitzman \& Fink, 1985; Weitzman \& Menezes, 1998; Malabarba, 1998; Serra, 2003; Bührnheim, 2006; Serra, 2010; Jerep, 2011; Carvalho, 2011; Ferreira et al., 2011; Mattox \& Toledo-Piza, 2012). O caráter no entanto, foi interpretado e apresentado de diversas formas. Alguns apresentaram caracteres codificando a informação de presença ou ausência dos processos ósseos juntamente com informação de formato e às vezes distribuição destes nas nadadeiras (Weitzman \& fink, 1985: c. 7, 67, Weitzman \& Menezes, 1998: c. 28, Malabarba, 1998: c. 39; Bührnheim, 2006: c. 137; Serra, 2010: c. 126). Dentre os autores que codificaram apenas presença ou ausência dos processos ósseos nas nadadeiras, Bührnheim (2006: c. 138), Lima (2006: c. 60), Mirande (2009: c. 306 e 2010: c. 307) e Carvalho (2011: c. 307) interpretaram a presença de processos ósseos em todas as nadadeiras como dependentes uma da oura. Benine (2000: c. 9), Serra (2003: c. 91), Bührnheim (2006: c. 138) e Mirande (2009: c. 307) interpretaram a presença de processos ósseos nas nadadeiras anal e pélvica como dependentes. Mirande (2009: c. 308) interpretou a presença de processos ósseos nas nadadeiras peitoral, dorsal e caudal como dependentes. Mirande (2010: c. 308, 309, 310, 3011 e 312) redefiniu os caracteres relacionados à presença de processos ósseos de Mirande (2009) e interpretou a presença de processos ósseos em cada 
$\overline{\text { nadadeira como independentes, embora redundantes em relação ao seu caráter número 307. } \mathrm{O}}$ mesmo caso se aplica a Carvalho (2011: c. 308, 309, 3010, 311 e 312) que utilizou basicamente os mesmos caracteres de Mirande (2010). Apenas, Jerep (2011: c. 138, 151, 169, 184) e Mattox \& Toledo-Piza (2012; c. 147) interpretaram a presença de processos ósseos em cada nadadeira como aquisições independentes.

Em relação à dependência dos processos ósseos nas nadadeiras, concluimos que em Characidae, embora grande parte dos táxons apresentem processos ósseos nas nadadeiras anal e pélvica, a presença de processos ósseos nestas nadadeiras ocorre independentemente e da presença de processos ósseos nas demais nadadeiras, uma vez que em alguns táxons (i.e. Brycon falcatus, Bryconexodon juruenae, Hasemania kalunga, Piabucus melanostomus, Hemigrammus bleheri, H. rhodostomus, Parecbasis cyclolepis e Markiana nigripinnis) estes estão presentes apenas na nadadeira anal e em outros (i.e. Paracheirodon axelrodi e Spintherobolus papiliferus) apenas na nadadeira pelvica. Em relação à presença de processos ósseos na nadadeira peitoral, concluímos que é dependente da presença de processos ósseos nas nadadeiras anal e pélvica, uma vez que todos os táxons que apresentam processos ósseos na nadadeira peitoral (i.e. Astyanax courensis, A. goyanensis, A. rivularis, Heterocharax virgulatus, Hoplocharax goehtei, Hyphessobrycon vinaceus e H. luetkenii) apresentam necessariamente processos ósseos nas nadadeiras anal e pélvica. O mesmo ocorre com a presença de processos ósseos na nadadeira dorsal (i.e. Jupiaba yarina, Hypessobrycon luetkenii e Tyttobrycon marajoara), e caudal (i.e. Scopaeocharax rhinodus, Gephyrocharax atracaudata, Hysteronotus megalostomus, Acinocheirodon megalostomus, Hyphessobrycon vinaceus e $H$. luetkenii). Embora em alguns táxons (i.e. Hyphessobrycon luetkenii e $H$. vinaceus) os processos ósseos estão presentes em todas as nadadeiras, concluímos que a 
presença de processos ósseos nas peitoral, dorsal e caudal são independentes entre si, mas cada uma dependente da presença de processos ósseos nas nadadeiras anal e pelvica.

Em relação à dependência de processos ósseos em Crenuchidae concluímos que a presença de processos ósseos na nadadeira pélvica ocorre independentemente da presença de processos ósseos na nadadeira peitoral, uma vez que Characidium xavante apresenta processos ósseos apenas na nadadeira pélvica. A presença de processos ósseos na nadadeira peitoral, por outro lado, é dependente da presença de processos ósseos na nadadeira pélvica, uma vez que Characidium xanthopterum apresenta processos ósseos nas duas nadadeiras. Os representantes de Distichodontidae apresentam processos ósseos apenas na nadadeira peitoral (Ferraris \& Vari, 1984; F. Jerep, com. pess.).

Vimos que processos ósseos na nadadeira anal estão presentes apenas em representantes de Gasteropelecidae e Characidae, na nadadeira pélvica apenas em representantes de Crenuchidae e Characidae, na nadadeira peitoral apenas em representantes de Characidae, Crenuchidae e Distichodontidae e nas nadadeiras dorsal e caudal apenas em representantes de Characidae.

Embora a presença de processos ósseos em algumas nadadeiras seja compartilhada por representantes de diferentes famílias em Characiformes (sensu Mirande, 2010) e por diferentes grupos menos inclusivos em Characidae, a análise anatômica comparada realizada junto a informações da literatura, possibilitou a observação de uma série de caracteres que são potencialmente informativos filogeneticamente em diferentes níveis de inclusividade. Estes caracteres estão relacionados ao formato dos processos ósseos e sua presença e distribuição nos raios e na sequência de raios de cada nadadeira em que estão presentes. Estes caracteres serão apresentados e discutidos nas subseções seguintes. 
Processos ósseos na nadadeira anal

Dentre os táxons analisados, processos ósseos na nadadeira anal estão presentes apenas em representantes de Gasteropelecidae (i.e. Carnegiella strigatta e Thoracocharax stellatus) e em todas as espécies de Characidae (sensu Mirande, 2010) com exceção de Paracheirodon axelrodi (Tetragonopterinae) e Spintherobolus papiliferus (Cheirodontinae). A presença de processos ósseos em Gasteropelecidae foi descrita por Weitzman (1954) na nadadeira anal de Carnegiella vesca Fraser-Brunner 1950 (= Carnegiella strigata). Collette (1977) assinalou a presença de processos ósseos (seu "contact organ") na nadadeira anal de pelo menos cinco espécies de Gasteropelecidae [i.e. Gasteropelecus maculatus Steindachner 1879, G. sternicla (Linnaeus 1758), Carnegiella marthae Myers 1927 e C. strigata]. Nesta ocasião o autor ressaltou que não conseguiu encontrar processos ósseos no material que tinha disponível de Thoracocharax Fowler 1907. Machos maduros de Gasteropelecus sternicla analisados por mim e não foram encontrados processos ósseos. A presença de processos ósseos na nadadeira anal de Carnegiella strigata e Thorachocarax sternicla também foi assinalada por Mirande (2010). Gasteropelecidae (sensu Mirande, 2010) inclui Engraulisoma Castro 1981 e tentativamente Clupeacaharax Pellegrin 1926 como grupo irmão de Gasteropelecidae (sensu Weitzman, 1954). Nenhum destes dois gêneros possuem processos ósseos em nenhuma das nadadeiras.

Malabarba \& Weitzman (2003) consideraram a condição na nadadeira anal de Serrasalmidae homóloga à condição presente em Characidae e Gasteropelecidae. No entanto, a condição presente na nadadeira anal do único representante de Serrasalmidae analisado, Myloplus rubripinnis (Figs. 10; “crochets" de Jégu, 1989; fig. 8) consiste de uma extensão pontiaguda de todo o corpo do segmento de hemitriquium mais distal dos raio ramificados, 
direcionada lateroventralmente que sai do tecido que recobre os raios ramificados. Os processos ósseos diferem desta condição por consistirem de projeções ósseas que se desenvolvem na face externa dos segmentos de hemitriquium, em geral perpendicularmente ao seu eixo proximodistal. Sendo assim a condição é completamente diferente daquela presente em representantes de Gasteropelecidae e Characidae e não é considerada aqui como um processo ósseo, corroborando Jégu (2004) e Lima (2006). Em Serrasalmidae no entanto, a presença de "crochets", quase sempre restritos aos raios que compõem o segundo lobo da nadadeira anal de machos, está presente também em representantes de Mylesinus Valenciennes 1850, Myleus Müller \& Troshel 1844, Ossubtus Jégu 1992, Tometes Valenciennes 1850 e Utiaritichthys Miranda Ribeiro 1937, gêneros que compõem um grupo monofilético recobrado por Dahdul (2007) e todos eles menos Utiaritichthys por Jégu (2004). Sendo assim, a presença de "crochets" na nadadeira anal deve representar uma sinapomorfia adicional para este grupo.

A história da documentação de processos ósseos na nadadeira anal de membros de Characidae se sobrepõe à da presença de processos ósseos em Characiformes. A documentação da presença de processos ósseos na nadadeira anal em muitas espécies em Characidae, entretanto, existe de maneira esparsa na literatura. Como resultado das análises realizadas no presente trabalho, juntamente com informações da literatura, foi possível constatar a presença de processos ósseos na nadadeira anal em pelo menos uma espécie dos gêneros da família Characidae. A constatação da existência dos processos ósseos será feita grupo por grupo de acordo com a proposta de relações de Mirande (2010) partindo dos clados mais inclusivos para os menos inclusivos em Characidae. A composição de alguns grupos, como Characinae e Cheirodontinae seguem Mattox \& Toledo-Piza (2012) e Jerep (2011) respectivamente. 
Em Characidae os processos ósseos na nadadeira anal estão presentes em representantes de Salminus Agassiz 1829 (obs. pess.; Lima, 1006) (Salmininae sensu Mirande, 2010), em Brycon Müller \& Troschel 1844 (obs. pess.; Lima, em prep.) e Lignobrycon Eigenmann \& Myers 1929 (Malabarba \& Weitzman, 2003) (parte de Bryconinane sensu Mirande, 2010), em Iguanodectes Cope 1872 (Moreira, com. pess.) e Piabucus Oken 1817 (obs. pess.) (Iguanodectinae sensu Moreira, 2002 e Mirande, 2010), em Bryconops Kner 1858 (obs. pess.) (Bryconops Clade sensu Mirande, 2010), em Gilbertolus Eigenmann 1907 (obs. pess.; Malabarba \& Weitzman, 2003), Gnathocharax Fowler 1913 (obs. pess; Mattox \& Toledo-Piza, 2012), Heterocharax Eigenmann 1912 (obs. pess.), Hoplocharax Géry 1966 (obs. pess.), Lonchogenys Myers 1927 (Mattox \& Toledo-Piza, 2012), Priocharax Weitzman \& Vari 1987 (Weitzman \& Vari, 1987; Mattox \& toledo-Piza, 2012) e Roestes Günther 1864 (Malabarba \& Weitzman, 2003) (Heterocharacinae sensu Mattox \& Toledo-Piza, 2012), em Bryconexodon Géry 1980 (obs. pess.) (parte do Clado 277 em Characinae sensu Mirande, 2010; clado 16 de Mattox \& Toledo-Piza, 2012), em Acanthocharax Eigenmann 1912 (Mattox \& Toledo-Piza, 2012), Acestrocephalus Eigenmann 1910 (obs. pess.), Charax Scopoli 1777 (obs. pess.), Cynopotamus Valensciennes 1850 (Mattox \& Toledo-Piza, 2012), Galeocharax Fowler 1910 (Mattox \& Toledo-Piza, 2012), Phenacogaster Eigenmann 1907 (obs. pess.; Malbarba \& Lucena, 1995) e Roeboides Günther 1864 (obs. pess.) (clado 212 em Characinae sensu Mirande, 2010; Characinae sensu Mattox \& Toledo-Piza, 2012), em Bramocharax Gill 1877 (Malbarba \& Weitzman, 2003) e Oligosarcus Günther 1864 (obs. pess.) (Clado Bramocharax sensu Mirande, 2010), em Hollandichthys Eigenmann 1910 (obs. pess.) (parte de Pseudochalceus sensu Mirande, 2010) em Carlana Strand 1928 (Mirande, 2010) e Nematocharax Weitzman, Menezes \& Britski 1986 (obs. pess.) (parte de Rhoadsiinae sensu Mirande, 2010), em Bario Myers 1940 (Mirande, 2010), 


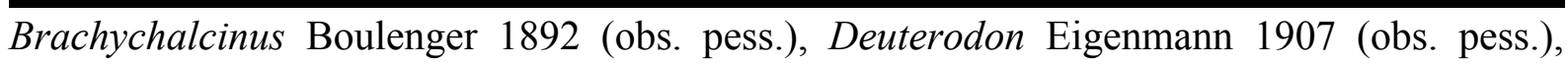
Gymnocorymbus Eigenmann 1908 (obs. pess.), Hasemania Ellis 1911 (obs. pess.), Hemigrammus Gill 1858 (obs. pess.), Hyphessobrycon Durbin 1908 (obs. pess.), Jupiaba Zanata 1997 (obs. pess.), Moenkhausia Eigenmann 1903 (obs. pess.), Orthospinus Reis 1989 (Reis, 1989), , Parapristella Géry 1964 (Lima \& Sousa, 2009), Petitella Géry \& Boutière 1966 (Malbarba \& Weitzman, 2003), Poptella Eigenmann 1908 (obs. pess.), Pristella Eigenmann 1908 (obs. pess.), Probolodus Eigenmann 1911 (Mirande, 2010), Stethaprion Cope 1870 (obs. pess.) e Tetragonopterus Cuvier 1816 (obs. pess.) (Tetragonopterinae sensu Mirande, 2010), em Astyanacinus Eigenmann 1907, Astyanax Baird \& girard 1854 (obs. pess.), Ctenobrycon Eigenmann 1908 (Schoenfeld, 1935 appud Wiley \& Collette, 1970), Hyphessobrycon, Markiana Eigenmann 1903 (obs. pess.) e Psellogrammus Eigenmann 1908 (obs. pess.) (Clado Astyanax sensu Mirande, 2010; Mirande et al., 2011), em Aphyocharax Günther 1868 (obs. pess.), Prionobrama Fowler 1913 (obs. pess.) e Rachoviscus Myers 1926 (obs. pess.; Weitzman \& Cruz, 1981) (clado 193 menos o clado 207 de Aphyocharacinae sensu Mirande, 2010), em Aphyocharacidium Géry 1960 (Jerep, 2011), Axelrodia Géry 1965 (Mirande, 2010), Leptobrycon Eigenmann 1915 (Jerep, 2011), Microschemobrycon Eigenmann 1915 (obs. pess.), Parecbasis Eigenmann 1914 (obs. pess.) e Tyttobrycon Géry 1973 (obs. pess.) (parte de Aphyoditeinae sensu Mirande, 2010), em Acinocheirodon Malabarba \& Weitzman 1999 (obs. pess.), Aphyocheirodon Eigenmann 1915 (Jerep (2011), Cheirodon Girard 1855 (obs. pess.), Cheirodontops Schultz 1944 (Jerep, 2011), Compsura Eigenmann 1915 (obs. pess.), Ctenocheirodon Malbarba \& jerep 2012, Heterocheirodon Malabarba 1998 (obs. pess.), Kolpotocheirodon Malbarba \& Weitzman 2000 (Malabarba et al., 2004; Jerep, 2011), Macropsobrycon Eigenmann 1915 (Jerep \& Malabarba, 2011), Nanocheirodon Malabarba 1998 (Jerep, 2011), Odontostilbe Cope 1870 (obs. pess.), 
$\overline{\text { Prodontocharax Eigenmann \& Pearson } 1924 \text { (Mirande, 2010; Jerep, 2011), Pseudocheirodon }}$ Meek \& Hildebrand 1916 (Jerep, 2011), Saccoderma Schultz 1944 (Jerep, 2011), Serrapinnus Malbarba 1998 (obs. pess.) (Cheirodontinae sensu Mirande, 2010; Jerep, 2011) e em Acrobrycon Eigenmann \& Pearson 1924 (Arcila et al., 2013), Argopleura Eigenmann 1913 (Weitzman \& Fink, 1985), Attonitus Vari \& Ortega 2000 (Vari \& Ortega, 2000), Aulixidens Böhlke 1952 (Mirande, 2010), Boehlkea Géry 1966 (Géry, 1966), Bryconadenos Weitzman, Menezes, Evers \& Burns 2005 (Weitzman et al., 2005), Bryconamericus Eigenamnn 1907 (obs. pess.), Carlastyanax Géry 1972, Chrysobrycon Weitzman \& Menezes 1998 (Weitzman \& Menezes, 1998), Creagrutus Günther 1864 (Vari \& Harold, 2001), Cyanocharax Malabarba \& Weitzman 2003 (obs. pess.), Cyanogaster Mattox, Britz, Toledo-Piza \& Marinho 2013, Diapoma Cope 1894 (obs. pess.), Eretmobrycon Fink 1976 (obs. pess.; Fink, 29176), Gephyrocharax Eigenmann 1912 (obs. pess), Glandulocauda Eigenmann 1911 (Menezes \& Weitzman, 2009), Hemibrycon Günther 1864 (obs. pess.), Hypobrycon Malabarba \& Malabarba 1994 (Almirón et al., 2001), Hysteronotus Weitzman \& Thomerson 1970 (obs. pess.), Iotabrycon Roberts 1973 (Roberts, 1973), knodus Eigenmann 1911 (obs. pess.), Lepidocharax Ferreira, Menezes, Quagio-Grassioto 2011 (Ferreira et al., 2011), Lophiobrycon Castro, Ribeiro, Benine \& Melo 2003 (Castro et al., 2003), Mimagoniates Regan 1907 (Menezes \& Weitzman, 2009), Odontostoechus Gomes 1947 (Mirande, 2010), Phallobrycon Menezes, Ferreira \& Netto-Ferreira 2009 (Menezes et al., 2009), Phenacobrycon Eigenmann 1922 (Eigenmann, 1927; Roberts, 1973), Piabarchus Myers 1928 (Mahnert \& Géry, 1988), Piabina Reinhardt 1867 (Vari \& Harold, 2001), Planaltina Böhlke 1954 (Menezes et al., 2003), Pseudocorynopoma Perugia 1989 (obs. pess.), Pterobrycon Eigenmann 1913 (pela imagem de Bussing, 1974), Ptychocharax Weitzman, Fink, MachadoAlisson \& Royero 1994 (Weitzman et al., 1994), Rhinobrycon Myers 1944 (Malabarba \& 
Weitzman, 2003), Rhinopetitia Géry 1964 (Malabarba \& Weitzman, 2005), Scopaeocharax Weitzman \& fink 1985 (Weitzman \& finak, 1985), Trochilocharax Zarske 2010 (Zarske, 2010), Tyttocharax Fowler 1913 (Weitzman \& Fink, 1985) e Xenurobrycon Myers \& Miranda Ribeiro 1945 (Weitzman \& Fink, 1985) (Stevardiinae sensu Mirande, 2010 e Thomaz et al., 2015). Dentre os táxons listados como incertae sedis em Characidae (sensu Mirande, 2010) os processos ósseos na nadadeira anal estão presentes em Bryconella Géry 1965 (Géry, 1965a), Britttanichthys Géry 1965 (Géry, 1965b) e Thrissobrycon Böhlke 1953 (obs. pess.).

Além dos gêneros litados na seção aterior como não detentores de processos ósseos em nenhuma nadadeira, os processos ósseos na nadadeira anal estão ausentes também em Caiapobrycon Malabarba \& Weitzman 2000 (Malbarba \& Weitzman, 2000), Ceratobranchia Eigenmann 1914 (Chernoff \& Machado-Alisson, 1990), Landonia Eigenamm \& Henn 1914 (Weitzman \& Fink, 1985), Nantis Mirande, Aguilera \& Azpelicueta 2004 (Mirande et al., 2004), Paracheirodon axelrodi Géry 1960 (obs. pess.) e Spintherobolus papiliferus (obs. pess.).

A existência de processos ósseos é desconhecida em Chilobrycon Géry \& de Rham 1981 e Henochilus Garman 1890 (Bryconinae sensu Mirande, 2010), Roeboexodon Géry 1959 (Clado 277 em Characinae sensu Mirande, 2010; Clado 16 de Mattox \& Toledo-Piza, 2012), Pseudochalceus Kner 1863 (Clado Pseudochalceus sensu Mirande, 2010), Parastremma Eigenmann 1912 (Rhoadsiinae sensu Mirande, 2010), Stichonodon Eigenmann 1903 (Tetragonopterinae sensu Mirande, 2010), Leptagoniates Boulenger 1887, Phenagoniates Eigenmann \& Wilson 1914 (Aphyocharacinae sensu Mirande, 2010), Aphyodite Eigenmann 1912, Oxybrycon Géry 1964 (Aphyoditeinae sensu Mirande, 2010), Amazonspinther Bührnheim, Carvalho, Malabarba \& Weitzman 2008 (Cheirodontinae sensu Mirande, 2010 e Jerep, 2011), Bryconacidnus Myers 1929, Corynopoma Gill 1858, 


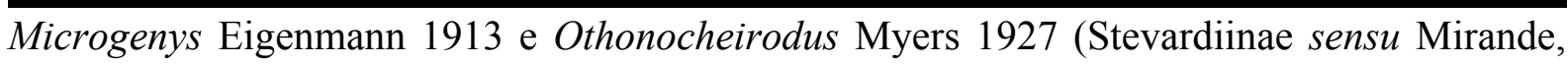
2010 e Thomaz et al., 2015), Atopomesus Myers 1927, Bryconella Géry 1965, Dectobrycon Zarske \& Géry 2006, Ectrepopterus Fowler, 1943, Erythrocharax Netto-Ferreira, Birindelli, de Sousa, Mariguela \& Oliveira 2013, Genycharax Eigenmann 1912, Gymnotuchthys Fernández-Yepes 1950, Mixobrycon Eigenmann 1915, Oligobrycon Eigenmann 1915, Schultzites Géry 1964, Scissor Günther 1864, Serrabrycon Vari 1986, Stygichthys Brittan \& Böhlke 1965 e Tucanoichthys Géry \& Römer 1997 (incertae sedis em Characidae sensu Mirande, 2010).

Desta forma, cento e treze gêneros dos cento e sessenta e dois gêneros de Characidae (Schemeyer \& Fong, 2016) possuem processos ósseos na nadadeira anal.

A otimização da presença ou ausência de processos ósseos na nadadeira anal em Characiformes que aparece em Mirande (2010) e Ortí \& Meyer (1997) indica o surgimento independente de processos ósseos na nadadeira anal de Gasteropelecidae e Characidae mas de acordo com as propostas de Buckup (1998) e Moreira (2007) os processos ósseos na nadadeira anal terima surgido apenas uma vez.

A otimização deste caráter em Characidae, Mirande (2010) indicou a presença de processos ósseos na nadadeira anal como um estado plesiomórfico na família, com uma perda (308: 1>0) listada como autopomorfia em Mimagoniates rehocharis. No entanto, a presença de processos ósseos na nadadeira anal de Mimagoniates rheocharis foi descrita e ilustrada por Menezes \& Weitzman (1990: fig. 21 e 2009: fig. 73). Isto provavelmente se deve ao fato do autor ter interpretado em sua análise a presença de processos ósseos em qualquer nadadeira como um caráter homólogo (c. 307: Processos ósseos nos raios das nadadeiras), assim a otimização de presença ou ausência de processos ósseos na nadadeira anal (c. 308) se restringiu aos táxons pré-codificados como possuidores de processos ósseos em qualquer 
nadadeira (c. 307: 1). No entanto, na seção anterior, foi indicado que a presença de processos ósseos na nadadeira anal deve ser tratada como aquisição independente das demais nadadeiras. Com os dados levantados nos sentimos confiantes em corroborar Mirande (2010) quanto à presença de processos ósseos na nadadeira anal ser um estado plesiomórfico em Characidae, com perdas secundárias ao longo da evolução da família.

Em grande parte dos gêneros monofiléticos todos os seus representantes possuem (e.g. Brycon, Bryconops, Heterocharax, Salminus e Scopaeocharax) ou não (e.g. Triportheus) processos ósseos na nadadeira anal. Em alguns gêneros monofiléticos no entanto, alguns representantes apresentam e outros não (e.g. Charax e Spintherobolus); no entanto é interessante notar que grande parte dos gêneros que possuem representantes com e sem processos ósseos na nadadeira anal são gêneros parafiléticos e foi justamente nestes gêneros que a presença ou ausência de processos ósseos foi testada filogeneticamente (e.g. Hasemania Serra, 2003, Hemigrammus Serra, 2006 e Hyphessobrycon Carvalho, 2011). Este caráter nunca foi testado em uma análise filogenética em nível intragenérico de um gênero monofilético, mas tudo indica que o caráter é mais informativo em nível intragenérico.

Embora presente em Gasteropelecidae e em grande parte das espécies de grupos menos inclusivos de Characidae (sensu Mirande, 2010) os processos ósseos apresentam variações relacionadas ao formato (tipo), número de tipos diferentes por nadadeira e tipo de distribuição destes nos raios e na nadadeira (conjunto de raios com processos ósseos). Estas variações serão apresentadas a seguir.

\section{Forma dos processos ósseos.}


As análises dos caracteres que foram utilizados para determinar a forma do processo ósseo em cada táxon foram realizadas no maior processo ósseo da nadadeira. Estes variam de tamanho e ligeiramente de formato anteroposteriormente em raios adjacentes e proximodistalmente no raio. Assim, o maior processo ósseo da nadadeira pode estar em um raio na região posterior ou anterior da nadadeira e próximos à primeira bifurcação ou à segunda ou terceira bifurcações deste raio. Portanto, há o risco de estar comparando processos ósseos não homólogos. No entanto, a definição de homologia neste caso se mostrou extremamente complicada. Assim, escolhemos o maior processo ósseo independentemente de sua posição na nadadeira por acreditar que é a expressão máxima de desenvolviemento (formato e tamanho) apresentada em cada táxon.

Com relação ao formato dos processos ósseos na nadadeira anal, a analise anatômica comparada revelou que existe alguma certa variação. Esta variação foi analisada através dos seguintes caracteres: o formato da inserção dos processos ósseos no segmento em que estão inseridos, variação dos processos ósseos em corte transversal (da inserção à extremidade distal do processo ósseo), presença ou ausência de curvatura, tipo de curvatura, grau de curvatura, direção da curvatura e do desenvolvimento pós curvatura, porcentagem do diâmetro de sua extremidade distal em relação ao seu maior comprimento (em processos ósseos com inserção ovalada proximodistalmente) ou diâmetro (em processos ósseos com inserção arredondada) de sua inserção e porcentagem do maior comprimento (em processos ósseos com inserção ovalada proximodistalmente) ou diâmetro (em processos ósseos com inserção arredondada) de sua inserção em relação ao maior comprimento do processo ósseo. A combinação das diferentes condições de caráteres foram utilizados para a definição dos diferentes tipos de processos ósseos. 
Quanto ao formato da inserção dos processos ósseos (caráter 1), duas condições foram observadas: 1 - ovalada proximodistalmente, mais comprida proximodistalmente que lateromedialmente em relação ao eixo proximodistal do segmento em que está inserido e 2 processos ósseos com inserção arredondada.

A condição 1 está presente nos taxons analisados de Gasteropelecidae (Figs. 7 e 9) e em todos os taxons analisados de Characidae, com exceção dos taxons citados como possuindo a condição 2. Esta está presente nos seguintes taxons de Characidae: Heterocharacinae [i.e. Hoplocharax goethei (Fig. 130c,d) e Heterocharax virgulatus (Fig. 127c,d)], Characinae [i.e. Acestrocephalus sardina (Fig. 85b,c), Charax stenopterus (Fig. 90a,c) e Roeboides descalvadensis (Fig. 93a,c)], Rhoadsinae [i.e. Nematocharax venustus (Fig. 153c,d)], Tetragonopterinae [i.e. Brachychalcinus copei, Poptella paraguayensis (Fig. 185c,d), Stethaprion crenatum (Fig. 188c,d), Moenkhausia sanctafilomenae (Fig. 182c,d) e Hemigrammus unilineatus (Fig. 172c,d)], Clado Hyphessobrycon luetkenii [i.e. Hyphessobrycon bifasciatus (Fig. 136c,d) e Hyphessobrycon luetkenii (Fig. 142)], Clado Astyanax [i.e. Hyphessobrycon anisitsi (Fig. 38b,c) e Markiana nigripinnis (Fig. 41b,c)], Grupo Astyanax scabripinnis sensu Teixeira et al. (em prep.) [i.e. A. brachypterygium (Fig. 47c,d), A. courensis (Fig. 51b,c), A. cremnobates, A. goyanensis (Fig. 57c,d), A. rivularis (Fig. 63c,d), Hasemania kalunga (Fig. 69c,d), Hyphessobrycon vinaceus (Fig. 72c,d), Aphyocharacinae [i.e. Aphyocharax ansitsi (Fig. 12a,c,d) e Prionobrama paraguayensis (Fig. 16c,d)], Cheirodontinae [i.e. Serrapinnus caliurus (Fig. 123b,c)] e Stevardiinae [i.e. Bryconamericus cf. peruanus (Fig. 195c,d), Diapoma speculiferum (Fig. 199c,d) e Scopaeocharax rhinodus (Fig. 239c,d)].

A primeira condição aparentemente representa um estado plesiomórfico em Characidae com transformação para a condição 2 em Heterocharax virgulatus e Hoplocharax 
goethei. Mirande (2010) recobrou Hoplocharax como grupo irmão de um clado monofilético composto por Lonchogenys e Heterocharax. Mattox \& Toledo-Piza (2012) por outro lado recobraram Lonchogenys como grupo irmão de Heterocharax e Hoplocharax. Embora também presentes, os processos ósseos na nadadeira anal de Lonchogenys e nas demais espécies de Heterocharax não foram analisados. Portanto, embora este caráter represente uma condição sinapomórfica para Heterocharax e Hoplocharax, corroborando Mattox \& ToledoPiza (2012) a análise deste caráter nas outras espécies é necessária para entender em que nível de inclusividade este caráter é informativo em Heterocharacinae.

Quanto à variação do formato dos processos ósseos em corte transversal na área de inserção junto à extremidade distal (Caráter 2), três condições foram encontradas: 1 - de ovalado proximodistalmente a cilíndrico, 2 - cilíndrico e 3 - de ovalado proximodistalmente a ovalado horizontalmente, com o maior comprimento horizontal da metade do comprimento total do processo.

A condição 1 é a mais comum e está presente em todos os taxons de Gasteropelecidae e grande parte dos taxons analisados de Characidae e sugere que esta condição poderia ser caracterizada como plesiomórfica em Characidae. O estado 2 está presente em todos os taxons listados acima como detentores de inserção arredondada. Dentre os taxons analisados o estado 3 está presente exclusivamente em Iguanodectinae (Piabucus melanostomus).

Quanto à curvatura (caráter 3), duas condições foram encontradas (modificado do caráter 149 de Buhrnheim, 2006): 1 - curvatura presente e 2 - ausente ou presente no máximo de $5^{\circ}$ em relação ao eixo do segmento em que estão inseridos.

Nos taxons analisados de Gasteropelecidae e em grande parte dos taxons analisados de Characidae, os processos ósseos apresentam curvatura com ângulo superior a $10^{\circ}$ (condição 1). Quando presente, os processos ósseos se desenvolvem geralmente perpendicularmente à 
sua inserção e em seguida apresentam uma curvatura. Esta curvatura ocorre de formas diferentes (caráter 4). Dentre os taxons analisados, processos ósseos retos, sem curvatura, ou com curvatura com ângulo inferior a $5^{\circ}$ (estado 2) estão presentes apenas em Heterocharcinae [i.e Heterocharax virgulatus (Fig. 127) e Hoplocharax goethei (Fig. 130)], Characinae [i.e. Roeboides descalvadensis (Fig. 95)] e Stevardiinae [i.e. Bryconamericus cf. peruanus (Fig. 195)]. No caso de $H$. virgulatus, H. goethei e $R$. descalvadensis, os processos ósseos se desenvolvem perpendicularmente ao eixo proximodistal do segmento em que estão inseridos, mas em $B$. cf. peruanus os processos ósseos se desenvolvem retos formando um ângulo de 45 a $60^{\circ}$ em direção distal em relação ao raio da nadadeira (caráter 7). Hemigrammus unilineatus, Moenkhausia sanctafilomenae, Stethaprion crenatum e Poptella paraguayensis apresentam tanto processos ósseos retos quanto curvos (estados 1 e 2). Isto aparentemente é característico deste tipo de processo ósseo.

Quanto ao tipo de curvatura, independentemente do ângulo da curvatura (caráter 4), dois estados foram encontrados: 1 - curvatura gradual ao longo do comprimento total do processo ósseo, com mudança gradual de direção da inserção à extremidade distal, 2 curvatura visível, com mudança de direção acentuada geralmente em sua metade proximal.

O estado 1 é mais comum e está presente em todos os taxons analisados de Gasteropelecidae (Figs 7 e 9) e nos seguintes representantes de Characidae: Salminus Salmininae [i.e. S. brasiliensis (Fig. 155d) e S. hilarii (Fig. 157d)], Bryconinae [i.e. Brycon falcatus (Fig. 79d)], Iguanodectinae [i.e. Piabucus melanostomus (Fig. 145d)], Clado Bryconops [i.e. Bryconops affinis (Fig. 82d)], Characinae [i.e. Acestrocephalus sardinae (Fig. 85c), Bryconexodon juruenae (Fig. 88b), Charax stenopterus (Fig. 90d) e R. microlepis (Fig. 95d)], Clado Pseudochalceus [i.e. Hollandichthys multifasciatus (Fig. 149c)], Rhoadsiinae [i.e. Nematocharax venustus (Fig. 153d)], Tetragonopterinae [i.e. Brachychalcinus copei, 


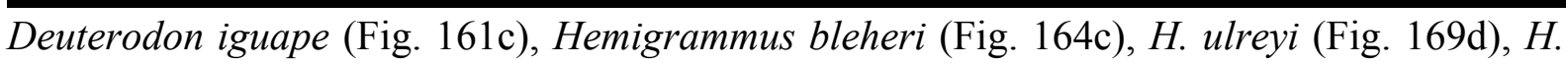
rhodostomus (Fig. 166d), H. unilineatus (Fig. 172d), Hyphessobrycon herbertaxelrodi, Jupiaba abrammoides, Jupiaba yarina (Fig. 179d), Moenkhausia sanctafilomenae (Fig. 182d), M. xinguensis, Stethaprion crenatum (Fig. 188d) e Poptella paraguayensis (Fig. 185d)], Clado Hyphessobrycon luetkenii [i.e. H. bifasciatus (Fig. 136d) e H. luetkenii (Fig. 141b)], Clado Astyanax [i.e. Astyanax abramis (Fig. 27d), Hyphessobrycon anisitsi (Fig. 38c), Markiana nigripinnis (Fig. 41c) e Psellogramus kennedyi (Fig. 43c)], Grupo Astyanax scabripinnis [i.e. Astyanax brachypterygium (Fig. 47d), A. courensis (Fig. 51c), A. goyanensis (Fig. 57c), A. rivularis (Fig. 63c), Hasemanis kalunga (Fig. 69c) e Hyphessobrycon vinaceus (Fig. 72d)], Aphyocharacinae [i.e. Aphyocharax anisitsi (Fig. 12), Microschemobrycon casiquiare (Fig. 20d), Parecbasis cyclolepis (Fig. 23d) e Prionobrama paraguayensis (Fig. 16d], Cheirodontinae [i.e. Heterocheirodon yatai (Fig. 113d) e Serrapinnus calliurus (Fig. 124d)] e Stevardiinae [i.e. Bryconamericus peruanus (Fig. 195d) e Pseudocorynopoma doriae (Fig. 230d)].

O estado 2 está presente apenas nos seguintes taxons de Characidae (estado 1 do caráter 1): Clado Astyanax [i.e. Astyanax lineatus (Fig. 30d), e Astyanax cf. jordani (Fig. 35d)], Aphyocharacinae [i.e. Aphyocharax anisitsi (Fig. 12e)], Cheirodontinae [i.e. Acinocheirodon melanograma (Fig. 97d), Cheirodon interrupstus (Fig. 102d) e Compsura heterura (Fig. 108d] e Stevardiinae [i.e. Diapoma speculiferum (Fig. 199d), Eretmobrycon bayano (Fig. 207d), Knodus heteresthes (Fig. XX), Gephyrocharax atracaudata (Fig. 214d), Hysteronotus megalostomus (Fig. 217b) e Scopaeocharax rhinodus (Fig. 239d)].

Notamos que o primeiro e segundo estados podem ser claramente distinguidos também pela forma de transição do formato em corte transversal do processo ósseo junto de sua inserção à sua extremidade distal, ao longo de todo o seu comprimento. Nos táxons 


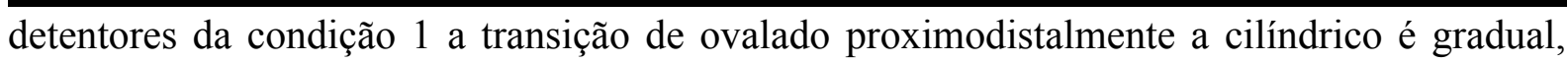
sem mudança visível, naqueles detentores da condição 2; por outro lado a transição é visível, acentuada, na porção proximal à mudança de direção drástica (condição 2 do caráter 1) é ovalada proximodistalmente e a porção distal à mudança de direção é reta e cilíndrica. Estes caracteres estão aparentemente relacionados.

Em relação ao grau de curvatura (caráter 5), três condições foram encontradas: 1 curvatura de 10 a $25^{\circ}, 2$ - de 30 a $65^{\circ}$ e 3 - de 70 a $85^{\circ}$.

A condição1 está presente apenas em grupos menos inclusivos em Characidae; Clado Bramocharax [i.e. Oligosarcus jenynsii], Tetragonopterinae [i.e. Hemigrammus unilineatus e Poptella paraguayensis], Clado Hyphssobrycon luetkenii [i.e. Hyphessobrycon bifasciatus e H. luetkenii], Grupo Astyanax scabripinnis [i.e. Astyanax brachypterygium, A. courensis, A. cremnobates, A. goyanensis, A. rivularis, Hasemania kalunga e Hyphessobrycon vinaceus] e Aphyocharacinae [i.e. Prionobrama paraguayensis].

A condição 2 está presente nos taxons analisados de Gasteropelecidae e nos seguintes taxons de Characidae: Salmininae, Iguanodectinae, Clado Bryconops, Cheirodontinae (exeto R. descalvadensis), Clado Pseudochalceus, Rhoadsiinae, Tetragonopterinae (com exceção dos táxons detentores do estado 1), Clado Astyanax, Aphyocharacinae [i.e. Aphyocharax anisitsi], Aphyoditeinae, Cheirodontinae (com exceção de Compsura heterura) e Stevardiinae (com exceção de Scopaeocharax rhinodus).

A condição 3 está presente apenas em Cheirodontinae (i.e. Compsura heterura) e Stevardiinae (i.e. Gephyrocharax atracaudata, Hysteronotus megalostomus e Scopaeocharax rhinodus).

Em relação à direção da curvatura e desenvolvimento dos processos ósseos pós curvatura (caráter 6), cinco condições foram reconhecidas (modificado do caráter 146 de 
$\overline{\text { Buhrnheim, } 2006 \text { e } 137 \text { de Jerep, 2011): } 1 \text { - direcionados proximalmente, desenvolvendo-se }}$ paralelamente ao eixo proximodistal do segmento em que estão inseridos, 2 - direcionados proximalmente, denvolvendo-se medialmente em relação ao eixo proximodistal do segmento em que estão inseridos, sem ultrapassar a linha mediana do segmento, 3 - direcionados proximalmente, desenvolvendo-se lateralmente ao eixo proximodistal do segmento em que estão inseridos, 4 - direcionados proximalmente, desenvolvendo-se proximomedialmente em relação ao eixo proximodistal do segmento, ultrapassando a linha mediana ou a face lateral anterior do segmento em que estão inseridos e 5 - direcionados medialmente perpendicularmente ao eixo proximodistal do segmento em que estão inseridos.

A condição 1 é a mais comum e está presente nos taxons analisados de Gasteropelecidae, e nos seguintes taxons de Characidae: Iguanodectinae (i.e. Piaubucus dentatus], Tetragonopterinae (i.e. Brachychalcinus copei, Hemigrammus bleheri, H. unilineatus, Jupiaba abrammoides, Moenkhausia sanctafilomenae, Poptella paraguayensis e Stethaprion crenatum), Grupo Astyanax scabripinnis (i.e. Astyanax brachypterygium, A. courensis, A. cremnobates, A. rivularis, Hasemania kalunga e Hyphessobrycon vinaceus, Aphyocharacinae (i.e Aphyocharax anisitsi), Aphyoditeinae (i.e. Parecbasis cyclolepis), Cheirodontinae (i.e. Acinocheirodon melanogramma, Cheirodon interruptus, Heterocheirodon yatai, Odontostilbe pequira e Serrapinnus calliurus) e Stevardiinae (Bryconamericus cf. exdon, B. cf. peruanus, B. cf. inheringii e Scopaeocharax rhonodus).

A condição 2 está presente apenas em grupos de Characidae: Salmininae (i.e. Salminus brasiliensis), Bryconinae (i.e Brycon falcatus), Clado Bryconops (i.e. B. affinis), Tetragonopterinae (Deuterodon iguape, Hemigrammus rhodostomus, H. ulreyi, $H$. unilineatus, Hyphessobrycon herbertaxelrodi, Jupiaba yarina, Stethaprion crenatum e Tetragonopterus argenteus), Clado H. luetkenii (Hyphessobrycon bifasciatus e 
Hyphessobrycon luetkenii), Grupo Astyanax scabripinnis (A. abramis, A. lineatus e A. goyanensis) e Stevardiinae (Eretmobrycon bayano, Hemibrycon surinamensis, Knodus heteresthes, K. monekhausii e Pseudocorynopoma doriae).

A condição 3 está presente apenas em Characidae: Salmininae (Salminus hilarii), Characinae (Acestrocephalus sardina, Bryconexodon juruenae e Roeboides microlepis), Clado Bramocharax (Oligosarcus jenynsii), Clado Pseudochalceus (Hollandichthys multifasciatus), Tetragonopterinae (Moenkhausia xinguensis e Hemigrammus unilineatus) Clado Astyanax (Hyphessobrycon anisitsi e Markiana nigripinnis), Aphycharacinae (Prionobrama paraguayensis) e Aphyoditeinae (Microschemobrycon casiquiare).

A condição 4 está presente apenas em Characidae: Clado Astyanax (Astyanax cf. jordani), Cehirodontinae (Compsura heterura) e Stevardiinae (Diapoma speculiferum, Gephyrocharax atracaudata e Hysteronotus megalostomus).

A condição 5 está presente apenas em Characidae: Characinae (Charax stenopterus) e Rhoadsiinae (Nematocharax venustus).

As condições 1, 2 e 3 são em alguns casos, difíceis de codificar, no entanto embora podendo estar ligeiramente direcionados medialmente ou lateralmente em relação ao eixo proximodistal do segmento em que estão inseridos, todos os taxons detentores destes padrões são claramente voltados proximalmente. Sendo assim, se interpretado de forma mais geral, estes padrões podem ser agrupados em um só (i.e. processos ósseos direcionados proximalmente). Interessante notar que Hemigrammus unilineatus e Stethaprion crenatum possuem as condições 1 e 2, provavelmente devido à presença do mesmo tipo de processo ósseo.

Em relação à direção de desenvolvimento dos processos ósseos retos, sem curvatura (caráter 7), duas condições foram encontradas: 1 - desenvolvimento perpendicular à sua 
inserção e ao eixo proximodistal do segmento em que estão inseridos, em alguns casos ligeiramente inclinados, mas não como na condição 2 e 3 (?) - em direção distal em relação ao raio em que estão inseridos.

Dentre os táxons analisados, a condição 1 está presente em Heterocharax virgulatus, Hoplocharax goethei (Heterocharcinae), Roeboides descalvadensis (Characinae) e a condição 2 em Bryconamericus cf. peruanus (Stevardiinae). Em B. cf. peruanus os processos ósseos se desenvolvem retos em direção distal formando um ângulo de 40 a $60^{\circ}$ com a superfície do segmento em que estão inseridos.

Em relação à porcentagem do diâmetro da extremidade distal dos processos ósseos em relação ao maior comprimento (em processos ósseos com inserção ovalada proximodistalmente) ou diâmetro (em processos ósseos com inserção arredondada) de sua inserção (caráter 8), três condições foram encontradas: $1-8$ a 33\%, 2 - 40 a $56 \%$ e $3-63$ a $65 \%$.

A condição 1 está presente em todos os taxons analisados de Gasteropelecidae e nos seguintes taxons de Characidae: Salmininae, Iguanodectnae, Bryconinae, Clado Bryconops, Characinae (com exceção de Charax stenopterus e Acestrocephalus sardinae), Clado Bramocharax, Clado Pseudochalceus, Tetragonopterinae (com exceção Stethaprion crenatum, Moenkhausia sanctafilomenae e Hemigrammus unilineatus), Clado Astyanax (com exceção de Hyphessobrycon anisitsi e Markiana nigripinnis), Grupo Astyanax scabripinnis (Hasemania kalunga e Hyphessobrycon vinaceus), Aphyocharacinae (Aphyocharax anistsi), Aphyoditeinae, Cheirodontinae e Stevardiinae.

A condição 2 está presente apenas em Characidae: em todos os taxons analisados de Heterocharacinae, Charax stenopterus, Acestrocephalus sardinae (Characinae), Rhoadsinae, Clado Hyphessobrycon luetkenii, Hyphessobrycon anisitsi, Markiana nigripinnis (Clado 
$\overline{\text { Astyanax), Grupo Astyanax scabripinnis (exceto Hasemania kalunga e Hyphessobrycon }}$ vinaceus), Aphyocharacinae.

A condição 3 está presente apenas em Characidae: Tetragonopterinae [i.e. Hemigrammus unillineatus (Fig. XX), Moenkhausia sanctafilomenae (Fig. XX) e Stethaprion crenatum (Fig. XX)] e Grupo a. scabripinnis [i.e. Astyanax goyanensis (Fig. XX), A. rivularis (Fig. XX)].

Este caráter representa basicamente o formato dos processos ósseos ao longo de seu comprimento total, como pode ser observado nas figuras dos táxons listados como detentores de cada estado. Obviamente o valor da proporção varia através de duas medidas, o comprimento ou diâmetro da inserção e do diâmetro da extremidade distal. Embora listados como detentores do mesmo estado, esta condição em alguns taxons se deve ao aumento do comprimento da base e em outros da extremidade distal. A condição 1, por exemplo, indica a diminuição acentuada desde a inserção à extremidade distal do processo ósseo. Em grande parte dos taxons detentores deste padrão a extremidade distal é pontiaguda em Hemigrammus bleheri, H. rhodostomus, Parecbasis cyclolepis e Carnegiella marthae que detêm os menores valores neste padrão no entanto ( 8 a $12 \%$ ), na extremidade distal arredondada. A condição nestes taxons portanto se deve ao grande comprimento proximodistal da inserção. Sendo assim estas condições foram consideradas como não homólogos, mas úteis para, em conjuto com as condições dos demais caracteres, determinar o formato dos processos ósseos (ver a seguir nesta seção). O mesmo vale para o próximo caráter.

Em relação à porcentagem do maior comprimento (em processos ósseos com inserção ovalada proximodistalmente) ou diâmetro (em processos ósseos com secção transversal inserção arredondada) de sua inserção em relação ao seu comprimento total (caráter 9), 
quatro condições foram definidas: 1 - 20 a 36\%, 2 - 42 a 58\%, 3 - 66 a $100 \%$ e 4 - 107 $225 \%$.

A condição1 está presente apenas em Characidae: Heterocharacinae (Heterocharax virgulatus e Hoplocharax goethei), Charcinae (Charax stenopterus e Roeboides descalvadensis), Tetragonopterinae (Hemigrammus unilineaus, Moenkhausia sanctafilomenae, Poptella paraguayensis e Stethaprion crenatum), Clado Astyanax (Markiana nigripinnis), em todos os taxons do Grupo Astyanax scabripinnis e Stevardiinae (i.e. Gephyrohcarax atracaudata, Hysteronotus megalostomus e Scopaeocharax rhinodus).

A condição 2 está presente apenas em Characidae: Characinae (Acestrocephalus sardina), Rhoadsiinae (Nematocharax venustus), Clado Hyphessobryco luetkenii (H. bifasciatus, $H$. luetkenii), Tetragonopterinae (Jupiaba yarina), Aphyocharacinae (Prionobrama paraguayensis), Cheirodontinae (Acinocheirodon melanogramma, Compsura heterura e Cheirodon interruptus) e Stevardiinae (Diapoma speculiferum, Eretmobrycon bayano e Pseudocorynopoma doriae).

A condição 3 está presente apenas em Characidae: em todos os taxons analisados de Salimininae, Bryconinae, Iguanodectinae, Clado Bryconops, Characinae (com exceção de Acestrocephalus sardina, Charax stenopterus e Roeboides descalvadensis), Clado Bramocharax, Clado Pseudochalceus, Tetragonoterinae (Deuterodon iguape, Tetragonopterus argenteus, Hemigrammus ulreyi e Hyphessobrycon herbertaxelrodi), Clado Astyanax (A. abramis, A. cf. jordani, A. lineatus e Psellogrammmus kennedyi), Aphyocharacinae (Aphyocharax anisitsi), Aphyoditeinae (Microschemobrycon casiquiare), Cheirodontinae (Heterocheirodon yatai, Odontostilbe pequira e Serrapinnus calliurus) e Stevardiinae (Bryconamericus cf. peruanus e Knodus heteresthes). 
A condição 4 está presente em Gasteropelecidae (Carnegiella strigatta e Thoracocharax stellatus) e nos seguinte taxons de Characidae: Iguanodectinae (Piabucus melanostomus), Tetragonopterinae (Hemigrammus bleheri e H. rhodostomus), Aphyocharacinae (Aphocharax anisitsi) e Aphyoditeinae (Parecbasis cyclolepis).

A combinação das diferentes condições de cada caráter foram utilizadas para a definição dos tipos de processos ósseos no universo analisado. Os seguintes tipos de processos ósseos foram definidos.

\section{1 - Ganchos}

Os ganchos são caracterizados pela seguinte combinação de condições dos caracteres listados acima: inserção ovalada proximodistalmente (comprimento proximodistal maior que o comprimento lateromedial) em relação ao eixo proximodistal do segmento em que está inserido (condição1 do caráter 1); formato do processo ósseo em secção transversal de ovalado proximodistalmente a cilíndrico ao longo de seu comprimento total (condiçãol do caráter 2), curvatura presente (condição 1 do caráter 3) e gradual (condição1 do caráter 4) ou acentuada (condição2 do caráter 4) ao longo do comprimento total do processo ósseo, com mudanças gradual (estado 1 do caráter 4) ou drástica (estado 2 do caráter 4) de formato em secção transversal junto à inserção até sua extremidade distal; grau de curvatura de 30 a $85^{\circ}$ (condições 2 e 3 do caráter 5), curvatura direcionada proximalmente e desenvolvimento póscurvatura paralela (condição 1 do caráter 6), ligeiramente medial sem ultrapassar a linha mediana (condição 2 do caráter 6), ligeiramente lateral (condição 3 do caráter 6) ou medialmente, ultrapassado a linha mediana ou a porção anterior (condição 4 do caráter 6) em relação ao eixo proximodistal do segmento; diâmetro de sua extremidade equivalendo de 8 a $33 \%$ do maior comprimento de sua inserção no segmento (condição 1 do caráter 8 ) e maior 
comprimento de sua inserção equivalendo de 52 a 225\% de seu comprimento total (condições 2 e 3 do caráter 9) (vs. de 20 a 58\%, condições 1 e 2 do caráter 9 nos espinhos).

Os ganchos, como definidos aqui estão presentes em Gasteropelecidae e nos seguintes taxons de Characidae: Salmininae, Bryconinae, Iguanodectinae, Clado Bryconops, Characinae (Bryconexodon juruenae e Roeboides microlepis), Clado Bramocharax (Oligosarcus jenynsii), Clado Pseudochalceus (Hollandichthys multifasciatus), Tetragonopterinae (Deuterodon iguape, Hemigrammus bleheri, H. rhodostomus, H. ulreyi, Hyphessobrycon herbertaxelrodi, Jupiaba abrammoides, J. yarina, Moenkhausia xinguensis, Pristella maxillaris e Tetragonopterus argenteus), Clado Astyanax (A. abramis, A. cf. jordani, A. lineatus e Psellogrammus kennedyi], Aphyocharacinae (Aphyocharax anisitsi), Aphyoditeinae (Microschemobrycon casiquiare e Parecbasis cyclolepis), Cheirodontinae (Acinocheirodon melanogramma, Compsura heterura, Cheirodon interruptus, Heterocheirodon yatai, Odontostilbe pequira e Serrapinnus calliurus) e Stevardiinae.

Os ganchos diferem dos espinhos e Lappets essencialmente por possuirem a inserção ovalada proximodistalmente (exceto em Diapoma speculiferum e Scopaeocharax rhinodus) (condição1 do caráter 1 vs condição 2 nos espinhos), por variarem de ovalado proximodistalmente a cilíndrico em secção transversal ao longo de seu comprimento total (exceto em Diapoma speculiferum e Scopaeocharax rhinodus) (condição 1 do caráter 2 vs. Condição 2 nos espinhos e condição 3 nos lappets), por apresentar o ângulo de curvatura variando de 30 a $85^{\circ}$ (condições 2 e 3 do caráter $5 v$ s. condições 1 e 2 nos espinhos) e por apresentarem uma variação grande do maior comprimento de sua inserção em relação ao diâmetro de sua extremidade distal, o que é representado pela condição1 do caráter 8 (de 8 a $33 \%$ ) e 2, 3 e 4 do caráter 9 (de 52 a 225\%). 
Além disso os ganchos e espinhos diferem dos Lapetts por afilarem gradualmente desde sua inserção à sua extremidade ( $v s$. aumentando e diminuindo proximodistalmente). Em Diapoma speculiferum e Scopaeocharax rhinodus as estruturas foram consideradas ganchos, por apresentarem a condição 2 do caráter 4 e curvatura com $57^{\circ}$ e $85^{\circ}$ (condições 2 e 3 do caráter 5).

Dentro do que é definido aqui como gancho, existem ainda alguns subpadrões bem definidos.

O primeiro subpadrão (gancho tipo 1) está presente em Salminus brasiliensis (Fig. 155) (Salmininae), Brycon falcatus (Fig. 79) (Bryconinae), Piabucus melanostomus (Fig. 143) (Iguanodectinae), Bryconps affinis (Fig. 82) (Clado Bryconops), Bryconexodon juruenae (Fig. 88), Roeboides microlepis (Fig. 95) (Characinae), Oligosarcus jenynsii (Fig. 77) (Clado Bramocharax), Hollandichthys multifasciatus (Fig. 149) (Clado Pseudochalceus), Jupiaba yarina (Fig. 179), Deuterodon iguape (Fig. 161), Tetragonopterus argenteus (Fig. 191), Moenkhausia xinguensis, H. ulreyi (Fig. 169), Hyphessobrycon herbertaxelrodi (Tetragonopterinae), Astyanax abramis (Fig. 27), Psellogrammus kennedyi (Clado Astyanax), Microschemobrycon casiquiare (Fig. 20) (Aphyoditeinae), Heterocheirodon yatai (Fig. 112), Odontostilbe pequira (Fig. 118), Serrapinnus calliurus (Fig. 123) (Cheirodontinae), B. cf. peruanus (Fig. 195), B. cf. Inheringii, Cyanhocharax alburnus, Hemmibrycon surinamensis, Knodus heteresthes (Fig. 108), K. monekhausii, e Pseudocorynopoma doriae (Fig. 230) (Stevardiinae).

O gancho 1 é caraterizado por apresentar uma curvatura, mudança de direção e variação no formato em secção transversal ao longo de seu comprimento total (desde sua inserção à sua extremidade distal) graduais (condição 1 do caráter 4) e por apresentar curvatura direcionada proximalmente, com desenvolvimento pós-curvatura em direção 
paralela (condição 1 do caráter 6), ligeiramente medial (condição 2 do caráter 6) e/ou ligeiramente lateral (condição 3 do caráter 6) em relação ao eixo proximodistal do segmento em que está inserido.

Embora todas as espécies mencionadas acima possuam gancho tipo 1, como definidos aqui, apresentam variações no tamanho em relação ao segmento em que estão inseridos. $\mathrm{O}$ tamanho foi mensurado através da proporção do maior comprimento de sua inserção em relação ao comprimento proximodistal do segmento em que está inserido. Salminus brasiliensis (62\%), S. hilarii (53\%), Brycon falcatus (52\%), Bryconops affinis (52\%), Oligosarcus jenynsii (63\%) e Hemigrammus ulreyi (55\%) foram os únicos taxons em que a inserção dos ganchos ocupa mais de $50 \%$ do comprimento proximodistal do segmento em que estão inseridos. Nos demais taxons a proporção do maior comprimento de sua inserção ocupa de 24 a 44\% do comprimento total do segmento em que está inserido. Quanto ao número de ganchos por segmento nestas espécies, Deuterodon iguape, Hemigrammus ulreyi (Tetragonopterinae), Astyanax abramis, Psellogrammus kennedyi (Clado Astyanax), Kanodus heteresthes, Bryconamericus cf, peruanus e Pseudocorynopoma doriae (Sevardiinae) possuem um gancho por segmento; Bryconecodon juruenae e Roeboides microlepis (Characinae), Jupiaba yarina, Moenkhausia xinguensis, Tetragonopterus argenteus e Hyphessobrycon herbertaxelrodi (Tetragonopterinae) e Odontostilbe pequira (Cheirodontinae) possuem até dois ganchos por segmento; Heterocheirodon yatai (Cheirodontinae) possui até três ganchos por segmento e Serrapinnus calliurus (Cheirodontinae) possui até nove ganchos por segmento. Heterocheirodon yatai e Serrapinnus calliurus diferem das demais espécies pela inserção e direção de desenvolvimento dos ganchos. Nestas espécies os ganchos estão inseridos na face posterior/lateroposterior, desenvolvendo-se posteriormente em relação à nadadeira, enquanto 
que nas demais espécies, apesar de uma pequena variação, os processos ósseos estão inseridos na face lateroposterior, desenvolvendo-se em direção lateroposterior em relação à nadadeira.

O segundo subpadrão (gancho tipo 2) está presente em Astyanax lineatus (Fig. 30), A, cf. jordani (Fig. 35) (Clado Astyanax), Aphyocharax anisitsi (Fig. 12) (Aphycharacinae), Acinocheirodon melanogramma (Fig. 97), Cheirodon interruptus (Fig. 102) (Chreirodontinae), Diapoma speculiferum (Fig. 199) e Eretmobrycon bayano (Fig. 207) (Stevardiinae).

O gancho 2 é caraterizado por apresentar inserção ovalada proximodistalmente ou arredondada (condições1 e 2 do caráter 1), uma curvatura, mudança de direção e variação do formato em secção transversal (de sua inserção à sua extremidade distal) acentuadas (condição 2 do caráter 4), por apresentar curvatura direcionada proximalmente, com desenvolvimento pós-curvatura paralela (condição 1 do caráter 6) ou ligeiramente medial (condição 2 do caráter 6), por apresentar ângulo de curvatura variando de 45 a $60^{\circ}$ (condição 2 do caráter 5).

Ainda dentro do que é considerado ganchos 2 algumas variações estão presentes. Em relação ao caráter 6, apenas os membros do Clado Astyanax apresentam o estado 2, onde sua extremidade distal (em vista lateral) estão direcionadas proximomedialmente, no máximo alcançando a linha mediana do segmento. O estado 1 está presente apenas em Cheirodontinae (Acinocheirodon melanogramma e Cheirodon interruptus) e Stevardiinae (Eretmobrycon bayano e Scopaeocharax rhinodus). Quanto ao número de ganchos por segmentos nestes taxons Astynax cf. jordani, A. lineatus, Diapoma speculiferum e Eretmobrycon bayano apresentam apenas um gancho por segmento de nadadeira. Acinocheirodon melanograma e Cheirodon interruptus apresentam até dois ganchos por segmento. 
O terceiro subpadrão (gancho tipo 3) está presente apenas em Cheirodontinae [Compsura heterura (Fig. 108)] e Stevardiinae [Gephyrocharax atracaudata (Fig. 214), Hysteronotus megalostomus (Fig. 217) e Scopaeocharax rhinodus (Fig. 239)].

O gancho 3 é caracterizado por apresentar inserção ovalada proximodistalmente ou arredondada (estados 1 e 2 do caráter 1), uma curvatura, mudança de direção e do formato em secção transversal (de sua inserção à sua extremidade distal) acentuadas (condição 2 do caráter 4), por apresentar curvatura direcionada proximomedialmente, com desenvolvimento pós-curvatura paralela (condição 1 do caráter 6) ou ultrapassando a linha mediana ou a face anterior do segmento em que estão inseridos (condição 4 do caráter 6) e por apresentar ângulo de curvatura variando de 70 a $85^{\circ}$ (condição 3 do caráter 5).

A condição presente em Scopaeocharax rhinodus ainda difere da condição presente nas demais espécies por apresentar a inserção arredondada (condição 2 do caráter 1) e apresentar desenvolvimento pós-curvatura paralela ao eixo proximodistal do segmento (condição 1 do caráter 6). Todos estes taxons apresentam apenas um gancho por segmento.

O quarto subpadrão (gancho tipo 4) está presente em Gasteropelecidae [Carnegiella strigatta (Fig. 7) e Thoracocharax stellatus (Fig. 9]), e nos seguintes membros de Characidae: Tetragonopterinae [Hemigrammus bleheri (Fig. 163) e H. rhodostomus (Fig. 169)] e Aphyoditeinae [Parecbasis cyclolepis (Fig. 23)].

O gancho 4 é caraterizado pelo maior comprimento de sua inserção e ocupar 100\% do comprimento proximodistal do segmento em que está inserido. Nestes processos ósseos podem ser observado, com clareza, uma linha separando o que parece ser a base do gancho na superfície do segmento em que está inserido (Figs. $7 d-9 c-163 d-169 a-23 d$ ). Dentro do que é definido aqui como gancho tipo 4 existem ainda algumas variações. Em Hemigrammus rhodostomus e H. bleheri os processos ósseos são mais longos que nas demais espécies, seu 
comprimento total equivalendo de 67 a $90 \%$ do comprimento proximodistal do segmento em que está inserido. Enquanto que em Gaseropelecidae esta proporção é de $42 \%$ e em Parecbasis cyclolepis de 38\%. Todos estes taxons apresentam apenas um processo ósseo por segmento.

\section{3 - Espinhos}

Este tipo de processo ósseo é definido com base na seguinte combinação de condições de caracteres listados acima: processos ósseos com inserção arredondada (estado 2 do caráter 1); formato do processo ósseo em secção transversal cilíndrico ao longo de seu comprimento total (condição 2 do caráter 2); curvatura ausente e/ou presente (condições 1 e 2 do caráter 3); curvatura gradual ao longo do comprimento total do processo ósseo, com mudança gradual de direção da inserção à extremidade distal (condição1 do caráter 4); grau de curvatura de 10 a $30^{\circ}$ (condição 1 do caráter 5); curvatura direcionada proximalmente, podendo se desenvolver paralelamente (condição 1 do caráter 6), ligeiramente medial, não ultrapassando a linha mediana (condição 2 do caráter 6), ligeiramente lateral (condição 3 do caráter 6) ou medialmente, perpendicularmente (condição 5 do caráter 6) em relação ao eixo proximodistal do segmento em que está inserido; desenvolvimento perpendicular à sua inserção no segmento, podendo estar inclinados ou não (condições 1 e 2 do caráter 7) em relação ao eixo proximodistal do segmento em que está inserido; porcentagem do diâmetro de sua extremidade distal em relação ao diâmetro de sua inserção no segmento de $32 \%$ a $65 \%$ (condições1, 2 e 3 do caráter 8); porcentagem do diâmetro junt à inserção em relação ao seu comprimento total de 20 a 58\% (condições 1, 2 e 3 do caráter 9).

Dentre os taxons analisados os espinhos estão presentes em Heterocharacinae virgulatus e Hoplocharax gothei (Heterocharacinae), Acestrocephalus sardina, Charax 
stenopterus (Characinae), Nematocharax venustus (Rhoadsiinae), Hemigrammus unilineatus, Moenkhausia sanctafilomenae, Stethaprion crenatum, Poptella paraguayensis (Tetragonpterinae), Hyphessobrycon bifasciatus, H. luetkenii (Clado Hyphessobrycon luetkenii), Markiana nigripinnis, (Clado Astyanax), Astyanax brachypterygium, A. courensis, A. cremnobates, A. goyanensis, A. rivularis, Hasemania Kalunga, Hyphessobrycon vinaeus (Grupo A. scabripinnis), Aphyocharax anisitsi e Prionorbama paraguayensis (Aphyocharacinae).

Os espinhos diferem dos ganchos e Lappets basicamente por possuirem a inserção arredondada (estado 2 do caráter 1), serem cilíndricos em secção transversal transversal ao longo de seu comprimento total (condição 2 do caráter 2), por não apresentarem curvatura (condição 2 do caráter 3) e quando presente, com ângulo variando de 10 a $30^{\circ}$ (condições $1 \mathrm{e}$ 2 do caráter $5 v s$. condições 2 e 3 presentes nos ganchos) e por serem mais delgados e apresentarem uma variação pequena no diâmetro de sua inserção em relação ao diâmetro de sua extremidade distal, o que é representado pelos valores do caráter 8 (de 32 a $65 \%$ vs. 8 a $33 \%$ ) e 9 ( 20 a $58 \%$ vs. 52 a 225\%) respectivamente. Dentro do que é definido como espinho, existem alguns padrões bem definidos.

O primeiro subpadrão (espinho tipo 1) está presente em Heterocharax virgulatus (Fig. 108) e Hoplocharax goethei (Fig. 130) (Heterocharacinae), Roeboides descalvadensis (Fig. 93) (Characinae).

O espinho 1 é caractereziado por ser geralmente reto, podendo apresentar (raramente) uma curvatura de no máximo $5^{\circ}$ (condição 2 do caráter 3), apresenta uma variação pequena do diâmetro em secção transversal desde sua inserção à sua extremidade distal (de 43 a 56\%: condição 2 do caráter 8) e é relativamente espesso, o diâmetro de local de inserção equivalendo a $36 \%$ de seu comprimento total (condição 1 do caráter 9). O espinho 1 é muito 
$\overline{\text { pequeno, o seu comprimento total ocupando de } 15 \text { a } 23 \% \text { do comprimento proximodistal do }}$ segmento em que está inserido. Estes taxons apresentam de dois a três espinhos por segmento.

O segundo subpadrão (espinho tipo 2) está presente em Hemigrammus unilineatus (Fig. 172), Moenkhausia sanctafilomenae (Fig. 182) e Stethaprion crenatum (Fig. 188) (Tetragonopterinae).

O espinho 2 pode ser reto ou apresentar uma curvatura (condições 1 e 2 do caráter 3); quando presente, a curvatura varia de 10 a $30^{\circ}$ (condições 1 e 2 do caráter 5), quando reto se desenvolve perpendicularmente à sua inserção (condição 1 do caráter 7), apresenta uma variação pequena do diâmetro em secção transversal ao longo de todo o seu comprimento 1 (de 64 a 65\%: condição 3 do caráter 8) e é delgado, o diâmetro no local de inserção equivalendo de 20 a $23 \%$ do seu comprimento total (condição 1 do caráter 9 ). A condição presente em Moenkhausia sanctafilomenae difere daquela presente nas outras duas espécies pelo desenvolvimento organizado dos pinos. Em Hemigrammus unilineatus e Stethaprion crenatum o espinho 1 desenvolve-se de forma errática em relação ao eixo proximodistal do segmento em que está inserido, o que parece ser característico deste tipo de espinho. O espinho 2 é relativamente pequeno, seu comprimento total ocupando de 32 a $40 \%$ do comprimento proximodistal do segmento em que está inserido. Estes táxons apresentam de dois a quatro espinhos por segmento.

O terceiro subpadrão (espinho tipo 3) está presente em Acestrocephalus sardina (Fig. 85) (Characinae), Hyphessobrycon bifasciatus (Fig. 136), Hyphessobrycon luetkenii (Clado Hyphessobrycon luetkenii), Hyphessobrycon anisitsi (Fig. 12) (Clado Astyanax) e Prionobrama paraguayensis (Fig. 16) (Aphyocharacinae).

O espinho 3 apresenta curvatura (condiçãol do caráter 3) de 15 a $55^{\circ}$ (condição 1 e 2 do caráter 5), quase nenhuma variação no diâmetro em secção transversal ao longo de todo o 
seu comprimento (de 41 a 56\%: condição 2 do caráter 8) e é relativamente espesso, o diâmetro no local inserção equivalendo a 42 a $58 \%$ do seu comprimento total (condição 2 do caráter 9). $\mathrm{O}$ espinho 3 é relativamente curto, seu comprimento total equivalente a 12 a 36\% do comprimento proximodistal do segmento em que está inserido. Todos estes taxons apresentam apenas 1 espinho por segmento. Dentro do que é definido como espinho 3, as condições em Hyphessobrycon anisitsi, H. bifasciatus e H. luetkeni, são muito semelhantes. A condição presente em Aphyocharax anisitsi se diferencia daquelas destas três espécies por apresentar uma curvatura de $55^{\circ}\left(v s .15\right.$ a $\left.30^{\circ}\right)$ e por apresenta 3 processos ósseos por segmento (vs. 1).

O quarto subpadrão (espinho tipo 4) está presente em todos os taxons do Grupo Astyanax scabripinnis (Figs. 47, 51, 57, 63) (exceto Hasemanis kalunga e Hyphessobrycon vinaceus).

O espinho 4 apresenta curvatura (condição 1 do caráter 3) de 10 a $25^{\circ}$ (condição 1 do caráter 5), apresenta uma variação pequena em seu diâmetro em secção transversal ao longo de todo o seu comprimento (de 50 a 65\%: condições 2 e 3 do caráter 8) e é delgado, o diâmetro no local de sua inserção equivalendo de 20 a $24 \%$ do seu comprimento total (condição 1 do caráter 9). O espinho 4 é mais comprido do que os espinhos 1,2 e 3, o seu comprimento total equivalente a 55 a $93 \%$ do comprimento proximodistal do segmento em que está inserido. Todos estes taxons apresentam um espinho por segmento.

O quinto subpadrão (espinho tipo 5) está presente em Poptella paraguayensis (Fig. 185) (Tetragonpterinae), Hasemania kalunga (Fig. 69) e Hyphessobrycon vinaceus (Fig. 72) (Grupo astyanax scabripinnis).

O espinho 5 apresenta curvatura (condição 1 do caráter 3) de 10 a $15^{\circ}$ (condição 1 do caráter 5), apresenta uma variação maior em seu diâmetro em secção transversal ao longo de 


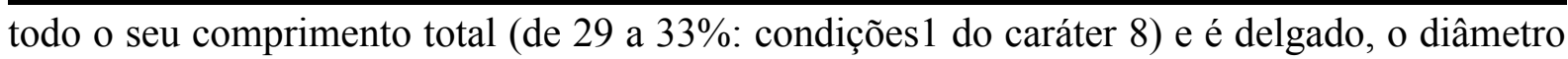
no local de inserção equivalendo de 29 a $36 \%$ do seu comprimento total (condição 1 do caráter 9). O espinho 5 é mais comprido do que os espinhos $1,2,4$ e 6 , seu comprimento total equivalente a 48 a 98\% do comprimento proximodistal do segmento em que está inserido. Estes taxons apresentam um espinho por segmento.

O sexto subpadrão (espinho tipo 6) está presente em Charax stenopterus (Fig. 9) (Characinae) e Nematocharax venustus (Fig. 153) (Rhoadsiinae).

O espinho 6 apresenta curvatura (condição 1 do caráter 3) de 45 a $50^{\circ}$ (condição 2 do caráter 5), em direção medial, perpendicular ao eixo proximodistal do segmento em que está inserido (condição 5 do caráter 6), apresenta uma variação pequena em seu diâmetro em secção transversal ao longo de seu comprimento total (de 40 a 43\%: condição 2 do caráter 8), o diâmetro de sua inserção equivalendo a 35 a $43 \%$ do seu comprimento total (condição 2 do caráter 9). O espinho 6 é muito pequeno, seu comprimento total equivalendo a 20 a $22 \%$ do comprimento proximodistal do segmento em que está inserido. Estes taxons apresentam um espinho por segmento.

O sétimo padrão (espinho tipo 7) está presente em Bryconamericus cf. peruanus (Fig. 195).

O espinho 7 é reto, (condição 2 do caráter 3), desenvolve-se linearmente em direção distal formanto um ângulo de 40 a $60^{\circ}$ (condição 2 do caráter 7), apresenta uma variação grande em seu diâmetro em secção transversal ao longo de todo o seu comprimento (de 13\%: estado 1 do caráter 8), o diâmetro de sua inserção equivalendo $88 \%$ do seu comprimento total (estado 3 do caráter 9). O espinho 7 é muito pequeno, seu comprimento total equivalendo a 32 $\%$ do comprimento proximodistal do segmento em que está inserido. Este táxon apresenta um espinho por segmento. 


\section{4 - Lappets}

Este tipo de processo ósseo é definido com base na seguinte combinação de condições dos caracteres listados acima: processos ósseos com inserção ovalda proximodistalmente (estado 1 do caráter 1), equivalendo a 100\% do comprimento proximodistal do segmento em que está inserido; formato do processo ósseo em secção transversal de ovalado proximodistalmente a ovalado horizontalmente ao longo de todo o seu comprimento (condição 3 do caráter 2), curvatura presente (estado 1 do caráter 3); curvatura gradual ao longo do comprimento total do processo ósseo, com mudança gradual de direção desde a inserção até a extremidade distal (condição 1 do caráter 4); grau de curvatura equivalente a $55^{\circ}$ (condição 2 do caráter 5); curvatura direcionada proximalmente, desenvolvendo-se paralelamente (condição1 do caráter 6) ao eixo proximodistal do segmento em que está inserido.

Dentre os táxons analisados, os lappets estão presentes apenas em Iguanodectinae (i.e. Piabucus melanostomus). A presença de Lappet foi assinalada por Moreira (2002) como uma sinapomorfia de Iguanodectinae exceto Iguanodectes geisleri Géry 1970.

O gancho (gancho 1) é o tipo de processo ósseo mais comum em Characidae, presente tanto em táxons de clados basais (Salmininae, Bryconinae e Bryconops) quanto em taxons de clados mais derivados (Knodus heteresthes). Os taxons dos clados mais basais em Characidae, com osso supraorbital (Mirande, 2010: c. 70: 1), apresentam apenas o gancho 1 e os maiores do tipo dentre os taxons como gancho 1 , com sua base ocupando mais que $50 \%$ do comprimento proximodistal do segmento em que está inserido. O tamanho do ganchos 1 diminui ao longo da evolução da família, com sua base ocupando menos que $50 \%$ do comprimento proximodistal do segmento em que está inserido, assim como aumenta de 
número por segmento, geralmente até dois. É interessante notar que o gancho gancho 1 está presente em taxons de clados basais de todos os grupos menos inclusivos de Mirande (2010) [e.g. Jupiaba e Deuterodon em Tetragonpterinae (sensu Mirande, 2010); Cyanocharax, Hemibrycon e Knodus em Stevardiinae (sensu Mirande, 2010) e Odontostilbe em Cheirodontinae (sensu Jerep, 2011)]. O gancho 2 por sua vez está restrito basicamente a clados mais basais dos grupos mais derivados em Characidae (com exceção de Astyanax lineatus e Aphyocharax anisitsi) [e.g. Acinocheirodon melanogramma em Compsurini (sensu Jerep, 2011), Cheirodon interruptus em Cheirodontini (sensu Jerep, 2011) e Diapoma speculiferum em (Stevardiinae sensu Ferreira et al, 2011) e Eretmobrycon bayano em (Stevardiinae sensu Thomaz et al., 2015). O gancho 3 está presente em taxons ainda menos inclusivos nestes clados [e.g. Compsura heterura em Compsurini (sensu Jerep, 2011) e Gephyrocharax atracaudata, Hysteronotus megalostomus e Scopaeocharax rhinodus em Stevardiinae (sensu Ferreira et al., 2011 e Thomaz et al., 2015). Um dos caracteres utilizados aqui para definir o gancho 3 foi listado como uma sinapomorfia de Compsuirini por Jerep (2011). Tudo leva a crer, que o gancho 1 representa o estado plesiomórfico em Characidae, transformando-se ao longo da evolução (diminuindo de tamanho e aumentando de número por segmento) e presente na base de grande parte dos clados menos inclusivos na família. Há também uma especialização do gancho 1 (na base dos clados) ao gancho 3 ao longo da evolução de Cheirodontinae e Stevardiinae, nos quais a presença do gancho 3 é exclusiva. No clado Astyanax e Aphyocharacinae, a direção de especialização se dá do gancho 1 ao gancho 2.

Como já mencionado, o gancho 1 representa a estrutura plesiomórfica em Characidae, portanto os espinhos são derivad na família. O espinho 1 aparentemente surgiu duas vezes na evolução de Characidae, uma vez em Heterocharacinae, como uma possível sinapomorfia de 
$\overline{\text { Heterocharax e Hoplocharax e em Characinae onde, pelo visto, representa uma sinapomorfia }}$ de Roeboides. A revisão da literatura revelou a presença do espinho 2 também no grupo RosyTetras, encontrados até agora apenas em Hyphessobrycon socolofi Weitzman, 1977 (Teixeira, 2010: fig. 16) e Hyphessobrycon erythrostigma Fowler 1943 (Teixeira, 2010: fig. 6). A relação de Hyphessobrycon unilineatus com os taxons do grupo Rosy-Tetras, é praticamente um consenso e aparentemente um dos clados mais derivados em Tetragonopterinae (Weitzman \& Palmer, 1997a; Mirande, 2010). Sendo assim, a presença do espinho 2 ao que tudo indica, além de ser uma provável sinapomorfia sustentando a relação destes taxons, indica este estado como derivado em Tetragonopterinae.

Como listado acima, os espinhos 2, 3, 4 e 5 estão presentes em Brachychalcinus copei, Hemigrammus unilineatus, Hyphessobrycon bifasciatus, H. luetkenii, H. anisitsi, Stethaprion crenatum, Poptella paraguayensis e Moenkhausia sanctafilomenae. Sendo assim, a presença dos espinhos reforça uma relação entre Stethaprioninae (sensu Mirande, 2010), Moenkhausia sanctafilomenae, Hyphessobrycon bifasciatus e H. luetkenii. Na seções anteriores mostramos evidências de uma possível relação entre estes taxons e Markiana nigripinnis, outra espécie do Clado Astyanax e com H. elachys (membro do grupo $H$. loweae) outra espécie de um dos clados mais derivados em Tetragonopterinae. A presença de espinhos sugere a relação destes taxons com $H$. anisitsi outro táxon do Clado Astyanax e H. unilineatus, outro táxon de um dos clados mais derivados em Tetragonopterinae. Neste caso, sendo o espinho 2 a condição supostamente derivada em Tetragonopterinae, a presença dos espinhos 3 , 4 e 5 poderiam indicar uma condição plesiomórfica em um suposto clado composto pelos taxons atualmente incluídos no Clado Astyanax, Clado H. luetkenii e Tetragonopterinae. Mais uma vez, táxon equivalente ao Clado C de Javonillo et al., (210). Isto apoia, assim como discutido nas seções anteriores, a inclusão dos taxons nos Clados Astyanax e Clado H. luetkenii em uma posição 
$\overline{\text { basal em um provável clado composto pelos membros destes dois clados e Tetragonopterinae, }}$ com $H$. elachys e H. unilinatos em um dos clados mais derivados. Indicaria também que os espinhos 2, 3, 4 e 5 são homólogos. Esta conformação indicaria apenas duas origens de espinhos em Characidae, mas apenas uma em Tetragonopterinae (equivalente ao Clado C de Javonillo et al., 2010) e sua transformação para o espinho 2 em um dos clados mais derivados nesta interpretação da subfamília.

É importante notar que todos os taxons analisados de Gasteropelecidae e Characidae apresentam apenas um tipo de processos ósseos nas nadadeiras, com exceção de Piabucus melanostomus (Fig. 143 e 145, Iguanodectinae) e Bryconamericus cf. peruanus (Fig. 194, Stevardiinae) que apresentam gancho 1 e Lappet e ganchos 1 e espinho 7 no mesmo raio respectivamente. A revisão da literatura também revelou a presença de gancho e espinho na nadadeira anal de Hemigrammus bosemani e H. stictus (Lima \& Sousa, 2009: fig. 6) e Hyphessobrycon otrynus (Benine \& Lopes, 2008: fig. 6). A presença de duas estruturas no mesmo raio sugere que estas não são homólogas. Por tanto, os ganchos, espinhos e Lappets devem ser tratadas com tal em relação à sua presença e distribuição na nadadeira.

\section{Distribuição dos processos ósseos no raio ramificado com maior número de segmentos com processos ósseos na nadadeira anal}

A análise anatômica comparada do raio com o maior número de segmentos com processos ósseos revelou padrões interessantes e constantes de distribuição e organização dos processos ósseos neste raio entre os taxons analisados (ver Fig. 2 para esquema). Descobrimos dentre os taxons analisados até dez séries de processos ósseos neste raio. As séries de processos ósseos são sequências interrompidas ou não de segmentos com processos 
ósseos inseridos na mesma região (ver Fig. 242 para esquema). A série de processos ósseos pode ainda variar de espécie para espécie quanto ao número de segmentos que possuem estas estruturas e quanto à extensão das sequências de segmentos nas mesmas. A seguir apresentamos a distribuição das séries de processos ósseos nos taxons analisados.

A primeira série de processos ósseos (Fig. 242) está presente em todos os raios ramificados da nadadeira anal de todos os táxons de Gasteropelecidae (Fig. 7 e 9) e Characidae (Fig. 77 e 155).

A segunda série de processos ósseos (Fig. 242) está presente apenas nos seguintes taxons de Characidae: Iguanodectinae, Heterocharacinae, Clado Bramocharax, Tetragonopterinae (com exceção de Tetragonopterus argenteus, Gymnocorymbus ternetzi, Moenkausia sanctafilomenae, Hemigrammus bleheri, H. rhodostomus e Pristella maxillaris), Clado Hyphessobrycon luetkenii, Clado Astyanax (com exceção de Psellogrammus kennedyi e Markiana nigripinnis), Clado Astyanax (com exceção de A. braquypterygium, A. courensis e Hasemania kalunga), Cheirodontinae (Heterocharacinae yatai e Serrapinnus calliurus), Stevardiinae (exceto Bryconamericus cf. exodon, B. cf. inheringii, B. cf. peruanus e Scopaeocharax rhinodus).

A terceira série de processos ósseos (Fig. 242) está presente apenas nos seguintes taxons de Characidae: Iguanodectinae, Heterocharacinae, Clado Bramocharax, Tetragonopterinae (Jupiaba abrammoides, J. yarina, Stethaprion crenatum, Poptella paraguayensis, Brachychalcinus copei, Hemigrammus ulreyi e Hemigrammus unilineatus).

A quarta série de processos ósseos (Fig. 242) está presente apenas nos seguintes táxons de Characidae: Heterocharacinae, Clado Bramocharax, Tetragonopterinae (Jupiaba yarina, Hemigrammus ulreyi e H. unilineatus), Clado Astyanax (A. abramis), Stevardiinae (Knodus heteresthes, K. moenkhausii e Pseudocorynopoma doriae). 
A quinta série de processos ósseos (Fig. 242) está presente apenas nos seguintes táxons de Characidae: Heterocharacinae, Clado Bramocharax, Tetragonopterinae (Jupiaba yarina, Poptella paraguayensis, Brachychalcinus copei, Hyphessobrycon herbertaxelrodi), Clado Hyphessobrycon luetkenii (Hyphessobrycon luetkenii), Stevardiinae (Pseudocorynopoma doriae).

A sexta, sétima, nona e décima séries de processos ósseos (Fig. 242) estão presentes apenas em Tetragonopterinae (Jupiaba yarina).

Oitava série de processos ósseos (Fig. 242): a oitava série de processos ósseos está presente apenas nos seguinte táxons de Characidae: Tetragonopterinae (Jupiaba yarina e Stevardiinae (Pseudocorynopoma doriae).

Como observado acima, todos os taxons com processos ósseos na nadadeira anal apresentam sempre e em muitos casos, apenas a primeira série de processos ósseos. Isto a torna independente da presença das demais séries de processos ósseos. Segundo o observado até agora a presença da segunda série de processos ósseos é dependente da presença da primeira série. A presença da terceira série é dependente da presença da segunda e da primeira. A presença da quarta série é dependente da presença da terceira, segunda e primeira. A presença da quinta é independente da terceira e da quarta, mas dependente da presença da segunda e da primeira. A presença da sexta, sétima, oitava, nona e décima são dependentes de todas as anteriores.

A primeira série de processos ósseos é a única nos representantes de Gasteropelecidae e nos táxons de Characidae (sensu Mirande, 2010) sem osso supraorbital (i.e. Salmininae, Bryconinae e o Clado Bryconops, com exceção de Piabucus melanostomus). É também aparentemente, a primeira série de processos ósseos a surjir na nadadeira anal ontogenéticamente (obs. pess.). Sendo assim, a presença da primeira série de processos ósseos 
é considerada por nós como representando a condição plesiomórfica em Characidae (sensu Mirande, 2010) com surgimento secundário da segunda, terceira e demais séries, provavelmente nesta sequência, ao longo da evolução da família. Provavelmente representa também uma condição sinapomorfica em Gasteropelecidae e Characidae. Todas as outras séries de processos osseos (com exceção da segunda e terceira em Piabucus melanostomus) estão presentes apenas em táxons sem supraorbital, em clados derivados em relação ao nó 205 de Mirande (2010).

Em grupos menos inclusivos em Characidae (sensu Mirande, 2010), a presença apenas da primeira série de processos ósseos é uma provável sinapomorfia para Hemigrammus bleheri e H. rhodostomus em Tetragonopterinae, para Characinae (sensu Mirande, 2010 e Mattox \& Tolesdo-Piza, 2012), para o clado 227 de Mirande (2010; Clado Pseudochalceus e Rhoadsiinae), para Aphyocharacinae (sensu Mirande, 2010), Aphyotideinae (sensu Mirande, 2010) e para as tribos de Cheirodontinae (sensu Jerep, 2011), Odontostilbini, Compsurini e para o Clado 136 de Cheirodontini (sensu Jerep, 2011). Dentre os taxons analisados, a presença apenas da primeira, segunda e terceira série de processos ósseos sugere uma provável sinapomorfia para o clado 144 em Cheirodontini (sensu Jerep, 2011) (Heterocheirodon yatai e Serrapinnus calliurus). Sendo assim, a presença de apenas uma série de processos aparenta ser o estado plesiomórfico para (Aphyocharacinae (Aphyoditeinae, Cheirodontinae)) (clado 195 de Mirande 2010 e 70 de Oliveira et al., 2011), com o surgimento da segunda e terceira séries como uma condição derivada em Cheirodontini (sensu Jerep, 2011). Outro padrão interessante encontrado foi a condição presente em Brachychalcinus copei, Poptella paraguayensis e Stethaprion crenatum. As duas primeira espécies apresentam a primeira, segunda, terceira e quinta séries de processos ósseos, enquanto que Stethaprion crenatum apresenta apenas a primeira e segunda séries. Isto sugere 
a relação (Brachychalcinus (Poptella, Stethaprion)), contrariando Reis et al. (1989). A presença de Brachychalcinus como grupo irmão das demais é suportada pelo fato de, e ao mesmo tempo reforça, a presença da primeira e segunda série de escama com processos ósseos como representando uma condição plesiomórfica neste nível de inclusividade. Esta relação foi proposta anteriormente por Oliveira et al. (2011). No entanto, um número maior de taxons nestes grupos precisam ser analisados afim de entender a variação intragenérica destes caracteres e consequentemente a evolução deste no grupo.

A análise anatômica comparada da primeira série de processos ósseos dentre os taxons analisados revelou também alguns padrões relacionados ao número de segmentos da primeira série com processos ósseos, à sequência de segmentos com processos ósseos e à presença de um ou mais tipos de processos ósseos nos raios.

Quanto ao número de segmentos da primeira série com o mesmo tipo de processos ósseos duas condições foram encontradas dentre os taxons analisados: $1-4$ ou mais segmentos (geralmente mais de 8) com processos ósseos, 2 - dois a três segmentos com processos ósseos e 3 - um segmento com processo ósseo.

Dentre os taxons analisados, apenas a primeira e segunda condições foram contempladas. A primeira condição está presente em todos os taxons de Gasteropelecidae e Characidae, com exceção dos táxons que possuem a segunda condição. Est condição está presente apenas em Hemigrammus bleheri (Fig. 164) e H. rhodostomus (Fig. 166).

Além dos taxons mencionados acima, a revisão da literatura revelou a presença da condição 2 apenas em Hemigrammus bosemani Géry, 1959, H. stictus (Durbin 1909), Hyphessobrycon otrynus Benine \& Lopes (2008: fig. 4), Hyphessobrycon reticulaturs (obs. pess.) e Petitella georgiae Géry \& Boutière 1964 (Lima \& Sousa, 2009), portanto o estado 2 está restrito, até agora, apenas a Tetragonopterinae. A condição 3 está presente em 
$\overline{\text { Stevardiinae [Mimagoniates Regan } 1905 \text { (Weitzman \& Menezes, 2009) e Tetragonpterinae }}$ [i.e. Hemigrammus stictus Durbin 1909 (Lima \& Sousa, 2009: fig. 6), H. yinyang Lima \& Sousa 2009, H. ocellifer (Lima \& Sousa, 2009: fig. 6) H. neptunus Zarske \& Géry 2002, H. haraldi Géry 1961, H. luelingi Géry, 1964, H. pulcher Ladiges 1938 e Hyphessobrycon diancistrus Weitzman (1977: fig. 3)].

A presença da condição 3 em Mimagoniates é um perfeito exemplo da direção de modificação deste caráter. Menezes \& Weitzman (2009: fig. 2) recobraram um grupo monofilético formado por Lophiobrycon Castro, Ribeiro, Benine, \& Melo 2003 como gênero irmão de Glandulocauda Menezes \& Weitzman 2009 e Mimagoniates. Os autores não deixaram de mencionar a diminuição do número de segmentos da primeira série com processos ósseos em Lophiobrycon (condição1: gênero do clado mais basal) a Mimagoniates (condição 3: gênero dos clados mais derivados). Os autores atribuíram esta transformação de estado como resultado de pedomorfose. Entretanto, essa condição representa, na verdade, uma derivação, uma especialização gerada por uma pressão seletiva possivelmente relacionada ao modo reprodutivo dessa espécies. Assim como os demais caracteres sexuais secundários nestes três gêneros, como o órgão caudal (ver Menezes \& Weitzman, 2009) e o dimorfismo no formato da nadadeira caudal.

Lima \& Sousa (2009) discutiram o formato e a distribuição dos processos ósseos na nadadeira de todas as espécies mencionadas acima, exceto Mimagoniates e Hyphessobrycon diancistrus. Os autores definiram cinco padrões de distribuição dos processos ósseos nestas espécies, nos quais se basearam para propor o monofiletismo de dois grupos, o "grupo Hemigrammus ocellifer" composto por H. guyanensis, H. haraldi, H. neptunus, H. ocelifer, H. luelingi, $H$. pulher e $H$. yinyang e um grupo formado por H. bleheri, H. rhodostomus e Petitella georgiae, todos com até três processos osseos por raio (estados 2 e 3). Como 
$\overline{\text { observado aqui a presença de mais de } 4 \text { (normalmente mais 10) segmentos com processos }}$ ósseos na primeira série de processos ósseos parece representar a condição plesiomórfica em Characidae. Sendo assim, a diminuição no número de segmentos com processos ósseos parece indicar uma condição derivada que aparentmenete surgiu duas vezes em Characidae, já que foi encontrada apenas neste pequeno grupo de Tetragonopterinae e em Mimagoniates em Stevardiinae. Embora Lima \& Sousa (2009) tenham dividido estas espécies em dois grupos, cada um potencialmente monofilético, acreditamos que todas, junto com Hyphessobrycon diancistrus formam um grupo monofilético baseado nos seguintes caracteres: presença apenas da primeira série de processos ósseos, presença de processos ósseos em até três segmentos da primeira série com processos ósseos e distribuição anterior do pacote de ganchos. É importante mencionar que, segundo o observamos, os padrões definidos por Lima \& Sousa (2009) são válidos e potencialmente informativos, portanto acreditamos que os agrupamentos propostos por eles sejam legítimos em níveis menos inclusivos dentreo do suposto clado monofilético formado por todos eles. Vale notar que são sustentados, basicamente, pelo número de segmentos na primeira série de processos ósseos e pelo número de raios com processos ósseos, caracteres sexuais secundários. Notamos também que destas espécies, Hyphessobrycon otrynus e Hemigrammus stictus possuem dois tipos de processos ósseos, gancho e espinho. No entanto, como observado na seção anterior a presença dos ganchos e espinhos devem ser tratadas como independentes e não homólogas. Portanto a condição presente no mesmo tipo de processo ósseo que as demais é considerada como homóloga. $\mathrm{Na}$ análise de Mirande (2010) Hemigrammus bleheri está proximamente relacionada a espécies que possuem apenas espinhos, como Moenkhausia sanctafilomenae, Hemigrammus unilineatus, Stethaprion crenatum e Poptella paraguayensis. Isto pode explicar a presença dos pacotes de espinhos em H. stictus e H. otrynus. 
Quanto à sequência de segmentos com processos ósseos na primeira série (caráter 11), duas condições foram encontrados: 1 - todos os segmentos da primeira série de segmentos com processos ósseos, do segmento mais proximal ao segmento mais distal da série e 2 presença de segmentos sem processos ósseos intercalados com segmentos com processos ósseos ao longo da primeira série.

Dentre os táxons analisados o primeiro estado está presente em todos os taxons de Gasteropelecidae (Fig. 7) e Characidae (Fig. 240), com exceção daqueles que possuem a segunda condição. Esta, está presente em Tetragonopterinae [Hemigrammus bleheri (Fig. 164) e H. rhodostomus (Fig. )], Clado Astyanax [A. cf. jordani (Fig. XX), A. lineatus (Fig. 166) e Markiana nigripinnis (Fig. 40)] e em todos os táxons do Grupo A. scabripinnis (Figs. $47,51,57$ e 63$)$.

Este caráter também está relacionado à perda de segmentos com processos ósseos, a primeira série de processos ósseos. No entanto, como não sabemos como ocorre a diminuição no número de segmentos com processos ósseos na primeira série de segmentos com processos ósseos, optamos por apresenta-lo separadamente. Quanto à sequência de segmentos, observamos que a distribuição compacta com processos ósseos do segmento mais proximal ao mais distal da primeira série (condição 1 do caráter 11) representa a condição plesiomórfica em Characidae. Por tanto, a presença de segmentos sem processos ósseos intercalados com segmentos com processos ósseos parece ser aparentemenete uma perda secundária de processos ósseos nestes segmentos. Como pode ser observado a condição 2 está presente em Hemigrammus bleheri e H. rhodostomus (taxons de um dos clados mais derivados em Tetragonopterinae sensu Mirande, 2010), em Astyanax cf. jordani, A. lineatuse Markiana nigripinnis e nos táxons do Grupo A. scabripinnis. Este é mais um caráter que indica um relacionamento próximo entre taxons do Clado Astyanax e taxons de clados derivados em 
$\overline{\text { Tetragonopterinae. A presença do estado } 2 \text { portanto, reforça um possível agrupamento }}$ monofilético entre as espécies atualmente incluída nestes dois taxons. Neste caso, sendo a perda de processos ósseos uma modificação secundária em Characidae, a condição 2 deste caráter poderia tratar-se de uma condição intermediária entre as condições 1,2 e 3 do caráter anterior. Isto apoia, assim como discutido nas seções, um posicionamento basal dos taxons atualmente incluídos no Clado Astyanax e Clado Hyphessobrycon luetkenii em um provável clado composto pelos membros destes dois clados e Tetragonopterinae, mantendo os clados derivados nesta subfamília (sensu Mirande, 2010). Naturalmente, uma análise filogenética incluindo outros ccomplexos de caracteres com uma representatividade mais expressiva de taxons é necessária para entender tanto a evolução destes caracteres quanto as relações deste taxons. 


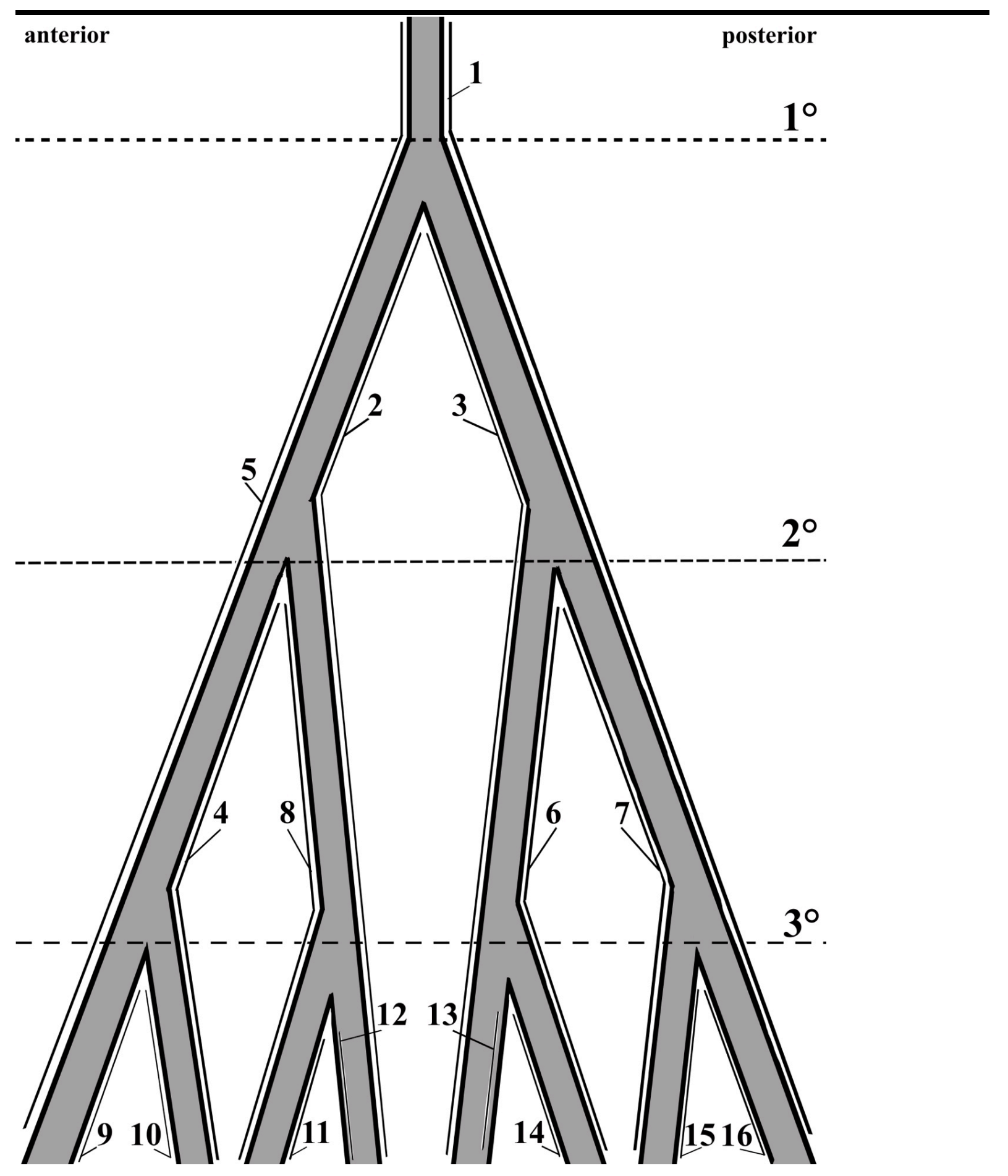

Figura 2. Esquema de um raio ramificado em vita lateral esquerda. Linha pontilhadas na horizontal repreantam o local e o número de cada bifurcação. Os número (1 a 16) apontam para cada série de segmentos com processo ósseos, cuja estenção máxima estáuma linha paralela à margem dos raios em diferentes locais. 


\section{Distribuição dos processos ósseos na nadadeira anal.}

A distribuição dos processos ósseos nas nadadeiras é presumivelmente a combinação do número de segmentos em cada raio individualmente e da sequência ininterrupta de raios adjacentes com processos ósseos. Nesta contribuição nos referimos à sequência ininterrupta de raios com o mesmo tipo de processo ósseo, como "pacote". Como observado na seção os diferentes tipos de processos ósseos, como definidos aqui devem ser tratados como não homólogos. Sendo assim, consequentemente devem ser tratados como pacotes diferentes e independentes, que podem inclusive apresentar o mesmo tipo de distribuição, quando os diferentes tipos de processos ósseos estão presentes nos mesmos raios.

Cada pacote apresenta, mesmo que levemente, uma variação linear na forma (basicamente tamanho) em direção anteroposterior na nadadeira. Esta variação no entanto, é menor que a variação entre dois tipos diferentes de processos ósseos e não descaracteriza o tipo de processo ósseo como definido aqui. Sendo assim, quando dois pacotes estão presentes na mesma nadadeira, eles são facilmente identificáveis uma vez que apresentam uma variação de forma conspícua, acentuada e não linear entre eles. Os pacotes geralmente variam em sua extensão anteroposterior (número de raios com processos ósseos) e em sua localização na nadadeira. Quanto à distribuição dos pacotes de processos ósseos no eixo anteroposterior da nadadeira, três padrões foram encontrados em Characiformes:

\section{1 - Distribuição anterior}

Na distribuição anterior o pacote de processos ósseos está deslocado anteriormente na nadadeira, estendendo-se anteroposteriormente sempre do último, penúltimo e mais raramente do antipenúltimo raio simples ou do primeiro raio ramificado, podendo se restringir aos raios da metade anterior da nadadeira (Fig. 118) ou se estender acima de $90 \%$ dos raios ramificados 


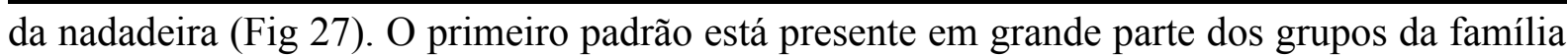
Characidae. Dentre os taxons analisados está presente em todos, com exceção de Gasteropelecidae (i.e. Thoracocharax stellatus e Carnegiella strigata), Iguanodectinae (i.e. Piabucus melanostomus), Characinae (i.e. Roeboides microlepis), Clado Pseudochalceus (i.e. Hollandichthys multifasciatus) e Stevardiinae (i.e. Pseudocorynopoma doriae e Scopaeocharax rhinodus). Grande parte dos táxons analisados que apresentam a distribuição anterior, possuem processos ósseos no ultimo raio simples, alguns inclusive no penúltimo raio simples (i.e. Hysteronotus megalostomus, Fig. 217). Dentre os táxons que apresentam a primeira condição, a ausência de processos ósseos no raio simples foi observada apenas em Brycon falcatus, Bryconexodon juruenae, Hemigrammus bleheri, Hemigrammus rhodostomus, Prinobrama paraguayensis e Bryconamericus cf. peruanus. Na literatura, apenas Jerep (2011) utilizou a presença ou ausência de processos osseos no último raio simples como caráter em sua análise, no entanto interpretou a ausência e a presença de poucos processos ósseos (1-3) como homóloga. Jerep (2011) codificou a redução ou ausência de processos ósseos no último raio simples como um estado derivado de Nannocheirodon insignis (Steindachner, 1880), Serrapinnus micropterus (=Cheirodon micropterus Eigenmann 1907), Prionobrama paraguayensis e sinapomorfia do clado 151 (i.e. Serrapinnus n sp. ac e Serrapinnus n sp. a). Lima \& Sousa (2009) também utilizaram a presença ou ausência de processos ósseos no raio simples para diferenciar o seu grupo $H$. ocellifer de H. bleheri, $H$. rhodostomus e Petitella georgiae. Isto indica que este caráter é informativo em níveis muito pouco inclusivos. A presença de processos ósseos no raio simples é aparentemente o estado plesiomórfico em Characidae, com perdas secundárias ao longo da evolução em níveis muito pouco inclusivos.

\section{2 - Distribuição mediana}


$\mathrm{Na}$ distribuição mediana, o pacote está deslocado posterioremente em relação à primeira condição, extendendo-se anteroposteriormente do segundo raio ramificado ou raios ramificados posteriores a este, sem ocupar os últimos dois ou três raios ramificados da nadadeira. Dentre os taxons analisados a distribuição mediana está presente apenas em de Gasteropelecidae (i.e. Thoracocharax stellatus e Carnegiella strigata), Iguanodectinae (i.e. Piabucus melanostomus), Characinae (i.e. Roeboides microlepis), Clado Pseudochalceus (i.e. Hollandichthys multifasciatus) e Stevardiinae (i.e. Pseudocorynopoma doriae e Scopaeocharax rhinodus). O levantamento da literatura revelou a presença da distribuição mediana também em Sevardiinae [i.e. Argopleura insignis (Weitzman \& Fink, 1985: fig. 38), Chrysobrycon myersi (Weitzman \& Thomerson, 1970) (Weitzmqn \& Menezes, 1998: fig. 9), Iotabrycon praecox Roberts 1973 (Weitzman \& Fink, 1985: fig. 39), Scopaeocharax atopodus (Böhlke, 1958) (Weitzman \& Fink, 1985: fig. 40), Tyttocharax madeirae Fowler 1913 (Weitzman \& Fink, 1985: fig. 41) e T. metae Román-Valência, García-Alzate, Ruiz-C. \& Taphorn 2012 (Román-Valencia et al., 2012: fig. 4)] e em Cheirodontinae [i.e. Nanocheirodon insignis (Steindachner 1880)].

Dentro do que definimos aqui como distribuição mediana exitem pequenas variações, que foram interpretadas em três estados de acordo com a extensão e posição do pacote de raios com processos ósseos na nadadeira: 1 - o pacote está composto por raios da metade anterior da nadadeira, 2 - o pacote está composto por raios das metades anterior e posterior da nadadeira e 3 - o pacote está composto por raios da metade posterior da nadadeira e está presente.

A condição 1 está presente em Argopleura insignis (Weitzman \& Fink, 1985: fig. 38), Chrysobrycon myersi (Weitzman \& Thomerson, 1970) (Weitzman \& Menezes, 1998: fig. 9), 
$\overline{\text { Iotabrycon praecox Roberts } 1973 \text { (Weitzman \& Fink, 1985: fig. 39) e Pseudocorynopoma }}$ doriae (Fig. XXa_P. doriae).

A condição 2 está presente em Gasteropelecidae [Thoracocharax stellatus (Fig. XX_T. stellatus) e Carnegiella strigata], Characinae (Roeboides microlepis), Clado Pseudochalceus (Hollandichthys multifasciatus), Cheirodonttinae (Nanocheirodon insignis) e Stevardiinae [Scopaeocharax atopodus (Weitzman \& Fink, 1985: fig. 40) e S. rhinodus].

A condição 3 está presente apenas em Tyttocharax madeirae (Weitzman \& Fink, 1985: fig. 41) e T. metae (Román-Valencia et al., 2012: fig. 4).

\section{3 - Distribuição interrompida}

Neste padrão, o pacote (mesmo tipo de processos ósseos) de raios com processos ósseos é interrompido medianamente. Estão presentes tanto na região anterior da nadadeira (mesma distribuição do primeiro padrão), estendendo-se anteroposteriormente do ultimo raio simples ou primeiro raio ramificado, como na região posterior da nadadeira, podendo ou não ocupar o último raio ramificado, com raios sem processos ósseos entre eles. Este padrão foi encontrado apenas em Piabucus melanostomus (Fig. 143a e 144a) e através da dsecrição de Weitzman \& Fink (1985: 28 e 59) em Argopleura praecox.

De acordo com o observado aqui, a distribuição anterior do pacote de processos ósseos (padrão 1) aparenta representar a condição plesiomórfica em Characidae, com modificações secundárias para os padrões 2 e 3 ao longo da evolução da família. A distribuição interrompida (padrão 3) aparentemente surgiu duas vezes na evolução de Characidae, em Stevardiinae e Iguanodectinae (sensu Mirande, 2010). As espécies de Iguanodectinae devem ser analisadas para constatar em que nível de inclusão este caráter é informativo na subfamília. A distribuição mediana (Padrão 2B) aparentemente surgiu duas vezes em Characiformes, em Gasteropelecidae e Characidae. Em Characidae o padrão 2B surgiu pelo 
$\overline{\text { menos três vezes (i.e. Clado Pseudochalceus, Cheirodontinae e Stevardiinae). O padrão } 2 \mathrm{C}}$ por outro lado, surgiu apenas uma vez e, aparentemente, representa uma sinapomorfia de Tyttocharax, corroborando Weitzman \& Fink (1985: c. 67).

Como obaservado nas seções anteriores algumas espécies possuem dois pacotes de processos ósseos que podem ou não apresentar a mesma distribuição. Em Piabucus melanostomus o pacote de ganchos 1 apresenta a distribuição anterior e o pacote de Lappet a distribuição interrupta. Em Bryconamericus cf. Peruanus, por outro lado, tanto o pacote de ganchos 1 quanto o pacote de espinhos 8 apresentaram a distribuição anterior, embora com distribuição nos raios e extensão nas nadadeiras diferentes. Com isto queremos evidenciar que, como os diferentes processos ósseos definidos acima não são homólogos visto que aparecem na mesma nadadeira e muitas vezes no mesmo raio, os pacotes e os caracteres relacionados a eles, como tipo de distribuição, extensão e a forma como os processos ósseos aumentam de tamanho também não são. Sendo assim, estes caracteres devem ser comparados apenas entre pacotes com o mesmo tipo de processo ósseo.

Weitzman \& Fink (1985) brilhantemente e com extremo detalhe exploraram o padrão de distribuição dos processos ósseos em sua análise filogenética de Xenurobryconini. Neste trabalho os autores citaram a presença de dois grupos de processos ósseos na região anterior da nadadeira anal como uma sinapomorfia de Argopleura Eigenmann 1913 (Weitzman \& Fink, 1985: c. 7. fig. 38). Os autores mencionam também a presença de um terceiro grupo de processos ósseos muito pequenos nos raios posteriores ao segundo grupo de processos ósseos descrito por eles. Estes processos ósseos, se iguais àqueles do primeiro grupo, caracterizaria a presença da distribuição interrompida (padrão 3). No entanto estes pequenos processos ósseos não foram ilustrados e nenhum exemplar de Argopleura foi analizado, mesmo assim a condição em Argopleura foi interpretada como possuidor desse padrão. Sendo assim 
$\overline{\text { Argopleura possui tanto um pacote (pacote 1) com a distribuição mediana (2b) quanto um }}$ pacote (pacote 2) com distribuição interrompida (padrão 3). Na interpretação de Weitzman \& Fink (1985) a condição de Iotabrycon praecox trata-se de uma distribuição de um grupo só, embora tenham ilustrado claramente a presença de dois pacotes distintos na nadadeira, o primeiro aparentemente equivale ao pacote 1 de Argopleura e o segundo pacote ao pacote 2 (Weitzman \& Fink, 1985: fig. 39). Esta interpretação se deve provavelmente ao fato de não haver nenhum raio ramificado sem processos ósseos entre os dois pacotes em I. praecox. Em nossa interpretação no entanto, I. praecox apresenta a distribuição anterior do pacote 1 e distribuição mediana (padrão $2 \mathrm{~A}$ ) do pacote 2. Os autores também citaram a presença de processos ósseos restritos aos seis ou oito raios ramificados (pacote provavelmente equivalente ao pacote 2 de Iotobrycon e Argopleura) posteriores da nadadeira (metade posterior), com exceção dos raios posteriores (= padrão $2 \mathrm{C}$ ) como uma sinapomorfia de Scopaeocharax (Weitzman \& Fink, 1985: c. 67. fig. 41). Xenurobryon apresenta o pacote 2 (= pacote 2) e aparentemente duas condições de distribuição. De acordo com o descrito por Weitzman \& Fink (1985: fig. 42 e 43 respectivamente) Xenurobrycon macropus apresenta a distribuição anterior (padrão 1) e X. pteropus a distribuição mediana (padrão 2B). De acordo com as descrições de Moreira (2005) e Mendonça et al., (2016: fig. 4) X. coracoralinae, X. heterodon e $X$. macropus possuem a distribuição anterior (padrão 1). Em X. pteropus e $X$. polyancistrus no entanto, Moreira (2005) citou a presença de dois tipos morfológicos distintos de processos ósseos: processos ósseos pequenos e relativamente do mesmo tamanho do último raio simples ao quinto raio ramificado e posterioremente, do sexto ao décimo segundo raios ramificados, processos ósseos maiores que aqueles dos raios anteriores. Esta interpretação de Moreira (2005) provavelmente se deve ao fato de os processos ósseos presentes a partir do sexto raio ramificado apresentarem uma curvatura menor e serem 
maiores que os processos ósseos nos raios anteriores e também ao fato de haver uma menor número de segmentos com processos ósseos nos raios posteriores. A variação de tamanho e curvatura dos processos ósseos e número de segmentos com processos ósseos nos raios da nadadeira podem variar linearmente ao longo da mesma, variações estas que são comuns em Characidae e não definem um tipo diferente de processos ósseos segundo nossa interpretação. Mesmo assim, existe ainda uma controvérsia quanto à distribuição de processos ósseos na nadadeira anal de $X$. macropus, segundo a ilustração de Weitzman \& Fink (1985), a espécie se enquadraria no padrão 2B; por outro lado, segundo Moreira (2005) a espécie se enquandraria no padrão 1 .

Em sua análise filogenética, Weitzman \& Fink (1989: fig. 79) recobraram um Xenurobryconini monofilético com a seguinte relação: (Argopleura (Iotobrycon (Xenurobrycon (Scopaeocharax, Tyttocharax)))). Menezes \& Weitzman (1998: fig. 1) recobraram um Xenurobriconini monofilético com a seguinte relação: (Chrysobrycon (Argopleura (Ptychocharax (Iotabrycon (Xenurobrycon (Scopaeocharax, Tytthocharax)))))), com o acréscimo de Chrysobrycon e Iotabrycon. Logo, Ferreira et al. (2011) sem incluir Argopleura, Iotabrycon e Ptychocharax recobraram um Xenurobryconini monofilético com a seguinte relação: (Scopaeocharax (Xenurobrycon, Tyttocharax)). A composição deste clado corrobora as duas análises anteriores mas discorda quanto à relação interna, com Scopaeocharax como grupo irmão das demais. Thomaz et al. (2015) em análise molecular incluiu todos estes gêneros exceto Iotabrycon e Ptychocharax e restringiu Xenurobryconini a (Scopaeocharax (Xenurobrycon e Tyttocharax)), corroborando a relação recobrada por Ferrira et al. (2011). Na análise de Thomaz et al. (2015) Argopleura sai como grupo irmão de Glandulocaudini + Stevardiini e Chrysobrycon como grupo irmão de Pseudocorynopoma em Stevardiini. Como mencionado acima Chrysobrycon e Pseudocorynopoma possuem o padrão 


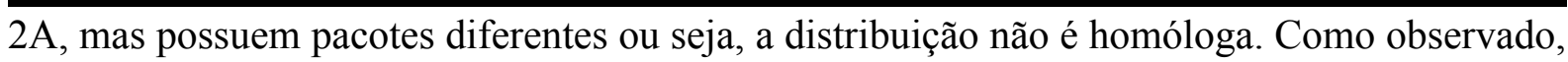
as relações de Argopleura e Crysobrycon continua controversas, no entanto todos corroboram o monofiletismo de Xenurobrycon, Scopaeocharax e Tyttocharax. As relações intergenéricas desses gêneros é ainda controversa, com duas analises (Weitzman \& Fink, 1985 e Menezes \& Weitzman, 1998) propondo Xenurobrycon como gênero irmão das demais e duas (Ferreira et al., 2011 e Thomaz et al., 2015) propondo Scopaeocharax como gênero irmão das demais. As análises que incluíram Iotabrycon corroboram o posicionamento do gênero como grupo irmão dessas três espécies (Weitzman \& Fink, 1985 e Menezes \& Weitzman, 1998). A otimização mais parcimoniosa da presença dos pacote e seu padrões de distribuição no clado monofilético (Iotabrycon (Xenurobrycon (Scopaeocharax, Tyttocharax))), considerando Xenurobrycon macropus como possuidor do padrão 2B, indicou a seguinte evolução dos caracteres: os pacotes 1 e 2 com padrão de disribuição 1 e 2 A respectivamente estão na raiz do clado (Iotabrycon (Xenurobrycon (Scopaeocharax, Tyttocharax))) com perda secundária do pacote 1 e transformação para a distribuição 2B no clado (Xenurobrycon (Scopaeocharax, Tyttocharax)) e transformação para a distribuição estado C em Tyttocharax. Estes dados, corroboram (Weitzman \& Fink, 1985 e Menezes \& Weitzman, 1998) tanto quanto ao monofiletismo de (Iotabrycon (Xenurobrycon (Scopaeocharax, Tyttocharax))) com a presença do pacote 2 e o padrão de distribuição 2 como sinapomorfia e também quanto ao clado (Xenurobrycon (Scopaeocharax, Tyttocharax)) com a ausência do pacote 1 e a presença do padrão de distribuição 2B como sinapomorfia. Xenurobrycon como grupo irmão dos outros dois gêneros no clado se deve à presença do padrão de distribuição $2 \mathrm{C}$ em Tyttocharax, uma possível derivação do padrão de distribuição $2 \mathrm{~A}$ do clado mais basal. No entanto, naturalmente estes caráteres devem ser analisados em conjunto com todos os outros caracteres dos diversos complexos morfológicos para entender sua evolução nos taxons onde ocorrem. 


\section{Processos ósseos na nadadeira pélvica}

Dentre os taxons analisados os processo ósseos na nadadeira pélvica está presente em Crenuchidae [Characidium xanthopterum (Fig. 3) e C. xavante (Fig. 5)] e em todos os taxons analisados de Characidae, com exceção de Brycon falcatus, Iguanodectinae, Bryconexodon juruenae (Characinae sensu Mirande, 2010), Tetragonopterinae (Hemigrammus bleheri e H. rhodostomus) e Clado Astyanax (Psellogrammus kennedyi). Em algum dos clados analisados os processos ósseos estão presentes apenas na nadadeira pélvica, como é o caso de Paracheirodon axelrodi (Tetragonopterinae) e Spintherobolus (Stevardiinae). Podemos observar que o representante analisado de Brycon não apresenta processos ósseos na nadadeira anal. Isto mostra mais uma vez, como a presença ou ausência de processos ósseos (caráter sexual secundário) não só na nadadeira pélvica, mas em qualquer nadadeira pode ser informativa em nível interespecífico.

Ao contrário do que ocorre na nadadeira anal, a nadadeira pélvica geralmente apresenta processos ósseos nos segmentos de apenas um dos hemitriquium, com algumas exceções em Characidae. A análise anatômica comparada mostrou alguns padrões muito interessantes quando ao hemitriquium em que os processo estão presentes: 1 - processos ósseos nos segmentos do hemitriquium dorsal e 2 - processos ósseos nos segmentos do hemitriquium ventral.

Esta condição é bastante interessante uma vez que, ao contrário dos caracteres sexuais secundários discutidos até agora, apresenta-se como informativo em um nível muito inclusivo. Os processos ósseos na nadadeira pélvica em Crenuchidae foram, até agora, encontrados apenas em representantes de Characidium. Já foi mencionada como presentes em 
$\overline{\text { C. bahiensis, C. bimaculatum, } C \text {. deludens, C. lagosantense, C. litorale, C. mirim, C. nupelia, }}$ C. satoi, C. stigmosum, C. xanthopterum (Fig. XX) e C. xavante (Fig. XX). No entanto dentre estas espécies vemos duas condições completamente distintas e consideradas por nós, como não homólogas (tratado a seguir). Embora essas condições não sejam homólogas, ambas ocorrem apenas nos segmentos do hemitriquium dorsal (estado 1) (Figs. 4 e 5). Por outro lado, em todos os taxons em Characidae, os processos ósseos estão inseridos e restritos aos segmentos do hemitriquium ventral. Dentre os taxons analisados, processos ósseos no hemitriquium dorsal foram encontrados em Heterocharax virgulatus e Hoplocharax goethei (Characinae), Hyphessobrycon luetkeni (Clado H. luetkenii) e Pseudocorynopoma doriae (Stevardiinae). No entanto, estes táxons também apresentam processos ósseos no hemitriquium ventral. Sendo assim, acreditamos que a presença de processos ósseos nos segmentos de hemitriquium ventral tenha surjido uma vez só em Characiformes e é uma potencial sinapomorfia para Characidae (sensu Mirande, 2010), com surgimento secundário de processos ósseos nos segmentos de hemitriquium dorsal ao longo da evolução da família. A presença de processos ósseos nos segmentos do hemitriquium ventral e dorsal é provavelmente mais uma sinapomorfia para Heterocharax e Hoplocharax (Characinae), mais uma autopomorfia para Pseudocrocynopoma doriae (Stevardiinae) e Hyphessobrycon luetkenii (Clado H. luetkenii). É interessante notar também que os processos ósseos presentes nestas espécies é o espinho 1 em Heterocharacinae e o espinho 2 em Hyphessobrycon luetkenii e Pseudocorynopomea doriae. Em Crenuchidae duas condições estão sendo descritas como processos ósseos. Uma delas equivale à definição de processos ósseos utilizadas por nós, que se trata basicamente do desenvolvimento de um processo ósseo na face lateral dos segmentos de hemitriquium (Fig. 5). Dentre as espécies de Crenuchidae listadas acima como detentoras de processos ósseos, analisadas por nós, os processos ósseos foram 
encontrados por nós apenas em C. bahiense Almeida 1971, C. xavante (Fig. XX) e $C$. deludens Zanata \& Camelier 2015. Em todas estas espécies, os segmentos possuem apenas um processo ósseo. Characidium mirim, Characidium nupelia, C. satoi, C. stigmosum e $C$. xanthopterum (Fig. XX) apresentam uma condição completamente diferente. A condição apresentada por estas espécies se trata de um desenvolvimento dorsal de uma extensão nas extremidades distal e proximal de cada segmento de hemitriquium dorsal, de maneira que a extensão da extremidade distal de um segmento fique confrontada à extensão da extremidade proximal do segmento imediatamente distal (Fig. 3 e 4). A esta condição damos o nome de "cume" (= a ridge na tradução para o inglês). Ambas as condições no entanto, são cobertas por um tecido arredondado, o que provavelmente foi a razão destes padrões não terem sido identificados até hoje.

\section{Considerações finais}

Podemos concluir com tudo o discutido acima, que os caracteres sexuais secundários são potencialmente informativos em níveis muito pouco inclusivos em Characidae. Vimos que cada caráter apresenta uma aparente direção de especialização em cada grupo menos inclusivo, apresentado em seus clados mais basais a condição plesiomórfica na família. Conluimos com tudo, que a análise destes caracteres em conjunto com outros complexos anatômicos poderam potencialmente recobrar grupos melhor corroborados.

\section{Referências Bibliográficas}


Andrade, D. R., Menin, E. \& Ribeirso, S. P. 1984. Periodicidade da característica sexual secundária em Astyanax bimaculatus (Linneaus, 1758) Pisces, Characidae. Ver. Seiva, 44(93): 9-12.

Amorim, D.S. 2002. Fundamentos de sistemática filogenética. Holos Editora, Ribeirão Preto. $153 \mathrm{pp}$.

Azevedo, A. A., Malabarba, L. R. \& Burns, J. H. 2010. Reproductive biology and development of gill glands in the inseminating characid, Macropsobrycon uruguayanae Eigenmann, 1915 (Cheirodontinae: Compsurini). Neotropical ichthyology, 8(1).

Buckup, P. A. 1991. The Characidiinae: A Phylogenetic Study of the South American Darters and Their Relationships With Other Characiform Fishes. Teses não publicada, University of Michigan, Ann Arbor, 391p.

Buckup, P. A. 1993. Phylogenetic interrelationships and reductive evolution in Neotropical Characidiine fishes (Characiformes, Ostariophysi). Cladistics, 9(3): 305-341.

Buhrnheim, C. M. 2006. Sistematica de Odontostilbe Cope, 1870 com a proposição de uma nova tribo Odontostilbini e redefinição dos gêneros incertae sedis de Cheirodontinae (Ostariophysi: Characiformes: Characidae). Tese de Doutorado não pbulicada, Universidade Federal do Rio Grande do Sul, Instituto de Biociências, Programa de PósGraduação em Biologia Animal, Porto Alegre, BR-RS.

Burns, J. R., S. H. Weitzman, H. J. Grier \& N. A. Menezes. 1995. Internal fertilization, testis and sperm morphology in Glandulocaudinae fishes (Teleostei: Characidae: Glandulocaudinae). Journal of Morphology, 224(2): 131-145.

Burns, J. R., S. H. Weitzman \& L. R. Malabarba. 1997. Insemination in eight species of Cheirodontinae fishes (Teleostei: Characidae: Cheirodontinae). Copeia, 1997(2): 433438. 
Bushmann, P. J., J. R. Burns \& S. H. Weitzman. 2002. Gill-derived glands in glandulocaudine fishes (Teleostei: Characidae: Glandulocaudinae). Journal of Morphology, 253(2): 187-195.

Calcagnotto, D., S. A. Schaefer \& R. DeSalle. 2005. Relationships among characiform fishes inferred from analysis of nuclear and mitochondrial gene sequences. Molecular Phylogenetics and Evolution, 36(1): 135-153.

Carvalho, F. R. 2011. Sistemática de Hyphessobrycon Durbin, 1908 (Ostariophysi: Characidae). Tese de Doutorado não pulbicada, Universidade Federal do Rio Grande do Sul, Instituto de Biociências, Programa de Pós-Graduação em Biologia Animal, Porto Alegre, BR-RS.

Cordiviola de Yuan, N. Oldani, O. Oliveros \& C. Pignalberi de Hassan. 1984. Aspectos limnologicos de ambientes proximos a la ciudad de Santa Fe (Parana Medio): poblaciones de peces ligadas a la vegetacion. Neotropica, 30(84): 127-139.

Costa, W. J. E. M. \& Géry, J. 1994. Two new species of the genus Hyphessobrycon (Characiformes: Characidae) from the rio Xingú basin, central Brazil. Revue Français d'Aquariologie, 20(1993): 71-76.

Eigenmann, C. H. 1912. The freshwater fishes of British Guiana, including a study of the ecological grouping of species and the relation of the fauna of the plateau to that of the lowlands. Memoirs of the Carnegie Museum, 5(1): 1-578.

Eigenmann, C. H. 1915. The Cheirodontinae, a subfamily of minute characid fishes of South America. Memoirs of the Carnegie Museum, 7(1): 1-99.

Eigenmann, C. H. 1917. The American Characidae. Memoirs of the Museum of Comparative Zoology, 43(1): 1-102.

Eigenmann, C. H. 1918. The American Characidae. Memoirs of the Museum of Comparative Zoology, 43(2): 103-208. 
Eigenmann, C. H. 1921. The American Characidae. Memoirs of the Museum of Comparative Zoology, 43(3): 209-310.

Eigenmann, C. H. 1927. The American Characidae. Memoirs of the Museum of Comparative Zoology, 43(4): 311-428.

Elredge, N. \& Cracraft, J. 1980. Phylogenetics Patterns and the Evolutionary Process. Columbia University Press, New York. 349 pp.

Eschmeyer, W.N. \& J.D. Fong. 2011. Species by family/subfamily in the catalog of fishes.http://research.calacademy.org/redirect?url=http://researcharchive.calacademy.or g/research/Ichthyology/catalog/SpeciesByFamily.asp. Acessado em 14/6/2011.

Farris, J.S. 1983. The logical basis of phylogenetic analysis. In: Platnick, N.I., Funk, V.A. (Eds.). Advances in Cladistics II. Columbia University Press, Nova Iorque, pp. 7 - 36.

Géry, J. 1965. A new genus from Brazil - Brittanichthys. Tropical Fish Hobbyist, 13(6): 1323, 61-69.

Godoy, M.P. 1975. Peixes do Brasil. Subordem Characoidei. Bacia do rio Mogi Guassu. Vol. II. Franciscana, Piracicaba.

Gonçalves, T. K., M. A. Azevedo, L. R. Malabarba \& C. B. Fialho. 2005. Reproductive biology and development of sexually dimorphic structures in Aphyocharax anisitsi (Ostariophysi: Characidae). Neotropical Ichthyology, 3(3): 433-438.

Goloboff, P.; Farris, J. \& Nixon, K.. 2003. T.N.T.: Tree Analysis Using New Tecnology.

Hennig, W. 1950. Grudzüge einer theorie der Phylogenetischen Systematik. Deutscher Zentralverlag, Berlin.

Hennig, W. 1966. Phylogenetic Systematics. University of Illinois Press, Urbana. 263 pp. 
Javonillo, R., Malabarba, L. R., Weitzman, S. H. \& J. R:, Burns. 2010. Relationships among major lineages of characid fishes (Teleostei: Ostariophysi: Characiformes), based on molecular sequence data. Mol. Phylogenet. Evol., 54:498-511.

Jégu, M., Santos, G. M. \& E. Ferreira. 1989. Une nouvelle espèce du genreMylesinus (Pisces, Serrasalmidae), M. paraschomburgkii, dècrite des bassins du Trombetas et du Uatumã (Brésil, Amazonie). Revue d'Hydrobiologie Tropicale, 22(1): 49-62.

Jégu, M. 2003. Subfamily Serrasalminae. Pp. 182-196. In: Check List of the Freshwater Fishes of South and Central America. Reis, R. E., S. O. Kullander \& C. J. Ferraris Jr. (Eds.). Porto Alegre, Edipucrs, 742p.

Jenyns, L. 1842. Fish. In The zoology of the voyageof H. M. S. Beagle. Part IV, 1-72.

Jerep, F. C. \& L. R., Malabarba. 2011. Revision of the genus Macropsobrycon Eignemann, 1915 (Characidae: Cheirodontinae: Compsurini). Neotropical Ichthyology, 9 (2): 299312.

Kitching, I.J.; Forey, P.L.; Humphries, C.J. \& D. M. Williams. 1998. Cladistics - The theory and practice of parcimony analysis. Oxford University Press, Oxford. 228 pp.

Kluge, A.G. \& T. Grant. 2006. From conviction to anti-superfluity: old and new justifications of parsimony in phylogenetic inference. Cladistics, 22: 276-288.

Lagler, K. F., Bardach, J. E. \& R. R. Miller. 1962. Ichthyology. John Wiley and Sons, Inc., New York. 505pp.

Lima, F.CT. \& P. Gerhard. 2001. A new Hyphessobrycon (Characiformes: Characidae) from Chapada Diamantina, Bahia, Brazil, with notes on its natural history. Ichthyological Exploration of Freshwaters, 12(2): 105-114.

Lima, F. C. T., L. R. Malabarba, P. A. Buckup, J. F. Pezzi da Silva, R. P. Vari, A. Harold, R. Benine, O. T. Oyakawa, C. S. Pavanelli, N. A. Menezes, C. A. S. Lucena, M. C. S. L. 
Malabarba, Z. M. S. Lucena, R. E. Reis, F. Langeani, L. Cassati, V. A. Bertaco, C.

Moreira \& P. H. F. Lucinda. 2003. Characidae, genera incertae sedis. Pp. 106-169. In:

Check List of the Freshwater Fishes of South and Central America. Reis, R. E., S. O. Kullander \& C. J. Ferraris Jr. (Eds.). Porto Alegre, Edipucrs, 729p.

Lima, F. C. T., H. A. Britski \& F. A. Machado. 2007. A new Moenkhausia (Characiformes: Characidae) from central Brazil, with comments on the area relationships between the upper rio Tapajós and upper rio Paraguai systems. Aqua, International Journal of Ichthyology, 13(2): 45-54.

Lima, F.C.T. \& L.M. Sousa. 2009. A new species of Hemigrammus from the upper rio Negro basin, Brazil, with comments on the presence and arrangement of fin hooks in the genus (Ostariophysi: Characiformes: Characidae). Aqua, International Journal of Ichthyology 15 (3): 153-168.

Lucena, C. A. S. 1987. Revisão e redefinição do gênero neotropical Charax Scopoli, 1777 com a descrição de quatro espécies novas (Pisces, Characiformes, Characidae). Comunicações do Museu de Ciências e Tecnologia da PUCRS, 40: 5-124.

Lucena, C. A. S. 1993. Estudo Filogenético da Família Characidae com uma Discussão dos Grupos Naturais Propostos (Teleostei, Ostariophysi, Characiformes). Tese de doutorado não publicada, Universidade de São Paulo, São Paulo, 158p.

Lucena, C. A. S. \& N. A. Menezes. 1998. A phylogenetic analysis of Roestes Günther and Gilbertolus Eigenmann, with a hypothesis of the relationships of the Cynodontidae and Acestrorhynchidae (Teleostei: Ostariophysi: Characiformes). Pp. 261-277. In: Phylogeny and classification of Neotropical fishes. Malabarba, L. R., R. E. Reis, R. P. Vari, Z. M. S. Lucena \& C. A. S. Lucena (Eds.). Porto Alegre, Edipucrs, 603p. 
Maddison, W.P. \& D.R. Maddison. 2006. Mesquite: A modular system for evolutionary analysis. Version 1.1.

Machado-Allison, A. 1982. Estudios sobre la subfamilia Serrasalminae (TeleosteiCharacidae). Parte I. Estudio comparado de los juveniles de las "cachamas" de enezuela (géneros Colossoma y Piaractus). Acta Biológica Venezuélica, 11(3): 1-102.

Machado-Allison, A. 1983. Estudios sobre la subfamília Serrasalminae (TeleosteiCharacidae). Parte II. Discusión sobre la condición monofilética de la subfamilia. Acta Biológica Venezuélica, 11(4): 145-196.

Machado-Allison, A. 1985. Estudios sobre la subfamília Serrasalminae. Parte III: sobre el estatus genérico y relaciones filogenéticas de los géneros Pygopristis, Pygocentrus, Pristobrycon y Serrasalmus (Teleostei-Characidae-Serrasalminae). Acta Biológica Venezuélica, 12(3): 19-42.

Machado-Allison, A. 1986. Osteología comparada del neurocráneo y branquicráneo en los géneros de la subfamilia Serrasalminae (Teleostei - Characidae). Acta Biológica Venezuélica, 12(Suppl. 2): 1-66.

Malabarba, L. R. \& S. H. Weitzman. 1999. A new genus and species of South American fishes (Teleostei: Characidae: Cheirodontinae) with derived caudal fin, including comments about inseminating cheirodontines. Proceedings of the Biological Society of Washington, 112(2): 410-432.

Malabarba, L. R. \& S. H. Weitzman. 2000. A new genus and species of inseminating fish (Teleostei: Characidae: Cheirodontinae: Compsurini) from South America with uniquely derived caudal-fin dermal papillae. Proceedings of the Biological Society of Washington, 113(1): 269-283. 
Malabarba, L. R. \& S. H. Weitzman. 2003. Description of a new genus with six species from southern Brazil, Uruguay and Argentina, with a discussion of a putative characid clade (Teleostei: Characiformes: Characidae). Comunicações do Museu de Ciências e Tecnologia da PUCRS, Série Zoologia, 16(1): 67-151.

Malabarba, L. R. 1998. Monophyly of the Cheirodontinae, characters and major clades (Ostariophysi, Characidae). Pp. 193-234. In: Phylogeny and classification of Neotropical fishes. Malabarba, L. R., R. E. Reis, R. P. Vari, Z. M. S. Lucena \& C. A. S. Lucena (Eds.). Porto Alegre, Edipucrs, 603p.

Mattox, G. M. T. \& M. Toledo-Piza. 2012. Phylogenetics study of the Characinae (Teleostei: Characiformes: Characidae). Zoological Journal of the Linnean Society, 165: 809-915.

\section{Mendonça et al. xenuro}

Menezes, N. A. 2003. Family Acestrorhynchidae. Pp. 231-233. In: Check List of the Freshwater Fishes of South and Central America. Reis, R. E., S. O. Kullander \& C. J. Ferraris Jr. (Eds.). Porto Alegre, Edipucrs, 729p.

Menezes, N. A. \& S. H. Weitzman. 2009. Systematics of the neotropical fish subfamily Glandulocaudinae (Teleostei: Characiformes: Characidae). Neotropical Ichthyology, 7(3): 295-370.

Menezes, N. A., Ferreira, K. M. \& A. L. Netto-Ferreira. 2009. A new genus and species of inseminating characids fish from the rio Xingu basin (Characiformes: Characidae).Zootaxa, 2167: 47-48.

Mirande, J.M. 2010. Phylogeny of the family Characidae (Teleostei: Characiformes): from characters to taxonomy. Neotropical Ichthyology 8(3): 385-568. 
Moraes Filho, M.B. \& O. Schubart. 1955. Contribuição ao estudo do dourado (Salminus maxillosus Val.) do Rio Mogi Guassu (Pisces, Characidae). Ministério da Agricultura, Divisão de Caça e Pesca, São Paulo, 130 pp., 13 prs.

Moreira, C. R. 2002a. Relações Filogenéticas em Iguanodectinae (Teleostei; Characiformes; Characidae). Dissertação de Mestrado não publicada, Universidade de São Paulo, São Paulo, 276p.

Moreira, C. R.; Landim, M. I.; Costa, W. J. E. M. 2002b. Hyphessobrycon heliacus: a new characid fish (Ostariophysi: Characiformes) from the upper Rio Tapajós basin, Central Brazil. Copeia, (2): 428-432.

Moreira, C. R., Lima, F. C. T \& Costa, W. J. E. M. 2002c. Hyphessobrycon moniliger: a new characid fish from rio Tocantins basin, Central Brazil (Ostariophysi: Characiformes). Ichthyol. Explor. Freshwaters, 13(1): 73-80.

\section{Moreira 2005. xenuro}

Moreira, C. R. 2007. Relações Filogenéticas na Ordem Characiformes (Teleostei: Ostariophysi). Tese de Doutorado, não publicada. Museu de Zoologia da Universidade de São Paulo, 485p.

Nelson, G. \& Platnick, N. 1981. Systematics and biogeography, cladistics and vicariance. Columbia University Press, New York. 567 pp.

Oliveira, C, Avelino, G. S, Abe, K. T., Mariguela, Benine, R. C., Ortí, G. Vari, R. P. \& M. C., Castro. 2011. Phylogenetic relationships within speciose family Characidae (Teleostei: OStariophysi: Characiformes) based on multilocus analysis and extensive ingroup sampling. BMC Evolutionary Biology. 11:275. 
Ortí, G., P. Petry, J. I. R. Porto, M. Jégu \& A. Meyer. 1996. Patterns of nucleotide change in mitochondrial ribosomal RNA genes and the phylogeny of piranhas. Journal of Molecular Evolution, 42(2): 169-182.

Ortí, G. \& A. Meyer. 1997. The radiation of characiform fishes and the limits of resolution of mitochondrial ribosomal DNA sequences. Systematic Biology, 46(1): 75-100.

de Pinna, M. C. C. 1991. Concepts and tests of homology in the cladistic paradigm. Cladistics, v.7, p. 367-394.

Rapp Py-Daniel., L. h. \& Cox-Fernandes, C. 2005. Dimorfismo sexual em Siluriformes e Gymnotiformes (Ostariophysi) da Amazônia. Acta Amazonica. 35(1): 97-110.

Reis, R. E. 1989. Systematic revision of the Neotropical characid subfamily Stethaprioninae (Pisces, Characiformes). Comunicações do Museu de Ciências e Tecnologia da PUCRS, Série Zoologia, 2(6): 3-86.

Rieppel, O. 1988. Fundamentals of Comparative Biology. Birkhäuser Verlag, Basel.

Roberts, T. R. 1973. The glandulocaudine characid fishes of the Guayas basin in western Equador. Bull. Mus. Comp. Zool. 144: 489-514.

Rosen, D. E. 1972. Origin of the characid fish genus Bramocharax and a description of a second, more primitive, species in Guatemala. American Museum Novitates, 2500: 121.

Taylor, W. R. \& Van Dyke, G. C. 1985. Revised procedures for staining and clearing small fishes and other vertebrates for bone and cartilage study. Cybium, 9: 107-119.

Toledo-Piza, M. 2000. The Neotropical fish subfamily Cynodontinae (Teleostei: Ostariophysi: Characiformes): a phylogenetic study and a revision of Cynodon and Rhaphiodon. American Museum Novitates, 3286, 1-88. 
Toledo-Piza, M. 2003. Family Cynodontidae. Pp. 234-237. In: Check List of the Freshwater Fishes of South and Central America. Reis, R. E., S. O. Kullander \& C. J. Ferraris Jr. (Eds.). Porto Alegre, Edipucrs, 729p.

Toledo-Piza, M. 2007. Phylogenetic relationships among Acestrorhynchus species (Ostariophysi: Characiformes: Acestrorhynchidae). Zoological Journal of the Linnean Society, 151(4): 691-757.

Uj, A. 1990. Etude Comparative de l'Osteologie Cranienne dês Poissons de la Familie des Characidae et son Importance Phylogenetique. Tese de doutorado não publicada. Université de Geneve, Geneve, 247p.

Vari, R. P. \& A. S. Harold. 1998. The genus Creagrutus (Teleostei: Characiformes: Characidae): Monophyly, relationships, and undetected diversity. Pp: 245-260. In: Phylogeny and classification of Neotropical fishes. Malabarba, L. R., R. E. Reis, R. P. Vari, Z. M. S. Lucena \& C. A. S. Lucena (Eds.). Porto Alegre, Edipucrs, 603p.

Vari, R. P. \& A. S. Harold. 2001. Phylogenetic study of the Neotropical fish genera Creagrutus Günther and Piabina Reinhardt (Teleostei: Ostariophysi: Characiformes), with a revision of the cis-Andean species. Smithsonian Contributions to Zoology, 613: $1-239$.

Vari, R. P. \& H. Ortega. 2000. Attonitus, a new genus of sexually dimorphic characiforms (Ostariophysi, Characidae) from western Amazonia; a phylogenetic definition and description of three new species. Ichthyological Exploration of Freshwaters, 11(2): 113140.

Vazzoler, A. E. 1996. Biologia da reprodução de peixes teleósteos: teoria e prática. EDUEM, Maringá. 280pp. 
Von Hireng, R. \& Azevedo, P. 1936. As piábas dos açudes nordestinos (Characidae, Tetragonopterinae). Arch. Inst. Biol., 7:75-106 + 12 est.

Weitzman, S. H. 1962. The osteology of Brycon meeki, a generalized characid fish, with an osteological definition of the family. Stanford Ichthyogical Bulletin, 8(1): 3-77.

Weitzman, S. H. 1977. A new species of characoid fish, Hyphessobrycon diancistrus, from the Río Vichada, Orinoco River drainage, Colombia, South America (Teleostei: Characidae). Proceedings of the Biological Society of Washington, 90(2): 348-357.

Weitzman, S.H. \& W.L. Fink. 1983. Relationships of the neon tetras, a group of South American freshwater fishes (Teleostei, Characidae), with comments on the phylogeny of New World characiforms. Bulletin of the Museum of Comparative Zoology, 150(6): 339-395.

Weitzman, S. H. \& S. V. Fink. 1985. Xenurobryconin phylogeny and putative pheromone pumps in Glandulocaudinae fishes (Teleostei: Characidae). Smithsonian Contributions to Zoology, 421: 1-119.

Weitzman, S.H. \& L. Palmer. 1997a. A new species of Hyphessobrycon (Teleostei: Characidae) from the Neblina region of Venezuela and Brazil, with comments on the putative 'rosy tetra clade'. Ichthyological Exploration of Freshwaters, 7(3): 209-242.

Weitzman, S. H.; Palmer, L. 1997b. The Bleeding-heart Rosy Tetras. Tropical Fish Hobbyist, 46(1): 166-171.

Weitzman, S. H. \& L. R. Malabarba. 1998. Perspectives about the phylogeny and classification of the Characidae. Pp. 161-170. In: Phylogeny and classification of Neotropical fishes. Malabarba, L. R., R. E. Reis, R. P. Vari, Z. M. S. Lucena \& C. A. S. Lucena (Eds.). Porto Alegre, Edipucrs, 603p. 
Weitzman, S. H. \& L. R. Malabarba. 1999. Systematics of pintherobolus (Teleostei: Characidae: Cheirodontinae) from eastern Brazil. Ichthyological Exploration of Freshwaters, 10(1): 1-43.

Weitzman, S. H. \& N. A. Menezes. 1998. Relationships of the tribes and genera of the Glandulocaudinae (Ostariophysi, Characiformes, Characidae) with the description of a new genus, Chrysobrycon. Pp. 171-192. In: Phylogeny and classification of Neotropical fishes. Malabarba, L. R., R. E. Reis, R. P. Vari, Z. M. S. Lucena \& C. A. S. Lucena (Eds.). Porto Alegre, Edipucrs, 603p.

Weitzman S. H., N. A. Menezes, H. G. Evers \& J. R. Burns. 2005. Putative elationships among inseminating and externally fertilizing characids, with a description of a new genus and species of Brazilian inseminating fish bearing an anal-fin gland in males (Characiformes: Characidae). Neotropical Ichthyology, 3(3): 329-360.

Wiley, E.O. 1981. Phylogenetics: the theory and practice of phylogenetic systematics. John Wiley \& Sons, New York. vi+439 pp.

Wiley E.O., Siegel-Causey, D., Brooks, D.R., \& Funk, V.A. 1991. The complete cladist. A primer of phylogenetic procedures. The University of Kansas, Lawrence. 158 pp.

Zanata, A. M. 1997. Jupiaba, um novo gênero de Tetragonopterinae com osso pélvico em forma de espinho (Characidae, Characiformes). Iheringia, Série Zoologia, 83: 99-136.

Zanata, A. M. 2000. Estudo das Relações Filogenéticas do Gênero Brycon Muller \& Troschel, 1844 (Characidae; Characiformes). Tese de doutorado não publicada, Universidade de São Paulo, São Paulo, Brazil, 276p.

Zanata, A. M. \& R. P. Vari. 2005. The family Alestidae (Ostariophysi, Characiformes): a phylogenetic analysis of a trans-Atlantic clade. Zoological Journal of the Linnean Society, 145(1): 1-144. 
Museu de Zoologia

Universidade de São Paulo

PROGRAMA DE PÓS-GRADUAÇÃO EM SISTEMÁTICA, TAXONOMIA

E BIODIVERSIDADE

\section{Errata da tese:}

"Evolução dos caracteres sexuais secundários em Characidae (Teleostei:

Characformes)"

Tulio Franco Teixeira

Orientador: do Prof. Dr. Naércio Aquino Menezes

São Paulo 


\section{1 - Substituição do ítem "Agradecimentos" da tese pelo seguinte:}

“...bom, agora falta só agradecer...." - Mas gente, descobri que este "só", foi subestimar este processo. Eu, particularmente acredito que uma das maiores qualidades que um ser humano pode ter é a gratidão, esse sentimento é enaltecedor, é dar amor ao receber. Meu caros amigos, tenho para mim que todos os momentos, todos os atos, todas as coisas que ouvimos, falamos, sentimentos, enfim, todas as experiências que temos move um pouco a direção de nossa vida. Todos, definitivamente todos vocês contribuíram no processo de desenvolvimento pessoal e consequentemente profissional do TULIO que está aqui, pensando, neste momento. Peço a cada um que feche os olhos e lembrem de algum momento comigo, Lembrou?...saiba que este momento, mexeu comigo, me fez crescer como ser humano. Portanto, não acho que seria justo citar alguém em específico neste tópico, a não ser aqueles que contribuíram diretamente com o processo. Sendo assim, em primeiro lugar gostaria de agradecer ao professor Naércio A. Menezes, a quem respeito profundamente como cientista, mas ainda mais, e para mim mais mportante, como ser humano. Professor, muito obrigado por ter me recebido como aluno com a mente aberta e principalmente pelos exemplos através de atitudes, sempre se posicionando e absolutamente, implacavelmente fazendo de tudo em seu alcance para que tudo corra bem e com tranquilidade. É para mim, uma honra enorme conviver com um grande homem como o senhor, ver como o senhor trabalha e como lhe dá com as questões do dia a dia. Ao senhor, o meu muito obrigado. Saiba que estarei por perto pra aprender sempre mais e mais. Professor Heraldo A. Britski, outro grande ser humano que tive a oportunidade de conhecer. Professor Heraldo, ao senhor agradeço todos as longas conversas nos mais diversos âmbitos, sempre muito paciente, interessado e sempre com enorme ternura e atenção. Saiba que estas conversas 
forneceram elementos preciosos para meu desenvolvimento como ser humano. Logo, agradeço ao meu pequeno grande senhor Oswaldo Oyakawa. Meu grande Oswaldo, muito obrigado pela paciência e pelas, no momento certo, puxadas de orelha. É pra mim um grande prazer ter construído essa amizade com você. Gostaria de agradecer também aos meus amigos Vitor Abrahão (Fio de luz) e Murilo Pastana (Vavé). Meus amigos, de verdade, não há como agradecer a vocês pela imensa ajuda e paciência. Muitíssimo obrigado, estou aqui pra vocês sempre que precisarem. Por último, mas tão importante quanto, gostaria de agradecer ao meu irmão escolhido, Michel Giannetti (Titin). Meu irmão, sem você saber segurou meu braço nesse tempo que passamos juntos, sem saber iluminou o caminho quando o bicho estava pegando. Tenho sorte por sempre ter um ser de luz em todas as etapas de minha vida e nesta etapa foi você, agradecido demais.

Finalmente, meu agradecimento a eles, Francisco Donizete Teixeira, Emília Maria Franco Teixeira, Tales Franco Teixeira e Rafaela Franco Teixeira, a quem simplesmente eu devo a minha vida, meus princípios, meu caráter. Estas pessoas são a minha raiz, a minha inspiração, estão no meu ninho me mantendo quentinho sempre que chove, me mantendo protegido contra tudo. Você são os amores da minha vida, amo vocês de uma forma indescritível.

Com tudo, este projeto não seria viável sem o apoio financiamento da FAPESP: processo (2012/01263-2). 


\section{2 - Substituição do ítem "introdução" da tese pelo seguinte:}

\section{Introdução}

A ordem Characiformes compreende atualmente 2089 espécies válidas (Eschmeyer \& Fong, 2016). O número de famílias reconhecidas na ordem tem variado historicamente em decorrência das diferentes delimitações da família Characidae (Moreira, 2007), principalmente em relação à conceituação de Serrasalmidae, Acestrorhynchidae, Cynodontidae e Alestidae, que podem ser reconhecidas como famílias distintas ou apenas como subgrupos de Characidae (Machado-Allison, 1982; 1983, 1985, 1986; Uj, 1990; Lucena \& Menezes, 1998; Jégu, 2003; Malabarba e Weitzman, 2003; Menezes, 2003; Toledo-Pizza, 2000, 2003 e 2007; Calcagnotto et al.,2005; Zanata, 2005; Orti et al.,1996; Javonillo et al.,2010; Mirande, 2010; Oliveira et al.,2011).

Dentre todas as famílias, Characidae, com 1209 espécies válidas (Eschmeyer \& Fong, 2016) é, sem dúvida, a mais problemática, suas relações intra e interfamiliares dentro de Characiformes ainda não resolvidas. Isto se deve à imensa diversidade e variação morfológica presente em seus representantes. Os membros de Characidae (Sensu Mirande, 2010) variam entre alguns milímetros de comprimento padrão, como espécies de Cyanogaster Mattox et al., (2013) e Xenurobryconini (Weitzman \& Fink, 1985; Moreira, 2005), e mais de um metro de comprimento padrão, como é o caso de algumas espécies de Salminus (Lima \& Britski, 2007). Existe também uma variação enorme de hábitos alimentares, desde espécies carnívoras como as de Acestrorhynchus Eigenmann \& Kennedy 1903 (Silva \& Goitein, 2007) a espécies lepidófagas (que se alimentam de escamas) como as de Roeboides Günther 1864 (Novakowski \& Hahn, 2004). Os membros de Characidae apresentam também uma grande diversidade de hábitos reprodutivos, existindo 
espécies migradoras com fecundidade alta e período reprodutivo curto (e.g. Salminus Agassiz 1829) e espécies inseminadoras, que depositam pacotes de espermatozoides na luz do ovário das fêmeas (e.g. membros de Glandulocaudinae sensu Weitzman \& Menezes, 1998) (Vazzoler \& Menezes, 1992; Burns et al., 1995; Vazzoler, 1996; Weitzman et al., 2005; Azevedo, 2010). Tão impressionante quanto à diversidade do modo reprodutivo e provavelmente relacionada a esta, é a incrível variação de caracteres sexuais secundários presentes.

Embora alguns trabalhos, baseados tanto em caracteres morfológicos (Mirande, 2009, 2010) quanto em caracteres moleculares (Javonillo et al., 2010; Oliveira et al, 2011), incluindo um grande número de táxons terminais tenham sido realizadas, as relações intra e interfamiliares continuam muito controversas. Estes trabalhos, no entanto, corroboram o monofiletismo de um grupo caracterizado, principalmente, pela ausência do osso supra-orbital, um caráter aparentemente redutivo: (clado 204 de Mirande, 2010; Clado 37 de Oliveira et al.,2011; Clado A de Malabarba \& Weitzman, 2003 - semelhante ao "ortí clade" proposto em Ortí \& Meyer, 1997)

Weitzman \& Fink (1983), Weitzman \& Palmer (1997b) e Weitzman \& Malabarba (1998) resumiram as principais dificuldades enfrentadas por ictiólogos no estudo de relações intra e interfamiliares em Characidae: 1) grande diversidade aliada à relativa pouca divergência morfológica, 2) redução em tamanho, com consequente perda/truncamento de muitas estruturas por pedomorfose, 3) falta de boas séries de exemplares bem preservados e sexualmente desenvolvidos em coleções, e 4) necessidade de mais informação quanto ao colorido em vida e quanto à diversidade de caracteres sexuais secundários.

De fato, alguns grupos monofiléticos bem corroborados em Characidae apresentam caracteres relacionados ao dimorfismo sexual como sinapomorfia $[$ e.g. 
Xenurobryconini (Weitzman \& Fink, 1985), Glandulocaudainae (Menezes \& Weitzman, 2009), Compsurini (Malabarba, 1998; Jerep, 2011). Observamos também que embora tentativamente, sem análise filogenética, pequenos grupos supostamente monofiléticos, atualmente incluídos em Tetragonopterinae (sensu Mirande, 2010), como o grupo Rosy-Tetras (Weitzman \& Palmer, 1997ª), grupo Hyphessobrycon loweae (Ingeninto et al., 2013), grupo Hemigrammus ocellifer (lima \& Sousa, 2009) e o grupo Hemigrammus bleheri, H. rhodostomus e Petitella gerogiae (Lima \& Sousa, 2009) foram propostos baseado no compartilhamento de caracteres sexuais secundários e colorido.

De modo geral, caracteres sexuais secundários são aqueles que diferenciam machos de fêmeas da mesma espécie, que não estão diretamente relacionados ao processo reprodutivo e que são selecionados através de seleção sexual (Darwin, 1871). Os caracteres sexuais secundários encontrados em Characidae são, basicamente, relacionados ao tamanho, comprimento e formato das nadadeiras, presença e distribuição de ganchos (= órgão de contato de Wiley \& Collette, 1970 e Collette, 1977) nos raios de nadadeiras e estruturas associadas, glândula branquial, modificações de escamas e raios de nadadeiras, modificação de raios procurrentes ventrais e padrão de colorido. Em Characidae a condição dimórfica relacionada ao formato do corpo pode estar associada tanto a diferenças no comprimento padrão, as fêmeas geralmente maiores que os machos: Salminus (Moraes \& Schubart, 1955; Cordiviola, 1966; Godoy, 1975; Lima, 2006) e Astyanax Baird \& Girard 1854 (Von Ihering \& Azevedo, 1936; Andrade et al.,1984) ou na altura e comprimento do pedúnculo caudal: Hyphessobrycon negodagua (Lima \& Gerhard, 2001) e quase todos os membros de Glanulocaudinae (Menezes \& Weitzman, 2009).

Dimorfismo sexual quanto ao comprimento e formato das nadadeiras tem sido bastante discutido, principalmente em gêneros incertae sedis: Hyphessobrycon Durbin 
1908 (Weitzman \& Palmer, 1997a,b; Costa \& Géry, 1994; Moreira, et al.,2002b,c; Teixeira et al, 2013), em gêneros da tribo Compsurini (Malabarba, 1998), em gêneros atualmente alocados em Stevardiinae sensu Mirande (2010), Bryconadenos (Weitzman et al.,2005), Attonitus (Vari \& Ortega, 2000) e Bryttanichthys (Weitzman et al.,2005) e todos os gêneros de Glandulocaudinae (Menezes \& Weitzman, 2009).

A presença de ganchos nas nadadeiras é um dos caracteres sexuais secundários mais evidentes dentro da família. Ganchos são processos desenvolvidos na superfície de segmentos individuais dos raios, podendo diferir em forma, posição e possivelmente função entre as espécies que os apresentam (Malabarba \& Weitzman, 2003). Segundo Roberts (1973) a primeira referência a ganchos foi feita por Jenyns (1842) quando mencionou a presença de "asperities" nas nadadeiras de Cheirodon (= Astyanax scabripinnis). Naquela ocasião, que aparentemente constitui a primeira menção de caracteres sexuais secundários em Characidae, Jenyns (1842) concluiu que essas estruturas representavam um caráter dimórfico presente nos machos, mas não fez menção alguma quanto ao formato ou distribuição destas estruturas. Foi Eigenmann (1908 - 1929) o primeiro a referir-se a estas estruturas, atribuindo forma e distribuição nas nadadeiras, usando inclusive como caracteres diagnósticos de chaves de identificação de espécies. Eigenmann referiu-se a estas estruturas como "Hooklets" (tradução para espínula), na descrição de Gymnocorymbus thayeri, mas logo referiuse a elas (Eigenmann 1908) em Moekhausia ceros como "hooks" (tradução para ganchos). Desde então, a presença de ganchos foi mencionada e/ou descrita em vários trabalhos, principalmente os que contém descrição de novos táxons.

Outra estrutura bastante interessante é a glândula branquial, resultante de modificações dos filamentos branquiais anteriores do primeiro arco branquial de machos maduros e, possivelmente, relacionadas à liberação de feromônio (Burns \& Weitzman, 1996; Bushman et al.,2002). A distribuição, morfologia e propostas de 
homologia das glândulas branquiais foram extensamente estudadas em Characidae (Bushmane et al., 2002; Oliveira et al., 2012; Terán et al., 2014).

Os caracteres sexuais secundários se mostraram extremamente informativos em análises filogenéticas, sustentando grupos bem corroborados, principalmente aqueles incluídos tradicionalmente em Glandulocaudinae (sensu Weitzman \& Menezes, 1998). No entanto, embora tenha havido um notável avanço no conhecimento dos caracteres sexuais secundários em Characidae, nota-se que grande parte dos estudos se restringem aos táxons com caracteres sexuais secundários mais evidentes, mais especializados e em grupos muito pouco inclusivos, muitas vezes compostos por menos de cinco espécies.

O estudo dos caracteres sexuais secundários realizado no presente estudo, revelou padrões interessantes, pouco explorados, principalmente em taxons incertae sedis em Characidae (sensu Lima et al., 2003). Foi possível, também, verificar tendências de especialização em grupos monofiléticos bem corroborados, como Glandulocaudinae (sensu Weitzman \& Menezesm, 2009) e Stevardiinae (sensu Ferreira et al., 2011). Estas observações e a comprovada informação filogenética dos caracteres sexuais secundários na resolução de grupos em níveis menos inclusivos em Characidae, levaram-me a realizar uma análise anatômica comparada detalhada de alguns destes caracteres de forma abrangente em grupos da família Characidae com o intuito de fornecer informações que, quando analisadas em conjunto com caracteres de outros complexos anatômicos, auxiliem na resolução de grupos cuja relações continuam controversas na literatura. 


\section{3 - Substituição do ítem "Material e Métodos" da tese pelo seguinte:}

\section{Material e Métodos}

\section{Seleção dos grupos estudados}

A lista de material examinado é apresentada na TABELA I. A classificação de Characidae utilizada nesta contribuição segue Mirande (2010). Sendo assim, a escolha dos táxons baseou-se, primariamente, nas espécies que Mirande (2010) considerou basais ou derivadas em seu esquema filogenético. Dentre estas, prioridade foi dada a espécies representantes de todos os grupos menos inclusivos previamente apontados na literatura e pelos especialistas do respectivo grupo como portadoras de caracteres sexuais secundários. Nos grupos com propostas filogenéticas disponíveis [e.g. Characinae (Mattox \& Toledo-Piza, 2012), Cheirodontinae (Jerep, 2011), Stevardiinae (Ferreira et al., 2011 e Thomaz et al., 2015)], sempre que possível, foram analisados táxons em diferentes níveis de inclusão na filogenia. Um total 79 representantes da ordem Characiformes foram analisados, 3 representantes da família Crenuchidae, 2 representantes da família Gasteropelecidae, 1 representante de Serrasalmidae e 73 representantes de Characidae. Dentre os representantes da família

Characidae foram analisados 2 representantes de Aphyocharacinae, 3 de Aphyoditeinae, 7 do Astayanax Clade, 7 do grupo Astyanax scabripinnis, 1 do Bramocharax Clade, 1 de Bryconinae, 1 do Bryconops Clade, 5 de Characinae, 7 de Cheirodontinae, 2 de Heterocharacinae, 2 do Hyphessobrycon luetkenii Clade, 1 de Iguanodectinae, 1 do Pseudochalceus Clade, 1 de Rhoadsiinae, 2 de Salmininae, 17 de Tetragonopterinae e 13 de Stevardiinae.

Todo o material examinado pertence à coleção ictiológica do Museu de Zoologia da Universidade de São Paulo. 


\section{Nomenclatura anatômica}

A nomenclatura osteológica seguiu Weitzman (1962). Aos ganchos (tradução para "hooks") de Eigenmann (1908) e órgão de contato (tradução para "contact organ”) de Wiley \& Collette (1970) nos referimos como processos ósseos, já que como veremos a seguir apresentam formatos diferentes que por si só podem vir a ser caracteres informativos filogeneticamente. Os processos ósseos são definidos neste trabalho como projeções ósseas que se desenvolvem da face externa de cada segmento de hemitriquium, seguindo definição de (Malabarba \& Weitzman, 2003).

\section{Caracteres sexuais secundários analisados}

Os caracteres estudados nesta contribuição são: tamanho, medido através do maior comprimento padrão; formato de nadadeiras; processos ósseos, glândula abranquial e órgão caudal.

\section{Preparações anatômicas e anatomia comparada}

Para descrição e análise anatômica comparada dos caracteres sexuais secundários neste trabalho, a utilização de exemplares adultos maduros com os caracteres em seu estado ótimo de desenvolvimento é imprescindível. Como observado ao longo do trabalho, existe uma certa variação intrasexual no desenvolvimento de alguns dos caracteres, principalmente com relação aos processos ósseos. Alguns machos possuem hipertrofia dos processos ósseos, seja em sua forma ou em sua distribuição nos raios e nadadeira, apresentando uma condição que naturalmente não representa a expressão ótima na espécie. A análise de um macho hipertrofiado com certeza afetaria os resultados da análise. Sendo assim, no intuito de entender a variação existente e definir o estado que melhor representa cada espécie, 
uma análise anatômica comparada intrasexual exaustiva incluindo o máximo possível de machos de cada espécie e sempre que possível de lotes coletado em períodos e locais diferentes foi realizada.

Após a definição do exemplar cujo estádio de desenvolvimento dos caracteres sexuais secundários represente a espécie, este era inserido em uma solução de alizarina Red S com álcool 70\% para corar os raios, processos ósseos, escamas e as glândulas branquiais.

O formato dos processos ósseos em cada espécie se baseou no maior processo ósseo da nadadeira. Para isto, o raio da nadadeira como maiores processos ósseos foi desarticulados dos interradiais. Logo o hemitriquium esquerdo e direito no caso das nadadeiras ímpares ou dorsal e ventral no caso das nadadeira pares foram separados e acomodados em uma plataforma de KY em uma placa de Petri para fotografia. Para a análise e descrição da glândula branquial, os ossos hiomandibular, opérculo, inter e subopéruclo, infraorbitais, maxilar, dentário e prémaxilar foram desarticulados do lado direto da cabeça. A descrição e medidas dos processos ósseos e glândula branquial foram realizadas através de imagens realizadas em uma lupa de automontagem (Leica MZ16 com câmera acoplada). Todos os caracteres foram sempre que possível ilustrados.

\section{Descrição dos processo ósseos.}

Como mencionado acima, o raio das nadadeiras com maiores processos ósseos foi utilizado para a descrição dos mesmos. No caso das nadadeiras ímpares, o hemitriquium esquerdo foi utilizado sempre que possível e no caso das nadadeiras pares, o hemitriquium ventral, com exceção dos membros de Crenuchidae. Os processos ósseos, em algumas espécies, se distribuem em quase todos os segmentos da nadadeira. A descrição desta distribuição acabou se tornando bastante complicada 
uma vez que o raio ramificado apresenta várias bifurcações e cada ramo destas bifurcações se bifurca mais uma vez. Para facilitar o entendimento destas descrições, sugerimos a observação do esquema apresentado (Fig. 1). Na descrição dos processos ósseos apresentamos referências anatômicas como proximais ou distais, anterior ou posterior e lateral ou medial.

A referência a proximal ou distal está sempre relacionada às bifurcações (ver Fig.1), onde proximal e distal equivalem à base e extremidade dos raio respectivamente, por exemplo: raios ramificados com processos ósseos presentes tanto em segmentos proximais quanto distais à primeira bifurcação.

Como pode ser observados também na Figura 1, após cada bifurcação existem dois ramos, um anterior e outro posterior no caso das nadadeiras ímpares, ou lateral e medial no caso das nadadeiras pares. Sendo assim a referência a ramo anterior e/ou posterior ou lateral e/ou medial está sempre relacionada à posição da nadadeira em relação ao eixo horizontal do corpo dos exemplares, por exemplo: 1 - Distalmente à segunda bifurcação do ramo posterior da primeira bifurcação, os processos ósseos estão presentes em todos os segmentos do ramo posterior e em até três segmentos do ramo anterior, a partir do segundo segmento distal à bifurcação neste ramo (no caso da nadadeira anal) e 2 - Distalmente à segunda bifurcação do ramo medial da primeira bifurcação, os processos ósseos estão presentes em todos os segmentos do ramo medial e em até três segmentos do ramo lateral, a partir do segundo segmento distal à bifurcação neste ramo (no caso da nadadeira anal).

Quanto à referencia a medial e lateral dos raios vale ressaltar que, quando é em relação à nadadeira anal por exemplo, lateral é a face externa do hemitriquium, ou seja em direção ao observador e a medial a face interna do hemitriquium. Isto é suficiente para descrever o local de inserção dos processos ósseos no segmento, por exemplo: processos ósseos inseridos na face láteroposterior do segmento em relação à 
nadadeira. Neste caso, a localização láteroposterior está relacionada à posição anatômica da nadadeira anal.

Já a referência a lateral e medial em relação ao raio é diferente. Neste caso, a posição anatômica é relacionada ao eixo proximodistal do segmento em que está inserido e consequentemente do raio no qual o segmento faz parte. Como podemos ver na figura 1, existe uma linha no centro do segmento dos raios da nadadeira; esta é a linha mediana que, ao se afastar, desta linha está se direcionando lateralmente e ao se aproximar, medialmente. Esta foi a premissa utilizada para descrever a direção de curvatura e desenvolvimento pós-curvatura dos processos ósseos, por exemplo: Ao longo de seu comprimento total, os processos ósseos apresentam uma curvatura de $45^{\circ}$ em relação ao eixo proximodistal do segmento no qual está inserido e desenvolvem-se em direção proximomedial em relação ao eixo do segmento em que está inserido. 
4 - Substituição do item "Sumário" da tese pelo seguinte.

\section{Sumário}

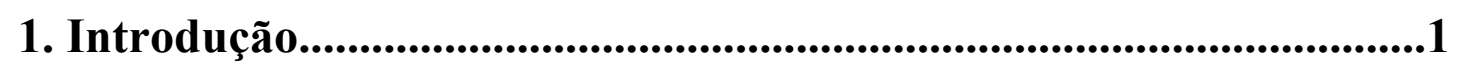

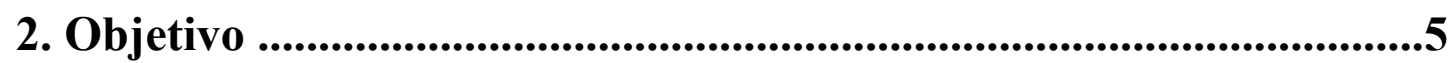

3. Material e Método....................................................................................6

4. Resultado e discussão..................................................................10

Descrição dos caracteres sexuais secundários e anatomia comparada.............10

Caracteres sexuais secundários em Characiformes...........................................349

Caracteres morfométricos..................................................................................349

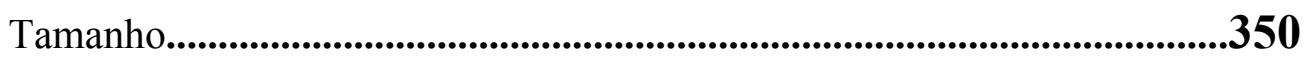

Formato de nadadeiras.............................................................................351

Nadadeira anal....................................................................................................351

Nadadeira pélvica....................................................................................................359

Nadadeira caudal ......................................................................................................360

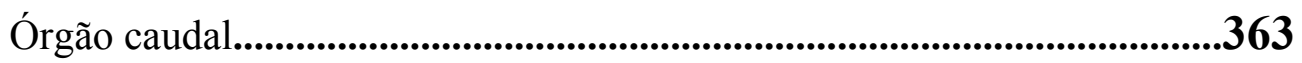

Caracteres estruturais............................................................................366

Processos ósseos nas nadadeiras...........................................................366

Processos ósseos na nadadeira ana1....................................................................372

Forma dos processos ósseos.......................................................................381

Distribuição dos processos ósseos no raio ramificado com maior número de segmentos com processos ósseos na nadadeira

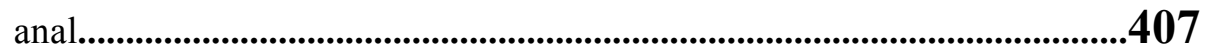

Distribuição dos processos ósseos na nadadeira anal.....................................417

Processos ósseos na nadadeira pélvica................................................................425

5. Considerações finais......................................................................................427

6. Referências Bibliográficas.........................................................................428 
5 - Acréscimo das seguintes referências no item "Referências Bibliográficas".

Almirón, A. E., Casciotta, M. Azpelicueta, M. \& Cione, A. L. A new species of Hypobrycon (Characiformes: Characidae) from Uruguay basin in Missiones, Argentina. Neotropica (La plata), (47): 33-40.

Arcila, D., Vari. R. P. \& N. A. Menezes. 2013. Revision of the Neotropical Genus Acrobrycon (Ostariophysi: Characiformes: Characidae) with description of Two new species. Copeia, 4: 604-611.

Benine, R. C. \& G. A. M. Lopes. 2008. A new species of Hyphessobrycon (Characiformes: Characidae) from río Portuguesa, río Orinoco basin, Venezuela. Zootaxa, 1747: 61-68.

Bussing, W. A. 1974. Pterobrycon myrnae, a remarkable new glandulocaudine characid fish from Costa Rica. Revista de Biología Tropical, 22(1): 135-159.

Castro, R. M. C., Ribeiro, A. C., Benine, R. C. \& A. L. Melo. 2003. Lophipbrycon weitzmani, a new genus and species of glandulocaudine fish (Characiformes: Characidae) from the rio Grande drainage, upper rio Paraná system, southeastern Brazil. Neotropical Ichthyology, 1(1): 11-19.

Chernoff, B. \& A. Machado-Alisson. 1990. Characid fishes of the genus Ceratobranchia, with descriptions of new species from Venezuela and Peru. Proceedings of the Academy of Natural Science of Philadelphia, 142: 261-290.

Collette, B. B. 1977. Epidermal breeding tubercles and bony contact organs in fishes. Symp. zoo. Soc. Lond, 39: 225-268.

Dahdul, W. M. 2007. Phylogenetics and diversification of the neotropical serrasalminae (ostariophysi: characiformes). Dissertação de Mestrado não publicada. Faculties of the University of Pennsylvania. 115p.

Darwin, C. 1871. The descent of man an selection in relation to sex. London, Murray.

Eschmeyer, W. N. \& J. D. Fong. 2016. Species by family/subfamily in the catalog of fihes.http://research.calacademy.org/redirect?url=http://researcharchive.calacad emy.or g/research/Ichthyology/catalog/SpeciesByFamily.asp.

Géry, J. 1965. Pissons characoids sud-américans du Senckemberg Muséum, II. Characidae et Crenuchidae de l'Igarapé Préto (Haute Amazonie). Seckembergiana Biological, 46(1): 11-45. 
Géry, J. 1966. A review of certain Tetragonopterinae (Characoidei), with the description of two new genera. Ichthyologica, the aquarium journal, 37(5): 21136.

Ferreira, K. M. Menezes. N. A. \& I. Quagio-Grassiotto. 2011. A new genus and two new species of Stevardiinae (Characiformes: Characidae) with a hypothesis on their relationships based on morphological and histologica data. Neotropical Ichthyology, 9(2): 281-298.

Ingenito, L. F. S., F. C. T. Lima \& P. A. Buckup. 2013. A new species of Hyphessobrycon (Characiformes: Characi- dae) from rio Juruena basin, Central Brazil, with notes on H. loweae Costa \& Géry. Neotropical Ichthyology 11:3344.

Jégu, M. 2004. Taxonomie des Serrasalminae phytophages et phylogenie des Serrasalminae (Teleostei: Characiformes: Characidae). These, Museum National D’Histoire Naturelle, Paris.

Lima F.C.T. 2006. Revisão taxonômica e relações filogenéticas do gênero Salminus (Teleostei: Ostariophysi: Characiformes: Characidae). Tese de doutorado não publicada, 253 pp. Universidade de São Paulo, São Paulo, Brasil.

Mahnert, V. \& Géry. J. 1988. Les genres Piabarchus Myers et Creagrutus Günther du Paraguay, avec la description de deux nouvelles espèces (Pisces, Ostariophysi, Characidae). Revue française d'Aquariologie Hépetologie, 15(1): 1-8.

Malabarba, L. R., Lima, F. C. T \& S. H. Weitzman. 2004. A new species of Koplotocheirodon (Teleostei: Characidae: Cheirodontinae: Compsurini) from Bahia, northeastern Brazil, with a new diagnosis of the genus. Proceedings of the Biological Society of Whashington, 117(3): 317-329.

Malabarba, L. R. \& F. C. Jerep. 2014. Review of the species of the genus Serrapinnus Malabarba 1998 (Teleostei: Characidae: Cheirodontinae) from the rio TocantinsAraguaia basin, with descritpion of three new species. Zootaxa, 3847(1).

Mendonça, M. B., Peixoto, L. A. W., Dutra. G. M. \& Netto-Ferreira, A. L. 2016. A new miniature of Xenurobryconini (Characiformes: Characidae) from the rio Tapajós basin, Brazil. Neotropical Ichthyology, 14(1): 45-52.

Menezes, N. A., Weitzman, S. H. \& J. R. Burns. 2003. A systematic review of Planaltina (Teleostei: Characiformes: Characidae: Glandulocaudinae: Diapomini) with a description of two new species from the upper rio Paraná, Brazil. Proceedings of the Biological Society of Washignton, 116(3): 557-600. 
Menezes, N. A., Netto-Ferreira, A. L. \& K. M. Ferreira. 2009. A new species of Bryconadenos (Characiformes: Characidae) from the rio Curuá, rio Xingú drainage, Brazil. Neotropical Ichthyology, 7(2): 147:152.

Menezes, N. A. \& S. H. Weitzman. 2011. A systematic review of Diapoma (Teleostei: Characiformes: Characidae: Diapomini) with descriptions of two new species from Southern Brazil. Papéis Avulsos de Zoologia, 51(5): 59-82.

Menezes, N. A., Weitzman, S. H. \& I. Quagio-Grassiotto. 2013. Two new species and a review of the ineminating freshwater fish genus Monotocheirodon (Characiformes: Characidae) from Peru and Bolivia. Papéis Avulsos de Zoologia, 53(10): 129-144.

Mirande, J. M., Aguilera, G. \& M. de las M. Azpelicueta. 2004. A new genus of small characid (Ostariophysi, Characid) from the upper río Bermejo basin, northwestern Argenina. Reveu Suisse de Zoologie, 111(4): 715-728.

Mirande, J. M. 2009. Weighted parsimony phylogeny of the Family Characidae (Teleostei: Characiformes). Cladistics, 25(6): 574-613.

Moreira, C. R. 2005. Xenurobrycon coracoralinae, a new glandulocaudine fish (Ostariophysi: Characiformes: Characidae) from central Brazil. Proceedings of the Biological Society of Washington, 118(4): 855-862.

Román-Valencia, C., Ruiz-C, R. I., Taphorn, D.C., P. Jiménez-Prado \& C. A. GarcíaAlzate. 2015. A new species of Bryconamericus (Characiformes, Stevardiinae, Characidae) from the pacific coast of northwestern Ecuador, South America. Animal Biodiversity and Conservation, 38(2).

Román-Valencia, C., García-Alzate, C. A., Ruiz-C, R. I. \& Taphorn, D. C. 2012. A new species of Tyttocharax (Characiformes: Characidae: Stevardiinae) from the Güeyer River, Orinoco River basin, Colombia. Neotropical Ichthyolgy, 10(3): 519-525.

Serra, J. P. 2003. Análise filogenética e revisão taxonômica de Hasemania (Characiformes, Characidae). Dissertação de mestrado não publicada, Universidade Estadual Paulista.

Serra, J. P. 2010. Análise filogenética das espécies de Hemigrammus Gill, 1858 (Characiformes: Characidae). Tese não publicada, Universidade estadual paulista. Teixeira, T. F. 2010. Revisão taxonômica das espécies de Hyphessobrycon Durbin do grupo rosáceos pingo-de-sangue (Ostariophysi: Characiformes: Characidae): 
comentários sobre biologia reprodutiva do grupo. Dissertação não publicada, Instituto Nacional de Pesquisas da Amazônia.

Teixeira, T. F., F. C. T. Lima \& J. S. Zuanon. 2013. A New Hyphessobrycon Durbin from the Rio Teles Pires, Rio Tapajós Basin, Mato Grosso State, Brazil (Characiformes: Characidae). Copeia 13(4):612-621.

Thomaz, A. T., Arcila, D. \& L. R. Malabarba. 2015. Molecular phylogeny of the subfamily Stevardiinae Gill 1858 (Characiformes: Characidae): classification and the evolution of reproductive traits. BMC Evolutionary Biology, 15: 146.

Vanegas-Rios, J. A., Azpelicueta, M. M. \& H. Ortega. Chrysobrycon eliasi, new species of stevardiine fish (Characiformes: Characidae) from the río Madre de Dios and upper río Manuripe basins, Peru. Neotropical Ichthyology, 9(4): 731740 .

Vanegas-Rios, J. A., Azpelicueta, M. M. \& H. Ortega. Chrysobrycon yoliae, a new species of stevardiine (Characiformes: Characidae) from the Ucayali basin, Peru. Neotropical Ichthyology, 12(2): 291-300.

Weitzman, S. H. 1985. Hyphessobrycon elachys, a new miniature characid from eastern Paraguay (Pisces: Characiformes). Proceedings of the Biological Society of Washington, 98(4): 799-808.

Weitzman, S. H. \& R. P. Vari. 1987. Two new species and a new genus of miniature characid fish (Teleostei: Characiformes) from northern South America. Proceedings of the Biological Society of Washignton, 100(3): 640-652.

Weitzman, S. H., Fink, S. V., Machado-Allison, A. \& L. Royero. 1994. A new genus and species of Glandulocaudinae (Teleostei: Characidae) from southern Venezuela. Ichthyological Exploration of Freshwaters, 5(1): 45-64.

Wiley, M. L. \& B. B. Collette. 1970. Breeding tubercles and contact organs in fishes: their occurrence, structure, and significance. Bulletin of the American Museum of Natural History 143 (3): 145-215.

Zarske, A. 2010. Der Kolibrisalmler Trochilocharax ornatos gen. et spec. nov. ein neuer Slamler aus Peru (Teleostei: Characiformes: Characidae). Vertebrate Zoology, 60(2): 75-98. 
Apêndice 


\section{Família}

Crenuchidae 


\section{CHARACIDIINAE}

Characidium xanthopterum Silveira, Langeani, Graça, Pavanelli \& Buckup

\section{8}

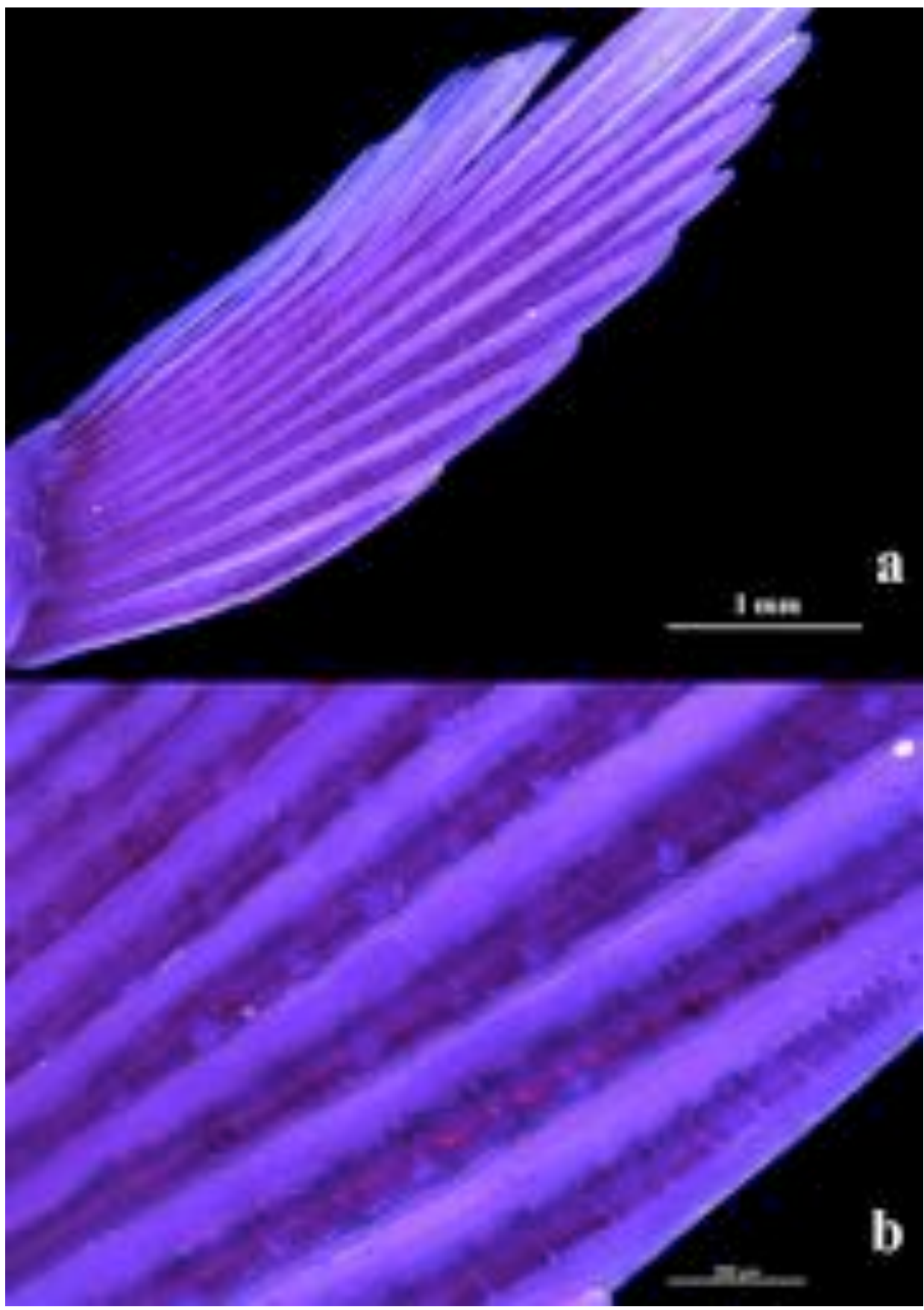

Figura 3. Nadadeira peitoral de macho de Characidium xanthopterum em vista dorsal (a) e detalhe em vista dorsal (b), evidenciando a distribuição dos processos ósseos. 


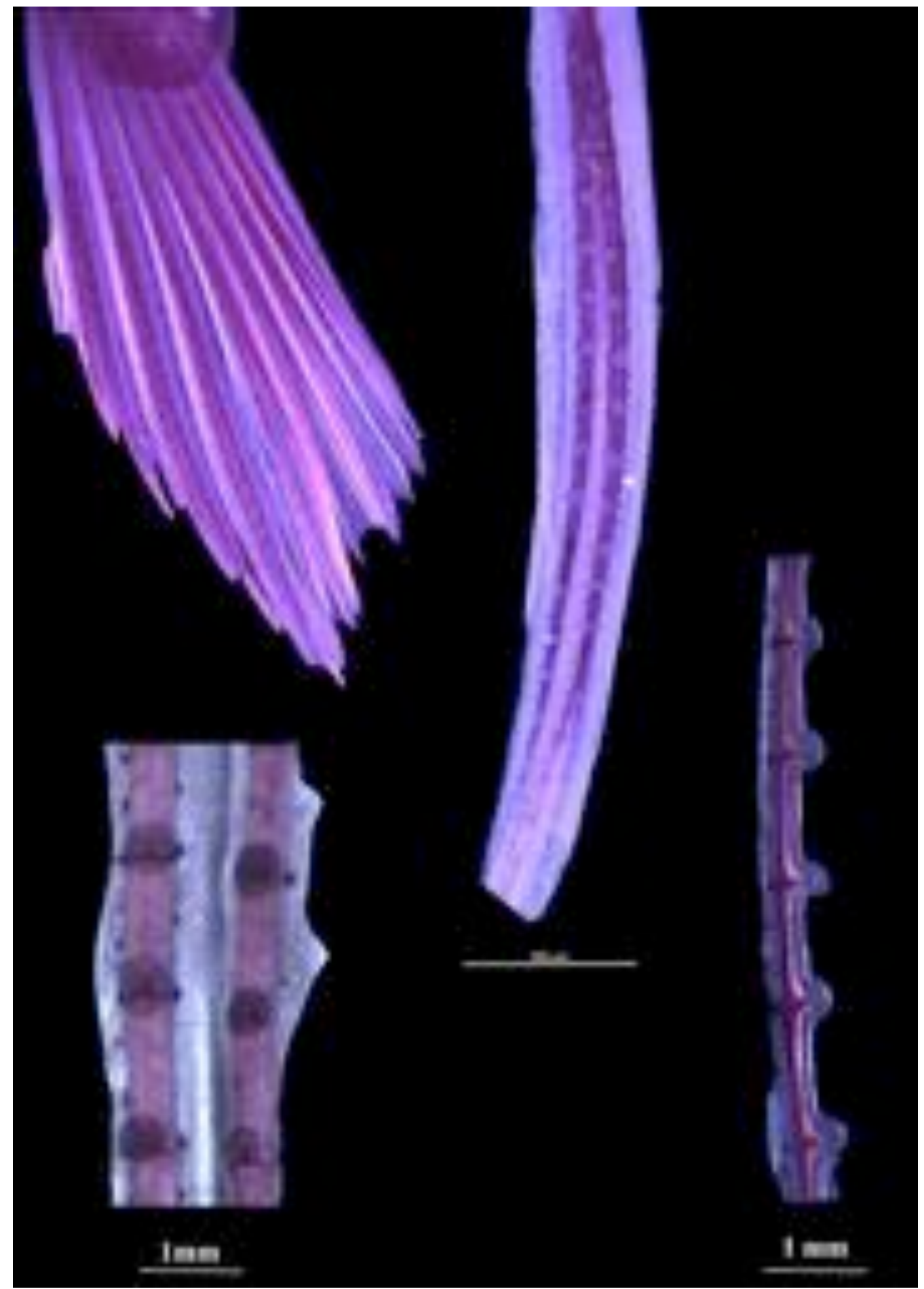

Figura 4. Nadadeira pélvica de macho de Characidium xanthopterum em vista dorsal (canto superior esquerdo), raio ramificado em vista dorsal (central), detalhe dos processos ósseos em vista dorsal (canto inferior esquerdo) e detalhe dos processos ósseos em vista lateromedial (Canto inferior direito). 
Characidium xavante Graça, Pavanelli \& Buckup 2008

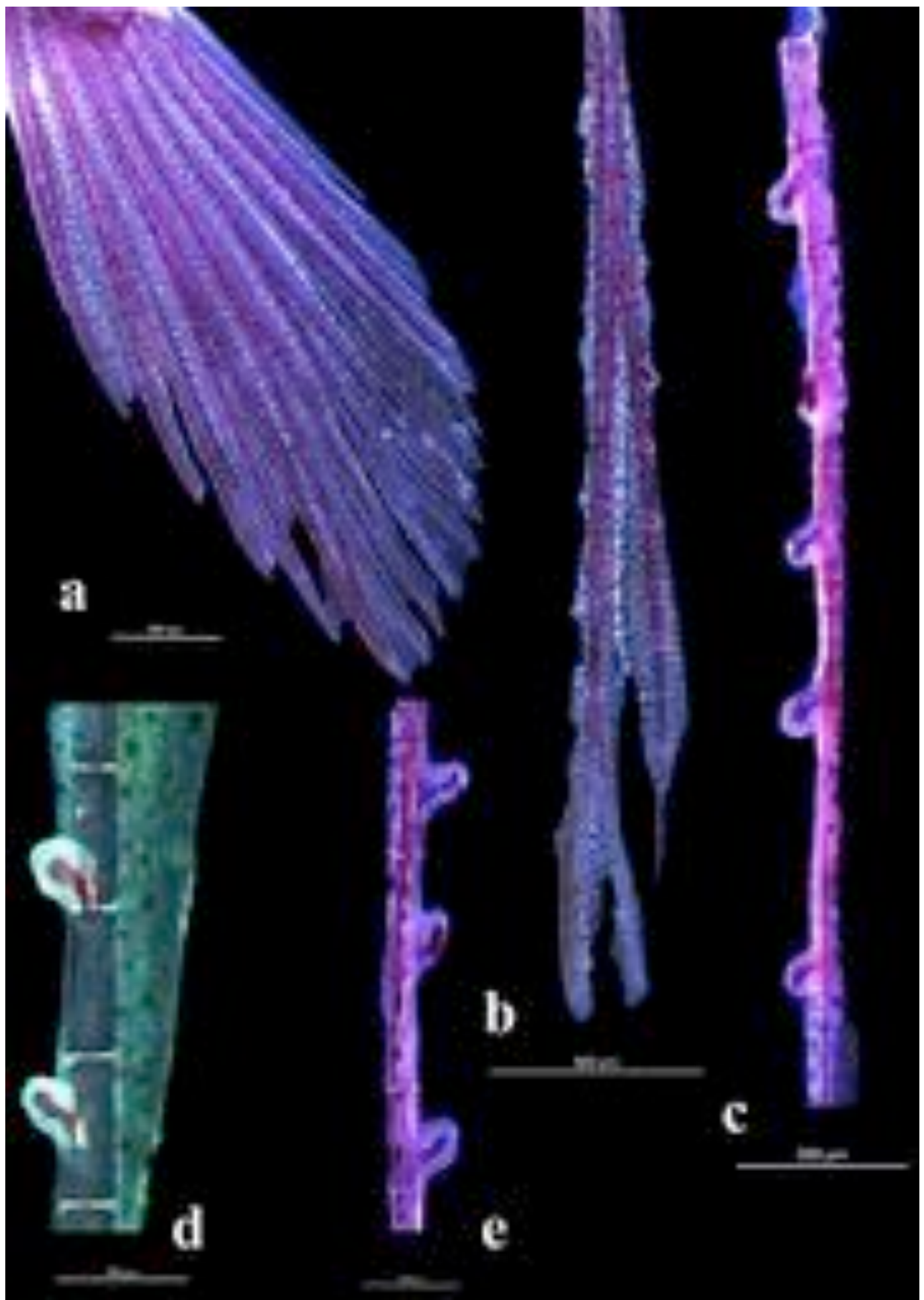

Figura 5. Nadadeira pélvica de macho de Characidium xavante em vista dorsal (a) vista dorsal do raio ramificado (b), vista lateromedial (c), detalhe em vista dorsal (d) e detalhe em vista lateromedial 


\section{Família}

Gasteropelecidae 


\section{Carnegiella strigatta (Gunther 1864)}

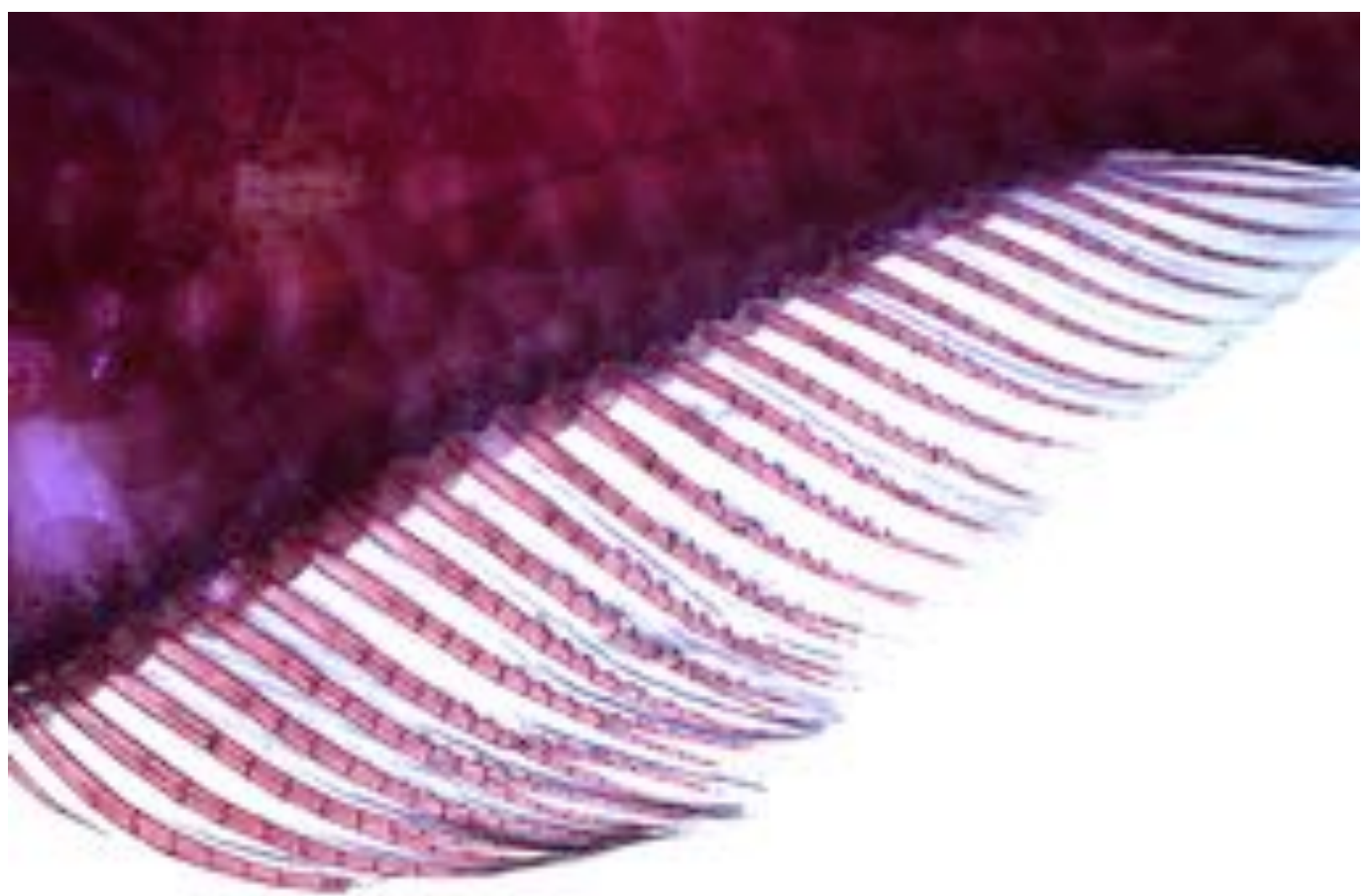

Figura 6. Nadadeira anal de machos de Carnegiella strigata em vista lateral esquerda, evidenciando o formato do perfil da margem distal da nadadeira e distribuição dos processos ósseos. 

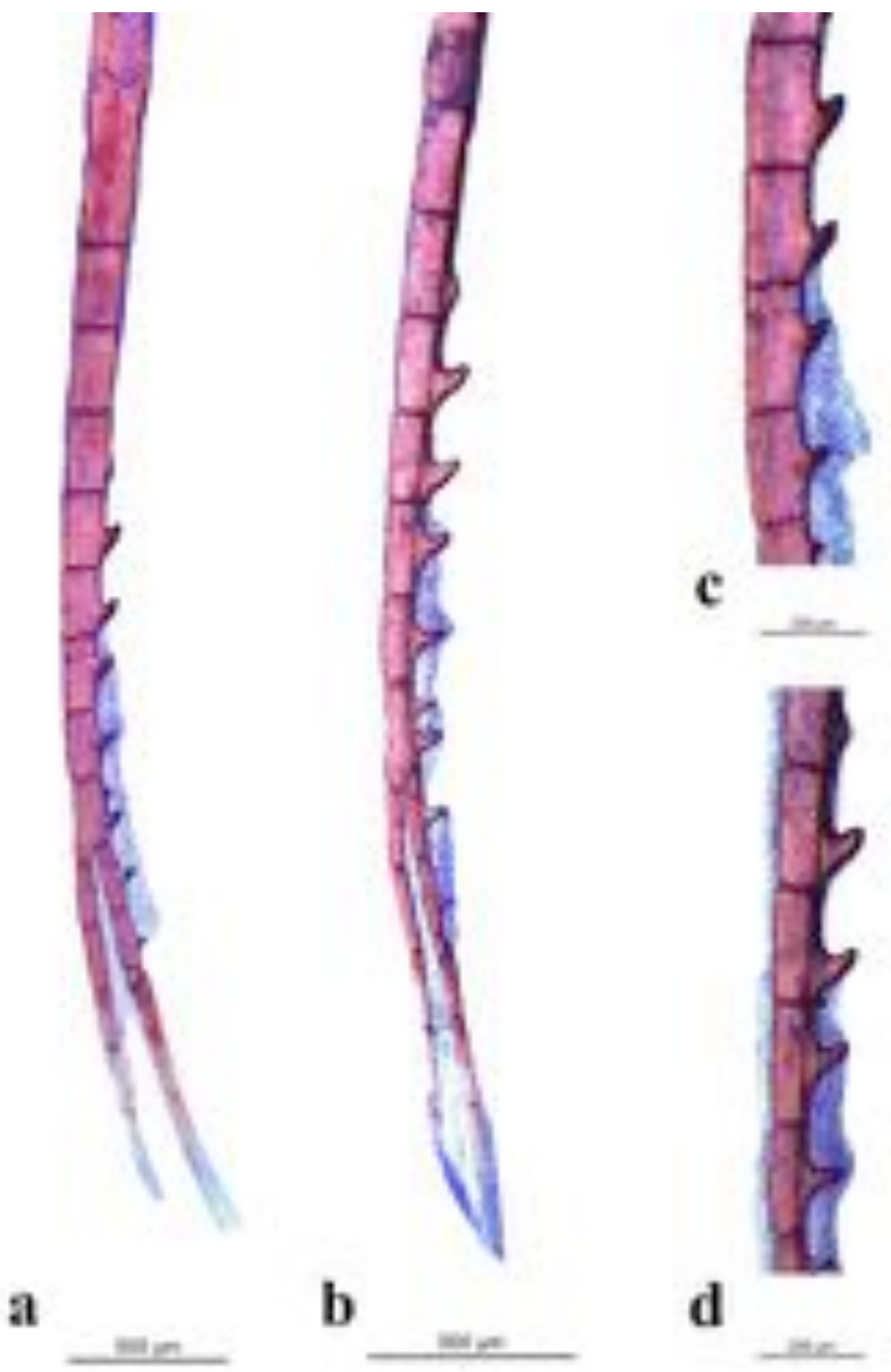

Figura 7. Distribuição, posição e formato dos processos ósseos no hemitriquium esquerdo do raio ramificado da nadadeira anal de machos de Carnegiella strigata. (a) vista lateral, (b) vista anteroposterior, (c) detalhe em vista lateral e (d) detalhe em vista anteroposterior. 
Thoracocharax stellatus (Kner 1858)

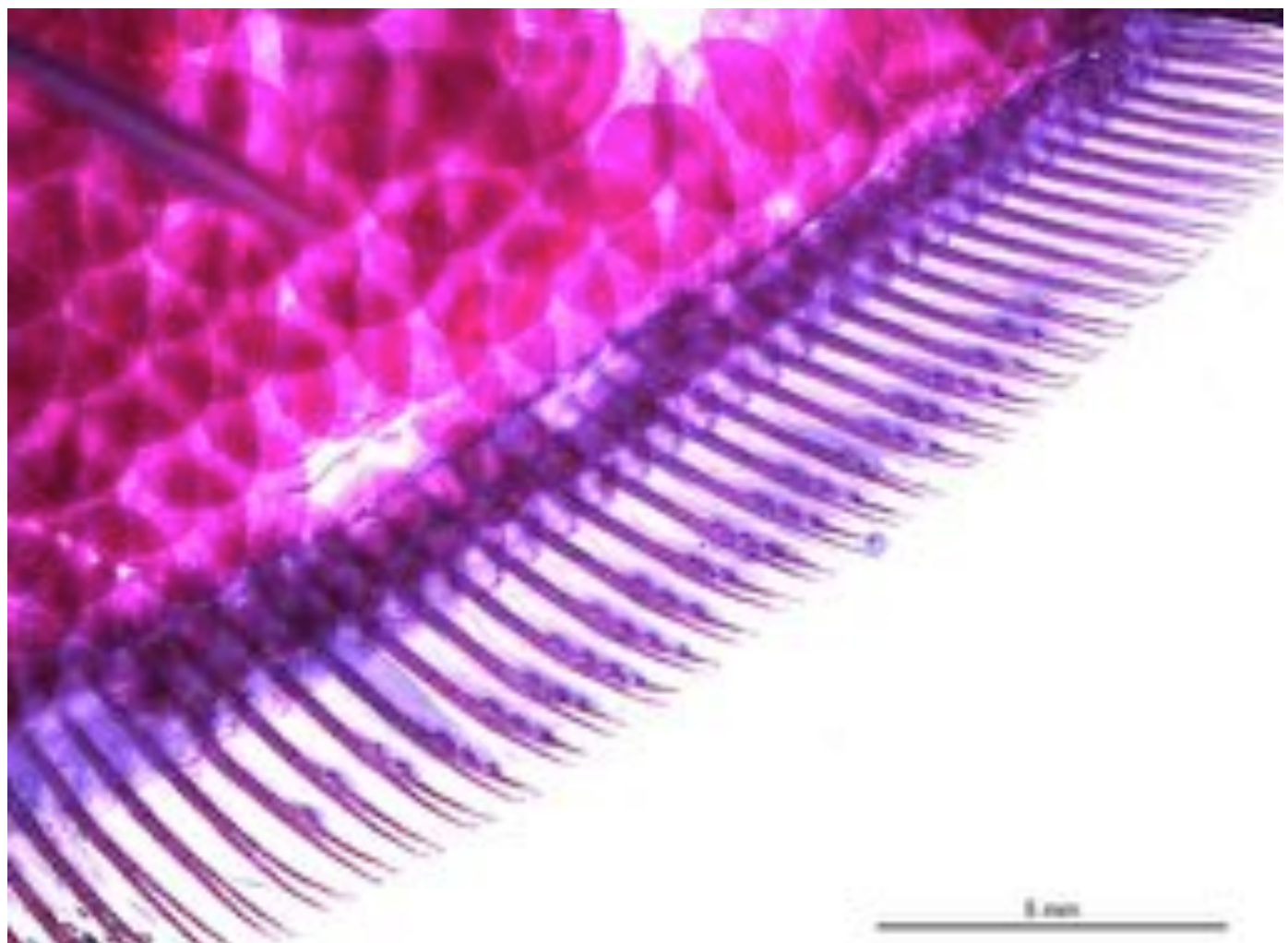

Figura 8. Nadadeira anal de machos de Thoracocharax stellatus em vista lateral esquerda, evidenciando o formato do perfil da margem distal da nadadeira e distribuição dos processos ósseos. 

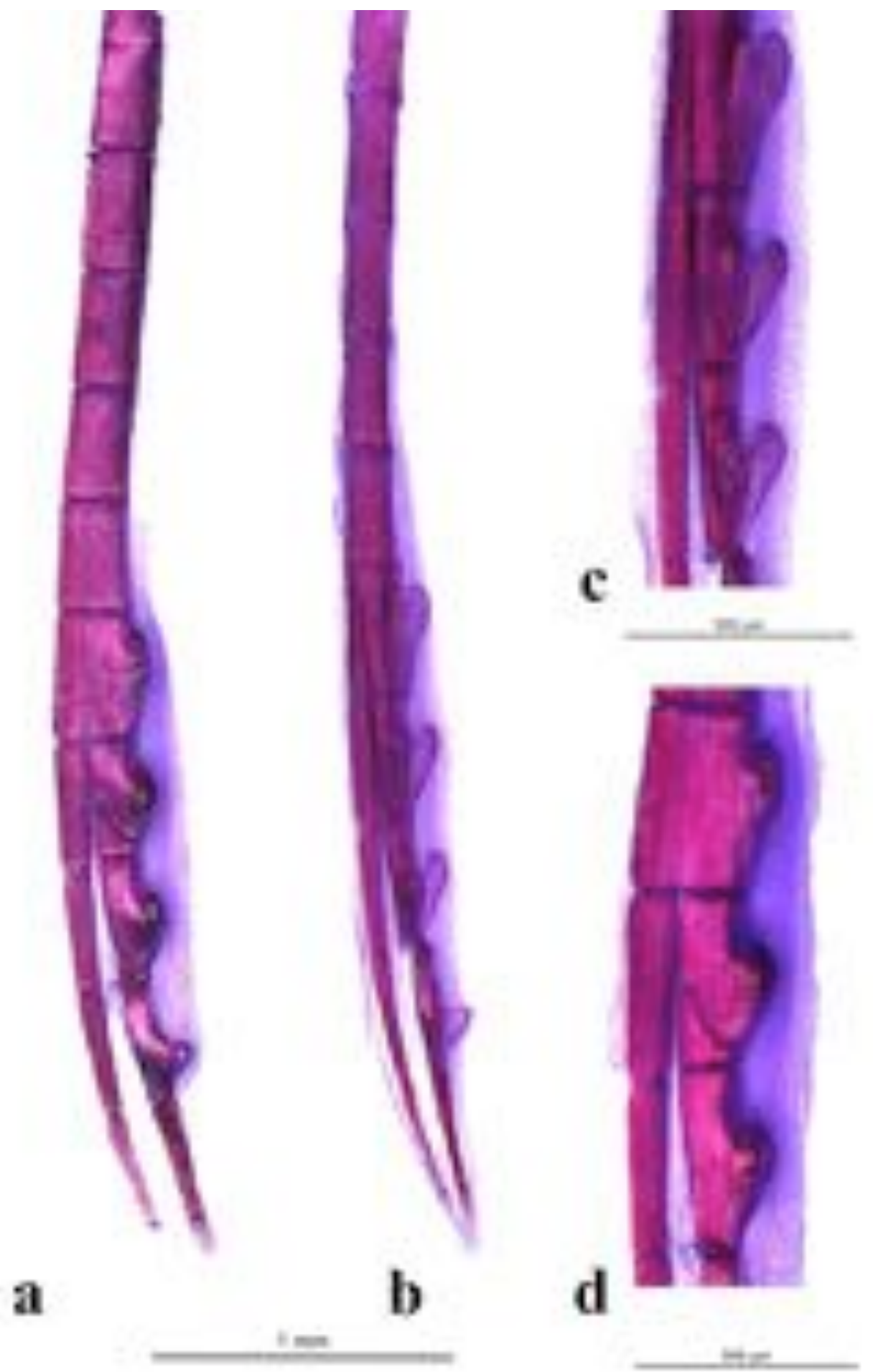

Figura 9. Distribuição, posição e formato dos processos ósseos no hemitriquium esquerdo do raio ramificado da nadadeira anal de machos de Thoracocharax stellatus. (a) vista lateral, (b) vista anteroposterior, (c) detalhe em vista lateral e (d) detalhe em vista anteroposterior. 


\section{Família}

Serrasalmidae 


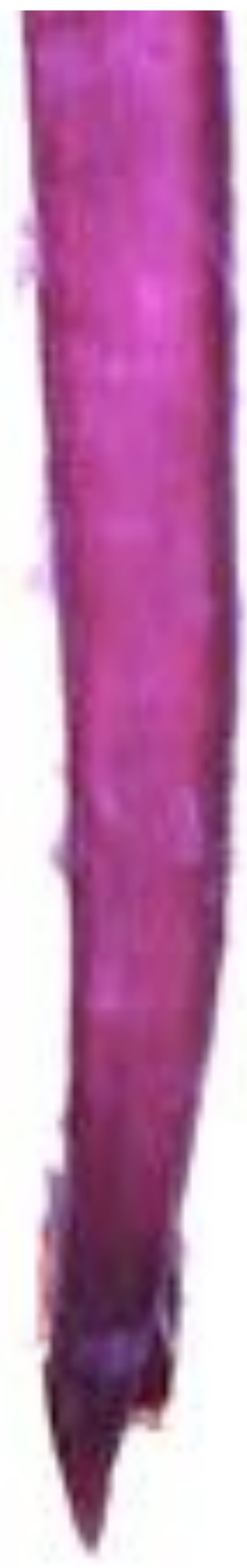

a

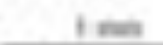

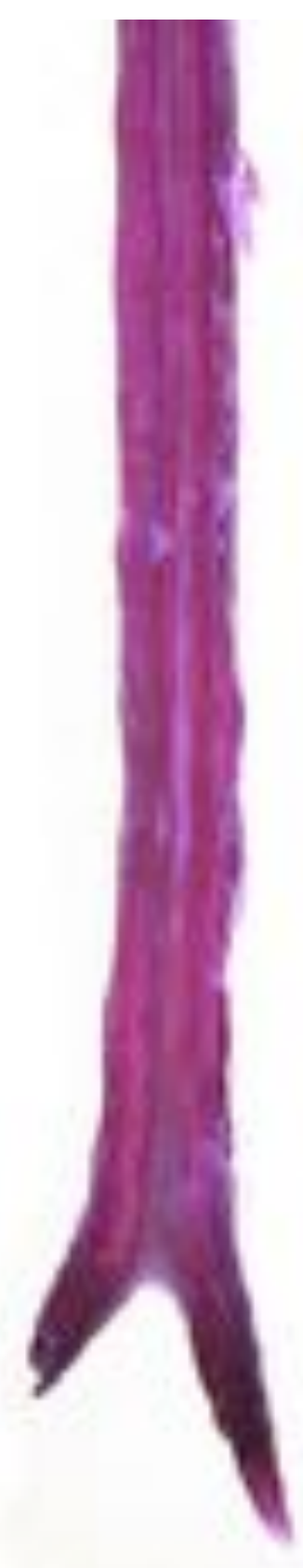

b

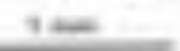

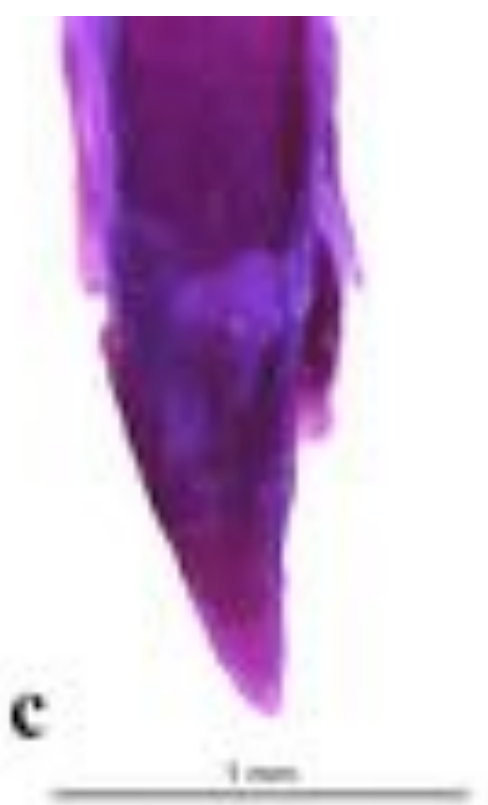

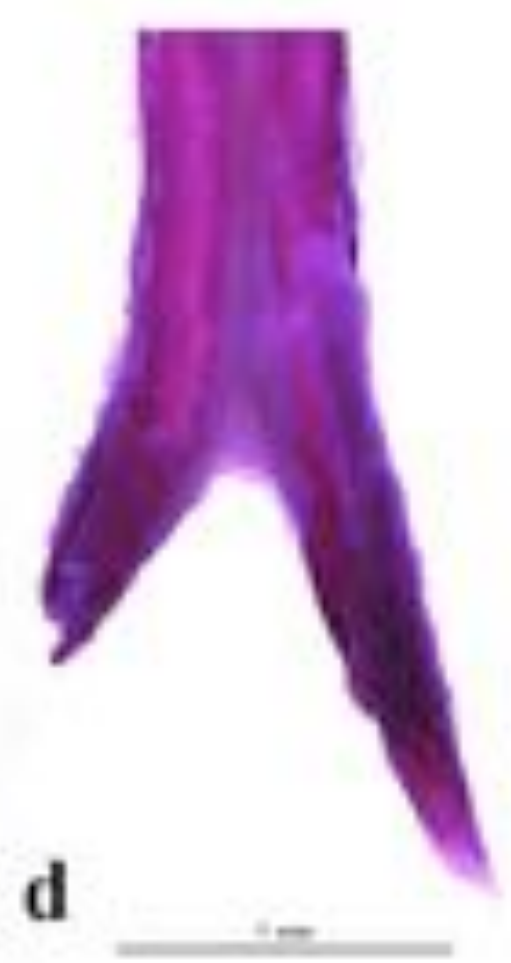

Figura 10. Porção anterior da nadadeira anal de machos de Myloplus rubripinnis. (a) distribuição e orientação das duas formas de processos ósseos e (b) detalhe da primeira forma (lappet) nos raios anteriores. 


\section{Família}

\section{Characidae}




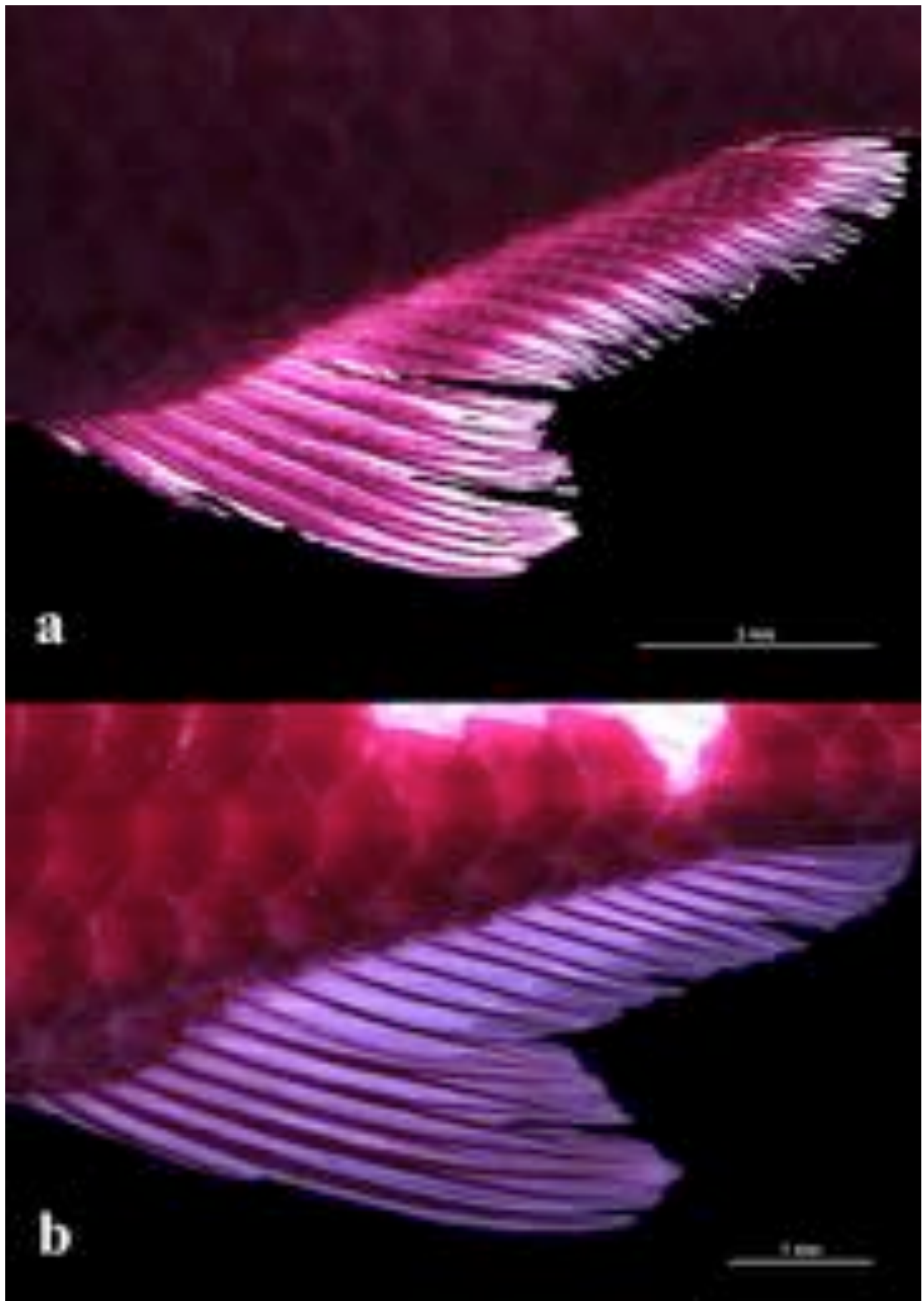

Figura 11. Nadadeira anal de machos (a) e de fêmeas (b) de Aphyocharax anisitsi em vista lateral esquerda, evidenciando o formato do perfil distal das nadadeiras nos dois sexos e distribuição dos processos ósseos na nadadeira anal de macho. 


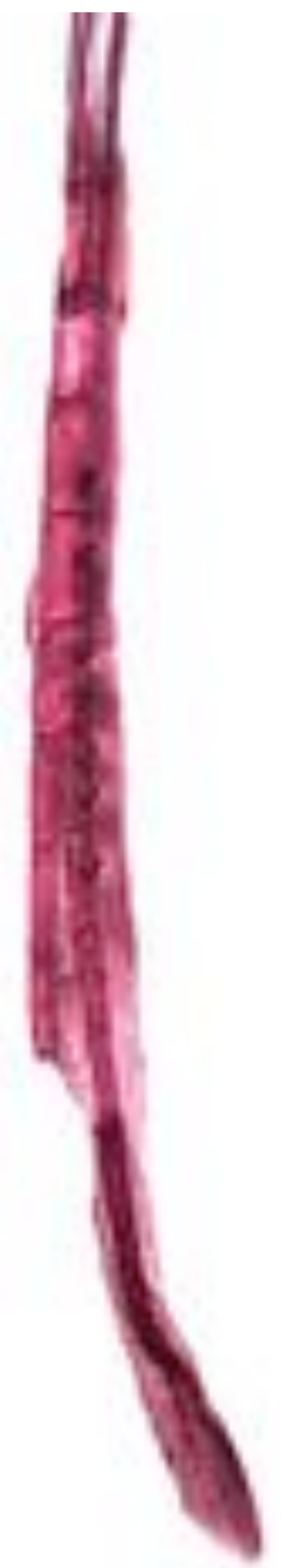

a

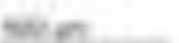

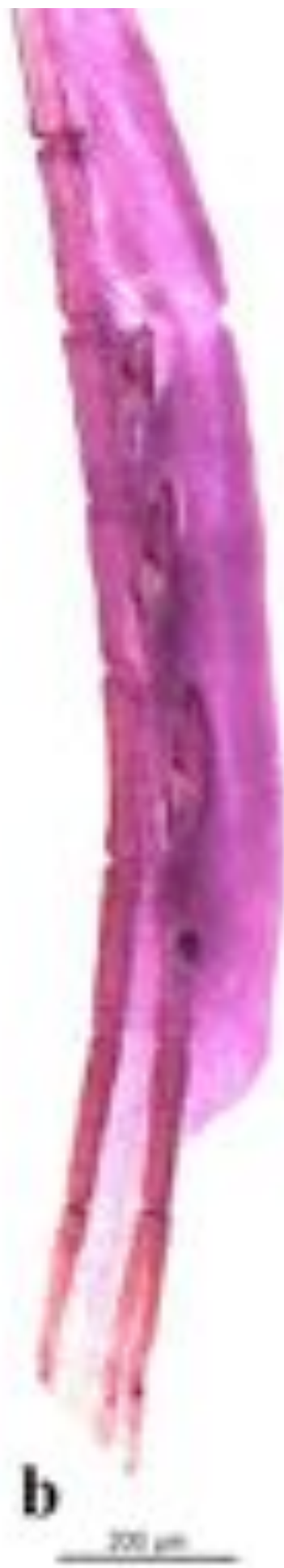

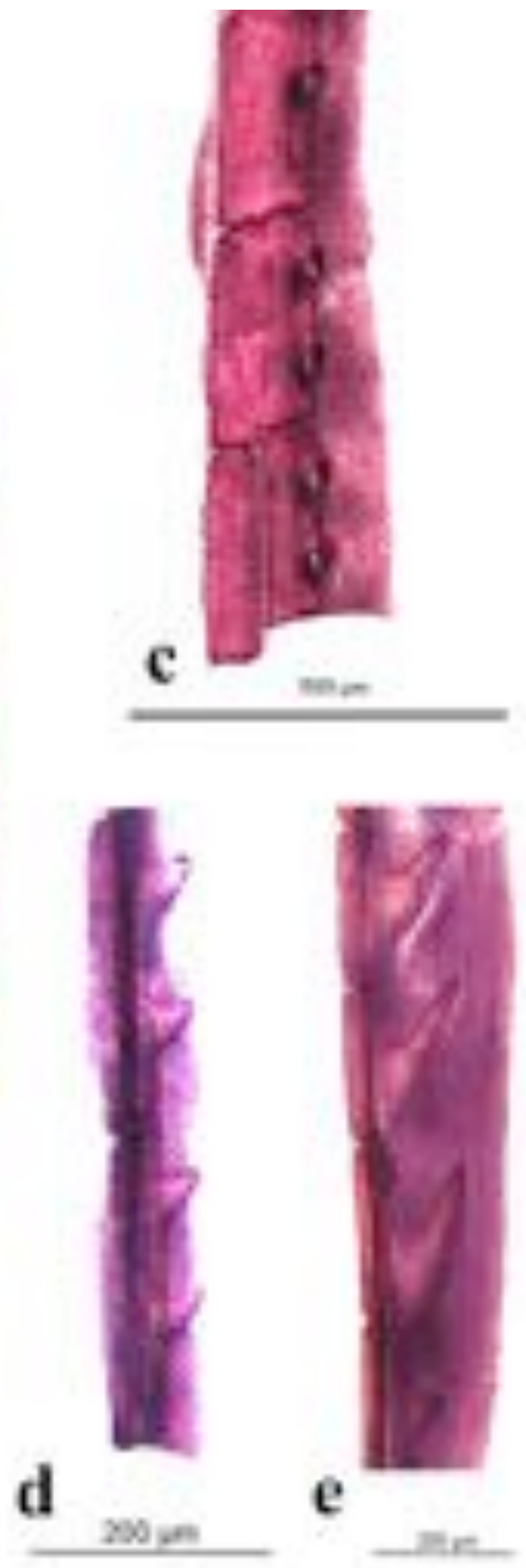

Figura 12. Distribuição, posição e formato dos processos ósseos no hemitriquium esquerdo do raio ramificado da nadadeira anal de machos de Aphyocharax anisitsi. (a) vista lateral do primeiro raio ramificado, (b) vista lateral do décimo sexto raio ramificado, (c) detalhe em vista lateral do primeiro raio ramificado, (d) detalhe em vista anteroposterior do primeiro raio ramificado e (e) detalhe em vista anteroposterior do décimo sexto raio ramificado. 


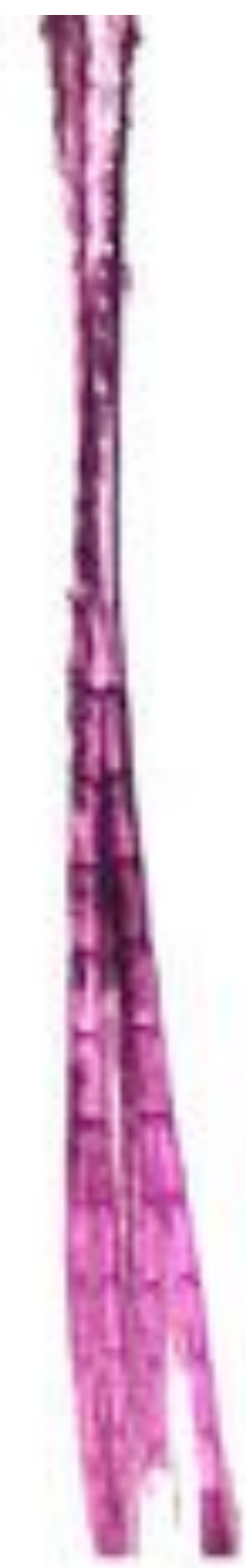

a

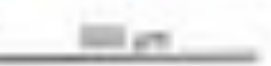

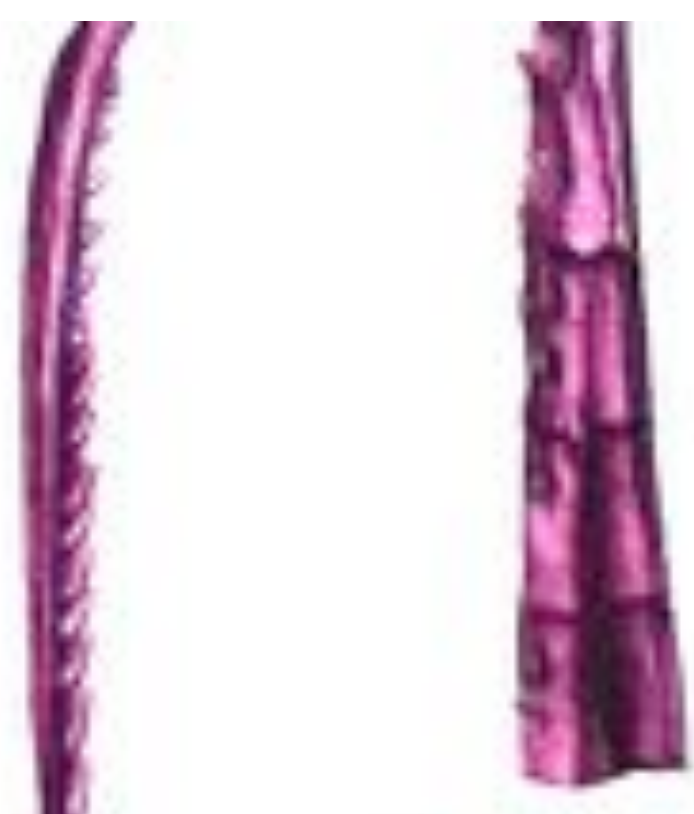
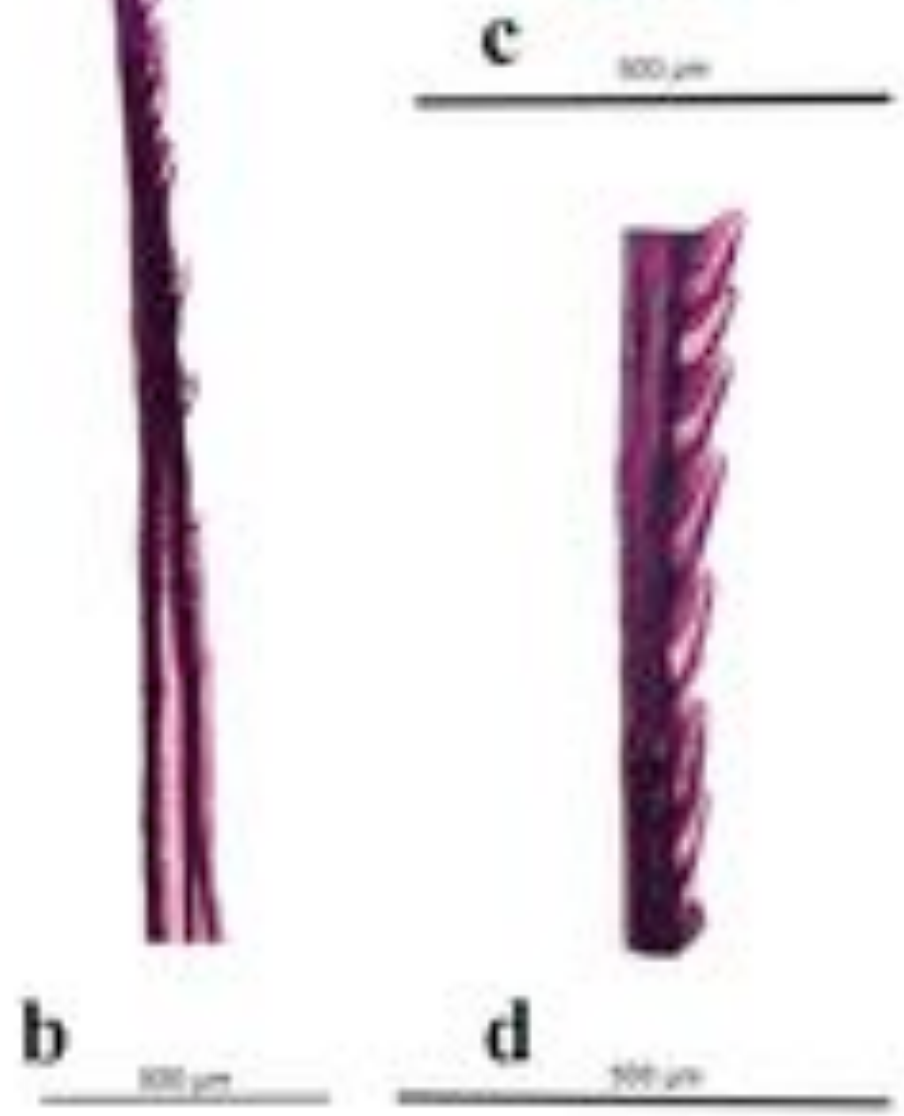

Figura 13. Distribuição, posição e formato dos processos ósseos no hemitriquium ventral da nadadeira pélvica esquerda de machos de Aphyocharax anisitsi. (a) vista ventral, (b) vista lateromedial, (c) detalhe em vista ventral e (d) detalhe em vista lateromedial. 


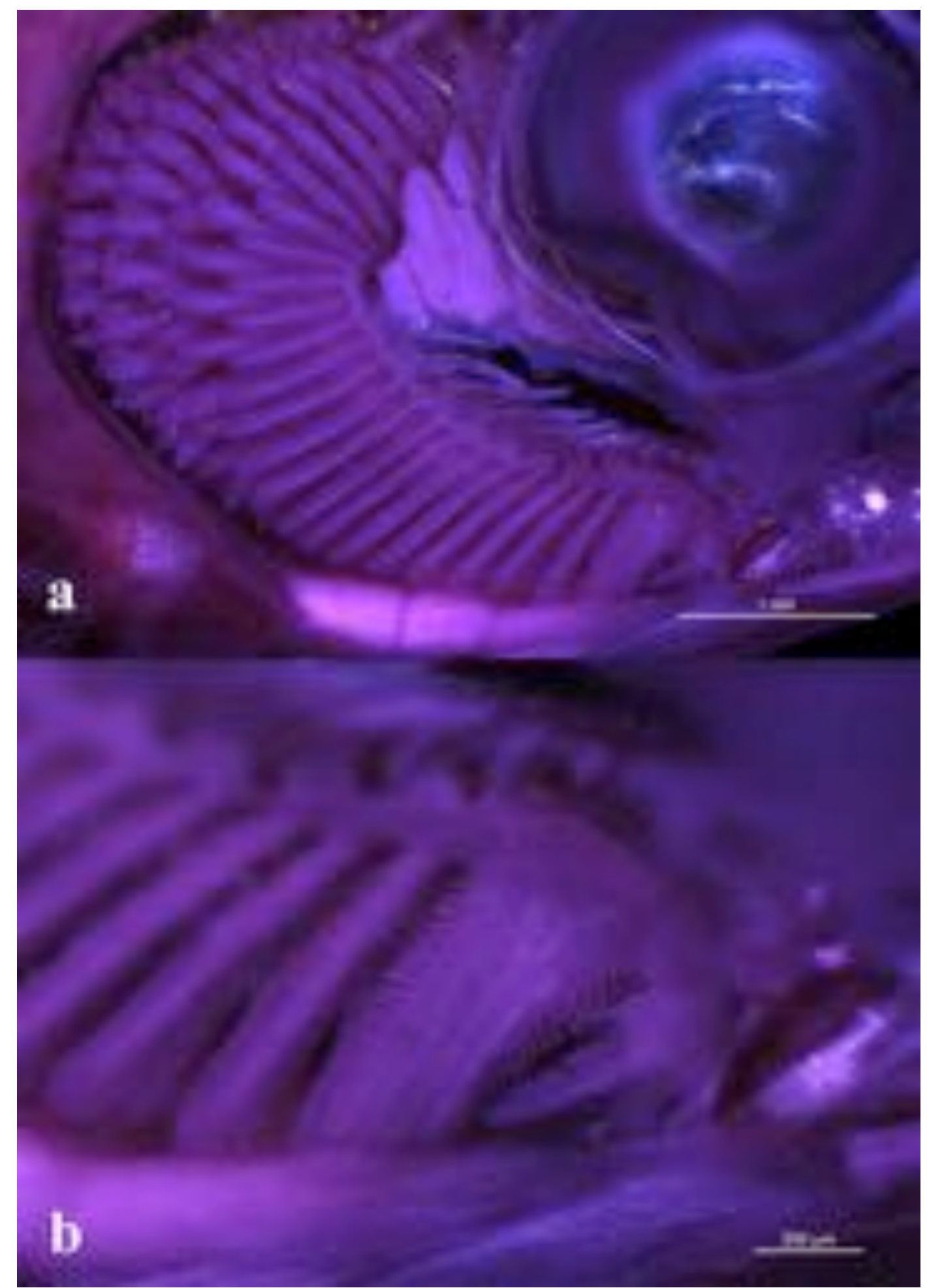

Figura 14. Brânquia com glândula branquial em vista lateral direita (a), detalhe da região anterior do ceratobranquial direito, evidenciando a glândula branquial (b) em Aphyocharax anisitsi. 
Prionobrama paraguayensis (Eigenmann 1914)

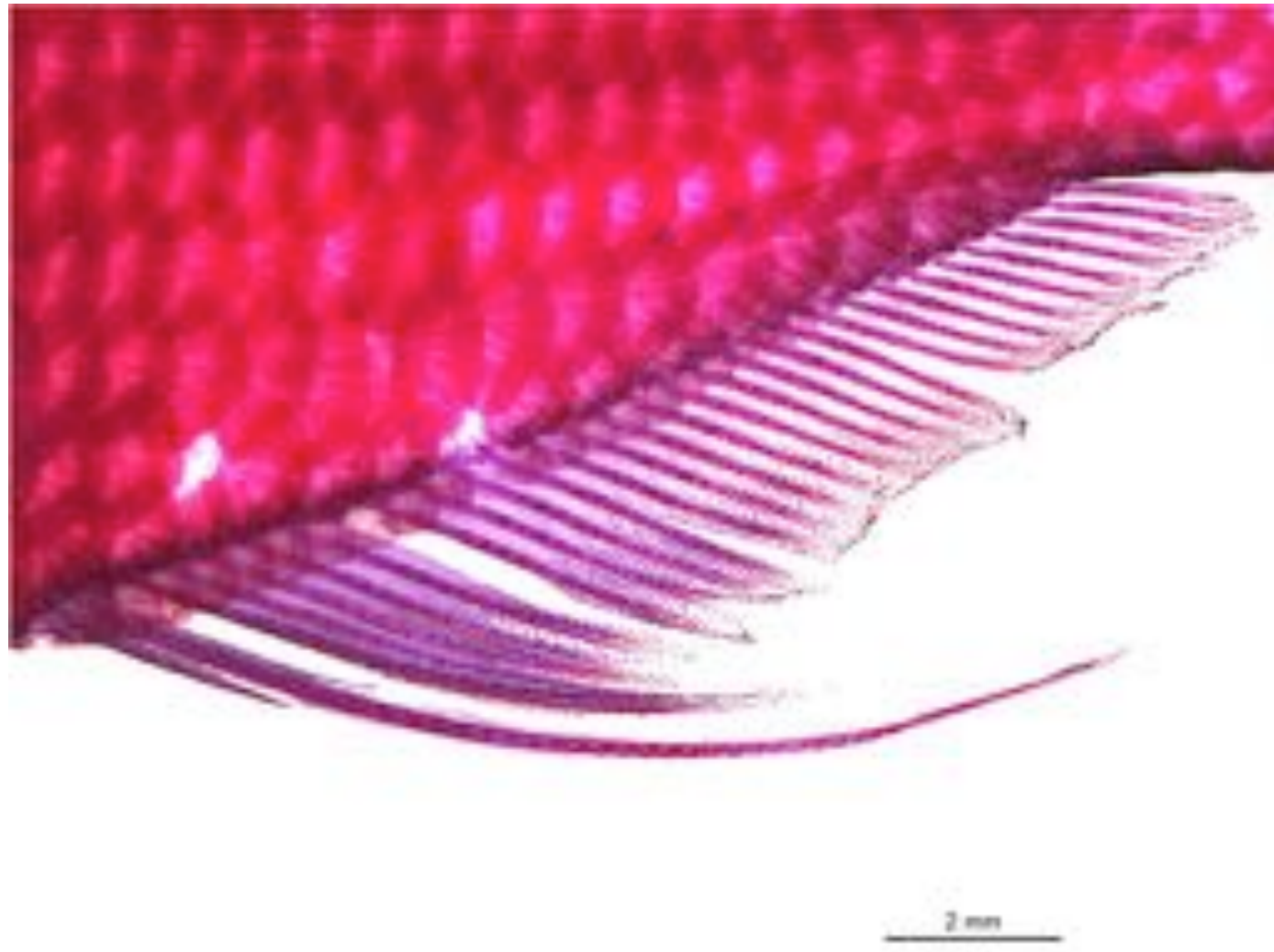

Figura 15. Nadadeira anal de machos de Prionobrama paraguayensis em vista lateral esquerda, evidenciando o formato do perfil distal da nadadeiras e distribuição dos processos ósseos. 

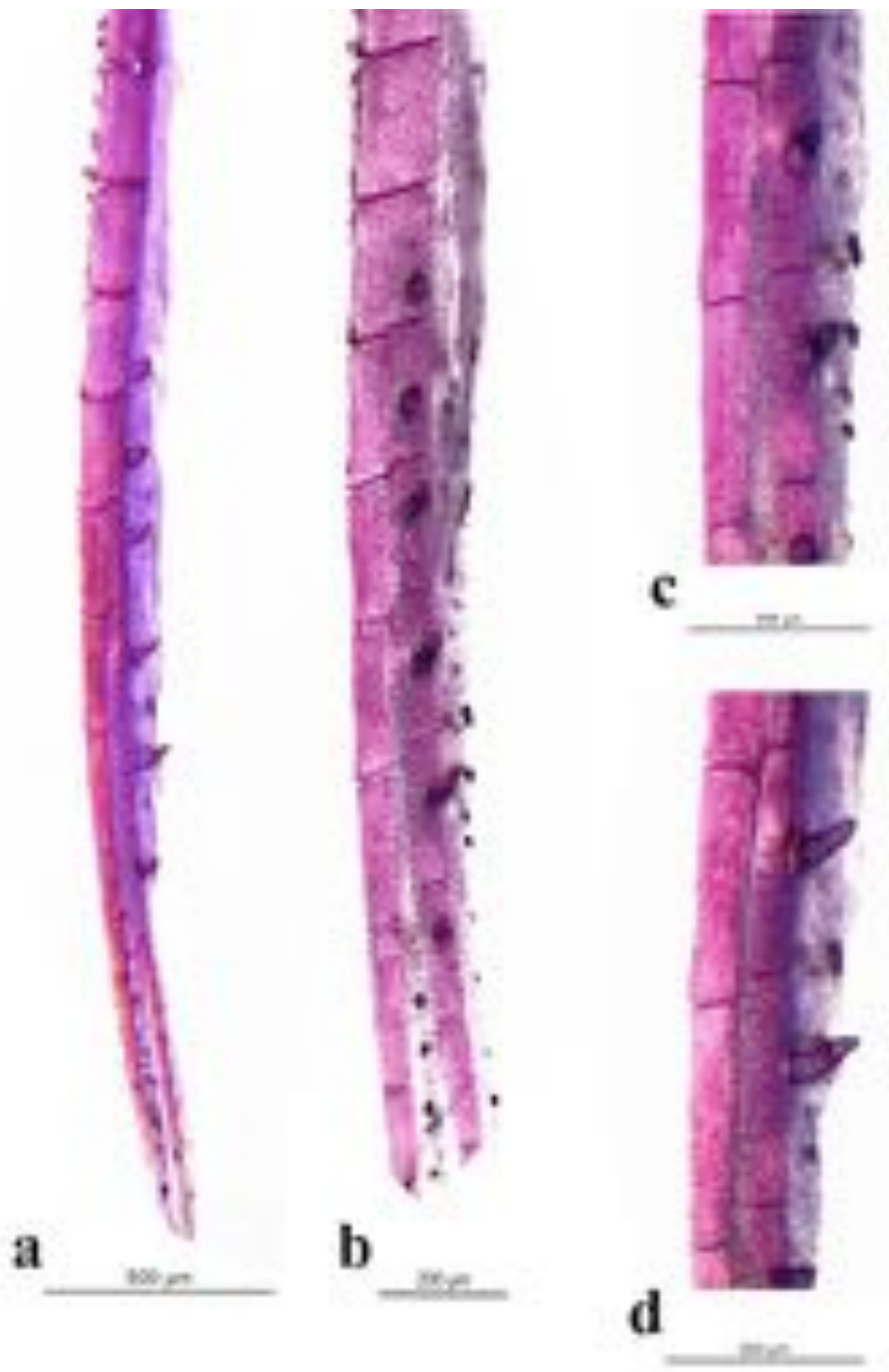

Figura 16. Distribuição, posição e formato dos processos ósseos no hemitriquium esquerdo do raio ramificado da nadadeira anal de machos de Prionobrama paraguayensis. (a) vista anteroposterior, (b) vista lateral, (c) detalhe em vista lateral e (d) detalhe em vista anteroposterior. 

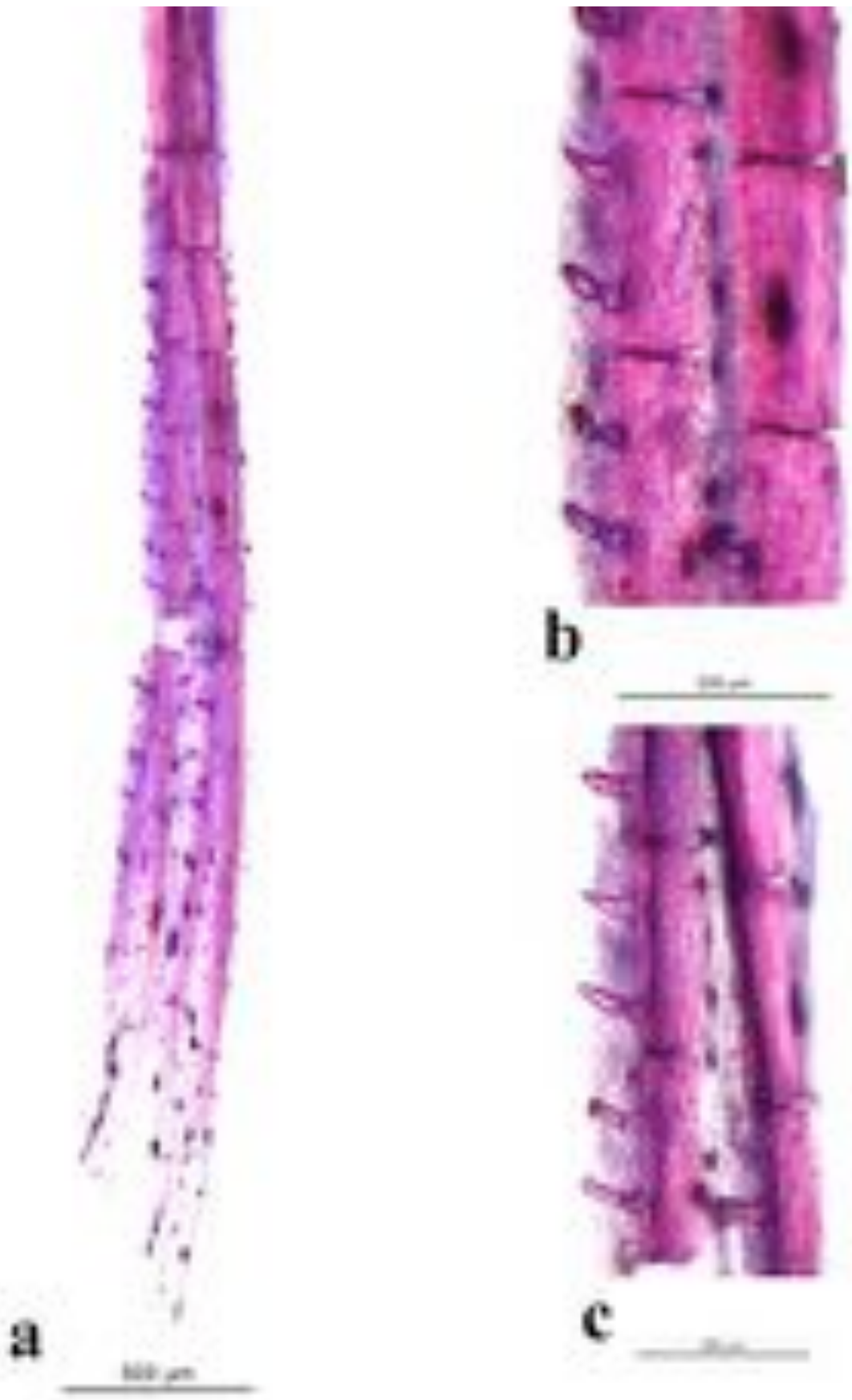

Figura 17. Distribuição, posição e formato dos processos ósseos no hemitriquium ventral da nadadeira pélvica esquerda de machos de Prionobrama paraguayensis. (a) vista ventral, (b) detalhe em vista lateral, (c) detalhe em vista lateromedial. 


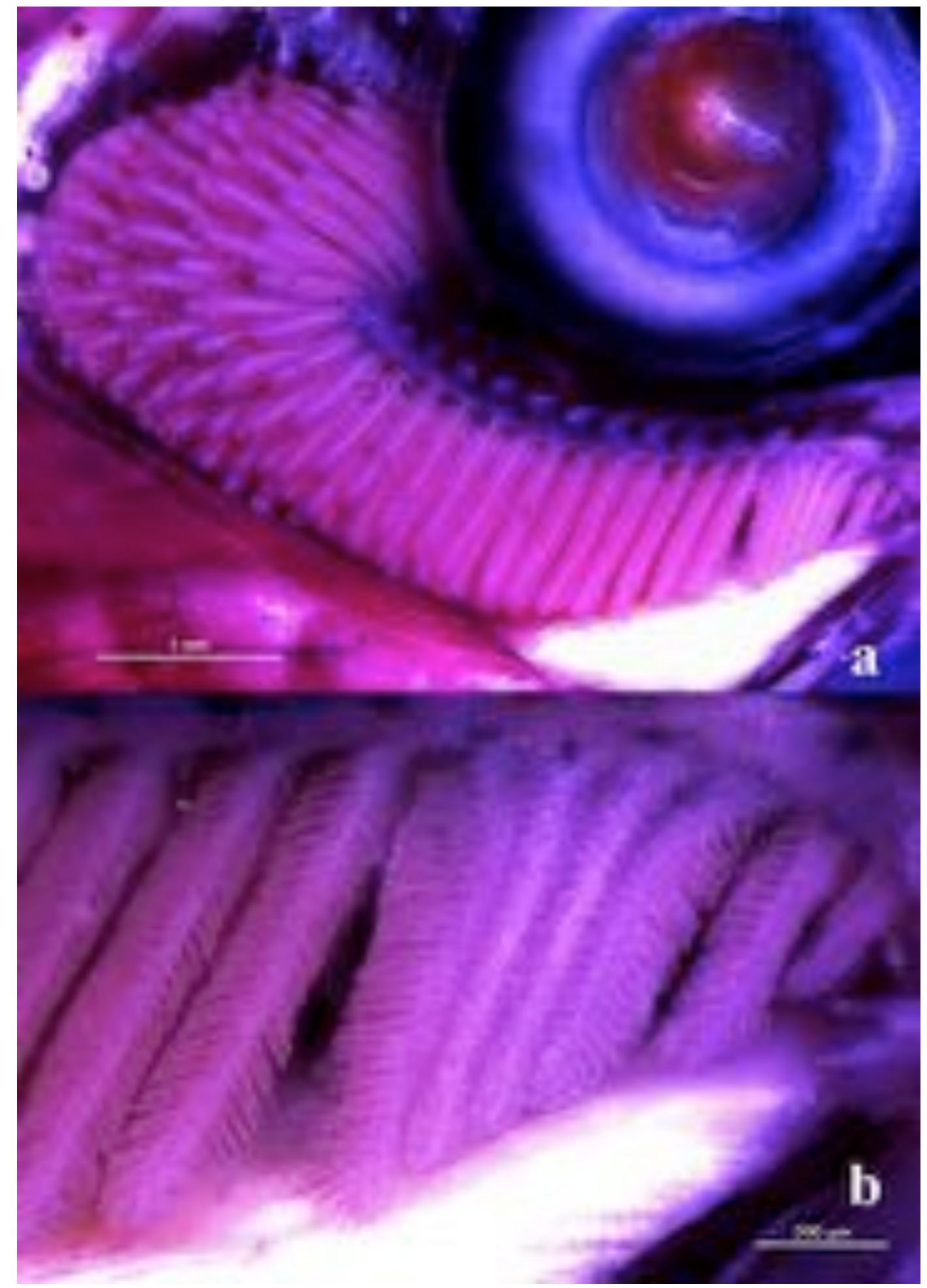

Figura 18. Brânquia com glândula branquial em vista lateral direita (a), detalhe da região anterior do ceratobranquial direito, evidenciando a glândula branquial (b) em Prionobrama paraguayensis. 


\section{APHYODITEINAE}

Microschemobrycon casiquiare Bohlke 1953

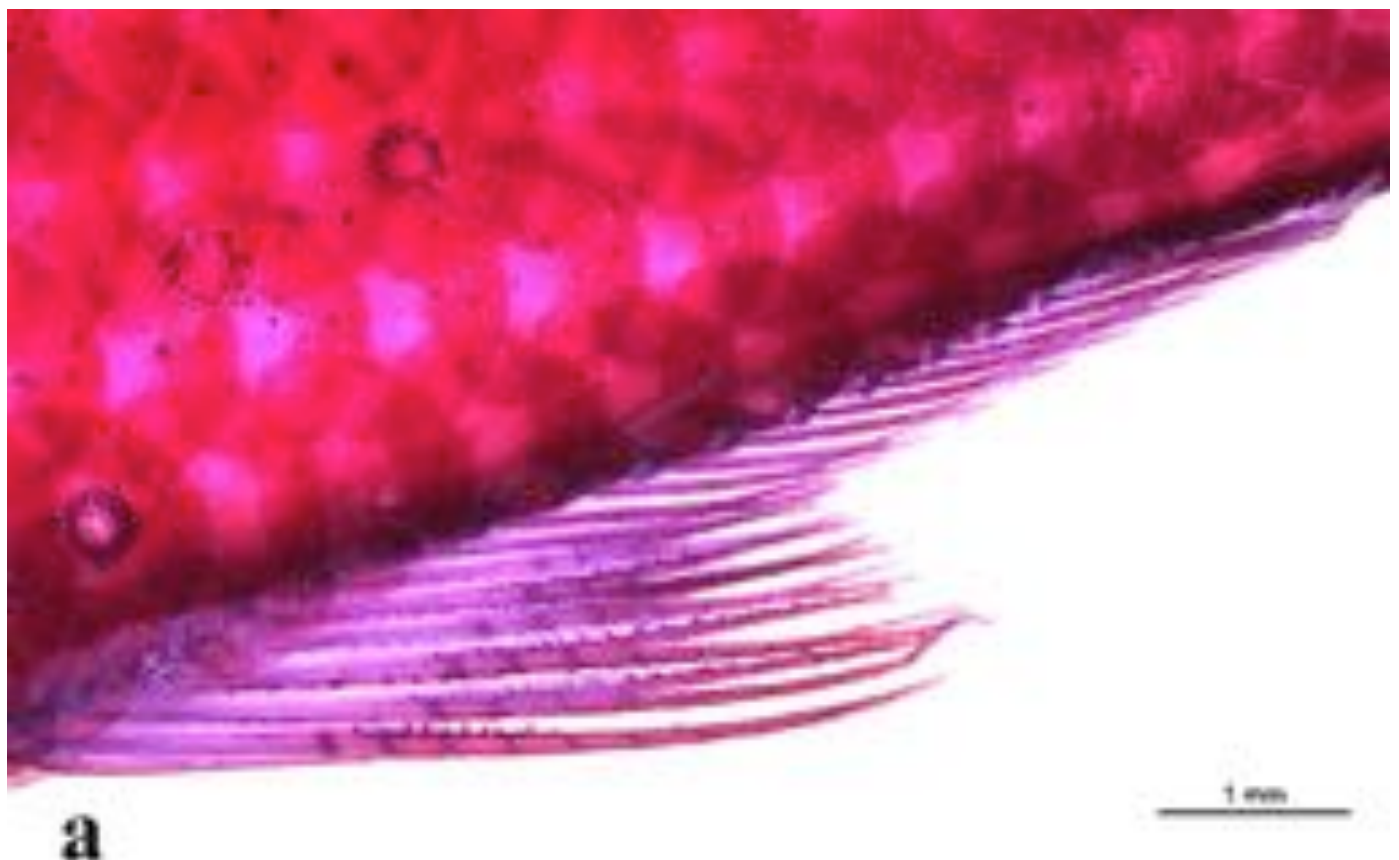

Figura 19. Nadadeira anal de machos de Microschemobrycon casiquiare evidenciando o formato do perfil distal da nadadeira e distribuição dos processos ósseos. 

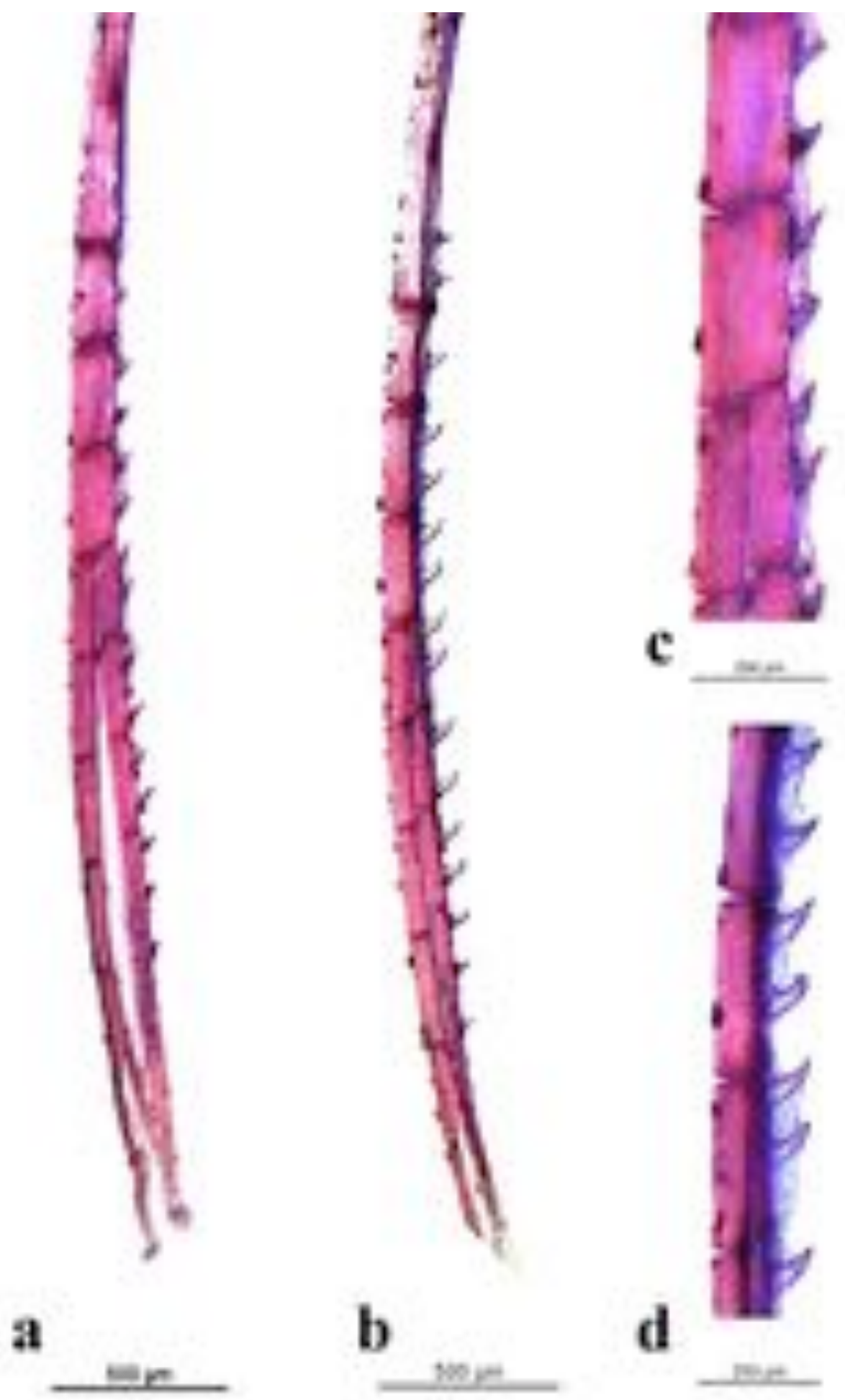

Figura 20. Distribuição, posição e formato dos processos ósseos no hemitriquium esquerdo do raio ramificado da nadadeira anal de machos de Microschemobrycon casiquiare. (a) vista lateral, (b) vista anteroposterior, (c) detalhe em vista lateral e (d) detalhe em vista anteroposterior. 

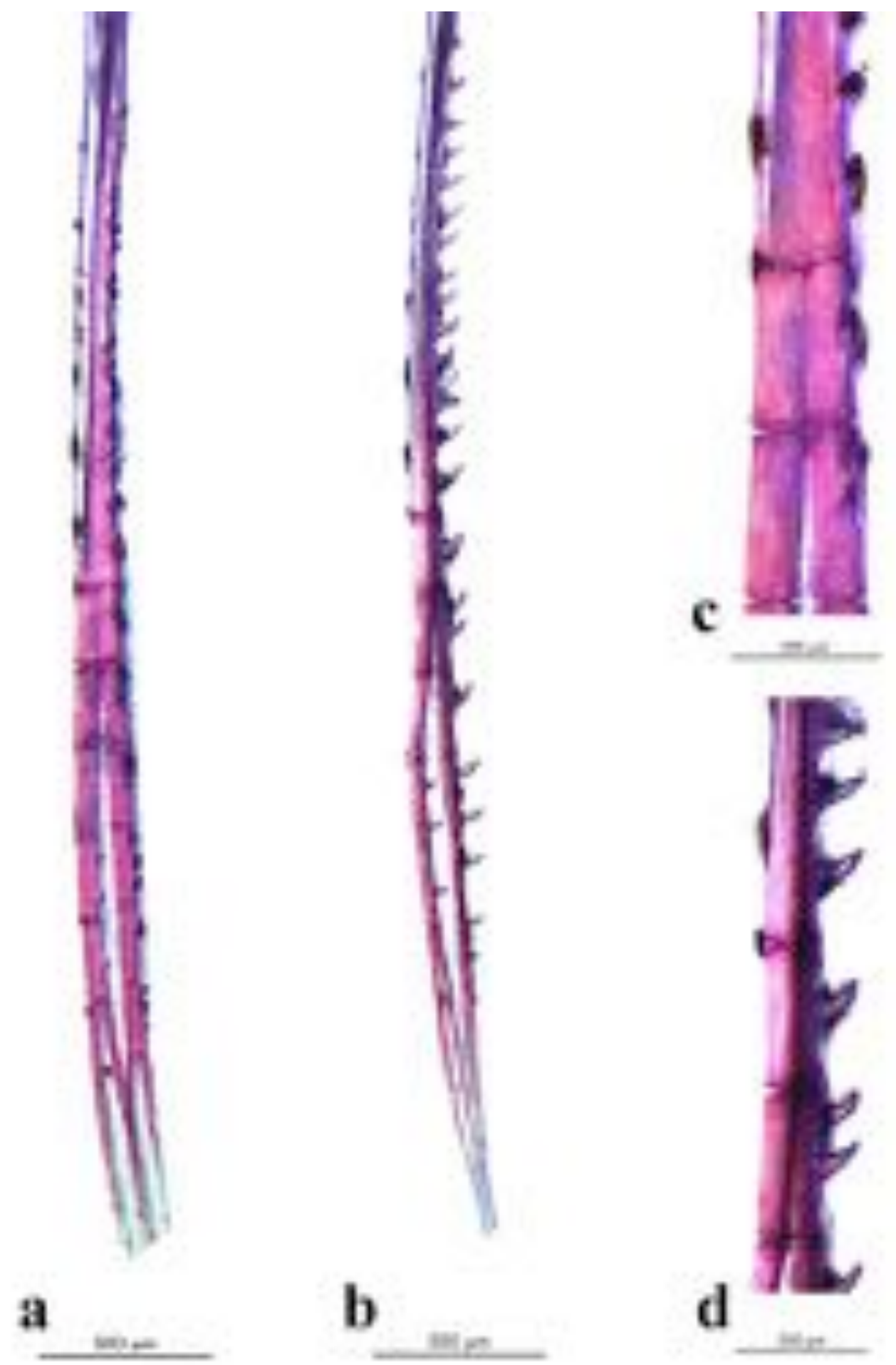

Figura 21. Distribuição, posição e formato dos processos ósseos no hemitriquium ventral do raio ramificado da nadadeira pélvica direita de machos de Microschemobrycon casiquiare. (a) vista ventral, (b) vista lateromedial, (c) detalhe em vista ventral e (d) detalhe em vista lateromedial. 


\section{Parecbasis cyclolepis Eigenmann 1914}
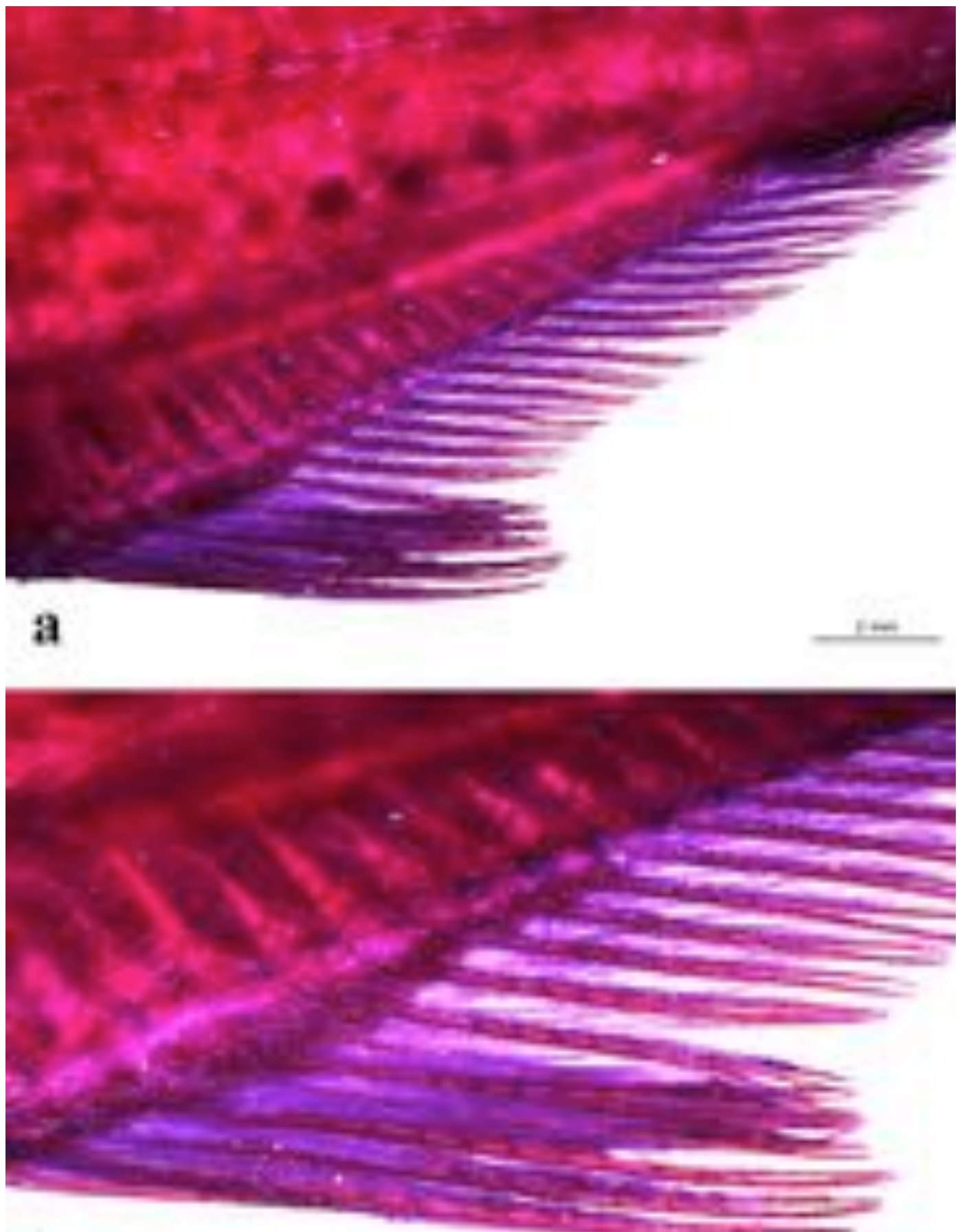

b

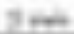

Figura 22. Nadadeira anal de machos de Parecbasis cyclolepis (a), detalhe da porção anterior da nadadeira anal (b), evidenciando o formato da nadadeira e a distribuição dos processos ósseos. 

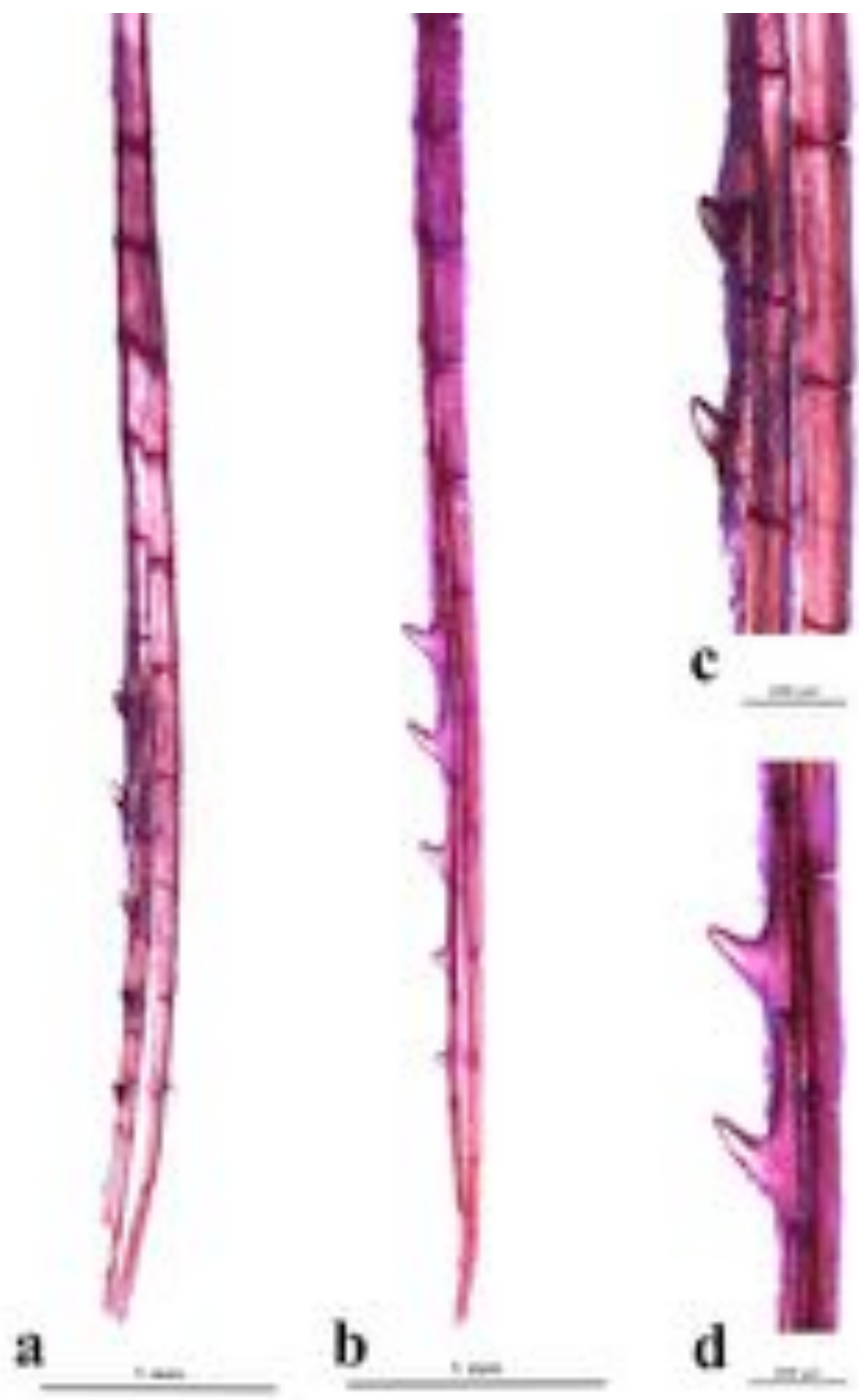

c

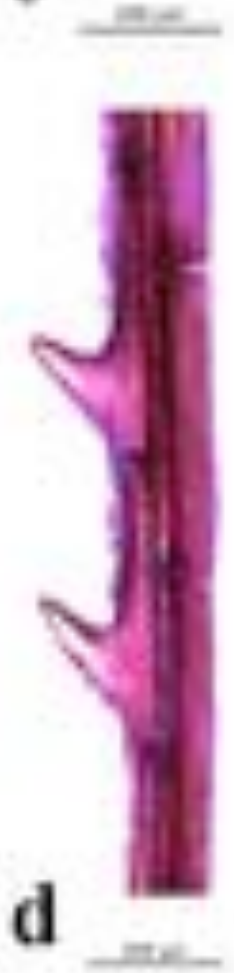

Figura 23. Distribuição, posição e formato dos processos ósseos no hemitriquium direito do raio ramificado da nadadeira anal de machos de Parecbasis cyclolepis. (a) vista lateral, (b) vista anteroposterior, (c) detalhe em vista lateral e (d) detalhe em vista anteroposterior. 
CLADO Astyanax

Astyanax abramis (Jenyns 1842)

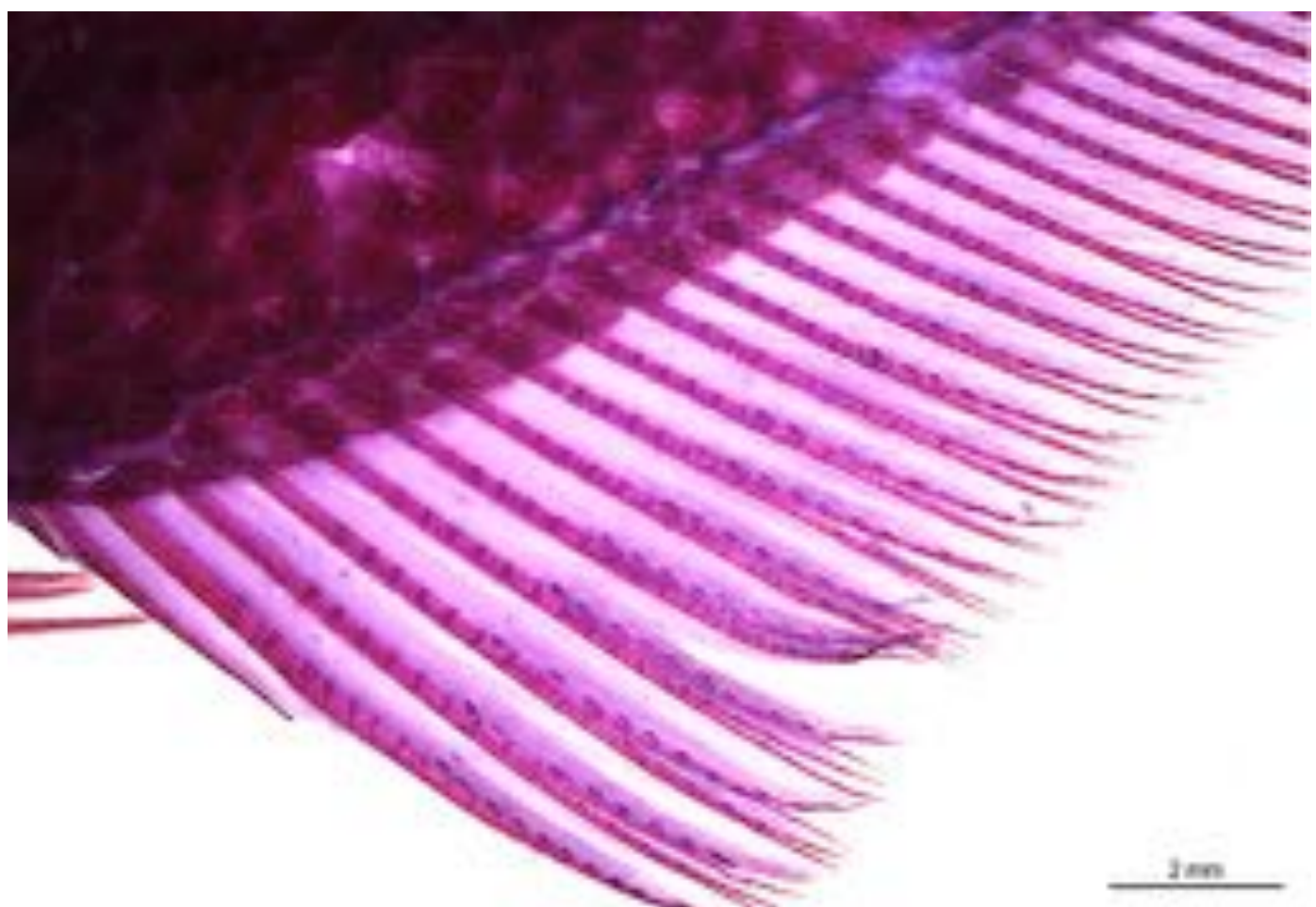

Figura 24. Nadadeira anal de machos de Astyanax abramis em vista lateral esquerda, evidenciando o formato do perfil da margem distal da nadadeira a distribuição dos processos ósseos. 

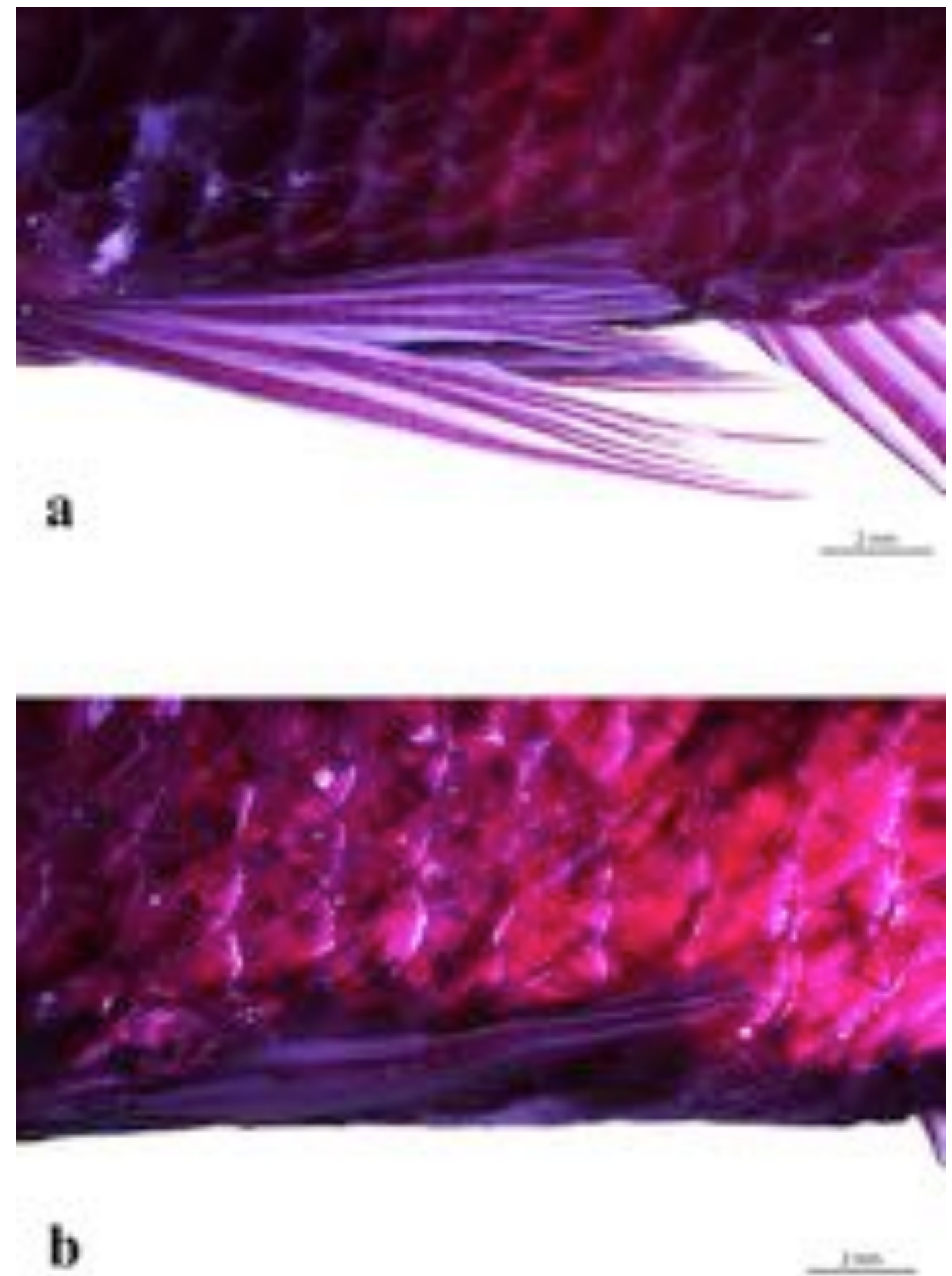

Figura 25. Nadadeira pélvica de machos (a) e de fêmeas (b) de Astyanax abramis em vista lateral esquerda, evidenciando o formato e comprimento da nadadeira nos dois sexos. 


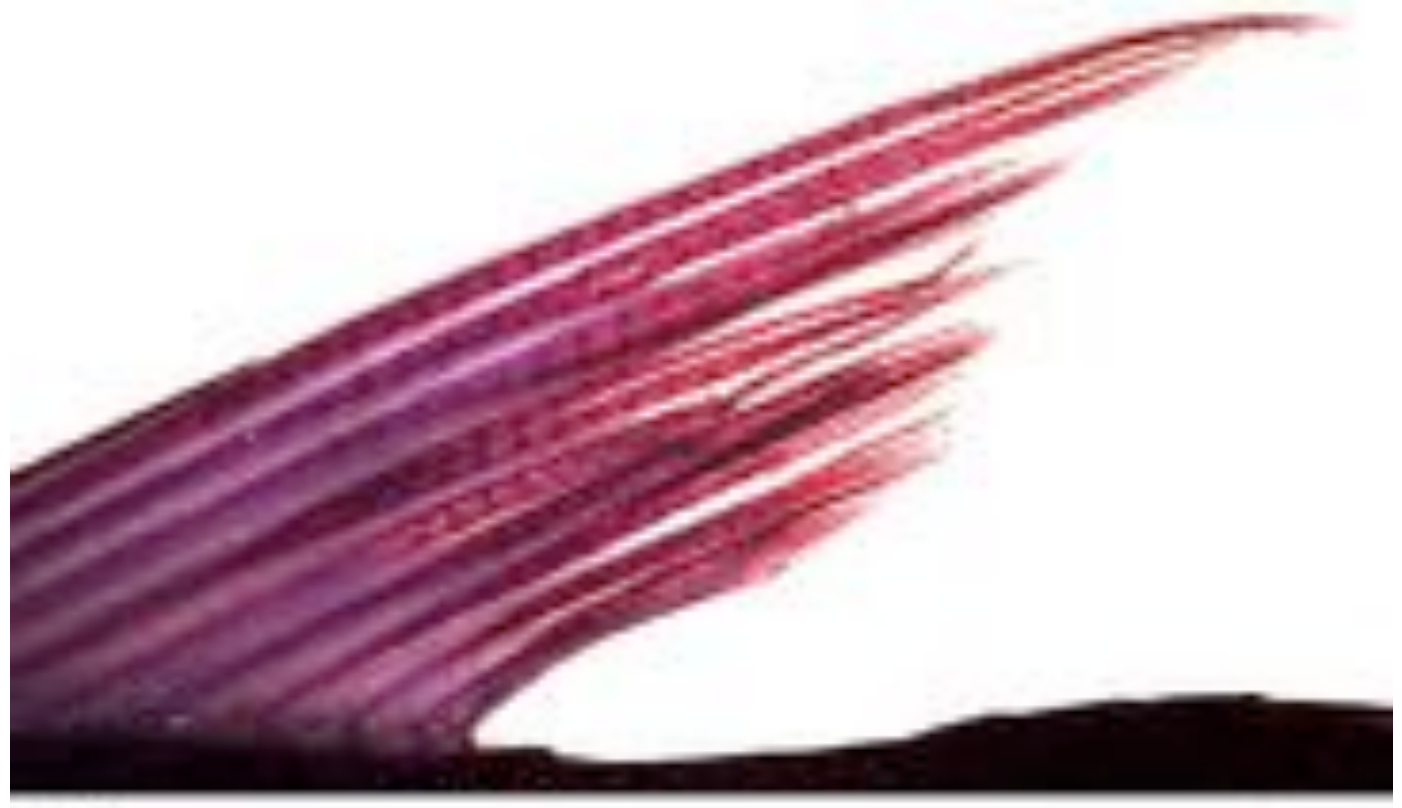

a

I는

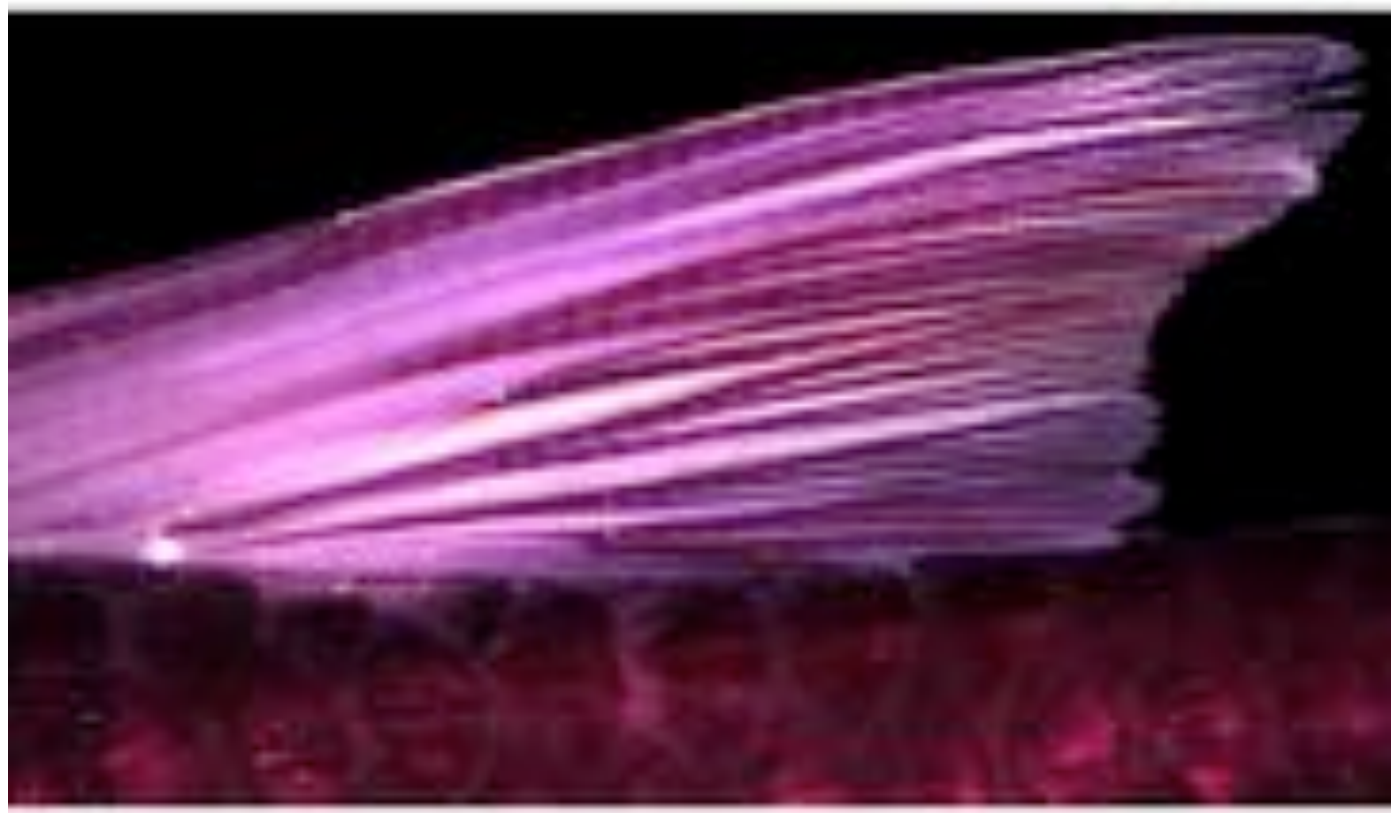

b

nase

Figura 26. Nadadeira dorsal de machos (a) e de fêmeas (b) de Astyanax abramis em vista lateral esquerda, evidenciando o formato e comprimento da nadadeira nos dois sexos. 


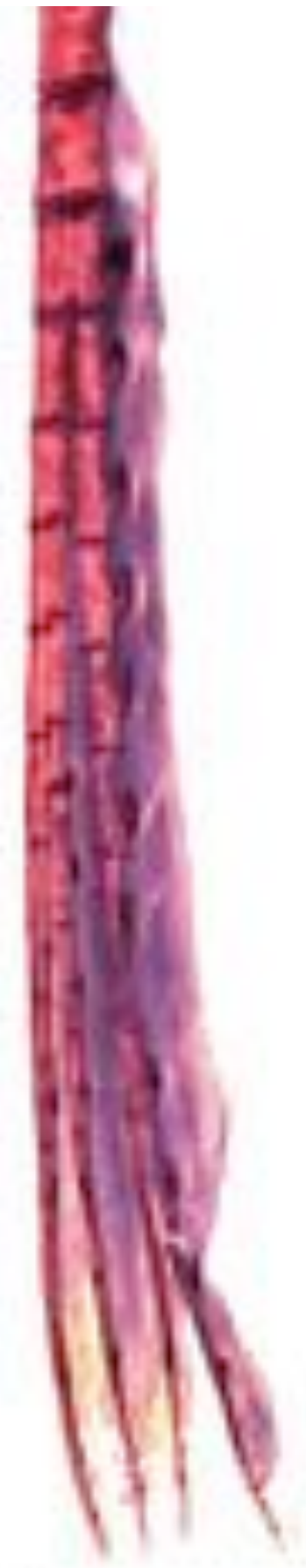

a

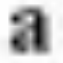

$3-$

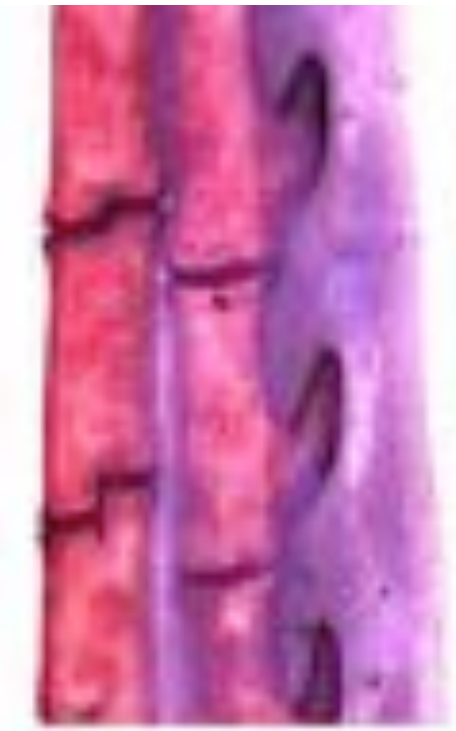

b
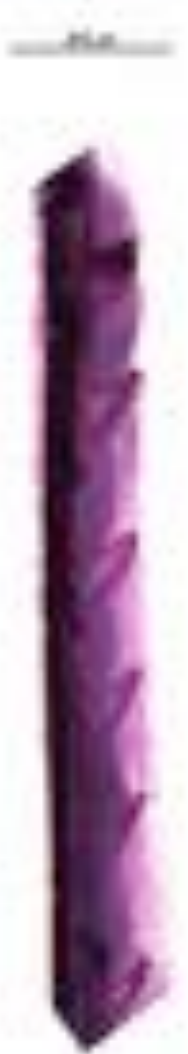

c

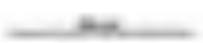

Figura 27. Distribuição, posição de inserção e formato dos processos ósseos no hemitriquium esquerdo do raio ramificado da nadadeira anal de machos de Astyanax abramis. (a) vista latera, (b) detalhe em vista lateral e (c) detalhe em vista anteroposterior. 

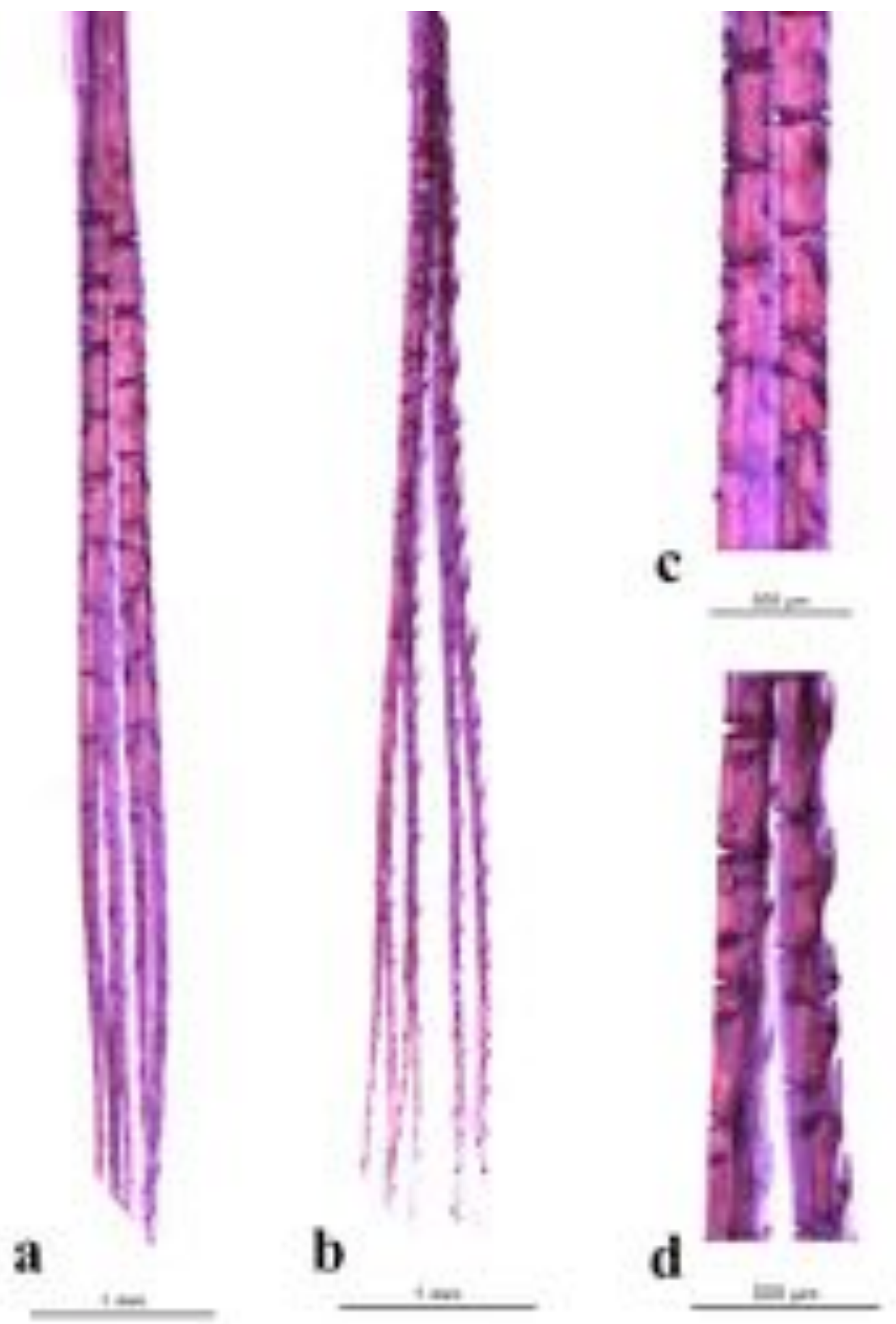

Figura 28. Distribuição, posição de inserção e formato dos processos ósseos no hemitriquium ventral do raio ramificado da nadadeira pélvica direita de machos de Astyanax abramis. (a) vista ventral, (b) vista lateromedial, (c) detalhe em vista ventral e (d) detalhe em vista lateromedial. 


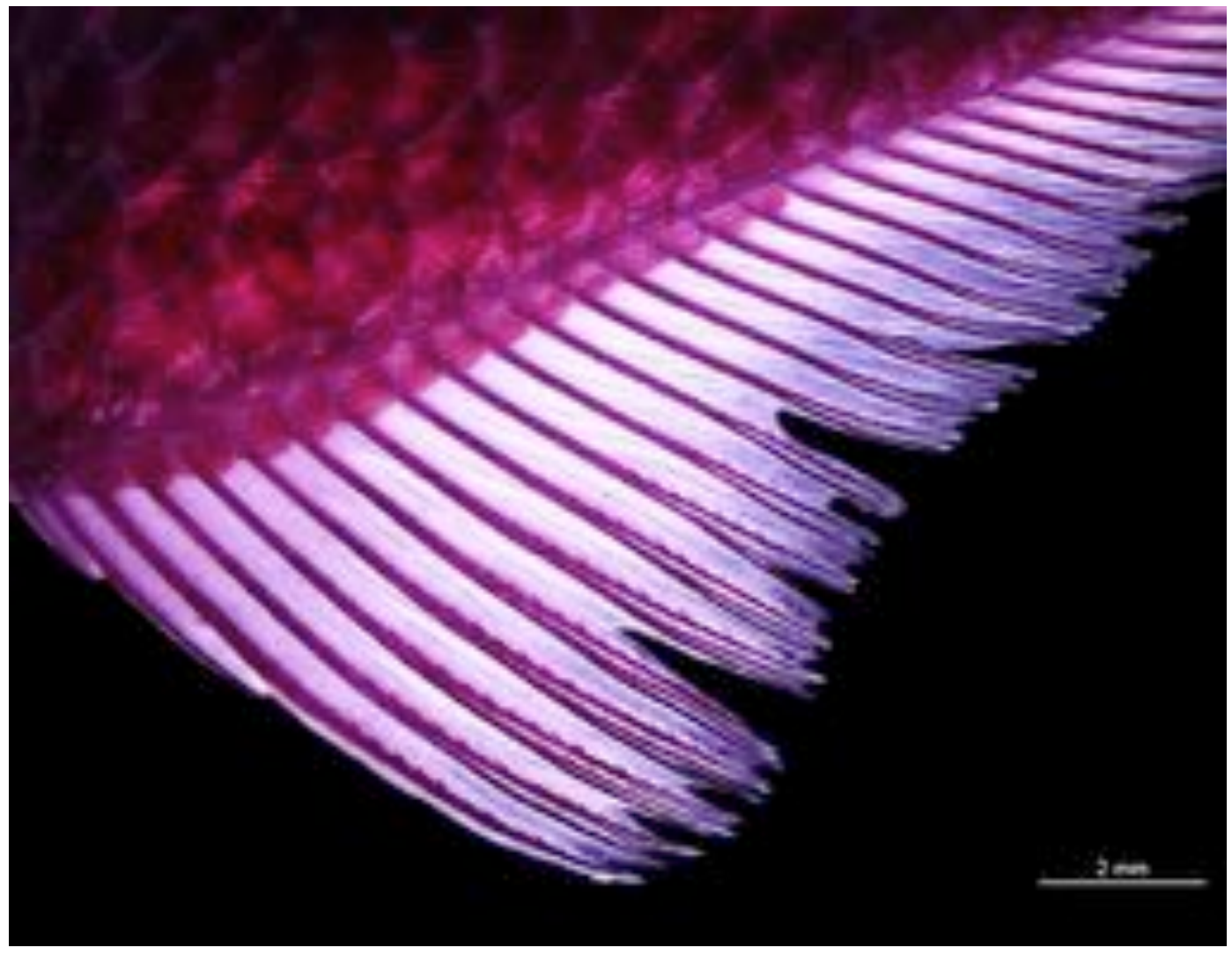

Figura 29. Nadadeira anal de machos de Astyanax lineatus em vista lateral esquerda, evidenciando o formato do perfil da margem distal da nadadeira e distribuição dos processos ósseos. 

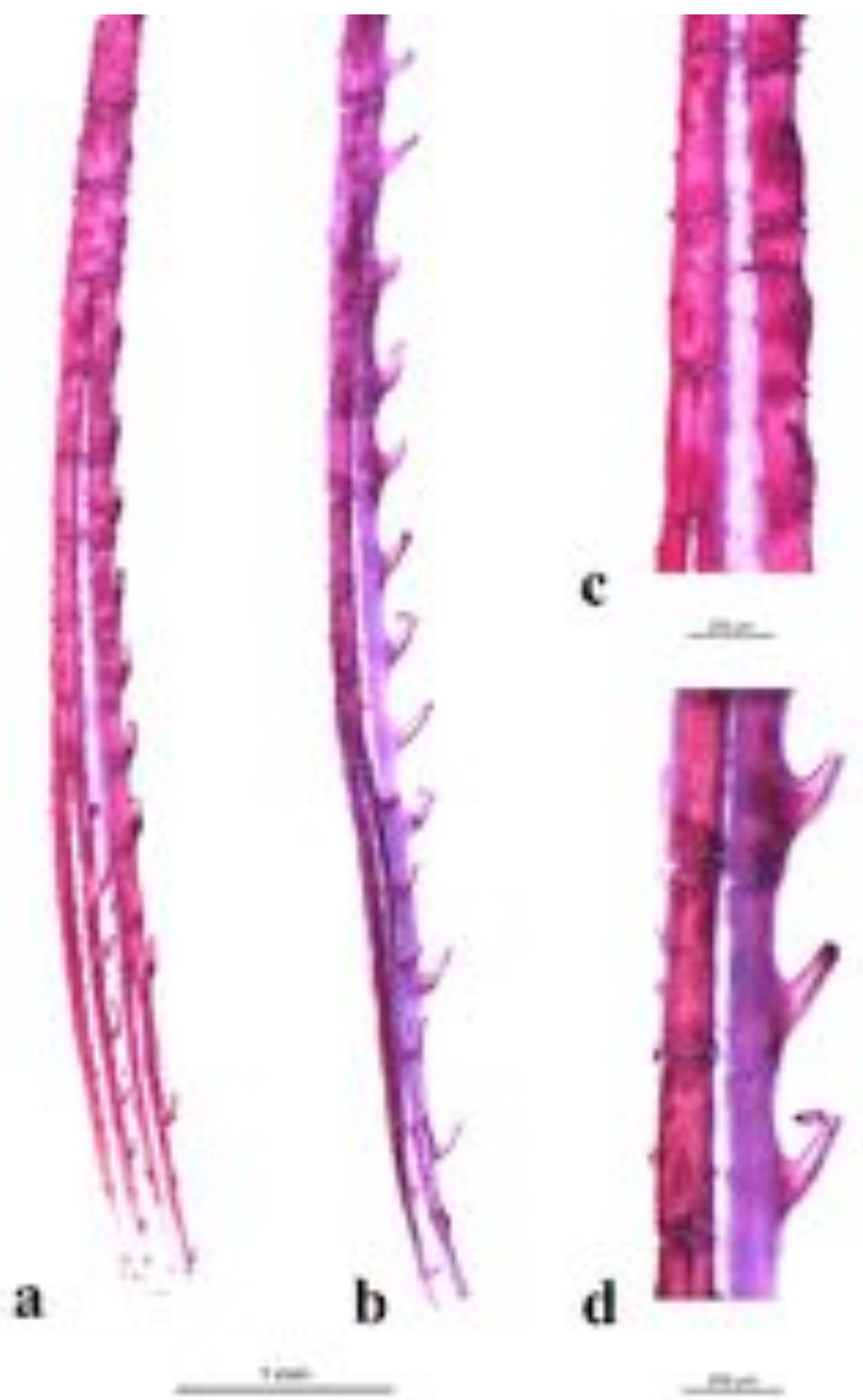

Figura 30. Distribuição, posição de inserção e formato dos processos ósseos no hemitriquium esquerdo do raio ramificado da nadadeira anal de machos de Astyanax lineatus. (a) vista lateral, (b) vista anteroposterior, (c) detalhe em vista lateral e (d) detalhe em vista anteroposterior. 


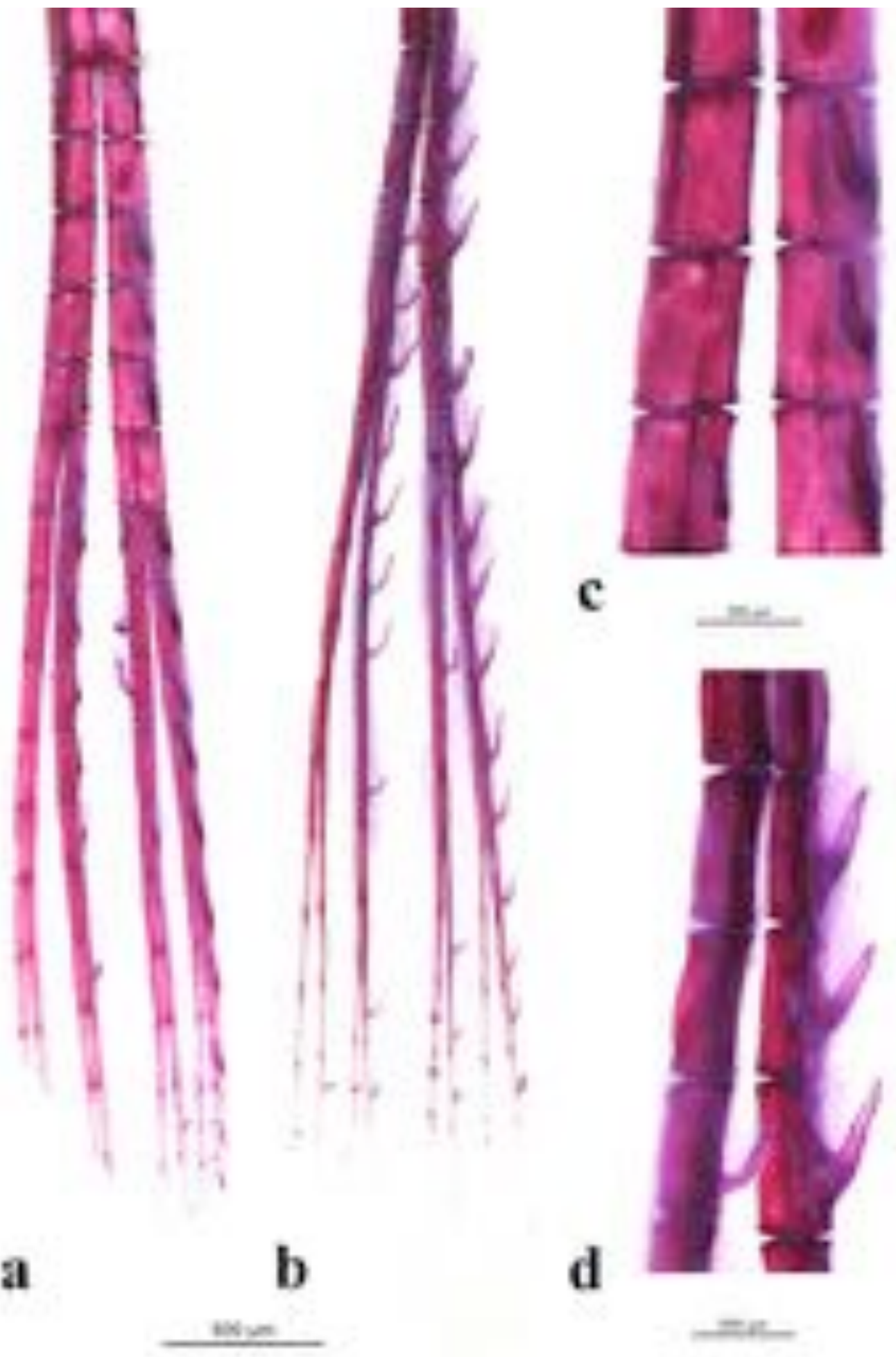

Figura 31. Distribuição, posição de inserção e formato dos processos ósseos no hemitriquium ventral do raio ramificado da nadadeira pélvica direita de machos de Astyanax lineatus. (a) vista ventral, (b) vista lateromedial, (c) detalhe em vista ventral e (d) detalhe em vista lateromedial. 


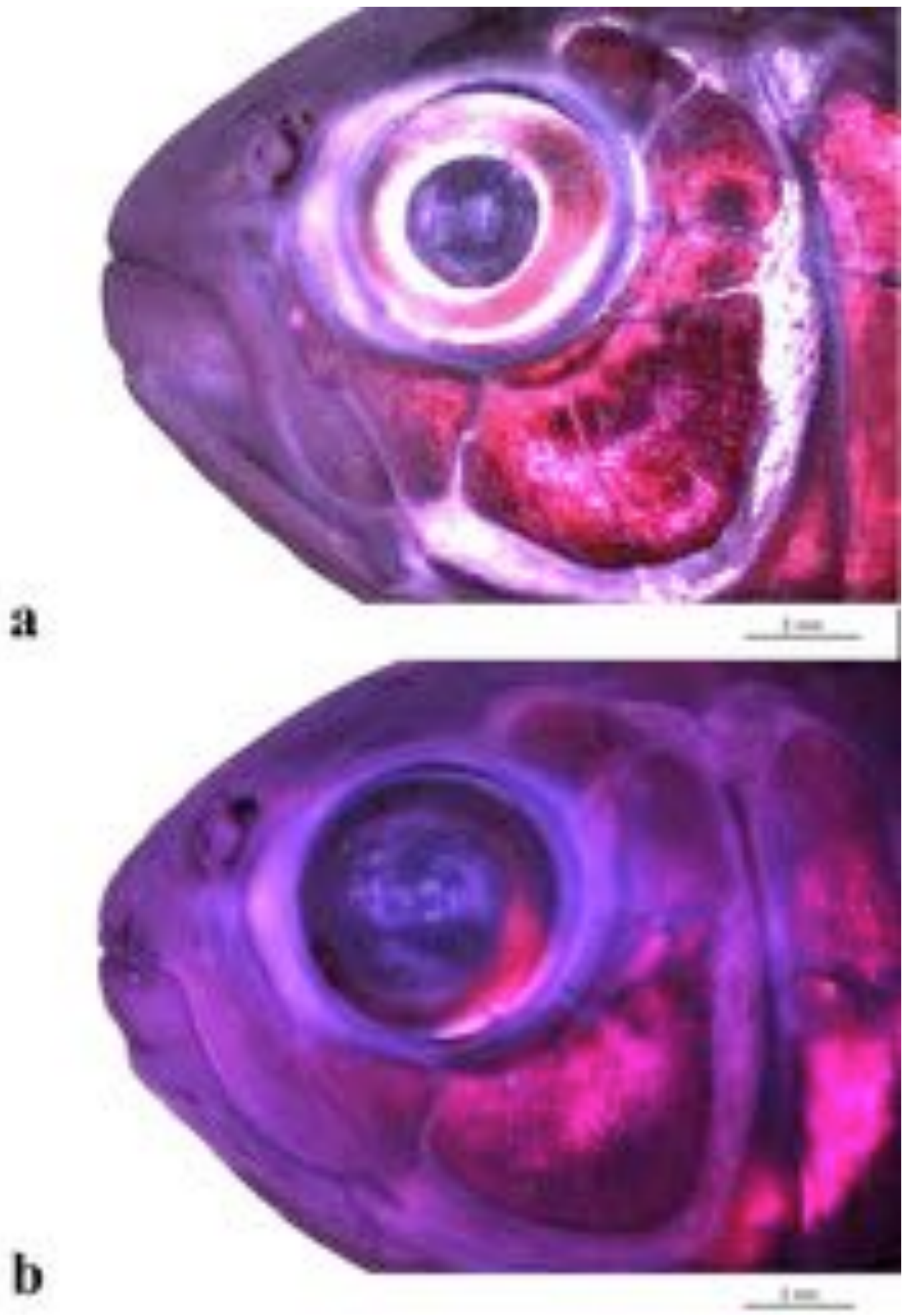

Figura 32. Cabeça de machos (a) e de fêmeas (b) de Astyanax lineatus em vista lateral esquerda, evidenciando a distribuição dos tubérculos reprodutivos na cabeça do macho. 
Astyanax cf. jordani (Hubbs \& Innes 1936)

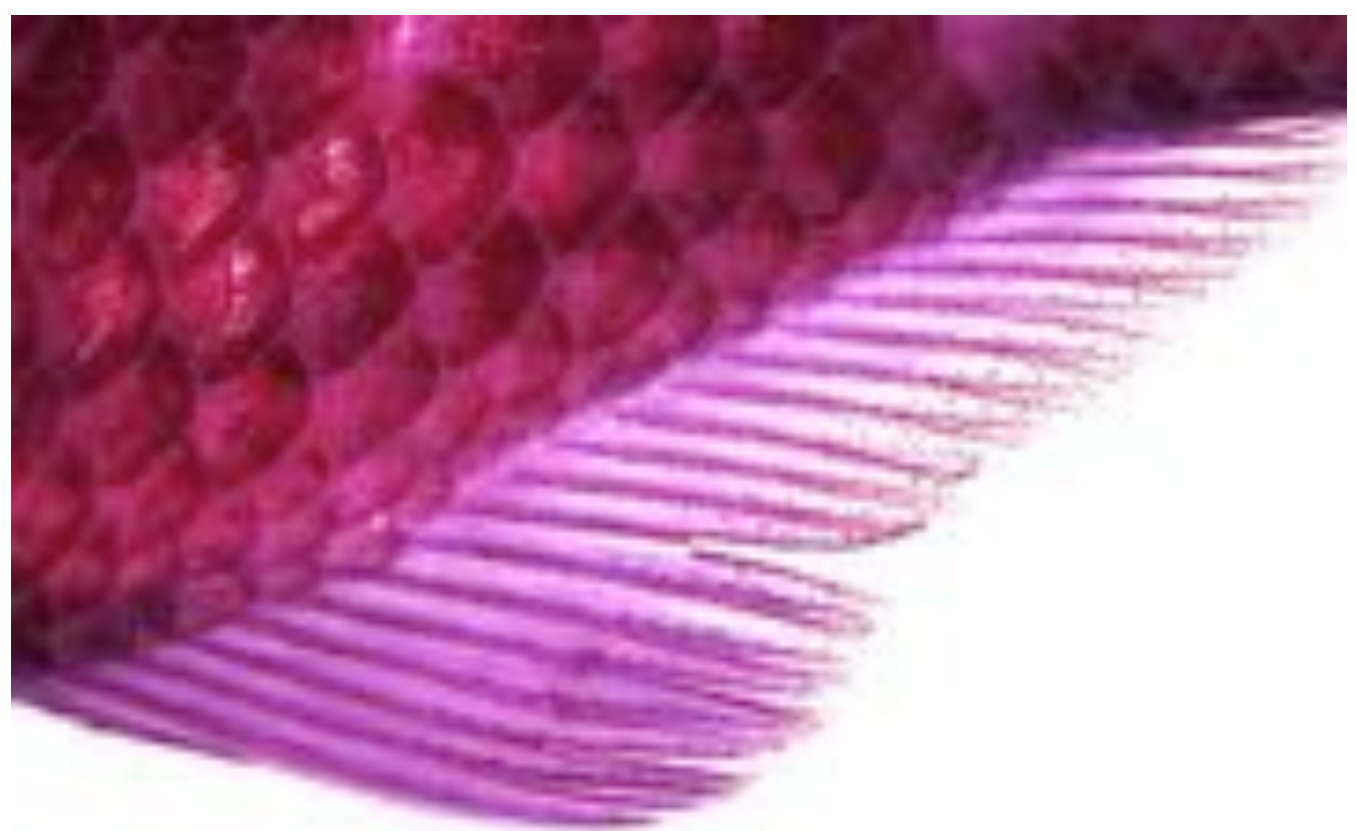

a
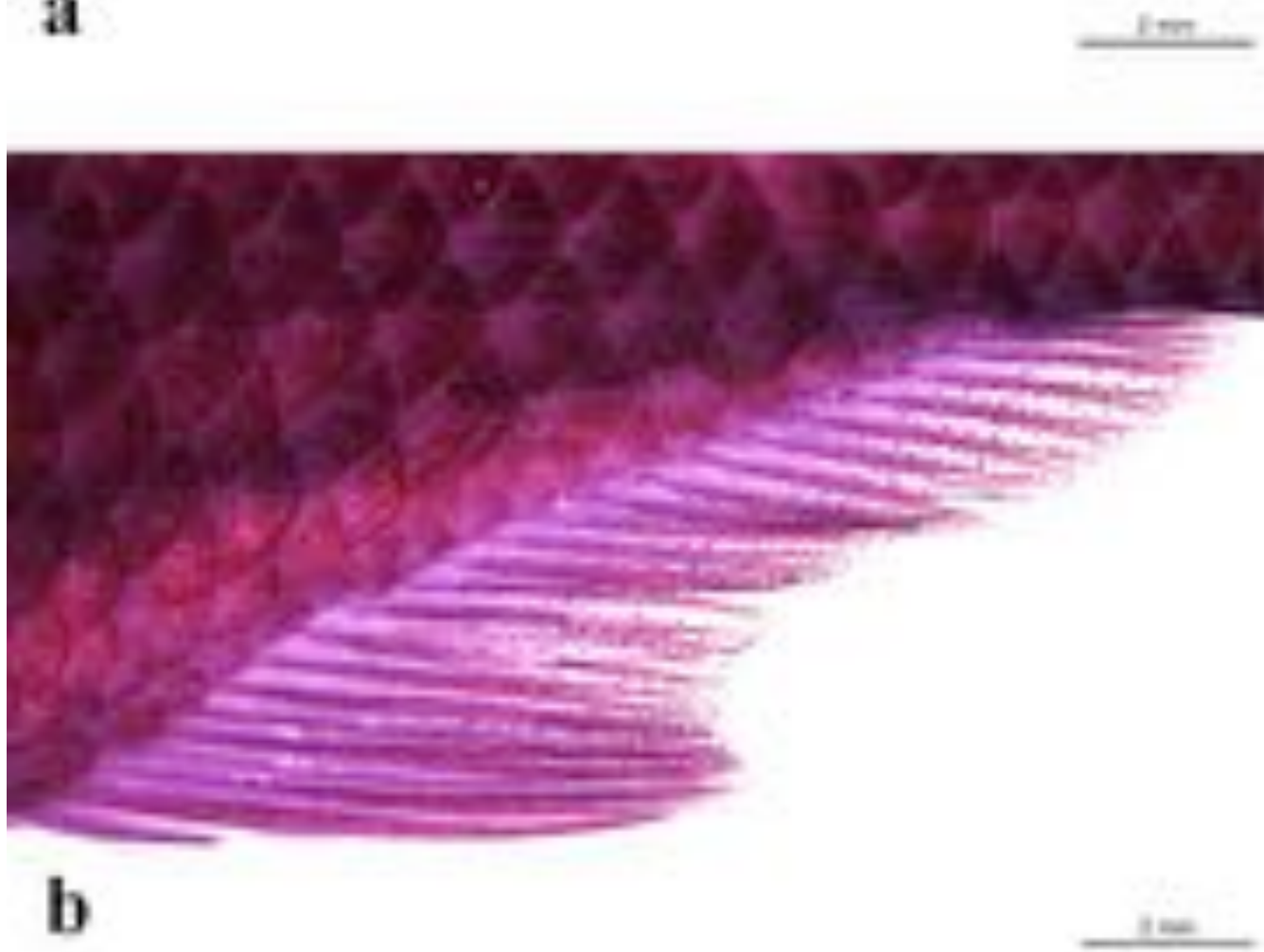

Figura 33. Nadadeira anal de machos (a) e de fêmeas (b) de Astyanax cf. jordani em vista lateral esquerda, evidenciando o formato da margem distal da nadadeira nos dois sexos e distribuição dos processos ósseos na nadadeira anal do macho. 


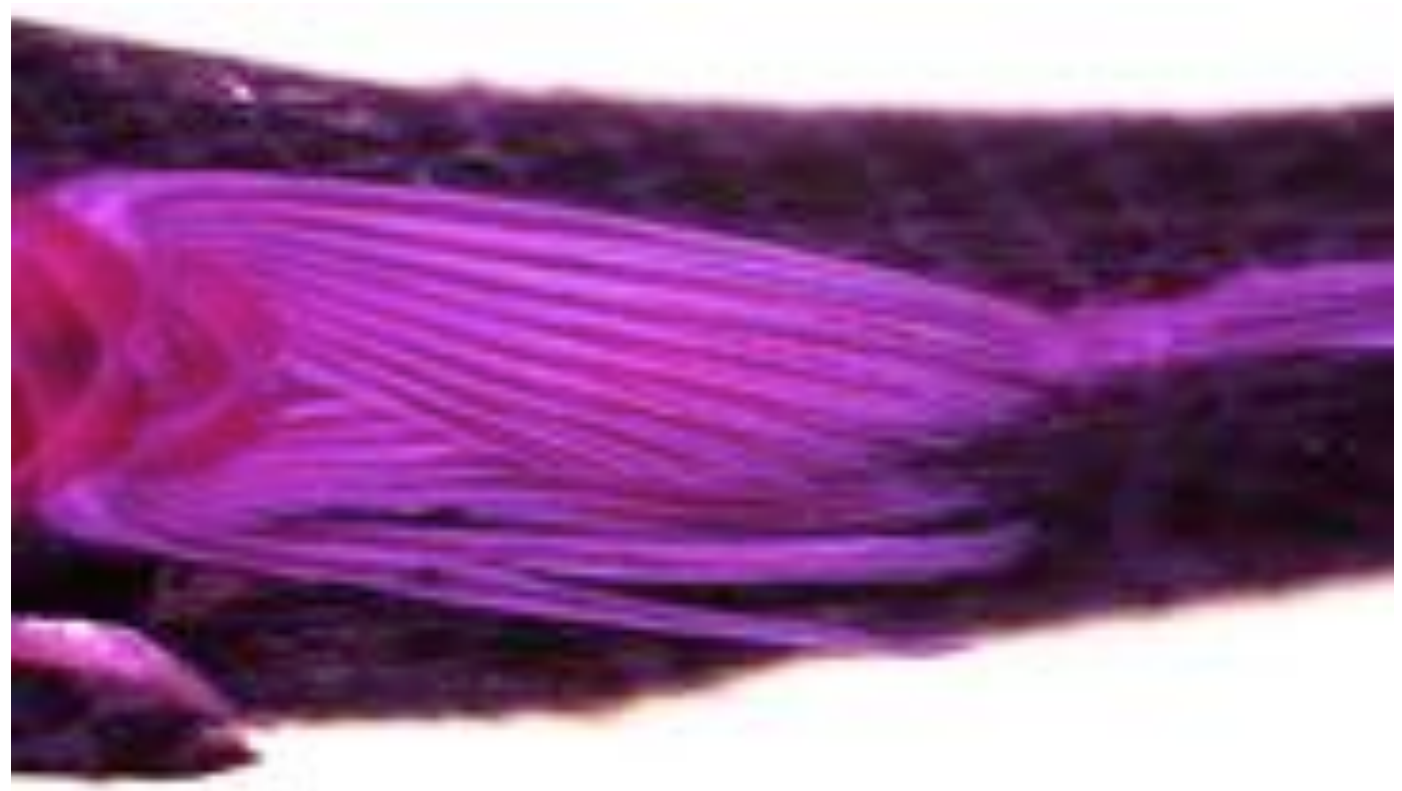

a
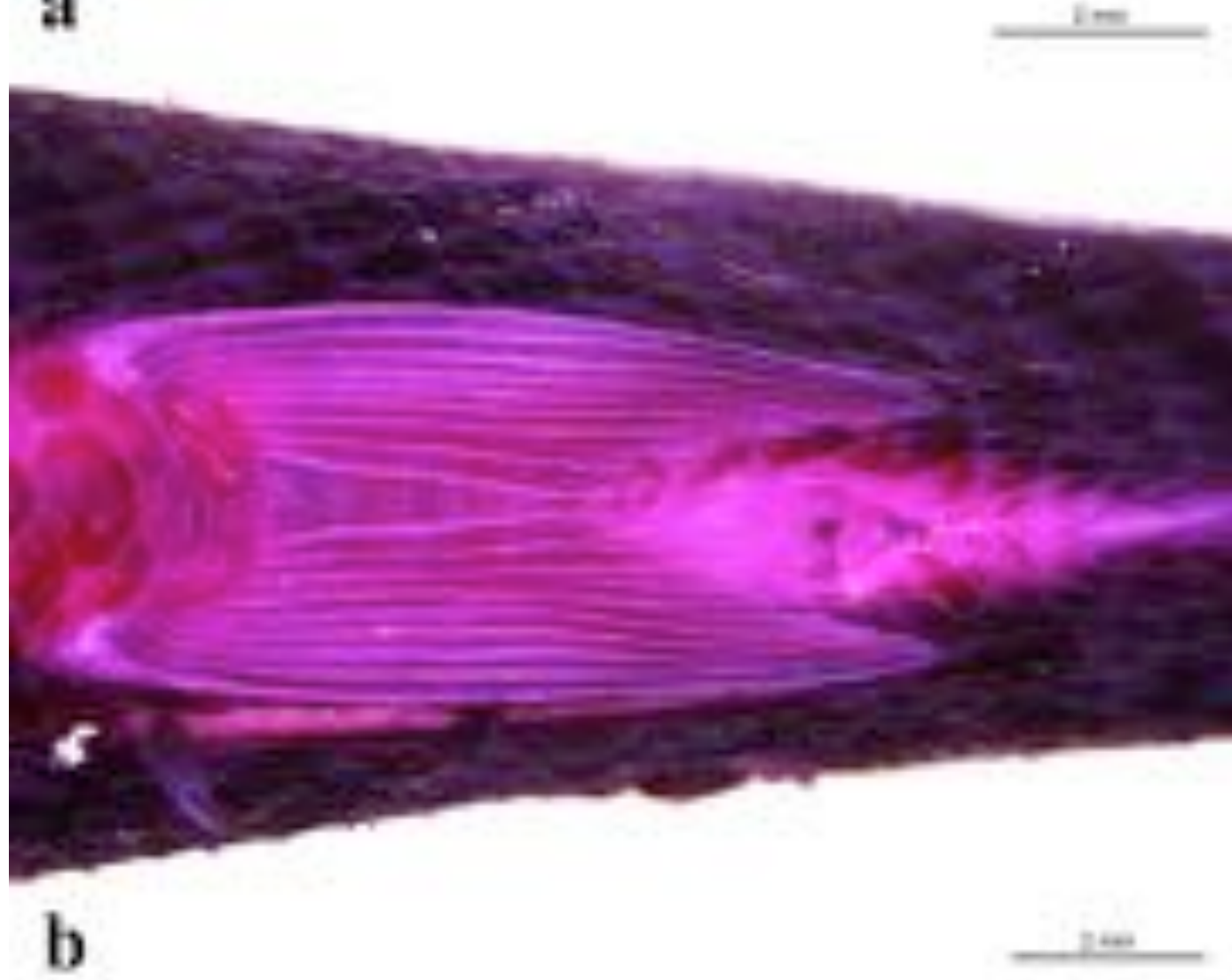

Figura 34. Nadadeira pélvica de machos (a) e de fêmeas (b) de Astyanax cf. jordani em vista ventral, evidenciando o formato da nadadeira nos dois sexos. 

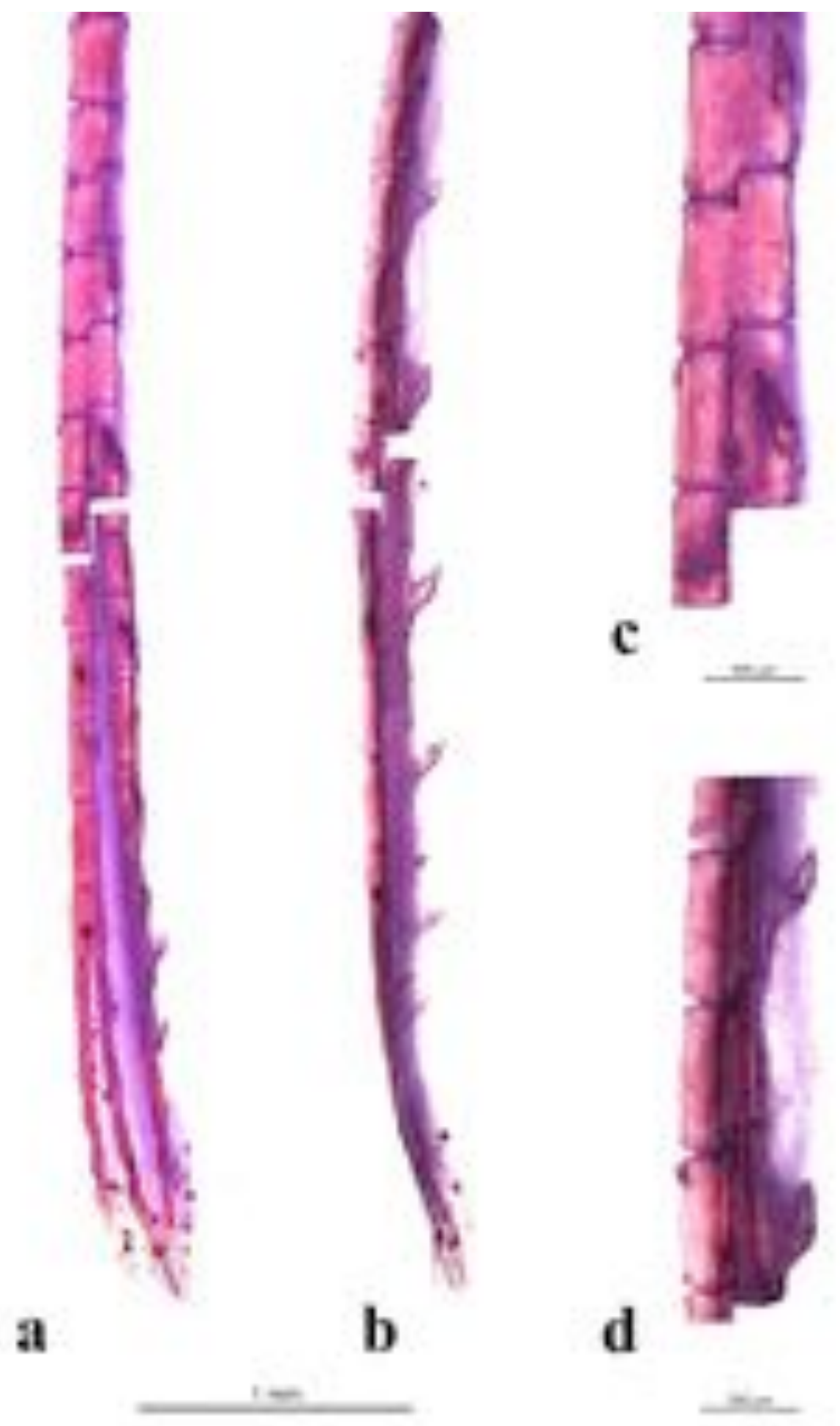

Figura 35. Distribuição, posição de inserção e formato dos processos ósseos no hemitriquium esquerdo do raio ramificado da nadadeira anal de machos de Astyanax cf. jordani. (a) vista lateral, (b) vista anteroposterior, (c) detalhe em vista lateral e (d) detalhe em vista anteroposterior. 


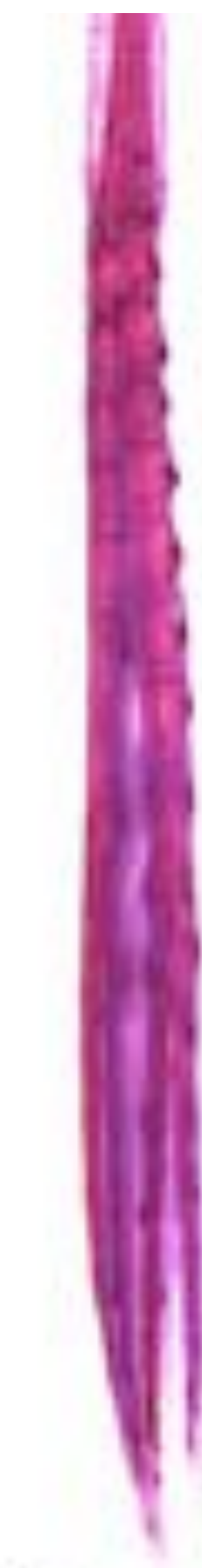

a
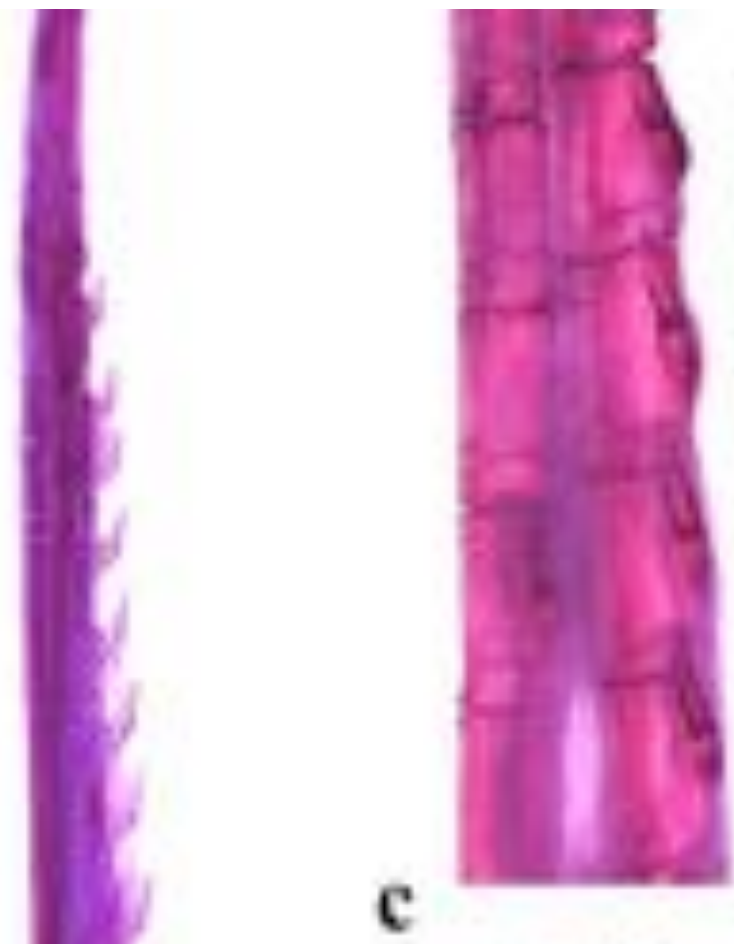

C
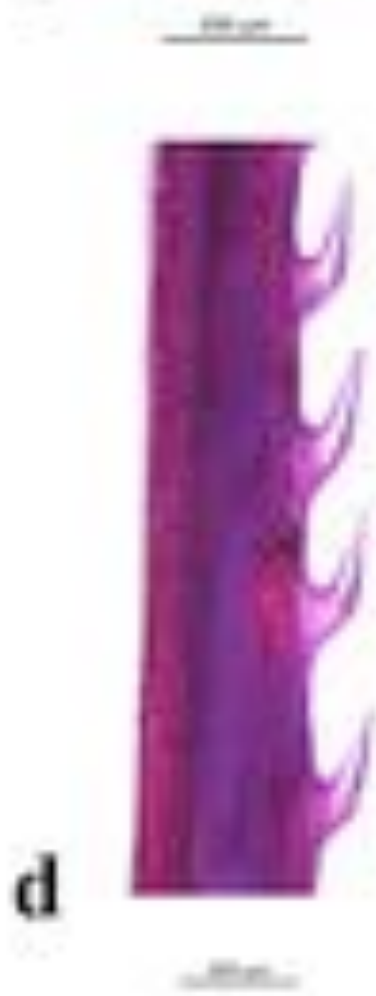

Figura 36. Distribuição, posição de inserção e formato dos processos ósseos no hemitriquium ventral do raio ramificado da nadadeira pélvica direita de machos de Astyanax cf. jordani. (a) vista ventral, (b) vista lateromedial, (c) detalhe em vista ventral e (d) detalhe em vista lateromedial. 


\section{Hyphessobrycon anisitsi (Eigenmann 1907)}

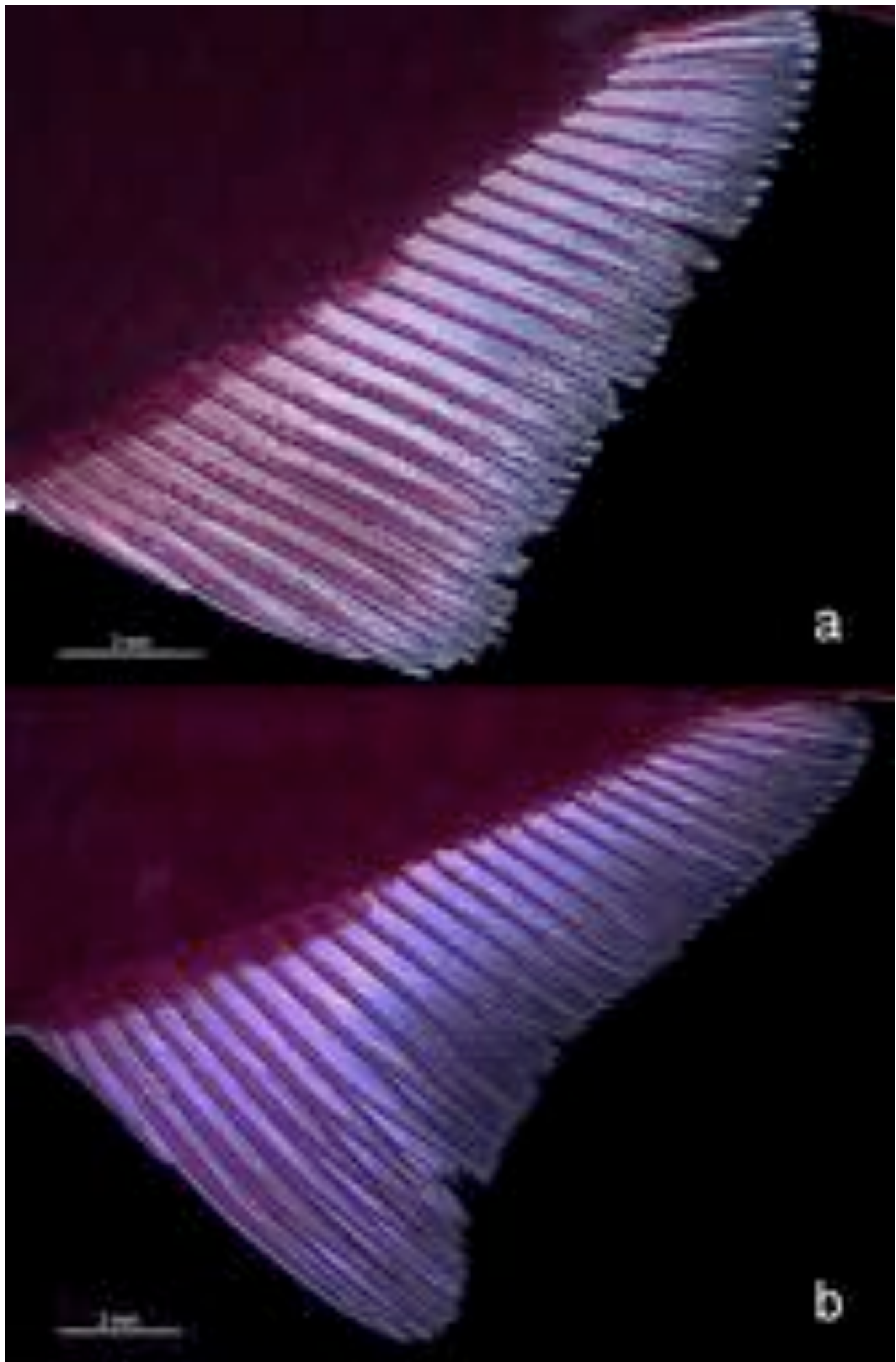

Figura 37. Nadadeira anal de machos (a) e de fêmeas (b) de Hyphessobrycon anisitsi em vista lateral esquerda, evidenciando o formato da margem distal da nadadeira nos dois sexos e distribuição dos processos ósseos na nadadeira anal de macho. 


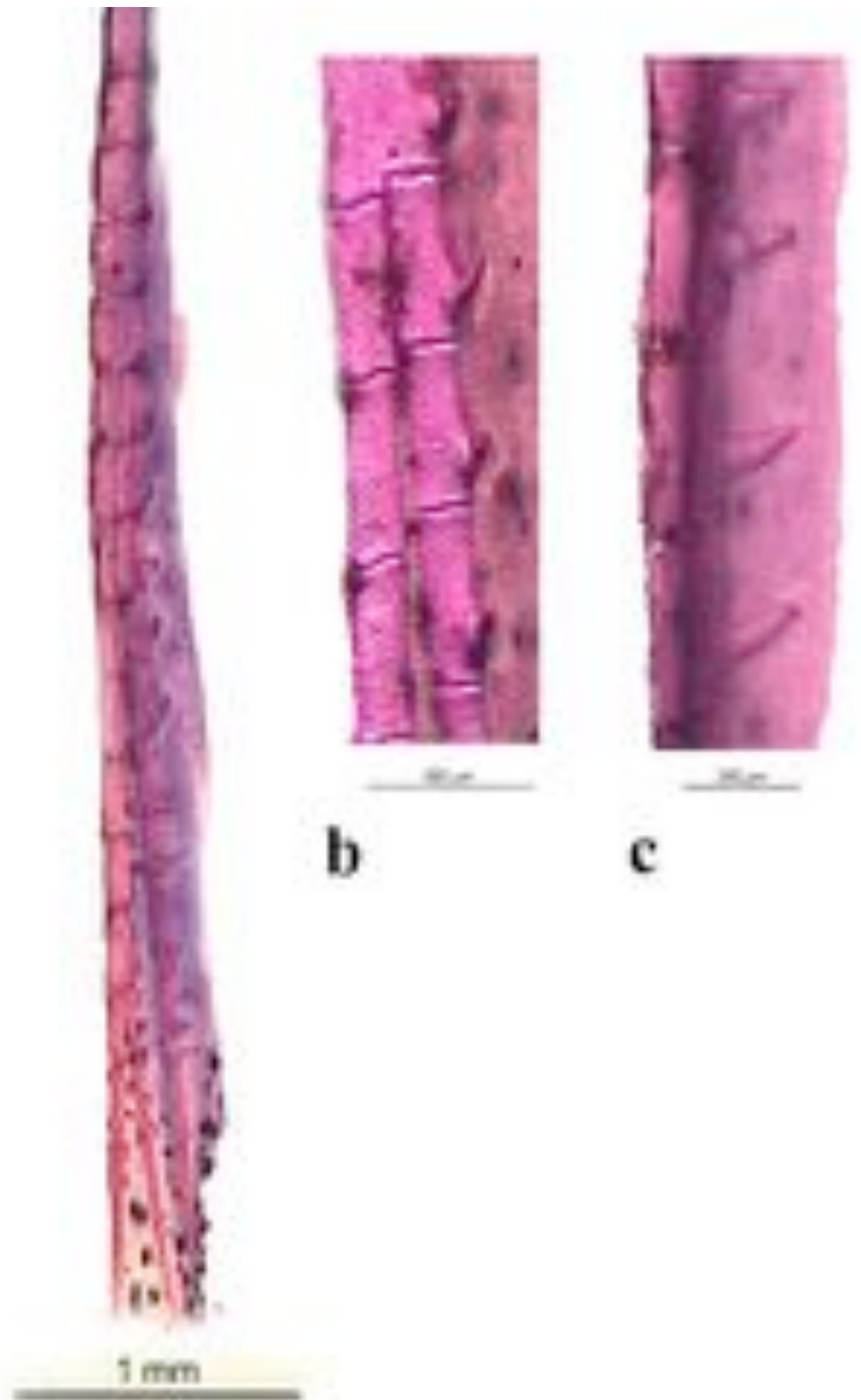

\section{a}

Figura 38. Distribuição, posição de inserção e formato dos processos ósseos no hemitriquium esquerdo do raio ramificado da nadadeira anal de machos de Hyphessobrycon anisitsi. (a) vista lateral, (b) detalhe em vista lateral e (c) detalhe em vista anteroposterior. 


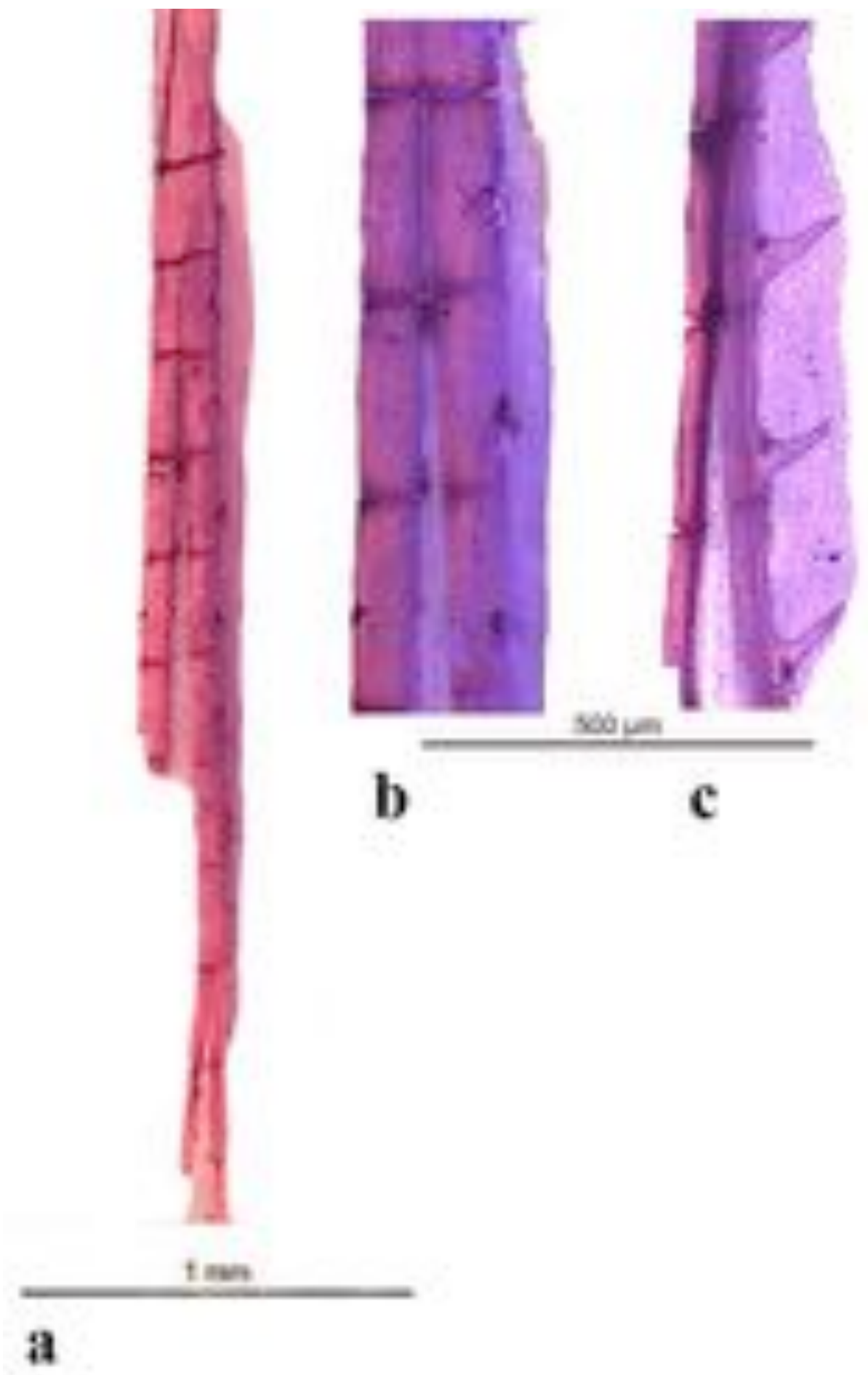

Figura 39. Distribuição, posição de inserção e formato dos processos ósseos no hemitriquium ventral do raio ramificado da nadadeira pélvica direita de machos de Hyphessobrycon anisitsi. (a) vista ventral, (b) detalhe em vista ventral e (c) detalhe em vista lateromedial. 
Markiana nigripinnis (Perugia 1891)

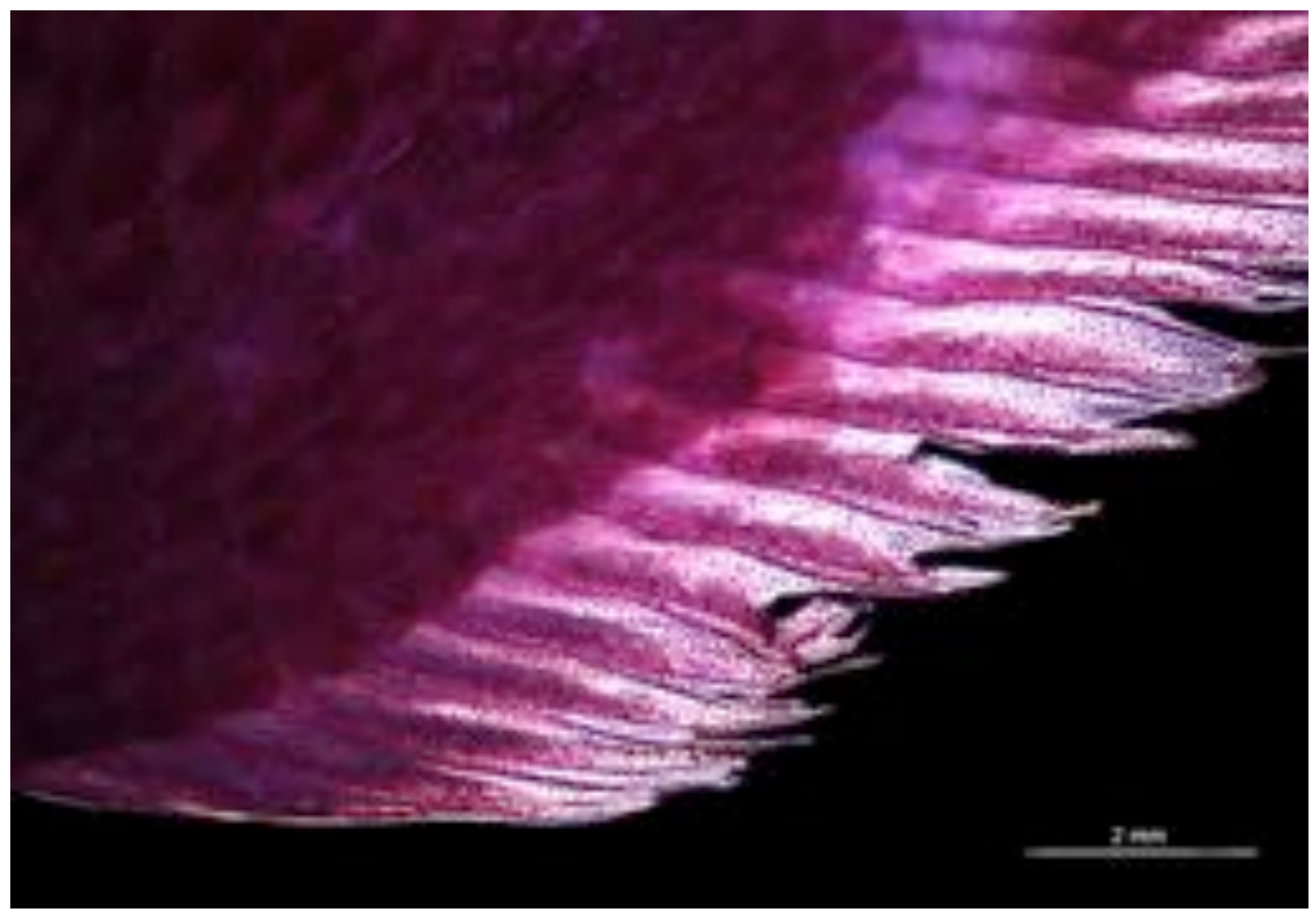

Figura 40. Porção anterior da nadadeira anal de machos de Markiana nigripinnis em vista lateral esquerda, evidenciando o formato da margem distal a distribuição dos processos ósseos na nadadeira. 

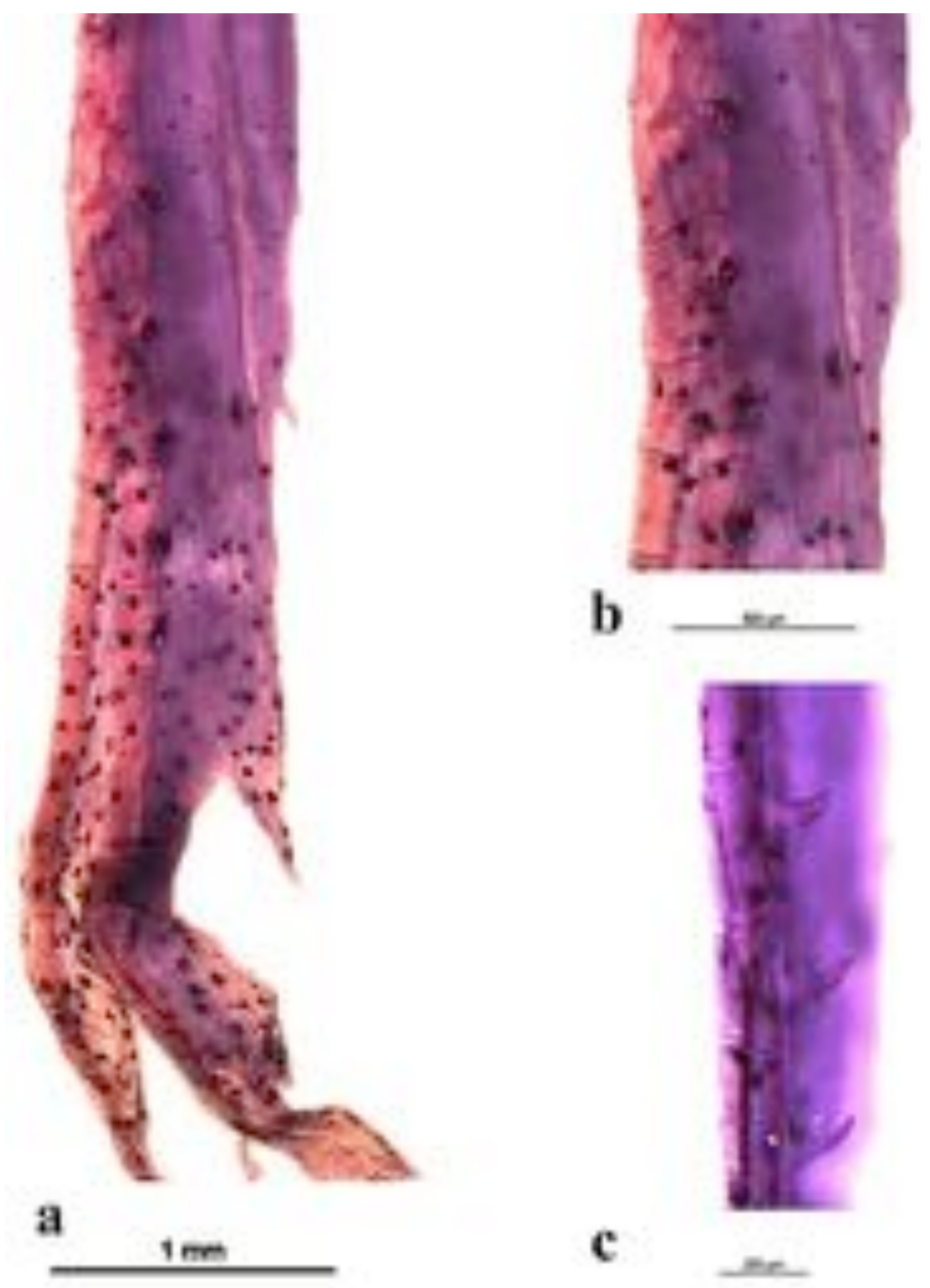

Figura 41. Distribuição, posição de inserção e formato dos processos ósseos no hemitriquium esquerdo do raio ramificado da nadadeira anal de machos de Markiana nigripinnis. (a) vista lateral, (b) detalhe em vista lateral e (c) detalhe em vista anteroposterior. 


\section{Psellogrammus kennedyi (Eigenmann 1903)}
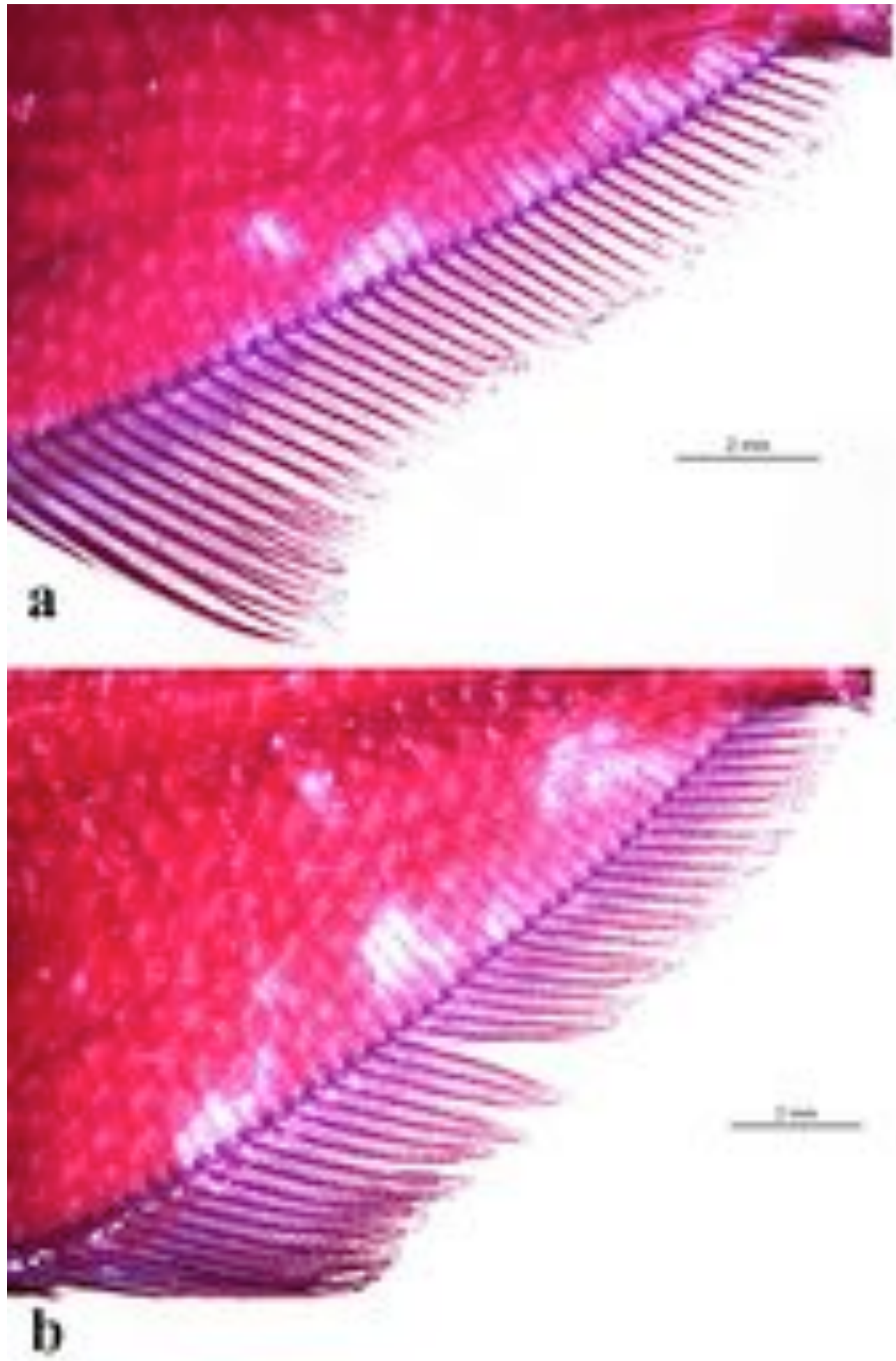

Figura 42. Nadadeira anal de fêmeas (a) e de machos (b) de Psellogrammus kennedyi em vista lateral esquerda, evidenciando o formato da margem distal da nadadeira nos dois sexos e a distribuição dos processos ósseos na nadadeira anal de macho. 

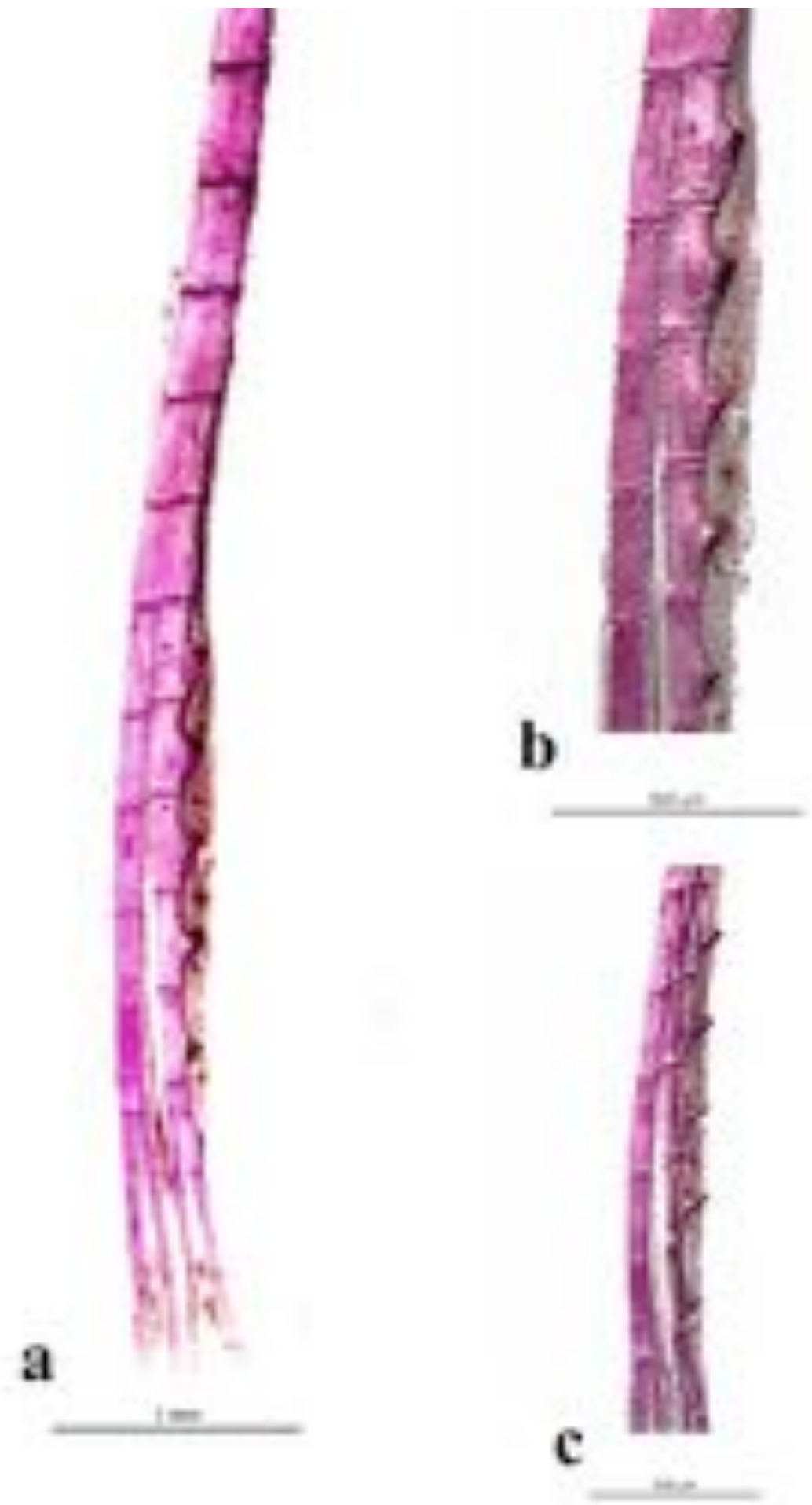

Figura 43. Distribuição, posição de inserção e formato dos processos ósseos no hemitriquium esquerdo do raio ramificado da nadadeira anal de machos de Psellogrammus kennedyi. (a) vista lateral, (b) detalhe em vista lateral e (c) detalhe em vista anteroposterior. 

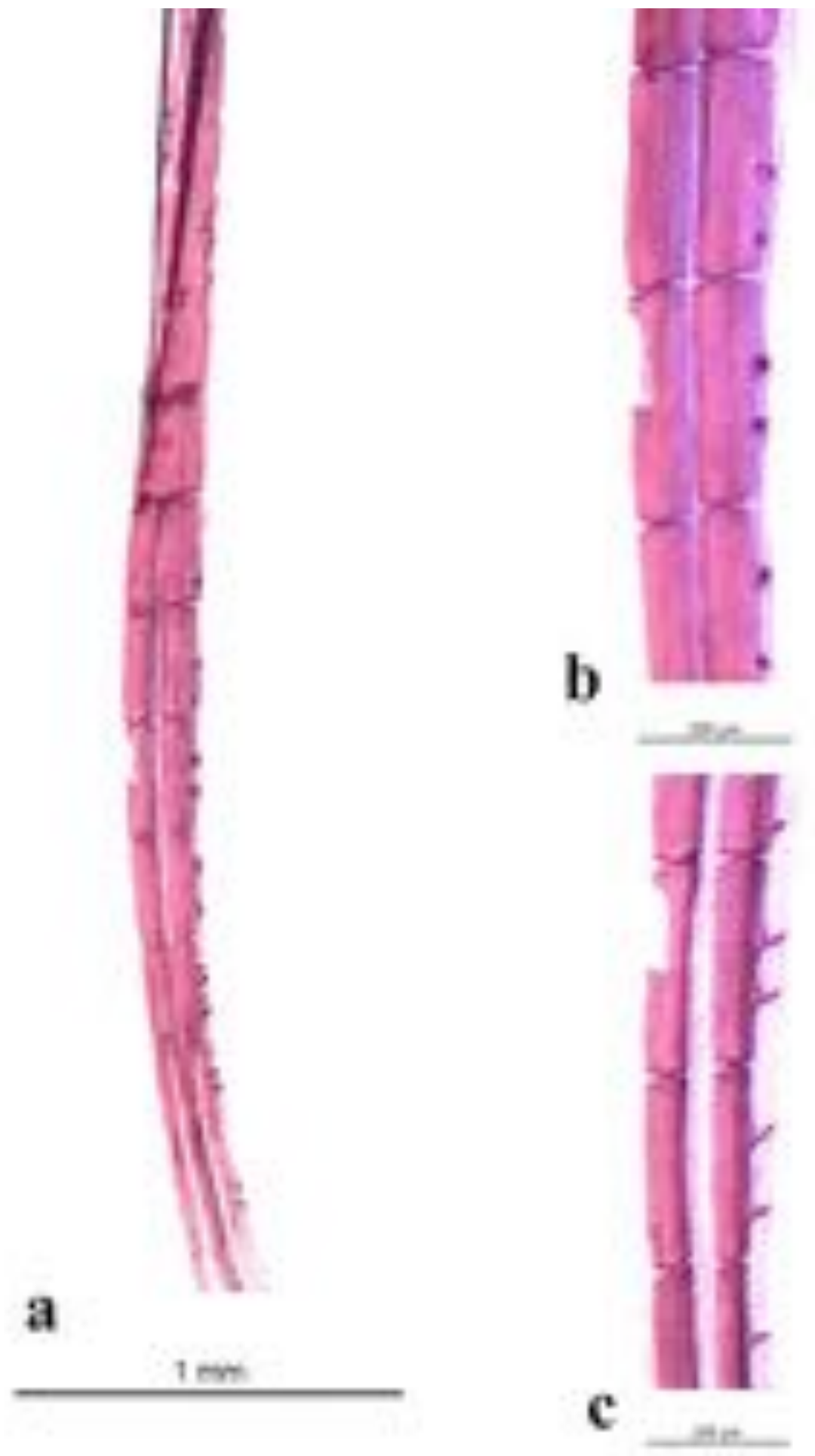

Figura 44. Distribuição, posição de inserção e formato dos processos ósseos no hemitriquium ventral do raio ramificado da nadadeira pélvica direita de machos de Psellogrammus kennedyi. (a) vista ventral, (b) detalhe em vista ventral e (c) detalhe em vista lateromedial. 
GRUPO Astyanax scabripinnis

Astyanax brachypterigium Bertaco \& Malabarba 2001
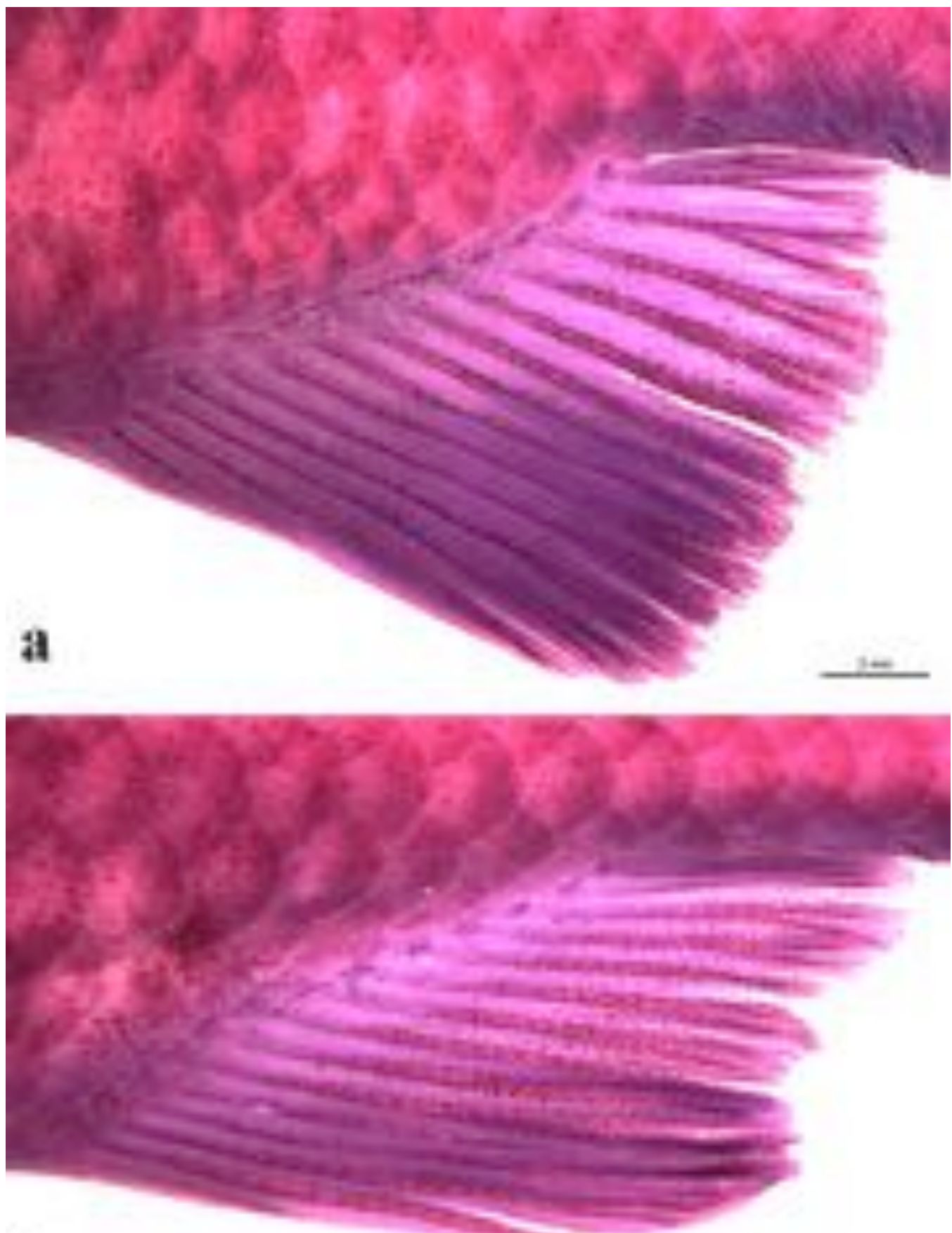

b

Figura 45. Nadadeira anal de machos (a) e de fêmeas (b) de Astyanax

brachypterigium em vista lateral esquerda, evidenciando o formato do perfil distal das nadadeiras nos dois sexos e distribuição dos processos ósseos na nadadeira anal de macho. 


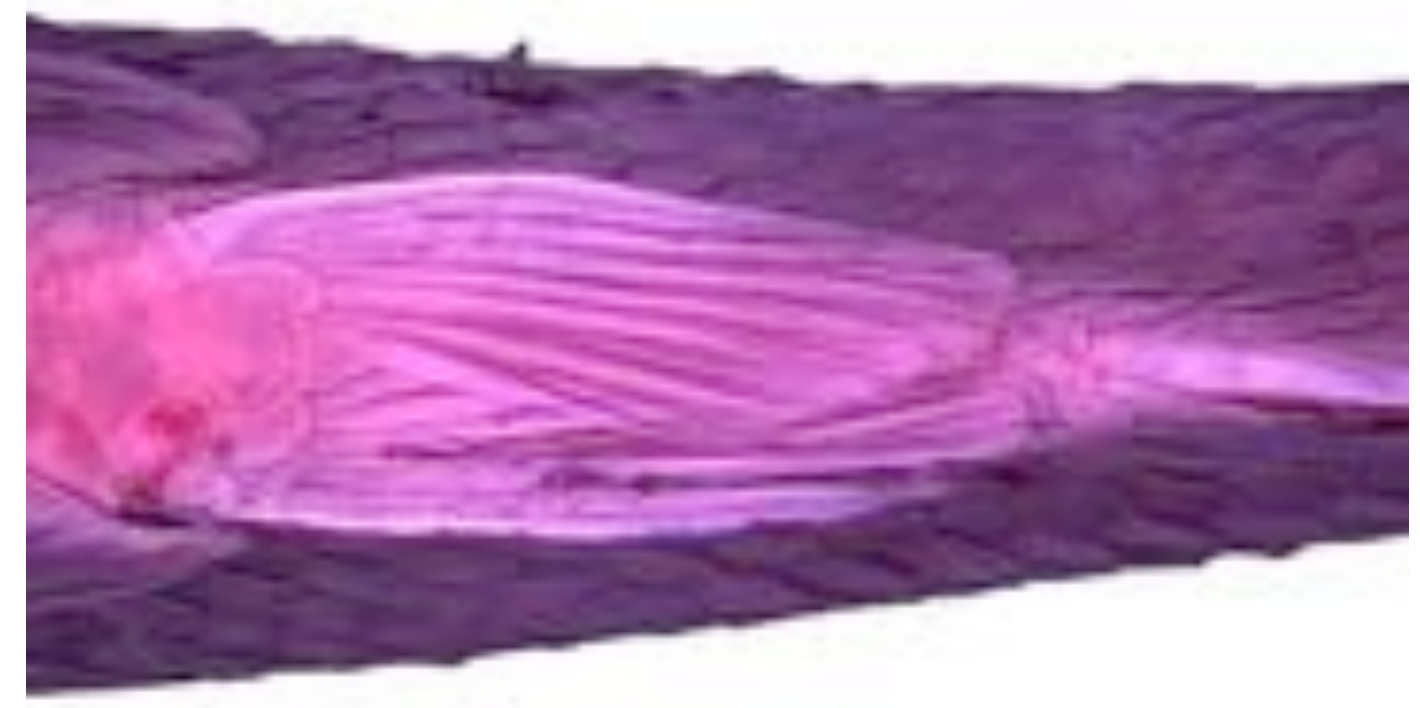

a
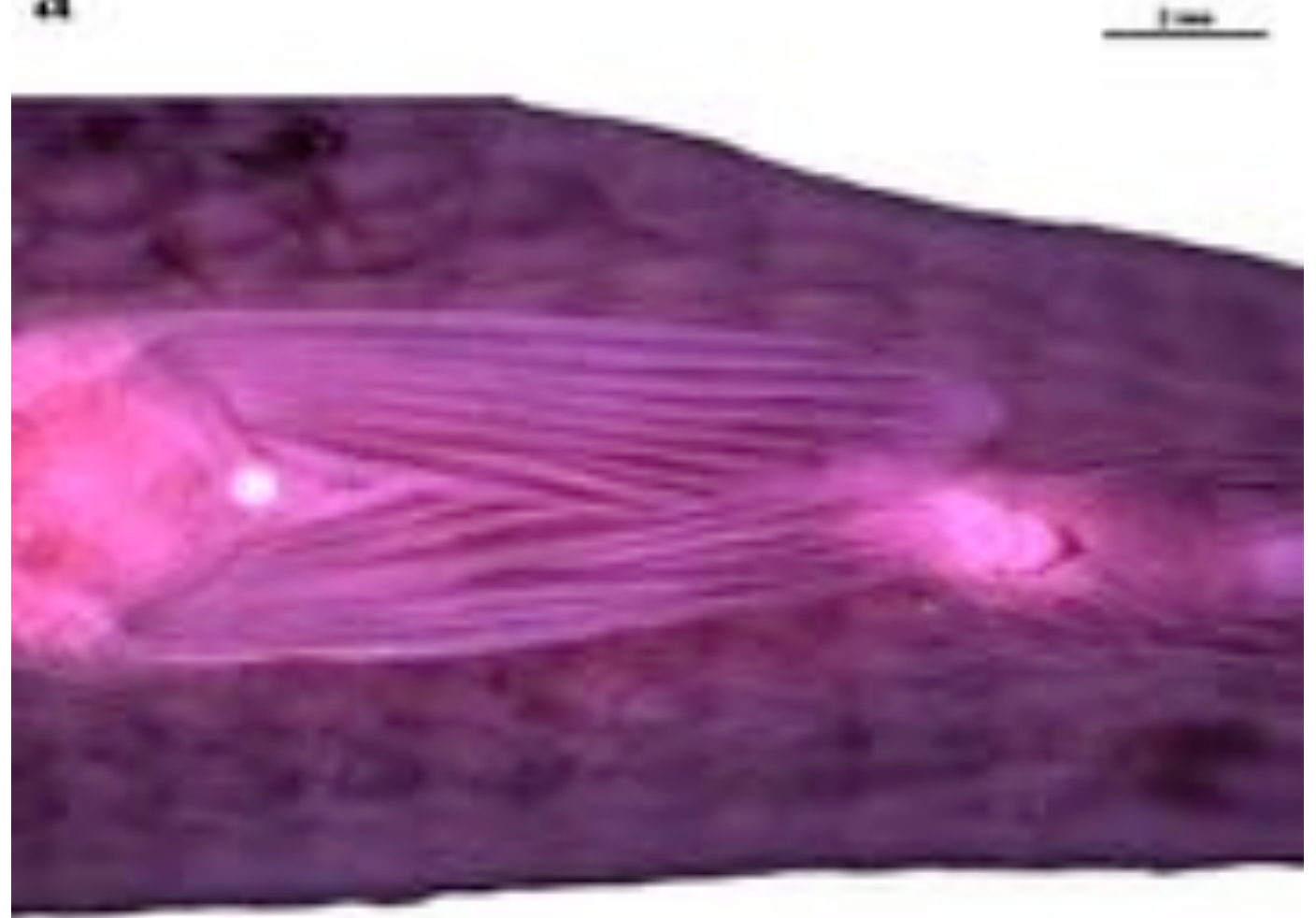

b

Figura 46. Nadadeira pélvica de machos (a) e de fêmeas (b) de Astyanax brachypterigium em vista lateral ventral, evidenciando o formato e comprimento da nadadeira nos dois sexos. 


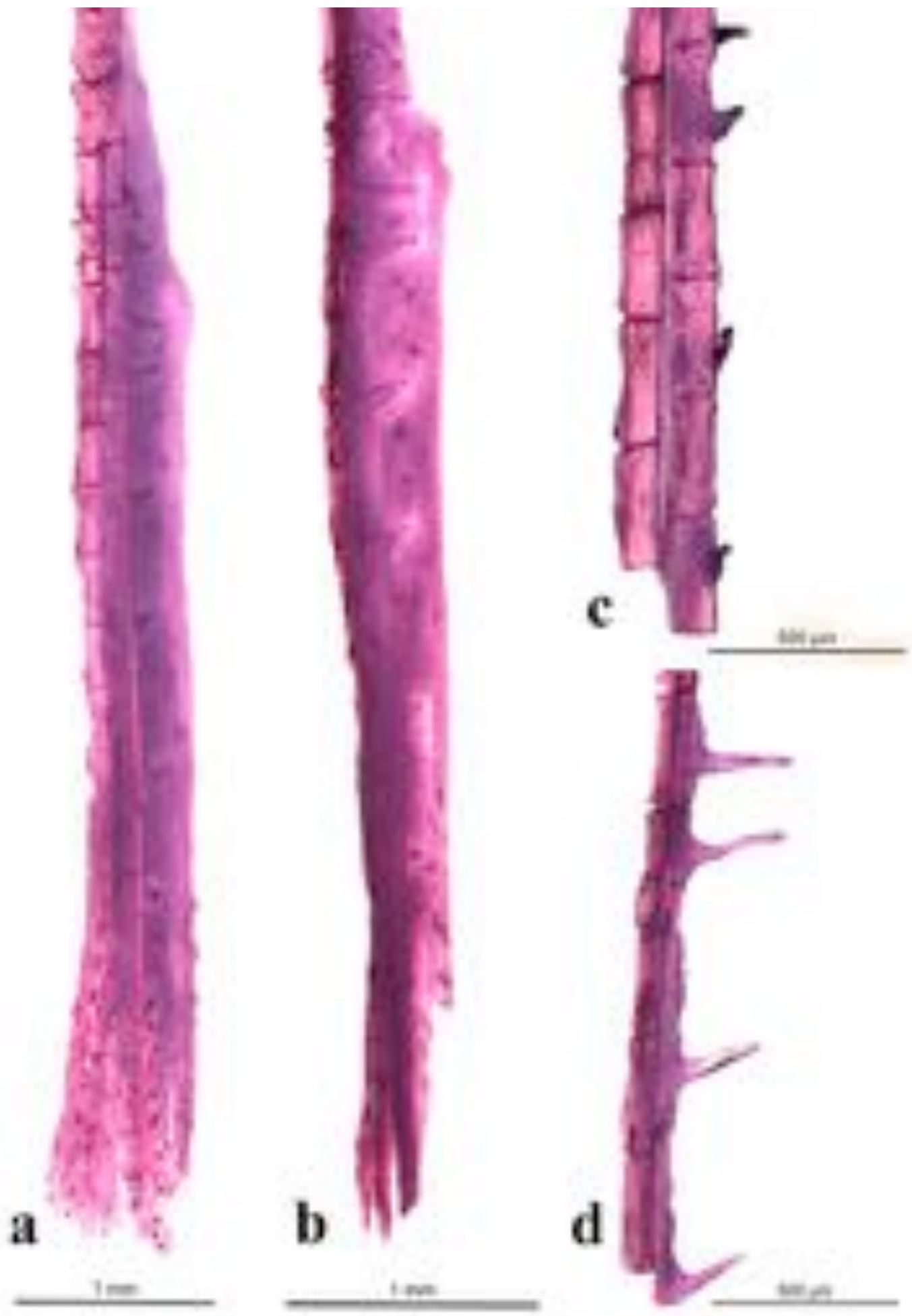

Figura 47. Distribuição, posição e formato dos processos ósseos no hemitriquium esquerdo do raio ramificado da nadadeira anal de machos de Astyanax brachypterigium. (a) vista lateral, (b) vista anteroposterior, (c) detalhe em vista lateral, (d) detalhe em vista anteroposterior. 

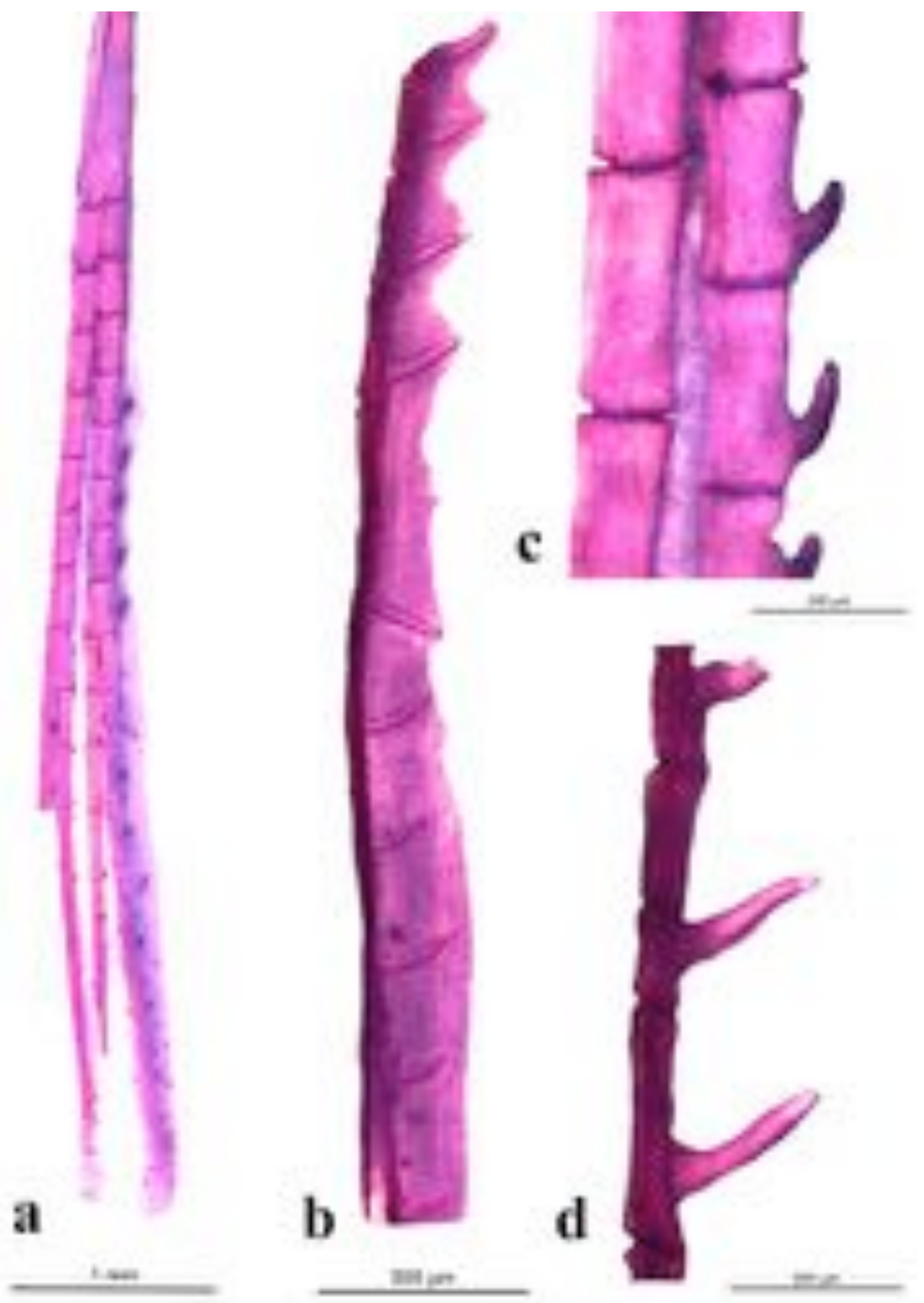

Figura 48. Distribuição, posição e formato dos processos ósseos no hemitriquium ventral da nadadeira pélvica direita de machos de Astyanax brachypterigium. (a) vista ventral, (b) vista lateromedial, (c) detalhe em vista ventral e (d) detalhe em vista lateromedial. 
Astyanax courensis Bertaco, Carvalho \& Jerep 2010
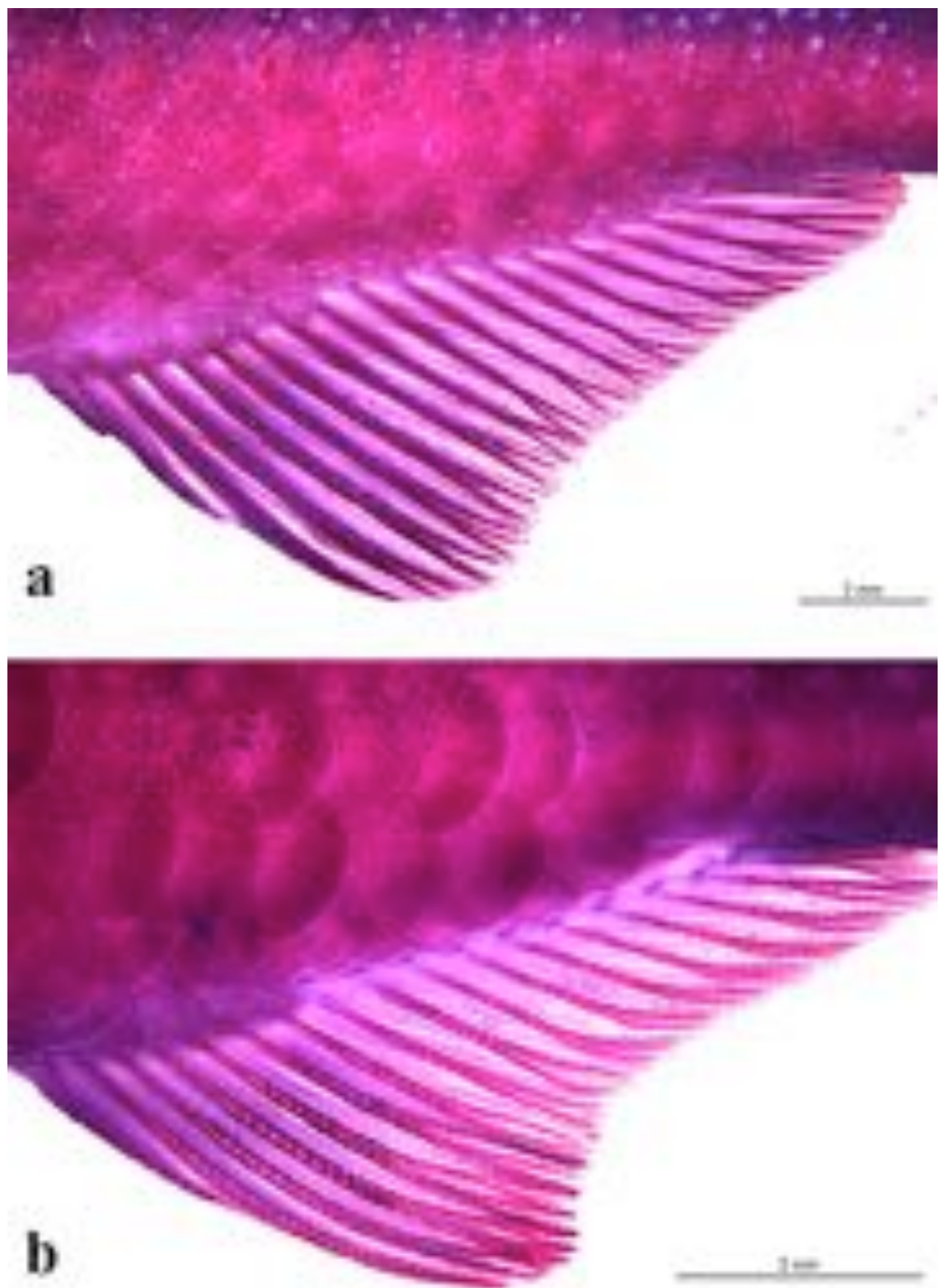

Figura 49. Nadadeira anal de machos (a) e de fêmeas (b) de Astyanax courensis em vista lateral esquerda, evidenciando o formato do perfil distal das nadadeiras nos dois sexos e distribuição dos processos ósseos na nadadeira anal e de tubérculos reprodutivos nas escamas de macho. 


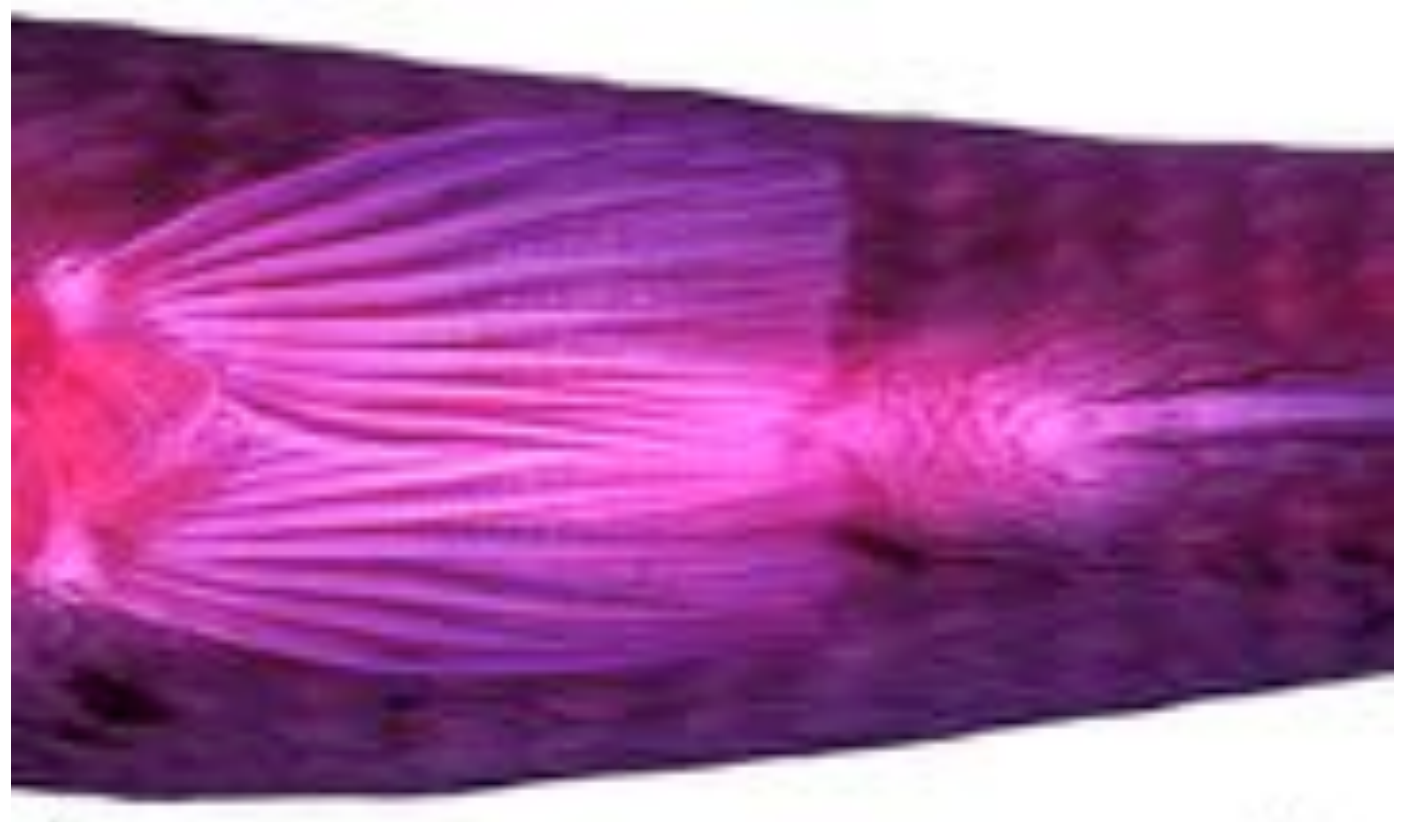

a

10

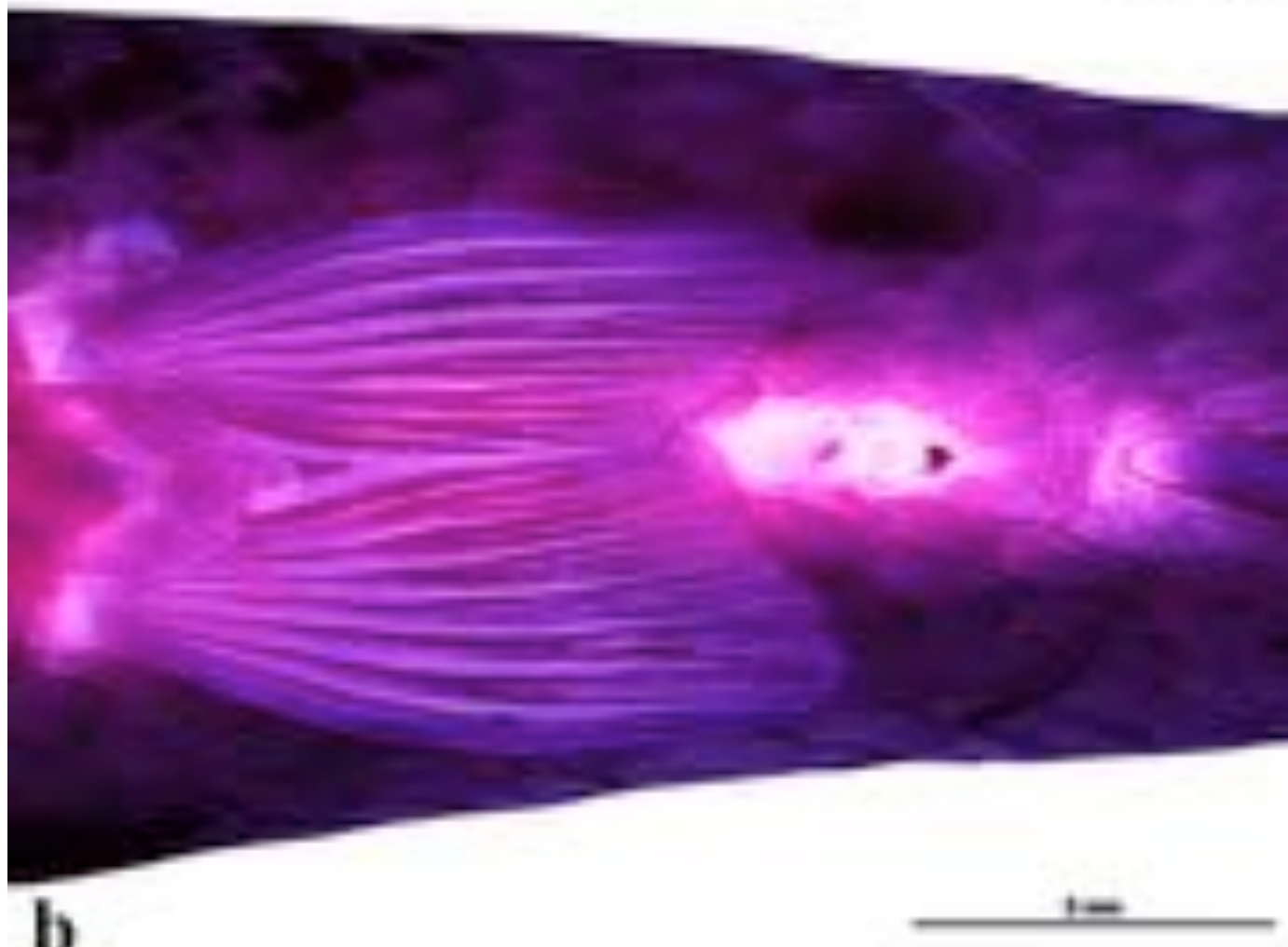

Figura 50. Nadadeira pélvica de machos (a) e de fêmeas (b) de Astyanax courensis em vista lateral ventral, evidenciando o formato e comprimento da nadadeira nos dois sexos. 

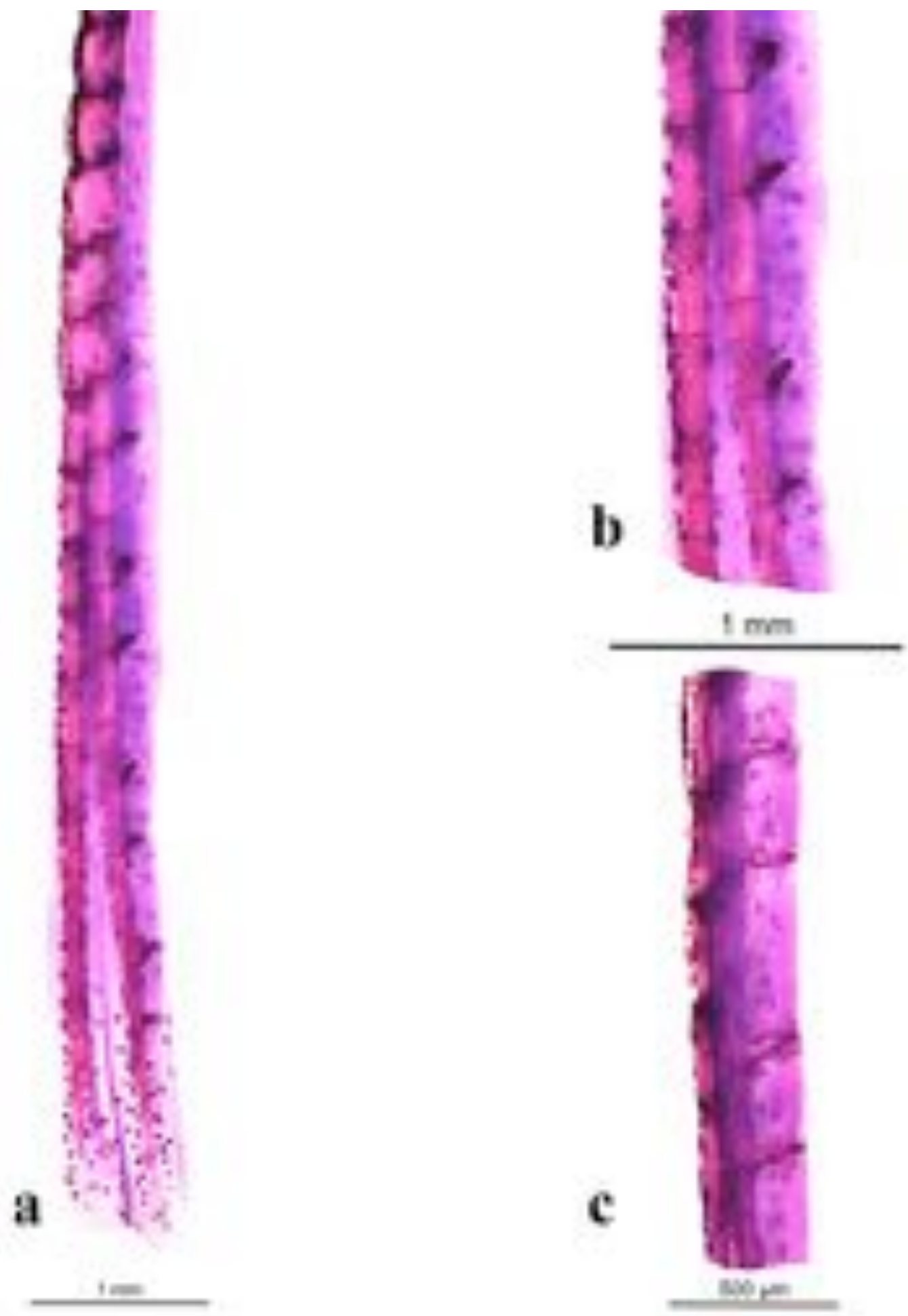

Figura 51. Distribuição, posição e formato dos processos ósseos no hemitriquium esquerdo do raio ramificado da nadadeira anal de machos de Astyanax courensis. (a) vista lateral, (b) detalhe em vista lateral e (c) detalhe em vista anteroposterior. 

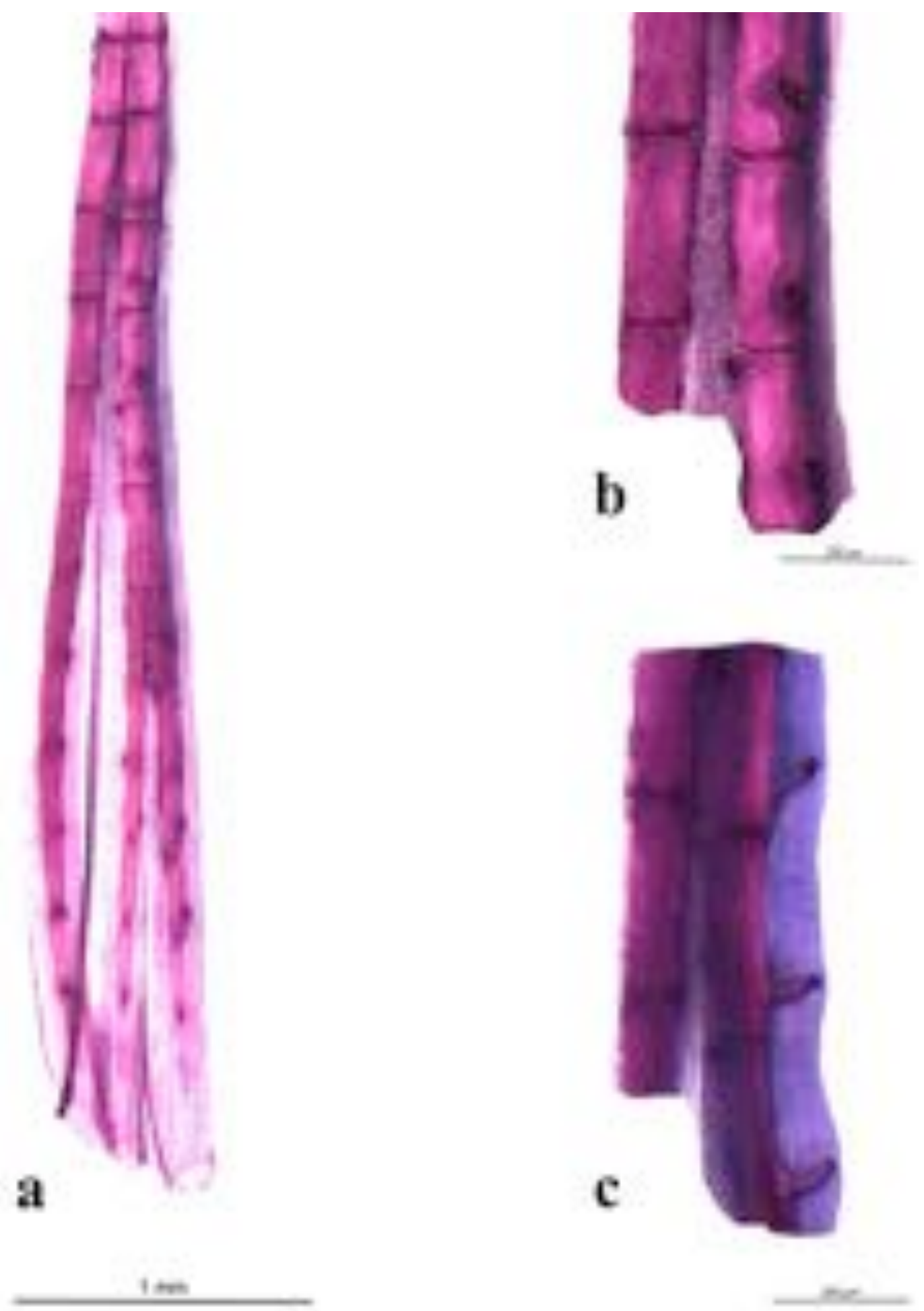

Figura 52. Distribuição, posição e formato dos processos ósseos no hemitriquium ventral da nadadeira pélvica direita de machos de Astyanax courensis. (a) vista ventral, (b) vista lateromedial, (c) detalhe em vista ventral e (d) detalhe em vista lateromedial. 

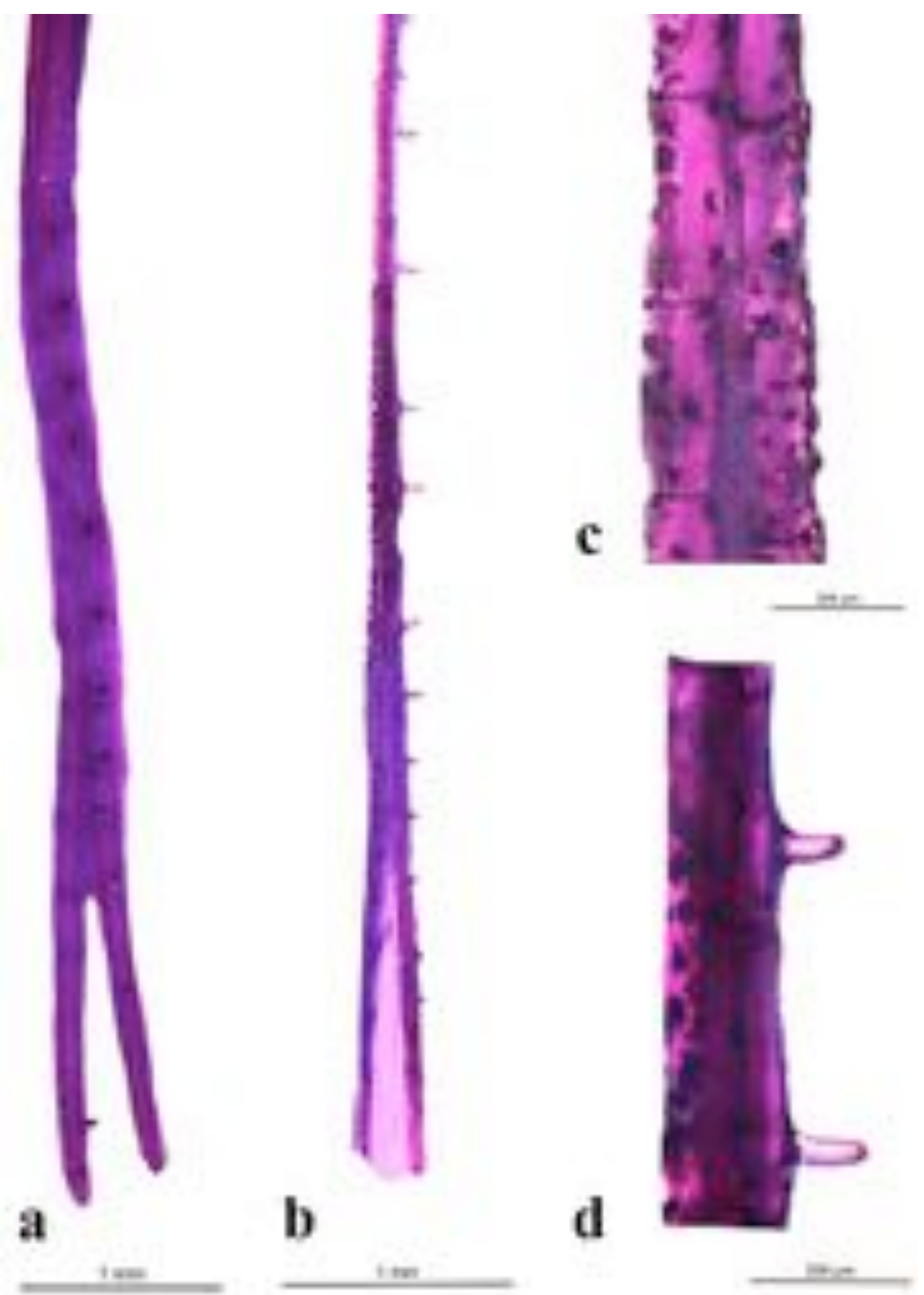

Figura 53. Distribuição, posição e formato dos processos ósseos no hemitriquium ventral da nadadeira peitoral direita de machos de Astyanax courensis. (a) vista dorsal, (b) vista lateromedial, (c) detalhe em vista dorsal e (d) detalhe em vista lateromedial. 


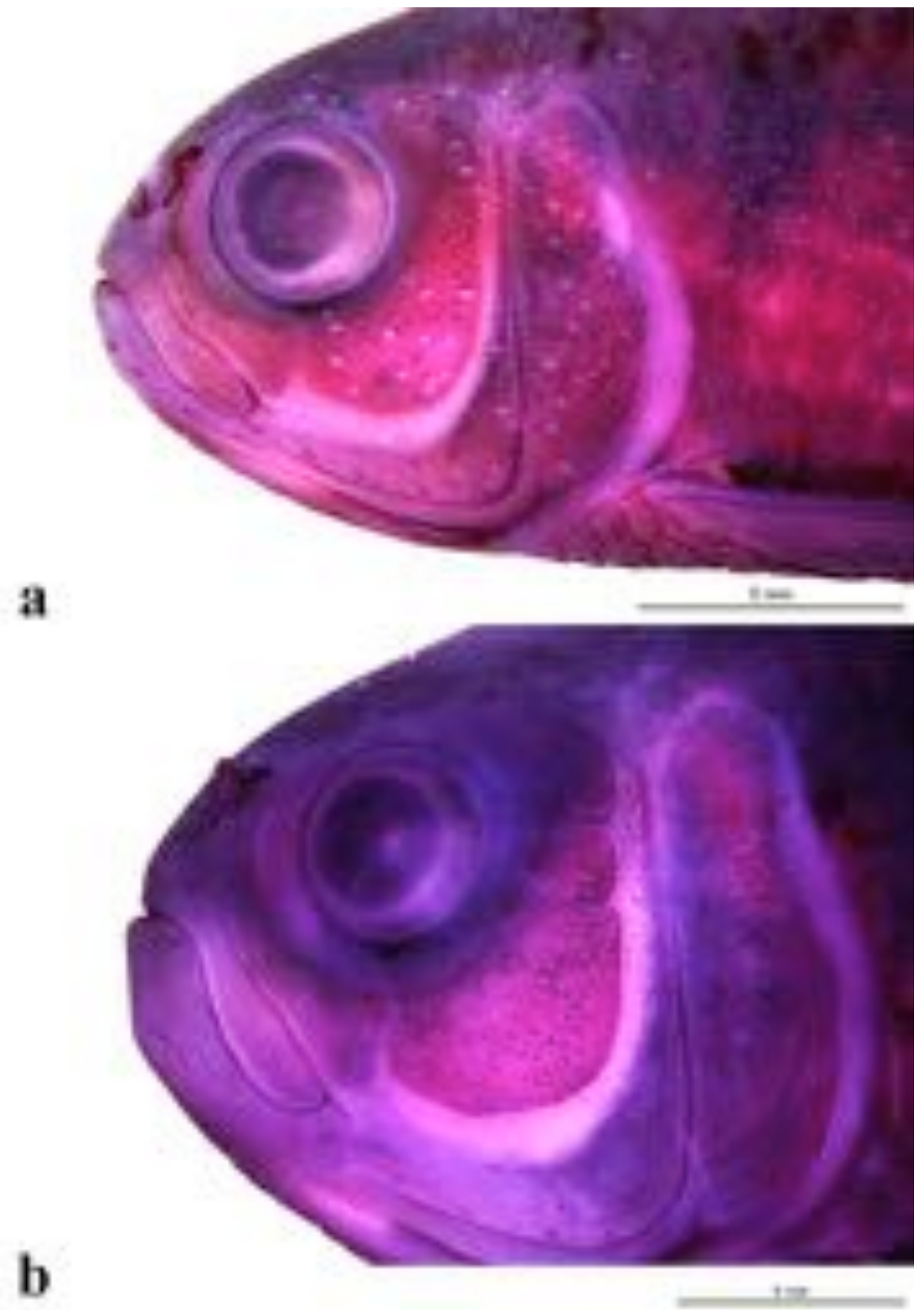

Figura 54. Cabeça de machos (a) e de fêmeas (b) de Astyanax courensis em vista lateral esquerda, evidenciando a distribuição dos tubérculos reprodutivos na cabeça do macho. 
Astyanax goyanensis (Miranda Ribeiro 1944)
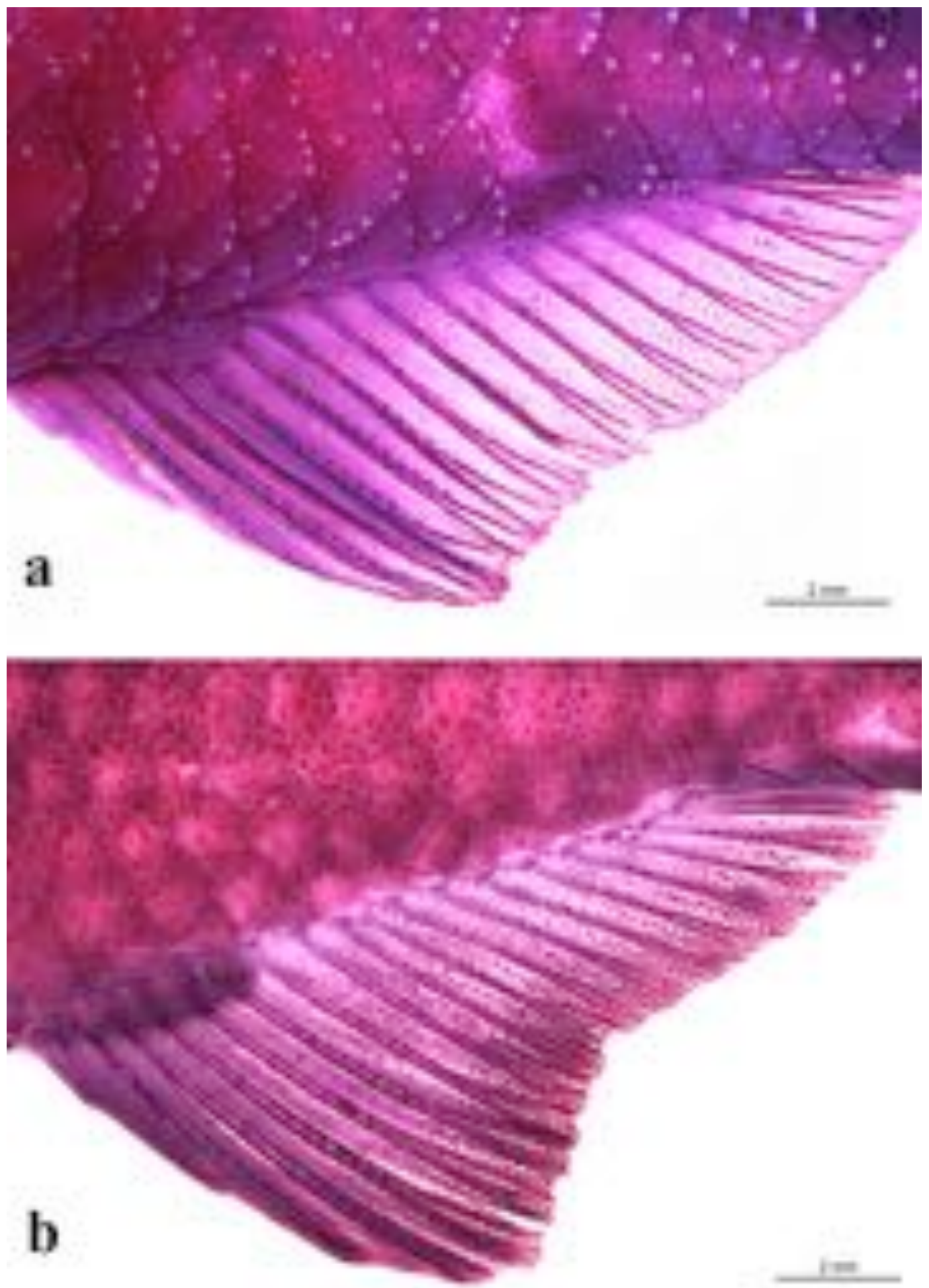

Figura 55. Nadadeira anal de machos (a) e de fêmeas (b) de Astyanax goyanensis em vista lateral esquerda, evidenciando o formato do perfil distal das nadadeiras nos dois sexos e distribuição dos processos ósseos na nadadeira anal e de tubérculos reprodutivos nas escamas de macho. 


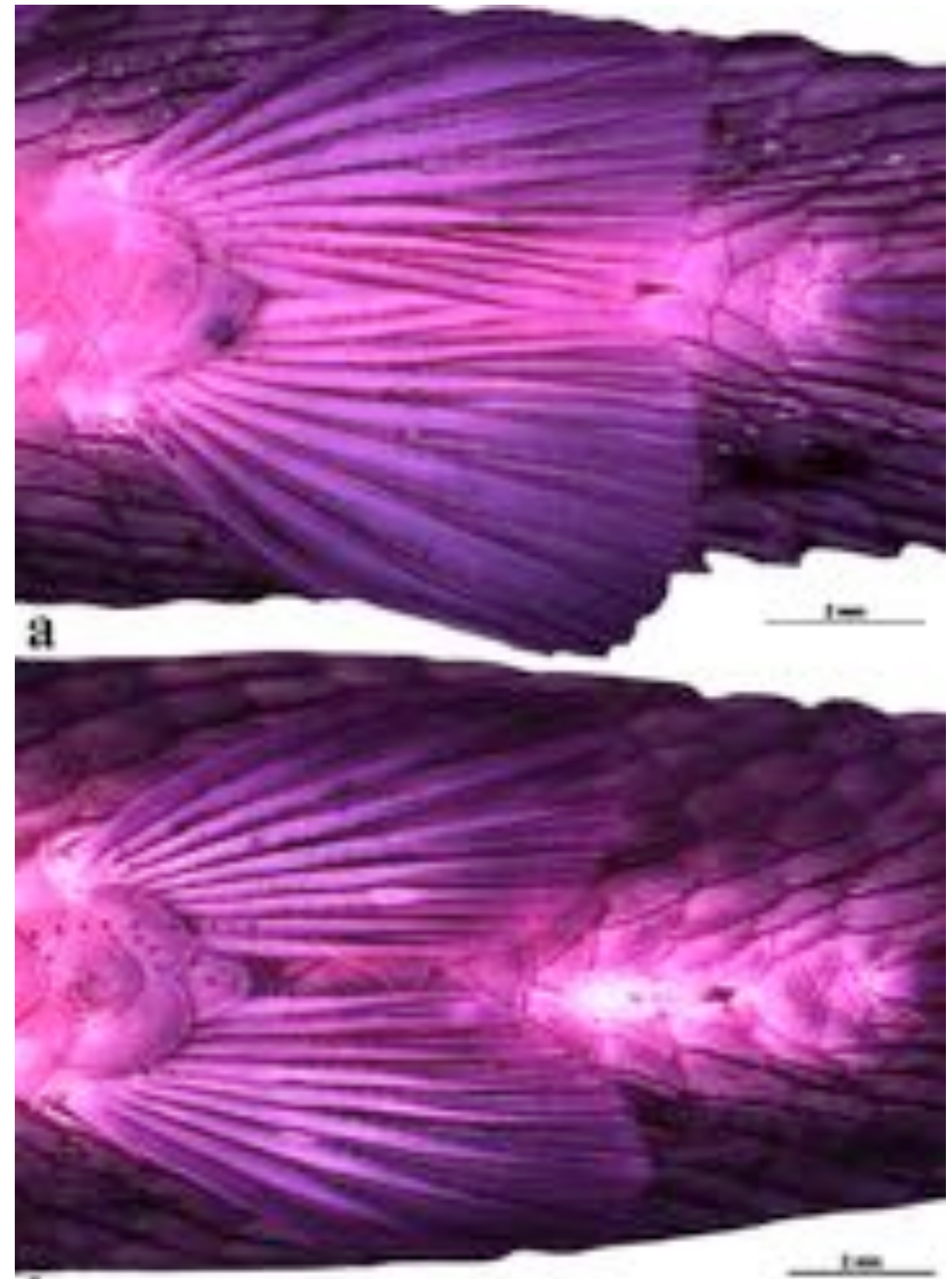

b

Figura 56. Nadadeira pélvica de machos (a) e de fêmeas (b) de Astyanax goyanensis em vista lateral ventral, evidenciando o formato e comprimento da nadadeira nos dois sexos. 

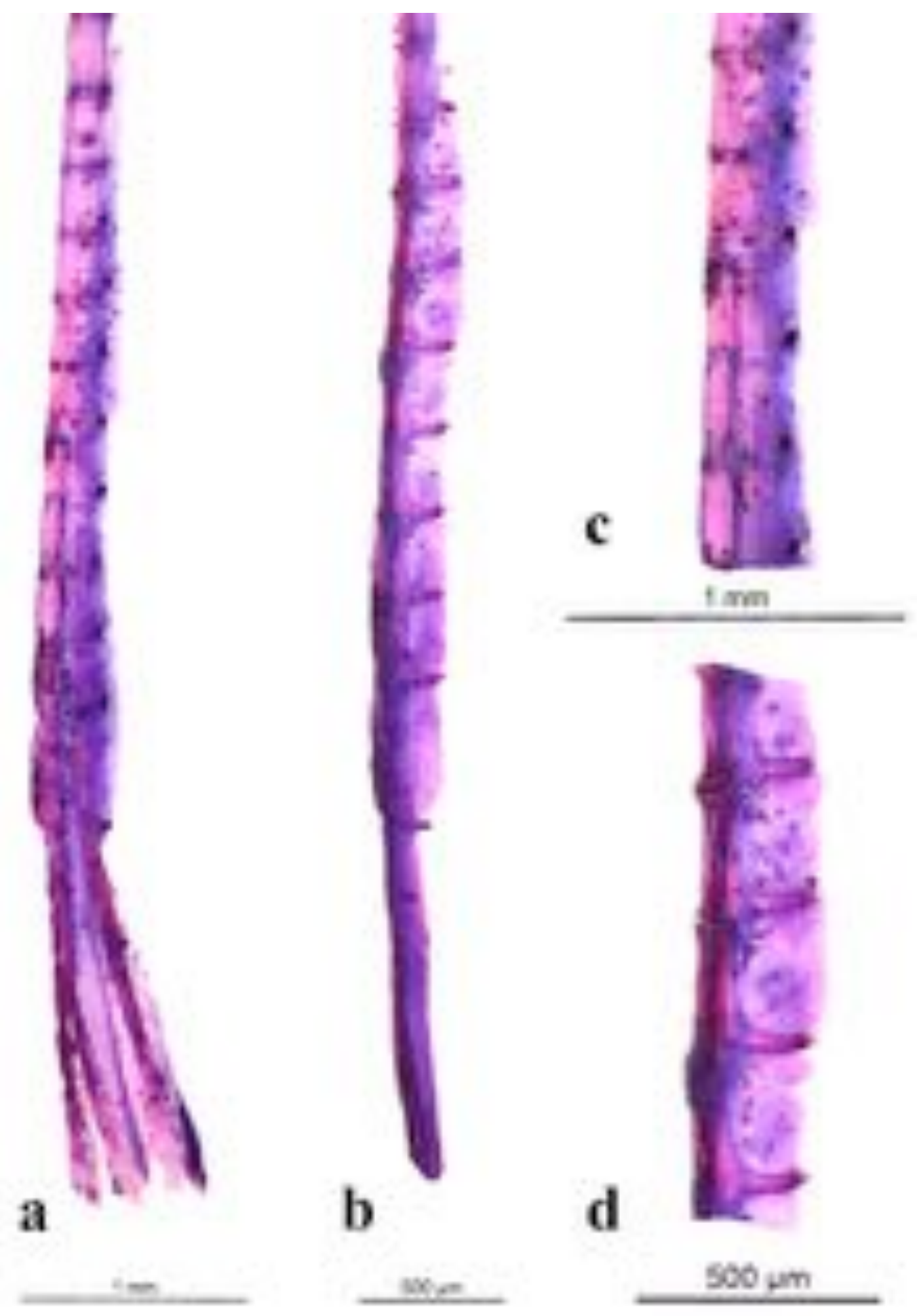

Figura 57. Distribuição, posição e formato dos processos ósseos no hemitriquium esquerdo do raio ramificado da nadadeira anal de machos de Astyanax goyanensis. (a) vista lateral, (b) detalhe em vista lateral e (c) detalhe em vista anteroposterior. 

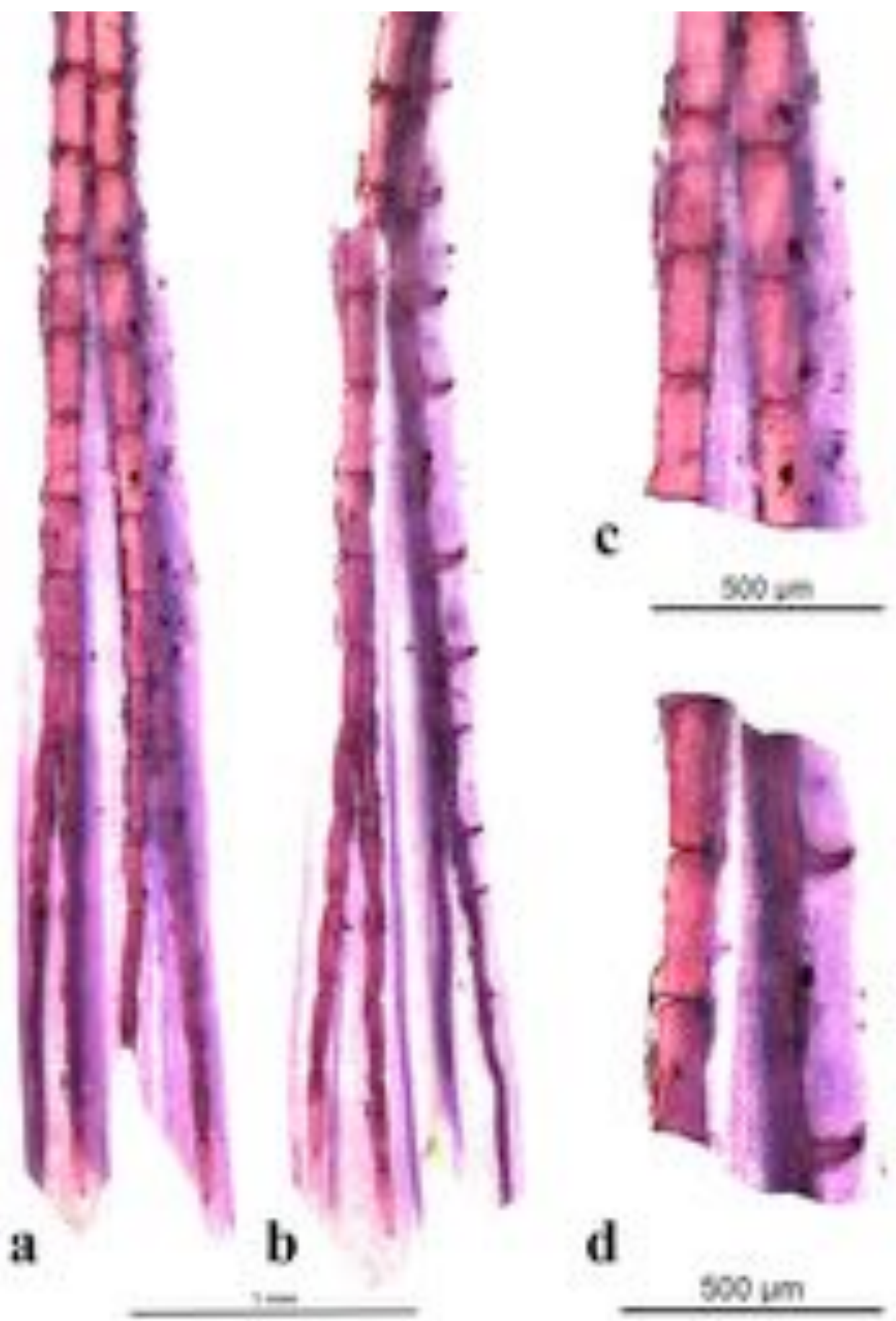

Figura 58. Distribuição, posição e formato dos processos ósseos no hemitriquium ventral da nadadeira pélvica direita de machos de Astyanax goyanensis. (a) vista ventral, (b) vista lateromedial, (c) detalhe em vista ventral e (d) detalhe em vista lateromedial. 

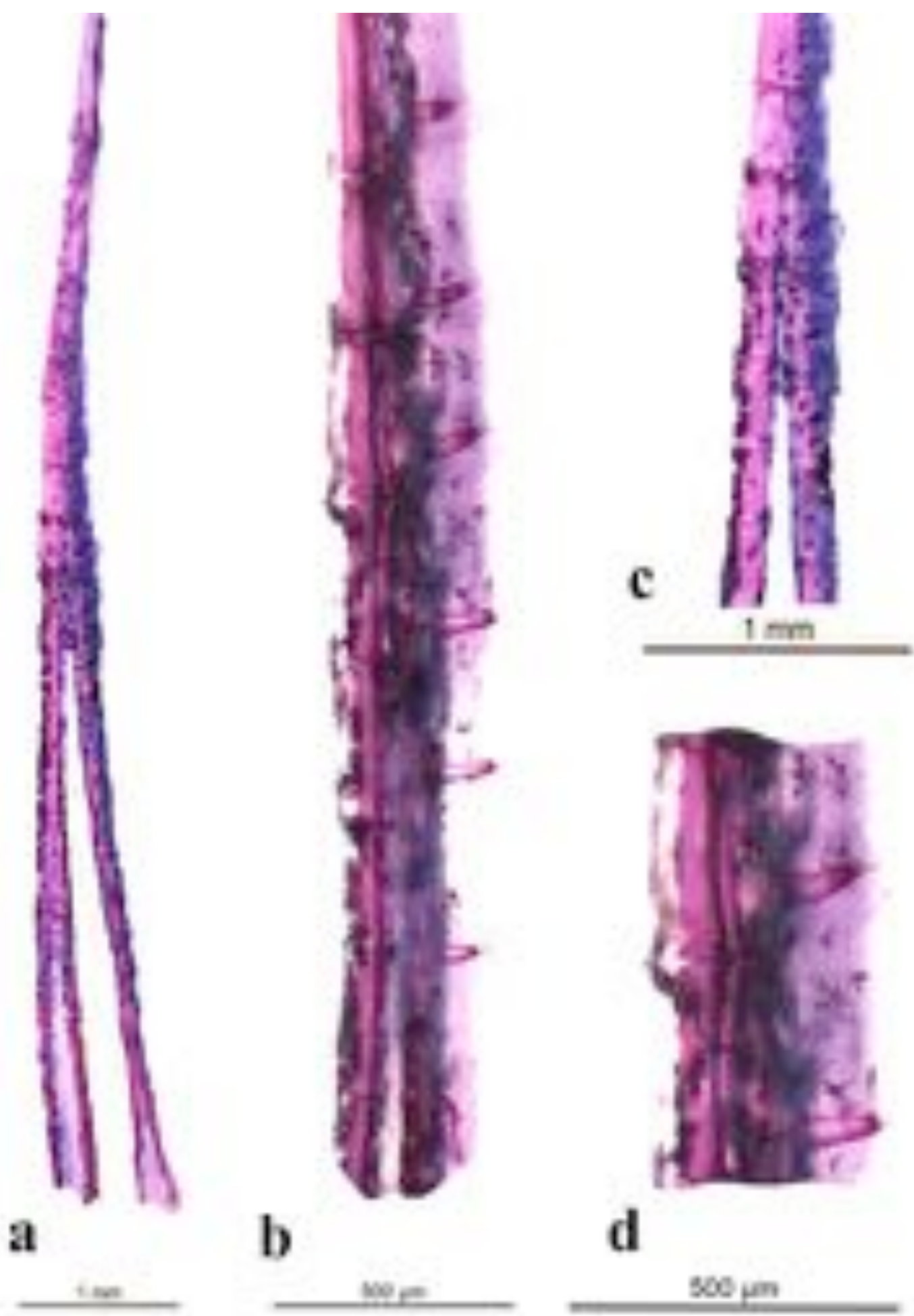

Figura 59. Distribuição, posição e formato dos processos ósseos no hemitriquium ventral da nadadeira peitoral direita de machos de Astyanax goyanensis. (a) vista dorsal, (b) vista lateromedial, (c) detalhe em vista dorsal e (d) detalhe em vista lateromedial. 

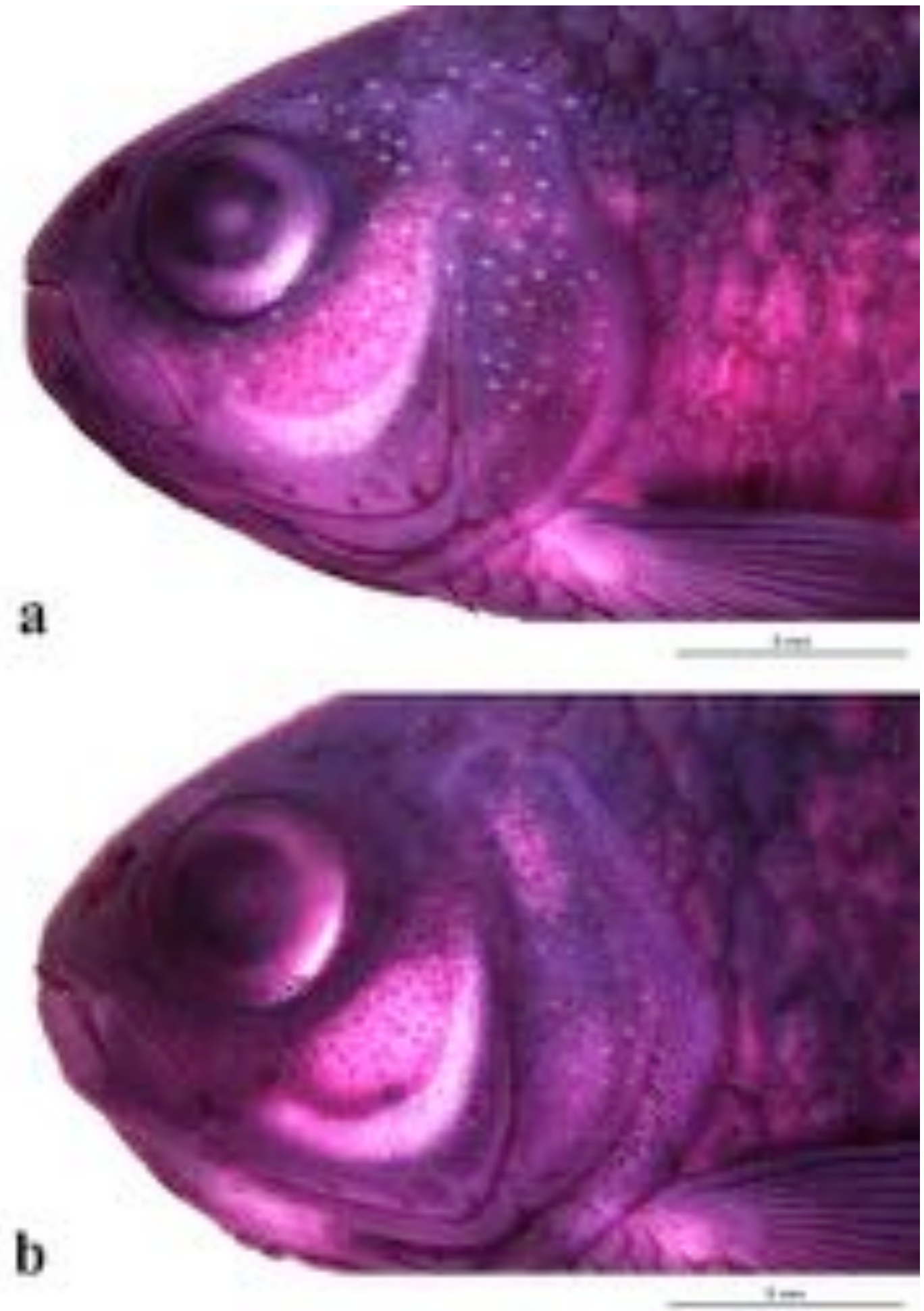

Figura 60. Cabeça de machos (a) e de fêmeas (b) de Astyanax goyanensis em vista lateral esquerda, evidenciando a distribuição dos tubérculos reprodutivos na cabeça do macho. 


\section{Astyanax rivularis (Lutken 1875)}
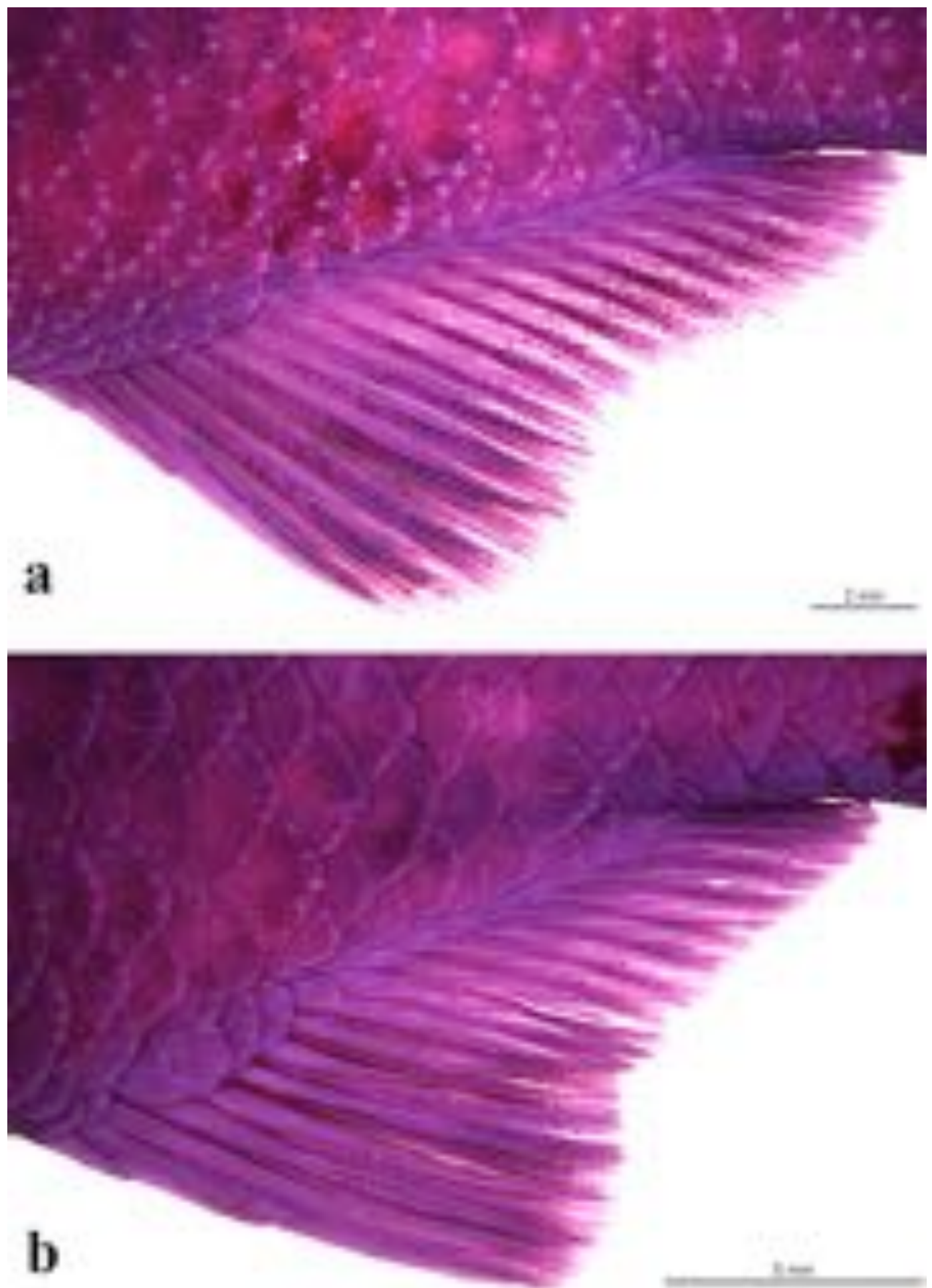

Figura 61. Nadadeira anal de machos (a) e de fêmeas (b) de Astyanax rivularis em vista lateral esquerda, evidenciando o formato do perfil distal das nadadeiras nos dois sexos e distribuição dos processos ósseos na nadadeira anal e de tubérculos reprodutivos nas escamas de macho. 

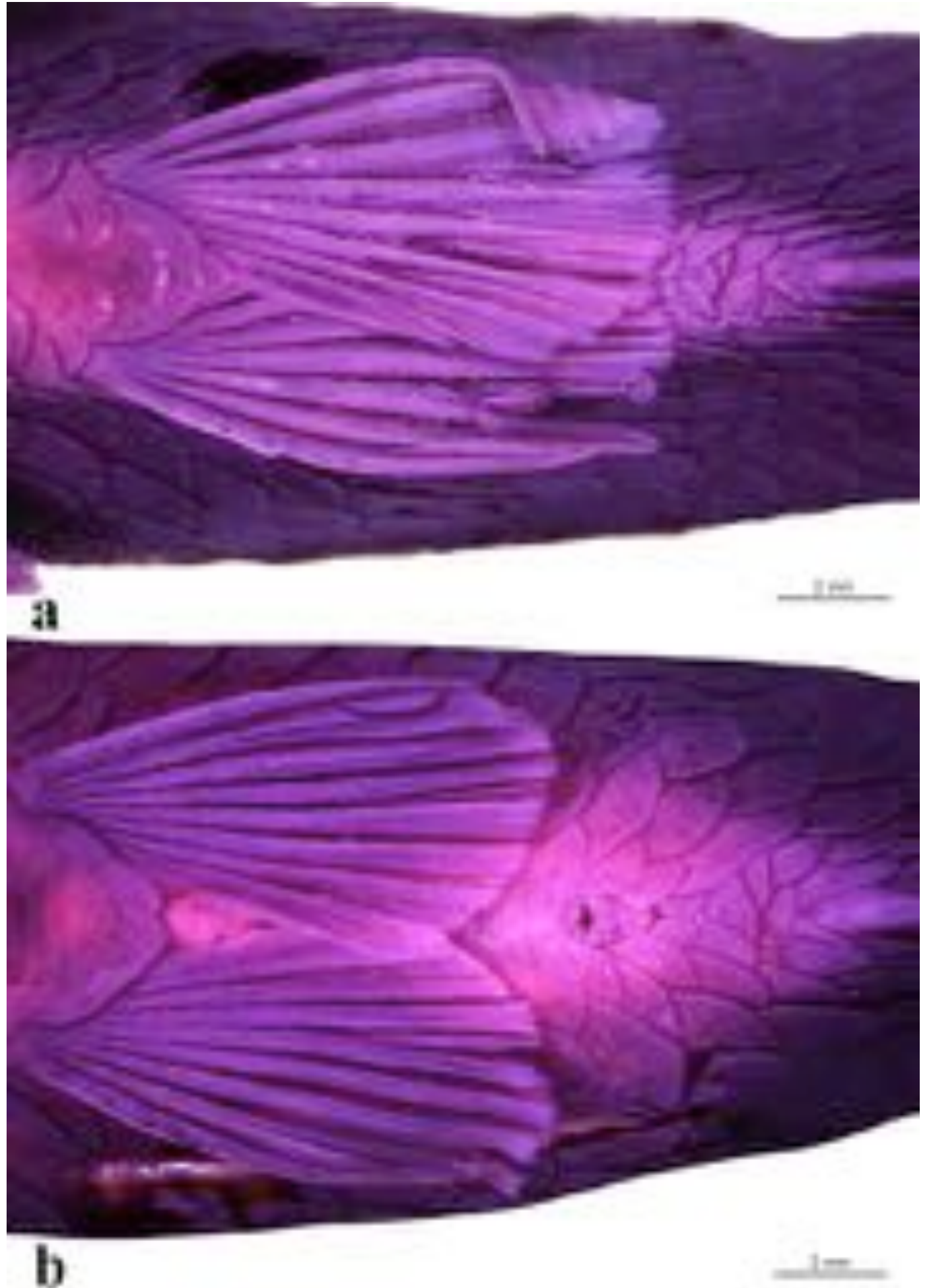

Figura 62. Nadadeira pélvica de machos (a) e de fêmeas (b) de Astyanax rivularis em vista lateral ventral, evidenciando o formato e comprimento da nadadeira nos dois sexos. 

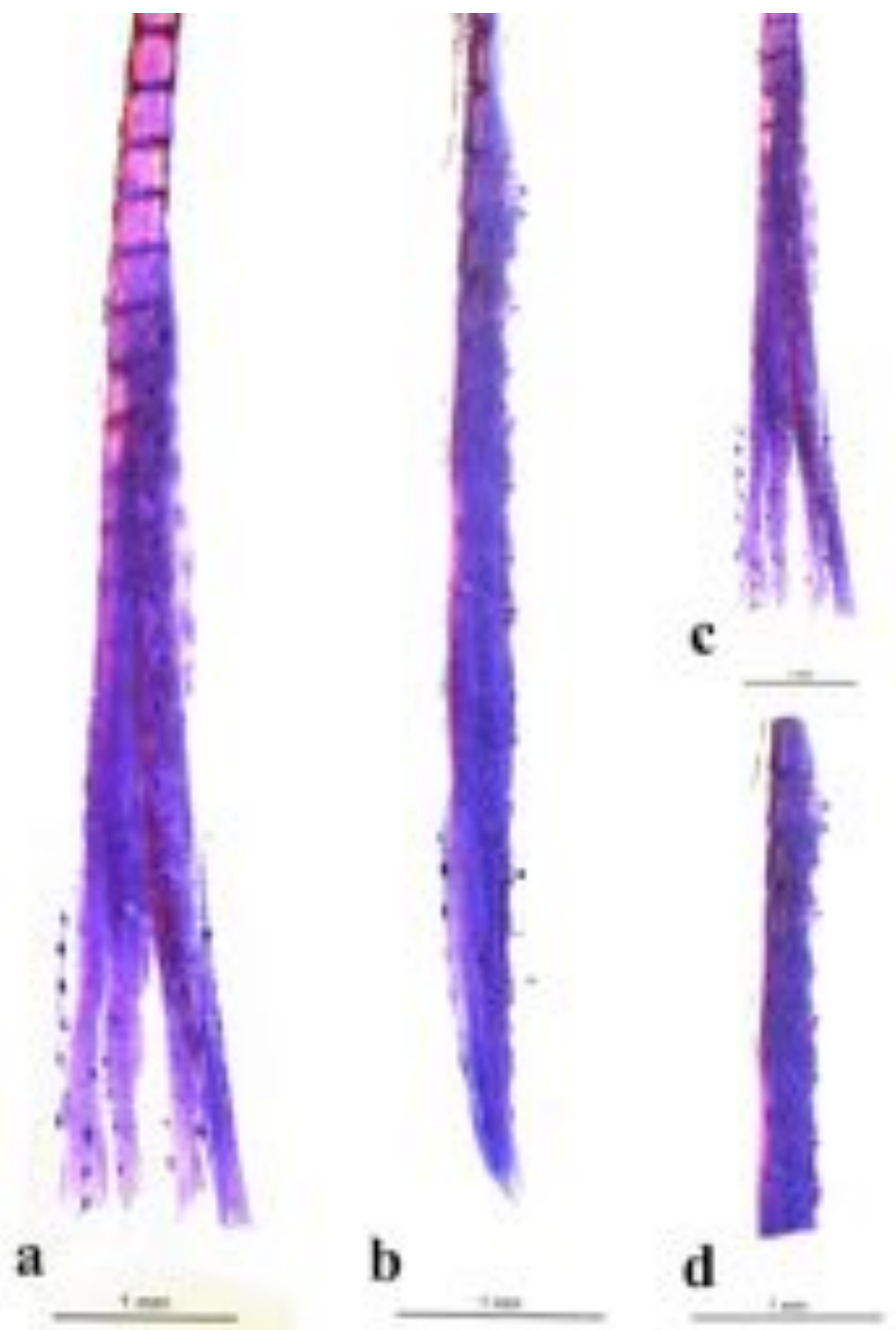

Figura 63. Distribuição, posição e formato dos processos ósseos no hemitriquium esquerdo do raio ramificado da nadadeira anal de machos de Astyanax rivularis. (a) vista lateral, (b) detalhe em vista lateral e (c) detalhe em vista anteroposterior. 

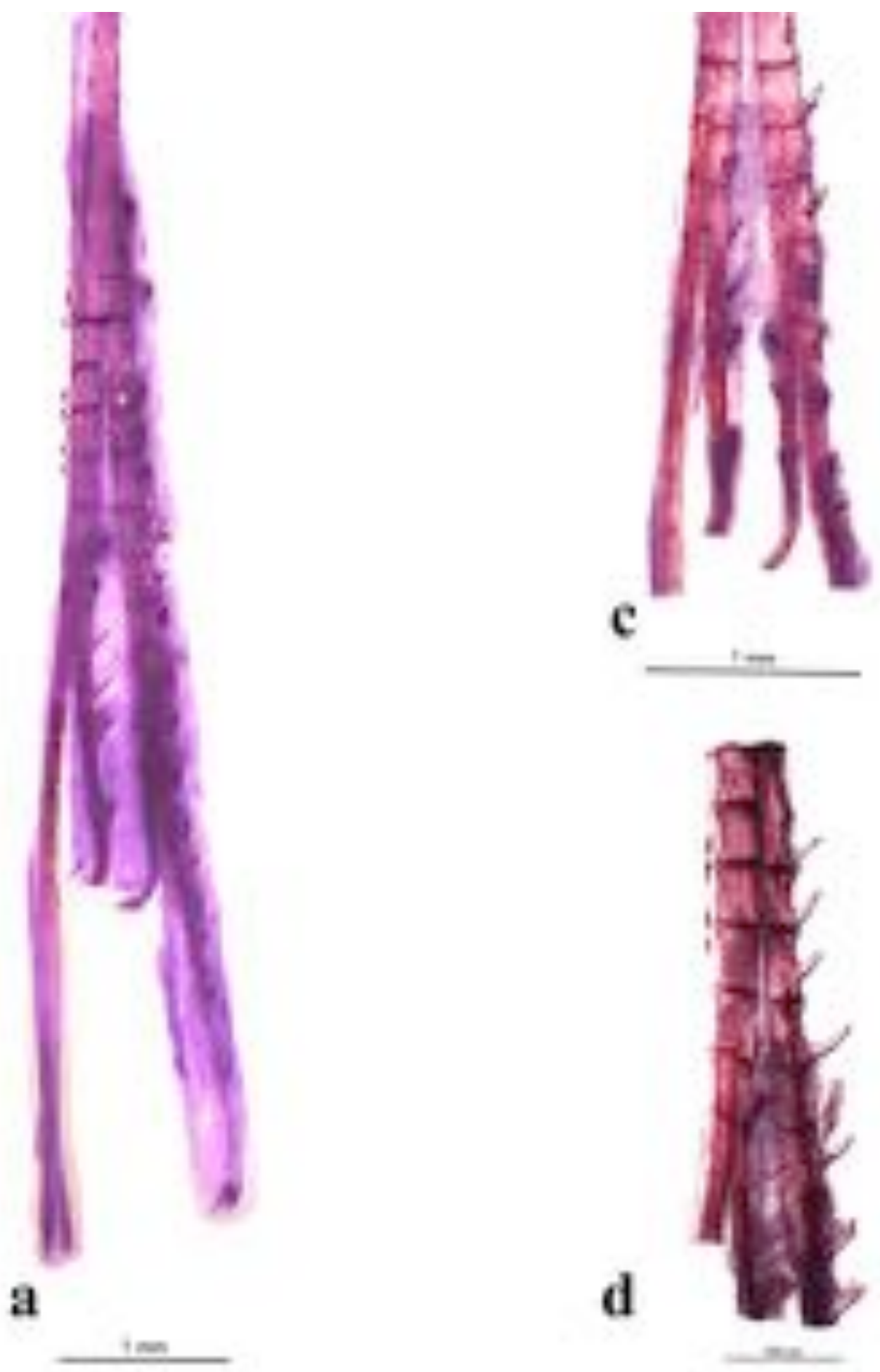

Figura 64. Distribuição, posição e formato dos processos ósseos no hemitriquium ventral da nadadeira pélvica direita de machos de Astyanax rivularis. (a) vista ventral, (b) detalhe em vista ventral e (c) detalhe em vista lateromedial. 

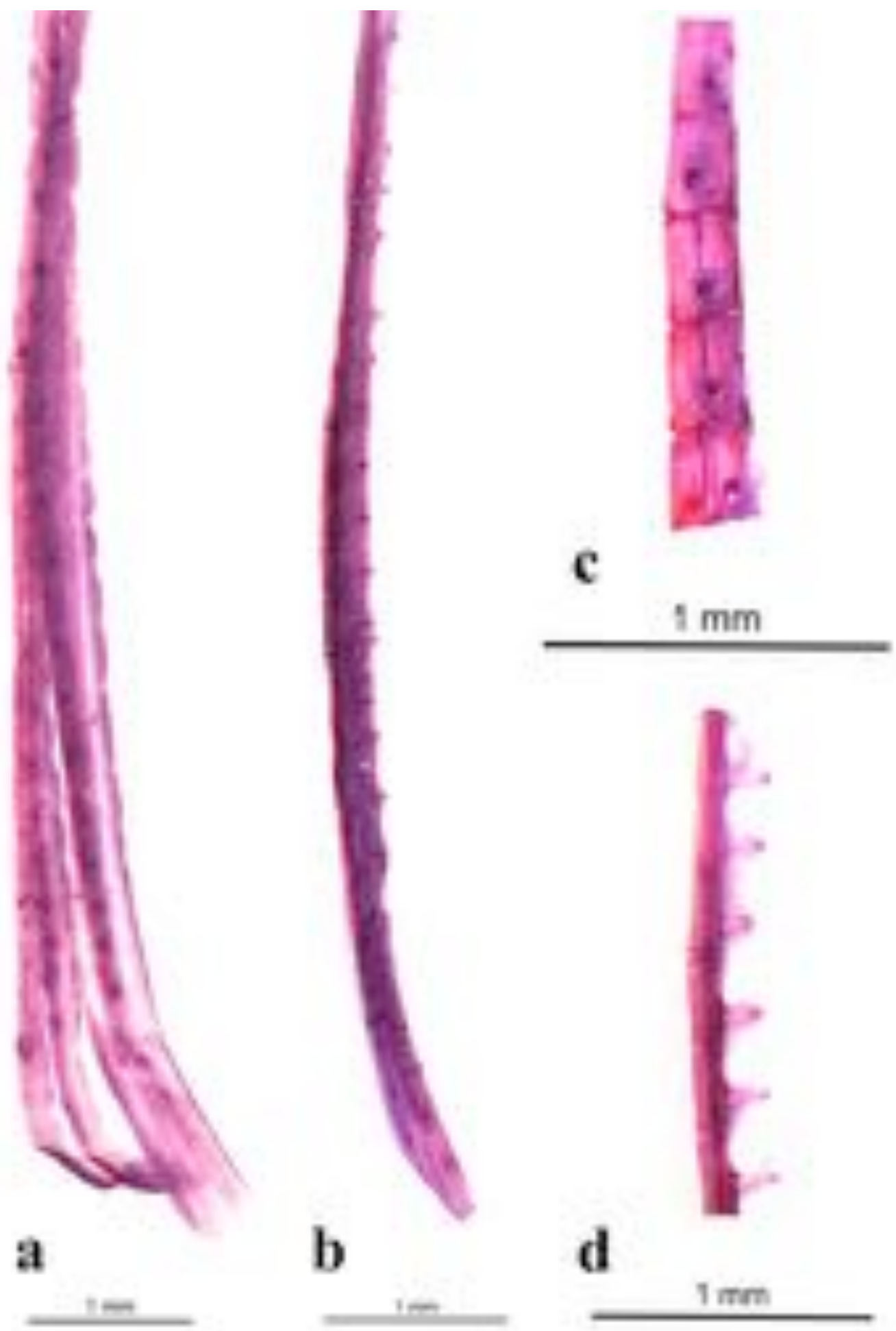

Figura 65. Distribuição, posição e formato dos processos ósseos no hemitriquium ventral da nadadeira peitoral direita de machos de Astyanax rivularis. (a) vista dorsal, (b) vista lateromedial, (c) detalhe em vista dorsal e (d) detalhe em vista lateromedial. 


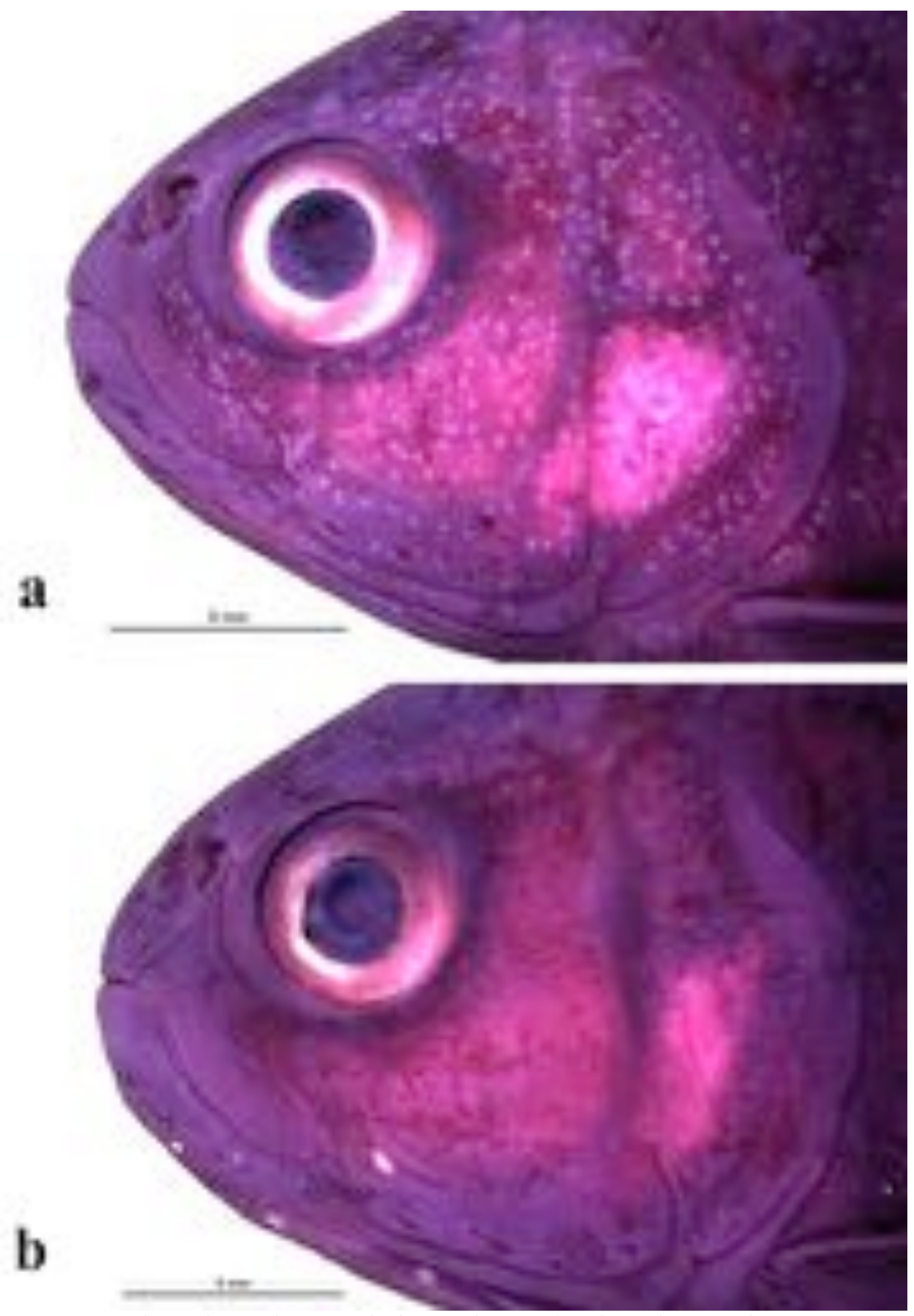

Figura 66. Cabeça de macho (a) e de fêmea (b) em vista lateral esquerda, evidenciando a distribuição dos tubérculos reprodutivos na cabeça do machos de Astyanax rivularis. 
Hasemania kalunga Bertaco \& Carvalho 2010
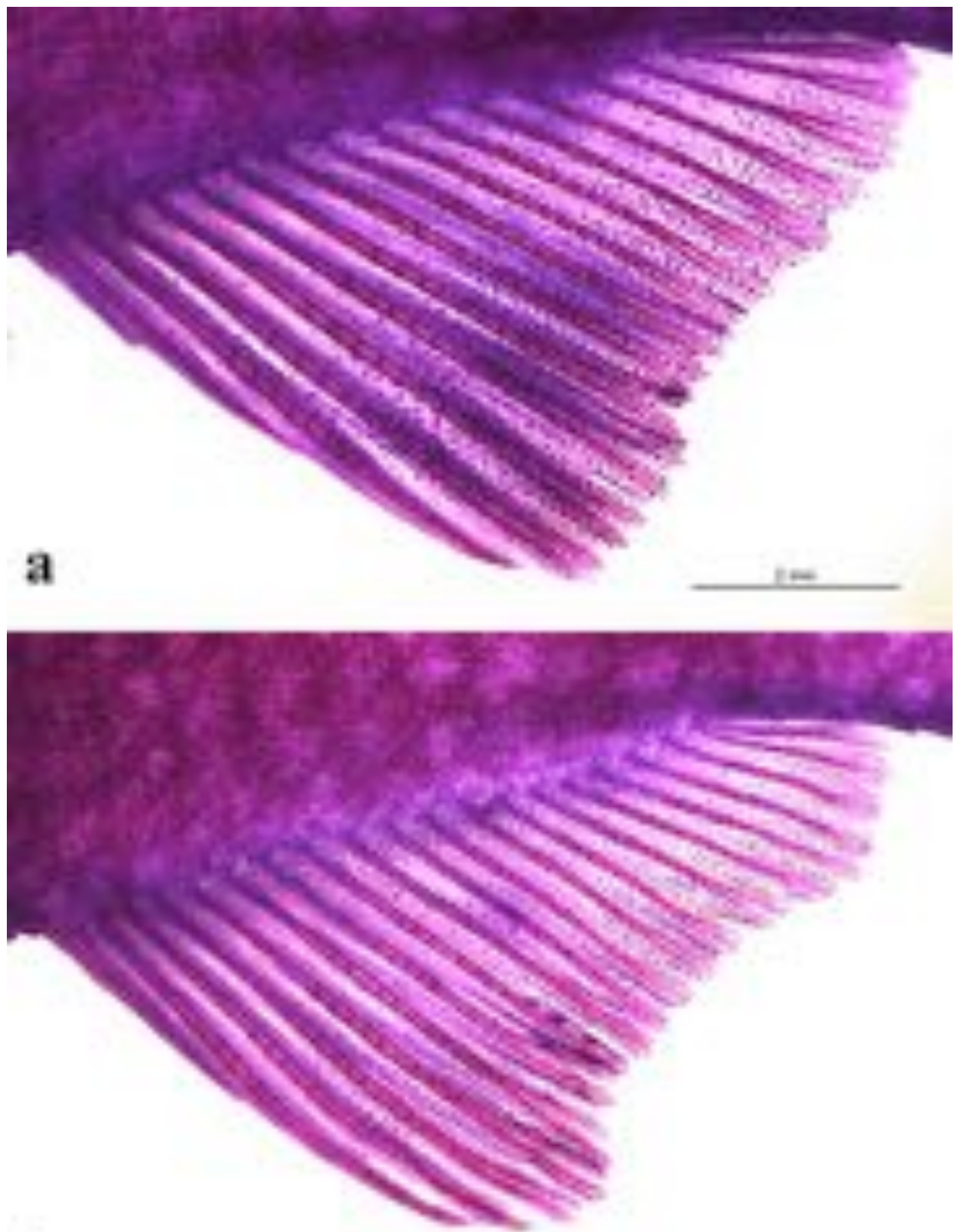

b

Figura 67. Nadadeira anal de machos (a) e de fêmeas (b) de Hasemania kalunga em vista lateral esquerda, evidenciando o formato do perfil distal das nadadeiras nos dois sexos e distribuição dos processos ósseos na nadadeira anal de macho. 

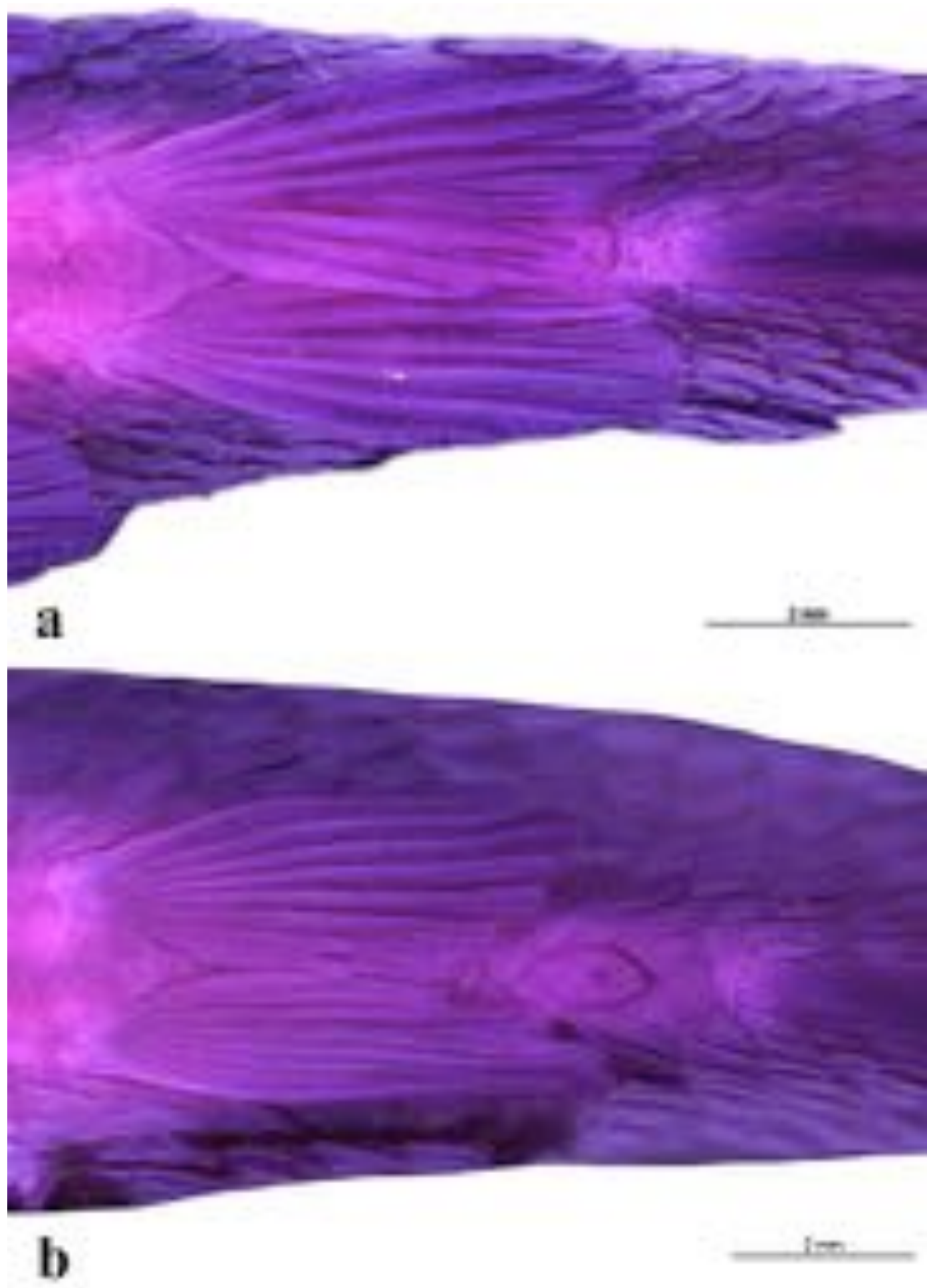

Figura 68. Nadadeira pélvica de machos (a) e de fêmeas (b) de Hasemania kalunga em vista lateral ventral, evidenciando o formato e comprimento da nadadeira nos dois sexos. 


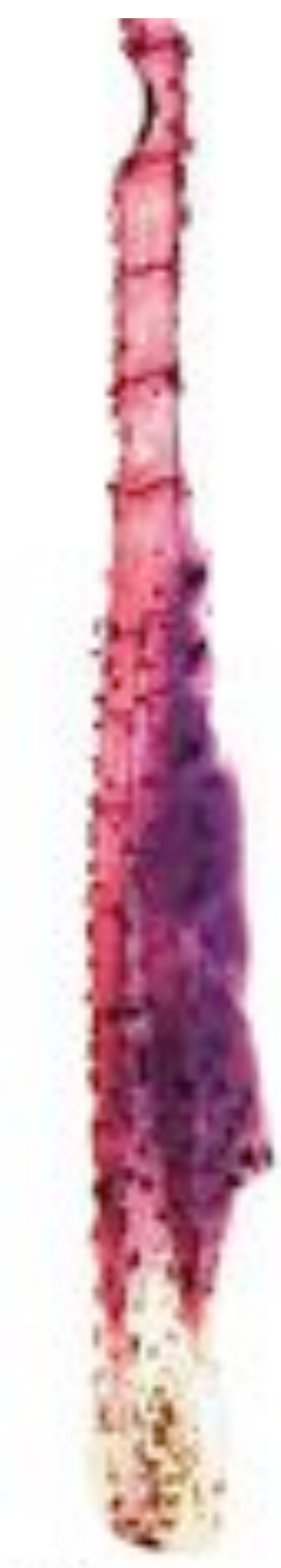

a

sen

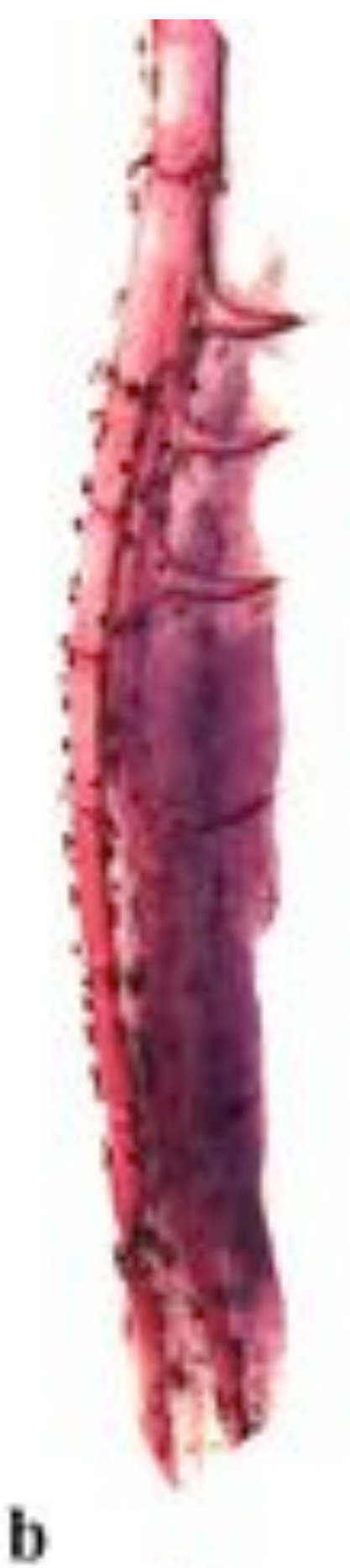

teis
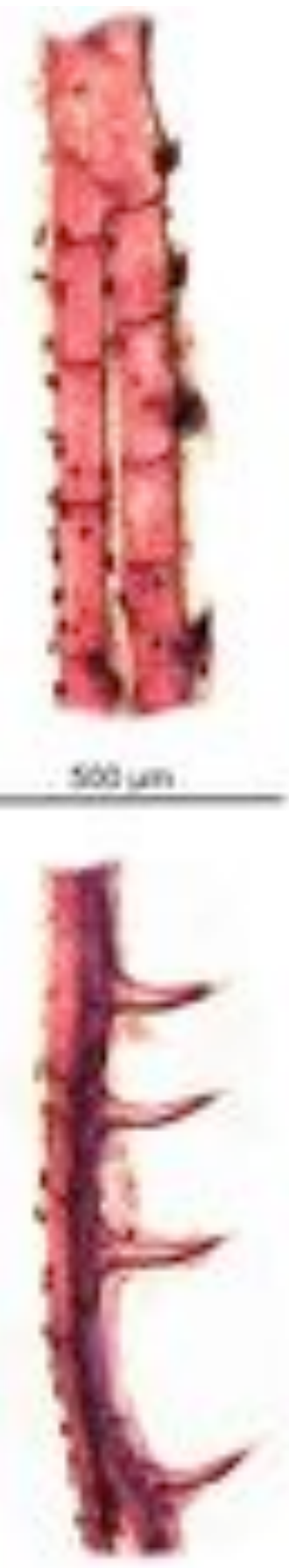

ve.

Figura 69. Distribuição, posição e formato dos processos ósseos no hemitriquium esquerdo do raio ramificado da nadadeira anal de machos de Hasemania kalunga. (a) vista lateral, (b) detalhe em vista lateral e (c) detalhe em vista anteroposterior. 
Hyphessobrycon vinaceus Bertaco, Malabarba \& Dergam 2007
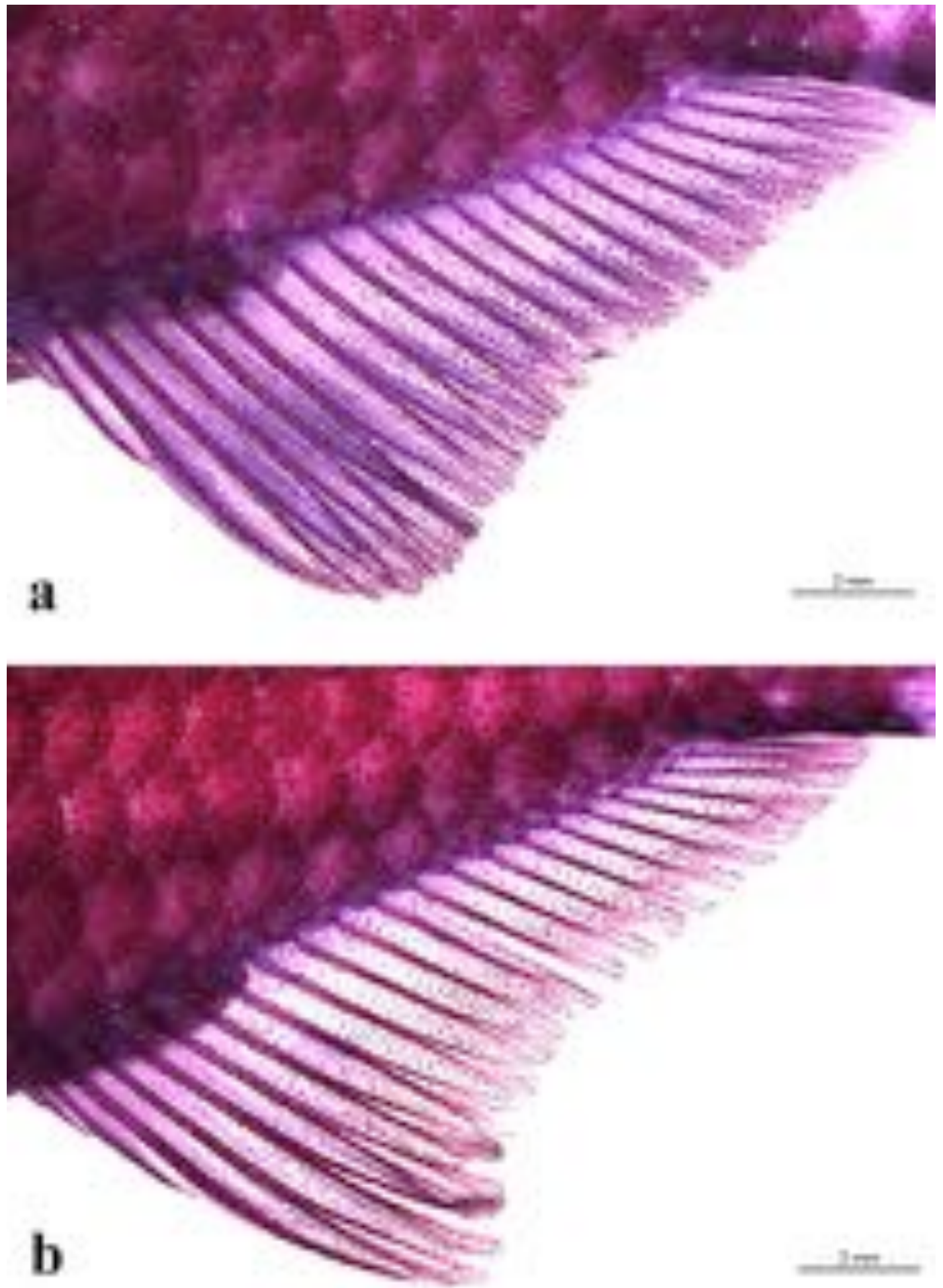

Figura 70. Nadadeira anal de machos (a) e de fêmeas (b) de Hyphessobrycon vinaceus em vista lateral esquerda, evidenciando o formato do perfil distal das nadadeiras nos dois sexos e distribuição dos processos ósseos na nadadeira anal e tubérculos reprodutivos nas escamas de macho. 


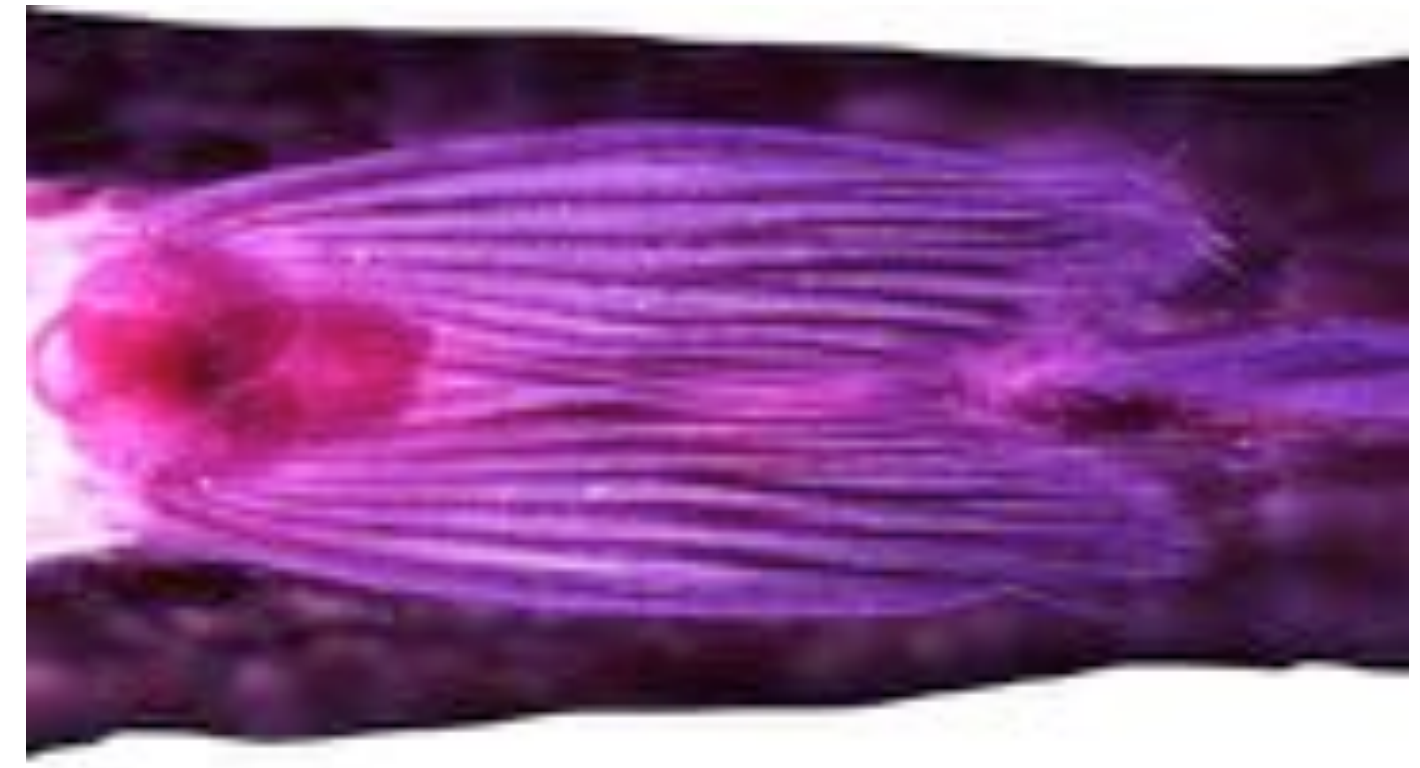

a

tes

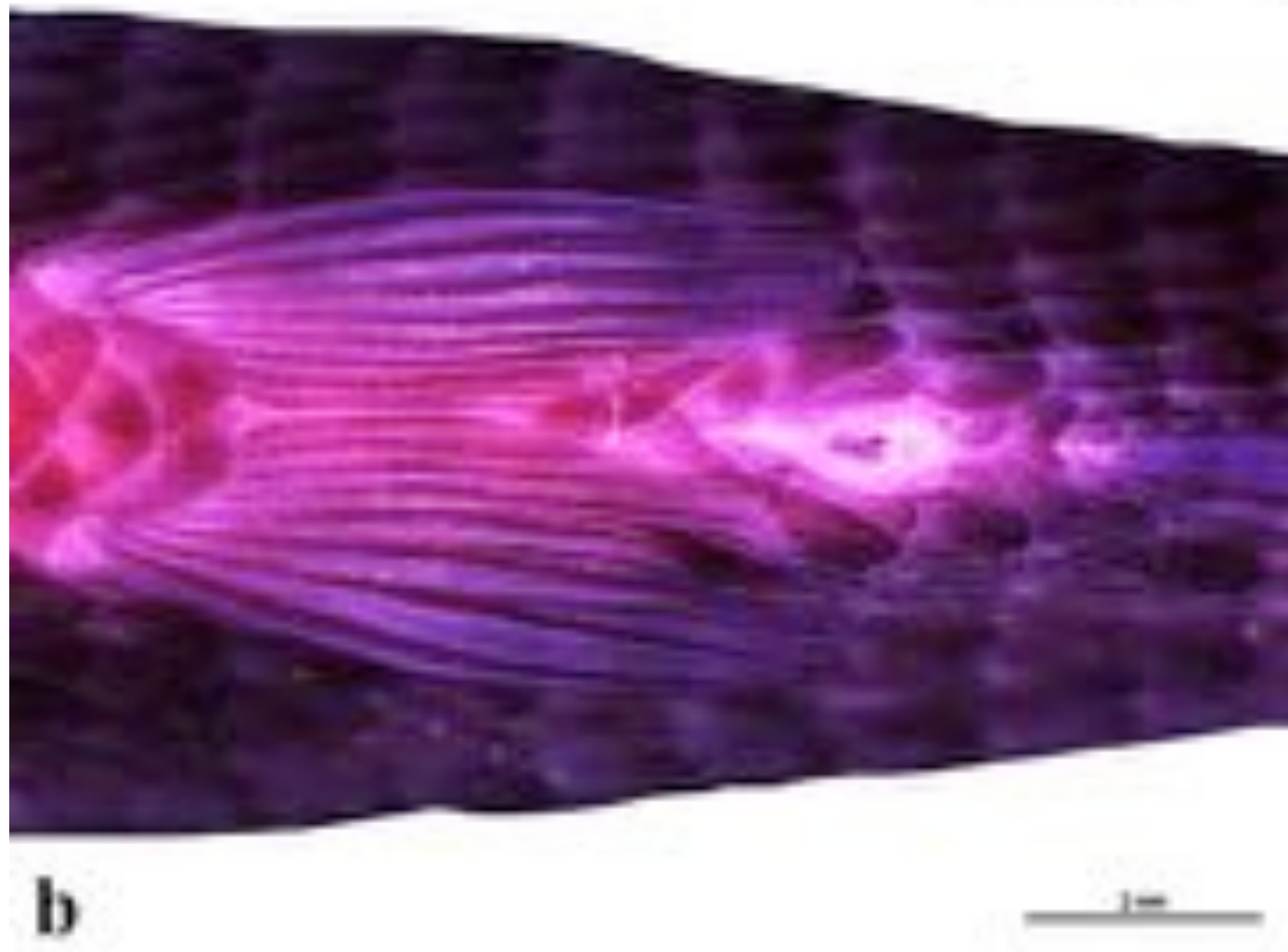

Figura 71. Nadadeira pélvica de machos (a) e de fêmeas (b) de Hyphessobrycon vinaceus em vista lateral ventral, evidenciando o formato e comprimento da nadadeira nos dois sexos. 


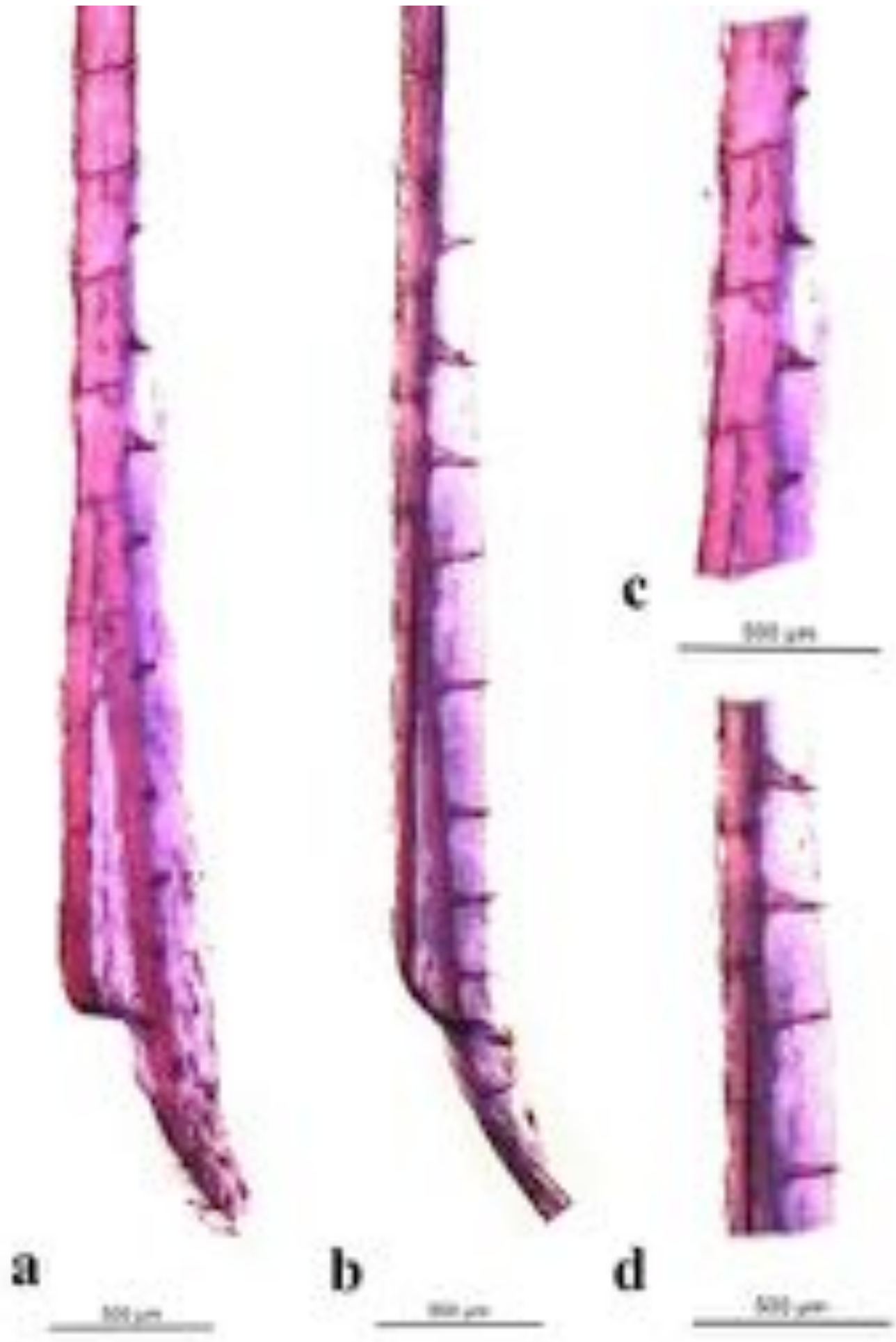

Figura 72. Distribuição, posição e formato dos processos ósseos no hemitriquium esquerdo do raio ramificado da nadadeira anal de machos de Hyphessobrycon vinaceus. (a) vista lateral, (b) vista anteroposterior, (c) detalhe em vista lateral, (d) detalhe em vista anteroposterior. 

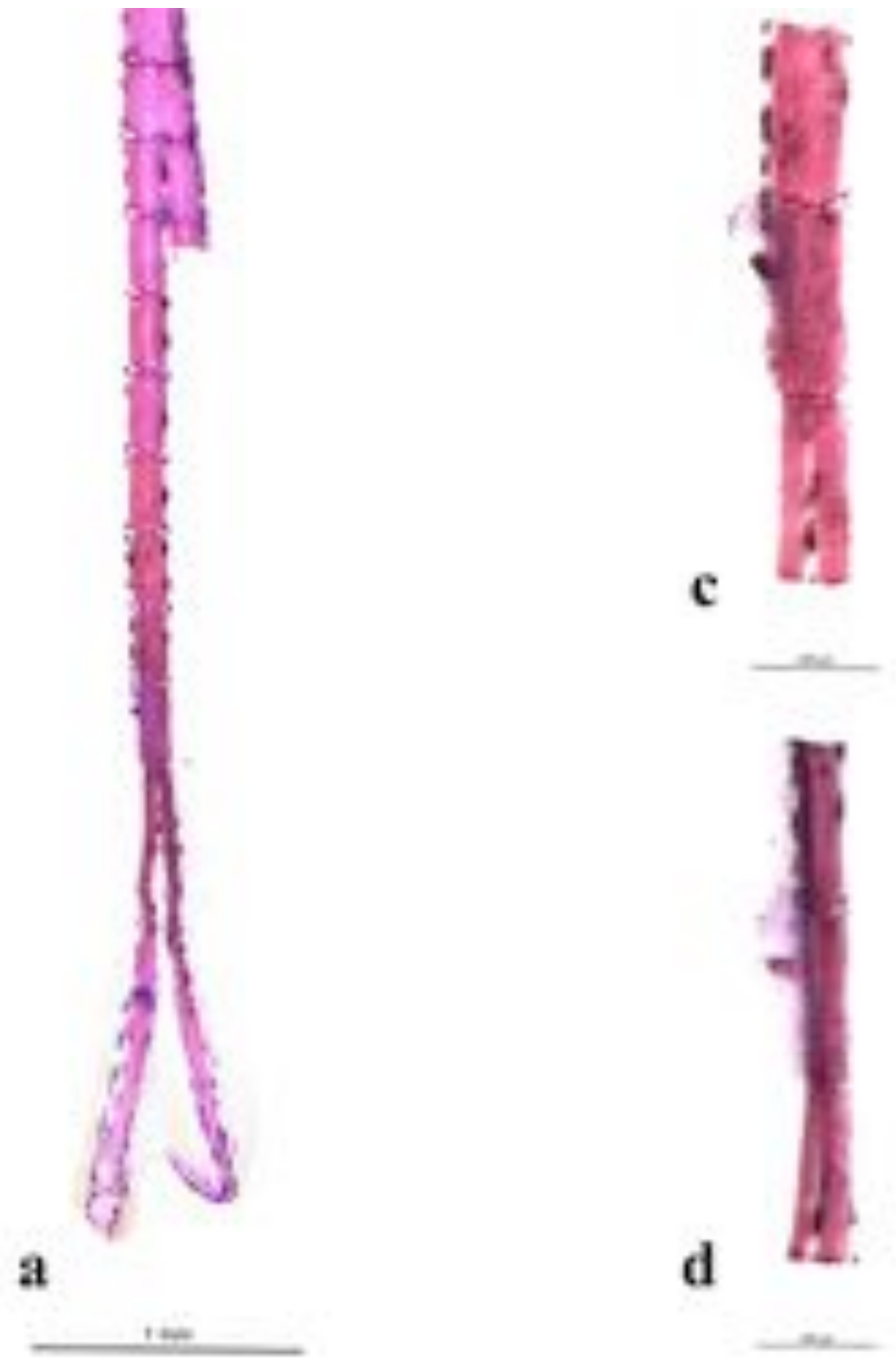

Figura 73. Distribuição, posição e formato dos processos ósseos no hemitriquium ventral da nadadeira pélvica direita de machos de Hyphessobrycon vinaceus. (a) vista ventral, (b) detalhe em vista ventral e (c) detalhe em vista lateromedial. 

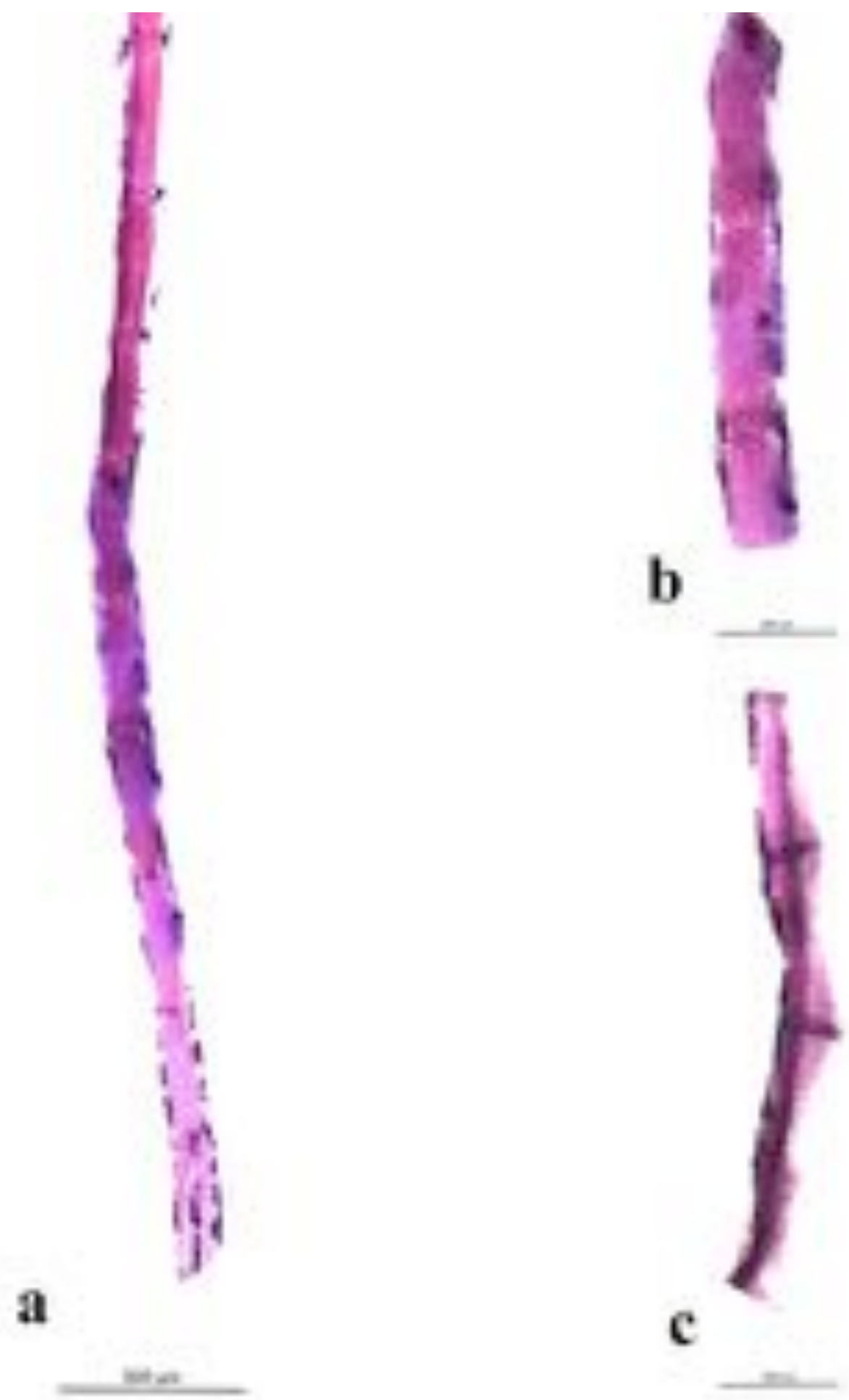

Figura 74. Distribuição, posição e formato dos processos ósseos no hemitriquium ventral da nadadeira peitoral direita de machos de Hyphessobrycon vinaceus. (a) vista dorsal, (b) detalhe em vista dorsal e (c) detalhe em vista lateromedial. 

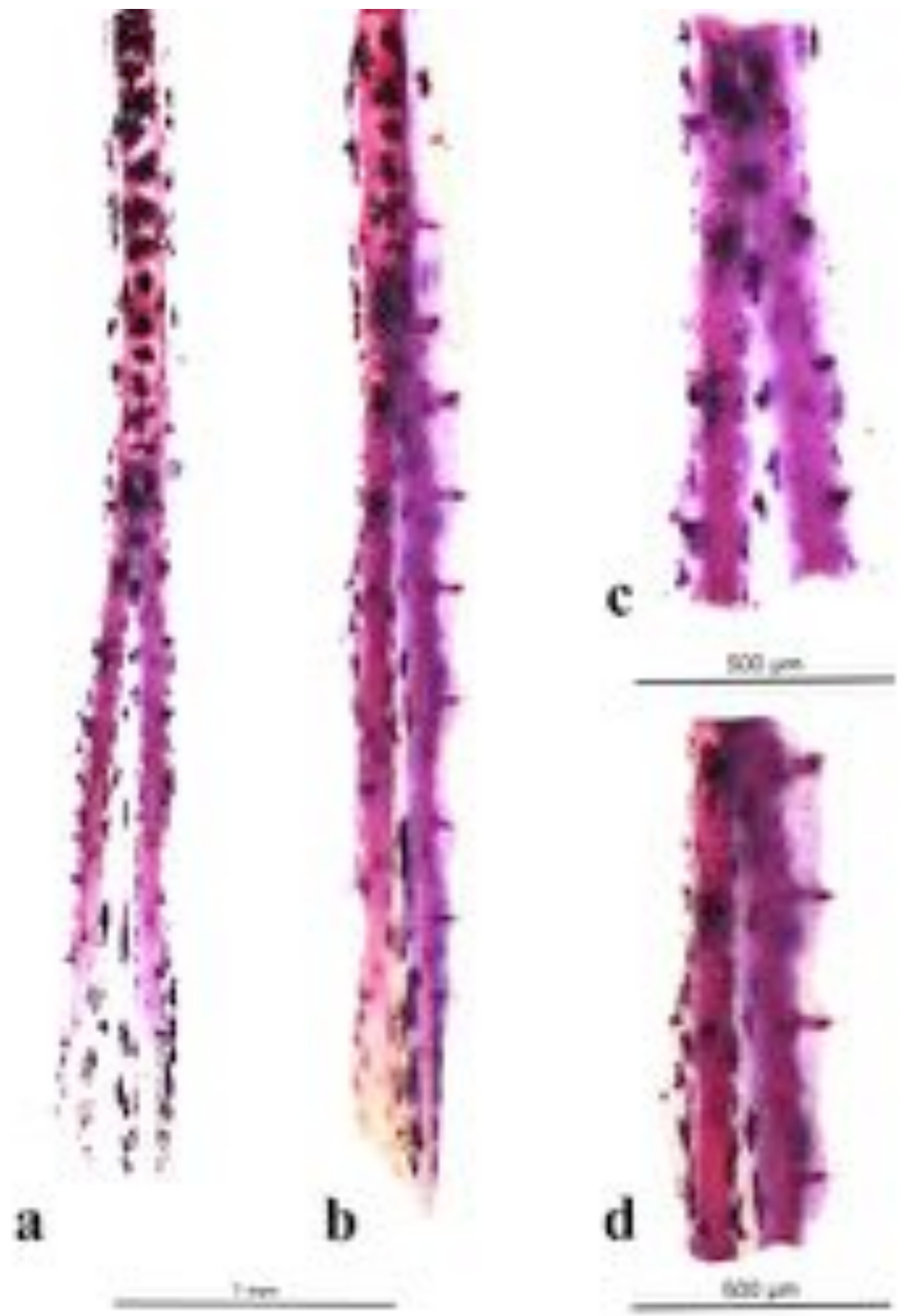

Figura 75. Distribuição, posição e formato dos processos ósseos no hemitriquium esquerdo do raio ramificado da nadadeira caudal de machos de Hyphessobrycon vinaceus. (a) vista lateral, (b) vista mediolateral, (c) detalhe em vista lateral, (d) detalhe em vista mediolateral. 


\section{CLADO Bramocharax}

\section{Oligosarcus jenynsii (Gunther 1864)}

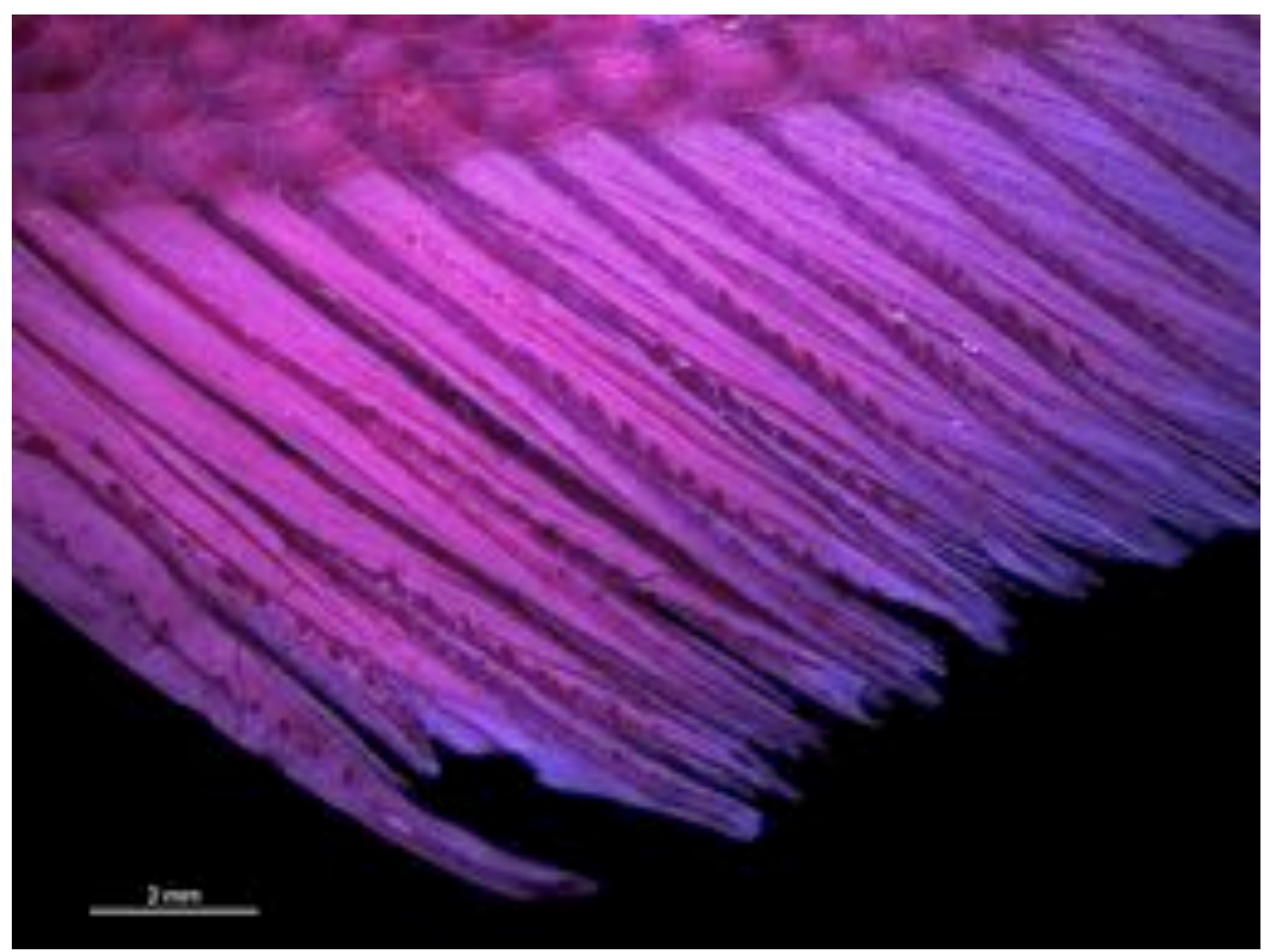

Figura 76. Nadadeira anal de machos de Oligosarcus jenynsii em vista lateral esquerda, evidenciando o formato do perfil da margem distal da nadadeira e distribuição dos processos ósseos. 

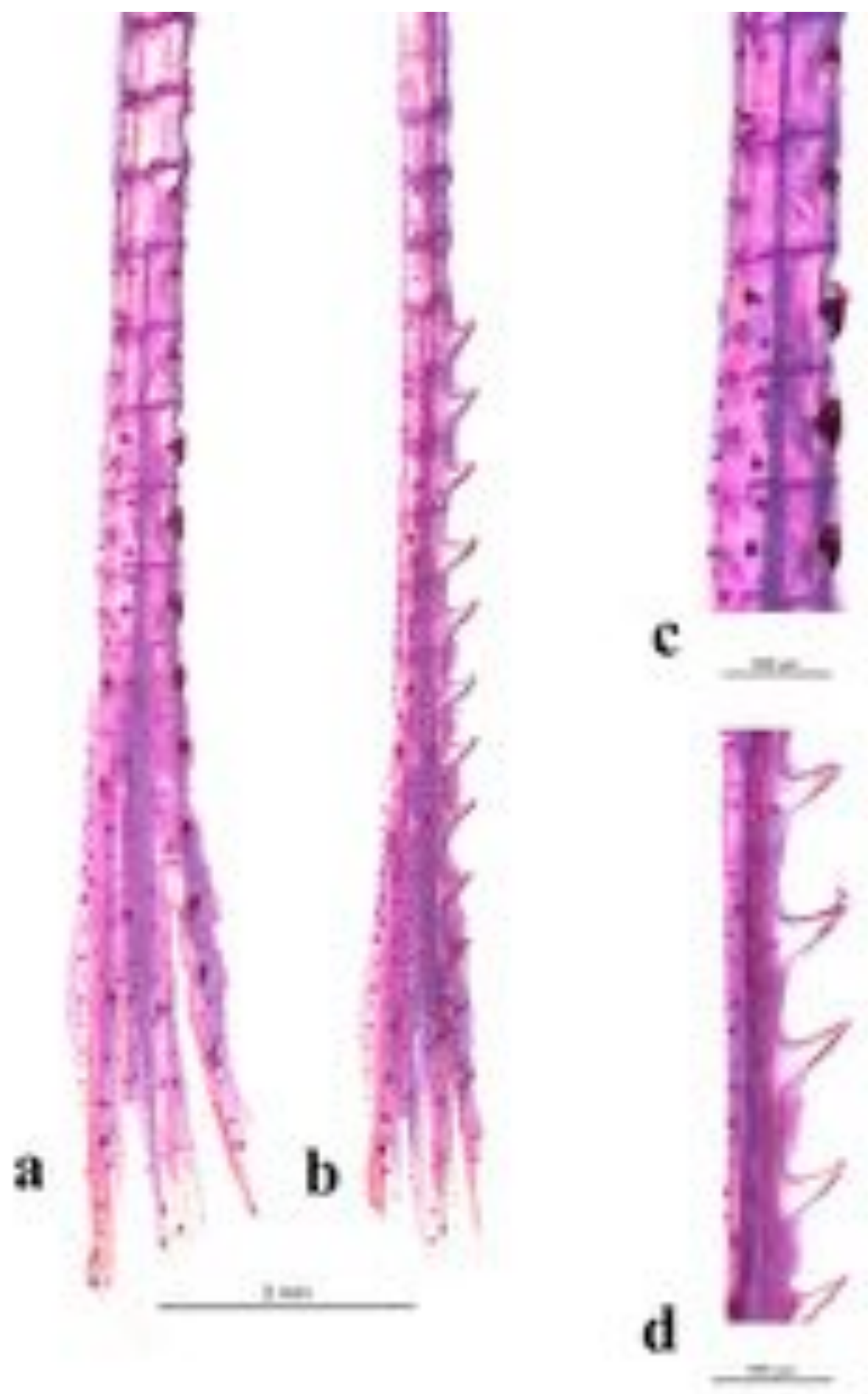

Figura 77. Distribuição, posição e formato dos processos ósseos no hemitriquium esquerdo do raio ramificado da nadadeira anal de machos de Oligosarcus jenynsii. (a) vista lateral, (b) vista anteroposterior, (c) detalhe em vista lateral, (d) detalhe em vista anteroposterior. 

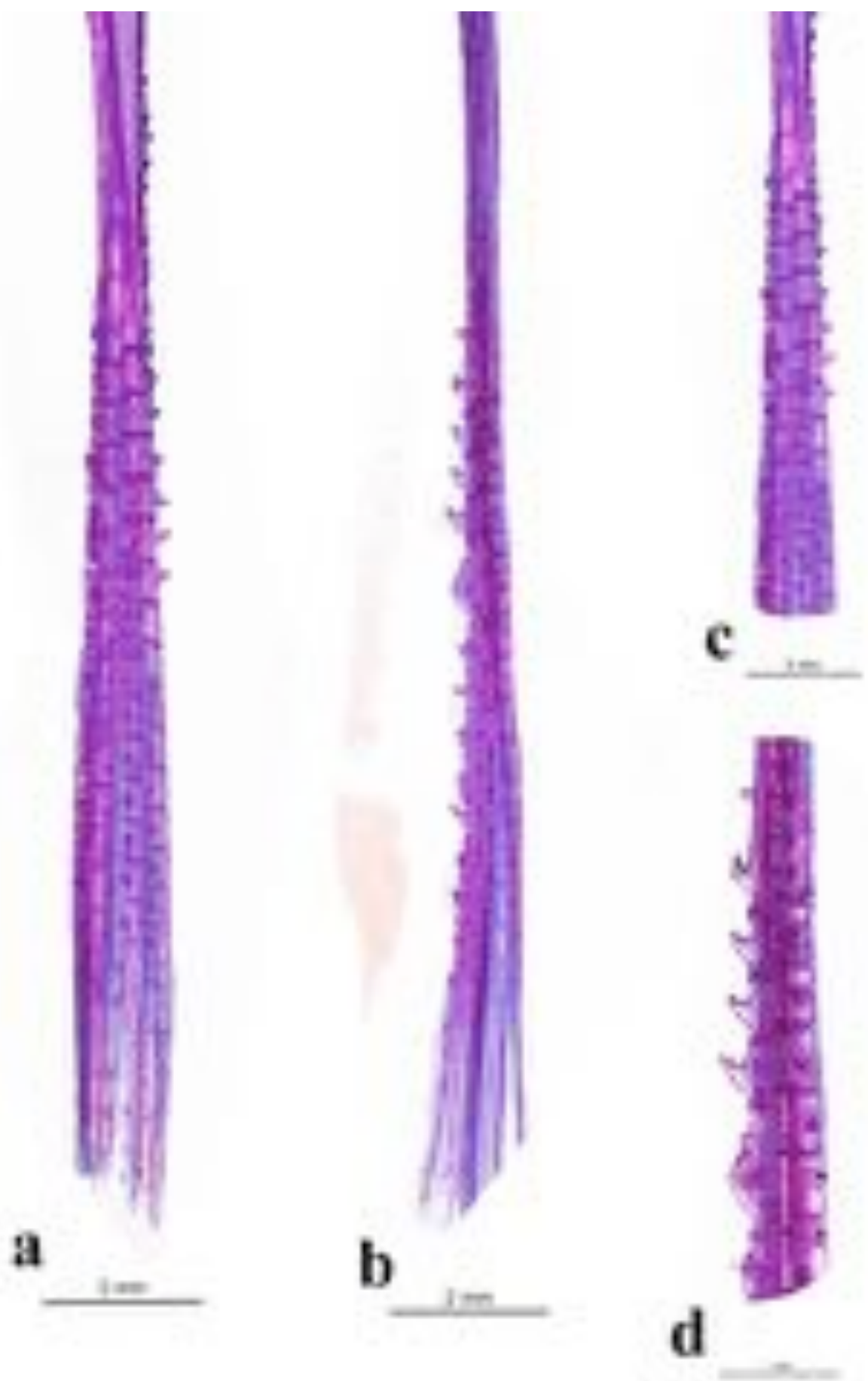

Figura 78. Distribuição, posição e formato dos processos ósseos no hemitriquium ventral da nadadeira pélvica direita de machos de Oligosarcus jenynsii. (a) vista ventral, (b) vista lateromedial, (c) detalhe em vista ventral e (d) detalhe em vista lateromedial. 
BRYCONINAE

Brycon falcatus Mulher \& Troschel 1844
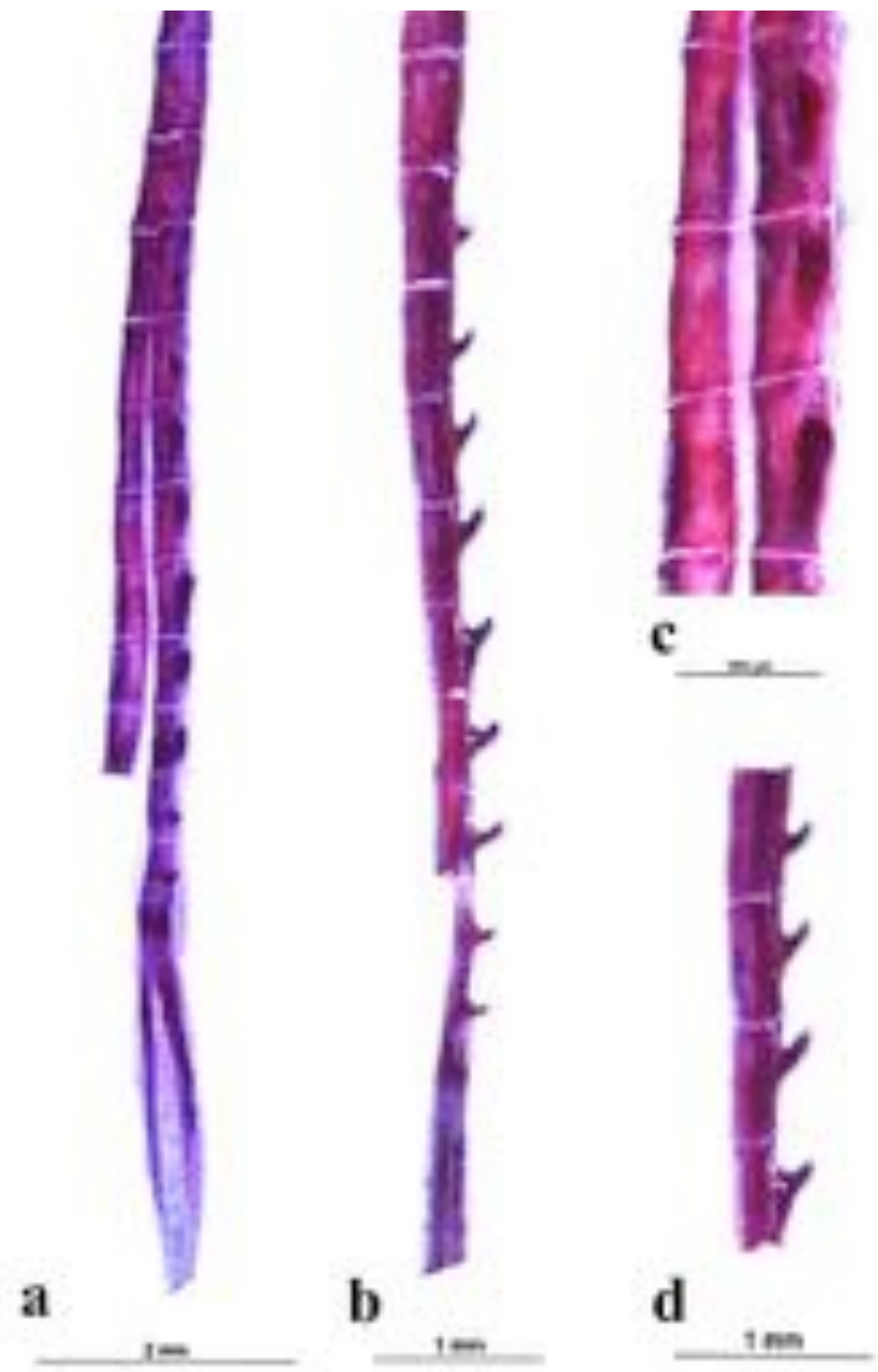

Figura 79. Distribuição, posição de inserção e formato dos processos ósseos no hemitriquium esquerdo do raio ramificado da nadadeira anal de machos de Brycon falcatus. (a) vista lateral, (b) vista anteroposterior, (c) detalhe em vista lateral e (d) detalhe em vista anteroposterior. 
CLADO Bryconops

\section{Bryconops affinis (Gunther 1864)}
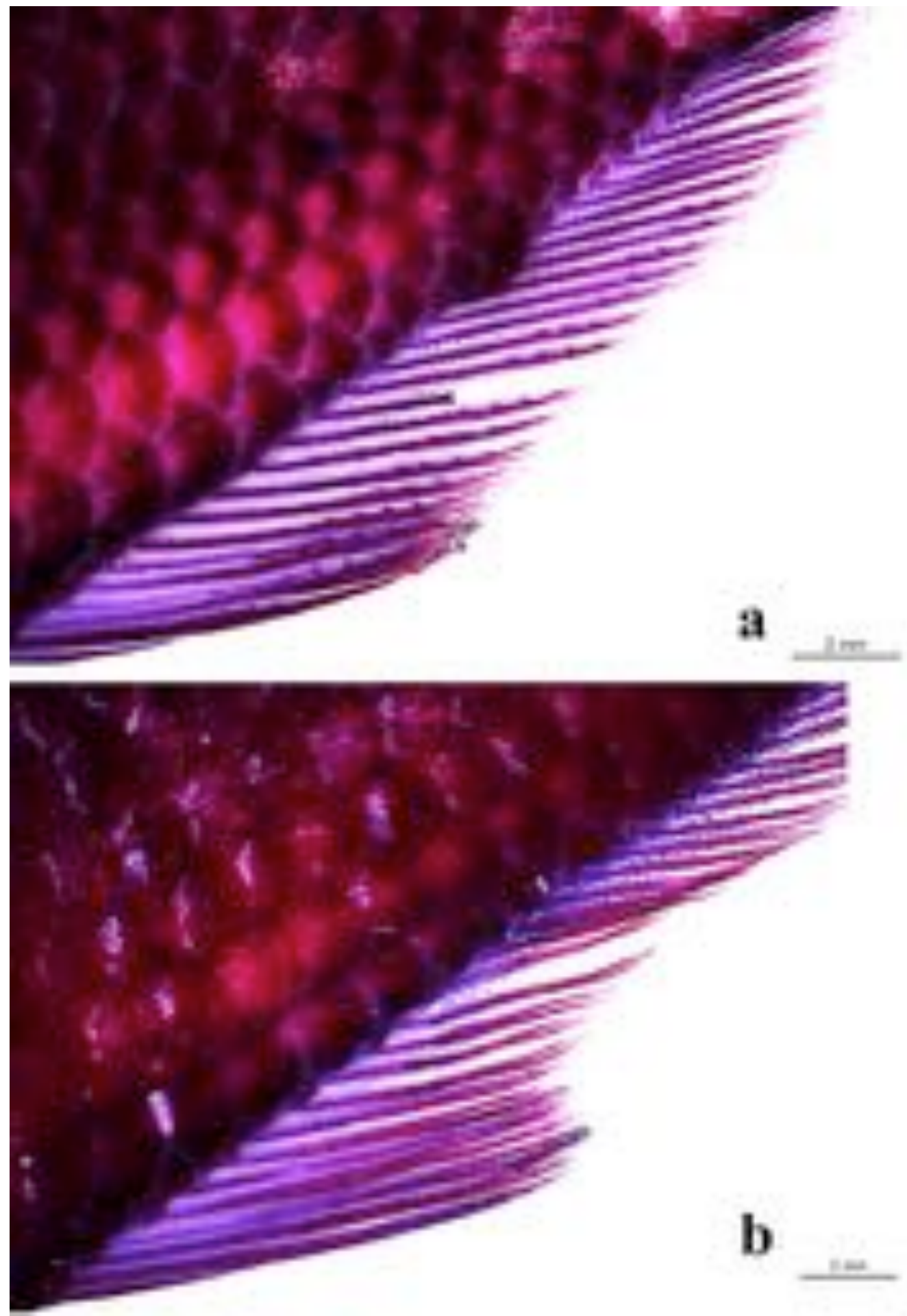

Figura 80. Nadadeira anal de machos (a) e de fêmeas (b) de Bryconops affinis em vista lateral esquerda, evidenciando o formato do perfil distal das nadadeiras nos dois sexos e distribuição dos processos ósseos na nadadeira anal de macho. 


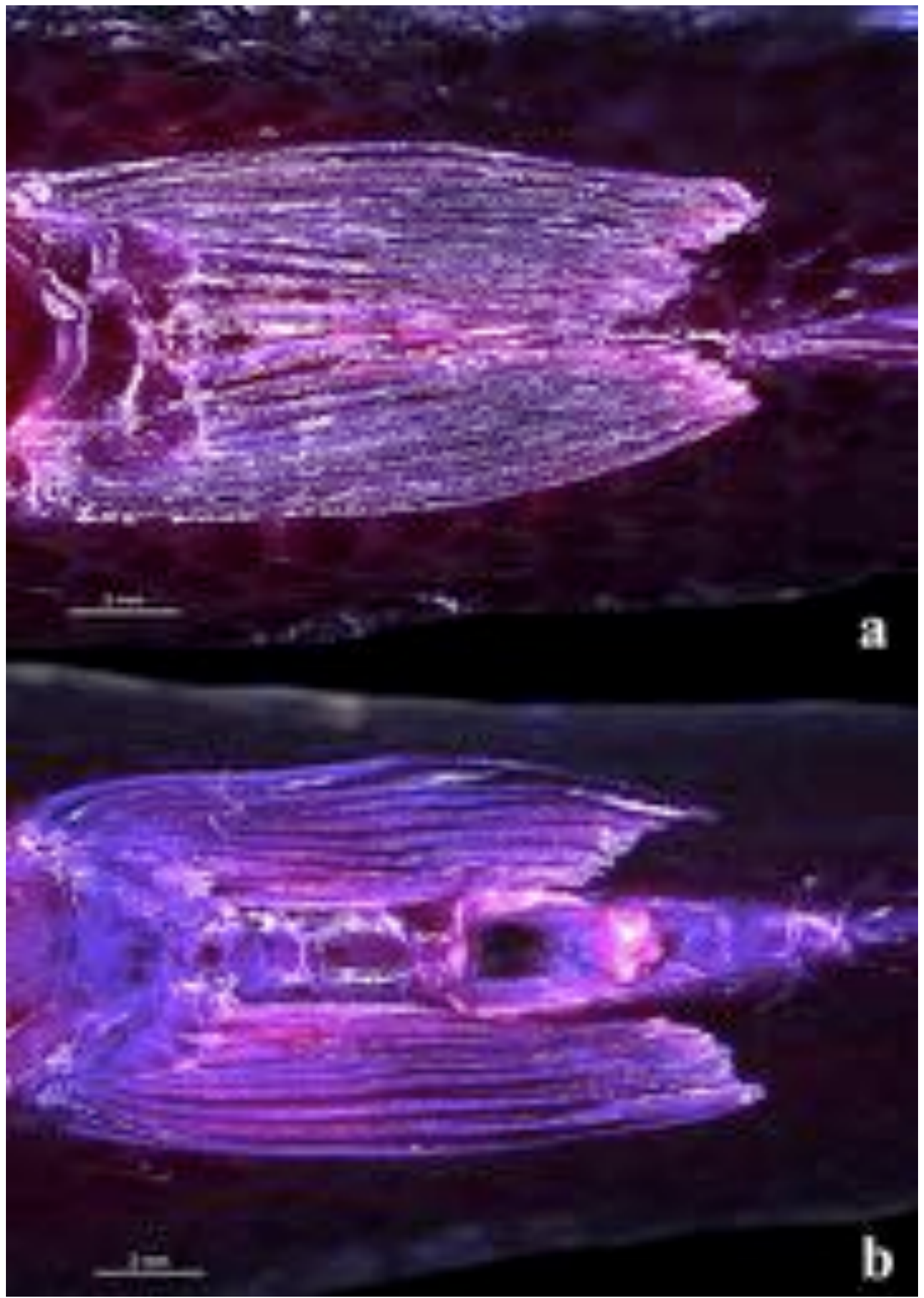

Figura 81. Nadadeira pélvica de machos (a) e de fêmeas (b) de Bryconops affinis em vista ventral, evidenciando o formato da nadadeira nos dois sexos. 

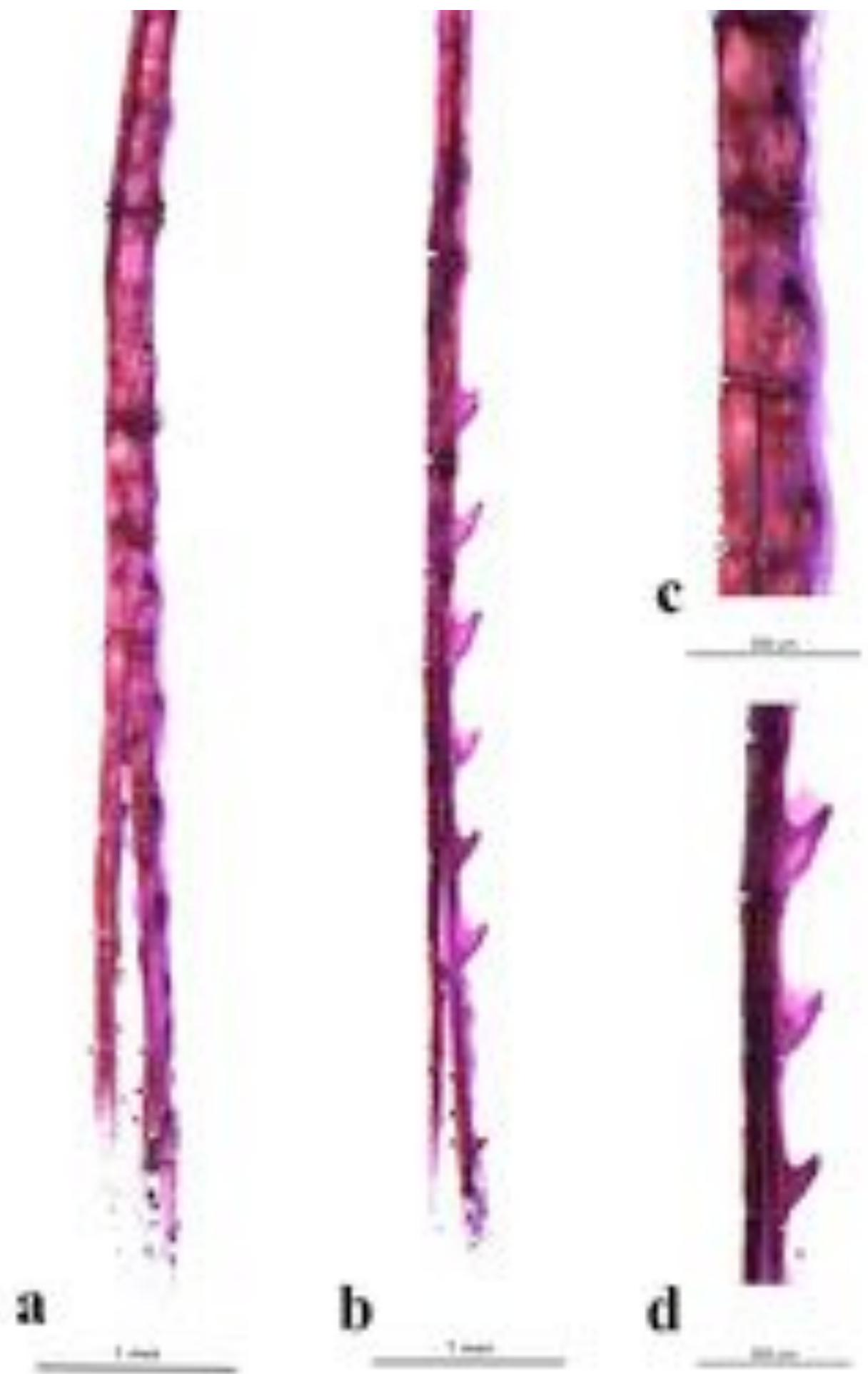

Figura 82. Distribuição, posição de inserção e formato dos processos ósseos no hemitriquium esquerdo do raio ramificado da nadadeira anal de machos de Bryconops affinis. (a) vista latera, (b) vista anteroposterior, (c) detalhe em vista lateral e (d) detalhe em vista anteroposterior. 

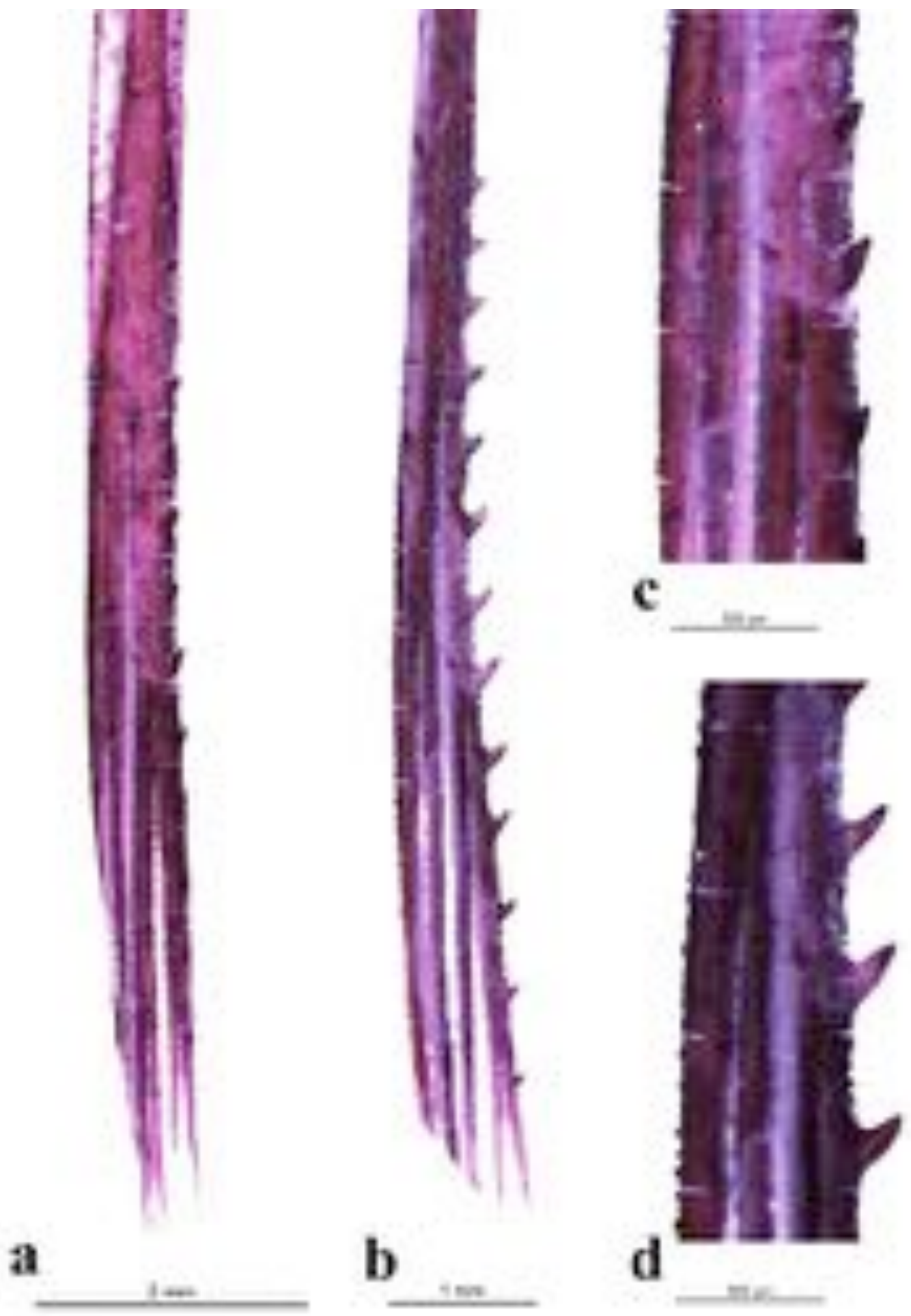

Figura 83. Distribuição, posição de inserção e formato dos processos ósseos no hemitriquium ventral do raio ramificado da nadadeira pélvica direita de machos de Bryconops affinis. (a) vista ventral, (b) vista lateromedial, (c) detalhe em vista lateral e (d) detalhe em vista lateromedial. 
CHARACINAE

Acestrocephalus sardina (Folwer 1913)

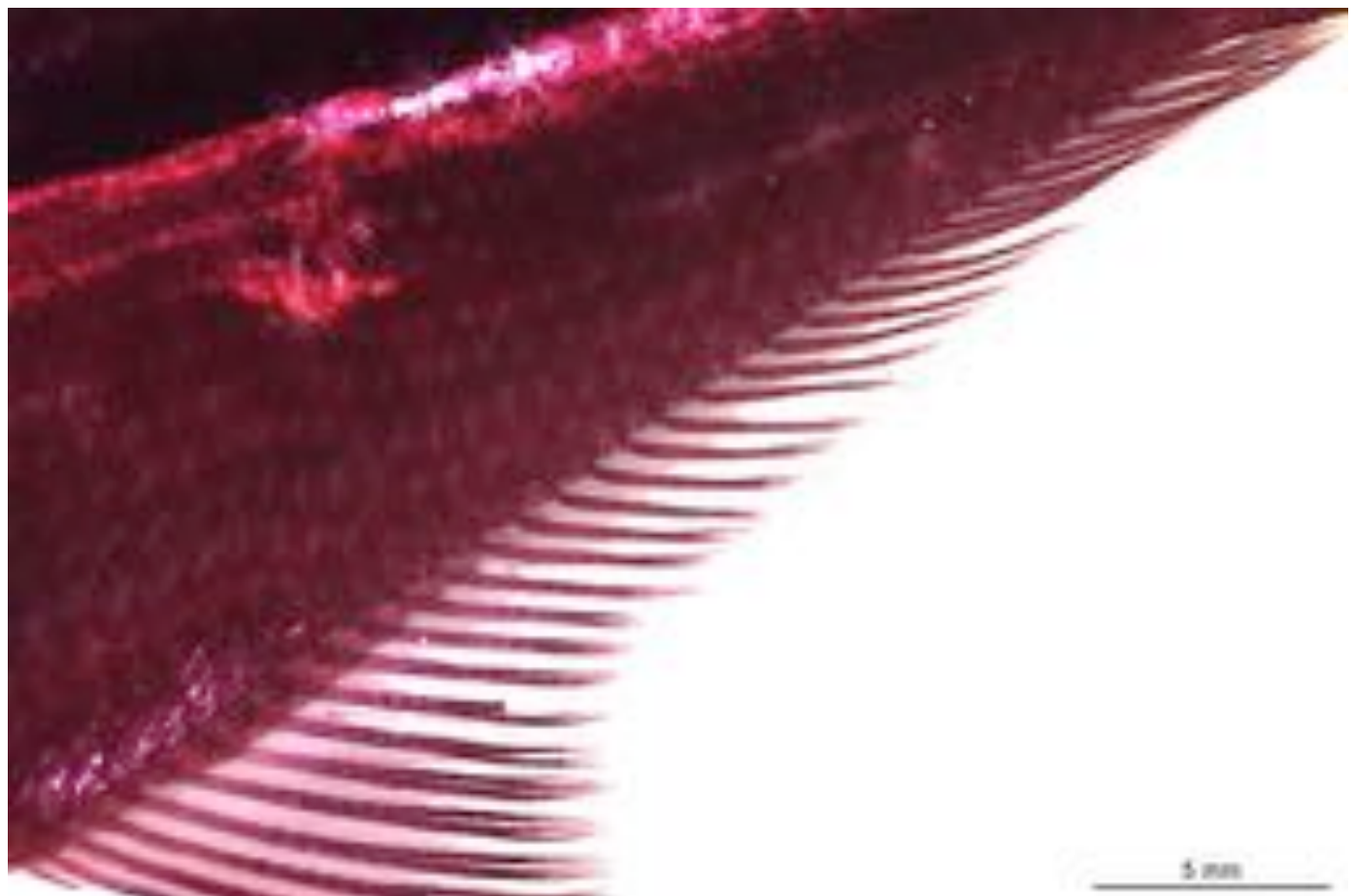

Figura 84. Nadadeira anal de machos de Acestrocephalus sardina em vista lateral esquerda, evidenciando o formato do perfil da margem distal da nadadeira e distribuição dos processos ósseos. 

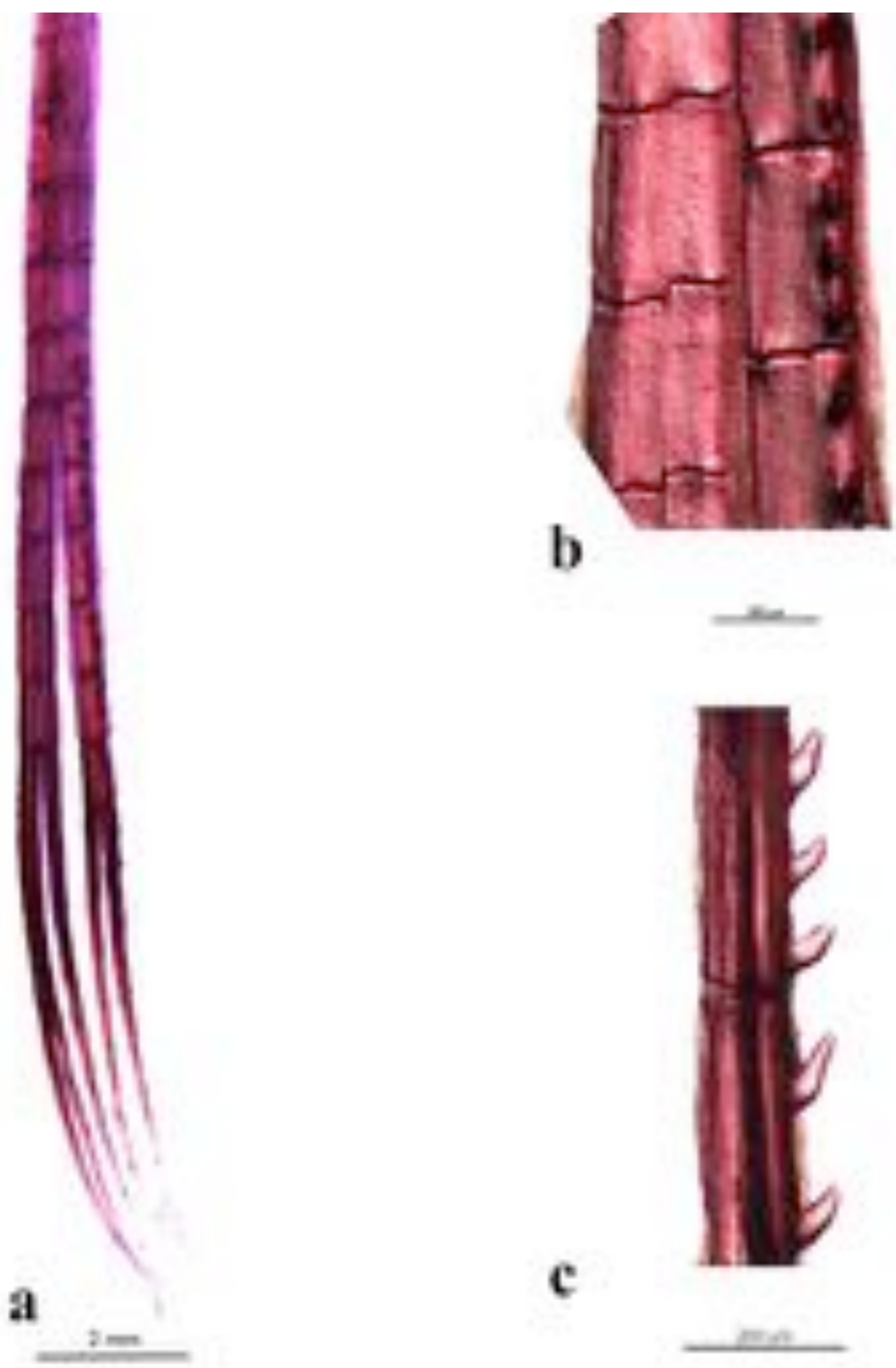

b

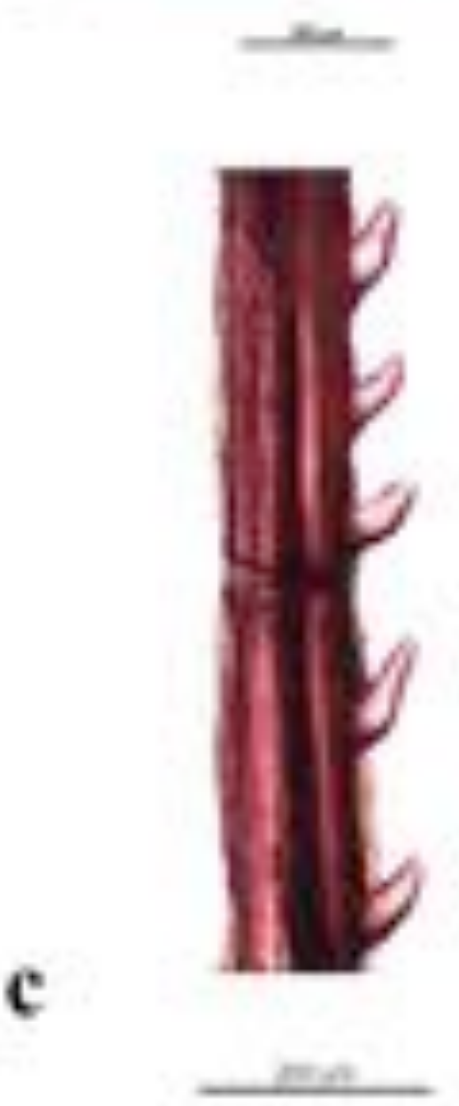

Figura 85. Distribuição, posição e formato dos processos ósseos no hemitriquium esquerdo do raio ramificado da nadadeira anal de machos de Acestrocephalus sardina. (a) vista lateral, (b) detalhe em vista lateral e (c) detalhe em vista anteroposterior. 

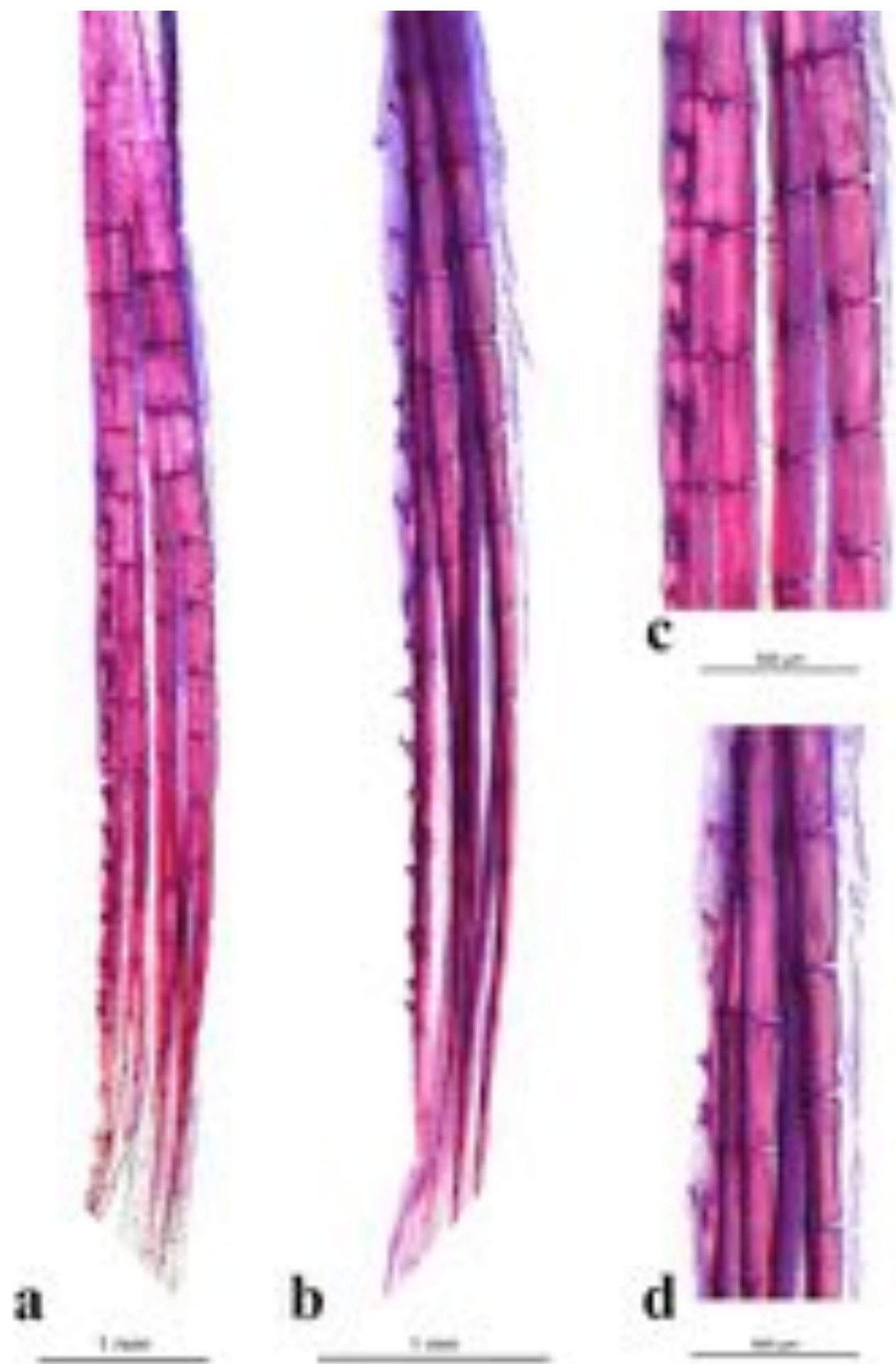

Figura 86. Distribuição, posição e formato dos processos ósseos no hemitriquium ventral da nadadeira pélvica esquerda de machos de Acestrocephalus sardina. (a) vista ventral, (b) vista lateromedial, (c) detalhe em vista ventral e (d) detalhe em vista lateromedial. 


\section{Bryconexodon juruenae Géry 1980}

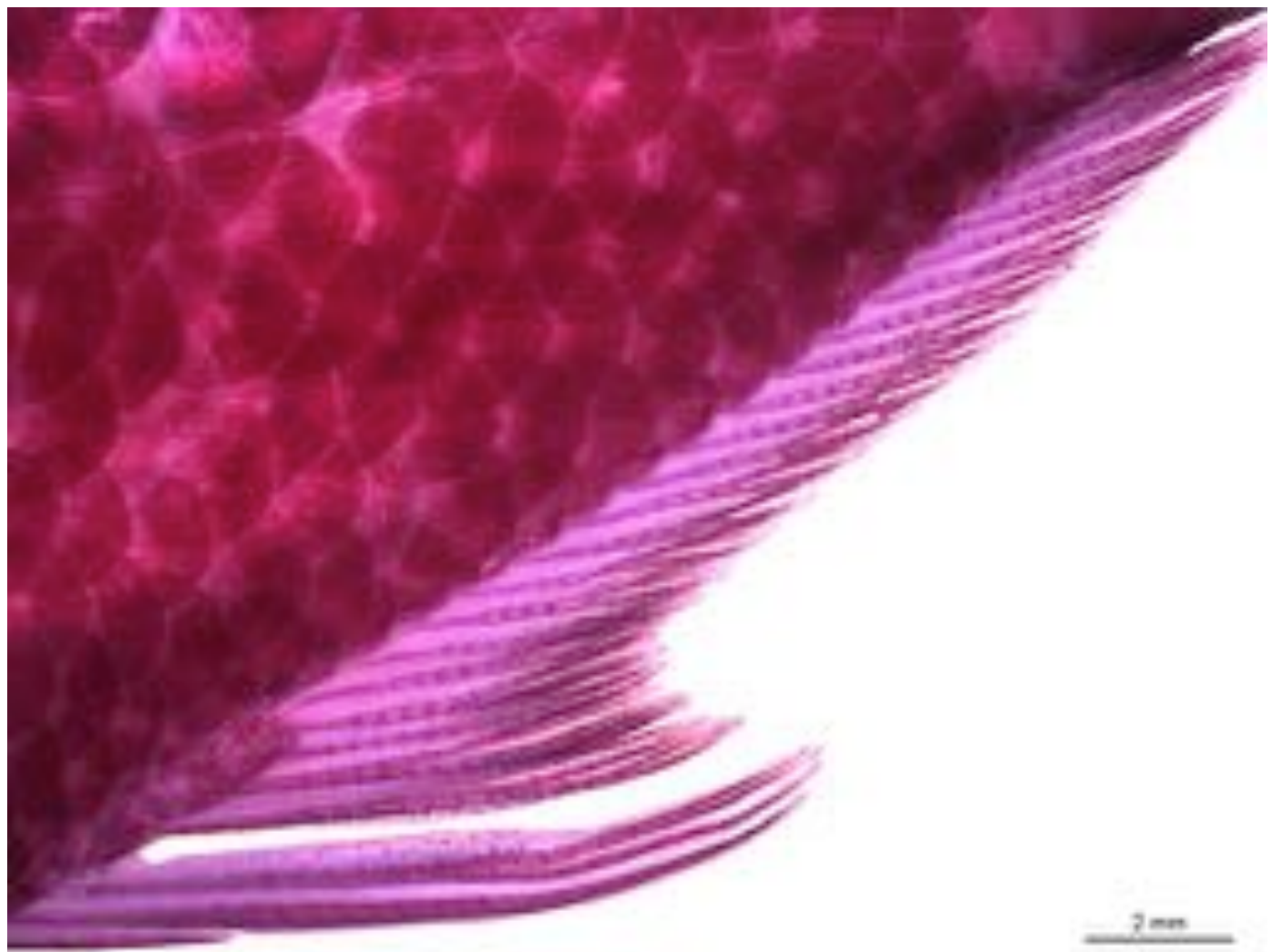

Figura 87. Nadadeira anal de machos de Bryconexodon juruenae em vista lateral esquerda, evidenciando o formato do perfil da margem distal da nadadeira e distribuição dos processos ósseos. 


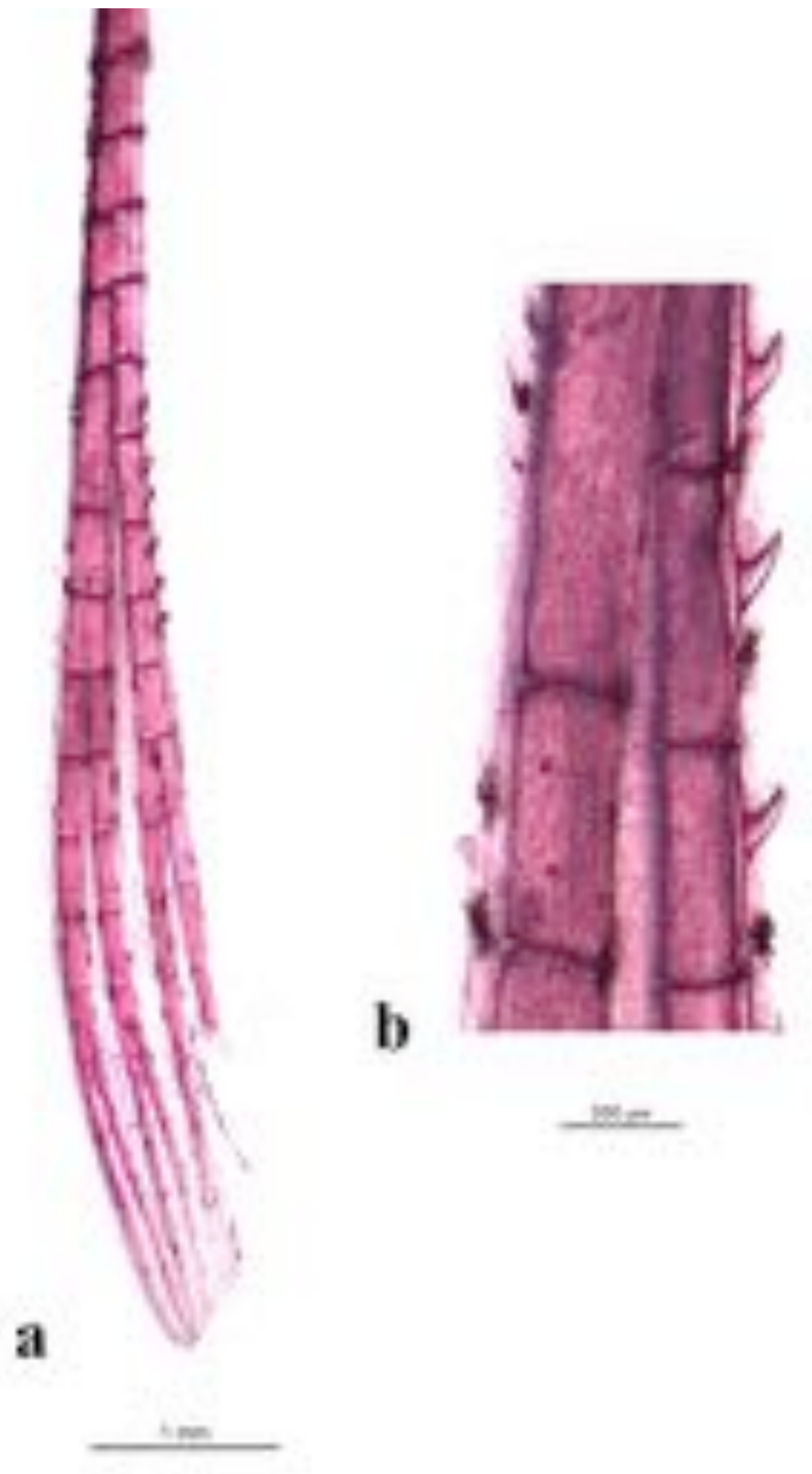

Figura 88. Distribuição, posição e formato dos processos ósseos no hemitriquium esquerdo do raio ramificado da nadadeira anal de machos de Bryconexodon juruenae. (a) vista lateral, (b) detalhe em vista anteroposterior. 


\section{Charax stenopterus (Cope 1894)}

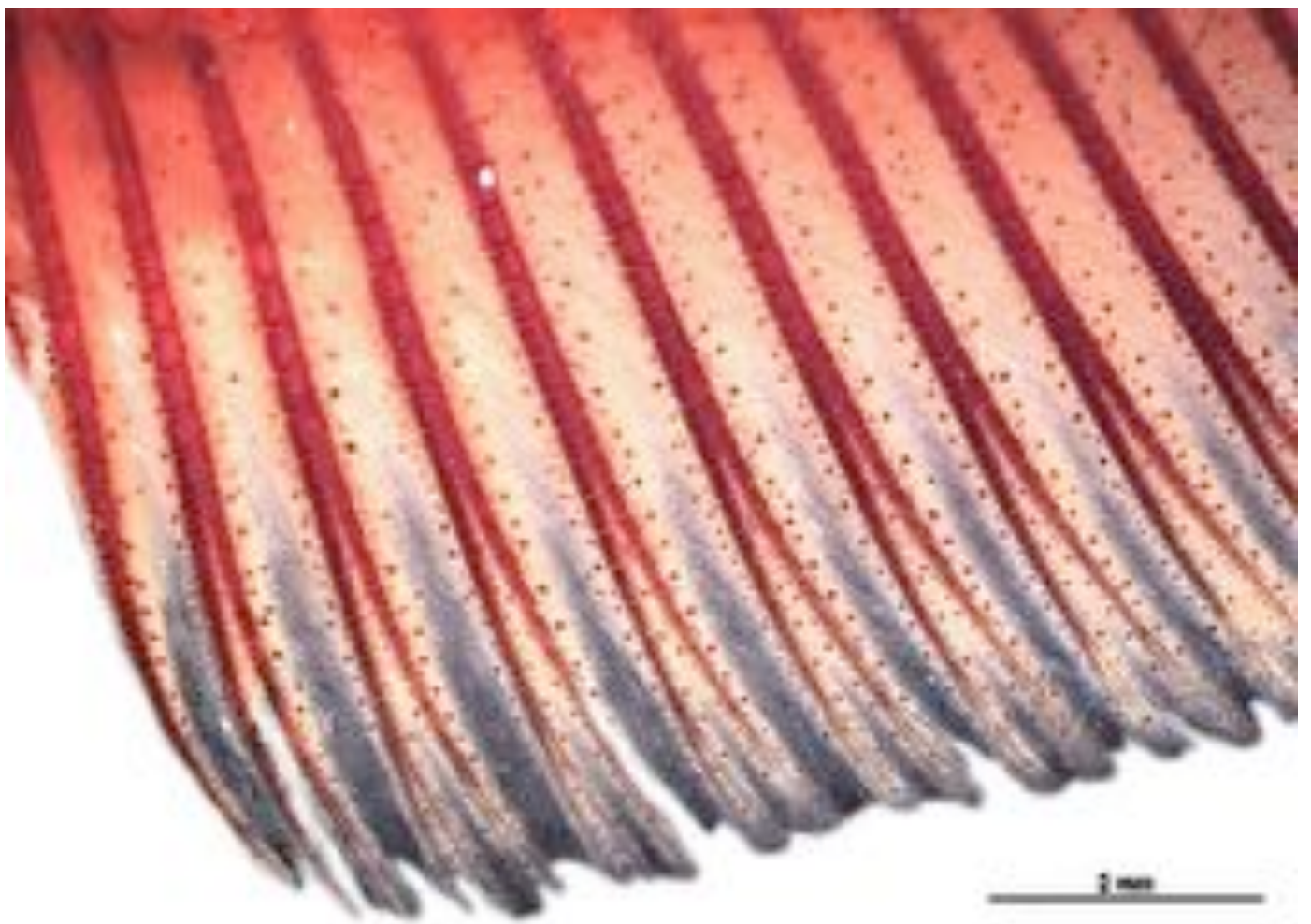

Figura 89. Nadadeira anal de machos de Charax stenopterus em vista lateral esquerda, evidenciando o formato do perfil da margem distal da nadadeira e distribuição dos processos ósseos. 


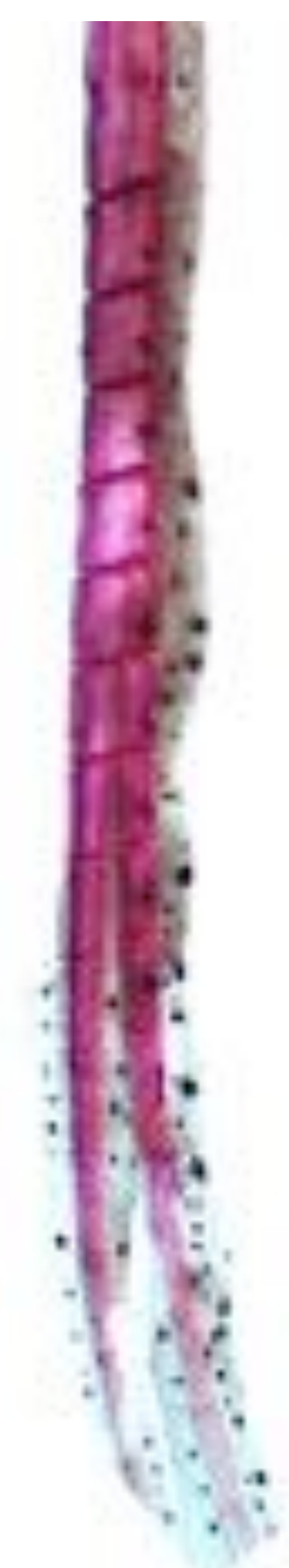

a

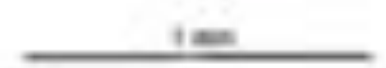

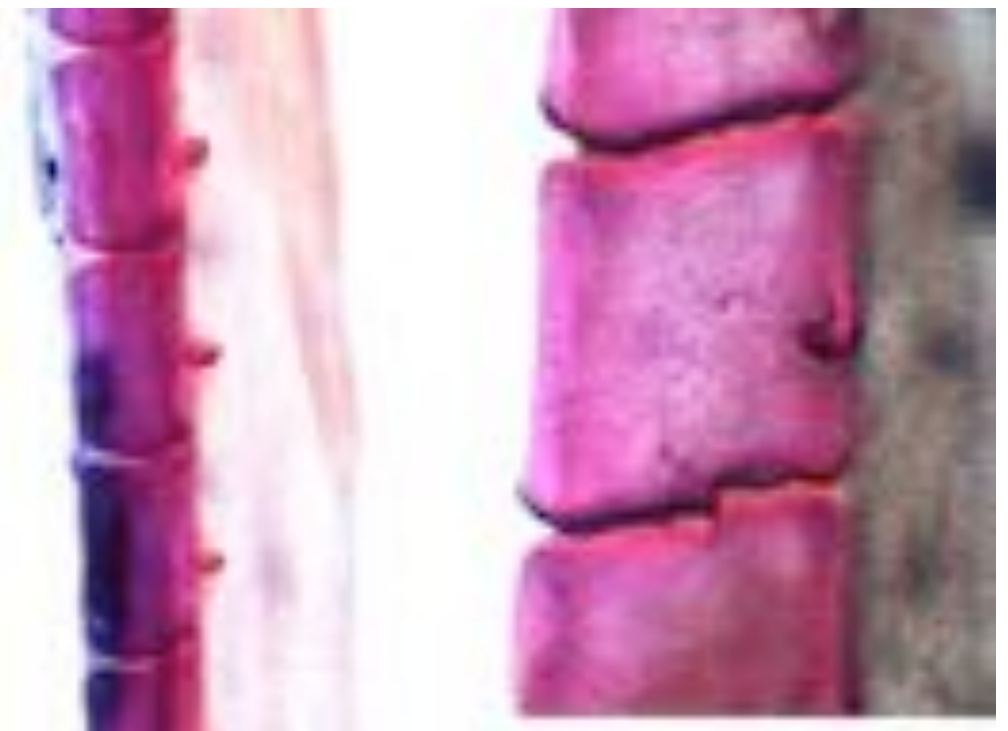
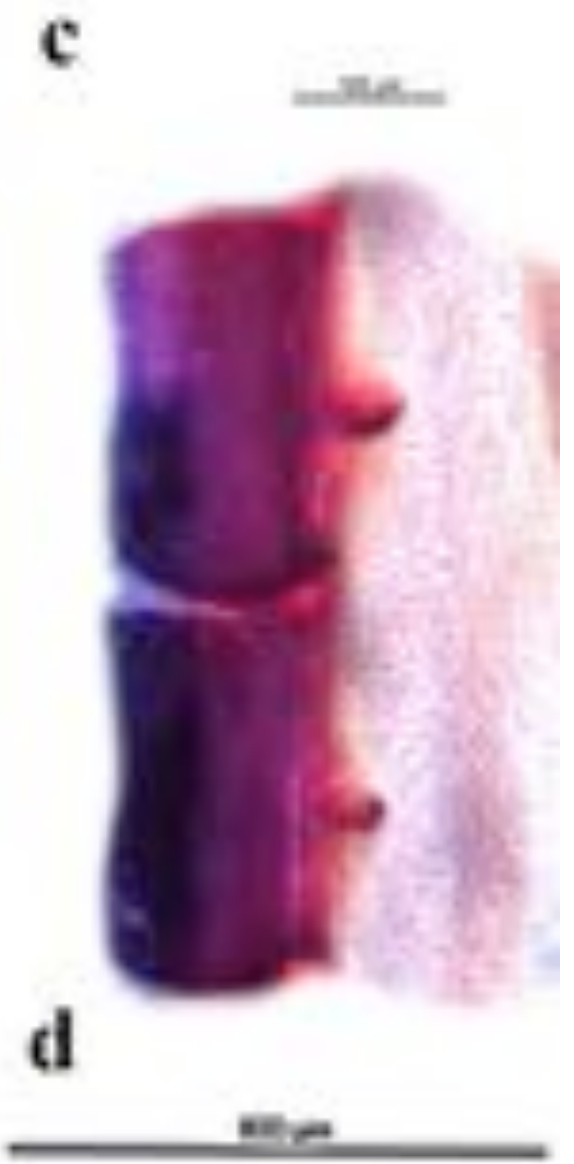

Figura 90. Distribuição, posição e formato dos processos ósseos no hemitriquium esquerdo do raio ramificado da nadadeira anal de machos de Charax stenopterus. (a) vista lateral, (b) vista anteroposterior, (c) detalhe em vista lateral, (d) detalhe em vista anteroposterior. 

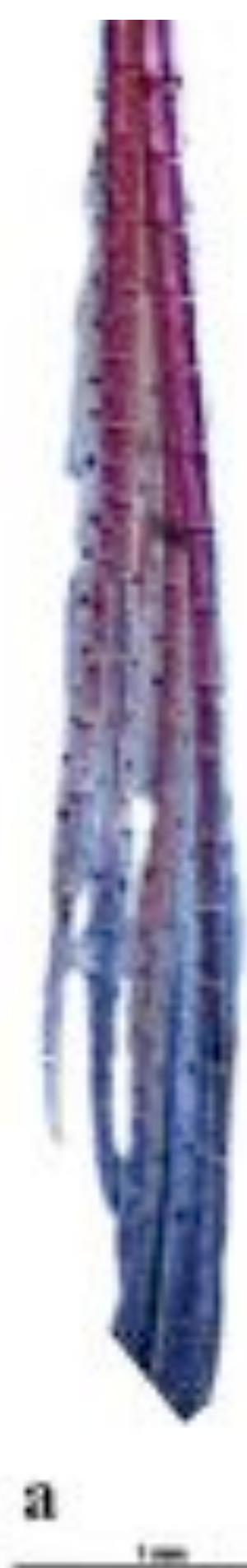
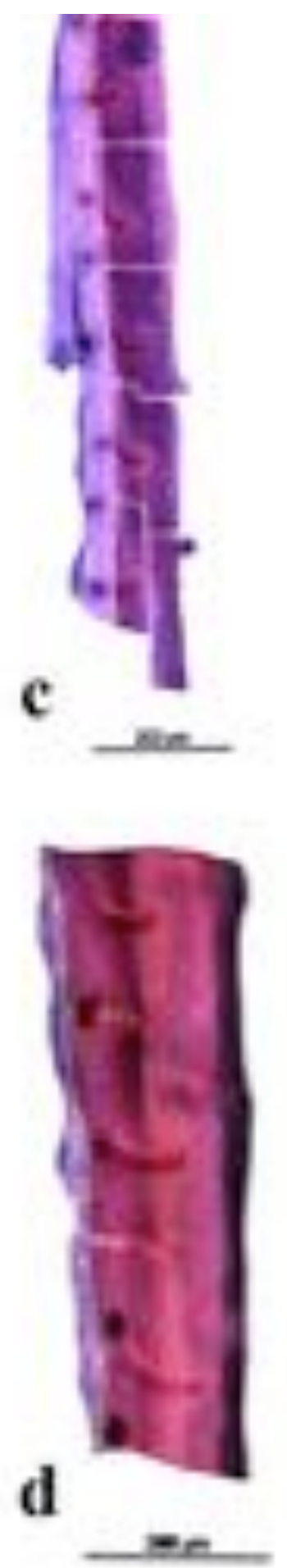

Figura 91. Distribuição, posição e formato dos processos ósseos no hemitriquium ventral da nadadeira pélvica esquerda de machos de Charax stenopterus. (a) vista ventral, (b) detalhe em vista ventral e (c) detalhe em vista mediolateral. 
Roeboides descalvadensis Fowler 1932

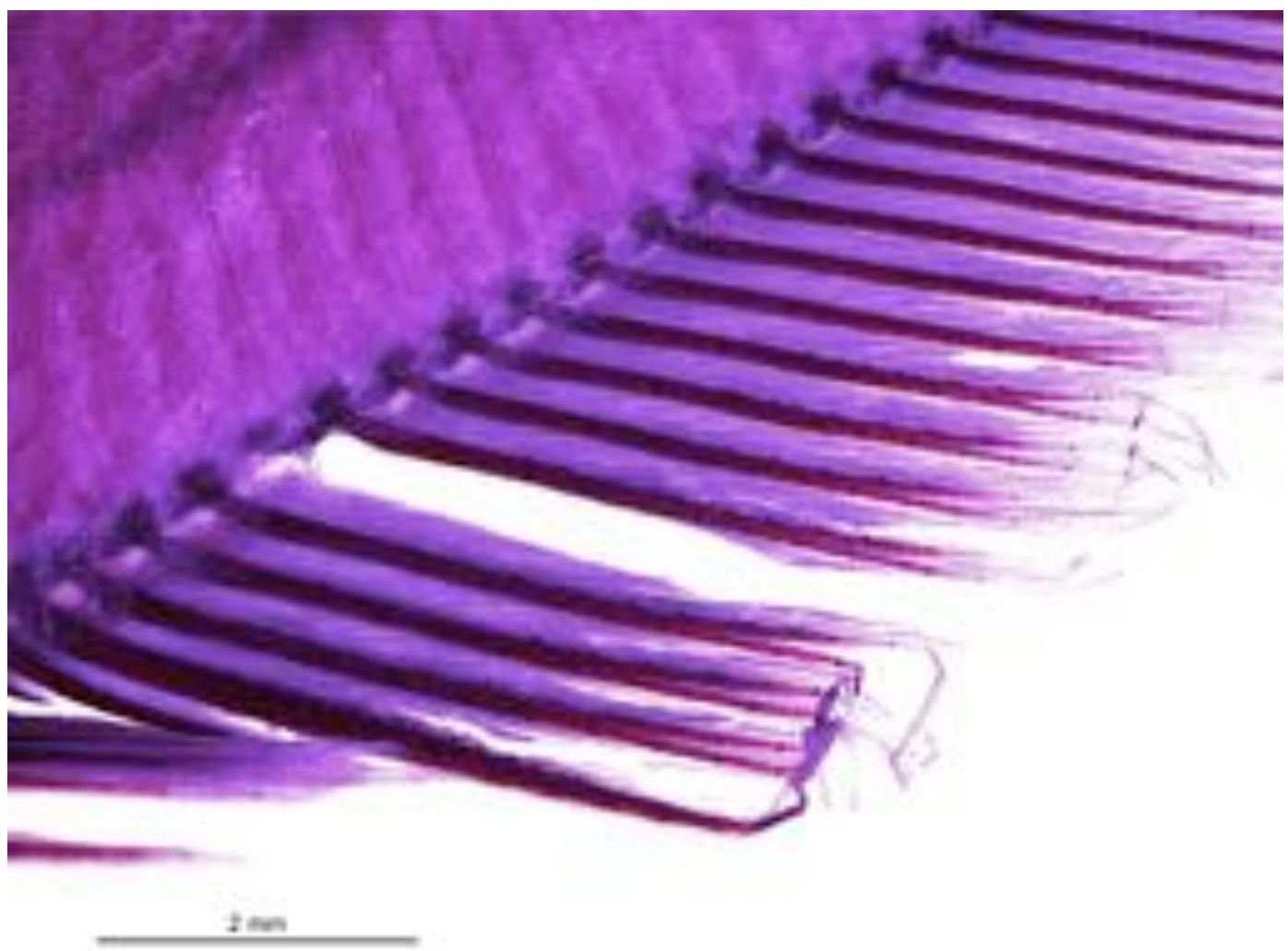

Figura 92. Nadadeira anal de machos de Roeboides descalvadensis em vista lateral esquerda, evidenciando o formato do perfil da margem distal da nadadeira e distribuição dos processos ósseos. 

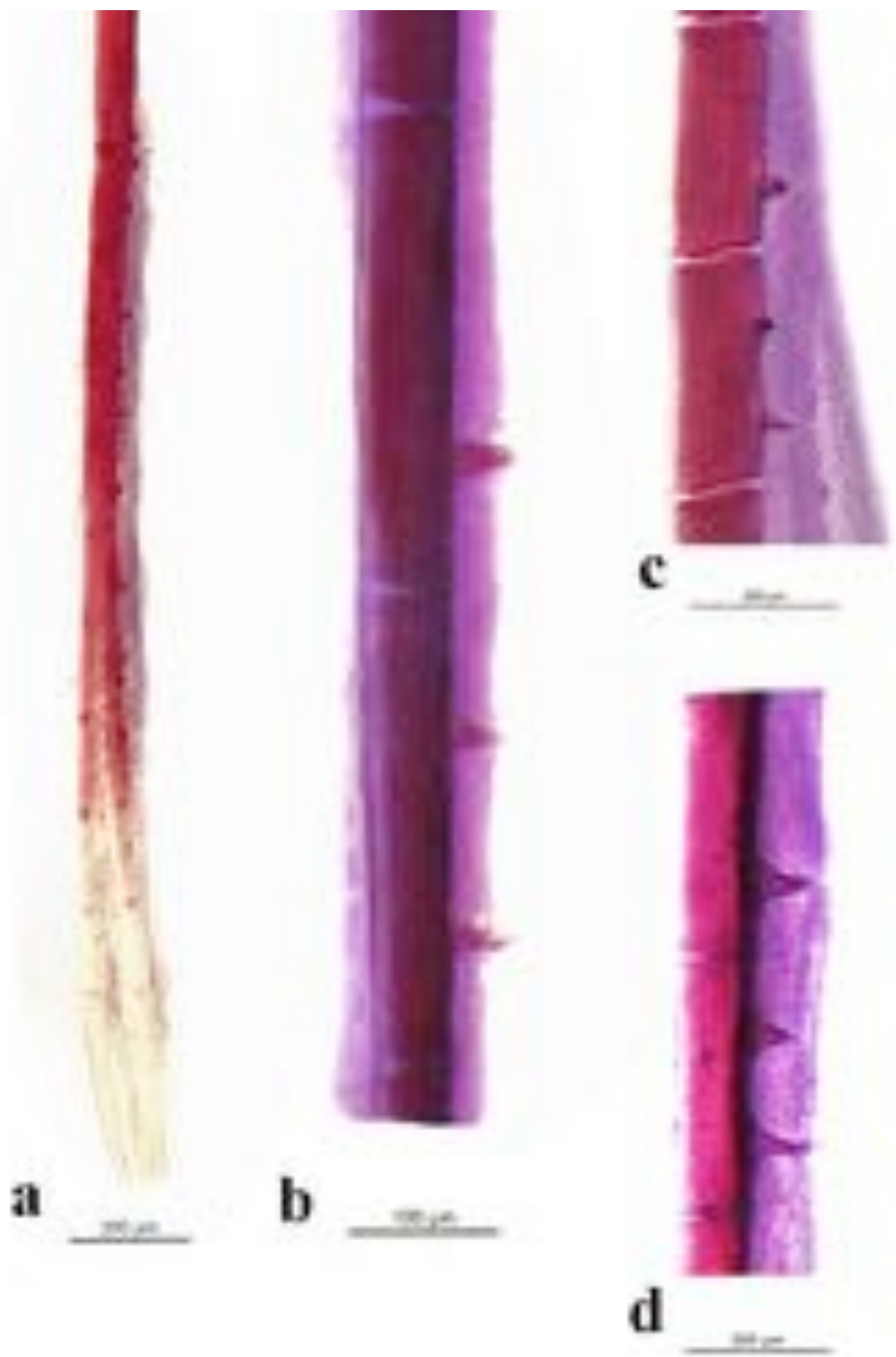

Figura 93. Distribuição, posição e formato dos processos ósseos no hemitriquium esquerdo do raio ramificado da nadadeira anal de machos de Roeboides descalvadensis. (a) vista lateral, (b) vista anteroposterior, (c) detalhe em vista lateral, (d) detalhe em vista anteroposterior. 

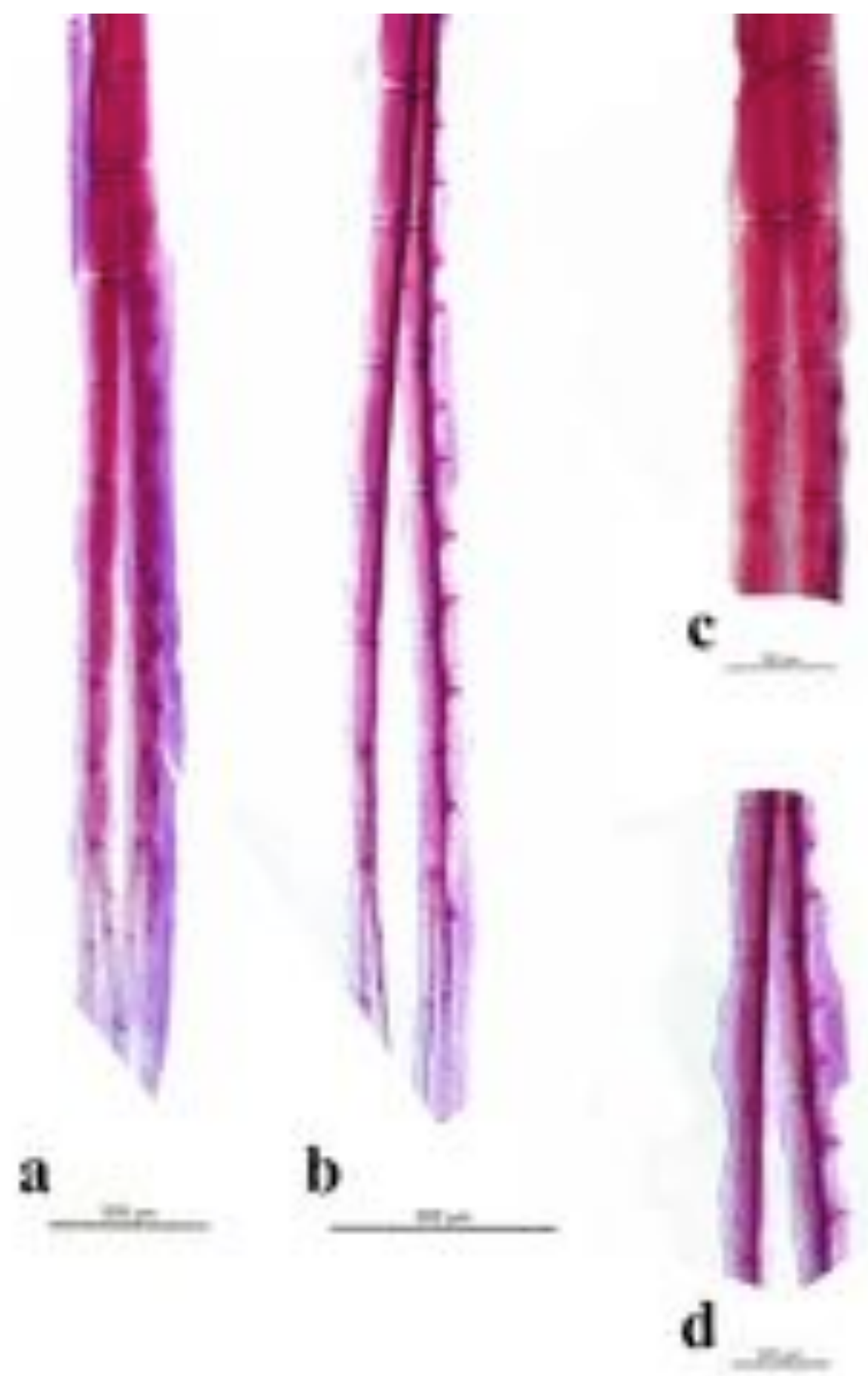

Figura 94. Distribuição, posição e formato dos processos ósseos no hemitriquium ventral da nadadeira pélvica direita de machos de Roeboides descalvadensis. (a) vista ventral, (b) vista lateromedial, (c) detalhe em vista ventral e (d) detalhe em vista lateromedial. 
Roeboides microlepis (Reinhardt 1851)
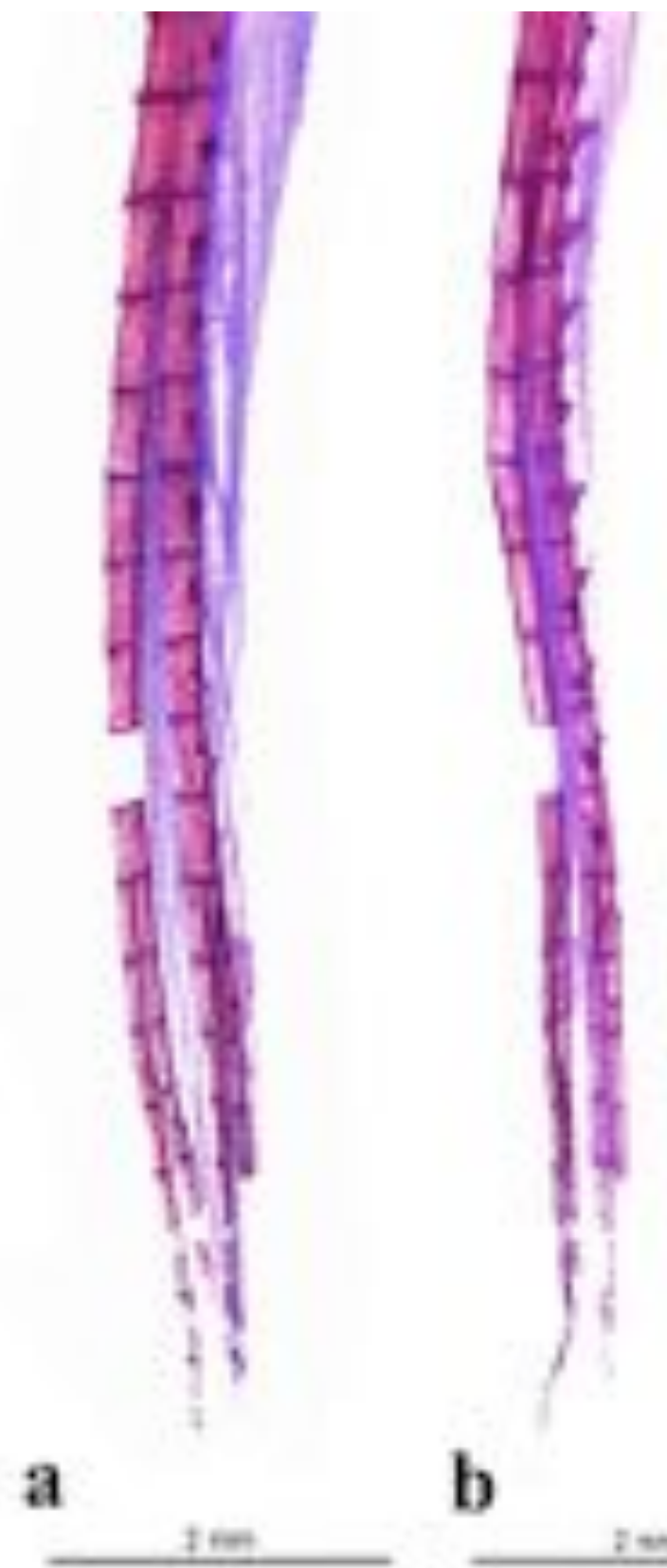

b
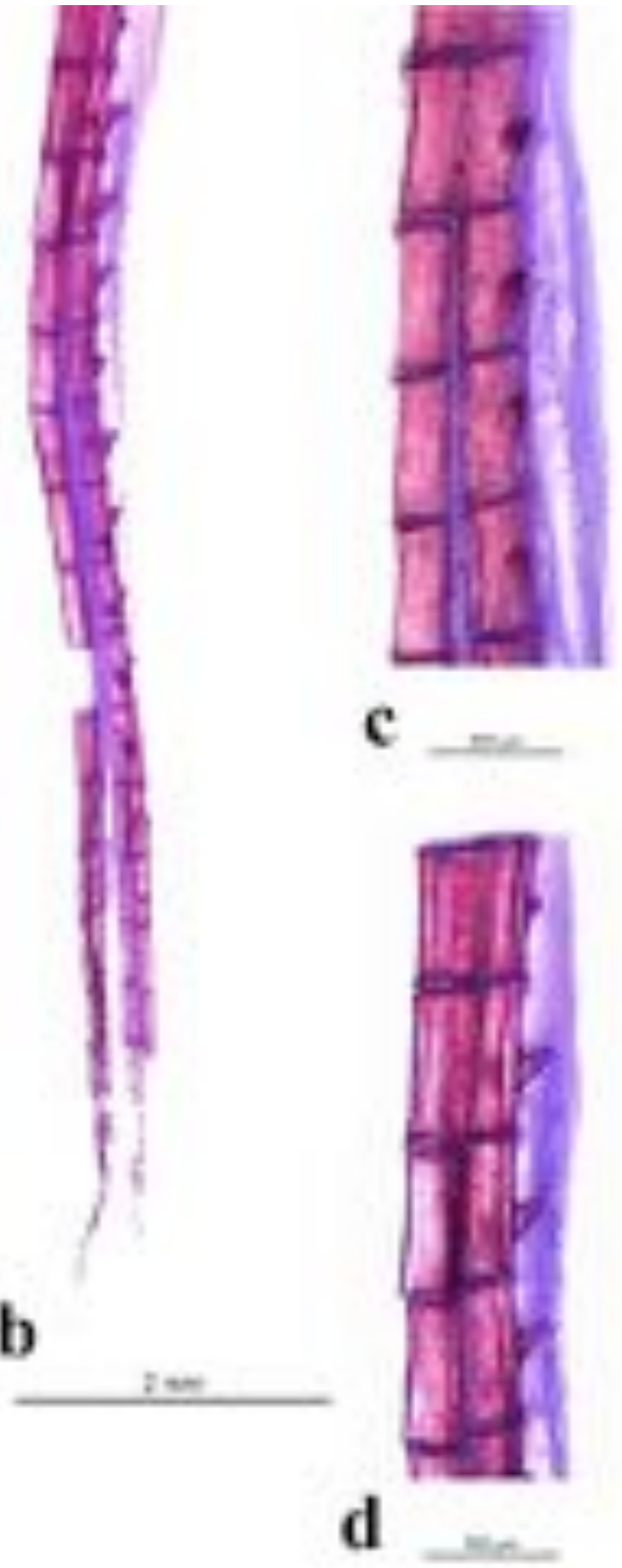

Figura 95. Distribuição, posição e formato dos processos ósseos no hemitriquium esquerdo do raio ramificado da nadadeira anal de machos de Roeboides microlepis. (a) vista lateral, (b) vista anteroposterior, (c) detalhe em vista lateral, (d) detalhe em vista anteroposterior. 

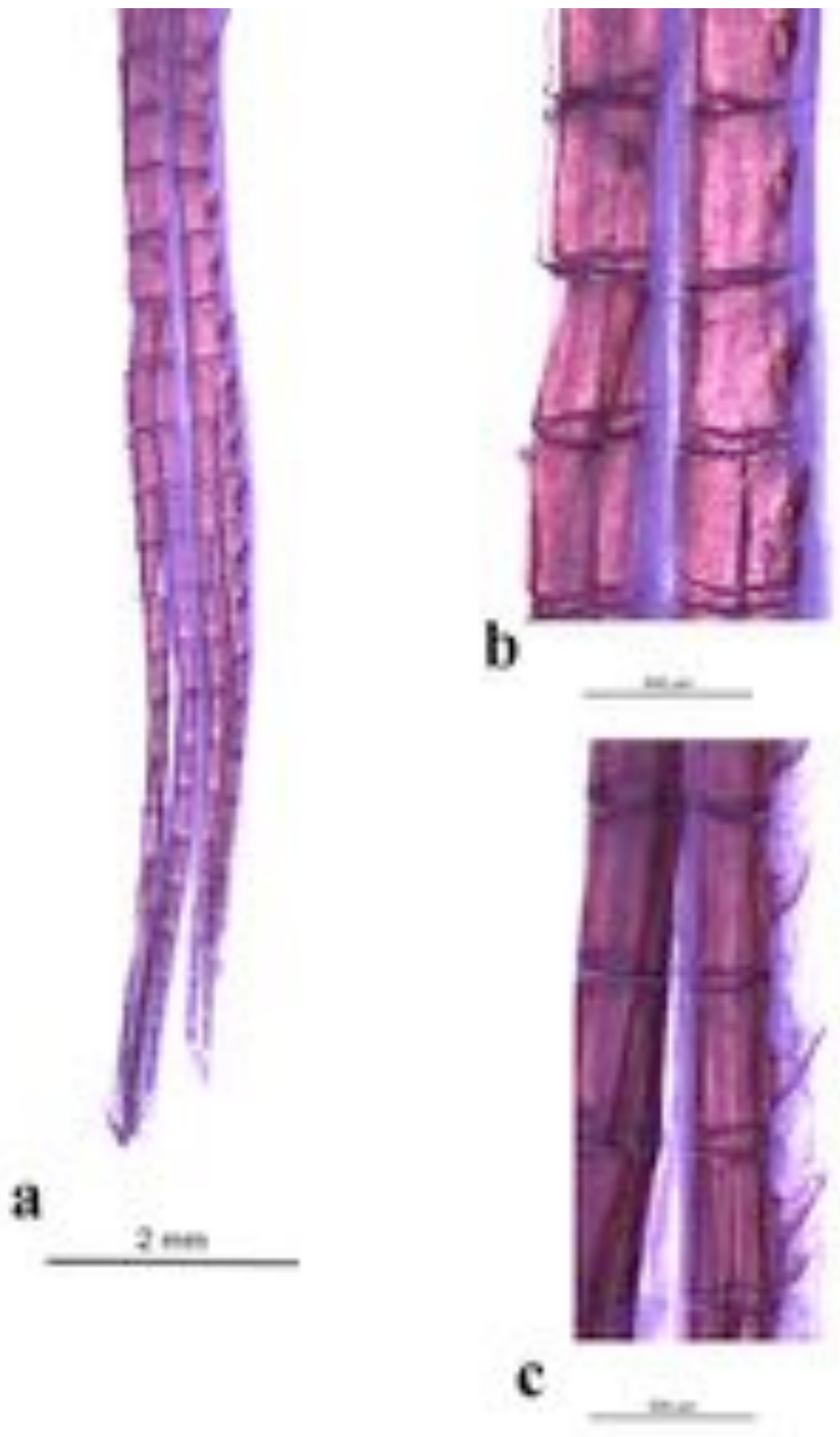

Figura 96. Distribuição, posição e formato dos processos ósseos no hemitriquium ventral da nadadeira pélvica direita de machos de Roeboides microlepis. (a) vista ventral, (b) detalhe em vista ventral e (c) detalhe em vista lateromedial. 


\section{CHEIRODONTINAE}

\section{Acinocheirodon melanogramma Malabarba \& Weitzman 1999}

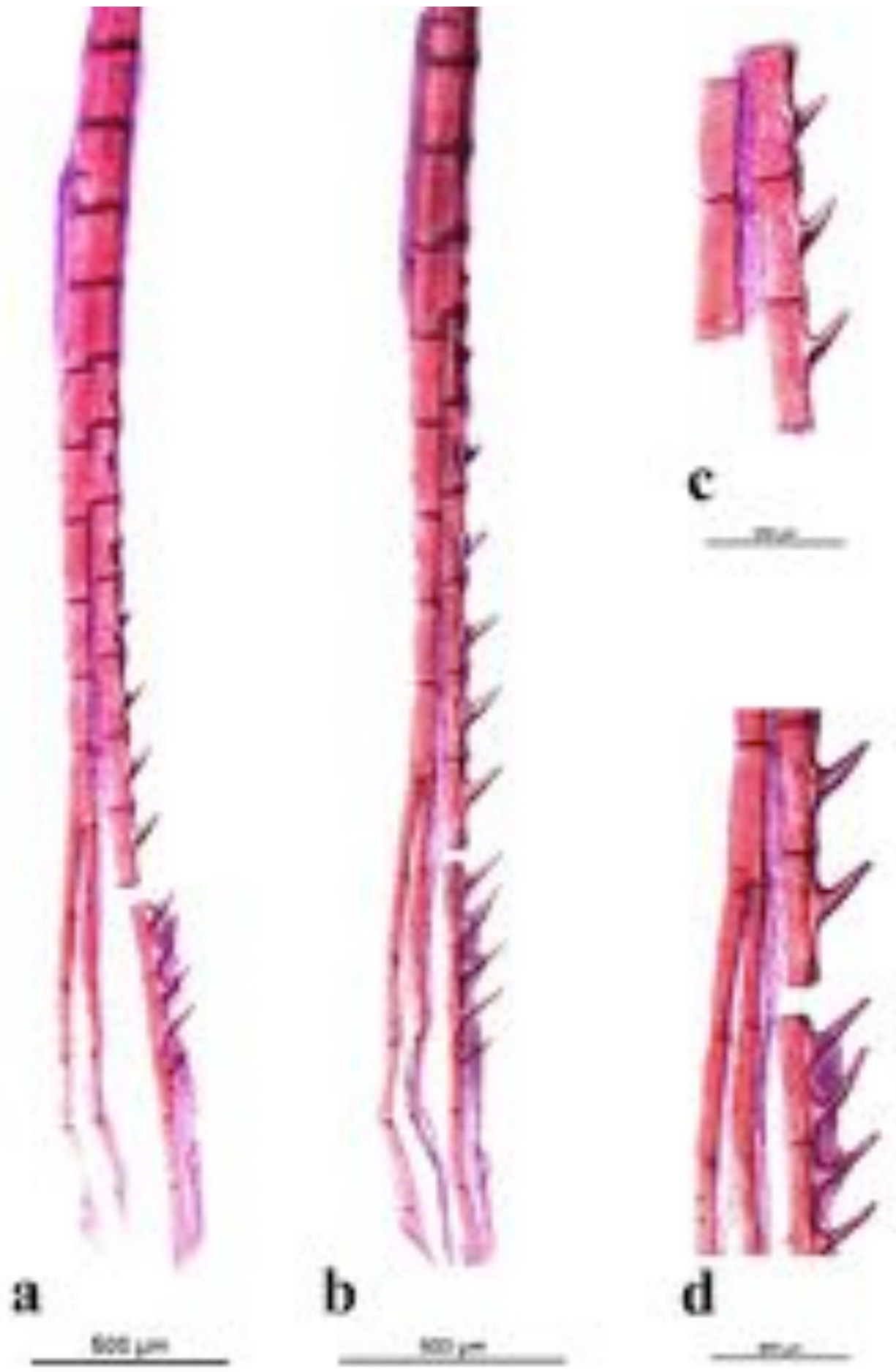

Figura 97. Distribuição, posição e formato dos processos ósseos no hemitriquium esquerdo do raio ramificado da nadadeira anal de machos de Acinocheirodon melanogramma. (a) vista lateral, (b) vista anteroposterior, (c) detalhe em vista lateral, (d) detalhe em vista anteroposterior. 

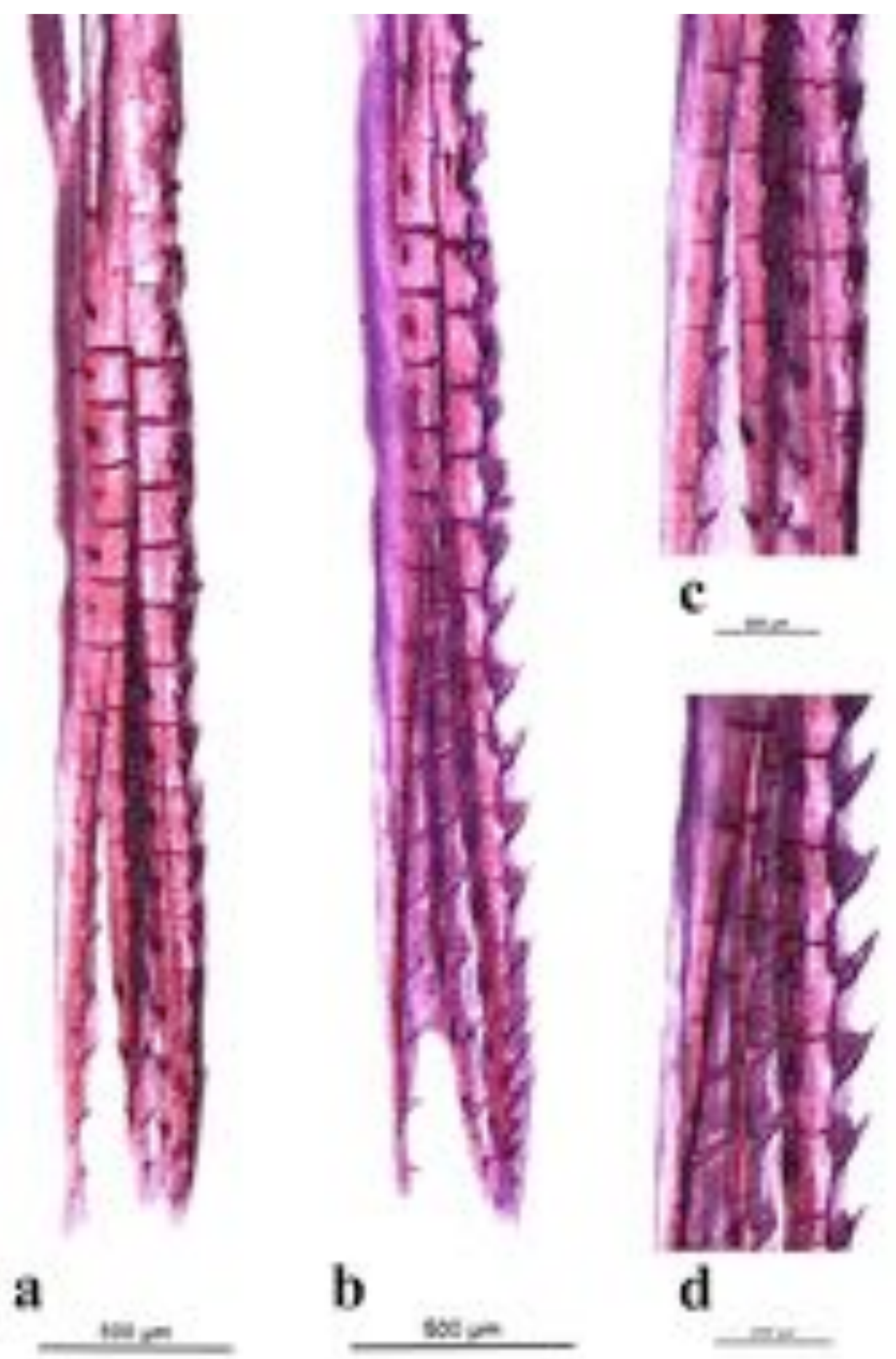

Figura 98. Distribuição, posição e formato dos processos ósseos no hemitriquium ventral da nadadeira pélvica esquerda de machos de Acinocheirodon melanogramma. (a) vista ventral, (b) vista lateromedial, (c) detalhe em vista ventral e (d) detalhe em vista lateromedial. 


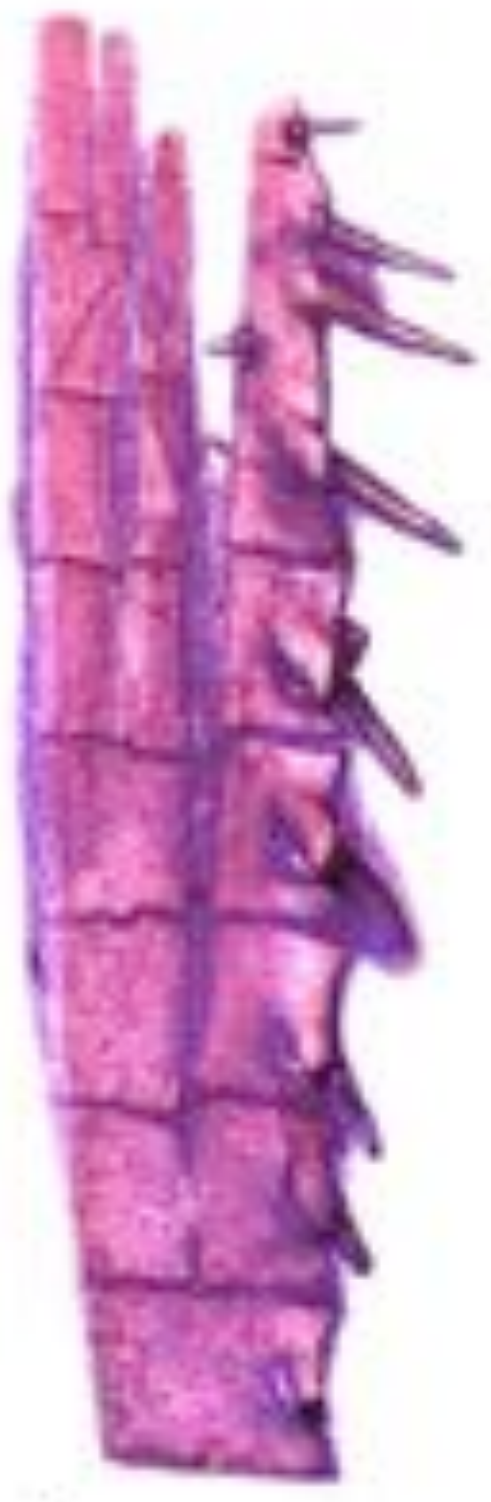

a

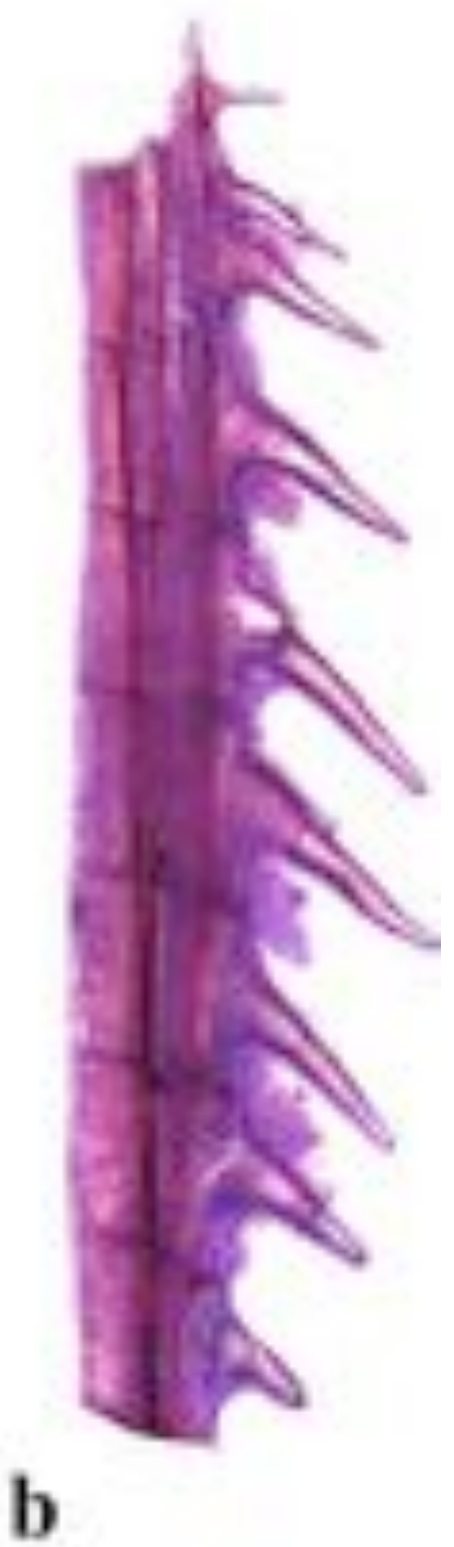

b

\section{$500 \mu \mathrm{m}$}

Figura 99. Distribuição, posição e formato dos processos ósseos no hemitriquium direito da nadadeira caudal de machos de Acinocheirodon melanogramma. (a) detalhe em vista lateral, (b) detalhe em vista lateromedial. 


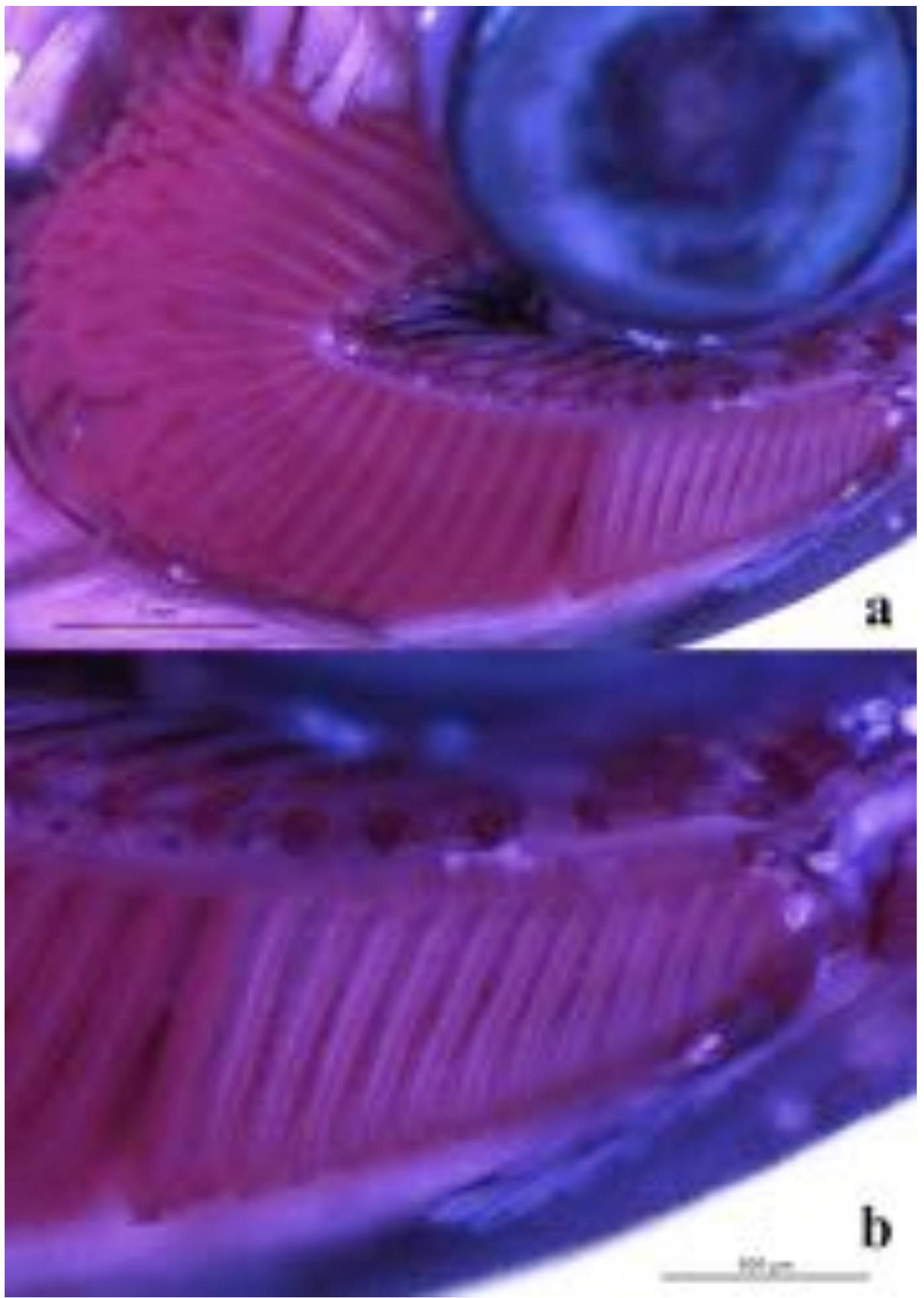

Figura 100. Brânquia com glândula branquial em vista lateral direita (a), detalhe da região anterior do ceratobranquial direito, evidenciando a glândula branquial em Acinocheirodon melanogramma. 

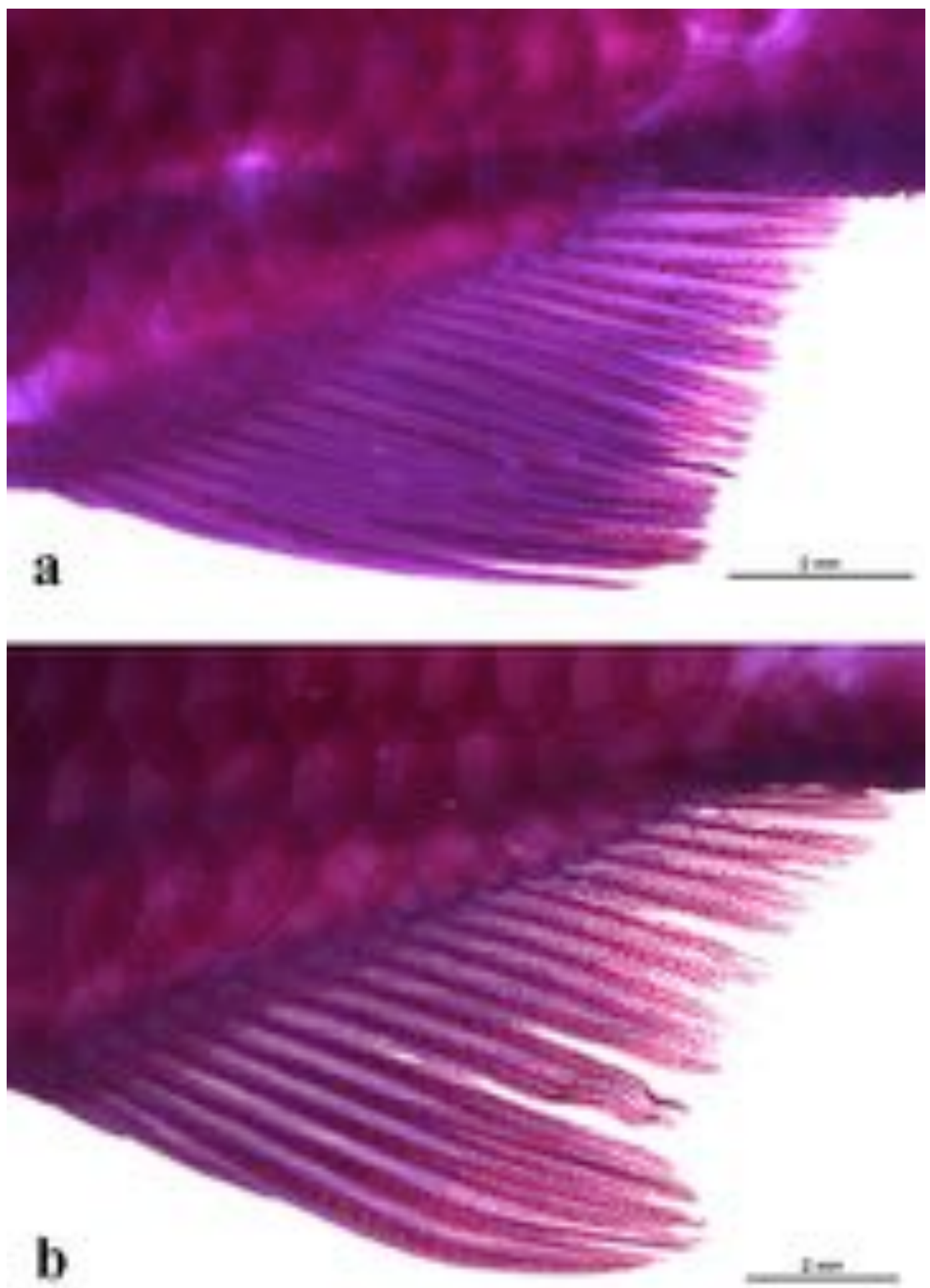

Figura 101. Nadadeira anal de machos (a) e de fêmeas (b) de Cheirodon interruptus em vista lateral esquerda, evidenciando o formato do perfil distal das nadadeiras nos dois sexos e distribuição dos processos ósseos na nadadeira anal de macho. 


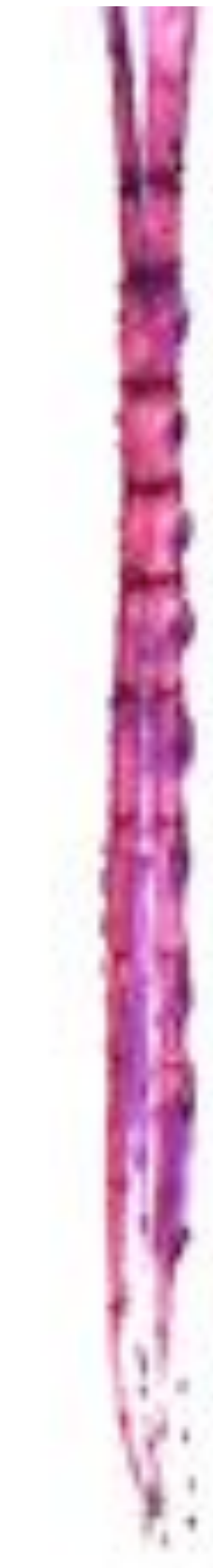

a

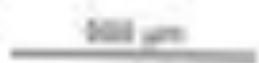

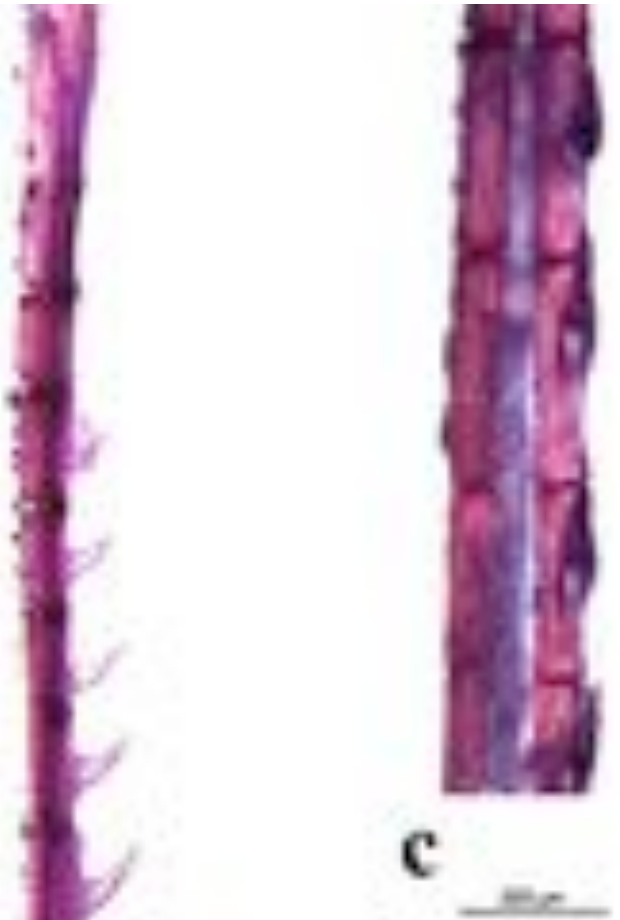

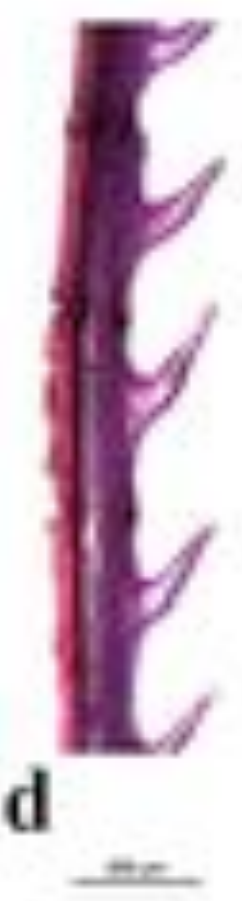

Figura 102. Distribuição, posição e formato dos processos ósseos no hemitriquium esquerdo do raio ramificado da nadadeira anal de machos de Cheirodon interruptus. (a) vista lateral, (b) vista anteroposterior, (c) detalhe em vista lateral, (d) detalhe em vista anteroposterior. 

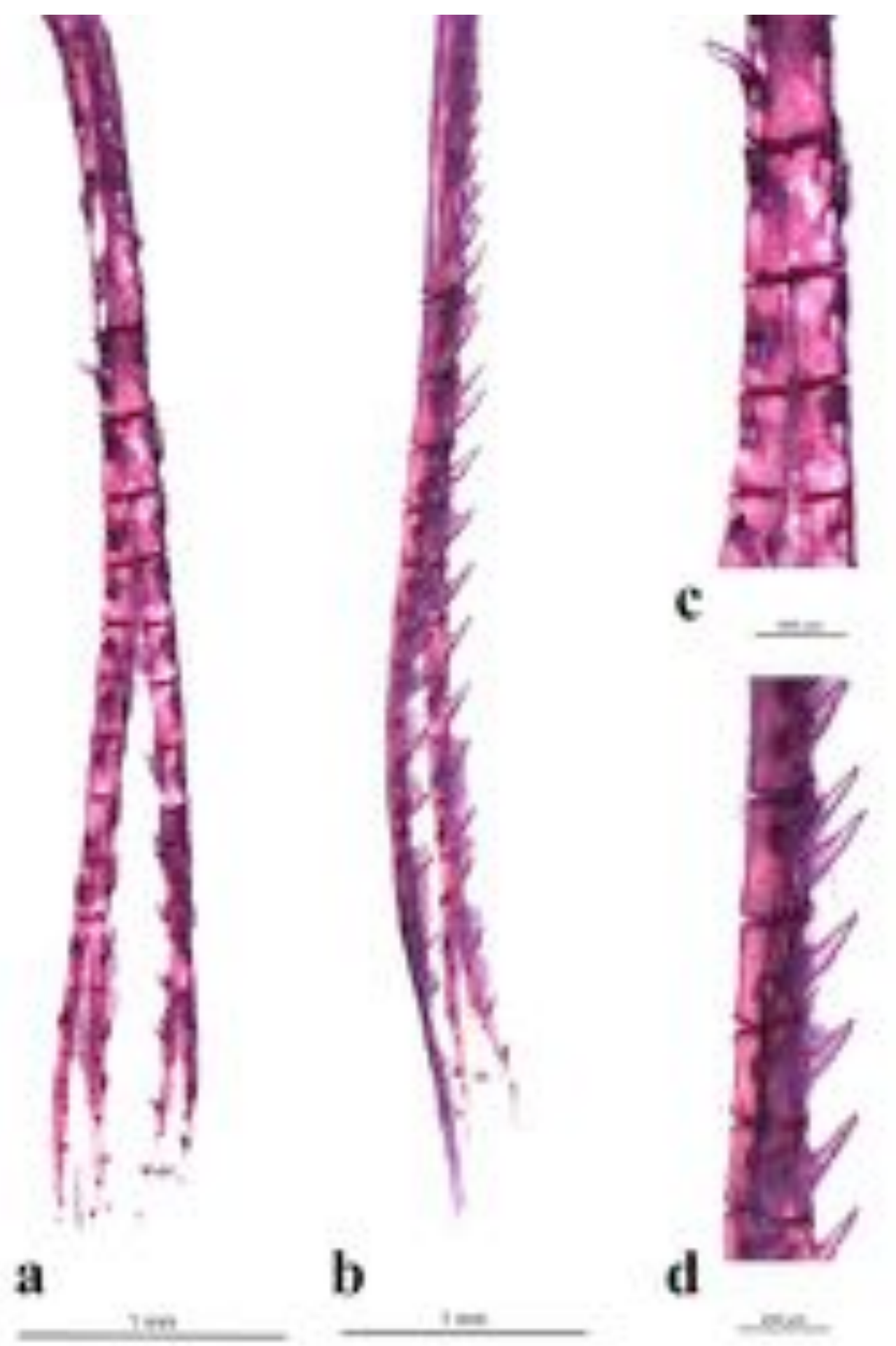

Figura 103. Distribuição, posição e formato dos processos ósseos no hemitriquium ventral da nadadeira pélvica direita de machos de Cheirodon interruptus. (a) vista ventral, (b) vista lateromedial, (c) detalhe em vista ventral e (d) detalhe em vista lateromedial. 

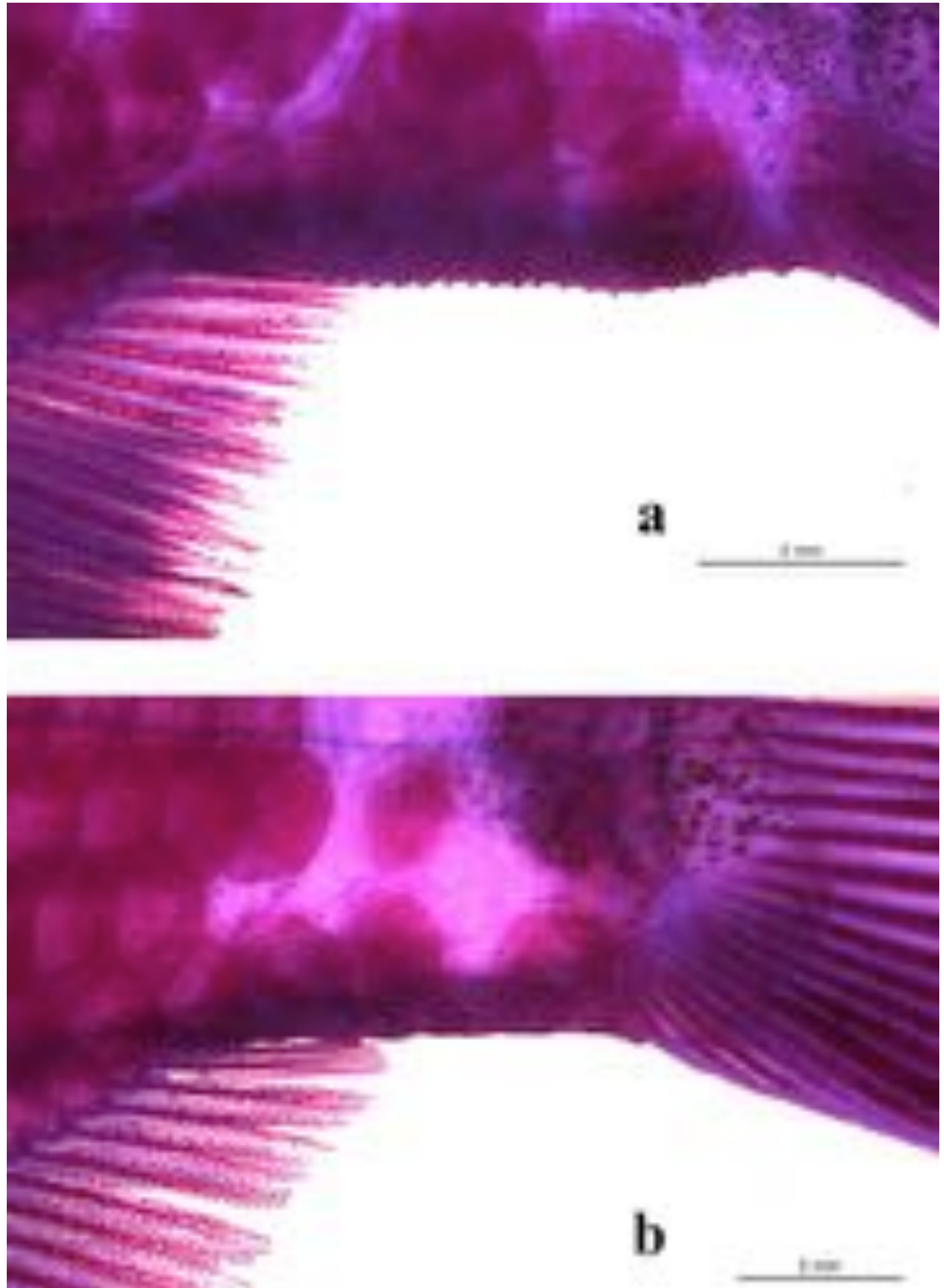

Figura 104. Pedúnculo caudal de machos (a) e de fêmeas (b) de Cheirodon interruptus, evidenciando a exposição e formato da extremidade distal dos raios procurrentes ventrais de macho. 

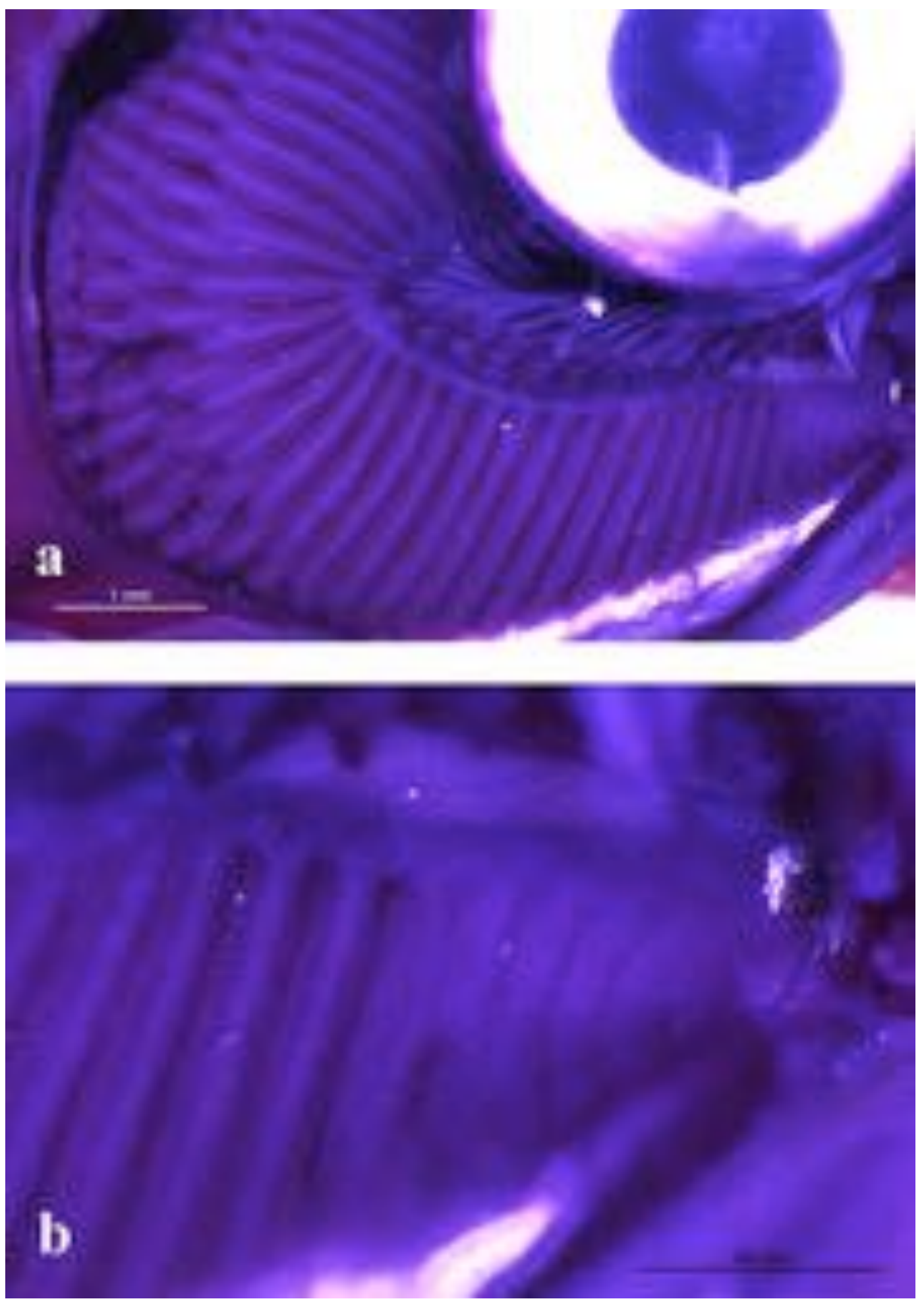

Figura 105. Brânquia com glândula branquial em vista lateral direita (a), detalhe da região anterior do ceratobranquial direito, evidenciando a glândula branquial (b) em Cheirodon interruptus. 


\section{Compsura heterura Eigenmann 1915}
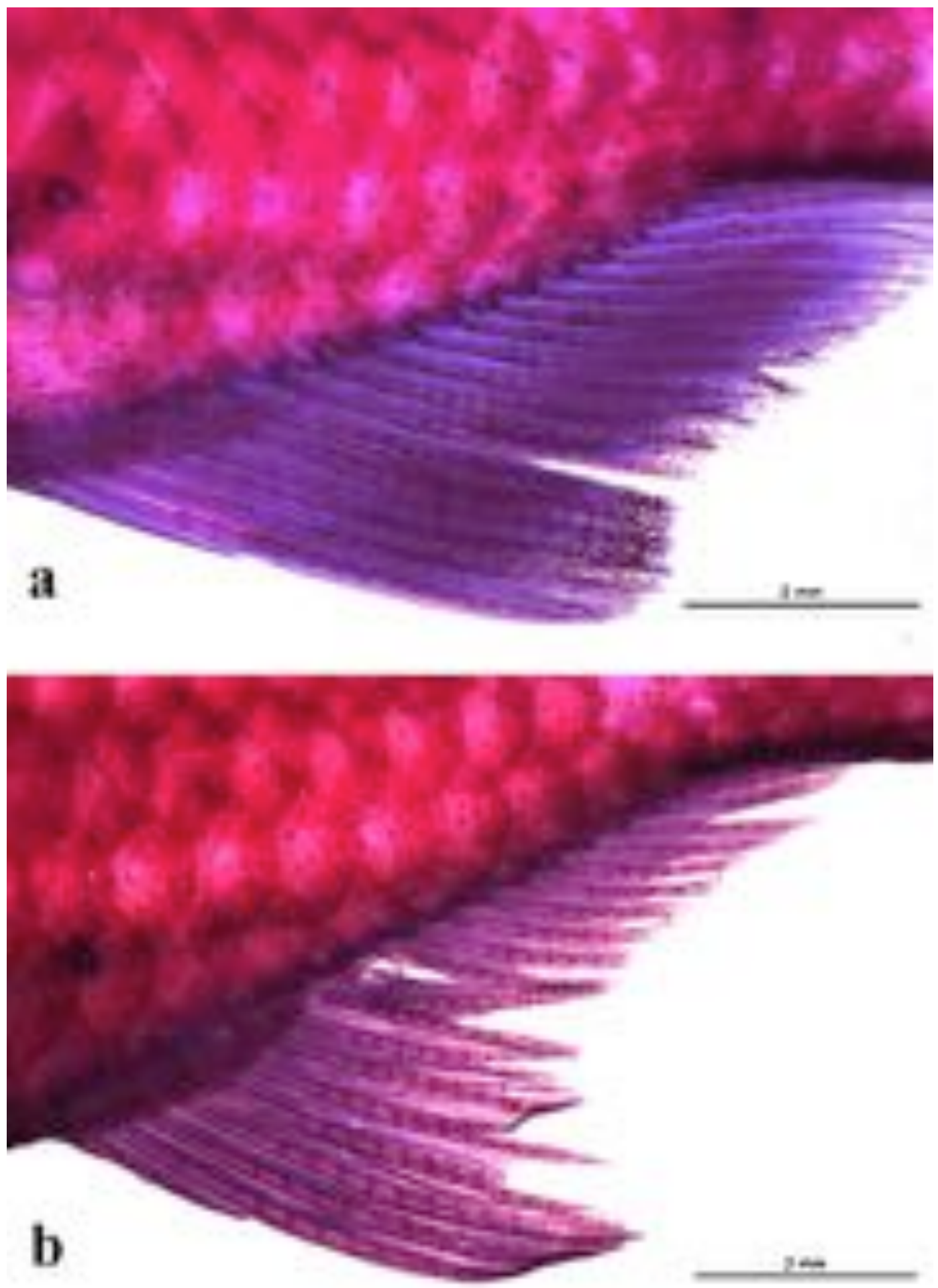

Figura 106. Nadadeira anal de machos (a) e de fêmeas (b) de Compsura heterura em vista lateral esquerda, evidenciando o formato do perfil distal das nadadeiras nos dois sexos e distribuição dos processos ósseos na nadadeira anal de macho. 


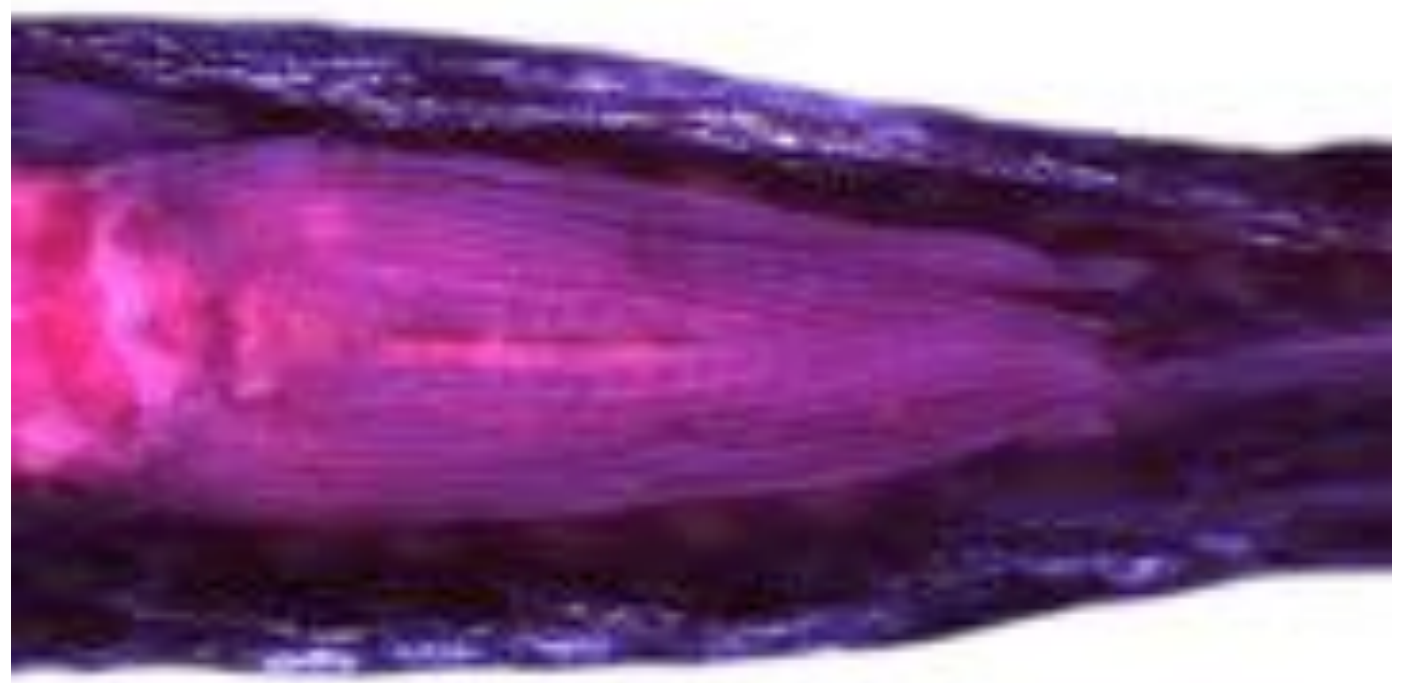

a

d

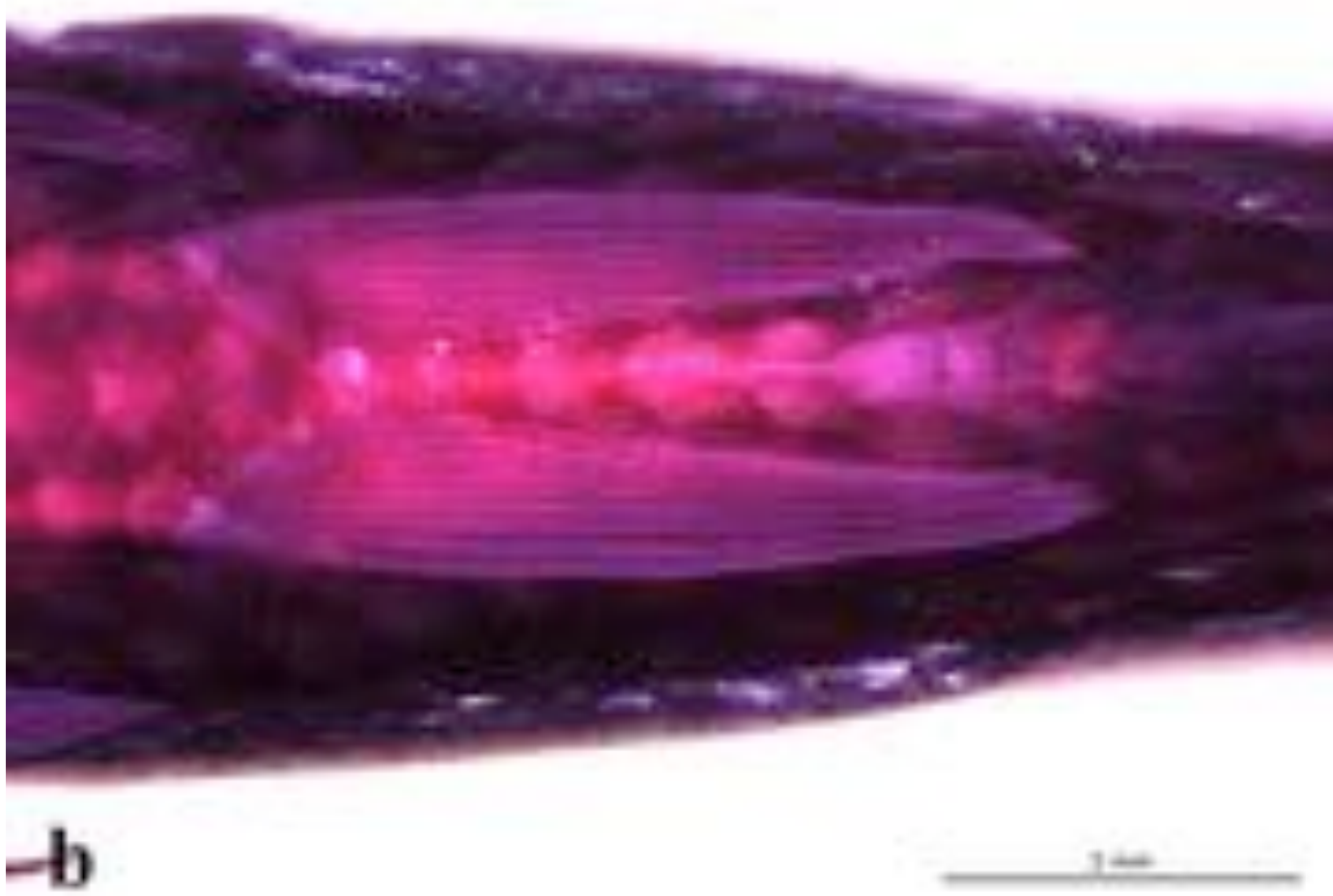

Figura 107. Nadadeira pélvica de machos (a) e de fêmeas (b) de Compsura heterura em vista lateral ventral, evidenciando o formato e comprimento da nadadeira nos dois sexos. 

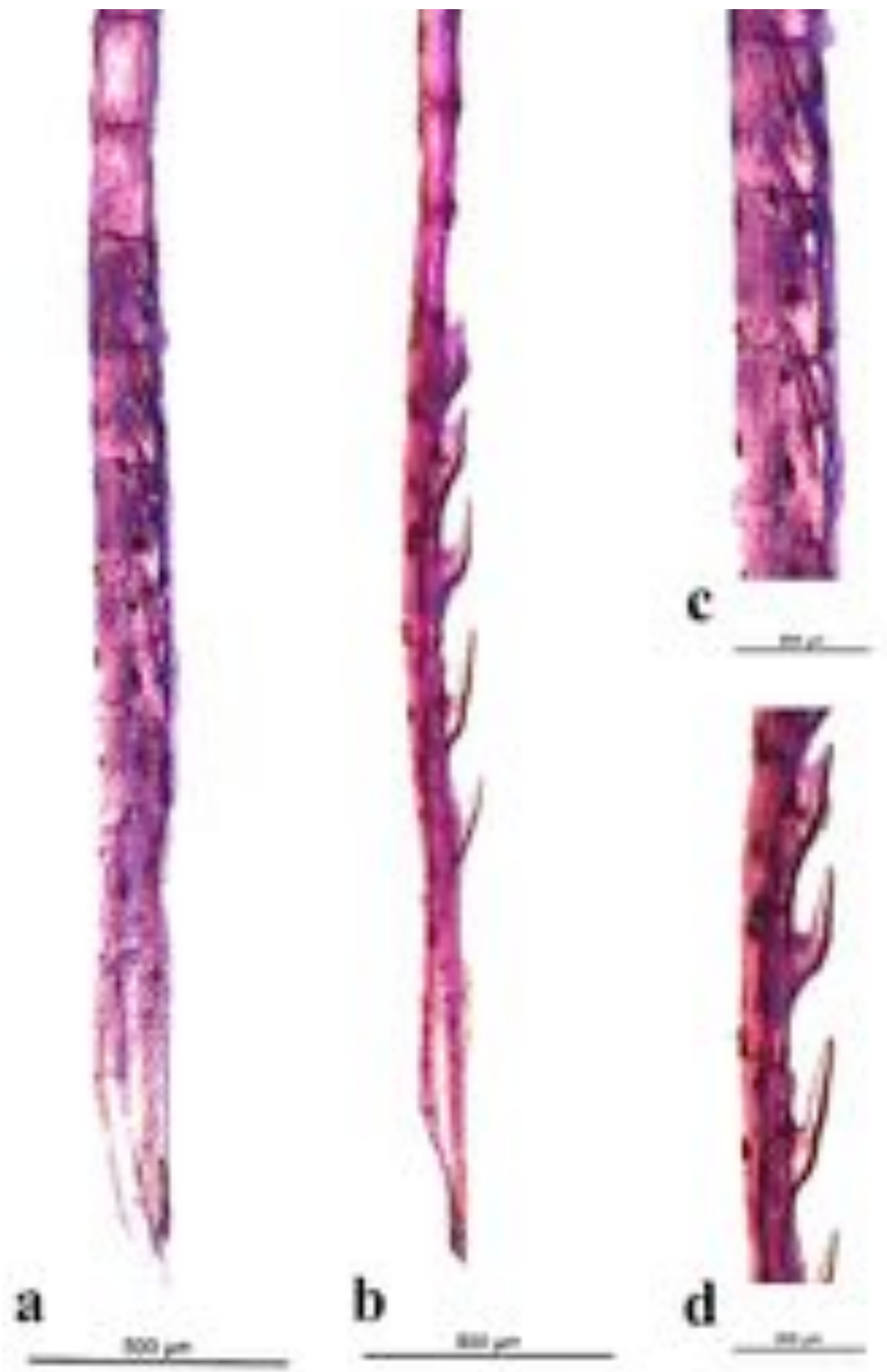

Figura 108. Distribuição, posição e formato dos processos ósseos no hemitriquium esquerdo do raio ramificado da nadadeira anal de machos de Compsura heterura. (a) vista lateral, (b) vista anteroposterior, (c) detalhe em vista lateral, (d) detalhe em vista anteroposterior. 

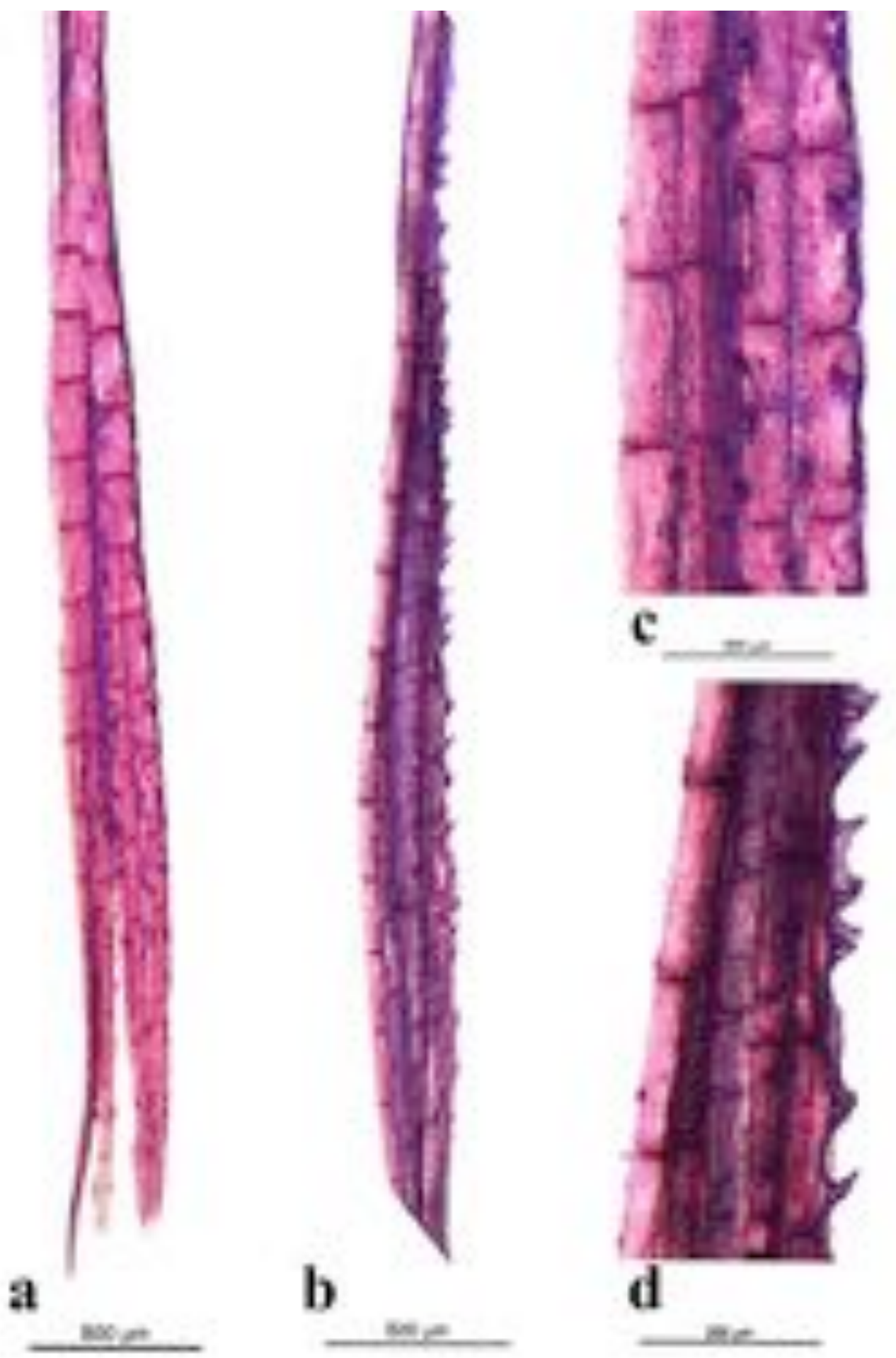

Figura 109. Distribuição, posição e formato dos processos ósseos no hemitriquium ventral da nadadeira pélvica direita de machos de Compsura heterura. (a) vista ventral, (b) vista lateromedial, (c) detalhe em vista ventral e (d) detalhe em vista lateromedial. 


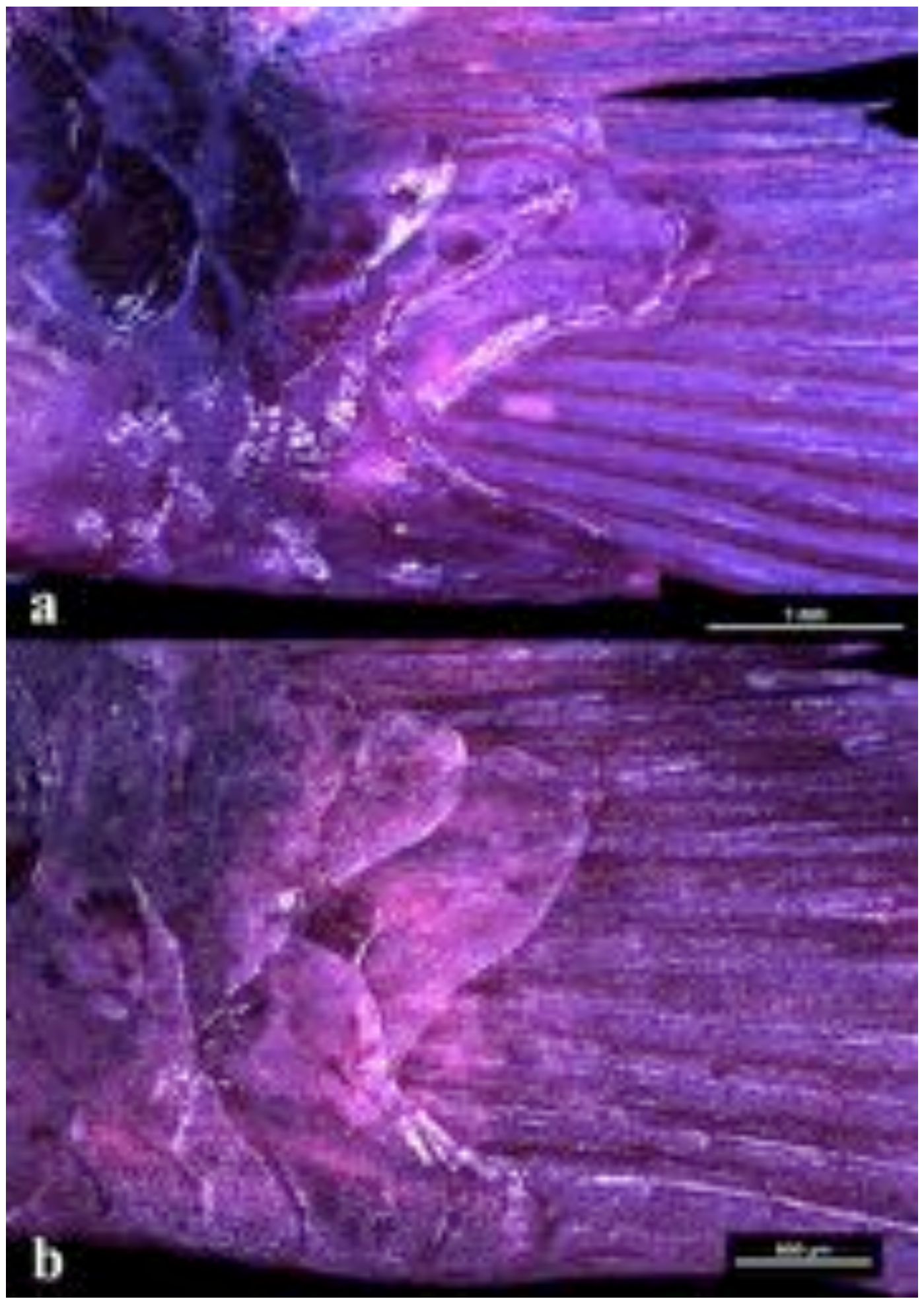

Figura 110. Detalhe do final do pedúnculo caudal e origem dos raios do lobo ventral da nadadeira caudal de machos (a) e de fêmeas (b) de Compsura heterura, evidenciando as escamas modificadas nos dois sexos. 
Heterocheirodon yatai (Casciotta, Miquelarena \& Protogino 1992)

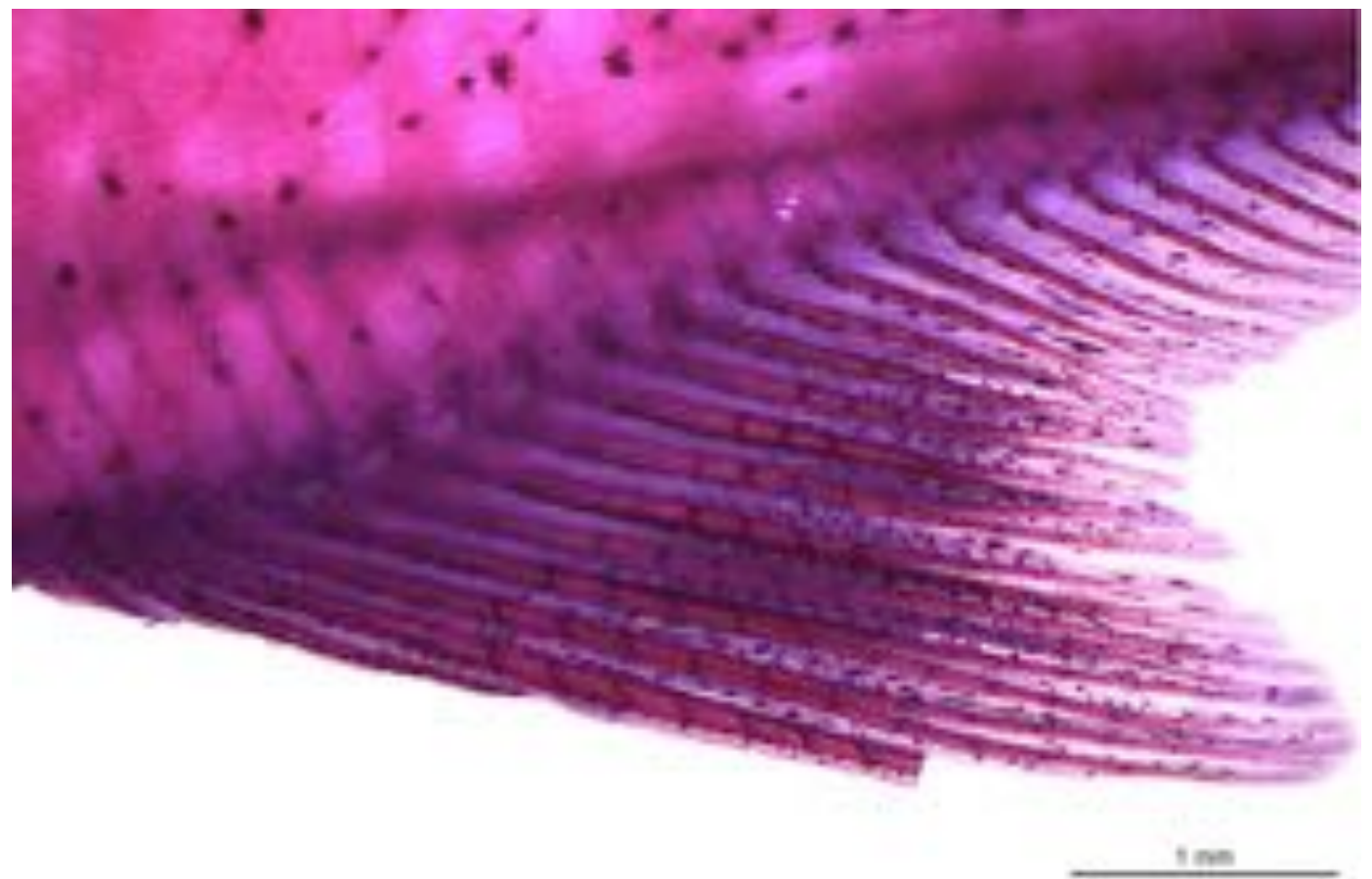

Figura 111. Nadadeira anal de machos de Heterocheirodon yatai em vista lateral esquerda, evidenciando o formato do perfil da margem distal da nadadeira e distribuição dos processos ósseos. 

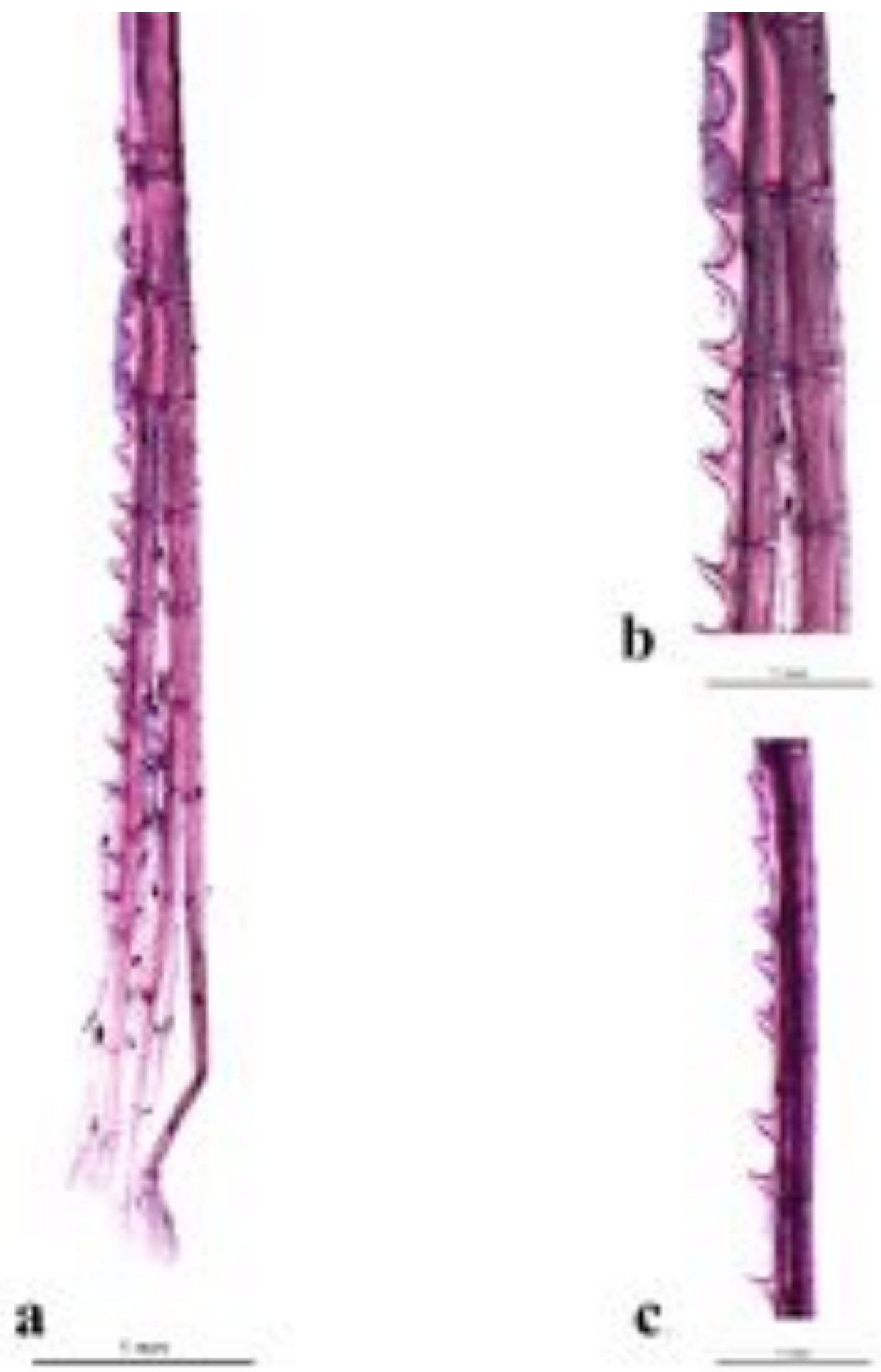

Figura 112. Distribuição, posição e formato dos processos ósseos no hemitriquium direito do raio ramificado da nadadeira anal de machos de Heterocheirodon yatai. (a) vista lateral, (b) detalhe em vista lateral e (c) detalhe em vista anteroposterior. 

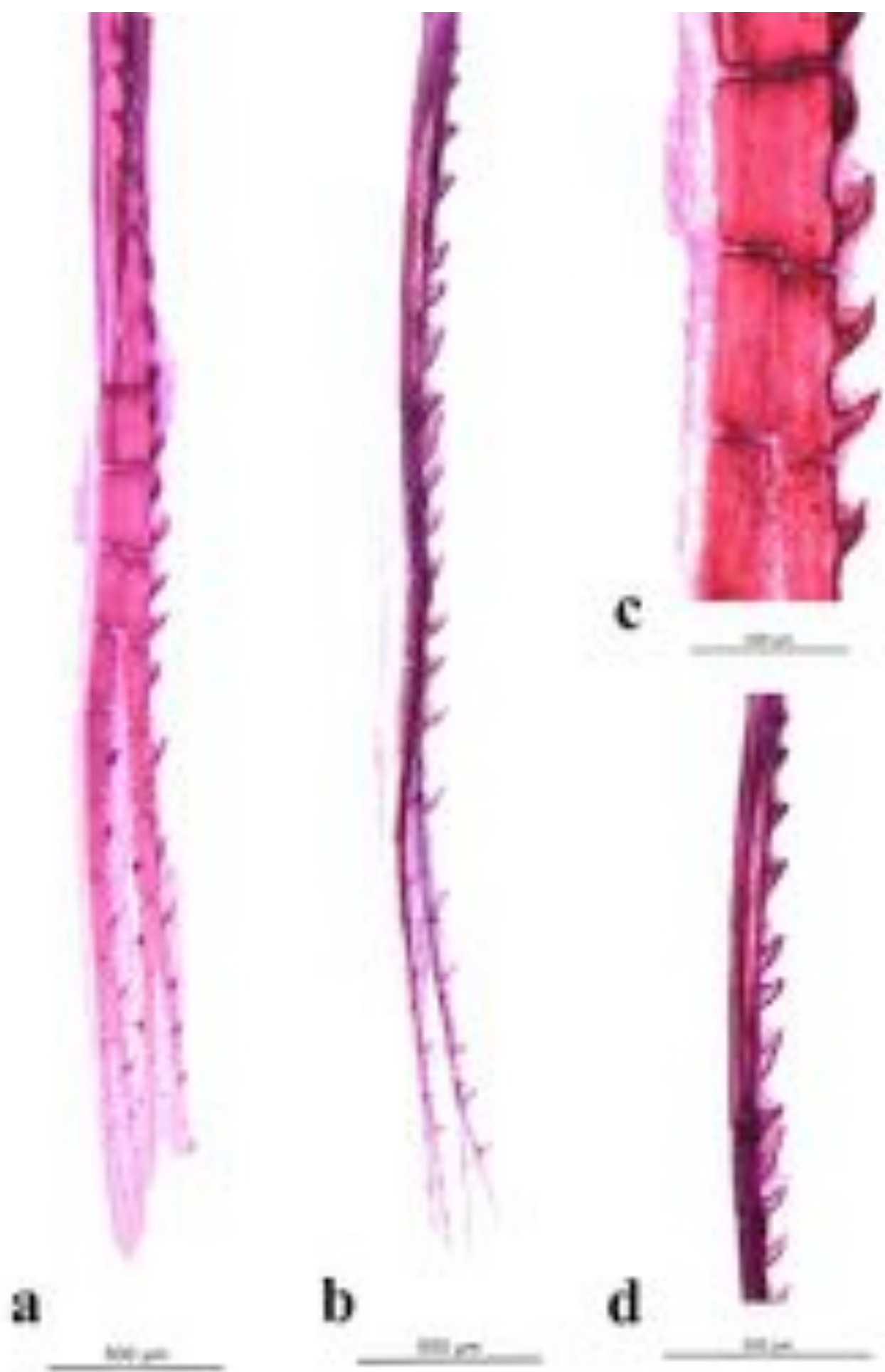

Figura 113. Distribuição, posição e formato dos processos ósseos no hemitriquium ventral da nadadeira pélvica direita de machos de Heterocheirodon yatai. (a) vista ventral, (b) vista lateromedial, (c) detalhe em vista ventral e (d) detalhe em vista lateromedial. 

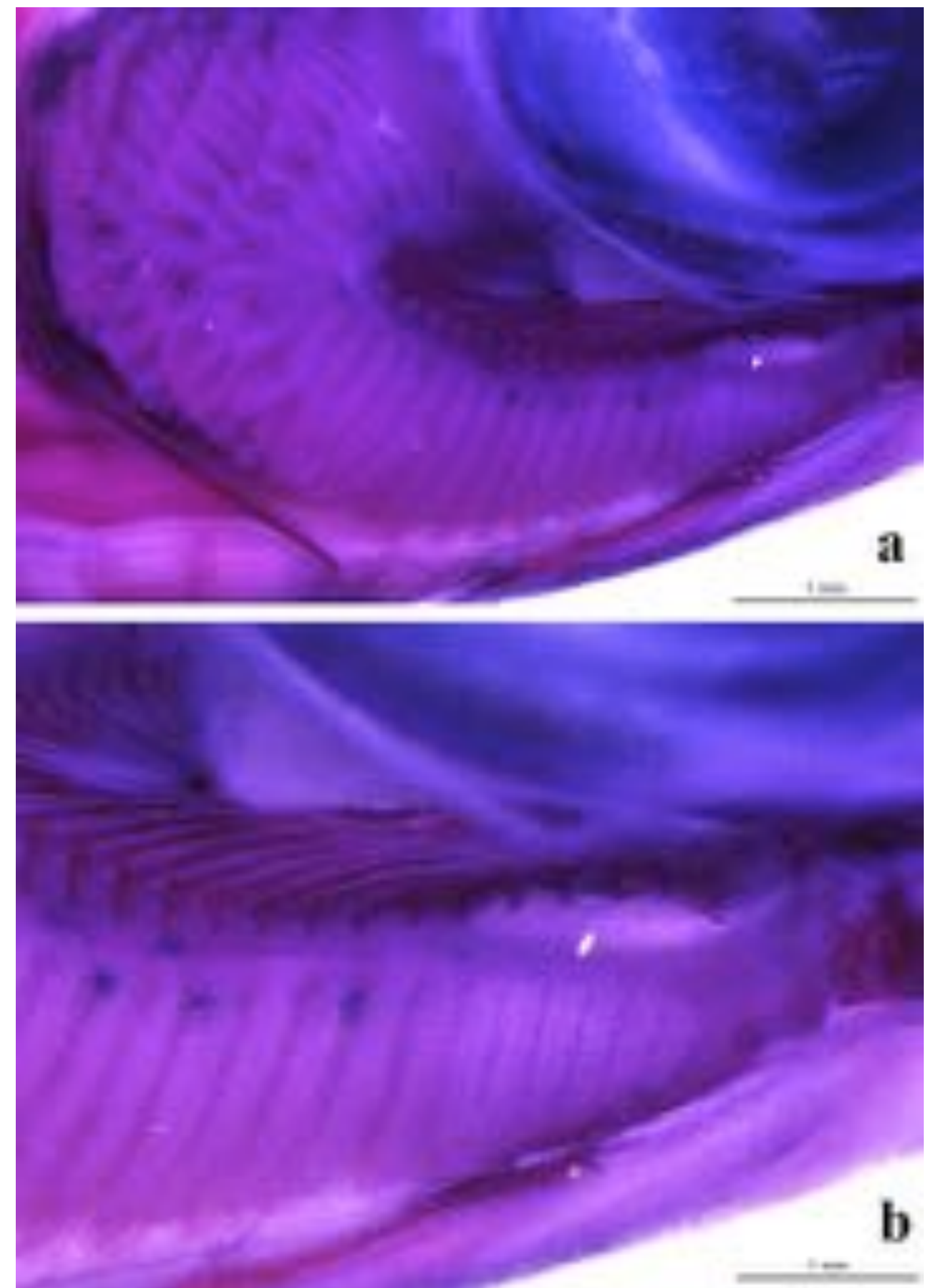

Figura 114. Brânquia com glândula branquial em vista lateral direita (a), detalhe da região anterior do ceratobranquial direito, evidenciando a glândula branquial (b) em de Heterocheirodon yatai. 
Odontostilbe pequira (Steindachner 1882)
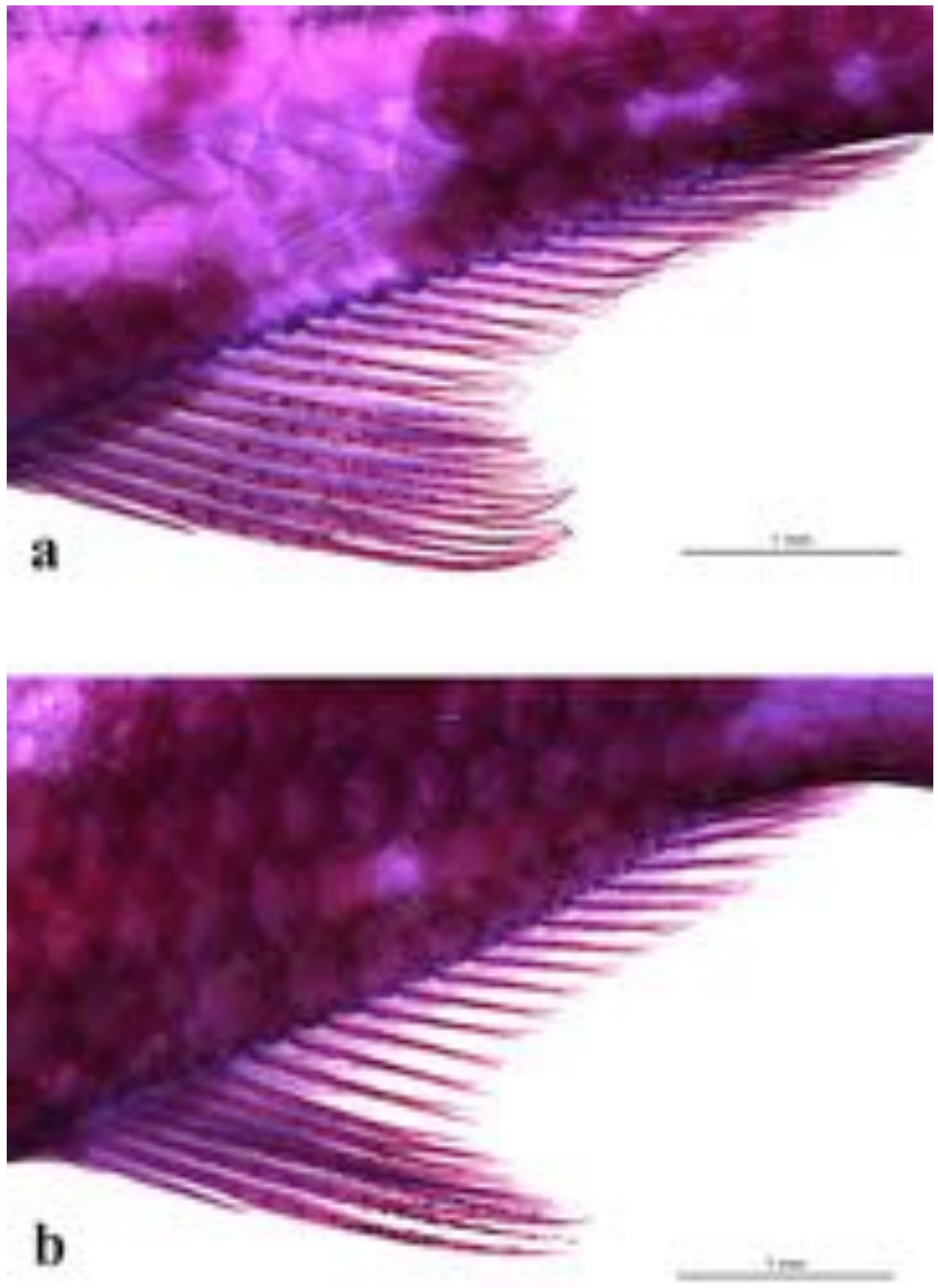

Figura 115. Nadadeira anal de machos (a) e de fêmeas (b) de Odontostilbe pequira em vista lateral esquerda, evidenciando o formato do perfil distal das nadadeiras nos dois sexos e distribuição dos processos ósseos na nadadeira anal de macho. 


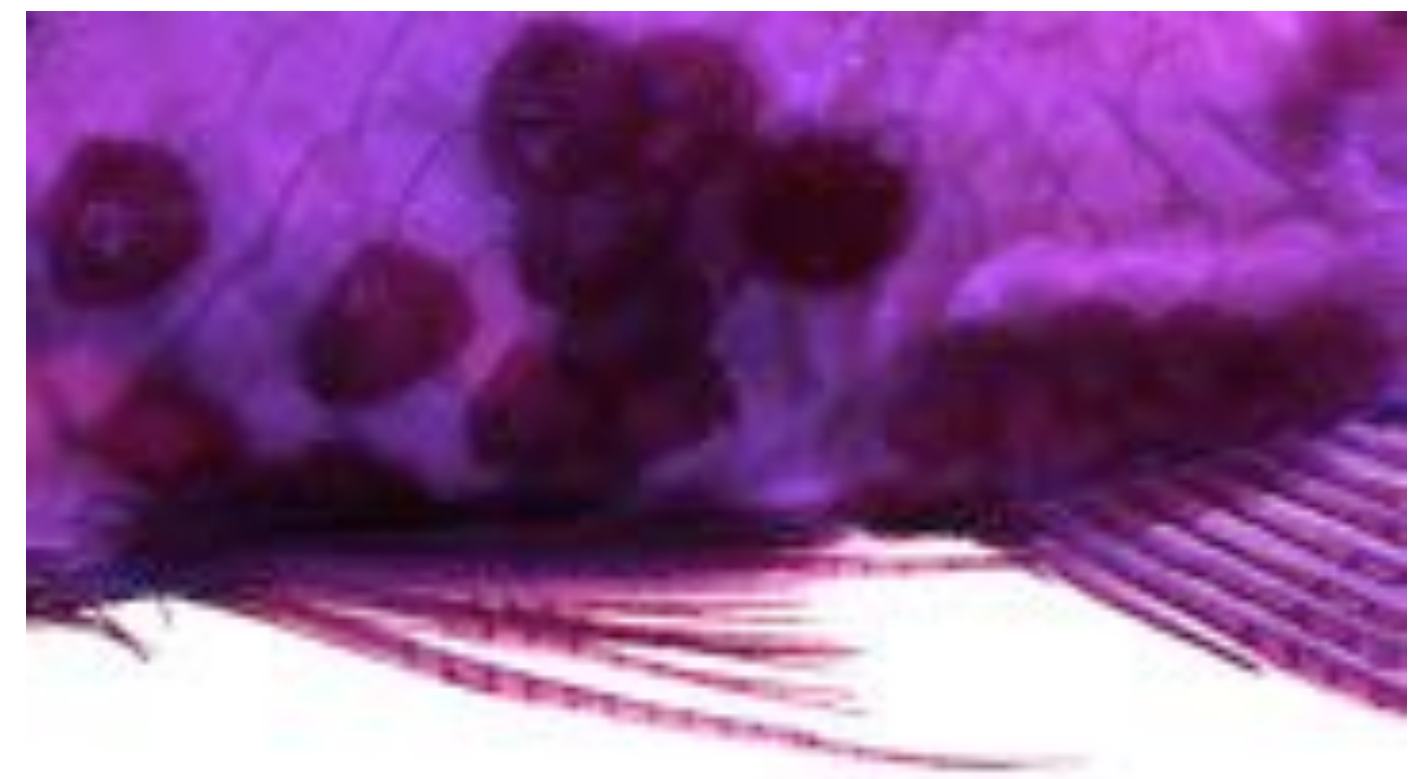

a

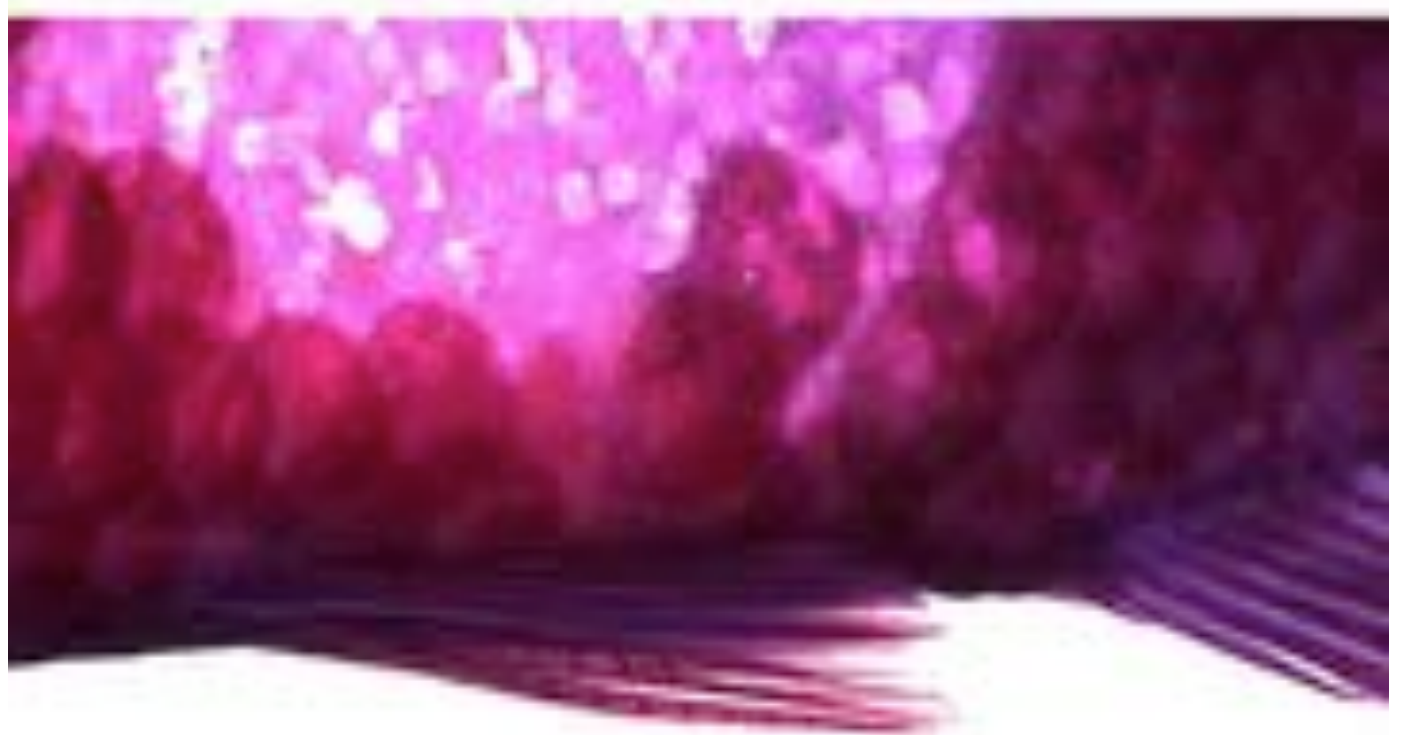

\section{b}

Figura 116. Nadadeira pélvica de machos (a) e de fêmeas (b) de Odontostilbe pequira em vista lateral esquerda, evidenciando o formato e comprimento da nadadeira nos dois sexos. 

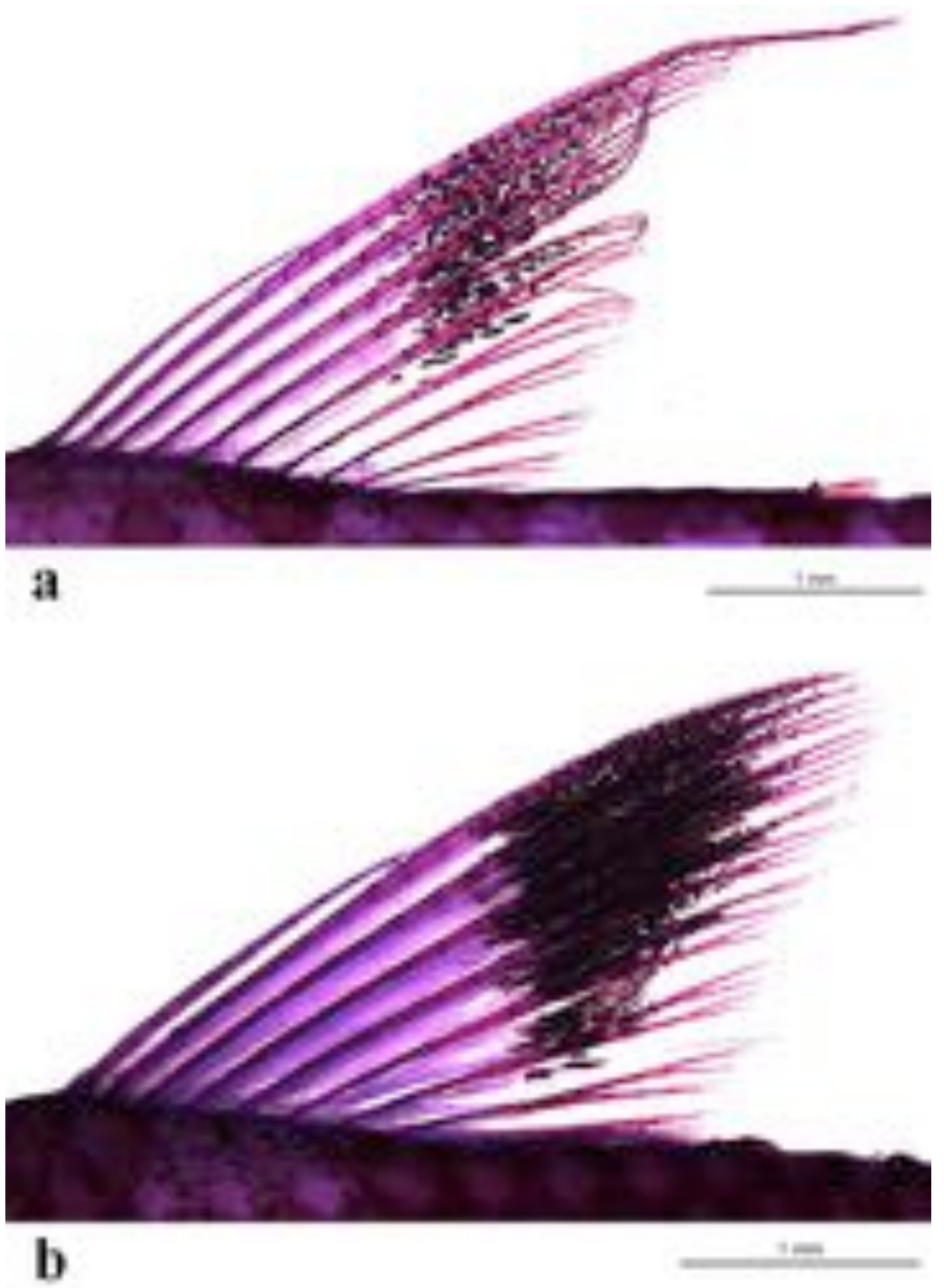

Figura 117. Nadadeira dorsal de machos (a) e de fêmeas (b) de Odontostilbe pequira em vista lateral esquerda, evidenciando o formato e comprimento da nadadeira nos dois sexos. 

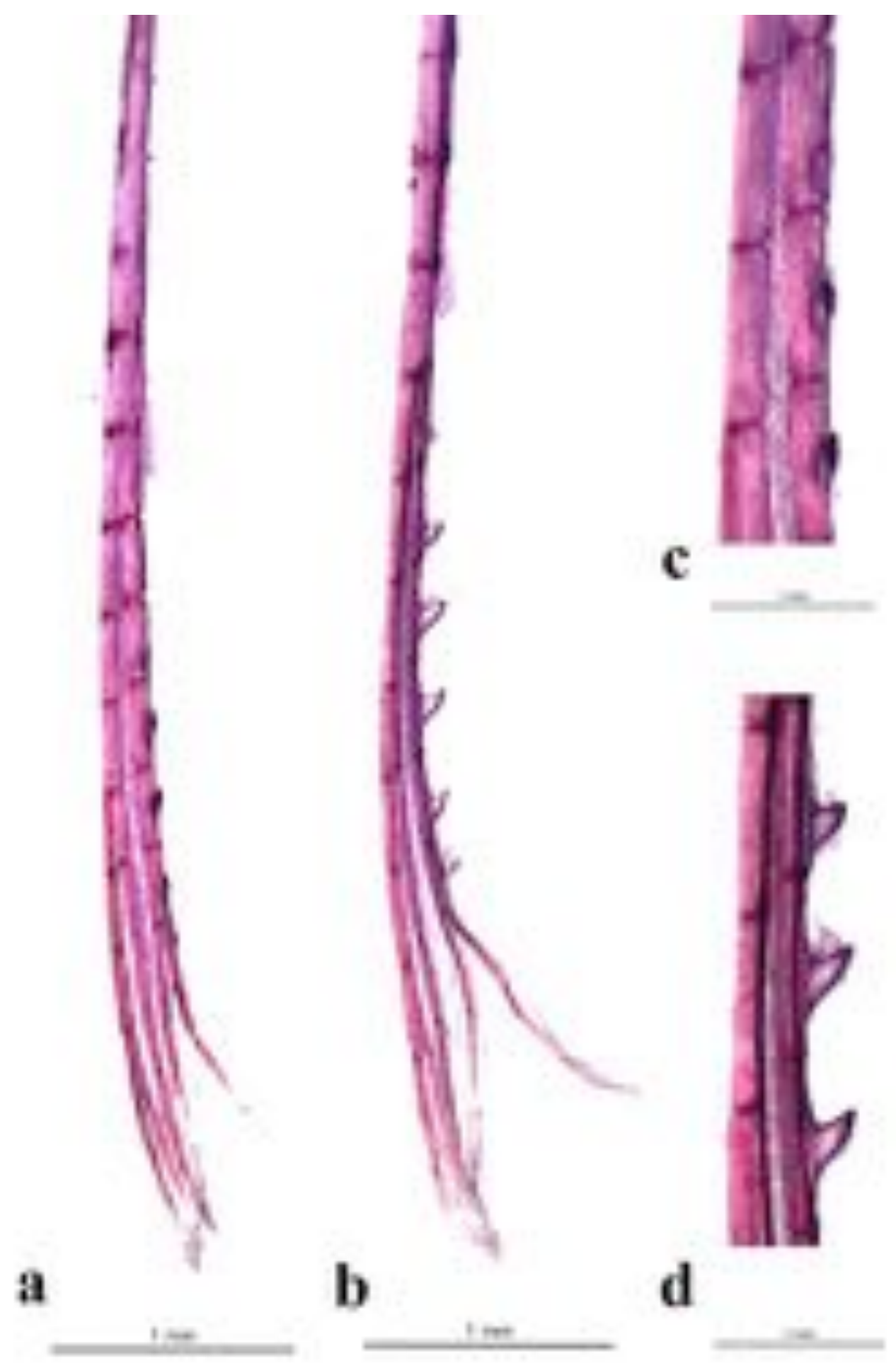

Figura 118. Distribuição, posição e formato dos processos ósseos no hemitriquium esquerdo do raio ramificado da nadadeira anal de machos de Odontostilbe pequira. (a) vista lateral, (b) vista anteroposterior, (c) detalhe em vista lateral, (d) detalhe em vista anteroposterior. 

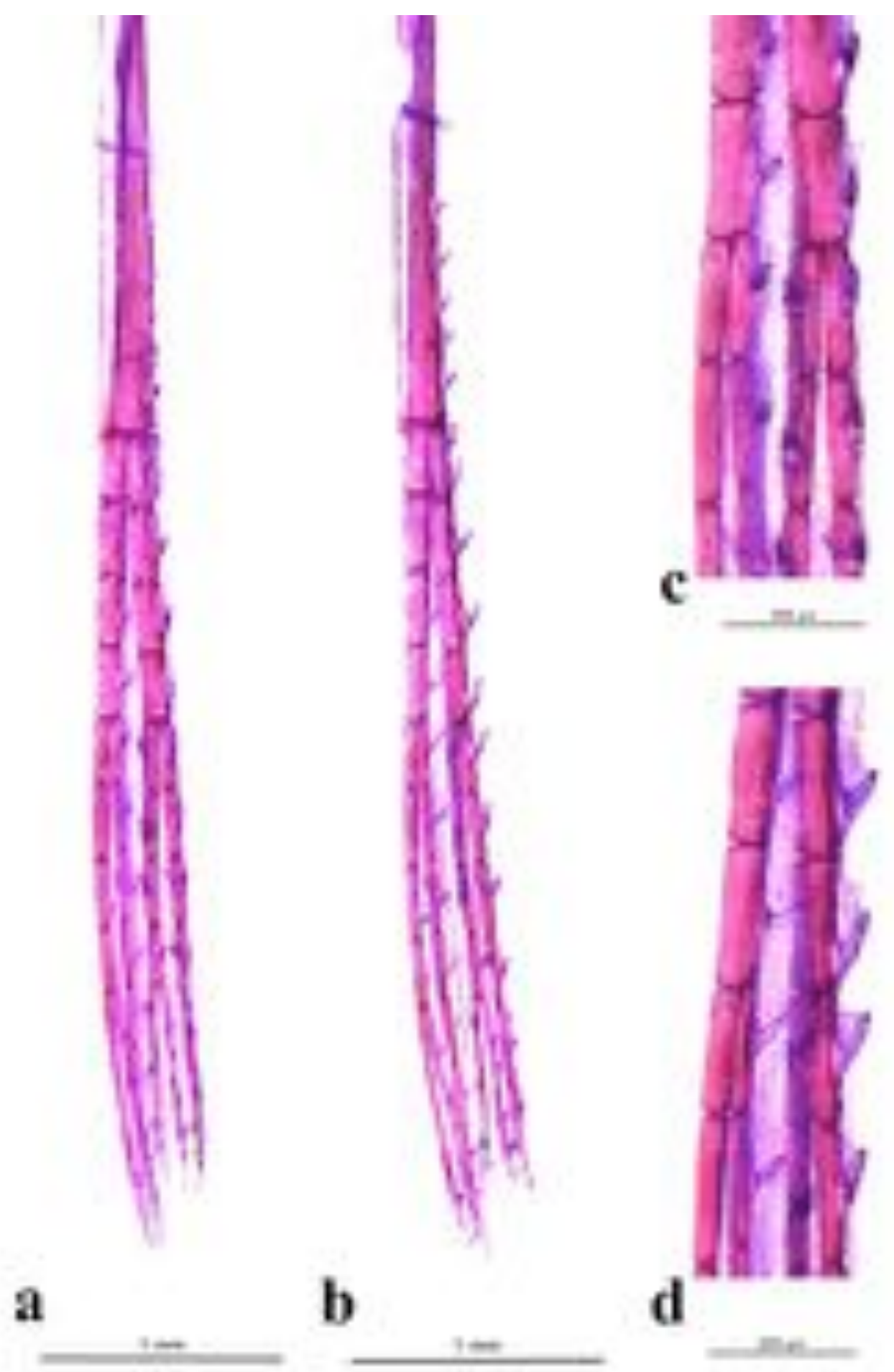

Figura 119. Distribuição, posição e formato dos processos ósseos no hemitriquium ventral da nadadeira pélvica direita de machos de Odontostilbe pequira. (a) vista ventral, (b) vista lateromedial, (c) detalhe em vista ventral e (d) detalhe em vista lateromedial. 

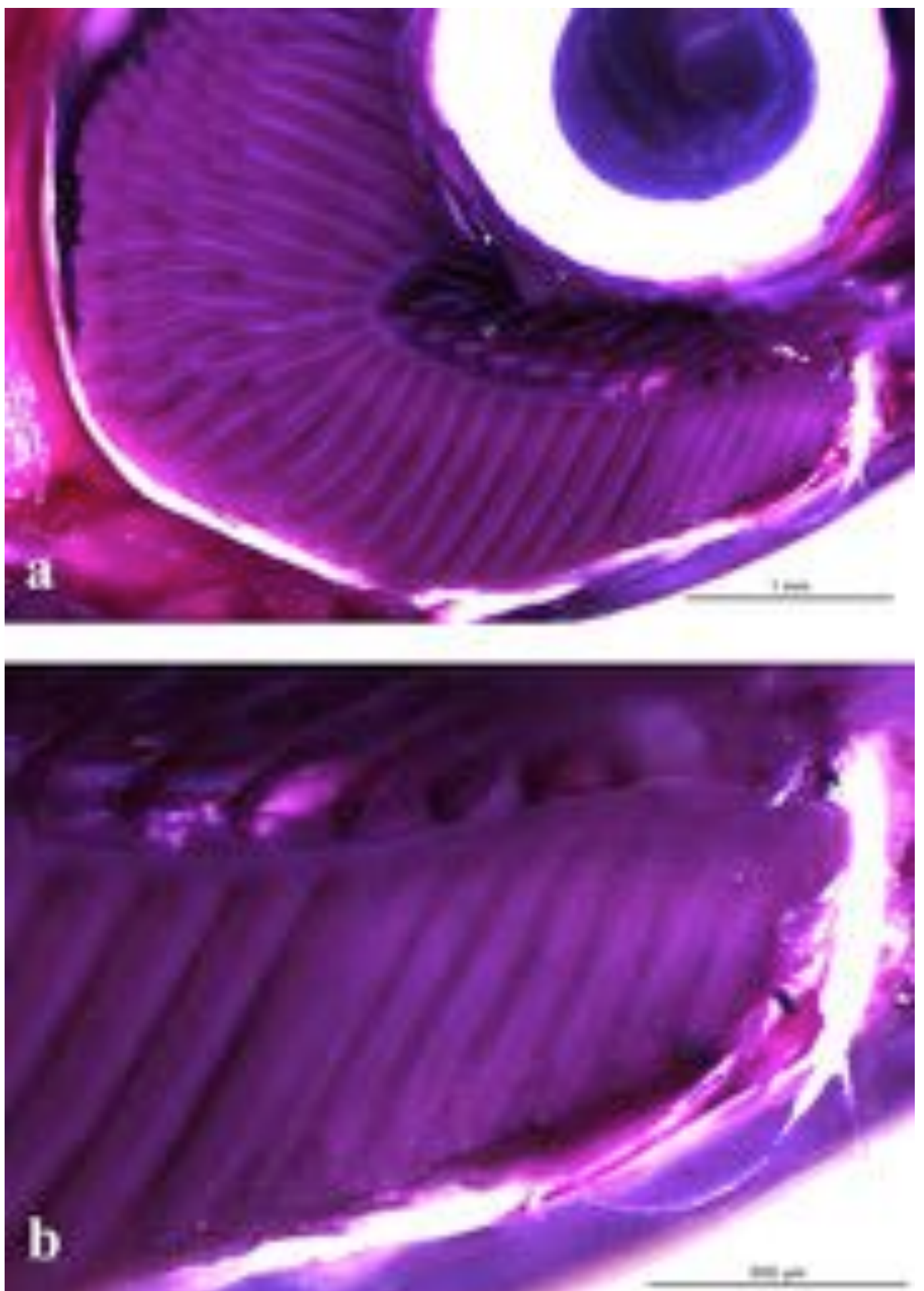

Figura 120. Brânquia com glândula branquial em vista lateral direita (a), detalhe da região anterior do ceratobranquial direito, evidenciando a glândula branquial (b) em de Odontostilbe pequira. 


\section{Serrapinnus calliurus (Boulenger 1900)}
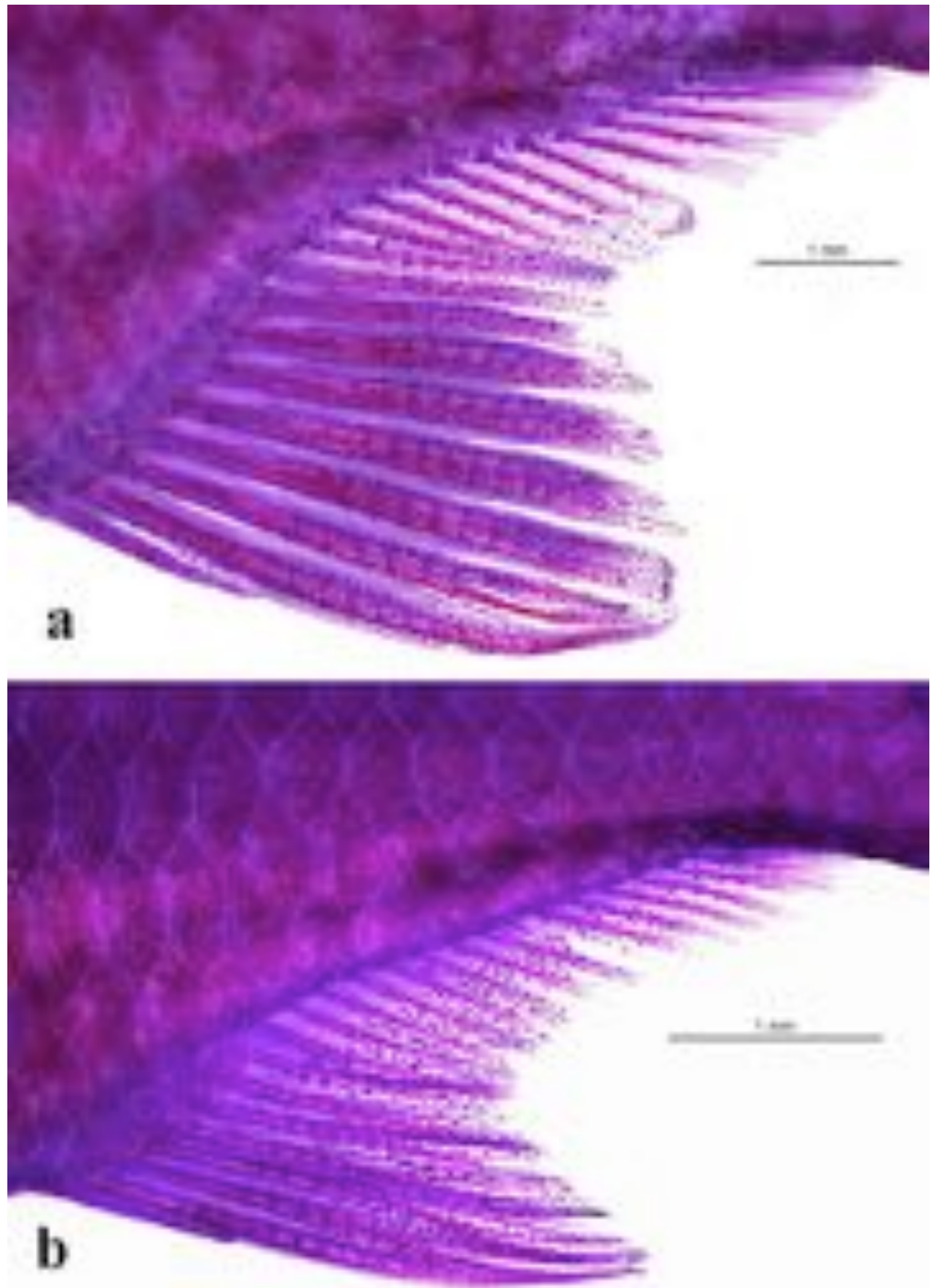

Figura 121. Nadadeira anal de machos (a) e de fêmeas (b) de Serrapinnus calliurus em vista lateral esquerda, evidenciando o formato do perfil distal das nadadeiras nos dois sexos e distribuição dos processos ósseos na nadadeira anal de macho. 

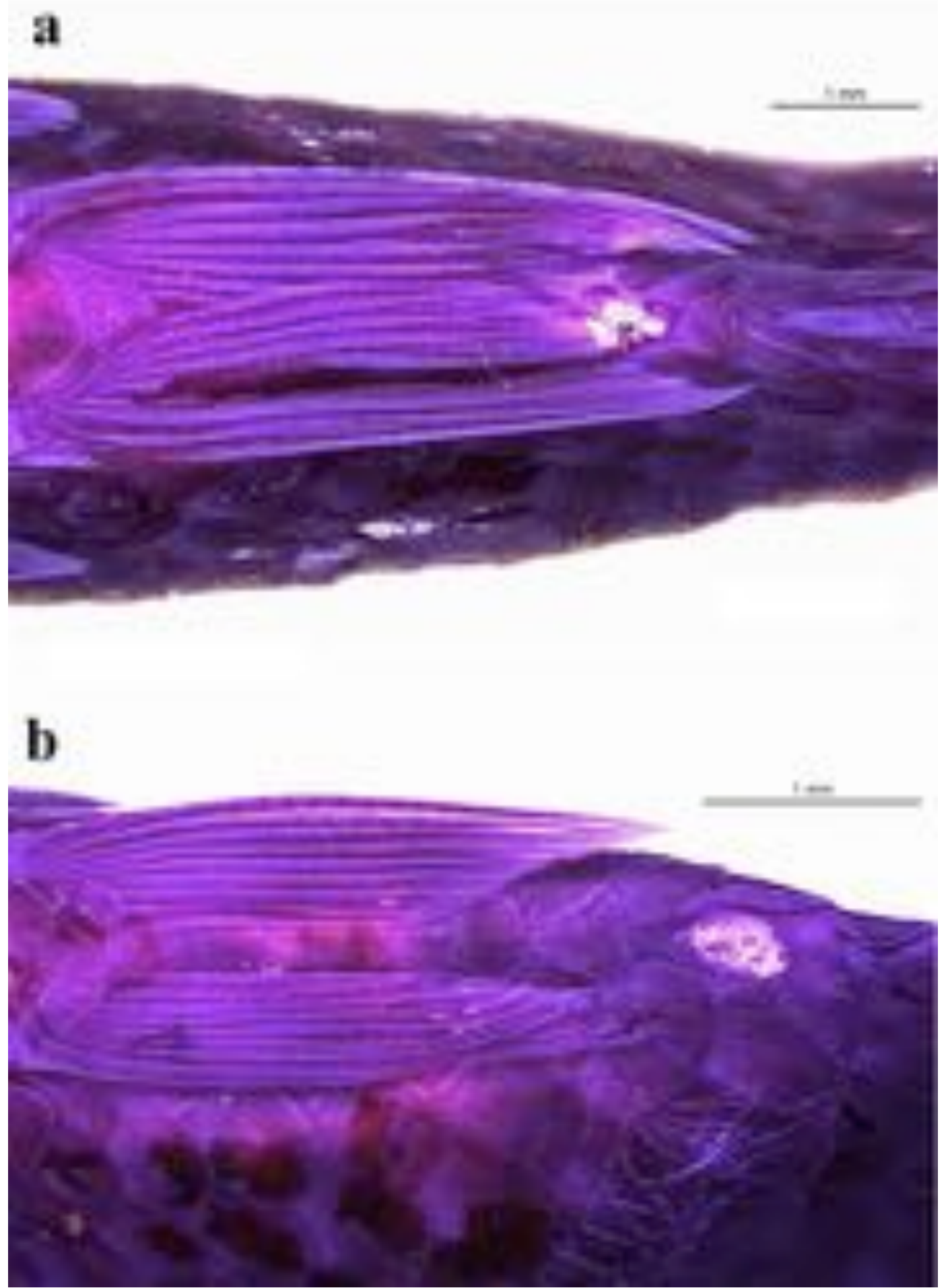

Figura 122. Nadadeira pélvica de machos (a) e de fêmeas (b) de Serrapinnus calliurus em vista lateral ventral, evidenciando o formato e comprimento da nadadeira nos dois sexos. 

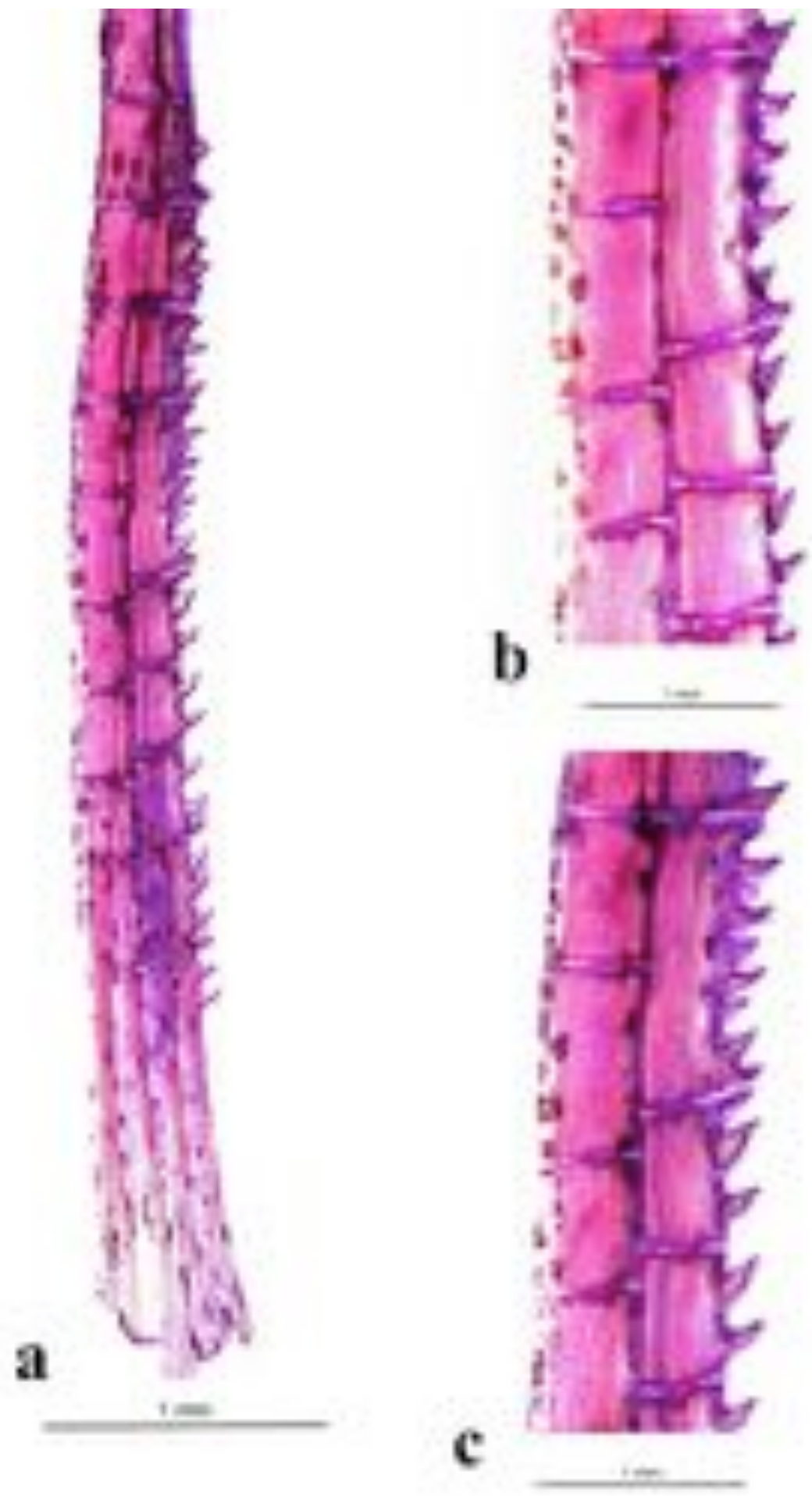

Figura 123. Distribuição, posição e formato dos processos ósseos no hemitriquium esquerdo do raio ramificado da nadadeira anal de machos de Serrapinnus calliurus. (a) vista lateral, (b) detalhe em vista lateral e (c) detalhe em vista anteroposterior. 

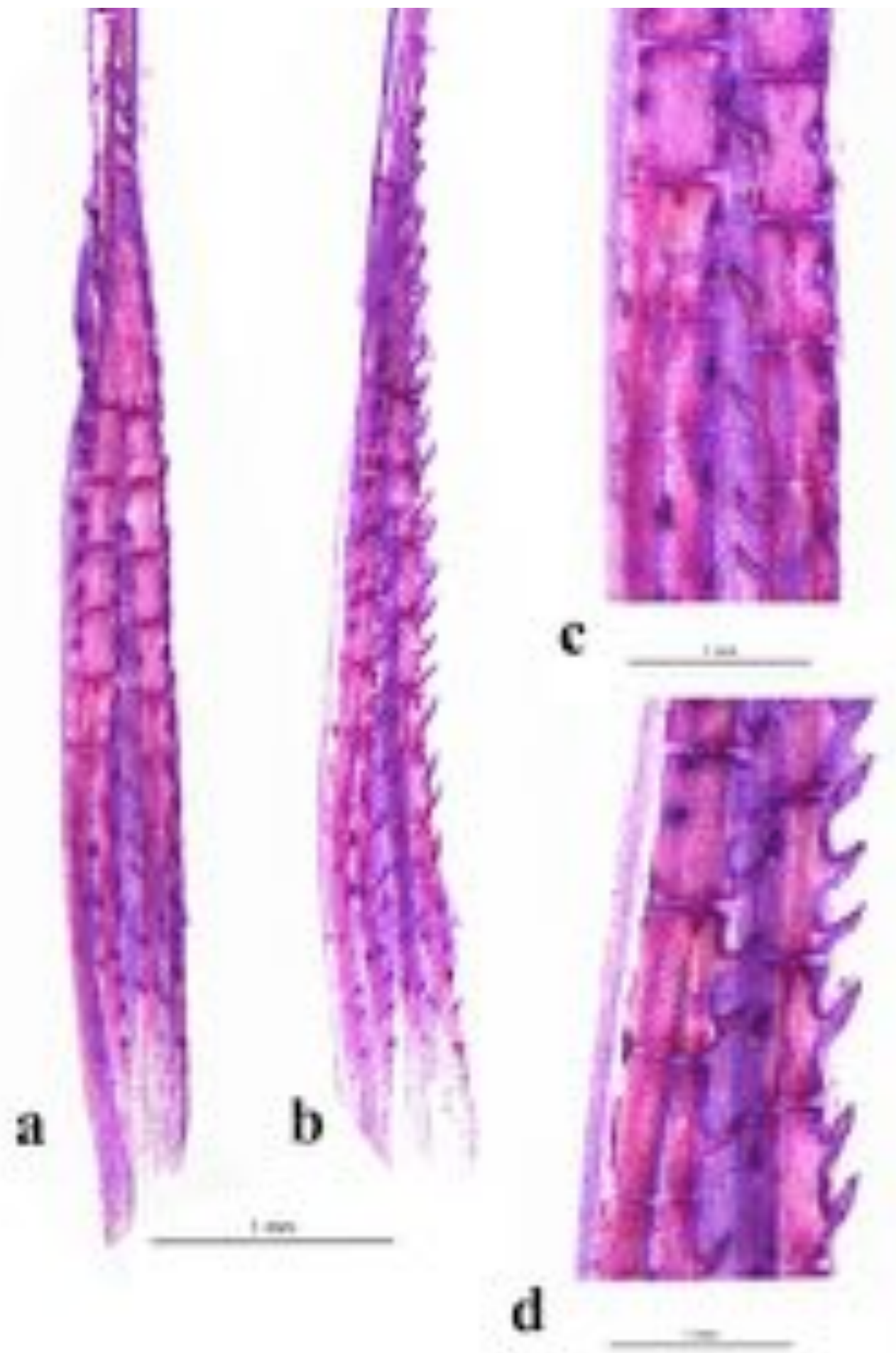

Figura 124. Distribuição, posição e formato dos processos ósseos no hemitriquium ventral da nadadeira pélvica direita de machos de Serrapinnus calliurus. (a) vista ventral, (b) vista lateromedial, (c) detalhe em vista ventral e (d) detalhe em vista lateromedial. 


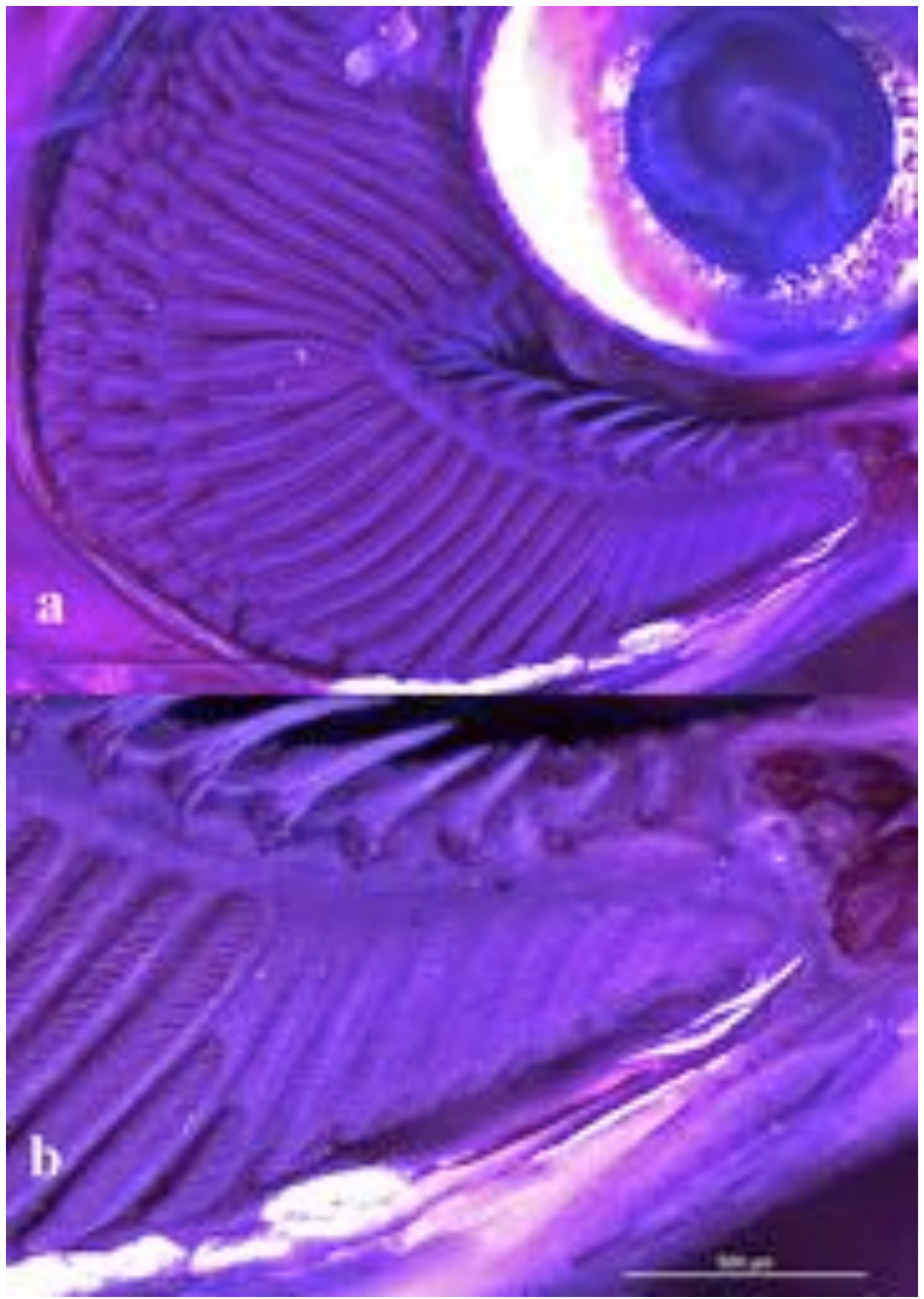

Figura 125. Brânquia com glândula branquial em vista lateral direita (a), detalhe da região anterior do ceratobranquial direito, evidenciando a glândula branquial (b) em Serrapinnus calliurus. 
HETEROCHARACINAE

Heterocharax virgulatus Toledo-Piza 2000
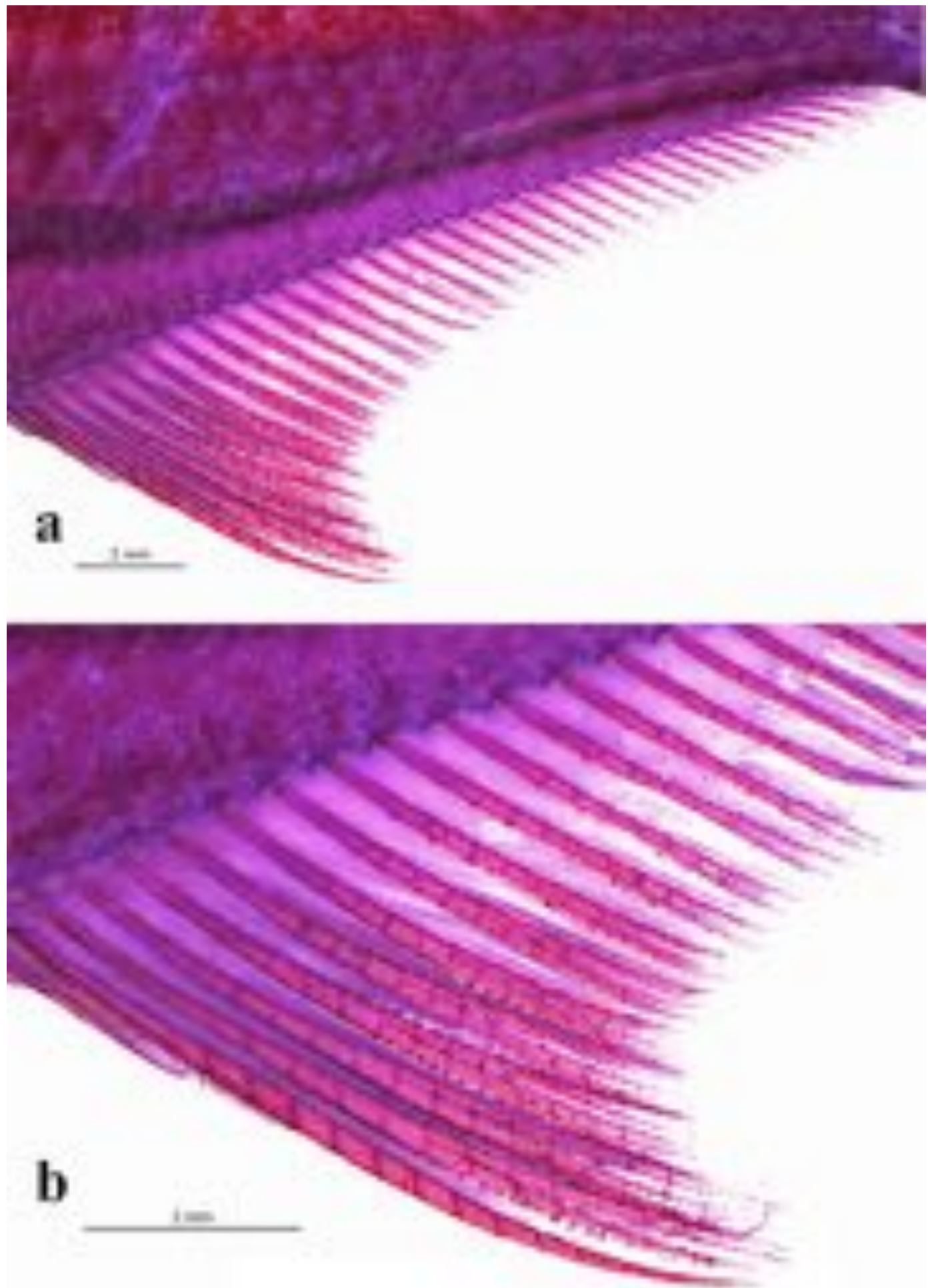

Figura 126. Nadadeira anal de machos de Heterocharax virgulatus (a) e detalhe da porção anterior (b) em vista lateral esquerda, evidenciando o formato do perfil da margem distal da nadadeira e distribuição dos processos ósseos. 

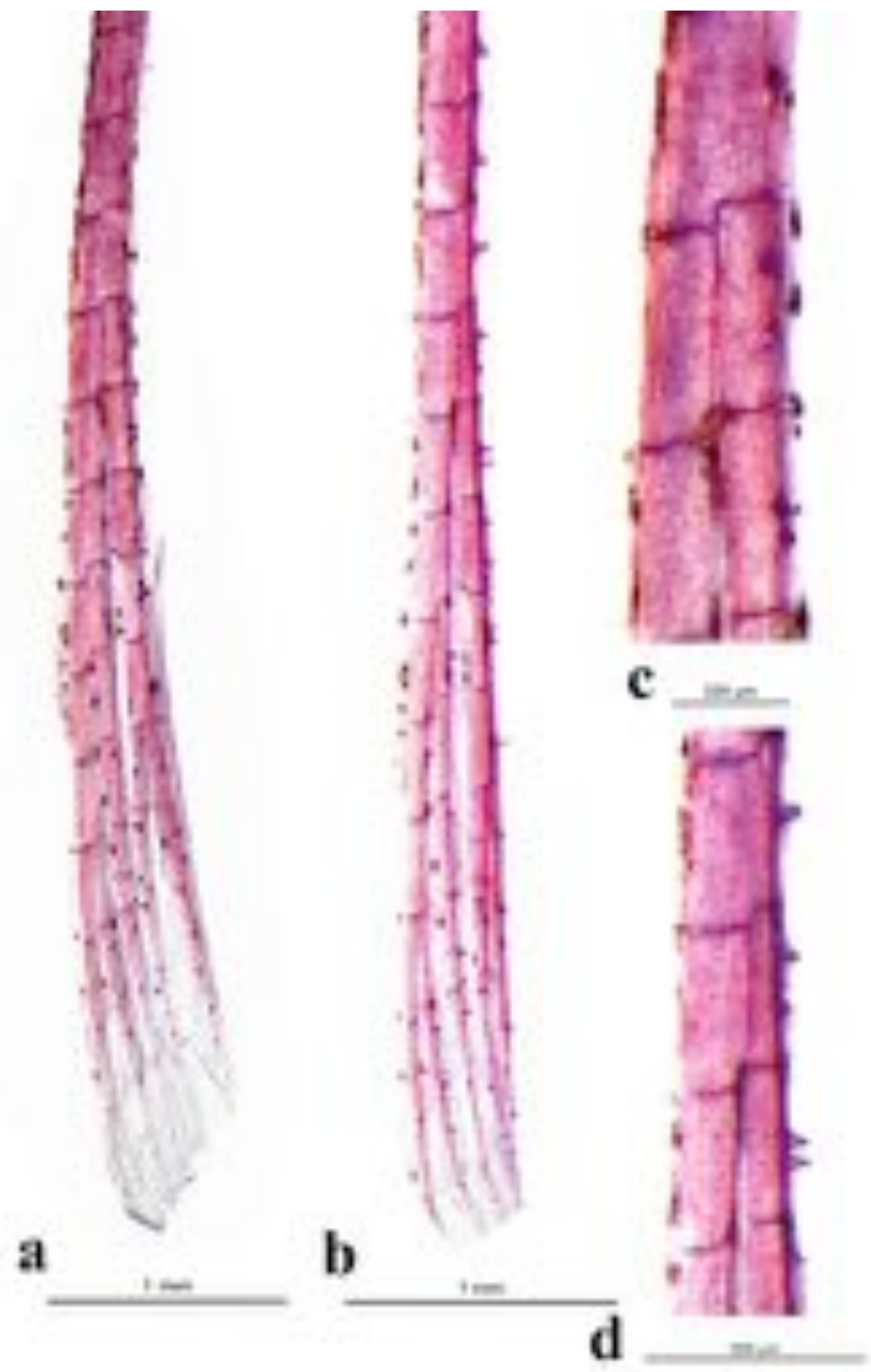

Figura 127. Distribuição, posição e formato dos processos ósseos no hemitriquium esquerdo do raio ramificado da nadadeira anal de machos de Heterocharax virgulatus. (a) vista lateral, (b) vista anteroposterior, (c) detalhe em vista lateral, (d) detalhe em vista anteroposterior. 

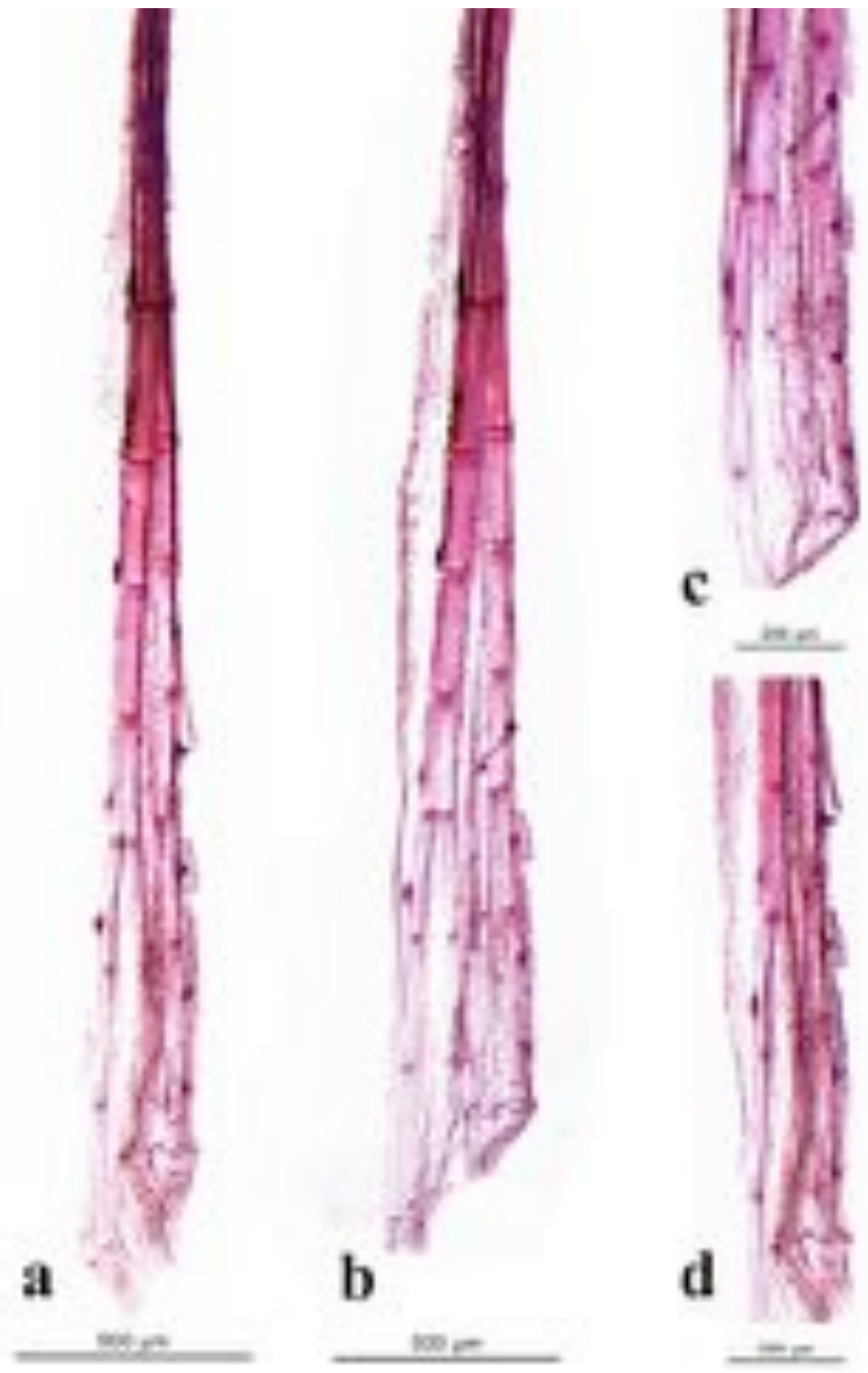

Figura 128. Distribuição, posição e formato dos processos ósseos no hemitriquium ventral da nadadeira pélvica direita de machos de Heterocharax virgulatus. (a) vista ventral, (b) vista lateromedial, (c) detalhe em vista ventral e (d) detalhe em vista lateromedial. 
Hoplocharax goethei Géry 1966

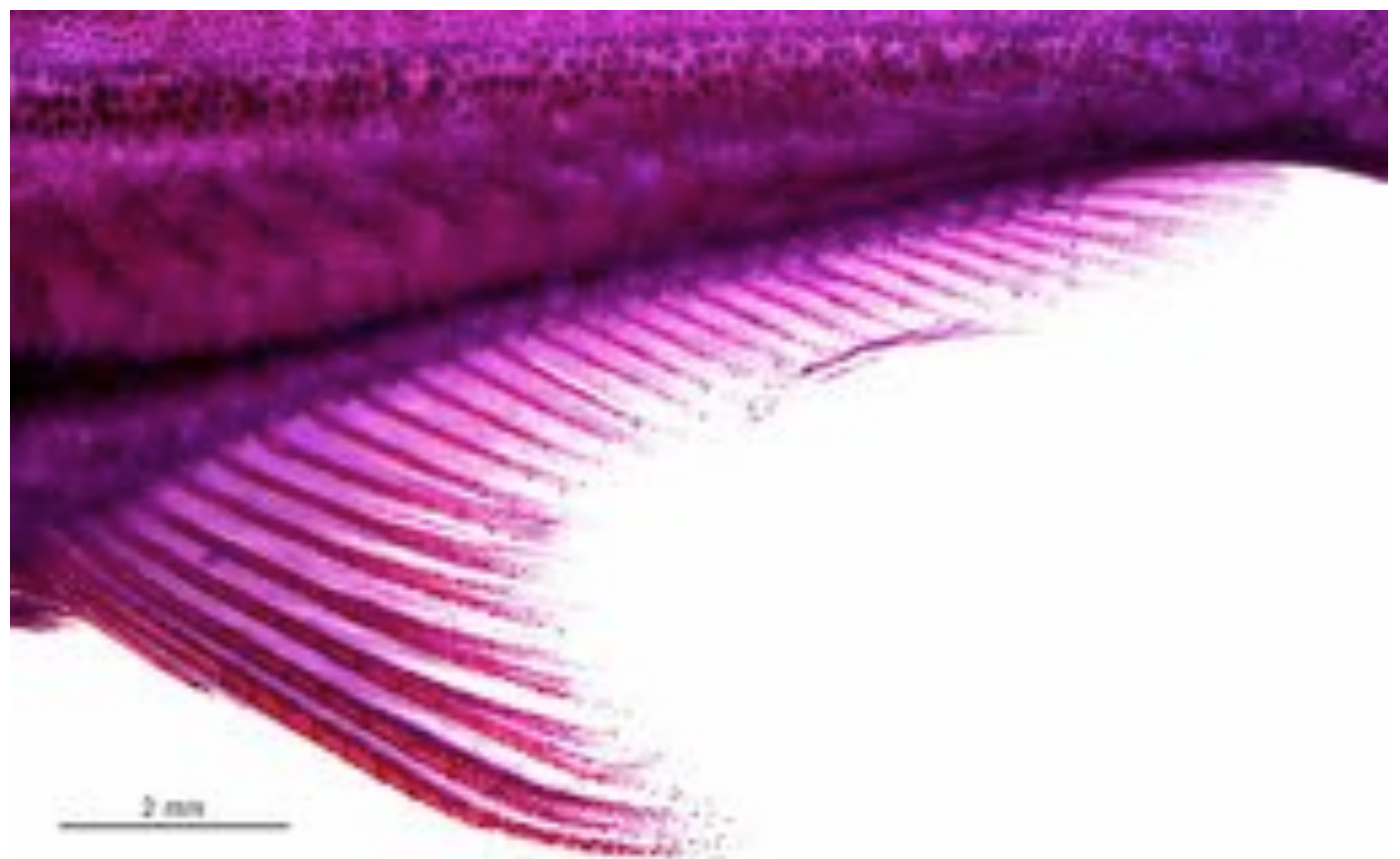

Figura 129. Nadadeira anal de machos de Haplocharax goethei em vista lateral esquerda, evidenciando o formato do perfil da margem distal da nadadeira e distribuição dos processos ósseos. 

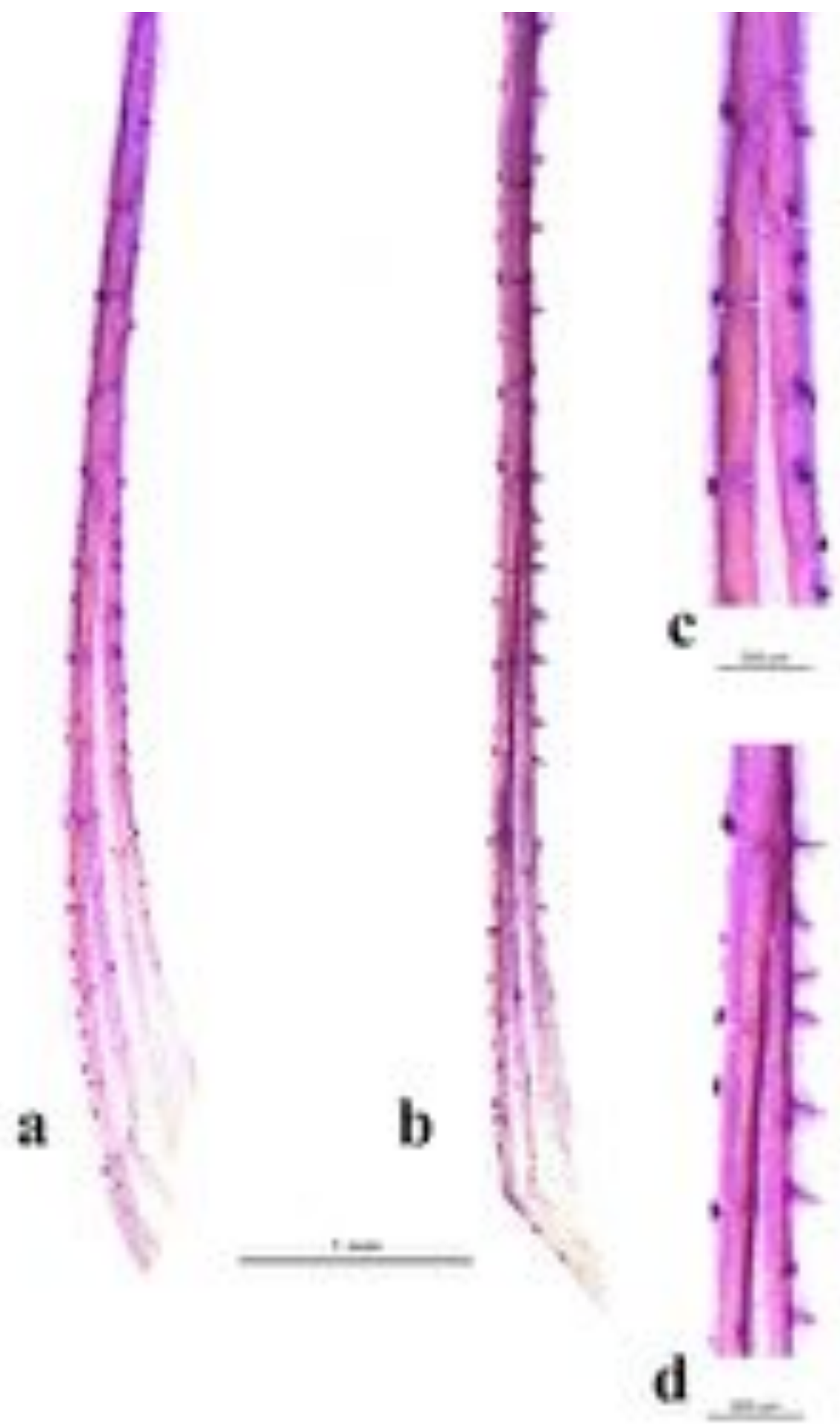

Figura 130. Distribuição, posição e formato dos processos ósseos no hemitriquium esquerdo do raio ramificado da nadadeira anal de machos de Haplocharax goethei. (a) vista lateral, (b) vista anteroposterior, (c) detalhe em vista lateral, (d) detalhe em vista anteroposterior. 

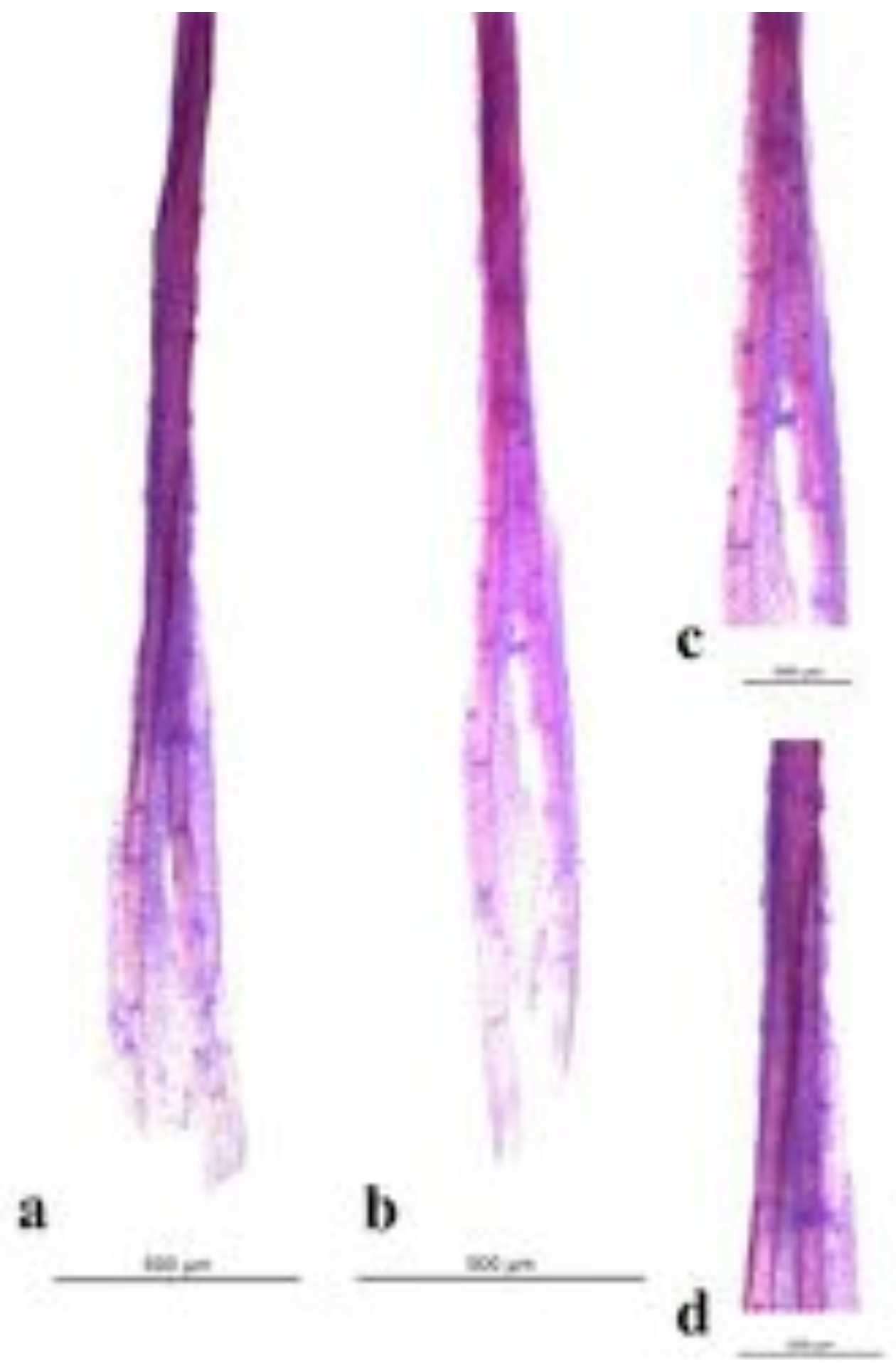

Figura 131. Distribuição, posição e formato dos processos ósseos no hemitriquium ventral da nadadeira pélvica direita de machos de Haplocharax goethei. (a) vista ventral, (b) vista lateromedial, (c) detalhe em vista ventral e (d) detalhe em vista lateromedial. 

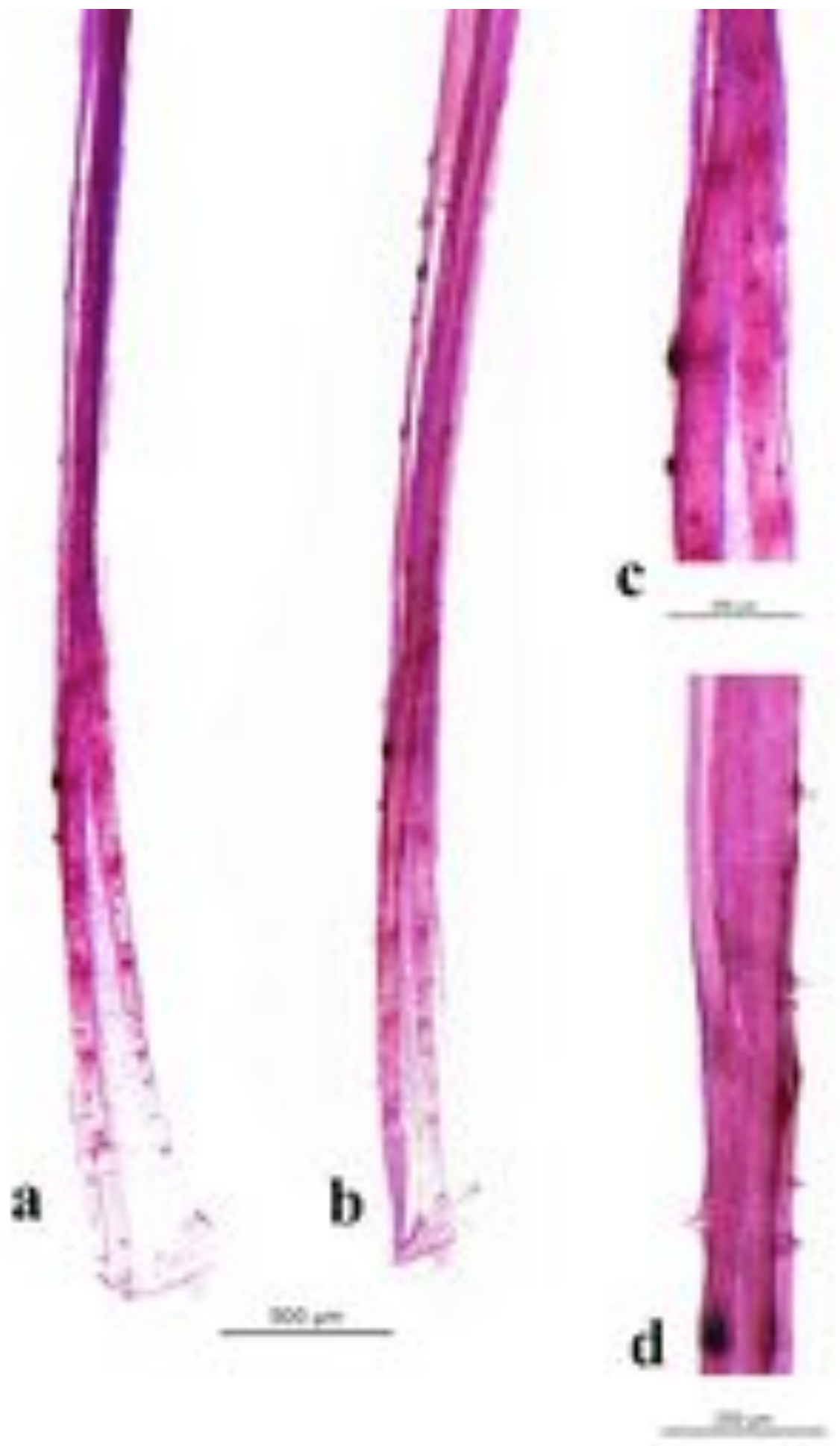

Figura 132. Distribuição, posição e formato dos processos ósseos no hemitriquium ventral da nadadeira peitoral direita de machos de Haplocharax goethei. (a) vista ventral, (b) vista lateromedial, (c) detalhe em vista ventral e (d) detalhe em vista lateromedial. 
CLADO Hyphessobrycon luetkenii

\section{Hyphessobrycon bifasciatus Ellis 1911}
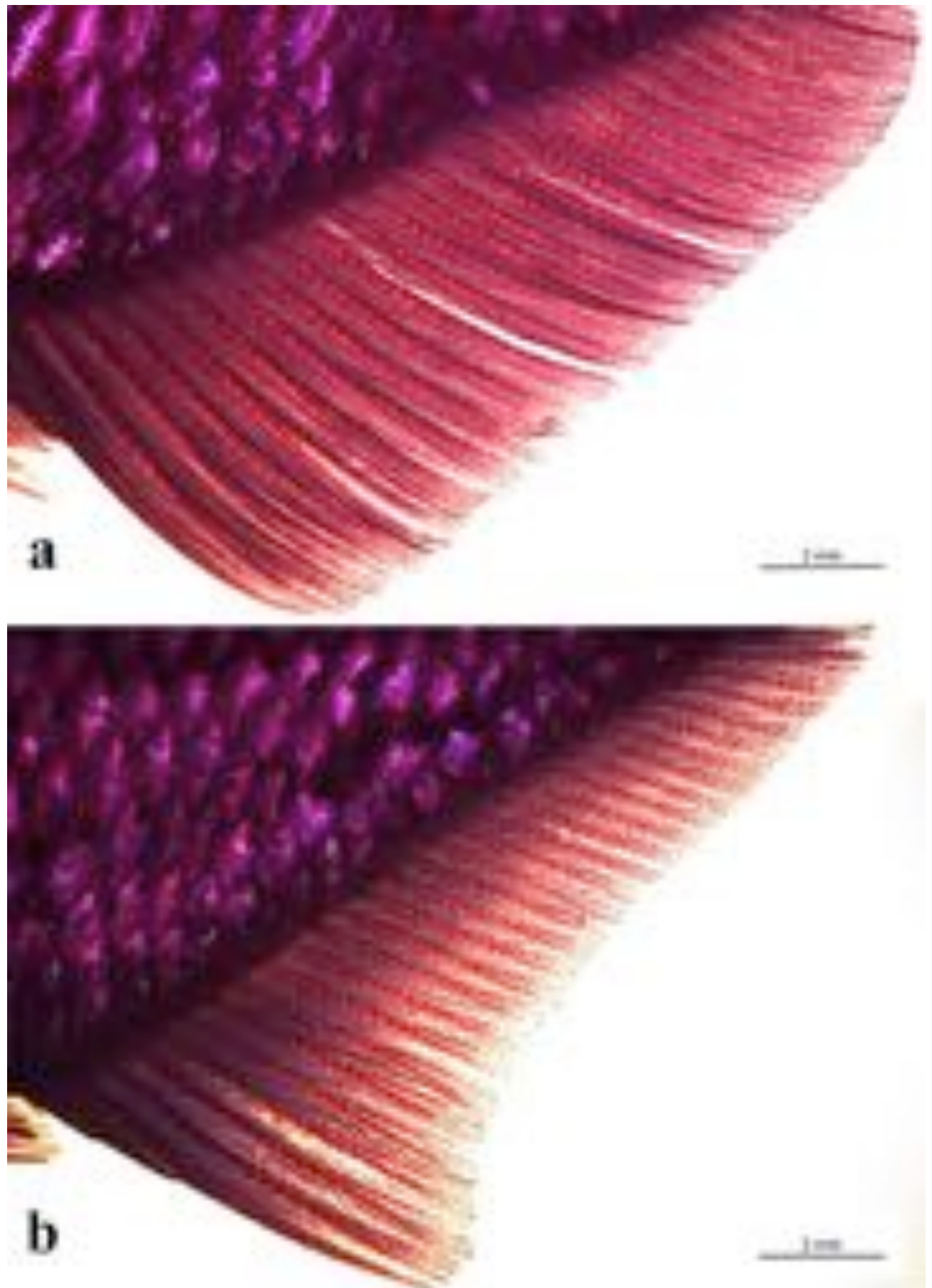

Figura 133. Nadadeira anal de machos (a) e de fêmeas (b) de Hyphessobrycon bifasciatus em vista lateral esquerda, evidenciando o formato do perfil distal das nadadeiras nos dois sexos e distribuição dos processos ósseos na nadadeira anal de macho. 

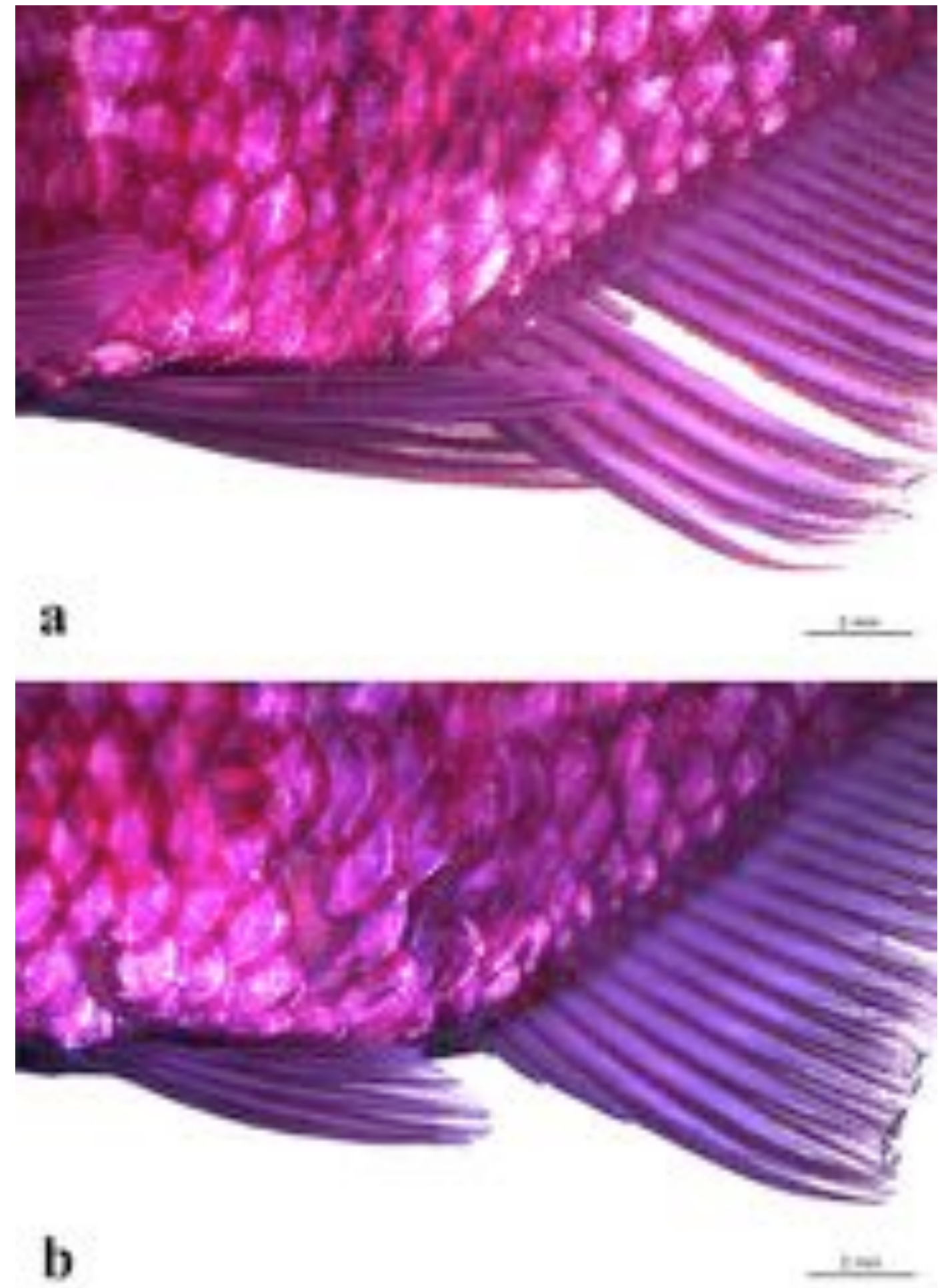

Figura 134. Nadadeira pélvica de machos (a) e de fêmeas (b) de Hyphessobrycon bifasciatus em vista lateral esquerda, evidenciando o formato e comprimento da nadadeira nos dois sexos. 


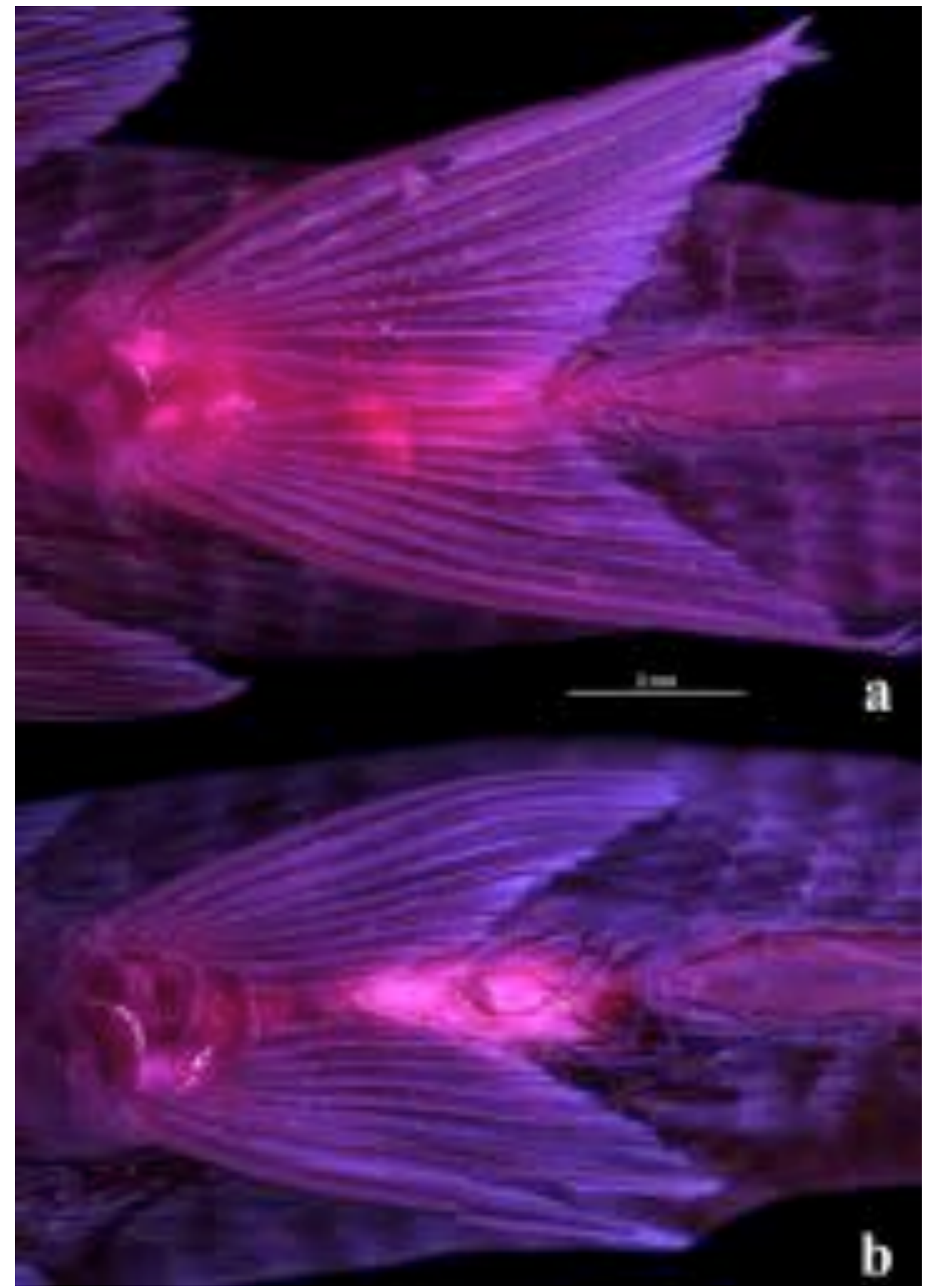

Figura 135. Nadadeira pélvica de machos (a) e de fêmeas (b) de Hyphessobrycon bifasciatus em vista lateral ventral, evidenciando o formato e comprimento da nadadeira nos dois sexos. 


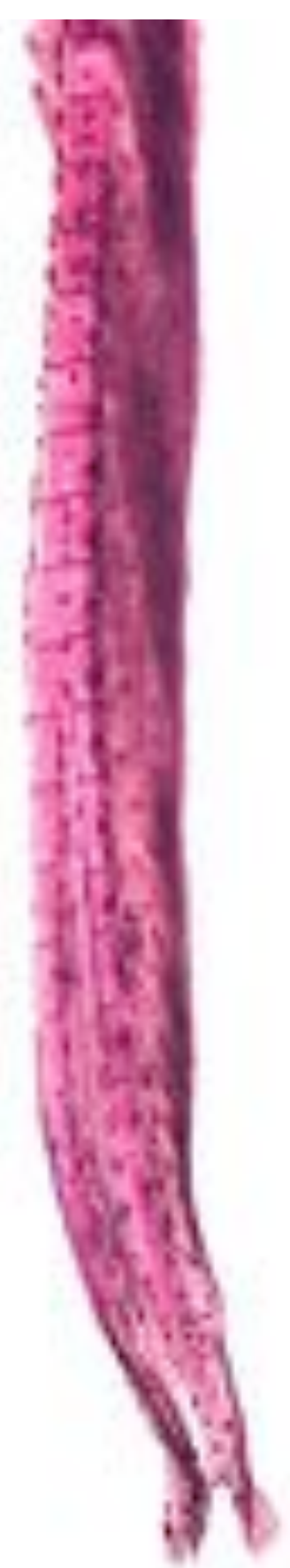

a

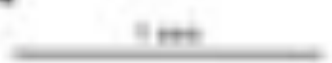

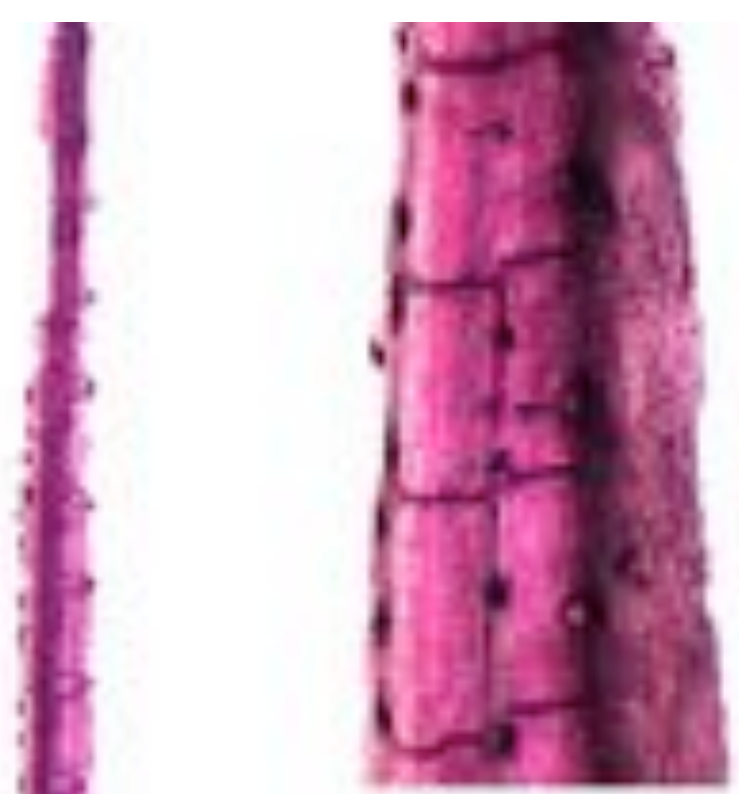

E
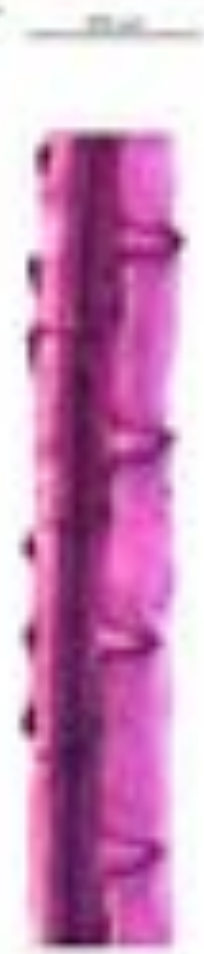

b

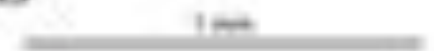

d

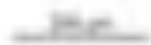

Figura 136. Distribuição, posição e formato dos processos ósseos no hemitriquium esquerdo do raio ramificado da nadadeira anal de machos de Hyphessobrycon bifasciatus. (a) vista lateral, (b) vista anteroposterior, (c) detalhe em vista lateral, (d) detalhe em vista anteroposterior. 


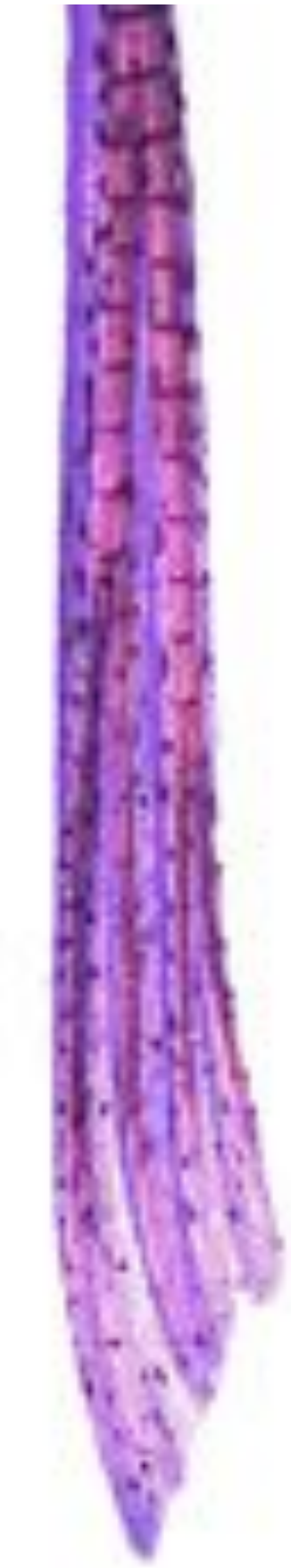

a

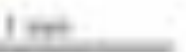

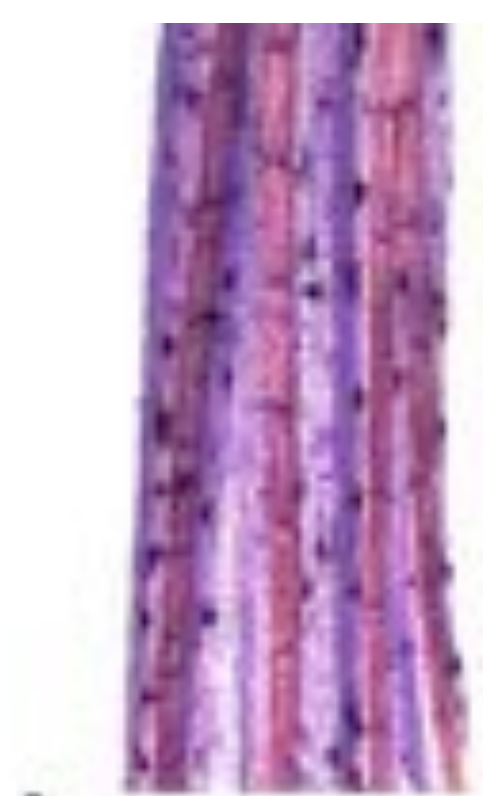

b
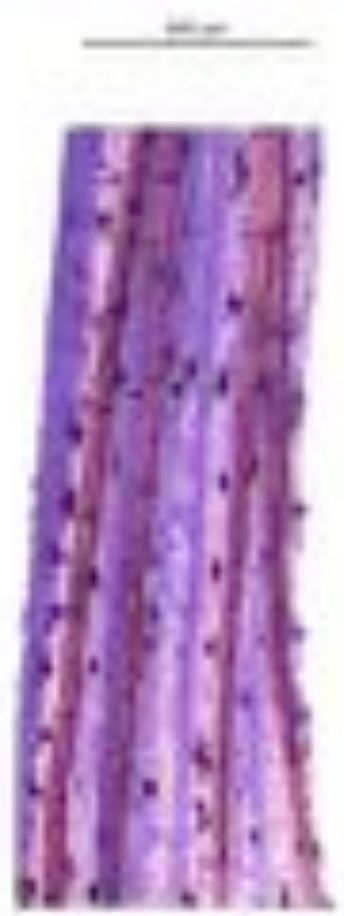

$\mathrm{c}$

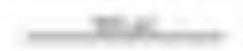

Figura 137. Distribuição, posição e formato dos processos ósseos no hemitriquium ventral da nadadeira pélvica direita de machos de Hyphessobrycon bifasciatus. (a) vista ventral, (b) detalhe em vista ventral e (c) detalhe em vista lateromedial. 


\section{Hyphessobrycon luetkenii (Boulenger 1887)}

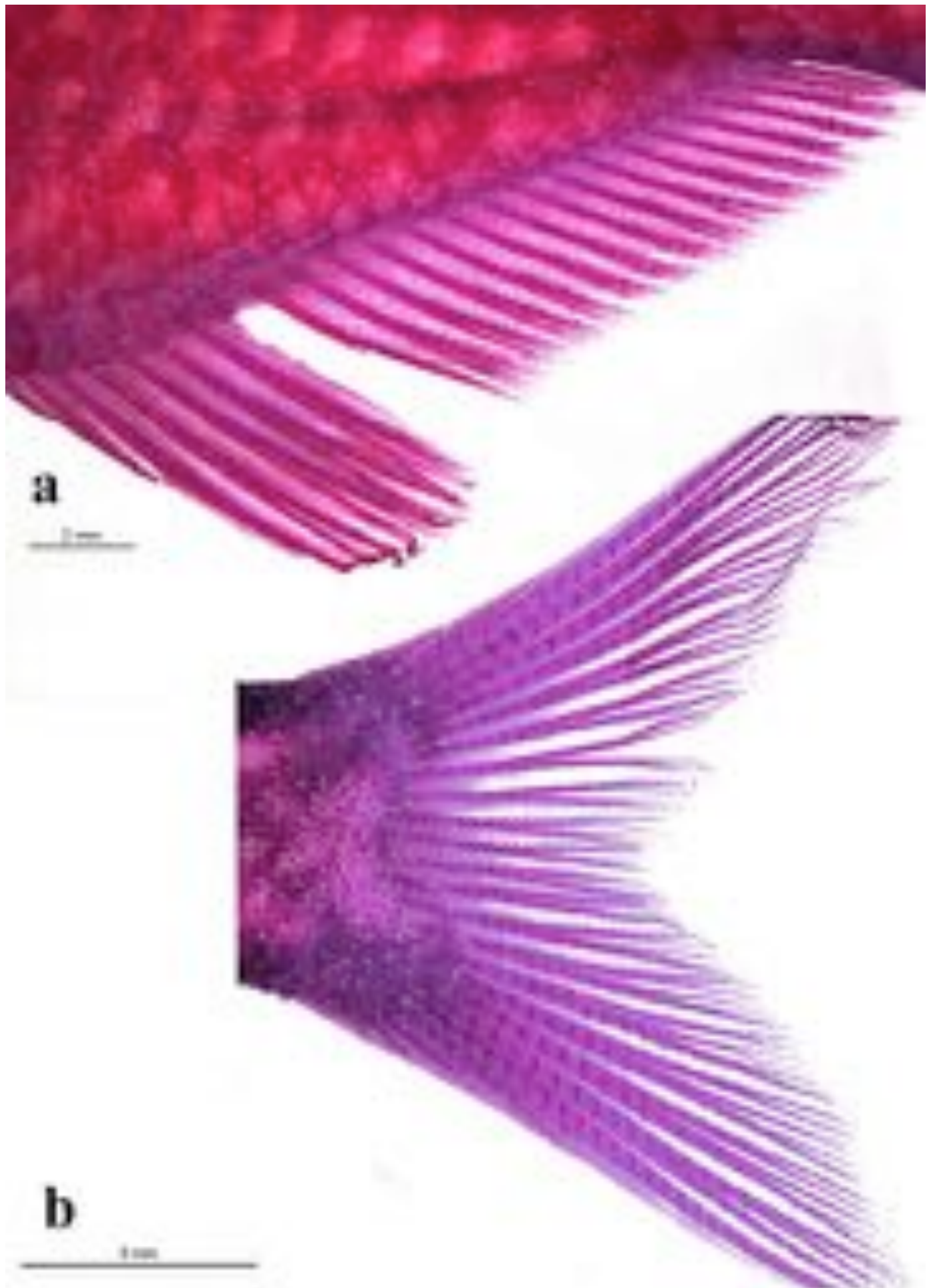

Figura 138. Nadadeira anal (a) e caudal (b) de machos de Hyphessobrycon luetkenii em vista lateral esquerda, evidenciando o formato e distribuição dos processos ósseos nas nadadeiras e presença de tubérculos reprodutivos nas escamas. 

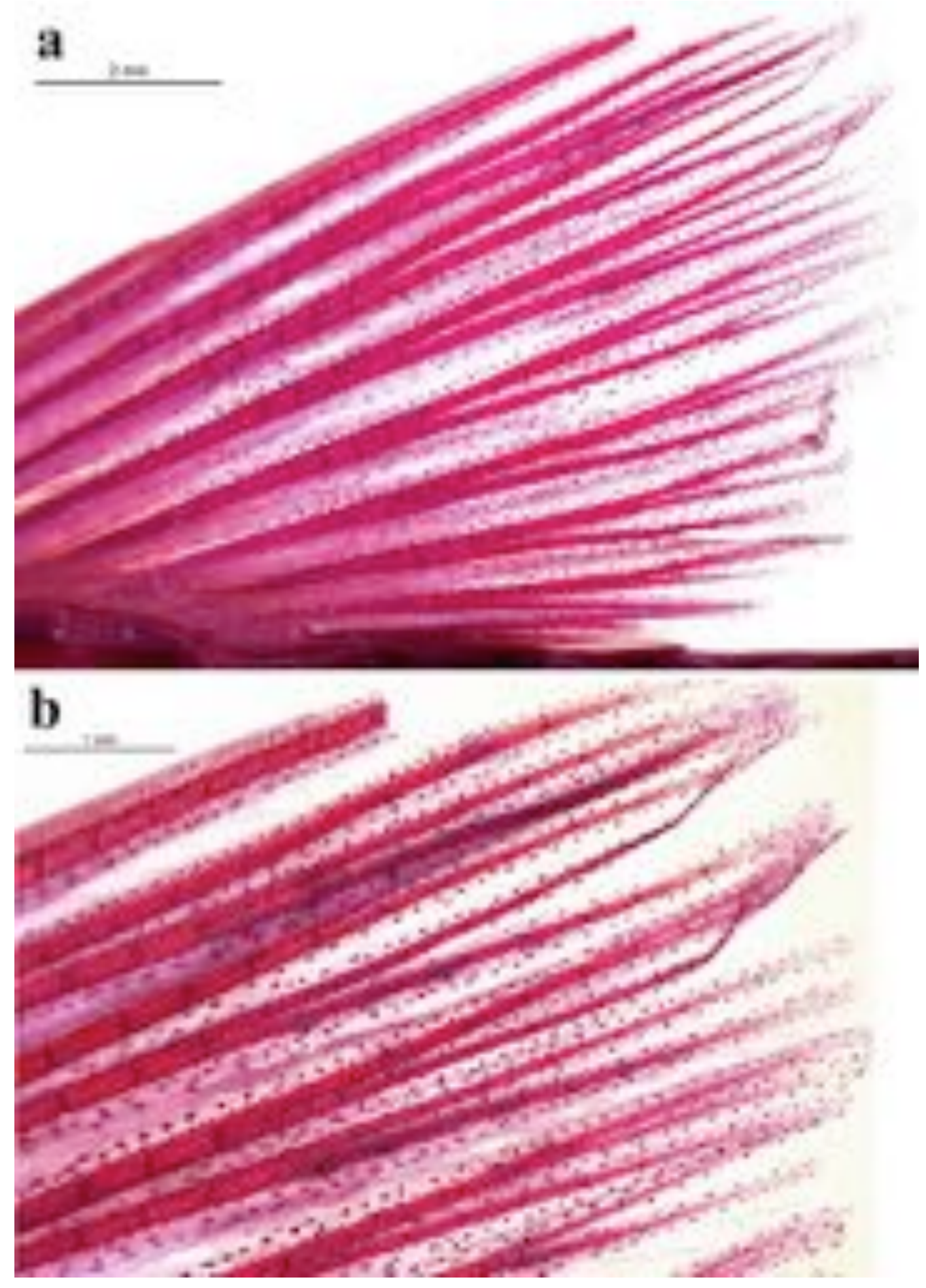

Figura 139. Nadadeira dorsal de machos de Hyphessobrycon luetkenii em vista lateral esquerda. (a) formato da nadadeira e (b) detalhe dos raios com processos ósseos. 


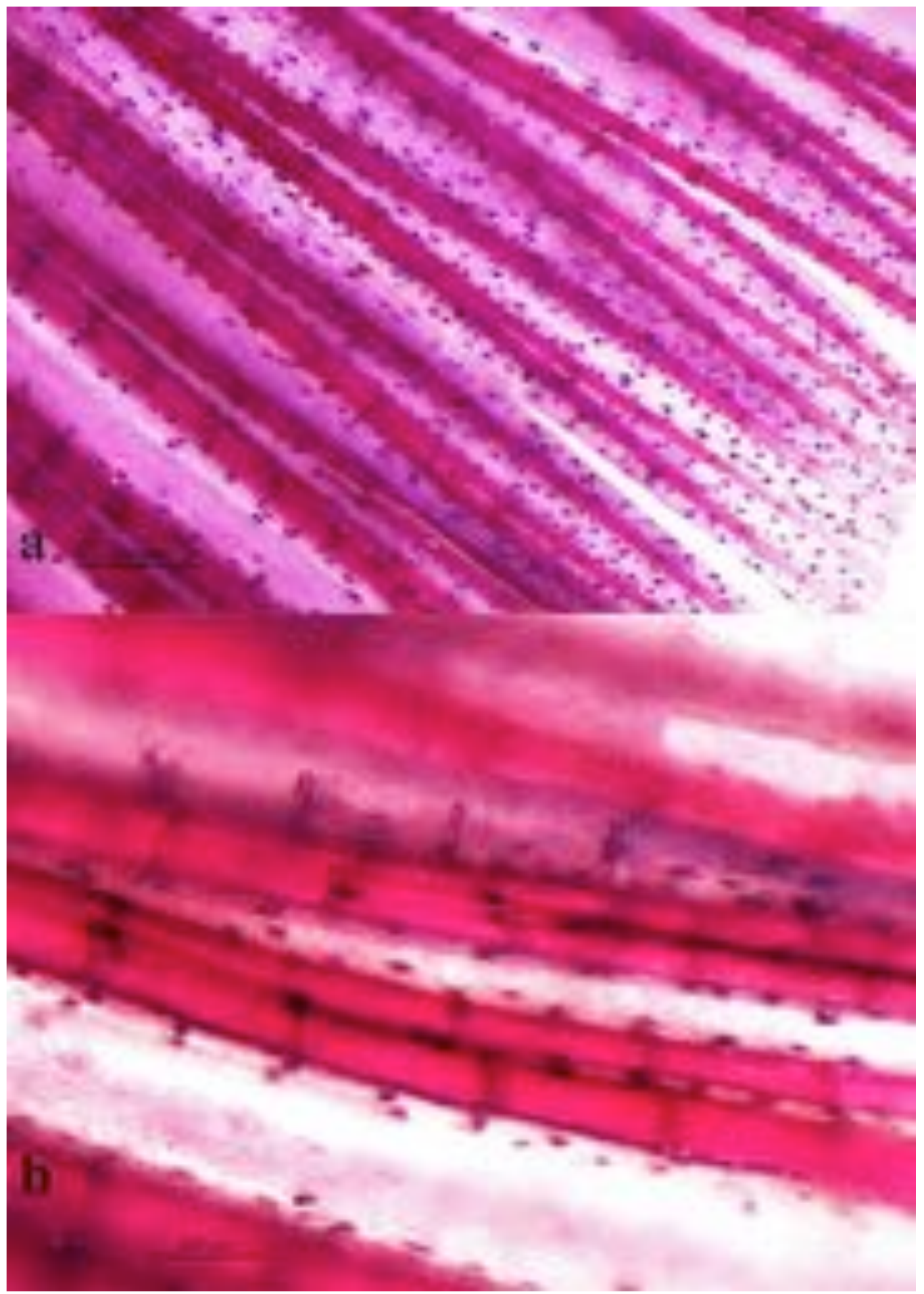

Figura 140. Detalhe dos raios da nadadeira caudal de machos de Hyphessobrycon luetkenii em vista lateral esquerda (a) e detalhe dos processos ósseos em vista mediolateral (b). 


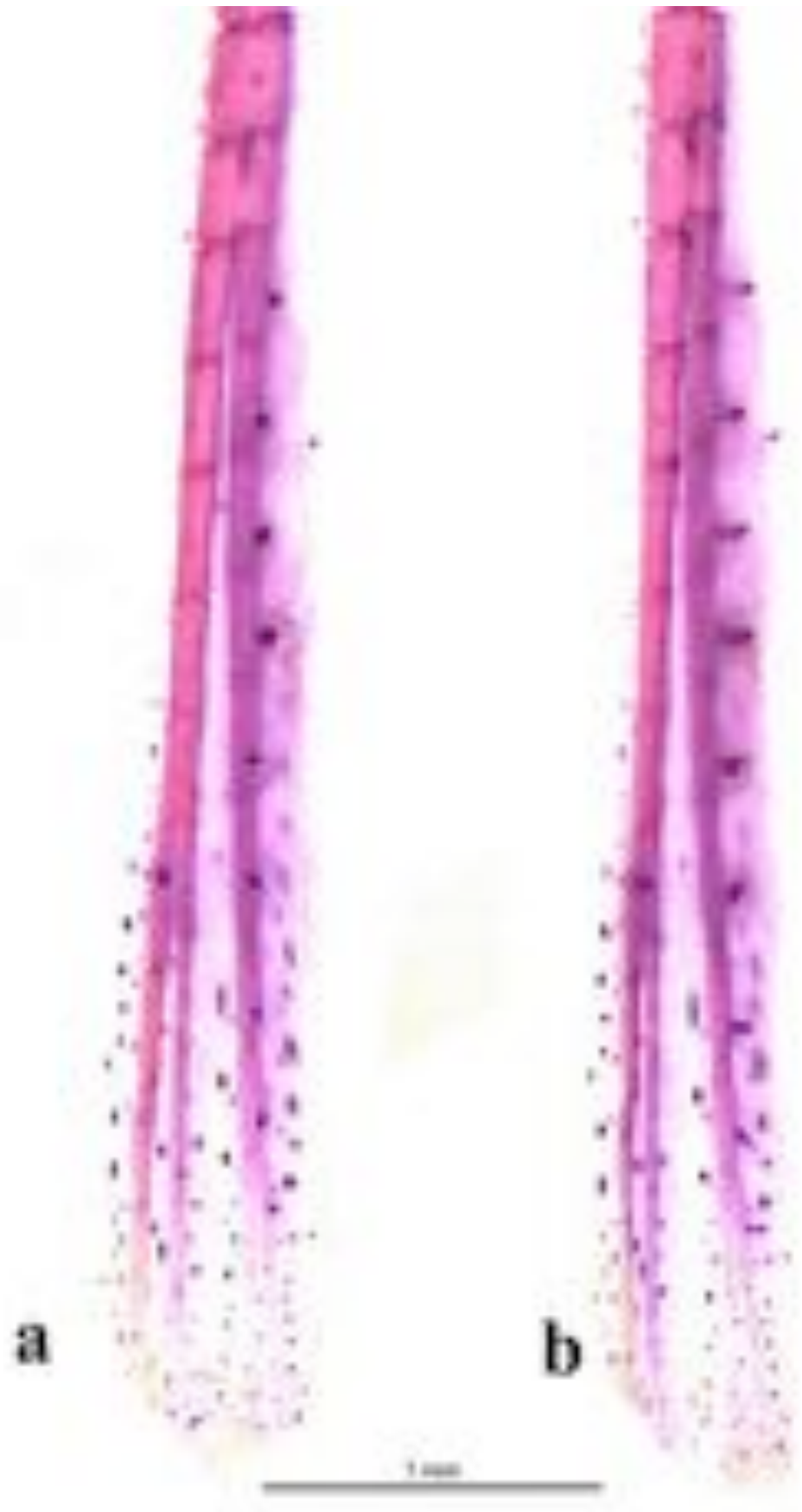

Figura 141. Distribuição, posição e formato dos processos ósseos no hemitriquium esquerdo do raio ramificado da nadadeira anal de machos de Hyphessobrycon luetkenii. (a) vista lateral e (b) vista anteroposterior. 

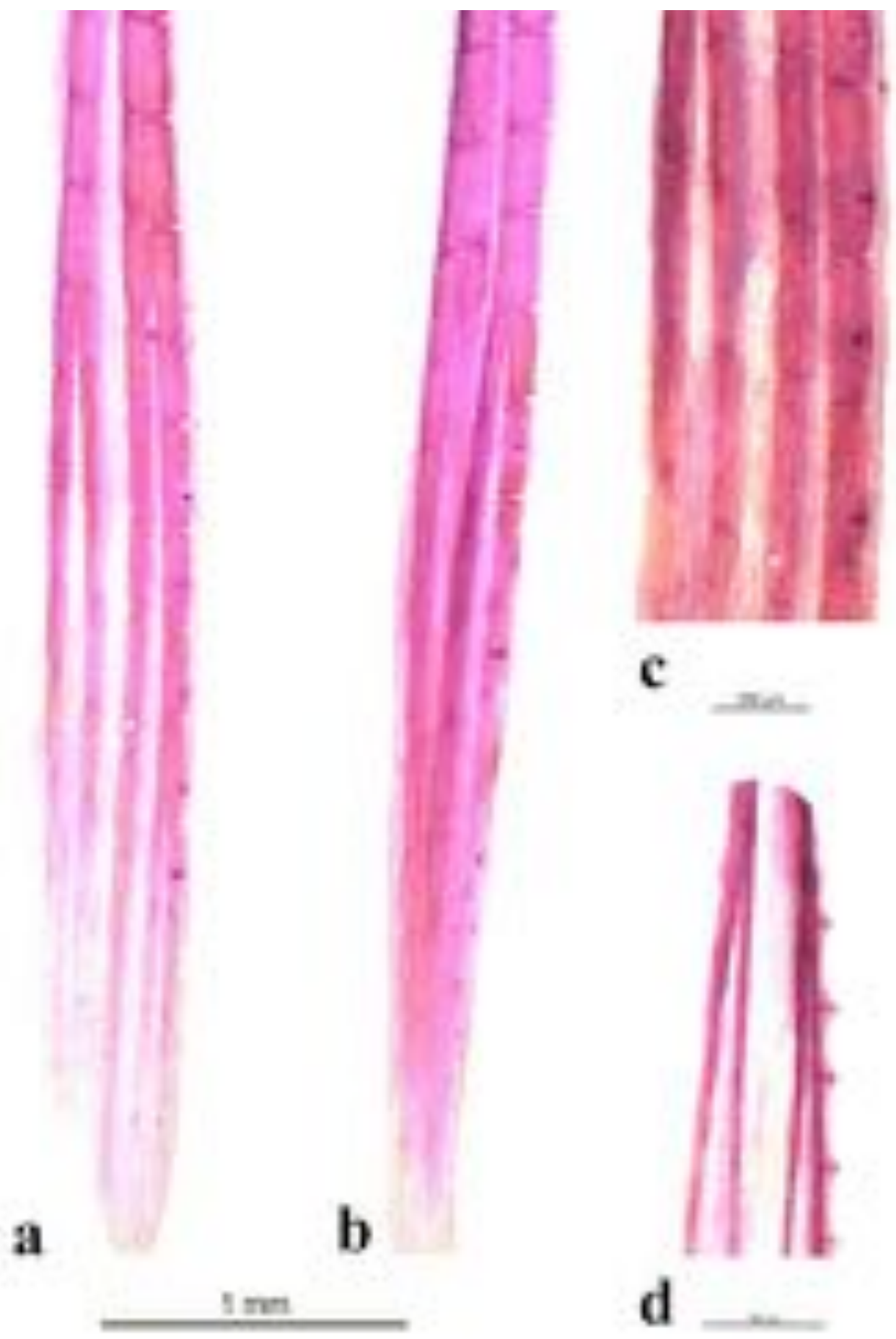

Figura 142. Distribuição, posição e formato dos processos ósseos no hemitriquium ventral da nadadeira pélvica direita de machos de Hyphessobrycon luetkenii. (a) vista ventral, (b) vista lateromedial, (c) detalhe em vista ventral e (d) detalhe em vista lateromedial. 


\section{IGUANODECTINAE}

\section{Piabucus dentatus (Koelreuter 1763)}
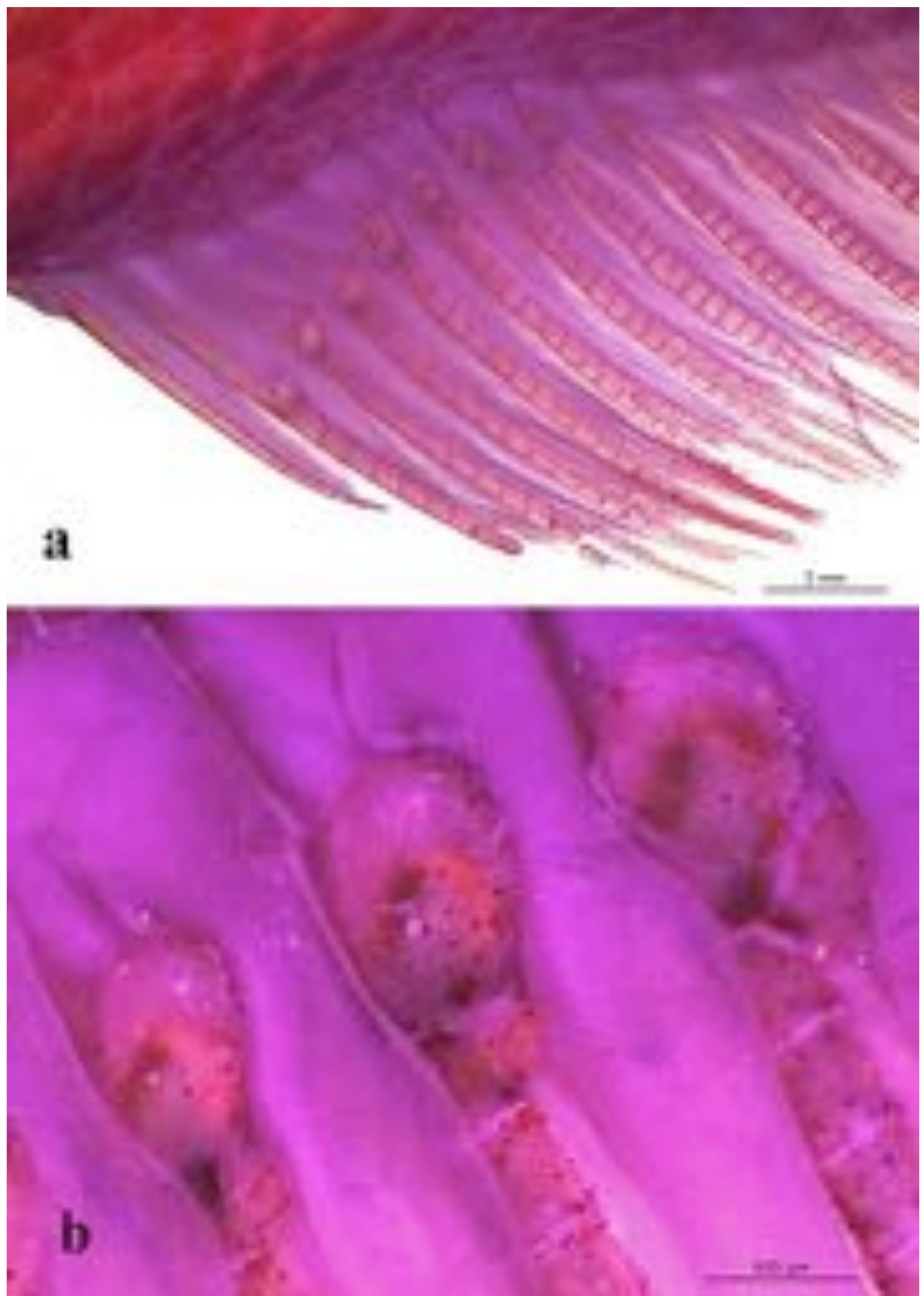

Figura 143. Porção anterior da nadadeira anal de machos de Piabucus dentatus. (a) distribuição e orientação das duas formas de processos ósseos e (b) detalhe da primeira forma (lappet) nos raios anteriores. 

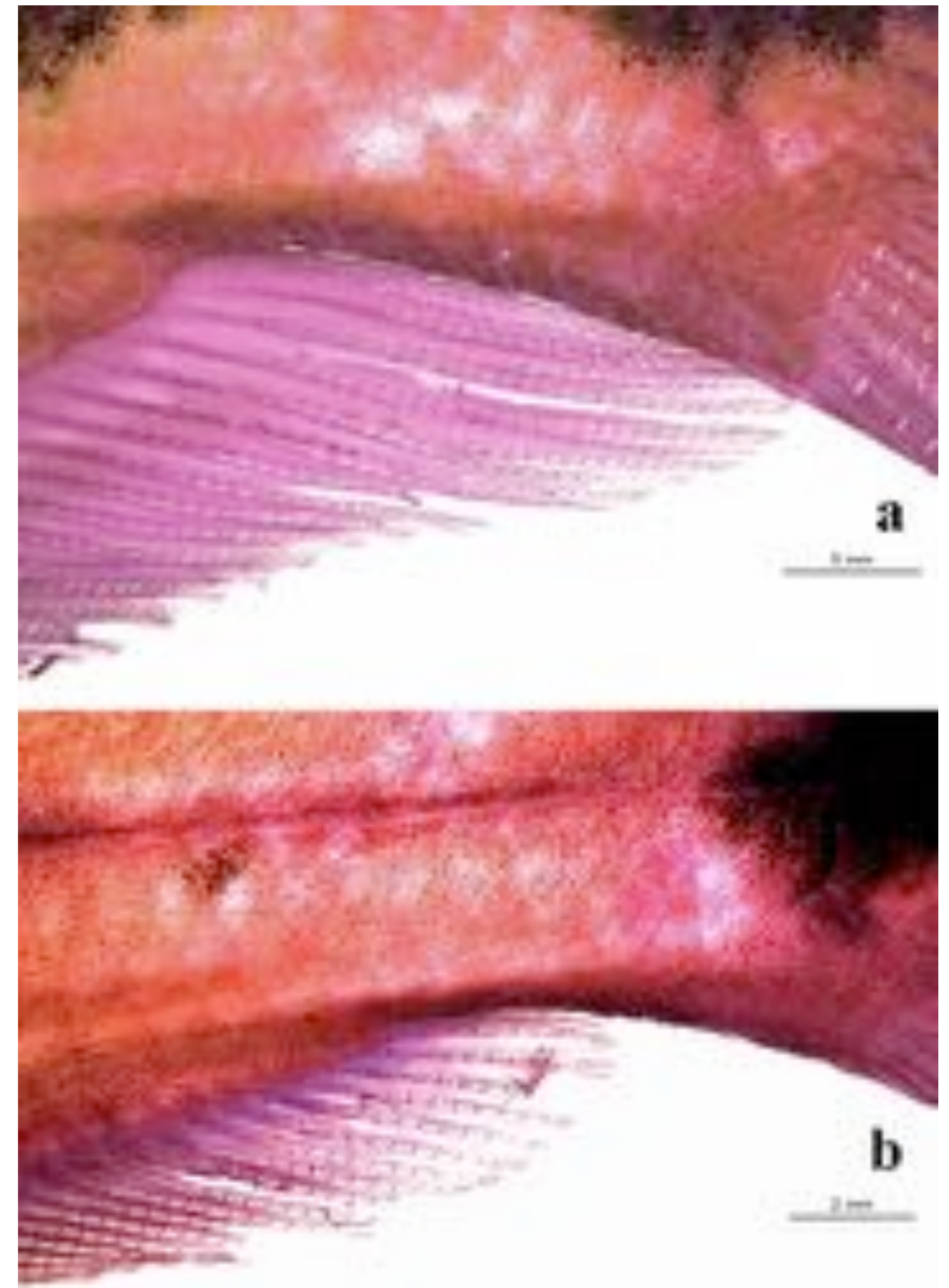

Figura 144. Porção posterior da nadadeira anal de machos (a) e de fêmeas (b) de Piabucus dentatus, evidenciando o formato do perfil da margem distal da nadadeira anal nos dois sexos e distribuição dos processos ósseos na nadadeira de macho. 

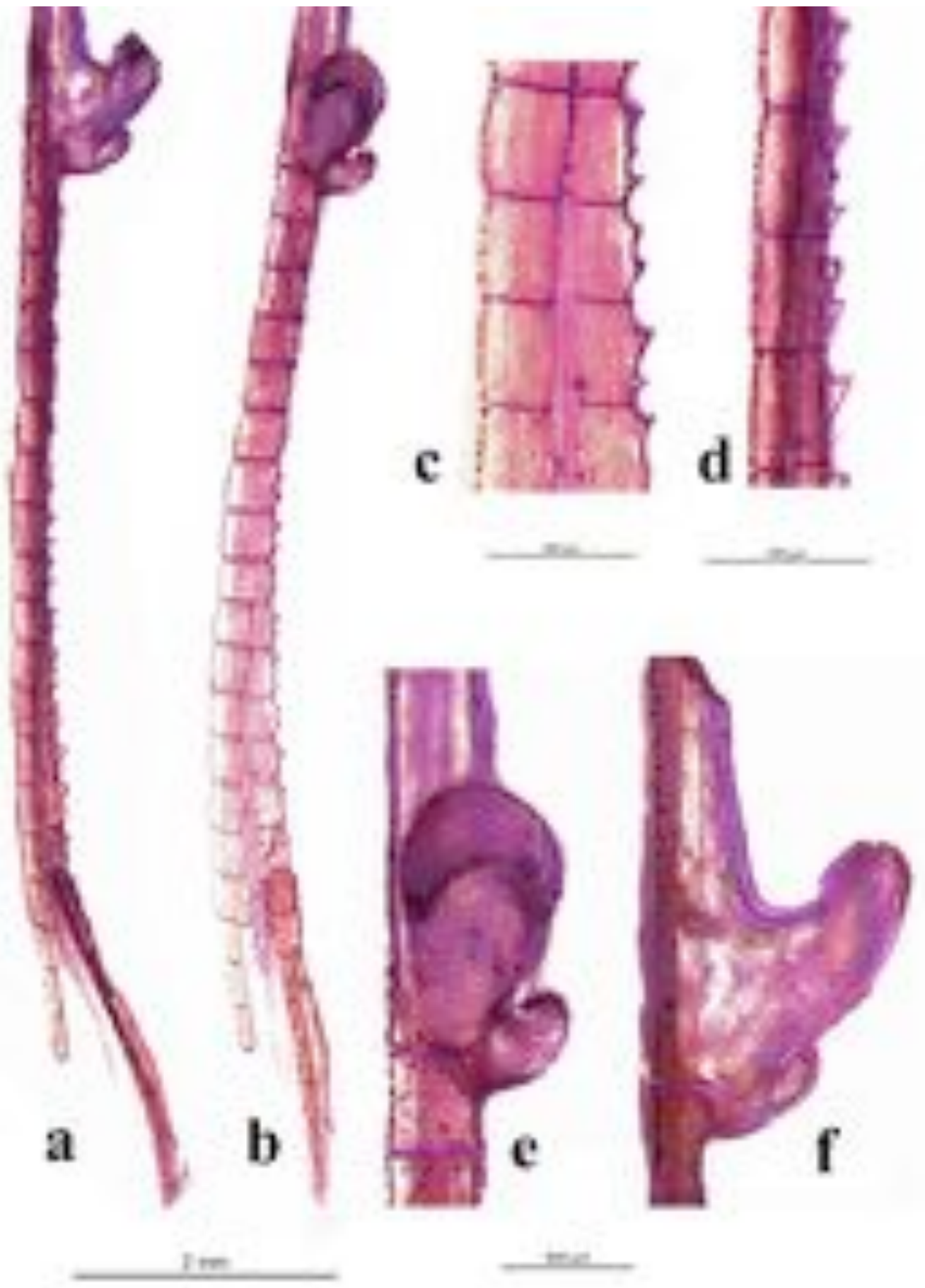

Figura 145. Distribuição, posição de inserção e formato dos processos ósseos no hemitriquium esquerdo do raio ramificado anterior da nadadeira anal de machos de Piabucus dentatus. (a) vista anteroposterior, (b) vista lateral, (c) detalhe em vista lateral da segunda forma de processos ósseos e (d) detalhe em vista anteroposterior da segunda forma de processos ósseos, (e) detalhe em vista lateral da primeira forma (lappet) de processos ósseos e (f) detalhe em vista anteroposterior da primeira forma (lappet) de processos ósseos. 

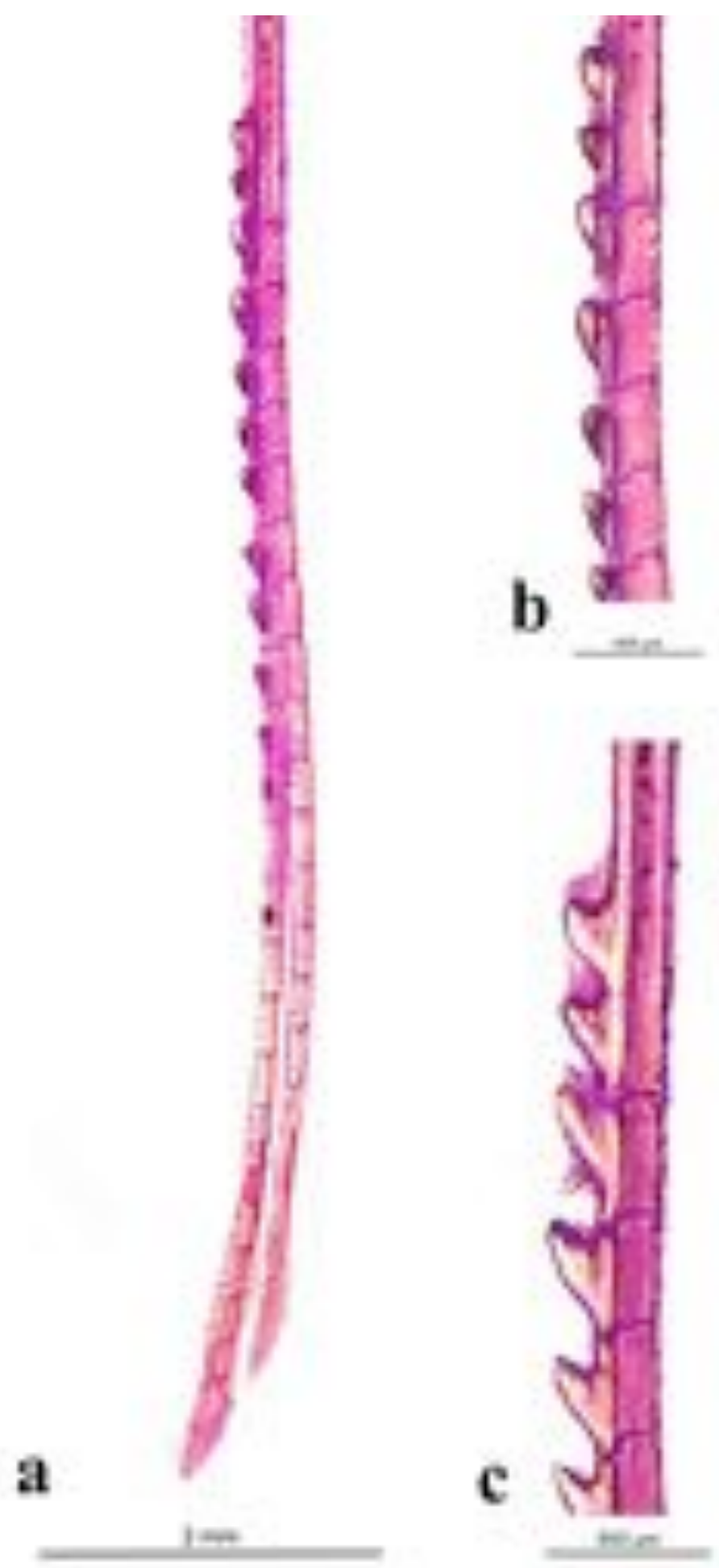

Figura 146. Distribuição, posição de inserção e formato dos processos ósseos no hemitriquium direito do raio ramificado posterior da nadadeira anal em Piabucus dentatus. (a) vista lateral da primeira forma (lappet), (b) vista anteroposterior da primeira forma (lappet), (c) detalhe em vista lateral da primeira forma (lappet) e (d) detalhe em vista anteroposterior da primeira forma (lappet). 
CLADO Peseudochalceus

\section{Hollandichthys multifasciatus (Eigenmann \& Norris 1900)}

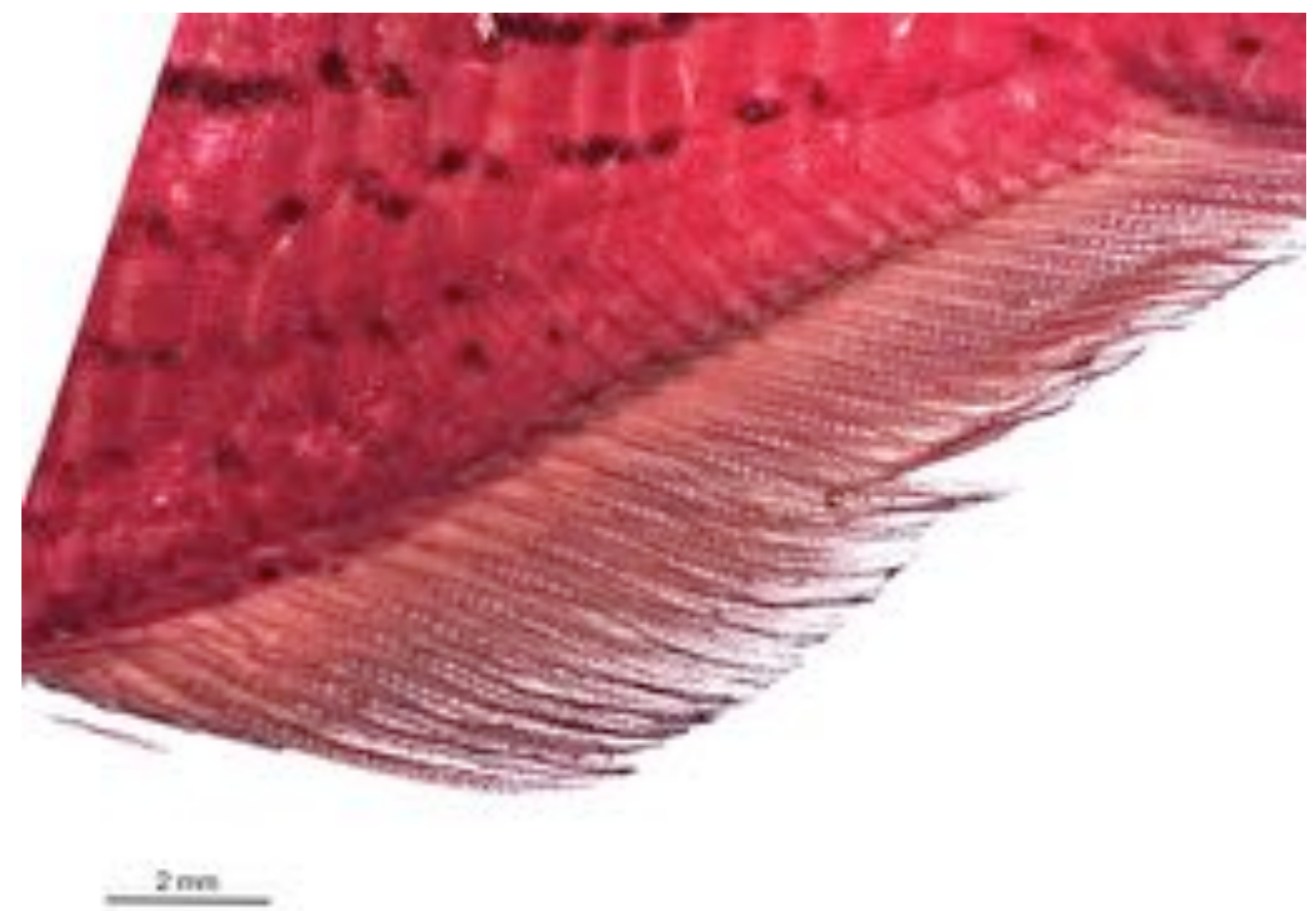

Figura 147. Nadadeira anal de macho de Hollandichthys multifasciatus em vista lateral esquerda, evidenciando o formato do perfil da margem distal da nadadeira e distribuição dos processos ósseos. 

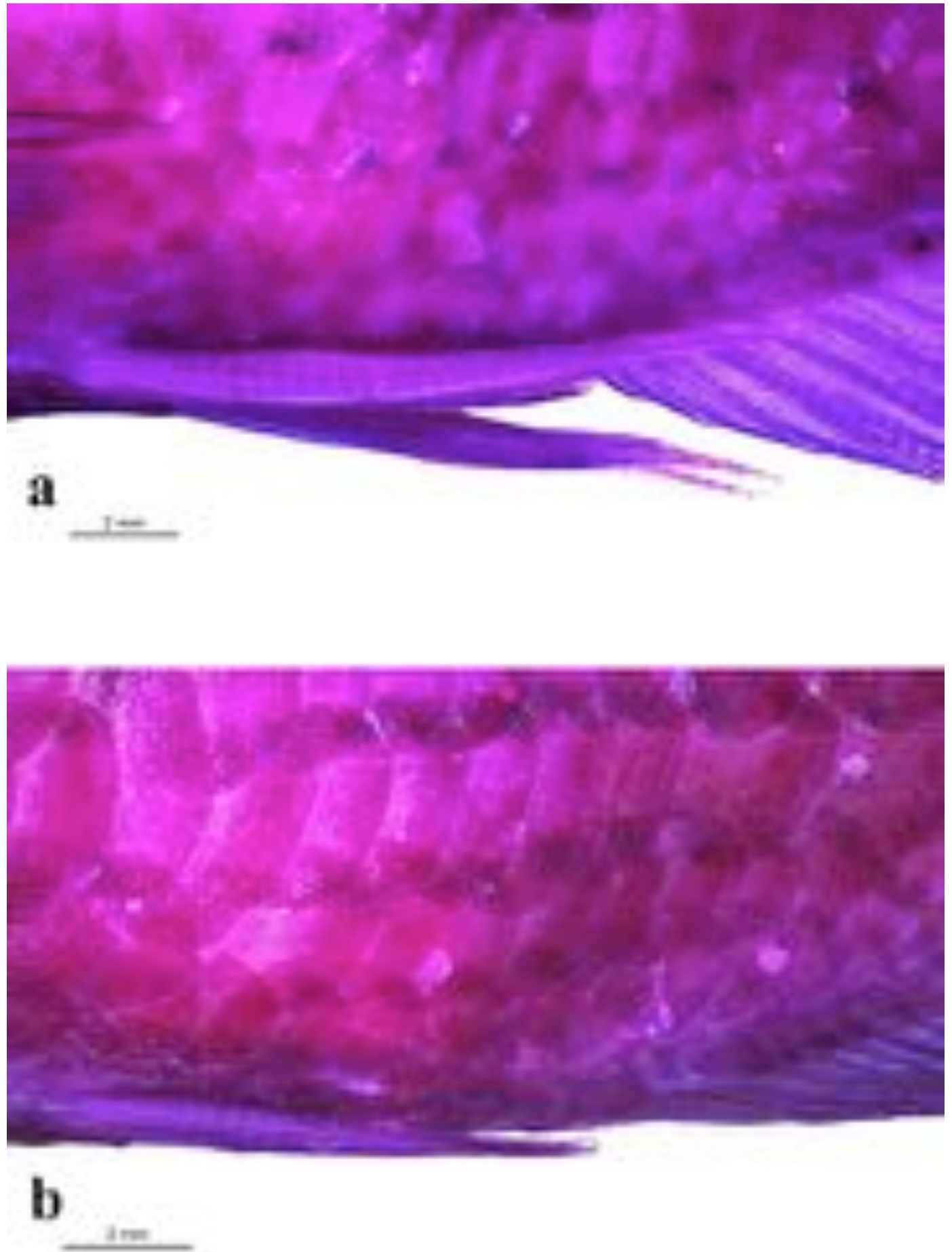

Figura 148. Nadadeira pélvica de machos (a) e de fêmeas (b) de Hollandichthys multifasciatus em vista lateral esquerda, evidenciando o formato e comprimento da nadadeira nos dois sexos. 

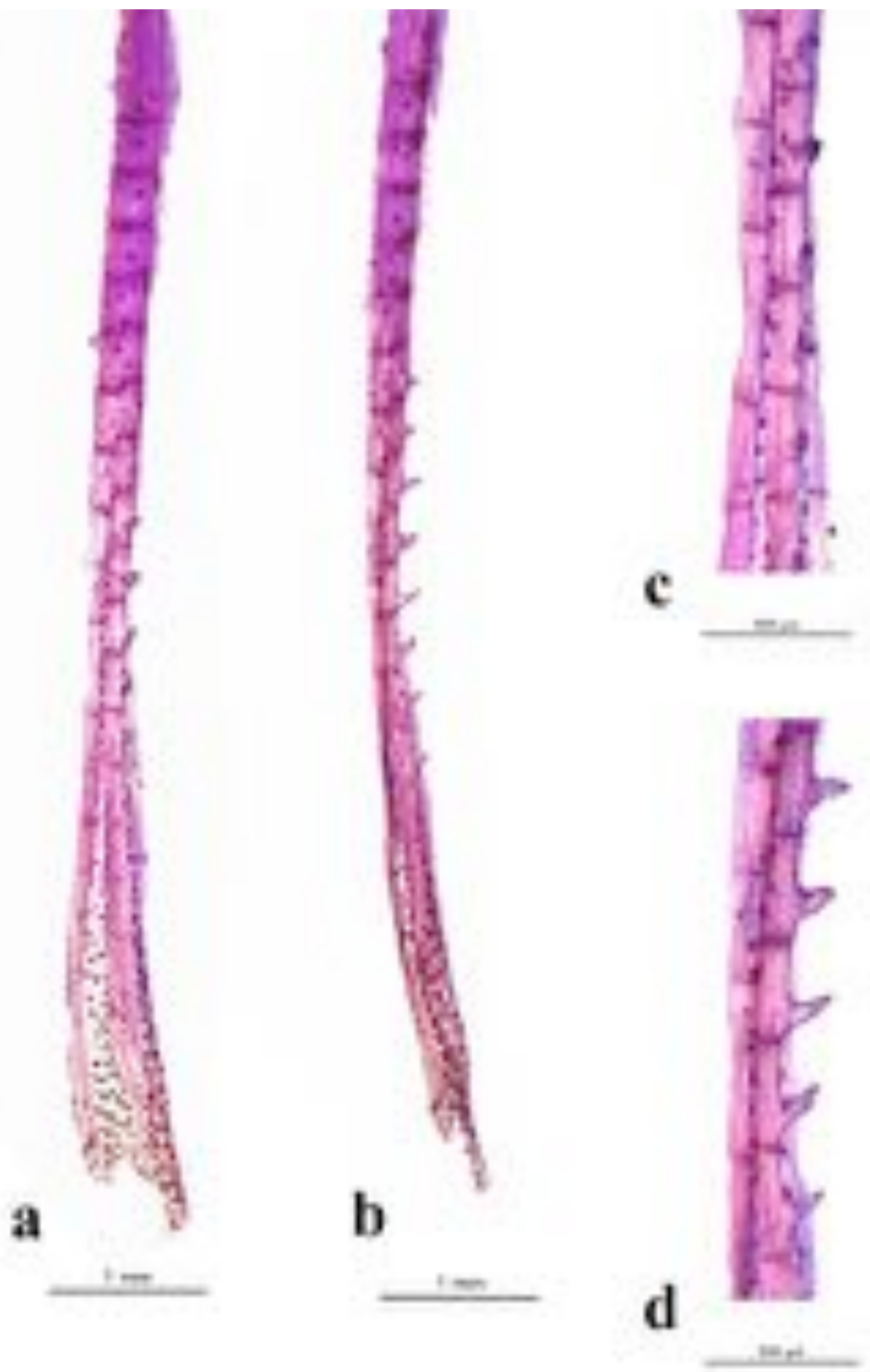

Figura 149. Distribuição, posição e formato dos processos ósseos no hemitriquium esquerdo do raio ramificado da nadadeira anal de machos de Hollandichthys multifasciatus. (a) vista lateral, (b) vista anteroposterior, (c) detalhe em vista lateral, (d) detalhe em vista anteroposterior. 

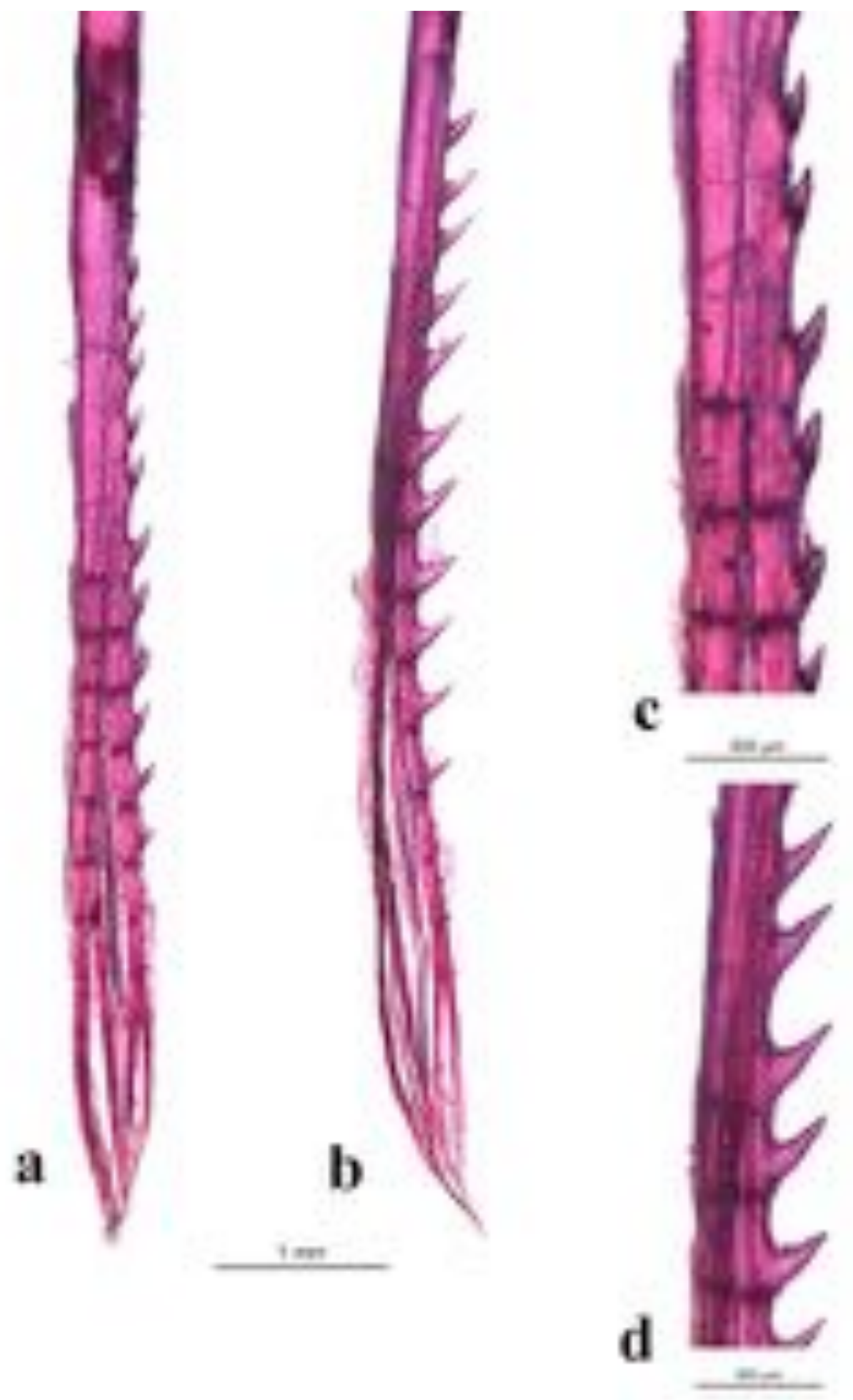

Figura 150. Distribuição, posição e formato dos processos ósseos no hemitriquium ventral da nadadeira pélvica direita de machos de Hollandichthys multifasciatus. (a) vista ventral, (b) vista lateromedial, (c) detalhe em vista ventral e (d) detalhe em vista lateromedial. 
RHOADSIINAE

Nematocharax venustus Weitzman, Menezes \& Britski 1986

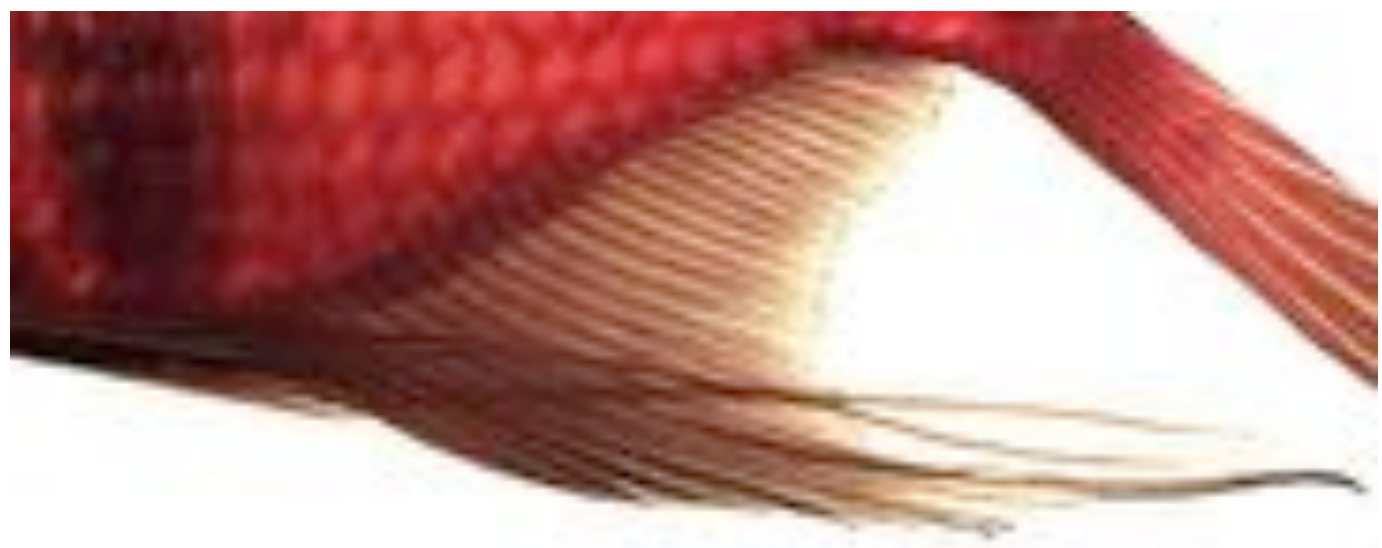

a

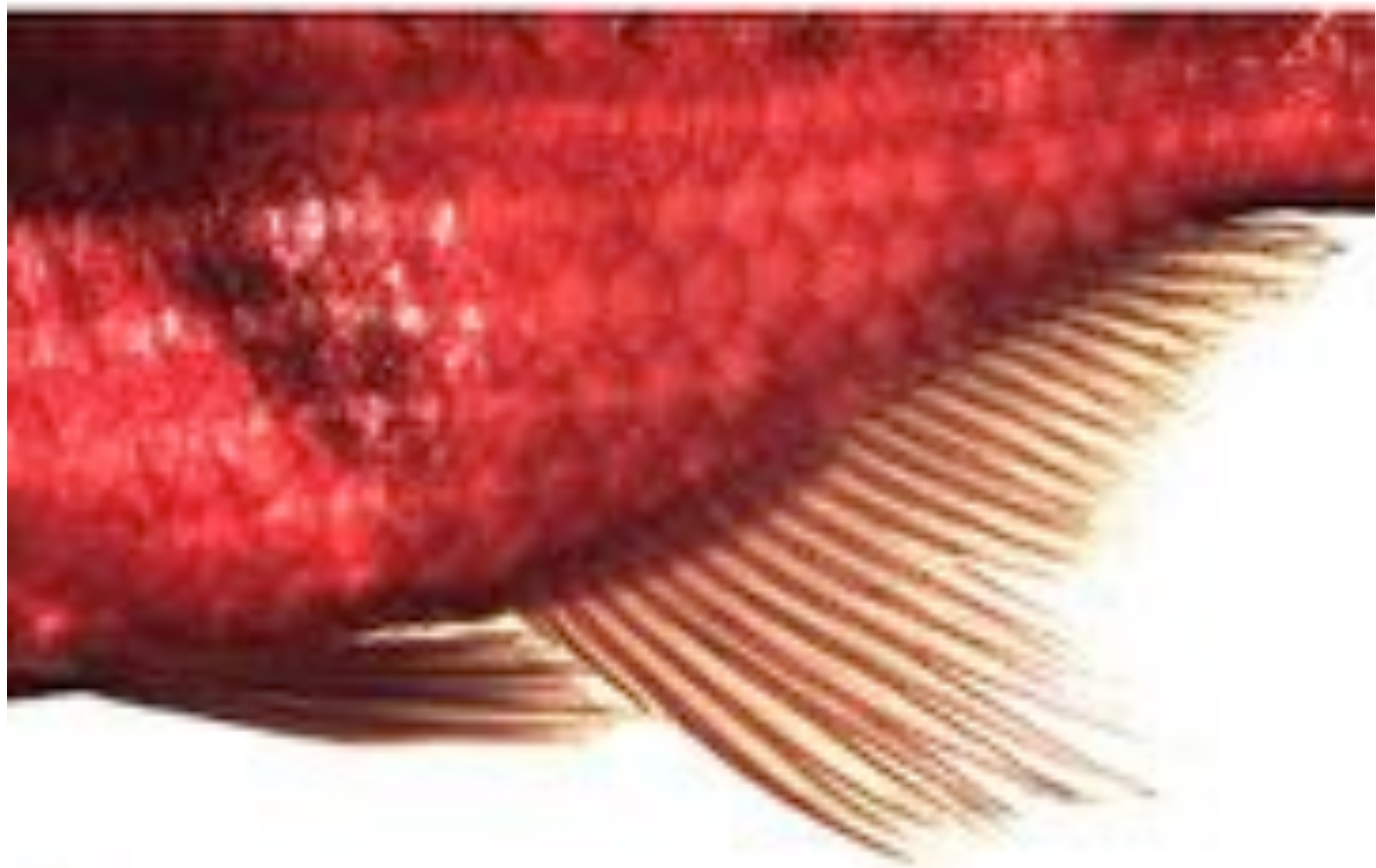

b

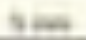

Figura 151. Nadadeira anal e pélvica de machos (a) e de fêmeas (b) de Nematocharax venustus em vista lateral esquerda, evidenciando o formato do perfil distal das nadadeiras nos dois sexos e distribuição dos processos ósseos na nadadeira anal de macho. 


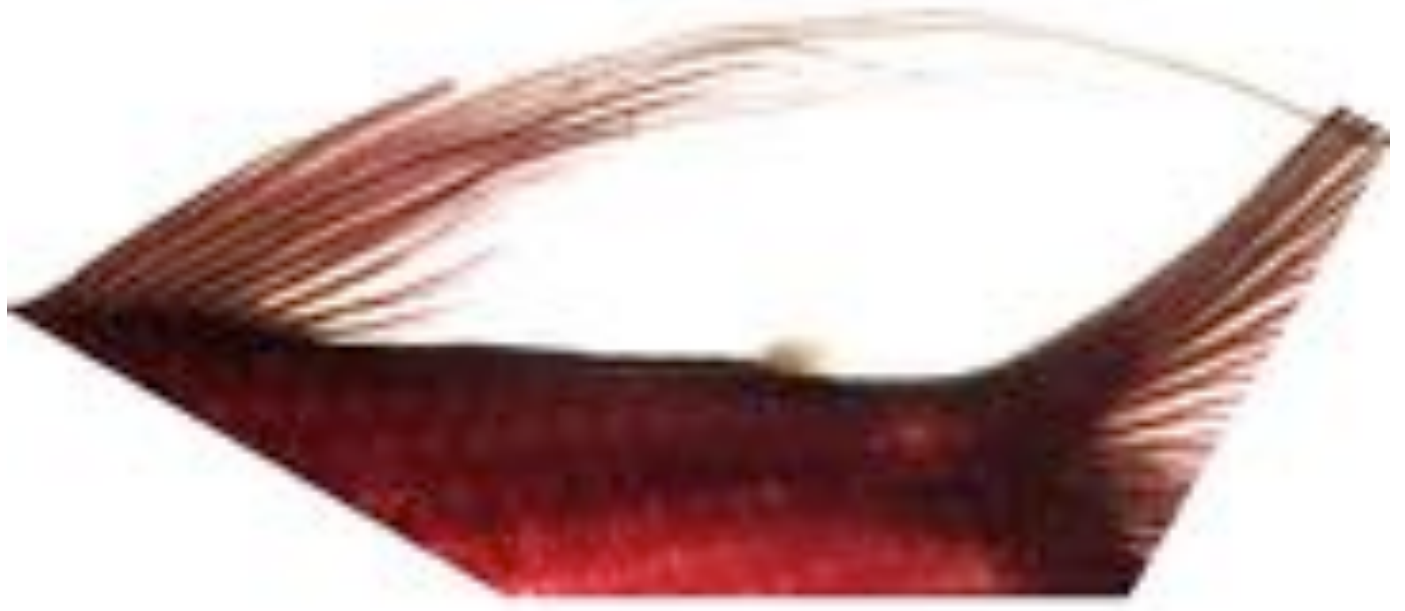

a
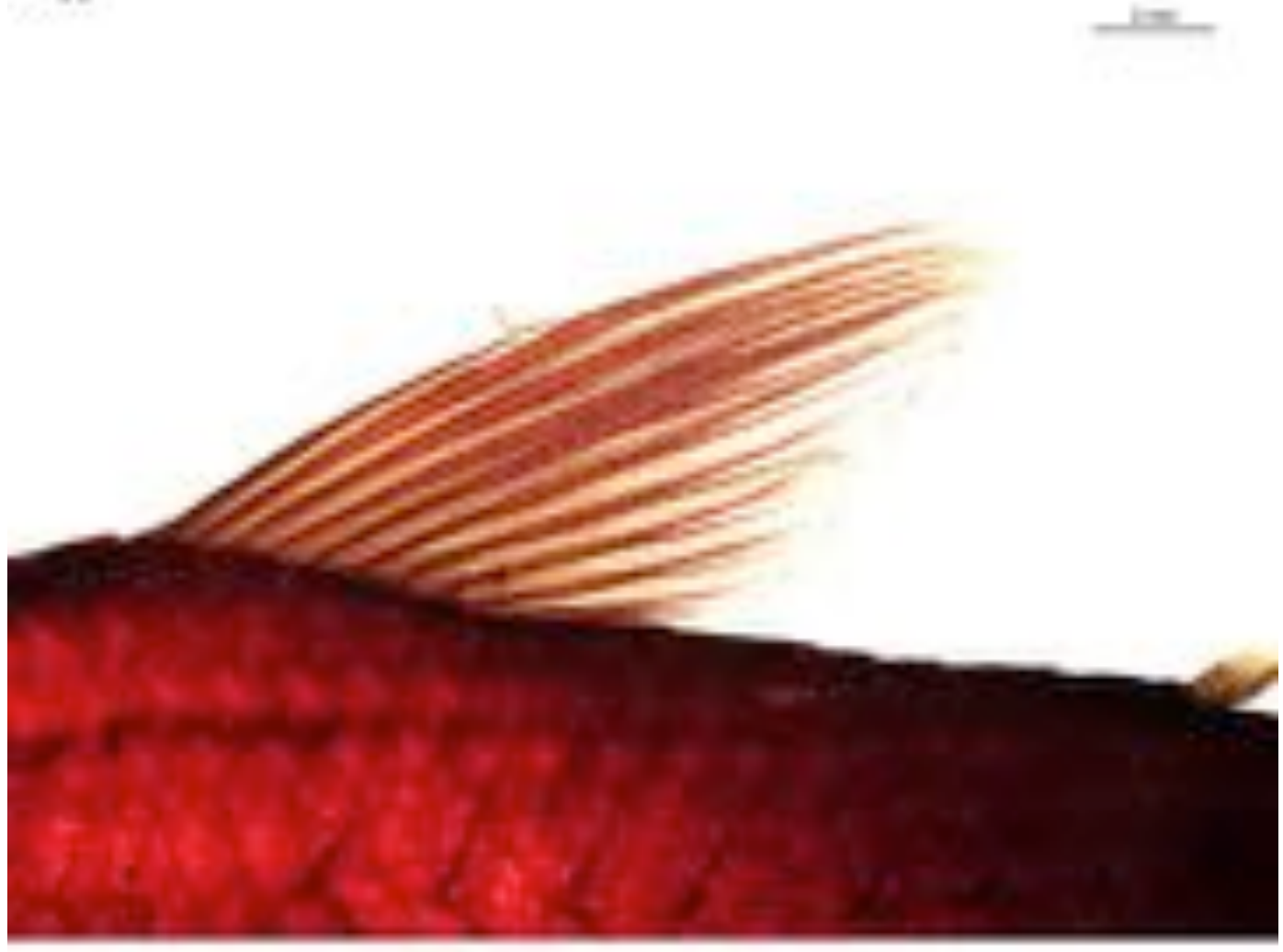

b

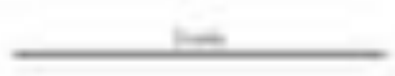

Figura 152. Nadadeira dorsal de machos (a) e de fêmeas (b) de Nematocharax venustus em vista lateral ventral, evidenciando o formato e comprimento da nadadeira nos dois sexos. 

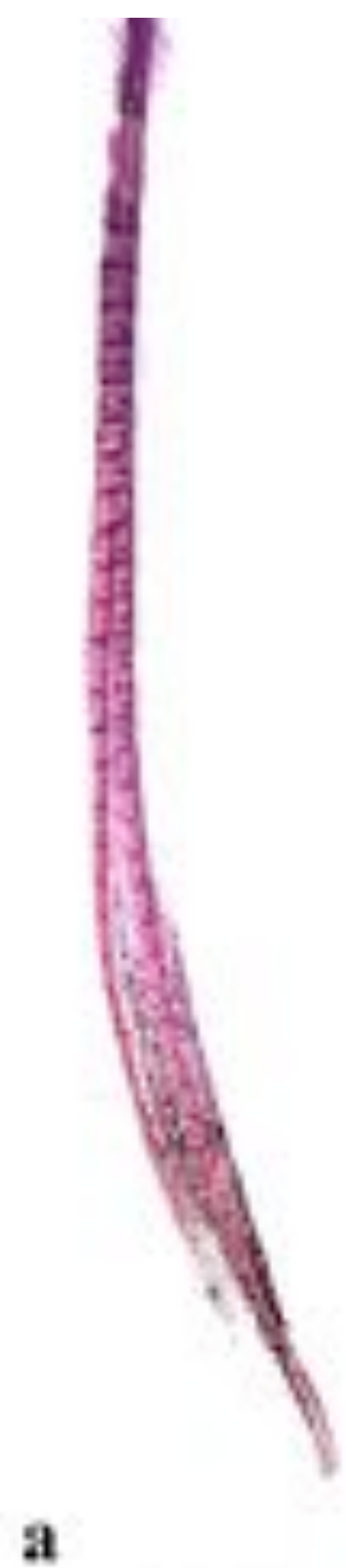

$1=$

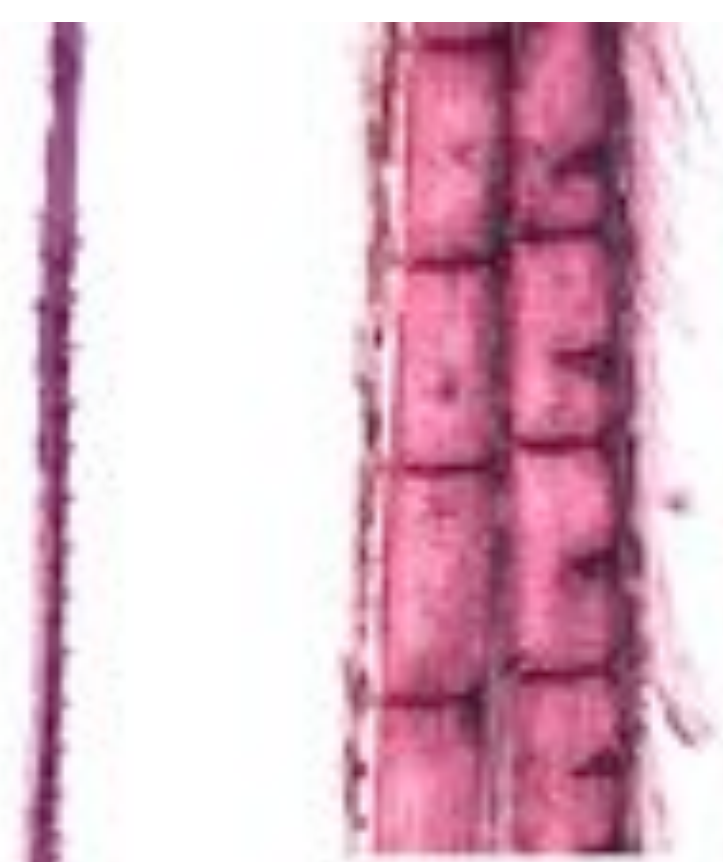

C

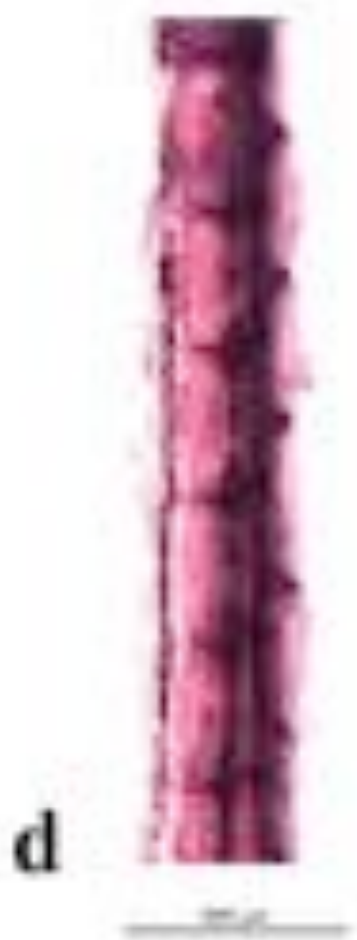

Figura 153. Distribuição, posição e formato dos processos ósseos no hemitriquium esquerdo do raio ramificado da nadadeira anal de machos de Nematocharax venustus. (a) vista lateral, (b) vista anteroposterior, (c) detalhe em vista lateral, (d) detalhe em vista anteroposterior. 


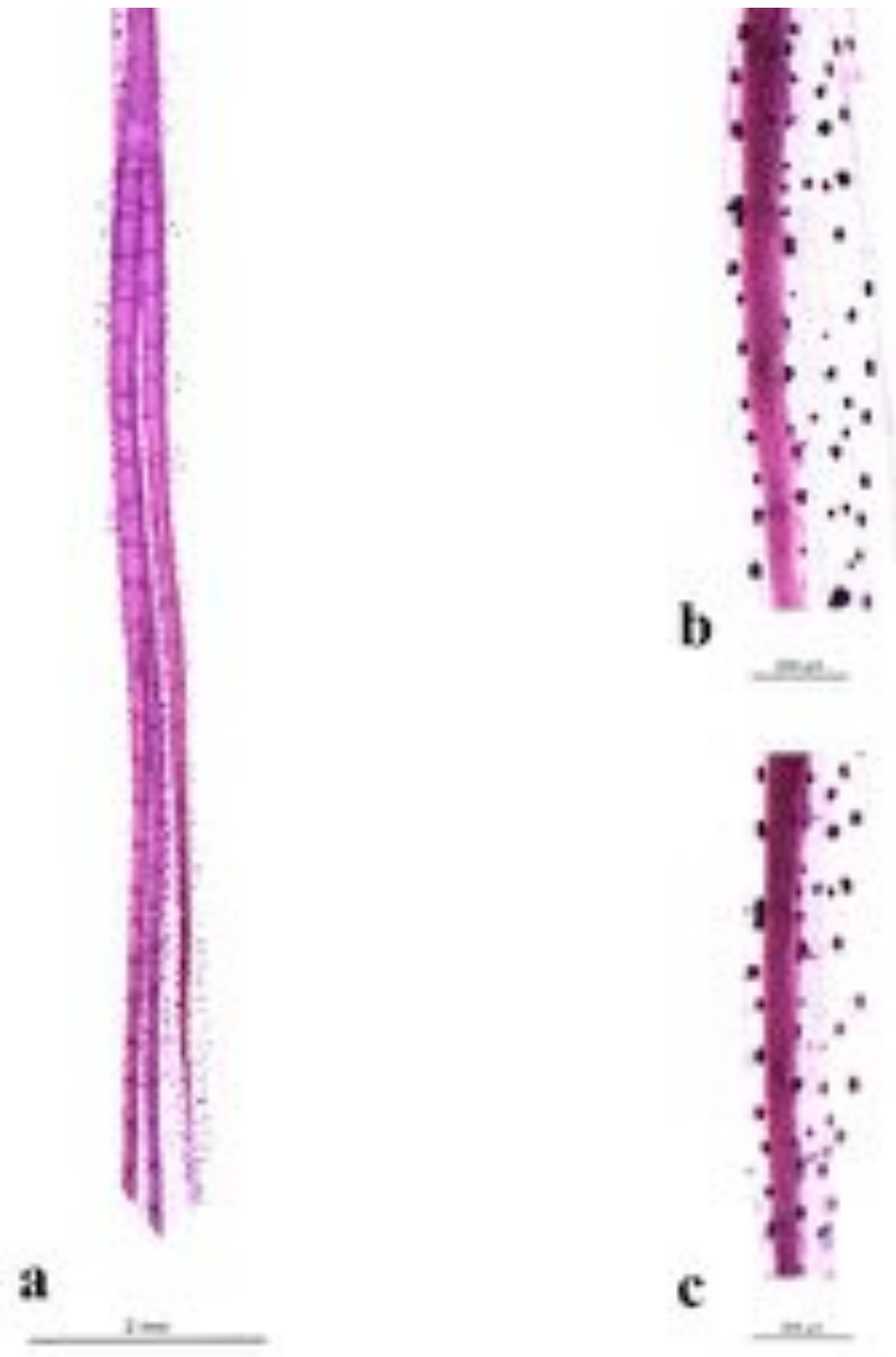

Figura 154. Distribuição, posição e formato dos processos ósseos no hemitriquium ventral da nadadeira pélvica direita de machos de Nematocharax venustus. (a) vista ventral, (b) vista lateromedial, (c) detalhe em vista ventral e (d) detalhe em vista lateromedial. 
SALMININAE

Salminus brasiliensis Cuvier, 1916

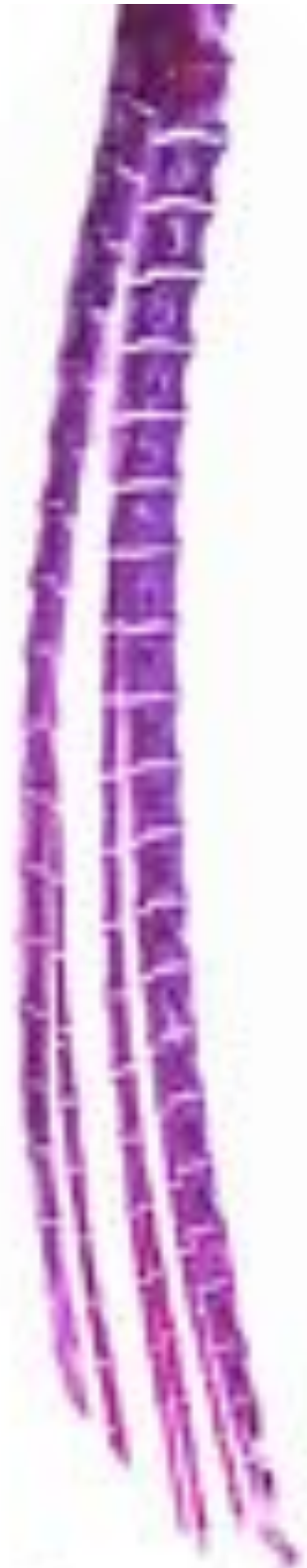

a

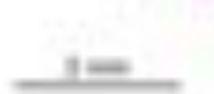

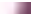

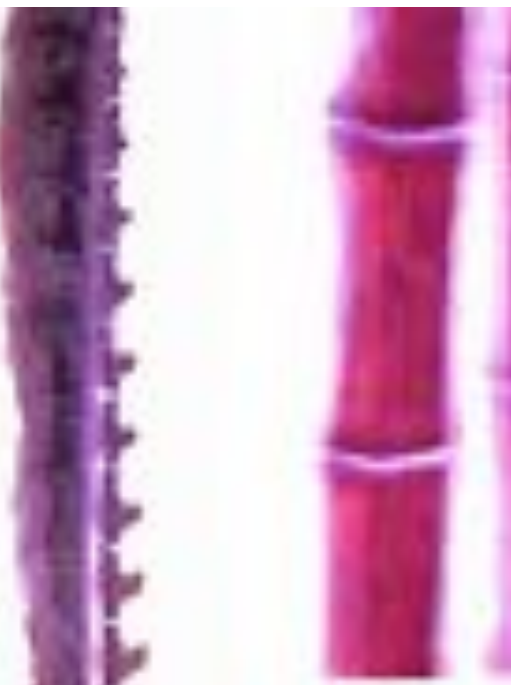

c
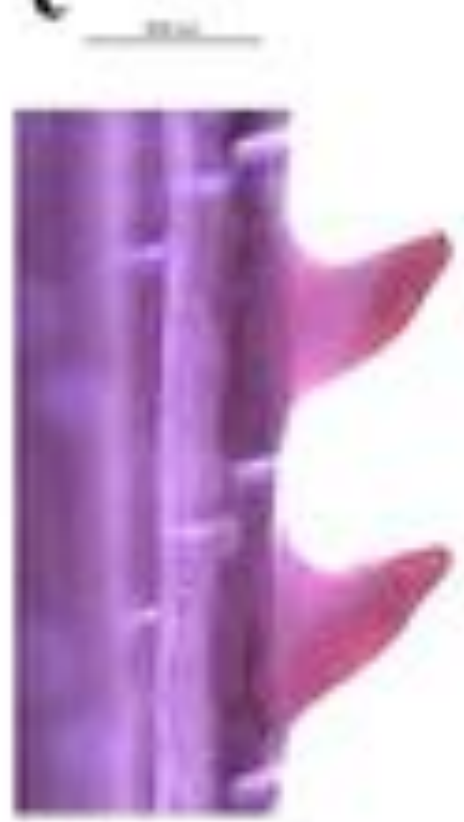

(1) b

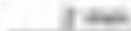

Figura 155. Distribuição, posição e formato dos processos ósseos no hemitriquium esquerdo do raio ramificado da nadadeira anal de machos de Salminus brasiliensis. (a) vista lateral, (b) vista anteroposterior, (c) detalhe em vista lateral, (d) detalhe em vista anteroposterior. 

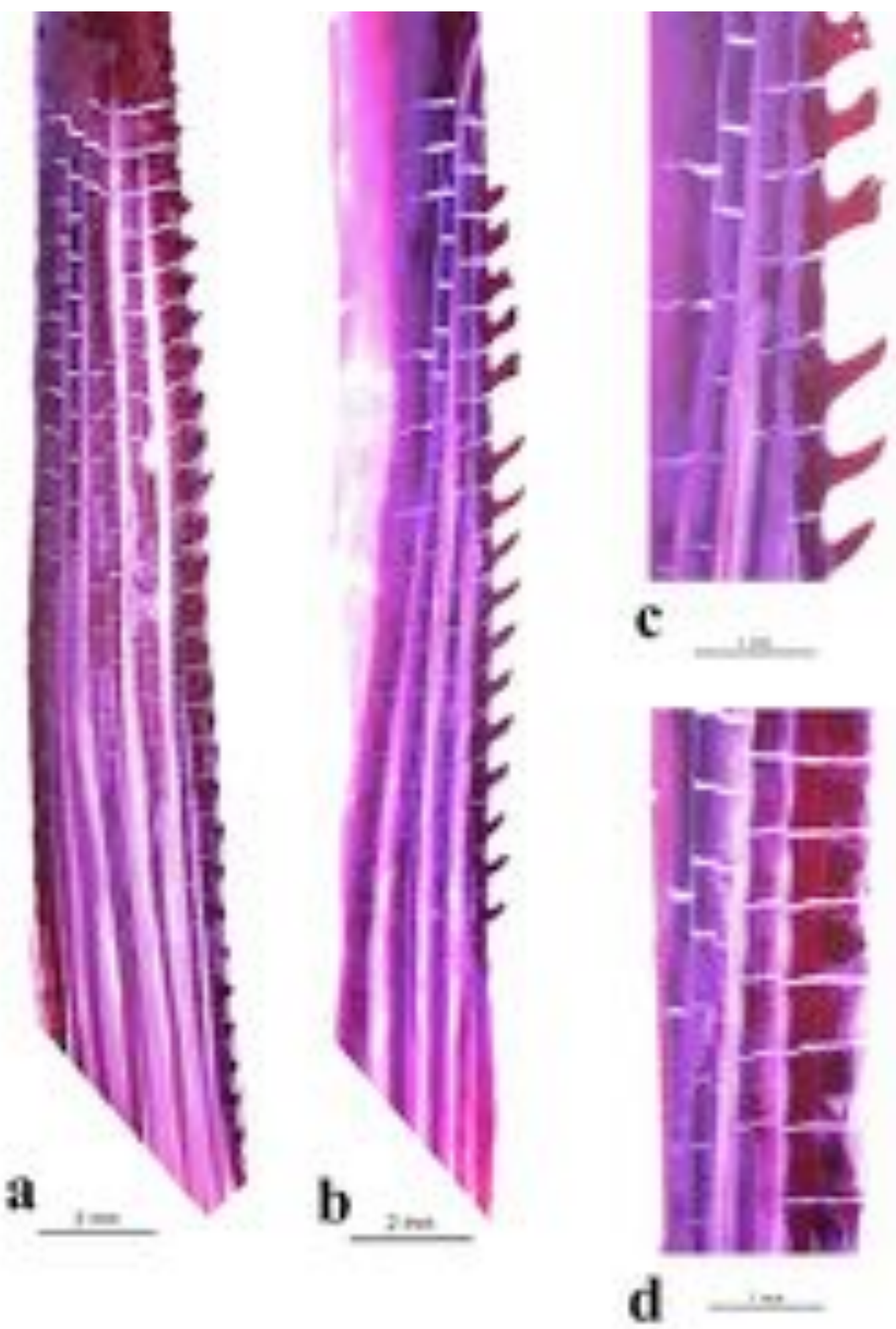

Figura 156. Distribuição, posição e formato dos processos ósseos no hemitriquium ventral da nadadeira pélvica direita de machos de Salminus brasiliensis. (a) vista ventral, (b) vista lateromedial, (c) detalhe em vista ventral e (d) detalhe em vista lateromedial. 

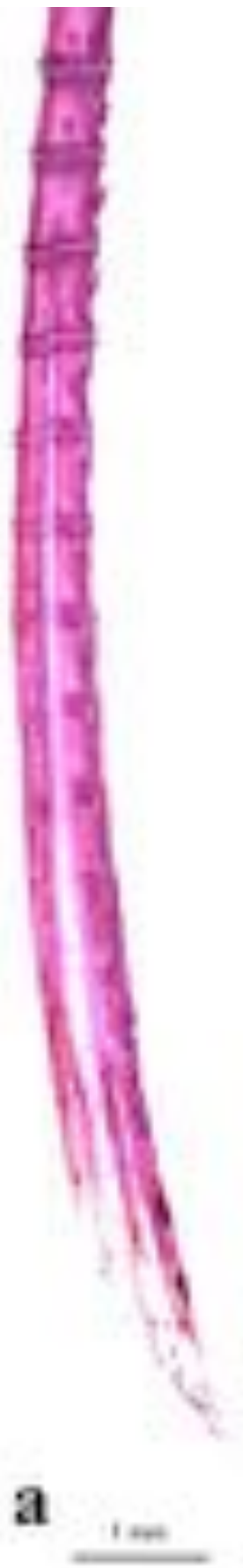

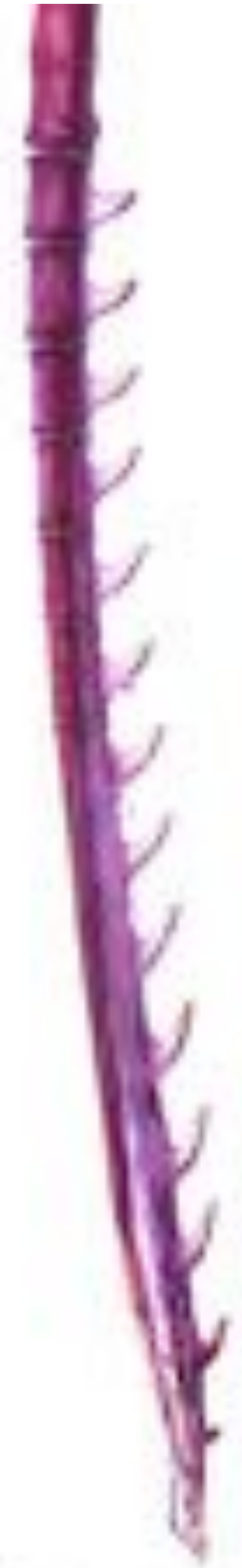

b

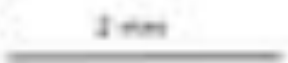

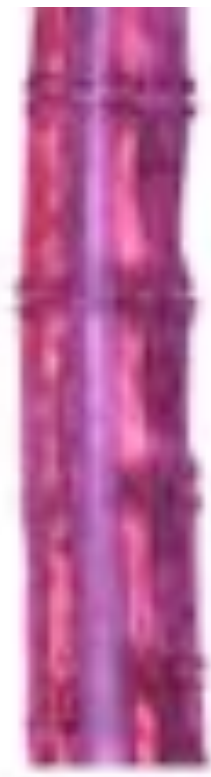

c
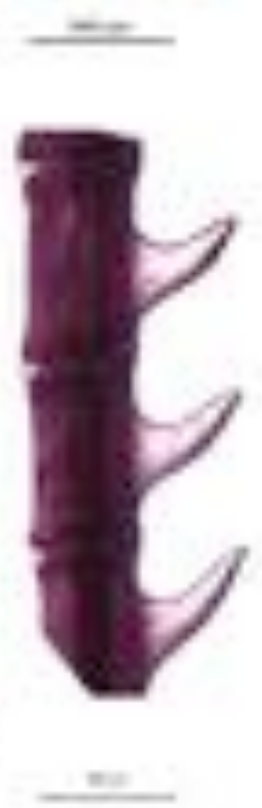

Figura 157. Distribuição, posição e formato dos processos ósseos no hemitriquium esquerdo do raio ramificado da nadadeira anal de machos de Salminus hilarii. (a) vista lateral, (b) vista anteroposterior, (c) detalhe em vista lateral, (d) detalhe em vista anteroposterior. 

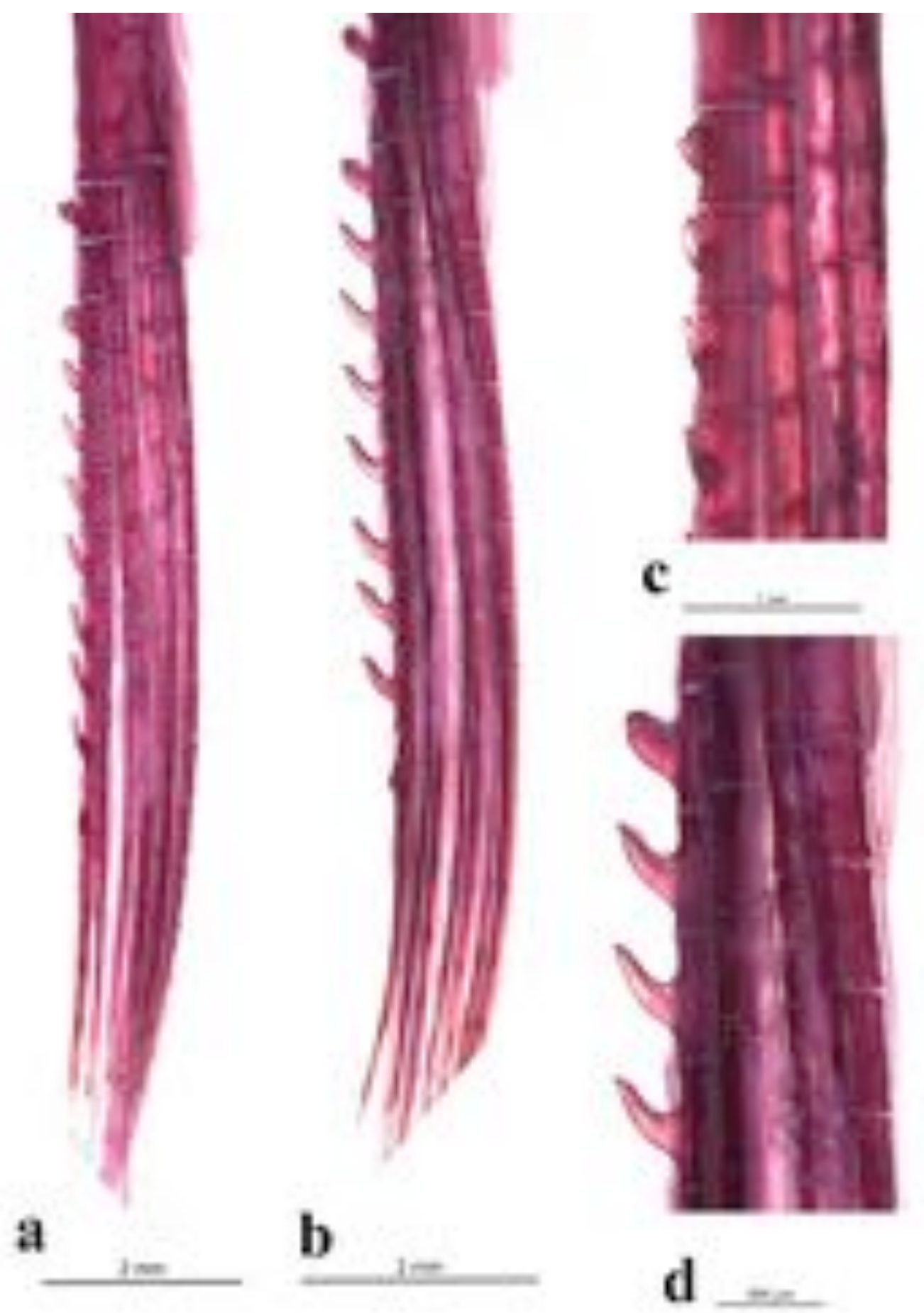

Figura 158. Distribuição, posição e formato dos processos ósseos no hemitriquium ventral da nadadeira pélvica esquerda de machos de Salminus hilarii. (a) vista ventral, (b) vista lateromedial, (c) detalhe em vista ventral e (d) detalhe em vista lateromedial. 


\section{TETRAGONOPTERINAE}

\section{Deuterodon iguape Eigenmann 1907}
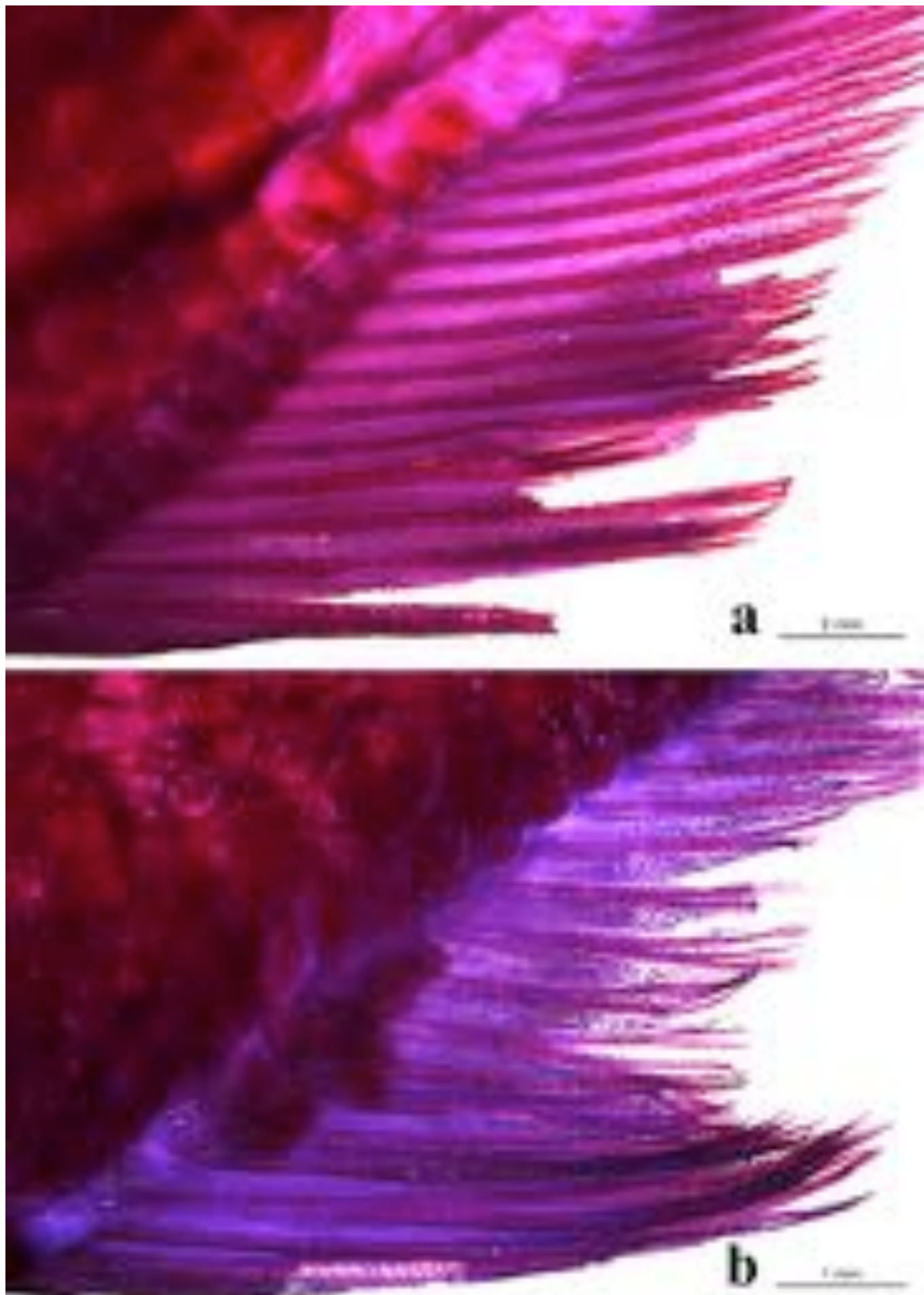

Figura 159. Nadadeira anal de machos (a) e de fêmeas (b) de Deuterodon iguape em vista lateral esquerda, evidenciando o formato do perfil distal das nadadeiras nos dois sexos e distribuição dos processos ósseos na nadadeira anal de macho. 


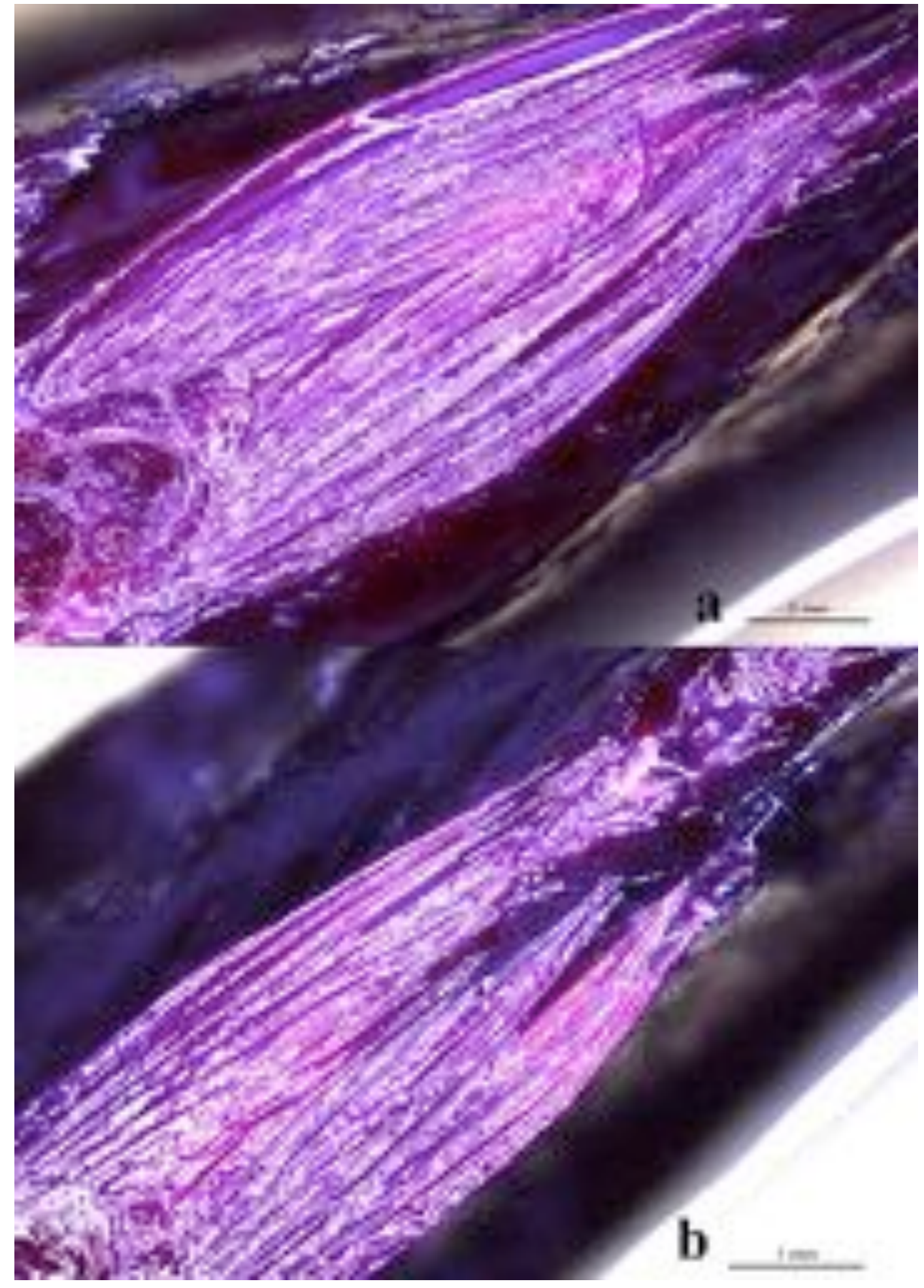

Figura 160. Nadadeira pélvica de machos (a) e de fêmeas (b) de Deuterodon iguape em vista lateral ventral, evidenciando o formato e comprimento da nadadeira nos dois sexos. 

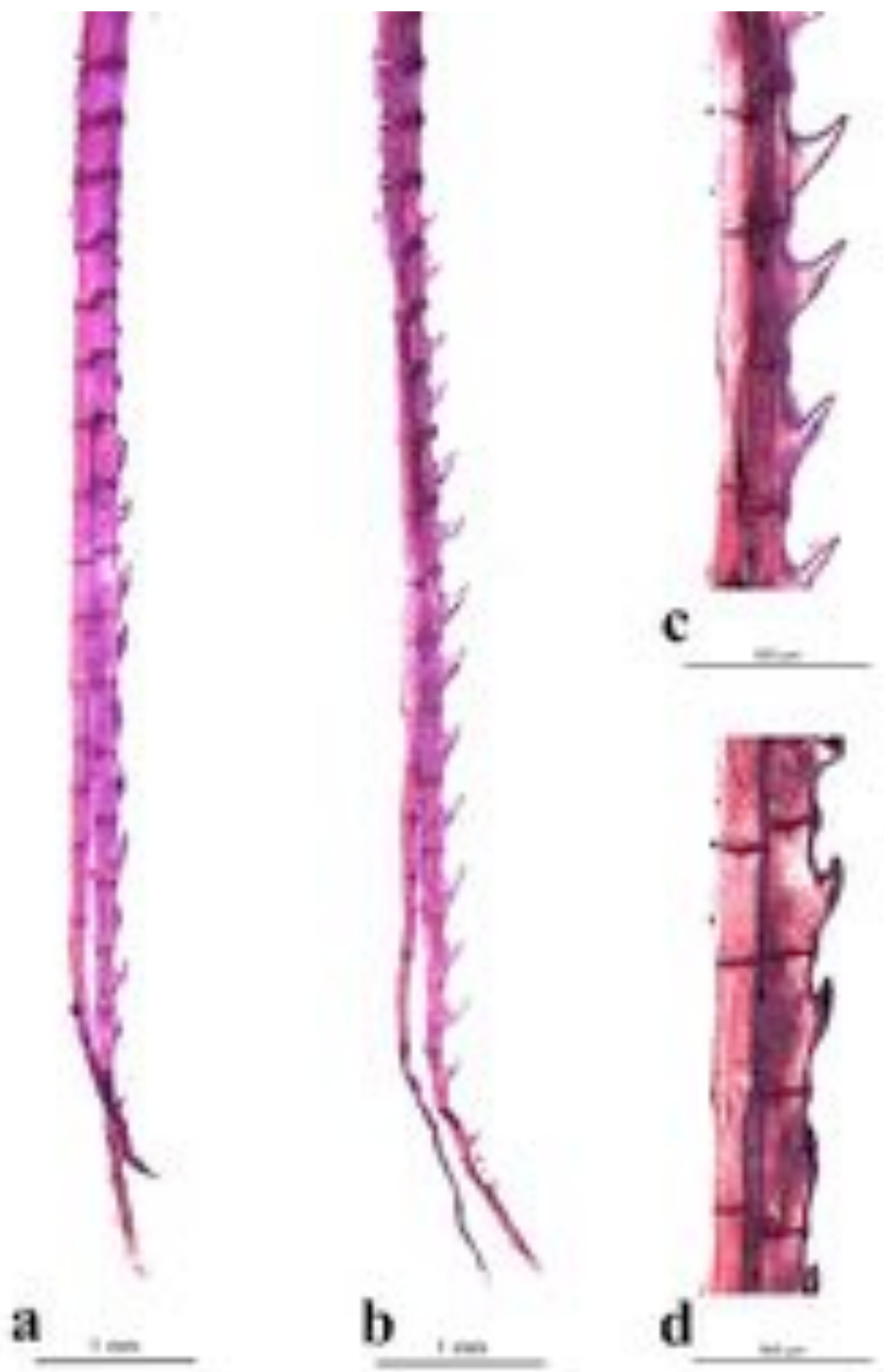

Figura 161. Distribuição, posição e formato dos processos ósseos no hemitriquium esquerdo do raio ramificado da nadadeira anal de machos de Deuterodon iguape. (a) vista lateral, (b) vista anteroposterior, (c) detalhe em vista anteroposterior, (d) detalhe em vista lateral. 


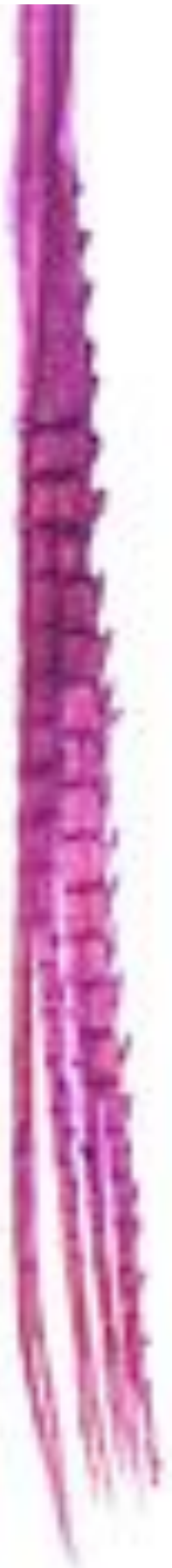

a

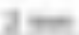

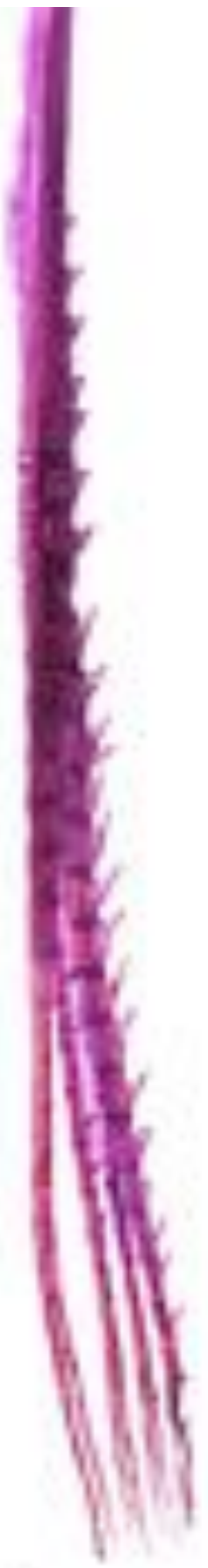

b

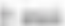

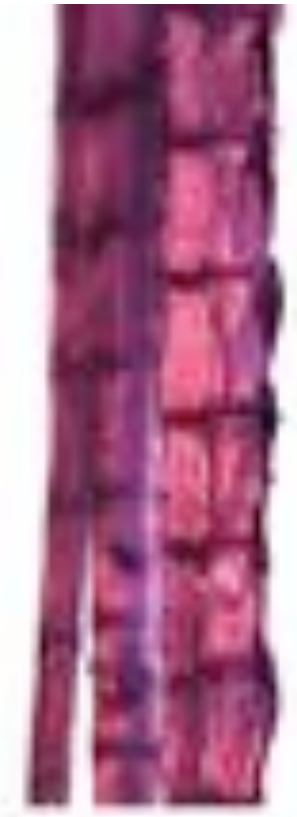

c
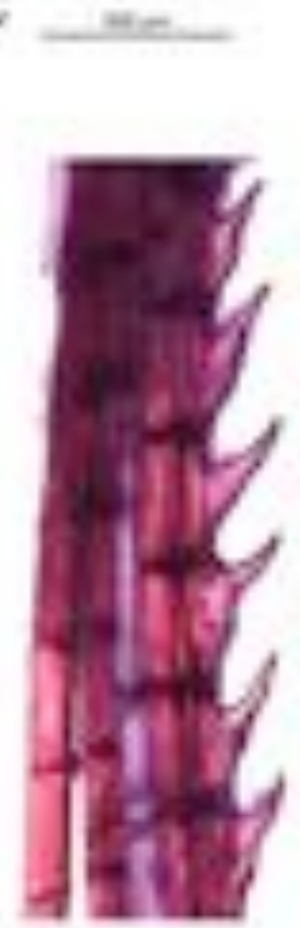

d

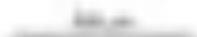

Figura 162. Distribuição, posição e formato dos processos ósseos no hemitriquium ventral da nadadeira pélvica direita de machos de Deuterodon iguape. (a) vista ventral, (b) vista lateromedial, (c) detalhe em vista ventral e (d) detalhe em vista lateromedial. 

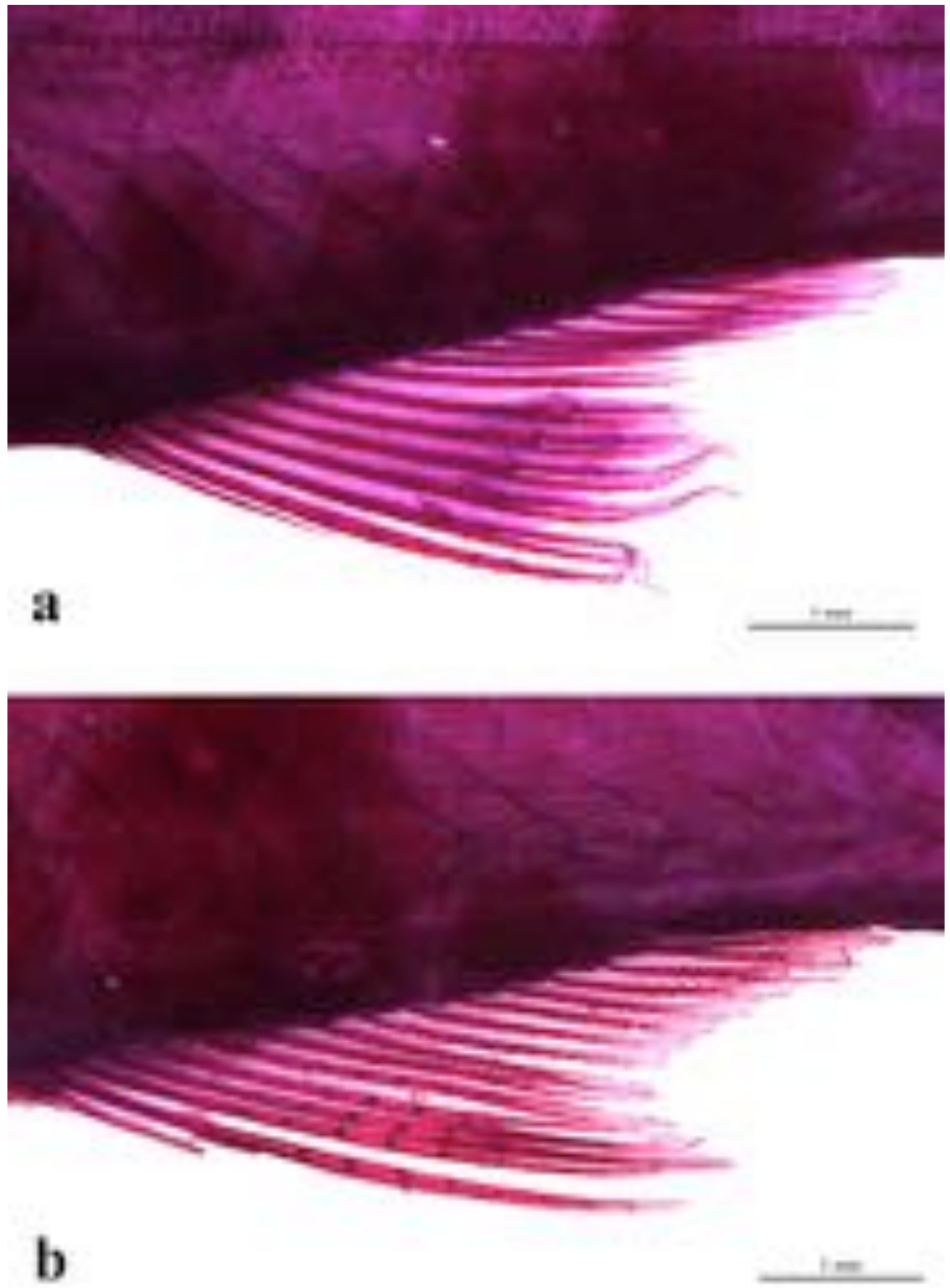

Figura 163. Nadadeira anal de machos (a) e de fêmeas (b) de Hemigrammus bleheri em vista lateral esquerda, evidenciando o formato do perfil distal das nadadeiras nos dois sexos e distribuição dos processos ósseos na nadadeira anal de macho. 


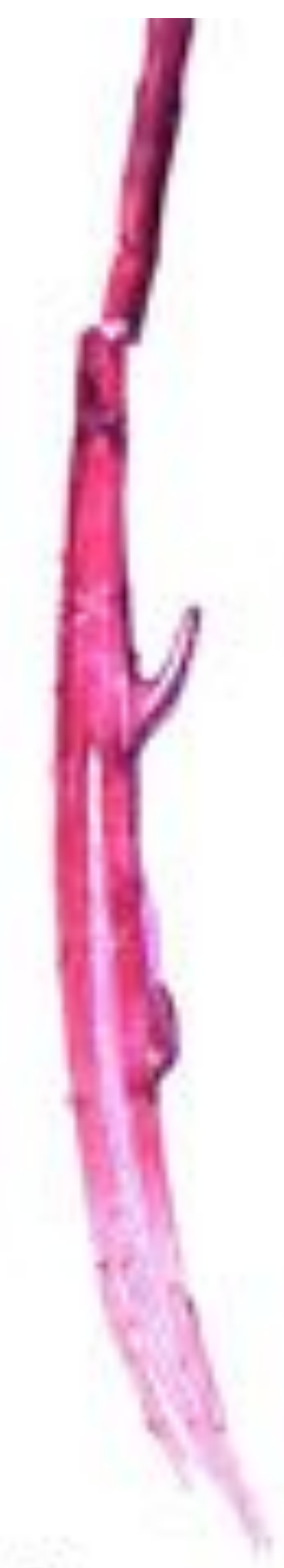

a wet $=$

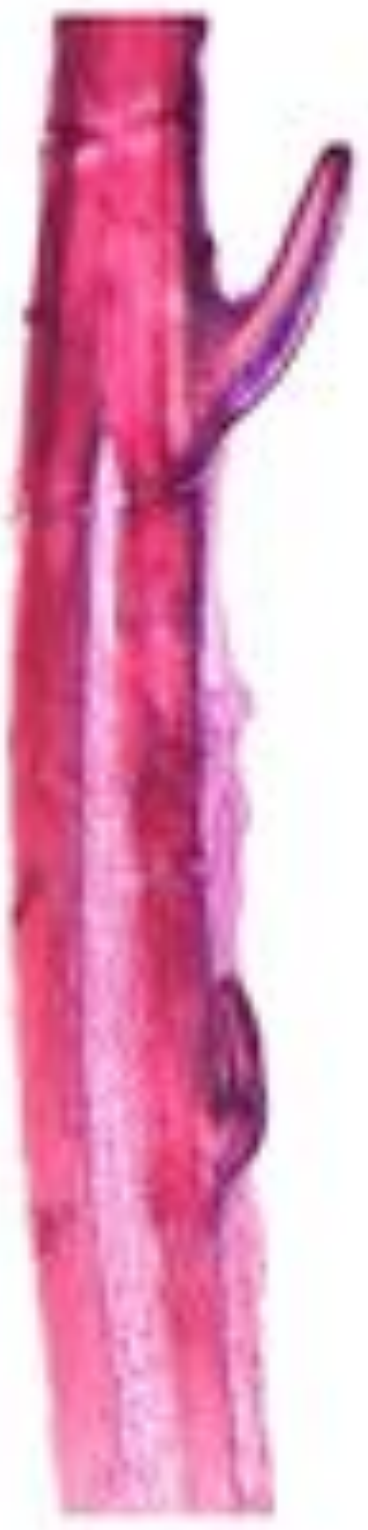

b

100 in

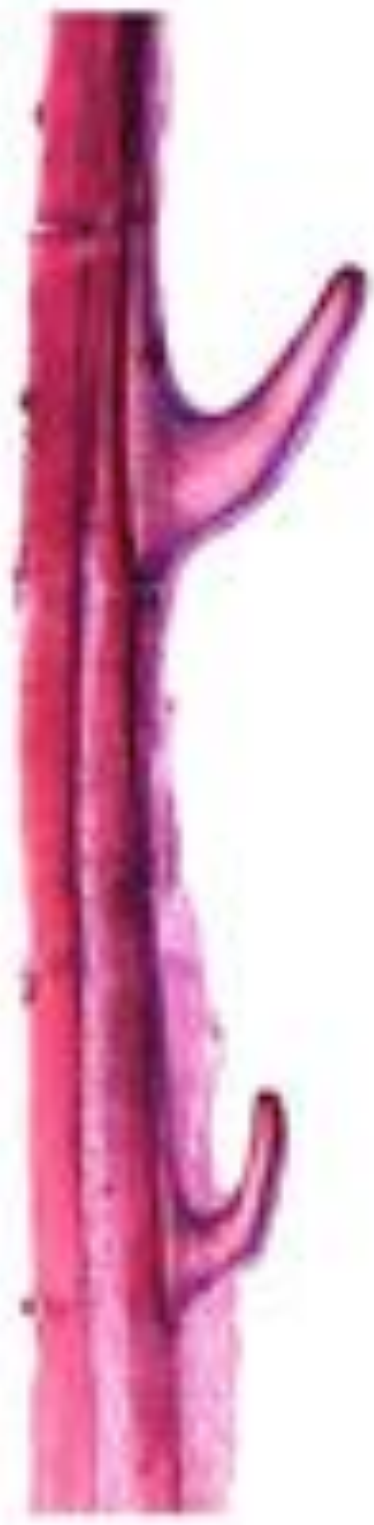

$E^{*}$ XW in

Figura 164. Distribuição, posição e formato dos processos ósseos no hemitriquium esquerdo do raio ramificado da nadadeira anal de machos de Hemigrammus bleheri. (a) vista lateral, (b) detalhe em vista lateral e (c) detalhe em vista anteroposterior. 


\section{Hemigrammus rhodostomus Ahl 1924}
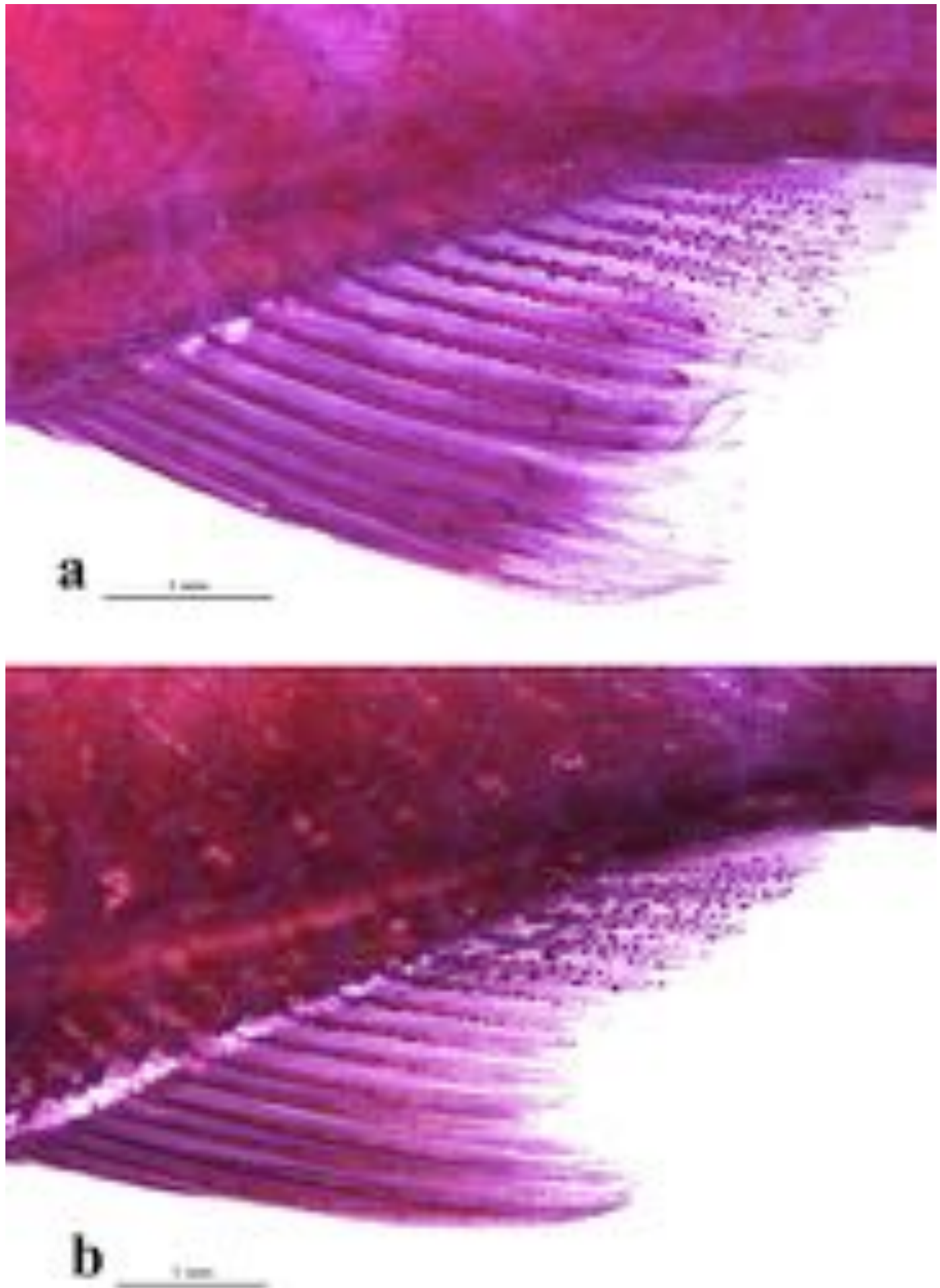

Figura 165. Nadadeira anal de machos (a) e de fêmeas (b) de Hemigrammus rhodostomus em vista lateral esquerda, evidenciando o formato do perfil distal das nadadeiras nos dois sexos e distribuição dos processos ósseos na nadadeira anal de macho. 

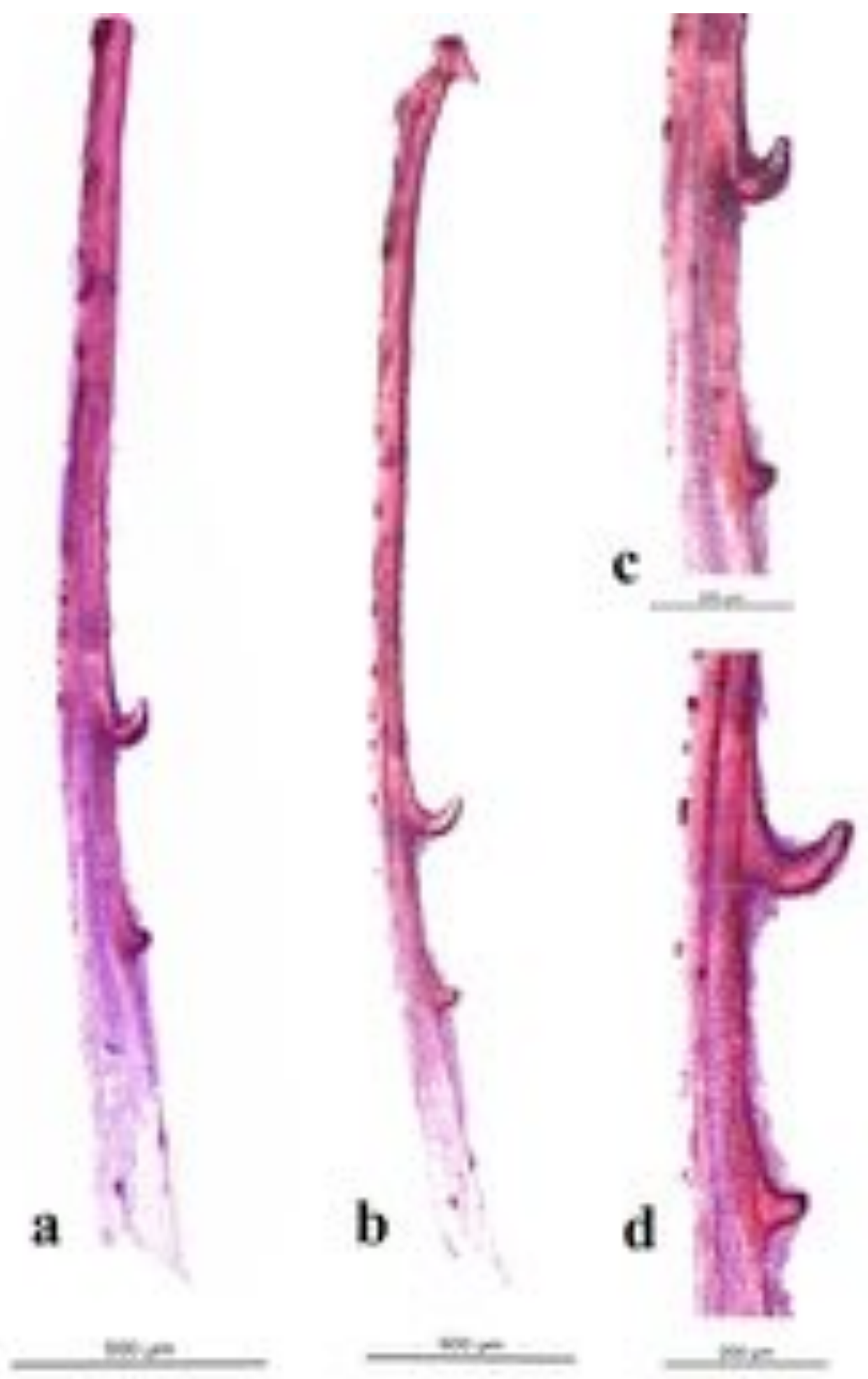

Figura 166. Distribuição, posição e formato dos processos ósseos no hemitriquium esquerdo do raio ramificado da nadadeira anal de machos de Hemigrammus rhodostomus. (a) vista lateral, (b) vista anteroposterior, (c) detalhe em vista lateral, (d) detalhe em vista anteroposterior. 


\section{Hemigrammus ulreyi (Boulenger 1895)}

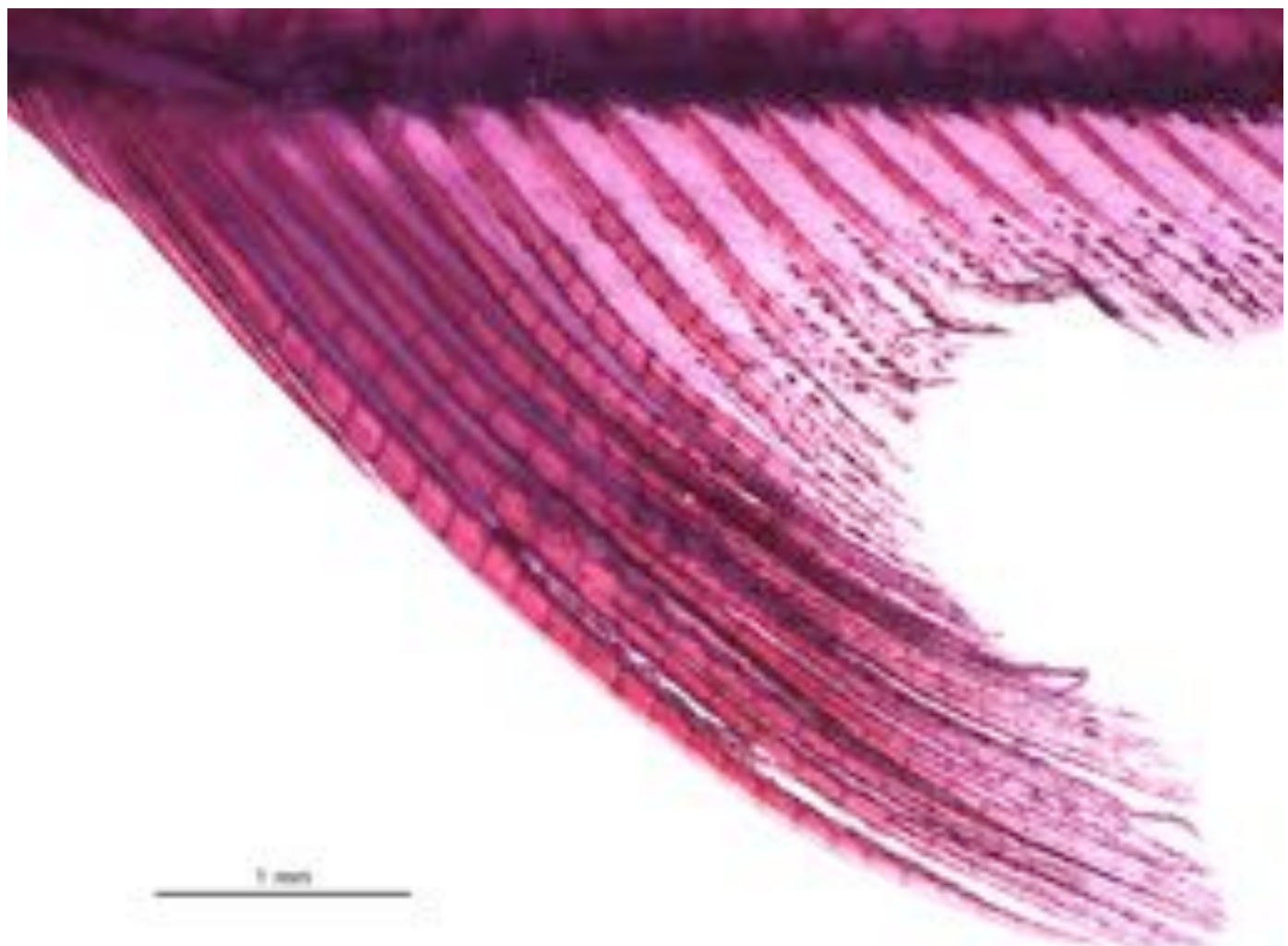

Figura 167. Nadadeira anal de machos de Hemigrammus ulreyi em vista lateral esquerda, evidenciando o formato do perfil da margem distal da nadadeira e distribuição dos processos ósseos. 


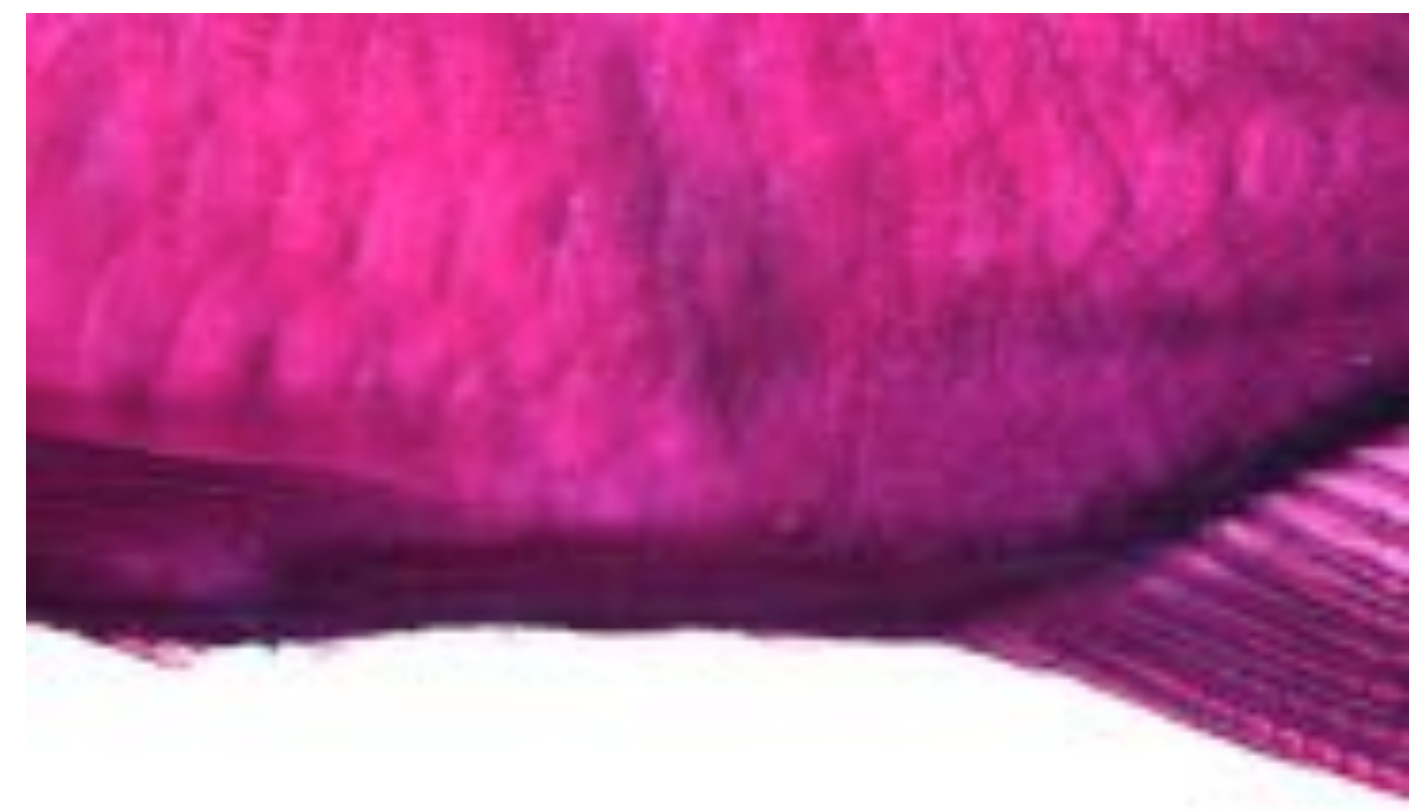

a
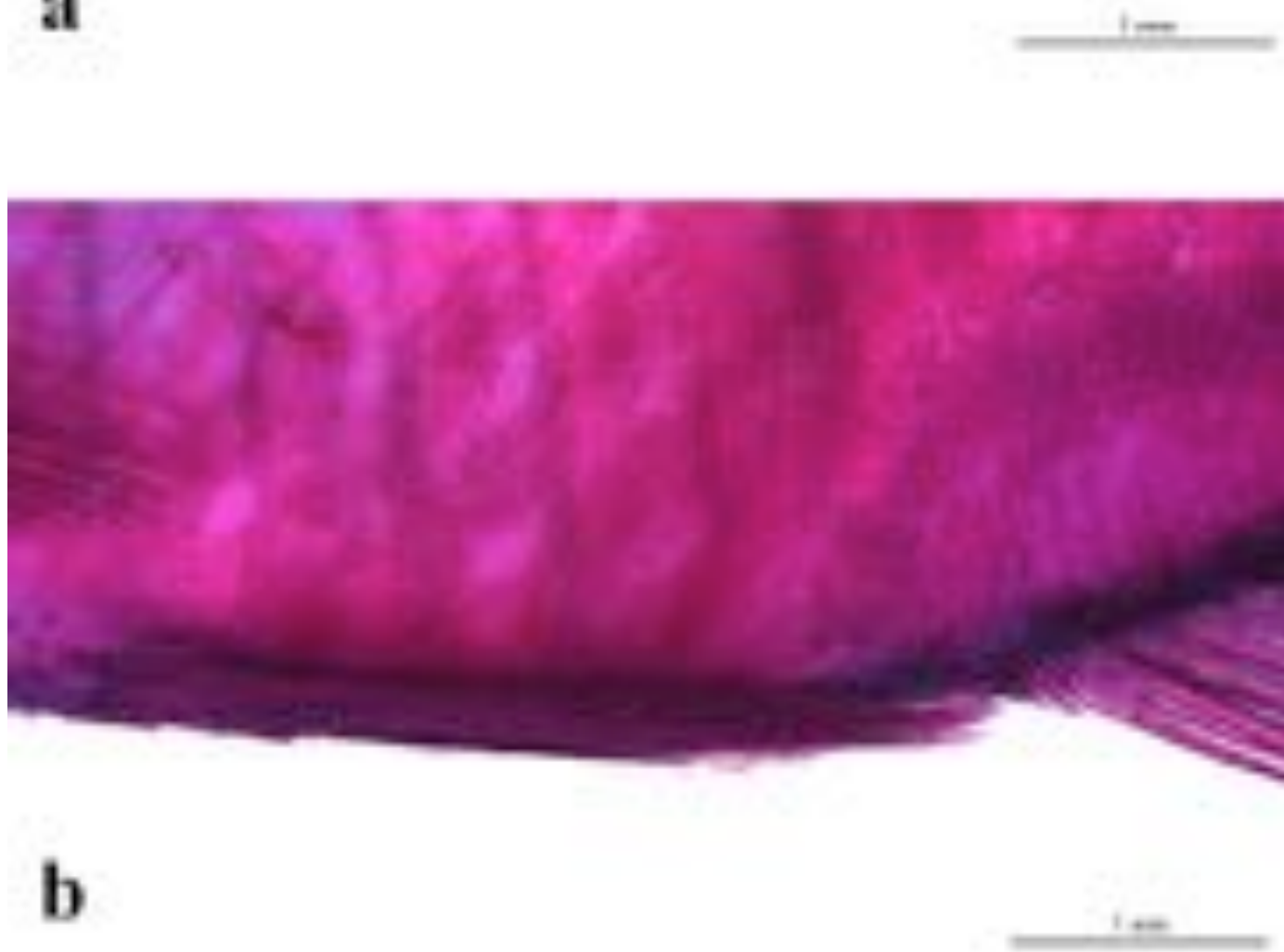

Figura 168. Nadadeira pélvica de machos (a) e de fêmeas (b) de Hemigrammus ulreyi em vista lateral esquerda, evidenciando o formato e comprimento da nadadeira nos dois sexos. 

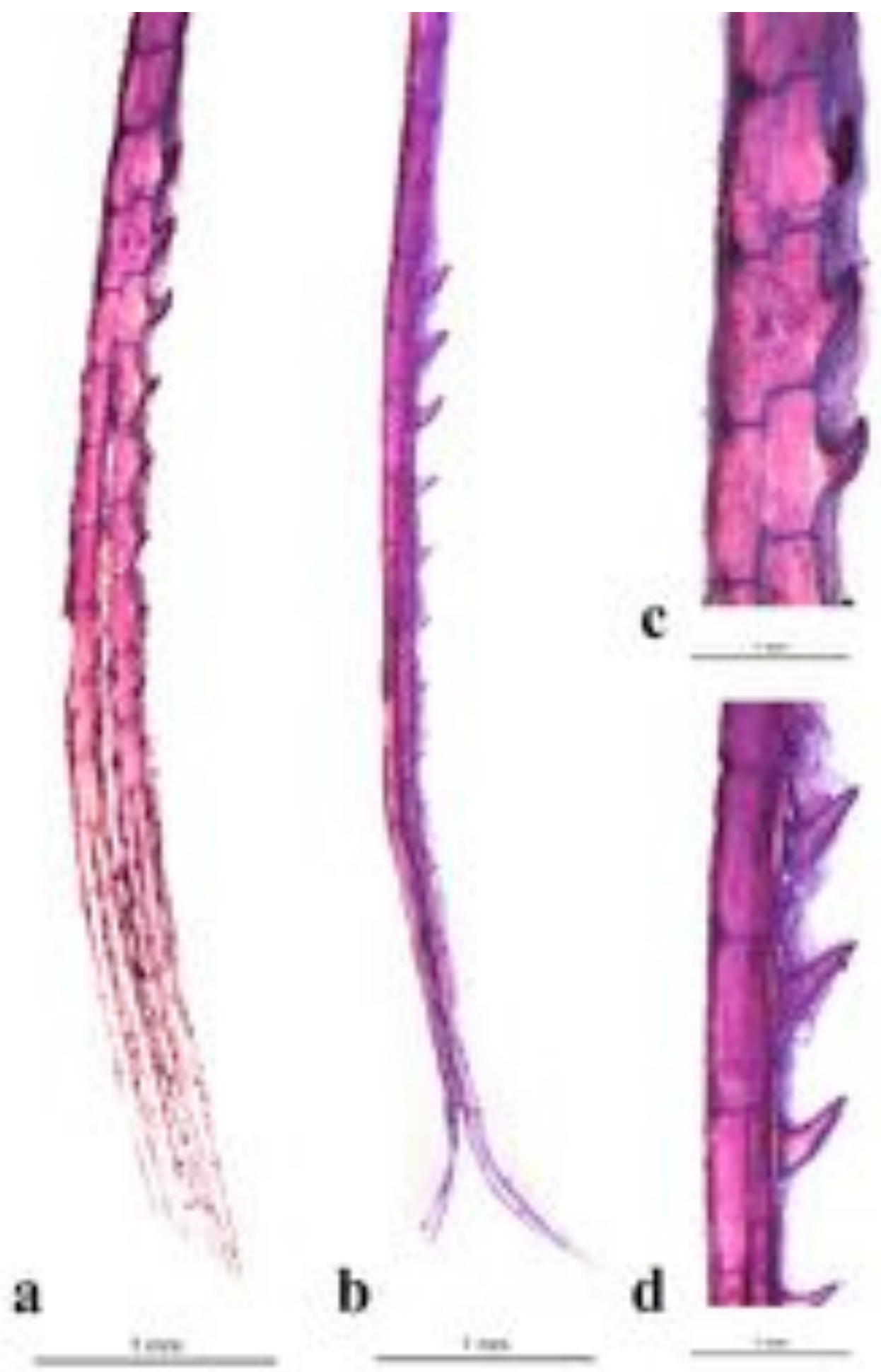

Figura 169. Distribuição, posição e formato dos processos ósseos no hemitriquium esquerdo do raio ramificado da nadadeira anal de machos de Hemigrammus ulreyi. (a) vista lateral, (b) vista anteroposterior, (c) detalhe em vista lateral, (d) detalhe em vista anteroposterior. 

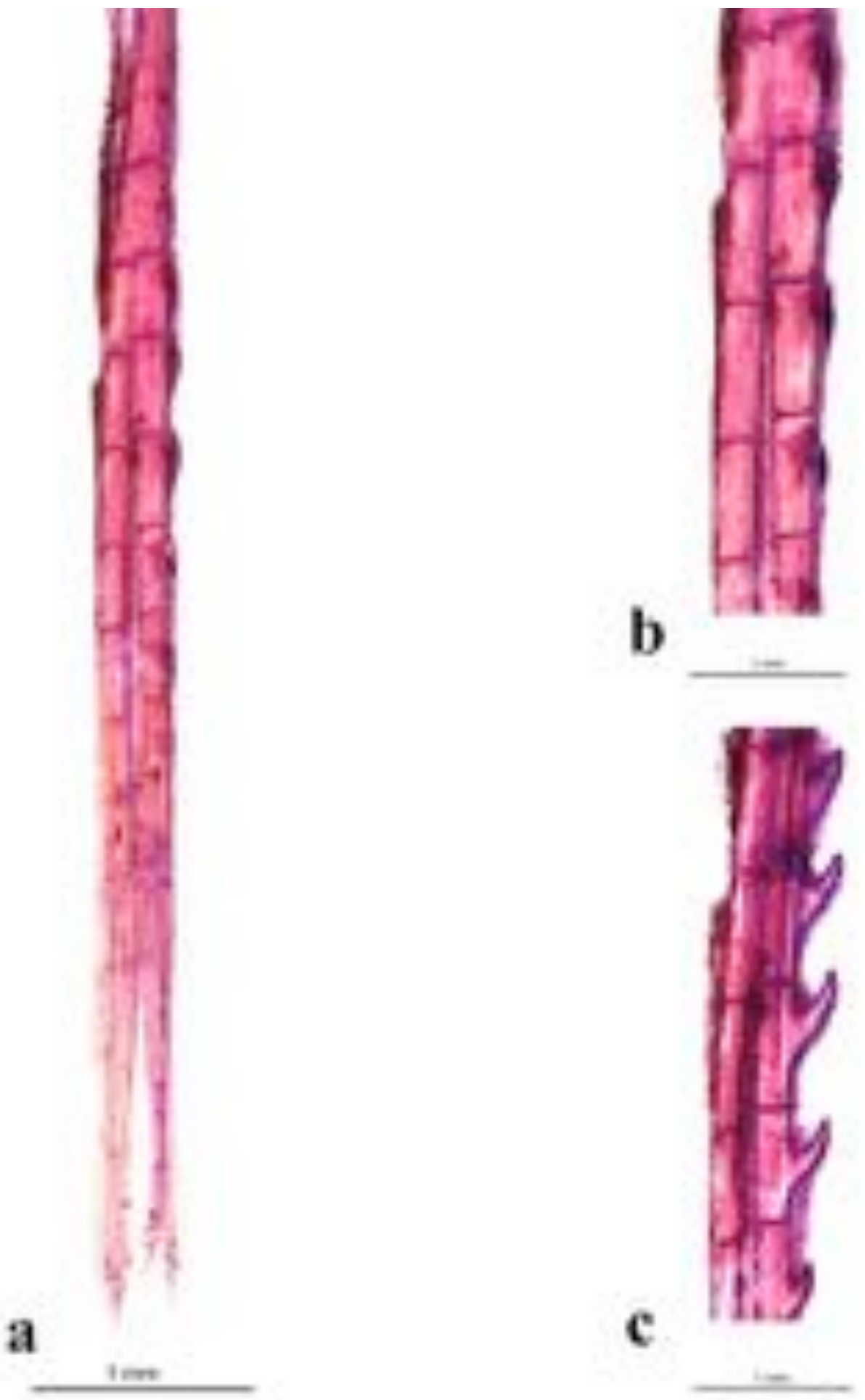

Figura 170. Distribuição, posição e formato dos processos ósseos no hemitriquium ventral da nadadeira pélvica esquerda de machos de Hemigrammus ulreyi. (a) vista ventral, (b) detalhe em vista ventral e (c) detalhe em vista lateromedial. 


\section{Hemigrammus unilineatus (Gill 1858)}
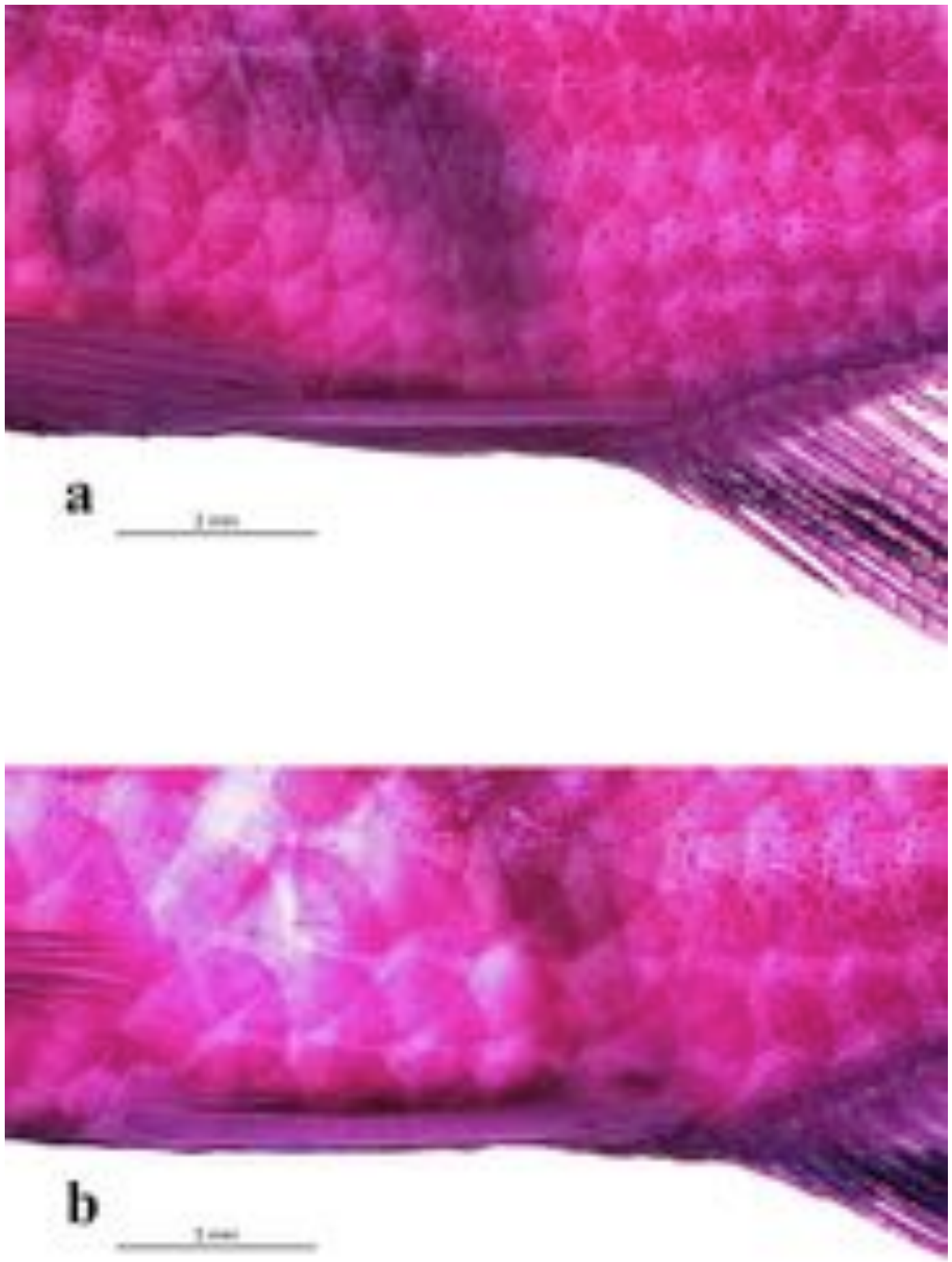

Figura 171. Nadadeira pélvica de machos (a) e de fêmeas (b) de Hemigrammus unilineatus em vista lateral esquerda, evidenciando o formato e comprimento da nadadeira nos dois sexos. 


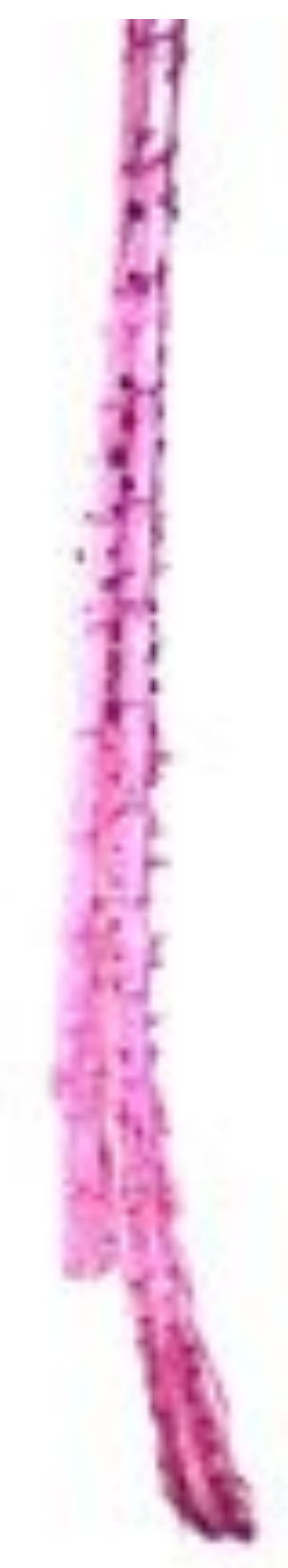

a

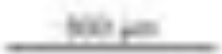

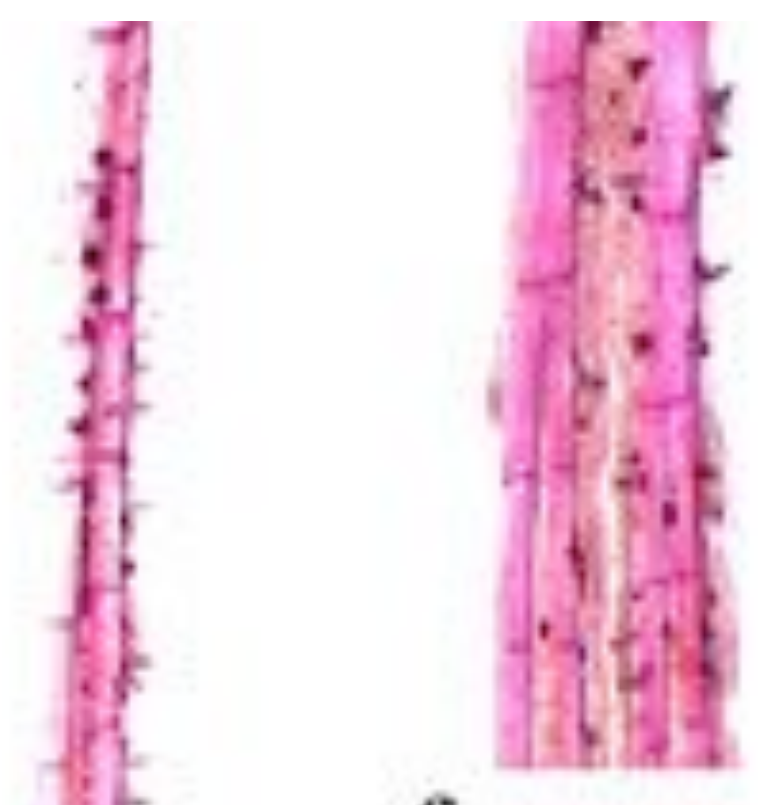

c
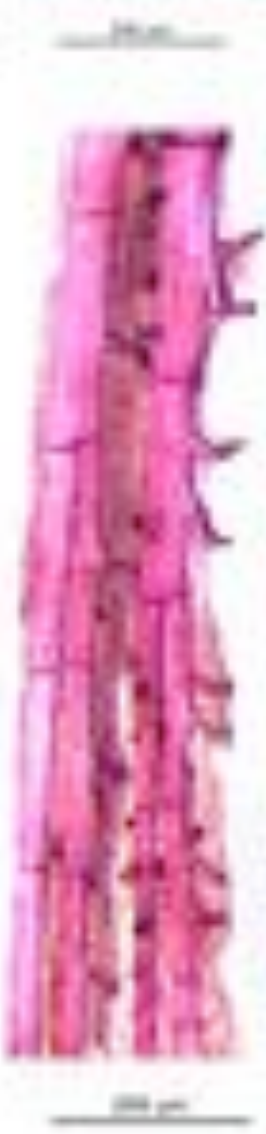

Figura 172. Distribuição, posição e formato dos processos ósseos no hemitriquium esquerdo do raio ramificado da nadadeira anal de machos de Hemigrammus unilineatus. (a) vista lateral, (b) vista anteroposterior, (c) detalhe em vista lateral, (d) detalhe em vista anteroposterior. 

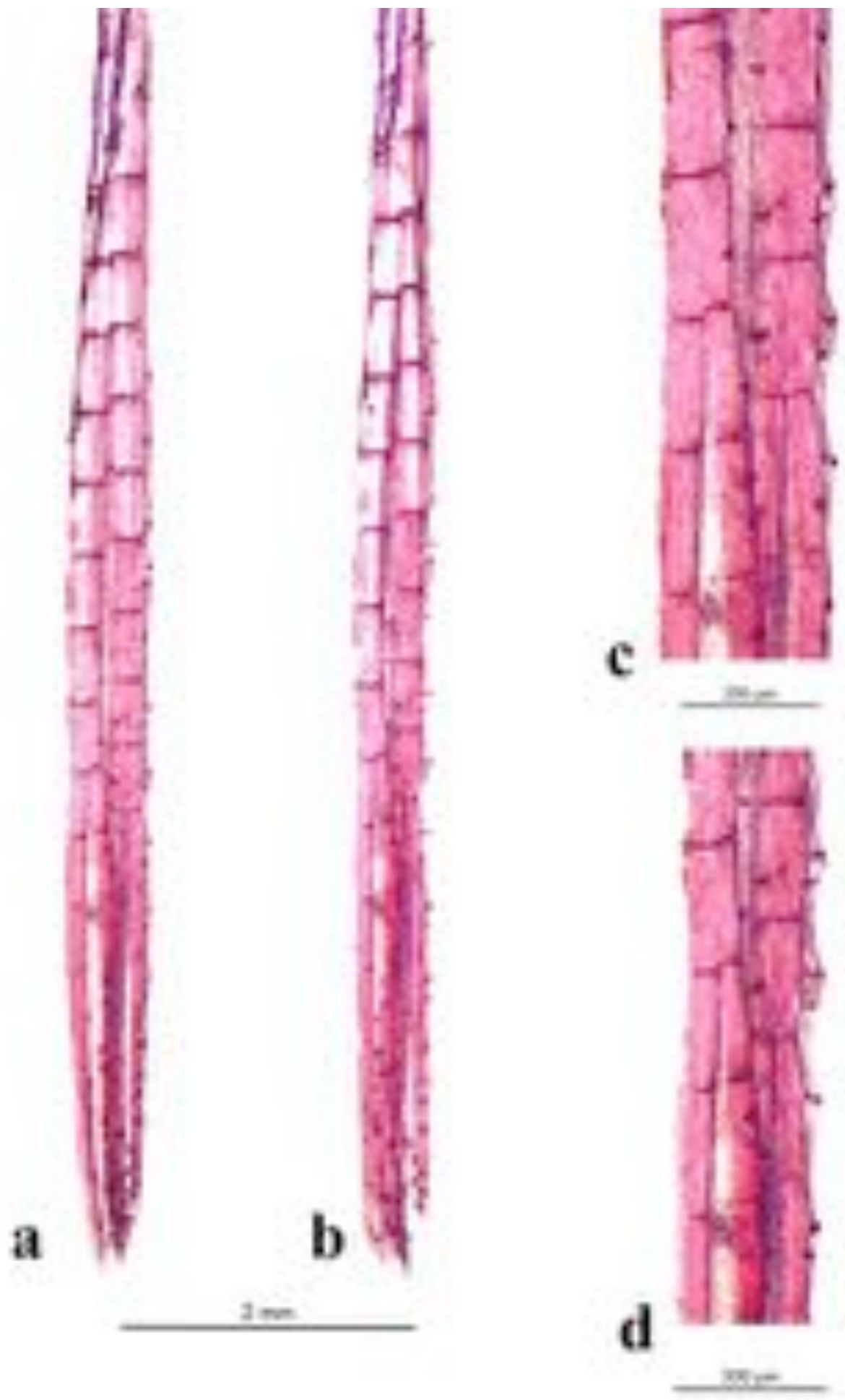

Figura 173. Distribuição, posição e formato dos processos ósseos no hemitriquium ventral da nadadeira pélvica direita de machos de Hemigrammus unilineatus. (a) vista ventral, (b) vista lateromedial, (c) detalhe em vista ventral e (d) detalhe em vista lateromedial. 


\section{Hyphessobrycon herbertaxelrodi Géry 1961}

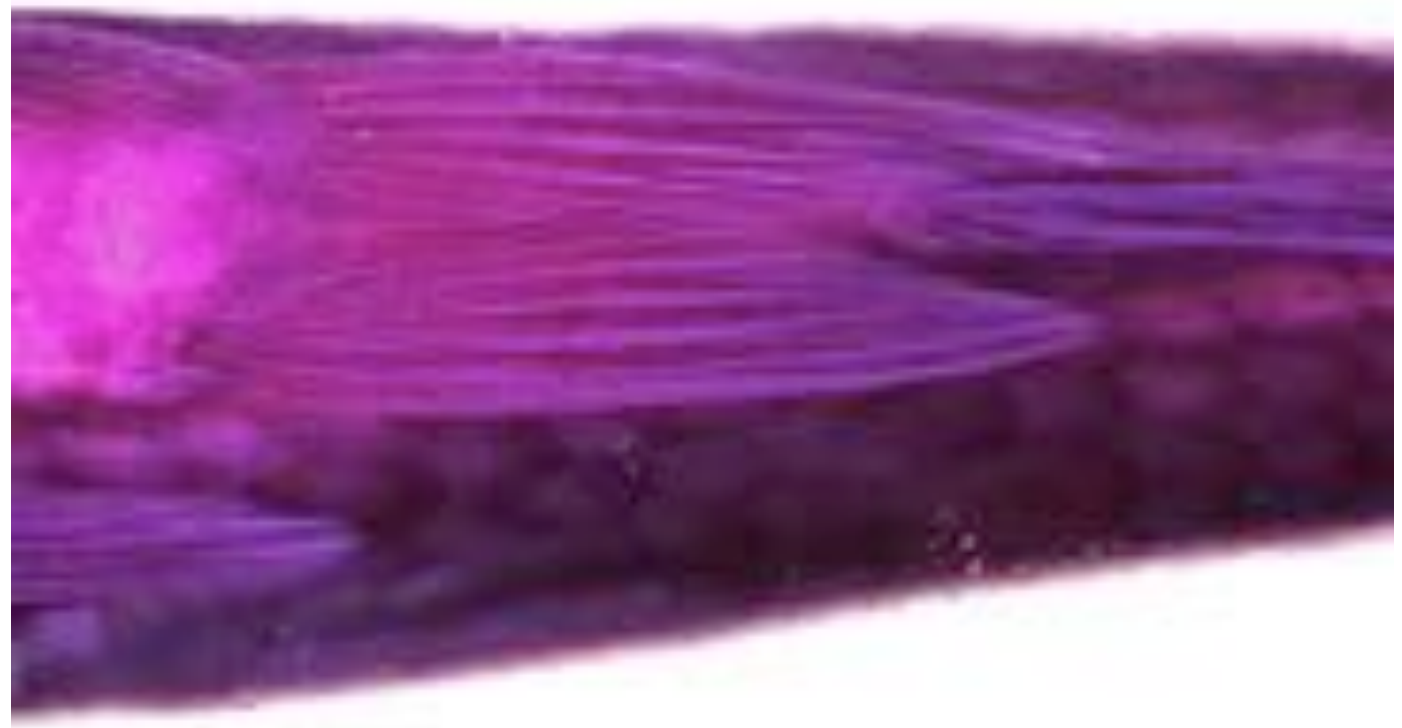

a $+5$

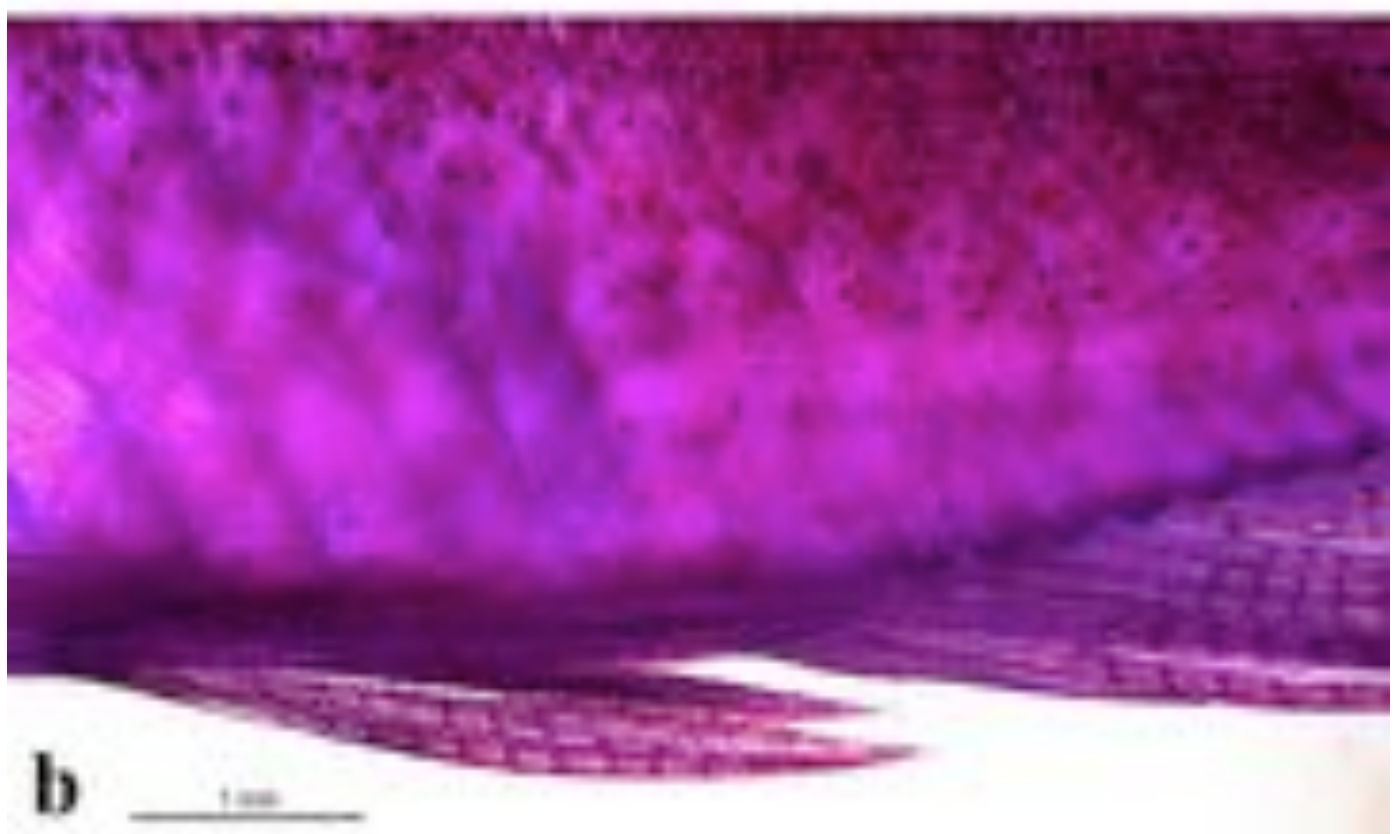

Figura 174. Nadadeira pélvica de machos de Hemigrammus herbertaxelrodi em vista ventral (a) e em vista lateral esquerda (b), evidenciando o formato e comprimento da nadadeira. 

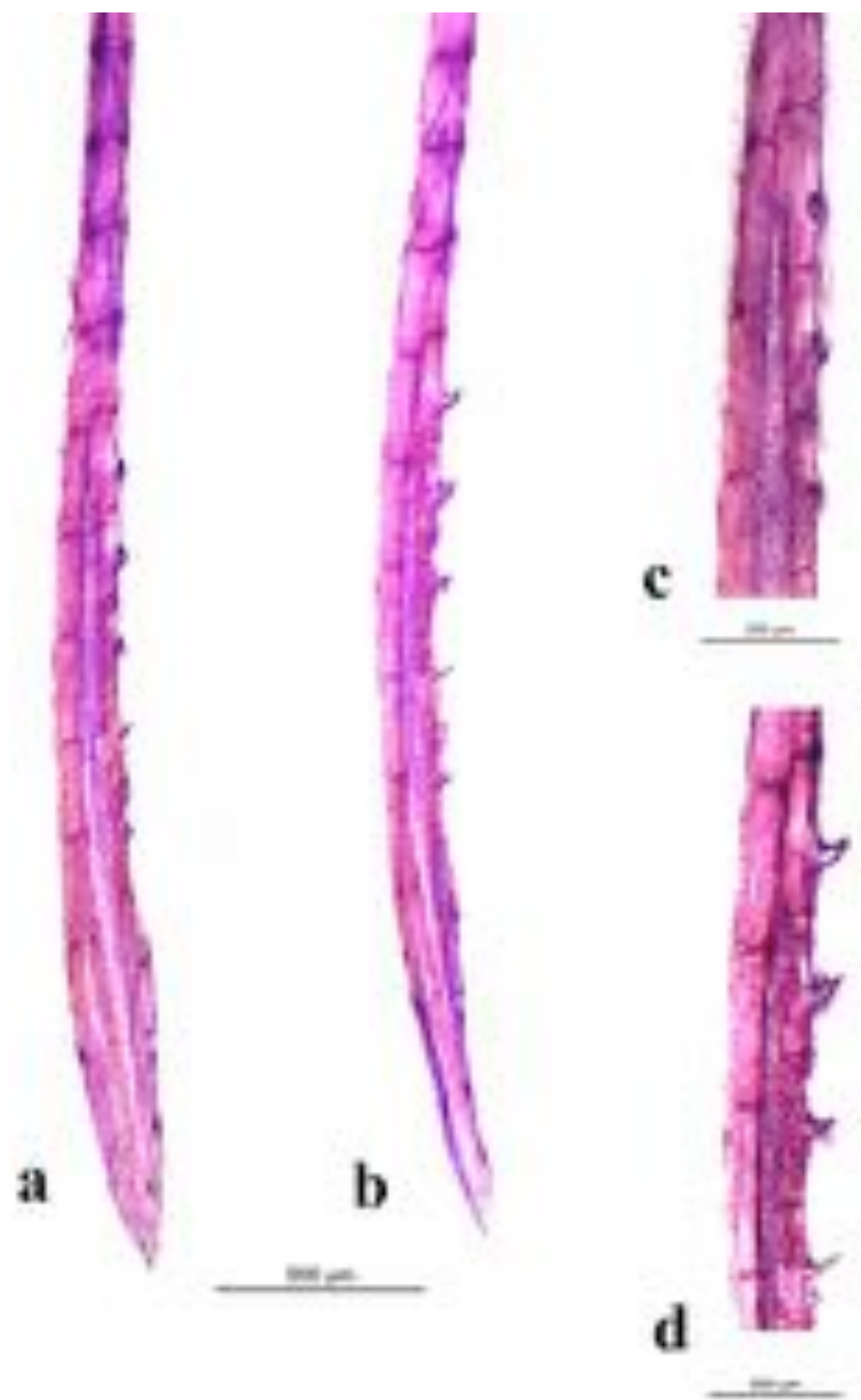

Figura 175. Distribuição, posição e formato dos processos ósseos no hemitriquium esquerdo do raio ramificado da nadadeira anal de machos de Hemigrammus herbertaxelrodi. (a) vista lateral, (b) vista anteroposterior, (c) detalhe em vista lateral, (d) detalhe em vista anteroposterior. 

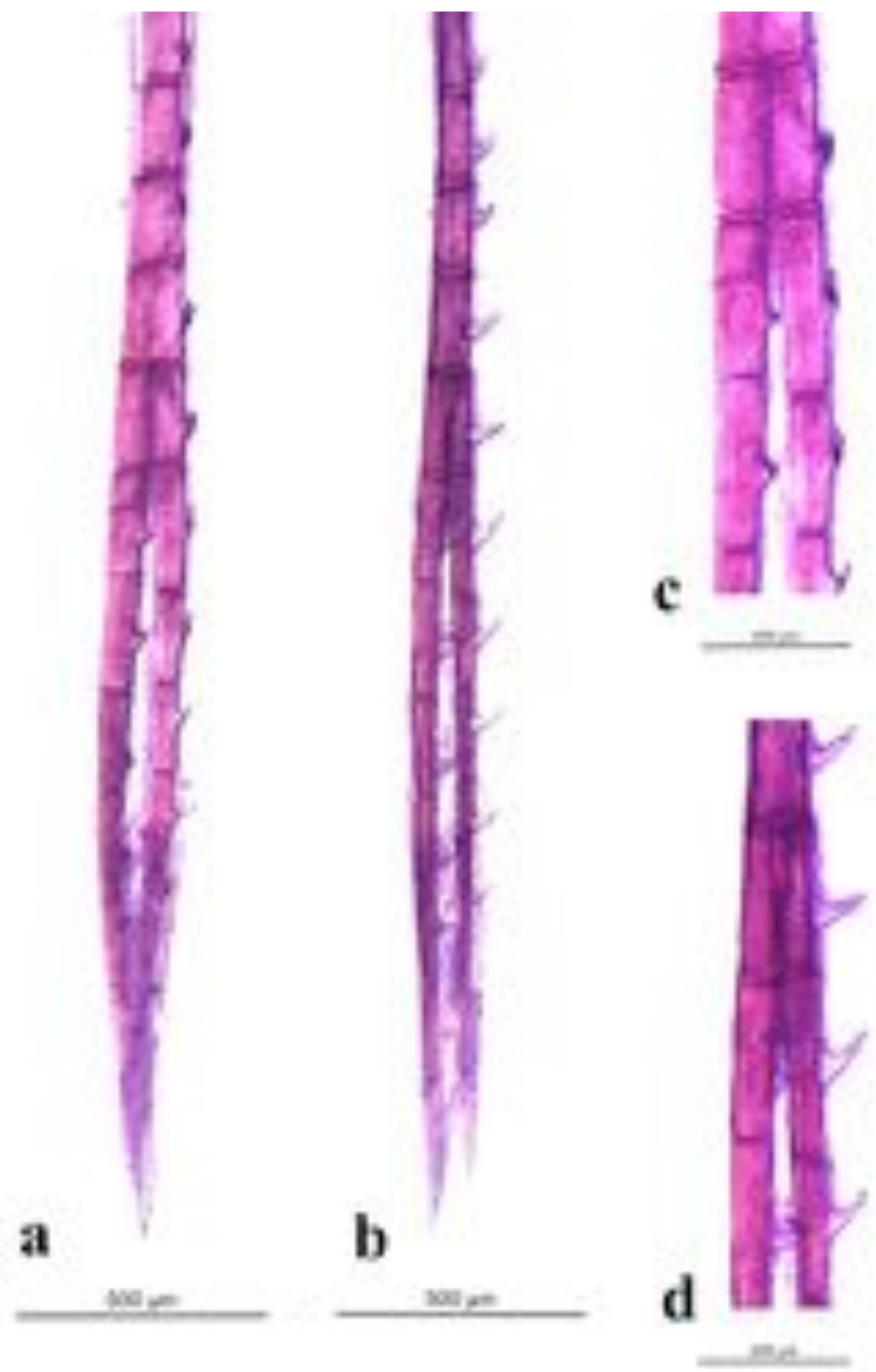

Figura 176. Distribuição, posição e formato dos processos ósseos no hemitriquium ventral da nadadeira pélvica direita de machos de Hemigrammus herbertaxelrodi. (a) vista ventral, (b) vista lateromedial, (c) detalhe em vista ventral e (d) detalhe em vista lateromedial. 


\section{Jupiaba yarina Zanata 1997}
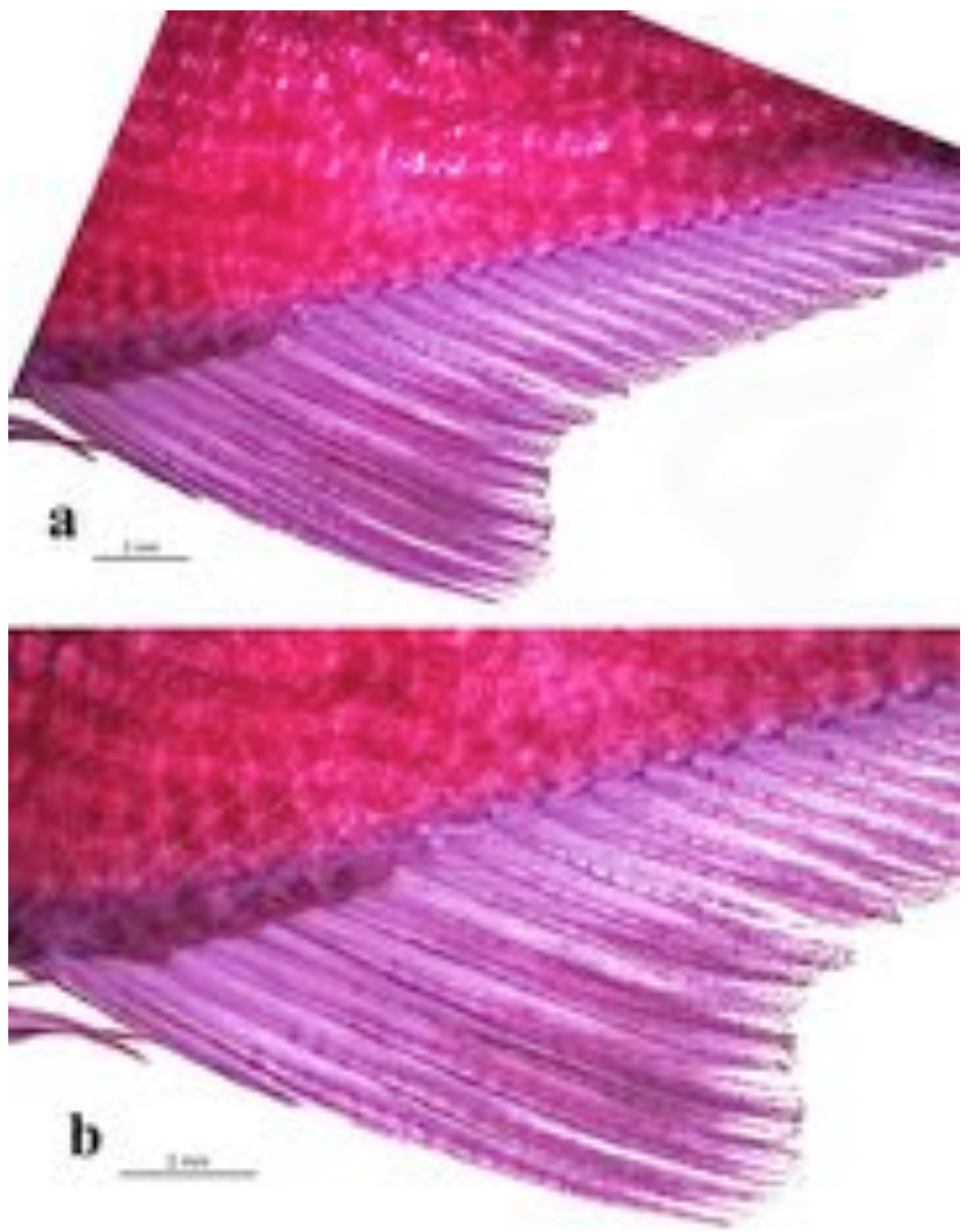

Figura 177. Nadadeira anal de machos (a) de Jupiaba yarina e detalhe da porção anterior (b) em vista lateral esquerda, evidenciando o formato do perfil da margem distal da nadadeira e distribuição dos processos ósseos. 

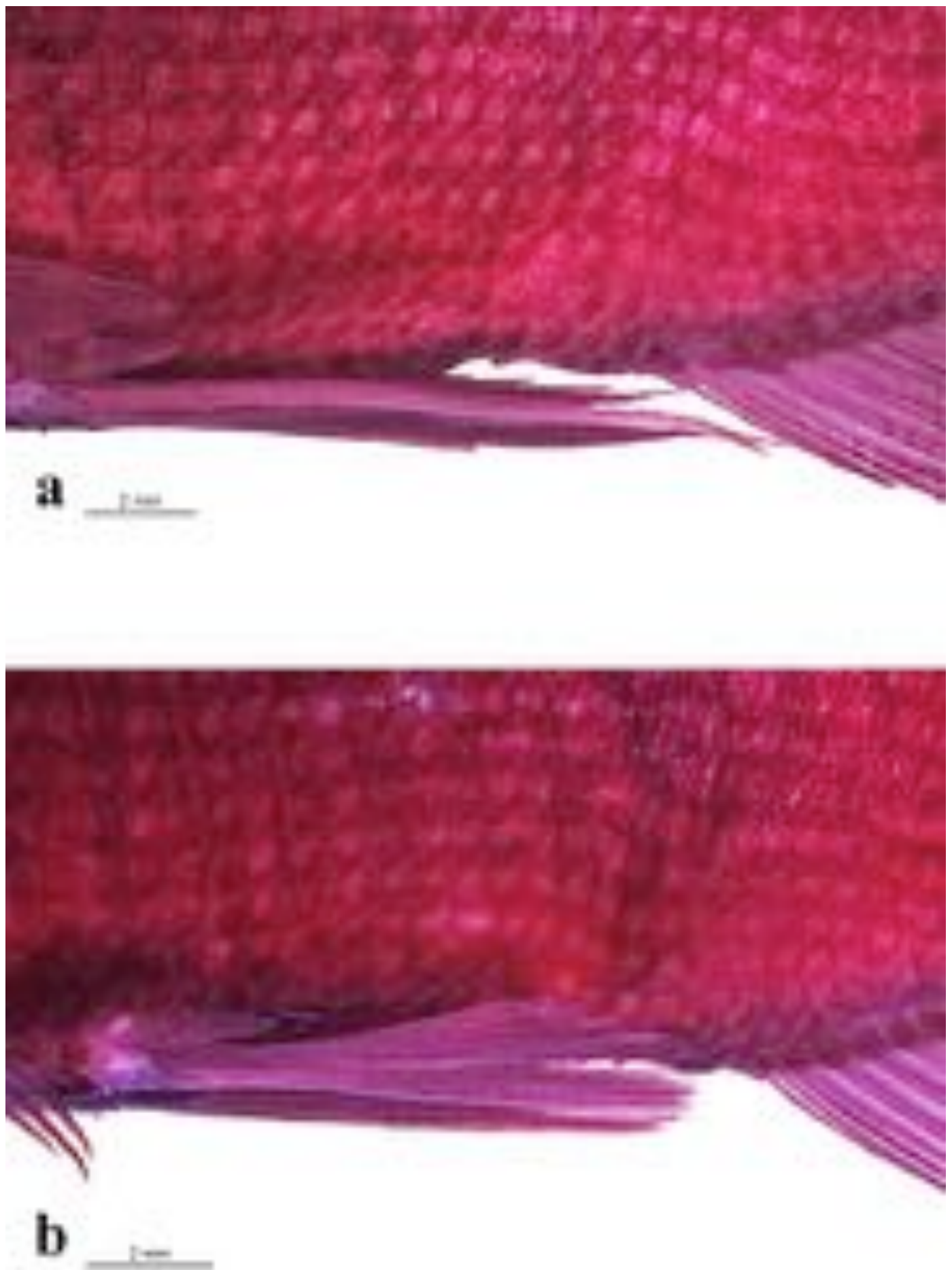

Figura 178. Nadadeira pélvica de machos (a) e de fêmeas (b) de Jupiaba yarina em vista lateral esquerda, evidenciando o formato e comprimento da nadadeira nos dois sexos. 

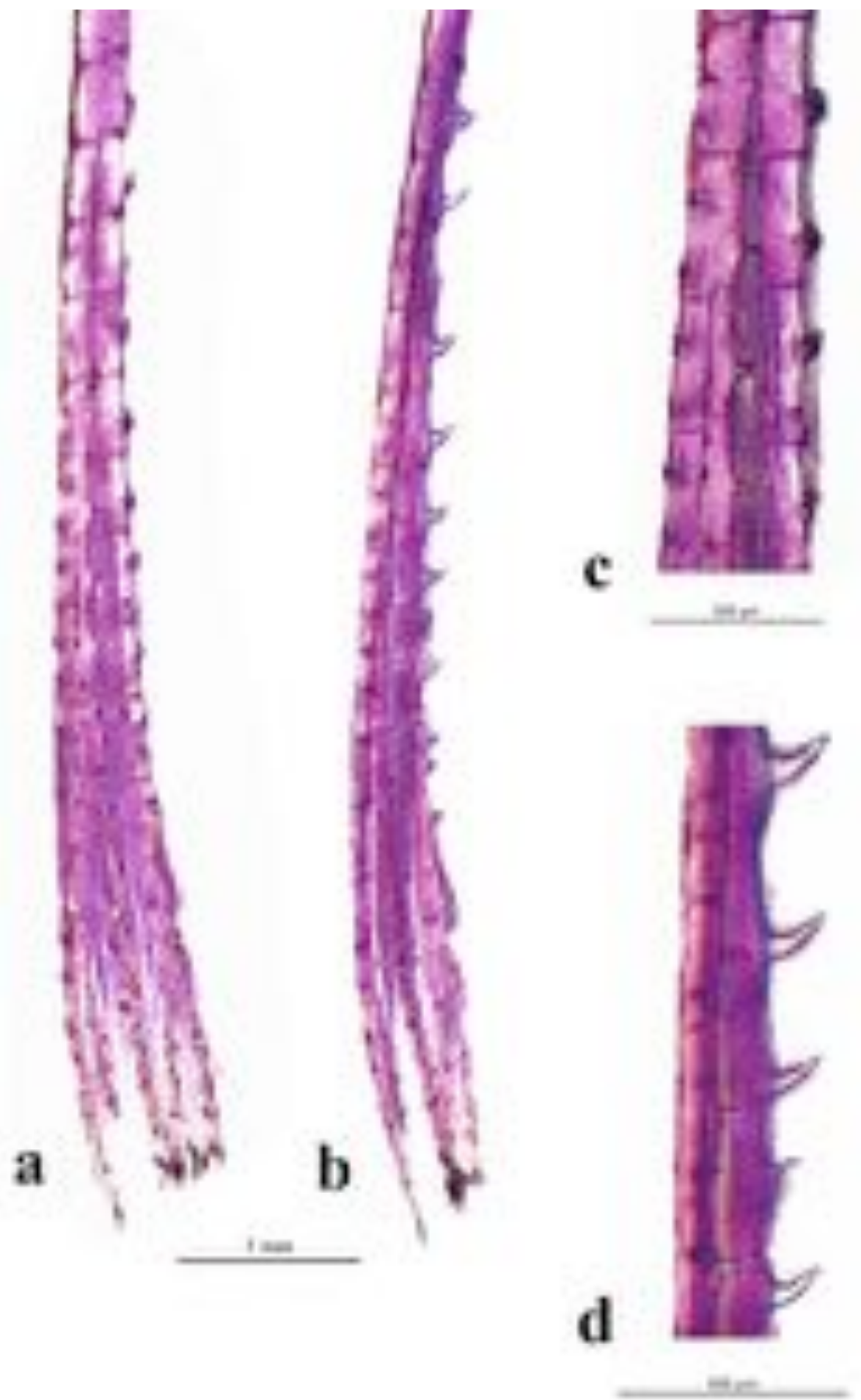

Figura 179. Distribuição, posição e formato dos processos ósseos no hemitriquium esquerdo do raio ramificado da nadadeira anal de machos de Jupiaba yarina. (a) vista lateral, (b) vista anteroposterior, (c) detalhe em vista lateral, (d) detalhe em vista anteroposterior. 

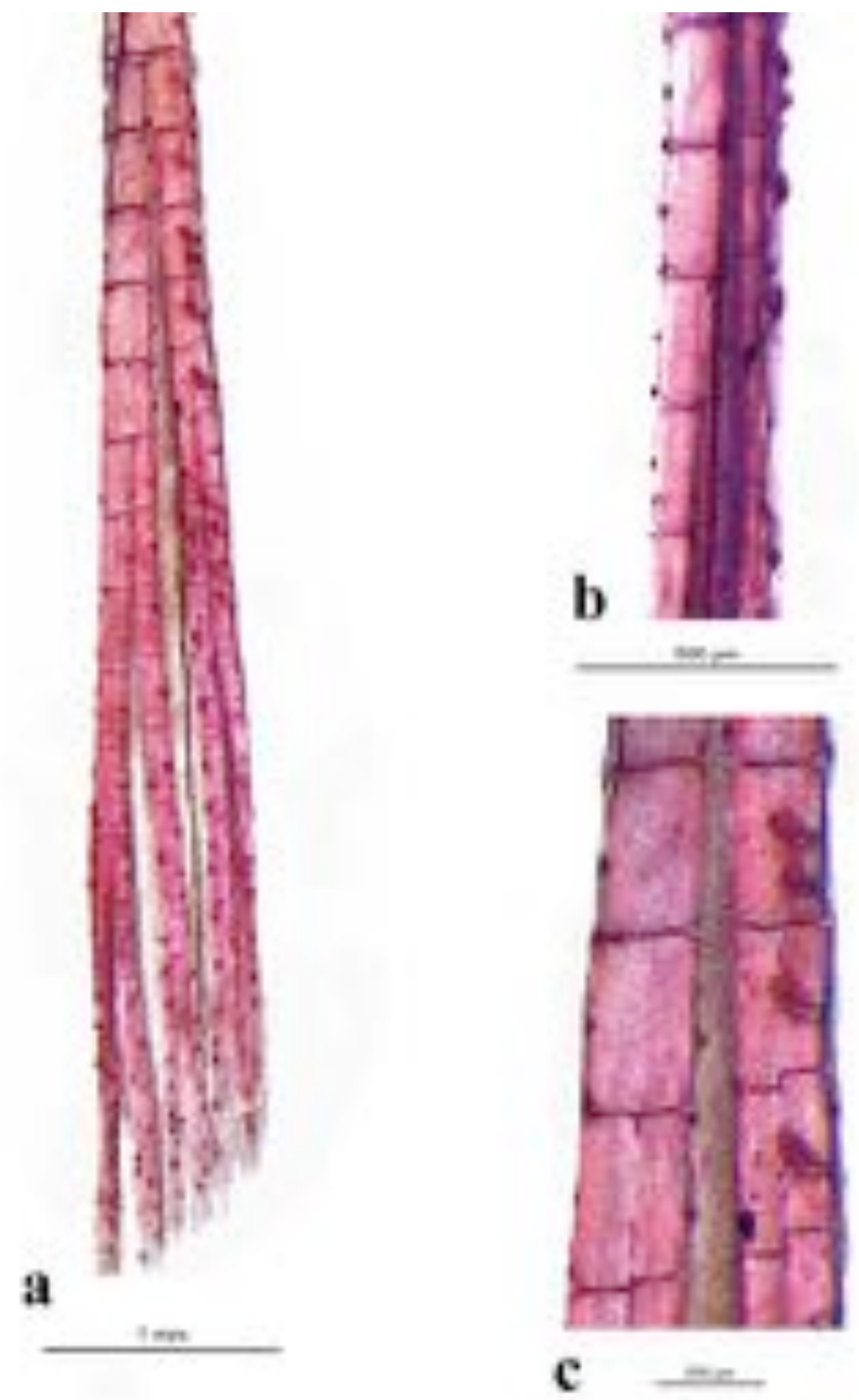

Figura 180. Distribuição, posição e formato dos processos ósseos no hemitriquium ventral da nadadeira pélvica direita de machos de Jupiaba yarina. (a) vista ventral, (b) detalhe em vista ventral e (c) detalhe em vista lateromedial. 


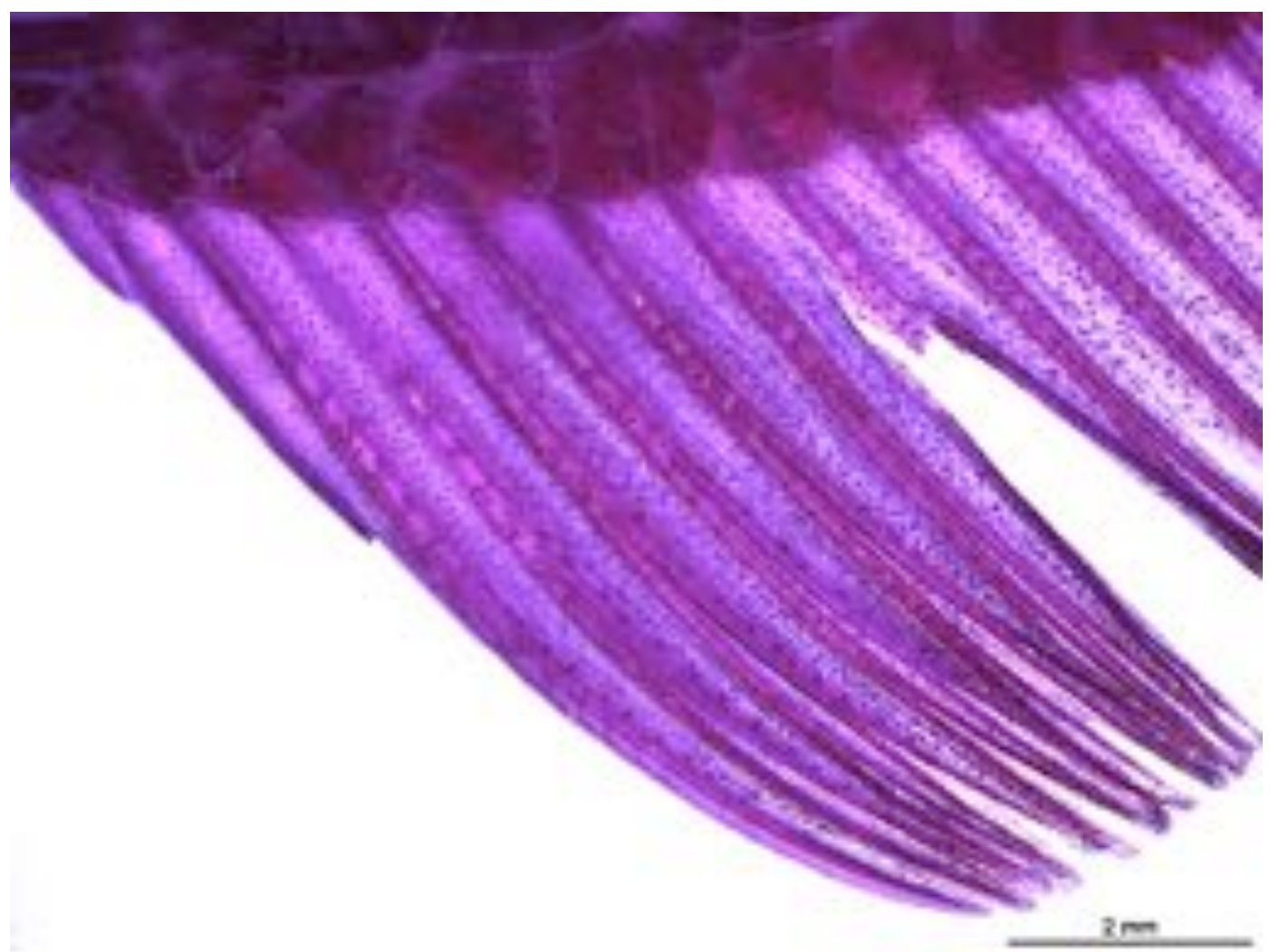

Figura 181. Nadadeira anal de machos de Moenkhausia sanctaefilomenae em vista lateral esquerda, evidenciando o formato do perfil da margem distal da nadadeira e distribuição dos processos ósseos. 


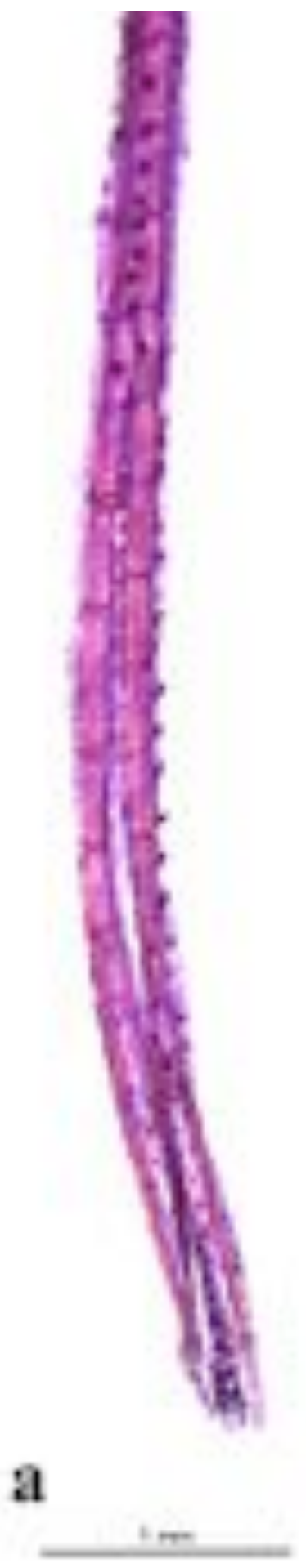

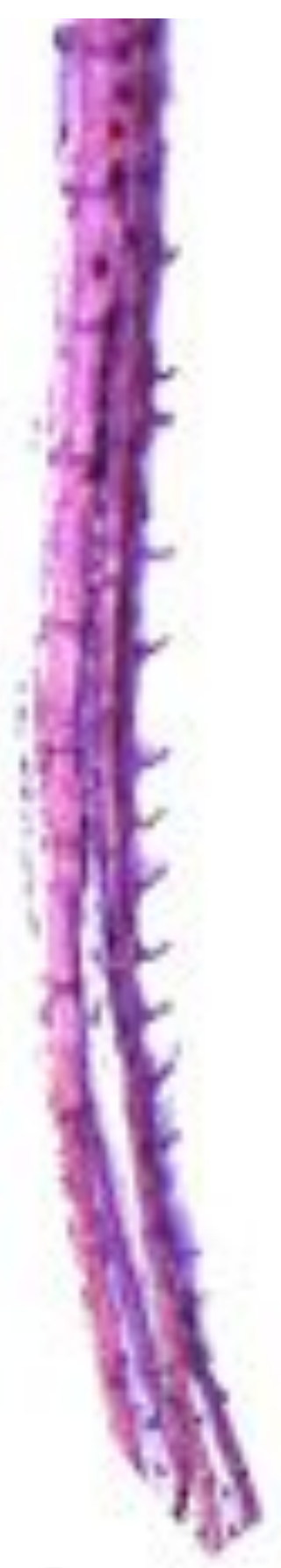

b

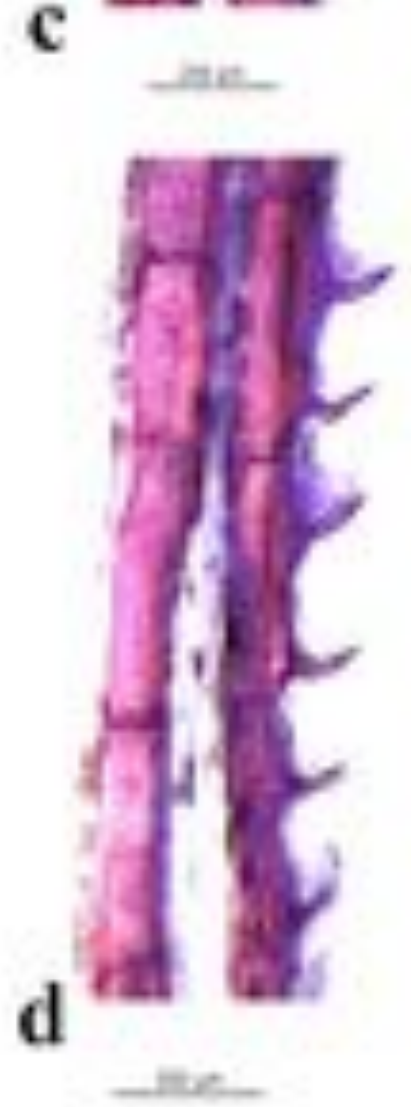

Figura 182. Distribuição, posição e formato dos processos ósseos no hemitriquium esquerdo do raio ramificado da nadadeira anal de machos de Moenkhausia sanctaefilomenae. (a) vista lateral, (b) vista anteroposterior, (c) detalhe em vista lateral, (d) detalhe em vista anteroposterior. 

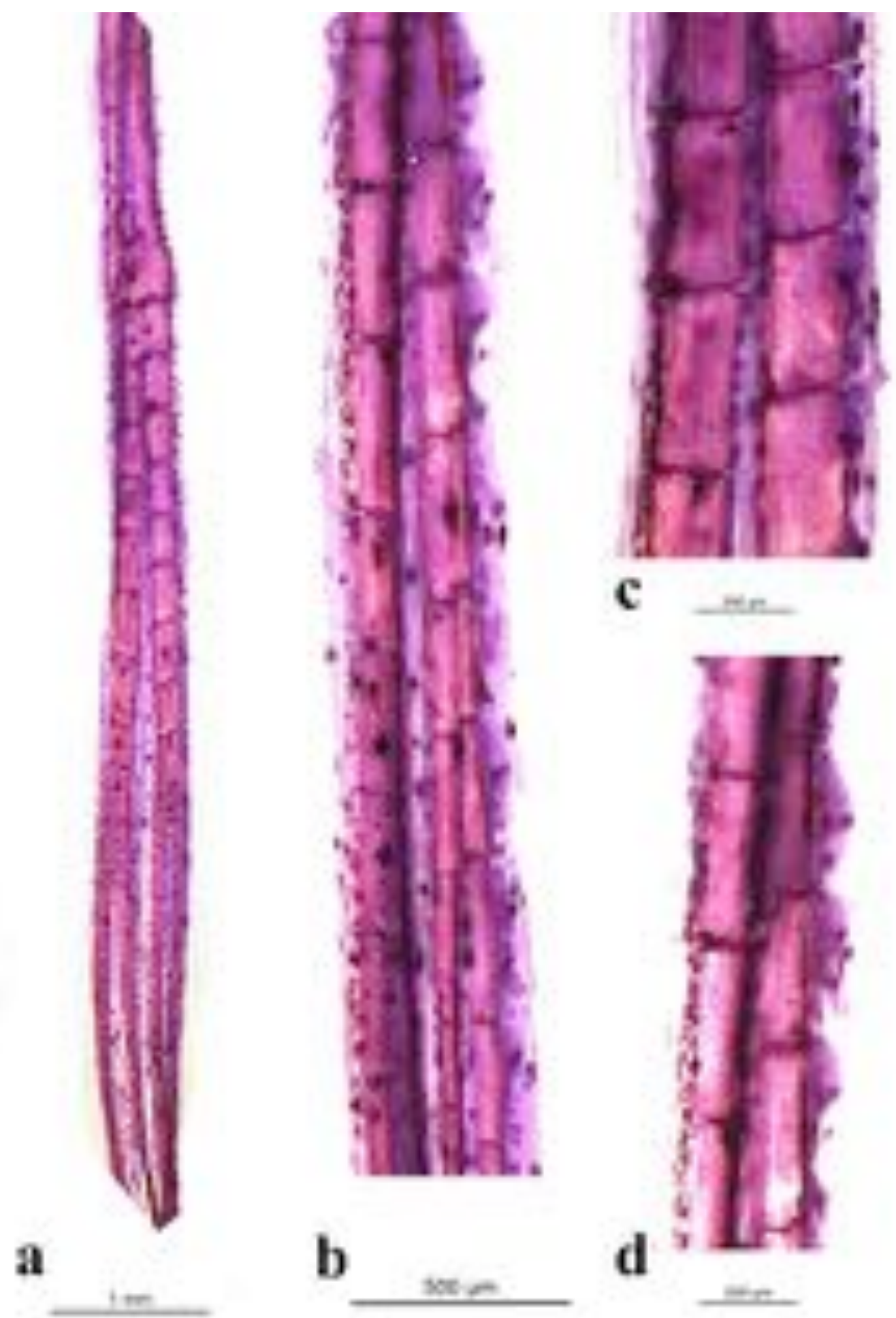

Figura 183. Distribuição, posição e formato dos processos ósseos no hemitriquium ventral da nadadeira pélvica direita de machos de Moenkhausia sanctaefilomenae. (a) vista ventral, (b) vista lateromedial, (c) detalhe em vista ventral e (d) detalhe em vista lateromedial. 
Poptella paraguayensis (Eigenamann 1907)

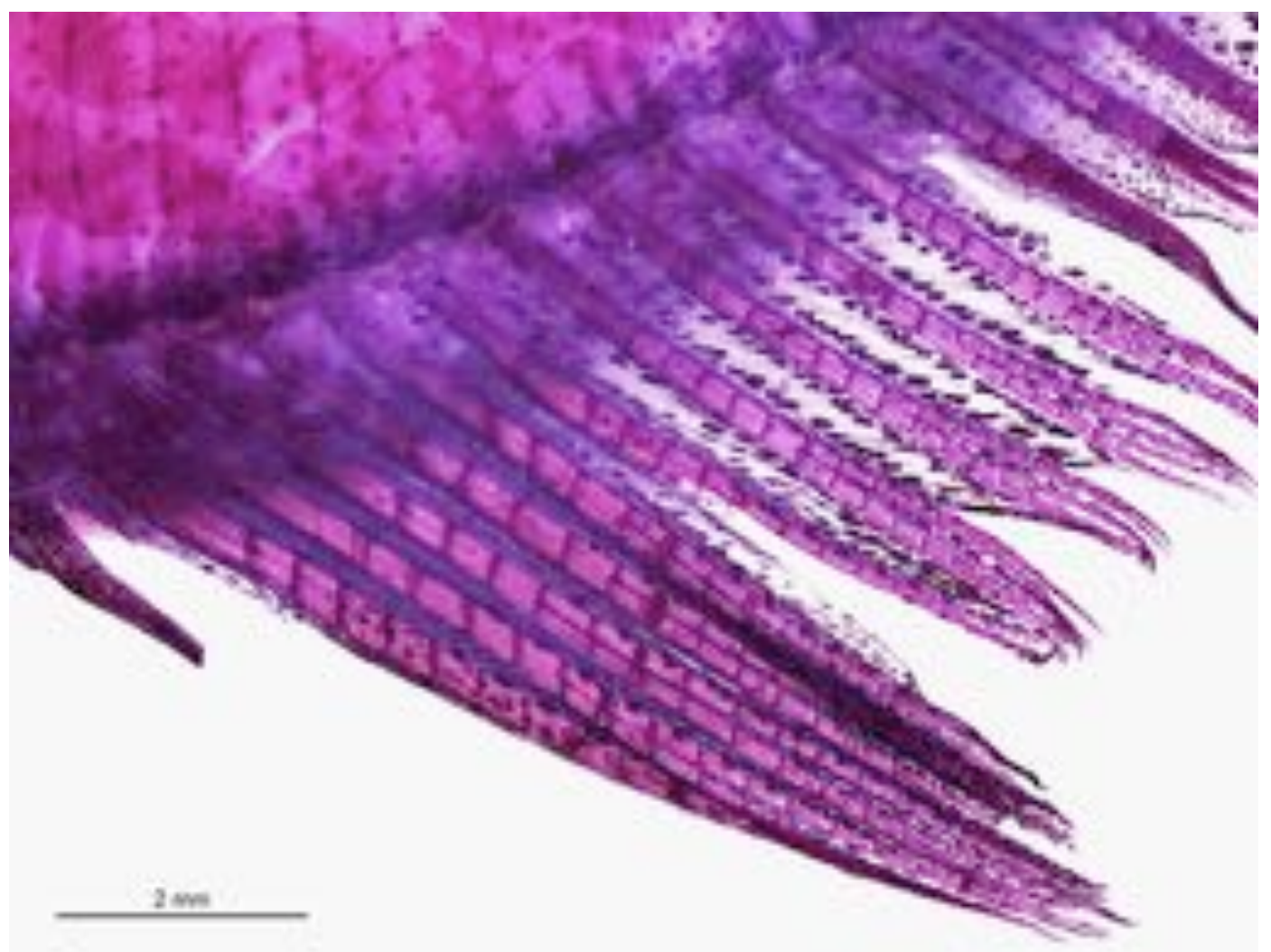

Figura 184. Nadadeira anal de machos de Poptella paraguayensis em vista lateral esquerda, evidenciando o formato do perfil da margem distal da nadadeira e distribuição dos processos ósseos. 

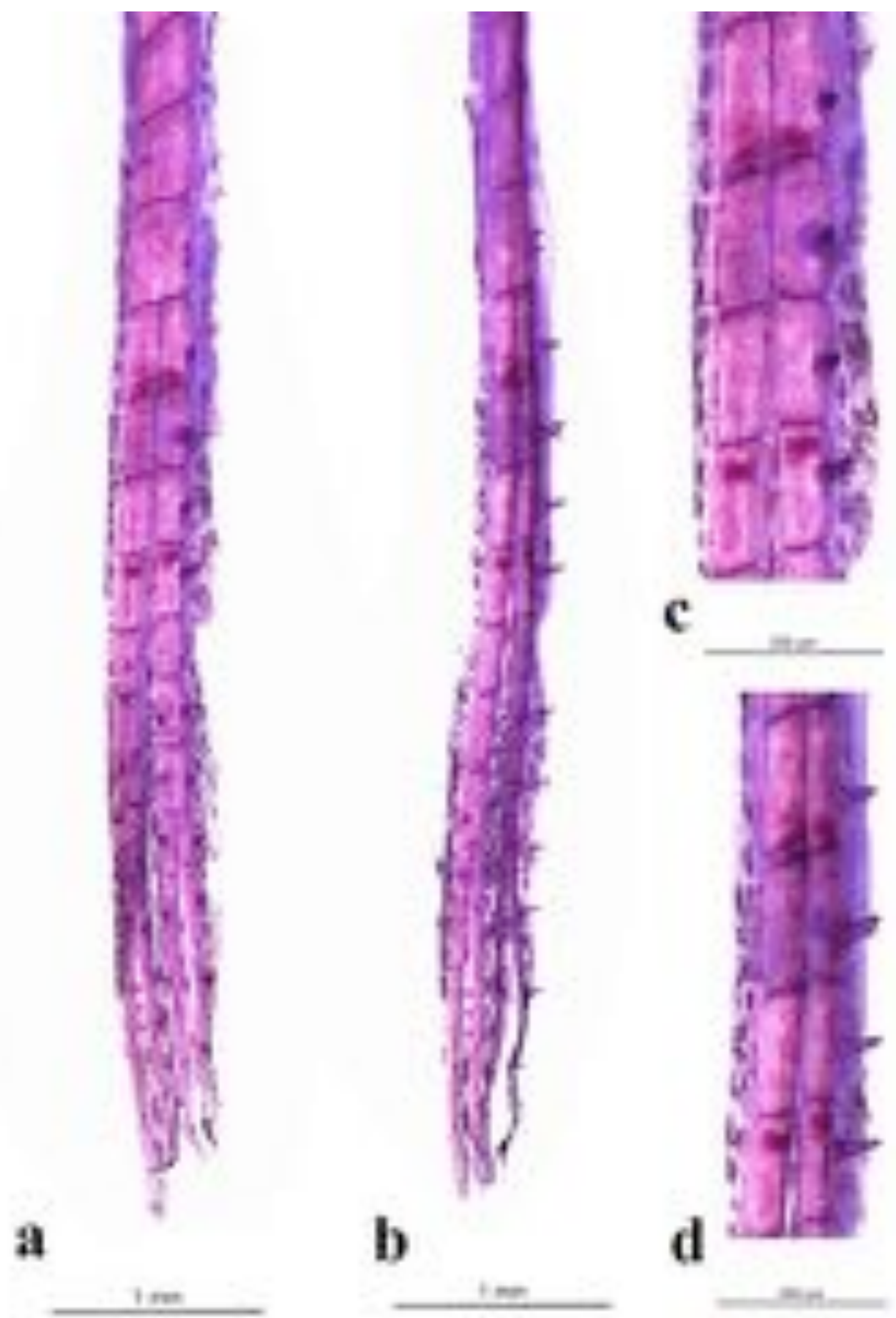

c
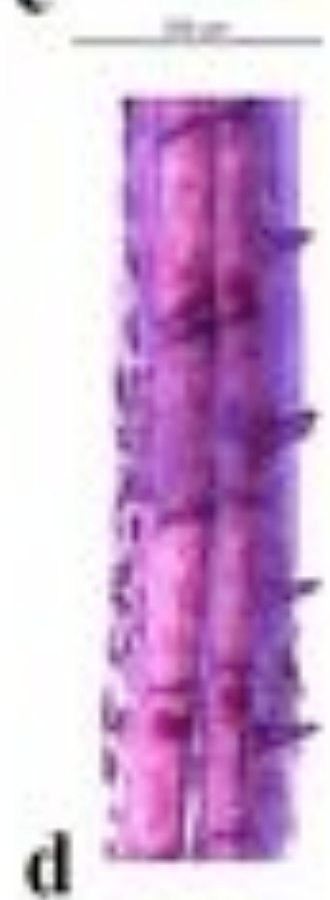

Figura 185. Distribuição, posição e formato dos processos ósseos no hemitriquium esquerdo do raio ramificado da nadadeira anal de machos de Poptella paraguayensis. (a) vista lateral, (b) vista anteroposterior, (c) detalhe em vista lateral, (d) detalhe em vista anteroposterior. 

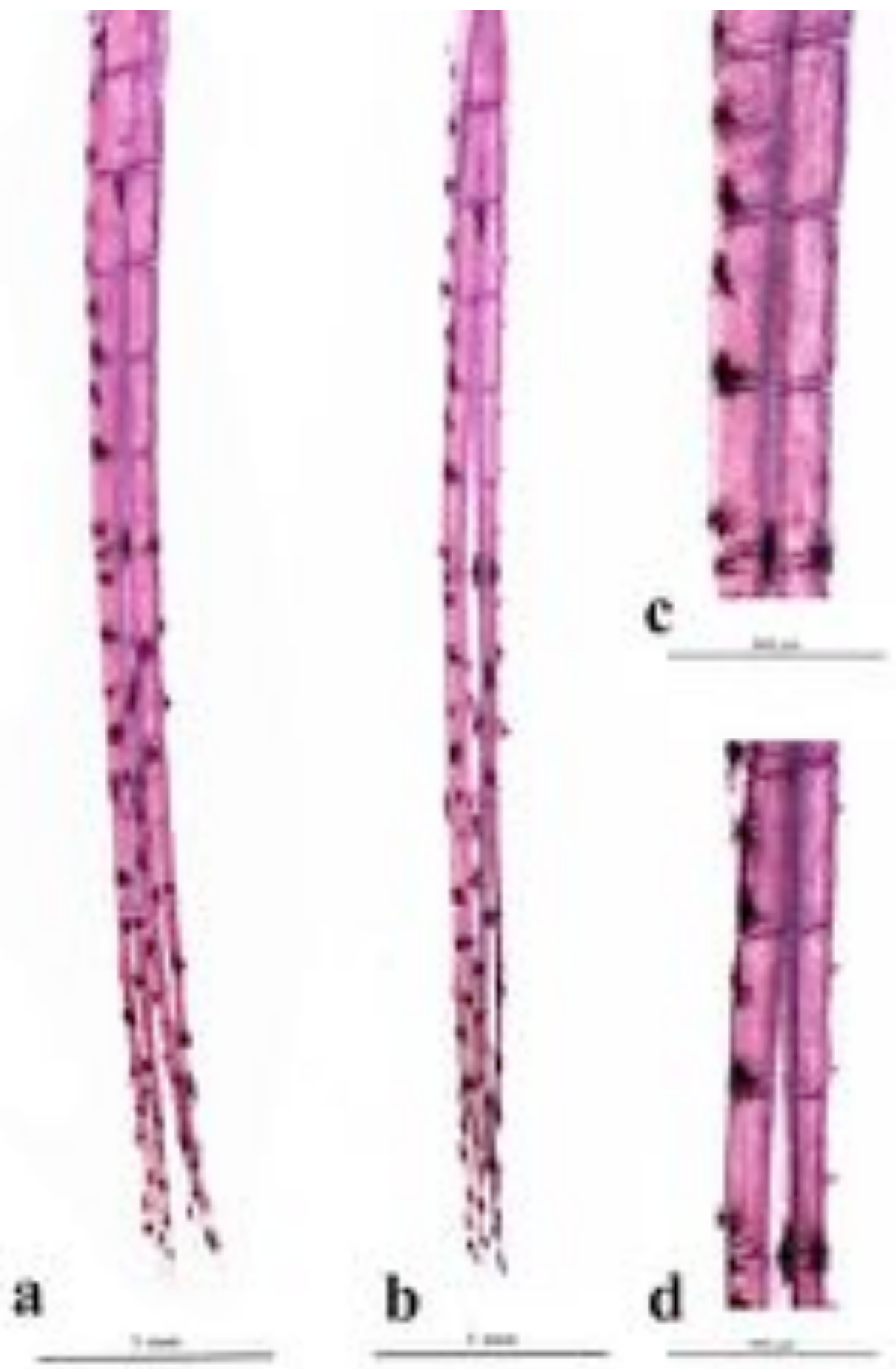

Figura 186. Distribuição, posição e formato dos processos ósseos no hemitriquium ventral da nadadeira pélvica direita de machos de Poptella paraguayensis. (a) vista ventral, (b) vista lateromedial, (c) detalhe em vista ventral e (d) detalhe em vista lateromedial. 


\section{Stethaprion crenatum Eigenman 1916}

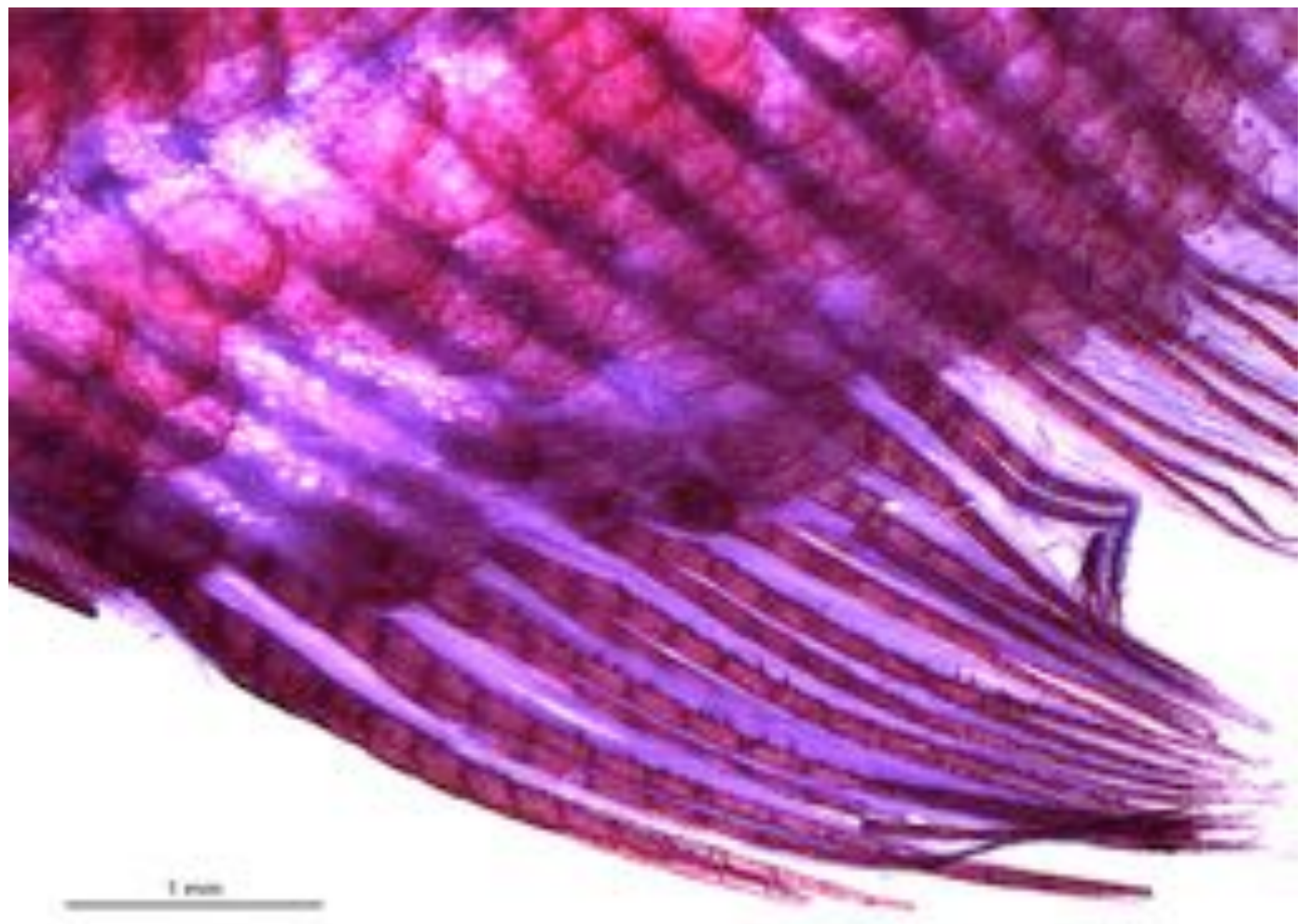

Figura 187. Nadadeira anal de machos de Stethaprion crenatum em vista lateral esquerda, evidenciando o formato do perfil da margem distal da nadadeira e distribuição dos processos ósseos. 

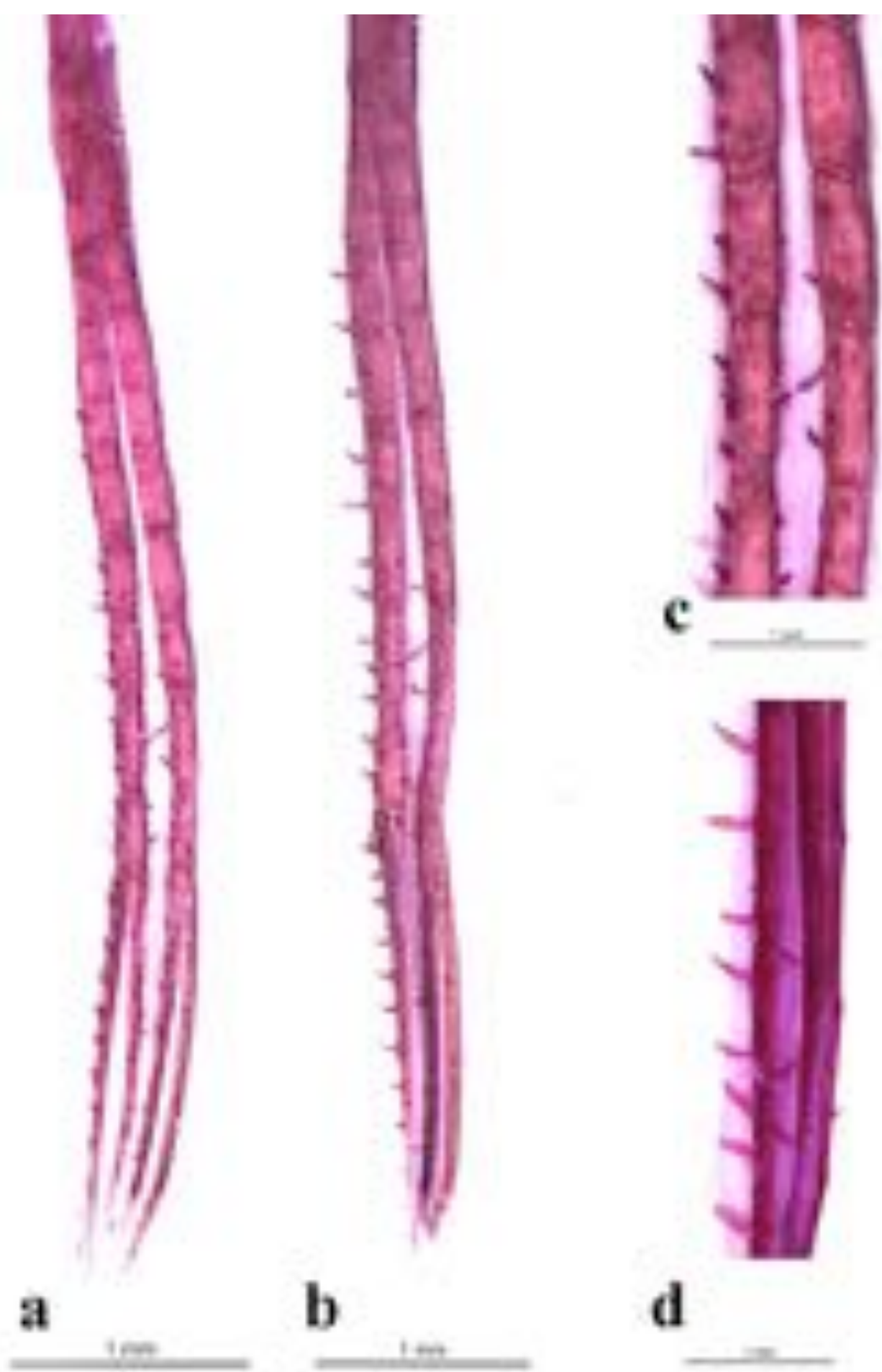

Figura 188. Distribuição, posição e formato dos processos ósseos no hemitriquium direito do raio ramificado da nadadeira anal de machos de Stethaprion crenatum. (a) vista lateral, (b) vista anteroposterior, (c) detalhe em vista lateral, (d) detalhe em vista anteroposterior. 

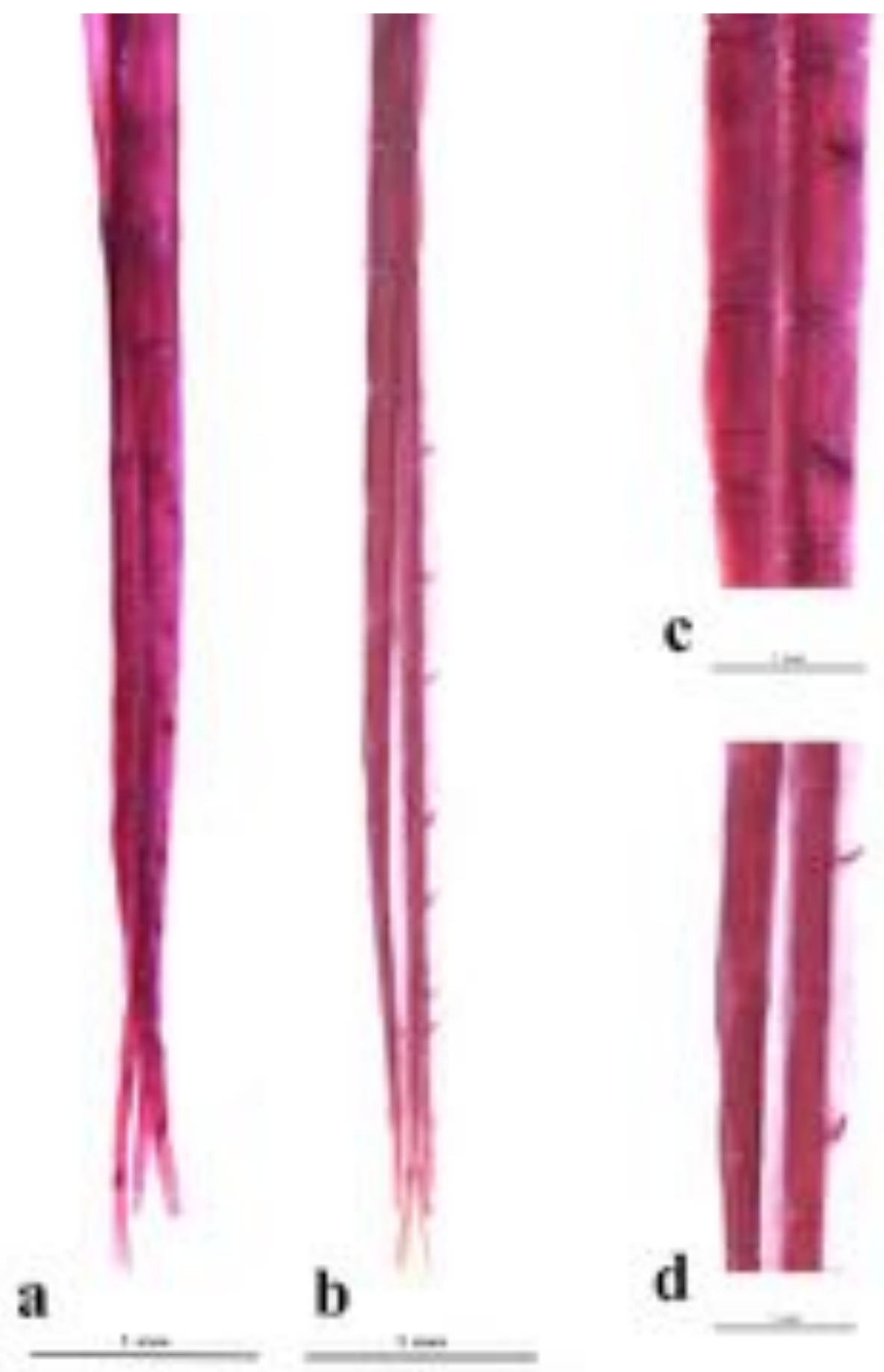

Figura 189. Distribuição, posição e formato dos processos ósseos no hemitriquium ventral da nadadeira pélvica direita de machos de Stethaprion crenatum. (a) vista ventral, (b) vista lateromedial, (c) detalhe em vista ventral e (d) detalhe em vista lateromedial. 
Tetragonopterus argenteus Cuvier 1816

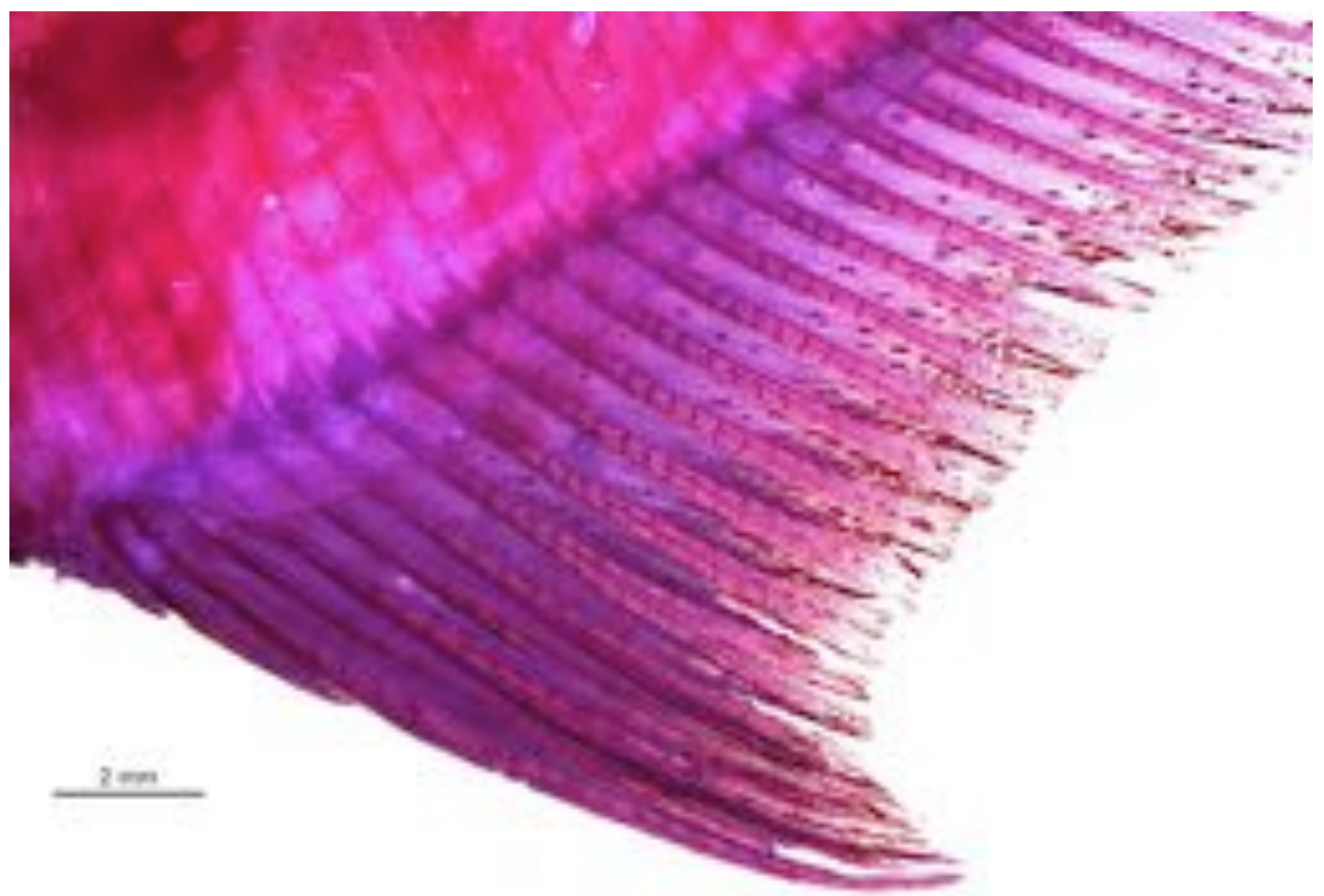

Figura 190. Nadadeira anal de machos de Tetragonopterus argenteus em vista lateral esquerda, evidenciando o formato do perfil da margem distal da nadadeira e distribuição dos processos ósseos. 

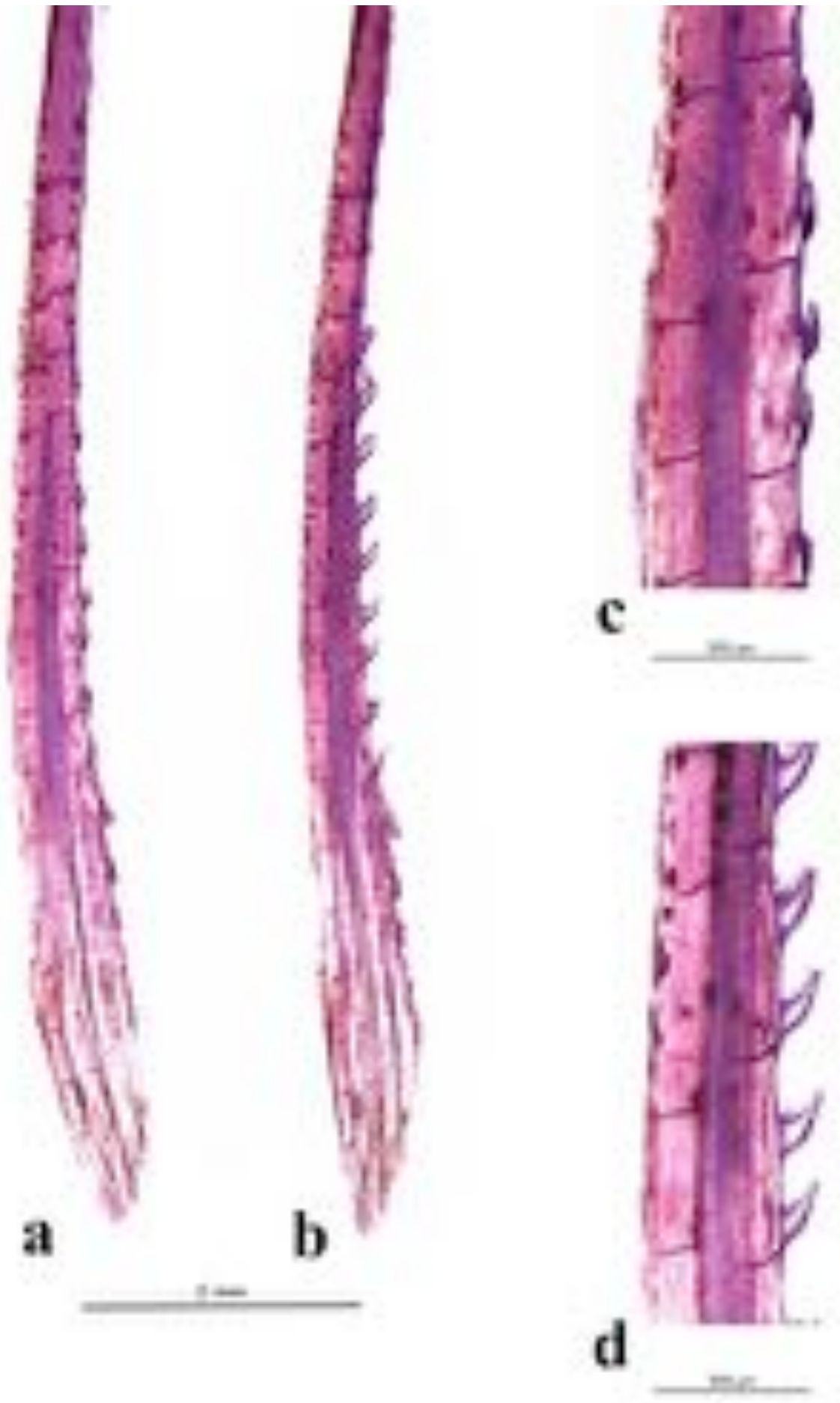

Figura 191. Distribuição, posição e formato dos processos ósseos no hemitriquium esquerdo do raio ramificado da nadadeira anal de machos de Tetragonopterus argenteus. (a) vista lateral, (b) vista anteroposterior, (c) detalhe em vista lateral, (d) detalhe em vista anteroposterior. 

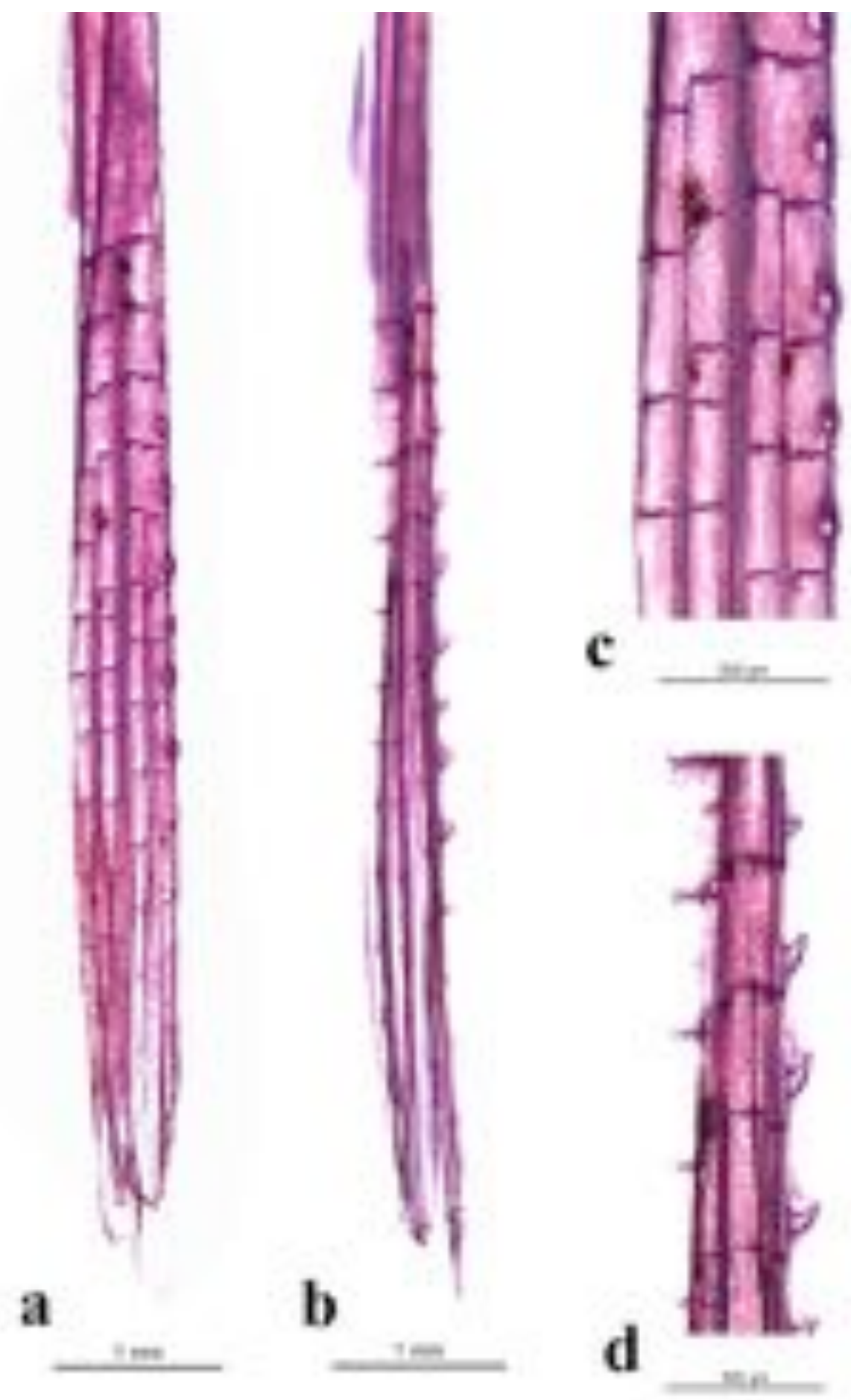

Figura 192. Distribuição, posição e formato dos processos ósseos no hemitriquium ventral da nadadeira pélvica direita de machos de Tetragonopterus argenteus. (a) vista ventral, (b) vista lateromedial, (c) detalhe em vista ventral e (d) detalhe em vista lateromedial. 


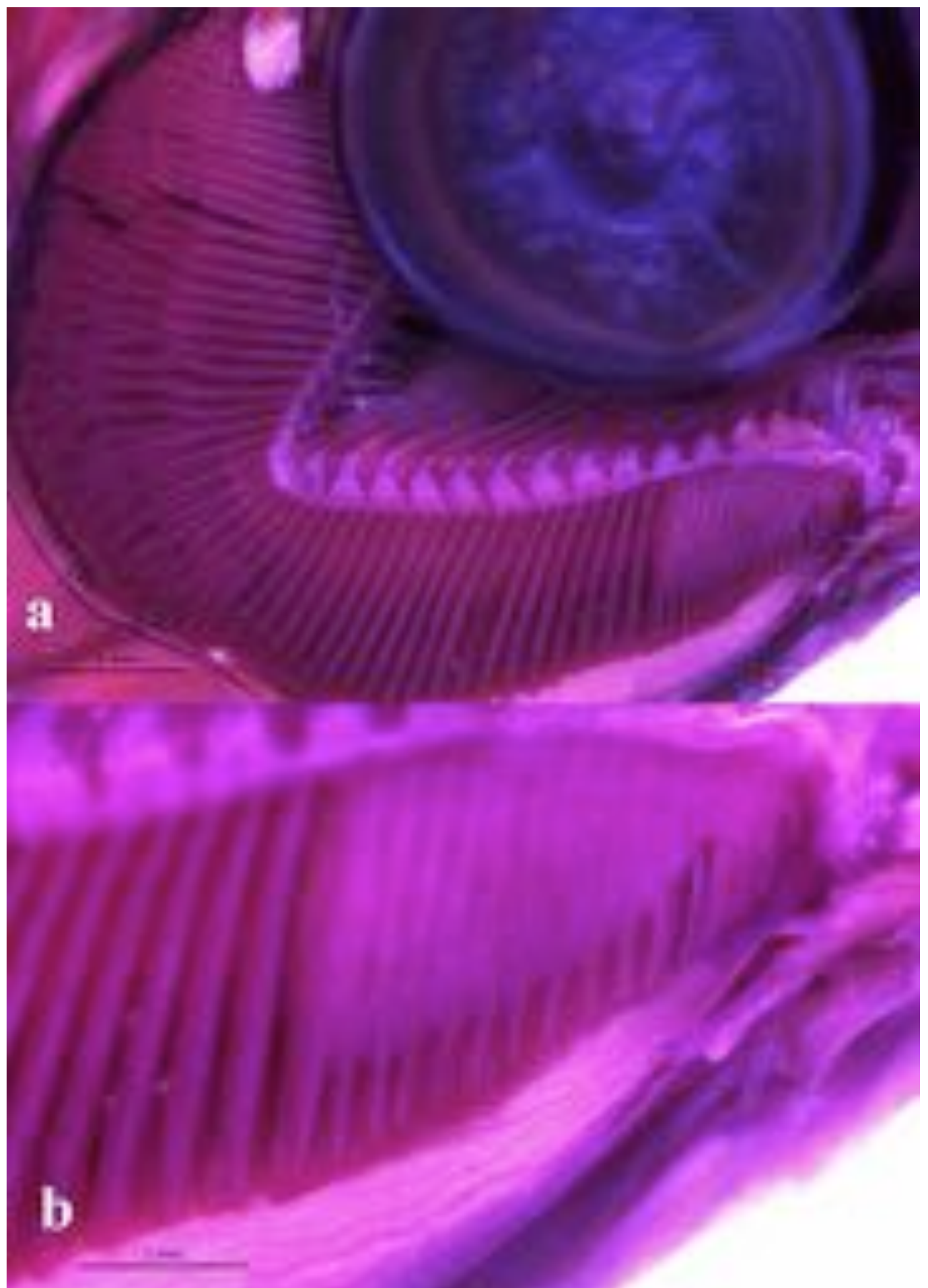

Figura 193. Brânquia com glândula branquial em vista lateral direita (a), detalhe da região anterior do ceratobranquial direito, evidenciando a glândula branquial (b) em Tetragonopterus argenteus. 


\section{Bryconamericus cf. peruanus (Müller \& Troschel 1845)}
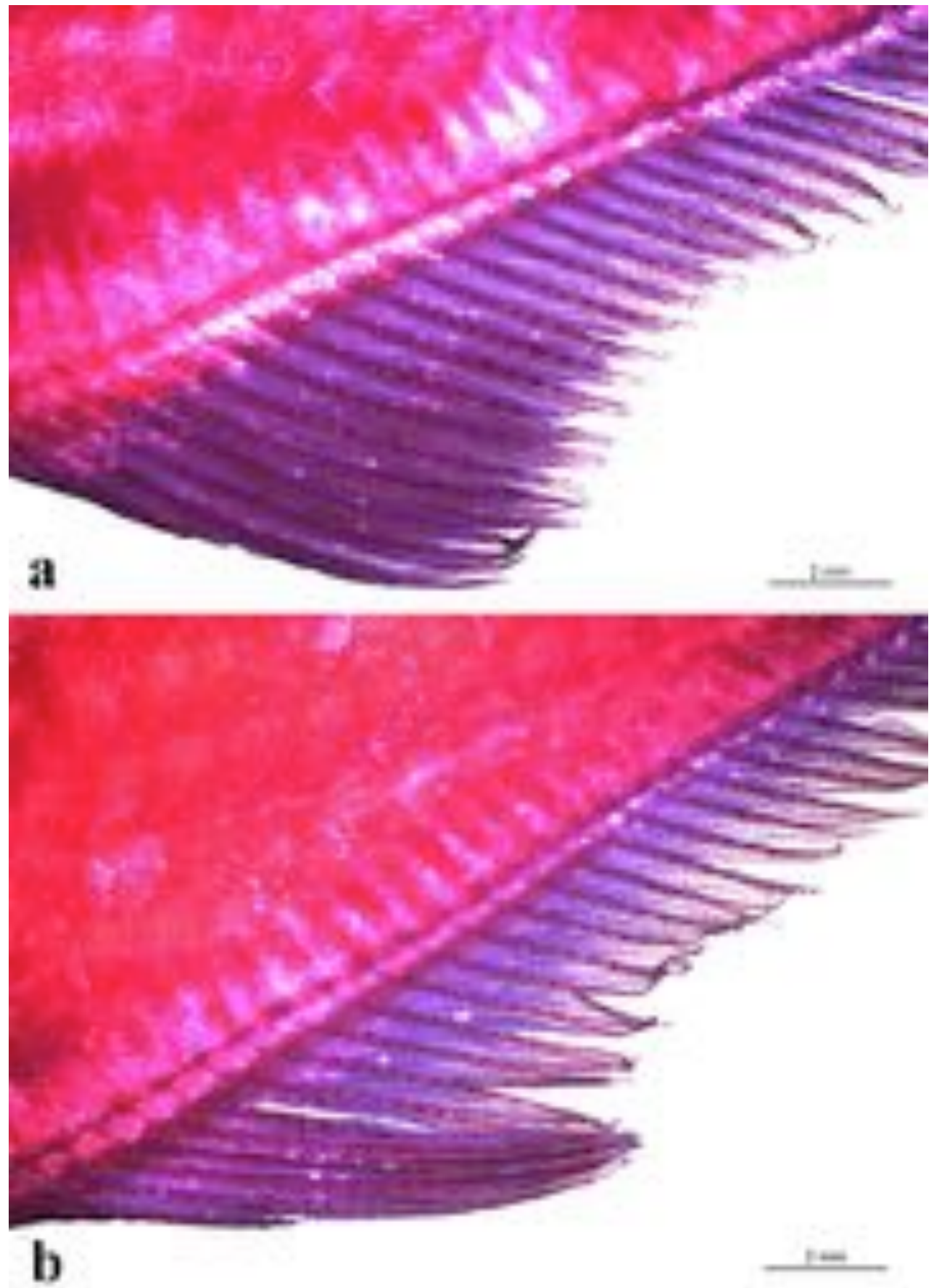

Figura 194. Nadadeira anal de machos (a) e de fêmeas (b) de Bryconamericus cf. peruanus em vista lateral esquerda, evidenciando o formato do perfil distal das nadadeiras nos dois sexos e distribuição dos processos ósseos na nadadeira anal de macho. 

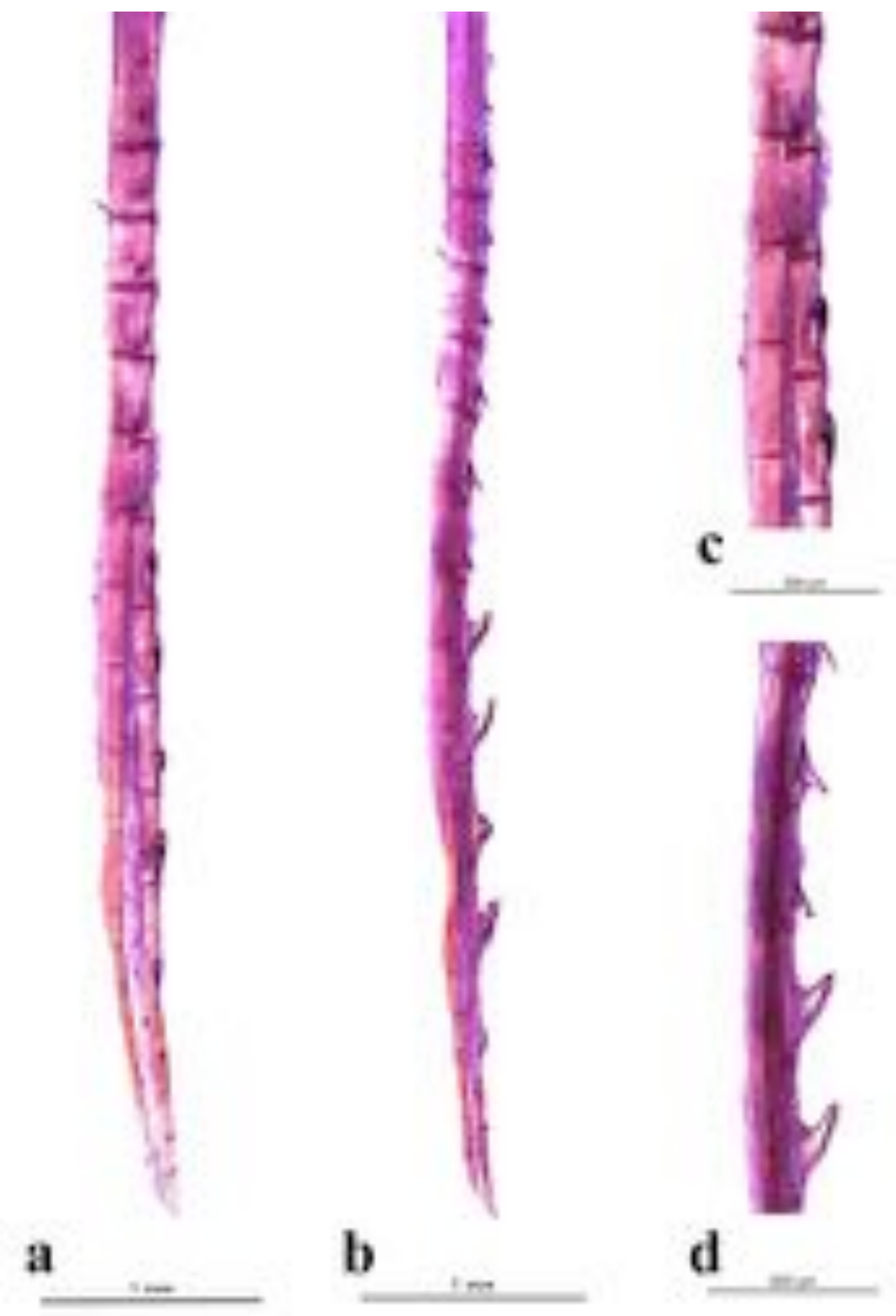

Figura 195. Distribuição, posição e formato dos processos ósseos no hemitriquium esquerdo da nadadeira anal de machos de Bryconamericus cf. peruanus. (a) vista lateral, (b) vista anteroposterior, (c) detalhe em vista lateral e (d) detalhe em vista anteroposterior. 

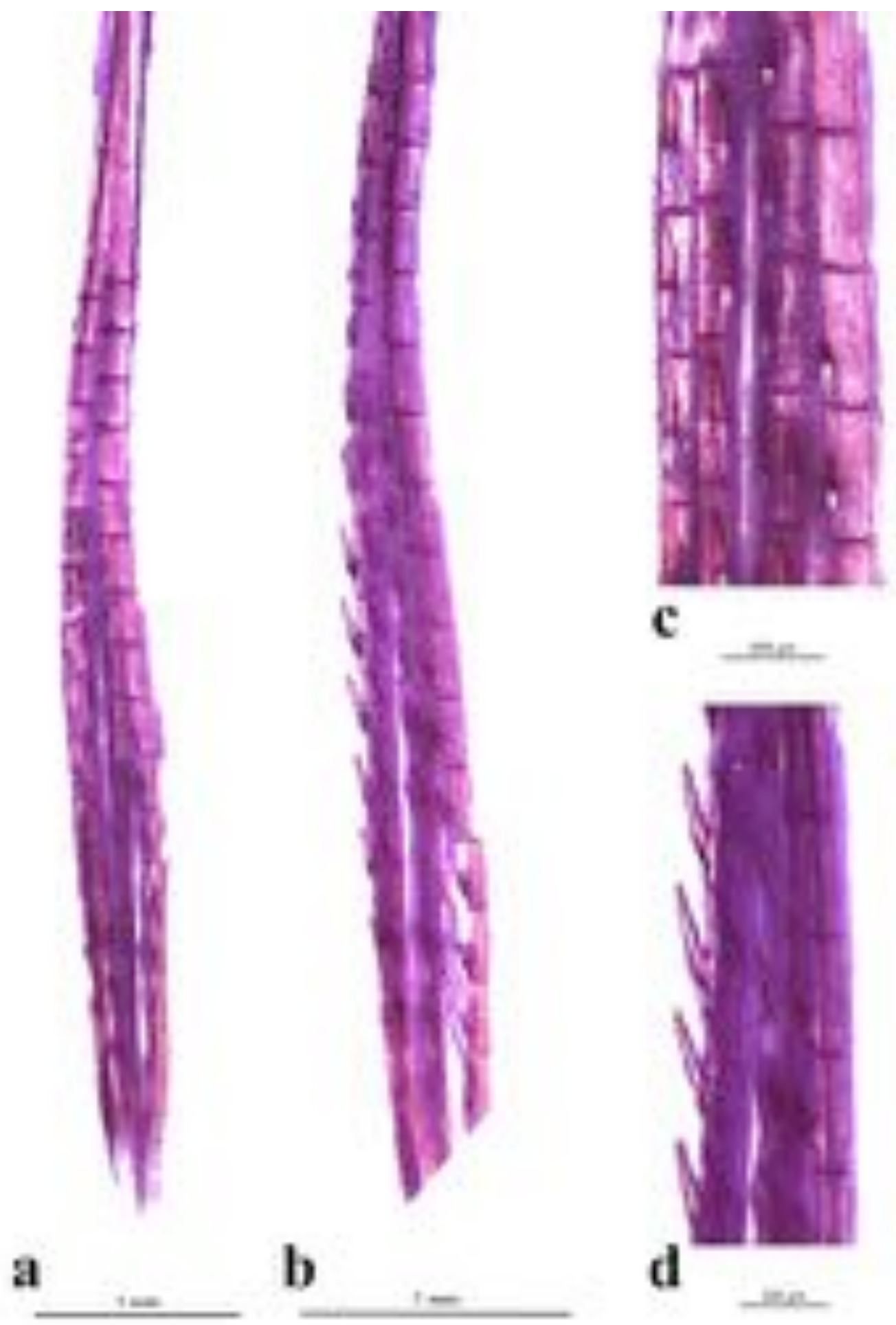

Figura 196. Distribuição, posição e formato dos processos ósseos no hemitriquium ventral da nadadeira pélvica de machos de Bryconamericus cf. peruanus. (a) vista ventral, (b) venta lateromedial, (c) detalhe em vista ventral, (c) detalhe em vista lateromedial. 


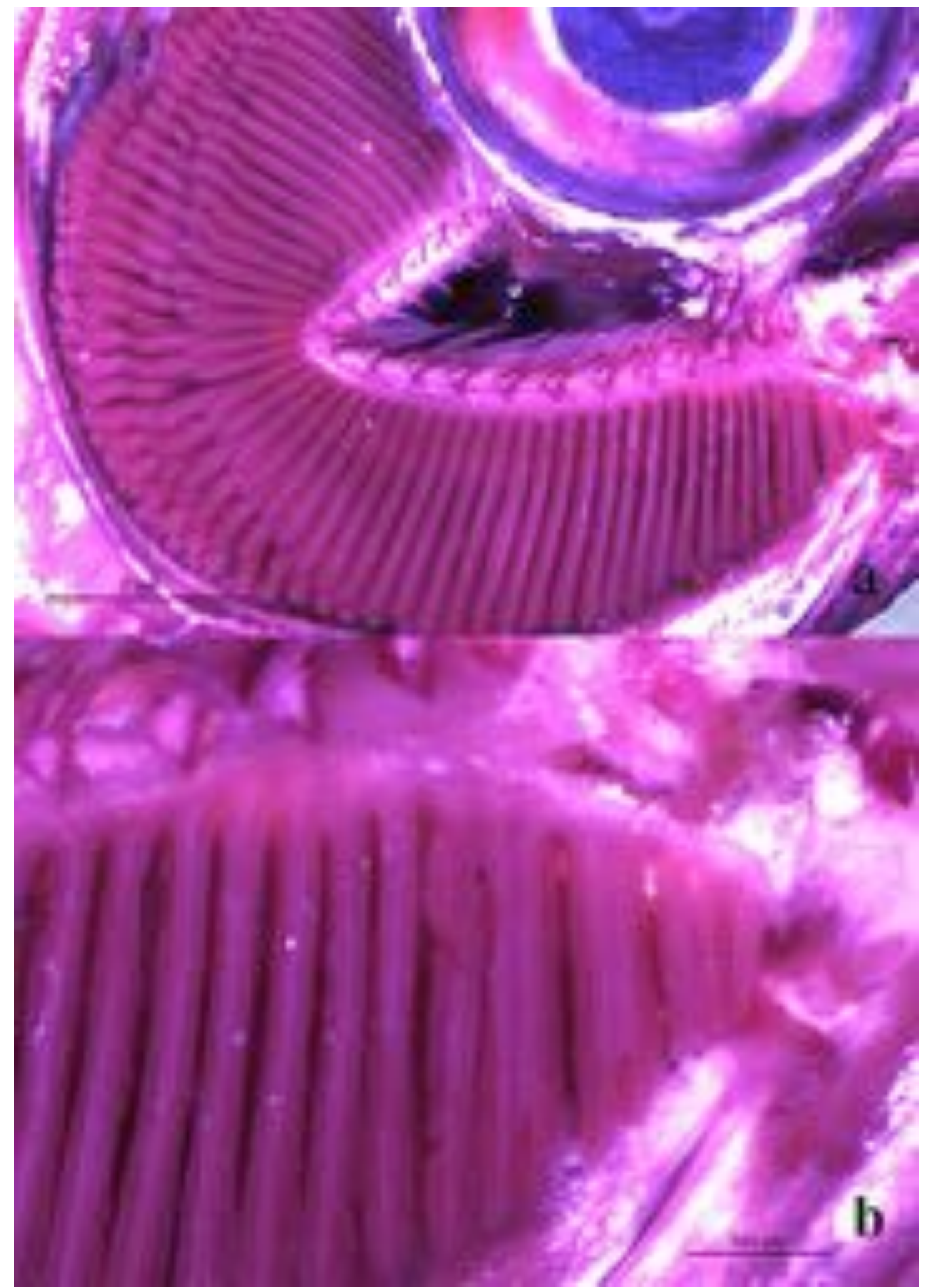

Figura 197. Brânquia com glândula branquial em vista lateral direita (a), detalhe da região anterior do ceratobranquial direito, evidenciando a glândula branquial (b) em Bryconamericus cf. peruanus. 

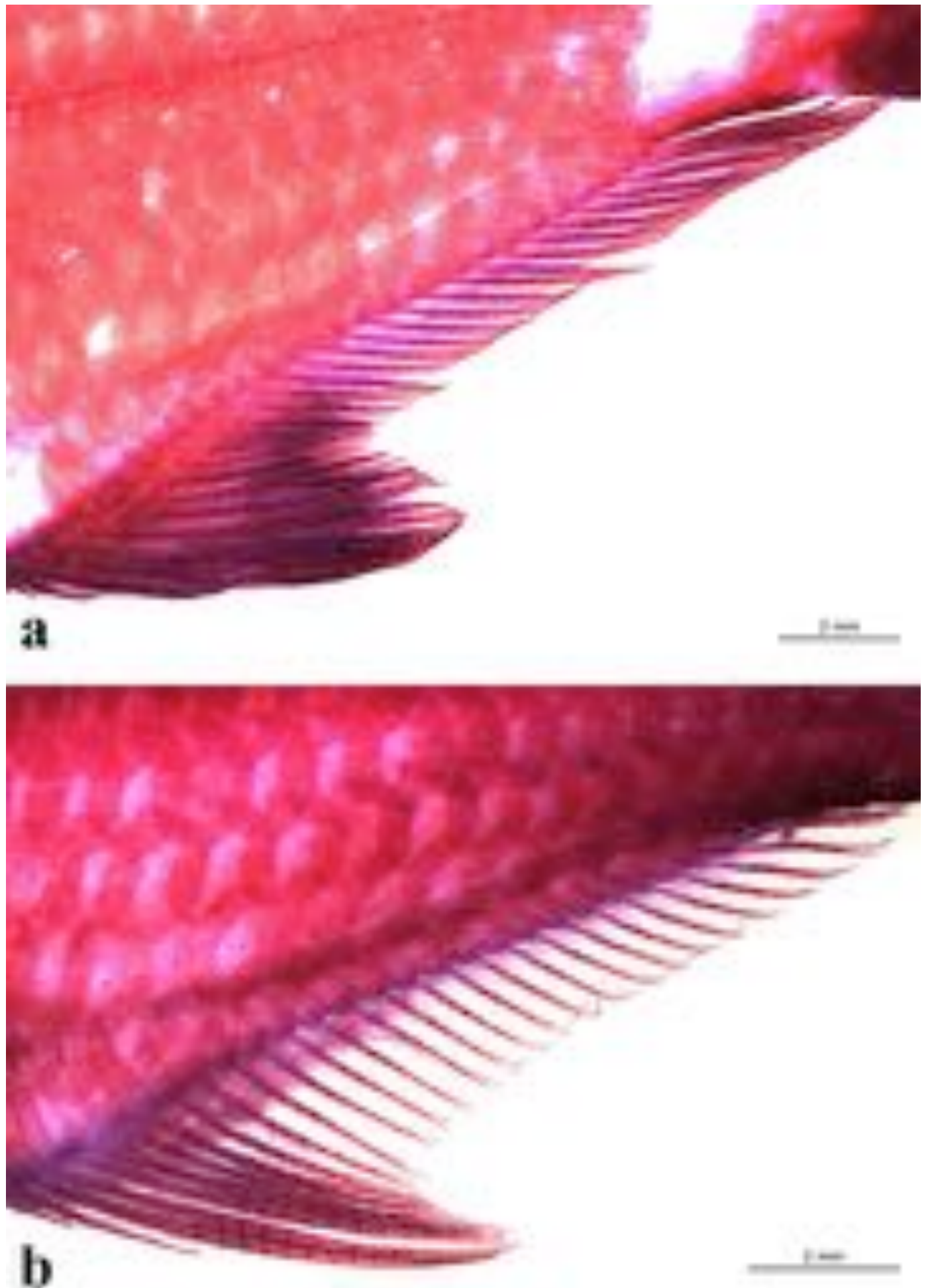

Figura 198. Nadadeira anal de machos (a) e de fêmeas (b) de Diapoma speculiferum em vista lateral esquerda, evidenciando o formato do perfil distal das nadadeiras nos dois sexos e distribuição dos processos ósseos na nadadeira anal de macho. 


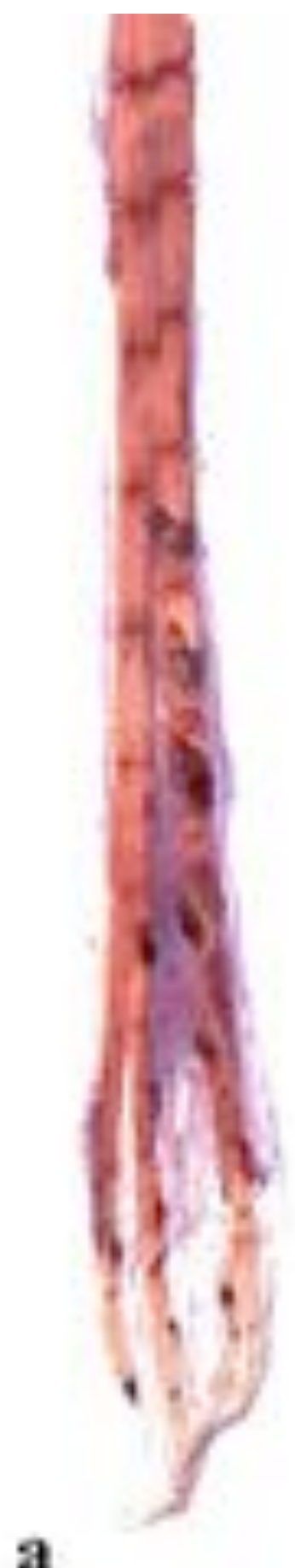

a Nore

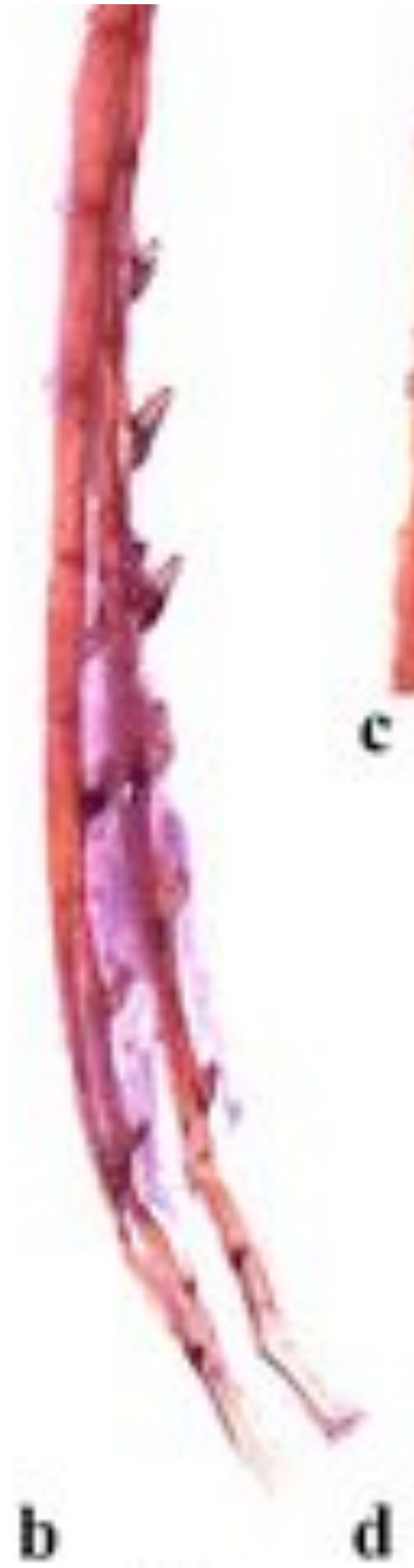

Min
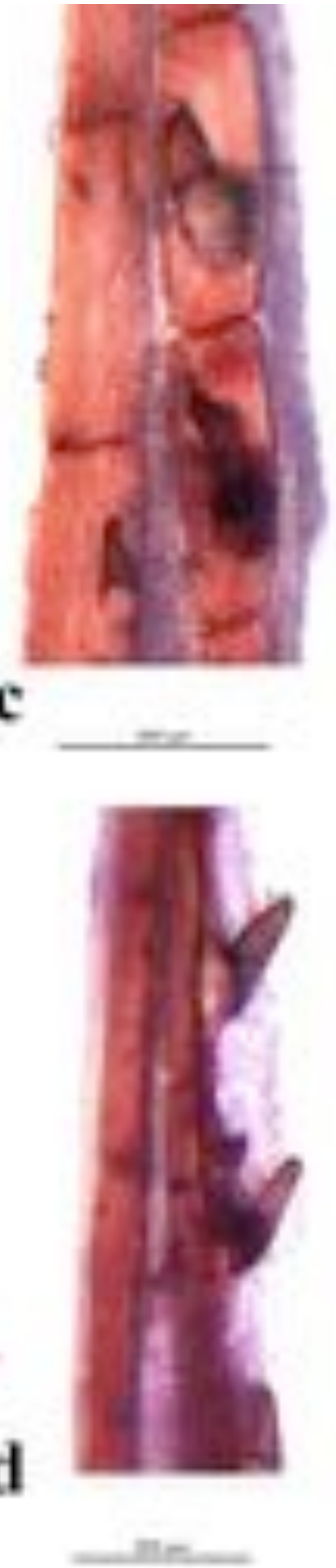

Figura 199. Distribuição, posição e formato dos processos ósseos no hemitriquium esquerdo do raio ramificado da nadadeira anal de machos de Diapoma speculiferum. (a) vista lateral, (b) vista anteroposterior, (c) detalhe em vista lateral, (d) detalhe em vista anteroposterior. 


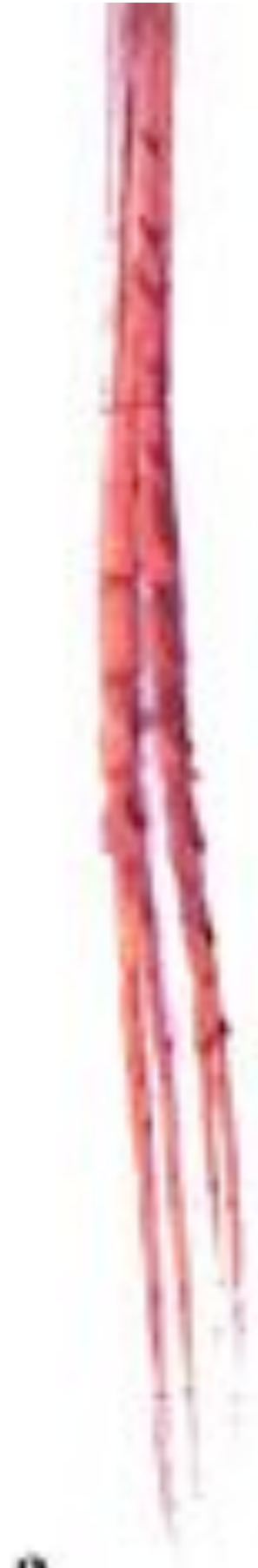

a

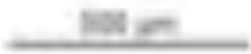

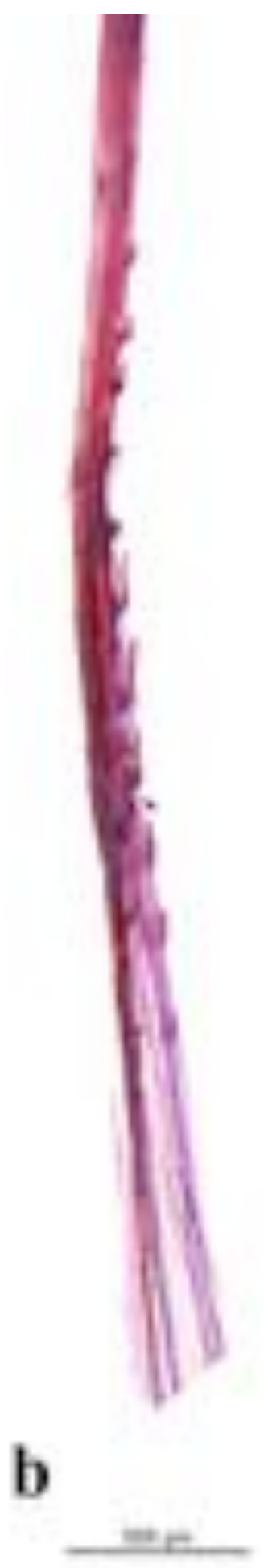

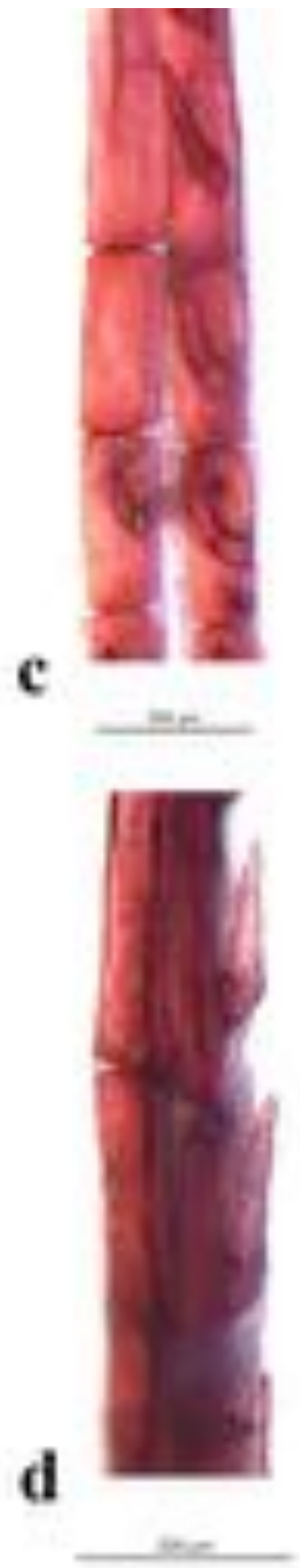

Figura 200. Distribuição, posição e formato dos processos ósseos no hemitriquium ventral da nadadeira pélvica direita de machos de Diapoma speculiferum. (a) vista ventral, (b) vista lateromedial, (c) detalhe em vista ventral e (d) detalhe em vista lateromedial. 


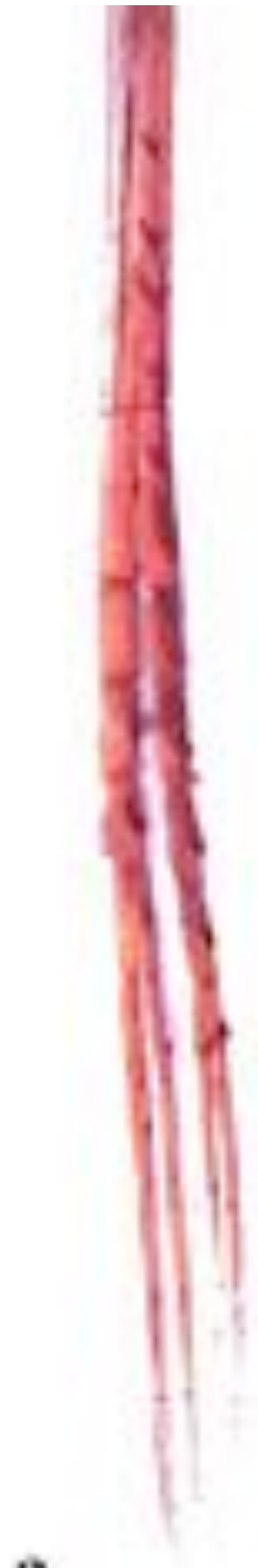

a

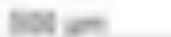

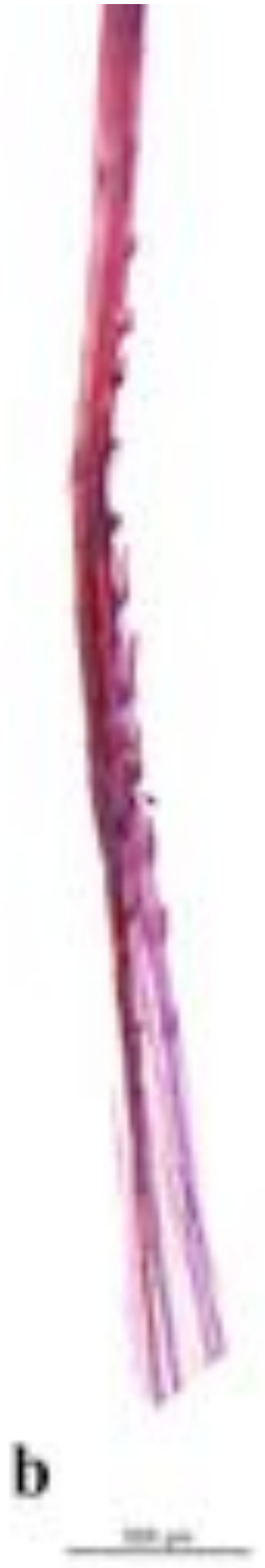
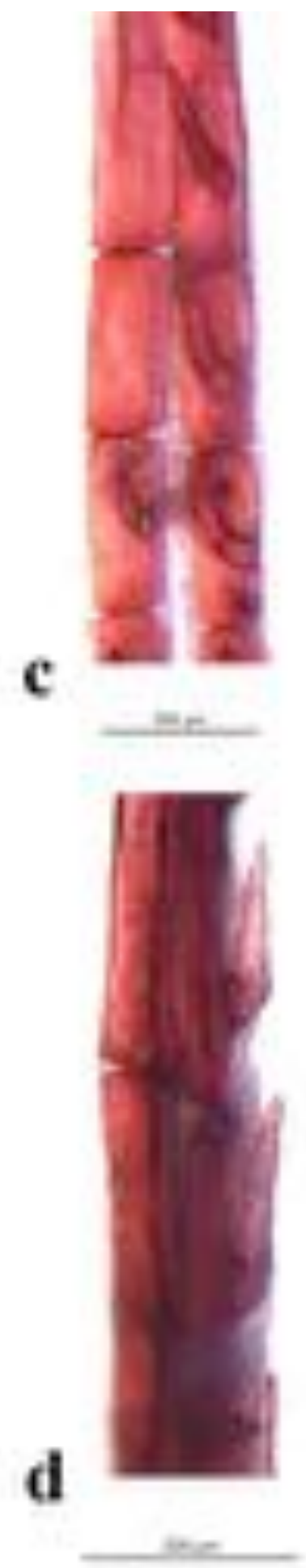

Figura 201. Pedúnculo caudal de machos (a) e de fêmeas (b) de Diapoma speculiferum, evidenciando a exposição e formato da extremidade distal dos raios procurrentes ventrais de macho. 


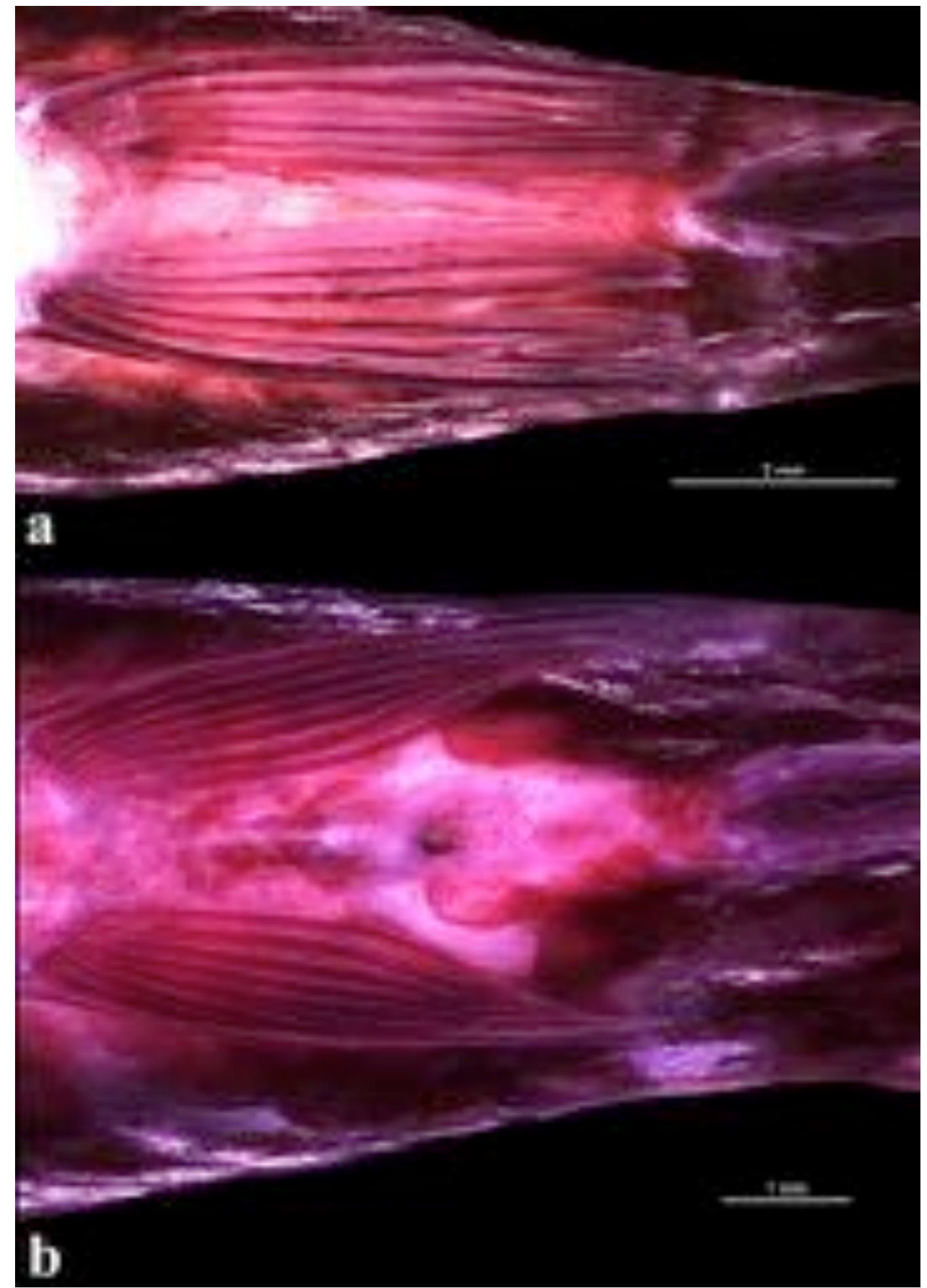

Figura 202. Nadadeira pélvica de machos (a) e de fêmeas (b) de Diapoma speculiferum em vista ventral, evidenciando o formato da nadadeira nos dois sexos. 


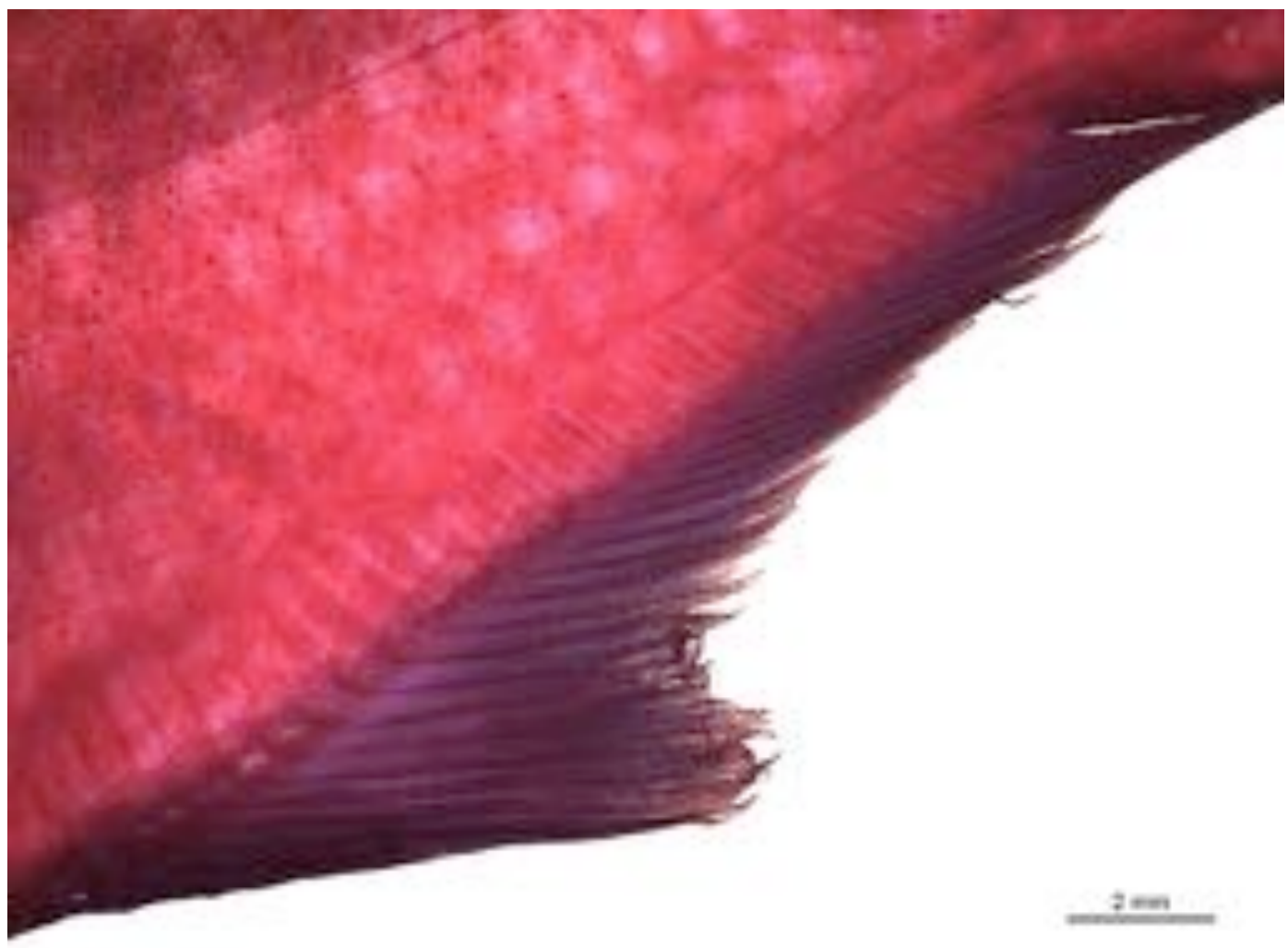

Figura 203. Nadadeira anal de machos de Eretmobrycon bayano em vista lateral esquerda, evidenciando o formato do perfil da margem distal da nadadeira e distribuição dos processos ósseos. 

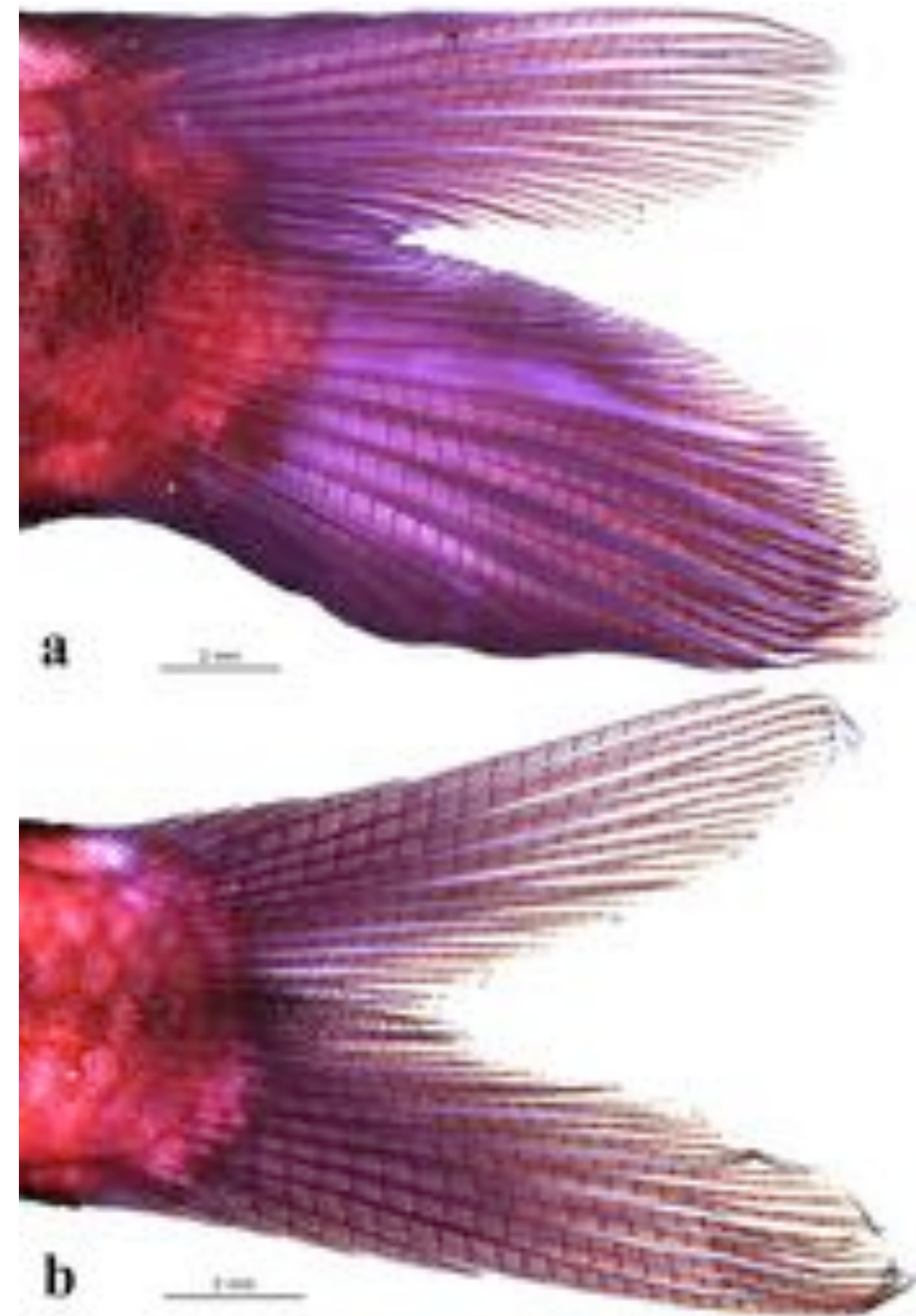

Figura 204. Nadadeira caudal de machos (a) e de fêmeas (b) de Eretmobrycon bayano em vista lateral esquerda, evidenciando o formato das nadadeiras. 


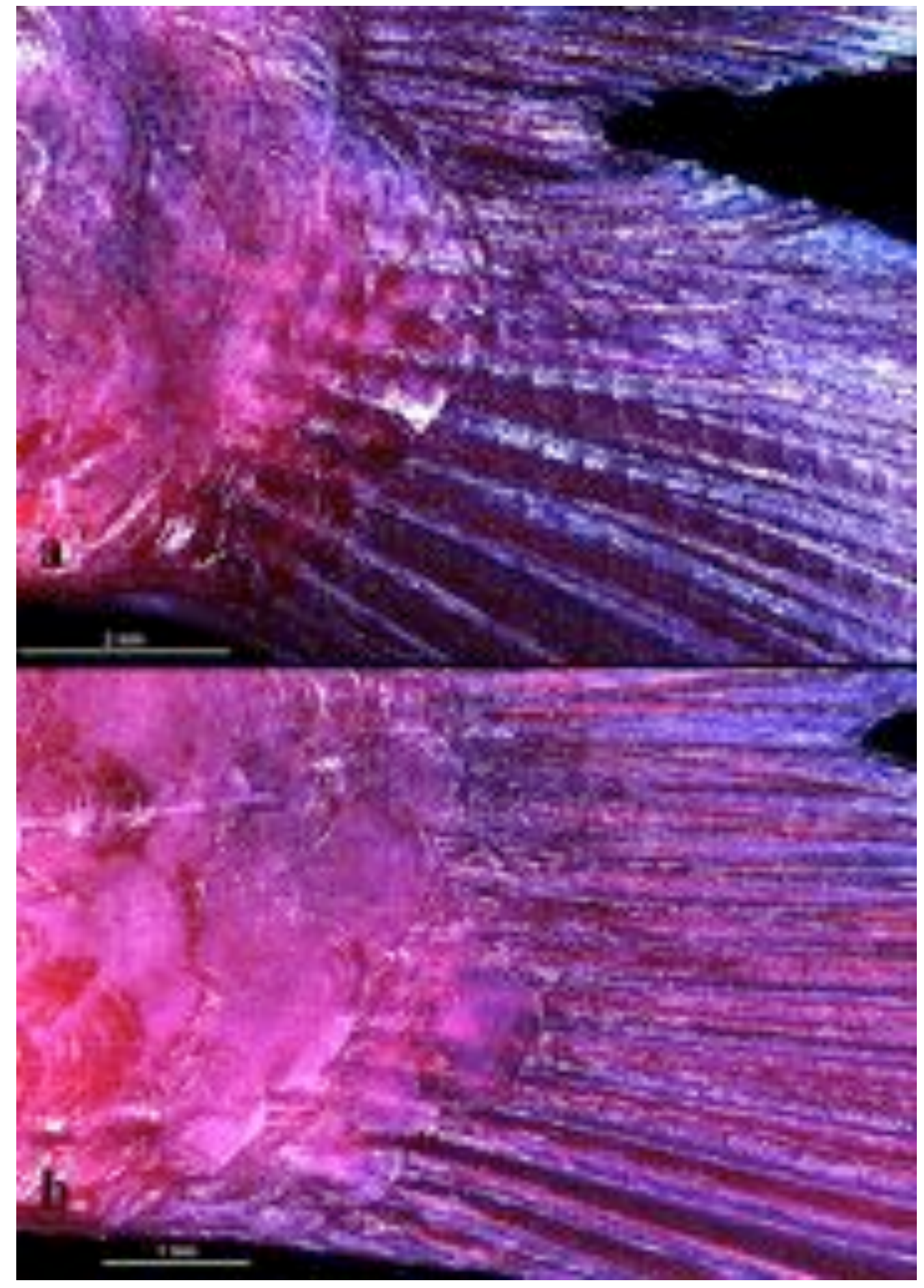

Figura 205. Pedúnculo caudal de machos (a) e de fêmeas (b) de Eretmobrycon bayano, evidenciando a disposição das escamas posteriores das séries de escamas ventrais à série de escamas mediana. 


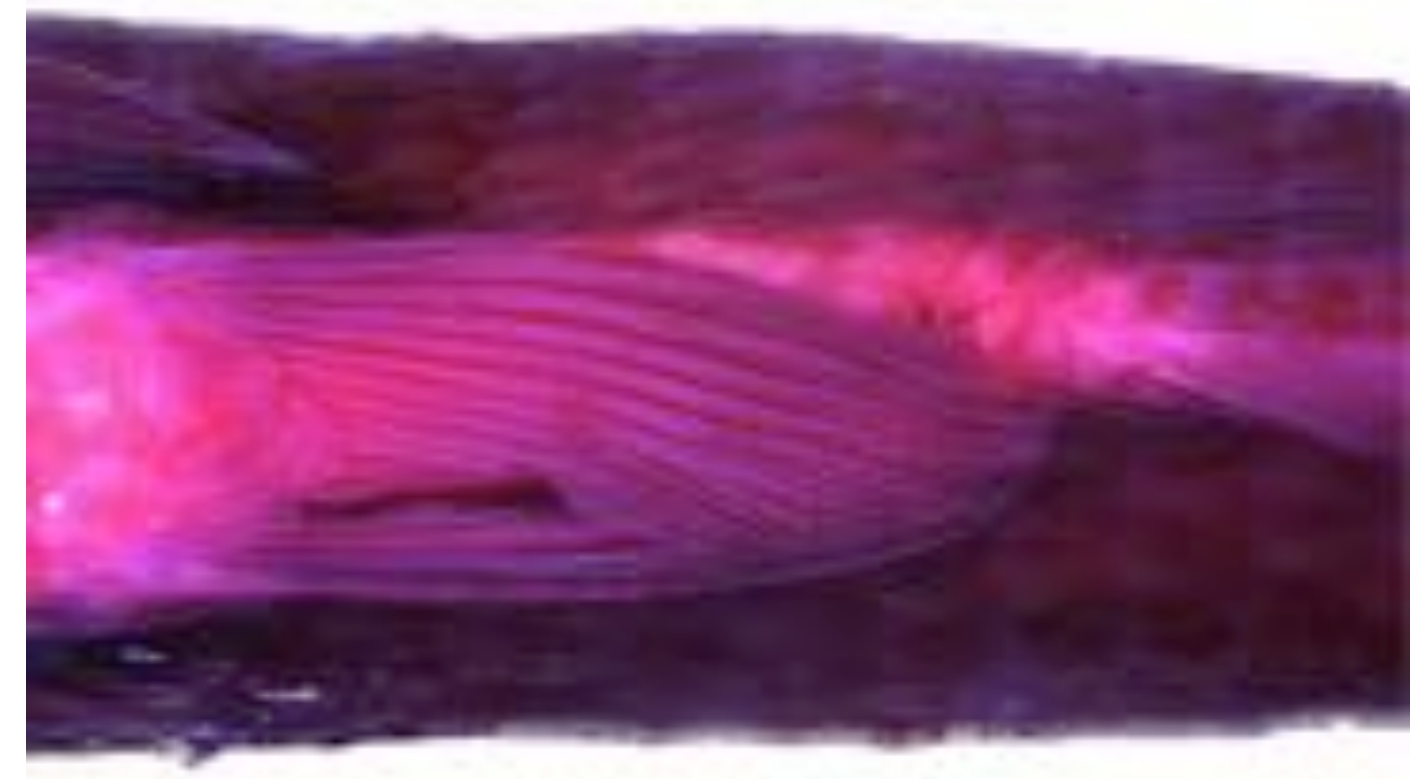

a

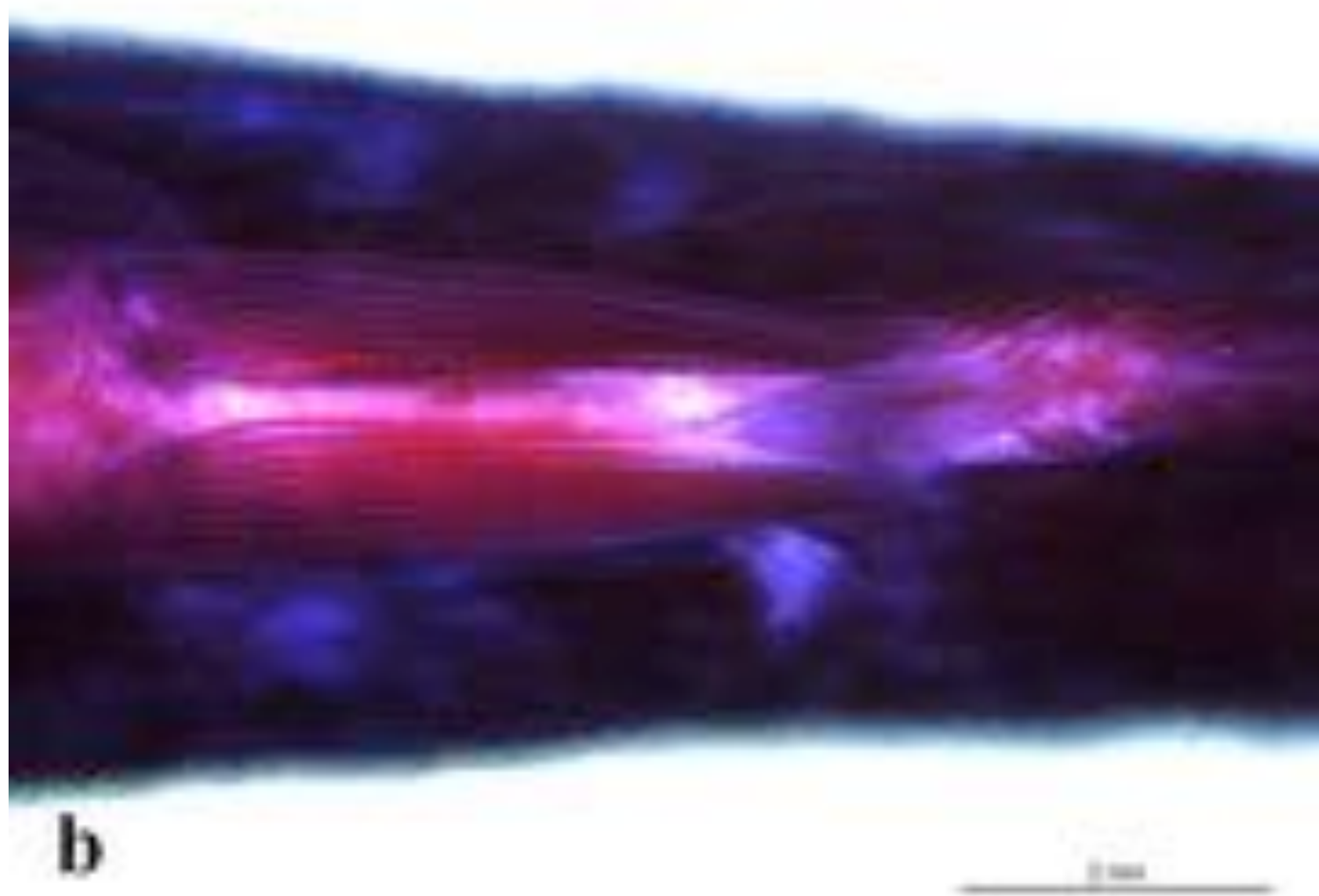

Figura 206. Nadadeira pélvica de machos (a) e de fêmeas (b) de Eretmobrycon bayano em vista lateral ventral, evidenciando o formato e comprimento da nadadeira nos dois sexos. 


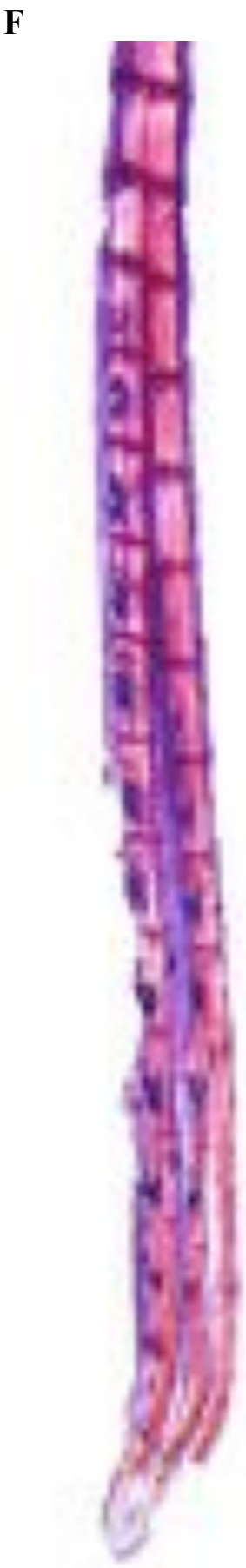

a

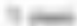

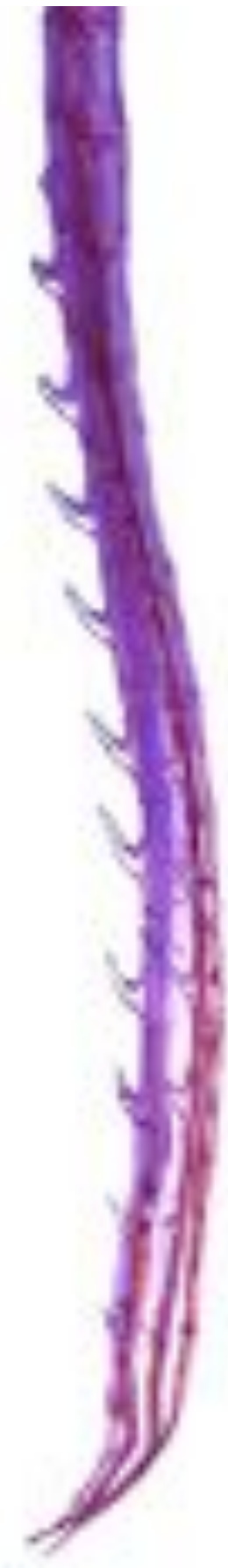

b

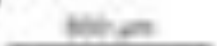

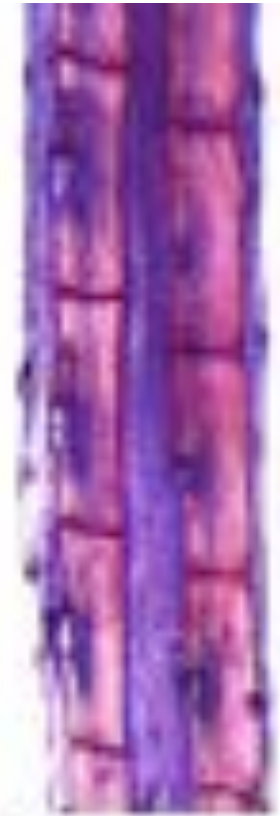

c
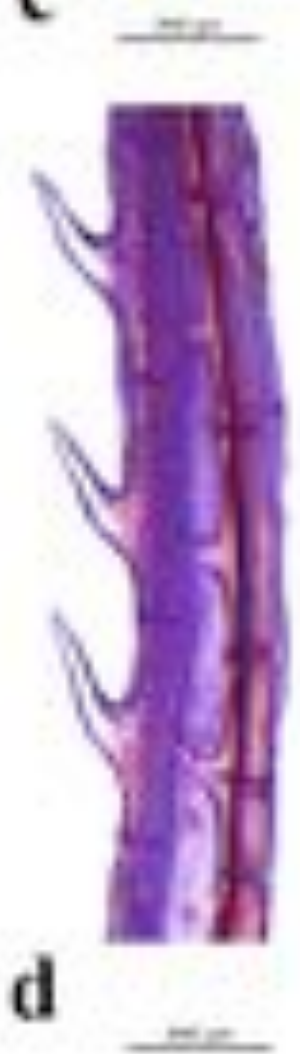

Figura 207. Distribuição, posição e formato dos processos ósseos no hemitriquium direito do raio ramificado da nadadeira anal de machos de Eretmobrycon bayano. (a) vista lateral, (b) vista anteroposterior, (c) detalhe em vista lateral e (c) detalhe em vista anteroposterior. 

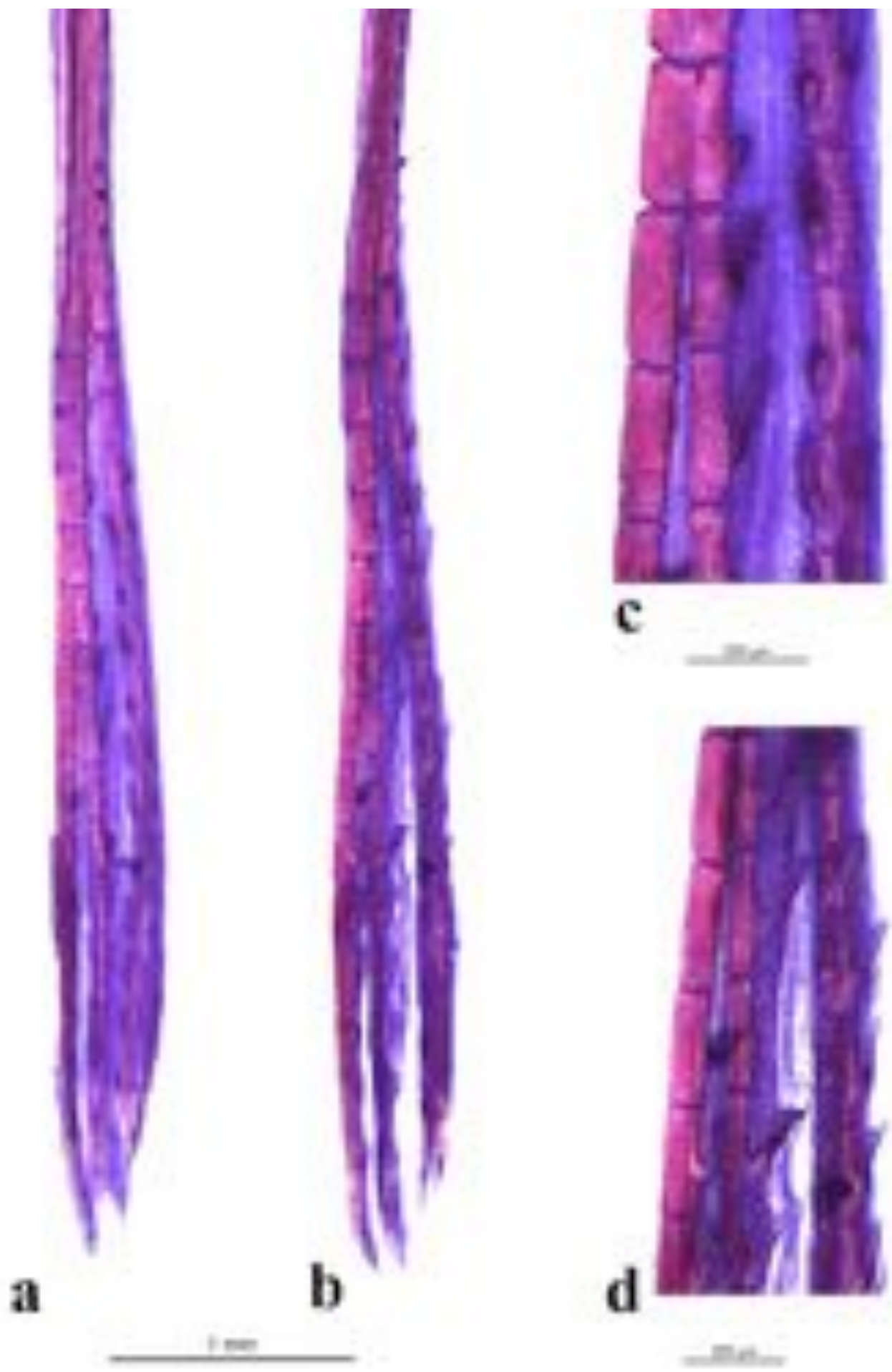

c
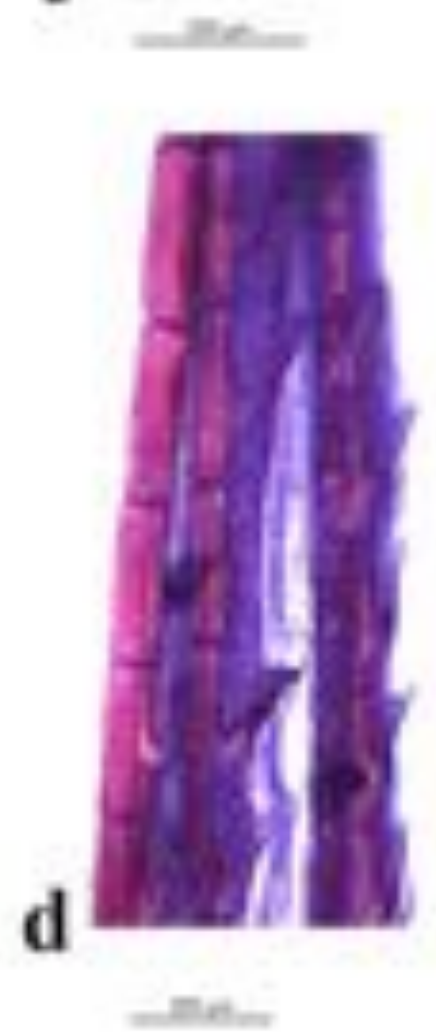

Figura 208. Distribuição, posição e formato dos processos ósseos no hemitriquium ventral da nadadeira pélvica direita de machos de Eretmobrycon bayano. (a) vista ventral, (b) vista lateromedial, (c) detalhe em vista ventral e (d) detalhe em vista lateromedial. 

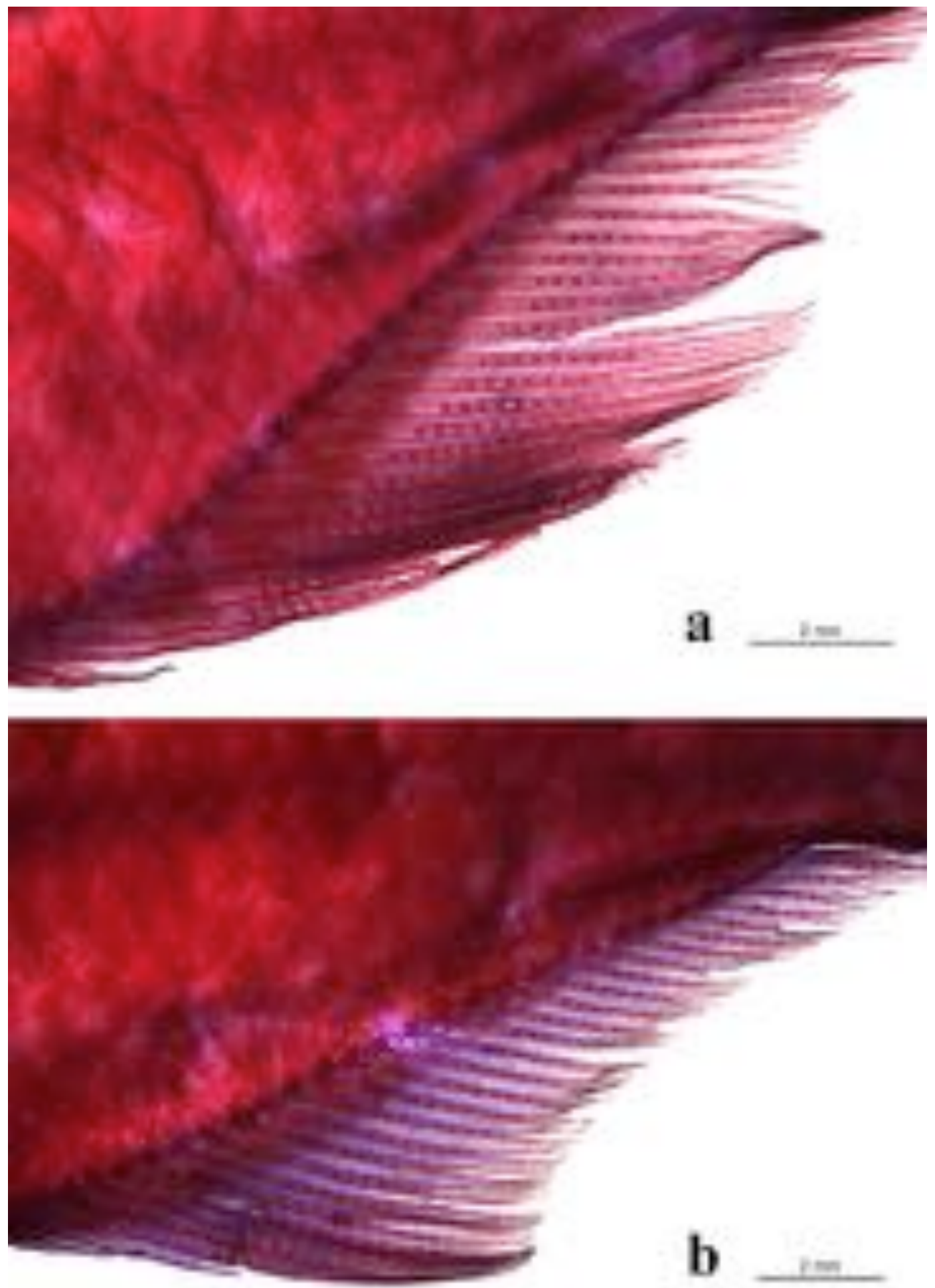

Figura 209. Nadadeira anal de machos (a) e de fêmeas (b) de Gephyrocharax atracaudata em vista lateral esquerda, evidenciando o formato do perfil distal das nadadeiras nos dois sexos e distribuição dos processos ósseos na nadadeira anal de macho. 
Figura 210. Nadadeira pélvica de machos (a) e de fêmeas (b) de Gephyrocharax atracaudata em vista lateral ventral, evidenciando o formato e comprimento da nadadeira nos dois sexos. 


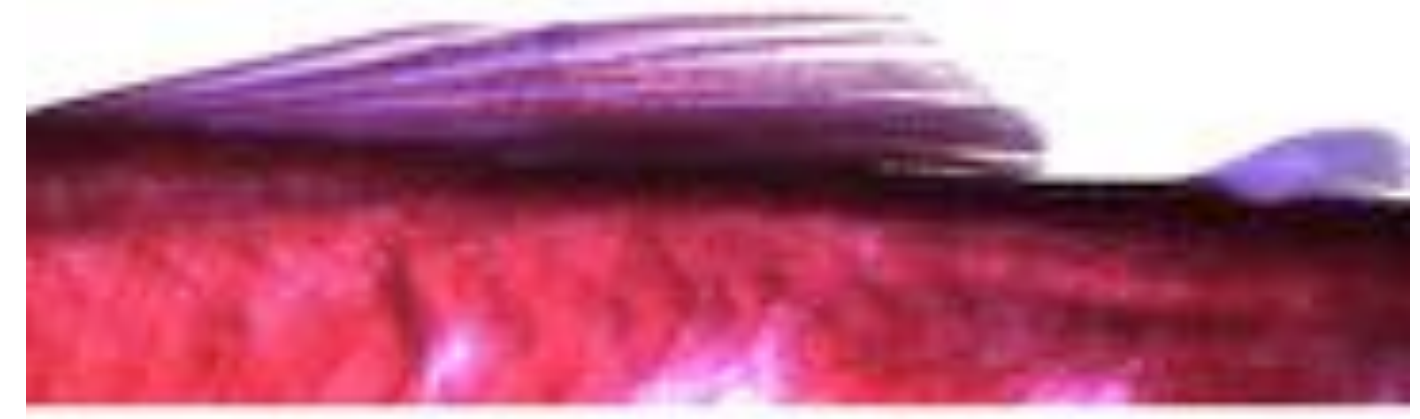

\section{a}

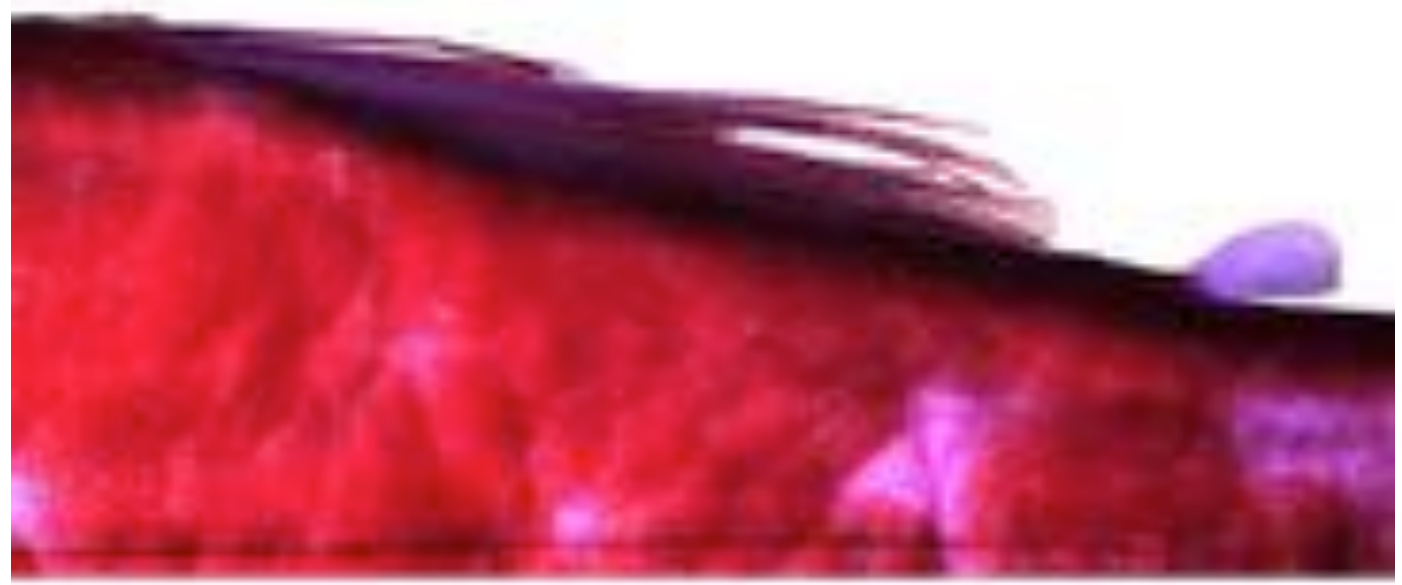

b

1

Figura 211. Nadadeira dorsal de machos (a) e de fêmeas (b) de Gephyrocharax atracaudata em vista lateral esquerda, evidenciando o formato e comprimento da nadadeira nos dois sexos. 

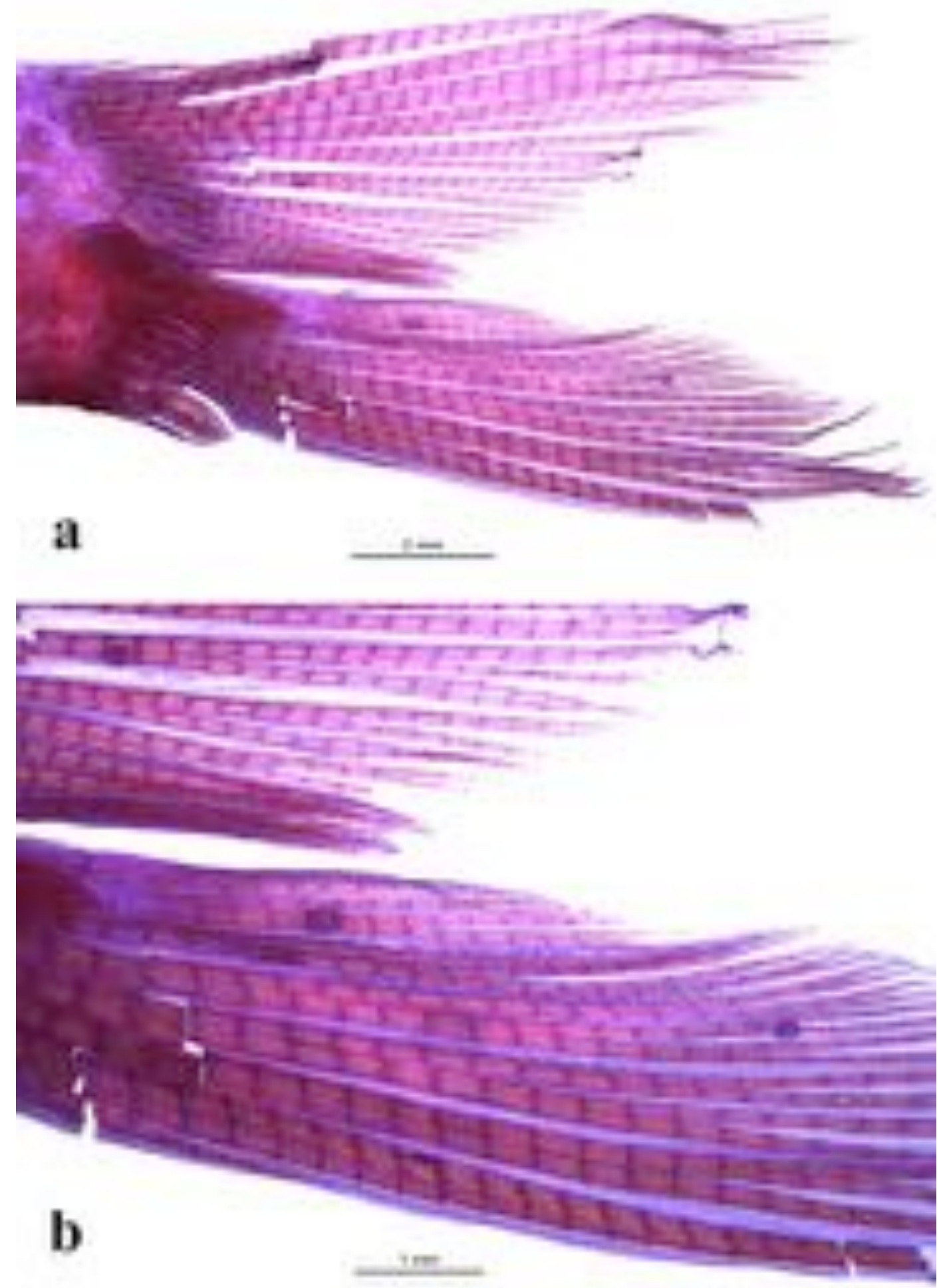

Figura 212. Nadadeira caudal de machos de Gephyrocharax atracaudata (a) e detalhe do lobo ventral (b) em vista lateral esquerda, evidenciando o formato do perfil da margem distal da nadadeira e distribuição dos processos ósseos. 


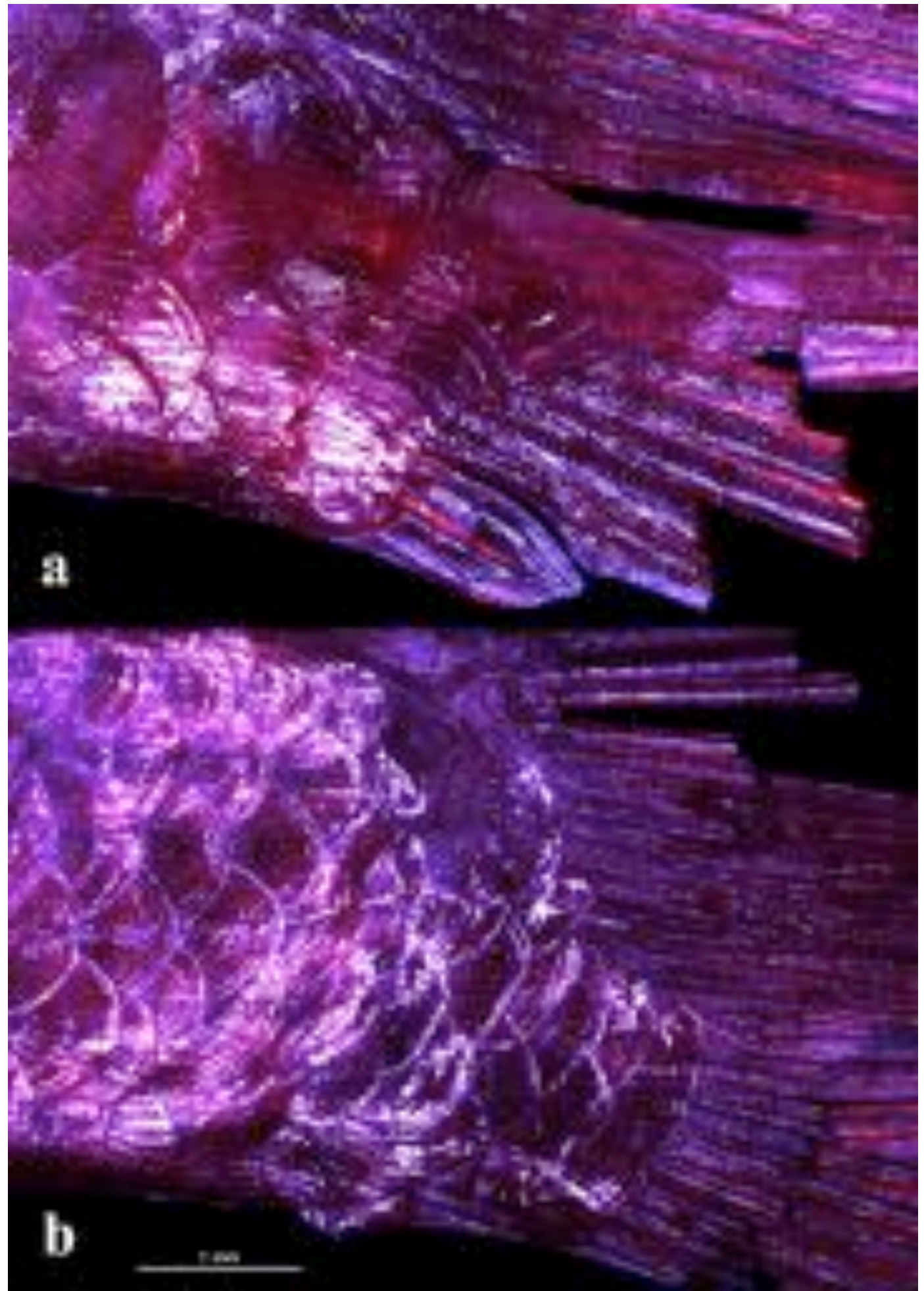

Figura 213. Pedúnculo caudal de machos (a) e de fêmeas (b) de Gephyrocharax atracaudata, evidenciando o número e disposição das escamas do lobo ventral da nadadeira caudal e o órgão caudal. 

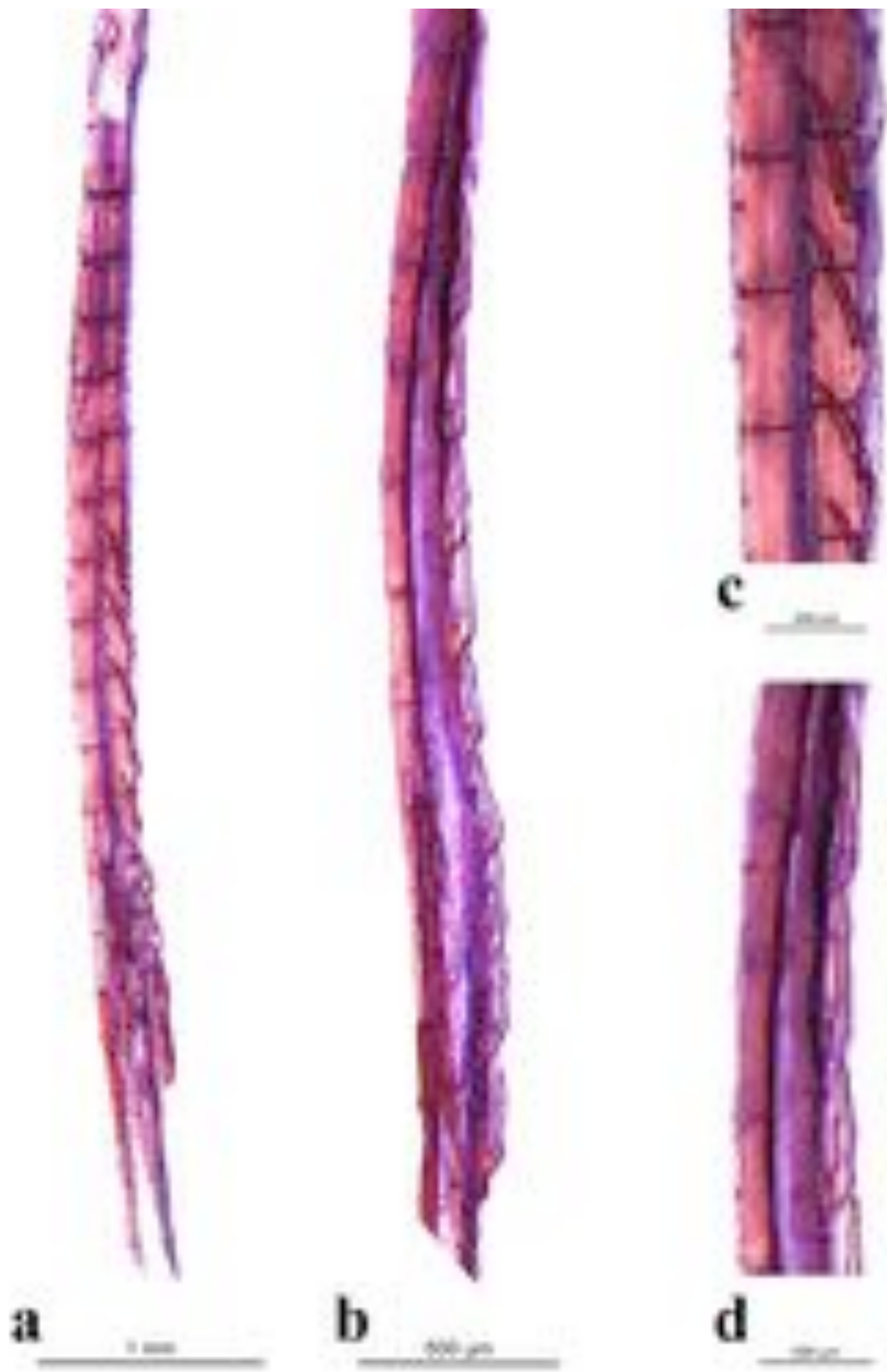

Figura 214. Distribuição, posição e formato dos processos ósseos no hemitriquium esquerdo do raio ramificado da nadadeira anal de machos de Gephyrocharax atracaudata. (a) vista lateral, (b) vista anteroposterior, (c) detalhe em vista lateral, (d) detalhe em vista anteroposterior. 


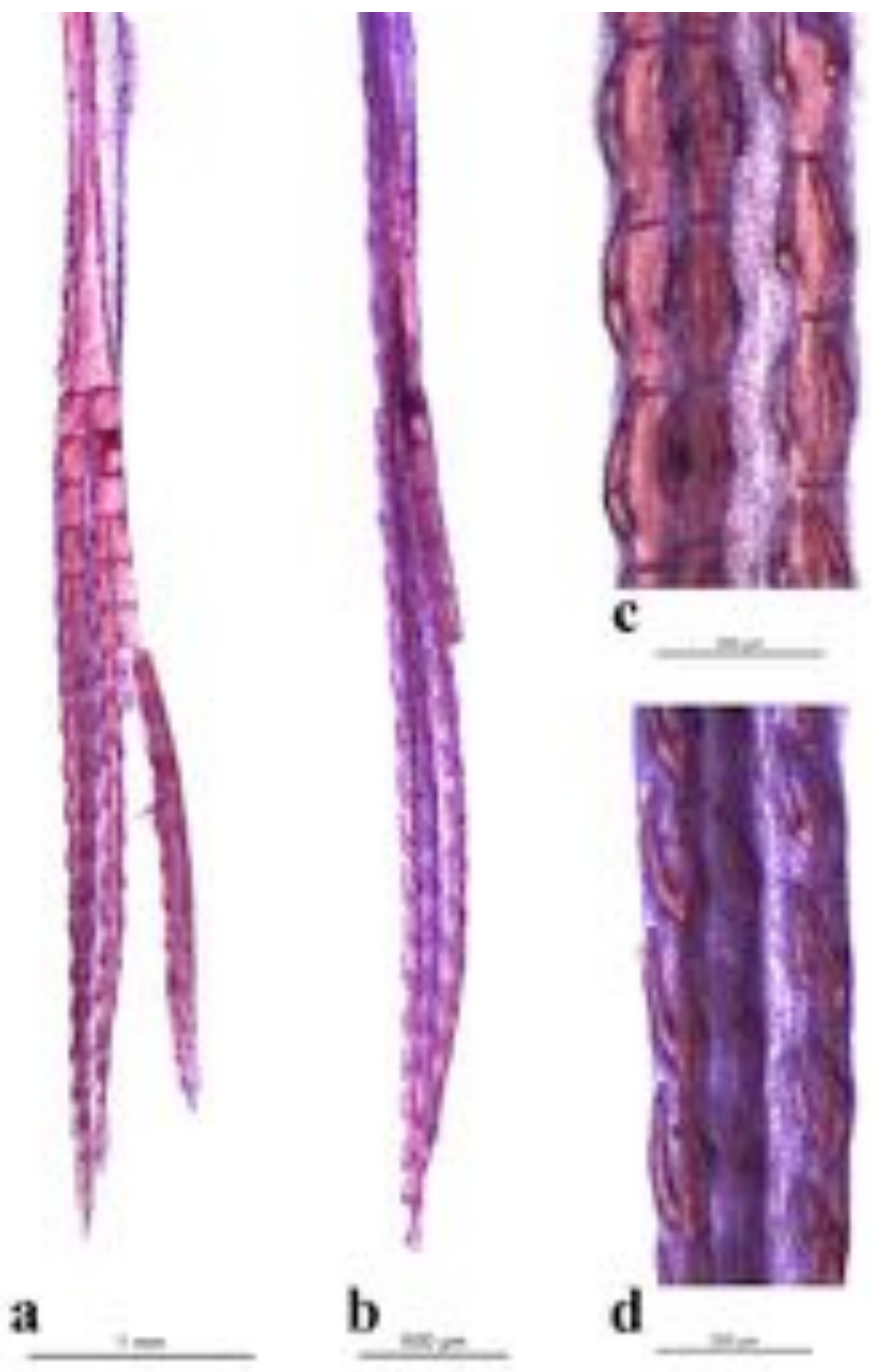

Figura 215. Distribuição, posição e formato dos processos ósseos no hemitriquium ventral da nadadeira pélvica esquerda de machos de Gephyrocharax atracaudata. (a) vista ventral, (b) vista lateromedial, (c) detalhe em vista ventral e (d) detalhe em vista lateromedial. 

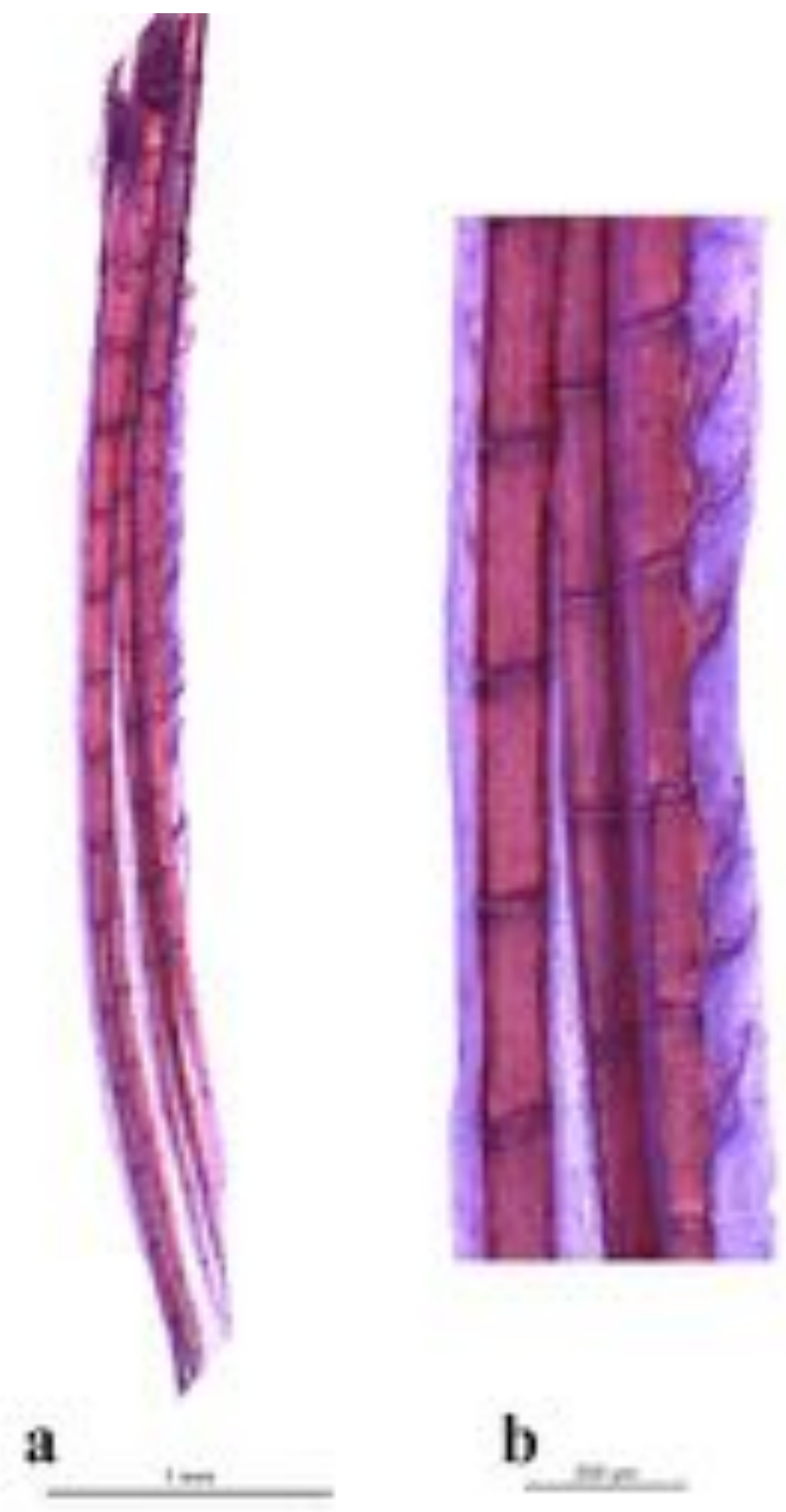

Figura 216. Distribuição, posição e formato dos processos ósseos no hemitriquium esquerdo da nadadeira caudal de machos de Gephyrocharax atracaudata. (a) vista lateral esquerda e (b) detalhe em vista lateral esquerda. 


\section{Hysteronotus megalostomus Eigenmann 1911}

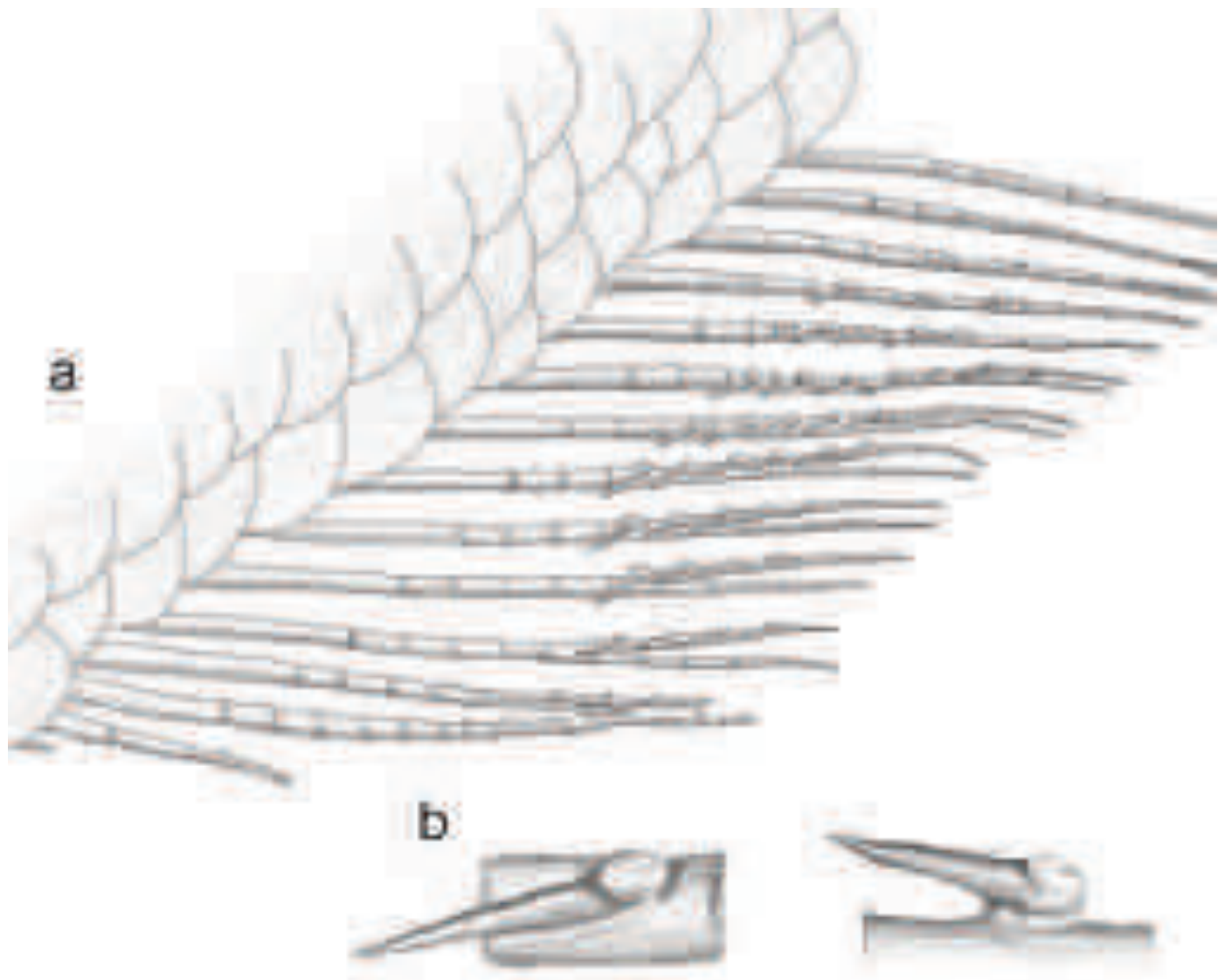

Figura 217. Nadadeira anal de machos de Hysteronotus megalostomus: (a) porção anterior evidenciando a distribuição dos processos ósseos e (b) detalhe dos processos ósseos em vista lateral e anteroposterior.

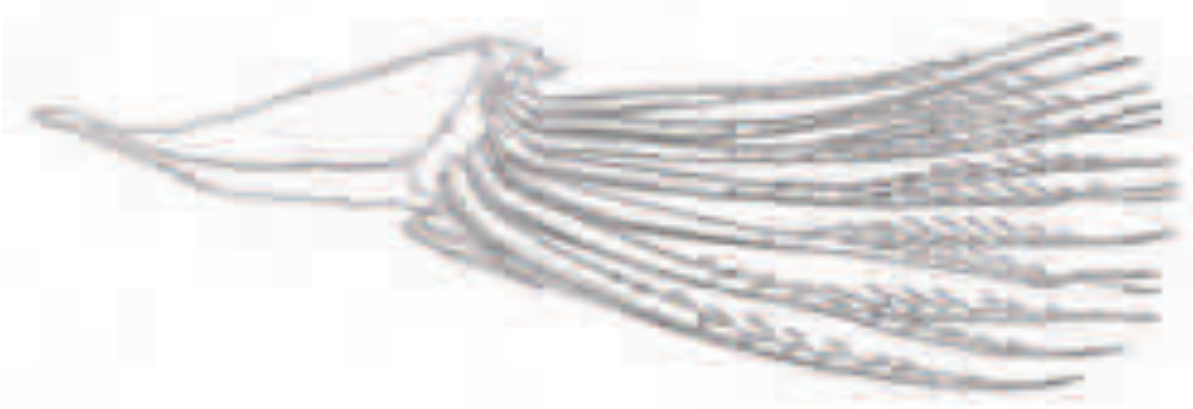

Figura 218. Nadadeira pélvica direita de machos de Hysteronotus megalostomus em vista ventral, evidenciando a distribuição dos processo ósseos na nadadeira. 


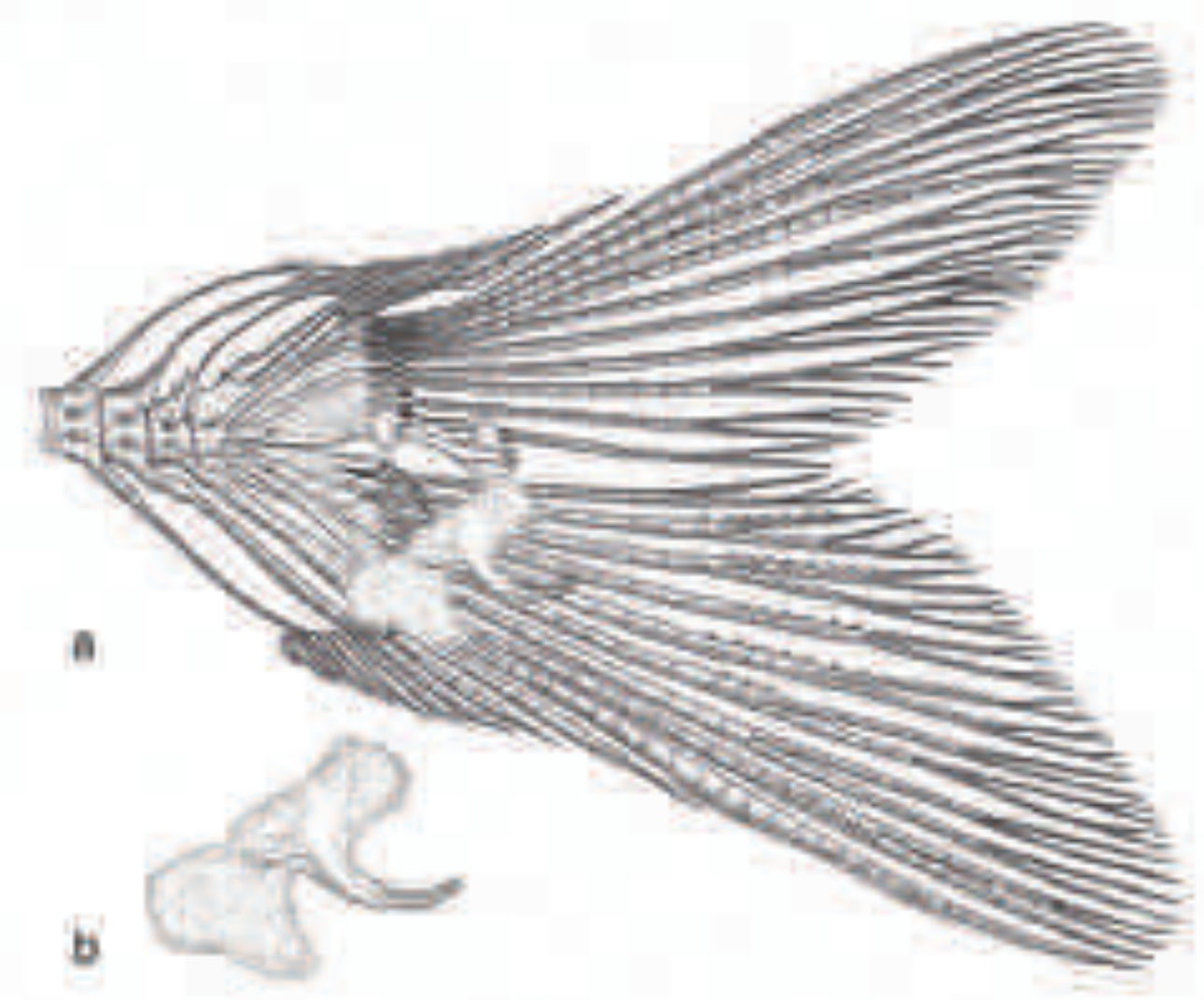

Figura 219. Nadadeira caudal de machos de Hysteronotus megalostomus em vista lateral esquerda, evidenciando a distribuição dos processos ósseos e posição da escama modificada (a) e detalhe da escama modificada (b). 


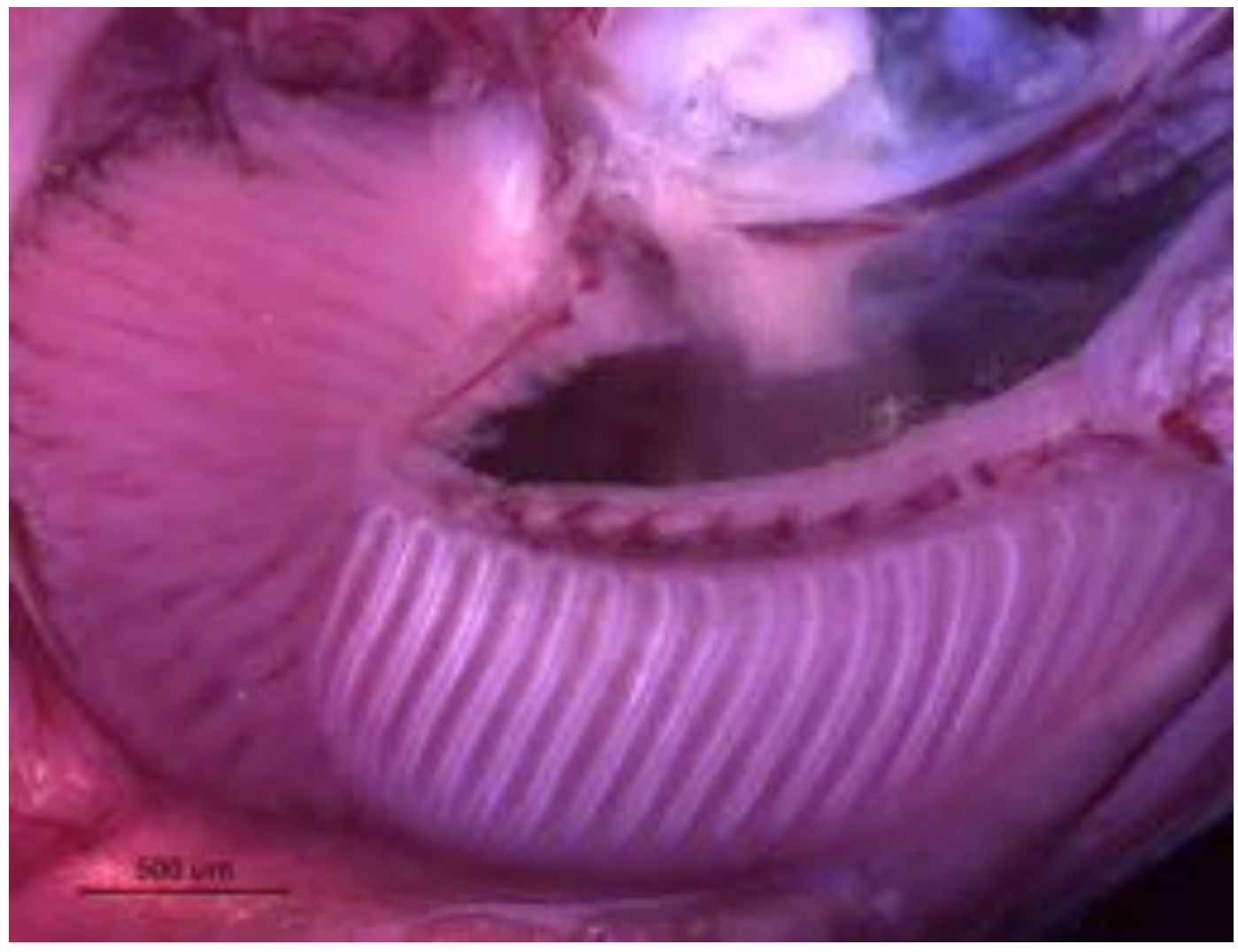

Figura 220. Brânquia com glândula branquial em vista lateral direita, evidenciando a glândula branquial ocupando todos os filamentos branquiais do ceratobranquial em Hysteronotus megalostomus. 


\section{Knodus heteresthes (Eigenmann 1908)}
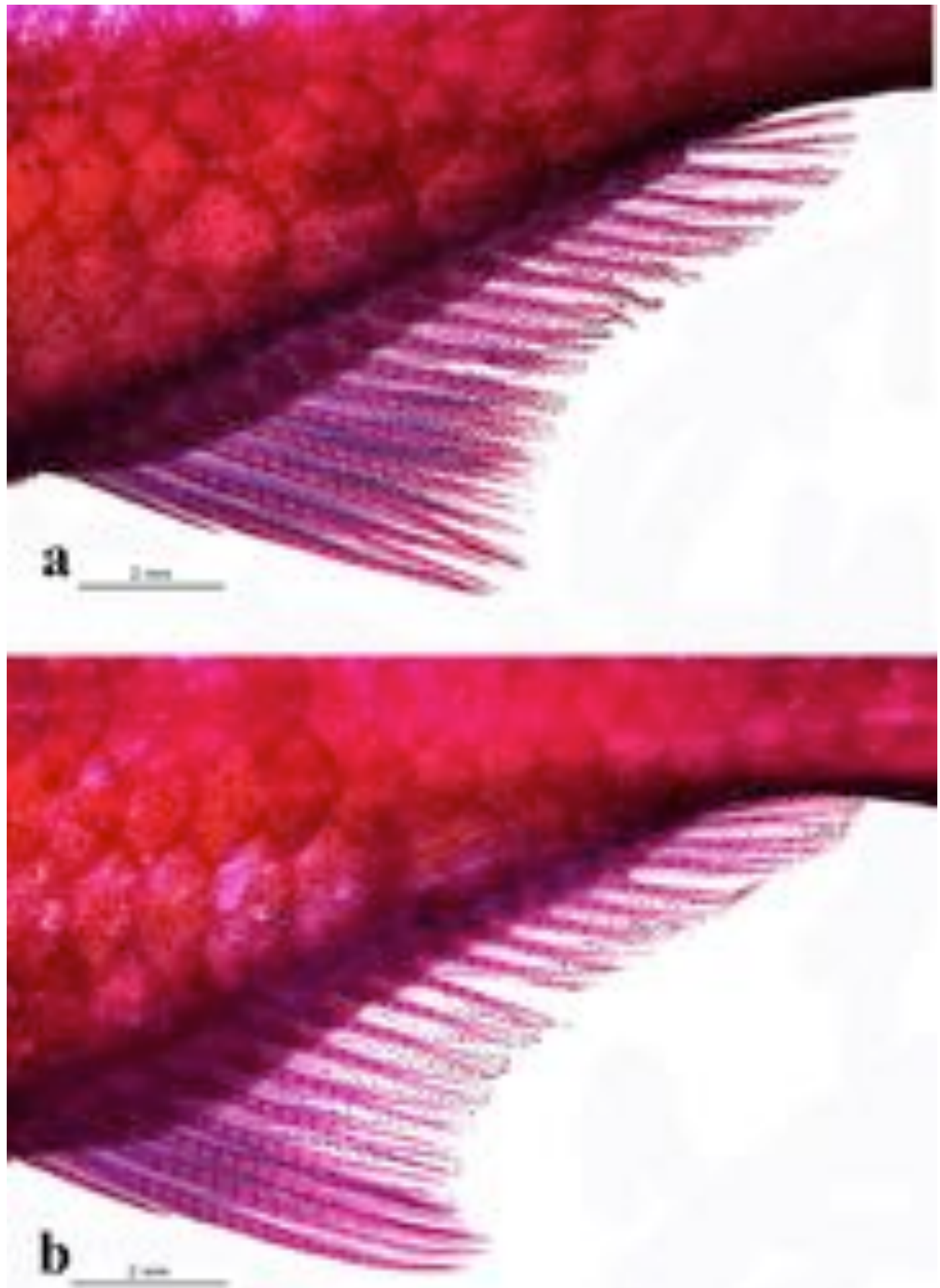

Figura 221. Nadadeira anal de machos (a) e de fêmeas (b) de Knodus heteresthes em vista lateral esquerda, evidenciando o formato do perfil distal das nadadeiras nos dois sexos e distribuição dos processos ósseos na nadadeira anal de macho. 


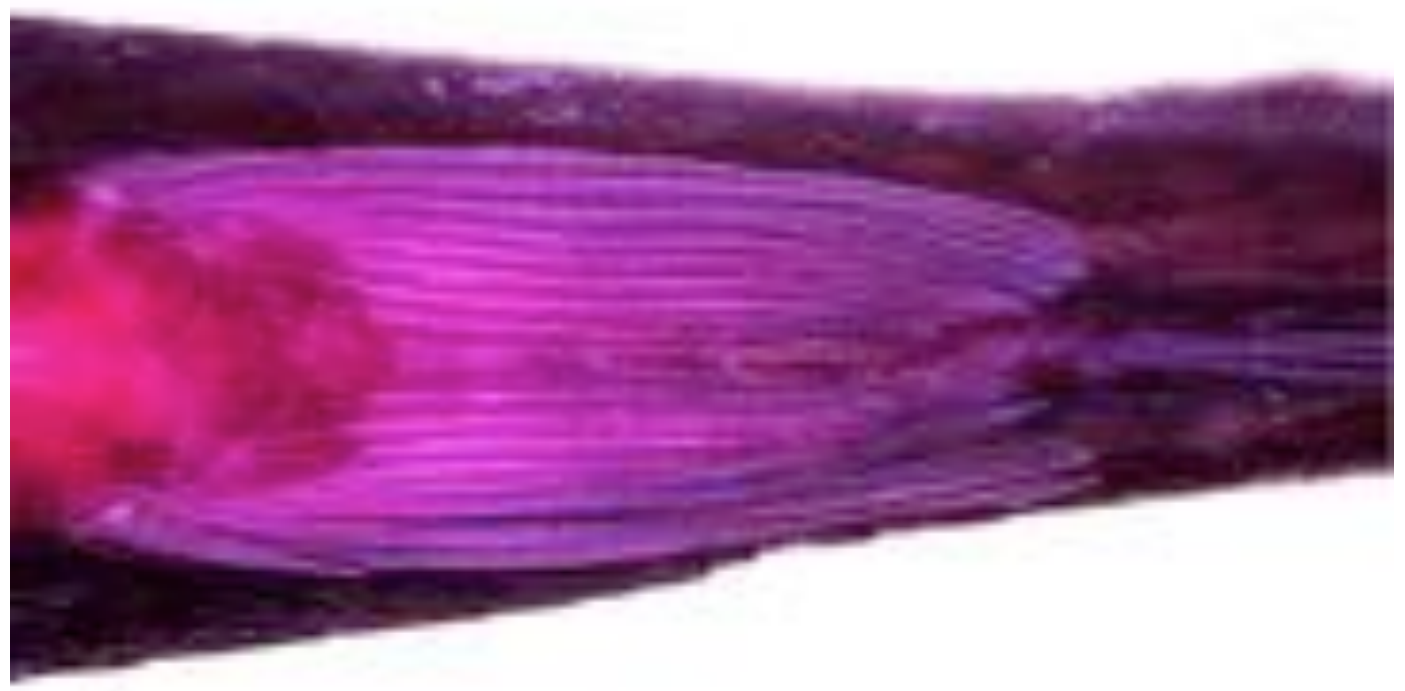

a
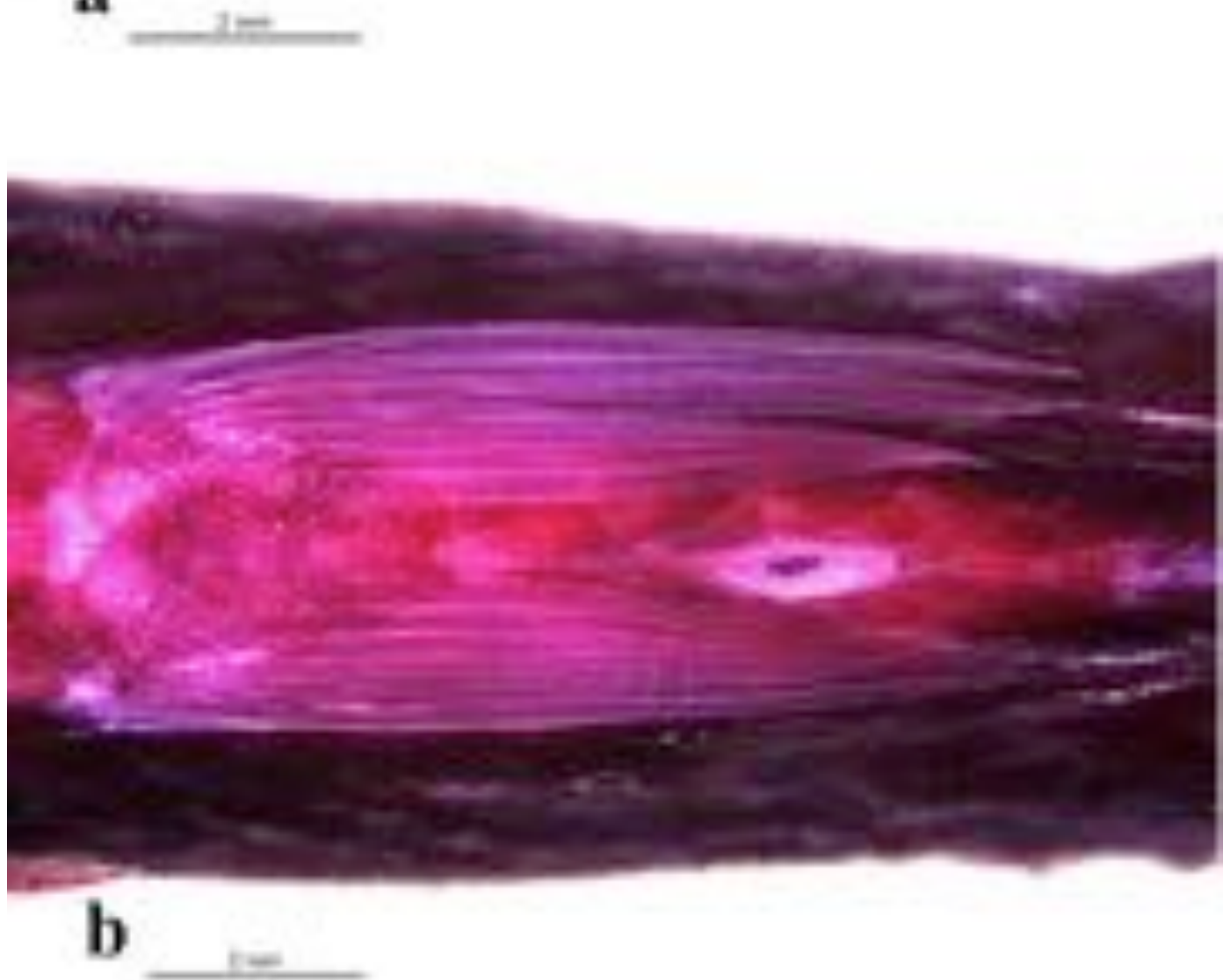

Figura 222. Nadadeira pélvica de machos (a) e de fêmeas (b) de Knodus heteresthes em vista ventral, evidenciando o formato e comprimento da nadadeira nos dois sexos. 

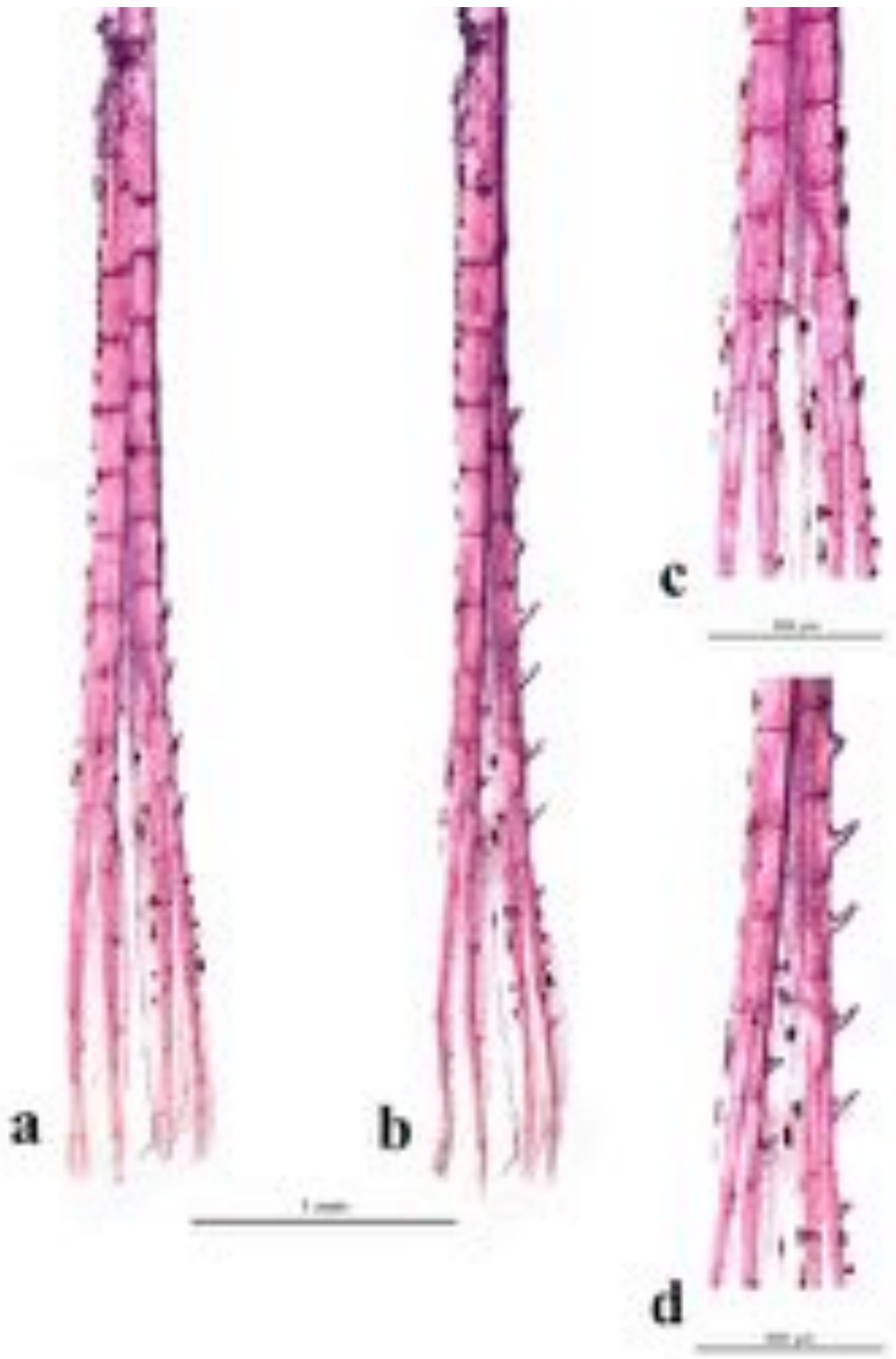

Figura 223. Distribuição, posição e formato dos processos ósseos no hemitriquium esquerdo do raio ramificado da nadadeira anal de machos de Knodus heteresthes. (a) vista lateral, (b) vista anteroposterior, (c) detalhe em vista lateral, (d) detalhe em vista anteroposterior. 

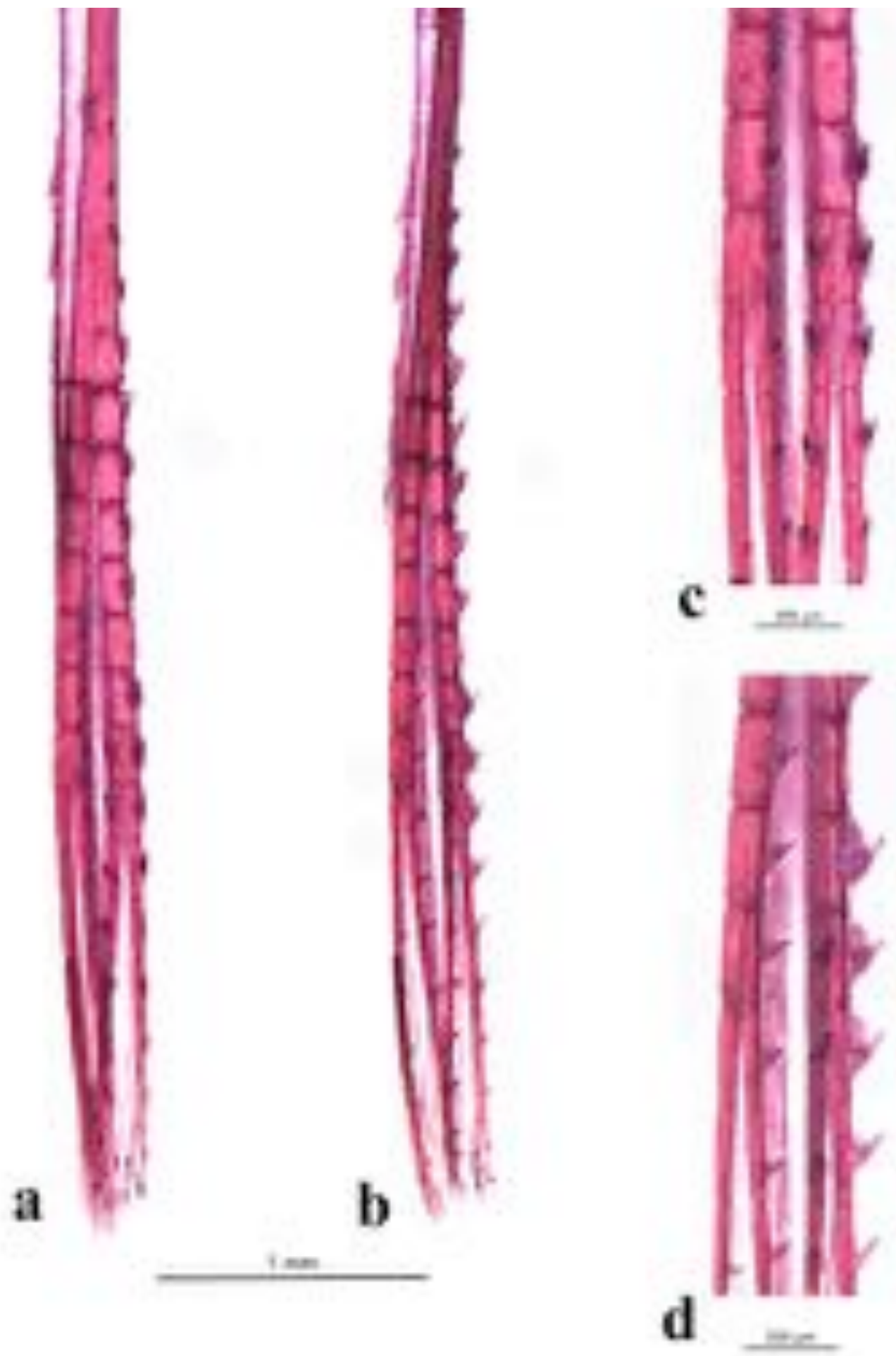

Figura 224. Distribuição, posição e formato dos processos ósseos no hemitriquium ventral da nadadeira pélvica direita de machos de Knodus heteresthes. (a) vista ventral, (b) vista lateromedial, (c) detalhe em vista ventral e (d) detalhe em vista lateromedial. 


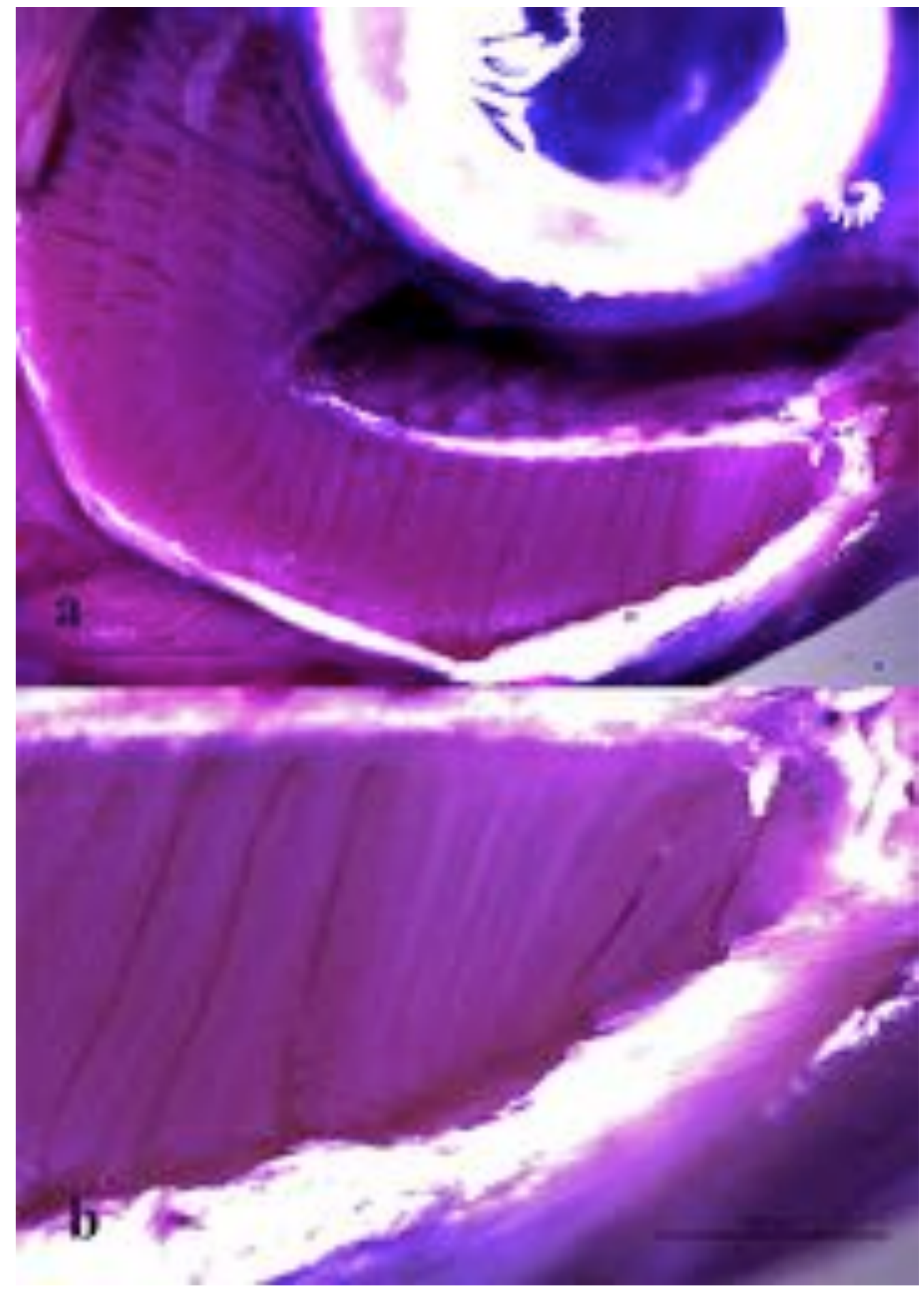

Figura 225. Brânquia com glândula branquial em vista lateral direita (a) e detalhe da região anterior evidenciando a glândula branquial (b) em Knodus heteresthes. 


\section{Pseudocorynopoma doriae Perugia 1891}
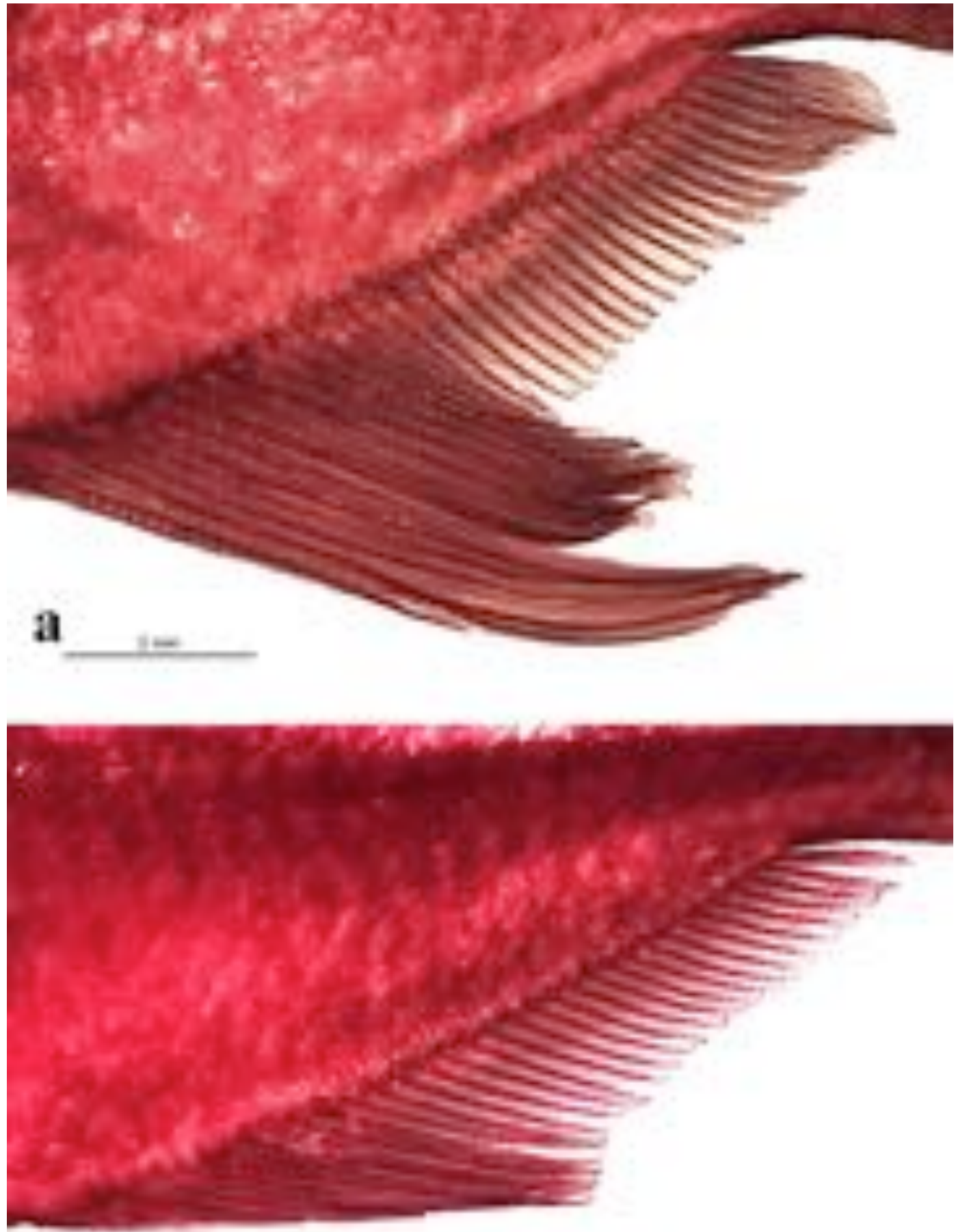

b

ine

Figura 226. Nadadeira anal de machos (a) e de fêmeas (b) de Pseudocorynopoma doriae em vista lateral esquerda, evidenciando o formato do perfil distal das nadadeiras nos dois sexos e distribuição dos processos ósseos na nadadeira anal de macho. 

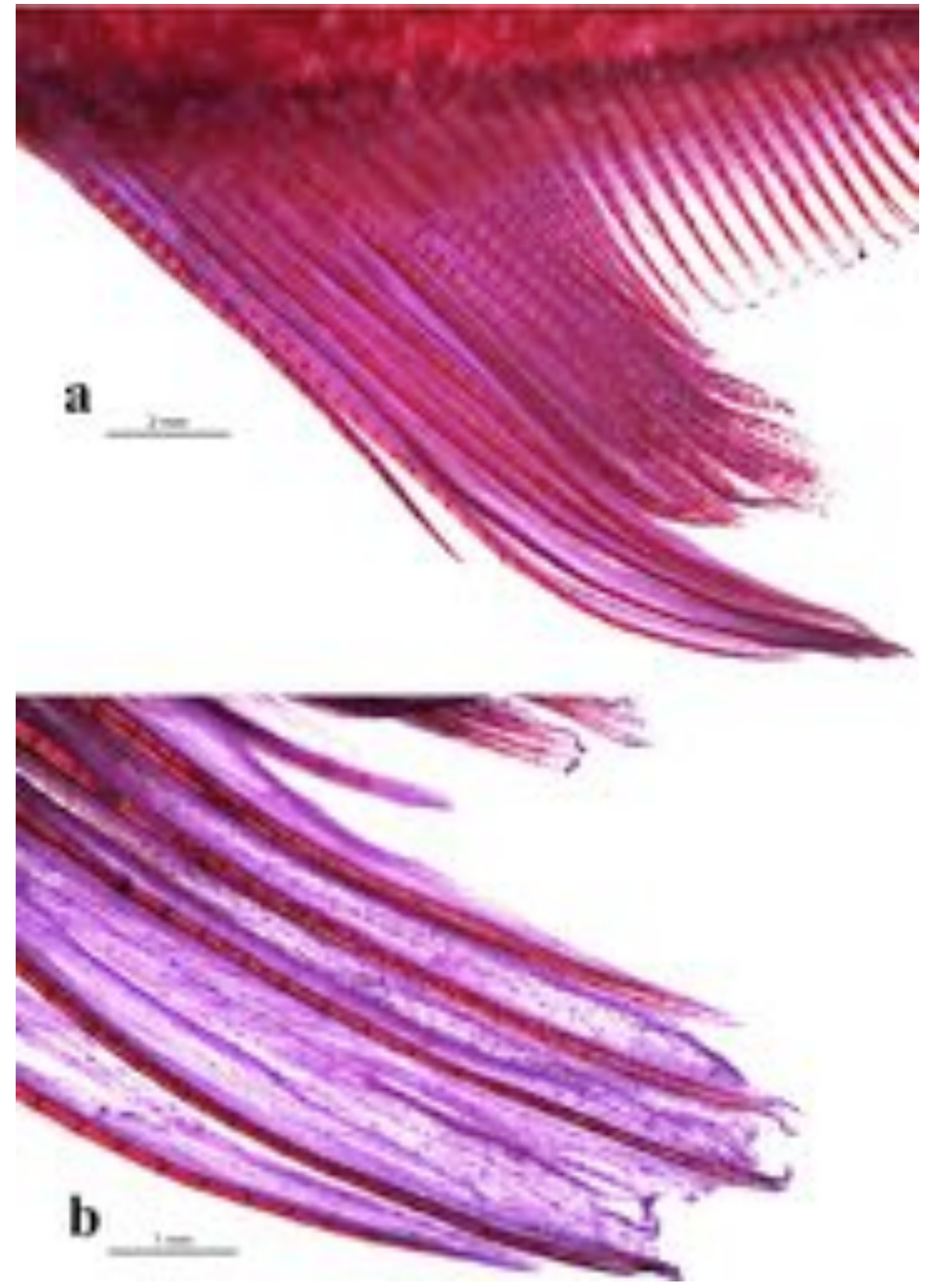

Figura 227. Porção anterior da nadadeira anal de machos de Pseudocorynopoma doriae (a) e detalhe das membranas interradiais de raios do lobo anterior da nadadeira, evidenciando as projeções digitiformes (b). 


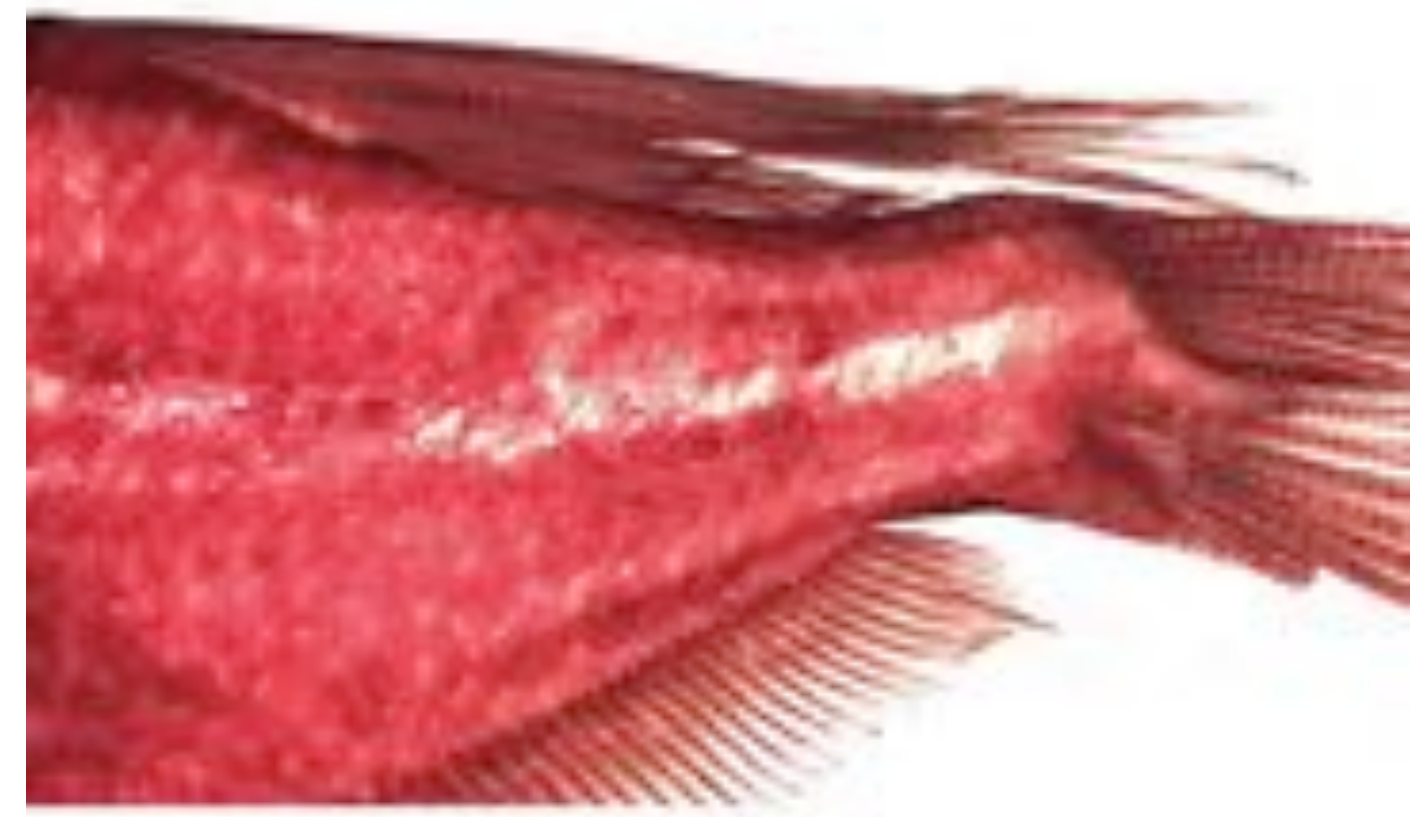

a
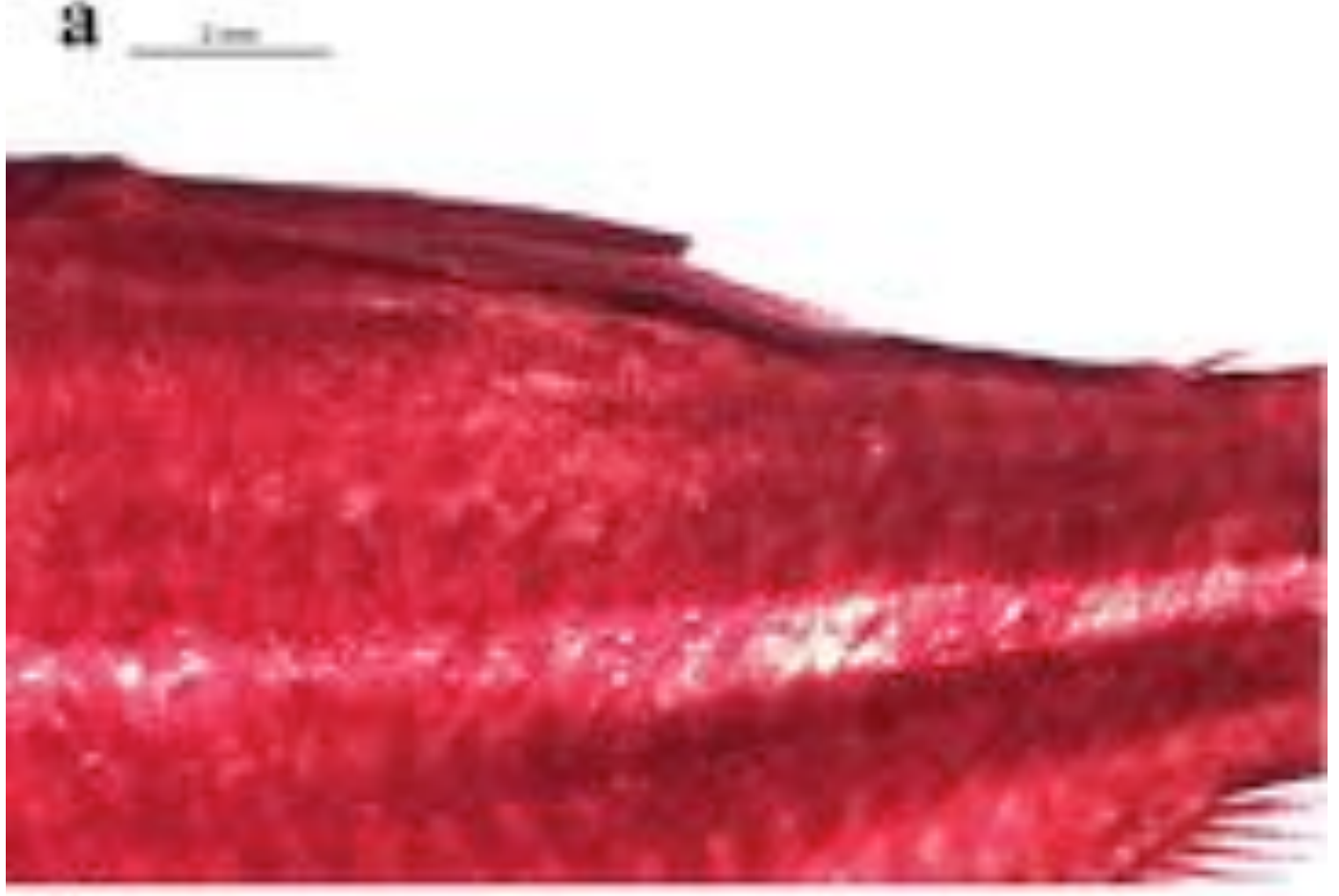

b

10

Figura 228. Nadadeira dorsal de machos (a) e de fêmeas (b) de Pseudocorynopoma doriae em vista lateral esquerda, evidenciando o formato e comprimento da nadadeira nos dois sexos. 

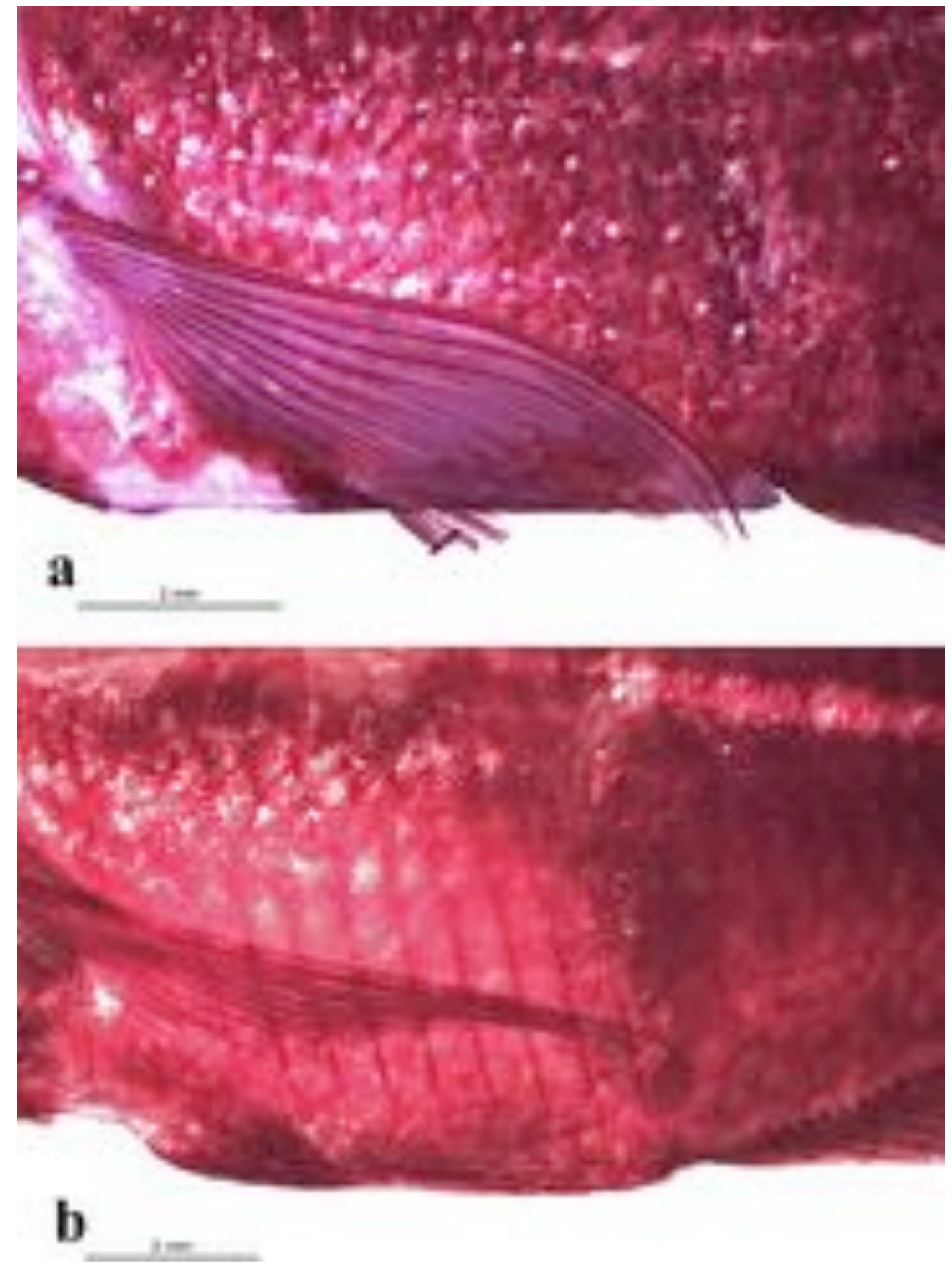

Figura 229. Nadadeira peitoral de machos (a) e de fêmeas (b) de Pseudocorynopoma doriae em vista lateral ventral, evidenciando o formato e comprimento da nadadeira nos dois sexos. 


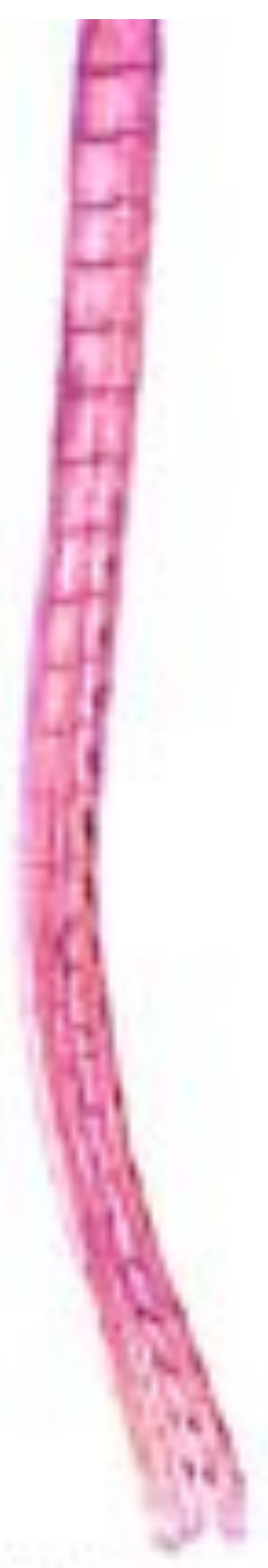

a

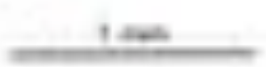

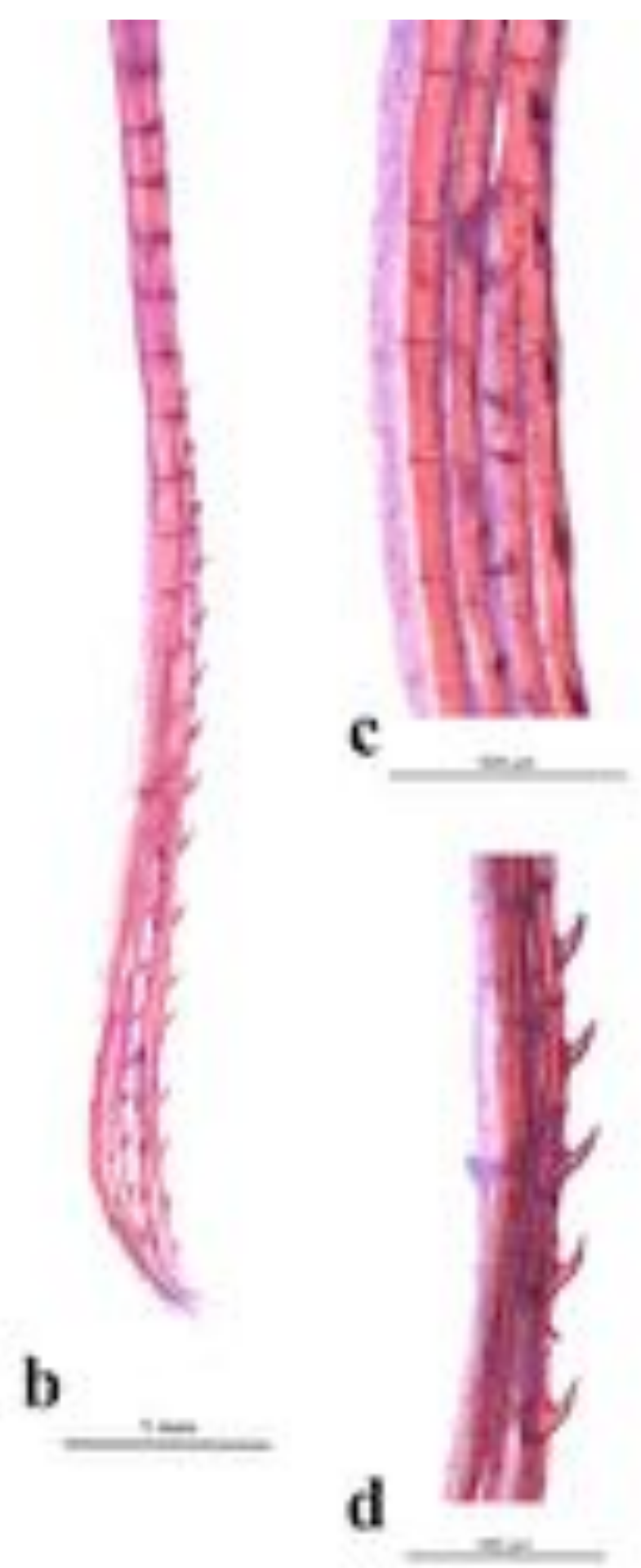

Figura 230. Distribuição, posição e formato dos processos ósseos no hemitriquium esquerdo do raio ramificado da nadadeira anal de machos de Pseudocorynopoma doriae. (a) vista lateral, (b) vista anteroposterior, (c) detalhe em vista lateral e (c) detalhe em vista anteroposterior. 

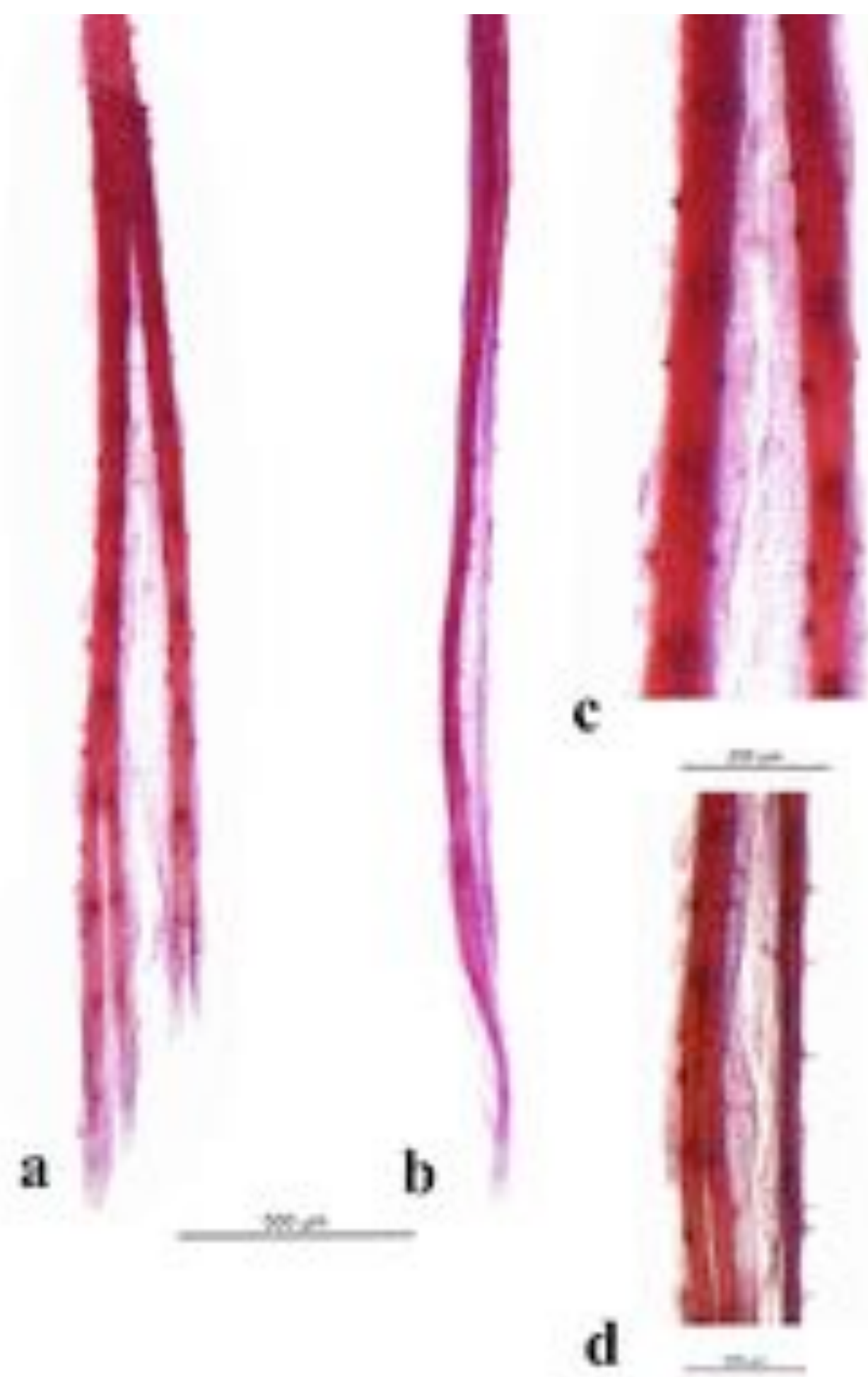

Figura 231. Distribuição, posição e formato dos processos ósseos no hemitriquium ventral da nadadeira pélvica direita de machos de Pseudocorynopoma doriae. (a) vista ventral, (b) vista lateromedial, (c) detalhe em vista ventral e (d) detalhe em vista lateromedial. 


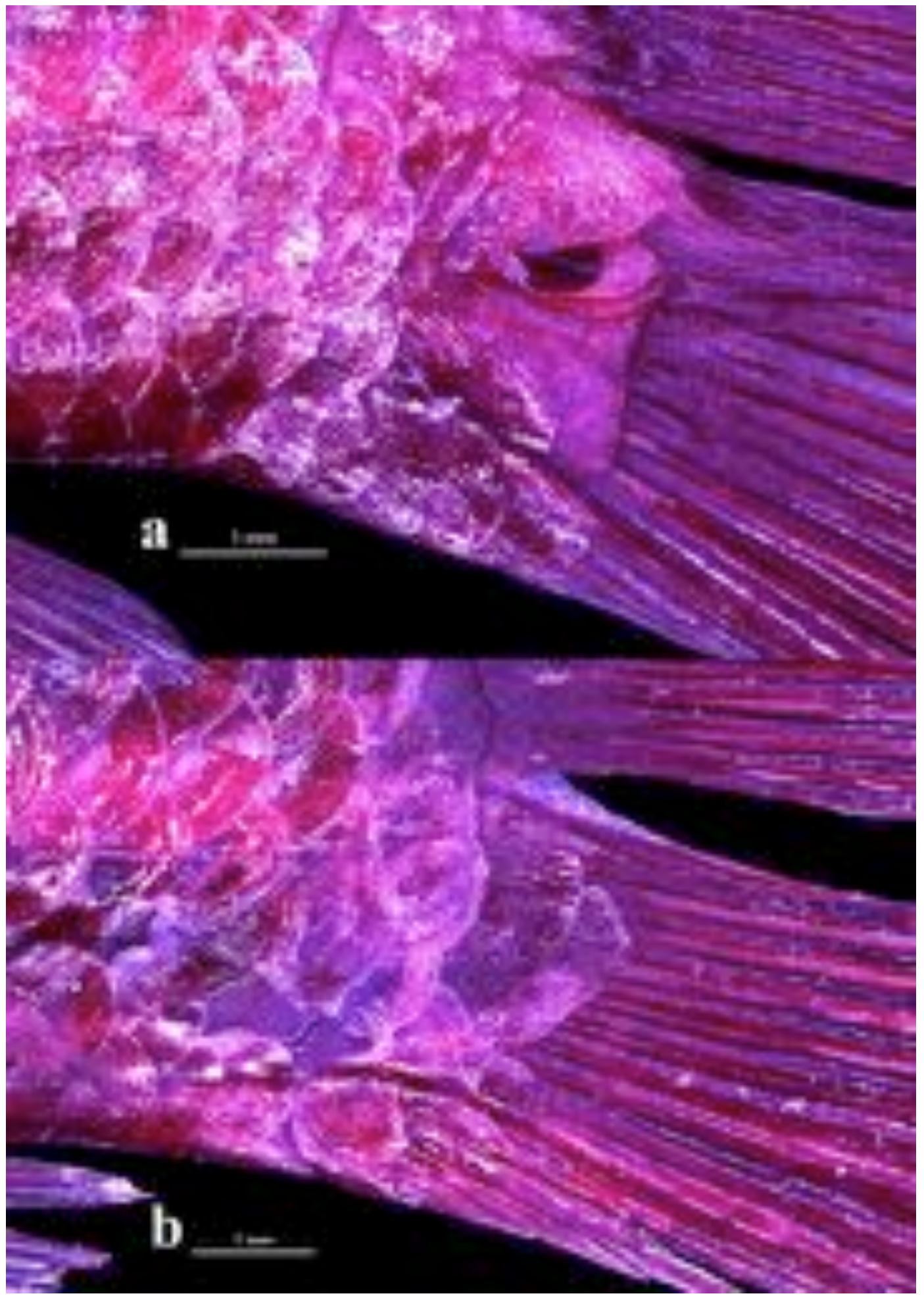

Figura 232. Porção ventral do pedúnculo caudal de machos (a) e de fêmeas (b) de Pseudocorynopoma doriae, evidenciando o formato e disposição das escamas posteriores das séries de escamas ventrais à série de escamas da linha lateral. 
Scopaeocharax rhinodus (Böhlke 1958)
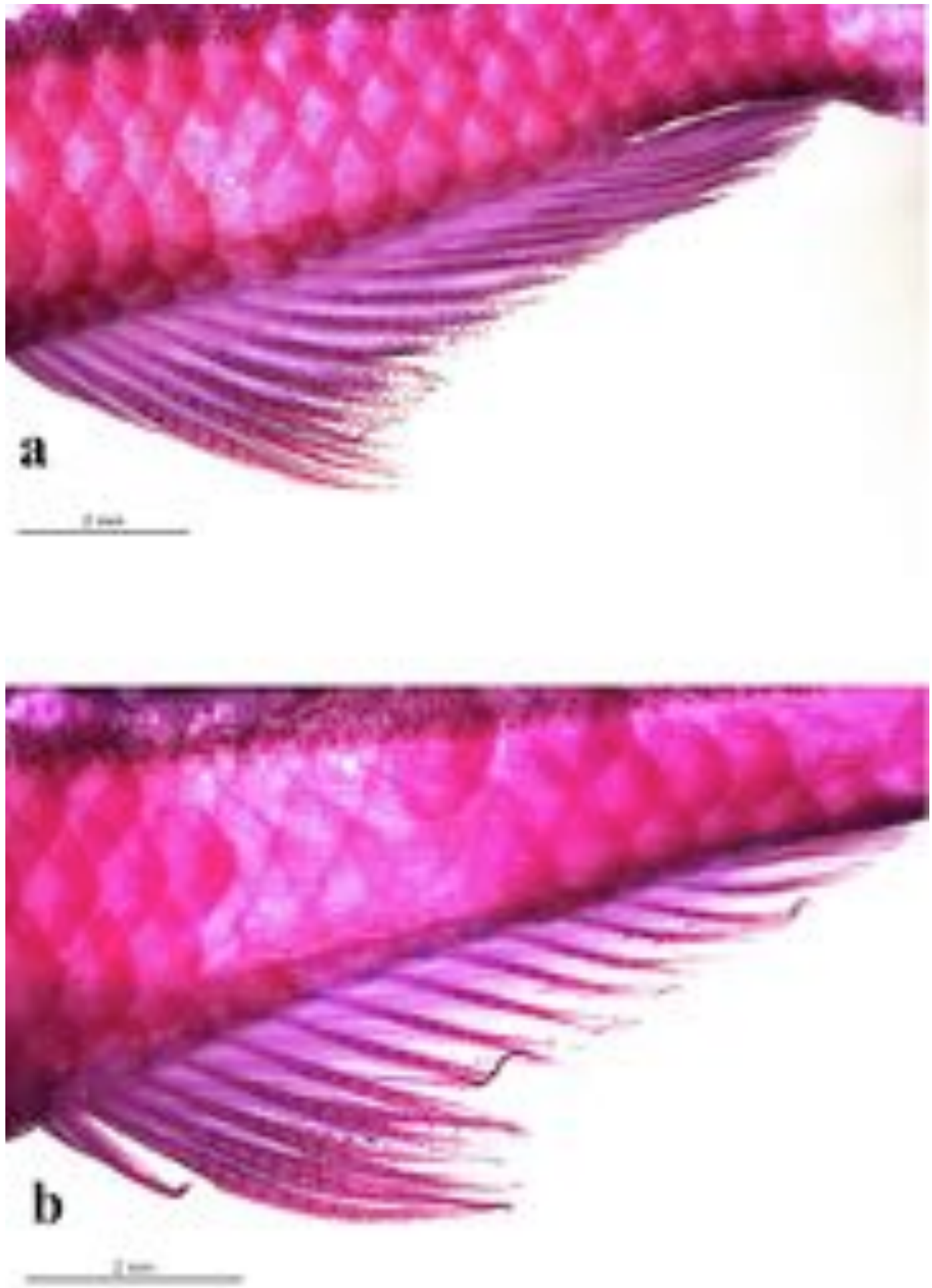

Figura 233. Nadadeira anal de machos (a) e de fêmeas (b) de Scopaeocharax rhinodus em vista lateral esquerda, evidenciando o formato do perfil distal das nadadeiras nos dois sexos e distribuição dos processos ósseos na nadadeira anal de macho. 

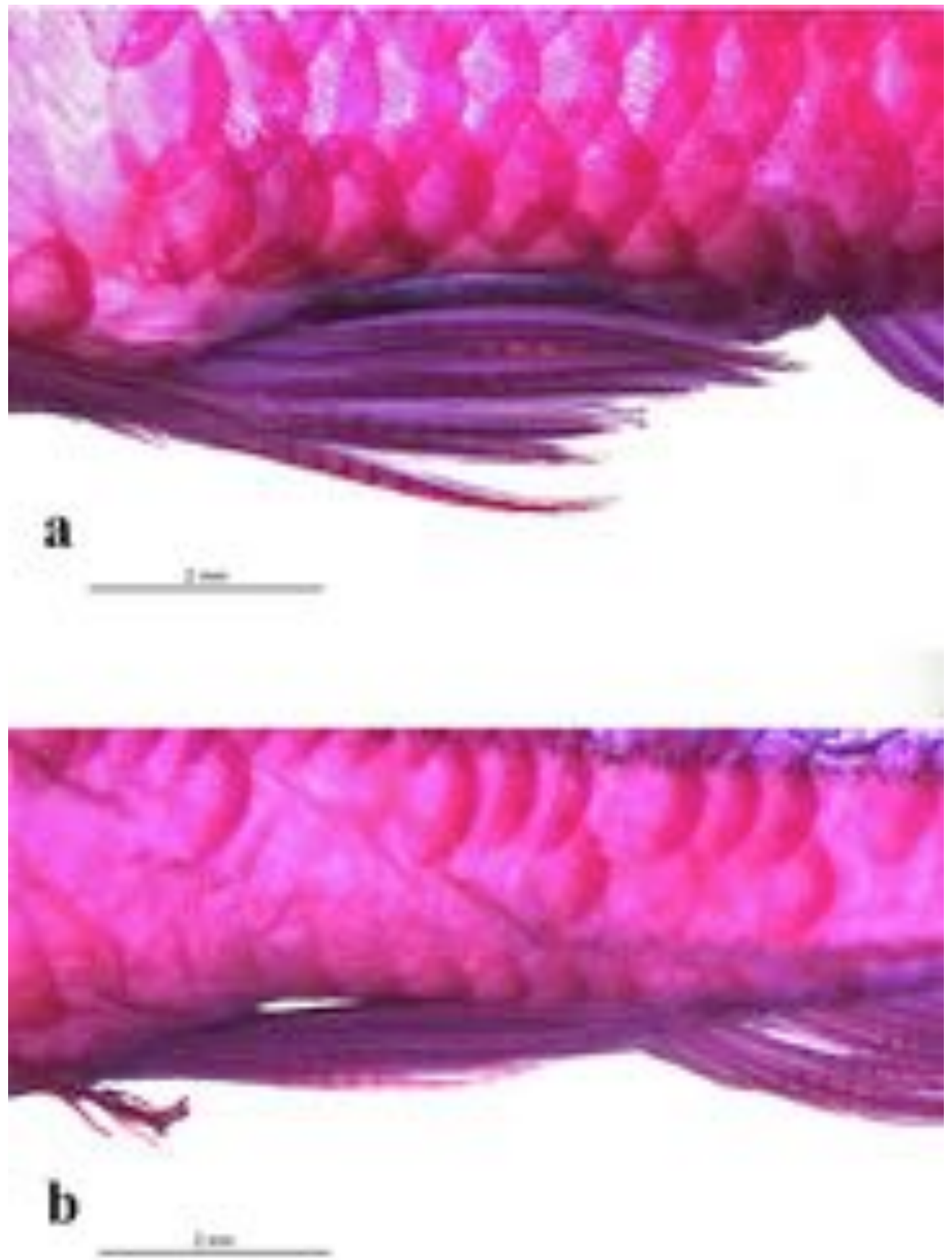

Figura 234. Nadadeira pélvica de machos (a) e de fêmeas (b) de Scopaeocharax rhinodus em vista ventral, evidenciando o formato e comprimento da nadadeira nos dois sexos. 


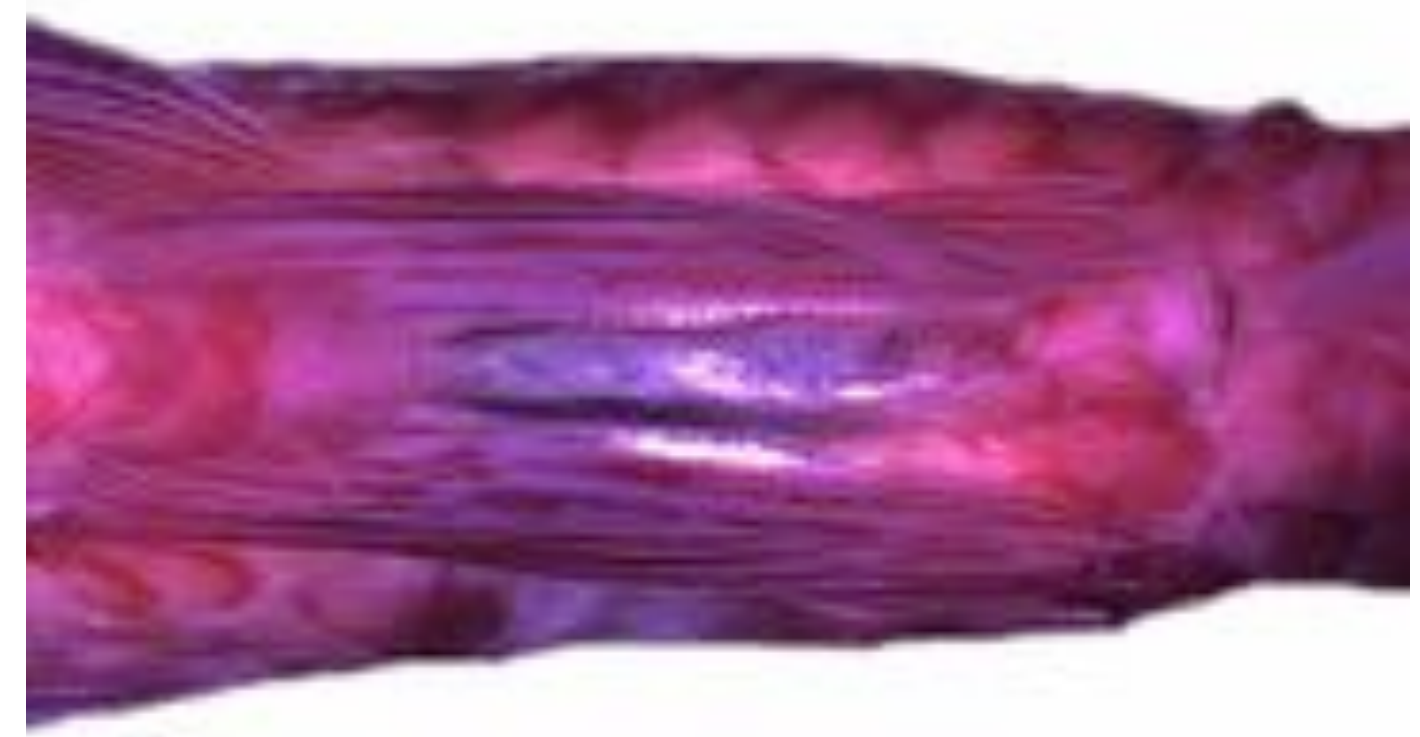

a

$1=$

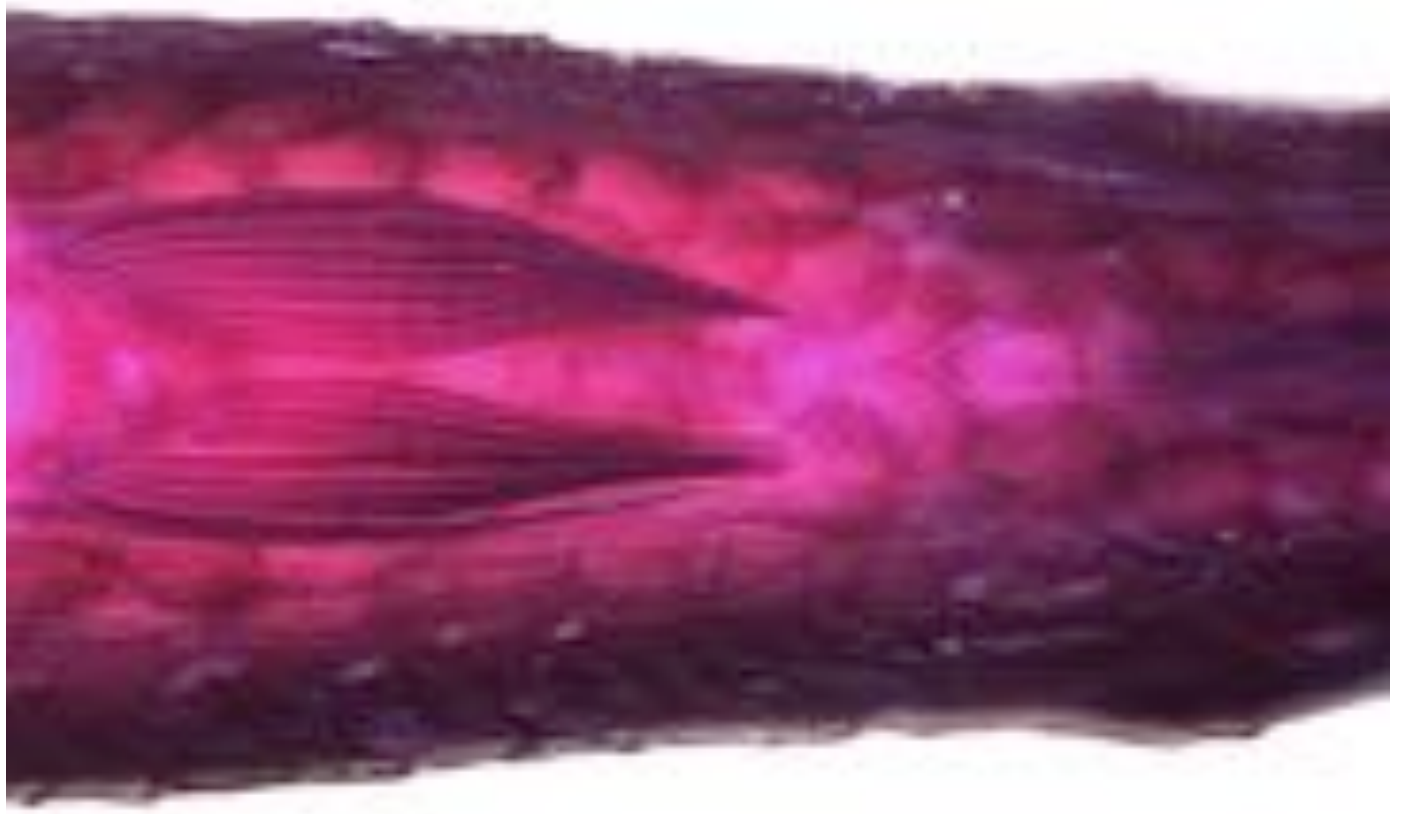

b ton

Figura 235. Nadadeira pélvica de machos (a) e de fêmeas (b) de Scopaeocharax rhinodus em vista lateral esquerda, evidenciando o formato e comprimento da nadadeira nos dois sexos. 

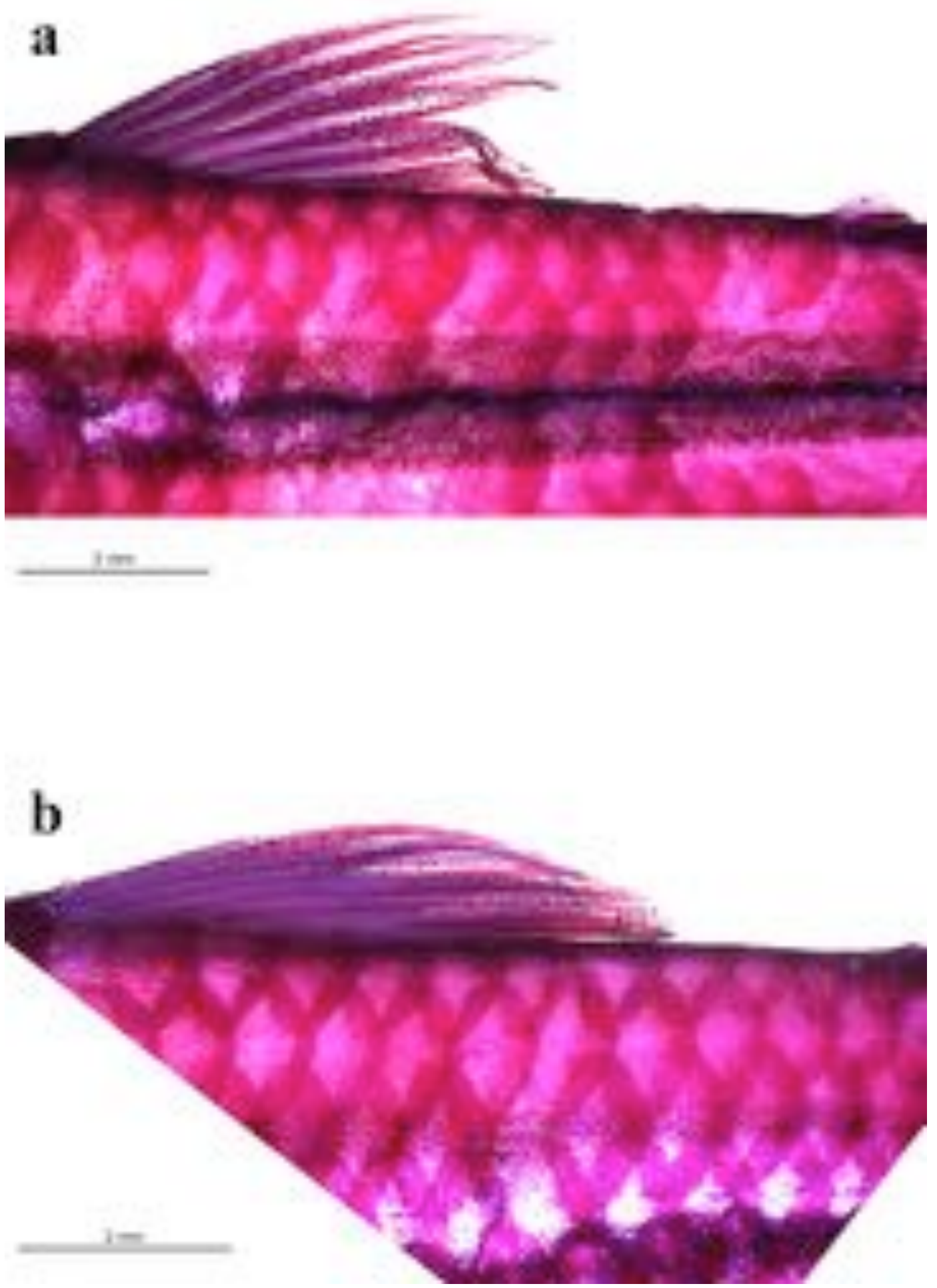

Figura 236. Nadadeira dorsal de fêmeas (a) e de machos (b) de Scopaeocharax rhinodus em vista lateral esquerda, evidenciando o formato e comprimento da nadadeira nos dois sexos. 

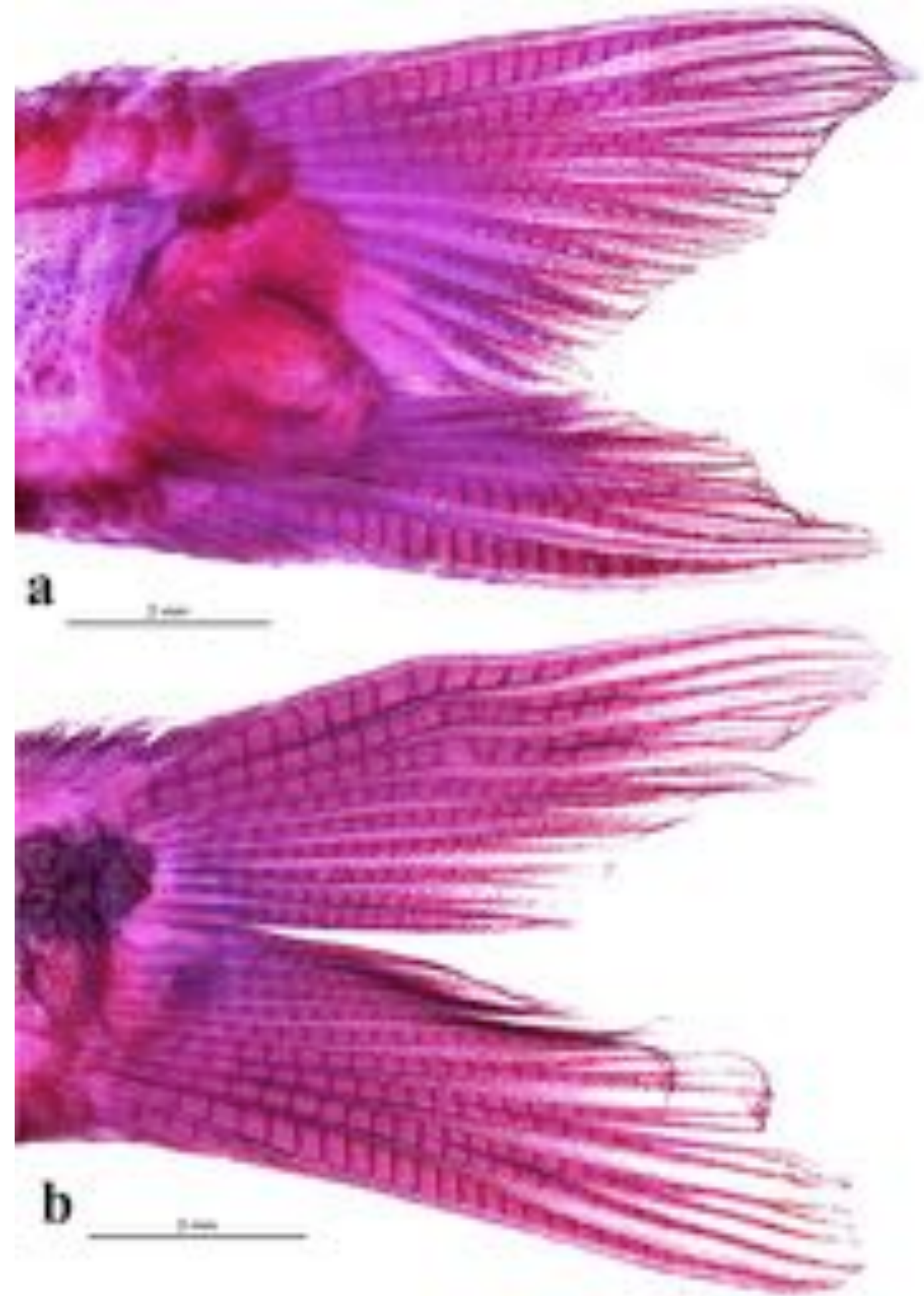

Figura 237. Pedúnculo caudal e nadadeira caudal de machos (a) e fêmeas (b) de Scopaeocharax rhinodus em vista lateral esquerda, evidenciando a escama modificada e o formato dos lobos nos dos sexos. 


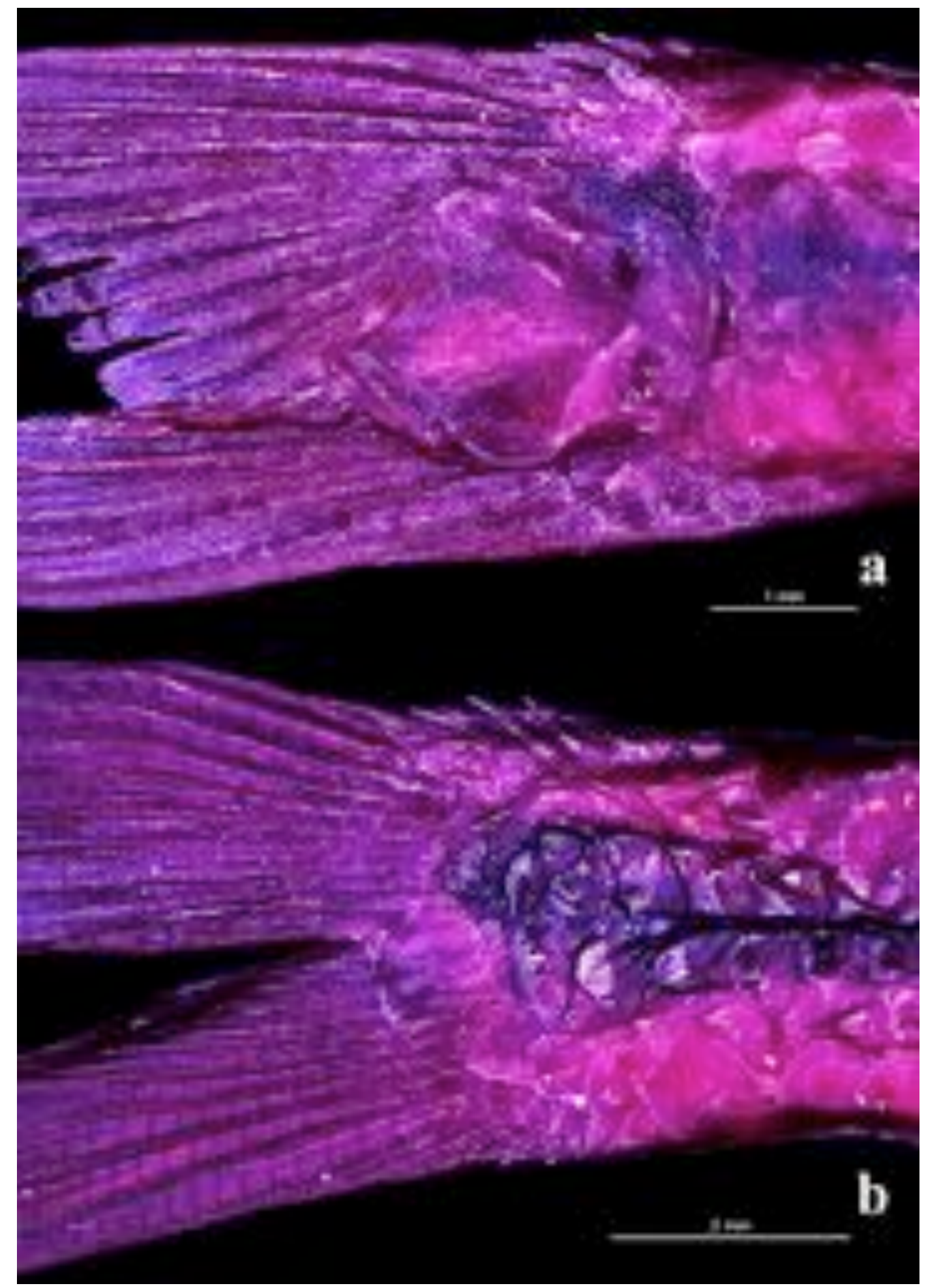

Figura 238. Pedúnculo caudal e nadadeira caudal de machos (a) e de fêmeas (b) de Scopaeocharax rhinodus, evidenciando o número e disposição das escamas. 

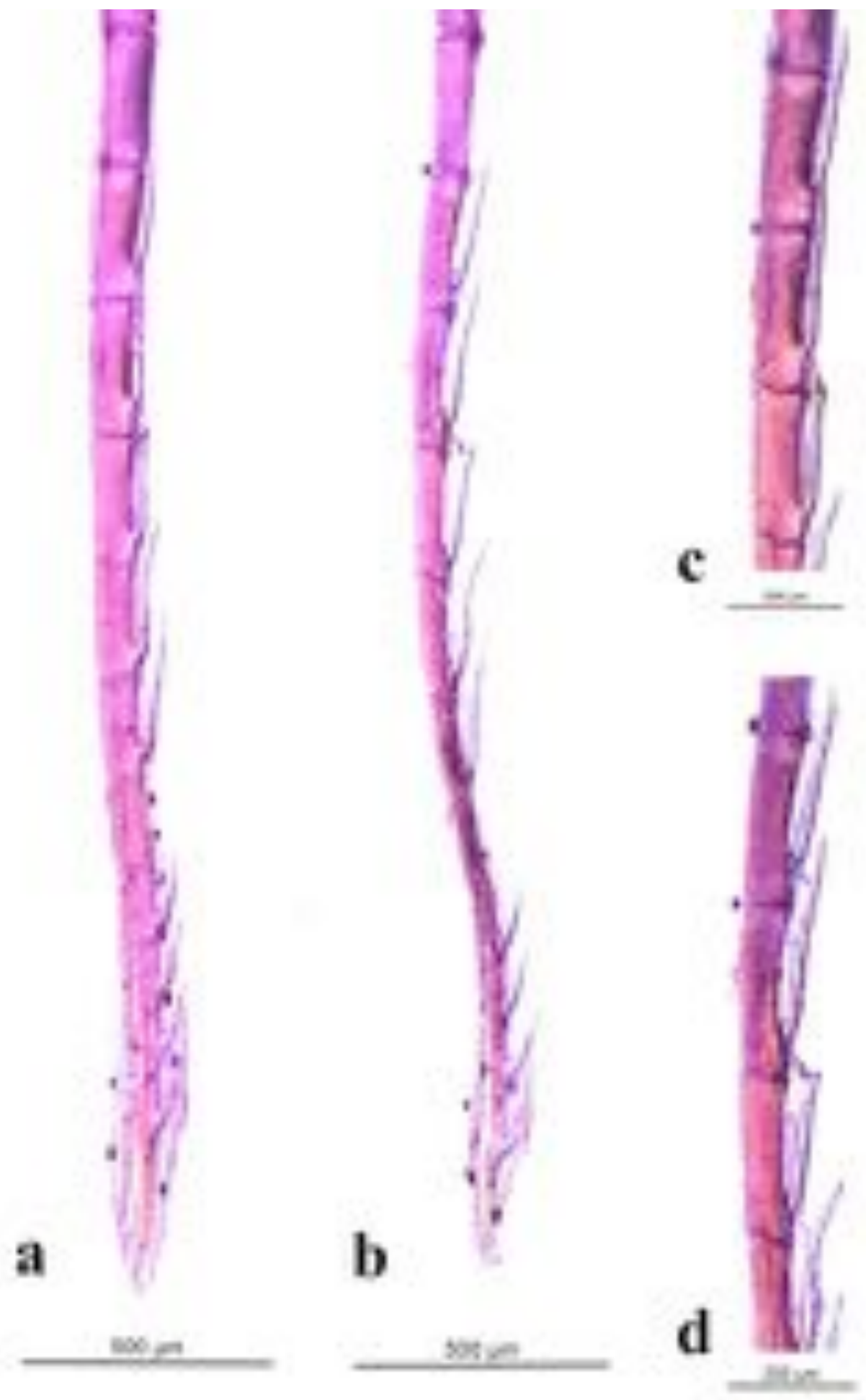

Figura 239. Distribuição, posição e formato dos processos ósseos no hemitriquium esquerdo do raio ramificado da nadadeira anal de machos de Scopaeocharax rhinodus. (a) vista lateral, (b) vista anteroposterior, (c) detalhe em vista lateral, (d) detalhe em vista anteroposterior. 


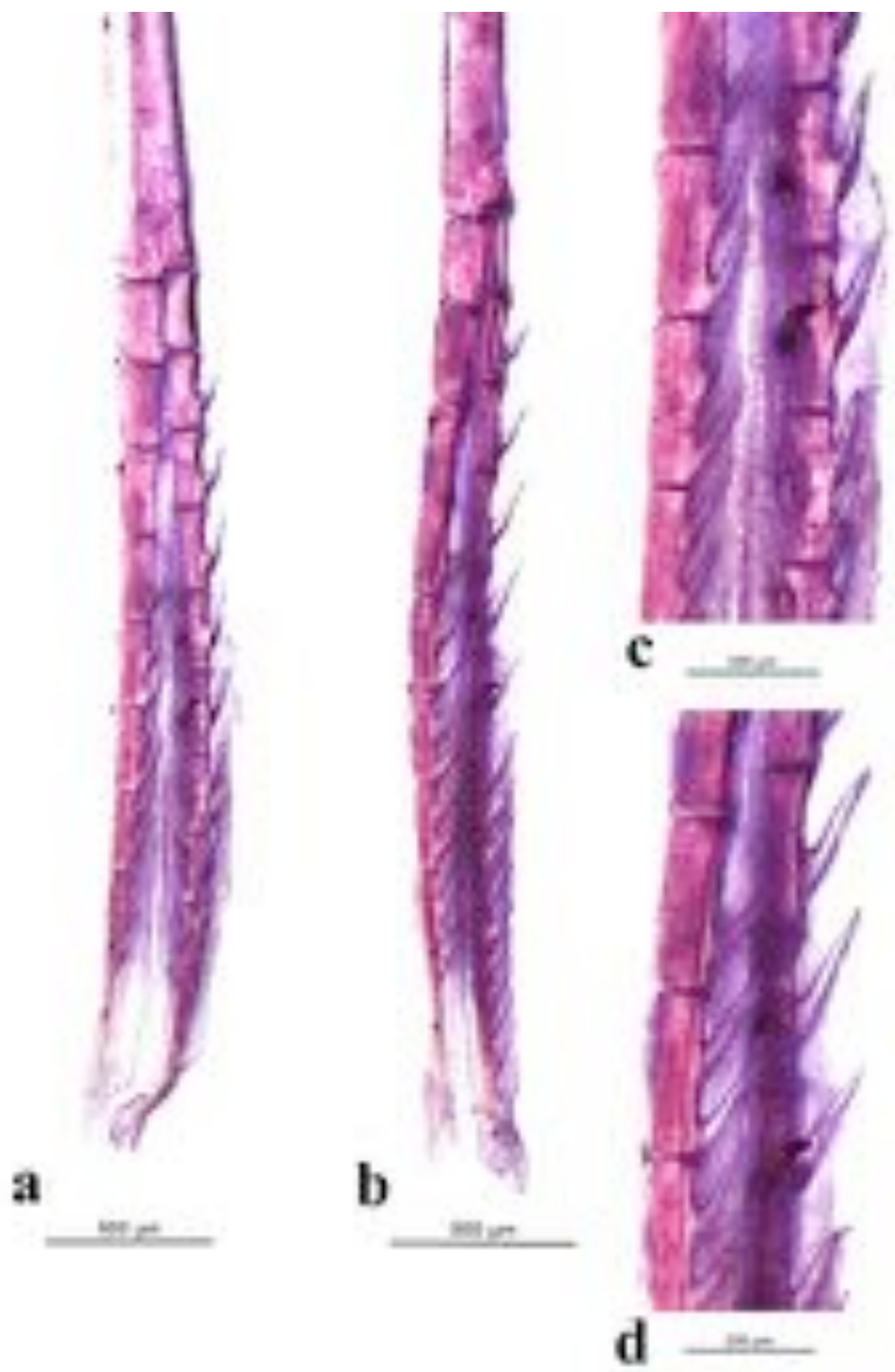

Figura 240. Distribuição, posição e formato dos processos ósseos no hemitriquium ventral da nadadeira pélvica direita de machos de Scopaeocharax rhinodus. (a) vista ventral, (b) vista lateromedial, (c) detalhe em vista ventral e (d) detalhe em vista lateromedial. 


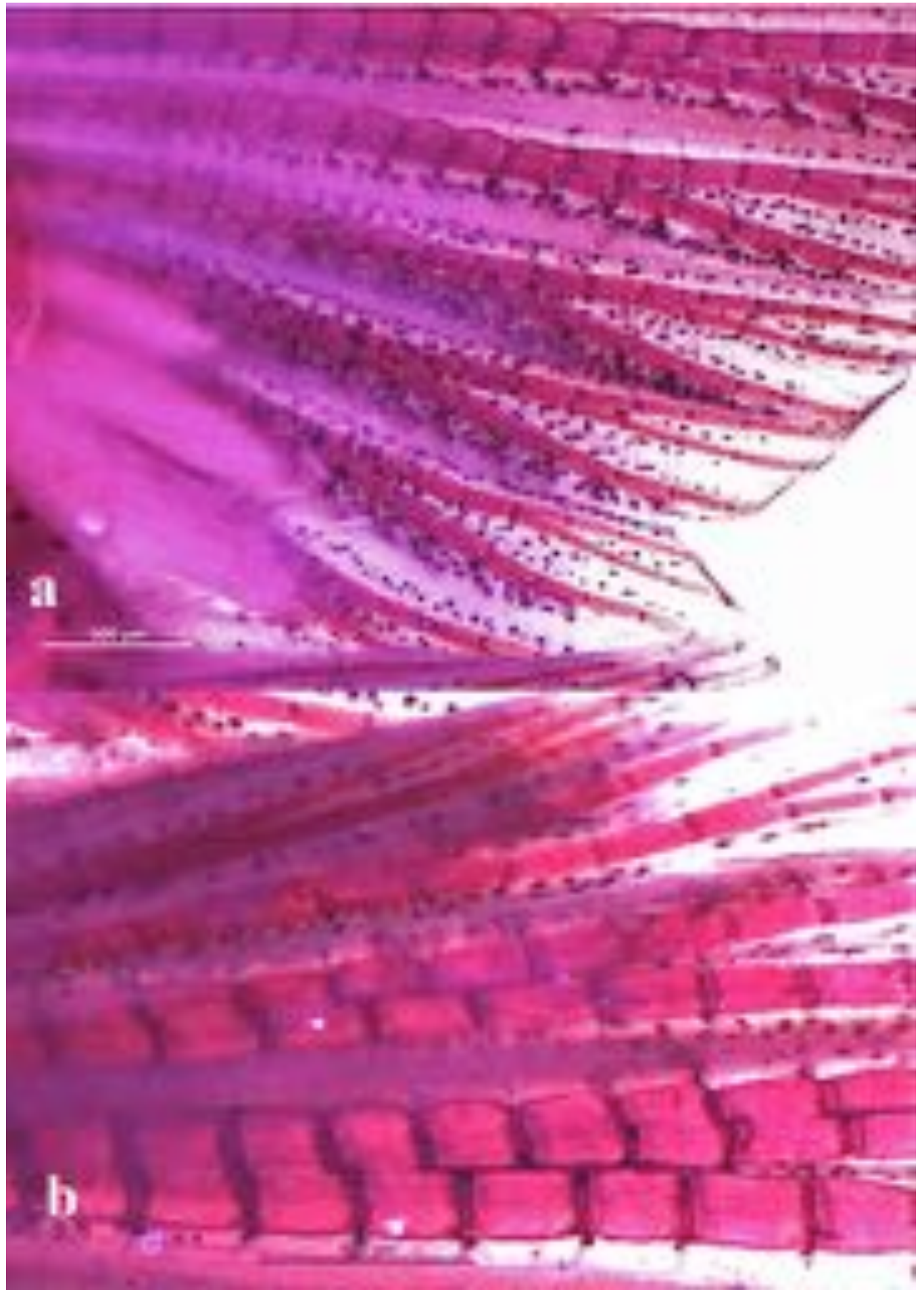

Figura 241. Distribuição, posição e formato dos processos ósseos no hemitriquium esquerdo da nadadeira caudal de machos de Scopaeocharax rhinodus. (a) vista lateral esquerda do lobo dorsal e (b) vista lateral esquerda do lobo ventral. 
6 - Substituição da capa do "Apêndice" pela seguinte:

\section{Apêndice da tese intitulada \\ "Evolução dos caracteres sexuais secundários em Characidae (Teleostei: Characiformes)"}

Tulio Franco Teixeira

Orientador: Prof. Dr. Naércio A. Menezes

São Paulo

2016 


\section{7 - Acréscimo do "sumário" no Apêndice.}

\section{Sumário}

Crenuchidae

Characidiinae 1

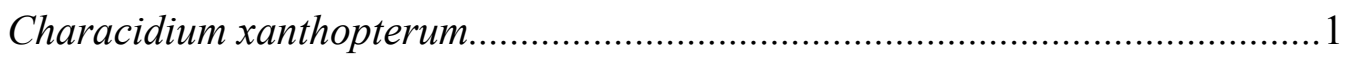

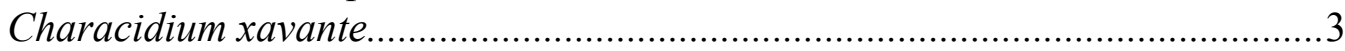

Gasteropelecidae

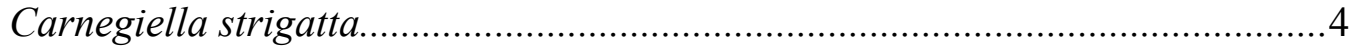

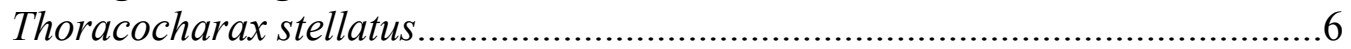

Serrasalmidae

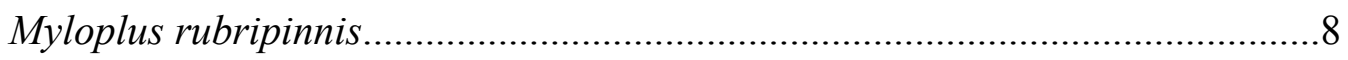

Characidae

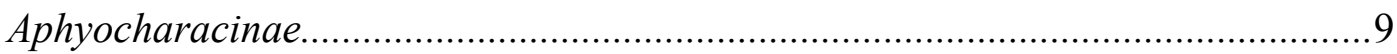

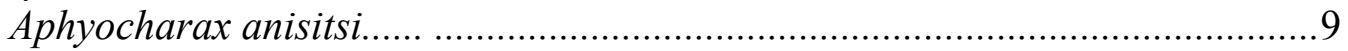

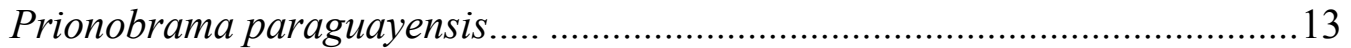

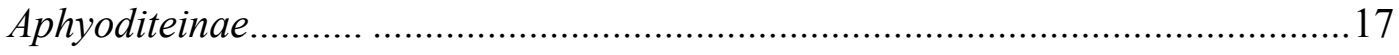

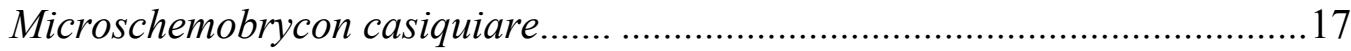

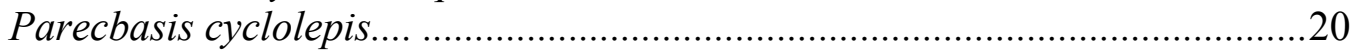

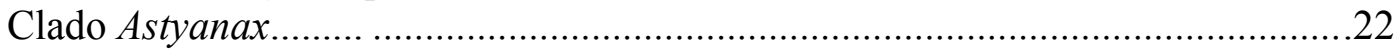

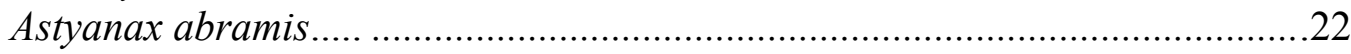

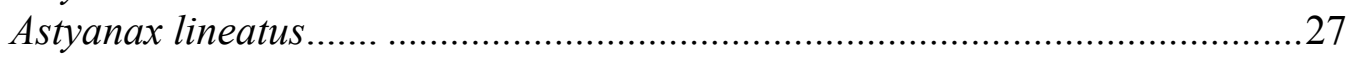

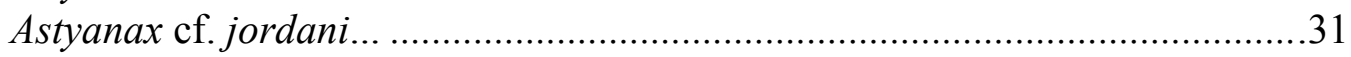

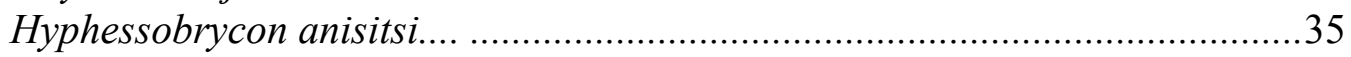

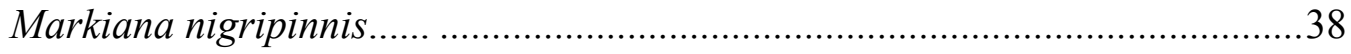

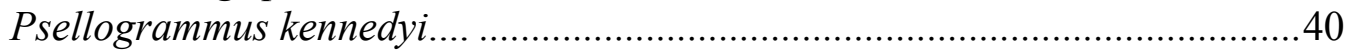

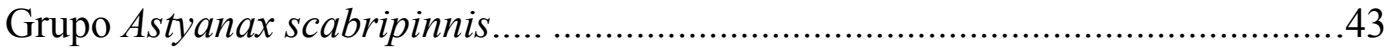

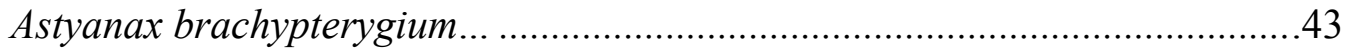

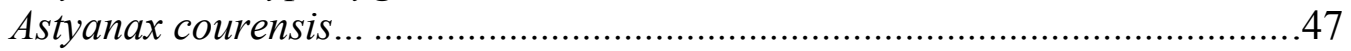

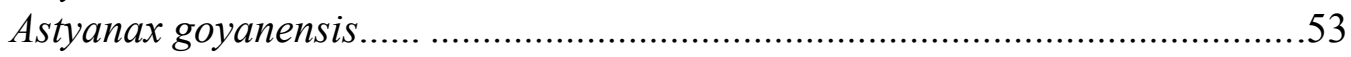

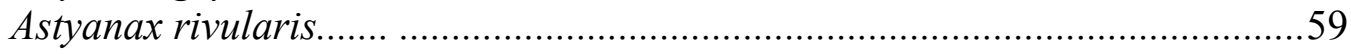

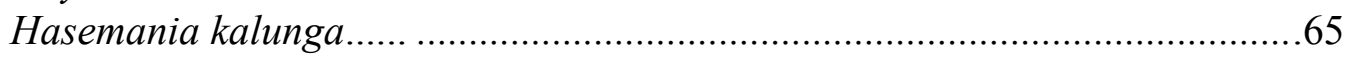

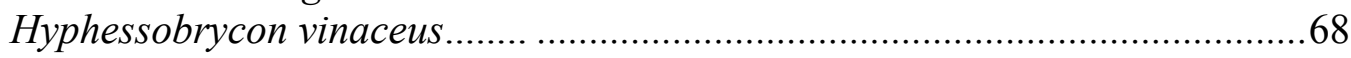

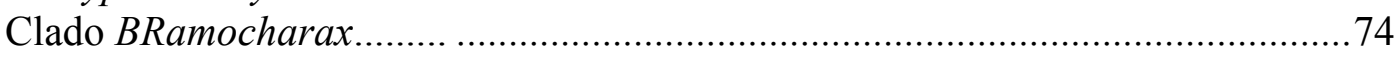

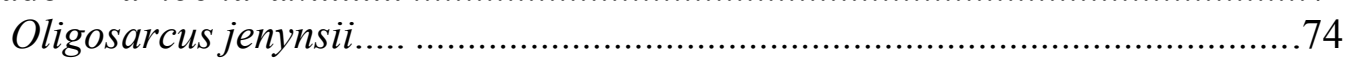

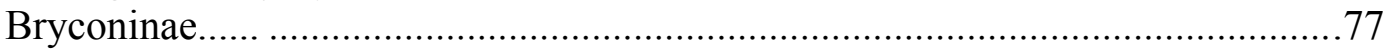

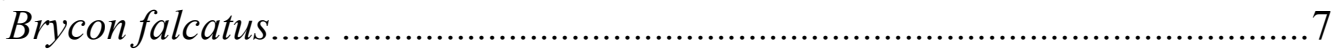

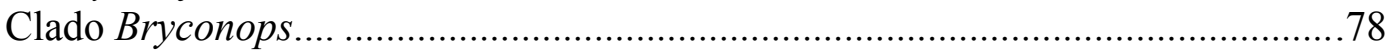

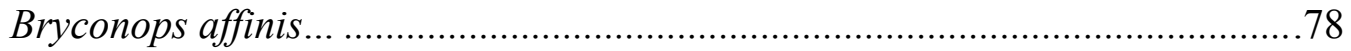

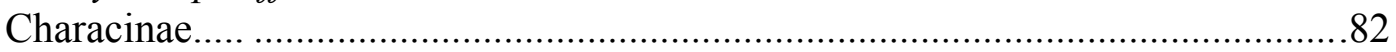

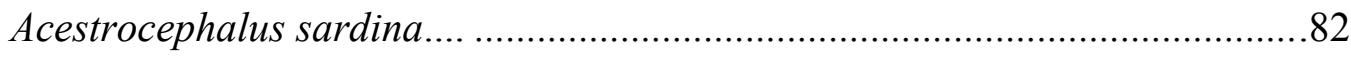

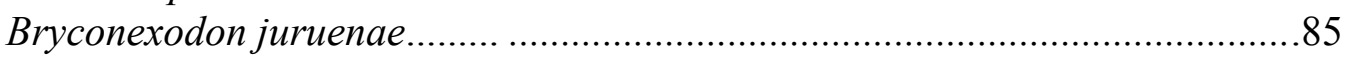

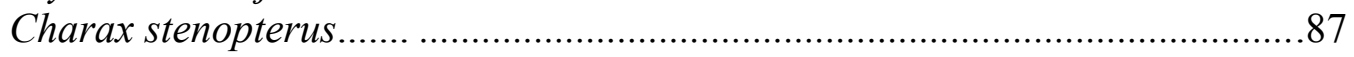




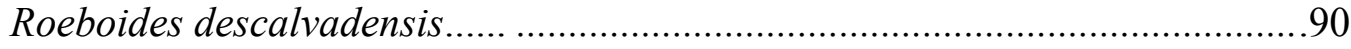

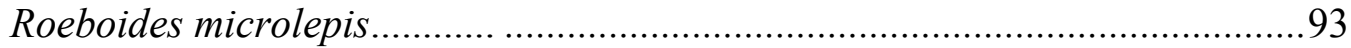

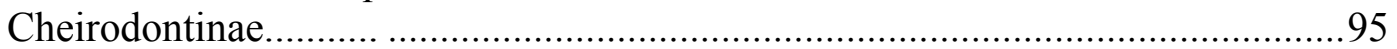

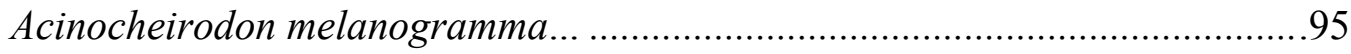

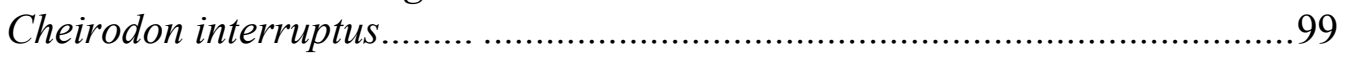

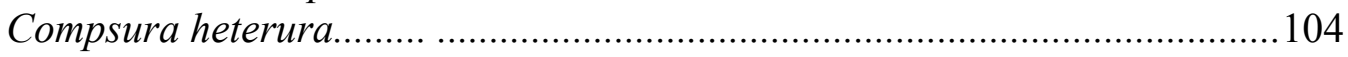

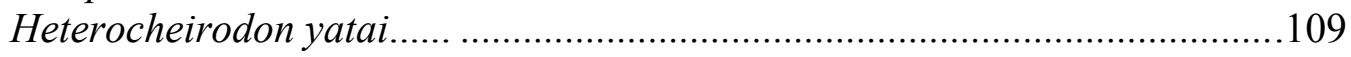

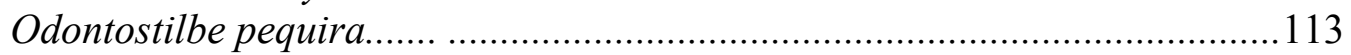

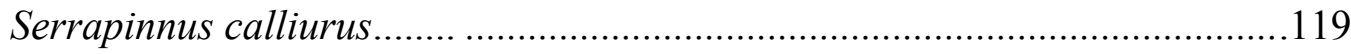

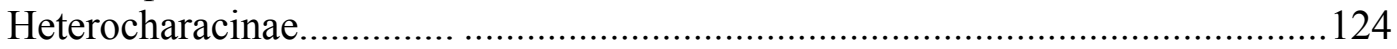

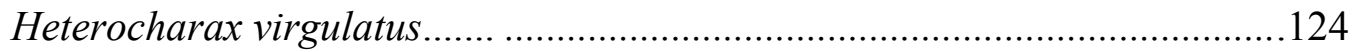

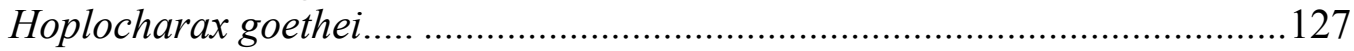

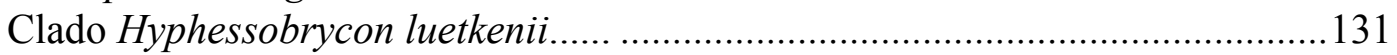

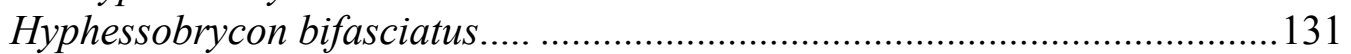

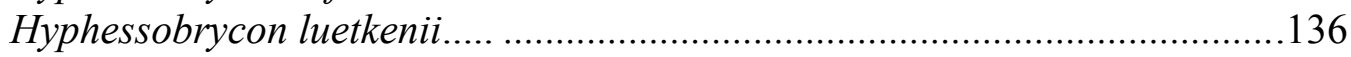

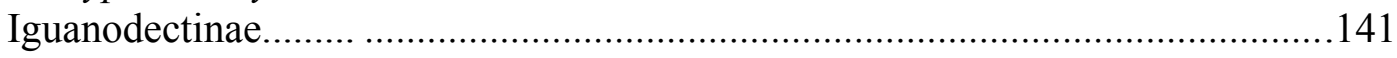

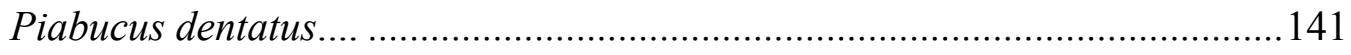

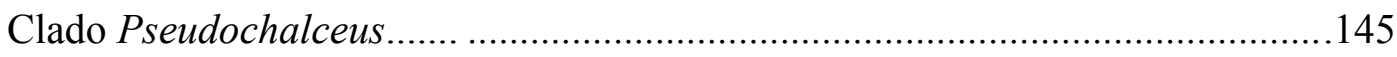

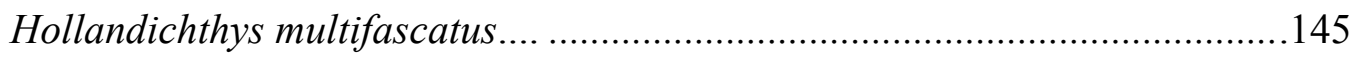

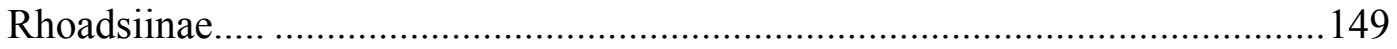

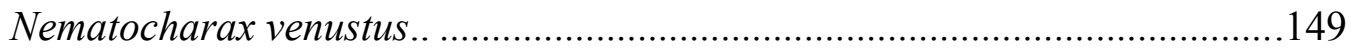

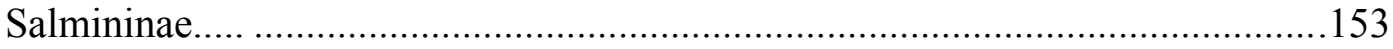

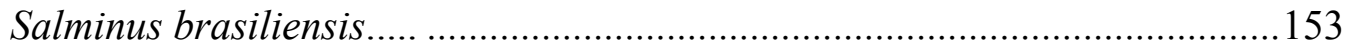

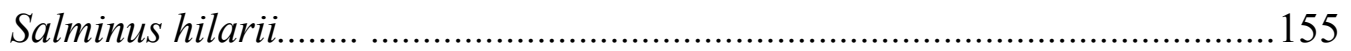

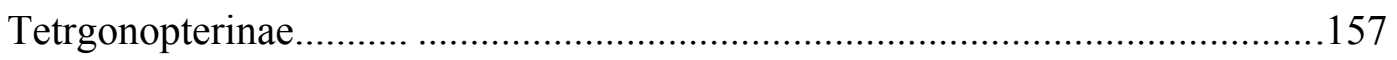

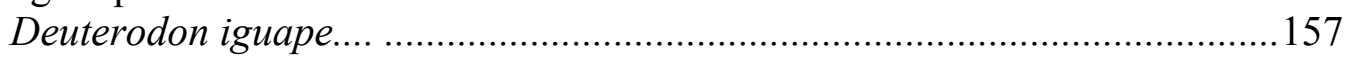

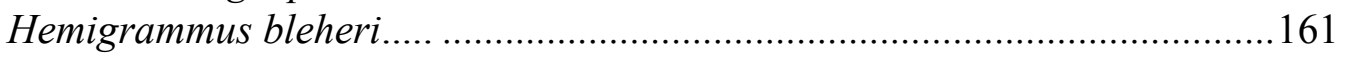

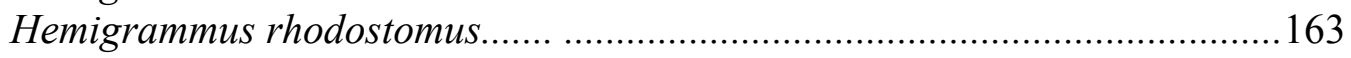

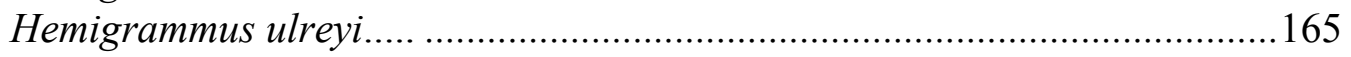

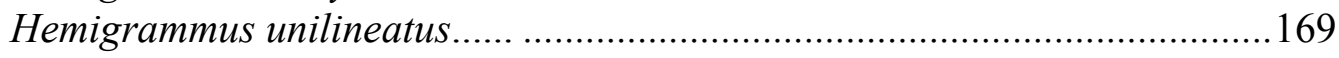

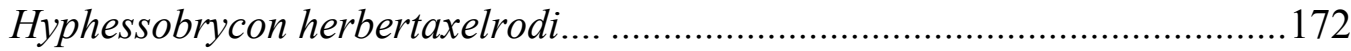

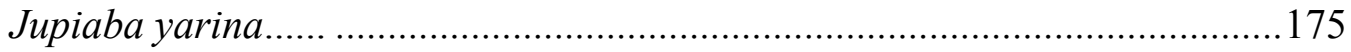

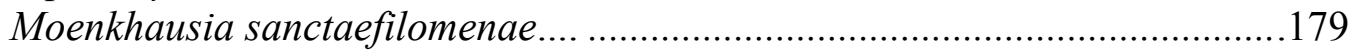

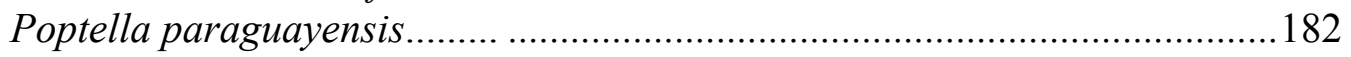

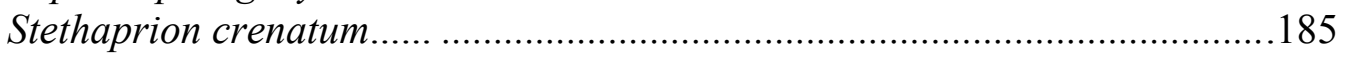

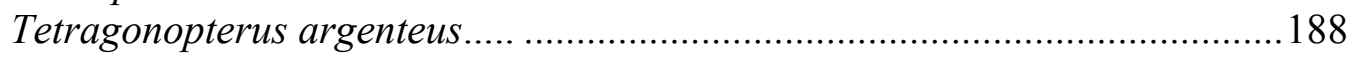

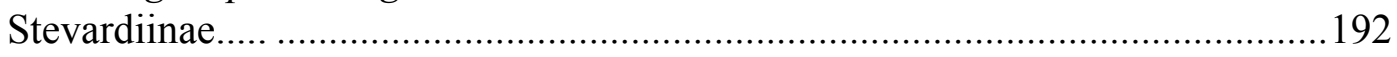

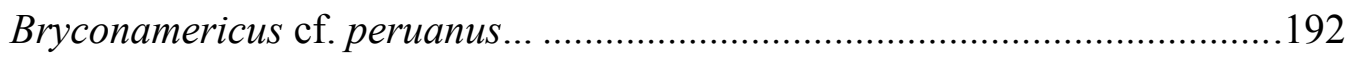

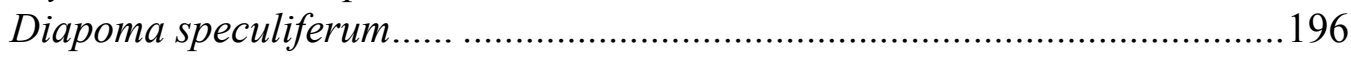

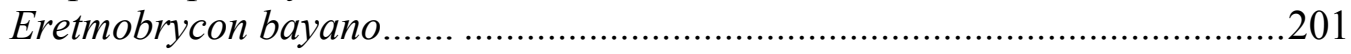

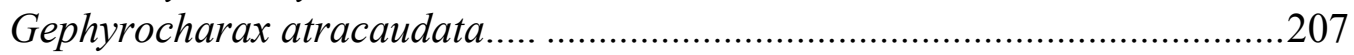

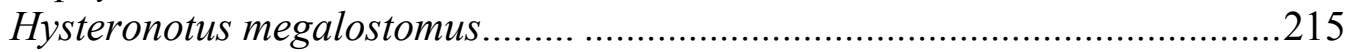

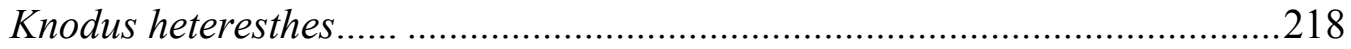

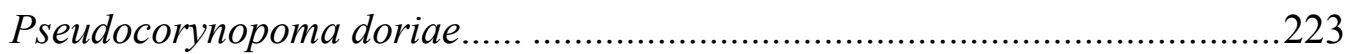

Scopaeocharax rhinodus..........................................................................2230. 
8 - Substituição da "Figura 201" do Apêndice pela seguinte:
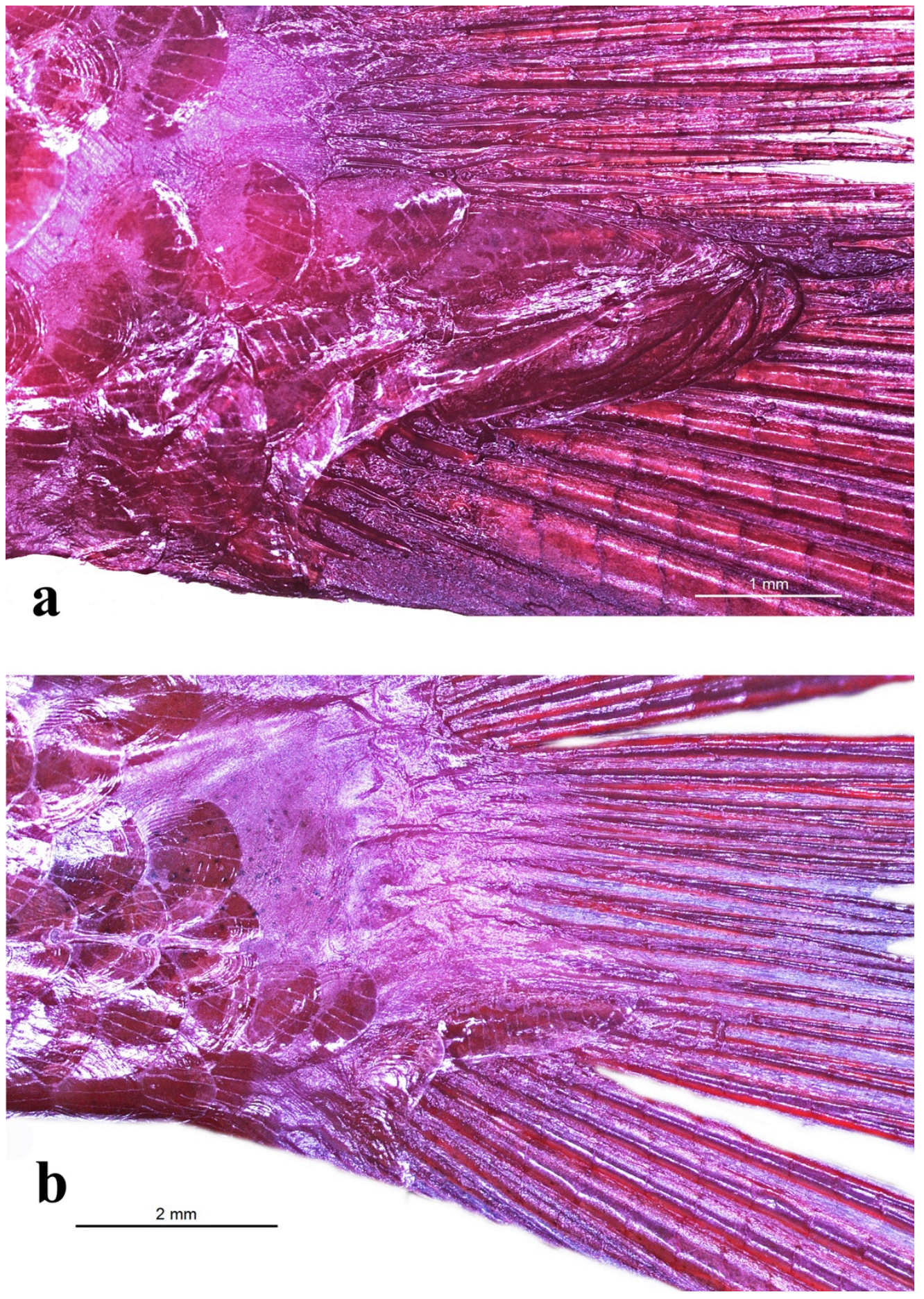

Figura 201. Pedúnculo caudal de machos (a) e de fêmeas (b) de Diapoma speculiferum, evidenciando a exposição e formato da extremidade distal dos raios procurrentes ventrais de macho. 